$3,1,1,0$

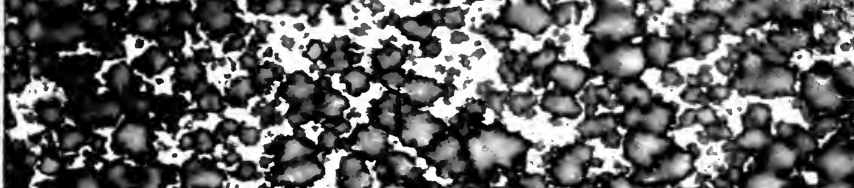

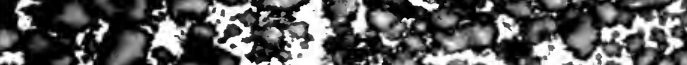

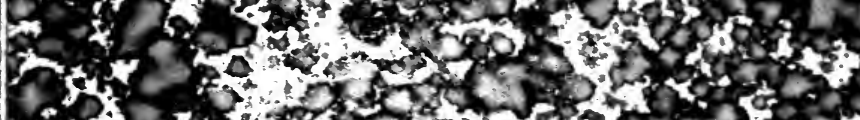

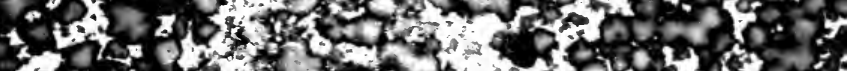

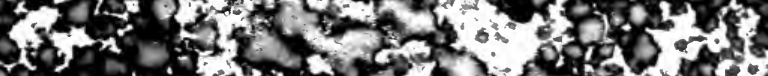

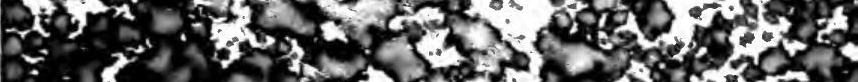
in

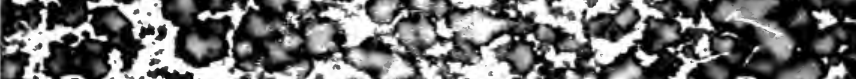

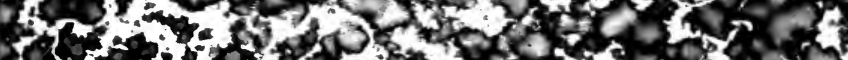
7.

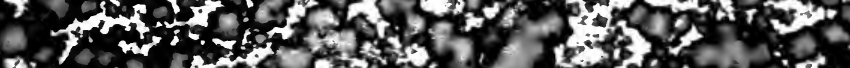

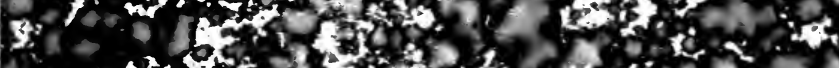

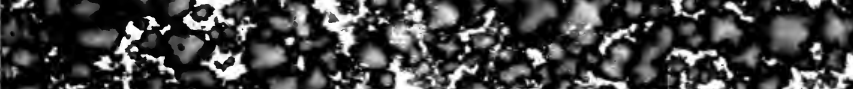

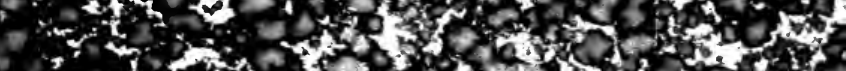

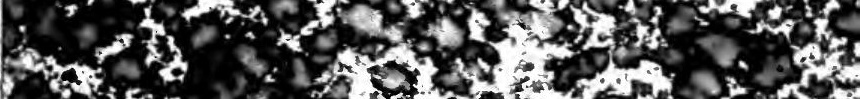

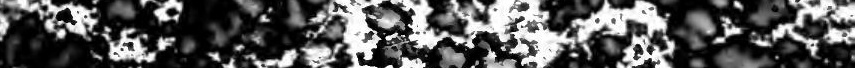

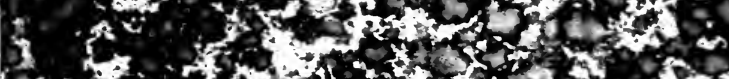

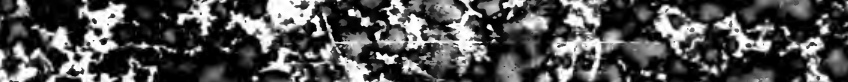

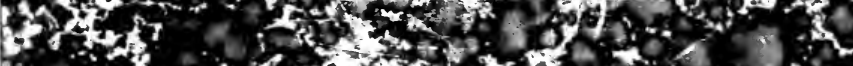
(3) 13.

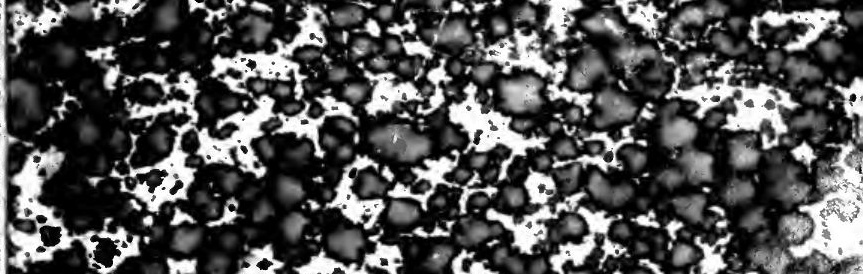




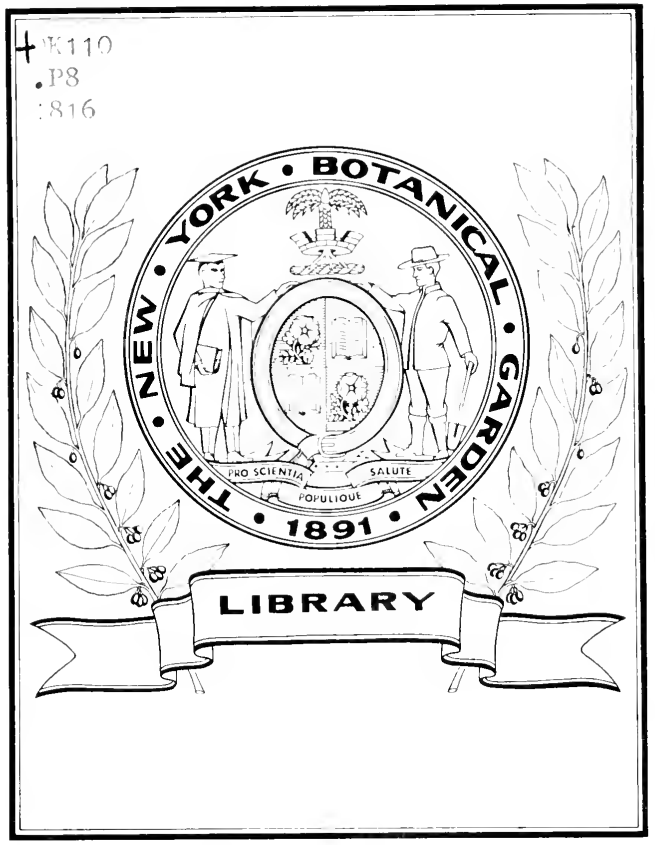

fibxaxy 




Flora America Septentrionalis; oR, $A$

SYSTEMATIC ARRANGEMENT AND

D ESC R I P'T I O N

$\mathrm{OT}$

\title{
Cije Plantos
}

\author{
$\mathrm{OF}$ \\ NORTH A M RTCA. \\ CONTAINING,
}

BESIDES WHAT HAYE BEEY DESCRIBED BY PRECEDIYG ALTIORE

MANI NEW AND RARE SPECIES,

COLLECTED DURING TWELVE YEARS' TRAVELS AND RESIDENCI. IN THAT COUNTRY.

BY FREDERICK PURSH.

I N T W O VOLU M E S.

HITIT THENTY.FOUR ENGRAVINGS

VOL. I.

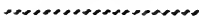

SECOND EDITION.

\section{London :}

PRINTED FOR JAMES BLACK AND SON, TAVISTOCK-STREET, COVENT.GARDEN. 



\section{AYLMER BOURKE LAHBERT, EsQ.}

$$
\text { F.R.S. F.A.S. }
$$

VICE-PRESIDENT OF THE LINNEAN SOCIETY.

\section{$S I R$,}

I AM conscious of offering but a small tribute of gratitude, zihen I beg to be permitted to inscribe the following pages with your name. Should they happily meet with approbation, the Public will have, in a great measure, to thank you for their existence; as, without the aid and assistance you so liberally afforded me, my own feeble excrtions would hate been inadequate to the performance of so important an undertaking.

Should the perusal of this work in any degree add to the pleasure you feel in
A 2
162405 
the cultivation of your favourite science, and in encouraging the efforts of others for its advancement, the utmost of the wishes are attained of,

\title{
Sir,
}

Your obedient and much devoted

\author{
humble Servant,
}

FREDERICK PURSH. 


\section{PR E F A C E.}

A movg the numerous useful and interesting objects of natural history discovered on the vast extent of the New Continent, none claim our attention in a higher degree than the vegetable productions of North America. Her forests produce an endless variety of useful and stately timber trees; her woods and hedges the most ornamental flowering shrubs, so much admired in our pleasure grounds; and her fields and meadows a number of exceedingly handsome and singular flowers (many of them possessing valuable medicinal virtues), different from those of other countries. All these are more or less capable of being adapted to an European climate, and the greater part of easy cultivation and quick growth; which circumstances have given thern, with much propriety, the first rank in ornamental gardening.

A country so highly abundant in all the objects of $m y$ favourite pursuits, excited in me, at an early period of life, a si-ong desire to visit it, and to observe in their natural soil and climate the plants which I then knew; and to make such discoveries as circumstances might throw in my way. This plan I earried into executiors in the year 1799; when I left Dresden, the place where I had received my education, and embarked for Balti. 
more in Maryland, with a determination not to return to Europe until I should have examined that country to the utmost extent of my means and abilities. In 1811, after an absence of nearly tivelve years, I returned to Europe, with an ample stock of materials towards a Flora of North America, an attempt at which I now venture to lay before the public, with the flattering hope, that a generous allowance will be made for its unavoidable imperfections, when the extent of the undertaking is considered; and that it will be accepted as it really is intended, as only the groundwork of some future more perfect work upon the subject.

$\Lambda$ it may be interesting to some readers to have a sketch of the particulars of my stay in America, and to be informed of the means by which I became possessed of so general a collection of its plants, I shall give a few outlines thereof, previous to the necessary remarks respecting the execution of the work itself.

My first object, after my arrival in Ameriea, was to form an acquaintance with all those interested in the study of Botany. Among these I had the pleasure to account one of the earliest, and ever after the most valuable, the Rev. Dr. Mühlenberg of Lancaster, in Pensylvania, a gentleman whose industry and zeal for the science can only be surpassed by the accuracy and acuteness of his observations; I only regret, that his extensive and interesting materials towards a Flora of the United States, in which he has been engaged for a number of years, should not before this have been communicated to the public.

I next visited the old established gardens of Mr. Marshall, author of a small " Treatise on the Forest-trees 
of North America." This gentleman, though then far advanced in age and deprived of his eye-sight, conducted me personally through his collection of interesting trees and shrubs, pointing out many which were then new to me, which strongly proved his attachment and application to the science in former years, when his vigour of mind and eye-sight were in full power. This establishment, since the death of Mr. Marshall, (which happened a few years ago,) has been, in some respects, kept up by the family, but is now very much on the decline, only a few old established trees being left as a memento of what formerly deserved the name of a respectable botanic garden.

Near Philadelphia I found the botanic garden of Messrs. John and William Bartram. This is likewise an old establishment, founded under the patronage of the late Dr. Fothergill, by the father of the now living Bartrams. This place, delightfully situated on the banks of the Delaware, is kept up by the present proprietors, and probably will increase under the care of the son of John Bartram, a young gentleman of classical education, and highly attached to the study of botany. In Mr. William Bartram, the well known author of "Travels through North and South Carolina," I found a very intelligent, agreeable, and communicative gentleman; and from him I received considerable information about the plants of that country, particularly respecting the habitats of a number of rare and interesting trees. It is with the liveliest emotions of pleasure I call to mind the happy hours I spent in this worthy man's company, during the period I lived in his neighbourhood. 
Not far from the latter place are also the extensive gardens of William Hamilton, Esq., called the Woodlands, which I found not only rich in plants from all parts of the world, but particularly so in rare and new American species. Philadelphia being a central situation, and extremely well calculated for the cultivation of plants from all the other parts of North America, I found this collection particularly valuable for furnishing me with a general knowledge of the plants of that country, preparatory to more extensive travels into the interior, for the discovery of new and unknown subjects." Mr. John Lyon, (of whom I shall have an opportunity to speak hereafter,) who had the management of these gardens, was then about to give them up: having the offer of being appointed his successor, I embraced it, and accordingly in IS02 I entered upon the situation. During my stay in this place, which was until 1805 , I received and collected plants from all parts of North America ; and when Michanx's "Flora Boreali-Americana" appeared, which was during that time, I was not only in possession of most of his plants, but had then a considerable number not described by him.

Within this period I had also formed a connection with Dr. Benjamin S. Barton, Professor of Botany in the University of Pensylvania, \&c. whose industrious researches in all the different branches of natural history are so well known to the literary world. He likewise, for some time previous, had been collecting materials for an American Flora. As I was now very anxious to explore the more remote parts of the country, particularly the interesting ranges of the Allegany Mountains, I was enabled, by the kind assistance of this gentleman, to 
take a more extensive range for my botanical excursions, which during $\mathrm{my}$ stay at the Woodlands had been confined within a comparatively small compass, the necessary attention to the duties of that establishment not permitting me to devote more time to them.

Accordingly, in the beginning of 1805 , I set out for the mountains and western territories of the Southern States, beginning at Maryland and extending to the Carolinas, (in which tract the interesting high mountains of Virginia and Carolina took my particular attention,) and returning late in the autumn through the lower countries along the sea-coast to Philadelphia. The following scason, 1S06, I went in like manncr over the Northern States, beginning with the mountains of Pensylvania and extending to those of New Hampshire, (in which tract I traversed the extensive and highly interesting country of the Lesser and Great Lakes,) and returning as before by the sea-coast.

Both these tours I principally made on foot, the most appropriate way for attentive ohservation, particularly in mountainous countries; travelling over an extent of more than three thousand miles each season, with no other companions than my dog and gum, frequently taking up my lodging in the midst of wild mountains and impenetrable forests, far remote from the habitations of men. The collections and observations made in the course of these journeys, all of which I communicated to Dr. Barton, were considerable, in respect to the discovery of many new and interesting subjects of natural history in general. But the knowledge which I thereby acquired of the geography, soil, and situation of the plants of that country, (points of the greatest interest 
to the practical botanist) was of the greatest importance to me.

Soon after my return from the last-mentioned journey, I had the pleasure to form an aequaintance with Meriwether Lewis, Esq., then Governor of Upper Louisiana, who had lately returned from an expedition across the Continent of America to the Pacific Ocean, by the way of the Missouri and the great Columbia rivers, executed under the direction of the Government of the United States. A small but highly interesting colleetion of dricd plants was put into my hands by this gentleman, in order to describe and figure those I thought new, for the purpose of inserting them in the account of his Travels, which he was then engaged in preparing for the press. This valuable work, by the unfortumate and untimely end of its author, has been interrupted in its publication; and although General Daniel Clark, the companion of Mr. Lewis, (to whom I transmitted all the drawings prepared for the work,) undertook the editorship after his death, it has not, to my knowledge, yet appeared before the public, notwithstanding the great forwardness the journals and materials were in when I had the opportunity of perusing them.

The collection of plants just spoken of was made during the rapid return of the expedition from the $\mathrm{Pa}$ cific Ocean towards the United States. A much more extensive one, made on their slow ascent towards the Rocky mountains and the chains of the Northern Andes, had unfortunately been lost, by being deposited among other things at the foot of those mountains. The loss of this first collection is the more to be regretted, 
when I consider that the small collection communicated to me, consisting of about one hundred and fity specimens, contained not above a dozen plants well known to me to be natives of North America, the rest being either entirely new or but little known, and among them at least six distinct and new genera. This may give an idea of the discerning eye of their collector, who had but little practical knowledge of the Flora of North America, as also of the richness of those extemive regions in new and interesting plants, and other natural productions.

The description: of those plants, as far as the specimens were perfect, I have insertel in the present work in their respective places, distinguisling them by the words " $v$. s. in Herb. Le uis." Several of them thave had an opportunity of cxamining in their living state, some being cultivated from seeds procured by Mr. Lewis, and others since my arrival in England from sceds and plants iistroduced by .Mr. Nuttall.

Here I cannot refrain from drawing the attention of future botanists travelling thove region, to two highly interesting plants, of which I have only secn imperfect specimens. The first is what Mr. Lewis in his journals calls " the Osage Apple," or "Arrowwood of the Missouris." This is a tree, or rather shrub, with leaves resembling those of a pear-tree, but broader in proportion; they are alternate, and have a recurved thorn near their base; the flowers are of separate sexes, and appear in axillary, peduncled, globular catkins, which produce a depressed globular fruit, in size and colour resembling an orange, in interior structure approaching near to the genus Morinda. This shrub, on account of its fruit 
to the practical botanist) was of the greatest importance to me.

Soon after my return from the last-mentioned journey, I had the pleasure to form an acquaintance with Meriwether Lewis, lisq., then Governor of Upper Louisiana, who had lately returned from an expedition across the Continent of America to the Pacific Ocean, by the way of the Mlissouri and the great Columbia rivers, executed under the direction of the Government of the United States. $\Lambda$ small but highly interesting collection of dried plants was put into my hands by this gentleman, in order to deseribe and figure those I thought new, for the purpose of inserting them in the account of his Travels, which he was then engaged in preparing for the press. This valuable work, by the unfortmnate and untimely end of its author, has been interrupted in its publication; and although General Daniel Clark, the companion of Mr. Lewis, (to whom I transmitted all the drawings prepared for the work,) undertook the editorship after his death, it has not, to my knowledge, yet appeared before the public, notwithstanding the great forwardness the journals and materials were in when I had the opportunity of perusing them.

The collection of plants just spoken of was made during the rapid return of the expedition from the $\mathrm{Pa}$ cific Ocean towards the United States. A much more extcnsive one, made on their slow ascent towards the Rocky mountains and the chains of the Northerı Andes, had unfortumately been lost, by being deposited among other things at the foot of those mountains. The loss of this first collection is the more to be regretted, 
when I consider that the small collection communicated to me, consisting of about one hundred and fifty specimens, contained not above a dozen plants well known to me to be natives of North America, the rest being either entirely new or but little known, and among them at least six distinct and new genera. This may give an idea of the discerning eye of their collector, who had but little practical knowledge of the Flora of North America, as also of the richness of those extensive regions in new and interesting plants, and other natural productions.

The descriptions of those plants, as far as the specimens were perfect, I have inserterl in the present work in their respective places, distinguishing them by the words " $v$. s. in Herb. Lewis." Several of them Ihave had an opportunity of exanining in their living state, some being cultivated from seeds procured by Mr. Lewis, and others since my arrival in England from seeds and plants iistroduced by Mr. Nuttall.

Here I cannot refrain from drawing the attention of future botanists travelling those regions, to two highly interesting plants, of which I have only seen imperfect specimens. The first is what Mr. Lewis in his journals calls " the Osage Apple," or "Arrowwood of the Missouris." This is a tree, or rather shrub, with leaves resembling those of a pear-tree, but broader in proportion; they are alternate, and have a recurved thorn near their base ; the flowers are of separate sexes, and appear in axillary, peduncled, globular catkins, which produce a depressed globular fruit, in size and colour resembling an orange, in interior structure approaching near to the genus Morinda. This shrub, on account of its fruit 
and handsome foliage, must be highly ornamental: the wood, being excessively hard, is preferred by the natives to any other for making their arrows; and as it does not spontaneously grow in their neighbourhood, they travel annually to a considerable distance South-west, to procure it. About the village of the Osage Indians a few trees have been planted, from which one has been introduced into one of the gardens at St. Louis on the Mississippi. Perfect seeds from the last-mentioned tree were given hy Mr. Lewis to Mr. M`Mahon, nursery and seedsman, at Philadelphia, who raised several fine plants from them, and in whose possession they were when I left America. The other plant alluded to is called by Mr. Lewis " A bulbous Rush, which serves the Indians for bread." Of this I have only seen the root, which is of a yellowish-brown colour, about the thickness of a finger, and jointed; on each joint, which are about three inches asunder, several tubers of about an inch and a half long are produced, of an oblong ovate shape, tapering into a point towards the end; these tubers are filled with an exquisite white and fine farina, resembling starch; these roots are used in the same manner as those of Psoralea esculenta, vid. vol. ii. p. 475. I take this to be a larger species of tuberous Cyperus.

While I was thus engaged in describing and figuring those new acquisitions to the American Flora, another opportunity offered to augment my resources. $\mathrm{Mr}$. Aloysius Ensien, who had been sent to America by Prince Lichtenstein of Austria, as a collector of new and interesting subjects of natural history, returned to Philadelphia from his extensive travels through the Western Territorie; and Southern States. This gentle- 
man, with whom I had previously been on terms of intimate friendship, was now in possession of an exirenely valuable collection of living and dried plants, to which I had unrestrained access. To his liberality I am indebted for many new and scarce specimens, which filled up a desideratum in my collection, particularly in the plants of Lower Louisiana and Georgia. Those species exclusively received from his collection I have distinguished by "v. s. in Herl. Enslen."

At the same time I had frequent opportunities of seeing the herbarium and collection of living plants of Mr. John Lyon, a gentleman through whose industry and skill more new and rare American plants have lately been introduced into Europe than through any other channel whatever. Those plants particularly adopted from his collection I have marked with " v. s. in Herl. Lyon."

By these and several other connections, which it is unnecessary to mention here, added to my own occasional excursions through the different parts of the United States, I was put in possession of an extensive herbarium, containing plants from all the different parts of North America; which when summed up would nearly double the number of those described in Michaux's excellent Flora. As that work was then extremely scarce in America, I determined to publish a Compendium of it, executed on the plan of Hoffmann's Flora Germanica, which work I had no doubt would be acceptable to the botanist, and particularly so to the cultivator. I communicated my design to Messrs. Bradford and Inskeep, booksellers at Philadelphia, who gave me every encouragement towards the prosecution thereof. 
While I was engaged in arranging my materials for this publication, I was called upon to take the management of the Botanic Garden at New York, which had been originally established by the arduous zeal and exertions of Dr. David Hosack, Professor of Botany, \&c. as his private property, but has lately been bought by the Government of the State of New York for the public service. As this employment opened a further prospect to me of increasing my knowledge of the plants of that countrv, I willigiy dropped the idea of my intended publicat . Cor that time, and in 1807 took charge of that estabis siment.

Here $I$ again endeavoured to pay the utmost attention to the collection of American plants, as the establithment was principally intended for that purpose. In this I was supported by my numerous botanical comoctions and friends, anong whom I must particularly mention John Lc Conte, Esq. of Georgia, whose unremitting exertions added considerably to the collection, particularly of plants from the Southem States.

The additions to my former stock of materials for a Flora were now considerable, and in conjunction with Dr. D. Hosack I had engaged to publish a periodical work, with coloured plates, all taken from living plants, and if possible from native specimens, on a plan similar to that of Curtis's Botanical Magazine; for which a great number of drawings were actually prepared. But at this period I was attacked by a serious and obstinate intermitting fever, which made a change of air and cli mate absolutely necessary to me; I therefore, in 1810 , took a voyage to the West Indies, visiting the islands of Barbadoes, Martinique, Dominique, Guadaloupe, and 
St. Bartholomew's, from which I returned in the autumn of 1811 in a perfect state of recovered health. The vessel in which I returned landed at the town of Wiscasset in the province of Main. This being a country I had never visited before, I examined its vegetation with all possible attention; and althutigh the season was too far advanced for making any new discoverics, I gained considerable information respecting the geography of plants, a point I always concidered highly interesting to the science. During my journey towards New York, I had an opportunity of visiting l'rofessor Peck of Cambridge College near Boston, and seeing his highly interesting collection of plante, collected on a tour to the alpine regions of the Wiritc lith of New Hampshire. As the scason was too fur advancel when I was in that country to suffer me to think of ascending those mountains, this collection was highly gratifying to me.

On my return to New York, I found thims in a situation very unfavourable to the publication of scientitic works, the public mind being then in agritation abont a war with Great Britain. I therefore determined to take all my materials to England, where I conceived I should not only have the advantage of consulting the most celebrated collections and libraries, but also meet with that encouragement and support so necessary tu works of science, and so generally bestowed upon them there.

These expectations I found amply realized on my arrival in London. I had very soon the pleasure of forming a circle of acquaintance among those attached to the science of Botany, by whom I was gradually introduced 
to the most eminent botanical characters of our age Sir Joseph Banks, with his accustomed liberality, supported my undertaking by giving me access to his extensive library and herbarium. A. B. Lambert, Esq. favoured me not only with the same assistance, but very handsomely offered me the entire use of his library and collection during the compilation of the work. To this gentleman I am in the highest degree indebted for his strenuous support under all the difficthiss I had to eiscounter during its progress; which by his generous exertions he endeavoured to remove whenever they occurred.

Among the many new sources of information now opened to me, I must particularly mention the following original collections, by the assistance of which I have been enabled to correct many errors of former publications, particularly respecting the synonyms.

I. Clayton's Herbarium.-The whole of this interesting collection, from which the "FLORA VIRGINica" of Gronovius was compiled, is preserved in the Banksian Museum. This has been particularly useful to me in tracing the plants which Linnæus had adopted from that work.

II. Professor P. S. Pallas's Herbarium.-This extensive collection, now in the possession of A. B. Lambert, Esq. was highly useful to me, in comparing the plants of North America with those of the North of Asia, to some of which they have a great affinity, and others are common to both continents.

III. Plukenet's Herbarium.-Preserved in the British Míseum, as also part of

IV. Catesby's Herbarium. 
V. Walter's Herbarium. This interesting collection, from which Walter's "Flora Carolisiana" was compiled, is in possession of the Messrc. Frasers of Sloane Square, whose father was the intimate friend of Mr. Walter. They very kindly permitted me to make use of it whenever I had oteasion to refer to it.

I am alou highly indebted to William Roscoe, Esq., who very obligingly commmicated to me Mr. Bradbury's Plants collected in Upper Louisiana. This valuable collection contains many rare and new species, having been collected in a tract of country never explored before: those which were entircly new I have described in the Supplement to the present work.

Besides these general collections, there were a number of interesting now plants in the Banksian Ilerbarium collected by different persons in Xisth America. Among them I found a number of those coilected by Arcibald Menzies, Esy., during the famous expedition under Vancouver, on the nurth-west coast of America. As several of them had been described by me from the Lewisian collection, I requested permi-ion of Mr. Menzies to adopt such as were immediately eonnected with my plan, which he very obligingly complied with.

The number of American plants in the different murseries and private collections in the vicinity of London, contributed considerably to my resources, and I am highly indebted to those who gave me their assistance, particularly to Messrs. Lee and Kemedy, whose extensive collections exceed any other in Europe.

The accomits I had frequently heard of the celebrated Sherardian Herbarium at Oxford, made me particularly

yOL. $I$. 
anxious to examine it. Dr. G. Williams, professor of botany in that University, received me with that kindness so congenial to the true friend of science, and supported my researches to the utmost of his power. Besides the entire Hcrbarimn of Morison, and other valuable collections, I found a general collection of North American plants, among which I was particularly gratificd to find all those sent by Mr. M. Catesby to Dr. Sherard. This collection, thongh made a century ago, is in very fine preservation, and contains specimens of most of the new species of Walter, Michaux, \&c. and even some entirely new ones, with the remarks and synonyms of Dr. Sherard, and frequently accompanied with the origmal letters of M. Catesby. In the same collection are also a number of rare specimens collccted by a Mr. Tilden at Hudson's Bay, and those of John Bartram and other correspondents of Dr. Sherard. In fine, I consider this the most complete collection of North American plants now extant. The notes and remarks made here are given in the Appendix and Addenda, as it was not until the body of the work was printed that I had the opportunity of seeing this valuable collection.

Having thus given a general view of the means and resources I had in composing the present work, I shall only add a few remarks respecting its execution.

On a slight inspection of the work, it will be readily perceived that my clief object has been, throughout, to comprise as much matter as possible in the smallest space which attention to perspicuity would allow.

In respect to nomenclature I lave followed Willdenow's "Species Pldxtarud" and Miehaux's "Flora 
Bormali-Americaya" as near as possible, avoiding carefully to change old established names, however faulty, unless in eases where good authority furnished a more appropriate one. As for example, 1 have adopted Fraxinus acuminata of Lamarck, instead of Fraxinus americana, Linn., and Cynoglossum amplexicaule of Michaux for Cynoglossum virginicum, Linn. But I have never approved of such changes as Juglans alba and cincrea of Linneus to Juglans squamata and cuthartica, as the younger Michaux in his "Arbres Fores. tiers" has done. This otherwise very useful publication is full of such new names, imposed on well known and long established species, and sometimes even without the least hint respecting their names in other authors.

The specific characters in most instances have been modelled anew or altered as it was found necessary. Whereever any alteration had been made it was necessary to quote the author from which the species had been taken in a separate line, as page 16 Monarda didyma; after the specific description I had to repeat that it was the same with $M$. didyma, Willd. sp.pl. 1.p. 12.). To avoid this superfluous repetition, and save as much room as possible, I found it expedient to adopt, from page 72 to the end, the following mark (-), to be placed after the specific character whenercr it had been amended; so that Stipa avenacer, page 72 , is the same species described by Willd. sp. pl. 1. p. 442 , but the character is new or augmented. Wherever the author follows the description without this mark, as page 73 , Saccharum giganteum, Pers. ench. 1. p. 103, in that case the character has been adopted without alteration. 
In some of the more intricate genera, as Monurda, Iaccinium, Andromeda, Sulix, \&c. the specific characters have been extended to a rather unusual length, which may be oujected to by some, but I am persuaded will be approved of by most. The beaty of a short and percpicuous character is without doubt preferable to a long one, which the more it is extended the more ambiguous it will becone; but the nature of ccrtain genera wiil absolutely not admit this conciseness, and the works of some of the most celebrated authors have lately proved that it is inconrenient to be limited by a certain number of words in forming the specific character. Anong many others l only need to mention Willdenow's last volume of the Specics Plantarun, partienlarly the genus Aspidium, and Mr. Robert Prown's excellent "Treatise on the Proteacea," in the telith rolume of the Transactions of the Limean Society. In both these works examples will be found, where the length of the specific character equals if not cxceeds in number of vords the longest in the present work.

It would have been needless to encumber the work with a superfuous number of synonym, which can be fund in the atthors referred to; but those of a late date, or any way illistrative toward the true determination of the species, have ban carefully collected, as the means I was possecsed of were particularly farourable to the ascertainnent of those point, which may be of the highest ntility to future puilications on the same subject.

In respect to the figures referred to, care has been tuken to quote the most correct whenever there was a choice. The plates which accompany the work have 
been carefully selected, either from highly interesting new plants, or those which will not admit of cultivation, as some of the Pliexias, Lapinus, Gerarilia, Ac. Is the plates were executed during the progress of the work through the press, references to them could not be inserted in the proper places; but as the plates themselves refer to the pages of the work, it will be easy to supply this deficieney.

Particular attention has been paid in decribing t!e soil, situation, and range of comtry each species is found in, which will be found very useful to the practical botanist, and especially so to the eultivator of those plants.

After the usual sign of durution, and the time of fowcring, eath species has been fathfully marked whether I have secn it nyself in a living state ( $v . v$.), or only in a dried specimen ( $\iota .$. ) : in the leterer case the name of the herbarium I hat it rrom is renerally mentioned. Those I have adopted without sexing them mỵsclf in either state, and which are but lew, I hase marked $(+)$.

To each species a short note has been added, respecting the eolour and size of the Aower, the habit of the plant, or some other interesting subject illustrative of the species.

Very full descriptions have been given of only some of the most interesting new species, as the limits of the work would rot adnit of it in gencral. The eareful references to authors and good figures will amply supply this deficiency.

In the alteration made in the systematic arrangement, 
I have becn guided by the hints given by the learned Dr. J. E. Smith, in his excellent "Introduction to Botany." The classes Dodecandria and Polyadelphia are entirely onitted, and their genera inserted in their proper places in the other classes. Asarum next to Aristolochia, in Gynandria. Bejaria, Portulacca, Talinum, Calligonum, and Hypericum, in Polyandria. Hudsonia next to Helianthemum, with which it is closely related in the same class, Decumaria, Lythrum, Cuphea, and Agrimonia, in Icosandria. Halesia near Styrax, in Monadelphia. Euphorbia in Diclinia, where it forms, with its other genera, a natural as well as artificial order. The nineteenth class, Diclinia, contains the natural families of Tricoccx or Euphorbia, Amentaceæ, and Coniferæ. The other genera of the classes Monœcia, Diøcia, and Polygamia, having been referred to their proper classes. The genus Diotis more properly belongs to Tetrandria, but had been omitted in that cless. Najas and Valisneria are genera of an order of this class, to which probably might be added all the Aroidere. How far these alterations may meet the approbation of those best qualified to judge, I have yet to learn, but I am strongly persuaded they will facilitate the study of this lovely science to the young beginner.

In the last class, Cryptogamia, I have gone no further than the family of the Fiiices, according to the forma tion of the plan of this work, which only included plants which either are, or can be cultivated. The other orders, Musci, Alga, and Fungi, will form a distinct work from the present, and may appear at some future 
period in a more perfect shape than the limits of this work would admit; it being absolutely necessary to illustrate those minute objects with correct figures, without which mere words are useless in describing them.

At the end of the work I have given a Table of Anomalous Flcwers; great pains have been taken to make it as correct as possible. This will be found of infunite service, particularly to the young botanist. For this purpose I shall give an example of the use of it. Should the young beginner, unacquainted with the genus $G$ rlium, happen to find Galium trifidum, vol. i. p. 103, he would in vain look for its genus in Triandria ; but by referring to this table among the anomalous genera, he will very easily fund its proper genus. Again, by exanining a flower of Aiclepias, he might very probably consider the ten pollen masses for as many anthers, and look for its genu; in Decandria, which by the assistance of this table he will trace to be Pentandria.

For the accommodation of the English reader, I have given a double Latin and English Index. Great attention has been paid to the correctness of the General Index, in which the first number in parentheses refers to the number of the genus, the other to the page. The synonyms are distingnished by being in Italics.

Notwithstanding the unremitting attention paid to the correctness of this work, the anthor is well aware that it will not be found fice from those errors which are unavoidable in (nay almost inseparable from) publications of this nature, where so great a number of authorities are to be referred to. But he still consoles himwelf with the idea of having given to the world a work: 
which, with all its imperfections, will be found useful, and contribute to the general advancement and progress of the science. This has been the only aim, and will be the highest reward of the labours of

THE AUTHOR:

LONDON,

December 1813 . 


\section{REFERENCES TO THE PLATES,}

Tab. Page.

1. 17 . Mnnarda Kalmiana.

2. 62. Milium amphicarpon.

3. 175. Claytonialanceslara.

4. 219. Be. beris Aquifolium.

1. A single pirna of a full grown leaf, from the uuder side.

2. An expanded flower; with its component parts viewed from behind, natural size.

3. A petal with its stamen, magnified.

4, 5. $\Lambda$ stamen and pistillum, more magnified.

3. 219. Berbelis nervosa.

1. The caly $x$, natural size.

2. A petal with its stamen, magnified.

6. 22. Conoutylis amcricana.

7. 150. Solanum heterandrum.

8. 228. Lilitim pulicum.

1. The pistil.

2. A stamen, both natural size.

9. 243. Helonias tenax.

10. 258. Rhexia ciliosa, and Rhexia lutea. Both specirs, by a mistake of the engraver, have been represcnted with tive petals, which ought to be only four.

2. A variety of Rhexia lutea.

11. 20ิo. Clarkia pulchella.

12. 2s3. Gaultheria Shallon; with a stamen magnified.

13. 283. Gaultheria serpyllifolia; a tlowering branch, magnified.

21. Ceratiola ericoides; a female branch, natural size.

178. The fruit of Hamiltonia nleifera, natural size.

2. A longitudinal cut of the same.

3. The kernel.

14. 302. Mylocarium ligustrinum. The dissections are: an opened corolla with the stamens; a back view of the calyx and the germ with its sligma; all magtrified. 
Tal. Page.

15. 333. Tigarea tridentata.

1. A flower divested of its petals.

2. A fruit.

3. The same longitudinally cut to show the seed.

16. 248. Rubus spectabilis.

17. 390. Caltha flabellifolia.

18. 423. Gerardia fruticosa.

19. 423. Gerardia quercifolia.

20. 427. Mimulus Lewisii.

21. 468. Lupinus villosus.

22. 475. Psoralea esculenta.

1. The calyx.

2. The vexilium.

3. The carina with the ala .

4. A fruit.

23. 479. Lupinaster macrocephalus.

24. 499. Prenanthes Serpentaria. 


\section{INDEX AUCTORTM.}

Albot. insect. - The Natural History of the rarer Lepidopsterous Insects of Georgia, collected from the Observations of J. Abbot, by J. E. Smith. 2 vols. London, 1797. 4to.

Act. hulm.-Kongl. Vetenskaps Academiens Handlingar. Stockholm, 1739 et seq. 8vo.

Act. petrop.-Acta Academiæ. Scientiarum Imperialis Petropolitanæ pro Amnis 1777-1782. Petropoli, 17781756. 410.

Act. soc. anner.-Transactiong of the American Philosophical Society, held at Philadelphia, for promoting useful Knowledge. Philad. 1771 et seq. 4 to.

Acl. soc. hist. nat. par.-Actes de la Société d'Histoire N3turelle de Paris. Tom. 1, 1 partie. Paris, 1792. fol. Act. soc. nat. scrut. haf.-Skrivter of Naturhistorie Selskabel. Kiobenhaven, 1790 et seq. 8 ro.

Act. soc. linn. lond.-Transactions of the Linnean Society of London. London, 1791 et seq. 4to.

Act.ups.-Acta Societatis Regiæ Scientiarum Upsaliensis. Stockholmia, $i>-1+$ et seq. 4 to.

Ait. keu'-_-Hortus Kewensis; or, A Catalogue of the Plants cultivated in the Royal Botanic Garden at Kew, by W . Aiton. Vol. 1-3. London, 1789. 8vo.

Ait. kew. $\epsilon d .2 .-$ The second edition enlarged, by IV. Turnsend Aiton. Vol. 1-5. London, 1810. Allion. fl. ped.-Car. Allioni Flora Pedemontana. Toni 3. Augustæ Taurinorum, 1785. fol.

Aip. exot.-Prosp. Alpini de Plantis exoticis Libri 2. Vene. tiis, 1629. 4 to.

Amœen. acad.-Caroli Linnæi Amœnitates academicæ. Vol. 10. Holniæe, 1749-1769. Erlangæ, 1785. 1790. sio.

Amm.rath.-Stirpium rariorum in Imperio Rutheno sponte 
provenientium Icones et Descriptiones collectæe a $\mathbf{Y}$. Ammano. Petropoli, 1739. Ito.

Anuales du mus. d'list. nat. Ann. mus. hist. nat.-Annales du Museum d'Histoire Naturelle, par les Professeurs de cet Etablissement. Paris, 1802 et seq. 4 to.

Annals of lot.-Annals of Potany, ty C. Konig and $J$. Sims. 2 vols London, $1805,1500.800$.

Ard. spec. Arduin. spect-Fetr. Arduini Animdversicnum botanicarum Specimen 1. Patarii 1750. Specimen 2. Venetiis, 1764. 4to.

Aull. guj. Aubl.fl. guj.-Histoire des Plantes de la Gujone Francoise, par M. Fusée Aublet. Tom. 4. Paris, 1375. 4 to.

Barrel. ic. Barr.rar.-Plantæ per Galliam, Hispaniam et Italiam obscrvatæ, Iconibus æneis exhibitæ a Jac. Barrcliero. Parisis, 1714. fol.

Bartr. it. Bartr. trav.--Travels through North and South Carolina, Georgia, East and West Florida, \&rc., by W. hartram. London, 1794. Sro.

Biatiw.-Herbarium Black wellianum emendatum ef auc. tum, cum Præfatione D. Chr. Trew. Cant. 1-6. Norimb. $1750-17 \% 2$. fol.

Bocc. sic.- Icones et Descriptiones rariorum Plantarum Sí. cilix, Melitæ, Gallix, ct Italiæe; Auctore Paulo Boc. cone, Oxonii, 16\%4 sto.

Bolton, filic-Jam. Bolton, Filices Britanniæ, an History of the British proper Fens, partes 1-2. Leeds and Huddersfield, 1755-1790. 4to.

Eot. mag.-Curtis's Botanical Magazine, continued by J. Sims. London, $1801 \mathrm{et}$ seq. 8 ro.

Bot. rep. - The Botanist's Repository for new and rare Plants, by H. Andrews. London, 1797 et seq. 4to.

Breyn. cent.-Jac. Breynii Exoticarum aliarumque minus cognitarum Plantarum Centuria prima. Gedani, 1678. fol.

Brown. jam. - The Civil and Natural History of Jamaica, by Patr. Browne. London, 1756. fol.

Bullet. de la soc. plitomat.-Bulletin des Sciences, par la Société Philomatique. Paris, 1797 et seq. 4to.

Cam. epit.-De Plantis Epitome Petr. Andr. Matthioli, aucta a Joach. Camerario. Francof. ad Mon, 1586. 4io.

Catesb. cur.-The Natural History of Carolina, Florida, and the Bahama Islands, by Mark Catesby. 2 vols, London, 1731. 1743. fol.

Cav diss.-Ant. Jos. Cavanilles, Monadelphiæ Classis Dis- 
sertationes decem. Parisiis et Matriti, $1 / 55-1790$. 4to.

Cav. ic.-Ejusdem Icones et Descriptiones Plmarum que aut sponte in Hispanial crescunt, aut in Hortis hospitantur. Vol. 1-6. Matriti, 1791-1501. fol.

Clayt. Al. virg-vid. Gron. Alvirg.

Col. ecphr. - Tab. Columna minus cognitarum rariormmque nostro Colo orientium Stirpium Ecphrasis. Rome, 1013. Purs 2da. ilizl. 1616.4 to.

Com. oxet.- Commentarii Sociotatis Rerix Scientiarum Gœertingensis. Gütlingæe, $1751 \mathrm{et} \mathrm{seq}$. 4to.

Comm hort.-Horti Meciici Amstelodamensis rariorum Plantarum Descriptio et Icones, Auctore Io. Comme. lino. Amstelodani, 1097. Pars altera, Auctore Casp. Commelino, 1701. fol.

Comm. preel.-Casp. Commelini Præludia Botanica. Ingd. Batav. 1703. 4io.

Corn. canad.-Jac. Cornuti Canadensium Plantarnm aliarumque nondım editarum Historia. Parisiis, 1635. 4 to. Crantz.fl. unstr.-ISear. Joan. Nepom. Crantz, stirpium Austriacaum. Pars 1, 2. Viell. 170y. 4 to.

Curt. lond. Curt. fe. lont.- William Curris's Fluñ Londinensis. 2 vols. London, 17\%7. 1799. fil.

Dclarache erzing.-Eryngionn istoria, Auctore F. Delaroche. Parisiis, 1808. fol.

Desf. atl.-Flora Atlantica, Auctore Renuto Desfontaines. Tomi 2. Parisiss. 4to.

Diar. Kist. nut.-Junrual d'Histoire Naturelle. Tom. 1, 2. Paris, 1792. Svo.

Dill. elth.-Joh. Jac. Dillenii Hortus Elthamensis. Vol. 2. Londini, 173\%. fol.

Dill. musc.-Ejusdem Historia Musçorum. Oxon. $17+1$. 4 to,

Dod. mem. Dodurt. mem.-M'moircs pour servir à l'Histoire des llantes, par M. Dodirt. Zaris, 1070 fol.

Donn. catal. Donn. hort. cant.--Hortus Cantabrigiensis, by James Doun. Cambridge, Jsi2. 8vo.

Duhamel. arb. - Du Hamel du Monceau, Traité des Arbres et Arbustes qui se cultivent en France en pleine Terre. Tomes 2. Paris, 1755. 4to. ed. nov.-Ejusdem Operis Editio nova. il. fol. Du Roi harlk.--Jol. Phil. Du Roi, Die Harbkesche wilde Baumzucht. 1. 2. Theil. Braunschw. 1771, 1772. ovo. ed. 2.-Ejusden Operis Editio nova. $i b$,

1795. sro. 
Ehret. pict.-Plantx et Papiliones rariores, depictæ et xil incisæ a Ge. Dion. Ehret. Londini, 1748, 1759. fol.

Ehrh leitr.-Frid. Ehrhart Beiträge zur Naturkunde. 1-\% Baud. Hann. 1757-1792. Svo.

Engl. lot.-English Botany, by J. E. Smith, the Figures by J. Sowerby. London, 1790 et seq. Svo.

Exot. bot.-Exotic Botany, by J.E. Smith, the Figures by J. Sowerby. London, $1804 \mathrm{et} \mathrm{seq.} 4$ to.

Feuil. feruv._-Journal des Observationis faites sur les Côtes Orientales de l'Amérique Néridionale, par le R. P. Louis Feuillée. Tomes 3. Paris, 1714. 1725. 4to. Fl. dan.-Icones Plantarum sponte nascentium in Regnis Daniæ et Norwegiæ, editæ a G. C. Oeder, O. F. Muller, et Mart. Vahl. Hafniæ, 1761 et seq. fol.

Fl. grcec.-Flora Græca, sive Plantarum rariorum Historia, quas in Provinciis aut Insulis Græciæ legit, investigavit, et depingi curavit Joh. Sibthorp ; Characteres omnium, Descriptiones et Synonyma elaboravit J. E. Smith. Londini, 1806 et seq. fol.

Fl. lapp-Car. Linnæi Flora Lapponica. Amstelod. 1738. 8vo.

Fl. per. Fl. peruv.-Flora Peruviana et Chilensis : sive Descriptiones et Icones Plantarum Peruvianarum et Chilensium, Auctoribus Hipp. Ruiz et Jos. Pavon. Matriti, 1-98-1802. fol.

Gert. de fr. et sem.-Jos. Gxrtner, de Fructibus et Seminibus Plantarum. Vol. 1 et 2. Stutgard, 1788-1791. 4 to.

Gart. carp.-G. F Gærtner, Carpologia: seu Continuatio Operis de Fructibus et Seminibus Plantarum. Vol. 3. Tubingæ, 1805 . 4to.

Gen. pl.-Car. a Linné, Genera Plantarum, Ed. 8ro. curante J. C. D. Schreber. Vol. 2. Francof. 1789. 1791. svo.

Gmel. sil. Gmel. fl. sib.-J. G. Gmelin, Flora Sibirica. Tom. 1-4. Petrop. 1747-1769. 4 to.

Gmel. syst. nat. Gmel. syst. veg.-Car. a Linné, Systema Naturæ, Editio Gmelini. Lips. 1788-1793. Svo.

Gron.virg. Gron. fl. virg.-J. F. Gronovius, Flora Virginica, exhibens Plantas quas J. Clayton in Virgiinia collegit. Lugd. Batav. 1702 . 4 to.

Eall.hely. Hall. fl, helv. - Alb. v. Haller, Historia Stirpium indigenarum Helietiæ inchoata. Tomi 3. Bernæ, 1768 . fol. 
Herm. lugdl.-Pauli Hermanni Catalogus Horti Acadenici Lugduno-Batavi. Lugd. Batav. 1087. Svo.

Herm. parad.-Ejusdem Paradisus Batavus, ib. 1698. 4to.

Hoffm. phytogr.-G. F. Hoffmann Phylographische Blätter.

1 Band. Götting. Svo.

Hoffm. sal.-Ejusdem Historia Salicum. Tom. 1, 2. Lipsiæ, 1787 . fol.

Houttuyn. linn. syst:-Mart. Houttuyn des Ritters von Linné, Volständiges Pflanzensystem. 1-14 Theils. Nurnb. 1771--1788. 8vo.

Hort. angl.-A Catalogue of Trees, Shrubs, Plants, and Flowers which are propagated for Sale in the Gardens near.London. London, 1730. fol.

Hort. cliffort.-Car. Linnæi Hortus Cliffortianus. Amstelodami, 1737. fol.

Hort. schonlr. - Plantarum rariorum Horti Cæsarei Schøn. brunnensis Descriptiones et Icones, opera N.J. Jacquin. Vol. 1-3. Viennæ, 1797--1798. fol.

Host gram.-N. V. Host, Icones et Descriptiones Graminum Austriacorum. Vol. 1-3. Vindobonæ, $1801-$ 1 S03. fol.

Huds. angl.-G. Hudson, Flora Anglica. Tom. 1, 2. Lond. 1778. 8vo.

Humb. et Bonpl.equinoct.-Alex. de Humboldt et Amati Eonpland Plantæ Equinoctiales. Parisiis, 1805. finl. Jacq. austr. Jacq. fl. austr.--R. J. Jacouin, Flora Austriaca. Vol. 5. Viemix, 1773--17;s. fol.

Jacq. collect. Jacq. coll.-Ejusdem Collectanea, ad Botanicam, Chemiam et Historiam Naturalem spectantia. Vol. 4 et Supplementum. Vindobonæ, 1785--1796. 4to.

Jacq. hort. Jacq. hort. vind.-Ejusdem Hortus Botanicus Vindobonensis. Tomi 3. Viennæ, 1770-1; 6 . ' fol. Jacq. hort. schcenlb. Jacq. schcenbr.-Vid. Hort. schenlr. Jacq. ic. Jacq. ic, rar,-Ejusdem Icones Plautarum rariorum. Vol.3. Vindobons, 1781-1793. fol.

Jacq. ols. lot.--Ejusdem Observationum Botanicarum Partes 4, Vindobonæ, 1764--1771. fol.

Jacq. oxal.-Ejusdem Oxalis, Monographia Iconibus illustrata. Viennæ, 1794. 4to.

Journ. hist. nat.-_Vid. Diar. hist. nat.

Juss. gen. $p l--$ A. L. Jussieu, Genera Plantarum secundum Ordines Naturales disposita, Edirio Usteri, Turici, 1791. Svo.

Knorr delic. Knorr thes.-C. Wolfig. Knorr, Thesaurus 
Rei Herbarix Univcrsalis. Vol. 2. Nurnberg. 17tz. fol.

Lam. encycl.-- Encyclopédie Méthodique; Botanique, par M. le Chevalier de Lamarck. Paris, 1783 et seq. 4 to. Lam. il!ustr.-Ejusdem Illustration des Genres. Paris, $179 t$ et seq. 4 to.

Lamlert monogr. $-A$ Description of the Genus Pinus, by Aylmer Butuke Lanbert. London, 1503. fol.

Lipeyr.--Figures de la Flore des Prronées, pai P. Picot Lapeyrouse. Tom. 1. Jaris, 1705. fol.

Leers, fl. henl.--J. D. Leers, Flora Herbornensis. Herbornæ, $1775.8 \mathrm{vo}$.

L'Her. Corn.-C. L. L'INeritier Cornus. Parisiis, 1788. fol.

L'Herit. sert. angl.--Ejusdem Sertum Anglicum. Parisiis, 1788. fol.

L'Herit. stirp.-Ejusdem Stirpes noræ aut minus cognitæ. Parisiis, 1781, 1785. fol.

Linn. fl. lupp.--Vid. Fl. latp.

Linn. fil. dec.-Car. a Linné Filius Decas 1-2 Plantarum rariorum Horti Upsaliensis. Stochholmiæ, 1762, 1763. fol.

Linn. hort. cliff.-Vid. Hort. Cliffort.

Linn. mant.--C. a Line Mantissa Plantarum. Holmix, $176 \%-17 \% 1.850$.

Limn. sp. pl.-Ljusdem Species Plantarum. Holmiæ, 1753. sio.

Linn. stippl.--C. a Limé Filius Supplementum Plantaruni. Drunswigæ, J 7 S1. 8vo.

Linn. syst. vey.--C. a Linné Systema Vegetabilium, curante Niurray. Gottingæ, $178 \div$. 8vo.

Limn trans. Linn. sos. trans.--Vid. Act, soc. linn. lond.

Lob. ic.-Petro Pena et Matthia de Lobel Piantarum seu Stirpium Icones. Tom. 1, 2. Antverp. 1581--1591. 4 :0. obl.

Loss. pruss.--J. Loeselii Flora Prussica. Regiomonti, 1703. tio.

Afo;n. hort.-Petr. Magnol Hortus Regius Monspeliensis. Monspelii, 1697. Sro.

Marsh. arb.-Humph. Marhall Arbustum Americanum. Pliviadelphixe, 1758. 8vo.

Marl.dec. Alart. ceni.-J. Martyn, Historia Plantarum rariorum. Londini, 1728 . fol.

Men. de binstit. se. /hyss.--Mémoires de l'Institut National cles Science ot Aits. Paris, an 6 et seq. 4 tọ. 
InIeerl. ic.-Afbeeldingen van Zeldzaane Gewassen, door Nic. Neerburgh. Leyden, 1775 fol.

- latarum selectarum f́cones pictæ, editæ a Nic, Meerburgh Lugd. Betav. '798. fol.

Merian surin.-M. Sibylla Merian d. Generatione et Metamorphosibus Insectorum Surinanensium. Haye Conirum, 1726. fol.

Mich arl.-Histore des Arbres Forestiers de l'Amérique Septe: trionale, par F. André Michaux. Tom.3. Paris, $1810-1812$. Svo.

Mich $f$ amer.--1 ndr. Michanx Flora Eoreali-Americana. Tom. 2. Paris, 1803.8 ro.

Mich querc.-Ejusden Histoir des Chênes de l'Amćrique. Paris, 1801. fol.

Mich. gen. Michel gen.-Nova Plantarum Genera, Aucwre Petro A. Michelic. Florentiæ, 1;29. fol.

Mill. ic. Mill. icon.-Figures of Plants, described in the Garcener's Dictionary, by Phil. Miller. 2 vols. Lon. don, 1760. fol.

J. F. Mill. ic.-6o Coloured Plates of Plants and Animals, by J. F Miller. 17,00-3794. fol.

Monch meth.-C. Monch, Netholus Plantarum Horti Botanici et Agri Marbargensis a Staminum Situ. Murburg. 1794. sio.

Mrench weissenst. - Ejusdem Verzeichnis Auslándischer Bäune und standen cies Lustschlosses Weissentein by Cassel. Franct. 1785. Evo.

Moris. hist.-Rob. Morison, Plantarum Historix Universalis. Pars 2, 3. Oxrn. 1650--169y. fol.

Mhurray com. geett. - Vid. Com. gcett.

Ort. dec.- C. G. Oriegæ novarum aut rariorum P'antarum Horti Reg. Botan. RIatrit. Descriptionum Decadcs. Matriti, : 797 et seg. 40 .

Pall astrag.-Petr. Sim. Pallas Species Astragalorum descriptix et Iconibus coloratis illustratæ. Lipsiæe, 1890. fol.

Pall. $f$. ross.-Ejusdem Flora hossica. Tom. 1, 2 . Fetrop. 1784-1788. fol.

Pall. illustr.-Ejusdem Illustrationes Plantarum imperfecte vel nondum cognitarum. Lipsix, lse; fil.

Pall. itin.-Ejusdern I.eise durch rerschiedene Russische Provinzon des Rnssischen l.eichs. P. $1-3$. Petrob. $17 \% 1-1770$. 4to.

Parad. tont.--The Paradisus Londmensis, containing Plants cultivated in the Vicmity of the Metropolis; the Descriptions by R. A. Salisbury, the Figures by Wrilliam Hooker. London, 1806 et ser. 45.

vol. I. 
Pers, ench. Pers. syn._-Synopsis Plantarum, seu Enchiridium Botanicum, curante C. H. Persoon. Pars 1, 2. Parisiis, 1805. 12!no.

Petiv. gaz.-Jac. Petiver, Gazophylacium Naturæ et Artis. fol.

Philad. philos, trans,-Vid. Act. soc. amer.

Pl. rar. h'mg. - Erane Cominis Wald'stein et Pauli Kitaibel Descriptiones et Icones Plantarum ratiorum Hungariæ. Toin. 1, 2. Viennæ, 1802-1505. fol.

Pluk alm - Leon. Pinkenett, Almagestum Botanicum. Londini, i Cgô. 4to.

Pluk. am ilth.-Ejusdem A maltheum Botanicum. Londini, 1705. 4to.

Fluk. mant.-Ejusdem Mantissa Almagesti Botanici. Londini, 1\%00. 4to

Pluk. phyt.-Kjusdem Phytographia. Londini, 1691, 1692. 4 to.

Plum. amer-Carl. Flunier, Descriptions des Plantes de l'Anérique. Paris, 16g3. fol.

Plum. filic.--Ejusdem des Fungères de l'A mérique. Paris, 1705. fol.

Plum. ir.-Fjusdem Plantarum Americanarum Fasciculi decem, coninentes Plantas quas olim C. Plumicrius detexit : edudit J. Burmannus. Amstel. 1755-1700. fol.

Pollich . fl. palat.-J. A. Pollich, Historia Plantarum in Pa. latinatu El ciorali sponte crescentium. Tom, 1-3. Mannh. 1776-17is. 8vo.

Redonté lil-i,es Liliacées, par P. J. Redouté, Paris, 1802 et seq. fol.

Rt $x$ scand.-Andr. Joh. Retz, Floræ Scandinaviæ Prodronus. Jipsiæ, 1795. bio.

Petz ols.- Kjustem Observationes Botanicæ. Lipsiæ, $177 y-1791$. fol.

Pheed. mal.-Hotus Indicus Malabaricus, adornatus per Henr. van Rheede van Dakenstein. Tomi 12. Amstelodami, $1678-1703$. fol.

Rivin. nonop.-A. Q. Rivini Ordo P'antarum ouæ sunt Flure irregulari monopetalo. Lipsiæ, 1691. fol.

Fob. ic-319 Plates of Plant, engraved by Nic. Robert, A. Bosse, and L. de Chastillon. fol.

Riusth. junc.-F. G. Rostkovii Dissertatio Botanica de Junco. Hiate, 1831 sio.

Ioth catalut. $-\mathrm{A}$. W. Roth, Catalecta Botanica, Fascicul. 1, 2. Lipuid. 179--1500. svo.

Foih. germ.- Husdem ?eintamen Fluræ Germanicæ. Tom.3. Lipsia, 1788. 1800. 8 ro. 
Roth neve leitr.-Ejusdem Neue Beitrüge zur Botanik. Bremen. Svo.

Rottl. gram.-C. Friis Rottböl Descriptiones et Icones rariorum pro maxima parte norarum Plantarum. Hafn. 1786. fol.

Salb. hort.-Hortus Romanus secundum Systema Tourne. fortii, \&c. Species suppeditabat et describebat Libertius Sabbati. Tons: 4 . Rom $x, 17 / 2-177 \%$, fol.

Salisl. stirp. rur.-R. A. Salisbury, I cones Stipium rariorum Descriptionibus illustratæe. Londini, 1791. fol. max.

Scheuchx. gram.-Joh. Schenchzer, Agrostographia, sive Graminum, Juncor!m, Cyperorum, isque affinium Historia. Tiguri, 1719 . 4 to.

Schk. car.-C. Schkular, Albildungen der Riedgrïser. Wittenb. 1806 . Sro.

Schkuhr hancil.-Ejusdem Dotanisches Fiandbuch. 3 Theile. Wittenberg, 1791-1803. $8 v 0$.

Schkuhr flic.-i jusdem Abbiklangen der Farnkräuter. 4to. Schmidt arb.-Franz Schmidt, Oesterreichs Aligemeine l.aumzucht. Wien, 1792 et seq. fol.

Schrel. gram.--J. C. D. Schreber`s Beschreibung der Gräser.

Leupzig, 1769 et seq. fol.

Scop. del. insal,-_J. A. Scopoli Deliciæ Floræe et Faunæ Insubrica. Pars 1-3. Ticini, 17SO-17ss. fol.

Sloan. hist.jam. Sloan. jam.-A Voyage to the Islands of

Madeira, Barbadoes, Nevis, St. Clristopher's and Jamaica, with the Natural Fistory of the last of those Islands, by Hans Sloane. 2 vois. London, 1707172.5. fol.

Smilh lrit. Smilh fl. brit-J.E. Smith, Elora Eritannica.

Tol.1-3. Lundini, 1800-1801. Sso.

Smith exot. lot.--Vid. Exot. lot.

Smith ic. ined-Dlantarum Icones hactenus ineditre, Alic= tore J. E. Smith. Londini, 1789 et seq. fol.

Smith ic. pict.--Ejusdem Icones pictæ Plantarum rariorum. Londini, 17go et ser. fol.

Smith spicil.--Ljusdem Spicilegium Botanicum. Londini,

j7gl et seq. fol.

Sp.pl._-Vid. Linn. sp.pl.

Swartafl. ind. occid.-Ol. Swartz, Flora Indir Occidenta-

lis. Jom. 3. Erlangæ, 1797. 1506. Svo.

Swartz ir.-1 juadem Icones Plantarum incognitarum, quas

in India Uccidentali detexit atque delineavit. Fasc. 1, 2.

Erlangæ. $17 \succ 8$. fol.

Swartz olserv.-Ejuadem Observationes Botanicæ. Er. lang:e, 1791. Sro.

Swarlz prodr.-Ejusdem Prodromus Descriptionum Ve- 
getabilium quæ sub Itinere in Indiam Occidentalem digessit. Holn. 178s. 8vo.

Thuil. fl. par.-Thuillier, La Flore des Environs de Paris.

Paris, l'an 7. 8vo.

Trew ehr.-Plantæ Selectæ, quarum Imagine; pinxit G. D. Ehret, collegit et illustravit C. J. 1rew. Norimbergæe, 1750-17\%3. fol.

Trew pl. rar.--Plantæ rariores, quas depingendas ærique incidendas curavit C. J. Trew. Norimber ${ }^{2}, 1763$. fol.

Usteri annal.--Panl Usteri, Annalen der Botanik. 1-24 Stuck. Zurich, 1702 et seq. 8 vo.

Iahl. enum. pl.-Mart. Vahlii Enumeratio Plantarum vel ab aliis vel ab ipso o'sservatarum. Vol. 1, 2. Harniæ, 1804, 1805. Sro.

Tahl. syml.-Ejusdem Symbolæ Botanicæ. Partes 3. Havnix, 1790-1794. fol.

laill. par. - Scb. Vaillant, Botanicum Parisiense. Leide et Ansterdam, 1727. fol.

Vanlefl. fusc.-Domin. Fandelli Fasciculus Plantarum, curn novis Generibus et Speciebus. Olisip. 1771. 4to.

Fent. cels. Vent.hort. cels. Vent. jard. cels-Description des Plantes nouvelles et peu connues, cuitivies dans le Jardin de J. M. Cels, avec Figures, par E. P. Ventenat. Paris, 800 . fol.

Tint. choix de plint - Ejusdem Chnix de Plantes, dont la plupart sont cultivíes dans le Jardin de Cels. Paris, 1803.

Tent. malmais.-Ejusdem Jardin de la Malmaison. Paris, 1503 et seq. fol.

Willst. hung.- Vid. Pl. rar. hitne.

1"alt. Al. car.-Flora Carolinian, Auctore Thom. Walter. Londini, 178s. 8ro.

Iralth. hort.-Designatio Plantarum quas Hortus Ang. 'Trid. Walcheri complectitur: accedunt noræ Plantarum Icones 24. 1.ipsix, 1735. Svo.

Wangh. amer.-F. A. J. von Wangenheim Aupflanzuns North Amerikanischer Holzarten. Gotting. 1757. fol.

Irinal. hort. herrenh.-J. C. Wendland, Hortus Herrenhusianus. Fasc. 1--4. Hannov. 1799--1801. fol.

Willd amaranth.--C. Willdenow, Hist ria Amaranthorum. Turici, 17 90 . fol.

IVil!d emun.-Ejusdem Enumeratio Plantarum Berolinensium. Sro.

Willd. hort. ler.--Ejusdem Hurtus Berolinensis. Fasc. 1-3. Berol. 1803, : so4.

Willd. sf.pl.--Fjusdem Species Plantarum. Bcrolini, 1797 et seq. Svo. 


\section{MONANDRIA.}

\section{MONOGYNIA.}

1. ZOSTFri. Cal et Cor.nulla. Anth. sessilis. Caps. 1-sperma. Monnicum.

2. CAUtinia. Cal et Cor. nulla. Anth. sessilis. Styl. filiformis. Slisn. 2-tidum. Caps. 1-sperma. Monoicum.

3. SALICORNiA. Cal. ventricosus, integer. Cur. o. Stam. 1-2. Sem. 1. in fundu calycis.

4. HIPPURIS. Cal. nargo bilobus, superus $C_{\text {Cor. }} 0$. Sem. 1.

\section{DIGYNIA.}

5. PODOstemun. Cal squamæ 2-3. Cor. 0. Fil. furcatum. Anth. 2. Styl. O. Stigm, reflexa. Caps, 2-loc. 2-valv. polysperma.

6. CAllitriche. Cal. 2-partitus. Cor. o. Caps. 2-locularis, 4-sperma.

7. BLITUM. Cal 3-fidus, baccatus. Cor.0. Sem. 1.

s. CORISPERniUM. Cal.2-partitus. Cor.o. Sem.1.

\section{JII. POLYGYNIA.}

9. ZANNiCHELlia. Cal. 1-phyllus, turbinatus. Cor. O. Siyl. 3-5. Stigm. peltata. Sem. 3-5. nuda.

10. CHARA. Cal. et Cor. 0. Stigm. 5. Bac. polysperma. 


\section{MONOGYNIA.}

\section{ı. ZOSTERA. Gen.pl. 1390. Grass-wrack.}

marine.

1. Z. foliis integerrimis subtrinerviis, caule teretiusculo. l'ahl. enum. pl. I. p. 14.

Icon. Engl. lot. 467. Fl, dan. t. 15.

In salt-marsh ditches, in the bay of Delaware, scarce. 4. Aug. $v . v$. Leaves long; flowers very small.

The leaves are narrower and more obtuse than in the European plant; in every other respect it appears to be the same.

2. CAULINIA. Ifilld. in act. ac.ler. 1799. p.87.

jragilis.

1. C. foliis ternis oppositisve lineari-subulatis recurvatis aculeato-dentatis rigidis. Willd. sp. pl. 4.p. 182.

Icon. Willd. l. c. t. 1. f. 2.-Michel. gen. t.8.f. 3 .

In slow-flowing waters; Susquehanna, Kenhaway, \&c. rivers. $\odot$. Aug. v. v. Immersed, floating.

fexilis.

2. C. foliis senis linearibus apice denticulatis patentibus. Willd. sp.pl. 4. 1, 183.

Icon. Willd. l. c. t. 1. f. 1.

In small pends and old ditches : New York to Carolina. $\odot$. Aug. v. $v$. Immersed, floating; flowers very small.

3. SALICORNIA. Gen. pl. 1. Samphire or Glasswort.

herlacea. 1. S. lerbacea patula, articulis apice compressis emarginato bifidis, spicis axiliaribus oppositis pedunculatis, squamis obtusis. Willd. sp.pl. 1. p. 23.

annua. simplex. gracilis. $\alpha$ Engl. but. 415 .

$\beta$ ramis simplicis inis, caule prostrato.

$\gamma$ caule stricto ramoso, ramis laxis.

Var. $\alpha$ and $\beta$ are common along the sea-coast : var. $\gamma$ I observed on the Salt-lake of Onondago, New Yurk. $\odot$. $\delta$. Aug. $v . v$. Fleshy, smooth; salt taste.

virginica. 2. S. herbacea erecta, ramis simplicissinis indivisis: spicis longis articulatis. Willd. sp.pl. 1. p. 25.

Frequent on the coast of Virginia and Carolina. $\odot$. July, Aug. v. v.; $v$. s in Herlarno Gronoviano in Museo Banksiano asservato. Smaller than No. 1.

I consider this no nore than a sub-species, and probably the same with S. hirlacea $\%$. 
MONANDRIA MONOGYNia. Salicormia.

3. S. fruticulosa assurgens inordinate ramosa. Mïh. $f$. amligua. amer. 1. p. 2 .

In sedgy salt-meadows; New Jersey to Carolina. $\delta \cdot h$. July, Aug. v. $v$. Resembles S. fruticosa very much; taller than either No. 1. or 2 ; pale green.

4. HIPPURIS. Gen.pl. 15. Mare's-tail.

1. H. foliis plerumque senis linearibus. Mich. $f$. amer. 1 . vulgaris. p. 1 .

In ditches and small ponds: Canada to Pensylvania, rare. 2 . v. s. s. $f$. Upright, simple; may be a new species.

\section{II. $D I G Y N I A$.}

5. PODOSTEMUM. Mich. fl. amer. 2. p. 164.

1. Podostemum. Mich.l.c.p. 165.

Icon. Mich. l. c, t. 44.

ceratophyllum.

Closely attached to loose stones in shallow water of the rivers Ohio, Holston, Kenliaway, \&c. 24. July. $v$. $v$.

I take the liberty to place this plant in Monandria, as it will be more easily found by a young Botanist under this head, than under Monœcia Diandria.

\section{CALLITRICHE. Gen.pl. 17. Water-starwort.}

1. C. f liis superioribus spathulato-obovatis, inferioribus li- heterophylla. nearibus obtusis emarginatisque.

C. verna Willd.sp.pl.1.p 28?

Icon. Fl. dan. 129?

In springs and rivulets, very common. $\odot$. MayJuly. $v \cdot v$. Flowers white, axillary; upper leaves floating.

2. C. foliis omnibus linearibus apice bifidis.

C. autumnalis. Willd.sp.pl.1.p.29?

linearis.

In similar situations, not so common. $\odot$. May, June. $v . v$. More slender than No. 1. Upper leaves somewhat spathulate-linear.

3. C. foliis omnibus linearibus truncatis brevibus approxi- lrevifolia. matis. 
In sandy barren grounds, near mill-ponds, occasionally overflowed: New York to Virginia. ๑. Aug. v.v. Small, creeping along the ground, with a moss-like appearance; flowering seldom.

7. BLITUM. Gen.pl.18. Strayberry-spinage.

capitalum.

1. B. foliis acute triangulo-hastatis, capitulis alternis in $\mathrm{rit}$ cemum superne aphyltum approximatis. Mich. $f l$. amer. 1.p.2. Willd.sp.pl.i.p 30.

In woods and about houses, in Canada and the western parts of New York and Virginia. $\odot$. June, July. v. $v$. Flowers herbaceous; berries red.

8. CorispermuM. Gen. pl.16. Tick.seed.

hyssopifolio $u m$.

pialustris.

vilgaris.
1. C. spicis terminalibus, foliis linearibus enerviis muticis. Willd. sp. pl. 1.p. 28.

Icon. Pall. Al. ross. 2. t. 98.

In open plains, called Prairies, of Canada and on the banks of the Missouri River; found by M. Lewis, Esq. h. Aug. Sept. v. s. in Herlario Lewisiano. Small shrub, of a gray aspect : flowers small, in axillary clusters.

\section{POLYGYNIA.}

\section{y. ZANNICHELLIA. Gin. $p l .1391$.}

1. Z. anthera quadriloculari, stigmatibus integerrimis, seminibus dorso denticulatis. Hilld.sp. pl.4.p. 181. Icon. Nichel.gen. t. 34.f. 1 .

In ditches and small rivulets, in Virginia near the Sweet springs. $\odot$. July, Aug. $v . v$. Resembles Putamogeton marinum; flowers very small.

\section{CHARA. Gen. pl. 1397.}

1. C. caulibus ramulisque basi nudis, ramulis teretibus, articulis foliosis, foliolis oblongo-subulatis, bracteis bacca brevioribus. Willd.sp.pl.4.p. 183.

Icon. Engl. lot. 336.

Feather-leds. Floating in old ponds and ditches: Canada to Carolina, common. $\odot$.July, Aug. v. v. Incrusted; smells disagreeably. 
2. C. caulibus nudis superne papillosis, ramulis teretibus foliolosa. basi et in articulis foliosis, foliis linearibus, bracteis bacca brevioribus. Willd. sp.pl.4.p.184.

Icon. Willd. in act. ac. ler. t. $1 . f 2$.

In clear waters and small ponds : Pensylvania, Virginia, \&c. $\odot$.July. v.v. Green, shining, fragile.

3. C. caulibus diaphanis nudis, ramulis inarticulatis aphyllis compressis, baicis nudis lateral.bus. Willd. sp. flexilis, pl. 4.p.187.

Jcon. Engl. bot. 1070.

In muddy pools and ditches in the western part of Pensylvania, \&c. $\odot$. Aug. v. v, Green, flexile, tender, transparent. 


\section{D I A N D R I A.}

\section{MONOGYNIA.}

* Fl. completi, inferi, 1-pet. regulares.

12. OLEA. Cor. 4-fida: laciniis subovatis. Drupa 1sperma.

13. CHIONANTHUS. Cor. 4 fida : laciniis longissimis. Drupa 1-sperma : nuce striata.

14. ORNUS. Cor. 4 partita: petalis longis ligulatis. Fil. Jonga. Nux alata.

11. Ligustrum. Cor. 4-fida. Bac. 2-loc. : loculis 2spermis.

** Fl. completi, inferi, 1-pet. irregulares, angiospernii.

18. VERONICA. Cor. limbo 4-partito: lacinia inferiore angustiore. Caps. 2-loc.

17. MICRANTHEMUM. Cor. subcampanulata, 4-partita: lacinia superiore minore. Caps. 2-valv. 1-loc. polysperma.

19. GRATIOLA. Cor. irregularis, resupinata. Stam. 2. sterilia. Stigm. 2-lub. Caps. 2-loc.

16. CATALPA. Cor. irregularis, 5-fida. Cal. 2-phyllus. Caps. 2-locularis.

20. ElytraRia Cor. 5-fida, subæqualis. Stam. 2. sterilia. Caps. 2-loc.

21. JUSTICIA. Cor. irregularis. Caps. 2-loc. 2-valvis. Anth geminæ.

22. PINGUICULA. Cor ringens, calcarata. Caps.1-loc. Cal. 2-lab. 5-fidus.

23. UTRICULARtA. Cor. ringens, calcarata. Caps. 1-loc. Cal. 2-phyllus, æqualis.

**** Fl. completi, inferi, 1-pet. gymnospermi.

24. LYCOPUS. Cor tubulosa, subæqualis, 4-fida: lacinia superiore latiore emarginata. Sem. 4 retusa.

25. MONARDA. Cor. ringens : labium superius lineare, filamenta involvens. 
26. SALVIA. Cor. ringens. Filam, transverse pedicello atfixa.

27. COLLINSONIA. Cor. inæqualis : labio inferiore multifido, capillari. Stam. 2--4. Sem.4. 3. abortientia.

$$
\text { ******* Fl. completi, superi. }
$$

28. CIRCÆA. Cor. 2 petala. Caps. 2-loc. : loculis 1spernis.

$$
* * * * F \text {. incompleti. }
$$

15. FRAXINUS. Cor. o. vel 4 pet. Samara 2-loc. Sem. 1. Polygamum.

29. Cent1lulat. Cal gemma. Cor. o. Bac. 2-sperma. 30. B(IRYA. Cal. 4-piyllus. Cor.0. Bac. 1-sperma.

31. LEMNA. Cal.1-ph,llus. Cor. o. Caps, 1-loc.2。 sperma.

\section{MONOGYNIA.}

11. LIGUSIRUM. Gen.pl.23. Privet. Prim.

1. L. foliis lanceolatis acutiusculis, panicula coarctata. IVilld. sp. pl. 1. p. 41 .

Icon. Engl. lot. 70.4 .

In hedges on road sides, frequent; scarce in remote

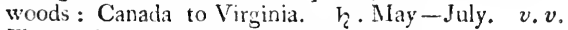
Flowers in white panicles; berries black.

12. OLEA. Gen.pl.25. Olive-tree.

1. O. foliis lanceolato-ellipticis integerrimis, racemis angustatis, bracteis omnibus persistentibus comiatis parvis. americana. IV illd. sp.pl.1.p. 45.

Icon. Catesb car.1.t. 01. Devil's-urood. On the sea-coast, in sandy boggy places : Carolina, florida, \&c. $h$. April, May. v. v. Flowers small, white; berries globular, purple, eatable.

13. CHIONANTHUs. Gen.pl.26. Fringe-tree.

1. C. panicula terminali trifida, pedunculis trifloris, foliis virginica, acutis. Willd. sp.pl.1.p. 46. 
Icon. Catesl. car. 1. t.68.

montanus. a foliis ovali lanceolatis coriaceis glabris, paniculis densis, drupis ovalibus.

C. v latifolia. Ait. keru. 1, p. 23.

maritimus. $\beta$ foliis obovato-lanceolatis membranaceis pubescentibus, paniculis la issimis, diupis ellipticis.

C. v. angustifolia Ait. keu. 1.p. 23.

Var. $\alpha$ in the mountains of Pensylvania and Carolina. $\beta$ on the sea-coast in boggy woods from New Jersey to Carolina. h. May, June. v. v. Flowers white, very bandsome; berries purplish-blue.

It is probable that those, as yet considered subspecies, are really distiuct species, which further observations will decide.

\section{ORNUS. Dalech. Flowering-ash:}

americana. 1. O. foliolis late ovatis serratis : impari fere obcordato. Pers. ench. 2. p 205.

In moist shady woods: Maryland and Virginia, rare. $\zeta$. May. $v v$. Flowers resembling those of Chionanthus; seeds small, winged.

\section{FRAXINUS. Gen.pl. 1597. Ash-tree.}

samlucifolia. 1. F. foliolis sessilibus ovato-lanceolatis serratis rugoso-nitidis, basi rotundatis inæqualibus, axillis venarum subtus villos's, floribus nudis. $I$ illd. sp pl.4. $p .1099$.

Icon. Mich.f. arb.t... Black-ush, Water-ash. In stony soil, on river sides from Canada to Virginia. h. April. $v, v$.

quadrangula- 2. F. foliolis subsessilibus lanceolato-ellipticis serratis, subta. tus pubescentibus, samaris utrinque obtusis. Willd. sp. pl. 4. p. 1102 .

Icon. Mich.f. arb.t.... Blue-ash. In rich bottoms of the western states: Ohio, Kentucky and Tennassee. h. May. v.v. s.fl.; v.s. c.fr.

epiptera.

3. F. foliolis lanceolato-ellipticis subserratis, samaris cuneatis apire obtusis emarginatis inferne teretibus. Vahl. enum.pl.1. 50

F. discolor. Mich.f. arl. 33.

F. canadensis, Gart. de fr. et sem. 1.p. 222, t. 49.

Icon. Mich.f. arb.t....

- On water-sides and rich bottom lands, from Canada to Carolina, frequent. $\zeta$. April. v. v. 
4. F. foliolis petiolatis oblongis nitidis acuminatis integerrimis subtus glaucis, floribus calyculatis. Lam. en. cycl. 2. p. 542 .

F. amer.cana. Willd. sp.pl.4.p. 1102.

F. concolor. Mich.f. arl.33.

icon. Mich.l.c... White-ash. Green-ash. Common in most woods from Canada to Carolina. $h_{q}$. April. $v, v$.

5. F. foliolis petiolatis lanceolatis serrulatis nitidis glabris, ramulis glauris, floribus calyculatis. Willd. sp. $p l .4$.

caroliniana. p. 1103 .

F. serratifolia. Mich.f. arb.p.33.

F. exceisior. Walt.fl.car.p.254.

lcon. Mich. f. $\operatorname{arb}$. t....

Shining-ash.

In rocky situations, from Pensylvania to Carolina, scarce. h. May. v. v. s $f$.

6. F. foliolis subsessilibus extrorsum serratis samarisque platycarpa. lanceolato-ellipticis. Willd. sp. pl.4.p. 1103.

Icon. Catesb. car. t. 80. Mich. f. arl.t....

In boggy woods of Virginia and Carolina. $\zeta$. April, May. $v . s$.

7. F. foliolis petiolatis elliptico-ovatis serratis subtus petic lis ramulisque tomentisis, floribus calyculatis. Willd. sp. pl. 4. p. 1103. Walt. fl. car. p. 234. Lam. encycl. 2. p. 543 .

F. nigra. Du Roi, ed.2. t. 1. p. 398.

F. tomentosa. Mich.f: arb.p.33.
Icon. Mich l. c. t....
Red-ash. Black-ash.

$\beta$ foliolis ovato-lanceolat is attenuatis subserratis.

$\gamma$ foliolis ovatis latioribus obsolete ad medium usque serratis.

$\delta$ foliolis elliptico oblongis acuminatis argute serratis inferne subpubescentibus, petiolo communi glaberrimo. Pers. ench. 2. p. 605.

Common in the woods of Canada and the United States. h. April, May. v. v.

pulescens.

acuminata.

caroliniana. 
16. CATALPA. Juss, gen. 138. Catalpa-tree.

syringerfolia. 1. C. foliis cordatis planis. Sims in lot. mag. 1094.

Bignonia Catalpa. IVilld.sp.pl.3.p. 289.

C. bignonioides. Walt.fl car.p. 64 .

Icon. Schmidt, arb. 1, t. 41 .

On the banks of Onio, Mississippi and Delaware, in gravelly soil. $h$.July, Aug v. $v$. Flowers white, speckled with purple and yellow.

17. MICRANTHEMUM. Mich. $f$. amer. 1. p. 10.

orliculatum. 1. Micranthemum. Mich l.c.

Anonymos umbrosa. Walt. fl. car. p. 63.

Globifera umbrosa. Gmel. syst. nat.t. 2. p.1.p. 32.

lcon. Mich $l$. c $t 2$.

In shady wet woods of Carolina and Georgia 24. Aug. $v . v$. stem creeping; leaves orbicular; flowers axil. lary, very small.

18 VERONICA. Gen.pl.32. Speedwell.

virginica.

1. V. spicis terminalibus, foliis quaternis quinisque. Willd. sp. pl 1 p 34.

Icon. Pluk. alm.t.70.f. 2.

On calcareous hills, in sunny exposures. 24. JulySept. $v . v$. Spikes long, white, or blush-colour.

On the momutains of Virginia I observed a very tallgrowing variety, with purple flowers, extremely beat?tiful.

officinalis.

2. V. spicis lateralibus pedunculatis, foliis oppositis obovatosubrotundis pilosis annuis, caule procumbente hirto. Willd. sp pl 1.p.59.

Icon. Engl bot. 765. Fl. dan. 248.

In barren, dry woods, very common from Canada to Carolin.t. 2. May-July. v. $v$.

reniformis. 3. V. spicis lateralibus pedunculatis, foliis oppositis reniformi-cordatis inciso-crenatis, caule repente.

Collected by Messrs. Lewis and Clark in boggy soil, on the banks of the Missouri. భ. June. v.s. in Herl. Leuis.

Caulis repens, filiform's, ad geniculos radicans. Folia opposita, longe petiolata, reniformi-cordata, incisocrenata, glabra. Pedunculi axillares, alterni, longitudine foliorum, teretes, glabri, superne unibracteati. Bractea cblonga, crenata. Spica oblonga, 
brevis. Flores magni, conferti, pallide cærulei. Cal. 4-fidus : laciniis 2 . superioribus oblongis; 2 . inferioribus linearibus, multo minoribus. Cor. Tubus brevissimus. Limbus planus : laciniis oblongis, acutis, calyce triplo longioribus, infima lineari. Fil. longitudine corollæ.

4. V. racemo terminali subspicato, foliis ovatis glabris cre- serpyllifolia. natis. Willd. sp.pl. 1.p. Ut.

Icon. Fl dan. 492 .

On road sides and in dry woods, common. 24. May -Aug. v. $v$. Crecping; flowess pale with blue stripes.

5. V. racemis lateralibus, foliis ovatis planis, caule repente. Beccalunga. Willd. sp. pl. 1. p. 64.

Icon. Engl. bot. 655. Fl. dan. 511.

In rivulets and springs; Pensylvania to Virginia, rare. 4. June, July. $v . v$. Leaves shining green, blunt; flowers large, blue.

6. V. racemis lateralibus, foliis lanceolatis serratis, caule Anagallis. erecto. IVilld. sp. pl. 1. p. 05.

Icon. Engl. lot.781. Fl. dan.g03.

In ditches and rivulets, more common: Canada to $\mathrm{Ca}-$ rolina. 4. Inne-Aug. v. $v$ Leaves acute.

7.V. racemis lateralibus alternis: pedicellis pentulis, foliis scutellata. linearibus. Willd sp. pl.1.p.65.

Icon. Engl. lot. 732 Fi. dan 209 .

Var. foliis integerrimis et serratis.

In wet meadows on gravelly soil. 24. July. v. v.

The American plant has longer leaves than any of the European specimens have seen.

४. V. floribus solitariis foliisque cordatis subsessilibus, caule *arvensis. hirto. Wilid. sp.pl. 1.p.73.

Icon. Engl. bot. 734 Fl. dan. 515.

Common in fields and cultivated grounds. $\odot$. MaySept. $v . v$. Hlowers blue, small.

9. V. floribus sessilibus, foliis lineari-lanceolatis dentatis peregrina. integerrimisque, caule erecto. Willd. sp.pl. 1.p. 76 .

Vuhl. enum. pl. 1.p. 85.

V. romana. Linn. mant. 317.

V. mary landica. Murr. in com. goet. 1782, p. 11,t.3.

V. caroliniana, Walt fl. car. p.61.

V. carnosula. Lam. illistr. 1.p. 47 .

Icon, MIurr. l. c. Fl.dan. 407. 
In cultivated ground, common. ๑. May-Aug. v. v.; $v$. s. in Hertario Walteriano, necnon Gronoviano. Very variable in habit. Flowers small, white.

\section{GRATIOLA. Gen. pl. 37 .}

aurea.

virginica.

1. G. foliis lato-linearibus sessilibus integerrimis $3 \cdot$ nerviis supra punctatis, pedunculis oppositis vix longitudine foliorum; filamentis castratus nullis.

G. offecinalis. Mi.h.fl amer 1.p. 6.

G. caroliniensis. Pers. ench. 1 p 14.

In sandy wet places, in the pine-barrens of New England, New Jersey and Carolina. 24. Aug. v. v; v. s. in Herlario Banksiano. Golden-pert.

Caulis bisulcatus, quadrangulus, basi ramosus. Folia basi dilatata, sessilia, acuta, glabra. Pellunculi longitudine foliorum, villosi. Cal. laciniis linearibus, apice glandulosis. Cor. aurea. Tubus hirsutus, medio ventricosus, obliquns. Lab. superius subroturdum, emarginatum : injtrius æqualiter trifidum, lacinis oblongis: intermedia emarginata. Faux hirsuta. Fil. 2. longitudine tubi corollæ. Stylus staminibus longior. Stigma infundibuliforme, obliquum. Capsula ovata, vix longitudine calycis.

2. G. foliis obovato-lanceolatis inferne attenuatis remote dentatis nervosis glabris, pedunculis alternis brevissimis, capsulis acuminatis calyce longioribus.

G. folis lanceolatis obtusis subdentatis. Gron. virg.3.

G. virginica. Willd. sp.pl.1.p.104.

G. acuminata. Vahl. enum. pl 1.p.92. exclus. syn.

In old ditches and pools from Pensylvania to Carolina. 4. June, July. v. v.; v. s. in Herb. Gronov. Stem rooting at the joints; flowers yellowish white.

quadridentata.

acuminata.
3. G. foliis lineari lanceolatis extrorsum remote pancidentatis, pedunculis longitudine foliorum, capsula calyce subulato triplo breviore. Mich. fl. amer. 1. p. 6.

G. ramosa. Walt. fl. car. p. 61 .

G. virginica. Lam. illustr. 1. p.54.t. 16.f.2. Vahl. enum. pl.1. p. 89.

In sandy wet fields, edges of ponds, \&c. Carolina. 4. June-Aug. v. v.; v. s. in Herl. Walt.

4. G. foliis lanceolat is serratis pubescentibus, pedunculis oppositis folio longioribus, calycis foliolis linearibus longitudine capsulæ subglobosæ. 
G. acuminata. Walt.fl. car. p. 61. nec Vahl. enum.

In ditches and pools: Pensylvania to Carolina. $\mathcal{4}$. July, Aug. v. v.; v. s. in Herl. Walt. Flowers pale yellow, large. Caps. larger than any other.

5. G. foliis cordato-ovatis, floribus axillaribus subsessilibus cauleque erecto pilosis. Vahl. enum.pl. 1. p.94.

G. peruviana. Walt. fl. cur. p. 62.

In pine-barrens: Carolina and Georgia. 4 . JuneAugust. v. v.; v.s in Herb. Walt. et Banks.

G. anagalloidea Afich. \&c. vill. Lindernia.

G. repens Swarlx. et Monniera Milli. vid. Herpestis.

20. ELYTRARIA. Mich. $f$. amer. 1.p. 8.

1. E. squamis fioriferis ovatis margine villosis, scapi foliisque lanceolatis integerrinis glabris. Vahl. enum. pl. 1. virgata. p. 106. Mich.fl. amer. 1. p. 9 .

Justicia acaulis $\gamma$. Willd. sp. pl. 1.p. 84.

Anonymos caroliniensis. Wult. fl. car. 60 .

Tubifora caroliniensis. Gmel. syst. nat.2.p. 1, 2\%.

Icon. Mich.l.c.t.1.

In wet sandy woods of Lower Carolina. 24. July, Aug. $v . v$. Flowers white, imbricated.

\section{JUSTICIA. Gen.pl. 35.}

1. J. spicis axillaribus, floribus confertis, pedunculis elon- pedunculosa. gatis alternis, foliis lanceolatis. Vahl. enum. pl. 1. p. 146. sub J. americana. Mich.fl.amer. 1.p.7.

Dianthera americana. Linn. syst. veg. 64.

Dianthera ensiformis. Walt fl. amer. 63.

Justicia linearifolia. Lam. illustr.1, p. 41 .

Icon. Pluk. alm. t. 423 f. 5 . Water-willow.

In bays and slow-flowing waers of the rivers St. Lallrence, Oswego, Ohio, Kenhaway, \&ic. July, Aug. v. v.; v. s. in Herl. Walt. et Gronov.

2. J. spicis axillaribus terminalibusque pauciforis, foribus distantibus, bracteis linearibus, folis lanceoiato-ob-

humilis. longis. Vahl, emum. pl. 1. p. 143.

Dianthera ovata. Walt. fl. car. p. 63.

In swamps of Carolina and Florida. 4. July, Aug. v. s. in Herl. Walt.

3. J. pedunculis axillaribus racemoso-verticillatis: pedicellis geminis, bracteis obovatis triforis, foliis ovatis acutis, petiolis longissimis, caule sexangulari ramosissimo. 
On the islands of Roanoak river in North Carolina. 4. July, Aug. $v . v$.

Caules plures, geniculati, hexagoni: angulis oppositis sulcatis, brachiato-ramosissimi, glabri. Folia opposita, longe petiolata, ovato-oblonga, sensim acuta, integerrima, glabriuscula ; nervis, venis, petiolisque tenue pilosa. Ramuli floriferi axillares, breves, foliosi. Pedunculi axillares gemini vel terni. Bractece duæ, obovatæ, altera minor. Flores $2-3$. sessiles, rubelli. Cal. simplex, 5-fidus : laciniis subulatis. Cor extus pilosa. Tubus tortuosus. Limbus resupinatus, 2-latbiatus : labium superius obliquun, oblongum, acu. tum, plerumque emarginatum: inferius truncatum, 3-4-dentatum, fauce striatum. Antherce 2. in singulo filamento. Stigm. bifidum. C'aps oblonga, compressa, mucronata. Sem. compressa, hispida, atıofusca.

\section{PINGUICULA. Gen. $p l .40$.}

clatior.

1. P. nectario subulato obtuso corolla breviore, superne tubo ventricoso, scapo inferne villoso. I ahl. emum. pl. 1.p. 19. Mich.fl. amer. 1.p.11.

P. cærulea. Walt. fl. car. p. 63.

In open swamps on the sands of Carolina and Georgia. 4. May. v. v. Flowers of a beautiful amethystine colour.

lutea.

2. P. nectario subulato iecurvo corolla campanulata breviore, fauce barbata, labiis dentatis, scapo subvilloso. Valil. enum. pl.1. p.93. Walt.fl.car. p.63. Mich. fl. amer. 1.p.11.

P. campanulata. Lam. in diar. hist. nat. 1.n.9.p. 336. t. 18. $f .1$.

In pine-barrens of Lower Carolina. 4. April, May. $v$.s. Flowers yellow; leaves obovate.

pumila.

3. P. nectario tubo breviore, corolla oblonginscule tubulosa, scapo brevi glabello. Mich. fl. amer. 1. p 11.

In open swamps of Georgia. 2\%. May. t. Flowers small, purple.

acutifolia. 4. P. glaberrima, foliis erectis ovalibus acutissimis. Vahl. enum.pl.1.p. 194 . Mich.fl. amer. 1.p. 11.

In shady woods, near rivers about Lake Mistassins. 4. July. + . 


\section{UTRICULARIA. Gen.pl.41.}

1. U. scapi foliis vesiculosis cylindricis divisis apice ramen- ceratophylla. taceis Vahl. enum. pl. 1.p.197. Mich. fl. amer. 1. p. 12.

U. inflata. Wult. fl. car.p. 64 .

Floating in ponds and lakes of Virginia and Lower $\mathrm{Ca}$ rolina. June, July. v.v.; v. s. in Herb. Walt. Flowers yellow.

2. U. nectario conico, labio superiore lateribus reflexo longitudine palati, scapo stricto. Vahl. enum. pl.1. vulgaris. p. 198. Willd sp.pl.1.p. 112.

Icon. Fl. dan. 139.

In stagnant waters in the western parts of New York and Pensylvania. 4 . July. v. v. Flowers large, yellow, with red veins.

3. U. nectario gibbo carinato, corollarum fauce aperta. minor. Vahl. enum. pl. 1.p. 199. W' Hilld.sp. pl.1.p.112, Icon. Fl. dan. 128 .

In swamps and ditches, in the pinc-barrens of New Jersey. 4. Aug. v. v. Flowers small, deep yellow.

4. U. nectario obtuso. scapo subunifloro filiisque setaceis. Vahl. enum. pl. 1. p. 199. Halt.fl. car. p 6.1.

In morasses of the pine barrens of Carolina. July. v.s. in Herl. Walt. Stems purple; fowers orange.

5. U. rectario subulato recto labio superiore subequante, scapo subbiforo, fillis setaceis. Tuhl. cmum. pl. 1. filrosa. p. $200 . \quad$ Lam. illustr. 1.p. 50.

U. pumila. Walt.fl.car.p.64.

On the margin of ponds in Lower Carolina. July. v.s. in Herl. If ult. Flowers small, yellow.

6. U. nectario obtuso labio inferiore breviore; scapo subbifloro.

U. nectario subulato. Gronou. virg.5. exclus, syn. Clayt.

U. setacea. Mich. Al amer. 1. p. 12. Vahl enum. pl.1. p. 201 .

In sandy wet places near ponis and rivers, from Canada to Carolina, conmon. $\odot . J u l y$, Aug. v.v.; $u . s$. in Herl. Gronov. Flowers small, bright yellow.

7. U. nectario carinato brevissimo, laciniis corollæ rotundatis, scapo 2-3-floro. Wa't.fl. car. p. 64.

Eloating on the lakes and ponds in Carolina; I observed

purpurea. 
it likewise in Pensylvania, on the Broad-mountains。 $\odot$. Aug. v. v. Flowers bright purple, small.

cornuta.

8. U. nectario subulato porrecto, corollæ labium infer:us amplissimum, scapo subsessiliter bifloro. Mich. $f$. amer. 1. p 12.

Near mountain lakes from Canada to Virginia. July. $v . v$. Flowers large, bright yellow.

gibla.

9. U. nectario gibboso, laciniis corollæ rotundatis, scapo subunifloro. Willd sp.pl.1.p.113.

In boggy soil of New Jersev and Carolina. July. $v$. $v$.; v. s. in Herb. Gronov. Very small; flowers yellow.

\section{LYCOPUS. Gen.pl.44. Water-horehound.}

europaus.

1. L. foliis inferioribus incisis, superioribus lanceolatis serratis, calycibus subspinescenti-acuminatis. Mich. $f$. amer, 1. p. 14. Willd. sp. pl. 1.p. 120.

Near rivers and ponds from Canada to Virginia. 24. July, Aug. v. $v$. Flowers white, small, in whorls.

virginicus.

2. L. foliis lato-lanceolatis serratis basi integra angustatis, calycibus brevissimis muticis. Mich. $f l$. amer. 1. p. 14.

quercifolius. $\beta$ foliis sinuato-pinnatifidis.

In wet places from New Fugland to Carolina ; var. $\beta$ in high mountain woods of Virginia. 24. June, Aug. v. v. Flowers white; leaves smooth.

pumilus.

3. L. folis lanceolatis subser atis glabris, stolonibus procumbeutibus. Vahl. emum. pl.1.p. 211.

L. uniflurus, Mich. fl. amer. 1. p.14.

In Canada. 24. Flowers solitary; stems low.

- blusifolius. 4. L. foliis lanceolatis remote obtuse serratis. Vahl. enum. pl. 1. p. 212.

At Hudson's Bay. Michaux. 4. +.

\section{NONARDA. Gen, pl. 48 .}

didyma.

1. M. glabrituscula, capitulis magnis proliferis, bracteis exterioribus coloratis mamis oblungis acuminat is subirtegerrimis : calycibus corollisque longis glabriusculis, foliis lato-cratis subcordatis acuminatis serratis rugoe sis : serraturis mucronatis, caule acutangulo glabro.

M. didyma. Wilid. $s p . p l .1 . p .125$.

M. parpurea. Lam. encycl. 4, p. 256. 


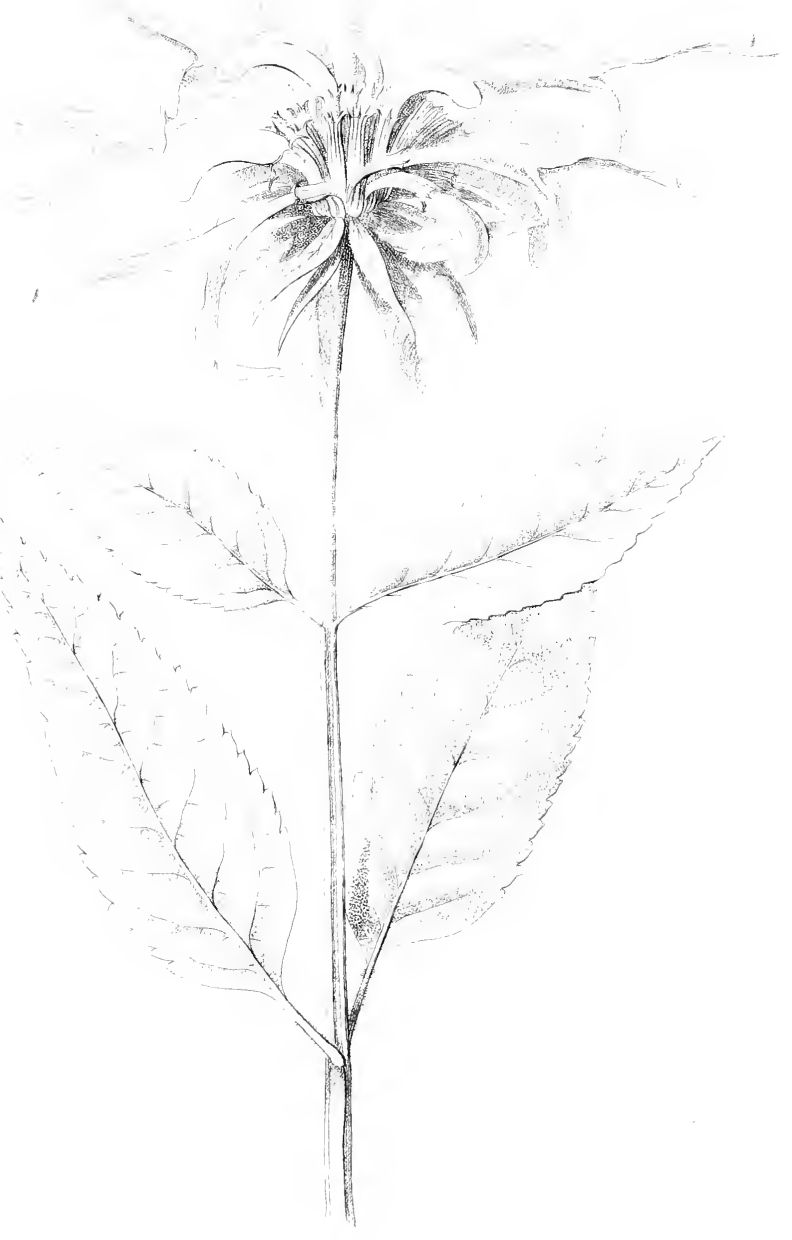
M. coccinea. Mich. fl. amer. 1.p. 16.

Icon. Mill. ic. t. 183.f. 1. Bot. mag. 546. Oswego tea. In rivulets on the high mountains of North Carolina. Michaux. 4. June-Sept. v. v. in Hortis. Flowers long, scarlet.

2. M. sparse hirsuta, capitulis magnis simplicibus, bracteis exterioribus coloratis lanceolatis attenuatis, calycibus corollisque pubescentibus, corollis longissimis, foliis oblongis attenuatis serratis undique pilis sparsis hirsutis, caule acutangulo petiolisque ciliato-piloso.

In boggy woods in black rich soil, near Onondago and Oswego, New York. 4. v. v.; v.s. spec. Kulmianum in Museo Banksiano, sul nomine M. didymae. Flowers very long, beautiful crimson; leaves somewhat fragrant; stems double the size of M. didyma.

3. M. glabriuscula, capitulis mediocribus simplicibus, bracteis exterioribus oblongis, calycibus glabriusculis, foliis ovatis subcordatis acutis rugosis glabris, nervis subtus coloratis pilosis, caule acutangulo hirto.

M. rugosa. Ait. kew.ed.2.1.p. 51 .

In Canada. 4. July-Sept. v. s. in Museo Banksiano. Flowers small, white.

1. M. glabra, capitulis parvis simplicibus terminalibus, bracteis exterioribus lato-ovatis acutis integerrimis glabriusculis, calycibus brevibus ciliatis, corollis pubescentibus tenuibus, foliis ovato-oblongis acuminatis serratis pilosiusculis, caule obtusangulo glabro.

M. clinopodia. Willd. sp. p!. 1. p. 125. excl. syn. Gronov.

M. glabra. Lam. encycl. 4. p. 256?

In dry gravelly soil from Canada to Carolina, particularly on the mountains. 24. July-Sept. v. v. Flowers yellow with purple specks.

The specimen of Gronovius in the Banksian Museum is Clinopodium incanum.

5. M. glaberrima, capitulis parvis nudiusculis lateralibus terminalibusque, bracteis exterioribus linearibus ciliatis, calycibus pubescentibus ciliatis, corollis brevibus tenuissimis glabris, foliis lineari-lanceolatis acuminatis serratis glabris, caule obtusangulo glabro.

In the mountains of South Carolina and Virginia. $v . v$; $v$. s. in Herb. Lyon. Flowers yellowish white.

6. M. glabriuscula, capitulis magnis foliosis, bracteis exterioribus magnis coloratis lato-ovatis acuminatis ser.

Kalmiana.

rugosa.

clinoportia.

gracilis.

purpurea. VOL. I. 
ratis, calycibus coloratis fauce barbatis, corollis longis glabriusculis, foliis ovato oblongis acutis grosse serra. tis: nervis undique pilosis, caule acutangulo glabro.

M. clinopodia. Vahl. enum. $p l$ 1. p. 218. aescriptio.

M. fistulosa iar. crimson. Bot. mag. 145.

Icon. Bot. mag 145.

In the mountains of Virginia. 24. July-Sept. v. v. ; v. s. in Herl. Lambert. Flowers crimson, large.

obiongata. 7. M. undique birsuta, capitulis simplicibus, bracteis exterioribus ovatis acutis, calycibus brevibus fauce barbatis : dentibus divaricatis, caule obtusangulo superne hirsuto.

M. oblongata. Ait. kcu'.ed. 2. 1.p 51 .

M. longifolia. Lam. encycl. 4 p. 255.

Frequent in the mountains of Pensylvania and Virginia. 4. July, August. v. $v$. Flowers pale purple.

mollis.

8. M. cano-pubescens, capitulis simplicibus, bracteis exterioribus cordato-ovatis acutis, calycibus brevibus fauce dense barbais, corollis hirsutis: galea apice longissime barbata, foiiis oblongis attenuatis basi rotundatis serratis utrinque cano-pubescentibus, caule acutangulo hirsuto.

M. mollis. Lin. amoen. arad.3.p. 399.

M. fistulosa $\beta$. Willd. sp. pl. 1.p. 124 .

M. allophylla. Mich. $f$ l. amer. 1 p. 16.

In the mountains of Virginia and Carclina. 24. JulySept. $v . v$. Flowers pale purple.

fistulosa. 9. M. villis sparsis hirsuta, capitulis simplicibus proliferisque foliosis, bracteis exterioribus oblongis acutis glabriusculis, calycibus longis barbatis, corollis hirsutis mediocribus, foliis ovatis acuminatis serratis, petiolis longis ciliatis, caule obtusangulo glabro.

M. fistulosa. Willd. sp.pl. 1.p. 124.

Icon. Mill. icon. t. 122. f. 2.

In hedges and woods, from Canada to Carolina, common. 4. July--Sept. v. $v$. Flowers purplish.

punclata. 10. M. glabriuscula, fluribus meliocribus verticillatis, brac. teis lanceolatis nervosis coloratis verticillo longioribus, foliis lanceolato-oblongis remote serratis glabris, caule obtusangulo villoso-canescente.

M. punctata. Willd. sp.pl. 1.p. 126.

M. lutea. Mich.fl. amer. 1. p. 16.

Icon. Pluk. alm. t. 24 f. 1. Bot. rep. t. 546. 
In sandy fields from New Jersey to Carolina. 24. June -August. v. v. Flowers yellow, punctated.

11. M. hirsuta, floribus parvis verticillatis, bracteis ovatis glabris venosis ciliatis calycem æequantibus, foliis ovato-oblongis attenuatis subsessilibus serratis subpilosis, caule acutangulo hirsuto.

M. ciliata. Willd. sp. pl. 1.p. 126.

On slate hills in Virginia and Carolina. 24. June-Aug. $v, v$. Flowers small, blue.

12. M. undique pilis longis albidis hirsutissima, floribus par. vis verticillatis, bracteis brevissimis oblongis acuminatis, calycibus longe aristatis, foliis ovatis acuminatis serratis longe petiolatis, caule acutangulo hirsuto.

M. ciliata. Mich. $f$ l amer. 1.p. 16 .

In high mountains of North Carolina and Virginia. 4 . August. $v . v$. Flowers small, rery pale purple.

\section{SALVIA. Gen. pl. 50. Sage.}

1. S. foliis lineari-lanceolatis inferioribus extrorsum serratis cauleque glabris, calyce pubescente brevissime trifido.

S. azurea. Lam. encycl. 6. p. 625.

S. acuminata. Vent. rels. p. 50.

S. angustifolia. Mich. fl. amer. 1.p. 15.

S. mexicana. Walt. fl. car. p. 65 .

Icon. Vent. cels. 50.

B Lam. encycl. 6. p. 625.

In open sandy situations of Carolina and Georgia. 4 . July-Sept. v. $v$. Flowers beautiful blue, sometimes white.

2. S. foliis cordatis acutis tomentosis serratis, corollis calyce duplo longioribus angustioribus. Willd. sp. pl. 1 . p. 141.

Icon. MIurr. in com. gat. 1778. p. 86. t. 1 .

On the banks of rivers in Florida. h. 4. July-Sept. v. $\iota$. Flowers scarlet.

3. S. foliis lanceolatis serratis, floribus in racemis terminalibus oppesitis, corollis calyce trifido subæquantibus, caule brachiato-ramosissimo.

In open plains of the Missouri river. M. Lewis. $\odot$. v. s. in Herb. Lewis. Flowers small, sky-blue.

Caulis erectus ramosissimus: ramuli tetragoni 4 -sulcati. Folia opposita, brevi-petiolata. Flores oppositi, in racermis foliosis. Bractece vel folia foralia lineares, longitudine pedicellorum. Cal. tubuloso-campanulatus, c 2

hirsuta.

azurta.

coccinea.

inichostem. moides.

elata.

ciliate.

moides. 
striatus, hispidus. Lab. superius subrotundum, inte. grum: inferius 2-fidum: laciniis oblongis, acutis. Corolla labium superius subrotundum, concavum : inferius 3-lobum, laciniis lateralibus brevissimis : intermedia major, dilatata, undulatim-crenata. Stylus corollæ duplo longior. Sem. 3-gona, glabra, venosa. Habitus Trichostemme dichotome.

urticifulia.

4. S. villoso-viscosa, foliis ovatis oblongis dentatis, per petiolum decurrentibus. V'ahl. enum. pl. 1. p. 201. Willd. sp pl. 1. p. 131.

Icon. Moris. hist. 3. s 11. t. 13. f. 31 .

In the mountains of Virginia and Carolina. 24. July, Aug. $v v$. Flowers blue, viscous.

lyrata.

obovata.

5. S. foliis radicalibus lyratis dentatis, corollarum galea brevissima, caule subaphyllo retrorsum piloso. Vahl. enum. pl. 1.p. 257. Willd. sp. pl. 1. p. 128.

Icon. Moris. hist. 3. s. 11.t.13.f: 27.

$\beta$ foliis obovatis repando-dentatis.

Icon. Dill. elth. 219. t. 175. $f 216$.

In meadows from Canada to Carolina. 4. May. v. 2\% Flowers blue.

A number of varieties are comprehended under this spe. cies, which prubably may prove to be distinct species. In the Banksian Miseum, among the plants of Gronovius, is one of those under the name of S. verle. naca.

27. COLLINSONIA. Gen.pl.51. Horse-weed.

canadensis. 1. C. foliis lato-cordato-ovatis, glabris, calycis dentibus brevi-subulatis, panicula terminalis composita.

C. canadensis. Willd sp. pl.1.p.152.

Icon. Linn. hort. cliff. 14. t. 5.

cordata. $\quad \beta$ foliis lato-cordatis, superioribus integerrimis.

ovata.

$\gamma$ foliis ovatis basi attenuatis omnibus serratis.

In shady woods, rocky rich soil from Canada to Carolina. 4. July-Sept, v.v.; var. \& v. s. in Herl. Lamlert. Flowers yellow, large.

scalra.

2. C. foliis minoribus ovatis sub-cordatis pilosiusculis, calycis dentibus brevi-subulatis, panicula terminalis simpliciuscula, caule piloso scabro.

C. scabrinscula. Ait. kew.ed.2.1.p.66.

C. præcox. Walt.fl. car. p. 65 .

In Carolina and Florida. 24. July-Sept. v. s. in Musea Banks. Flowers small, reddish-yellow. 
In the collection of Mr. Lyons is a specimen, nearly allied to the present one, with larger flowers and four stamina.

3. C. foliis oblongo-ovalibus utrinque subacutis glabris, petiolis longissimis, calycis dentibus brevissimis, panicula terminalis simplex nudiuscula, caule glabro.

In South Carolina. Fraser. 24. Aug. v. s. in Herl. Lamlert Flowers very small, yellow.

4. C. foliis subrhombeo-ovalibus utrinque acutis glabris, calycis dentibus setaceis tubo longioribus, panicula composita foliosa, caule ramoso subvilloso.

C. luberosa. Mich.fl amer. 1.p. 17.

C. serotina. Walt. fl. car. p. 65.

In shady wet woods of Carolina. 4. Sept. Flowers small, yellow ?

5. C. foliis ovatis cordatis rugosis glabriusculis, nervis subtus pubescentibus, calycis dentibus linearibus tubum subæquantibus, panicula composita foliosa pubescente, floribus tetrandris, caule ramoso pubescente.

Icon. Bot. mag. $t .1213$.

In the mountains of Georgia. Lyon. 24. July, Aug. $v . v$. Flowers large, pale yellow.

28. CIRCAA. Gen.pl.31. Enchanter's nightshade.

1. C. caule erecto, foliis ovatis denticulatis opacis glabriusculis. Vahl. enum. pl.1.p.301.

ovalis.

tulerosa.

arisata.

Icon. Engl. lot. 1056?

In shady woods from Canada to Carolina. 24. June, July. $v . v$. Flowers small, reddish white.

2. C. caule adscendente, foliis cordatis dentatis nitidis, calyce membranaceo. Vahl. enum. pl.1. p. 301.

Icon. Engl. bot. 1057.

In high mountain woods, on rotten trees and rocks, from Canada to Carolina. $\& \mathrm{July,} \mathrm{Aug.} v v$. Smaller, very smooth; flowers reddish-white.

29. CERATIOLA. Mich. $f$ l. amer. 2, p. 221.

1. Ceratiola. Willd.sp.pl.4.p 712. Mich.l. c. p.222. In gravelly dry soil of Georgia and Florida; in great plenty on the lslands in the mouth of St. Mary's River. h.—v.v.s.fl.; v.s. c.fl. in Herl. Fraser. Leaves verticillate; flowers very small; resembles a Heath very much.

lutetiana : canadensis.

alpina. ericoides. 
30. BORYA. Willd.sp.pl.4.p.711.

porulosa.

ligustrina.

acuminata.

1. B. foliis oblongo-lanceolatis obtusis sessilibus coriaceis, margine revolutis subtus punctatis. Willd. l.c.

Adelia porulosa. Mich fl. amer. 2. p. 224.

On the coast of Georgia and Florida. $々 . v . v$.

2. B. foliis ovato-lanceolatis acutis subsessilibus submemtranaceis. IVilld $l$. c.

Adelia ligustrina. Mich.l.c.

In woods on river-sides in the Illinois country. $\boldsymbol{r}_{c}$. July, Aug. v. s. in Herb. Lyon.

3. B. foliis ovato-lanceolatis utrinque attenuatis petiolatis membranaceis serrulatis. Willd. l.c.

Adelia acuminata. Mich.l.c. p. 225.

Icon. Mich.l.c. t. 48.

On banks of rivers in Carolina and Georgia. $々$. v. s. in Herb. Lyon.

\section{LEMNA. Gen. pl. 1400 . Duck-weed.}

minor.

1. L. foliis ellipticis utrinque planis basi cohærentibus, ra= dicibus solitariis. Willd. sp.pl.4.p. 195.

Icon. Engl. bot. t. 1095.

In ditches and stagnant waters, common. $\odot$. June, July. v. v. Floating; flowers exceeding small.

2. L. foliis ellipticis subtus bullato-convexis basi cohæren-

gibla.

polyrhixa. tibus, radicibus solitariis. Willá. $l$. c.

Icon. Engl. lot. t. 1233.

In similar situations, rare. $\odot$. June, July. v. v. c. $f$. Observed near Liverpool in tie western part of New York State.

3. L. follis ellipticis planis basi cohærentibus, radicibus fasciculatis Willd.sp.pl.4.p.195.

Icon. Vail. par. t. 20.f. 2.

Cummon in ditches, \&c. ๑. July, A ug. v. v.s.fl. 


\section{TRIANDRIA.}

\section{MONOGYNIA.}

* Flores superi, completi.

32. VAleriana. Cor. 1-petala, sæpe calcarata. Sem. calyce corticatum, c ronatum.

33. FED!A. Cal. 3-4-dentatus. Cor. 5-fida. Caps. coronata, 3-locularis : loculamento 1 . fertili.

** Flores superi, incompleti.

34. TRIPTERELlA. Cor. 6-fida: laciniis alternis minutis ; tubo basi ventricoso.

35. IXIA. Cor. 6-partita, patens, æqualis tubo recto.

36. IRIS. Cor.6-partita : petalis alternis reflesis, alternis conniventibus. Stigm. 3. petaliformia.

37. DILATRIS. Cor. 6-petaloidea, hirsuta. Stigm. 3-tidum.

38. SISYRINCHiUm. Spatha. Petala 6. plana, Fil. connata.

$$
\text { ** Flores inferi. }
$$

39. BOERHAVIA. Cal. tubulosus. Cor. 1-petala. Sent. 1.

40. COMMELINA. Cal. 3-phyllus. Cor. 3-petala. Nectar. staminiforme. Caps. 3-locularis.

41. SYENA. Cal.3-phyllus, Cor, 3-petala. Caps, 1locularis, 3-valvis.

42. HETERAN IHERA. Spatha 1-flora. Cor tubulosa : limbo 6-partito : laciniis subæqualibus. Stigm. tubulosum.

43. SERPICULA. Spatha 1-fora. Cor tubulosa : limbo 6-partito: laciniis æqualibus. Stigm. 3. ligulata.

44. XYRIS. Cal. cartilagineo glumaceus, 3-valvis. Cor. 3-petala. Caps. 1-locularis, 3-valvis. 
**** Flores glumacei.

45. SPARGANIUM. Amentum subrotundum. Cal. 3 phyllus. Cor. 0. Stigm.2-fidum. Drupa 1-sperma. Monoicum.

46. TYPHA. Amentum cylindricum. Cal. obsoletus. Sem. 1. pedicellatum basi papposum. Monoicum.

47. CAREX. Amentum imbricatum. Cal. squama. Stigm. 2-3. Semen tunicatum, 3-quetrum. Monoicum.

48. SCLERIA. Cal. gluma 2-6-valvis. Stigm.1-3. Nux colorata subglobosa. Monoicum.

49. ZEA. Cal. gluma 2-flora, 2-valvis. Spadix simplex, cylindricus: gluma 2-valvis, 1-flora. Sem. subrotundum. Monoicum.

50. KYLLINGIA. Flores distincti, in spicam subimbricati. Cal. 2-valvis, 1-florus. Cor. 2-valvis, calyce major. Stylus bifidus.

51. MAPANIA. Flores capitati. Cal. 6.valvis. Cor. 0. Sem. 1.

52. DICHROMENA. Cal. squamæ in spicam undique imbricatæ, inferiores vacuæ. Cor.o. Styl. basi persistens. Seta 0 .

53. SCHOENUS. Cal. squamæ in spicam fasciculatæ, inferiores vacuæ. Cor. o. Siyl. deciduus.

54. RYNCHOSPORA. Cal. squamæ in spicam fascicu. latæ, inferiores vacuæ. Cor. 0 . Styl. basi persistens. Stte basi seminis.

55. FIMBRISTYLis. Cal. squamæ in spicam undique imbricatæ. Cor. 0. Stylus basi bulbosus, ciliatus, deciduus.

56. CYPERUS. Cal. squamæ in spicam distiche imbricatæ. Cor. o. Styl. deciduus.

57. DULICHIUM. Cal. squamæ in spicam distiche imbricatæ: spiculis racemosis, ex axillis foliorum. Cor. 0. Stylus longissimus, 2-fidus.

58. SCIRPUS. Cal. squamæ in spicam undique imbricatæ. Cor. o. Styl. filiformis, imberbis, deciduus. Sem. 1. nudum s. setulis cinctum.

59. TRICHOPHORUM. Cal. squamæ in spicam undique imbricatæ. Cor. 0. Styl. deciduus. Sem. setis $(6-9)$ longissimis calyculatum.

60. ERIO HORUM. Cal. squamæ in spicam undique imbricatæ. Cor.o. Sem. lana longissima calyculatum.

61. VAGINARIA. Cal. squamæ in spicam undique im= 
bricatæ. Sitgm. 3. Seminis involucellum alternatim tripaleaceum et trisetum.

62. FUIRENA. Cal. squamæ mucronatæ in spicam undique imbricatæ. Sem. involucellum latum, palexforme, sæpius aristatum.

63. MARISCUS. Flores distincti, in spicam subimbricati. Cal. 2-valvis, subtriflorus. Corollula 1-val. ves, inferior superiorem amplectens. Styl. 3 -fidus.

64. MIEGIA. Cal. multiflorus, 2-valvis. Cor. 2-valvis, mutica. Appendices bini, lato-lanc olati. Stigm. 3. Sem. nudum, maximum.

65. LIMNETIS. Spica lateriflora: flosculis subbifariam imbricatis. Cal. 2-valvis : valv. altera minore. Cor. 2-valv. mutica, compressa, carinata. Styl. longus.

66. CENCHRUS. Involucr. laciniatum, echinatum, 34 florum. Cal. 2 valvis, 2 -florus. Cor. 2-valvis, mutica. Styl. 2-fidus.

67. ORYZUPSIS. Cal. 2-valvis, 1-forus. Cor. 2-valvis : exteriore aristata. Nectar 2-phyllum.

\section{DIGYNIA. \\ * Flores uniflori, vagi.}

63. ZIZANIA. Cal. o. Cor. 2-valvis : valva exteriore aristata. Stam.6. Monoicum.

69. MUHLENBERGIA. Cal. minutissimus, 1-valvis. Cor. 2-valvis, basi pilosa: vaiv. exteriore apice aristata.

70. TRICHODIUM. Cal. 2-valvis: valvis subæqualibus acutis. Cor. 1-valvis, brevior, mutica. Stigm. subsessilia.

71. LEERsiA. Cal. o. Cor. 2-valvis, clausa: valv. compressis, muticis.

72. MILIUM. Cal. 2-valvis : valvis ventricosis, corolla majoribus, subæquaiibus. Cor. 2-valv. brevissima. Stigm. villosa.

73. AGROSTIS. Cal. 2-valvis: valvis acutis corolla brevioribus. Cor. 2-valvis.

74. ANTHOXANTHUM. Cal.2-valvis. Cor. 2-valvis, acuminata, aristata. Stam.2.

75. PHALARIS. Cal. 2-valvis : valvis carinatis, æqualibus. Cor. 2-valvis, inclusa, basi pilosa.

76. PHLEUM. Cal. 2-valvis, truncatus, mucronatus, sessilis. Cor. inclusa.

77. ALOPECURUS. Cal. 2-valvis. Cor. 1.valvis, aristata. Spica. 
78. PANICUM. Cal.3-valvis: valvula tertia dorsali minima. Cor. 2-valvis.

79. DIGITARIA. Cal. 2-3.valvis, concavus. Cor. $2-$ valvis, oblongo-ovata, teres, mutica. Nectar. fissum. Spica digitatæ: flores gemini.

80. CYNODON Cal.2-valvis, patens, lanceolatus, Cor. major, 2-valvis : valv. exteriore maxima ovoidea. Nectar. truncatum. Suicce digitatæ: floribus solitariis

81. PASPALUM. Cal. 2-valvis : valvis subrotundis, figura corollæ. Flores unilat rales.

82. ARiSTi1)A. Cal. 2-valvis. Cor. 1-valvis: aristis tribus terminalibus.

83. STIPA. Cal.2-valvis. Cor.2-valvis: valvis involutis truncatis. Arista terminalis, basi contorta, longissima.

84. SACCHARUM. Cal. 2-valvis : valvis basi villis densis involucrata. Cor. 2-valvis : valva interiore longe aristata. Monandra.

85. ANDROPOGON. Flores genini : altero masculo. Cal. 2-valvis. Cor. 3-valvis : valv. secunda minore aristata, tertia intima minuta. Recept. plerumque villosum. Involucrum villis fasciculatis.

* Flores biflori, vagi.

86. ATHEROPOGON. Cal. 1-valvis, biflorus. Cor. 2-valvis : valvula exteriore 3-aristata. Polygamum.

87. TRISETUM. Cal. 2-3-fiorus, acuminatus, carinatus. Cor. aristis 2. terminalibus, 1 . dorsali recta nec contolta, flosc. glabris.

88. ANTHISTIRIA. Cal. 4-valvis, 2-4-flora. Cor. 2-valvis. Arista tortilis e fundo corollæ. Polyga. mum.

89. AllA. Cal. 2-valvis. Cor. 2-valvis. Flosculi absque rudimento tertii.

90. MELICA. Cal 2.valvis, colorarua, obtusus. Cor. 2-valvis, ventricosa. Rudimentum tertii inter flores.

91. HOLCUS. Cal.2-valvis. Cor.minor: valv, altera aristata Nectar. 2-partitum. Polygamum.

92. SORGHUM. Flores gemini : altero pedicellato, masculo. Cal. 2-valvis. Cor, 3-valvis: valv. secunda aristata, tertia nectaria villosa connectens. Polygamum. 


\section{***** Flores multiflori, vagi.}

93. PO 1. Cal. 2-valvis. Spicula ovata mutica : valvulis margine scariosis.

94. BRIZA. Cal. 2-valvis. Spicula distichæ: valrulis ventricosis, c rdatis, obtusis : interiore minuta.

95. UNIOLA. Cal. mulcivalvis, Spicule ancipites ovatæ: valvulis muticis, interiore minore, intra exteriorem recumbente.

96. FESTUCA. Cal 2-valvis. Spicula oblonga, teretiuscula : valvulis mucronatis.

97. DACTYLiS, Cal 2 valvis, carinatus: valvula altera longinre. Cor. 2-valvis. Spic. aggregatæ.

98. BROMUS. C'al. 2 valvis. Spicula oblonga, disticha arista infra apicem sæpius bifidum.

99. KUELER!A. cal. 2-vaivis, compresso-carinatus. Cor. 2-valvis, brevi-aristata: glumis nervosis.

100. AVENA. Cal. 2.valvis : arista dorsali, contorta.

101. ARUNDO. Cal. 2-valvis, glaber. Cor. lana cincta.

***** Flores spicati: receptaculo subulato.

102. ELEUSINE. Spica digitatæ. Flor. secundi, mutici. Cal multitiorus. Cor 2-valvis, mutica.

103. CHLURIS. Spica digitata, unilateralis, Cal. 2-valvis, 2-6-florus: valv, carinatæ muticæ aut aristatæ. Polygamum.

104. ROT'BOELLIA. Rachis articulata, teretiuscula. Cal ovato-lanceolatus, planus, uni-vel bivalvis. Cor. minor, 2-valvis. Flosc, alterni in rachi flexuoso. Polygamum.

105. TRIPSACUM. Mas. Cal. gluma 2-flora, exteriore masculo. Cor. gluma membranacea. Fem. Cal. gluma 1-flora, involucro tecto monophyllo, sinubus perforato. Cor. gl ıma 2-valvis.

106. ELYMUS. Cal. involucriformis 4-phyllus, lateralis, 2-valvis, aggregato ternus multiflorus.

107. HORDEUM. Cal. 1-2-florus, hexaphyllus, involucriformis. Flosc. terni, intermedio sessili, lateralibus stipitatis. Cor.2.valvis.

108. SECALE. Cal. oppositus, 2-valvis, aut multifiorus, solitarins.

109. TRITICUM. Cal. 2-valvis, solitarius, multiflorus. Florilus obtusiusculis. 


\section{TRIGYNIA.}

110. HOLOSTEUM. Cor. 5-petala. Cal. 5-phyllus. Caps. apice dehiscens.

111. POLYCARPON. Cor. 5 petala. Cal. 5-phyllus. Caps. 3-valvis.

112. LECHEA. Cor. 3-petala. Cal. 5-phyllus. Caps.3cocca.

113. ERIOCAULON. Cor. 3-petala. Cal. compositus. Sem. 1. coronatum corolla.

114. MOLlugO. Cor. 0. Cal. 5-phyllus. Caps. 3-10. cularis.

15. PROSERPINACA. Cor. o. Cal.3-partitus. Nux 3-) locularis, infera.

\section{POLYGYNIA.}

116. EMPETRUM. Cal.3-5-part. Cor.3-petala. Styl. 9 . Bac. 9-sperma.

\section{MONOGYNIA.}

\section{VALERIANA. Gen. $p l .60$.}

fauciflora. 1. V. foliis radicalibus pinnatis, caulinis ternatis : foliolis ovalibus acutis serratis, paniculis laxis paucifloris. Mich.fl. amer. 1. p. 18.

In shady woods on the Allegany mountains: Tennassee. 4. June, July. v. v. Flowers white.

33. FEDIA. Gart. defr. et sem, 2. p. 36.

radiata.

1. F. foliis spathulato-oblongis subintegris, fructu pubescente subtetragono apice nudo. Mich. $f$. aner. 1. p. 18 .

Valeriana locusta radiata. Linn. sp. $p l .48$.

In fields from Pensylvania to Carolina; very plentifully in Virginia. $\odot$.June, July. v. v.

34. TRIPTERELLA. Mich. $f$. amer, 1. p. 19.

capitata.

1. Tripterella. Mich. l. c. Anonymos capitatus. Walt. fl. car. 68. 
Vogelia capitata. Gmel. sysl. nat.2.p. 107.

Icon. Mich.l.c.t. 3.

In wet places, borders of ponds, \&c. in Lower Carolina. $\odot$. May-July. v. $v$. Stem filiform; flowers white, in a small head.

\section{IXIA. Gen.pl. 76.}

1. I. foliis lineari-subulatis scapo unifloro multoties breviore. Willd. sp.pl.1.p. 200.

Icon. Bartr. it. 152.t.3.

Found by Mr. W. Bartram in South Carolina and Georgia. 4. Flowers bright blue.

\section{IRIS. Gen.pl.97. Flag.}

1. I. barba cristata, caule brevissimo compresso subunifloro, foliis gladiatis longitudine florum, laciniis corollarum æqualibus.

I. cristata. Ait. kew.ed.2. 1.p.117. Willd. sp. pl. 1. p. 225.

I. virginiana pumila. Pluk. alm. 198.t. 196.f.6. Icon. Bot. mag. $412 . \quad$ Ladies' Calamus. On the banks of rivers in rocky situations in the mountains of Virginia and Carolina. 4. May. v. v. Flowers blue, handsomely crested with yellow.

The roots of this species when chewed are very remarkable; they at first occasion a pleasant sweet taste, which in a few minutes turns to a burning sensation, by far more pungent than Capsicum. The liunters of Virginia, notwithstanding those properties, use it very frequently to alleviate thirst.

2. I. imberbis, caule ancipiti multifloro foliis altiore, foliis ensiformibus, stignatibus petalis interioribus brevioribus, capsulis oblongis : angulis sulcatis.

I. virginica. Willd.sp.pl.1.p.232.

I. hexagona. Walt. fl.car. 66 .

Icon. Bot. mag. 703. Jacq. ic. rar. 2. t.223. Dill。 elth. t. $155 . f .188$.

On river sides and near ponds from New York to Florida. 4. June, July. v. v. Flowers beautiful purple, with the bottom of the outside petals yellow.

3. 1. imberbis, caule tereti flexuoso folia æquante, foliis ensiformibus, stignatibus petalis interioribus æquan. tibus, capsulis ovatis : angulis obtusis.

I. versicolor, Willd. sp. pl, 1.p. 233.

cristata.

virginico

versicolor. 
Icon. Bot. mag. 21. Dill. elth. t. 155. $f 18 \%$.

Very common in wet places, and on the banks of ditches from Canada to Carolina. 4. June, July. v. v. Flowers purple, stigmata white.

cuprea.

4. I. imberbis, caule tereti fiexuoso folia xquante, foliis lato-ensiformibus, stigmatibus linearibus brevibus, petalis omnibus reflexis emarginatis obovatis, interioribus brevioribus, capsulis magnis hexagonis.

On the banks of the Mississippi near New Orleans; discovered by Mr. Enslen, Collector to the Prince Lichtenstein of Austria. 4. July. v. $v$. Flowers of a beautiful copper colour, veined with purple.

tridentata. 5. I. imberbis, caule tereti foliis longiore, foliis ensiformibus, rudimentis petalorum interiorum tridentatis, denticulo medio acuminato, capsulis trigonis.

I. tripetala. Walt. $f$. car, 66 .

On the sea-shore of Lower Carolina. Walter. 4. Flowers blue, with purpie veins.

zerna. 6. I. imberbis, acaulis, uniflora, foliis longissimis gramineis glaucis, tubo longissimo, petalis subæqualibus, capsulis subrotundis ad terram sessilibus.

I. verna. Willd. sp.pl. 1.p. 235. excl. syn. Pluk.

On high mountains of Virgiuia and Kentucky; pientifully on the Cacapoon mountains near Winchester. 24. April, May. v. v. Flowers pale blue, striped with purple.

silirica. 7. I. imberbis, caule fistuloso tereti foliis altiore subtrifloro, foliis linearibus; capsulis abbreviato-trigonis utrinque obtusis.

I. sibirica Willd. sp.pl. 1.p. 237.

Jcon. Bot. mag. 50. Jacq. austr. 1.t. 3.

On the banks of the Missouri. M. Lewis. 4 . July. v.v.; v.s. in Herl. Lewis. Flowers blue.

prismatica. 8. I. imberbis, caule solicio tereti folia æquante, foliis angustissimis longis, capsulis elongato-prismaticis utrinque acutis.

In deep swanips of New Jersey, near Egg harbour. $\psi$. July. $v . v$. Hlowers pale purple.

\section{DILATRIS. Gen.pl. 82.}

incloria. 1. D. petalis lanceolatis extus villosis, panicula corymbosa tomentusa, foliis longis nudis linearibus.

D. carolibiand. Lam. illuslr. 1.p.127. 
Anonymos tinctoria. Walt. fl. car. 68.

Heritiera Cmelini. Mich fl. amer.1.p.21.

Icon. Mich.fl. amer 1.t 4.

In sandy swamps of New .ersey, and from Carolina to Florida. 4. June, July. v. v. Root red; stem and corymb very tomentose; petals yellow inside.

\section{SISYRINCHIUM. Gen. pl. 1101.}

1. S. foliis scapisque simplicibus subsetaceis, spatha colo- mucronatum. rata: valva altera in mucronem longum desinente. Pers. ench. 2. p. 50. Mich $f l$ amer. 2. p. 33.

In wet meadows of short grass in Pensylvania and Virginia. 4. June, July. v. v. Flowers beautiful blue, smaller than the following species.

2. S. scapo simplici alato, spathis inæq!alibus flores superantibus. Pers. ench. 2. p. 50 Cav diss.6. p. 345.

anceps.

S. gramineum. Lam encycl. 1. p. 408.

Icon. Bot.mag. 464 Cav.l. c t. 190.f.2.

On dry hills and grass plots from Canada to Carolina. 4. July, Aug. v. v. Flowers blue.

\section{BOERHAVIA. Gen. pl. 13.}

1. B. caule tetragono glabro, internodiis viscosis, floribus corymboso-paniculatis. Willd.sp.pl.1.p. 19.

erecta.

Icon. Pluk. alm.t. 226. f. 7 .

On the sea-coast of Carolina and Florida. 4. July. v. v.; v. s. in Herb. Walter.

\section{Commelina. Gen. pl. 86.}

1. C. foliis lineari-lanceolatis glabris, vaginis subciliatis, angustifolia. involucris cordatis conduplicatis. Vuhl. enum. pl. 2. p. 165. Mich. fl. amer. 1. p. 24.

In sandy woods of Carolina. 4 . July. v. v. Flowers in this as well as all the following species sky-blue.

2. C. foliis lanceolatis petiolatis cauleque erecto-pilosis conduplicatis, involucris lateralibus terminalibusque sessi-

hirtella. libus. I'ahl. enum pl. 2. p. 166.

C. longifolia. Mich. fl. amer. 1.p. 23.

In shady rocky situations in Virginia and Carolina. 4 . July. $v . v$. Stems long, tranchy.

3. C. foliis lanceolatis subpetiolatis supra glabris, vaginis subpubescentibus, canle erecto simplici. Vahl. enum. pl.2.p.167. Willd.sp.pl 1.p.251. 
In shady woods from Pensylvania to Carolina. 4.July, Aug. v. v. Flowers large.

communis.

erecta

Aluviatilis.

acita.

limosa.

graminea.
4. C. foliis ovato-lanceolatis subsessilibus acutis cauleque repente glabris, involucris cordatis conduplicatis. $\mathbf{V} a h l$. enum. pl.2. p.170. Willd. sp.pl. 1. p.249.

Icon. Dill. elth. t. 78. f. 89.

C. caroliniana. Walt.fl. car. 68.

In sandy fields in Carolina. Waller. 24. July. v. s. in Herb. Walier.

5. C. foliis ovato-lanceclatis scabris, involucris cucullatis turbinatis, caule erecto. Vahl. enum.pl.2.p.172. Willd. sp. pl. 1. p. 251.

C. communis. Walt.fl.car. 68 .

Icon. Dill. elth.t. $77 . f .88$ ?

In sandy shady places in Virginia and Carolina. 24. July. v. v. Pet. 2. large.

41. SYENA. Gen.pl. 88.

1. Syena. Willd. sp.pl.1.p.254.

Mayaca fluviatilis. Aul.l. guj. 1. p. 42.

Icon. Aubl. guj. l.c.t. 15. Lam. illustr. 1. t. 36

In small rivulets of Virginia and Carolina. 24. July, $v . v$. Flowers white, solitary, small.

42. HETERANTHERA. Beauvois in act. soc. amer. 4 :

1. $\mathrm{H}$. foliis subrotundo-reniformibus acutis, spathis subtrifloris glabris. Vahl. enum. pl.2.p. 42. Willd. in act. soc. am. h. nat. 3. p. 438 .

Leptanthus reniformis. Mich. fl. amer. 1.p.25.

Icon. Beauvois in act. soc, amer. 4. p. 173. H. reniformis.

In small rivulets and ditches, on a clay soil, in Pensylvania, Virginia, \&c. 4. June, July. v. v. Flowers white; leaves floating.

2. H. foliis ovato-oblongis, spathis lanceolatis unifloris: Vahl. enum. pl. 2. p. 44.

Pontederia limosa. Sucartz. $f$. ind. occid. 1.p. 611.

Leptanthus ovalis. Mich.fl.amer. 1. p. 25.

Icon. Mich.l.c. t. 5.f. 1. Sloan. hist. 1.t. 149.f. 1 . On the banks of rivers and small rivulets in the southwestern parts of the United States. 24. July. v. s. Flowers blue; leares erect.

3. H. foliis onnibus linearibus. Vahl. enum.pl.2. p. 45: L.eptanthus gramineus. Mich.fl.amer. 1. p. 25. Comnelina dubia. Jacq. obs. bot. 3.p. Q. 
Anonymos aquatica graminifoila. Cluyt. num. 814. Icon. Mich.fl.amer. 1. t. 5.f. 2. Jacq l. c. t.59. Floating, in the waters of Pensylvania, Virginia, 8c. 4 . July. v.v.; v.s. in Herb. Gronov. Flowers yellow.

\section{SERPICULA. Gen. pl. 1413.}

1. S. foribus triandris hermaphroditis, stizmatibus ligulatis occidentalis. reflexis bifidis, foliis ternatis linearibus acutis. Elodea canadensis. Mich. fl. amer. 1. p. 20.

In stagnant waters, frequent; from Camala to Virginia. 4. July. v. v. Hlowers very small and delicate, white; leaves when magnified very finely serrulate. Michaux describes the leaves to be ublong and obtuse, which is only the case in the early part of the season : at flowering time they certainly are long, linear, and acute.

\section{XYRIS. Gen.pi. 89.}

1. X. foliis longissime-gramineis scapisque tortuosis, capiindica. tulo globoso: squamis subrotundis ubtusis.

X. indica. IVilld. sp.pl. 1.p.25i?

lcon. Pluk alm. $t+10 . f .4$ ?

In overfowed mead ws and small ponds : Pensylvania to Virginia. 4 . June, July. v. $v$. Flowers yellow.

2. X. foliis lineari-gramineis, scapo ancipiti, capitulo ovato

caroliniana. acuto: squamis obtuis.

X. caroliniana. Lam. illustr. 1. p. 132. Hult. fl. car. 69.

X. Jupicai. Mieh. fl. amer. 1. p. 23.

In low grassy fields, in sandy soil, from New Jersey to Florida. 24. June-Aug. v. v. Heads small; fiowers yellow; it is extremely variable.

3. X. foliis subulato-gladiatis, scapo tereti, capitulo globoso. Mich. fl. amer. 1.p. 23 .

In low meatows of Lower Carolina and Georgia. 4. July. v.s. The smallest species; Howers yellow.

45. SPARGANIUM. Gen.pl. 1402. Bü-reed.

1. S. foliis basi triquetris lateribus concavis. pedunculo ramosum. communi ramoso, stigmate lineari. Smith. brit. 3. p. 901 . Willd.sp. pl.4. p. 199.

s. erectum. Sp. pl. 1378.

Icon. Curt. lond. 5. t.66. Engl. lot. $7+4$. 
In ditches and ponds from Canada to Virginia, rare. 24. July, August. v.v. Flowers in round heads, white.

simpiex.

2. S. foliis basi triquetris lateralibus planis, pedunculo $\mathrm{com}-$ muni simpiici, stigmate lineari. Smitiz. brit.3. p $9^{62}$. Willd. sp.pl.4. p. 199.

S. erectum $\beta$. Sp. pl. $137 \mathrm{~s}$.

Icon. Curt. lond. 5. t. 67. Engl. bot. 745.

In similar situations with the former; more frequent. 4. July, Aug. v.v.

natans.

3. S. foliis decumbentibus planis, podunculo communi simplici, stigmate ovato brevissimo, capitulo masculino subsolitario. Smith. brit.3.p. 962. Willd. sp.pl.4. p. 200.

Icon. Engl. lot. 273 . Fl. dan. 260.

angustifoliuim.

$\beta . \mathrm{s}$. foliis planis angustissimis, caulem longissime superantibus, debiliter fluitantibus. Nich. fl. amer. 2. p. 189.

In rivulets of Canada, and very frequent on the outlets of the small lakes of New York. 24. Aug. v. $v$. Floating; heads small.

46. TYPHA. Gen.pl. 1401. Cat's-tail. Reci-mace.

latifolia.

1. T. foliis linearibus planis, spica mascula femineacue approximatis, utraque cylindrica. Willd. sp. pl. 4. p. 197. Icon. Bot. mag. 1455. Fl. dan. 645. Coopers-reed. In marshes and pools very common. 24. July, Aug. $v . v$. Flowers in a long cylindrical spike.

angustifolia.

2. T. foliis linearibus canaiiculatis, spica mascula femineaque remotis, utraque cylndrica. Willd. sp. pl. 4. p. 198.

Icon. Bot. mag. 1456.

In similar situations, only more rare. Pensyivania and Virginia. 4. July, Aug. v.v.

\section{CAREX. Gen. pl. 1407. Sedge-grass.}

\section{A. Stigmatilus binis.}

$\dagger$ Spicis divicis.

scirpoidea.

1. C. spica solitaria imbricato-cylindrica, capsulis dense pubescentibus, foliis planis. Mich.fl.amer.2.p.171. Near Hudson's Bay. Mich. $4 .+$.

sterilis.

2. C. spicis subsenis, fructibus ovatis compresso-triquetris acuminatis, apice recurvis bicuspidatis, margine ciliato-serratis. Willd. sp.pl.4.p.208. 
Icon. Schk.car.t. Mmm.f. 146.

In wet meadows; frequent from Canada to Virginia. 4. May. v. $v$.

\section{t† Spicis androgynis.}

* Spica unica apice mascula.

3. C. spicis in formam ellipticam aggregatis, fructibus ovatis compresis bifidis marginatis superne ciliato-serratis. Willd. sp. pl.4. p. 220.

C. typhina. Mich. $f$ l. amer. 2. p. 169.

Icon. Sehk. car. t. Hihh.f. 133.

In shady woods: Pensylvania, Virginia, \&c. 4. June. $v . v$.

$$
\text { * Spicis pluribus apice masculis. }
$$

4. C. spiculis alternis confertis, superioribus masculis, inferioribus femineis, intermediis apice masculis, capsulis ovatis marginatis bifidis ciliato-serratis, culmo incurvo. Willd. sp. pl. 4. p. 223.

Icon. Schk car. t. B. Dd.f. 6. Host. gram. 1. t. 49. On the sea-coast in looce sands; New York to Virginia. 4. June, July. $v, v$.

5. C. spiculis oblongis alternis remotiusculis sessilibus, capsulis oblongis acuminatis rostratis bicuspidatis, squamis oblongis mucronatis. Schk. car.2.p.s. Willd.sp. pl. 4. p. 258.

Icon. Schk. car. t. Xxx.f. 176.

In dry fields and woods. 24. May. v. v.

6. C. spiculis subquaternis remotiusculis, fructibus ovatis bidentatis margine glabris reflexo-patentibus, squamis oblongo-lanceolatis. Schk. car. 2. p. 11.

Icon. Schk. car. t. Kkk.f. 140.

On dry lills: Pensylvania, \&.c. 4 . v. v.

7 . C. spiculis subquinis oblongis aggregatis, fructibus patentibus ovatis acuminat is bicuspidatis convexo-planis nervosis, culmo triquetro asperrimo. Willd. sp.pl. 4. p. 233.

Icon. Schk. car. t. Hhh. f. 132.

In bogs and swamp meadows : New England to Virginia. 4. June. v. $v$.

8. C. spiculis ovatis approximatis, fructibus horizontalibus oratis plano-convexis bidentatis, basi marginatis, margine ciliato-serratis. Willd. sp. pl. 4.p. 234.

Icon. Schk. car. t. E. Dd.f. 22. 
In wet woods and meadows: New York, \&ic. 4. May, June. $v, v$.

Muhlenbergii.

9. C. spiculis subquinis ovatis alternis approximatis, fructibus subrotu do-ovatis marginatis compressis bidentatis ciliato-serratis, squamis mucronatis. IVilll. sp. pl. 4. p. 231.

C. vuipinoidea. Mich. $f$ amer. 2.p. 169 .

Icon. Schk.car.t. Yyy.f. 178.

On dry hills and in barren woods. 24. May, June. v. v.

multiflora. 10. C. spicis anguste paniculatis oblongis oblusis, fructibus ovatis acuminatis bicuspidatis, squamis ovatis mucronatis, bracteis foliaceis filiformibus. IVilld.sp.pl. 4. p. 243.

Icon. Schk. car. t. Lll. f. 144.

In wet meadows: Pensylvania, Virginia, \&c. 24. v.v.

sparganioi- 11. C. spiculis multifioris suboctonis ovatis subapproximatis, des. fructibus ovatis compressis marginatis bifidis margine ciliato-serratis horizontalibus. Willd. sp. pl. 4. p. 237. Jcon. Schk. car. t. Lll.f. 142.

On the edges of ponds: New England, Pensylvania, \&c. 4. May-July. v. v.

divulsa.

12. C. spica basi subramosa, spiculis ovatis a'proximatis, inferiorioribus remotis, fructibus erectiusculis ovatis planis convexis bidentatis marginatis, margine glabris. Willd. sp. pl. 4.p. 235.

Icon. Schk. car.t. $D d$. $W^{\prime} u, f .89$.

In shady boggy places: New York, Virginia, \&ic. 24. June, July. $v$. $v$.

rosea.

13. C. spiculis subquaternis remotis, fructibus ovatis acuminatis bidentatis margine ciliato-serratis horizontalibus, squamis ovatis obtusis, iractea foliacea ad basin spiculæ inferioris. Willd. sp. pl.4.p. 237.

C. echinata $\beta$ rosea. Wahlb. act. holm. 1803.p.147.

Icon. Schk. car. t. Zzz.f. 179 .

In dry woods : Canada, Pensylvania, Virginia, \&c. 4. $v . v$.

paniculata. 14. C. spicis paniculatis, fructibus ovatis superne marginatis bidentatis margine ciliato-serratis, culmo triquetro. Willd. sp. pl. 4. p. 244.

Icon. Schk. car. t. D.f. 20. et var. t. Ttt.f. 163.

In bog-meadows: Virginia, \&c. 24. July. v.v.

*** Spicis pluribus apice femineis.

leporina. 15. C. spiculis tribus subrotundo-ellipticis alternis congestis, 
fructibus ellipticis compressis acuminatis ore integris, IVilld. sp.pl. 4. p. 229 .

C. Lachenaiii. Schk. car. 1. p.51.

Icon. Sihk. car. t. Y.f.29. Fl. dan. 294.

In the western parts of New York, Pensylvania, \&c. 4. June. v. $v$.

16. C. spiculis subquaternis approximatis ellipticis, fructibus ovatis bidentatis compressis margine ciliato-serratis erectis, squamis ellipticis obtusis. Willd. sp. pl. 4. p. 237.

C. triceps. Mich. fl. amer. 2. p. 170 ?

Icon, Schk. car. t. Zzz. f. 180.

In wet meadows, common. 4. May-July. v. v.

17. C. spiculis duodenis alternis ellipticis obtusis approximatis, fructibus ovato-lanceolatis marginatis bicuspictatis, bractea foliacea longissima ad basin spicæ ultimæ. Willd. sp. pl. 4. p. 230.

C. Richardi. Mich. fl. amer. 2. p. 170.

Icon. Schk. car. t. Yyy.f. 177.

In swamp meadows, common. 2 . June, July. v. $v$.

18. C. spiculis subsenis subrotundo-ellipticis alternis subap. proximatis inferne masculis, fructibus ovatis marginatis bidentatis ciliato-serratis. Willd. sp. pl.4.p.229.

C. leporina. Wahll. act. holm. 1803. p. 145.

Icon. Schk. car. t. B.f. 8.

In wet places: New York, \&c. 4. June. v. v.

19. C. spiculis subquinis alternis ellipticis obtusis subapproximatis, fructibus ovato-lanceolatis marginatis bacuspidatis, bracteis oblongis mucronatis. Wilid.sp.pl. 4 . p. 230.

C. viridula. Mich. fl. amer. 2. p. 170?

Icon. Schk. car. t. Xxx.f. 175 .

In wet and sometimes even very dry places, common. 4. May-July. v. $v$.

20. C. spiculis subsenis alternis approximatis cylindraceis, fructibus ovatis plano-convexis acutiusculis ore integris erectis, squama ovata acuta longioribus. Willd. sp. pl. 4. p. 241 .

C. canescens. Wahll. act. holm. 1803. p. 148.

Icon. Schk. car. t. C. f. 13.

In wet woods: New York, \&c. 4. June. v. v.

21. C. spiculis alternis remotis, bracteis foliaceis longissimis scirpoides.

lagopodioides.

ovalis.

scoparia. suffultis, fructibus ovatis acuminatis bifidis compressiusculis. Willd. sp.pl.4.p.239.

remota. 
Icon. Schk. car. t. E. t. 23.

In shady woods: Pensylvania mountains, \&cc, 24. Sute. $v . v$.

festucacea. 2. C. spiculis suboctonis subapproximatis alternis cylin. draceis, fructiferis clavatis, fructibus subrotundo-ovatis rostratis bidentatis margine ciliato-serratis, squarna lanceolata mucronata majoribus. Willd. $s p . p l .4$. p. 242.

Icon. Schk. car. t. Www.f. 173.

On dry hills, frequent. 24. May, June. v. v.

\section{t† Spicis sexu distinctis.}

* Spica mascula solitaria, reliquis femineis ex parte anára. gynis.

saxatilis, 23. C. spicis femineis geminis inferiore pedunculata oblongis, fructibus ellipticis obtusis squaman oblongam obtusam æquantibus, bracteis oblongis amplexicaulibus apice subtoliaceis, culmo glabro. Willd. sp. pl. 4 . p. 272.

Icon. Schk, car. t. I. et Tt. f. 40.

In hemlock woods of Vermont and New Hampshire. 4. June. v. $v$.

caspitosa.

24. C. spicis femineis cylindraceis obtusis subternis distantibus infima brevissime exerte pedunculatis, fructibus ovatis ubtusis ore pertusis, squama oblonga obtusa majoribus, foliis patulis. Willd. sp. pl.4. p. 287.

C. polyandra. Schk. car. 1.p.59. t. Dd.f.g0.

Icon. Schk. car. t. Aa et Bb.f. 85 .

In bog-meadows, very common. 4. May, June. v.v.

crinita.

25. C. spicis masculis geminis, femineis quaternis distantibus pedunculatis pendulis cylindraceis, fructibus subrotundo-ellipticis ventricosis brevissime rostellatis ore integris squama oblonga arista brevioribus. Willd. $s p$. pl.4. p. 300 . Lam. encycl.3.p. 379.

Icon. Schk. car. t. Eee.f. 125. et t. Ttt.f. 164.

poleacea. $\quad$ B. C. spicis cylindraceis, masculis pluribus, pedunculis longis reclinatis, bracteis foliaceis distantibus, squamis cuspide longa serrata terminatis, capsulis suborbiculatis, ore emarginato, culmo laxo. Wahlb. act. holm. 1803. p. 164 .

In wet woods, common. 24. June, July. v. v.

acuta, 26. C. spicis masculis binis ternisve, femineis subquaternis subpedunculatis subnutantibus cylindraceis remotis; fructibus oblongis brevissime rostellatis, ore integro 
pertuso, squuamam oblongam acutam subxquantibus. Willd. sp. pl.4. p. 304.

Icon. Sihh. car. t. Ee. et Ff. f.92. Host. gram. 1. t. 95 .

Iis swamps, very common. 24 . June, July. $v . v$.

B. Stigmatilus trilus.

+ Spicis androgynis, apice masculis.

27 . C. spica simplici ovata, fructibus ovato-subglobosis ore Fraseri. integris squama oblonga longioribus, foliis lanceolatis undulat is crenulatis, scapo basi vaginato.

Icon, C. Fraseri. Bot.mag. 1391. Bot. rep. 639.

On the mountains of Norih Carolina. Fraser. 24. April. v. $v$.

25. C. spica sinplici, fructibus alternis oblongis tereti-tri- Willdenouii. quetris scabris accminatis, squamis ovatis acuminatis, infina apice foliacea. Willd.sp.pl.4.p.211.

Icon. Schh. car. t. Mmm. f: 145.

In barren wet soil, common. 24. May, June. v. v.

29. C. spica simplici, fructibus oblongo-lanceolatis compresso triquetris obtusis emarginatis, squamis oblong is obtusis mucronatis. Willd. sp. pl. 4.p. 213.

C. leptalea. Wahll. act. holm. 1803. p. 139.

C. nicrostachya, Mich. fl. aner. 2. p. 169.

Icon. Sikk. car. t. Jii. t. 138.

In low wet places : Pensylvania, \&c. 24. June. v.v.

30. C. spicis subquaternis pedunculatis ranosissimis, fructi- pedunculaia. bus obovatis triquetris obtusis, squamis oblungris obtusis mucronatis. iVilld. sp. pl 4.p.222.

Icols. Schk. car. t. Ggg. f. 131.

On dry hills: New Eingland, New York, Pensylvania, Sic. 2. May-July. v.v.

31. C. spicis subquinis pedunculatis ovatis penduls, fiuctibus obovatis utrinque acutis, squanis ovatis at utis ovatu. c:apsulam æquantibus.

C. ovata. Rudge in linn. trans. 7.p. 96 .

Icon. Rudge l.c. t. 9.f. 1 .

In Canada and Newfoundland. $4 .+$.

tot Spicis terminalilus masculis, reliquis androgynis.

32. C. spica androgyna lineari-pedunculata inferme mascula, fenineis subapp:oximatis binis subpedunculatis linea- 
ribus, fructibus globoso-triquetris obtusis pubescentibus. IVilld. sp.pl.4.p.251.

Icon. Schk, car. t. Mmm.f.147.

On barren dry soil, common. 4. May. v. v.

hirsuta. 33. C. spica androgyna oblonga obovata inferne mascula, femineis remotiusculis subternis subsessilibus oblongis, fructibus ovatis obtusissimis obtuse triquetris, fuliis vaginisque hirsutis. Willd. sp.pl. 4. p. 252.

Icon. Schk.car. t. WWwe, f. 172.

On dry hills, frequent. 24. May, June. v.v.

Buxbaumii. 34. C. spica androgyna pedunculata obovata inferne mascula, femineis subternis remotis subpedunculatis, fructibus ellipticis triquetris obtusis obsolete bidentatis squamam oblongam inucronatam subæquantibus. Willd.sp. pl. 4. p. 252.

C. polygama. Schk.

Icon. Schk. car. t. X. Gg.f. 76 .

In swamps and wet woods: New York, Pensylvania, \&c. 2. July, Aug. v. v.

trichocarpa. 35. C. spicis androgynis tribus, femineis binis pedunculatis erectis cylindraceis remotis: fructibus ovatis acuminatis bicuspidatis pilosis squama ovato-lanceolata ariotata longioribus. Schk. car. 2. p. 47.

C. lanuginosa, Mich. fl. amer.2.p. 175 .

lcon. Schk. car. t. Nnn.f. 148.

In woods and wet fields: New England, Pensylvania, sic. 4. June. v. v.

\section{†† Spicis sexu distinctis.}

* Spica mascula solitaria, femineis sessilibus seu incluso. pedunculatis.

varia.

36. C. spicis femineis subternis subapproximatis sessilibus subglobosis, fructibus subgloboso-triquetris rostratis bidentatis pubescentibus squama oblonga brevioribus, culmo erecto. Willd. sp. pl.4.p. 259.

Icon. Schk.car. t. Uuu.f. 167.

On dry hills, frequent. 2. May, June. v. v.

sutulata. 37. C. spicis femineis subquaternis remotissimis sessilibus, mascula sessilis, fructibus subulatis divaricat is reflexis, culmo tenui, foliis planis. Mich.fl. amer. 2. p. 173.

In Canada. Michaux. +.

marginata. 38. C. spicis femineis subgeminis approximatis subglobosis subsessilibus, fructibus globosis tomentosis bidentatis 
squama oblongo-ovata majorious, foliis radicalibus annotinis culmo longioribus. IVilld. sp. pl.4. p. 201. Icon. Sihk. car, t. Lll. $f .143$.

On dry hills and rocks, commun. 4. April, May. $v, v$.

39. C. spica mascula lanceolata, femineis geminis ovatis sessilibus approximatis, fructibus ovatis rostratis ore vestilc. obliquis pubescentibus squamam ovatam acutam subæquantibus. Willd. sp.pl.4.p. 203.

Icon. Schk. car. t. Blbb. f. 182.

In wet meadows: Pensylvania, \&c. 4 . June. v. $v$.

40. C. spicis femineis tribus incluso-pedunculatis ovatis subapproximatis, bracteis longissimis foliaceis, fructibus ovatis ventricosis nervosis longissime rostratis ore bidentatis squama lariceolata mucronata longioribus. Willd. sp.pl. 4.p. 200.

Icon. Schk. car. t. Ggg.f. 130.

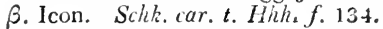

In swamps and wet woods, common. 24 . June, July.

rostrata. $v$. $\boldsymbol{~}$.

41. C. spica feminea plerumque solitaria sessili-ovata, bractea setacea, fructibus globosis glabris. Mich. $\mathrm{fl}$. amer. 2. p. 174 .

In bogs and shady woods: Canada, Vermont, \&ic. $\psi$. July. $v . v$.

42. C. spicis femineis tribus incluse pedunculatis oblongis approximatis, bracteis longissimis foliaceis, fructibus ovatis ventricosis nervosis longissime conico-rostratis ore bicuspidatis, squama ovata mucronata multoties longioribus. Willd. sp.pl.4. p. 266.

Icon. Schk. car.t. Ddd.f. 123. et t. Jii. f.104.

In swamps and woods, frequent. 4 . Jume-Aug. v.v.

43. C. spicis femineis subternis subapproximatis ellipticis incluse pedunculatis, fructibus ovatis reflexis rostratis, rostro curvato bidentato, squama ovato-lanceolata lengioribus. Willd. sp.pl. 4.p. 268.

C. Dederi. Schk. car. 1.p. 67.

Icon. Schk. car. t. H. f. 36. et t. F.f. 26. Hoșt.gram. 1. t. 65 .

In wet fields and meadows, frequent. 4 . June. $v . v$.

44. C. spicis femineis binis tri-s. quadrifloris inferiore pedunculata, fructibus subrotundo-triquetris obovatis oligocarpa. rostellatis ore integris squama oblonga mucromata longioribus. Willd.sp.pl.4.p. 279 .

tentaculata.

miliaris.

lupulina.

flava. 
C. paupercula. Mich. Al. amer. 2. p. 172?

Icon. Schk. car. $t$ lou, f. 1 jo.

In wet places: New York, Pensylvania, \&c. 24. May. $v . v$.

folliculata. 45. C. spic dunculata, fructibus ovatis ventricosis nervosis rostratis ore bipartitis squama ovata longionibus. Willd. sp.pl.4.p.2si.

Icon. Sihk. car, t. N.f. 52 .

major. B.C. intumescons. Kudge in linn. trans. 7. p.97. t.9. f. 3 .

In wet woods, common. 2f. June, July. v.v.

pulescens. 46. C. spucis femineis quaternis sessilibus infima exerte pedunculata, fructibus ovato-triquetris pubescentibus ro:tratis bidentatis, squana oblonga mucronata longioribus, culmo foliis pubescentibus. Willd. sp. pl. 4. p. 281 .

Icon. Schk car. t. Eee. f. 126.

In shady woods: Pensylvania, Virginia, Sic, 24. May. v. $v$.

* Spica mascula solitaria, femineis longe-pedunculatis, vaginis breviorilus.

plantaginea. 47. C. spicis pedunculatis femineis quaternis distantibus, fiuctibus ellipticis trignetris pedicellatis glabris squama ovata cuspidata brevioribus, bracteis vaynatis apice subfoliaceis, radicalibus lanceolatis nervosis. Willd. sp.pl. 4.p. 257.

C. latifolia. Wahll. act. holm. 1803.p. 156

Icon. Schk. car. t. U.f.70. et t. Kkkk.f. 195.

In dry woods, very common. 24. May, June. v. v.

anceps.

48. C. spicis femineis tribus remotis, inferioribus pedunculatis, fructibus ovatis nervosis ore membranaceis squama oblonga mucronata longioribus. Wiild. sp. pl. 4. p. 278 .

C. striatula. Mich. fl. amer. 2. p. 173.

Icon. Schk.car. t. Fff. $f .128$.

In wet fields on the sides of ditches, from New Jersey to Carulina. 24. June. v.v.

granularis. 49. C. spicis femineis tribus remotis, binis inferioribus pednnculatis, fructibus globoso-ovatis nervosis ventricosis brevissime rostellatis ore obsolete emarginato squama ovato-lanceolata longioribus. Willd. sp. pl.4. p. 279 . 
C. lenticularis. Mich. fl. aner. 2. p. 172 .

Icon. Schk.car. t. Vov.f. 169.

In barren meadows and woods, from Canada to Carolina. 4. May-July. v. v.

50. C. spicis femineis binis remotis, suprema subsessili, infima longe pedunculata, fructibus oblongo-conicis obtusis squamam aristain æquantibus. Willd. sp.pl.t. p. 280.

Icon. Schk. car. t. $V_{v v}$. f. $16 \mathrm{~s}$.

In dry woods, common. 4 .June. v. v.

51. C. spicis femineis binis remotis, suprema snbsessili, inconoilca. fina longe pedunculata, fructibus obovatis apice recurvis ore integris squamam obiuso-oratam longioribus. Schk. car. 2. p. 68.

Icon. Schk. car. t. Ggg. f. 100. et t. Oooo. f. 207.

In woods and dry meaduws, frequent. 4. May, Junc. $v . v$.

52. E. spicis femineis tribus 6-8-floris distantibus, infima remote pedunculata, fructibus oblongis ventricosis obtusis squama orata mucronata majoribus. Willd. sp.pl. 4. p. 281.

C. paupercula. Mich.fl.amer. 2. p. 172 .

Icon. Schk. car. t. Kkk.f. 141.

On dry grassy hills, common. $\psi$. April, May. v. v.

53. C. spica mascula solitaria, squamis ovato-oblongis submucronatis, femineis cylindraceis binis, intina pedunculata, fructibus ovatis multinerviis rostratis ore bifidis squama oblonga aristata longioribus. Wrilld. $s p . p l .4 . p .282$.

C. erinacea. Mhull. in litt....

Icon. Schk. car. t. Fff.f. 127 .

In swamps and boggy woods, frequent. 4. June, July. $v . v$.

54. C. spicis femineis tribus oblongis distantibus, suprema sessili, reliquis pedunculatis, fruct.bus ovatis acuminatis bicuspidatis squamam ovatam acuminatam subæquantibus. Willd.sp. pl.4.p.271.

Icon. Schk. car. t. T. et Yy.f.63.

In wet nieadows, frequent. 4 . June, July. v. $v$.

55. C. spicis femineis subquaternis remotis filifornibus pedunculis cernuis, fructitgs distantibus alternis oblongis rostratis bifidis squama ovata mucronata duplo longioribus. Willd. sp. pl. 4.p. 297.

C. debilis, Mich. fl amer. 2. p.172.

hystericina.

distans.

flexuosa.

tetanica.

laxiflora. 
C. tenuis. Rudge in linn. trans.t.7.p.97.

Icon. Schk.car.t. Ddd. et Aaaa.f. 124.

In sandy wet meadows: Canada to Carolina. 4. June. v. $v$.

digitalis. 56. C. spicis femineis subternis remotis filiformibus pedunculatis cernuis, fructibus ellipticis obtusis squama ob. longo-lanceolata longioribus. Willd. sp. pl. 4. p. 298. In Pensyliania. Muhll. $4 .+$

*** Spica mascula solitaria, fenineis pedunculatis, vagince sulnulla.

umbellata. 57. C. spicis femineis tribus pedunculatis octofloris ovatis vertcillatis, fructibus ovatis pubescentibus rostratis ore integris squamam ovato-lanceolatam æquantibus. Willd. sp pl. 4.p. 290.

Icon. Sihk. car. t. Wiww.f. 171 .

On dry sunuy hills : New York to Virginia. 24. May. $v v$.

miliacea. 58. C. spicis femineis tribus filiformibus, summa subsessili, reliquis pedunculatis, fructibus ovatis triquetris breve rostratis ore integris squama oblonga emarginata aristata longioribus. Wilid. sp. pl. 4.p. 290.

Icon. Scht. car. t. Ooo. f. 151 .

lin wet meadows: Cumada to Carolina. 24. July. v.v.

Fseudo-Cyperus.

recurva.

59. C. spicis femineis quaternis geminatis pedunculatis pendulis cylindricis, fructibus ovato-lanceolatis bicuspidatis reflexis squamam setaceam æquantibus. Willd. sp. pl. 4. p. 295.

Icon. Sihk. car. t. Mm.f. 102.

In ditches and swamps, frequent. 24. June, July. v. v. **** Spicis masculis plurilus.

60. C. spicis masculis geminis, femineis cylindricis subternatis pedunculatis pendulis, fructibus ellipticis obtusis sæe scabriusculis squamam ovato-cuspidatam æciuantibus. Willd.sp.pl.t.p.2gs.

C. flacca. Schk. car. 1. p. 117.

C. glauca. Siop.

Icon. Schk. car. t. O. P.f. 57. et t. Zz.f. 113.

In bogs and wet words, common. 4. June. v.v.

pellita. 61. C. spicis masculis geminis femineis geminis cylindraceis erectis remotis, superiore sessili, fructibus ovatis bifidis pilusis squama oblonga aristata brevioribus. $W i l l d$. sp.pl. 4.p. 302 . 
C. striata. Mich. fl. amer. 2. p. 17t?

lcon. Schk. car. t. Nnn.f. 149 et 150.

In wet meadows and woods, frequent. 4 . June, July. v. $v$.

62. C. spicis masculis quaternis, femmeis binis erectis cylin-

iacustris. draceis pedunculatis, fructibus oblongis multinerviis rostratis bifurcatis squana oblonga mucronata longio. ribus. Willd. sp.pl.4.p. 200.

Icon. Schk. car. t. Ooo. $f .152$.

f. Rudge in linu. trans.t.7.p.99. t. 10. f. 2.

In deep swamps and on the edges of ponds: Canada to Carolina. 4. June, July. v. v.

63. C. spicis masculis tribus, femineis subgeminis pedunculatis cylindraceis, fructibus oblongis intlat is rostratis bicuspidatis squama lanceolata majoribus, culmo acute triquetro. Wilid. sp.pl. 4.p. 307 .

Icon. Schk. car.t. Ss.t. 100.

In swamps and wet meadows, common. 24. May-July. $v . v$.

64. C. spicis nasculis tribus, femineis binis cylindraceis pedunculatis erectiusculis, fructibus ovato-globosis rostratis bifurcatis, rostris hispidis squama lanceolata majoribus. Willd. st.pl. 4. p. 309 .

Icon. Schk. car. t. Uuu.f: 106.

In bogs, very common. 4 . June. v.v.

45. SCLERIA. Gen.pl. 1408.

1. S. culmo foliisque glabris, paniculis terminalibus et late-

reticularis. ralibus paucitloris, nucibus reticulatis. Willd. sp. pl. 4. p. 31 . . Nich. Al. amer. 2. p. 167.

Carex lithosperma. Wult.jl. car. 227.

In sandy barren fields: New Jersey to Carolina. 24. July, Aug. $v . v$.

2. S. culmo simplicissimo triquetro foliisque glabris, spica verticillata. glomerata nuda, glomerulis alternis distantibus, glimis glabris, nucibus globosis mucronatis transversim rugoso-verrucosis. IVilld. sp. pl. 4. p. 317.

In wet fields: Virginia, Carolina. Mukll. 4. June, July. $v . v$.

3. S. culmo simplicissimo triquetro foliisque pubescentibus, interrupla. spica glomerata nuda, glomerulis alternis distantibus, glumis setosis, nucibus globosis mucronatis transver-

lullata.

vesicariz.

gigantea. 
sim rugoso-verrucosis. Willd. sp. pl. 4. p. $31 \%$. Mich. fl. amer. 2. p. 168.

In wet nieadows of Lower Carolina and Florida. 4.+.

kirtella. 4. S. culıno simplicissimo triquetro foliisque pubescentibus, spica glomerata nuda, glomerulis altern is distantibus, glumis setosis, nucibus elliptico-glubesis mucronatis levibus nitidis. Willd. sp.pl.4.p.318. Mich. fl. amer. 2. p. 168 .

In dry woods on slate rocks: Tirginia, Carolina. 2 . June. $v, v$. The smallest species.

ciliata.

5. S. culmo erecto glabriusculo, foliis ciliatis fasciculo terminali ciliato, nucibus globosis scabriusculis. Willd. sp.pl.4. p. 318. Nivh.fl amer. 2.p. 167.

In dry wonds: Virginia, Carolina, \&c. 24.July. v. v.

paucifora. 6. S. culmo erecto simplici triquetro scabro, foliis anguste linearibus canaliculatis margine scabris, fasciculis pancifloris binis terminalibus unico remotissimo axillari, nucibus globosis acutiusculis transversim rugosis. Willd. sp.pl. 4. p. 318.

S. oligantha. Mich.fl. amer. 2.p.167.

In low grassy places in the woods of Carolina. $4 .+$.

triglomerata. 7. S. culmo erecto simplici triquetro scabro, folis margitue scabris, fasciculis pauciforis terminalibus, gimis ovatis mucronatis scabris, nucibus glo'josis acutis rugosis. Mich.fl. amer.2.p. 168.

In dry sivamps and old fieids: Pensylvania to Carolina. 4. June, July. v. v.

\section{ZEA. Gen. pl. 1403. Indian Corn.}

Mays. 1. Z. foliis integerrimis. Willd. sp. pl.4. p. 200.

Cultivated throughout all $A$ merica, and sometimes found as it were in a native state. It would take up too much room to mention all the numberless varieties; but one of those brought by M. Lewis, Esq. from the Mandan nation, on the Missouri, deserves particular attention, as it ripens sooner and produces as excellent ears as any sort $\mathbf{I}$ know. It would be calculated to cultivate in climates not quite so warm as all the other sorts require.

50. KYLLINGIA. Gen. pl. 91.

tumila. 1. K. capitulo globoso sessili solitario, iwvolucro brevi, cul- 
TYIANDRIA MONOGYNIA. Fyllingia.

mo setacen, flosculis diandris. lahl. enum. pl. 2. p. 350 . Mich.fl. amer, 1. p. 28.

In the western parts of Sotith Carolina and Georgia. 4. June. v. $v$.

2. K. capitulis subternis sessilibus glomeratis, involucro $3-$ maculata. phyllo, glumis obiongis: valvulis cuneato-lanceolatis, flosculis monandris. Wich. Al. aner. 1. p. 29.

Scirpus cephalotes. Wralt.fl.car. 71 .

In inundated places: Carolina, Florida, \&c. 24. July. v. $s$.

51. MAPANIA. Aull.fl.gui. 1.p. 47 .

1. Mapania. Alll.fl.gui. 1.p. 47.t.17.

In remote parts of the Cherokee mountains. 24. July. syluatica. $v$.s. A beautiful grass, which I found in a collection made by Mr. Kinn of Philadelphia, corresponded in every respect with Aublet's plant.

\section{DiCHROMENA. Mich.fla amer. 1.p.37.}

1. D. glabra, involucris basi utrinque coloratis. Vahl. enum. leucocephala. pl.2. p. 2to. Mich. fl. aner. 1.p.37.

In wet places in Lower Carolina and Georgia. 24. July. v. s.

2. D. pilosa, involucris supra basin coloratis. Vahl. enum. cilialt pl. 2. p. 240 .

Schœnus stellatus. Suartz. fl. ind. occid.1.p. 102.

Jcon. Sloan. hist. jam. 1. t. 78.f. 1 .

In inundated places of Georgia and Florida. 4. July. v. $v$.

53. SCHCENUS. Linn. et Vahl. enum. pl. 2.p. 207.

1. S. pedunculis axillaribus terminalibusque subtrifioris, culmo trigono foliisque setaceis. Vahl. enum. pl. 2.

setaceus. p. 219.

Icon. Roltl. gram.t. 21 .

In Carolina. Vahl. 4 . +

2. S. pedunculis axillaribus terminalibusque tristachyis, spicis subglobosis pedicellatis, foliis filiformibus hispilispidulus, dis. Vahl enum. pl.2. p. 219.

In Carolina. Lam. $4 ;.+$ 
sparsa

micrantha.

laxa.

inexpansa.

fascicularis.

gloncrata.

distans.
54. RHYNCHOSPOR. Tahl. enum. pl. 2. p. 220.

1. R. corymbis diffusis axillaribus compositis, terminalibus decompositis, pedunculis capillaribus, seminibus rostro longiuribus. Fahl. e'mum. pl. 2. p. 230.

Schuenus sparsus. Mivil. fl. amer. 1.p.35.

Schouus niliacens. Lam. illustr. 1, p. $13 \%$.

In shady woods: Virgma-Georgia. Junc. v. v

2. R. corymbis diffusis axillaribus simplicibus, terminalibus compositis, pedunculis capillanubs, culmo folitoque filiformibus glabris. Vahl. enum. pl. 2. p. 231.

Schcenus raritlurus. Mich.fl. amer. 1. p. 35.

In Georgia. Mich. $4 .+$.

3. R. corymbis terminalibus compositis, spicis solitariis, rostello seminum longissimo, culno acutangulo scabro. Tahl. enum. fil. 2. p. 231.

Schanus Jongirostris. Mich. fl. amer. 1. p. 35.

Schornus comiculitus. Lam. illustr. 1. $\mu .132$.

In wet wonds and near ponds in Virginia and Carolima. 4. July. v. v.

4. R. corymbis coarctatis axillaribus simplicibus compositisque, teminalibus decompositis, culno filiforin. lahl. enum. pl.2. p. 232.

Schonus inexpansus. Mich. fl. amer. 1.p. 35.

In Carolina. Wich. 4 . +

5. R. spicis corymboso-fasciculatis, foliis linearibus latitudine culmi. Fahl. enum. pl.2. p. 234 .

Schoenus fascicularis. Aich. fl. amer. 1.p.37.

In Carolina. 2 . v.s.

6. R. spicis corymboso-fasciculatis remotissimis geminatis, culmo obtusangulo, foliis linearibus. Fahl. enum. $p l .2$. p. 234.

Schœenus glomeratus. Willd. sp.pl.1.p. 260.

ln wet meadows along ditches: Pensylvania-Carolina. Walter. 24. June, July. v, $v$.

7. R. spicis corymboso-fasciculatis remotissimis solitariis, culmo obtusangulo, foliis filiformibus. Iah!. enum. pl. 2. p. 235.

Schcenus distans. Mich.fl. amer. 1.p. 36 .

Schœnus axillaris. Lam. illısir. 1.p. 137.

In ponds which are dry in summer : Virginia, Carolina. 4. July, Aug. $\imath . v$. 
3. R. spicis corymboso-fasciculatis approximatis subgeminatis, bracteis glabris, culmo filiformi actitangulo,

cafitellata. Vahl. enum. pl. 2.p. 235.

Schœnus capitellatus. Mich. fl. amer. 1.p. 36.

In Carolina. Mich. $4 .+$.

9. R. spicis corymboso-fasciculatis terminalibus, bracteis foliisque obtusiusculis ciliatis. Vuhl. enum. pl. 2. ciliata. p. 235 .

Schcenus ciliaris. Mich., fl. amer. s.p. 36.

In Carolina and Florida. 2\%. v. s.

o. R. spicis corymboso-fasciculatis, culmo foliisque setaceis Vahl. enum. pl. 2.p. 236.

alla

Schonus albus. Willd. sp.t,l. 1.p. 267.

Icon. Engl. lot. 985 . Fl. dan. t. 320 .

$\beta$ Schœenus fuscus. Willd. sp. $p l .1 . p .262$.

Schœenus setaceus. Thouil. $f$. par. 19.

In bog-meadows, common. 4 . July, Aug. v. $v$.

55. FIMBRISTYLIS. Vahl. enum. pl. 2. p. 285.

1. F. spicis ovatis pubescentibus, involu ro involucellisque diphyllis umbella composita umbellulisque longioribus.

pulerulum. Vahl. enum. pl. 2.p. 289.

Scirpus puberulus. Mich. fl. amer. 1. p. 31 .

In low grounds: Virginia to Florida. 4 . July, Aug. $v . v$.

2. F. spicis ovato-oblongis obtusis, involucro diphyllo rigido unibellam subcompositam æquante. Vahl.enum. pl. 2.

castanewn. p. 92.

Scirpus castaneus. Nich. fl. amer. 1. p. 31 .

Scirpus carolinianus. Lam. illustr. 1. p. 142.

Schœenus umbellatus. Walt. $\mathrm{fl}$. car. 70.

In Carolina and Florida. 4 . July. v. v.

3. F. spicis cylindricis obtusissimis, involucro submonophyllo rigido umbellam simplicem æequante. Vahl.

cylindricum, enum. pl. 2. p. 293.

Scirpus palustris altissimus, \&c. Gron. fl. virg. 11.

In North America. Bosc. $\%$. +

4. F. spicis oblongis teretibus acutis, involucro diphyllo rigido umbellam decompositam aquante. Vahl. enum. pl. 2. p. 294.

Scirpus spadiceus. Willd. sp. $p l .1 . p .305$.

Icon. Sloan. hist. 1.t.76.f. 2 .

On the banks of rivers in Carolina and Florida. 2 . July, $v$. s.

VOL, I. 


\section{CYPERUS. Gen.pl. 93.}

* Culmo tereti.

articulatus. 1. C. spiculis compressis elongatis nitidiusculis, involucro subnullo, culmo articulato. Vahl. enum. pl.2.p. 301. Icon. Sloan. hist.jam. 1. t. 81.f.1.

In small slow streams : Carolina and Georgia. 4. July. $v$. $v$.

\section{** Culmo triquetro.}

\section{|| Spiculis aggregatis.}

Kyllingrooides.

uncinatus.

pocefornis.
2. C. capitulo globoso, spiculis oblongis convexis suboctofloris, involucro tetraphyllo foliisque carinatis laxis. Vahl. enum.pl.2. p. 312.

Icon. Rottl.gram. t. 4.f.5. C. dubius, p. 20.

In wet pine-woods: New Jersey, Carolina, \&c. $\mathcal{4}$. June. $v . v$.

3. C. capitulo subgloboso glomerato, spiculis linearibus suboctofloris : valvulis lanceolatis recurvato-acuminatis, involucro subdiphyllo longissimo.

On overflowed gravelly banks of rivers and lakes: Canada, in New York, on Lake Champlain. $\delta$. June. $v . v$.

Planta pusilla. Folia linearia glabra, longitudine culmi. Culmus setaceus, acute triquetrus, biuncialis. Involucri foliola 2. interdum 3 . unum culmo longius, structura foliorum. Capitulum solitarium, conglomeratum, ratione plantæ magnum. Spiculae numerosæ, divaricatæ, lineari-oblongæ, 6-8-floræ: valvulæ lanceolato-ovatæ, longe acuminatæ, apice divaricato quasi uncinatim reflexæ, nervosæ, pallide castaneæ, margine albidæ. C. pygmaeo affinis.

4. C. spiculis oblongis complanatis fasciculato-corymbosis : fasciculis sessilibus pedunculatisque, involucro triphyllo longissimo.

In sandy fields: South Carolina, \&c. 24. July. v. v. Planta spithamæa. Folia angusto-linearia, glabra, vix longitudine culmi. Culmus trigonus, glaber. Involucrum triphyllum; foliolis 2 . longissimis. Fasciculis florum ovatis, sessilibus, uno alterove brevi pedunculato. Ochrea truncatæ, coloratæ. Spiculce ovatooblongæ, circiter octo, breves, quatuor-sex-floræ: valvulæ fovatæ, obtusæ, carinatæ, flavescentes. An C. difformis? 
\|I Umbella radiis elongatis: spiculis terminulilus, umbellatis.

5. C. spiculis linearibus digitato-subternis, umbella involucrum diphyllum subæquante. Vahl. enum. pl. 2. p. 318.

Scirpus autumnalis. Rottl.gram.p. 58.

Cyperus juncoides. Lam. illustr. 1.p. 147.

Cyperus complanatus. Willd. sp.pl. 1.p.270.

Icon. Rottl. gram.t.17.f.3.

On the edge of ponds and ditches in Virginia and Caro. lina. 24. July, Aug. v. $v$. Spikes very slender; valves purple with a green carina; stem nearly cylindric.

o. C. spiculis digitatis subquaternis lanceolato-oblongis valvulis mucronatis latioribus membranaceis. Vahl.

compressus. enum. pl. 2.p.324. Willd.sp.pl.1.p. 282.

Icon. Rottl. gram. t. 9.f.3. Sloan. hist. jam. 1. t, 17. $f .1$.

In low meadows: Pensylvania to Carolina. 4 July. $v . v$.

7. C. spiculis oblongo-ovatis obtusis, umbellulis confert is aphyllis, foliis angustis. Rich. in act. soc. linn. par. p. 106.

In swamps of Carolina. 2. July. v. $v$.

8. C. spiculis lanceolatis subgloboso-capitatis compactis, valvulis ovatis uninervibus, involucro umbella lon-

autumnalis. 
flicinus.

fiavescens.

castaneus.

Hydra.

bulierosus.

ienuifiorus.

virens.

odoratus.

strigosus.

\section{IIII Unbella radiis elongatis: sficulis alternis.}

11. C. spiculis !ncari-lancelatis remotio culis lave imbricatis, involucro tiiplyllo uiabella longiore foliisque lasis. Wahl cnum. pl. 2. p. 332 .

In swamps of Virginia and Norti Carolina. 24. July. v. $v$.

12. C. spiculis lineari-lanceolatis confertis, involucro triphyllo umbella rifida longiore. Vuhl, enum. pl. 2. p. 335. Willd. sp.pl. 1.p. 279.

Icon. Fl. greea, t. 47 .

$\beta$ C. pusillus, spiculis brevioribus castaneis.

Common in low grounds. 4 . Jume, July. v. v.

13. C. spicis corymbosis, spiculis lineari-lanceolatis distantibus, foliis recurvatis, tuberibus oblongo-subrotundis. Vahl. enum. pl. 2. p. 34t. Mich. fl. amer. 1. p. 27.

In cultivated fields and barren woods: Virginia to Florida. 4 . July. v. $v$.

14. C. spiculis lineari-lanceolatis convexiusculis, involucro triphyllo umbella quinqueradiata longiore. Vahl. enum. pl. 2. p. 340.

Jcon. Rottb. gram.t.7.f. 1 .

Nul-grass.

On the banks of Delaware and other rivers: Pensylvania to Carolina. 2\%. June, July. v. v. The roots are very sweet, and eaten by children.

15. C. spicis corymbosis, spicuiis linearibus convexiusculis, involucro umbella longiore, culmo folioso. Vahl. enum. pl. 2. p. 347 .

lcon. Rottl. gram. $t, 14 . f .1$.

In wet fields in Carolina and Georgia. 24. July. v. v.

16. C. spicis corymbosis, spiculis ovalibus, involucro longissimo. Fahl. enum. pl. 2. p. 353. Mich. fl. amer. 1. p. 28.

In wet meadows and woods: Pensylvania to Carolina. 2. July, Aug. $v . v$.

17. C. spicis corymbosis, spiculis subulatis remotis distichis, valvulis subdistantibus, umbellis patentissimis involucellum subrquantibus. Vuhl. enum. pl. 2. p. 356. Willd. sp.pl. 1.p. 284.

Icon. Sloan. list.jam. 1.t.74.f.1. et t.8.f.1.

On the banks of rivers: Pcnsylvania to Florida, rare. 2. Aug. v. $v$.

15. C. spicis oblongis laxis, spiculis subulatis patentibus re- 
motiusculis, involucellis subrullis, umbellulæ radiis alternis. Wahl. enum.pl. 2, p. 358. Willd. sp.pl. 1. p. 281.

In swamps and ditches, common. 24. July. v. v.

19. C. spiculis lincari-lanceolatis, valvulis oblongis obtusis, flavicomus. fructiferis patentibus, involucro long:ssimo. Vahl. enum. pl. 2. p. 300. Mich.fl. amer. 1. p. 27.

C. elegans. Walt.fl. car. 7o.

In boggy woods: Pensylvania to Carolina. 4. July, Aug. v. v.

20. C. spicis distichis, spiculis filiformibus patentibus, flosculis distantibus, umbella stricta. Vahl. enum. pl. 2. distans. p. 36. . Willd. sp.pl. 1. p. 28 s.

Icon. Rottl.gram.t. 10. C. elatus.

In sandy wet woods: Carolina and Georgia. 4.v.s.

21 . C. spicis corymbosis, spiculis subulatis distichis, umbellulis involucello brevioribus, ochreis biaristatis, culmo speciosus. acutangulo. Vahl. enum. pl. 2. p. 364.

C. virginicus, Jacq. in Herl. Lamlert.

In Virginia. Vahl. 4. v. s. in. Herl. Lomlert.

22. C. spicis corymbosis oblongis basi ramosis nudis, spiculis numerosis divaricatis confertis linearibus subsex thoris, valvulis oblongis striatis, involucro octophyllo umbellam subrequante.

In ditches and near ponds: Virginia to [lorida, rare. Aug. v. v.

Folia radicalia, linearia, 3-nervia, glabra, margine carinaque scabra, culmo breviora. Ciulmus lævigatus, triquetrus. Involucrum suboctophyllum : foliola interiora breviora, exteriona radiis umbellæe longiora. Umlella composita: radii octo vel decem. Spica oblongæ, basi ramosæ, magnæ. Spiculce numerosæ (circiter 100), horizontales, castaneæ. An var. C. speciosi?

I have named this species in memory of Mr. Enslen, through whose generous communication I have been put in possession of a number of grasses and other plants growing in the southern States.

\section{DULICHIUM. Pers. ench. 1. p. 65.}

1. D. culmo triquetro folioso, spiculis patulis subsexfloris. spathaceum. Pers. ench.!. c.

Pleuranthus floribundus. Rich.

Cyperus spathaceus. Willd. sp.pl. 1. p. 289. 
Schœnus angustifolius. Vahl. enum. pl.2. p. 225.

Scirpus spathaceus. Mich. fl. amer, 1. p. 32.

Icon. Pluk, alm, t.301. $t$. 1.

ln swamps and bogs from Canada to Florida. \%. July, Aug. $v . v$.

canadense. 2. D. racemis simplicibus pedunculatis, spiculis paucis crectis subdecemfloris. Pers. $l$. c.

In Canada and New York, in similar situations, rare. 2. Aug. $v, v$. Lower growth and shorter leaves than No. 1.

\section{SCIRPUS. Gen.pl. 94 .}

* Culmo monostachyo.

acicularis. 1. 3. spica ovata, squamis duabus infimis majoribus, culmis tetragonis setaceis, vaginis muticis. Vahl. cnum. pl.2.p. 245. IVilld. sp.pl. 1.p. 295.

Icon. Pluk. alm. t. 40.f.7. Host. gram. 3.t. 60.

In shallow ponds and pools, under water, common. $\psi$. July, Aug. $v \cdot v$.

pusillus.

2. S. spica oblonga acuta (pauciflora): squamis linearibus acut is, culmis angulatis capillar?bus. Vahl. enum. pl. 2. p. 246 .

S. capillaris. Mich. fl. amer. i. p. 30.

In springs and ditches, frequent. 4 . June, July. v. v. The smallest of the genus.

palustris. $\quad 3$. S. spica ovali, squamis lanceolatis acutis, culmis teretibus, vaginis muticis lanceolatis acutis, radice repente. Vahl. enum.pl.2.p. 247. Willd.sp.pl.1.p.291. Icon. Fl. dan.t. 273. Host. gram. 3, t. 55.

In overflowed fields and ditches, frequent. 4 . July. $v$. $v$.

iulerculosus.

4. S. spica ovata acuta, squamis subrotundis, seminibus tuberculo ovato coronatis, culmis teretibus. V'ahl. enum. pl. 2. p. 248. Mich.fl. amer. 1.p. 30.

In Lower Carolina. Michaux. $4 .+$.

filiformis.

5. S. spica cylindrica oblonga obtusa, squamis subrotundis, seminibus vertice nudis, culmis filiformibus teretibus. Vahl. enum. pl.2.p. 248. Lam. illustr. 1.p. 138.

In wet fields, near ditches: New Jersey to Carolina. 4. July, Aug. v. $v$.

ovatus. 6. S. spica ovata, squamis oblongis, floribus subdiandris, culmis subcompressis, vaginis nuticis. Hahl. enum. pl.2.p.249. Willd. sp.pl. 1.p. 294. 
S. compressus. Mœnch. meth. 394 .

Icon. Moris. hist. 3. s. 8. t. 10.f. 34. Host. gram. 3. t. 56 .

Near ponds and ditches: Pensylvania. 4. July. v. '.

7. S. spica subglobosa, culmis sulcato-angulatis setaceis, capitatus. vaginis muticis, spica subglobosa. Vahl. enum.pl. 2. p. 250 . Willd. sp.pl.1.p. 294.

Icon. Rottl. gram. t. $15 . f .3$.

In small ponds, very common. 4. Aug. v. $v$.

8. S. spica ovato-oblonga, squamis ovato-subrotundis, culmis teretibus approximate interstinctis. Vahl. enum. pl. 2. p. 250. Willd. sp.pl. 1.p.291.

Icon. Sloan. hist. 1. t.83,f.3.

On the sea-shore of Virginia and Carolina. 4 . July. v. $v$.

9. S. spica cylindrica, squamis oblongo-subrotundis, cul-quadrangulamis tetragonis. Vahl. enum. pl.2.p.252. Mich. $f$. tus. amer. 1. p. 30.

In Carolina. Michaux. $4 .+$.

** Culmo polystachyo : spicis lateralibus.

10. S. spicis ovatis acutis subsolitariis, culmis foliisque capilminimus. laribus curvatis. Vahl. enum. pl.2. p. 253.

Icon. Pluk. alm. t. 300.f.5. Rottb. gram.t. 15.f. 4. S. setaceus.

In wet sandy fields and near ponds : Virginia to Carolina. 4. July. v. $v$.

11. S. spicis brevi-ovatis conglomerato-sessilibus, squamis geniculatus. subrotundis membranaceis, culmis striatis.

In wet meadows : Pensylvania. 24. July, Aug. v. $v$. Culmi teretes, striati, pedales et ultra. Spicula 4-6. crassæ. Squamis latis, acutiusculis. Setula semine duplo longiores. Affinis S. setaceo.

12. S. aphyllus, spicis oblongis, squamis integerrimis mumucronatus. cronato-acuminatis, culmo triquetro. Vahl. enum. pl.2.p.256. Willd. sp.pl.1.p.303.

Icon. Host. gram. 3. t. 66.

In swamps and salt-marshes: Canada to Carolina. $\mathcal{\psi}$ Aug. v. $v$.

\section{*** Culmo polystachyo: spicis terminalilus.}

13. S. aphyllus, spicis oblongis, squamis glabris mucronu-

lacustris. 
latis, stylis trifidis, umbella decomposita, culmo tereti. Vahl. enum. pl.2.p. 267. Willd.sp.pl. 1.p. 296.

Icon Fl.den. $t$ 1142. Host. eram. 3. t.61.

In stagnant waters: Canacia to Carolina. 24.July. v. v.

valiảus.

rolustus.

americanus.

16. S. spiculis sessilibus conglomeratis oblongo-ovatis mucrone brevioribus, culno acute triquetro nudo. Pers. ench. 1.p. 68 .

S. trigteter. Nich. $f l$. amer. 1. p. 30 .

In salt marshes, frequent. 4 . July, sug. $v . v$.

sylvaticus.

17. S. spicis oblongis congestis, corymho supradecomposito folinso, squamis oblongis obtusiusculis viridibus, culmo folioso trigono.

Icon. Host. gram. 3. t. 68. Fl. dan. t. 307.

In Canada. Michaux. 4 . + .

exaltatus. 15. S. spicis brevi-ovatis congestis, corymbo composito, squamis rhomboideis carinatis mucronatis coloratis, culmo folioso obtuse trigono.

S. brunneus. Muhlb. in litt.

viviparus. $\quad \beta$ S. culmo altissimo subscandente, corymbis viviparis basi ranulorum floriferis.

In shady woods: New York to Carolina. 2 . July, Aug. v. v. The viviparons variety grows in deep shady swamps, and frequently acquires the height of ten feet and more.

nitens.

19. S. spicis ovatis pedicellatis, corymbis subcompositis axillaribus terminalibusque, culno tereti. Vahl. enun:. $p l .2 . p .272$.

In Virginia and Carolina. 24.July. v. v.

lineatus. 20. S. spicis oblongo-ovatis pedicellatis, corymbis axillaribus terminalibusque supradecompositis, pedunculis elon. 
gatis, culmo trigono. Vahl. enum. pl. 2. p. 273.

Mich. fl. amer. 1.p. 32.

Trichophorum lineatum. Pers. ench. 1.p. 69.

In sandy wet woods : New Jersey to Carolina. 24.July. $v . v$. The seeds are naked, consequently it is no Trichophorum.

21. S. spicis capitulisque subglobosis glomeratis, corymbo polyphyllus, terminali, culmo folioso. Vahl enum.pl. 2.p.274.

Schœnus cymosus. Willd. sp. pl.1.p.265?

In shady wo ds: Virginia and Carolina. 4 . July. $v, v$.

22. S. spicis ovatis, umbeila biradiata, culmo capillari. capillaris. Vakl. enum. pl. 2, p. 276. Linn. Mani. 321.

S. pusillus autumnalis, \&c. Gron. A.virg. 11. In Virginia. 4. July. v. s. in Herb. Gronov.

23. S. spicis oblongis acutis, involucro diphyllo umbella autumnalis. composita breviore, culmo ancipiti, foliis linearibus. Willd. sp pl. 1. p. 301. excl. syn. Rottboellii.

S. foliosus pusillus autumnalis, xic. Gron. fl. virg. 10.

S. mucronulatis. Mich.fl amer. 1.p.32.

In sardy wet fields : New Jersey to Carolina. 2r. Aug. v. v.; v. s. in Herl. Gronov.

59. TRICHOPHORUM. Fers. ench. 1.p. 69.

1. T. culmo triquetro folioso, panicula decomposita, spi* cyperinum. culis confertis ovatis. Pers.l.c.

Scirpus Eriophorum. Mich. fl. amer. t. p. 33.

Eriophorum cyperinum. Willd.sp.pl, 1. p. 313.

Icon. Pluk. mant t. 419, f. 3 .

In ditches and near ponds, from Canada to Carolina. 4. July, Aug. v. v. Very tall.

2. T. culmo triquetro nudo, folits conaliculato-setaceis, spica simplici.

Eriophorum hudsonianum. Mich fl. amer. 1. p. 34.

In bogs on the mountains of Pensylvania, Vemont, \&c. 4. Aug. v. $v$.

\section{ERIOPHORUM. Gen.pl. 95.}

1. E. culmis superne trigonis, spica oblonga unica, squamis scariosis. Host. gram. 1.p. 33.

Icon. Host.l. c. t. 39 .

On high mountain meadows: Canada to Virginia. 4. June, July. $v . v$. 
polystachium. 2. E. culmis foliosis teretibus, foliis planis, spicis pedunculatis, seminibus ovatis. Roth. neue beytr. 1.p.94. Willd. sp. pl. 1. p. 312.

Icon. Host. gram. 1.t.37. Engl. bot. 563 .

In bog-meadows: common. 24. May. v. $v$.

angustifoli- 3. E. culmis foliosis teretibus, foliis canaliculato-triquetris, um. spicis pedunculatis, seminibus ovatis. Roth. neue beytr. 1.p. 94. Willd. sp.pl. 1.p.313.

Icon. Engl. bot. 564 .

In mountain meadows, frequent. 24. May. v. $v$.

virginicum. 4. E. culmo tereti folioso, foliis planis, spicis congestis subsessilibus involucro brevioribus. Vahl. enum. pl. 2. p. 390. Willd. sp. pl. 1. p. 313.

Icon. Pluk. alm. t. 299.f. 4 .

Common in bog-meadows, from Canada to Georgia. 4. April, May. v. v.

\section{VAGINARIA. Pers. ench.1.p. 70.}

Richardi. 1. V. culmo aphyllo vaginato, spica ovata subsolitaria, squamis lanceolato-spathulatis. Pers.. . $c$.

Fuirena scirpoidea. Mich.fl. amer. 1, p. 38.

Icon. Mich. l. c. t. 7.

In overfluwed fields: Georgia to Florida. $4 . v . s$.

\section{FUIRENA. Gen.pl.go.}

squarrosa. 1. T. umbellis simplicibus, spiculis ovatis, culmo glabro, foliis ciliatis, vaginis pilosis. Vahl. enum. pl.2. p. 385 . Mich. fl. amer. 1. p. 37.

In bog-meadows: New Jersey, Carolina, \&c. 4.July. $v . v$. A very handsome little grass.

\section{MARISCUS. Vahl. enum.pl. 2. p. 372.}

ovularis. 1. M. spicis ovali-subrotundis, involucris polyphyllis. Vahl. enum.pl. 2. p.374.

Schœnus umbellatus. Jacq. collect. 1. p. 113.

Kyllingia ovularis. Mich. fl. amer. 1.p. 29.

Icon. Pluk.alm.t. 91.f. 4. Jacq. ic. rar. 1. t. 10?

In sandy wet places: Georgia and Carolina. $4 . v$. s.

retrofractus. 2. M. spicis retrorsum subimbricatis, spiculis subulatis retrofractis, involucro triphyllo. Vahl. enum. pl. 2. p. 375 . 
Scirpus retrofractus. IVilld.sp.pl. 1.p.304.

Icon. Pluk. alm. t. 415. f. 4 .

In rocky shady situations, on the banks of rivers: Virginia, Carolina, \&c. 4 . July. v. v. Stems and leaves very rough.

3. M. spicis cylindricis retrorsum imbricatis, involucris polyphyllis. Vahl. enum. pl.2.p.376.

Scirpus cyperoides. Linn. mant. 181.

Kyllingia umbellata. Linn. supjl. 105.

Icon. Rottl. gram.t. 4.f. 2.

In shady woods : Virginia and Carolina. 4. Aug. v.v.

The American specimen is without partial involucres, in every other respect it agrees with the description.

64. MIEGIA. Pers. ench.1. p. 101.

1. Miegia. Pers.ench. 1. p. 102.

Arundinaria macrosperma. Mich. fl. amer. 1.p.74.

umbellatus.

Arundo gigantea. Walt. fl. car. 81 .

In extensive tracts on the Mississippi and Floridas, called Cane brakes, almost impenetrable. Arundo tecta of Walter seems to be only a variety of this species. 4. March, April. v.v.

\section{LIMNETIS. Richard in Pers. ench. 1.p. 72.}

1. L. foliis distichis breviusculis setaceo-convolutis, spicis paucis remotis patulis, calyce acuminato : carinis asmacrosperma. peris. Pers ench. 1. p. 72.

Trachynotia juncea. Mich. fl. amer. 1.p. 64.

Dactylis patens. Donn. hort. cant. 25.

In dry salt-meadows, common. 24. July. v. $v$.

2. L. subglauca, foliis longissimis, spicis plurimis alternis cynosuroides. secundis, calyce aristato acuminato : carinis aculeatis. Pers. ench. 1.p. 72 .

Trachynotia cynosuroides. Mich. fl. amer. 1.p.64. On rocky sea-shores, frequent. 4 . July. v. $v$.

3. L. foliis latis planis, spicis pluribus undique versis longis polystachya。 linearibus, carinis aculeatis. Pers. ench. 1.p. 72.

Trachynotia polystachya. Mich. fl. amer. 1. p. 64.

Dactylis cynosuroides. Willd.sp.pl. 1.p. 407.

Common in salt-marshes, from Canada to Florida. 4. Aug. $v . v$. 
66. CENCHRUS. Gen.pl. 1574.

trilulozies. 1. C. spica spiculis alternis, glumis femineis globosis muricato-spinosis hirsutis. IV illd. sp.pl.1.p.317.

C. carolinianus. IValt. fl. cur. 79.

Icon. Sloan. hist. 1. t.65. $f .1$.

Near the sea-shore, from New Jersey to Florida. $\odot$. June, July. v. v.; v.s. in Herb. Walter.

67. ORYZOPSIS. Mich.f. amer. 1.p. 51.

asfieriolia. 1. O. culmo subnudo, foliis erectis subpungentibus asperis. Mich.l.c.

Icon. Mich.l.c.t.9.

On high monntain meadows : Canada and Pensylvania. 24. July, Aug. v. $v$. I observed this grass on the Broad mountains of Pensylvania, and consider it worth the attention of farmers, as the considerable large seeds contain the finest flour of any grain I know.

\section{II. $D I G Y N I A$.}

68. ZlZANIA. Gen.pl. 1433. Indian Rice.

aquatica.

1. Z. panicula pyramidata, inferne divaricata mascula, superne spicata feminea, fulcris florum clavatis aristis longis, senine elongato.

Z. agpatica. Lamlert. in linn. trans. 7. p. 264.

Z. palustris. Linn. mant. 295. Gron. virg. 148.

Z. ciavulosa. Mich fl. amer. 1.p.75.

Icon. Lamlert. l.c. t. 13 . Tuscarora or IVild Rice. In all the waters from Canada to Foricia, common. 4. July, Aug. v.v.

miliacet.

2. Z. panicula effusa: glumis brevi-aristatis: masculis et femineis mixtis, semine ovato lævi. Mich. fl. amer. 1. p. 74 .

Z. aquatica. Willd.sp. pl.4.p.394?

Icon. Sloan. hist. 1. t.67?

On the tide water meadows and ditches: Pensylvania and Carolina. 24. Aug. v. $v$. 
3. Z. pusilla, culmis gracilibus ramosis, foliis linearibus planis, spicis solitariis axillaribus setaceis subquadrifluitans. floris, glumis muticis. Mich.fl. amer. 1. p. 75 .

On the banks of Lake Champlain and St. Laurence. 4. July. v. v.

\section{MUHLENbergia. Gen.pl. 103.}

1. M. culmo debili ramoso foliisque glabris, panicula coarctata, calyce univalvi. Pers. ench. 1.p. 73 .

diffusa.

Dilepycum minutiforum. Mich. fl. amer. 1. p. 40.

On dry grassy hills, frequent. 4 . June, July. $v v$.

2. M. culmo firmo simplici folisque pubescentibus, panicula laxa, calyce bivalvi, arista longissima. Purs. ench. 1. p.73.

Dilepycum aristosum. Mich fl. amer. 1. p. 40.

In dry shady woods, from Canada to Carulina. 4 . July. $v . v$.

70. TRICHODIUM. Mich.fl. amer. 1.p.41.

1. T. culmis erectis, foliis angustis breviusculis, vaginis asperiusculis, glumis lanceolatis. Mich. fl. amer. 1 . p. 42.

Cornucopiæ hyemalis. IValt. l. car. 73.

Agrostis scabra. Willd. sp.pl.1.p. 370.

Agrostis laxa. Schrel. gram.

Icon. Mich. fl. amer. 1. t. 8.

Common in all grassy situations. 24. May-Aug. v. v.

2. T. culmis decumbentibus, foliis patulis, vagina lavi, decumben. glumis lineari-lanceolatis sensim acutis. Mich. $f$. amer. 1. p. 42.

Cornucopiæ perennens. Walt. fl. car. 7-1.

Agrostis anomela. Willd. sp.pl.1.p.370.

Agrostis cornucopia. Fraser, monogr. cum icone.

Icon. F,aier. monogr.

On moist hilis and short grass meadows, from Canada to Carolina. 24. June-Aug. v. v. This and the first species are highly valuable grasses. Vide Fraser's Monogr. and Walter's Flora.

3. T. culmis erectis, foliis angustis scabris, vaginis glabris, elatum. valvis membranaceis ovato-lanceolatis acuminatis.

Cornucopiæ altissima. Walt.fl. car. 74.

Agrostis dispar. Mich. Al. amer. 1.p.52. 
In sandy deep swamps: New Jersey, Carolina, \&c. 4. July, Aug. v.v. Near three feet high; panicle close, coloured.

71. LEERSIA. Gen. $p l .105$.

oryzoides. 1. L. panicula effusa, spiculis triandris patulis, glumis oblongo-ovalibus carina ciliatis. Willd.sp. pl.1. p. 325. L. virginica. Willd. l. c.

Icon. Host. gram. 1. t. 35.

In wet woods and ditches, frequent. $4 . J u l y . v . v$.

lenticularis. 2. L. paniculæ ramis subsolitariis, spiculis imbricatis, gltnis orbiculatis ciliatis majusculis. Mich. fl. amer. 1. p. 39 . Fly-catch-grass.

In wet gravelly woods in Illinois and Virginia. 24. July. $v . v$. This singular and elegant grass $I$ found on the islands of Roanoak river in North Carolina, and observed it catching flies in the same manner as Dioncea muscipula: the valves of the corolla are nearly of the same structure as the leaves of that plant. I communicated specimens with this particular circumstance to Dr. B. S. Barton of Philadelphia, who has made men tion of it in a paper on the irritability of plants.

\section{MILIUM. Gen.pl. 110. Millet-grass.}

amphicarpon. 1. M. paniculæ ramis strictis simpliciusculis, floribus masculis alternis pedunculatis ; floribus femineis in scapis uniforis radicalibus vaginatis, demum subterraneis.

In light sandy fields of New Jersey near Egg-harbour. July, Aug. v. $v$.

Culmi plures teretes, vaginati, sesquipedales et ultra.

Folia lato-linearia, striata, geniculis breviora, undique pilis longis albidis rigidis tuberculo insidentibus tecta. Vagine teretes, striati : suprema aphylla, more foliorum pilosæ. Ligula barbata.

Panicula in summitate culmi, pauciflora, stricta: ramis simpliciusculis; pedicellis florum clavatis. Glumis oblongis, acutis, nervosis, æqualibus, glabriusculis. Floribus ommibus masculis.

Flores feminei in scapis radicalibus unifloris basi vaginatis. Flores ante anthesin erecti, dein reflexi, ad maturitatem seminis magni subrotundi subterranei.

This singular grass deserves particular examination in the living plants, as I had no opportunity to describe 


it on the spot where I first found it ; not being aware of its curiosity, until I examined the dried specimens.

\section{AGROSTIS. Gen.pl.111. Bent-grass.}

\section{* Aristata.}

1. A. petalo exteriore arista recta stricta longissima, panicula patula. Willd.sp.pl. 1.p. 361 .

Icon. Host. gram. 3. t. 47. Engt. lot. 951.

In rye-fields in Pensylvania and Virginia; brought there by seeds of grain from Europe. $\odot$. June, July. v.v.

2. A. paniculæ simplicissimæ ramis adpressis, corollis aristatis, arista flore longioribus. Willd. sp. $p l .1$. p. 364 .

On the banks of rivers: Virginia and Carolina. 4. July. $v \cdot v$.

3. A. paniculæ ramis unifloris filiformibus, corollis aristatis calyce inæquali duplo longioribus hirsutis vaginis villosis.

On high mountains in Virginia and Carolina. 24. July. v. $v$.

Culmus sesquipedalis, glaber. Folia longissime-linearia, villosa, nervosa. Vagina striatæ, viliosæ. Ligula brevis. Panicula simplicissima, ramis elongatis unifloris. Cal. valvis inæqualibus, villosis, brevi-aristatis. Cor. oblonga, villosa, calycis valvula interiore duplo longior, brevi-aristata.

4. A. panicula elongata stricta, corollis calyce minoribus : arista e basi petali tortili flore longiore. Willd. sp. pl. 1. p. 366 .

In good meadow grounds, very frequent. $\psi$. June, July. $v . v$.

5. A. calycibus elongatis, petalorum arista dorsali recurva, culmis prostratis subramosis. Willd. $s p . p l .1 . p .307$.

pauciflia.

tenuiflora.

Spicaventi. teruiflora.

pariflira.

stricta. Icon. Fl. dan. 161 .

In wet meadows, frequent. Brought from Europe. 4. July. v.v.

\section{* Mutice.}

6. $\Lambda$. panicula patente, ramulis divaricatis capillaribus, calycibus æqualibus, petalo interiore duplo breviore revulgaris. tuso. Smith. fl. brit. 1. $p 79$.

A. hispida. Willd. sp.pl.1.p.370.

A. capillaris. Retz. scand.no. 95 . 
Icon. Fl. dan. 161.

Conamon in all grassy fielus. 2. July. v.v.

aspera. 7. A. paniculis coarctatis lateralibus terminalibusque, va. ginis barbatis, foliis recurvatis asperis, glumæ valvis interioribus triplo majoribus. Mich fl. amer. 1.p. 52.

A. barbata. Pers ench. 1. p. 75 .

A. littoralis. Lam.illust. 1. p.161.

In the western districts of the United States, in rocky situations. Alichaux. On the sea-shore of Florida. Lam. 4. July. v. s. in Herb. Enslin.

alla.

8. A. panicula laxa, calycibus muticis æqualibus, culmo repente. Willd. sp pl 1.p. 371.

On the banks of rivulets and springs, frequent. 24 . July. ข. $v$.

pungens.

a. A. panicula contracta spicæformi, foliis involutis rigidis pungentibus superioribus oblique oppositis, culmo ramoso. Schrel. gram. 2. p. 46.

A. virginica. Willi.sp. pl.1.p. 373 .

Icor. Schreb. l. c. t. $27 \cdot f .3$.

On dry gravelly hills in Virginia. 2. July, Aug. v.v.

Cinna. 10. A. panicula nagna debili, foliis lato-linearibus glabris, ralvula altera infra apicem subaristata, caule glabro.

Cinna alundinacea. Willd. sp.pl.1.p. 31.

On rivers and islands, under the tide waters, common; from Canada to Carolina. 24. Aug. v.v.

moxicana. I1. A panicula cblonga congesta, calycibus corollisque acuninatis subæqualibus muticis. Willd. sp. pl. 1. p. 374 .

In wet meadows: Virginia, \&ic. 24. June. $v v$.

indira.

12. A. panicula contracta mutica, racemis lateralibus erectis alternis, glumæ valvis exterioribus longissimis, foliis longissimis, sensim setaceo-convolutis. Mich. $\mathrm{fl}$. amer. 1.p.52. Willd.sp.pl. 1.p. 375.

In Curolina, Horid, \&c. Michaux. ๑. t. v. s. in Herl. Lamkert.

juncer. 13. A panicnla oblongo-pyranidata, florbus muticis: valvula extina diplo minore, foliis stricte erectis convoluto-setaceis rigidulis. Mich. Jl. aner, 1. p. 52.

In barren sandy places: New Jersey to Florida. 4. July, Aug. v. v.

laterifora. 14. A. paniculis lateralibus terminalibusque coarctatis, floribus muticic, valvulis acutissinis : interioribus ma- 
triandria digynia. Agrostis.

joribus basi barbatis, foliis planis brevibus. Mich $\ell$. amer. 1. p. 53.

In rich soil on the edges of woods, from New York to Florida, especially in the western countries. Y . Jume, July. $v \cdot v$. Apparently a grass worth the attention of the cultivator.

15. A. racemo oblongo, e spicis densifioris interrupto, glunæ racemosa. exterioris valvis in mucronem aristiformem desinentibus, glunsa interiore mutica longioribus. Mich. $f$. amer. 1.p. 53.

On the overflowed banks of the river Mississippi. + .

\section{ANTHOXANTHUM. Gen.pl. 58.}

1. A. spica oblonga ovata, flosculis subpedunculatis arista longioribus. IFilld. sp.pl.1.p. 150.

Icon. Host.gram. 1. t. 5. Fl. dan. 600. Engl. Lot 647.

Common in meadows; probably -brought with grass seeds from Europe. 4 . May-july. v. v.

odoratum.

\section{PHALARIS. Gen. pl. 106.}

1. P. panicula oblonga ventricosa coarctata, glumis acumi- arundinacea . natis. Pers. ench. 1.p.78. Willd. sp.pl.1.p.326.

Arundo colorata. Ait. kew. ed. 2. 1.p. 174 .

Icon. Host. gram. 2. t. 33. Engl. lot. 402.

On river banks, Irequent: Canada to Virginia. 4. July, Ang. $v . v$.

2. P. panicula multiflora stricta, floribus ovatis villosis. villosa. Mich. fl. aner. 1.p. 43.

In woods of Carolina. Michaux. $t$.

76. PHLEUM. Gen. pl. 123. Timothy-grass.

1. P. spica cylindrica longissina ciliata, culno erecto. Willd. sp.pl. 1.p. 354.

Icon. Host.gram. 3. t. 9 .

In fields and meadows, common. 4 . $\delta$. June-Sept. $v . v$.

77. ALOPECURUS. Gen. $p l .102$.

1. A. culmo erecto, glumis villosis, corollis muticis. Willd. pratensis. sp.pl. 1.p. 357 .

Icon. Host. gram. 2.t.31. Envl. lot. 759.

In fields and gardens, frequent, introduced from Europe. 4. May-Aug. v. v.

VOL. I. 
subaristatus. 2. A. culmo erecto, glumis ovalibus obtusis, arista vix exerta. Mich.fl. amer. 1. p. 43.

A. carolinianus, culno radicante, panicula sisbspicata, glumis lævibus, corollis aristatis. W'alt. fl. car $7 \mathrm{t}$ ?

In swamps of Canada. Michaux. 4 . v. s. in Herb. líalter.

78. PANICUM. Gen.pl.107.

* Spicata.

glaucum. 1. P. spica tereti subflavida, involucellis bifloris fasciculatosetosis, seminibus transversim rugosis. Lam. encycl. 4 . p. 736 . Willd.sp.pl. 1.p. 235.

lcon. Host. yram. $2 . t 16$.

Common in fieids and on road sides; probably from Europe. $\odot$. June-Aug. v. v.

iride.

2. P. spica tereti suhcomposita indivisa, involucellis setosis mitibus, seminibus nervosis. Lam. encycl. 4. p. 737 . Willd. sp. pl. I. p. 335

Icon. Host gram. 2. t. 14. Engl lot 875.

In sandy fields: Pensylvania and Virginia. $\odot$. July. $v, v$.

verticillatum. 3. P. spica verticillata, racemulis quaternis, involucelis uniftoris bisetis, culmis diffusis Willd. sp. pl. 1 . p. 3.34 .

P. alopecuroideum. Wult. A. car. 72 .

Icon. Host. gram. 2.t.13.

In sandy woods: New Jersey to Carolina. $\odot$. June, July. v. v.; v. s, in Herl. Walter.

hirtellum. 4. P. spica composita: spiculis adpressis alternis, calycibus gemini, : valvulis omnibus aristatis: extima longissima. Willd. sp. pl. 1.p. 340.

Icon. Fiost. grom. 3. t. 52.

In shady places: Carolina and Florida. Michaux. +.

Crus galli. 5. P. spicis alternis conjugatisque crassis squarrosis, glumis hispidis aristatis, rachi angulato vaginis glabris. Lam. encycl. 4. p.744. Willd.sp.pl.1.p.337.

Icon. Host.gram. 2. t. 19. Engl.bot. $\$ 76$. Fox-tail.

aristatum. $\quad$.P. Plumis omnibus aristatis : aristis prelongis.

mite.

6. P. glumis omnibus muticis mucronatis.

purpureum.

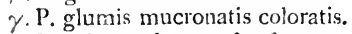

In cultivated grounds, frequent. $\odot . J u l y . ~ v . v$.

Wulteri. $\quad 6 . \mathrm{P}$. spicis alternis erectis solitariis simplicibus, glumis ovatis, muricato-hispidis aristatis: arista altera lon- 
gissima, rachi trigona, vaginis hispidissimis, foliis giabris.

P. muricatum. Mich. fl. amer. 1.p. 47.

P. hirtellum. Wult. fl. car. 72 .

Near the salt-water: Canada and New York. $\bigcirc$. JulySept. v.v.; v.s. in Herb. Lamhert, nec non Walter.

7. P. spicis solitariis alternis simplicissimis, rachi glumisque molle. dense pubescentibus, glunis solitariis alterms ovais muticis bitloris: flore altero masculo, altero hermaphrodito. Mich.fl amer. 1. p. 47.

In sedgy meadows: Florida. Michaux. + .

\section{* Paniculata.}

3. P. racemis linearibus virgatis, glumis clavatis coloratis, fusco-rubenis. pilis sub panicula divisuris, Lan. encycl. 4. p.737.

Icon. Sluan. hist. 1, t. 72 f. 2 ?

In rice fields in Georgia. 4. Aug. v.s.

9. P. panicula oblonga, glunis majusculis glabris viridibus pulcire strialis. Lam. encycl. 4. p. 748.

In Carolina. Fraser. t.

10. P. panicula virgata ramosissima, glumis ovatis acuminatis muticis bifioris, fo.its lungissimis planis.

virgatum.

P. virgatum. Anch.fl amer. 1. p. 352.

P. coloratum. IValt.fl. car. 73 .

On river sides: New England to Carolina. 24. July, Aug. v. v. Very tall.

11. P. panicula capillacea ramosa, glumis striatis pubescentibus, seminibus nitidis, foliis remotis lanceolato-linearitus collo barbatis, caule glabro.

P. nitidum. Lam, encycl. 4. p. 7to. Mich. fl.amer. 1. p. 49 .

B.P. omnibus partibus nulto majus.

Common in woods and tiells. ๑. June-Aug. v. v. striatum. P. larlulatum Mich. I consider a variety of th s species.

12. P. paniculis simplicissimis paucifloris, glumis obovatis, dichotomum. folis lneari-lanceolatis divaricatis glabris basi ec collo barbatis, caule dichotomo.

P. dichotomum. Willd.sp. pl. 1. p. 3\$6.

Iu dry woods, fequent. 4. July, Aug. v. v.

13. P. panicula capillari ramosissima laxa, floribus minutis E 2

nitidum.

majus.

capillare. 
omnibus pedicellatis solitariis oblongo-ovatis acuminatis muticis, foliis vaminisque hirsutissimis. Mich. $f$. amer. 1.p. 47. Willd. sp. pl.1.p. 349.

In sandy fields: New . Jersey to Florida. ๑. JuneAng. v. ${ }^{2}$. This grass is remarkably variable in size. I have seen specimens frum three inches to five feet high.

diffusum. 14. P. panicula simpliciuscula capillari patente, flosculis remotiusculis acutia, culmo simplici, foliis long ss linearibus collo vagin isque villosis. Swartz. prodr. 23.

P. crespitition. Lam. encycl. 4. p. 743 .

In try sandy woods: Virginia, Carolina, \&c. $\odot$. July. v. $r$.

scopariam. 15. P. panicula erecta composita setaceo-ramosissima, glumis obovatis pubescentibus, foiiis lanceviatis villosis. Nich. fl amer. 1.p. 49.

In dry swamps of Carolina. Michaux. $\odot \cdot+$.

roliforum. 16. P. paniculis ninimis lateralibus terminalibusque, glumis ovatis pubescentibus, folitis angust is brevinsculis collo barbatis. I.am encycl. 4.p.7t4.

P. ramulostun. Wiet fl amer. 1.p.30.

In dry fields: Pensylvonia to Cirolina. ๑. July. v. v.

proliferum. 17. P. glaberrimum, paniculis oblongis erectis lateralibus teminaliburque, glumis oblongis acutis striat is, caule ramoso dichotumo. Lam. encycl 4. p. 747.

P. dichotomiforum. Mich. fl. amer. 1. $p 48$.

In rich soil, in woods, on elges of ditches: Pensylva. nia to Carolina. 2\%. Iu y, Aug. v. $v$.

pubescens. 18. P. erectum ranosisimum pubescens, paniculis parvis paucithris laxis sestibus, glumis gluboso-uvatis subpedicellitis pubescentibus. Lam. encycl 4. p. 748 . Mich flamer. $t$. p. 49 .

In shady rich wods : Virginia to Carolina, $\odot$. July. v.v.

laxiftorum. 39. P. panicula patente laxa pilusa, glumis raris obtusis pubencentibus. Lan encych.4. p. 7-18.

In North America. Lamarck. $\odot .+$.

latifulium. 20. P. panicula patenti mediocri, olmmis ovatis acutiusculis subpubescentibus, foliis ovato-lanceolatis amplexicauJibus glabris, vaginis pilosis.

P. latifolium. Willd. sp.pt. 1. p. 350.

clandesti- B. P paniculis inclusis paucifloris. Willd. sp. pl.1. p.351.

num., In shady woods: New England to Geoigia. 2f. July. v. $v$. 
21. P. erectutn, paniculæ ramis simplicibus interrupte racemulosis, thore accessorio neutro: hermaphrodito valanceps. vis prinariis semibreviore obtusissimo, folits longis, vaginis compressis pilosis. Mich.fl. amer. 1.p. 40.

In shady wet woods: Carolina. Michaux. + .

22 P. debile, glaberrimm, panicula gracili longa : ramulis raris adpressis, gluma nembranacex valvis subeogualibus lanceolatis, fuliis angustis longis. Mich. $f$. amer. 1. p. 50 .

P. nudum. IV Thlt. fl. car. 73 ?

In Carolina and Geurgia. 4 . July, Alig. v. v.

23. P. glabrum, erectum ; panicula pyramidata, ramis paucis dissitia, plerisque geminis simpliciusculis divaricatis retlexisque, floribus muticis binis : altero pedicellato neutro, fulits angusto-longis. Mich. fl. amer. 1. p. 50.

In high nountains of Carolins. Nichaux. + .

24. P. glabrum, elatum; paniculis pyramidatis lateralibus geminis elongato-peduculatis teminalibusque: ramulis alternis divaricatis, glumis alternis oblongis acutis p dicellatis coloratis, folits longis : collo subbarbato, caule compr.sso.

In ditches and near ponds: New Jersey to Virginia. 4. July. $v . v$. A very handsome grass, sometimes five teet high; panicle a dark purple nixed with green.

25. P. panicula solitaria folio terminali breviora : ramis simplicibus tiexuosis, glumis alternis pedunculatis obovatis turridis: valvulis multistriatis acutis, foliis !inearibus sirictis sensim acutissimis, supra striatis scabris suluius pilosis, vaginis longissime pilosis.

On the banks of Delaware: Pensylvaniz. $\odot$. July. v. v.

\section{DIG'TARIA. Hall. Crop-grass.}

1. D. spicis p'uribus, floribus imbricatis geminis, vaçinis folisque papilloso-pilosis, culmo repente. Mich. $f l$.

Sanguinale. anier. 1. p. 45 .

Panicum sanguimale. Willd. sp. pl. 1.p. 342.

Paspalum sancuinale. Lam. encycl. 5. p. 33.

Syntherisua præcox. Walt. fl. car. 76 .

Icon. Host. gram. 2.t.17. Curl. lond. 4. t.7.

Common in cultivated ground. $\odot$. June-Aug. v. $v$.

2. D. spicis piuribus $(2-5)$ : erectis filiformibus, floribus

divaricatum.

elongatum.

strictum.

melicarium 
remotis hirsutis geminis : altero vix pedicellato, folis brevibus, vaginis pilosis, culmo erecto glabro superne nudo. Mich.fl. amer. 1.p. 45.

Syntherisma villosa. IValt. $f$ car. 77 .

Panicum filiforme. IVilld. sp. pl. 1.p.343.

Paspalum debile. Lam. encycl. 5. p. 34 .

In sandy dry fields and on hills : New Jersey to Georgia. $\odot$. May-Aug. v. $v$.

paspaloides. 3. D. spicis geninis basi subvillosis, rachi latiuscula giabra, floribus solitariis bufariani imbricatis glabris, foliis patentibus, vaginis glabris collo villosis, culnı repente. Mich.fl. amer. 1.p. 46.

Paspalum supinum. Bosc. in lam. encycl. 5. p. 29.

On hills of red clay and iron ore: Virginia. $\odot$. July. $v, v$.

serolina.

4. D. spicis pluribus setaceis, floribus binis vel ternis minutis pedicellatis, foliis vaginisque villosis, culno decumbente. Mich.fl. amer. 1. p. 45 .

Syutherima serotina. Wult. $f l$. car. $\% 6$.

In low wet places: Carolina. $\odot$. June-Aug. v. v.

80. CYNODON, Richard in Pers. ench. 1. p. 85.

Dactylon. 1. C. spicis digitatis patentibus, basi interiori villosis, floribus solitarits, sarmentis repentibus Pers.l.c.

Panicum Dactylon. IVilld. sp. pl. 1.p 342.

Digitara Dactylon. Allion. $f$. ped. 11. $23 \mathrm{~s}$.

Parpalum Dactylon. Lam. encycl. 5. p.32.

Paspalum præcox. Walt.fl. car. 75.

On road sides and in rultivated ground, frequent. 4 . v. v.; v. s. in Herb. Walter.

\section{PASPALUM. Gen. pl. 81.}

setaceum. 1. P. spica unica gracili, glumis geminis suborbiculato-nbovatis glabris, foliis villosis, culmo setaceo erecto. Mich. fl. amer. 1. p. 43.

P. dissectum. Walt. ll. car. 75 .

In dry sandy fields in Lower Carolina. $\odot$. June, July. $v$. $s$.

delile. 2. P. spica plerumque unica tenui, glumis uniseriatis, contigue alternis solitariis pubescentibus, brevi-obovatis, foliis birsutis, culmo debili setaceo. Mich. $f$, amer. 1. p. 43 .

On the sea-shores of Carolina and Georgia. Michaux. + . 
3. P. spicis alternis subbinis, glumis subtriseriatis geminis cilialum. orbiculato-obovatis obtusis glabris, foliis lanceolatolinearibus serrulato-ciliatis, culuo decumbente. Mich. $f$ amer. 1 p. 44.

In clay soil where iron ore abounds : Virginia and Carolina. 4.July. v. v.

4. P. spicis pluribu; alternis, glumis biseriatis suborbiculato-ovatis glabris lavibus, foliis g'abris, ligula ciliata, vaginis compressis, cuule suberecto. Mich. fl. amer. 1. 1. 44.

P. lentifernm. Lam. enrycl. 5. p. 30.

P. nembranacemu. W' Halt. H. car. 75 .

In dru meadow and grassy hills : Pensylvania to Carolina. 2). June Aug. v. $v$.

5. P. spicin pancis erectis, glumis biseriatis suborbiculatis floridanum. glabic le:ibus, foliis interioribus pilssis, superioribus glatris, vaginis longissinis, caule erecto. Mich. $f$. amer. 1. p. 44 .

P. virgatum. Walt. $f$. car. 75 ?

In sandy fieids: Carolina to Georgia. $\odot$. June. v. s.

6. P. glaherrimum; spicis pluribus altcrnis erectis, glumis plicalum. subtriseriatis brevibus ovatis rufecentibus glabris, valvula plana juxta margines transverse plicata, folits longis, caule erecto. Wich fl amer. 1.p.45.

P. paniculatum ltalt.fl. rar. 75 ?

In Georgia and Florida. Michaux. +.

7. P. spiculis elongato-racemosis subverticillatis p tentibus, stoloniferum. glumi: altems ovatis scurulato ciliatis transverie-rugosis, foliis brevibus basi subcordatis, caule basi :rostrato.

P. stowniferum. Bosc in linn. trans. 2. p. 83.

P. ricemostum. $J$ cq. ic rar. t. 302.

Milium hatifolium. 1.av. ic .3.p.37.t. 273.

Icon. Busc.l. c. Jacy. l. c.

In cudar swamps of New Jersey. 21. July, Aug. v. v. I found this plant among a parcel of grasses and other plants collected in autumn 1811, in Monmouth couniy, New Jersey. As I had no time to examine the collection then, I was much surprised on finding this very interesting grass among them. That it is the same with P. stoloniferım of Peru, I have no dotibt, as I carefully compared it with the specimens in the collection of A. B. Lambert, Esq. 
82. ARISTIDA. Gen. $p l .125$.

dichotoma. 1. A. cespitosa, culmis dichotomis, floribus subspicatis, subuniaristatis: arista contorta gluma breviore: lateralibus brevissimis. Mich. fl. amer. 1. p. 41.

On dry gravelly soil: New England to Carolina, com. mon. ơ. May-July. v. v. Resembles Nandus stricta.

stricta.

2. A. culmis folisque stricte erectis, racemo longo spicafo coarctato: aristis giuma longioribus, foliis convolutofiliformibus, glabris. Mich. fl. amer. 1. p. 41.

In shady rocky situations, on river sides: Virginia, $\mathrm{Ca}$ rolitsa, \&c. 4 . June, July. $v v$.

oligantha. 3. A. culno stricto subramoso, foliis convoluto-filiformibus, floribus distantibus solıtariis, aristis longis divaricatis. Mich. A. amer. 1. p. 41 .

A. adscensionis IValt. $f$. car. 71 .

On the banks of rivers, in rocky places: Illinois, Virginia, sic. 4. June, July. v. v.

\section{S3. STIPA. Gen. pl.}

juncea.

1. S. foliis convoluto-filiformibus, panicula laxa, calycibus subaristatis semine longioribus, aristis longis vix pubescentibus.

S. juncea. Willd. sp.pl. 1.p. 440 .

Icon. Desf: atl. 1.t. 28.

On the banks of the Missouri. M. Lewis. 4. Aug. $v$ s. in Herl. Lewis. By a careful comparison of this plant and one trom the north-west coast of America, collected by Mr. Menzies, in possession of A. B. Lambert, Esq. and a specimen from the south of Furope in the same collection, I could find no other distinction from S. juncea than tlic seeds being more pubescent, and the arista not so much as figured in Desfontaines' Flora.

canadensis.

2. S. foliis setaceis, panicula parva, calycibus glabris obtuse-ovatis semine pubente æequantibus, aristis crassis brevibus. Lam. encycl. 7.p. 452 .

A. juncea. Mich.fl. amer. J.p.54.

In rocky places: Canada, Hudson's Bay, \&c. +

avenacea.

3. S. foliis striatis glabris, panicula patente subunilaterali: ramis verticillat is ramulosis, calycibus acutis membranaceis semine glabro æquantibus, aristis nudis, tortuosis.-Willd. sp.pl. 1.p. 442. 
In barren dry woods: Virginia, Carolina, \&c. 4 . June. $v$. $v$.

4. S. foliis convoluto-filiformibus, panicula pauciflora : ramis simplicibus 1-2-thoris, calycibus oblongis acuminatis semine vix longioribus, corollis stipitatis: stipite barbato.-Vahl. symb. 2.p.24.

S. barbata. Mich. fl. amer. 1. p. 53.

S. avenacea. Halt. $\beta$ cur. 77 .

S. virginica. Pers. ench. 1. p. 99.

lcon. Cav. ic. 5. t. $400 . f .2$ ?

Winter-green.

In shady woods: Viiginia to Georgia. 4. July, Aug. r. $v$.

5. S. foliis tereti-filiformibus longissimis, panicula effusa tenuissime capillacea, calyce corolla parva triplo bresericea, viore, aristis nudis strictis. Wich. fl. amer. 1, p. 5t.

S. capilluris Lam. encycl. 7. p. 450.

S. difiusa. Iralt. fl.car. 78 .

In sandy fields: New Jersey to Carolina. 4 . JuneAug. $v, v$. This elegant grass, whose silky purple panicles exceed in beauty any other I know, seens to deviate from the rest of this genus, particularly in the short glumes of the calyx, and almost deserves to be a separate genus.

6. S. foliis striatis giabris glancescentibus, spicis alternis paniculatis expansis, Horibus sessilibus remotis, calycibus corolia longioribus, arista brevissima nuda.Lam. encycl. 7. p. 453 .

In Carolina. Bosc. + .

7. S. foliis arundinaceis, panicula elongata aristata, pedunculis articulatis strictissinis, aristis nudis subfex-

licolor. nosis. Lam. encycl. 7. p. 453.

In Caroina. Fruser, + .

\section{SACCHARUM. Gen.pl. 104.}

1. S. vaginis lanatis, gluma villis breviore, valvis exterioribus villosis. Pers. ench. 1. p. 103.

expansa.

Eriantius saccharoides. Mich. fl. amer. 1. p.5.5.

Anthoxanthum gigantenm. Walt. fl. car. 65 .

Andropogon culmo paniculato. Gron. fl. virg. 133.

In low places generally among rocks : Virginia to Florida, rare. 4 . July, Aug. v. $v$. From five to nine feet ligh, with very large panicles, which when in flower are cxtremely handsome. 
brevilarlis. 2.S. vaginis collo subvillesis, panicula stricta, glema vijo lis loniore, valvis acutissimis nudis. l'ers. ench. 1. p. 103.

Erianthus brevibarbis. Wich fl. amer. 1. p. 55.

On clry hills, in ntountains: Virginia Tennassee, Carorolina, \&c. 4. July. v. v. Nut above two feet high.

\section{ANDROPCGON. Gen. $p l .1566$.}

\section{* Panicula terminali.}

nutans.

1. A. panicula ramosa coarctata nutante, florihus geminatis aristatis, calycibus hirutis, hermaphrodito sessili, masculo pedicellato caduco. Willd. sp pl.4. p. g06.

In barren dry situations : New England to Florida. 4. June, July. $v . v$.

avenaceus. 2. A. foliis asperis vaginisque glabris, panirula nuda subpyramidatim obionga muliflora, flotibus rufescentibus trianclris, glumæe valva altera villusa, arista valde contolta. Nich. fl. amer. 1.p. 58.

In the prairies of Illinois. Michaux. + .

ambiguus.

3. A. foliis amplexicanlibus subcordato-lanceolatis, panicula ramis pronisse setaceis simplicibus erutis, glumis solitarie alternis mifloris, flore imberbi longisime aris. tato trandro, flosculi accessorii incremento aristifonni. Mich. fl amer. 1. p. 58.

In sandy woods: Carolina. Michaux. + .

alopecuroides.

4. A. panicula simplici oblonga elongata, spicis verticillatis simplicibus, floribus arintatis geminatis, aiters sensili, altero perlicellaıo, rachi lanata, lana floribus longriore. lVilld. sp.pl. + p. 911 .

J con. Sloan. hi.t. 1.t. 70.f. 1.

In North Anerica. Linn. sp. pl. 1045. +.

Thin species is very doubtful as a North American plant; the synonym of Gromovius evidently belongs to Saccharum gigantum. Neither Michux nor any other botaniat (as far as I could learn) collected it in North Ame: ica.

Scoparium. 5. A. spicis simplicihus pedunculatis geminatis stricte paniculatis, foribus geminis, hermaphrodito sessili lanceolato aristato, neutro pedicellatu aristato, rachi ciniata.- Mich. $f$ amer. 1. p. 57 .

A. purpuraicens. Willd. sp pl.4. p. 913 .

A. divaricatum. Willd. sp.pl.4. p.y05? 
Common in old fields and dry meadows ; called Proom. grass. 4. June-Aug v.v. A very obnuxious weed.

* Spicis conjugatis s. fasciculatis.

6. A. vaginis margine villosis, paniculis lateralibus fascicnlatim polystachyis, floribus monandris, arista 4-5tuilo glome longitudine, valvis anterioribus glabris. Nich fl. amer. 1. p. 56.

Cinna giomerata. Walt. $f$. car. 59 .

In low meadows and woods : Carolina and Florida. $4 .+$.

7. A. vaginis glabris, culmis erectis, spicis lateralibus dissitis, floribus nonandris, arista longa recta, valvis interioribus glabris. Mich fl. amer. 1. p. 57 .

Cinna lateralis. Walt. $f$ l. car. 59.

In dry woods and old fields, frequently found on high mountains: Pensylvania to Ftorida. 4.July. v.v.

8. A. ramis remote alternis solitariis simplicibus plerisque tristachyis, spicis distanter alternis bifidis, villis incolucri gluma brevioribus, floribus triandris, valvis interioribu; subvillosis, intima ex incisua aristam kngam contortam emittente. Mich. fl. amer. 1.p. 57.

In the aountains of Virginia and North Carolina. 4 . July. vv.

9. A. panicula spicis conjugatis, pedunculis simplicibus, rachi lanata. flosculis muticis: mascula tabescente. lV'illd. sp. pl 4. p. 916.

In Virginia. Gronov. $4 .+$.

10. A. spicis conjugatis paniculatis, panicula bracteata fastigiato-corymbosa, fioribus ternis muticis, intermedio hermaphrod to sessili, lateralibus netitris pedicellatis, rachi longissime ciliata. Willd. sp. pl. 4. p. 916 .

In Virginas. Gronov. 24. +.

11. A spicis digitatis subquaternis, floribus geminatis, hermaphrodito sessili aristato, inasculo nutico pedicellato, rachi pilosa. Wilid. sp.pl 4. p. 910.

In rocky sitnations : Canada to Virginia, rare. 4. June, July. v. v.

86. ATHEROPOGON. Muhll. in Willd.sp.pl.4. p. 937.

1. Atheropogon. IVilld. l. $c$.

In Noth America. Muhll. +. Abont a foot high;

apludoites. leaves narrow; flowers alternate in a spike.

ternarius.

virginicus.

bicornis.

furcalus.

dissiliflorus.

bicornis.

(Jurcalus.

nacrourus. 
87. TRISETUM. Pers. ench. 1.p. 97 .

pratense. 1. T. panicula subcontracta, spicis nitidis, vaginis longis striatis glabris, foliis superne villosis. Pers. l.c.

Avena flavescens. Willd. sp. pl. 1. p. 449 .

Icon. Selhreb. gram. t. 9. Host. gram. 3. t. 38.

In meadows: Pensylrania and Virginia, rare. 4. July. $v, v$.

\section{Sg. AIRA. Gen.pl. 112 .}

pumila.

aquaica.

meitcoides.

1. A. panicula parva fastigiata (pauciflora): pedicellis brevibus, floribus muticis obtusis calyce duplo longioribus: valuulis margine membranaceis, foliis planis glabris, culno erecto vix foliis aitiore.

On barren clay soil, near brick-yards : Pensylrania. 4 . June. $v, v$. Scarce au inch high; in close tufts.

2. A. panicula patente semiverticillata, floribus muticis obtusis lævibus calyce longioribus, foliis planis, culmo repente.-Willd. sp. pl. 1. p. 376 .

Icon. Host. gram. 2. t. 41 . Engl. bot. 1557.

On water sides and sometimes fleating in water, frequent. 4. May-July, v'v.

3. A. panicula parva subracematim coarctata: gluma communi partialibusque majusculis lineari-lanceolatis $\mathrm{mu}$ ticis : Horibus basi villusis, rudimento flosculi tertii, folis planis glabris, culno crecto. Wich.flamer. 1. p. 62 .

In shady woods: Canada to Pensylvania. 24. July.v.v.

oliusata. 4. A. panicula in racemum oblongum confertiforum coarctata, foribus muticis apice compressis, glumævalva altera angusto-lineari acuta: altera laro-obovali rotundato-obrusissima, foliis planis, culmo gracili erecto. Mich. fl. amer. 1. p. 62 .

In dry fields: New England to Florida. 2f. June, July. $v . v$.

brevifolia. 5. A. panicula semiverticillata patente : ramis simpliciusculis alterniforis, fioribus muticis calycem xquantibus, glumis mnibus lancenlatis acutis, foliis planis, culmo stricto glabro nudinsculo.

In the plains of Missouri. M. Leuis. 4 . June, July. $v$. s. in Herb. Lewis. This grass is the most common in those plains.

capillacea. 6. A. panicula capillacea effusa, flosculis muticis calyce 
longioribus: altero pedicellato, glumis acutis carina asperis, foliis angustis gl:ibris brevibus, culmo erecto.

A. capillacea. Lam. illustr. 1. p. 177.

On slate hills and in sandy fields: V'irginia to Carolina. 4. July. v.v. About eight inches high; panicle purple.

7. A. foliis setaceis, vaginis angulatis, floribus paniculatospicatis, flosculis basi aristatis. IVilld. sp. pl. 1.

precox. p. 380 .

Icon. Fl. dan. 383.

On dry sandy hills : Virginia, \&c. ๑. June. v. $v$.

8. $\Lambda$. panicula patente, petalis aristatis basi villosis: arista recta brevi. Willt. st. pl. 1. p. 378.

Icon. Host. gram. 2. t.42. Engl. lot. 1153.

In meadows, frequent. 4 . June, July. v. $v$.

ß. A. foliis subsetaceis. Mich. fl. amer. 1. p. 61.

In Canada. +. Appears to be only a variety of A. cespitosa.

9. A. panicula patente trichotoma: pedunculis flexuosis, aristis geniculatis, foliis setaceis, culmo subnudo.Willd. sp.pl. 1.p.37s.

Icon. Host. gram. 2. t. 43. Engl. bot. 15i9. Fl. dan. 157.

In shady woods and meadows: Canada to Carolina. 4. July. $v . v$.

10. A. panicula sparsa purpurea, floribus aristatis, glumis altera bifida nervo aristata: altera integra plumosa concava, foliis subulatis, culmo crecto.-Walt. $f l$. car. $7 \mathrm{~s}$.

In Carolina. Wult:r. + .

\section{MELICA. Gen. pl. 113.}

1. M. panicula laxa pauciflora: ramulis simplicibus, floribus obtusis imberbibus, caule erecto glabro.-Mich.

glalra. fl. amer. 1. p. 62.

M. mutica. Wult. fl. car. 78 .

Icon. Moris. hist. 3. s. 8. t.7.f. 51 .

In shady places: Virginia to Florida. 24. July. v. s.

2. M. panicula diffusa ramosissima, foribus acutis imberbibus, caule erecto pubescente.

M. altissima. Walt. fl. car. 78.

In sandy swamps: Virginia and Carolina. 24. June. $\iota$.s.

purpurea.

cespitosa.

ambigua.

flexuosa.

diffusa. 


\section{HOLCUS. Gen. pl. 1565.}

striatus.

fragrans.

lanatus.

1. H. panicula conferta oblonga: pedunculis brevissimis cuntertis ramosis, glumis bifloris striatis muticis acuminatis, folits planis longis.-Willd. sp. pl. 4. p. 935 . In swamps of Virginia. Clryt. + . This species appears to belong to Aira.

2. H. panicula patula, glumis triforis muticis, flosculis contertis, hermaphroitito intermedio diandro glabro, masculis triandris, valvula exteriore levissime ciliata, dorso lavibus. $\quad W$ illd. sp pl.4.p. 936.

H. odoratus. Mich. fl. amer. 1. p. 56 .

In low meadows on the borders of lakes: Canada to Virginia. 24. July. v. $v$. A very fine grass.

canclus.

3. H. glumis bifioris, hermaphrodito mutico, masculi arista fiore multo breviore recurva. Willd. sp. pl. 4 . p. 9.33 .

Icon Host. gram, 1. t. 2. Sihrel. gram. t. 20.f. 1 .

In low meaduws, frequent. 4 . June, July. v. $v$.

92. SORGHUM. Pers. ench. 1.p. 101. Broom-grass.

saccharatum. 1. S. panicula subverticillata patentissima, seminibus ellipticis glumis villosis persisientibus tectis. Pers. ench. 1. p. 101 .

Icon. Mich. in act. helv. 8. t. 4. f. 1 .

Cultivated for the purpuse of making brooms, and frequently found in an apparently wild state. $\odot$. July. $v . v$.

\section{POA. Gen. Hl.114. Meadow-grass.}

tricialis. 1. P. panicula difrusa, spiculis trifloris, glumis lanceolatis quinquenervibus basi villo connexis, ligula elongata. Smilh fl. lrit. 1. p. 103. Willd. sp. pl. 1. p. 387.

Icon. Host.gram. 2. t. 02 Engl lot. $t$. 1072.

Common in meaduws and fields. 24. June-Aug. $v . v$.

pratensis. 2. P. panicula diflusa, spiculis qualrithoris, glumis lanceolatis quinquenervibus villo connexis, ligula abbreviata obtusa. Smithfl. brit. 1.p. 104. Willd. sp.pl. 1. p 388.

Icon. Host. gram. 2.t. 61. Engl. lot t. 1073.

In grassy fields, not so frequent. 4 . May, June. v. . 
3. P. panicula diffusa, spiculis ovatis subquadrifloris, glumis lanceolatis trinervibus, ligula brevi truncata. Schrel. viridis. gram.

In all meadows and grass plots, common. 4. JuneAug. $v . v$.

4. P. panicuia foliisque attenuatis, spiculis lanceolatis subtrifloris, glumis acuits obcolete quinquenervibus, ligula brevissima crenata. Snith fl. brit. 1.p. 106.

Jcon. Host. gram. 2. t.71. Engl. lot. 1205.

In grassy shady places, rure. 4 . June, July. v. v.

5. P. panicula divaricata, spiculis oratis, flosculis remotiusculis quinquenervibus liberis, culni obliquo compresso. Sinith fl. brit. 1. p. 105. Willd. sp. pl.1. p. 390 .

Icon. Host gram. 2. t 64. Leersfl.herl. t. 6.f. 1 . In fields and grass plots, trequent. $\odot$. April-Sept. v.v.

6. P. panicula difinsa, spiculis quadrifloris cordatis, glumis ovat is subtalcatis liberis, ligulis inferioribus brevisimis. Smith fl. brit. 1. p. 100. Willd. sp. pll. 1.p. 3s.j.

Icon. Engl lot. 1003. Scheuchz. gram. l. 3.

On the Allegany monntains, frequent. 2. July. v.v.

7. P. panicula diffisa, spiculis ovato-oblongıs nitidis. Willd. sp. pl. 1. p. 390 .

In Pensylvania and Virginia. $4 . v$. s. in Herb. Walter.

8. P. panicula secunda coarctata, culmo adscendente compresso, Hosculis angulusis basi villo complecato connexis. Smith fl. brit. 1. p 99. Willd. sp. pl. 1. p. 397 .

Icon. Host. gram. 2. t. 70. Engl lot. 355 . Blue-grass. In dry fields and meadows, common. 24. June-Aug. v. $v$.

9. P. panicula æquali diffusa, spiculis ovatis quinquefloris, foribus liberis septemnervibus obtusia, culmo sulcato subangulato, radice subrepente. Willd. enum. 105. Willd.sp. pl. 1. p. 389.

P. striata. Mich.fl. amer. 1. p. 69.

P. lineata. Pers. ench. 1. p. 89.

In mealows and fields, conmon. 4. June-Aug. v. $v$.

10. P. panicula laxa patentissima capillari, sp culis tri-quinquefloris, floribus ovat is acutis pubescentious, fuliis collo pilosis, culmo ranosissimo.-Willd. sp. pl. 1. p 394.

Icon. Moris. hist 3.s. 8 t 6.f. 33 .

In fields and sandy woods : Canada to Florida, common. ๑. June-Aug. v.v. Very variable.

nemoralis.

annua.

alpina.

flava.

compressa.

nervata.

capillaris. 
tenella.

crocata.

hirsuta.

Qqualica.

parviflora.

\section{crocata.}

11. P. panicula subverticillata capillari, pedunculis flexuosis, spiculis linearibus subsextoris pedicellatis, floribus oblongis acutis minutis glabris, foliis brevibus planis apice subulatis glabris, vaginis collo barbatis culmo decumbente.

P. tenella. Willd. sp. pl. 1.p.395?

In sandy fields: New Jersey to Carolina. $\odot . J u l y . v . v$; $v$. s. in Herb. Lamlert. sub nomine P. pilosce.

12. P. panicula laxa patula, spiculis ovatis quadri-quinqueforis pedicellatis, floribus oblongis subpubescentibus. foliis glabris, vaginis collo nudo, culmo erecti glabro. Mich. fl. amer. 1.p. 08.

In Canada, Hułson's Lay, a d Lake Mistassins. Michaux. $+$

13. P. panicula ramosissima capillari, spiculis sparsis longe pedicellatis subquinqueforis, floribus oblongis acutis glabris, foliis culmo longioribus glabris, vaginis lirsutissimis, culmo erecto crisso. Wich. fl. amer. 1. p. 68.

In sandy fields: New Jersey to Carolina, frequent. $\odot$. July. v. $v$.

14. P. panicula erecta semiverticillata: ramulis flexuosis, spiculis ovatis quinqueforis crassis, floribus obtusis glabris septemnervibus, culmo erecto glabro tereti.

P. aquatica. Willd. sp.pl. 1.p.385?

In ditches, frequently in salt-marshes: Canada to Virginia. 4 . Jube-Aug. $v \cdot v$. It approaches P. aquatica very nearly, but seems to difficr in halitus and other characters considerably.

15. P. panicula difrusa capillari semiverticillata ramosissima spiculis parris subquadriforis, Horibus oblongis subacn is exquisite striaris, foliis distichis culmum superantibus glabris, ligulis lanceolatis acuminatis, culino exerto vaginato.

P. striatid. Lam. encycl. 5. p. 84?

In close copses and shady places: New York to Virginia. 4. July. v.v. About a foot high; very slender.

subverticilla - 16. P. panicula laxa basi subverticillata, pediceliti elongatis, ta. spicuit; raris subquanquetoris, cal,cibus crassiusculis subangulat is obtusis. Pers. ench. i. 1. 94.

P. laxa. Lain. illustr. 1. p. 153.

In Virginia. Lamarck. +.

Eregrostis. 17. P. panicula patente pyramidata, ramulis divaricatis, spiculis linearibus decontoris, מs ribus ovatis acatis tri- 
nervibus glabris, foliis brevibus.-Willd. sp. pl. 1. p. 392

Icon. Hast. gram. 2. $t 69$ ?

In low sandy grass tields: Virginia, Carolina, sic. 4. June, July. $v . v$. The spikes are of a greenish colour and long.

18. P. panicula erecta: ramis inferioribus inferne nndis, sni-

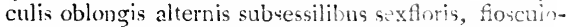
rum valva exterore dorso inferne nambinhorue vil. lo:a apice quinguetida, viginamm collo axilisgue paniculæ pilosis, foliis culmogue erecto rlabris.

P. seslerioides Mich an amer. 1. \%.63.

In mountain mearlows, fiequent. New England to Carolina. Co.nmonly called Red-top. 4. Jaly, Aur. $v . v$. A most excellent orass. I have seen mourtain neacows in Penovlvanis, where they now this grass twice a year, producin most excel!ent cro's esch time, without manure, or any other trouble thon the mowing, lasting for the space of sixiwen yoars, withotit the last decline in the crops, the soil at the same time being a very indifierent one.

19. P. panicula laxa patula erecta, spiculis linearihus duodecimioris : rachi deflorata valvutis tosculorum interıribus persistentibus pecinata, fioribus ovatis acuninatis trinervibus, vaginarum collo axillisque panıcule pilosis, foliis culmoque erecto glabris.-Mich. $f$. amer. 1. p. 69 .

In saudy fields : New Jersey to Carolina, and the westen territories, frequent. $\odot . j u l y, v v$.

20. P. panicula divaricata ramosissima, spiculis pendulis linearibus decemfloris, fluribus ovatis acutis mar rine dorsoque scabris, vaginarun collı axıilisque panicula pilosis, foliis culnooque erecio orevi ytabris.

Poa amabilis. Walt fll car. 80.

In dry barren sand. fields : New Ycrk to Cartina. $\odot$. July. $v \cdot v$. A beautiful grass: the lare pancle is purple mixed with green stripes.

21. P. paniculis fasciculatis, spiculis subsessilibus longissimis multiforis, floribus obion is acutis lar's, fol is bre. quinqueficia.

pectinacea. vibus pubescentibus, cuimo ramoso repente. - 1ich́. fl. amer. 1.p. 69 .

P. hypnoides. Lam. encycl. 5. p. S7.

Icon. Mich. l. c. t. 11 .

In mossy swamps and shac'y places: Persyluania, Virvol. I. 
ginia, and on the banks of the Mississippi. ๑ . Iuly. $v . v$. This is the most delicate grass in North America.

\section{BRIZA. Gen.pl. 115.}

Eragrostis.

1. B. spiculis ovali-lanceolatis vigintifloris, floribus subacutis, collo vaginarum piloso, culmo geniculato decumbente. Mich. fl. amer. 1. p. 72 . Willd. sp. pl. 1. p. 405.

B. caroliniana. Walt. fl. car. 79 .

Icon. Schreb. gram. 2. t. 39.

In wet fields and swamps : Virginia to Carolina. $\odot$. Inne. $v, v$.

canadicnsis.

2. B. panicula laxa, spiculis erectis 4-10-floris, gluma communi parvula, florum valva exteriore acuta ovata, foliis longis, culmo erecto. Mich. fl. amer. 1.p. 71 .

In Canada. Michaux. +.

virens.

3. B. spiculis ovatis, calyce flosculis (7) æquali, pedun. lis longis. Walt. fl. car. 79 .

In Carolina. Walter. + .

\section{UNIOLA. Gen.pl.116.}

latifolia. 1. U. panicula laxa, spiculis omnibus longe pedicellatis, calyce trivalvi, floribus monandris subfalcatis carina pilosis, foliis latis planis. Mich.fl. amer. 1. p. 70.

On the Allegany mountains, in shady woods, among rocks. $\psi$. June. v.v. A very handsome grass.

paniculata.

2. U. panicula longa, spiculis subsessilibus, calyce mulijvalvi, floribus triandris carina glabris, foliis convolutis, culno altissimo.-Willd. sp pl. 1.p. 406 .

U. maritima. Mich. fl. amer. 1. p. 71 .

Icon. Catesl. car. 1. Ł. 32. Pluk. alm. t.32.f.6.

On sandy sea-shores: Virginia to Florida. 24. June, July. $v . v$.

sracilis.

3. U. panicula longissima subspicata, ramis brevibus adpressis, spiculis subsessilibus, floribus monandris divaricatis actuminatis glabris, calyce trivalvi, foliis planiusculis, vaginis culmoque glabris conupressis.-Mich. fl. amer. 1.p. 71 .

U. virgata. Bartram. in Herb. Banks.

Holcus laxus. Willd. sp. pl. 4. p.934.

In shady rocky situations : Virgitia to Georgia. 24. July. $v$. $v$. 
96. FESTUCA. Gen. pl. 119 .

1. F. spiculis alternis sessilibus erectis subquinquefloris, floribus subulatis glabriusculis, aristis longis scabris,

spicata. foliis linearibus culnoque glabris.

On the waters of the Missouri and Colnmbia rivers. June. v. s. in Herb. Lew's.

2. F. panicula simplicissima secunda, spiculis subnovemfloris aristatis, foliis lineari-setaceis, ligula biaurita, culmo superne tetragono, basi ramosa. Willd. enum. 113. IVilld. sp. pl. 1. p. 419.

F. bromoides. Mich. fl. amer. 1.p. 66.

F. octoflora. Walt. fl. car. 81.

Common in sandy fields. $\odot$. May-July. v. $v$.

3. F. panicula coarctata simplici, spiculis subquadrifloris, floribus subulatis aristatis, culmo foliisque tcnuissime setaceis.-Wich. fl. amer. 1. p. 66.

F. quadriflora. Walt. $f$. cur. 81 .

In dry fields: Virginia and Carolina. $\odot$. June. $v, v$. Appears to be different from F. Myurus of Linnæus.

1. F. panicula secunda diffusa, flosculis aristatis, culmo tereti, foliis caulinis planis, radice fibrosa. Smith $f$. brit. 1.p. 115. Willd. sp.pl.1.p 421.

Icon. Host. gram. 2. t.83. Engl. lot. 470.

In dry pastures, frequent. 4 . July. v. $v$.

7. F. panicula subdiffusa nutante ramosissima laxa, spiculis ovato-lanceolatis acutis, flosculis cylindricis obsolete elatior. nervosis. Smith fl. amer. 1.p. 124. Willd. sp. pl.1. i. 425 .

Icun. Host.graml. 2. t. 79. Engl. lot. 1593.

In wet meadows: Pensylvania, New England, \&c. introduced with grass seeds from Europe. 4 . July. $v$. $v$.

durinscula.

Myurus.

tenella.

6. F. panicula elongata, ram:s approximatis strictis, spiculis oblongis 8 - 10 -floris adpressis aristatis. Willd. enum.

polystachya. 117. Mich. Al. amer. 1. p. 66.

In dry meadows: Virginia and Carolina mountains, Illinois, \&c. 2\%. July. v. v.

7. F. panicula stricte contracta, ramis simplicibus sparsis, diandra. spiculis tereti-lanceolatis subquinqueflor is, floribus acuminatis diandris, foliis latis planis, caule erecto asperrimo. Mich. fl. amer. 1. \%,67.

Icon. Mich. fb, amer. 1.t. 10. 
In shady woods, in the western parts: Kentuky, Tennassee, \&c. $2 !$ July. v. $v$.

grandiflora. 8. F panicula simp'iri erect!, spicnlis perpaucis subseptemAoris, flosculis acutis distantibus. Lam. illustr.1. p 101 .

In Carolina. Fraser. + .

fuitans. 9. F. panicula longa laxa, ramis simplicibus, spiculis adpres.is tercti-linearibus multiftoris, floscnlis muticis stristis, culmo decumbente foliisque glaberrimis.Willd sp pl. 1 p. 42ij.

Icon. Host gram. 2. t. 77 . Engl. lot. 1520.

In ditches and slow-tlowing waters, frequent. 24. June 一 Aug. v.v.

distichiphyl- 10. F. panicula racemoso-coarctata, spiculis approximatis la. adpressis subsex for is nuticis, foliis convolnto-subulatis rigidis alternis distichis, culmo erecto glabro.Micri.fl amir. 1. p. 167.

F. triticea. Lam illus!r. 1.p. 190.

Uniola spicata. Hilld.sp.pl. 1.p. 406.

Icon. Pluk alm.t.33.f 4 ?

In salt meadows, common along the coast from Canada to Florida. 24. July, Aug. v.v.

pocooides. 11. F. panirula sube onferta, ramis inferioribus simplicibus, spiculis atternis oblugis subessilibus muticis, foliis planis glabenimis. - Nish fl. amer. 1. p.67.

Ot the banks of the river st. Laarence. $4 .+$.

12. F. panicula nutante fatula, spicusis oblongo-lanceolatis compressis of tofor is mutici4. folioram vaginis apice barbatis, ratice fibrowa. IVilld. enum. 115.

Icon Wille. hort.ler.t. 3.

In rich bottum lands: Pensylvania to Carolina. 24. July, Ang. $\therefore v$.

nutans. 13. F. panicule ramis secundis nutamibus scabris, spiculis ovatis comprescis subscxfloris, spiculis acutis muticis, folis linear-hanccolatis. Willd. emum. 116.

In shady wouds: New England to Caruliaia. 4. July. $v, v$.

97. DACTYLIS. Gen.pl.117. Orchard-grass.

glomeraia. 1. D. panicula secunda glomerata. W illd.sp. pl. 1. p.403. Icon. Host. gram, 2. t. 94. Schreb gram. 8 f: 2. In meadows and woods: Pensylvania, \&c. Probably originally bronght from Europe. 4. June. v. v. 
g8. BROMUS. Gen. pl. 120.

1. B. panicula nutante, spiculis oratis compressis, glumis seca!inus. nudis distinctis, arintis suburtis brevoribus flexuosorectis. Willd. (1). pl. 1. p. 4.8.

Icon Ho, grtim i t. 1'2.

In rye- and w reat-fiel h, fiequent; introduced from Euvope. ค. July v. v.

2. B. panicula erecun ruartata, reituculis ramosis, spicumollis.

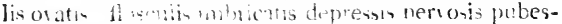
centihus. Smehfelrit. 1.p.12. IVilld. sp.pl.1. p. $42(1)$.

Icon Host gram. 1.t. !g. Engt.lot. 1073.

In arr fielth and pastures; probably from Europe. $\delta$. Jinte. I" $v$.

3. B. panicula unante, spoulis lanrendatis teretibus, fons-

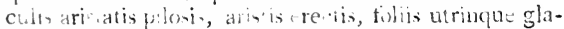
bris. va ius pilosis. Willl. enum. 120. Whild sp. pl 1. p. 431 .

In old tirlds and ou roarl-sides: Canada to New England. 4. May Aug. v. $v$.

4. B. pancula mutate, siculis nbonres compressis 6-sriilatus.

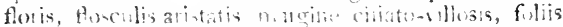

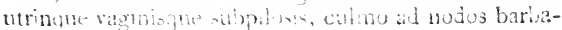

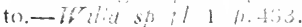

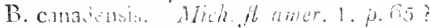

In barren and sandy soil: Cunata to Carolina. 24.Jnig. $v . v$.

99 KOELERIA. Pers. ench. 1.p. 97.

1. K. spina binacnla, spiculis diverenenbus 3-4-floris subarinatis rurtiosis carina subcinatis, Pers.l.c.

purgans.

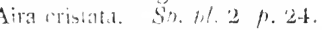

Poa cristalta. Wilit sp. $\mu$. 1. p 402 .

Icon. Minis hist. 3. s. 8 t. t. fi.

On the phan of Columbia river. M. Leuis. 24. July. $\boldsymbol{v}$ s. in Herb Leurs.

cristata.

100. AVEN.1. Gen pl 122. Oats.

\. A. panicula antenuara, calicibns bitluris, seminibus vil-pensylvanica. losis, aristis calyce duplo !ongioribus. Willd. sp $p l .1$. p. 445

In fields and open woods: New England to Carolina, firequent. $\odot$.Jume. v. $v$. 
palustris.

2. A. panicula conferta, calycibus bifloris, floribus glabris: altero mutico, altero tenuissimé aristato, folis planis linearibus. Mich.fl. amer. 1.p. 72.

A. caroliniana. Walt. $f$. car. 81 .

In low grassy fields and woods: Virginia to Florida. 24. May-July. $v v$.

striata.

3. A. panicula coarctata rariflora, calycibus quinquefloris, floribus calyce longioribus subimberbibus, valva exteriore striata, dorso longe aristata: semine nudo. Mich. fl. amer. 1. p.73.

On the mountains near Hudson's Bay. Michaux. + .

mollis.

4. A. racemo confertiuscule adpresso-spicato, calycibus bifloris, floribus imberbibus aristatis: aristis longitudine florum strictis, foliis culmoque molliter pubescentibus. -Mich.fl. amer.1.p. 72.

In Canada. Michaux. +.

spicata.

5. A. panicula subspicata pauciflora, calycibus spiculis sexfloris pubescentibus longioribus, valva exteriore ex apice bicorni aristata : arista basi spirali, foliis subsctaceis collo villosis. - Willd. sp. pl. 1. p. 453.

A. glumosa. Mich.fl. amer. 1.p. 72 .

On dry hills, on the banks of rivers: New England to Carolina. 24. June-Aug. v. v.

\section{ARUNDO. Gen.pl. 124. Reed.}

Phragmites. 1. A. calycibus quinquefloris, panicula laxa. Willd.sp. $p l$. 1.p. 454 .

Icon. Engl. bot. 401. Leers. herl. t. 7. f. 1.

On the banks of rivers and in large salt-marshes: $\mathrm{Ca}$. nada to Virginia, common. 4 . July. $v v$.

airoides. 2. A. panicula subcoarctata incurva, calycibus bifloris glabris inæqualibus, corollis membranaceis longitudine calycis, pilis corollam æquantibus, foliis planis scabris. -Lam. encycl.6. p. 270.

In North America. Michaux. $4 .+$.

agrostoides.

3. A. panicula laxa diffusa, calycibus uniforis acuminatis glabris, corollis calyce brevioribus membranaceis, valva exteriore apice incisa, dorso brevissima aristata, interiore minima, piis corollam æquantibus, foliis planis scabriusculis, culmis vaginisque glabris.

In bogs of New Jersey and Pensylvania. 24. July. v. v.

canadensis. 4. A. panicula oblonga, calycibus unifloris lanceolatis ca. rina scabris pubescentibus, corollis dorso aristatis: 
arista longitudine corollæ, pilis corollam æquantibus, foliis culmisque glabris angustis.-Mich. fl. amer. 1. p. 73 .

On mountain meadows: Canada to Carolina. $2 /$. July. v. v. Resembles A. Calamagrostis very much.

5. A. panicula patente, calycibus uniforis acuminatis, pilis confinis. corollam æquantibus, arista dorsali geniculata calycem excedente. Willd. enum. p. 127.

In North America. Willdenow. +.

6. A. panicula spicata, calycibus unifloris corolla longioriarenaria. bus, floribus erectis muticis, foliis involutis pungentibus. Smith fl. brit. 1. p. 148.

Icon. Fl, dan. 917.

On the sea-coast : Canada to New England. 24. July. v. $v$.

102. ELEUSINE. Gert. de fr. et sem. 1.p. 7.

1. E. glabra ; vaginis conpressis, collo pilosis : spicis diindica. gitatis strict is longo-linearibus recti;, spiculis subsextoris, floribus lanceolatis. Mich.fl. amer. I. p. 64.

In sandy cultivated grounds: New Jersey to Florida. $\odot$. June-Aug. v. v. In Virginia it is known by the name of Wire-grass, as a wect very noxions to the cultivator.

2. E. vaginis pilosis, spicis numerosis filiformibus panicumucronata. latis, spiculis minutissimis, calyce mucronato quadrifloro, floribus muticis. Mich. fl. amer. 1.p.65.

In cultivated fields: Virginia, Carolina, Illinois, \&c. $\odot$ : June, July. v. v.

103. CHLORIS. Surartz. 7. ind. 1.p. 189.

1.C. spica unica, spiculis subsexfloris, floribus aristatis monostachya. nargine barbatis, glumis calycis exteriore scrobiculatoglandulosa corso aristata. Mich. fl. amer. 1. p.59.

Aegilops aromaticum. IVall. fl. car. 249.

In woods and cultivated fields: Virginia to Florida. $\odot$ July. $v . v$. The spike of this grass is most singularly beautiful.

2. C. spicis 4-6. strictis erectis, flosculis imbricatis subpetraa. glabris muticis, glumis calycis exterinre aristata, culmo compresso glaberrimo. Swarlz. fl.ind. 1. p. 194. Cynosurus paspaloides. Vahl.symb.1.p. 21. Agrostis complanata. Ait. kei'. 1. p. 96 .

Icon. Vahl.l. c.t. 27. 
On the gravelly sea shores of Georgia and Florida. $\odot$. June. $v \cdot v$.

mucronata. 3. C. culmo repene, spicis plenmq̨ue 4. rachi triangulari mucronata, spicis subquatrfioris, gluma exteriore aristata.- Mich. Al amitr 1. p.50.

Aegilo's sacciarinum. IValt fl. car. 249.

Jcon. Pluk alm $t .300 f \mathrm{~s}$. Wire-grass. In cultivated grounds: Vilsinia to Georgia. $\odot$. June. v. $v$.

curtipendula. 4. C. culmo adscendente racemoso, spiculis plurimis brevibus distichis alternis pendulis sexloris, calycibus quadriftris. - Nich. Al amer 1. p. 59.

In diry situations in the wertern parts of America, Illinois, ¿.c. Michaux. $4 .+$.

\section{0-1. rOTTBOZLLIA. Gen. pl. $15 \% 2$.}

dimiciata.

1. R. spica dimiliata compressa lineari, latere exteriore agsregato-flosculosa, interion lavi nudo, vaginis conpressis, culmo decumbente. Willd. sp pl. 1.p. 466. Ischanim secundum Wult th. car. 249

On the sea-shores of Carolina and llorida. vas. in Herb. Wuller.

\section{TKIPSACUAI. Gen.pl. 1134.}

dactyioides. 1. T. spicis subternis agregatis s:aperne masculis inferne femineis. Willd. si l.l 4.p. 201 .

Ischamum glaustim. Ifall fl. car. 249.

Icon. Pluk alm. l. 190.j.2.

On the biaks of vivers and atong the sea-shore: Virginia, Carolina, Illinois. 4 . Ang. $v . v$

monostachy-

on.

2. T. spica solitaria superne mascula inferne feminea. IV illl. sp pl. 4. p. 202.

Icon. Willd hort. ler. 1.t. 1.

In salt meadows and ditcines : New York to Carolina. 4. Ang. v. v. Not sulficiently distinct firom the former.

cylindricum.

3. T. spica solitari: hermaphrodita cylindrica, spiculis contiguis in anticulos secedentibus. Willd. sp. pl. 4. p. 202. Mlich. $R$ aner. 1.p. 60.

In sandy barren fields in Firrida. Michaux. +. 
100. ELYMUS. Gen. pl. 125. Will Rye.

i. E. spica pendul? patula, -piculis sexp pis aristatis. Willd. philadelphienum. 131. Willd.sp.p.1.p.4ts.

In shady woods: Canadi and Ciew lork. 24. July. $v$. 2 .

2. E. spica nut ne patula, piculis aexg ris aristatis, inforioribus ternutis, neri ribus binatis. Wiild. enum. 131. Willd. sp.pl. 1.p tijs.

In rocky situations: Cumla, s. . 2!. July. + .

3. E. spica nutante patula, spiculis sexfloris arintatis geminatis, follis subtus glancis. Wille enum. 131 .

In the mountains of Virginia, Pensylvania, \&.c. 24.July. $\imath^{*} \cdot v$.

4. E. spica erecta, spiculis triforis aristatis villosis ternatis, villosus. calycibus aristatis spiculis superantibus, Itilld. enum. 131.

In dry rocky soil: Pensylvania, Virginia, \&cc. 2\%. June. v. $v$.

5. E. spica erecta, spiculis triforis aristatis glabris geminatis. calrcibus ban eulatis nersosis spiculis xuantibus.

cus.

canadensis. Willd enum. 131. Wilid sp ill.1.p 409.

In the mountains very common. 24. Alay-July. v.v.

6. E. spica erecta, spiculis bilh ris aristatis hispidis geniglaucifolius. natis, calycibus linearibus nerrosis artstatis spiculis fere superantitus, follis vaginisque glabis. Willd. enum. 131. Wilid. st.pl.1.p.4jo.

In shady situations: Pensylvania, Virginia, \&c. 4. June, $v \cdot v$.

\section{HORDEUM. Gon.pl.129. Barley.}

1. H. fosculis omnitus hermaphroditis aristatis, ordinibus duobus erectionibus. $I V$ illd. sp. pl. 1.p. 472.

virginicus.

striatus.

Icon. Host. gram. 3.t. 34 .

In fields an hedge-rows, apparently in a wild state; introduced frum Europe. $\odot$. July. $v . v$.

2. H. aristis involucrisqne setaceis lon issimis. Willd. $s p$. pl. 1.p. 476. exci. synon. Ait. kew. ed. 2.p. 180.

On the islancis of the Nissouri river. M. Lewis. $\delta$. July. v. s. in Herl. Leu'is, et Lamlert. This species I considered at first a new one; but on examication of the specimens in the Herbarium of A. B. Lambert, Esq., I found it to be the same as the H. jubatum of the Hortus Kewensis.

vulgare.

julalum. 
108. SECALE. Gen. pl.127. Rys.

cereale.

astivun.

1. S. glumarum ciliis scabris. Willd. sp. pl. 1.p. 471 . Icoll Host. gram. 2. t. 48.

Frequently found apparently in a wild state. $\delta$. June. v. $v$.

i09. TRitiCUM. Gen, pl. 130. Wheat.

astivun.

1. T. calycibus quadrifioris ventricosis glabris imbricatis aristatis. Willd.sp. pl 1.p. 470 .

Icon. Host. gram . 3. t. 26.

In corn-fields; introduced from Europe. (‥ June. v.v.

\section{TRIGYNIA.}

110. HOLOSTEUM. Gen. pl. 136.

succulentum. 1. H. foliis eilipticis carnosis, petalis subtrifidis calyce minorihus. - Willd. sp pl 1.p. 489 .

Polycarpon unifforum. Walt. fl. car 83.

A doubtful plant, which I never have been able to find, either in New York or Carolina.

\section{POLYCARPON. Gen.pl. 138.}

stipulifidum. 1. P. erectum ramosissimum, ramis setaceis, foliis (radicalibus) spathulatis, floribus terminalibus fasciculatis, stipulis setaceo-multifidis Pers. ench. 1.p. 111.

Stipulicida setacea. Mich. $f$ amer.1.p. 26.

Icon. Mich. l. c. t. 6.

In barren gravelly soil of Lower Carolina. ๑. May, Iune. v. s. in Herl. Lyon. The style is so very short, that it scarcely can be called monogynous.

\section{LECHEA. Gen.pl. 142.}

major.

1. I. undique hirsuta : foliis oblongo-lanceolatis mucronatis, panicula foliosa pyramidata : ramis apice floriferis, floribus fasciculato-racemosis secundis brevissime pedicellatis, caule erecto-Willd.sp.pl. 1. p. 495.

L. minor Linnæi. Smith in encyclop. ed. nov.

Cn sandy barren soil: Canada to Florida. 4.July, Aug. $v . v$. I have frequently observed from three to nine stamina in this species, which I suppose is the case with the following one likewise. 
2. L. glabriuscula ; foliis lineari-lanceolatis acutis, panicula minor. foliosa, ramis elongatis undique floriferis, floribus brevi-pedicellatis, caule assurgente.-IVilll. sp. pl. 1 . p. 495.

Icon. Lam. illustr.t. 52.f. 1.

On dry gravelly hills : Canada to Pensylvania. 4. July, Aug. v. $v$. Lower in growth and larger in fruit than No. 1.

3. L. undique adpresso-pubescens ; foliis linearibus acutis ciliatis, panicula gracilis ramosissina pyramidata, racemulis nudiusculis, Horibus parvis alternis pedicellatis, caule erecto.-Which fl. amer. 1.p. 77.

In sandy fields: New Jersey tw Carolina. 24. July. v.v.

4. L. undique adpresso-cano-villosa; foliis linearibus acutis, panicula foliosa elongata : ramis brevibus, floribus fasciculatis lateralibus terminalibusque, pedicellis brevissimis, floribus parvis cano-tomentosis, caule erecto.

L. thymifolia. Mich.fl. amer 1.p. 77 ?

In barren dry woods, on slate hills: Virginia, \&c. 24 . July. $v . v$. The lower brasches, which in most species of this genus trail on the ground, have a great resemblance to Thymus Serpyllum.

5. L. sparse pilosa ; foliis angustissimis, panicula diraricata nudiuscula, ramulis alternis, pedicellis elongatis divaricatis, caule erecto.-Mich.fl. aner. 1. p. 77 .

On dry graveliy hills : Virginia to Georgia. 4. May$\mathrm{July}$. $v . v$. The lower branches in this species have linear leaves, by which it is easily distinguished from the rest.

\section{ERIOCAULON. Gen.pl. 132.}

1. E. scapo decemstriato, foliis ensiformibus glabris, capi- decangulare. tulo magno depresso-globoso, squamis involucri ovalibus acutis, paleis receptaculi nucronatis.-Mich. $f l$. amer. 1.p. 165. Willd. sp.pl. 1.p. 485 .

E. serotinum. Walt fl. car. 83. Lam. encycl.3.p.276. Icon. Pluk. amalth. t. 409. f. 5.

In deep swamps: New Jersey to Carolina. 24. Aug. $v . v$. From three to four feet high.

2. E. scapo subcompresso decemstriato, foliis brevibus su- gnaphalodes. bulato-ensiformibus glabris: capitulo hemisphærice convexo, involucri squamis ovalibus rotundato-obtusis scariosis argenteo-lucidis. Mich. fl. amer, 1. p. 165.

E. decangulare. Walt. fl. car. 83. 
E. compressum. I am. encycl.3. $p 276$.

In sandy mosy swamps: Virginia to Carolina. 4 . July. v. v. Alout a joot high.

pellucidum. 3. E. scapo tenuissime suh-eptemstriato, foitis subulato-linearihus canaliculatis gatsis pel nedis quinquenerviis

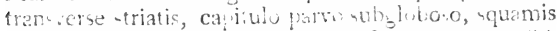
involucri colibus obtusis. - The $f$ amer. 1 p. 100.

In prols of water, flutung: Canadi to Aew Jersey. 2i. Aug. 2.v. About a foct ligh; iery slender.

villosum.

4. E. scapi- agrecratis conpresis subchar ri-ulc is villosia,

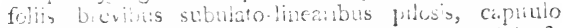

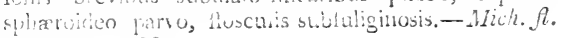
cinter. 1. i) 100 .

F. anceps. Itit fl.car. 83.

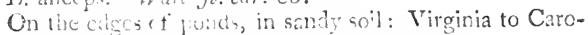
lina. July. v. $v$; v.s.in Hert. Whitir.

flavidulum.

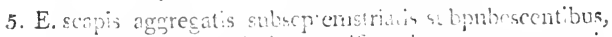

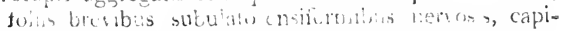
tulo convex's, siquanis mo'ucai stibubicuatio, flusculis vis papillesis. - Nith fl. anter. 1 is 160.

Cn the banks of rivers, below high-water nath: Fensyliania to Carolina. $\odot$. July. v. v. from one to two inches high.

\section{MOLLUGO. Gen.pl.139.}

verticillala. 1. M. foliis verticillatis cuneiformibus acutis, caule sutidiviso dicumbente, pedunculis unifuris. Wilid. sp. pl 1. p. 492 .

Icon Pluk mant. t. 332,f 5. Ehret.pirt. t. 6.f.3. In cultivated grounds: Canada to Geurgia. ๑. MayAug. $v . v$.

\section{PROSERPINACA. Gen. pl. 134.}

palustris.

1. P. foliis lineari-lanceolatis ser ratis, infimis pinratifidis. Lam. i!lustr. 1. p. 214. Wrilld. sp.pl. 1. p. $4 \div 8$.

In ditches and pools: Canadia to Carulina. $\odot$. Juy y.v. v.

pectinata.

2. P. foliis omnibus pectinato-pinnatifidis. Lam. illustr. 1. p. 214 .

P. palus:ris $\beta$. Milh. fl. amer, 1. p. 76 .

In overflowed places and diches: New Jersey to Carolina. $\odot$. July, Aug. v.v. This is certainly a distinct specics, as I never found them growing promiscuoubly or near one another. 


\section{POLYGYNIA.}

116. E.MPETRUM. Gen. pl. Crake-berry.

1. E. procumbens; folits oblongis obtusis margine revolutis. Mich fl. amer. 2. p.255. Willd sp. pl.4.p.713.

nigrum. Icon. Engl lot. 520. Fl dan. 075 .

On rocks near the sea-cosst in Carad.. Michaux. $\zeta$. May, June. v.s. Mray be distinct from the Europeat species. 


\section{TETRANDRIA.}

\section{MONOGYNIA.}

* Flores monopelali, superi, monospermi. Aggregatx.

117. DIPSACUS. Cal. communis foliaceus. Recept. conicum, paleaceum. Sem. columnaria.

118. ALLIONIA. Cal. communis 5-fidus, 3-florus : propritus obsoletus, superus. Corollule irregulares. Recept. nudum.

** Flores monopetali, monocarpi, inferi.

119. LYCIUM. Cor. tubulosa, fauce clausa filamentorum barba. Cal.4-fidas. Bac. 2-locularis, polysperma.

120. Callicarpa. Cor.tubulosa. Cal.4-fidus. Bac. 4-sperma.

121. CentunCulus. Cor. rotata. Cal.4-fidus. Stam. brevia. Cops. 1-locularis, circumscissa.

122. Plantago. Cor. limbo retiexo. Cal. 4-fid's. Stam. longissina. Caps. 2-locularis, circumscissa.

123. POLYPREMUM. Cor rotata, fauce barbata. (ai. 4-partitus. Stam. inclusa. Caps, 2-locularis, obcurdata.

124. Centaurella. Cor. urceolata. Cal. 4-partitus, adpressus. Stigm. crassum, glandulosum, subbifidum. Caps.1-Jocularis, 2-valvis, calyce corollaque persistentibus involucrata.

125. EXACUM. Cor. subcampanulata. Cal. 4-phyllus. Caps. 2-locularis, compressa.

126. SWERTIA. Cor. rotata. Nectariferi pori ad basin laciniarum corollæ. Caps, oblonga 1-locularis, 2valvis.

127. FRASERA. Cor. 4-fida, patens : petala medio glandula barbata. Cal. 4-fidus. Caps. compressa, submarginata, 1-locularis. Sem. pauca, imbricata, marginata. 
*** Flores monopelali, monocarpi, superi.

12s. MITCHELLA. Cor. binx, infundibuliformes $\mathrm{Cal}$. 4-dentatus. Stigm. 4-fidum. Bacca ex germinum coalitione didrna, 4-sperma.

129. OI.DENLANDIA. Cor. tubulosa. Cal. 4-partitus. Caps. didyma, polysperma.

**** Flores monopetali, dicocci, superi.

130. RUBIA. Cor campanulata. Bacca 2., monospermæ.

131. GALIUM. Cor. plana. Sem. 2., subrotunda.

132. SPERMACOCE. Cor. tubulosa. Sem. 2., bidentata. 133. DI()DIA. Cor. infundibuliformis. Caps.4-gona, 2locularis, 2 sperma.

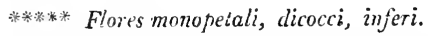

134. HOUSTONIA, Cor. infundibuliformis. Caps. seminitera, subglobosa, emarginata, 2-locularis, 2sperma.

*******or Flores tetropetali.

135. AMMANNIA. Cal. inferus, tubulosus, 8.dentatus. Caps. 4-locularis.

136. PTELEA. Cal. inferus, 4.partitus. Pet. coriacea. Sigm. 2. Samara monosperma.

137. CORNuS. Cal. superus, 4-dentatus. Drupa nuce 2-biloculari.

13s. LUDWIGIA. Cal. 4-partitus. Caps. 4-locularis, tetragona.

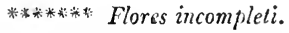

139. AlCHEMillLA. Cal. inferus, 4-fidus. Sem. 1. calyce inclusum.

140. BOEHMERIA. Cal inferus, 4-partitus, +.0 . Nectar. O. Sem. 1. Monoica.

141. URTICA. Cal. inferus, 4-phyllus, of. 2-valvis. Nec. tar. cyathiforme. Sligm. villosum. Sem. 1. ovatum. Monoica.

142. PARIETARIA. Cal. inferus, 4-fidus. Involucrum multipartitum. Sem. 1. calyce sicco elongato tectum. Polygamia.

143. VISCUM. Cal. superus, 4-partitus. Stigm. capitatum. Bacca monosperma. Dioicum.

144. CEPHALANTHUS. Cal. superus, infundibuliformis. Recept. globosum, nudum. Sem. 1. lanuginosum. 
145. EL,ASAGRUS. Cal. basi persistens, superne coarctatus et quasi superus, campanulatus, 4-ficlus. Drupa 1-sperma.

146. HIPPOPHiE. Col. decidnus, inferus, tubulosus, 2 fidus. Bacca globosa. Dinica.

\section{DIGYNIA.}

147. PLANERA. Cal. campanulatus, 4.fidus. Cor. 0. Nux 1-sperma, squamulosa. Polygrimia.

148. HAMANILLF. Cal 4 fidus, extus 2-squamosus. Pt.4. longissima. Nux2-locularis, 2-cornis.

149. CUsCUTA. Cal. 4-fidus. Cor. ovata, 4-fida. Cays. 2-locularis circumscissa.

150. SANGUISORBA. Cal. 2-phyllus, inferus. Cor. jlana, 4-Fid, supera. Caps. 4-gona, intra calycem et corollam.

\section{HII. TRIGINIA.}

151. PACHYSANDRA. Cal. 4-phyllus. Cor.o. Caps. 3-locularis. Monvica.

\section{TETRAGYNIA.}

152. HlEX. Cal. 4-dentatus. Cor. rotata. Styl. o. Bac. 4-sperma.

153. SAGiNA. Cal. 4-phyllus. Cur. 4-petala. Caps.4Incularis poysperma.

154. POTAMOGEIUN. Cal. 4. phyllus. Cor. o. Sem. 4. sessilia.

155. RUPPIA. Cul, et Cor. 0. Sem. 4. pedicellata.

\section{MIONOGYNIA.}

\section{DIPSACUS. Gen. pl. 148.}

sylvestris. 1. D. foliis connatis sinuatis, paleis rectis, involucro capitulo brevioribus patentibus.-.-Willd. sp pl. 1.p. 544? Icon. Jacq. $l$. aust. 5, $t, 403$.

On the edges of fields and on water sides: Pensylvania to Virgiria. $z$. July. v. v. Probably introduced from Europe, but sometimes found in very remote: parts from cuitivation. 
118. ALLiONiA. Gen. pl. 151.

I. A. caule erecto, foliis lato-cordatis acutis, glabris, pedunculis solitariis, calycibus fructiteris sub-hirsutis, involucro ampliato multo minoribus.-Mich. $\mathrm{fl}$. amer. 1.p. 100.

On the banks of the river Tenuassee and its branches. 4. July, Aug. v.v. Resembles Mirabilis Jalapa very much.

2. A. caule diffuso, foliis lanceolatis scabriusculis ciliatis, pedunculis solitariis, involucro subpentaphyllo : foliolis ovatis reticulato-venosis - Walt.fl. car. 84.

In Inwer Carolina. Wuller. ๑. July, v. s. in Herb. Wulter.

3. A. caule diffuso dichntomo, foliis ovatis scabriusculis nudis, floribus terninalibus fasciculato-racemosis, involucro semiquinquetido: laciniis subrotundis acutiusculis reticulato-renosis.

On the plains of the Missouri. M. Lewis. ๑. Alig. v. s. in Herl. Lewis.

nyctaginea.

allida.

\section{LYCIUM. Gen. pl. 343.}

1. L. inerme; foliis anguste spathulato-oblongis. Mich. flamer. 1.p. 95 . Walt fl.car. St.

carnlinias num.

L. sasum. Bartr. (rav. 50 .

In sa!t marshes of Carolina and Georgia. h. July. v. $v$. Flowers purple, the size of L. larbarum.

\section{CALLiCarPA. Gen.pl.17j.}

1. C. foliis ovalibus serratis subtus tomentosis, cymis sessilibus.-Willd. sp.pl.1.p.619.

Icon. Catest. car. 2. t. 47. Pluk. alm. t. 136.f. 3.

In dry gravelly soil, below the mountaiiss in Virginia and Carolina. $\zeta$. June, July. v. v. Flowers red, in small axillary bunches; berries red, apparently in a whorl round the branches, hang on very long.

\section{CENTUNCULUS. Gen.pl. 189.}

1. C. foliis deorsum angustatis : inferioribus ovalibus, sulanceolatus. perioribus lanceolatis, laciniis calycis subulatis, caule simplici.-Mich. fl. amer. 1. p. 193.

In wet barren fields: Lower Carolina, \&cc. $\odot$. May. rol. I.

americana. 
v. s. in Herb. Nuttall. A very small inconspicuous plant with axillary reddish flowers. The specimens of Mr. Nuttall's were collected on the Missouri, they are about four inches high: and according to his observations, very obligingly communicated to me, this species is generally pentandrous.

\section{Plantago. Gen.pl. 186.}

data.

major.

cucullata.

lanceolala.

virginica.

caroliniana.
1.P. foliis ovatis cordatis latissimis subdentatis glabris, spica longissima, floribus subimbricatis, inferioribus sparsis, bracteis ovatis obtusis.-Lam. encycl. 5. p. 369.

P. kentuckensis. Mich.fl. amer. 1.p. 94 .

P. canadensis. Hort par.

On river sides: Canada, Kentucky, Tennassee, and other western parts. 24. June-Aug. v. $v$.

2. P. foliis ovatis subdentatis glabriusculis, scapo tereti, spica oblonga imbricata. Lam. encycl. 5. p. 368. Willd. sp. pl. 1. p. 041 .

Icon. Engl. bot. 1558. Fl. dan. 461.

In fields and on road sides, common. 24. May-Sept. $v . v$.

3. P. foliis ovatis concavo-cucullatis novemnerviis subtus pubescentibus, spica cylindrica imbricata, scapo tereti alto. Lam. encycl. 5. p. 370.

P. maxima. Jacq.ic. 1. t.26. Willd. sp. pl. 1.p. 642. Icon. Jacq. l. c.

In wet rocky situations : Canada and Province of Main. 4. July, Aug. v. $v$.

4. P. foliis lanceolatis villosis, spica brevi cylindrica, bracteis ovatis acuminatis, scapo angulato adpresso piloso.

P. lanceolata. Willd.sp.pl.1. p. 643 ?

In fields and pastures, common. 24. June-Aug. $v \cdot v$. May be a new species. P. lanceolata of Europe, according to the specimens examined in the Herbarium of A. B. Lambert, Esq. is bracteis ollongis acutis.

5. P. undique canescenti-pubescens ; foliis lanceolato-ovatis subdenticulatis, floribus remotis, scapo angulato. IVilld. sp.pl. 1. p. 643.

Icon. Moris. hist. 3. s. 8. t. 15.f. 8.

In dry barren fields, common : New England to Florida. $\odot$. ${ }^{\lambda}$. May-Aug. v. $v$. There are a number of varieties in respect to size and pubescence.

6. P. undique glabra; foliis lanceolatis integerrimis longis, floribus :emotis, caule tereti.-- Walt. l. car. $\$ 5$. 
P. angustifolia glabra, \&c. Clayt. fl. virg. 753.

In sandy grassy woods: Virginia to Carolina. Jo. June, July. v. v.; v. s. in Herb. Walter.

7. P. foliis ovato-lanceolatis integerrimis villosiusculis, spica Jonga gracili interrupta, floribus glabris.-Lam. encycl. 5. p. 375 .

P. sparsillora. Mich. $f$ l. amer. 1.p.94.

In shady woods: Virginia to Carolina. 24. July, Aug. $v$. $v$.

8. P. foliis lineari-lanceolatis integerrimis glabriusculis, scapo tereti foliis breviore, spica pauciflora interrupta, bracteis ovatis acutis glabris.

On the sea-coast of New England and New Jersey. 4. Aug. $v . v$. In the Herbarium of A. B. Lambert, Esq. are specimens from Labrador, agreeing in every respect with this species.

9. P. undique argenteo-villosa ; foliis lineari-lanceolatis integerrimis supra nudiusculis, scapis teretibus foliis vix longioribus, spica cylindrica imbricata, bracteis linearibus longissime ciliato-villosis.

In dry situations on the banks of the Missouri. Nuttall. $\odot$. July. v. s. in Herb. Nuttall. This beautiful little plant is very variable in size.

10. P. foliis carnosis subulato-linearibus basi pilosis, scapo tereti pubescente, spica cylindrica, bracteis obtusis.IVill.t.sp. pl. 1.p. 647 .

Icon. Engl. lot. 175. Fl. dan. 243.

On the banks of rivers near the sea: Canada to New York. 4 . Aug. v. v.

11. P. foliis subsetaceo-linearibus, spica oblongro-cylindrica, bracteis subulato-aristatis flore longioribus. Mich. $f$.

interrupta.

paucifiora.

Lagopus. amer. 1. p. 95 .

In the natural meadows of Illinois. Michaux. +.

\section{POLYPREMUM. Gen. pl. 178.}

1. P. polypremum. Willd. sp.pl. 1.p. 623 .

Icon. Lam, illustr. 1. t. 71.

In dry pastures: Virginia to Georgia. ๑. May-Aug. $v . v$. Flowers white, very small.

124. CENTAURELLA. Mich. $f$. amer. 1.p. 97.

1. C. caule simplici, pedunculis sparsis subcorymboso-elonmaritima.

aristata. gatis, laciniis corollæ oblongis acutis calyce duplo

vernalis. 
longioribus, stylo germine longiore. Mich. fl, amer. 1. p.9s.

uniflora $\quad$ B. Icon. Mich.l.c.t. 12. f. 2

In mossy swamps: Virginia to Georgia. $\odot$. May-July.
In v.v. Var. $\beta$ v.s. in Herl. Lyon. About five inches high; the flowers white, and larger than the rest. The variety $\beta$ may be a distinct species?

cestivalis. 2. C. caule simplici, pedunculis oppositis simplicibus, laciniis corollæ spathulatis abrupte acutis calyce triplo longioribus, stylo longitudine germinis.

In mossy swamps : Carolina to Georgia. $\odot$.June-Aug. v. s. in Herl. Enslen. From two to four inches high; flowers smaller than No. 1; the calyx very short.

autumnalis. 3.C. caule subramoso, pedunculis oppositis, inferioribus ramosis, laciniis corollæ ovalibus acutis calyce vix longioribus, stylo brevissimo.

C. paniculata. Mich. Al. amer. 1.p. 98 .

Bartonia tenella. Muhll. in litt.

Sagina virginica. Willd. sp. pl. 1.p.719.

Icon. Mich.l.c.t.12.f. I.

In mossy swamps, in inundated grassy places: New England to Carolina, common. ๑. July-Sept. v.v.; $v$. s. in Herl. Gronov. sub nomine Sagina caule erecto subnudo, floribus oppositis. Sagina affinis planta minima, floribus allis. Clayt. MSS. 649. About a foot high, sometimes quite simple and very small; flowers smail, greenish-white.

\section{EXACUM. Gen.pl. 185.}

pubchellum.

1. E. corollis quadrifidis, calycibus quadripartitis: laciniis subulatis, panicula corymbosa, pedunculis filiformibus. Near the sea-coast of New Jersey ; rare. $\odot$. Aug. v.v. Flowers rose-coloured; resembling E. filiforme veiy much.

\section{SWERTIA, Gen. pl. 449 .}

corniculata. 1. S. corollis campanulatis corniculatis : cornibus deflexis, foliis ovatis, ramis brevibus.

S. corniculata. Willd. sp. pl. 1.p. 1330 ?

In swamps of Canada and round the lakes of the western part of the United States. ð. July. v. v. Flowers greenish yellow. The Siberian plant differs from the 
American in being cornilus divaricatis alscendentilus, foliis lanceolutis et ramis elongatis; by which the American plant appears to be a distinct species.

2. S. corollis campanulato-rotatis longitudine calycis, floribus fastigiato-aggregatis axillaribus terminalibusque, pedicellis geminis, foliis spathulato-obovatis nervosis, caule ramoso.

On the Missouri flats, near the Rocky mountain. $M$. Lewis. 4. July. v. s. in Herb. Leuis. Leaves large; flowers sky-blue.

3. S. corollis rotatis calyce duplo longioribus, caule simplicissimo unitloro, fol is oblongis.

On the alpine regions of the White-hills of New Hampshire. $\odot$. June. v. $v$. The whole plant scarcely above an inch high, with one or two pair of smail leaves, and a considerable-sized blue flower. Divisions of the corolla oblong, acuminate; of the calyx obtuse. In the Banksian Museum are specinens from Labrador, in every respect agreeing with the New Hamp. shire plant.

127. FRASERA. Mich. fl. amer. 1.p.96.

1. Frasera. Mich l. c.p. 97.

Frasera caroliniensis. Walt. fl. cur. 88.

In swamps of Lower Carolina and on the borders of the lakes in Pensylvania and New York. $\delta$. July. $v . v$. Stem firom three to six feet high; leaves in whorls or opposite; flowers in aggregate clusters, greenish-yellow, sometimes mix ed with purple. The whole of the plant hats a very stately appearance; its gen ric character approaches so near to Swertia, that, without seeing the fruit, it might be considered a species of that genus.

\section{MITCHELLA. Gen. pl. 174 .}

1. Mitchella. IVilld. sp. pl. 1. p. 617 .

Icon. Catesb. car. 1. t. 20. Pluk, amalth. t. 414.f. 2. pusilla.

fastigiata.

In shady situations on rocks and round the roots of trees: Canada to Georgia. $\zeta$. June. v.v. A small creeping plant; flowers white, hairy inside; berries red.

repens.

Walteri. 


\section{OLDENLANDIA. Gen.pl. 205.}

glomerata. 1. O. procumbens; foliis lanceolato-ovatis, floribus axillaribus terminalibusque conglobatis pedicellatis, germinibus hispidis. Mich. fl. amer. 1.p. 83.

O. uniflora. Willd. sp.pl. 1.p.675.

Hedyotis auricularia. Walt. fl. car. 85.

Hedyotis uniflora. Lam. illustr. 1. p. 271.

On sandy wet fields : New Jersey to Carolina. $\odot$. May -July. v. v. A small creeping plant; flowers greenish-white.

130. RUBIA. Gen. pl. 164. Madder.

Brownei. 1. R. hispida; foliis quaternis ovalibus, pedunculis solitariis unifloris, caule decumbente. Mich.fl. amer. 1. p. 81 .

R. subhirsuta scandens vel reclinata, foliis cruciatis, floribus singularibus ad alas. Brown.jam. p. 141 .

R. peregrina. Wult. fl. car. 86.

Valantia hypocarpa. Linn.

In shady woods: Carolina and Florida. $\psi .+$. Flowers yellow; berries purple, smooth.

\section{GALIUM. Gen.pl. 162.}

\section{* Fructu glabro.}

latifolium.

1. G. caulibus erectis lævibus, foliis quaternis ovatis acutis trinervibus: margine nervisque hispidis, pedunculis oppositis lateralibus terminalibusque dichotomis divaricatis laxe multifloris.-Mich. fl. amer. 1.p. 79.

In dry slaty mountains of Virginia and Carolina. 4. June, July. $v . v$. Leaves broad ; flowers purple. It generally has but one seed.

uniflorum. 2. G. caulibus flaccidis lævibus, foliis quaternis linearibus acutis glabris, pedunculis axillaribus solitariis unifloris brevissimis.-Mich. fl. amer. 1. p. 79.

In Carolina. Michaux. +. Flowers white.

tinctorium. 3. G. caulibus diffusis læviusculis, foliis caulinis senis, rameis quaternis linearibus acutiusculis, margine nervoque tenuissime aculeatis, pedunculis terminalibus elongatis plerumque trifloris.--Willd.sp.pl. 1. p.580.

In wet woods and along hedges: Canada to Virginia. 24. June-Aug. v. v. Flowers white. This is the plant with which the Indians of North America dye 
their feathers, porcupine quills, and other ornaments, of a beautiful red.

4. G. caulibus diffusis ramosissimis retrorsum aculeatis, foliis caulinis senis, rameis quaternis lanctolatis acumiasprellum. natis margine nervoque accleatis, ranulis floriferis divaricatis multifloris, pedicellis brevibus.-Mich. $f$. amer. 1. p. 78 .

In swamps and among low bushes: Canada to Virginia. 4. July. v. v. Flowers white, very small.

5. G. caulibus procumbentibus retro-scabris, foliis caulinis quinis, rameis quaternis linearibus obtusis margine nervoque scabris, fasciculis terminalibus paucifloris, pedicellis brevibus, corollis plerumque trifidis. - Willd. sp.pl. 1.p. 585 .

Aparine floribus albis, \&ic. Gron.fl.virg. 1s.

G. Claytoni. Wich. fl. amer. 1. p. 78.

In swamps and wet ficids : Canida to Carolina. 24. July. v. $v$. Flowers white, very small.

* Fructu hirsuto.

o. G. caulibus flaccidis retrorsum scabris, foliis suboctonis lineari-lanceolatis mucronatis supra hispidis, margine carinaque aculeatis, ramulis floriferis longitudine foliorum subtrifloris, fructibus uncinato-hispidis.Willd. sp.pl. 1. p. 59 \%.

Icon. Fl. dan. 495. Engl. bot. 816.

In hedges and small woods: Pensylvania, \&c. $\odot . ð$. June-Aug. v.v. Flowers small, white.

7. G. caulibus ramosissimis divaricatis retrorsum aculeatis, misranthum foliis brevibus lanceolatis mucronatis glabris, margine carinaque aculeatis, ramulis floriferis divaricato-ramulcsis, pedicellis subbifloris, fructibus hispidis.

In mountain swamps: Canada to New York. 4 .July. $v . v$. Flowers white, very numerous and exceeding small. It produces generally only one seed. Resem. bles $G$. uliginosum very much.

8. G. caulibus flaccidis elongatis brachiato-ramosis hispidis: ramis brevibus, foliis senis oblongo-lanceolatis acuminatis glabris, margine carinaque setaceo-ciliatis, ramis floriferis verticillis longioribus divaricato-dicho. tomis : pedicellis bifloris, fructibus uncinato-hispidis.

In meadows and on the edges of woods, frequent: New England to Virginia. 24. June-Aug, v. v. Flowers white. 
triflorum.

9. G. caulibus procumbentibus glabriusculis, foliis senis quinisque obovato-lanceolatis mucronatis glabris margine vix ciliatis, ramulis floriferis elongatis apice trifloris, floribus pedicellatis, fruct:bus yarvis hispidis. Mich. fl. amer. 1. p. 80.

Icon. IVendl. hort. $t .66$.

In shady rocky places: Pensylvania to Carolina. 4 .July. v. v. Flowers white, very small.

histidum. 10. G. caulibus procumbentibus ranosisimis hispidis, foliis quaternis ovali-Janceolatis acuminatis margine revolutis rugosis utrinque hispidis, foribus subsolitaric terminalibus, fructibus hispidis.-Mich.fl. amer. 1. p. 79 .

G. lappaceum. Fl. per. 1. p. 59?

In Lower Carolina. Michaux. + . Flowers white.

lermudia- 11. G. caulibus ramosissimis vix pubescentibus, foliis quaternum. nis ovatis obtusis glabris, margine nervisque pubescentibus pellucido-punctatis, ramulis floriferis elongatis, fructibus uncinato-hispidis.-Willd. sp.pl. 1.p. 596.

G. purpureum. Walt. $\{$ car. 87 .

G. puncticulosum. Mikh. fl. amer. 1.p. so.

In wet places: Virginia to Carolina. 24. July. v. v. Flowers purple.

pilosum. 12. G. caulibus subsimplicibus elongato-adscendentibus re. mote-geniculatis hispidis, follis quaturnis ovalibus brevissime mucronatis utrinque hirsutissimis enervibus, ramulis floriferis elongatis stbsimplicibus apice subtrifloris, fructibus pilosis. Willd. sp. pl. 1. p. 599 .

In dry woods: Pensylvania to Carolina. 24. June, July. v.v. Flowers brownish purple.

circazans. 13. G. caulibus erectis lævibus, foliis quaternis ovalibus obtusis glabris, margine nervisque ciliolatis, pedunculis divaricatis paucifloris, floribus remotis subsessilibns, fructibus cernuis uncinato-hispidis. Mich. A. anier. 1. p. 80 .

G. boreale. Walt. fl. car. 87 .

In diry barren woods and mountains: New England to Caroina. 24. June-Aug. v. v. Flowers yellowishwhite; stem not above six inches high.

loreale. 14. G. canlibus erectis lavigatis, foliis quaternis lineariuns acutis trinervibus glabris, margine nervoque scabris, panicula terminali divaricata, fructibus tenuissime muricato setosis.-- Willd. sp. pl. 1. p. 595.

Icon. Ft. dan. 1024? Engl. bot.105?

On the banks of the Susquehanna near Wilkesbure, among rocks: Pensylvania and about the lakes of $\mathrm{C}^{2}$ - 
nada and New York. 24. July. v. v. Flowers white, very numerous, collected in a regular panicle. Though I doubt of its being the G. Forea'e of Linnxus, I found so many intermediate specimens in the collection of A. B. Lambert, Esq., collected by Pallas in Russia, that I could draw no line of essential distinction between them.

\section{SPERMACOCE. Gen. pl. 155.}

1. S. caule erecto glabro, foliis lanceolatis supra scabris subteriuior. tus glabriusculis, floribus verticillatis, seminibus hirtis.-IVilld. sp.pl. 1.p. 56 s.

Icon. Schkuhr handl. 1.t.22. Lam. illustr. 1. t. 62. f. 1 .

In dry gravelly situations: Virginia to Carolina. ๑. June -Aug. v. v. 1 lowers white, very small.

2. S. caule procumbente glabro, foliis ovato-lanceolatis utrinque glabri", floribus verticillatis, seminibus glabris.-Mich. $A$ amer. 1.p. 82 .

On the banks of rivers in most of the western territories. $\odot$. July, Aug. v. v. Flowers white, lunger than No. 1.

3. S. caule diffuso tereti hirsuto, foliis lineari-lanceolatis diodina. glabriusculis, margine carinaque sermato-scabris, stipulis longissime multisetıs, Horibus axillaribus sessili. bus solitarnis alternis, seminibus hirsutis.-Mich. $f$. amer. 1.p. 52 .

In dry barren soil, on iron ore hills: Virginia to Caro. lina. $\odot$. July, Aug. v. $v$. Hlowers white, tery s.mall.

4. S. canle alterne ramoso hispidissimo, foliis ovato lanceoinvolucruta. latis acuminats utrinque hirsuts, stipulis multisetis, capitulis terminalibus involucratis, staminibus exertis.

In Carolina. Fraser. v. s, in Herl. Lambert. About a foot high; leaves broad and somew hat oblique; flowers white, with a very long tube.

\section{DIODIA. Gen. pl. 158.}

1. D. glabra ; caulibus procumbentibus teretiusculis, foiiis virginica. lanceolatis, corollis intus glabriusculis, fiuctibus ob. longis glabris.-Willd. sp. pl. 1. p. 580

D. teres. W'alt. $f$. car. 87 .

Icon. Jacq. ic, rar. 1, t. 29. lona. 
in sandy wet places, on road sides: Virginia to Carolina. 4. June-Aug. v. v. Stem smcoth, purple; flowers white.

hirsuta.

2. D. undique hirsutissima ; caulibus procumbentibus tetragonis, foliis lineari-oblanceolatis, corollis intus dense-barbatis, fructibus ovatis hirsutis.

In sandy fields: Georgia near Savannal. 4. July. v. v. Stems very branching; flowers white, larger than the former species.

\section{HOUSTONIA. Gen. $p l .161$.}

ccerulea.

elatior. $\quad \alpha$.H.caule pedunculisque erectis, floribus magnis cos-

1. H. caule erecto setaceo dichotomo, foliis radicalibus spathulatis, caulinis oblanceolatis oppositis, pedunculis unifloris elongatis.-Willd. sp. pl. 1. p. 583 .

Poiretia erecta. Gmel. syst. 263. $\Lambda$ nonymos. Walt. $f$. car. 86.

Icon. Bot. mag. 370. Pluk. alm. t. 97.f.9. ruleis.

minor. $\quad$ B. H. caule divaricato, floribus plerumque albis.

From New England to Florida: $\alpha$ in rocky situations: E along the sandy sea-coast. 4 . April, May. v. $v$. Hlowers a beautiful blue, sometimes white.

serpyllifulia. 2.H. caule procumbente cæspitoso, foliis spathulatis obtusis, pedunculis terminalibus unifloris longis. Mich. flamer. 1.p. 85.

In high mountains, near rivulets and springs: Virginia to Carolina. 2. May. v. v. Flowers blue.

tenella.

3. H. caule repente filiformi, foliis orbiculatis acutis nervosis, pedunculis terminalibus unifloris longissimis.

On high mountains: North Carolina. Lyon. 24. June. $v$. s. in Herl. Lyon. Flowers purple; smaller than the second species, which it resembles very much.

rolundifulia. 4. H. caule repente, foliis suborbiculatis abrupte petiolatis crassiusculis, pedunculis axillaribus solitariis unifloris. -Mich.fl. amer. 1. p. 55 .

Poiretia procumbens. Gmel. syst. 263. Anonymos. Walt. fl. car. 86 .

Along the sea-coast: Virginia to Florida. 24. MarchMay. v. $v$. Flowers white; leaves evergreen.

angustifolia. 5. H. caule erecto ramosissimo glabro, foliis linearibus, floribus terminalibus fasciculatis subsessilibus, sæpe ternis.-Mich̆. fl. amer. 1. p. 85 . 
H. longifolia. Willd. sp. pl. 1. p. 583 ?

Along the sea-coast, in sandy fields: Carolina to Florida 4. May--July. v. $v$. Flowers purple.

6 . H. caule erecto superne ramoso ad geniculis pubescente, foliis sessilibus ovatis lanceolatis vel lineari-lanceolatis, purpurea. fasciculis terminalibus corymbosis. Willd. $s p . p l .1$. p. 584 .

H. varians. Mich. fl. amer. 1.p. 86 .

Hedyotis umbellata. Walt. $f$ l. car. 85.

Knoxia purpurea. Lam. illustr. 1.p. 259.

In dry woods : Pensylvania to Carolina. 24. June, July. $v, v$. Flowers purple.

\section{AMMANNIA. Gen. pl. 206.}

1. A. caule erecto, foliis lanceolato-linearibus basi dilatata ranosior. semi-amplexicaulibus, floribus inferioribus verticillatis. -Willd.sp.pl. 1.p. 678 .

In swanps and inundated fields : Virginia, Carolina, and the western territories. $\odot$.July, Aug. v. v. Flowers purple.

2. A. caule procumbente, foliis lanceolatis in petiolnm angustatis, floribus solitariis oppositis sessilibus.-Mich. fl. amer. 1. p. 99 .

A. ramosior. Walt. fl. car. 88 .

In gravelly wet places, along rivers: Virginia to Carolina. ๑. Aug. Sept. v. v. Flowers red.

136. PTELEA. Gen. pl. 1505.

1. P. foliis ternatis. Willd. sp. pl. 1.p.670.

Icon. Schmidt arl. 2. t. 76. Mill.ic.2. t. 211.

a. P. foliis quinatis. $D u$ Roi.

$\beta$. P. foliis pubescentibus.

In shady moist hedges and on the elges of woods among rocks: New York to Carolina. h. June. v. $v$. A small tree or shrub from ten to fifteen feet high. Flowers small, greenish white, in corymbous clnsters. The variety $\beta$ grows in Pensylvania, and appears to be a new species.

137. CORNUS. Gen.pl.194.

* Involucratce capitatce.

1. C. herbace: ; foliis summis verticillatis venosis, involucris ovatis acuminatis, drupis globosis. Willd. sp. canadensis. pl. 1. p.661. 
Icon. L'Her. corn. t. 1. Bot, mag. sso.

In shady woods of Canada, and on bigh monntains in boggy ground, from New England to Carolina. $4 . h^{2}$ May. v.v. About six inches high; flowers purplishwhite; involucra white; berries red, ripe in July.

florida.

2. C. a:borea; foliis ovatis acuminatis, involucris magnis quasi obcordatis, drupis ovatis.-Willd. sp. pl. 1. p. 661 .

Icrn. Catest. car. t. 27. Schmidtarb. t.62, Bot. mag. 526.

Dog-wood.

Frequent in woods from Canada to Carolina. h. May. $v . v$. A beautiful small tree; flowers greenish-yellow ; involucre white, tinged with red; berries scallet, ripe in August. The wood is exceedingly hard, and of a very fine texturs.

$$
\text { * Nulce cymosce. }
$$

circinata. 3. C. ramis verrucosis, foliis lato-ovalibus acuminatis subtus albo-tomentosis, cymis patentissimis.-L'Herit. corn. p. 7 .

C. tomentulosa. Mich.,fl. amer. 1.p. 9 1.

C. rugosa. Lam, encycl. 2. p. 115.

C. virginiana. IIort. pur.

Icon. L'Herit. l. c. t. 3. Schmidt arl. 2. t.69.

On the banks of rivers: Canada to Virginia. iz. June, July. $v . v$. A shrub from six to ten feet high; leaves broad, waved on their edges; fowers white, as in all the follow ing species; berries blue.

sericea.

4. C. ramis patulis : ramulis lanuginosis, foliis ovatis acuminatis subtus ferrugineo-pubescentibus, cymis de. pressis lanuginosis.- Willd. sp.pl. 1.p. 663.

C. lanuginosa. Arich.fl. amer. 1. p. 92 .

C. aiba. Walt. fl. car. 88 .

C. cærulea. Lam. encycl. 2. p. 116.

C. amomum. Du Roi harlk. 1. p. 165.

C. rubiginosa. Ehrh. leitr. 4.p. 15.

C. ferruginea. Hort par.

Icon. L Herit. corn. t. 2. Schmidt art. 2. $t .64$.

In swampy woods and on river banks : Canada to Carolina. $h_{c}$. Iune, July. v. v. From five to eight feet high; berries bright blue.

asperifolia. 5. C. ramis erectis : ramulis cymisque pubescentibus, foliis brevi-petiolatis ovalibus acuminatis supra asperis subtus subtomentosis.- Mich. A. amer. 1.p. 93 .

In shady voods of Lower Carolina. Michaux. $h_{2}$. 
June, July. + . Probably only a variety of the former species.

6. C. ramis strictis fastigiatis, foliis ovatis acuminatis glabris subconcoloribus, cymis convexis subpaniculatis.

stricla. L'Herit. corn. p. 8.

C. fastigiata. Mich. fl. amer. 1. p. 92 .

C. sanguinea. Walt. fl.car. ss.

C. canadensis. Hort. par.

Icon. L'Herit. corn. t. 4. Schmidt arb. 2. t. 67.

On the banks of rivers : Canada to Carolina, frequent. $h$. June. $v, v$. From six to ten feet high; berries blue : anthers blue.

7. C. ramis strictis, foliis ovatis concoloribus utrinque pubescentibus, cymis patentibus. L'flerit.corn. p. 5.

Icon. Schmidt arb. 2. t.66. Fl. dan. 481.

Near the lakes of Canada and New York. h. June, July. $v . v$. From eight to twelve feet ligh ; anthers yellow; berries dark brown.

s. C. ramis recurvatis, ramulis glabris, foliis ovatis acutis alla. pubescentibus subtus canis, cymis depressis. L'Horit. corn.p.6. Willd. sp.pl. 1.p.662.

C. stolonifera. Mich.fl. amer.1.p. 92.

C. tartarica. Mill dict. n. 7 .

Icon. Schmidt art. 2, t. 65 .

On the banks of rivers and lakes: Canada to Virginia. h. May-July. v. $v$. From six to ten feet high; branches red; berries blueish-white.

9. C. ramis erectis, fuliis ovatis acuminatis glabris subtus canis, cymis thy rsoideis. L'Herit. corn.p. 9.

C. racemosi. Lam. encycl. 2. p. 116.

C. citrifolia. Hort. par.

f.C. foliis elliptico-lanceolatis. Ehrh.

$\gamma$.C. racemis sterilibus foliiferis.

Icon. L'Herit. corn. t. 5. Schimidt arb. 2. $t .68$.

In swamps and near rivulets among other bushes: Canada to Carolina, rare. h. July, Aug. v.v. From four to six feet high; berries white, depressed globolss.

10. C. ramis verrucosis, foliis alternis ovatis acutis subtus canis, cymis depressis patentibus. L'Herit.corn.p. 10.

paniculata.

sanguinea. IVilld. sp. pl. 1. p. 504 .

Icon. L'Herit. corn. t. 6. Schmidt art. 2. t. 70.

In shady woods, on river banks: Canada to Carolina. $h$. May-July. v.v. A small tree from fifteen to twenty feet high; berries purple.

albida. radiata. 
138. LUDWIGIA. Gen. pl. 204.

\section{* Corollata.}

nucrocarpa. 1.L. erecta, ramosa, glabriuscula ; foliis alternis lanceolatis subtus canis, pedunculis unifloris axillaribus, capsulis globoso-tetragonis, laciniis calycinis magnis coloratis coronatis. Mich.fl. amer. 1. p. 89 .

L. alternifolia. Willd. sp.pl.1.p.672.

Icon. Lam. encycl. 3. p. 77. Trew ehr. 2. t. 2.

In wet pastures and swamps : New England to Florida. 2. July. v. v. Stem purple, two feet high; flowers yellow.

hirsuta. 2. L. erecta, ramosa, hirsuta; foliis alternis oblongis sessilibus utrinque hirsutis, pedunculis unifloris axillaribus, capsulis globoso-tetragonis coronatis basi bibracteatis. Lam. encycl. 3. p. 587.

L. pilosa. IValt. fl. car. 89 .

In ditches and ponds on sandy soil : New Jersey to Carolina. 4. July, Aug. v. v. The same size and habit as No. 1.

linearis. 3. L. erecta, virgata, glabra; foliis alternis linearibus acutis, floribus axillaribus solitariis sessilibus, capsulis oblongis turbinatis, laciniis calycinis semilanceolatis. -Walt. fl. car. 89 .

L. angustifolia. Mich.fl. amer.1.p. 88 .

Near ditches and ponds in sandy soil : Virginia to Carolina. 4. July, Aug. v.v. From two to five feet high, very branchy; flowers small, yellowish-brown.

virgata.

4. L. erecta, virgata, glabra ; foliis alternis linearibus obtusis, floribus terminalibus subspicatis pedicellatis, cap. sulis globoso.tetragonis ecoronatis. Mich. fl. amer. 1. p. 89 .

L, ramosissima. Walt. f . car. 89 .

In dry sandy woods of Lower Carolina. Michaux. 24 . May, June. v.s. Flowers small.

decurrens. 5. L. erecta, ramosissima, glabra ; foliis alternis linearilanceolatis decurrentibus, floribus axillaribus subsessilibus solitariis alternis, capsulis clavatis coronatis, laciniis calycinis ovali-lanceolatis. Walt. fl. car. 89.

L. jussiæoides. Mich. fl. amer. 1.p. 89.

In shady woods near ponds and ditches: Virginia and Lower Carolina. $\odot$. July, Aug. v. $v$. About a foot bigh, very branchy; flowers large, yellow. 
o. L. erecta, glabra; foliis alternis lato-linearibus acutis basi rotundatis, capitulis spicatis terminalibus, petalis capitata. calyce brevioribus, capsulis subglobosis coronatis, laciniis calycinis dilatatis brevibus. Mich. fl. anter. 1. p. 90 .

L. suffruticosa. Walt. fl. car. go.

In swamps of North and South Carolina. 4. JulySept. $v . v$. The root is creeping; infertile branches have short obovate leaves; flowers small, yellow.

7. L. repens, pubescens; foliis oppositis lineari-lanceolatis pedunculosa. glabris, pedunculis axillaribus unifloris longissimis, capsulis clavato-oblongis coronatis, laciniis calycinis lanceolatis. Mich. fl. amer. 1. p. 88.

L. arcuata. Walt. $f$. car. 89 .

In swanps near the sea-coast: Virginia to South Carolina. 4. May-July. v.s. A small plant; flowers large, yelluw.

$$
\text { ** Apetala. }
$$

8. I. repens, lucida ; foliis oppositis ovato-larceolatis petionitida. latis, floribus axillaribus solitariis sessilibus, capsulis subovatis brevi-coronatis. Mich.fl. amer. 1.p. 87 .

L. apetala. Wäl. $f$. car. 89 .

L. repens. Suartz. $f$. ind. ocid. 1. p. 273. Isnardia palustris. Willd, sp. pl. 1. p. 080 .

Icon. Lam. encycl. 3. t. 77.

In ditches and ponds, common: Canada to Georgia. 4. $\odot$. May-Sept. v. v. Floating in the water; flowers exceeding snall, frequently with rudiments of petals.

9. L. procumbens, glaberrima ; foliis alternis spathulatoobovalibus superne glanduluso-marginatis; floribus sessilibus axillaribus solitariis, capsulis minimis coronatis, laciniis calycinis rotundis acuminatis. Walt. fl. car. 88 .

L. microcarpa. Mich. fl. amer. 1.p. 88.

In swamps of Lower Carolina. Michaux. 4. July. v.s. Flowers small ; leaves acuminate, small.

10. L, erecta, ramosa, pubescens ; foliis alternis lanceolatomollis. oblongis, floribus sessilibus alternis superioribus congestis, capsulis subrotundis. Mich. fl. amer. 1. p. g0.

L. rudis. Walt. fl. car. 89 .

In swamps of Lower Carolina. Michanx. July. +.

glandulosa.

\section{mollis.}


139. ALCHEMILLA. Gen.pl.222. Ladies-mantle.

alpina.

1. A. foliis digitatis apice dentatis sericeis. Willd.sp.pl.1. p. 698 .

Icon. Fl. dan. 49. Engl. bot. 244.

Un the peaks of high mountains in Vermont and New Hampshire. 4. June, July. v.s. Whether the American species is the true A. alpina or not, I am not able to determine, as $I \mathrm{am}$ at present in want of specimens to compare them; but the plate in the Flora Danica represents the American plant fully, as far as recollection can decicle.

Aphanes.

2. A. foliis tripartitis, laciniis trifidis pubescentibus, floribus axillaribus glomeratis monandris. Willd. sp. pl. 1 . p. 699 .

Aphanes arvensis. Linn. sp.pl. 179.

Icon. Engl. bot. 1011. Fl.dan.973. Lam.illustr. 1. t. 87 .

In fields of Virginia. Clayton. ๑. May-Aug. v. s. in Herb. Gronov.

\section{BOEHMERIA. Gen.pl. 1421.}

cylindrica. 1. B. foliis oppositis ovato-oblongis acuminat is clentatis glabris, floribus dioicis, spicis masculis glomeratis interruptis, fenineis cylindricis, caule herbaceo. Willd. sp.pl. 4. p. 3to.

Urtica cylindrica. Linn.sp. pl. 1306. Mich. f. amer. 2. p. 179 .

Icon. Sloan. hist.jam. 1.t. 82. f. 2.

In shady wet places : Canada to Florida. 4 . June-Aug. $v . v$. About two feet high.

lateriflora. 2. B. foliis alternis ovato-lanceolatis acuminatis serratis scabris, floribus glomeratis lateralibus, caule herbaceo. Willd. sp. pl. 4. p. 342.

In rocky shady woods : Pensylvania to Virginia. 4. July. $v . v$. Leaves on long petioles, trinerved.

141. URTICA. Gen. pl. 1422. Nettle.

pumila. 1. U. fuliis oppositis ovatis acuminatis trinerviis scrratis, petiolis incerioribus longitudine folii, floribus monoicis triandris capitato-corymbosis petiolo brevioribus. Willd.sp.pl. 4. p. 348. 
In shady woods among rocks: Canada to Carolina. $\odot$. July. $v . v$. Smooth and shining; very variable in size.

2. U. foliis oppositis ellipticis subquinquenervibus argute serratis, spicis glomeratis geminatis. IVilld. sp pl.4. urens. p. 352 .

Icon. Fl.dan. 739. Engl. bot. 1236.

In cultivated grounds: Canada to Virginia; rare. $\odot$. May-July. v. v. Probably introduced from Europe.

3. U. foliis oppositis cordatis ovato-lanceolatis grosse serra. dioica. ti;, floribus dioicis, spicis paniculatis glomeratis geminatis petiolo longioribus. Willd.sp. $\mu l .4 . p .352$.

Icon. Fl dan. 740 .

Un road sides and in waste places, frequent: Canada to Carolina. 24. June-Aug. v. v.

4. U. foliis oppositis cordatis ovato-lanceolatis serratis, petiolis cilianis, foribus dioicis, spicis subramusis glomeratis geminis petiolum subxquantibus. Willd. $s p$. pl. 4.p.353.

U. gracilis. Ait. kew. 3. p. 3.11?

On water sides in rocky situations: Canada to Pensylvania. 24. July, Aug. $v \cdot v$. The specimen of $U r$ tica gracilis in the Herbarium of A. B. Lambert, Esq. agrees in every respect with the present species.

5. U. foliis oppositis subsessilibus ovatis serratis subtus strigosis, glomerulis axillaribus sessilibus subglubosis reflexis, caule stimuloso.

On the islande of Georgia: St. Simon's, \&-c. ๑. May. $v$ s. in Herl. Lyon. The leaves are small : the stings white and very conspicuous.

6. U. folii, alternis cordato-oratis acuminatis serratis trinervibus petiolo duplo longioribus, glomerulis spicatis, spicis solitariis folio brevioribus, superne foliosis, caule nudo.-Willd. st.pl. 4.p. 363 .

In shady woods, near rocks; Canada to Carolina. $2 \%$. June, July. v. v. Resembles U. dioica.

7. U. foliis alternis ovatis acuminatis serratis, glabriusculis, petiolis longis ciliatis, paniculis axillaribus solitariis divaricato-ramosissimis petiolo longioribus, caule sti. muloso.-- lVilld. sp. pl. 4. p.365?

In shady woods, in rocky situations: Canada to Carolina. 24. July, Aug. v. v. This species is very near to the foilowing, but is sufficiently distinct in the vol. I.

chamadrois des.

capitata.

divaricata.

procera. 
leaves being not cordate and smooth, the panicles so. litary and mixed with female flowers, and the general appearance of the plant.

eanadensis.

8. U. foliis alternis cordato-ovatis acuminatis serratis utrinque hispidis, paniculis axillaribus plerumque geminatis, divaricato-ramosissimis, inferioribus masculis petiolo longioribus, superioribus elongatis femineis, caule hispidissimo stimuloso.-Willd. sp. pl. 4. p. 365.

Icon. Pluk. alm.t. $237 \cdot f \cdot 2$.

Near rivulets, in rocky or sandy situations : Canada to Carolina, especially in the mountains. 4 . July, Aug. $v . v$. From five to six feet ligh; leaves large.

\section{PARIETARIA. Gen. pl. 15;6. Pellitory.}

pensylianica. 1. P. foliis oblongo-lonceolatis venosis opaco-punctatis, involucro triphy!lo foribus longiore. Willd. sp. pl. 4. p. 955.

On moist rocks: Pensylvania, \&c. ๑.June. v. v.; v. s. in Herl. Nuttall.

143. VISCUM. Gen. pl. 1504. Misseltoe.

fiarescens. $\quad 1 . \mathrm{V}$. foliis lanceolatis obtusis, spicis axillaribus aggregatis. -Willd.sp.pl.4.p. 7 to?

V. album. W'alt. fl.car. 241.

Parasitic on onks and other trees; rare. h. May. v. $v$. It is doubtful whether this is truly V. flavescens; but the specimens observed by me in the West Indies were exactly the same as those of North America; berries white.

144. CEPHALANTHUS. Gen. pl. 147. Button-wood.

occidentalis. 1. C. foliis oppositis ternisque. Willd.sp.pl. 1.p. 543. Icon. Schmidt arb. t. 45. Pluk. alm.t. 77.f. 4.

In deep swamps and morasses, common: Canada to Florida. 々. July, $\Lambda$ ug. v. v. Flowers white, in a round ball.

\section{ELEAGRUS. Gen. pl. 213. Oleaster.}

Q) gentea.

1. E. inermis, foliis oblongis utrinque acutis argenteo-lepidotis, floribus subsolitariis nutantibus.

In the extensive plains on the banks of the Missouri. M. Lewis and T. Nuttall. 々. July. v. s. in Herb. 
Lewis. Missouri Silver-tree. In the collection of A. B. Lambert, Esq., are specimens from Dr. Pallas, under the name of E. latifolius, which approach very near to the present species; but the !eaves are longer, and but slightly covered with that silvery substance on the upper surface, which in the present one is equal on both sides: besides, the flowers aie generally aggregate: it is probable that both belon:y to the same species, different from E. latifolius of Linnæus, which I do not know.

\section{HIPPOPHAE. Gen. pl. 1509. Sea Buckthorn.}

1. H. foliis oratis acutiusculis, supra glabriusculis, subtus argenteo-pilosis lepidotisque: squamis sparsis terrugineis.-Willd. sp. pl. 4. p. 744 .

Neur lakes and rivers : Canada to New York. $\zeta$. May. v. v.

2. H. foliis ovatis obtusis utrinque glabris dense argenteolepidotis.

On the banks of the Missouri. M. Lewis. h. v.s. in Herb. Luis. c. fr. This shrub resembles Elaegrius argentea so much, that they might eavily be mistaken one for the other when without fruit; but this species bears really a berry, different from the drupa of the other genus. The flowers are according to information from Mr. Nuttall four cleft, and resemble those of Elcagrus very much.

\section{II. $D I G Y N I A$.}

147. PLANERA. Mich.fl.amer. 2. p. $24 \%$.

1. Planera. Willd. sp. pl. 4.p.g67.

P. Gmelini. Mich. $f$ amer. 2. p. 248.

canadensi:

argentea.

Anonymos aquatica. Walt. fl. car. 230.

On the banks of rivers in both Carolinas. $h$. May. $v . v$. A tree resembling an Elm in its foliage very much; the leaves are small, equal on their base and equally serrated; the flowers appear before the leaves at the end of the branches irs close bunches, are small and of a greenish-brown colour. 


\section{HAMAMELIS. Gen. pl. 226. Witch-hazel.}

virginica.

1. H. foliis obovatis acute dentatis sinu parvo cordatis.Willd. sp.pl. 1.p. 701 .

Icon. Catest. car.3.t. 2. Duham. arb. 1.t. 114.

In stony and dry situations, but fiequently near water: Canada to Florida. $h$. Octob.-Feb. v, $v$. This singular shrub, which grows about ten or twelve feet high, begins to show its yellow flowers in autumn, when all others have dropt their fruit, continues to flower all winter, and forms its fruit the spring following.

macrophylla. 2. H. foliis suborbiculatis cordatis grosse obtuse-dentatis subtus scabro-punctatis.

On river sides in the western part of Georgia. J.Lyon. h. v. s. in Herb. Lyon. The large leaves punctated on their lower side, with rough tubercles and other marks, give sufficient reasons to consider it a distinct species: besides this, it is very probable that under H. virginica are two distinct species, as the northern plant seems to differ very much from the southern in its outside appearance.

149. CUsCUTA. Gen. pl.227. Dodder.

americana. 1. C. floribus pedunculatis umbellatis quinquefidis. Willd. sp.pl. 1.p. 702 .

Icon. Sloan. litst. 1.t. 128.f. 4.

Parasitic in hedges and on other plants, in moist situations. ○. July. v. v. Twining round other plants; leatless; flowers in clusters; the whole plant has a reddish-yellow appearance.

\section{SANGUISORBA. Gen. pll. 190.}

canadensis. 1. S. spicis cylindricis longissinis, staminibus corolla multoties longioribus. Willd. enum. pl. Eซsp. pl. 1.p. 654. Icon. Corn. canad. $t .174$.

In wet meadows : Canada to New York. 24. July, Aug. $v . v$. Flowers in very long white spikes; leaves resembling Burnet.

media.

2. S. spicis cylindricis, staminibus corolla longioribus. Willd. enum. pl. छ sp. pl. 1. p. 654.

In wet meadows, principally on the mountains : Canada to Carolina. 24. July, Aug. $v$, v. The spikes shorter, and tinged with red. 


\section{III. $T R I G Y N I A$.}

151. PACHYSANDRA. Mich. Ala amer. 2.p. 177.

1. P. caule procumbente, foliis brevibus ovalibus superne procumbens. crenato-dentatis, calycibus minutim ciliatis, capsula puberula. Mich. Al. amer. 2. p. 178 .

Jcon. Mich.l.c.t. 45.

In shady rocky situations on the Allegany mountains. 4. June. v.v. Evergreen : flowers greenish-white.

\section{TETRAGYNIA.}

152. ILEX. Gen pl.232. Holly.

1. I. foliis uvatis acutis spinosis glabris planis, floribus ad basin ramulorum annotinorim sparsis. Willd.sp.pl.1. opaca p. 70 .

I. Aquifolium baccis rubris. Walt. fl. car. 241 .

Jcon. Merel. ic. 2. t. 5.

In sandy woods, Canada to Carolina ; particularly plenty in the state of New Jersey. h. May, June. v. $v$. An evergreen beantiful tree, sometimes eighty feet high and four in dıameter; berries scarlet.

2. I. foliis oratis sinuato.dentatis spinosis nitidis planis, pedunculis supra axillaribus in ramulis junioribus ag-

laxiflora. gregatio laxe-ranusis. Lam. encycl 3.p. 147 .

I. Aquifolium baccis flavis. IValt. fl.car. 241.

In shady sandy woods: Carolina. h. May, June. $v . v^{\prime} ; v$ s. in Herl. Fraver. An evergreen shrub of lower growth than the former species; berries yellowish-red.

3. I. foliis ovato-lanceolatis argute serratis planis, costa media subrus glabra, pedunculis lateralibus corymboso-

Cassine. ramosis. Ait. kezw. 1. p. 170.

Icon. Catesb. ar. 1. t. 31 .

In shady swamps: Lower Carolina to Florida. F. June. $v . v$ An evergreen strub from eight to twelve feet high.

4. I. folits lanceolato-ellipticis subintegerrimis margine re-

Dahoon.

flexis, costa media subtus villosa, yedunculis lateralibus 
terminalibusque corymboso-paniculatis. - Wall. fl. car. 241. Mich. fl. amer. 2. p. 228.

In open swamps: Carolina to Florida. $\eta_{2}$. May, June. $v$ v. A beautiful evergreen slirub and sometimes tree; the leaves are very coriaceous, and resemble those of Laurus Borbonia.

angustifolia.

5. I. foliis lineari-lanceolatis apice serratis margine reflexis, costa media subtus glabra, cymis lateralibus peduncu. latis panciforis. - IVilld. enum. $p l$.

I. myrtitolia. Walt. ft. car. 241.

I. rosmarinifolia. Lam. illustr. 1. p. 356.

ligustrifolia. $\beta$. I. foliis latioribus omnibus integerrimis. An species distincta?

In deep swamps: Virginia to Georgia. $\eta$.June. v.v. An evergi een shrub from six to ten feet high.

vomitoria. 6 . I. foliis oblongis utrinque obtusis crenato-serratis glabris umbellis lateralibus subsesslibus. Ait. kcw. 1.p.170. Willd. sp pl. 1. p. 709 .

I. Cassine. Walt. A. car. 241.

Ilex ligustrina. Jacq. collect. 4. p. 105.

Cassine Peragua. M7ill.ic. t. 83. f. 2.

Icon. Jarq. ic. rar. 2. t. 310 . Wendl. hort. t. 31 .

Along the sea-ceast: Carolina to Florida. $\zeta$. June, July. $v . v$. The leaves of this handsome shrub are used by the Indians to make their Black drink, so much in use among them, not only as a medicine, but also as a drink of etiquette on their conncils, when matters of consequence are to be transacted.

prinoides. 7.I. foliis deciduis lanceolatis in petiolum attenuatis leviter serratis, costa media subtu; villosa, pedunculis unifloris aggregatis, fertilibus solitariis. Ait. kew. 1. p. 169. Willd. sp pl. 1. p. 709.

I. decillua. Walt. A. car. 241 .

On rocky shady bauks of rivers : Virginia to Georgia. $h$. June, July. v. v. A small shrub; berries red.

sanadensis.

8. I ? foliis deciduis ovatis integerrimis seu apice rariter serratis glabris, pedunculis subsolitariis longissimis unifloris, fructu obtuse subtetragono. Mich.fl. amer. 2. p. 229 .

Icon. Mich. l. c. i.49.

On high mountains, near the edges of ponds : Canada to Carolina. $h$. April, May. $v \cdot v$. Not abore three feet high; berries large, beautiful crimson, very ornamental. 
9. I ? foliis oppositis oblongis obtusis serratis margine reflexis glabris sempervirentibus, pedunculis axillaribus brevissimis subsolitariis unifloris basi bibracteatis.

On the Rocky-mountain and wear the Pacific Ocean. M. Lewis. $\zeta_{c}$. July, Aug. v. s. in Herl. Lewis.

Frutex sempervirens, glaberrimus, 4-pedalis, ramosissimus: rami teretes, fusci, dense foliosi. Folia parva opposita, oblonga seu obovata, obtusa, superne serrata, postice integerrima, margine revoluta, vix petiolata. Pedunculi axillares, brevissimi, uniflori, solitarii seu terni, basi opposite bibracteati. Flores minuti, albi. Cal. 4-fidus : laciniis subrotundis, concaris. Cor, rotata, 4-fida: laciniis oblongis. Filum. 4. ad incisuras corollæ inserta? longitudine calycis. Germen superum, ovale. Styl. brevissimus, clavatus. Stig. 4lobum, crassum. Drupa maturitate monosperma, ovata, atro-purpurea, magnitudine pisi. Sem. 1. ellipticum.

This very curious shrub, of which $I$ have likewise observed a specimen in the museum of A. B. Lambert, Esq., collected by A. Menzies, deserves to be examined in the living plant. It approaches so near to Myginda Rhacoma of Jacquin, that at first I considered it to be the same plant. It likewise has great affinity to Palloria ovalis Flor.per. 1. p.44.t. S4. only the leaves are not opposite, but sparse and crenate not serrated, which is the case always in the present plant. As I do not know the Myginda Rhacoma, it would be a curious fact if this plant, from the high cold mountains of the north, should turn out to be the same with the tropical plant. I refer it to Ilex at present, till further observations will decide to which genus it belongs, or whether it may not form one by itself.

\section{SAGINA. Gen.pl. 236.}

1. S. caulibus procumbentibus glabris, petalis brevissimis. procumlens. Smith fl. lrit. 1.p.199. Willd. sp.pl.1.p.71s. Icon. Engl. lot. 880 . Pluk. alm. t. 74.f. 2.

In barren sandy fields : Virginia and Carolina. Walter and Clayton. $\odot$. May-Aug. v. s. in Herl. Walter. 


\section{POTAMOGETON. Gen. pl. 234.}

natans?

fuitans.

heterophyl. lum.

selaceum.

perfoliatum.
1. P. foliis longe petiolatis natantibus sublanceolato-ovalibus, primariis nonnullis subcordatis. Mich. flamer. 1. p. 101 .

In ponds and slow-flowing waters, common. 4 . June, July. $v . v$. Floating in the water; flowers, as all the following, in spikes axillary or sometimes terminal, small and of a greenish colour. It is doubtful whether this is not a new species, but I had no opportunitv to compare it in a living or dried state with the European plant.

2. P. foliis inferioribus longissimis linearibus, superioribus lanceolatis nervosis coriaceis, omnibus petiolatis.Willd. sp. pl. 1.p. 713 .

P. foliis lanceolato-oblongis, petiolis longis. Gron. $f$. virg. 39 .

In ponds on the barrens of New Jersey and Carolina. 4. Jily. v. $v$.

3. P. foliis superioribus petiolatis ellipticis utrinque attenuatis, inferioribus confertis sessilibus linearibus. Willd. sp.pl.1.p.713.

P. hybridum. Mich.fl. amer. 1.p. 101.

In slow flowing waters of Virginia and Carolina. 4. June, $v . v$.

4. P. foliis superioribus oppositis lanceolatis quinquenervibus brevi-poiolatis, inferioribus alternis filiformibus, spicis densis alternis folio brevioribus.-IVilld. sp.pl. 1.p.710?

In small lakes and rivers, on the pine barrens of Jersey. 4. July, Ang. $v, v$. The upper leaves are scarcely half an inch long; the whole plant very slender.

5. P. foliis cordato-ovatis amplexicaulibus omnibus immersis, spicis terminalibus, floribus alternis.-Mich. f. amer. 1.p.101. Willd sp.pl.1.p.713.

Icon. Fl. dan. 196. Engl. lot. 168.

In ponds and rivers, frequent: Canada to Pensylvania. 4. July, Aug. v. v. Spike of flowers only floating, brown.

lucens. 6. P. foliis lanceolatis subsessilibus, costa media crassa, spicis longis cylindricis. Mich. fl. amer. 1. p. 101. Willd. sp pl. 1.p.714.

Icon. Fl. dan. 195. Engl. lot. 376. 
In ponds and rivers on sandy soil : New Jersey to Carolina. $\psi$. July, Aug. v.v. Leaves larger thau any of the other sorts; spike greenish brown.

7. P. foliis alternis oppositisve lancenlato.ellipticis undulatis serratis spicis paucifloris.-Willd. sp. pl. 1.p.714.

Icon. Fl. dan. 927. Curt. lond.5. t. 15.

In rivers and ponds: Canada to Virginia. 24. June, July. $v v$. spikes greenish red, small.

8. P. foliosun ; foliis sessibibns angnsto-linearibus planis, pauciflorum. spic ss capitatim subquadrifloris.

P. gramineum. Micir. fl. amer. 1.p. 102.

In rivers near the sea-coast of Lower Carolina. 24 .

9. P. foliis prælongo-setaceis approximatis distichis basi va- pectinatum. ginantibus, spicis terminalibus interrupt:s verticillatis, fructibus ovatis turgidis.-Smith fl. brit. 1.p. 197 .

P. marinum. Nich fl. amer. 1.p. 102.

In pouds and slow-flowing waters : Canada to Pensylvania. 24. July. v. v. Only the spikes appear above water; flowers seldom.

155. RUPPIA. Gen.pl. 235.

1. Ruppia. IVilld. sp.pl. 1.p. 717 .

maritima. lcon. Engl. bot. 136. Mich. gen. 35 . Fl. dan.364. On the mouth of most rivers in North America. 24.v.v. 


\section{PENTANDRIA.}

\section{MONOGYNIA.}

* Flores monopetali, inferi, tetraspermi. Asperifolize.

155. ECHIUM. Cor. fauce nuda, irregularis, campanulata.

157. HELIOTROPIUM. Cor. fauce nuda, hypocrateriformis, lobis dente interjectis.

158. PULMONARIA. Cor. fauce nuda, infundibuliformis. Cal. prismaticus.

159. LITHOSPERMUM. Cor. fauce nuda, infundibuliformis. Cal. 5-partitus.

160. BATSCHIA. Cor. fauce nuda, hypocrateriformis, intus basi annulo barbato cinctus : laciniis rotundatis. Cal. 5-fidus.

161. ONOSMODIUM. Cor. fauce nuda, subcampanulata, limbo vertricoso: laciniis conniventibus acutis. Anth. sessiles inclusæ. Cal. 5-partitus.

162. LYCOPSIS. Cor. fauce fornicata, infundibuliformis, tubo curvato.

163. CYNOGLOSSUM. Cor. fauce fornicata, infundibuliformis. Sem. depressa, latere affixa.

164. MYOSOTIS. Cor. fance fornicata, hypocrateriformis, lobis emarginatis.

* Flores monopetali, inferi, angiospermi.

165. HYDROPHYLLUM. Caps. 1-locularis, 2-valvis. Cor. campanulata, interne striis 5. melliferis longitudinalibus. Stigm. 2-fidum.

166. ANAGALlis. Caps. 1-locularis, circumscissa. Cor. rotata. Stigm. capitatum.

167. LYSIMACHIA. Caps. 1-locularis, 10-valvis. Cor. rotata. Stigm. obtusum.

168. DODECATHEON. Caj's, 1-locularis, oblonga. Cor. 
rotata, reflexa. Stam, tubo insidentia. Stignt. obtusum.

169. Primula. Caps. 1-locularis. Cor. tubus cylindricus, ore patulo. Stigm. globosum. Involucr. umbellulæ.

170. ANDROSACE. Caps. 1-locularis. Cor. hypocrateriformis, fauce coarctata. Stigm. globosum.

171. SABBATIA. Caps. 1-locularis. Cor. tubo urceolato, limbo 5-12-partito. Stigm. 2-partitum: laciniis spiralibus. Anth. demum revoluta.

172. HOTTONIA. Caps. 1-locularis. Cor. hypocrateriformis. Stam. tubo corollæ imposita. Stigm. globosum.

173. MENYANTHES. Caps. 1-locularis, 2-valvis. Cor. rotata : laciniis disco longitudinaliter barbatis, margine planis. Stigm. 2-fidum.

374. Villarsia. Caps. 1-locularis, evalvis. Cor. rotata : lacinii; basi barbatis, margine infiexis. Stigm. 2-lobum. Glandula 5. staminibus alternæ.

175. SPIGELIA. Caps. 2-locularis, didyma. Cor. infun. dibuliformis. Stigm. simplex.

176. OPHIORRHIZA. Caps. 2-locularis, 2-partita. Cor. infundibuliformis. Stigm. 2-fidum.

177. PHACELIA. Caps. 2-locularis, 4-sperma. Cor. sub.campanulata. Stam. exerta. Styl. brevis.

17S. ELLISIA. Caps. 2-locularis, 2-valvis: loculi 2sperni, semine uno supra alterum. Cor. infundibu. liformis, angusta. Stam. inclusa. Stigm. 2-fidum. Cal. persistens.

179. DitURA. Caps. 2-locularis, 4-valvis. Cor. infun. dibuliformis. Cal. deciduus.

180. HYOSCYAMUS. Caps. 2-locularis, operculata. Cor. infundibuliformis, irregularis. Stam. inclinata. Stigm. capitatum.

18. NCUTIANA. Caps. 2-locularis, 2-valvis. Cor. infundibuliformis, limbo plicato, Stam. inclinata. Stigm. emarginatum.

1S2. VER 3ASCUM. Caps. 2-locularis. Cor. rotata, inæqualis. Fil. barbata. Stigm. obtusum.

183. CALY $S$ TEGIA. Caps semibiloculare, sub-4-sperma. Cor. campanulata, 5-plicata. Stigm. 2. globosa. Cal. basi bibracteatus.

184. CONvolv Ulus. Caps. 2-3-locnlaris. Cor. campanulata, 5-plicata. Stigm. 2. filiformia. Cal. nudus aut bibracteatus. 
185. IPOMOEA. Cans. :-3-locularis. Cor. infundibuliformis, 5-plicata. Stigm. capitatum, 2-3-lobum. Col nudus.

186. CAN1UA. Cops. 3-locularis, 3-valvis. Cor. infundibulifornis. Stigm. 3-fidum. Sem. alata.

187. DiAPE $\triangle S I A$. c aps. 3-lucularis, 3-valvis, polysperma. Cor hypocrateriformis : tubo brevi. Cal.5partitus, basi bracteatus. Styl. brevis. Stigm.3lobum.

1ss. PHIOX. Caps. 3-locularis, 1-sperma. Cor hypocrateriformis. Fil. inæqualia. Stigm. 3-fidum. Cal. prismaticus.

189. POLEMONIUM. Caps.3-locularis. Cor. 5-partita, fundo clausa valvis staminiferis, Stigm. 3-fidum.

190. AZALEA. Caf's. 5-locularis. Cur. infundibuliformis aut companulata. Stam. receptaculo inserta. Stigm. obtusum.

191. DUME1IA. Drupa 1-sperna. Cor. hypocrateriformis limbo dentitus interjecto. Nect. 5-pbyllum.

192. SOLANUM. Bacra 2-locularis. Cor. rotata, plicata. Antherce biperforatæ, subcoalitæ. Cal. persistens.

193. PHYSALIS. Bacca 2-locularis intra calycem inflatum. Cur. campanulato-rotata. Antherce approxinatie.

194. NICANDRA. Bacca 3-5-locularis, exsucca. Cor. can panulata. Stam. incurra. Cal. 5-angulatus: laciniis sagittatis.

* Flores monopetali, superi.

195. SAMOLUS. Caps. J-Jocularis, apice E-valvis. Cor. hypocrateriformis. Stign. capitatum.

196. PINKNEYA. Caps. 2 Jocularis : valvis medio septiferis. Cor. tubulosa. Cal. laciniis 1-2. bractexformibus. Fil basi tubi inserta. Sem. alata.

197. CAMFa NULA. Caps. 2-5-locularis, poris lateralibus deliscens. Cor. canspanulata, fundo clauso valvis staminiferis. Stigm. 3-5-fidum.

199. CHInCOCCA. Bacca 2-sperma, didyma. Cor. infundibuliformis. Stigm. simplex.

199. CAIRIHOL!UM. Bacca 3-Jocular is, polysperma, distincta. Cur, tubulosa, longa, 5-fida. Cal. 5-cientatus.

200. XYI.OSTEUM. Bacce duæ basi connatæ, 2-locu- 
lares, polyspermæ. Cor. infundibuliformis, subæqualis. Cal. 5-dentatus.

201. SYMPHOR1A. Bacca 4 locularis, 4-sperma, coronata. loculis interdum 2. abortivis. Cor. tubulosa, brevis, 5-fida, subæqualis. Cal, 4-dentatus.

202. DIERVII LA. Caps. 4-locularis, oblonga, polysperma. Cor. iufundibuliformi, 5-fida, patens. Cal. oblongus, 5 fidus.

203. TRIOSTEUM. Bacca 3-loculari, 3-sperma, Cor. calyce vix longior, tubuloss. Cal.5-fidus. Stigm. oblongum.

\section{* Flores pentapelali, superi.}

204. RIBES. Bucca polysperma. Cal. corollifer. Styl. bitidus.

* Fiores pentapetali, inferi.

205. RHAMNUS. Bacca 3-4-sperma. Cal. tubulosus, corollifer. Pet. oris 5, convergentia. Divicus.

205. CEANOTHUS. Bacca 3-cocca, sicca, Cal.tubuloins, corollifer. Petala fornicata.

207. Celastrus. Caps. 3-corca, 3-locularis. Sem. calyptrata. Cor. 5-petala, patens.

209. EVONYMUS. Caps. 5-gona, 5-valvis, colorata. Sem. calyptrata. Cor, 5-petala, piana.

209. VI . IS. Bacca 5-sperma. Petala apice cohærentia, emarcida. Siyl.o. Dioica.

210. CissUs. Bacca 2-locularis, 1-4-sperma. Petala reflexo-patula, decidua. Nectar, discus germen cingens.

211. CYRILLA. Bacca 2-locularis, 2-sperma, exsiccabilis. Petrla 5. stellatim patentia. Cal. minimus subturbinatus. Stylus 2-fidus.

212. ITEA. Caps. 2-locularis, 2-valvis: valvis margine introflexo seminiferis. Petala 5. reflexo-patentia. Cal. 5 -fidus, campanulatus. Stigm. capitatum, 2lobum.

213. IMPATIENS. Caps. 1-locularis, 5-valvis. Cor. irregularis, calcarata. Cal. 2-phyllus. Anther. cohærentes.

214. VIOLA. Caps. 1-locularis, 3-valvis, Cor. irregularis, calcarata. Cal.5-phyllus. Anther, cohærentes.

215. CLAYTONIA. Caps.1-locularis, 3-valvis. Cal.2valvis. Stigm. 3-fidum. 
* Flores incompleti.

216. GLAUX. Cal. inferus, 1-phyllus, coloratus, 5-lobus. Caps. 1-locularis, 5-valvis, 5-sperma, calyce cincta.

217. ANICHIA. Cal. inferus, connivens, 5-partitus : laciniis oblongis, apice subsaccatis. Stigm.2. Utriculus 1 -spermus.

218. THESIUM. Cal. superus, staminifer. Sem. 1. coronatum.

219. NYSSA. Cal. superus, 5-partitus. Drupa. Mas. Stam. 10. Polygama.

220. HAMILTONIA. Cal.superus, 5-fidus. Nect. discus 5-dentatus. Drupa. Dioica.

\section{DIGYNIA. \\ * Flores monopetali, inferi.}

221. ECHITES. Folliculi'. longi, recti. Sem. papposa. Cor. infundibuliformis, fauce nuda. Anther. conniventes in conurn.

222. GONOLOBUS. Folliculi 2. utplurimum costati seu angulati. Sem. papposa. Cor. rotata, profunde 5partita. Appendix brevissima, inclusa. Slyl. discoideo 5-gonus.

223. APOCYNUM. Folliculi 2. longi, lineares. Sem. papposa. Cor. campanulata. Filamenta 5. cum sta. minibus alterna. Styl. subnullus. Stigm. latum.

224. ASCLEPIAS. Folliculi 2. Sem, papposa. Cor. rotata, plerumque reflexa. Nectar 5. ovata, concava, corniculum exserentia. Anther. corneæ, longitudinaliter dehiscentes.

225. AMSONIA. Folliculi 2. Sem. nuda, teretia, oblique truncata. Cor. infundibuliformis fauce clausa.

226. GELSEMINUM. Caps. 2-locularis, 2-valvis, compresso-plana. Sem. plana, valvularum marginibus annexa. Cor. infundibuliformis, limbo patente, subxquali. Cal. 5 dentatus.

227. GENTIANA. Cops. 1-locularis, 2-valis. Receptaculis 2 . longitudinalibus. Cor. 1-petala, indeterminata.

228. HYDROLEA. Cats. 2-locularis, 2-valvis, Cor. rotata. Filam, basi cordata. Stign, capitato-peltata. Cal. 5-phyllus. 
229. DICHONDRA. Caps. subcompressa, didyma, 2locularis: loculis 1-spermis. Cor. brevi-campanulata. Stigm. peltato-capitata. Cal. 5-partitus: laciniis subspathulatis.

230. EVOLVULUS. Caps. 1-locularis, 4-valvis, 1-sperma. Cor. rotato-campanulata. Styli2. profunde 2 -fidi: laciniis capillaribus, divergentibus. Stigm. simplicia.

* Flores pentapetali, inferi.

231. HEUCHERA. Caps. 2-locularis, 2-rostris. Pet. 5. calyci inserta.

232. ZIZYPHUS. Drupa nuce 2 loculari. Discus carnosus, orbicularis, pistillum ambiens. Cal. tubulosus, corollifer. Dioicus.

* Flores pentapetali, superi dispermi. Umbellatæ.

233. ERYNGIUM. Flores capitati. Recep. paleaceum. Invol. polyphyllum. Cal. proprius 5-phyllus, superus.

234. HYDROCOTYLE. Umbella simplex. Invol. 4plyyllum. Pet. integra. Sem. semiorbiculato-compressa.

235. PANAX. Umlella simplex. Bacca cordata, 2sperma. Polygama.

236. SANICULA. Umlelle confertæ, subcapitatæ. Fruc. tus aculeatus. Flores disci abortientes.

237. DAUCUS. Corollce subradiatæ. Flosculi disci abortivi. Fructus pilis hispidus. Umbella fructus contracta, infundibuliformis. Involucra pinnatifida.

235. ANIMI. Corolle radiatæ: omnes hermaphroditæ. Fructus læris. Umbella laxa. Involucra pinnatifida.

239. SELINUM. Fructus ovali-oblongus, compresso-planus, in medio striatus. Invol. reflexum. Pet. cordata, æqualia. Cal. integer.

240. FERULA. Invol. universale caducum : partiale polyphyllum. Fructus ovalis, compresso-planus, striis utrinque 3.

241. HERACLEUM. Fructus ellipticus, emarginatus, compres sus, striatus, marginatus. C'or, difformis, inflexu-emarginata. Invol. caducum.

242. LIGUSTICUM. Fructus oblongus, 5-sulcatus utrinque. Corolla æquales. Pet. involuta, integra. Cal. 5-dentatus. 
243. ANGELICA. Fructus subrotundus, solidus, utrinque 3-alatus, stylis reflexis. Corollee xquales: petalis incurvis.

244. SIUM. Fructıs subovatus, compresssus, striatus. Invol. polyphyllum. Pet. cordata.

245. OENANTHE. Flosculi difformes: in disco sessiles, steriles. Iructus striatus, retusus, suberoso-cortica. tiis, coronatus calyce et pistillo. Umbelle globosæ.

246. PHELLANDRIUM. Flosculi disci minores. Fructus ovatus, levis, coronatus calyce et pistillo.

247. CICUTA. Fructus subovatus, sulcatus. Invol. 0: partiale 3-5-phyllum.

248. CONIUM. Fructus subglobosus, 5-striatus, utrinque crenatus. Involucella dimidiata, subtriphylla.

249. CHÆROPHYLLUM. Invol. reflexum, concavum. Pet. inflexo-cordata. Fructus oblongus, levis, aut striatus, glaberrimus.

250. PASTINACA. Fructus ellipticus, compresso-planus. Pet. involuta, integra.

251. SMYRNIUMI. Fructus subcompressus, gibbosus, striatus. Pet. acuminata, carinata.

252. SESELI. Umlella globosæ. Invol. foliolo uno alterove. Fruchus ovatus, striatus.

\section{* Flores incompleti.}

253. SALSOLA. Sem. 1. cochleatum, tectum. Cal. 5phyllus.

254. CHENOPODIUM. Sem. 1. lenticulare, superum. Cal. 5. phyllus, 5-gonus.

255. ATRIPLEX. Sem. 1. compressum seu depressum. Cal. 5-phyllus. Flor, feminei intermixti: quibus Cal.2-phylius. Polygama.

256. CANNABIS, Nux 2-valvis, intra calycem clausum. Mas. Cal. 5-partitu: Fem. Cal.5-phyllus, integer, latere hians. Dioica.

257. HUMULUS. Sem. 1. intra calycem foliatum (in strobilumı). Mas. Cal. 5-pbyllus. Fem. Cal. 1. phyllus, oblique patens, integer. Dioica.

258. ULMUS. Samara compressa, membranaceo-alata. Cal. campanulatus, 5-fidus, marcescens.

259. CELTIS. Drupa 1-sperina. Cal.5-6.partitus. Stam. 5-6. Styl. divaricati, crassiusculi. Polygama. 


\section{TRIGYN!A.}

260. VIBURNUM. Cal. superus, 5-partitus. Cor. 5 fida. Drupa 1-sperma.

261. SAMBUCUS. Cal. superus, 5-partitus. Cor. 5-fida. Bacca 3-sperma.

262. RHUS. Cal. inferus, 5-partitus. Pet.5. Bacca 1sperma.

263. STAPHYleA. Cal. inferus, 5-partitus. Pet. 5. Caps. inflatæ, connatæ. Nuces 2. globosæ cum cicatrice.

264. TURNERA. Cal. inferus, 5-fidus, infundibuliformis. Pet.5. calyce inserta. Stigmata multifida. Caps. 1-locularis, 3-valvis.

265. CROTONOPSIS. Cal. inferus, 5-partitus. Pet. 5. Stigmata bifida. Caps. 1-sperma, non dehiscens. Monoica.

266. KOCHIA. Cal. inferus, 5-fidus. Cor. 0. Stigm. simplicia. Sem. 1. orbiculatum, calyce persistente cinctum.

267. AMARANTHUS. Cal. 3-5-phyllus. Cor. 0. Stam.3-5. Caps. 1-locularis, 1-sperma, circumscissa. Monoicus.

26s. ACNIDA. Cal.3-5-partitus. Cor. 0. Stigm. sessilia. Caps, 1-sperma. Dioica.

\section{TETRAGYNIA.}

269. PARNASSIA. Cal. 5-partitus. Pet. 5. Nectar. 5. cordata, ciliata, apicibus globosis. Caps. 2-locularis, 4-valvis.

\section{PENTAGYNLA.}

270. ARAlia. Cal. superus, 5-dentatus. Pet.5. Bacca coronata, 5-sperma. Involucr. umbellulæ.

271. ZANTHOXYLUM. Cal. inferus, 5-partitus. Cor. 0. Caps. 3-5. 1-spermæ. Dioicum.

272. LINUM. Cal. inferus, 5-phyllus. Pet.5. Fil. basi coalita. Caps. 10-locularis, 5.valvis. Sem. solitaria. 273. DR.OSERA. Cal. inferus, 5-fidus. Pet. 5. Caps. 1vor. I. locularis, apice 3-5-valvis. Sem. plurima. 
274. SIBBaldia. Cal. inferus, 10-fidus. Pet. 5. calycí inserta. Styli e latere germinis. Sem. 5.

275. STATICE. Cal. inferus, 1-phyllus, tubulosus, plicatus, 10. dentatus. Cor. 1-petala, hypocrateriformis, 5-fida. Caps.1-locularis, basi 5-valvis. Sem. 1. teres.

\section{POLIGYNIA.}

276. ZANTHORHIZA. Cal. o. Pet. 5. Nectar. 5. pedicellata. Caps. 1-sperma.

277. SCHISANDRA. Cal. triplici serie 9-phyllus. Cor. o. Anther. subsessiles, apice cohærentes. Bacca numerosæ, 1-spermæ, receptaculo filiformi elongato insertæ. Monoica.

\section{I. $M O N O G Y N I A$.}

156. ECHIUN. Gen. pl. 267.

vulgare.

1. E. caule tuberculato-hispido, foliis caulinis laisceolatis hispidis, floribus spicatis lateralibus. IVilld.sp.pl. 1. p. 787 .

Icon. Fl. dan. 445. Lam. illustr. 94.f. 1.

On dry slate-hills: New York to Virginia, rare. In troduced from Europe? $\mathrm{o}^{x}$. July-Sept. v.v.

\section{Heliotropium. Gen. pl. 239.}

indicum.

1. H. foliis cordato-ovatis acutis scabriusculis, spicis solitariis, fructibus bifidis. Willd. sp.pl.1.p.740.

Icon. Pluk. pliyt. t. 205.f. 4 .

On road sides: Virginia to Carolina, rare. $\odot$. June -Aug. $v . v$.

\section{PULMONARIA. Gen. $p l .244$.}

virginica.

1. P. glabra, erecta ; foliis lanceolato-ovatis obtusiusculis, floribus fasciculato-terminalibus, corollis calyce multe longioribus.-Willd. sp. pl.1. p. 769 .

Icon. Mill. ic. 212. Bot. mag. 160. 
On gravelly shores of rivers: Pensylvania to Carolina. 4. March-May. v. v. Flowers beautiful blue.

2. P. subhirsuta, erecta; foliis ovato-oblongis acuminatis, paniculata. foribus paniculatis, calycibus abbreviatis quinquepartitis.-Willd. sp. pl. 1. p. 769 .

On Hudson's Bay. Aiton. May, June. + . Flowers blue or white.

3. P. glaberrima, procumbens; foliis ovali-spathulatis abrupte acuminat is carnosis, pelunculis lateralibus unifloris, corollis calyce vix duplo longioribus.-Mich. $f$. amer. 1. p. 131 .

P. maritina? Willd.sp.pl.1.p.7\%0.

Un the sea shore of New England and Canada. 4 . July. v. s. Flowers blue.

\section{LITHOSPERMUM. G.n. pl. 241.}

1. L. seminibus rugosis, corollis vix calycem superantibus, arvense. foliis obtusis aveniis. Smith fl. brit. 1. p. 213. Willd. sp. pl. 1.p. 751 .

Icon. Engl.bot. t. 123. Fl. dan, 456.

In waste fields, on diy ground : frequent in Pensylvania, probably introduced firom Europe. ค. May-July. $v . v$. Flowers pale white; seeds rough, brownish.

2. L. seminibus turgide ovatis lucidis undique cavo-punctatis, calycibus fructiferis patulis corollam superantibus, foliis ovato-oblongis nervosis. - Mich. $f$. aner. 1. p. 131.

In shady woods: Virginia to Kentuky. 2 . June, July. $v$ v. Flowers pale yellow.

3. L. seminibus turgide ovatis nitidis undique cavo-punctatis, floribus passim lateralibus, foliis linearibus adpresso-pubescentibus, caule procumbente.-Mich. $f$. amer. 1. p. 130.

In shady woods: on the river Ohio. Michaux. $\odot$. July, Aug. v. s. Flowers white.

4. L. seminibus muricatis, spicis terminalibus secundis, bracteis lanceolatis, foliis lineari-lanceolatis acutis.

latijolium. pariflora. Willd. sp.pl. 1.p.752.

Icon. Col. ecphr. 1.t. 192.

In dry woods : Virginia, Ohio and Mississippi. $\odot$. May-Aug. v. v. Flowers yellow, very small.

angustifolium.

apulum. 
160. BATSCHIA. Mich.fl.amer. 1. $p 129$.

Gmelini. 1. B. hirsuta; foliis foralibus ovatis, calycibus longis sublanceolatis.-Nich. fl. amer. 1. p. 130.

Anonymos carolinensis. IVait. fl car. p. 91.

In dry sunny wood of Lower Carolina. 24. May-July. $v$. s. in Herb. Lyon. Flowers pale jellow.

r anescens. 2. B. candicanti-villosa; foliis onuribus oblongis, calycibus brevissimis, Jaciniis corollæintegris. - Mich. fl. amer. 1. $p 130$

Anchusa floribus sparsis, caule glabro. Gron.fl. virg. p. 24 .

Icon. Mich.fl. amer. 1.t. 14.

On dry sunny hills, in sandy soil : Virginia, Tennassee, \&c. 24. June, July. v.v. Flowers of a deep golden yellow; the root is covered with a red substance, which is the true Puccoon of the Indians, and paints a beautiful red.

longiflora.

3. B. sericeo-villosa; foliis linearibus, calycibus longis linearibus, laciniis corollæe crenato-incisis, tubo elongato.

On the banks of the Missouri. Nuttall. 4 . July. v. s. in Herl. Nuttall. Flowers yellow.

\section{ONOSMODIUM. Mich. $f$. amer. 1.p.132.}

hispidum. 2. O. hispidum; fuliis obovali-lanceolatis acutis papillosopunctatis, laciniis coroliæ subulatis. - Mich. fl. amer.1. p. 133.

Kithospermum virginianum. IVilld.sp. pl. 1.p. 752.

On dry lime-stone hills: New York to Carolina. $\psi$. July, Aug. v. $v$. Flowers yellowish-white, similar to those of Symphytum.

molle.

2. O. candicanti-villosum; foliis oblongo-ovalibus subtriplinerviis, laciniis corollæe subovalibus.-Mich. $f l$. amer. 1. p. 133.

Lithospermum carolinianum. Lam. illustr. 1. p. 397.

Icon. Mich. l. c. t. 15.

In the western countries from Pensylvania to Tennassee. 4. June-Aug. v. $v$. Flowers white.

162. LYCOPSIS. Gen. pl. 250.

arvensis. 1. L. hispida; foliis lanceolatis repando-dentatis, racemis geminis, floribus sessilibus.-Willd.sp. pl. 1. p. 780. 
Icon. Fl. dan. 435. Engl. lot. 938. Lam. illustr. t. 92. In fields: Pensylvania to Virginia. Probably intruduced. $\odot$. June, July. v. $v$. Fluwers blue.

2. L. pusilia, hispidiš̌na ; foliis inferioribus spathulatis, superioribus lineari-oblongis integerrimis, racemis solitariis, toribas pedunculatis.-Willd. $s p$ pl 1. p. 781. In dry woods and on rocid sides : Pensylvania to Virginia. $\odot$. May-July. v. $v$. Flowers white, very small.

\section{CYNOGLOSSUM. Gen. pl. 243.}

1. C. mollissime pubescens; foilis lato-lanceolatis sessilibus, racemis paniculatis.-Willd. sp. pl. 1. p. $; 60$.

Icon. Curt. lond. 4. $t$ i6. Bot. mag.

In dry woods, in the lime-stone countries, frequent. $\delta$. June, July. $v, v$. Flowers brownish-red.

2. C. nudiusculum; foliis spathulato-lanceo'at is lucidis subtus scabris, racemis sparsis. Smilh, f. Lrit.1.p. 210.

C. virginicum. Willd. sp. pl. 1.p. 700 .

Icon. Engl. bot. $10+2$.

In similar situations in i irginia. $\delta$. June, July. $v . v$. Flowers blueish-brown.

3. C. hirsutissimum; foliis orali-oblongis, superioribus am-amplexicaule plexicaulıbus, corymbo terminali aphyllo longe pedunculato. Mich. fl amer. 1. p. 132.

C. foliis amplexicaulibus. Gron., , virg. p. 24.

C. virginicum. Linn sp.pl. 134.

In shady moist woods: Pensylvania to Virginia. 4 . May--July. v. v. Flowers beautiful blue and white. Willdenow's C. virginicum is certainly not the plant alluded to by Linnæus in his Species Plantarum, by which he refers to Clayton's plant, which evidently is the present species.

\section{MYYOSOTIS. Gen. pl. 240.}

1. M. perennis; seminibus lævibus, calycibus subovalibus glabris tubo corollæ fere longitudine, caule subramoso, palustris. foliis lanceolatis. Roth. germ. i. 87. ii. 221.

M. scorpioides. Willd. sp. pl. 1.p. 746.

Icon. Fl. dan. 583.

In rivulets and ditches, frequent. 4. May-Sept. v. v.

2. M. annua ; seminibus lævibus, calycibus ovalibus acuminatis hirsutissimis tubo corollæ longioribus, caule ra-

arvensis. 
mosissimo, racenuis conjugatis, foliis ovato-lanceolatis. Willd. sp.pl. 1. p. 747 .

In tields and shady woods: New York, Pensylvania, $\&$ c. $\odot$. June, July. v. v. Howers pale blue, very small.

virginiana.

3. M. pilosum; seminibus aculeato-glockidibus, foliis ovatoJanceolatis acuminatis, racemis divaricalis, - Willd. $s p$. pl. 1. p. 74 s.

In dry open woods : Virginia, Carolina, \&c. ๑. June, July. v. v. Flowers small, pale blue; leaves large.

Lappula. 4. M. hispidum; seminibus aculeis glochidibus, foliis lineari-oblongis, caule stricte ramosissimo.- $W$ illd. $s p$. pl. 1.p. $7+9$.

On way sides and among rubbish : Canada to Virginia. ๑. May-Aug. v. v. Flowers blue.

\section{HYDROPHYLLUM. Gen. pl. 267 .}

appendiculatum.

virginicum.

canadense.

lineare.
1. H. hirsutissimum, foliis radicalibus subpiunatifidis, caulinis sublobato-angulosis, calycis sinubus appendiculatis, fasciculis florum subpaniculatis.-Mich. fl. amer. 1. p. 134.

On shady rocks, near springs: Virginia, near Harper's Ferry, Tennassee, \&c. 4. May. v.v. Flowers pale blue; the calyx extremely hispid, and alnost the length of the corulla.

2. H. glabriusculam; foliis pinnatifidis pinnatisque, laciniis ovali-lanceolat is inciso-serratis, fasciculis florum con. glomeratis.-Willd. sp. pl. 1.p. 814 .

Icon. Lam. illustr. $t .97 \cdot f .1$.

In shady rocky situations: Canada to Carolina. 2 . May, June. v.v. Flowers beautiful blue.

3. H. hirsutum; foliis lobato-angulosis, fasciculis florum confertis.-Willd. sp. pl. 1. p. 815 .

Icon. Lam. illustr. t. $97 . f .2$.

On wet rocks and shady mountains : Canada to Pensyl. vania. 4. June, July. v. v. Flowers white, shaded with purple.

4. H. pilosum ; foliis linearibus, racemis elongatis.

On the banks of the Missouri, M. Lewis 4 . April. ข. s. in Herb. Lewis. 


\section{ANAGALLIS. Gen. pl. 2;0.}

1. A. foliis ovatis subtus punctatis, caule procumbente. arvinsis. Smith fl. lrit. 1.p. 230. Willd. sp.pl. 1.p. \$21. Icon Eingl. lot. 529. Fl. dan. 89.

In cultivated grounds: Pensylvania to Virginia; introduced from Europe? $\odot$. June, July. v. v. Flowers red.

\section{LYsIMACHIA. Gen. pl. 269.}

1. L. glaberrima, ramulosa ; foliis oppositis verticillatisque longo-linearibus punctatis, racemo terminali brevi, Jaciniis corollæ oblongis.-Mich. fl. amer. 1. p. 123.

In Lower Carolina. Atichaux. $4 .+$. Flowers yeliow, as the other species, very small.

2. L. glaberrima, elata; fuliis ovali-lanceolatis oppositis racemosa. punctatis, racemo terminali longissimo laxo, Jaciniis corollze oblongro-ovalibus.--Mich.jl. amer. 1. p. 125.

J.. vulgaris. IVult.fl. car. p. $9^{2}$.

L. stricta. Ait. kew. 1. p. 199.

L. bulbifera. Bot. mag. 104 .

Icon. Bot. mag. 104. Piuk. alm. t. 429. f. 4.

In - wet meadows, on the side of ditches: Canada to Virginia. 24. July, Aug. v.v. This species is trequently found viviparons, having oblong bulbs in the axillæ of the leaves; but this is not a general case.

3. L. glabra ; caule simplicissimo pun tato, foliis oppositis argustifolia. sesilibus late-lanceolatis acutis punctatis, pedunculis lateralibus elongatis, floribus capitatis congestis.

1. thyrsiflisa? Mich. fl. amer. 1.p. 127.

In sait-marsies, near New York. 24. June, July. v. v. Though nearly approaching to L. lhyrsiflora, it is certainly a distinct species.

4. I. pubescens; foliis subsessilibus quaternis quinisque quadrifolia. oval:bus acuminatis punctatis, pedunculis quaternis unithoris, corollæe laciniis ovalibus integris, - Willd. sp. pl. 1. p. 818 .

J. punctata. Walt. fl. car. p. 92 .

Icon. Pluk. alm. i.428.f. 4. Lam. illustr. t. 101. f. 2. In dry woods: Canada to Carolina. 4. June, July. $v . v$. It varies sometimes with smooth leaves and verticillated tlowers.

5. L. glaberrima, ramosissima ; fuliis oppositis sessilibus licapitata.

longifolia. 
nearibus longissinis: superioribus quaternis, pedunculis quaternis unifloris, corollac laciniis ovatis acuminatis serrulatis.

L. quadriftora. Bot. mag. 660 .

In wet woods, near ponds: Pensylvania to Virginia. 4. June-Aug. $v . v$. A handsome plant, with showy flowers.

heterophylla. 6. L glabra, gracilis; foliis oppositis linearibus sessilibus, basi ciliatis, imis suborbiculatis brevi-petiolatis, floribus cernuis. Mich. Al. amer. 1.p. 127.

Icon. Pink. alm. t. 333.f. 1 .

In wet neadow's: Virginia to Georgia ; rare. 4. July. $v . v$. Fluwers resembling those of L. ciliata.

hybrida. $\quad$ 7. L. glabra; foliis oppositis petiolatis lanceolatis utrinque acutis, petiolis cilistis, floribus cernuis, corollis calyce brevioribus: laciniis crenulatis.-Mich. fl. amer. 1. p. 126.

L. ciliata. Wult. fl. car. p. 92 .

L. angustifolia. I.am. illustr. 1. p. 440.

$\mathrm{O}_{\mathrm{i}}$ barls $\mathrm{s}$ of rivers, where the tide overflows: Pensylvaria to Carolina; rare. 4. June-Aug. v. v.

ciliata.

8. L. subpubescens ; foliis oppositis longe petiolatis, subcorduto-ovalibus nargine pubescentibus, petiolis ciliatis, pedicelis subgeminis, floribus cemuis, corollæ laciniis rotundatis, acuminatis crenatis.-Mich. $f$. amer 1.p. 126.

Icon. Walth. hort. t. 12.

In shady woods, in rich soil. 24. June-Aug. v. $v$.

\section{DODECATHEON. Gen. pl. 261.}

Meadia.

1. D. foliis oblongo-ovalibus repando-dentatis, umbellis multi? oris laxis, bracteis ovalibus. - Willd. sp.pl. 1 . p. 803.

Icon Bot. morg. 12. Lam. illustr. t. 99.

On wiver s.les, in rocky shady situations: Pensylvania to Virginis, a d on the Missotiri. 4. May. v.v. Flowers extrersely haudsome, purple.

integrifolium. 2. D. frlis subspathuiatis integerrimis, umbeilis paucifloris strieris, bracteic lin a ibus. Mich. fl. umer. 1. p. 123. Icon. Pluk alm.t 79. 6.

In the Allrga, mountains, in shady woods near rivers. 4 June. v. v. Flowers pale blue, smaller than the former species. 
169. PRIMULA, Gen. pl. 258.

1. P. pusilla, glabra; foliis ovali-spathulatis subdentatis, mistassinica. scapo elongato, umbella pauciflora, corolla limbo reflexo, lacinus cuneato-oblongis obtuse bifidis, capsula oblonga exerta. Mich. fl. amer 1. p. 124.

On lake Mistassins, and Hudson's Bay. Michaux. $4 .+$.

\section{ANDROSACE. Gen. pl.257.}

1. A. tenuissime pubescens; foliis involucrisve oblongooccidentalis. spathulatis inteserrimis, perianthiis angulatis, capsulis calyce brevioribus.

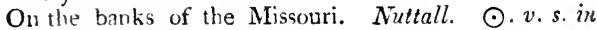
Herb. Nuttall. Approaches near to A. elongata, according to specimens of l'allas's in the Herbarium of A. B. Lambert, Esq.

171. SABBATIA. Adanson. Parad. lond. t. 32.

1.S. debilis; ramis laxis elongatis 1-fioris, foliis lineari-ellipticis, calycis lacıniis linearibus corollam subxquantibus, lacinus corollæ obovatis, caule angulato.-Parad. lond. t. 32 .

Chironia gracilis. Mich fl. amer. 1. p. 146.

Chironia campanulata. Linn. sp. pl. 272.

In wet pasiures, on the banks of rivers: Canada. Kalm. Pensylvania to Carolina. $\delta$. July, Aug. v. v. Fluwers rose-coloured, segments of the corolla obovate.

2. S. erecta ; ramis dichotomis elongatis 1 -floris, foliis Janceolatis acutis, calyce subulato corollæ semibreviore, lacinis corollæ obovatis, caule tereti.

Icon. Bartram ic. ined. t. 13. in Musco Bankiano.

In salt marshes: New York, New Jersey, \&c. ¿. Aug. $v . v$. The flowers are large and of a beautiful rose colour, with an elegant yellow star in the centre, which is surrounded by a deep red border; this plant is extremely shy of cultivation, though very desirable for that purpose. It varics with white flowers.

3. S. erecta ; foliis ovatis amplexicaulibus, pedunculis elongato-corymbosis, calyce corollæ semibreviore, laciniis lanceolatis, caule marginato-quadrangulo.

Chironia angularis. Willd. sp. pl.1. p. 1067.

In shady woods, on grassy hills : Canada to Carolina. c. July, Aug. $v \cdot v$. It varies with longer and

stellaris.

angularis. 
ealycosa.

chloroides.

paniculata.

latifolia.

angustifolia.

palustris. shorter, broader and narrower leaves. Flowers a purplish red. It is used by the inhabitants in the same way as Chironia C'entaurium is used in Europe.

4. S. erecta, foliosa ; foliis oblongo-obovalibus, floribus solitariis subseptempartitis, calyce foliaceo corollam superante, laciniis oblanceolatis. Mich. fl. amer. 1. p. 147 .

Chironia dichotoma? Wralt. fl. car. 95.

Icon. Bartram ic. ined. $t$. 1). in Musceo Banksiann.

In wet meadows: New York to Carolina. ठ․ Aug. $v . v$. Flowers dark rose-coloured, segments of the corolla obovate.

5. S. debilis; foliis lanceolatis erectis, ramis paucis unifloris, floribus 7-13-partitis amphoribus, laciniis calycis linearibus corollæ brevioribus.

Chironia chloroides. Mich. fl. amer. 1,p. 147.

Chironia dodecandra. Walt. fl. car. 95 .

Chlora dodecandra. Limn. syst. veg. 299.

In bogs: New York to Carolina. ¿. Aug. Sept. v. v. Howers rose-coloured, large.

6. S. crecta; foliis lanceolato-linearibus, panicula muliforra brachiata subfastigiata, calyce subulato corolla triplo-breviore, caule quadrangnlo.

Chironia paniculata. Nich. fl. amer. 1. p. 146.

Suertia difformis. Wiild. sp.pl. 1.p. 1330.

a.s. foliis brevi-ovatis, paniculis palucitioris.

Chironia lanceslata. IValt. fl. cur. 95.

คे. S. folis linearibus, panicula corymbosa multiflora.

In bogs and cedar swamps: New Jersey and Carolina. 4. July, Aug. v. v. Flowers white. This certainly is the long list Swertin difformis, as the specimens in the Herbarium of Clayton, now in possession of Sir Joseph Banks, suficiently prove.

\section{HOTTONIA. Gen.pl. 265.}

1. H. floribus verticillatis subsessilibus, canle geniculato, geniculis inflatis. Willd. sp. pl.1. p. 812 .

In stagnant waters of New Jersey and Virginia. 24. July. $v \cdot v$. Whether this is only an accidental variety or a distinct species, I cannot now decide; but certainly the habit of the plant, as well as its smaller fiowers, indicate that it maly, by further examination, turn out a new species. 


\section{MENYANTHES. Gen.pl. 299.}

1. M. folis ternatis. Willd. sp.pl. 1. p.s11.

trifoliala.

Icon. Engl. lot. 495. Fl. dan. 541. Lam. illustr. t. $1 \mathrm{CO}$ f. 1 .

In boss and stagnant waters: New Jersey, Virginia, $\mathrm{Ca}-$ nada. $2 !$. June, July. $v \cdot v$. Flowers palered, very handsome.

\section{VILLARSIA. Gmel. syst. veg. 447.}

1. V. fo'iis reniformibus subpeltatis, subtus iacunosis natantibus, petiolis floriferis, corollis glabris. Vent. chowa te plant. p 9.

V. aquatica. Gmet.syt. veg. 447.

Menyanthes trachysperma. Nich. fl. amor. 1. p. 126.

Anonynos aquatica. Walt fl amer. 109.

In ponds and Jakes, forting: New jersey to Carolina. 4. June, July, v.v. Howers white.

\section{SPIGELIA. Gen.pl. 272 .}

1. S. caule tetragono, foliis omnibus oppositis. Willd. marilandica. Icon. But. mug. 80 .

On the edges of woods, in rich moist soil: Maryland to Carolina. 4. July, Aug. v.v. A beautiful perennial, with large scarlet Howers. The roots are sold, under the name of Worm-grass or Pink-root, in the shops, and are really a must excellent medicine for children, when troubled with worms.

\section{OPHIORRHIZA. Gen. pl. 273.}

1. O. caule acutangulo, foliis sessilibus, cyma longius pedunculata. Mich. fl. amer. 1. p. 14s. Willd. sp. pl. 1. p. 826.

Cynoct num sessilifolium. Gmel. syst. veg. $4+3$.

Anonymos sessilitclia. IV alt.fl. car. 108.

B.C. petiolatum. Gmel. \&- Anonymos petiolata. Walt. Icon. Swartzots. t. 3.f.2. Lain. illustr.t. 107.f. 1 . In dry gravelly fields, on wood sides: Lower Virginia to Carolina. 24. July. v. v. Flowers pale blue, small.

I strongly suspect that Swartz's plant and Michaux's are two distinct species. 


\section{PHACELIA. Juss. Gen. pl. 144.}

lipinnatifida. 1. P. erecta ; foliis pinnatifidis, laciniis inciso-lobatis, racemis plerumque bitidis oblongis multiforis, laciniis corolix integerrimis.-Mich. fl. amer. 1. p. 134.

Icon. l. c. t. 16 .

In the western conntries, principally on the Allegany mountains : Pensylvania to Virginia. May, June. v.v. Flowers blue.

heterophylla. 2. P. erecta, hispida; foliis petiolatis pinnatifidis, laciniis Janceolatis integerrimis neriosis: impari elongata: floralibus simplicibus lanceolatis petiolatis, racemis bifidis densifloris, laciniis coroliæ integerrimis.

On dry tiils on the banks of the Kooskoosky. M. Leu'is. o. June, Juiy. v. s. in Herl. Lewis. Flowers pale blue.

Caulis erectus, ramosus : rami elongati. Folia petiolata : inferiora pinnatifida: laciniis lateralibus lanceolatis, 1-2 jugis : lacinia terminali longo-lanceolata : superiora et ramea simplicia, lanceolata. Petioli marginati. Racemi terminales pedunculati dichotomi, spirales, secundi. Pedicelli brevissimi. Calyx laciaiis linearibus. Corolla subcampanulata, cal ce duplo longior: laciniis oblongis, obtusis, integerrimis. Filamenta corollæ duplo longiora. Stylus staminibus longior, bifidus.

fimbriata. 3. P. assurgens, piiosa; foliis sessilibus pinnatifidis: laciniis lanceolatis acutis integris supra hispido-pilosis, subtus glabris : racemis solitariis, pedicellis elongatis, laciniis corollæ ciliato-fimbriatis.-Mïih. fl. amer. 1, p. 134. excl. syn. Pluk.

On bigh mountains in Carolina. Michanx. Near Harper's Ferry, on the Potowmac; collected by myself. $\odot$. May, June. $v v$. Fluwers beautiful blue. Michaux mentions white flowers, which I consider a mistake, though there may be a white variety.

parviflora. 4. P. diffusa, pubescens; foliis subsessilibus pinnatifidis: laciniis oblongis obtusinsculis integris, racemis solita. ris, pedicellıs brevibus, laciniis corollæ rotundatis integerrimis.

Polemonium foliis inferioribus hastatis, superioribus lanceolatis. Gronov. fl. virg. p. 29 .

Polemonium dubium. Willd.sp.pl.1.p. 887.

Icon. Pluk. alnı.t.245.f.5. 
On rocks, near Harper's Ferry, on the Potowmac. $\odot$. May. v.v. Flowers pale blue, not one fourth the size of the former species.

178. ELLISIA. Gen.pl. 268.

1. Ellisia. Willd sp.pl.1.p. 815.

Icon. Lam. illustr. t.97. Moris. hist.3. s. 11.t.28.f.3. Nyctelea. On the banks of the lotowmac: Virginia. $\odot$. May, June. $v . v$. Flowers white, very small.

\section{DATURA. Gen.pl.332.}

1. D. pericarpiis spinosis erectis ovatis, foliis ovatis glabris. Stramonium. Willd.sp.pl.1.p. 1008.

Icon. Fl. dan. 436. Engl. bot. 1288. Lam. illustr. 123. A mong rubbish and on road sides : common. $\odot$. June, July. v. v. Flowers white.

2. D. pericarpiis spinosis erectis ovatis, foliis cordatis glabris Tatula. dentatis. lizlld. sp. pl.1.p. 1008.

On road sides; not so frequent as the former. $\odot$. June, July. $v . v$. Flowers blue.

1so. HYOSCYAMUS. Gen.pl. 333.

1. H. foliis amplexicaulibus sinuatis, floribus sessilibus. Willd.sp.pl. 1. p. 1010.

Icon. Engl. lot. 52.

On way sides and among rubbish : Pensylvania, New York, near Oswego town, \&c. Probably introduced from Europe. $\odot$. June, July. v. v. Flowers yellow, with purple veins.

\section{NICOTIANA. Gen.pl. 334.}

1. N. foliis lanceolato-ovatis sessilibus decurrentibus, floribus paniculatis acutis. Willd. sp. pl.1.p.1014.

Icon. Blackw. t. 146. Lam.illustr. 113.

In cultivated grounds, frequently found in a wild state; introduced. $\odot$. July. v. $v$. Flowers red.

2. N. fuliis oblongo-ovatis petiolatis, floribus in summitate quadrivalvis, ramuloruın sparsis solitariis, corollis infundibuliformibus, laciniis oblongis acutiusculis, capsulis subglobosis 4-valvibus.

Cultivated and spontaneous on the Missouri ; principally among the Mandan and Ricara nations. $\odot$.July. v. v.; v. s. in Her b. Lewis. nec non Nuttall. Flowers white, with a tinge of blue. The tobacco prepared 
from it is excellent. The most delicate tobacco is prepared by the Indians fiom the dried flowers.

\section{Verbascum. Gen. pl. 331.}

Thapsus.

Lychnitis.

2. V. foliis ovatis aculis crenatis subtus tomentoso-incanis, spicis laxis lateralibus et terminalibus.-Willd.sp.pl.1. p. 1003.

Icon. Fl. dan. 586 .

On the banks of the Delaware near Philadelphia. $\delta$. June, July. v.v. Flowers yellow, as all the rest here mentioned, smaller than the former species.

Blattaria. 3. V. foliis amplexicaulibus obovato-oblongis serratis glabris, pedicellis solitariis unifforis. - Willd. sp. pl. 1 . p. 1005.

Icon. Engl. lot. 393.

In fields and on road sides; frequent. $\delta$. June, July. $\boldsymbol{v}$ v. Flowers yellow. There frequently occurs a variety witis white flowers, which are larger and sweet scented.

Claytoni. 4. V. foliis amplexicaulibus sublanceolato-oblongis: caulinis inciso-crenatis : crenis crenulatis, pedicellis solitari is unifloris.-Mich. fl. amer. 1. p. 148.

In woods and fields: Virginia to Carolina. June, July. $v . v$. Flowers yellow, and larger than the third species.

183. CALYSTEGIA. Brown fl. nov. holl. p. 483.

Sepium. 1. C. volubilis; foliis sagittatis acutissimis : postice obtusis truncatisve integris, bracteis acutis calyce longioribus dimidio corollæ brevioribus, pedunculo angulato pe* tiolum superante. Brown l.c. 
Convolvulus Sepium. IFilld. sp.pl. 1.p. 8t4.

Convolvulus repens, Linn. sp.pl. p. 153. wonente Cl. Brown.

Convolrulus repens. Mich. fl. ainer. 1. p. 137.

Convolvulus lactescens foins sagitiatis, radice longa alba perenni. Gron. Al. virg. p 28.

Icon. Engl. lot. 313. Fl. din. 453.

In hedges and bushes, sometimes trailing on the ground:

Canada to Carolina. 24 . June, July. v. $v$. Flowers pale red, white with a red horder or a beautiful crimson, as figured in tile Botanical Alagazine, No. 732 .

2. C. erecta, tomentosa ; foliis oblongo-lanceolatis acumitomentosa. natis cordatis: postice obtusis, pedunculis uniforis elongatis, bracteis ovatis acutis, laciniis calycis lanceolatis, caule in ferne Horifero.

Convolvulus stäils. Mich.fl. amer. 1. p. 136.

On dry rocky hills: Canada to Virrinia; rare. $\psi$. June, July. v. v. Flowers white, large.

3. C. erecta, pubescens; foliis subcordato-ovalibus obtusis, spithumae. pedunculis unifloris foliis brevioribus, bracteis ovatis acutis, caule superne Horifero.

Convolvulus spithamæus. Willd. sp.pl. 1. p. s73.

Ou dry hills : Pensylvania to Carolina; rare. 24 . June, July. v. v. Flowers white.

\section{CONVOLVULUS. Gen. pl. 287.}

1. C. humifusus, pubescens; foliis lanceolato-oblongis line-trichosanthes. aribus oblongisve obtusis nucronatis subsessilibus, pedunculis foliis longioribus i-5-Horis, corulla brevi campanulata, stylo bipartito.-Mich. fl. amer. 1. p. 137.

a. C. filiformis, suberectus; foliis linearibus mucronatis, pedunculis patentissimis folio longioribus. Lam. illustr. patens. 1. p. 453.

C. aquaticus. Wult. $f$. car. 94 .

ß. C. volubilis ; foliis oblongo-ellipticis obtusis mucronatis subsessilibus, pedunculis foliis longioribus subbitoris.

tenellus. Lam. illustr. 1. p. 459.

C. humistratus. IValt. $f$. car. p. 94 .

Icon. Pluk alm. t. $160 . f .4$.

In sandy woods : Virginia to Georgia. ๑. June, July. $v$. $v$. Flowers white, small.

2. C. repens, tuberosa; foliis cordatis hastatis anguloso-lo-

Batatas, 
batis quinquenervibus glabriusculis, pedunculis longis, floribus fasciculatis, calycis glabri laciniis lanceolatis acuminatis, corolla campanulata.-Mich. fl. amer. 1. p. 138. Willd. sp. pl. 1.p. 853 .

Cultivated throughout America. 4 .July. v. v. Flowers white, red, and sometimes purple Vid. Catesb. car. 2. $t .60$. There are a number of varieties, as is the case with most cultivated plants.

ol:tusilolus. 3. C. prostratus, glaber; foliis crassis sinuato-lobatis, lobisrotundato-obtusis : impari majore emarginato, pedunculis uniftoris, laciniis calycis oblongo-ovalibus, corolla brevi-can panulata.-Mich. fl. amer. 1.p. 139 .

On the sandy beach of Georgia and Florida. Michaux. 4. + .

sagittifolius. 4. C. volubilis, glaberrimus ; foliis oblongo-sagittatis : sinu profundissimo: auriculis subacuminatis, pedunculis unifloris, laciniis calycis rotundato-ovalibus, corolla infundibuliformi-campanulata.-Mich.fl.amer. 1.p. 138.

C. speciosus. Walt. fl. car.p.g3.

Icon. Cates b. car. 1.t. 35.

In wet situations, among bushes : Virginia to Carolina. 4. June, July. v.v. Flowers of a beautiful rose-colour, large.

panduratus. 5. C. volubilis, pubescens ; foliis lato-corditis integris lobatisve panduriformibus, pedunculis longis, floribus tasciculatis, calycibus glabris muticis, corollis sutulatocamponulatis. Mich.fl. amer. 1.p.138. Willd. sp. pl 1.p. 850 .

Icon. Dili. elth. t. 85.f. 99 .

In sandy fields and anın: bushes : Canada to Carolina. 4. June-Ang. v. v. Glowers white, with a red botton. There is a variety with double flowers, cultivaled in the gardens of imesica, which is a singular circumstance in tis genus. The root in some instances grows to an enomous size; I have seen one the thi hress of a man's thigh, and more than two feet long. Taken in the place of Jalap, it has the same effect, only in a less degree.

arvensis. 6. C. volubilis, glaber; foliis sagittatis utrinque acutis, pedunculis subunitioris, bracteis minutis a flore remotis. Smith, A. bril. 1. p. 232 .

Icon. Engl. bot. 312 . Fl. dan. 459.

In meadow s: Virginia. Gron. $f$. virg. 27. 24. June, July. Flowers rose-coloured. I never observed this 
species in any part of North America, and take it only on the authority of Gronovius.

\section{IPOMCEA. Gen. pl. 298.}

1. I. foliis pinnatifidis linearibus, floribus subsolitariis, corollis tubulosis. Willd. sp.pl.1.p. 879 .

Icon. Bot. mag. 244.

In cultivated ground, near gardens : Virginia and Carolina. $\odot . J u l y$, Aug. $i v$. Flowers scarlet or white; a most delicate and handiome plant.

2. I. pubescens; foliis cordatis acuminatis subangulatis, pedunculis sub-5-floris, calycibus aristatis, corollis tubulosis : limbo subintegro.-ATich. Al. amer. 1.p. 140. Willd. sp.pl. 1.p.880.

Icon. Bot. rep. t.99. Bot. mag. 221.

On banks of rivers: Virginia to Georgia, and Louisiana. $\odot$. June, July. v. v. Flowers yellowish-scarlet.

3. I. caule, petiolis pedunculisque pilosissimis; foliis glabris 7 -partito-lobatis: laciniis sinuatis, pedunculis unifloris, laciniis calycis ovalibus, corollis campanulatis.

Jcon. Jacq. hort.t. 159. Willd. phytog. 1. t. 2.f.3.

Convolvulus dissectus. Willd.sp.pl. 1.p. 864. Misk. fl. amer. 1.p. 139.

On calcarenus hills: Georgia and Florida. Michaux. 4. $r_{\imath}$. July. v.v. in Hortis.

4. I. glabriuscula ; foliis profunde sublanceolato-3-lobis integrisve, pedunculis subbifloris, laciniis calycis ovalilanceolatis pilosis, coroliis brevibus, capsulis pilosis.

Convolvulus carolinus. Mich. fl. amer. 1. p. 139.

Icon. Catesl. car. t. 87?

In hedges: Carolina. $\odot$. June-Aug. v. v. Flowers pale purple.

5. I. glabra; foliis cordatis acuminatis scrobiculatis basi angulatis, pedunculis brevibus subunifloris, calycibus pilosis, corollis tubulosis brevibus, capsulis pilosis. Mich. fl. amer. 1. p. 140. Willd.sp.pl. 1.p. 881.

Icon. Dill. elth. t. 87.f. 102.

In Carolina and Florida. Michaux. $\odot$. June, July. $v . v$. Flowers white, with a purple rim.

6. I. glaberrima; foliis cordatis integris seu angulatis, pedunculis $1-3$-floris, calycibus aristatis, corollis indi-

Bona nox. visis : tubo longissimo.-Willd. sp. pl. 1.p. 882.

VOL. I.

Quamoclit.

coccinea.

dissecta.

carolina.

lacunosa. 
Jcon. Bot. mag. t.752. Jacq. hort. 1. t. 36.

On river sides: Carolina and Florida. $\odot$. Juiy, Aug. $v . v$. Flowers white, very large.

tamnifolia. 7. I. hirsuta ; foliis cordatis acuminatis, floribus aggregatocapitatis involucratis: bracteis linearibus, corollis brevi-tubulosis: limbo patente, capsulis glabris.IVilld.sp.pl. 1.p. 885.

Icon. Dill. ellh.t.318,f.414.

In hedges: Carolina. $\odot$. July, Aug. v. v. in Hortis. Howcrs blue, very small.

purpurea. S. I. pubescens; foliis cordatis integris, pedunculis 2-5floris: pedicellis cernuis incrassatis, laciniis calycis lanceolatis, capsulis glabris.

Convolvuius pupureus. Willd. sp.pl. 1.p.852.

Icon. Bot. mag. 113.

About gardens, frequent. $\odot$. June-Aug. v.v. Flowers very variable in colour.

Nill.

9 I. hirsuta; foliis ventricoso-trilobis, pedunculis brevibus 1-2-floris, bracteis subulatis, calycitus villosissimis longissine acuminatis.

Convolvulus Nil. IVilld. sp. pl. 1. p.351. Mich.fl. amer. 1.p. 139.

Icon. Bol.mag.t. 138. Dill. elth.l. so.f.g1 et 92 .

Near gardens and in hedges, on river sides: Virginia to Carolina. $\odot$. June-Aug. v. v. Flowers beautiful pale blue, only open early in the morning, from which it has been called Morning-glory.

ciliusa. 10. I. glabra ; foliis eximie cordatis margine subciliatis, pe. dunculis longis unitoris, calycis ebractenti laciniis lato-ovalibus obtusis, corollis tubulato-campanulatis.

Crnvolvulus ciliosus. Mich.f. amer. 1.p. 137 .

Near Knoxville in Tenuassee. Michaux. +.

Julafa. 11. I. pubescens; foliis cordatis integris lobatisque plicatorngosis subtus subtomentosis, pedunculis 1 - 3 -floris, foliolis caly cis ovalibus m'ticis, coroliis campanulatis, senninibus prolixe lanuginosis, radice crassissimo.

Convolvulus Jalipa. livilld. sp. pl. 1. p. sco. Jponcea macrorhiza. Mich. H. amer. 1. p. 141. lcon. Desfont. in ann. mus. hist. nat. 2. $t$. to t't 41 . Near the sea shore of Georgia and Florida. 4 . June, July. $v . v$. Flowers white, very large.

Ols_- This very interesting plant was first discovered in Georgia by Michaux. After this I frequently have received secds and roots from Georgia myself; but 
little did I suspect it to be the true Convolvulus $J_{a}$. lapa, till two circumstances convinced me thereof. The first was seeing a paper on this stibject in the $A n-$ nales du Museum d' Histoire Vaturelle, by Desfontaines; and the other, on seeing the living plant recently raised out of a collection of seeds brought from Mexico, in possession of $\mathbf{A}$. B. Lambert, Esq., which in every respect proved to be Convolvulus Jitapa of Linnæus, as well as Ipomcea masrorhiza of Michaux, with only the small difference of colour, which was a light purple : but this is of no consequence in this family of plants.

186. CANTUA. Juss. gen. pl. 152.

1. C. glabriuscula ; foliis pinnatifidis, floribus terminalibus coronopifolia. laxe racemosis pedunculatis, laciniis corollæ amplis subrotundis brevi-acuminatis, stylo exerto.-Willd. sp.pl. 1.p. 879 .

Polemonium rubrum. Liin. sp.pl.ed.3. p. 231.

Ipomœa rubra. Linu. syst. veg. 171.

Ipomopsis elegans. Afich. fl. amer. 1. p. 112.

Gilia coronopitolia. Pers. ench. 1. p. 187.

Icon. Bot. rep.415. Exot. Lot. 13. Dill. elth. t. 241. f. 312 .

On river sides, in sandy soil : Carolina. $\delta$. June, July. $v . v$. Flowers beautiful red.

2. C. pubescens ; foliis tenuissime pinnatifidis, floribus terminalibus lateralibusque agorregato-subcapitatis subsessilibus, laciniis corollæe angustatis oblongis sensim acutis, stylo incluso brevissimo.

On the banks of the Mississippi. M. Lewis. $\delta$. June. $v$. s. in Herl. Lewis. Flowers scarlet, more slender than the former species; the segment of the corolla not spreading, but erect, and sinall in proportion to the tube.

\section{DIAPENSIA. Gen. pl. 255.}

1. D. foliis spathulatis glabris, antheris obliquis muticis. oblusifolia. Salisb. parad. lona. 10i.

D. lapponica. Willd.sp. pl. 1.p.795.

Icon. Fl. dan. 47. Bot. nlag. 1109.

On the highest mountains, among moss : New Hampshire. 24. May-July. v. s. in Herb. Prof. Peck. Flowers white. 
cuneifolia.

paniculata.

undulata.

pyramidalis.

litifolia.
2. D. foliis lanceolato-cuneatis inferne pubescentibus, antheris horizontalibus basi rostratis. Salisl. parad. lond. 104.

D. americana. Mus. Banks.

Pyxidanthera barbulata. Mich.fl.amer. 1.p. 152. Icon. Mich.l.c. t. 17. Salisb. parad. lond. 104.

On high mountains in North Carolina. Michaux. On the White mountains of New Hampshire. Prof: Peck. Plentifully on the pine-barrens of New Jersey near the sea coast, \&c. $\zeta$.June-Aug. $v . v$. Flowers small, white.

\section{8s. PHLOX. Gen.pl.2s4.}

1. P. erecta, glubra; fuliis lanceolatis sensim aigustatis planis margine asperis, corymbis paniculatis, corolla laciniis roturdatis, calycibus aristatis.-Willd. sp.pl. 1. p. 829 .

Icon. Mill.ic. t. 205. f. 2. Dill. elth.t. 166.f. 203.

In rich moist meadows : Virginia and Lower Carolina. 24. July-Sept. v.v. Flowers purple; stem from three to four feet high.

2. P. erecta, glabra ; foliis oblongo-lanceolatis subundulatis marzine scabris, corymbis paniculatis, corollæ laciniis oboratis subretusis, calycibus aristatis.-Willd. $s p$. pl. 1. p. 840 .

P. paniculata. Mich. fl. amer. 1.p. 144.

In high mountains and meadows of Virginia and Carolina. 2. July, Aug. v. $v$. A benutiful plant, resembling the former species, but taller; flowers the sane colour.

3. P. erecia, glabra ; caule scabro, foliis cordato-ovatis acutis, panicula fastigiata pyramidali, corollæ laciniis cuneato-truncatis, dentibus calycinis suberectis lanceolatis acutis. - Smith exot. lot. 2. p.55.

P. carolina. Walt. fl. car. 96 .

Icon. Smith l.c.t.s7.

In mountain meadows: Pensylvania to Carolina. 4. June-Aug. v.r. Flowers beautiful purple; plant not so tall as the two former species.

4. P. erecta, glabra; caule lavi, foliis cordato-ovatis, floribus fastigiato-corymbosis, corollæx laciniis sntiorbiculatis, dentibus calycinis lanceclatis vix acuminatis.-Mich. fl. amer. 1.p. 1-13.

An eatem cum priori ? 
In shady wet places, mossy woods, among Sphagnum: Carolina. Michanx. $4 .+$. Flowers purple, large.

5. P. erecta ; caule scabro maculato, foliis oblongo-lanceolatis glabris margine asperis, panicula oblonga confertifora, corolla laciniis rotundatis, dentibus calycinis acutis recurvatis.-Willd. sp pl. i. p. S40.

Icon. Jacq. hort. t. 127.

In wet meadows : New England to Carolina. 24. July, Aug. v. $v$. Flowers purplisis-violet or purple; stem siotted with brown dots.

6. P. erecta; caule glaberrino immaculato, folits ovatolanceo'atis undique lavibus, racemo paniculato, corolle laciniis rotundatis, dentibus calycinis lanceolatis acutis erectiusculis.-Willd. sp. pl. 1. p. S.40.

In meadows: Canada to Virginia. 2f. Julv, Aug. v. v. Flowers white, sweet-scented; plant not so tall as the foreguing species.

7. P. erecta; caule pubescente, foliis ovato-lanceolatis lævibus, corymbis subfastigiatis, ramulis subtrifloris, corollæ laciniis rotundatis, dentibus calycis glabri lanceolatis erectis.-IVilld.sp.pl. 1. p. 811 .

P. trifora? Nich. fl. amer. 1 p. 1.43.

Icon. Bot. mag. 134t. Mart. dec. 1. t. 10.

In sandy wet meadows : Carolina. $\psi . J$ ulyFlowers beautiful pale purple, the size of $P$. suaveolens.

8. P. cæspitosa, assurgens, glalra; foliis lineari-lanceolatis lævibus, corymbo terminali subtastigiato, corollæe laciniis rotundatis, dentibus calycis mucronatis.Willd sp pl.1.p.s+1.

Icon. Dill. elth. t. 165. f: 202 ?

In wet meadows of Lower Carolina, and on the mountains of Virginia. 4. June-Aug. v.v. Flowers deep purple.

9. P. erecta, glabra, frutescens, ramosissima ; foliis linearibus, superioribus alternis basi dilatatis, racemis paniculato-corymbosis, corolla laciuiis cuneato-oblongis emarginatis, dentibus calycis subulatis tubum æauantibus.

On the plains of Columbia. M. Leuis. $\zeta$. May, June. $v$. s. in Herl. Lewis. Flowers white, with a red or purple centre, similar to those of Vinca rosea, var. allia. They appear in such abundance, that they cover the whole shrub.

carolina.

glalerrima.

speciosa.

suaveolens.

maculata.

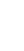


aristata.

virens.

canescens.

pilosa.

ancena.

divaricata.

ovila.

13. P. crecta, glabra; foliis radicalibus ovatis acutis subcarnonis. caulinis lanceolatis, corymbis subfastigiatis, coroliae laciniis undulatis retusis, dentibus calycis linearibus acutis.-Bol. mogr. 525. Willd. sp. pl. 1. t). 842 .

Icon. Bot. mag. l. c.

In Nurth Ancrica. 24. May-July. v. v. in Liortis. Flowers beautiful redaish-purple.

stulonifera. 14. P. reptanti-ctulunifera, pubescens; foliis radicalibus spathulato-obuatis, caulinis ovali-lancenlatis, corymbo divaricatim paucifloro, corollæ laciniis obovatis; dentibus calycis jinearibus reflexis. - Bot. mag. 563.

P, reptans. Mich. fl. amir. 1. p. 144. 
Icon. Bot. mag. 563 .

In the high mountains of Virginia and Carolina. $\mathcal{U}$. June-Sept. $v . v$. Flowers blue, with a purple centre, very handsome.

15. P. cæspitosa, candicanti-pubescens; foliis linearibus sululata. pungentibus ciliatis, corymbis pauciforis : peiticeilis tritidis, corolla laciniis cuneatis emarginatis, dentibns calycis subulatis tubo corolla vix breviorious.-Iiili. sp. pl. 1.p. 842 .

Jcon. Bot. magr. 411 .

Un dry sandy bills and rocks: New Jersey to Carolina. 4. April-June. v. $v$. Flowers pink-coloured, with a handsome purple star in the centre.

16. P. c.ripitosa, pubescens ; foliis fusciculatis stibuatis pungentibus ciliatis, pedicellis paucis terminulibus subumbellatis, corollæ laciniis cunedts emaruinatis, dentibus calycis subulatis tubo corolic truplo brevioribus. - IVilld. sp. pl. 1.p. 842 .

Icon. Bot. mag. 415 .

On rocks and barren sandy hills : Virginia to Carolina. 4. May-July. v. v. Flowers pale rose-coluule!, with a purple star in the centre.

\section{Sg. POLEMIONIUM. Gen. pl. $2 \$ 9$.}

3. P. foliis pinnatis septenis, floribus terminalious nutantibus. Willd.sp.pl. 1. p. $\$ 36$.

setacea.

Icon. Mill. ic. 2, $t .200$.

In the mountains, on the side of rich hills : Pensyluania to Carolina. 4. April, May. v. v. Flowers skyblue; there is a variety with white flowers.

$$
\text { 1gO. AZALEA. Gen.pl.27\%. }
$$

1. A. subnudiflora; foliis oblongis utrinque pubescentibus : calendulacea. acultis hirsutis, floribus amplis nur viscosis, calycis dentibus oblongis, corolla tubo hirsuto laciniis breviore-Mich. fl. amer. 1. p. 151.

a. A. floribus flammeo-calendulaceis.

replans.

ß. A. floribus croceis. Bot, mag....

๙. On the banks of the Savannah river, near Two-sisters. Michaux. On the Flint river, Georgia, \&c.

3 . On the highest mountains of Virginia and Carolina. $h$. April, May. v. $v$. Ilutvers of var. $\alpha$. a beautiful

flammea.

crocea. 
flame colour, sometimes deep yellow mixed with scarlet, as in Mrabilis Jalapa; var. $\beta$. bright yellow, resembling $A$ pontica. It is, without exception, the handsomest shrub in North America. Vid. Bartram's Travels p. 321 .

canescens.

2. A. subnudiflura; foliis obovato-oblongis supra pubescertibus subtus tometitosis, nervo non setigero, floribus non viscisis, tubo laciniis vix breviore, calycis dentibus brevisimis rotundato-obtusis, staminibus vix exerlis.-Mich. $l$ amtr 1.p. 150.

On the banks of rivers in Lower Carolina. Michaux. On the mountams of Cacapoon springs near Winchester, Virginia. ל. May, June, v. v. Flowers rosecoloured.

periclyme-

nuides.

coccinea.

rutilans.

carnea.

alba.

papilionacea.

partita.

polyandra.

3. A. subnudiflora; follis lanceolato-oblongis utrinque glabriuscuitis, crincoloribus, nervo supra lanuginoso, subtus setigero, margine ciliatis, floribus amplis non viscosis, tubo licinis longiore, calycis dentibus brevibus ovali-subrotundis, slaminibus longissine exertis. - Mirh. fl. amer. 1. p. 151.

A. nudiflurs. Willd. sp pl. 1. p. 831 .
o. A. Horibus coc coneis, fol is sanceolatis. Bot. mag. 180.

6. A. floribus saltrate rubris, calycibus minutis. Alt. kew.1. p.319.

$\gamma$. A. floribus pallide rubicundia, tubo basi rubro, calycibus foliaceis. Hit. $l$. $c$.

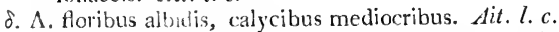

ع. A. foribus rubicundis: lacmia infima alba, caljcibus foliaceis. Ait. l. c.

ร. A. floribus carneis usque ad basin quinquepartitis. fit $l . c$.

$\eta$. A. Horibus roseis brevibus 10-20-andris.

On the side of litlls: Carata to Georgia. Var. $\alpha$. near Savinnah, Georgia. Var: . near Philadeiphia, Pensylıania, h. April-June. v. $v$. Tils beautiful shrub has a great nany varieties, besides the abovementioned, nung which is one with double flowers; but the var. $\gamma$. is the rnost remarkable. 'I his variety proves clearly, that Azalea and Rhociodonizon are one genus, A. procmmlens excluded, as Rhododendron is frequently found with less than ten, and all the species of Azalea with more than five stamina.

arborescens.

4. A. foliosiflora ; foliis obovatis obtusiusculis utrinjue gla bris subtus glaucis : nervo vix setigero, margine cilia- 
tis, floribus magnis non viscosis, tubo laciniis Jongiore, calycious foliaceis : laciniis oblongis acutis, filamentis exertis.

A. arborea. Bart.catal.

On rivulets, near the Blue mountains: Pensylvania. $h$. May July. $v$ v.-This beautiful tpecies has, to ny knowledge, not yet been introhiced into the gardens. I have ony seen it in its native place and in the gar. den of Mr. John Bartram, near Philatelphia, whose father introduced it many years ago. It rises from ten to twenty feet h:gh. and forms, with its elegant foliage and large abundant rose-coloured towers, the finest ornunental sirub I kuow. The thowers are not so much pubescent as the rest of the other species; the scales of the tower-buds are large, yellowishbrown, surrounded with a fringed white border.

5. A. nudifora: folis oblongis urrinque tenuissime canopubescentibus: nervo non setigero, floribus parvis non viscosis : tubu laciniis vix longiore, calycibus brerissinis : lacinia unica lineari reiiquis quadruplo longiore, filamentis exertis, ramulis ploso-hispidis.

A. nuditn a bicolor. Ait. kew. 1. p. 319.

Icon. Tiew ehret. t. 45.

On barren, sancy hills: Carolina and Georgia. 5 . May, June. $v v$. Flowers slender, and smaller than the rest, of a pale rose colour or nearly white, with a deep-red-culoured tube.

6. A. folosiflora; ranis hispidis, foliis oblongo-obovatis acutis utrinque glabris concoloribus: nervo sutigero, margine ciliatis, floribus viscosis: tubs lacinii, duplo long'ure, calycis dentibus brevissinis rotumatis, tilanentis corollæe vix longioribus.-Wilhl. sp. pl. 1. p. 8 is:.

In swamps and shady woods: Canad: to Georgia $\zeta$. July, Ang. v. v. Flowers white, sweet-scented. There are a number of varieties and ex en mtermediate species between this and the $A$. periclymenoides.

7. A. foliosiflora; ramis glabrinsculis, follis parvis oblanceolatis submucronati coriaceis utrinque glabris supra nitidis: nervo subtus setigero, margine revolutu-ciliatis, fl ribus viscosis: tubo laciniis paulo longiore, calycibus brevissimis, filamentis exertis.

In deep mossy swamps on the mountains: New York to Virginia. $\quad$. June, July. $v, v$. Flowers white

nitida.

viscosa. 
with a red tinge; leaves very dark green and shining is they are smaller than in any other species.

glauca.

8. A. foliosiflora; ramulis lispidis, foliis oblanceolatis acutis utrinque glabris subtus glaucis : nervo setigero, margine ciliatis, floribus viscosıssimis : tubo laciniis duplo longiore, calyce brevissimo, filamentis laciniis coroliæ subæquantibus.-Lam. illustr. . p. 493.

A. viscosa floribunda. Ait. kew. 1.p. 319 .

In swanps of a clayey soil : New England to Virginia. h. June, July. v.v. Flowers white, rery fiagrant; the shrub lower than the rest, and flowering in great abundance.

hispida. 9. A. foliosiflora; ramis strictis hispidissimis; foliis longe lanceolatis: supra hispidis, subtus glabris; utrinque glaucis: nervo setigero, margine ciliatis, floribus viscosissinis : tubo laciniis amplis vix longiore, calycis dentibus oblongis rotundatis, filamentis exertis.

A. viscosa glanca. Ait. kiw. 1.p. 319 ?

On the borders of lakes on the highest part of the Blue mountains : New York and Pensylvania. $\zeta_{2}$. July, Aug. v. $v$. Flowers white $w$ ith a red border, and a ringe of red on the tube, which makes them appear to be of a rose-colour before open. They have frequently ten stamina, as in var. $\eta$. of $A$. periclymenoides. This shrub generally grows to the height of from ten to fifteen feet, very upriglit, and has a blueish appearance, by which it may be distinguished from all others at a great distance.

procumlens, 10. A. foliosifora; ramis diffuso-procumbentibus, foliis oppositis ellipticis glabris margine revolutis, corollis campanulatis glabris, filamentis inclusis æqualibus.Willd. sp. pl. 1. p. 832 .

Icon. Fl. dan. 9. Engl. bot. 865 .

In the alpine regions of the White mountains, New Hampshire. Prof. Peck. On the Grandfather mourtain, Carolina. Lyon. 々. July. v. s. in Herl. Peck. nec non Lyon. v. v. in Hortis. Flowers small, rosecoloured. This plant has so much affinity to Ledum luxifolium, Ait. that I have scarcely been able to persuade myself that they are distinct plants. Comparing specimens of different varieties of the latter, with those of $A$.procumbens from difierent countries, in the herbarium of A. B. Lambert, Esq. I could find no other distinction between both, than that of the 
Ledum bein a a upright little shrub, with decandrous flowers which are white, whereas the present species has procumbent stems and pentandrous red flowers. It most certainly ought to be taken from this genus, or else all the rest but this cne united with Rhodo. dendron.

\section{BUMELIA. Gen. pl. 1736.}

1. B. spinosa, erecta ; foliis deciduis lato-lanceolatis utrinque glabris, pedunculis aggregatis unitturis, laciniis corolle trifilis.-Mich. fl. amer. 1. p. I22.

Sideroxylum ly cioides. Willd. sp. hl. 1. p. 1090.

Sidernxym leve. Wall. fl.car. 100.

Icon. Duham arl. 2. t. os.

In shady unods : Carolina and Georgia. $h$. July. Aug. $v . v$. s. $f$. A small tree, with mirute greenish flowers.

2. B. spinosa, dumosa, diffuse reclinata; ranis sterilibus divaricato-ramosis, foliis parvis obovilibus glaberrimis.

reclinata. Pers. syn. 1. p. 237.

Sideroxylum relinatum. Nïh. h amer, 1. p. 122.

Icon. Vent. choix de plant. t. 22

On the banks of rivers in Georgia. Mfichnux. $h_{c}$. July, Aug. v.v.s.fl. A small straggting shrub.

3. B. subspinosa; ramulis patentissimis pubescentibus, foliis ovali-lanceclatis, supra glabris, subtus lanuginosis. P'ers. syn. 1. p. 237.

Sideroxylum lanuginosum. Mich. fl. amer. 1. p. 122.

Sideroxylum tenax. Walt. fl. car. 100.

In wet copses of Georgia. Michaux. 々. +.

4. B. subspinosa ; foliis cuneato-lanceolatis plerumque ob- chrysophyltusis, subtus sericeo-nitentibus. Pers. syn. 1. p. 237. loides. IVilld.sp.pl.1.p. 1085.

Sideroxylum tenax. Linn. syst. veg.

Sideroxylum sericeum. Walt. fl car. 100.

Sideroxylum chrysophylloides, Mich. fl. amer. 1.p. 123.

In hedges and copses near the sea-crast of Carolina and Georgia. $\eta$.June. $v . v$. A small tree; leaves very handsome.

5. B. inermis; foliis sempervirentibus oblongo-lanceolatis utrinque acutis glabris subaculeato-serratis, racemis axillaribus sessilibus nultitioris.

On the banks of the Missouri. Nuttall $r_{q}$. July. v. s. in Herl. Nuttall. Berries biack, large.

lanuginosa.

lycioidls.

, 


\section{SOLANUM. Gen.pl.337.}

Dulcamara. 1. S. caule inermi fruticoso scandente, foliis cordatis glabris : superioribus auriculatis, corymbis oppositifoliis. lVilld. sp pl. 1.p. 1028.

Icon. Fl. dan. 607. Schmidt arl. 146. Engl. bot. 565. On banks of rivers, in hedges: Pensylvania. Barlram. 々. June, July. v. v. Flowers violet-blue; berries red.

nigrum.

a. virginicum.

mammosum.

virginiamum.

carolinense.

heterandrum. 6. S. caule aculeato annuo, foliis bipinnatifidis utrinque hirsuto-tomentosis aculeatisque: laciniis cbtusiusculis, racemis lateralibus, antheris patulis corniformibus: infima maxima longitudine corollæ, bacca subquadriloculare calyce echinato inclusa.

On the banks of the Missouri. Nuttall. $\odot . J u l y . ~ v . s$. in Herl. Nuttall.; v. v. in Horlis. Flowers large, 


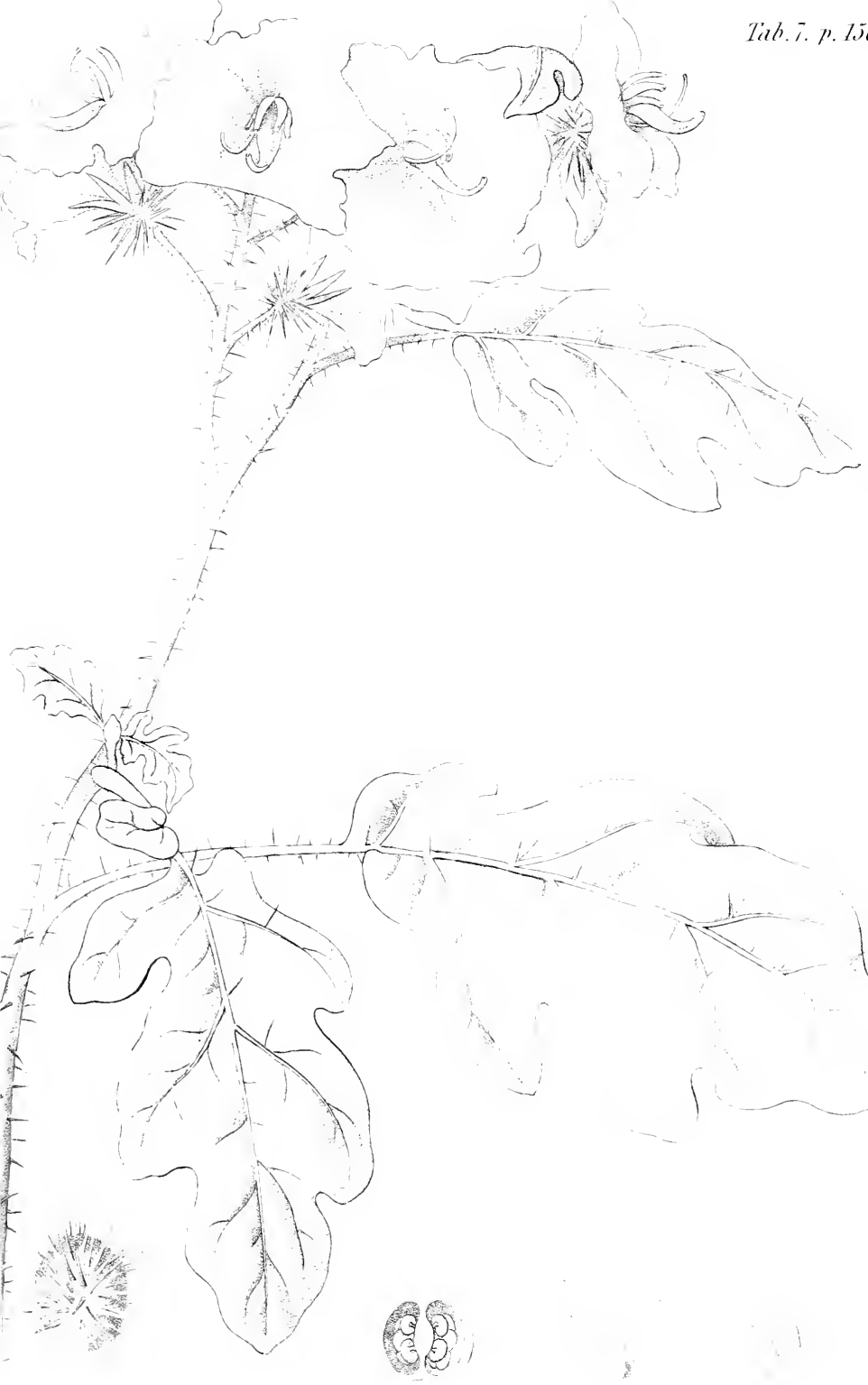

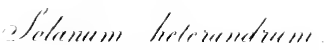



yellow. This singular species of Solanum is very nearly allied to $S$. cornutum, Juss. in Annales de MIus. hist. nat. 3. p. 120.t. 9. and they probably will form a new genus, to which some other not properly examined species may belong.

\section{PHYSALIS. Gen.pl. 336.}

1. P. foliis geminis subcordato-ovalibus repandis obtusis subtomentosis, caule herbaceo superne paniculato, calycibus fuctiferis pubescentibus. - IVilla. sp. pl. 1. p. 1021.

Icon. Jacy.hort. 2. t. 136. Dill. elth. t. 10. f. 10.

On road sides and among rubbish: Pensylvania to $\mathrm{Ca}$. rolina. 4. July $\rightarrow \Lambda$ ug. v. v. Flowers yellow; berries viscous.

2. P. foliis quasi cordato-suborbiculatis acuminatis inæqualiter destatis, caule herbaceo divaricato-ramosissimo: ramis angulatis.-Mich. $f$. amer. 1. p. 149.

a. P. summitatibus petiolisque vix pubescentibus.

P. angulata. IV Vult. fl. car. 99 .

$\beta$. P. viscido-pubescens.

In sandy fields of Lower Carolina. 4 . July, Aug. $v \cdot v$. Flowers yellow, with brown spots and blueish an. thers.

3. P. foliis geminis ovali-lanceolatis subintegris, in petiolum sensim angustatis pubescentibus, caule herbaceo dichotomo. calyce villoso.-Mich. fl. amer. 1.p. 149 .

In Iower Carolina. Michaux. 4 . July. v. s, in Herl. Walt.

4. P. foliis ovatis subrepandis obtusis nudiusculis, caule pensylvanica. herbaceo ramoso, pedunculis solitariis petiolis paulo longioribus.-Will sp.pl 1.p. 1021.

P. tomentosa. Walt.fl.car. 99 ?

On road sides, among rubbish: Pensylvania to Carolina. 4. June, July, v. v. Flowers entirely yellow.

5. P. foliis ovatis repando-dentatis glabris, caule herbaceo ramosissimo, pedunculis solitariis petiolo multo brevioribus. Lam. encycl. 2. p. 101.

obscura.

glabra.

pubescens.

lanceolata.

In div places on river sides; New England to Virginia. $\odot$. July. v.v. Flowers larger than the foregoing species, yellow, with brown stripes.

f. P. foliis villoso-viscosis cordatis, caule herbaceo ramo- pulescens. 
sissimo, floribus solitariis pendulis, calycibus fructiferis subrotundo-globosis angulatis. IVilld.sp.pl.1. p. 1023.

Icon. Fevil. peruv. 3. t. 1 .

On the sandy shores of Carolina. $\odot$. June, Iuly. v. $v$. Flowers yellow, with brown spots; berries round, yellow.

194. NICANDRA. Juss. gen. pl. 140.

physaloides. 1. Nicandra. Pers.syn. 1.p. 219.

Atropa phy saloides. Willd.sp.pl. 1.p. $101 \%$.

Calydermos erosus. Fl. peruv. 2. p. 44.

Icon. Fevil. peruv. t. 16.

In cultivated ground, near gardens : Pensylvania to Virginia ; introduced. $\odot$.July, Aug. v. v. Flowers blue.

105. SAMOLUS. Gen. $p l .294$.

Valerandi. 1. S. foliis obovatis, racenis elongatis, pedicellis medio bracteatis.-Willd.sp. pl. 1. p.927.

Icon. Fl. dan. 193. Engl. lot 703.

In nuarshes and near springs : Canada to Carolina; frequent. 24. July, Aug. v. v. Flowers white, small.

166. PINCKNEYA. Mich. fl. amer. 1.p. 103.

pul:escens.

1. P. foliis ovalibus utrinque acutis subtus subtomentosis. Mich.f. amer. 1.p. 105.

Icon. Wich. l.c.t.13.

On the banks of the river St. Mary, Georgia. $\zeta$. July, Aug. v. v. Flowers blusb-red, marked with purple lines, in large clusters. Each flower has one of the divisions of the calyx grown out to a large white leaf, tinged with red, which makes this shrub highly ornamenal. It is only to be regretted, that it is very shy of cultivation. The small difference of its fruit from Cinchora only makes it excusable to keep it separate frum that genus; but I have no hesitation in saying, that if Pinckneya is not united with Cinchona, there will be some of the latter genus found belonging to Pinckneya. 
197. CAMPANUla. Gen. $p l .889$.

1. C. glabra; foliis radicalibus reniformi-cordatis crenatis; caulinis linearibus integris, panicula laxa paucitlora, floribus nutantibus.-Filld. sp. pl. 1.p. 892.

Icon. Fl. dan. 855. Engl. lot. 866.

On rocks on the banks of the Susquebanna and in $\mathrm{Ca}$ nada. 24. July, Aug. v. v. Flowers azure blue, of considerable size.

2. C. glabra; caule erecto flexuoso, ramulis confertis foliosis, foliis lanceolatis subremote serratis, Horibus breviter pedicellatis nutantibus.-Mich.Al.amer. 1.p. 109.

On high nountains: Virginia and Carolina. 24. Aug. Sept. $v . v$. Flowers small, pale biue.

3. C. glabra, nitida, erecta ; foliis membranaceis remote serratis, panicula ramulis subaphyllis divaricatis, floribus nutantibus.-Mich. fl. amer. 1.p. 109.

On slate mountains in Virginia and Carolina. 24. July, Aug. $v . v$. Flowers snall, azure blue; a very graceful perennial.

4. C. glabra ; foliis cordatis lanccolatisque serratis, petiolis inferioribus ciliatis, foribus axillaribus sessilibus, corollis 5-partitis planis, stylis corolla longioribus. Wïlld. sp.pl. 1.p. 898 .

In shady wet places: Pensylvania to Virginil. $\delta$. June, July. $v . v$. Flowers small, pale blue, two or three in the axillæ of the leaf, nearly sessile; plant from two to three feet high.

5. C. glabriuscula, erecta; foliis orato-lanceolatis in longum acumen desinentibus subserratis, spica fasciculatomultiflora, corollis subrotatis.-Mich. fl. amer. 1. p. 108.

C. nitida. Ait. kew. 1. p. 346.

Icon. Dodart.mem. 4.t. $1 \mathrm{~s}$.

On the high mountains of Pensylvania and Virginia. 4. July, Aug. v. v. Flowers in size and co'our resemble the fourth species.

6. C. gracilis; caule simplici angulato : angulis foliorumque margine et nervo retrorsum aculeatis, foliis linearilanceolatis supra glabris, pedunculis paucis in summitate caulis Hexuosis axillaribus unifloris filiformibus.

In low inundated meadows, generally in company with Vironica scutellatd: Pelisylvania to Virginia. $\odot$. July. $v . v$. Flowers small, pale blue.

rotundifolia

flexuosa.

divaricata.

americana.

acuminata.

aparinoides. 
perfoliata. $\quad 7$. C. caule simplici erecto, foliis cordatis crenatis amplexis caulibus, floribus axillaribus sessilibus glomeratis. Willd.sp.pl.1.p. 915.

C. amplexicaulis. Mich. fl amer. 1.p. 108.

Icon. Moris. hist. 2. s. 5.t. 2. f. 23. Barr. rar.t. 1133. In cultivated grounds: common from North to South. $\odot$. May-Ang. v. v. Flowers small, pale blue.

\section{CHIOCOCCA. Gen. pl. 315.}

racemosa. 1. C. foliis ovato-oblongis acutis planis, racemis axillaribus pedunculatis simplicibus. - IV illd.sp.pl. 1.p.975.

Icon. Dill. elth.t. 228. f. 235. Bot. rep. t. $2 \mathrm{~S}^{2}$.

On the sea-shore of Georgia and Florida. Michaux. h. July. v. v. Flowers yellowish-white. It appears to differ in some respecis from the West Indian plant, but can be considered nothing more than a variety.

\section{CAPRIFOLIUM. Juss, gen. pl. 235.}

sempervirens, 1. C. spicæ verticillis subnudis distantibus, corollis subæqualibus: tubo superne ventricoso, foliis obovatis ovatisque subtus glaucis: summis connato-perfoliatis.Willd. sp. pl. 1. p. 983, sub Lonicera.

Icon. Bot. mag. 781. Schmidt arb. 104.

In stony dry woods : New York to Carolina. 々. May -Aug. v.v. Flowers a beautiful scarlet outside and ycllow inside; there are several varieties of it, particularly one with an almost upright sten.

ciliosum.

2. C. spicæ verticillis approximato-capitatis subsessilibus, corollis subæqualibus : tubo hirsuto medio ventricoso, foliis subamplexicaulibus sessilibus petiolatisque ovatis subtus glaucis, margine conspicue ciliatis : summis connato-perfoliatis.

On the banks of the Konskoosky. M. Leuis. $r_{\text {. }}$. June. $v$. s. in Herb. Lewis. Flowers of a deep yellow.

Frascri.

3. C. spicæe verticillis capitatis, corollis subringentibus : laciniis oblongis obtusis, foliis oratis subtus glaucis cartilagineo-marginatis : summis comato-perfoliatis.

Lonicera flava. Bot. mag. 1318.

Un the Paris mountains, South Carolina. Fraser. On the Catskill mountains, New York, \&c. h. June, July. v. v. Flowers bright yellow. 
4. C. spicæ verticillis approximatis, corollis ringentibus : gratum. tubo elongato, foliis perenuantibus obovatis submucronatis subtus reticulato-ven sis pallidioribus : summis connato-perfoliatis.-Willd. sp. pl. 1. p. 984. sub Lonicera.

Icon. Hort. ang!. 15. n. 10. t. S.

On the monntains, rambling among rocks in shady moist situations: New York to Carolina; rare. そ.JuneSept. v. v. Flowers inclining to scarlet.

5. C. spicæ rerticillis capitatis subsessilibus, corollis brevi- parviflorum. usculs ringentibus basi gibbis, filamentis barbatis, foliis deciduis subtus glaucis: omnibus connatis: bractea perfoliata horibus multo ampliore. - Lam. encycl. 1.p. 723.

Lonicera dioica. Willd. sp. pl. 1. p. $9 ₫ 3$.

Lonicera media. Murr. com. gott. 1776. p. 28. t. 3.

Caprifolium bracteosum. Nich. fl amer. 1. p. 105.

Icon. Murr. com. geett.t.3. Schmidt arl. 109.

In rocky shady situations: New England to Carolina. $h$. June, July. $v \cdot v$. Flowers yellow, smaller than in any of the foregoing species. There is a variety with purplish flowers, according to Michaux, which I never observed myself.

\section{XYLOSTEUM. Juss. gen. pl. 235.}

1. X. baccis distinctis, foliis ovatis subcordatisque margine ciliatis : junioribus subtus villosis, corollis conspicue calcaratis : tubo superne ventricoso : laciniis brevibuz acutis, stylo exerto.

Xylosteum tartaricum. Nich. fl.amer. 1. p. 106?

$\beta$. baccis albis.

On mountans, among rocks, in rich soil: Canada to Virginia. $\beta$. On the Rocky-mountain. M. Iewis. h. June, July. v. $v$. Flowers white, with a tinge of red or yellow. $X$. tarlaricum differs materially from this species, and the diagnosis might be thus: $\mathrm{X}$. larlaricum, baccis distinctis, foliis ovatis acutis utrinque glabris, corollis basi vix gibbosis: tubo brevi : laciniis oblongis obtusis, stylo incluso.

2. X. baccis distinctis, ramis villosis, foliis oblongoovalibus obtusis utrinģue subtomentoso-villosissinis, pzdunculis brevibus. Fich. fl. amer. 1.p. 106.

On rocks in the mountains of Canada. Michaux. $\zeta$. + . Berries blue.- Whether this is really a distinct

ciliatum.

album.

villosum. 
species from $X$ vulgare, I cannot ascertain, having never seen the plant.

201. SYMPHORIA. Juss. Pers. syn. 1.p. 214.

glmerata. 1.S. floribus axillaribus subcapitato-glomeratis. Pers. syn.l.c.

S. vulgaris. Mich. Al. amer. 1.p. 105.

Lenicera symphoricarpos. Willt. sp. pl. 1. p. 959 .

Icon. Schmilt arb. 115. Dill. elth. t.278.f. 300.

In sandy dry fields : Virginia and Carolina. $h_{\text {. July- }}$ Sept. v.v. Flowers small, red and yellow; berries purple.

racemosa.

2. S. racemo terminali, corolla intus barbata. Mich. $f$. amer. 1. p. 107.

On mountains, near lake Mistassins. Michaux. On the banks of the Misscuri. M. Leuis. h. Aug. v. s. in Herl. Lewis.

202. DIERVILLA. Juss. gen. pl. 235.

liclea.

1. D. pedunculis axillaribus et terminalibus dichotomis trifions, folis oratis serratis acuminatis.

D. Tournetortii. Mich.fl.amer. 1. p. 107.

I). humilis. Pers. syn. 1. p. 214.

Lonicera Diervilla. $l W$ illd sp. pl. 1.p. 989 .

Icon Sihmidt arb. 116. Duham, arb. $t$ 87.

On rocks and the highest mountains : Canada to Carolina. $I_{\imath}$. June, July. v.v. Flowers yellow; fruit a brown dry capsue. There are a number of varieties, in respect to size, flowers and leaves.

\section{TRIOSTEUM. Gen. pl. 300 .}

perfoliatum. 1.T. foliis ovalibus acuminatis connatis, floribus sessilibus verticillatis.-Willa.sp. pl. 1.p. ggo.

Icon. Dill. elth. l. $293 . f .378$.

In rich rocky grounds, principally lime-stone soil : New England to Carolina; rare. 4. June-Aug. v.v. Flowers and berries dark purple.

angustifoli- 2. T. foliis ovali lanceolatis subconnatic, pedunculis oppounn. sitis unifloris, canle hispido-Willd.sp.pl. 1.p. gg1. T. minus. Mich, fl. amer. 1. p. 107.

Icon. Pluk. alm. t. 104.f. 2.

On the borders of woods, in sandy soil : Virginia and 
Carolina. 4. June, July. v.v. Flowers and berries yellow.

\section{RIBES. Gen.pl. 390.}

1. R. inerme; foliis abbreviatis acute lobatis glabriusculis : allineritum. nervis albidis, racemis recurvatis, baccis glabris.Mi.h.fl.umer. 1.p. 110.

On lake Mistassins: Canada. Michaux. On the Catskill mountains: New York, \&c. h. April, May. $v . v$. Flowers small, greenish-yellow; berries red.

2. R. inerme; foliis modice lobatis supra glabris subtus pubescentibus, racemis laxis pubescentibus, floribus planiusculis, Jaciniis calycinis subtrifidis, petalis spathalatis obtusis, baccis hirsutis.-Mich. fl. amer. 1. p. 110.

In Canada. Michaux. On the Pensylvania mountains, \&c. দ. April, May. v. v. Flowers greenish-yellow; petals purple; berries red.

3. R. inerme; ramis rectis, foliis acute lobatis dentatisque reticulato-rugosis subtus pubescentibus, racemis laxis rigescenti-erectis, baccis hispidulis.-Mich.fl. amer. 1. p. 110.

On lake Mistassins: Canada. Michanx. In the Pensylvania mountains, \&c. দ. May, June, v. v. Berries red, erect as well as the flowers.

4. R. inerme; ramis reclinato-prostratis, foliis lobatis glabriusculis : junioribus pubescentibus, racemis suberectis, calycibus planiusculis, petalis deloideis, bracteis minutis, baccis hispidis.-L'Herit. stirp. 1.p.3.

R. glandulosum. Ait. kew. 1.p. 41 .

Icon. L'Herit. l. c. t. 2. Schmidt arl.05.

In rocky moist places: Newfoundiand, Canada, Pensylvania. $々$. April, May. v. v. Flowers yellow tinged with red; berriestred.

5. R. inerme; omnibus partibus pilis resinoso-glandulosis tectum ; foliis $3-5$-lobatis subrotnndis, racemis erectis, calycibus planiusculis, petalis obtuse-thonboideis, bracteis linearibus pedicello longioribus, baccis hissutis.

On the mountains of North A merica. Fraser. h. April, My. v. v. in Hort. Flowers green.

6. R. inerme; omnibus partibus pilis viscidis tectum; foliis cordatis obtuse-trilobis serratis, racemis erectis brevi-

trifidum.

rigens.

prostratum.

resinosum.

viscosissimum. 
bus, calycibus tubulatis, petalis oblongis, bracteis lineari-spathulatis pedicello duplo brevioribus, germinibus hirsutis.

On the Rocky-mountain in the interior of North America. M. Lewis. h. June. v. s. in Herl. Lewis. Flowers large, yellow; the whole plant covered with viscous hair. This species appronches near to $R$. glinduiosum. Fl. peruv 3. p. 13. $t$ 233.f. $b$. It differs principally in the leaves being equally lobated, not having the middle lobe projecting; its long slender pedicels, and its petals.

sanguineum.

7. R. inerme; foliis cordatis trilobis serratis venoso-lineatis supra giabris, subtus tenui tomento albicantibus, racenis laxis pubescentibus foliis duplo longioribus, calycibus tubulatis, petalis oblongis longitudine calycis, bracteis obovato-spathulatis longitudine pedicellorun, germinibus hirsutis.

On the Columbia river. Mr. Leuris. দ. March. v. s. in Herl. Lewis. Flowers beautiful, of a blood red or purple; branches purple. It approaches near to R. allinervium. Fl. peruv. 3.p. 12.t.232.f. $b$.

aureum.

8. R. inerme, glaberrimum ; foliis trilobis : lubis divaricatis inciso-panci-dentatis petiolo basi ciliato brevioribus, racemis laxis dense-multifloris, calycibus tubulatis pedicellis longioribus: tubo gracili : laciniis oblongis obtusis, pctalis linearibus laciniis calycis duplo brevioribus, bracteis linearibus longitudine pedicellorum, baccis gabris.

On the banks of the rivers Missouri and Columbia. M. Lewis. h. April. v. s. in Herl. Lewis.; v.v. in Hort. Flowers in close racemes, beautiful goldenyellow; berries red or brown, of an exquisitely tine taste, and considerably larger size than any of the garden currants. The shrub before flowering has the appearance of a speciês of Cratcegus.

reeurvatum. 9. R. inerme; ramis recurvatis, foliis latiusculis acute-lobatis pubescentibus glanduloso-punctatis, racemis reflexis, calycibus tubulatis glabris.

Near Hudson's Bay, Canada. Michaux. $\quad$. + . Berries black.

floridum. 10. R. inerme; foliis utrinque punctatis, racemis pendulis, calycibus cylindraceis, bracteis pedicellis longioribus. Willd.sp.pl. 1.p. 1156.

R. pensylvanicum. Lam. encycl.3. p. 47 . 
Icon. Dill. elth. t. 244.f. 315. Schmilt arb. 92, In hedges and woods : Canada to Virginia. h. April, May. v. v. Flowers pale yellow; berries black.

11. R. spina subaxillari ; foliis suborbiculatis subpubescentibus: lobis subrotundo-obtusis, pedunculis unifloric, limbo calycis tubuloso, baccis glabris. Mich. fl. amer. 1 . p. 110.

On the high mountains of Carolina, Nichıux. $h_{c}++$

12. R. spinula subaxillari, ramis subhispidis foliis parris semitrifidis : Jobis subdentatis, pedunculis unifloris, baccis glabris.-Mich. fl. amer. 1. p. 111.

Among rocks, in the Allegany mountains : Canada to Virginia. h. May, June. v.v. Berries red.

13. R. spinula subaxillari, foliis petiolis gracilibus utring̣ue pubescentibus : lobis acutis dentato-incisis, pedunculis capillaribus subbifloris, calycibus tubulato-campanulatis, baccis glabris.-Mich. fl. amer. 1. p 111.

On rocks and in mountain meadows: New York to Carolina. $々$. April-June. v. v. Berries purple or blue, of excellent taste.

14. R. spina subaxillari, fuliis glabris $3-5$-lobatis incisodentatis, pedunculis subtrifloris : pedicellis elongutis, bracteis brevissimis, petalis spatbulatis undulatis, stylo hirsuto semibifido exerto, baccis slabris.-Wilid. hort 1.p. 61.

Icon. Willd l. c. t. 61 .

On the Blue mountains: Pensylvania to Virginia. $h$. May, June. v.v. Flowers yellowish-green; petals white; berries pale red, small.

15. R. aculeis majoribus et subsolitariis ad gemmas, minoribus undique sparsis, foliis glabris: lobis dentatis, pedunculis brevibus subbitloris, baccis glabris.-IVilld. sp. pl.1.p. 1159 .

Icon. Dill. elth. t. 139. f. 166.

On rocks : Canada, New York, \&rc. h. April, May. v. $v$.

16. R. spina subaxillari multiplici, caule undique hispidoaculeato, foliis ultra medium lobatis, petiolis villosis, baccis racemosis hispidis.-Pers. syn. 1. p 252.

R. oxyacanthoides. Mich. fl. amer. 1. p.111.

In swamps, on the mountains : Canada to Virginia. $h$. April-June. v. v. Flowers smail, greenish-yellow; berries amber-coloured or brown.

lacustris.

rotunclifoliuin.

hirlelium.

gracile.

trifierum.

oxyacarthoides. 
Cynoslati. 17. R. passim subgeminis 2-aculeatum, foliis brevi-lobatis inciso-dentatis molliter pubescentibus, racemis nutanti-paucifloris, calycibus erecto-campanuiatis, baccis aculeatis.-Mich. fl. amer. 1. p. 111. Willd. sp. pl. 1. p. 1159 .

Icon. Jacq. hort. 2.t. 123. Schmidt arl.98.

On the sides of hills and rocks in the Allegany mountains, and in Canada. $々$. April-June. $v$. v. Flowers green; berries dark brown and full of thorns.

205. RHAMNUS. Gen.pl. 358.

franguloides. 1. R. inermis; foliis ovalibus acuminatis serrulatis subtus ad nervos pubescentibus, floribus diocis, pedunculis unifloris aggregatis, calycibus acutis, fructibus turbinatis.-Mich , fl. amer. 1. p. 153.

R. alnifolius. Willd. sp.pl.1.p. 1100.

On dry hills, near rirers: Canada to Virginia. $I_{\imath}$. June, July. v. v.; v. s. in Herb. Lambert. Flowers green; berries black; leaves small.

alnifolius. 2. R. inermis; foliis ovalibus denticulatis brevi-acuminatis basi sinu parvo cordatis subus ad nervos pubescentibus, pedunculis bis bifidis, baccis depresso-globosis.

Os the banks of the river Kooskoosky. M. Leuis. h. May. v. s. in Herb. Lewis. Berries purple, very highly esteemed by the Indians of that country.

caroliniarus. 3. R. inernis; foliis ovali-oblongis integriusculis glabris, unbellis peciunculatis, floribus hermaphroditis 4 -andris 1-gysis, stigmate bilobo, fructibus globosis.Mich. fl amer. 1. p. 153.

In woods and swamps: Virginia and Carolina. $h$. May-July. $v . v$. Berries black.

lanceolatus. 4. R. inermis, arborescens; foliis lanceolatis serrulatis utrinque acutis subtus pubescentibus.

On the side of hills: Ternassee. Lyon. $々$. v. s. in Herb. Lyon. Berries black.

minutiflorus. 5. R. inermis ; foliis suboppositis ovalibus serrulatis, floribus minutussimis dioicis spicatis in rachi alterne sessilibus, stylo 3-fido, bacca 3-sperma. Mich.fl.amer. 1. p. 154.

On the sea-coast of Carolina and Florida. Michaux. h. t. 
206. CEANOTHUS. Gen. pl.361.

1. C. foliis ovatis acuminatis serratis triplinervibus subtus americanus. nervis venisque pubescentibus, paniculis axill rribus longe pedunculatis, pelicellis corymbosis. Wilid. sp. pl. 1.p. 1114.

Icon. Duham. arb.51. Schmidt arl. 132.

In dry woods; common: Canada to Florida. h. May, June. v.v. Flowers small, white. It is commonly called New Jersey-tea or Red-root; having been actually used in the American war as a substitute for tea.

2. C. foliis oblongo-ovalibus acutis mucronato-serrulatis rriplinervibus subtus pubescentibus, pariculis axillaribus longissime pedunculatis, pedicellis corymbosis laxis.

Icon. Pluk. alm. t. 28,f. 6.

In the woods of Tennassee. Lyon. $h$. June, July. v.v. Leaves not one fourth the size of the foregoing species.

3. C. foliis obovatis serratis subtus pubescentibus, paniculis axillaribus thyrsoideis brevissime pedunculatis, pedicellis aggregatis.

Near the Rocky mountains on the banks of the Missouri. M. Lewis. そ. Myy, June. v. s. in Herb. Lewis. Branches blood-red or purple; panicles not longer than the leaves.

4. C. foliis ovalibus subserrulatis glabris, paniculis thyrsoideis terminalibus axillaribusque.

On rocks near rivers : Virginia and Carolina. 24. May. $v . v$ Leaves the size of the first species, but smooth; the stems scarcely ever remain over winter, but die down to the root.

5. C. subdecumbens; foliis minutis subfasciculatis oblongis microphyllus. subintegerrimis glabriusculis, corymbulis terminalibus. Nich. fl. amer. I. p. 154.

In sandy woods: Carolina to Florida. $々$. May, June. $v . v$. A very delicate little shrub, the root of which, like all the foregoing species, is large and red, from which they derive the name of Red-root.

207. Celastrus. Gen. pl. 372.

I. C. inermis, scandens; foliis oblongis acuminatis serratis, racemis terminalibus. Willd. sp.pl.1.p.1125.

scandens. 
Icon. Duham. art.95. Schmidt arb. 140.

In hedges and woods, among rocks : Canada to Virginia, h. May, June. v. v. Hlowers pale yellow; berries orange-scarlet.

lullatus. 2. C. inermis : foliis ovatis actits integerrimis, panicula terminali. Willd. sp.pl.1. p. 1123.

Icon. Pluk. alm. t. 28. f. 5.

In Virginia. $\quad .+$. Notwithstanding all my diligent researches at the place of its supposed nativity, as well as in the Herbariums of Plukenet and Bunister, now at the Pritish Museum, I have not been able to find any information respecting this species: consequently I strongly suspect its not being an American plant.

\section{EVONYMUS. Gen.pl.1.p.373.}

amerieanus.

1. E. ramis 4-angulatis, foliis subsessil bus elliptico-lanceolatis acut is serratis, pedunculis subtrifloris, fioribus omnious 5 -fidis, fructibus veriucoso muricatis.Willd.sp pl.1.p. 1132.

Icon. Pluk. alm, t. 1।5.f.5. Schmidt arb. 75 .

In hedges and shady woods, among rocks, and on the edges of swamps: New England to Carolina. $r_{c}$. June, uly. v. $v$. Flowe:s yellow, tinged with red; fruit scarlet, resembling those of Arcutus Unedo at first sighr. They are a gieat ornament to this almost elergreen shrub. The conmon name in America is Eurning-bush.

angustifolius. 2. E. ramis 4-angulatis, foliis subsessilibus elongato-lineariellipticis subtalcatis subintegerrimis, pedunculis plerumgne unith ris, foribus omnibus 5 -fidis, tructibus verrucoso-muricatis.

In shady woods: Genrgia. Lyon. 々. June, July. $v . v$. Fl, wers and fruit the same as the first species. Though nearly related to it, it is propagated by seeds, and keeps its owu distinction, according to information from Mr. Lyon.

atropurpureus.

3. E. foliis peti latis oblongo-lanceolatis acuminatis serratis, pedunrulis divaricatis multilloris, floribus 4 -fidis, fructibus levibus.- il illd. sp. pl. 1. $p 1132$.

Icon. Jo \% hort. 2.1 120. Schmidt arb. 73.

On the Uatiks of $r$ vulets: New York to Carolina. $h$. June, July, $v . v$. Flowers dark purple ; fruit red. 
209. VITIS, Gen.pl. 396.

1. V. foliis lato-cordatis sublobato-angulatis subtus incanotomentosis, racemis fertilibus pari is, baccis majoribus.

Lalnusca. Mich.fl. amer. 2. p. 230 . Wilid.sp.pl.1.p.1151. V. taurina. Walt. fl. car, 242.

Icon. Jacy. schoenlr. 426.

In shady woods: Canada to Florida. h. June, July. $\boldsymbol{v} v$. Berries black, large, of a disagreeable fox-smeil, commonly called Fox-grape. There is a variety with white berries called Bland's-grape.

2. V. foliis lato-cordatis $3-5$ lobis: junioribus subtus rufo-tomentosis, racemis fertilibus oblongis, baccis parvis.-_Hich. fl. amer. 2 p. 230.

V. vulpina. Willd. sp. pl. 1.p.1181.

V. Labru-ca. Walt.fl. car, $2+2$.

Icon. Jacq. schonbr. 425.

§. V. foliis sinuato-palmatis boideis. An species distincta?

In fields and woods: Virginia to Carolina. h. Nay, June. v. v. Berries dark blue, very agreeable to eat, and frequently converted into very good home-made wine. It is known by the name of Summer-grape.

3. V. foliis cordatis acuminatis inciso-dentatis utrinque glabris, racenis laxe multitloris, baccis parvis,-Mich. $f l$. amer. 2. p. 231.

V. incisa. Jac\%. schoenlr. 427 .

V. vulpina. Wult. $l$. car. 243.

Icon. Jacq. l. c.

On the edges of rivers and in wools : Canada to Florida. h. Jume, July. v.v. Berries green or amber-coloured, small, and ripen extremely late, of a very tart taste: commonly called $W$ inter-grape or Chicken-grape.

4. V. foliis inæqualiter inciso-dentatis breviuscule 3-fidis: petiolo nervis margineque pubescentibus. Mich. $f$. amer. 2. p. 231.

V. odoratissima. Donn cutal. 66.

On the gravelly shores and islands of the rivers: Pensylvania to Carolina, $\zeta$, May-July. v.v. Flowers of an exquisitely fine smell, somewhat resembling Reseda odorata. Female plants are very seldom tound north of the Potownac river, though the male extend very far beyond it.

5. V. utrinque lucidis reniformi-cordatis subæqualiter den- rotundifolia. 
tatis, racemorum floribus pluries capitulatis, baccis magnis. Mich.fl. amer. 2. p. 231.

On riter sides and islands: Virginia to Florida. $h$. June, July. $v v$. Berries very large, dark blue, ag! eeable, commonly called Bull-or Bullet-grapes.

palmala.

6. V. folis cordatis palmatis glabris: laciniis lanceolatis incisis, unbelis racemosis. lValld. sp.pl.1.p. 1180.

In Virginia. Vahl. 々. +.

210. CISSUS. Gen.pl.655.

Ampelopsis. 1. C. foliis truncato-cordatis acuminatis dentatis angulatisque : nervis subtus pubescentibus, racemis duplicatobifidis.- Pers. syn. 1. p. 142 .

Ampelopsis cordata. Mich. fl. amer. 1. p. 159.

On river sides and ansong hedges, in the A'legany mountains : Pensylvania to Carolina. $々$. June, July. v. $v$. Berries pale red.

hederacea. 2. C. radicans, scandens; foliis quinato-digitatis utrinque glabris : foliolis petiolatis oblongis acuminatis mucronato-dentatis, pedunculis dichotomis : racemis corymbosis.-Pers. syn. 1. p. 143.

Ampelopsis quinquefolia. Mich. fl. amer. 1. p. 160.

Vitis hederacea. Willd. sp. pl. 1. p. 1182.

Hedera quinquefolia. Linn. hort. cliff, $; 4$.

Icon. Corn. canad. t. 100.

hirsuta. $\quad \beta$.C. foliis utrinque pubescentibus : foliolis ovatis acuminatis grosse-dentatis.

Ampelopsis hirsuta. Donn catal. 166.

On the Allegany mountains : Pensylvania to Virginia. $\eta$. v. v. The variety $\beta$. appears to be a distinct species; but, as I never have seen its flowers, a sufficient cliaracter is wanting.

stans.

3. C. foliis bipinnatis: foliolis inciso-serratis, racenis pedunculatis duplicato-bitidis.-Pers. syn. 1.p. 143.

Ampelopsis bipinnaia. Mich. fl. amer 1. p. 160.

Vitis arborea. Willd. sp. $\mu l .1$. p. 1183.

Icon. Pluk. mant. l. $412 . f .2$.

In shady woods, on river sides: Virginia and Carolina. $h$. June, July. $v, v$. Stem uprright.

211. CYRILLA. Linn. Mich.fl.amer.1.p. 157.

earoliniana. 1. C. foliis cuneato-lanceclatis acutis membranaceis nervosis, spicis gracilibus, petalis pedicello longioribus. Mich. Al. amer. 1.p. 158. 
C. racemiflora. Linn. mant. 50.

Itea Cyrilla. Willd. sp. pl. 1. p. 1146.

Icon. Jacq. ic. 1. t. 47. L'Herit. stirp. 1. t. 66.

In sandy swamps of Carolina. $々$. June, July. $v, v$.

A very elegant shrub; Howers white.

212. ITEA. Gen.pl.381. Mich.gen. pl.1.p.156.

1. I. foliis oblongis serratis, spicis pubescentibus.-Willd. virginica. sp. pl. 1.p. 1146.

Icon. Duham. arb. 1, t. 126.

In swamps : Pensylvania to Carolina. F. June, July. $v . v$. From four to six feet high : flowers white.

\section{IMPATIENS. Gen. pl. 1365.}

1. I. pedunculis multifloris solitariis, foliis ovatis cbtuse Nolitangere. dentatis, geniculis caulinis tumentibus.-Willd. sp. pl.1.p.11706.

Icon. Fl.dan. 583. Engl. lot. 937.

Near springs and rivulets, in shady places: New England to Carolina. $\odot$. June, July. v. v. Flowers plain yellow.

2. I. pedunculis plerumque bifloris solitariis, foliis ovatis argute dentatis. - Willd. sp. pl. 1.p.1175. Walt. A. liflora. car. 219.

In wet shady places: Canada to Carolina. $\odot$. June, July. v. v. Flowers dark yellow, with red spots on the inside.

214. VIOLA. Gen. pl. 1364.

$$
\text { * Acaules. }
$$

1. V. foliis subpedato-multiparlitis: laciniis lineari-lanceolatis subintegris, calycis laciniis linearibus acutis.Willd. sp.pl.1.p. 1160.

Icon. Bot. mag. 89. Bot. rep. 153.

On dry sandy hills and fields : New England to Carolina. 4. May, June. v. v. Flowers large, beautiful blue. There is a very handsome variety with pale blue petals, ornamented with a dark purple velvet at the bottom, similar to Viola tricolor.

2 . V. foliis palmato-5-7-lobatis postice in petiolum attenuatis : lobis integris.

In Virginia. Leconte in litt. 2. May. v.s. Flowers pale biue.

pedata.

digitata. 
palmata.

sagittata.

dentata.

lanceolata.

blanda.

olliqua.
3. V. pubescens; foliis cordatis hastato-lobatis palmatisve ; laciniis dentatis, calycis laciniis lanceolatis glabris, petalis 2. oppositis basi barbatis.-Willd. sp. $p l$. 1. p. 1159 .

Icous. Bot. mag. 535. Pluk. alm. t. 447.f. 1.

On diy hills and pastures, generally in sandy soil. 4 . April-June. $v \cdot v$. Flowers blue; early in spring the leaves are generally kichey-shaped, and after the first flowe:s are gone they become palmated; sometimes it occurs with snlooth leaves.

4. V. pubescens; foliis oblongis acutis cordato-sagittatis subserratis basi incisis, pedunculis foliis longioribus, calycis lacinijs linearibus glabris, petalis 3. inferioribus basi barbatis. - Willt. sp. pl. 1, p. 1160.

On dry hills: New England to Virginia. 4. AprilJune. $v . v$. Flowers blue; lower petal white towards the bottom, with purple veins; the rest longer, narrower, and white towards the base.

5. V. glabra; foliis oblongis acuris basi truncatis serratis inferne subhastato-grandi-dentatis, peitunculis foliis brevioribus, calycis laciniis linearibus, petalis 3 . inferioribus basi barbatis.

In wet meadows and woods : Pensylvania. \%. May, June. $v . v$. Flowers of nearly the same colour and sbape as the preceding species.

6. V. glabra; foliis lanceolatis subserratis, pedunculis vix foliis longioribus, petalis imberbibus: 2. superioribus subrotundis.-Willd. sp.pl.1.p. 1161.

In overflowed meadows: Canada to Pensylvania. 4. June, July. $v \cdot v$. Flowers white; the upper petal panted with purple veins. There are several varieties of this species, some with ovate leaves attenuated in a petiole, some exceeding small, \&.c.

7. V. glabra; foliis cordatis acutiusculis planiusculis remote serratis, pedunculis longitudıne foliorum, petalis imberbibus: 2. lateralibus brevionibus, intimo reliquis longiore lanceolato - IVilld. hort. berol. 1. t. 24.

In wet places, bog-meadows: New York to Carolina. 4. April-June. v. v. Flowers yellowish white; lower petal marked with blue stripes and veins.

8. V. glabra; foliis cordatis acutis crenato-serratis planiusculis, floribus erectis, pedunculis longitudine foliorum, petalis oblique flexis : lateralibus angustioribus et lon- 
gioribus infra medium barbatis.-Willd.sp. pl. 1. p. 1161 .

In shady wet places: Pensylvania t• Virginia. 24. April -June. v. $v$. Flowers white with purple and yellow veins.

9. V. pubescens; foliis ovatis subcordatis crenatis : petiolis narginatis, calycibus ciliatis longis, petalis omnibus obovatis: 2. lateralibus barbatis.-Willd. sp. pl. 1 . p. 1162.

On dry hills: Canada to Virginia. 24. April-June. $v$. $v$. Flowers blue.

10. V. glabra ; foliis cordatis glabris serratis basi cucullatis, primulifolia. pedunculis longitudine petiolorum, petalis oblique flexis : lateralibus barbatis.-Willd.sp.pl. 1. p. 1102. In grassy wet places: common. 24. May, June. v. v. Howers blue, white at their base.

11. V. foliis cordatis crenato-serratis obtusis subtlis pubescentibur, pedunculis foliis brevioribus. petalis oblong is : infimo basi barbato.-Willd. hort. berol. 1. t. 72 .

In overflowed meadows: Pensylvania, \&c. 24. April -June. v.v. Flowers blue, white at the botton; lower petal veined.

12. V. foliis triangulari-cordatis acutis crenatis subcucullatis papilionacea. glabriusculis. pedunculis longitudine fuliorum, petalis obovatis: 3 . inferioribus infra nedium barbatis conniventibus, '2. superioribus retlexis.

Near Philadelphia, in wet places. 24. May, June. v. $v$. Flowers blue, elegantly striated and bearded with yellow down.

13. V. glabritiscula; foliis suborbiculatis obtusiusculis sinu cucullata.

sororia. clauso cordatis crenato-serratis : serraturis glandulosis, stolonibus floriferis, petalis linearibus calyce vix longioribus.

V. rotundifolin. Wich.fl. amer. 2. p. 150?

On the high mountains of Pensylvania, in shady beechwood, among rotten wood and rich vegetable mould. 24. June-Sept. v. v. This singular species differs from all the rest, in producing its flowers as it were under ground, as they always are covered with rotten wood or leaves; they are of a chocolate brown, very small; the seed-vessel buries itself still deeper in the ground, and is large in proportion to the plant. The inhabitants know it by the name of Heal-all, being used by them in curing all kinds of wounds or sores.

clandestina. 


\section{** Caulescentes.}

canadensis. 14. V. glabriuscula; foliis subcordatis acuminatis serratis, pedunculis lungitudine foliorum, stipulis brevibus integris.- $F^{\prime}$ illd. sp. pl. 1. p. 1166.

In shady woods, in rich moist situations: Canada to $\mathrm{Ca}-$ rolina, on the mountains. 4. June-Aug. v. $v$. Flowers outside purplish-blue, inside white and elegantly veined, sweet scented.

striata.

15. V. glabra; foliis cordatis acuminatis serratis planinsculis, pedunculis lungissimis, stipulis lauceolatis serrato-cilialis.-Wiild. sp. pl. 1. p. 1166.

In shady woods: Pensylvania to Virginia. 24. MayJuly. $v . v$. Flowers white, with purjle veins.

debilis.

16. V.glubra ; foliis reniformi-cordatis brevissime acuminatis crenatis basi cucullatis, pedunculis foliis duplo Jongioribus, stipulis serrato-ciliatis.-Mich. $f$. amer. 2. p. 150 .

V.cinina Ifult.fl. car. 219 .

In low grounds: Pensylvania to Carolina. 24. MayJuly. $v . v$. Flowers not one half the size of the preceding species, pale blue.

rustrata. $\quad 17 . \mathrm{V}$. glabra; foliis cordatis acutis serratis, pedunculis foliis duplo longioribus, stipulis lanceolatis serrato-ciliatis, nectariis rostrutis corolla longioribus.

On shady rucks : near Eastown, Pensylvania. 24. May, June. v. v. Flowers blie.

pulescens.

18. V. villoso-pubescens; caule erecto superne folioso, foliis lato-cordatis, stipulis oblongis apice serratis.-Irilld. sp.pl.1.p. 1160.

V. pensylvanica. Mich. fl. amer. 2, p. 149 .

In shady woods, anong rocks, particularly limestone rocks: New York to Virginia. 4. May, June. v. v. Flowers yellow.

Lastata. 19. V. glabra; caule simplici superne folioso, foliis hastatis brevissime petiolatis, stipulis minutis denticulatis. Mich. fl. amer. 2. p. 149.

On Ligh mountains: Pensylvania to Carolina. 4 . May, June. v. $v$. Flowers jellow.

Nuttallii. 20. V. pubescens; caule simplici erecto, foliis ovato-oblongis acutis obsolete-dentatis nervosis, in petiolum longum attenuatis, stipulis lanceolatis integris, pedunculis longitudine foliorum.

On the banks of the Missouri. 2!. June. v. s. in $\mathrm{Hcrb}$ Nuttall. Flowers yellow. 



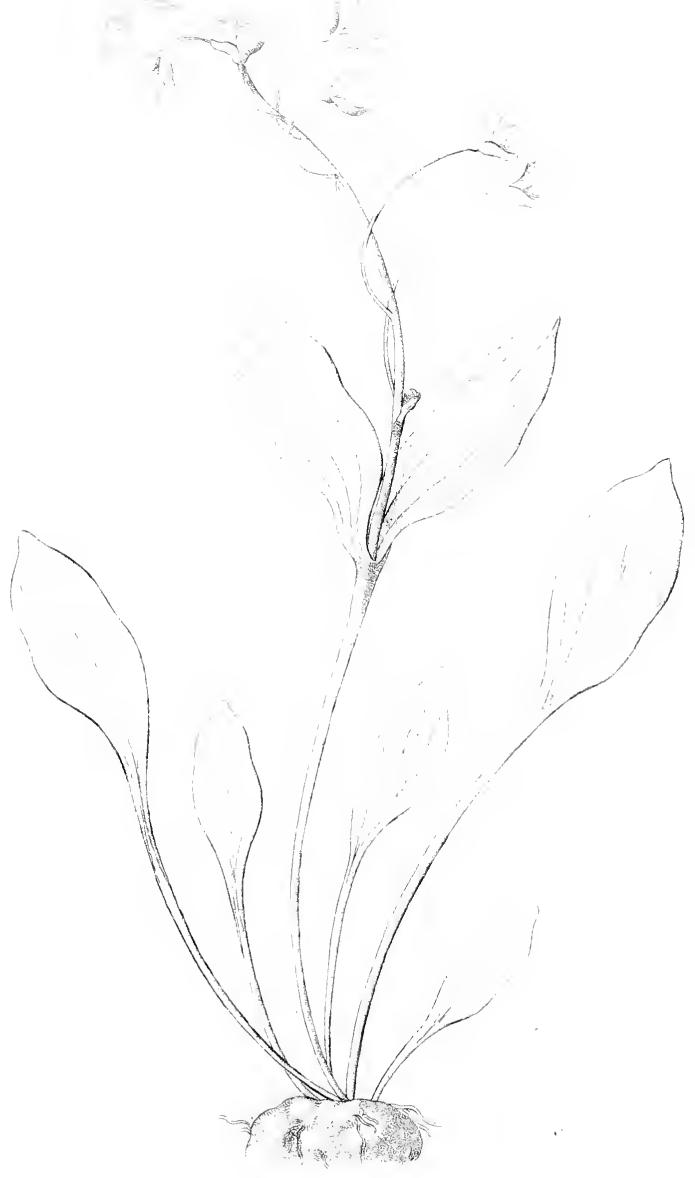


3. V. stricte-erecta: foliis lato-lanceolatis stipulisque lanceolato-linearibus integerrimis, pedunculis axillaribus concolor. geminis brevissimis. - Forster in Linn. trans. o. p. $30 \mathrm{y}$. t. 28 .

V. stricta. Munilb, Mss.

On lime-stone rocks: Pensylvania. భ. June, July, v. v. About two feet high; flowers small, green.

22. V. subpubescens; caule angulato simplici, folis inferioribus rotundato-spathulatis subdentatis, superioribus lanceolatis integris, stipulis pectinato-pinuatifidis, calycibus acutis corolia duplo brevioribas.

In fields of Pensylvania and Virginia. ๑. May-Jaly. $\because . v$. Flowers small white, with a few purple veins. Nearly approaches to it tricolur. Specimens in the collection of A. B. Lambert, Esg. from Pallas's Herbarium, are the same with his species.

\section{CLAYTONIA. Gen. pl. 402.}

1. C. foliis lineari-lanceolatic, racemis solitaris, calycis foliolis acutiusculis, petalis obovatis retusis, ravice tuberosa.-Wilid. sp. pl.1.p. $118 j$.

Icon. Bot. mag. $9+1$.

In wet woods, round the stumps of rotten trees: New England to Carolina. 2\%. March-May. v. v. Flowers white, with red veins.

2. C. foliis spathulatis, racemo solitario, calycis foliolis obtusis, petalis subrotundis retusis, radice tuberosa.Parad. lond. 71.

C. caroliniana. Mich. A. amer. 1.p. 1 6о.

Icon. Parad lond. 71 . Pluk. aim.t. 102. f. 3.

On high mountains of Virginia and Carolina. 4. March, April. v. v. Flowers smaller than the first species, rose-coloured with purple veins.

3. C. foliis lanceolatis: caulinis oratis sessilibus, racemo solitario elongato, calycis foliolis brevibus obtusissimis, petalis cuneatis bifidis, radice tuberosa.-Pull. Mss.

On the Rocky-mountains. Mr. Lewis. 24. June. $v$ s. in Herl. Leu'is. Howers white, nearly the size of the first species, without veins. In the collection of A. B. Lambert, Eiy. I found a specimen collected by Pallas in the eastern parts of Siberia, perfectly agreeing with the present species.

4. C. foliis radicalilus spathulato-ovatis, caulinis ovatis divirginica.

spathulafolia.

licolor.

virginica


teis ovatis linearibusque, petalis emarginatis, radicibus fibrosis - Sims in lot. mag.

C. sibirica, Hortul.

Icon. Bot. mag. 1309 .

On the Columbia river. M. Lewis. ๑. May, June. $v . v$. in Hortis. Flowers small, white.

perfuliata.

5. C. foliis radicalibus spathulato-rhomboideis: caulino suborbiculato perfoliato, racemis subsolitariis ebracteatis, petalis emarginatis, radicibus fibrosis-Donn catal 50. Willd so pl.1.p. 1156.

C. cubensis. Humb. ซ๐ Bnnpl. equinoct. t. 26. Annales du mus. dhist. nat. 7. p. s2.t. 6 .

Icon. Bit. mag. 1336.

On the Rocky-mountains. M. Lewis. $\odot$. April, May. $v$ v. in Hort. Flowers smaller than any of the foregoing species, white.

216. GLAUX. Gen.pl. 408.

maritima. 1. Glanx. Will.l.sp.pl.1.p.1216.

Icon. Fl. dan. 543 .

In overtlowed marshes, near the sea : Canada. 2f. July. v. $v$. Leaves oblong, smooth. Flowers axillary, sessile, flesh-coloured.

217. ANICHIA. Mich.fl amer.1.p.112.

dicholoma. 1. A. caule patulo dichotomo ramosissimo, foliis lanceolatis glabris erectis, stipulis floralibu calyce glabro subxqualibus. Mich. fl. amer. 1.p. 113.

Queria canadensis. Willd.sp.pl. 1.p. 494.

Icon. Ort. dec.t.15.f. 2.

On dry limestone hills: New York to Kentucky. 2 . June-Aug. v. v. Flowers exceeding small; very variable in the number of filaments, generally from two to five.

herniarioides. 2. A. humifusa, conferta, undique pubescens; foliis oblongo-ovalibus ciliatis mucronatis, laciniis subulatis: acumine setaceo patuloque. Mich.fl. amer. 1.p. 113.

On the dry sands of North Carolina. Nichunx. 4. +.

argyrocoma. 3. A. crespitosa, procumbens ; caulibus pubescentibus, foliis linearibus acutissimis subpilosis, capitulis fasciculato-terminalibus argenteis, calycis pilosi apicibus barbatis et longe acuminatis. Mich. fl. amer. 1. p. 113.

On rocks in Upper Carolina and Virginia. 24. June, July. $\boldsymbol{v} v \boldsymbol{v}$. 
21s. THESIUM. Gen. pl. 410 .

1. T. ercetum : foliis ovali-lanceolatis, fasciculis florum coumlellatum. rymboso-terminalibus. - IVilld. sp. pl. 1. p. 1214.

T. corymbulosum. Mich, fl. amer, 1.p. 112.

Icon. Pluk mant. t. $342 . f .1$.

On dry hills and fields: New York to Carolina. 4. June, July. $v, v$. Flowers white.

\section{NYSSA. Gen. pl. 1599.}

1. N. foliis oblongis integerrim's utrinque acutis, petiolo, villosa. costa media margineque villosis, pedunculis femineis subtriftoris, nucibus brevi-obovatis obtuse striatis.Willd. sp. pl. 4. p. 258.

N. multiflora. Walt.jl, car. 253.

N. montana. Hortul.

Icon. Mich. arb.21. Wench amer. t. 16.f.39.

In all the wools from New England to Carolina. $\zeta$. May. v. v. Hlowers small, greenish; berries black, the size of a pea. This tice is known by the name of Sour-gum.

2. N. foliis ovato-oblongis integerrinis utrinque actuis glabris, peduncalis temineis bilforis, drupis brevi-obovatis : nuce obtuse-strata.-Willl. sp. pl. 4. p.1113.

N. aquatica. Sp.pl. 1511.

N. integrifolia. Ait. keu, 3. p. 446.

Icon. Mich. arb. 22. CatesU. car. 1, t. 41.

In deep swamps: Virginia and Carolina. 々. April, May. $v . v$. Berries the size of the preceding specie:, blueish-black.

3. N. foliis brevissime petiolatis oblongis sub-integerrimis basi cuneatis subtus candicantibus, pedunulis fenineis urifloris, drupis oblongis.-Willd. sp. pl. 4. p. 1113.

N. capitata. Walt $f$ l car. 253.

Icon. Mich. arb. 20.

Un the banks of rivers: Carolina, principally on the river Ugechee. h. May, June. v.v. Fruit ldige, orange-coloured, full of an acid similar to a line, from which it is known by the name Ogechee-lime.

4. N. foliis longe petiolatis oblongis acuminatis remote serratis subtus tomentosis, pedunculis femineis uniflo.

lomentosa. ris, drupis oblongis.-Willd. sp. pl. 4.p. 1113.

VOL. I.

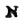

liflora.

candicans. 
N. grandidentata. Mich. arb. $t .19$.

On the banks of the river St. Mary, and in Florida. h. May. $v . s$. Fruit the size of the preceding, dark blue.

denticulata. 5. N. foliis longe petiolatis oblongis acuminatis remote serratis undique glabris. pedunculis femineis unifloris, drupis oblongis. Willd. sp pl.4.p. 1114.

N. uniflora. Walt fl. car. 253.

N. angulısans. Mich. fl. amer. 2.p. 259.

Icon. Wungh anter. t. $27 . f .57$. Catesb. car. $1 . t 60$. In swamps: Virginia and Carolina. $\zeta$. v. v. s. $f$.

220. HAMILTONIA. Willd. sp. pl. 4. p. 1114.

Pyrularia. Mich.fl. amer. 2.p. 231.

oleifera.

1. Hamiltonia. Willd.l. c.

Pyrularia pubera. Mich. l. c.

In shady woods, in the mountains of Pensylvania, Virginia near the Sweet springs, and in Carolina. $\boldsymbol{r}_{\text {. }}$. May, June. $v . v$. A shrub from four to six feet high, very pubescent; leaves oblong, entire, acuminate; flowers small, greenish-yellow, in terminal racemes, fruit known in the country by the name of Oil-nut.

\section{II. $D I G Y N I A$.}

221. ECHITES, Gen. pl. 421 .

diformis.

1. E. volubilis ; foliis ovali-lanceolatis acuminatis basi acutis : infimis linearibus, floribus fasciculato-corymbosis. -Walt. fl. car. $9 \mathrm{~s}$.

E. puberula. Mich. fl. amer. 1.p. 120.

In woods of Lower Virginia and Carolina. $\zeta$. July. $v . v$. Flowers small, dirty yellow; seed pods very slender and long.

\section{GONOLOBIUM. Mich.fl. amer. 1. p. 119.}

macrophyllum.

1. G. sarmentis petiolisque hirsutis, foliis amplis abrupte acuminatis puberulis, corollæ laciniis ovali-lanceolatis, folliculis costato-angulosis.-Mich. fl. amer. 1. p. 119. 
Vincetoxicum gonocarpus. Walt. fl. car. 104.

In shady woods of Carolina and Virginia. $1_{2}$. June. v. v. Flowers dark purple or dirty yellow.

2. G. sarmentis petiolisque hirsutissimis, foliis sensim acuminatis utrinque pubescentibus, corollæ laciniis oblongo-ovalibus obtusis, folliculis oblongis muricatis.Mich.fl. amer. 1. p. 119 .

Vincetoxicum acanthocarpos. Walt. fl. car. 104.

In hedges, near rivulets : Pensylvania to Carolina. 4. June, July. $v \cdot v$. Flowers dark purple.

3. G. sarmentis glabriusculis, foliis subconoideo-cordatis hirsutum. sensim acutis nervis subtus puberulis, floribus glabris, corollæe laciniis ovali-oblongis obtusiusculis, folliculis lævibus. Mich.fl. amer. 1.p. 119.

Cynanchum carolinense. Jac. ic. 2. t. 3.42 ?

In hedges on the banks of the Mississippi. 24. June. $v$. v. s. fr. Flowers dark purple.

Cynanchum obliquum. Jacq. ic. 2. t. 241. probably is another species of this genus. I have seen the plant in flower, but without frut, in a cultivated state, but never observed it growing spontaneously; consequently I shall omit it, as a doubtui North American plant.

\section{APOCYNUM. Gen.pl.426.}

1. A. caule rectiusculo patente, foliis ovatis utrinque gla-androscemifo. bris, cymis lateralibus et terminalibus glabris, corollis lium. limbo patentibus.-Willd. sp. pl. 1.p. 1259 .

Icon. Dod. mem. t. 50 .

In fields and along the edges of woods : Canada to Carolina. 4. July. v. v. Flowers pale red with darker stripes.

2. A. caule rectiusculo, foliis oblongo-ovalibus subtus can-cannatinum. dicante-pubescentibus, paniculis pubescentibus, corollis limbo erectis.-Willd. sp. pl. 1. p. 125y.

Icon. Pluk. alm. t. 13. $f$. 1 .

In sandy fields and wools; common. 24. June, July. $v, v$. Flowers yellowish-green, small. The plant is generally called Indian Hemp.

3. A. caule erectiusculo, foliis oblongis cordatis glabris, cymis folio brevioribus. Willd. sp.pl. 1. p. 1260.

lave.

A. sibiricum. Jacq. hort. 3. t. 66.

On the gravelly shores of rivers: New York to Virginia; scarce. 4.July, Aug. v. v. Flowers very 
Pentandria dieria. A pocynum.

small; plant lower than the preceding species, and very smooth.

\section{ASCI,EPIAS. Gen. pl. 429. \\ * Foliis oppositis.}

sijriaca.

1. A. caulibus simplicissimis, foliis lancenlato-oblongis sen$\sin$ acutis subtus tomentosis, umbellis subnutantibus tomentosis. Willd. sp.pl. 1.p. 1265.

In fieids and on the banks of rivers, very common : New England to Virginia. 24. July, Aug. v. v. from three to five feet high; flowers in large close cluster, pale purple, sweet-scented. The nectaries act as Ay-traps.

phytulaccoides.

devilis.

parvifora.

nivea.
2. A. caule erectr simplici, foliis lato-ovato-oblongis acutis glabris subtus pallidioribus, umbellis compositis lateraIibus solitariis longe pedunculatis nutantibus.-Gron. virg. 38 .

On the mountains of Virginia and Carolina. 4 . July, At:g. $v . v$. Stem about three feet or more high, spotted with purple; leaves large, middle rib purple; flowers steet-scented; petals reflexed, very dark purple. This plant was introduced into England in 1812, by $\mathrm{Mr}$. Lyon, under the above name.

3. A. glabriuscula; caule debili erecto simplici, fuliis petiolatis ovali-lanceolatis utrinque acutis membranace is, umbellis terminalibus laxifloris, pedicellis capillaribus. - Mich fla amer. 1. p. 110.

In shady rocky situations, near rivulets : New York to Carolina; rare. 4. July, Aug. v. v. Flowers v hive; leaves large. The fibres of the stem produce a kind of flax, as all the rest of this genus do, but far superior, being of a beautiful silky gloss and extreme strength.

4. A. foliis lanceolatis acuminatis glabris oppositis basi attenuatis, umbellis lateralibus solitariis, caule suffruticoso erecto. Willd. sp.pl. 1.p. $126 \%$.

A. perenuis. Walt fl. car. 107 .

In sandy fields : Carolina and Florida. 24. July, Aug. $v, v$. Flowers small, white.

5. A. fo'iis ovato-lanceolatis glabriusculis, umbellis erect is lateralibus solitariis, caule simplici. Willı. sp. pl. 1. p. 1266. 
Iron. Dill. elth.t. 29.f. 32. Bot. mag. 1187.

On the banks of rivers in sandy or gravelly soil : Virginia to Carolina. 4. July, Ang. v.v. Flowers white.

6. A. caule erecto superne ramoso tomentoso, foliis lanceoincarnata. latis utrinque subtomentoso-lanuginosis, umbellis pluribus origine geminis, corniculis appendicum exertis. Mich.fl.amer 1.p. 115. Willd.sp. pl. 1.p. 1207.

Icon. Jacq. hort. $t$. 107 .

ß. Willd. l. c.

In swamps and on river banks; common. 2. JuneAug. $v v$. Flowers red. The variety $\beta$. is more hairy, in every other respect no ways different; sometimes the leaves are quite smooth, and only pubescent on the upper part of the stem.

7. A. caule simplici bifariam puberulo, foliis subsessilibus oblongo-ovalibus subtus pubescentibus, umbellis terminalibus nectariisque erectis, appendicibus exertis.-Willd. sp.pl. 1.p. 1265.

Icon. Dill. elth.t. $27, f .30$.

In wet meadows, on the edges of woods and ditches : New England to Virginia. 4. July, Aug. v. v. Flowers beautiful purple.

8. A. caule simplici, foliis ovatis subtus villosis, umbellis erectis, nectariis resupinatis. Willd. sp.pl. 1. p. 1265.

purpurascens

Icon. Dill. elth. t. 28. f. 31 .

In shady swamps: Virginia and Carolina. 24.July, Aug. v. v. Flowers purple.

9. A. caule s:mplici erecto hirsuto, foliis lanceolato-oblongis viridigora. obtusiusculis subsessilibus utrinque tomentoso-hirsuu;, umbellis lateralibus solitariis subsessilibus nutantibus subgloboso-densiflori, appendicibus nullis.

In dry fields : Pensylvania to Virginia. 24. June, July. $v . v$. Hlowers green.

10. A. caule simplici erecto, fo!iis ovatis petiolatis rugosis nudis, umbellis subsessilibus pedicellis tomentosis. Willd. sp. pl. 1. p. 1265. Walt.fl. car. 104.

A. hybrida. Nicíl. $\mathrm{fl}$ amer. 1.p. 115.

Icon. Pluk. alm. t.77.f.1. Bit. m tg. 1182.

On dry sumy hills, on the borders of woods: New York to Carolina. 4. July, Aug. v. v. A very handsome species; flowers in dense umbels; petals and nectaries white; fructification red. 
obtusifolia. 11. A. foliis amplexicaulibus oblongis rotundato-ohtusis undatis, umbella terminali longius pedunculata multiflora glabra, corniculis exertis. Mich. fl. amer. 1. p. 115 .

A. purpurascens. Walt. fl. car. 105.

In sandy fields: New Jersey to Carolina. 24. JuneAug. $v . v$. Flowers large, purple.

amplexicaulis.

12. A. tota glauca; caulibus decumbentibus simplicibus, foliis cordatis amplexicaulibus venosis, conniculis delitescentibus compresso-ligulatis. Mich. fl. umer. 1 . p. 115.

A. humistrata. Walt. fl. car. 105.

In barren sandy fields: Carolina and Georgia. 24.June, $\mathrm{J} u l y . v . v$. Leaves red-veined, thick ; flowers handsome, red.

acuminata. 13. A. caule erecto glabro simplici, foliis ovatis subcordatis acuminatis brevi-petiolatis, superioribus sessilibus; umbellis lateralibus solitariis erectis.

A. cordata. Walt. fl. car. 105.

In deep cedar-swamps, and on the banks of rivers: New Jersey. 2. July. $v . v$. Flowers red and white; stem about $\mathrm{tw}$ o feet high; roots very large, resenbling those of $A$. tulerosa.

laurifolia. 14. A. caule erecto g!abro, foliis subsessilibus ovali-lanceolatis sensim angustatis acutissimis glabris : supra ad oras asperiusculis.-AFich. fl. amer. 1. p. 117.

On the river Althamaha, Georgia. Michaux. 24. July. v.s. Flowers purple.

paupercula. 15. A. caule erectiusculo glabro oligoplyllo, sursum nudo, foliis linearibus longissimis glabriusculis, umbellis terminalibus paucifloris.-Mich. fl. amer. 1. p. 118.

A. lanceolata. Walt. fl.cor. 105.

In sandy wet meaduws : Virginia and Lower Carolina. 4. June, July. v.v. Flowers red, with yellow ap. pendices.

pedicellata. 16. A. caule simplici erecto piloso, foliis elliptico-linearibus pubescentibus supra punctato-asperis, unbella lateralis solitaria pauciflora, petalis erectis calyce multoties longioribus, nectariis lunulatis patentibus corniculis nullis.-- Walt. fl. car. 106.

On dry sandy fields of South Carolina. Walter. Near Fort Barrington. Lyon. 4. June. v. s. in Herb. Lyon. nec non Walter. The whole plant not above 
three inches high ; flowers large in proportion, greenish yellow; fructification on a pedicel.

17. A. caulibus erectis, foliis petiolatis oblongis obtusis lævii idis. vious, unbeliis paucis terminalibus, petalis erectis calyce multo lon ioribus, nectariis integris patulis bre. vibus.-Walt. $f$ car. 107.

South Car lina. Wulter. 24. v. s. in Herl, Lyon. Flowers large ; petals green ; nectaries purple ; fructification white. This and the preceding species deviate from the general character of Asclefias, and pro. bably constitute a distinct genus; but having had no opportunity to examine the living plant, I refer $\mathrm{t}$ em to this genus until another opportunity may be had to investigate them.

18. A. caulibus erectis simplicibus glabris, foliis ovatis acuminatis petiolatis : in medio cauli majoribus quaternis, umbellis duabus terminalibus laxifloris, pedicellis filiformibus.-Jacq. obs. 2. t. 23.

On lime-stone rocks: New York to Virginia. 24. May - July. $v . v$. From nine inches to a foot high; flowers small, sweet-scented; petals white; nectaries rose-coloured.

\section{** Foliis sparsis.}

19. A. caule erecto simplicissimo lineatin puberulo, foliis verticillata. angustissime linearibus strictis glabris plerumque verticillatis, corniculis exertis. Mich. fl. amer. 1.p.116. Willt.sp.pl. 1.p.1272.

Icon. Pluk. mant. t. 336. $f .4$.

On dry hills and fields : New Jersey to Carolina. $\psi$. June, July. $v . v$. Petals yellowish-green; nectaries white.

20. A. caule decumbente foliisque sparsis prælongo-linearibus puberulis, appendicibus corollæ corpuscuio genitalifero brevioribus et corniculo vacuis. Mich. fl. amer.1. p. 116.

A. incarnata. Walt. fl. car. 100.

A. floridana. Lam. encycl. 1. p. 284.

In shady wet woods: Carolina and Georgia. 24. July, Aug. v. s. Flowers pale purple; fructification yellow.

2i. A. caule erectiusculo summitate divaricato-ramoso hirsutissimo, foliis sparsis oblongo-lanceolatis birsutis,

quadrifolia.

longifolia.

tulerosa. 
umbellis subcorymboso-terminalibus.-Willd. $s p . p l$. 1.p. $12 \% 3$.

Icon. Dill. ellh. t. 30.f. 34 .

decumbens. $\quad \beta$.A. caule decumbente, foliis sublinearibus hirsutissimis umbellis lateralibus. Willd. sp.pl. 1. p. 1268.

In stony or sandy fields and woods; common. $\beta$. In barren fields of Carolina. 4 . June, July. v. $v$. Flowers very showy; petals and nectaries bright orange; fructification yellow.

\section{4. $b$. CEROPEGIA. Gen. pl. 431.}

palustris. 1. C. foliis linearibus integerrimis, floribus unbellatis, pedunculis longitudiue foliorum, calycis laciniis linearibus.

In salt narshes, winding round Scirpi and Innci : $\mathrm{Ca}-$ rolina. Lyon. 2\%. v. s. in Herb. Lyon. ner non Wal. ter. The u hole habit of the plant is that of $C$. tenui. flora. Willd. sp. pl. 1. p. 1276. the flowers only considerably snaller.

\section{AMISONIA. Wull.fl.car. 98 .}

tatifolia.

salicifolia.

1. A. caule glabriusculo, foliis ovali-lanceolatis superioribus promisse acuminatis subtus ad nervos pubescentibus.-Mich. fl. amer. 1. p. 121.

Tabernemontana Amsonia. Willd. sp. pl. 1.p. 1246.

Icon. Pluk. phyt.t. $115 . f .3$.

In shady wet woods : Carolina. 4 . May. v. $v$. Hlowers in compound corymbous racemes, biue.

2. A. caule lævigato, foliis lineari-lanceolatis utrinque acutis glaberrinis.

In Carslina and Georgia. Lyon. 24. May. v. v. Flowers the sanie as the first species, more abundant.

angustifolia. 3. A. caule pubescente, foliis angusto-linearibus crebris erectis pubescentibus. Mich.fl. amer. 1.p. 121.

Amsonia ciliata. Wult. fl. car. 98.

In sandy barrens of Carolina and Georgia. 24. May, June. v. s. in Herb. Walter. \&c. Flowers of the same disposition and colour as both the foregoing species.

226. GELSEMINUM. Juss. gen.pl.p. 168.

nitidum. 1. G. scandens, glaberrimum; foliis lanceolatis, fasciculis axillaribus paucifloris. Micll. fl. amer. 1. p. 120. 
Bignonia sempervirens. IVilld. sp. pl.3. p. 291. Anonymos sernpervirens. Walt. fl. car. 98.

I con. Catesb. car. 1. t. 53. Pluk. alm. t. 112.f.5.

On the sea-coast near rivers: Virginia to Florida. $I_{2}$. June, July. $v . v$. Flowers large, deep yellow, fragrant; known by the name Carolina Jessamine.

\section{GENTIANA. Gen. pl. 450.}

1. G. caule tereti, ramis elongatis uniforis, foliis lanceolatis acutis, corollis 4-fidis, lacinits obovatis incisociliatis, plicis interioribus simplicibus.-Willd.sp. pl. 1 . p. 1352.

G. fimbriata. Bot. rep. 50 9.

In dry pastures and wuods: New York to Carolina. o. Aug. Sept. v. v. Flowers a beautiful sky-blue, elegantly fringed on their edges.

2. G. caule tereti, foliis lineari-lanceolatis obtusiusculis, floribus terminalibus fasciculatis, lateralibus solitariis pedunculatis, corollis 5-fidis campanulatis : laciniis rotundatis, plicis interioribus acute-unidentatis.Willd. sp. pl. 1.p. 1336.

Icon. Fl. dan. 269. Bot. mag. 1101.

On high mountains, near the borders of lakes and rivalets: Canada to Pensylvania. 24. Aug. Sept. v.v. Flowers large, dark-blue.

3. G. caule tcreti glabro, foliis oblongo-lanceolatis trinerviis, floribus sessilibus fasciculatis terminalibus axillaribusque, corollis 5 -fidis campanulatis ventricosis : laciniis obtusis, plicis interioribus laciniis dentatis.-IVilld. sp. pl. 1.p. 1338.

G. fimbriata, I tahl 3. p. 47.

G. Catesbæi. Whalt. fl. car. 109.

Icon. Catesl. car. 1. t. 70. Bot. mag. 1039. Bot. rep. 418.

In low meadows and woods: Canada to Carolina. 2 . Aug. Sept. v. v. Flowers very crowded, fine blue.

4. G. caule subangulato scabriusculo, foliis ovato-lanceolatis asperiusculis, foribus sessilibus fasciculatis terminalibus, corollis 5 -fidis campanulatis ventricosis : laciniis acutis, plicis interioribus simplicibus acutis.Willd. sp.pl. 1. p. 1338.

G. Saponaria. Walt. fl. car. 109. Mich. fl, amer. 1. p. 176.

G. villosa. Willd.sp.pl. 1.p. 1333.

Pneumonas-

Saponaria.

ochroleuca. the.

crinita.

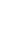


Icon. Pluk. alm t. 1 s6.f. 1.

In dry sandy fields and on gravelly hills: Pensylvania to Florida; more scarce. 24. Ang. Sept. v. v. Not so tall as the preceding species; flowers outside of a yellowish-green, inside, blue and striped with purple. That the present plant is the same with G. villosa, there remains no doubt, having seen the Gronovian specimen in the Banksian Herbarium, which is the same with G. Saponaria of Walter, and G. ochroleuca of Frolich.

linearis. 5. G. caule asperiusculo, foliis lineari-lanceolatis undulosis uti calyces clliolatis, floribus 5 -fidis campanulatis terminalibus sessilibus congestis, laciniis brevibus obtusis, plicis interioribus lacinis denticulatis.-Willd. sp. pl. 1. p. 1330 .

$\mathrm{G}$ puberula. Mich. fl. amer. 1. p. 176 .

In vallers, on the mouniains of Pensylvania and Virginia. 4. Aug. v. $v$. Flowers large, blue.

amarelloides. 6. G. canle quadrangulo ramoso, foliis semiamplexicaulibus ovalibus acutis trinervibus, floribus 5 -fidis tubuloso. campanulatis fauce glabris terminalibus et lateralibus ternis quinisve subpedicellatis, laciniis lanceolatis acuminatis, plicis simplicibus, calycibus brevissimis angustis.-Mich. Al.amer. 1. p. 175.

G. quinqueflora. Willd sp. pl. 1. p. 1339.

On hills, in sbady dry places : New York to Kentucky. o. July, Aug. v. v. Fiowers small, pale blue, not yellow as they are represented by Michaux.

acuta. 7.G. caule 4-gono, foliis sessilibus subamplexicaulibus erectis oblongo-ovatis acntissimis, floribus fasciculatis terminalibus et lateralibus, corollis 5 -fidis, laciniis lineari-lanceolatis, plicis ciliatis. Mich. $f$. amer. 1. p. 177.

On the high mountains of Carolina and in Canada. Michaux. +. Flowers very small, greenish-sellow.

angustifolia. 8. G. caule tereti simplici unifloro, foliis angusto-linearibus patulis, corollis 5 -fidis, laciniis ovalibus, plicis interioribus laciniis laceris.--Mich. fl. amer. 1.p. 177.

G. purpurea. Walt., A. car. 109 .

In meadows and near rivers, in sandy soil : New Jersey to Carolina. 4. Aug. Sept. v. $v$. Flowers large, a beautiful azure blue. 
22S. HYDROLEA. Gen.pl. 445.

1. H. spinosa, pilosa: foliis longo-lanceolatis, pedunculis quadrivalis. axillaribus ,brevissimis $1-5$-floris, capsulis glabris.Walt. fl. car. 110.

H. caroliniana. Mich fl. amer. 1.p. 377 .

In stagnant waters of Lower Carclina. 24. July. $v . s$. Flowers blue.

229. DICHONDRA. Gen. pl. 451. Mich.fl.amer. 1. p. 135.

1.D. pubescens; foliis absque emarginatura reniformibus carolinensis. co:acoloribus, calycibus villuso-ciliatis.-Mich. $f l$. amer. 1.p. 136.

Anonymos repens. Wilt. fl. car. 110.

Demidofia repens. Ginel syst nat. 158 .

In sandy fields, on ruad sides, about Charlestown, South Carolina. 4. June-Sept. v. v. A small crecping plant, with small herbaceous coloured flowers.

230. EVOLVULUS. Gen. pl. 524.

1. E. erectus; foliis oblongis utrinque sericeo-tomentosis, pedunculis unifloribus brevibus.

On the banks of the Missouri. Nuttall. v. s. Flowers yellow.

\section{HEUCHERA. Gen. pl.447.}

1. H. visciúo-pubescens; scapo foliisque asperiuscuiis, foliis modice rotundato-lobatis dentatis: dentibus dilatatis obtusis mucronatis, pedunculis paniculæ tres dichotomis divaricatis, calycibus brevibus obtusis, petalis lancenlatis longitudine calycis, staminibus longe exseritis.

H. americana. IVilhl. sp.pl. 1.p. 1328.

H. Curtusa. Nich. fl. aner. 1. p. 171 .

Icon. Pluk. rilme t. 58.f. 3 .

In shady rocky situatious : New England to Carolina; frequent. 24. May-July. v. v. Flowers in a long simple panicle, small ; petals red. It varies sometimes with nearly smooth leaves.

2. H. pulverulento-pubescens; scapo inferne foliisque subtus glabris, foliis subacuto-lobatis dentatis : dentibus rotundatis mucronatis, pedunculis paniculæ brevibus confertifloris, calycibus campanulatis majoribus, pe-

argenteus.

viscida.

pulescens. 
talis spathulatis calyce longioribus, staminibus vix exertis.

On the Blue mountains of Pensylvania and Virginia. 24 . May, June. $v v$. Flowers larger than the rest of the genus; petals pale red with yellow.

hispida.

3. H. hispida, scabra ; scapo petiolis foliisqne subtus glabris, foliis acute lobatis, supra hispicio-pilosis dentatis : dentibus brevissimis subretusis mucronatis, pedunculis paniculæ paucifloris, calvcibus mediocribus subacutis, petalis spathulatis longitudine calycis, staminibus exertis.

On high mountains of Virginia and Carolina. 4. May, June. $v . v$. Petals purple ?

villosa.

4. H. villosissima; foliis acute lobatis dentatis: dentibus acut is mucronatis, fasciculis paniculæ capillaribus laxifloris, calycibus parvis, staninibus exertis.-Mich. fl. amer. 1. p. 172 .

On high mountains of North Carolina and Virginia; collected on the Peaks of Otter. 4. June. v. $v$. Flowers small; petals white.

caulescens. 5. H. basi sufruticosa; scapo basi petiolisque pilosis, foliis supra glabris subtus ad nervos pilosis acute-lobatis ciliatis dentatis; dentibus acutis mucronatis, calycibus brevibus villosis, petalis linearibus calyce duplo longioribus, staminibus exertis.

On high monutains of Carolina. Lyon. 4. May, June. v. v. Ietals white. In the Herbarium of A. B. Lambert, Esq. are specimens of a Heuchera, collected by Pallas in Kamtschatka, which appear to be the same with the present species.

\section{ZIZYPHUS. Lam.encycl. 3. p. .03.}

rolulitis.

J. Z. inermis; foliis oratis costato-renosis integerrimis subunculatis, unbellis pedunculars axillaribus, caule volubi i. Wllid. sp.pl.1.p. 1102.

Than nus volubilis. Limn. suppl. 152. Walt. fl. car. 101. Icon Jacq. ir. 2. t.336. Schmiat arb.153.

In ceep swanps, near the sea-coast : Vir inia to Carolina. $\zeta$. lune. $v$. $v$. Flowers smail, greenishyellow; berries oblong, violet-coloured. It ascends the highest trees of Cupressus disticha, in the Dismal swamp, near Suffolk in Virginia, and is known there by the name of Supple-Jack. 
233. ERYNGIUM. Gen. pl.456. De'aroche monog. eryng.

1. E. præaltum ; foliis longissime lanceolato-linearibus ser- virginianum. ratis: rameis lineari-multipartitis, involucri foliolis capitulo ovoideo longioribus paleinque 3-5-fidis, capitulis paniculatis.-Lam. encycl.4. p.759. Delaroche eryng. p. 48.

E. aquaticuin $\beta$. Willd. sp. pl. 1. p. 1357. Mich. $f$. amer. 1.p. 163.

Icon. Delaroche eryng t. 19. Pluk. alm.t. $396 f 3$.

On the banks of rivers, in overflowed tide-meadows: Pensyluania to Virginia. 24. July, Aug. v. v. Stem hollow; flower-heads green or pale blue. I once found a beautifinl proliferous variety with pale purple flowers, one on the top of the others.

2. E. simplex; foliis orato-cordatis brevissime petiolatis, capitulis omnibus pedunculatis, involucri foliolis paleisque 3-tidis, caule virgato superne tantum ramoso. - Lam. encycl. 4. p. 757 . Delaroche eryng. p. 49.

E. ovalifolium. Wich. fl. amer. 1.p. 103.

E. integrifolium. Wolt. fl. car. 112.

Icon. Delaroche eryng. $t$. 20.

In wet meadows and woods: Carolina and Georgia. 21. July. $v . v$. About a foot high; flower-heads small, round, amethystine-blue.

3. E. punilum, graveolens; foliis serrato-spinosis: radicalibus lanceolatis, floralibns palnatis, capitulis cylinfotillum. dricis subsessilibus, paleis longissimis lineari-lanceolatis.-Willd. sp.pl. 1. p. 1356 .

Icon. Brown. jam. 1.t. 156.f. 3. 4.

In dry fields: Georgia to Florida. 24. July, Ang. v. v. Flowers in small heads, herbaceous. Very much esteemed among the natives as a medicine.

4. E. elatum; fol is late-linearibus remote ciliato-spinosis, floralibus lanceolatis dentatis, foliolis involucri capitulo globoso brevioribus paleisque integris, caule subdichotomo.-Willd. sp.pl. 1. p. 1357.

Icon. Jacq. ic. 2. t. 347. Pluk. alm. t.396.f.3.

In swamps: Virginia to Carolina. 24. Aug. v.v. Sometimes more than six feet high; leaves very long; flower-heads pale green. 


\section{HYDROCOTYLE. Gon.pl. 45\%.}

americana. 1.H. glabra, tuberosa; foliis subpeltato-orbiculatis dnplicato-crenatis, glomerulis paucifloris sessilibus.--Willd. sp.pl. 1.p. 136 i.

Hexicaulis. $\quad \alpha_{0}$ H. caulibus firmioribus brevioribusque quasi angulatim Hexuosis. Mich. fl. amer. 1.p. 102 .

gracilis.

unlgaris.

. H. gracilior, filiformis, non flexuosa ; foliis minoribus. Nich.l.c.

In bogs and sphamous swamps: $\alpha$. Canada to Virginia. $\beta$. In the mountains of Carolina, Virginia, and in Canada. 24. June-Aug. v.v. Flowers exceeding small, and of a greenish colour, as is the case with all the following species.

2. H. foliis orbiculatis peltatis leviter crenatis, scapo interrupto-spicato paucifloro.-Willd.sp.pl. 1.p. 1360.

Icon. Fl. dan. go. Engl. bot. 751.

In swamps and overliowed places: Canada to Georgia. 4. May-July. v. $v$.

umbellata. 3. H. foliis peltatis crenatis basi emarginatis, umbellis pedunculatis mulutioris, floribus pedicellatis. Willd. sp.pl.1.p. 1301.

In wet fields and mossy swamps : Virgin ia and Carolina. 4. May-July. v. $v$.

repanda. 4. H. foliis rotundato-cordatis subangulato-repandis, petiolis nervinque pilosis, cay itulo pedunculato trifloro villoso. Pers.syn. 1. p. 3 U2.

H. ficaroid's. Mich. fl. amer. 1.p. 161.

H. reniformis et cordata. Wult. fl. car. 113.

On overflowed banks of rivers in Lower Carolina and Georgia. 2L. June, July. v. v. Seeds larger than the preceding species.

lineata.

5. H. minuta, glaberrima ; foliis crassiusculis lineari-cuneatis transversim lineatis, umbella pedunculata.-Nich. fl. aner. 1. p. :6.

In overtlowed places of Lower Carolina. 4. April, May. + .

composita. 6. If radice globoso-bulbosa, caule simplici diphyllo bifido, folio laterali 3-partito, partitionibus subpinnatis, pinnulis divisis: terminali sub-biternato, umbellis terminalibus 3-5-floris.

Sison bulbosum. Mich. $l$. aner. 1. p. 160.

On rocks, in wet shaldy places, near linoxville, Kentucky. Michanx. 24. March, April. v, s, in Herb. 
Enslen. As far as I have been able to learn from a aried specimen, there remains no donbt that this platut belongs to this genus rather than any other I know. The flowers have white petals and dark purple anthers.

\section{PANAX. Gen. pl. 1604.}

1. P. radice fusiformi, foliis ternis quinatis, foliolis ovali-quinquefolibus acuminatis petiolatis serratis.-.Willd. sp. pl.4. um. p. $1: 24$.

Icon. Catesb. car. 3.t. 16. Trew ehret. t. 6.f. 1. Bot. mag. 1333.

In the mountains from Canada to Tennassee, in rich shady woods. 24. May. v.v. This plant produces the famous root called Ginseng, so much esteemed by the Chinese : it formerly was an article of exportation in America, but at present there is little deniand for it.

2. P. radice subrotundo-bulbosa; folis ternis ternatis quitrifolium. natisve, foliolis oblongo-lanceolatis subsessitibus serratis.-Willd. st. pl.4. p. 1124.

Icon. Bot. mag. 1334.

In low shady woods, near rivulets : New York and Pensylwania. 24. May. $v, v$. A small delicate plant, easily overlooked even when in search of it.

\section{SANICULA. Gen. $p l .458$.}

1. S. foliis digitatis, foliolis oblongis incisis, floribus fertili- marylandica. bus sessilibus subternis, sterilibus pedicellatis numerosis.-Willd. sp.pl. 1.p. 1367 .

Icon. Jacq. ic. 2. p. 348.

In dry woods, frequent: Canada to Carolina. 24. June, July. $v . v$. Flowers greenish-white; fruit a little bur.

2. S. foliis radicalibus compositis, foliolis ovatis. Willd. sp. canadensis. pl. 1.p. 1366.

In Virginia. +. A doubtfui species.

237. DAUCUS. Gen. pl. 466.

1. D. seminibus hispidis, petiolis subtus nervosis. Willd. Carota. sp. pl. 1. p. 1389 .

The $W^{-}$la Carrot is one of the most common weeds in dry fields. 
pusillus.

2. D. retrorsum-hispidus; foliolis laciniis minimis sublanceolatis, umbellis parvis, umbellulis paucifloris, seminibus S-fariam cristato-nuricatis.-Mich. fl. amer. 1. p. 164.

In dry fields of Carolina. Michaux. $\quad+$.

\section{AMMI. Gen.pl. 467.}

capillaceum. 1. A. caule ramoso, foliis omnibus composite capillaceomultipartitis, involucris umbella brevioribus multipar. titis, seminibus glabratis.

A. mojus. Walt. fi. car. 113 .

In sandy fields of Carolina and Georgia. ๑. June, July. $\boldsymbol{y}$. s. The plant small, with very finely divided leaves.

\section{SELINUM. Gen.pl. 470.}

canadense. 1. S. glaberrimum, lucidum ; foliis bipinnatis, foliolis multipartitis, laciniis lanceolatis, fructibus ovalibus. Mich. fl. amer. 1. p. 165.

Apium bipinnatum. Walt. fl. car. 115.

On the mouths of large rivers from Canada to Carolina. 4. July. v. v. Flowers white.

\section{FERULA. Gen. pl. 475.}

villosa.

1. F. foliis supradecomposito-ternatis, foliolis ovatis serratis rigidis venosis, caule pedunculis umbellisque villosis. Walt. fl. car. 115.

Cicuta venenata. Philad. philos. trans.

On dry bills : New York to Carolina. 24. July, Aug. $v$. $v$. Flowers white. In the Philosophical Transactions of Philadelphia, a description of this plant has been given, and a full account of its poisonous qualities.

\section{HerACLEUM. Gen. pl. 477.}

lanatxm. 1. H. foliorum peticlo nervisque subtus lanato-villosissimis, foliis trifoliatis, foliolis omnibus petiolatis amplis sub. rotundo-cordatis subpalmato-lobatis, seminibus orbiculatis. Mich fl.amer.1.p. 166.

In shady woods, on rich moist soil : Canada to Pensylvania; rare. $\mathcal{L}$. June, July. v.v. Flowers white. 
242. LIGUSTICUM. Gen.pl. 478.

1. L. foliis caulinis biternatis, summis tr:foliatis, foliis lateralibus trapeziformibus, terminali rhombeo, umbellis strictis, involucro involucellisque linearibus polyphyllis. Mich. $f$. amer. 1.p. 166.

On the river St. Laurence. Michaux. 4 . +. July.

2. L. foliis petiolo duplicato-tripartito, partitionibus secondariis 2-3 foliolatis, foliolis ovalibus æqualiter dentatis, involucellis setaceis, fructibus oblongo-ovalibus subulato-10-costatis. Mich.fl. amer. 1. p. 166.

On the river St. Laurence. Michaux. In Virginia near Staunton, \&c. 4. July. v. v. More than three feet high.

3. L. ? caule lævi glabroque, nodis confertim barbulatis, foliis plerisque biternatis margine nervisque puberulis, fructibus ovalibus utrinque margine subdipteris. Mich. fl.umer. 1. p. 167.

In Upper Carolina. Michaux. 4. v. s. in Herb. Lyon. I suspect this species to belong to another genus, probably Sium.

\section{ANGELICA. Gen. pl. 479 .}

1. A. petiolo tripartito, partitionibus pinnato-5-foliolatis, foliolis inciso-dentatis : terminalium impari rhombeo sessili, lateralibus decursivis. Mich. fl. amer. 1. p. 167.

In Canada and on the mountains of Virginla. 24. June, July. $v, v$. Smooth.

2. A. foliis compositis, foliolis oblongis sublobatis serratis subsessilibus : extimo pari coadunato : terminali petiolato.-Willd. sp.pl. 1.p.1430.

In Canada and on the mountains of Virginia. 24. July, Aug. v. v. From three to six feet high; root very fragrant; petals purple.

3. A. foliolis æqualibus ovatis inciso-serratis. Willd. $s p$. pl. 1.p. 1430.

actaifolium.

scoticum.

barlinode.

triquinata.

atropurpurea.

In shady woods : Canada to Pensylvania. 24. June, July. $v . v$. Flowers white.

lucida,

Vol, 1 , 


\section{SIUM. Gen. pl. 480.}

rigidius. $\quad$ 1. S. foliis pinnatis, folinlis lanceolatis integerrimis vel superne dentais. Willd. sp.pl. 1.p. 1433.

In wet meadov:s : Pensylvania to Virginia. 24. July, Aug. $v . r$ Flowers small. This and the following are considered very poisonous plants, especially in respect to horned cattle; and every farmer who knows their bad qualities is busily employed to destroy them.

lineare.

2. S. foliis pinnatis, foliolis longis sublanceolato-linearibus remotiuscule serratis, involucro oligophyilo, involucellis linearibus polyphyllis, umbella breviter radiata. Mich. fl. amer. I. p. 167.

S. suave. Walt. Al. car. 115.

In wet meadows and along ditches : Canada to Pensylvania. 4. July. v. v.

longifolium. 3. S. foliis pinnatis, foliolis inferioribus longissimis falcatolinearibus rariter dentatis, caule oligophyllo superne nudo, umbellis subgeminis nudiusculis.

In ditches and bogs: New Jersey. 4. Aug. v. $v$. Very slender.

\section{4. b. SISON. Gen. pl. 481.}

pusillum. 1. S. foliis biternatim multipartitis, umbellulis $3-5$-floris, seminibus scaberulis. Mich.fl. amer. 1.p. 168.

Daucus divaricatus. Walt. fl. car. 114.

In dry sandy fields: Carolina. $\odot$. April, May. v. s.

trifoliatum. 2. S. foliis omnibus trifoliatis, foliolis dentatis, inferioribus ovalibus 2-3-lobis, superioribus ovali-lanceolatis, umbella terminali solitaria pedunculata, seminibus subrotundis. Mich. fl. amer. 1.p. 168.

In Upper Carolina. Michaux. +.

marginatum. 3. S. foliis pinnatis, superioribus quinatis, foliolis omnibus sessilibus lanceolatis integerrimis albido-marginatis, involucro involucellisque nullis. Mich. $f$. amer. 1 . p. 168.

In wet meadows : Virginia to Carolina. 24. July, Aug. $v . v$.

\section{CENANTHE. Gen.pl. 484.}

carolinensis. 1. O. foliis omnibus simplicibus filiformibus. Walt. $f$. car. 113.

South Carolina. Walter. + . 
246. PHELLANDRIUM. Gen. pl. 485.

1. P. foliorum ramificationibus divaricatis. Willd.sp. pl.1. aquaticum. p. 1444.

On the waters of the Rocky-mountain. M. Leuis. 4 . July. $v$. s. in Herb. Lewis. The Indians of that country use it as a medicine in the diseases of horses.

\section{CICUTA. Gen.pl.486.}

1. C. foliorum serraturis mucronatis, petiolis membranaceis apice bilobis. Willd. sp.pl. 1.p. 1446.

Icon. Pluk, alm.t.76.f. 1 .

In wet meadows and ditches: New England to Carolina. 4. July, Aug. v. v.

2. C. foliis foniculaceis : ramis verticillatim bulbiferis.Willd.sp.pl.1. p. 1445. exclus. syn. Gronov.

In overflowed meadows and pastures : Canada to New Jersey. 4. July. v. v. A very singular small plant.

248. CONIUM. Gen. pl.469.

1. C. seminibus striatis. Willd. sp.pl. 1. p. 1395.

Icon. Jacq. austr. 156.

In cultivated grounds and near habitations; probably introduced: New York and Virginia. $\delta$. June-Aug. $v . v$. Very poisonous.

\section{CHAROPHYLLUM. Gen. pl. 490.}

1. C. seminibus nitidis lævibus, foliis decompositis, caule procumbente, umbellis paucifloris. Pers. syn. 1.p. 320. Scandix procumbens. Willd. sp. pl. 1.p. 1452.

On shady wet hills, on the foot of mountains : Virginia. $\odot$. May. v. v. A small and scarce plant; I observed it near Hager's 'Town, Maryland.

2. C. foliis ternatis, foliolis ovatis acutis subincisis, pedunculis geminis, fructibus oblongis.-Pers. syn. 1.p.320. Sison canadense. Willd. sp. pl.1.p. 1436.

Common in the woods: Canada to Virginia. 24. July. $v . v$.

3. C. petiolo tripartito, partialibus $3-5$-foliolatis, foliolis oblongo-ovalibus subpinnatifido-lobatis, umbella pauci-radiata divaricata, fructibus elongatis teretibus lavigatis.-Pers. syn. 1. p. 320.

procumbens.

maculatum.

maculata.

lullifera. 
Scandix dulcis. Muhlk. MIss.

Myrrbis Claytoni. Mich. fl. amer. 1. p. 170.

In the Allegany and other mountains; New England to Carolina. 24. June, July. $v . v$. The root has a very agreeable scent and sweet taste.

250. PASTINACA. Gen. pl. 494.

sativa.

1. P. foliis simpliciter pinnatis. Willd. sp. pl. 1. p. 1466. Common Parsnep is found frequently in a wild state apparently as a native, but certainly originated from European seeds.

\section{SMYRNIUM. Gen. pl. 495.}

cordatum.

1. S. foliis radicalibus suborbiculato-cordatis crenatis, caulinis petiolatis trifoliatis, supremis 3-partitis, umbella radiis brevibus.-Walt. $f$. car. 114 .

Thapsia trifoliata. Willd. sp. pl. 1. p. 1465.

In woods, frequently on the mountains: New England to Carolina. 4. June, July. v.v. Flowers yellow, as are all the following.

aureum.

2. S. foliis biternatis, partiaiium intermedio sæpe subquinato, foliolis ovali-lanceolatis serrulatis, umbella breviradiata.-Willd. sp. pl. 1. p. 1468.

On the mountains and hills, near banks of rivers : Pensylrania to Carolina. 4. June, July. v.v.

alropurpure. un.

3. S. foliis omnibus ternatis, foliolis ovatis acutis serratis. Lam. encycl. 3. p. 667.

S. barbinode. Niuhll. miss.

On dry slate hills: Virginia and Carolina. 24. MayJuly. $v . v$. Fluwers dark purple.

integerri. muni.

4. S. glaberrimum; foliis glaucis, inferioribus 3-ternatis, superioribus 2-ternatis, foliolis ovalibus integris, umbella radiis paucis setaceo-elongatis.-Willd.sp.pl. 1 . p. 1468.

On dry bills : New England to Carolina; scarce. 4. June. $v, v$.

nudicaule.

5. S. foliis radicalibus 3-ternatis, foliolis inæqualiter paucidentatis, scapo radicali, umbella radiis elongatis, involucro involucellisque subnullis.

On the Columbia river. M. Leuis. 4. April, May, v. s. in Herl. Lewis. The natives eat the tops of this plant and boil it in their soups, the same as we use celery. 
252. SESELI. Gen.pl.492.

1. S. foliis 3-ternatis, foiolis longo-linearibus, umbellis hemisphæricis, involucellis polyphylitis: foliolis linearibus longituane timbellularum.

On the waters of Columbia river. M. Lewis. 4. April, May. $\iota$ s. in Herl. Lentis. Flowers deep yellow. The rusiform root of this species is one of the grateful vegetables of the Indians: they use it baked or roasted.

\section{SALSOLA. Gen. pl.437.}

1. S. herbacea diffusa: foliis triquetro-subulatis mucronatis lineatis, caiycibus marginatis axillaribus. - $W$ illl. $s p$. pl. 1. p. 13 io.

Icon. Pall. illustr. t. 28 \& 29.

Near the sea-coast, in gravelly dry soil: frequent; plentifully in the city of New York. ๑. July. v. v. Flowers rery small; seeds in a membranaceous calyx.

2. S. berbacea, decumbons, glabra; foliis dilatato-subulatis spinescentibus, gemmis fructificantibus valde turgidis, calycibus fructiferis explanato-alatis. Mich. fl. amer. 1. p. 174. Walt. Al. car. 111.

In Carolina. Michaux. +. Probably only a variety of the preceling species.

3. S. herbacea, erectiuscula, ramosissima ; foliis linearibus salsa. muticis carnosis, glomerulis confertis subspicatis, caJycibus fructiferis depresso-subrotundis. - Willd. $s p$. pl. 1. p. 1312 . Mich. fl. amer. 1.p.17t.

Icon. Jacq. hort. 3. $t .83$.

On the mouth of the river St. Laurence. Michaux. $\odot$. $v$. $s$.

4. S. herbacea, humifusa, ramosissima; ramulis distichis, foliis succulentis linearibus acutis glabris, floribus axillaribus sessilibus, staminibus exertis.

Sueda prostrata. Pall. illustr. 55. t. 47.

On the volcanic plains of the Missouri. Nuttall. $\odot$. June. $t$.

caroliniana.

\section{CHENOPODIUM. Gen. pl. 435.}

1. C. foliis triangulari-sagittatis integerrimis, spicis compo. sitis aphyllis axillaribus. Willd. sp.pl.1,p.1299. Icon. Engl. lot. 717 . In Virginia. Gronov. 4. June-Aug. v. v. I never

triternatum. Raii. caroliniana. depressa.

Bonus Hen. ricus. 
murale.

album.

viride.

hybridum.

Botrys.

ambrosioides.

anthelminti. cum. observed this species myself in America, but it is very probable it may be found there, as Gronovius asserts.

2. C. foliis ovatis inæqualiter dentatis acutis nitidis, racemis ramosis cymosis aphyllis.-Willd. sp. pl. 1.p. 1301.

Frequent on road sides, among rubbish and in gardens. $\odot$. July-Sept. $v \cdot v$.

3. C. foliis rhomboideo-ovatis erosis postice integris : superioribus oblongis integerrimis, seminibus lævibus. Smith fl. l.rit. 1. p. 273. Willd. sp. pl. 1.p. 1302.

Icon. Engl. lot. 722 .

ß. Willd.sp.pl. 1. p. 1303.

In cultivated grounits, near roads and fences: common. O. July, Aug. v. v.

4. C. foliis cordatis angulato-dentatis acuminatis, racemis ramosissinis subcymosis divaricatis aphyllis. Smith fl. brit. 1.p.275. Willd.sp.pl.1.p.1303.

Icon. Curt. lond. 4.t.'23.

In wet rocky situations : on the North river ncar Catskill, New York. ๑. July, Aug. v. v.

5. C. foliis oblongis sinuatis, racemis nudis multifidis. Willd. sp.pl.1.p. 1304 .

On the banks of the Susquehanna, Pensylvania, and about Onondago, New York. $\odot$. July, Aug. v. v. Smell strong, but not disagreeable.

6. C. foliis lanceolatis dentatis, racemis foliatis simplicibus, Willd. sp. pl. 1. p. 1304.

Icon. Moris. hist. 2. s. 5. t. 35. f. 8.

In sandy fields: Georgia. $\odot$.July. $v . v$. Very sweet scented.

7. C. foliis ovato-oblongis dentatis, spicis longis intcruptis aphyllis. - IVilld. sp. pl. 1. p. 1304.

Icon. Dill. elth. $t .66 . f .76$.

On road sides : Pensylvania and Virginia ; plentifully in the streets of Philadelphia. 4. June-Aug. v. $v$. Smells very strong, but not äisagreeable to some persons.

maritimum.

8. C. foliis subulatis carnosis semiteretibus, floribus glomeratis axillaribus. Willd.sp.pl.1. p. 1307.

Icon. Moris. hist. 2. s. 5. t. 33. f. 3 .

On the sea-coast of Pensylvania and Virginia. $\odot$. July, Aug. $v . v$. 


\section{ATRIPLEX. Gen. pl. 157\%.}

1. A. caule fruticoso, foliis alternis oppositisve oblongo-subrhombeis integerrimis, IVilld.sp.pl.4. p. 957.

On the sea-coast of Virginia. Gronovius. $\eta_{2} v v, v$. in Hortis. I take this species up only on the authority of Gronovius, having never seen it myself as a native of America.

2. A. caule erecto herbaceo, foliis triangularibus dentatis concoloribus, calycibus fructus ovatis reticulatis integerrinis. Willd.sp.pl.4.p. 961 .

Frequent in fields and about gardens. $\odot$. July. $v . v$.

3. A. caule erecto herbaceo, foliis triangularibus profunde dentatis subtus albidis, calycibus tructus rhombeis trinerviis denticulatis. Willd. sp. pl. 4. p. g63.

Icon. Moris, hist. 2. s. 5. t.32.f. 17 .

Near the sea-coast, on banks of rivers: New York to Virginia. ๑. June-Aug. v.v. Leares gray.

4. A. caule herbaceo erecto, foliis triangulari-hostatis pro. funde dentatis concoloribus, calycibus fructus sinuato. dentatis, dente intermedio elongato. Willd. sp. pl. 1. p. 963 .

Frequent about gardens and in fields. ๑. July. $v, v$.

\section{CANNABIS. Gen. pl. 1522.}

1. C. foliis digitatis. Willd. si. pl. 4. p. 768 .

sativa.

Common hemp is frequently found in fields, apparently indigenous, though it is one of those plans introduced from Europe. $\odot$.

\section{HUMULUS. Gen.pl. 1523.}

1. Humulus. Willd.sp.pl.4.p. 769 .

hortensis.

laciniata.

hasiala.

In deep shady valleys on the mountains and on river sides in the lower countries, frequent. It is really indigenous. 4 .

258. ULMUS. Gen. $p l, 443$.

1. U. ramis lævibus basi inæqualibus : serraturis uncinatoamericana. acuminatis, floribus pedicellatis, fructibus villo densissimo fimbriatis.-Willd. sp.pl. 1. p. 1325.

Icon. Mich. arl. t....

Lupulus. 
pendula.

fulva.

alata.

nemoralis.

2. U. foliis oblongis glabriusculis æqualiter serratis basi subæqualibus, floribus sessilibus. Ait. kew. 1. p. 319.

U. campestris. Walt. fl. car. 111 ?

On the banks of rivers: New England to Virginia; scarce. h. April, May. v. v. River Elm.

kew. 1. p. 319 .

Common in all low lands and woods : New England to Carolina. . A April. v.v. Known by the name of White Elm.

U. ramis scabris albidis, foliis ovato-oblongis acuminatis basi subæqualibns, inrequaliter serratis utrinque pubescentibus scaberrimis, gemmis lana densa fulva tomentosis, floribus sessilibus.-Mich. fl. amer. 1. p. 172 .

Icon. Mich. arl. t. . .

On mountains from Canada to Pensylvania. $\zeta$. May. $v$. $v$. Red Elm. Slippery Elm. The viscous inside bark is used by the natives as a healing salve.

4. U. ramis utrinque alato-suberosis, foliis oblongo-ovalibus sensim acutis basi subxqualibus, fructu pubescente cilioso.-Mich. fl. amer. 1.p. 173.

U. pumila. Walt. fl. car. 111.

Icon. Mich. arl. t....

In sandy low woods: Virginia and Carolina. $\zeta$. April. v. v. Whahoo.

\section{CELTIS. Gen. pl. 1591.}

occidentalis. 1. C. foliis ovatis acuminatis æqualiter serratis basi inæqualibus supra scabris, subtus hirtis, fructu solitario.Willd.sp. pl. 4. p. 994.

Icon. Duham. arl. 1.t.53. Nich. art. t....

In woods and near rivers: Canada to Carolina. $々$. May. $v . v$. Nettle-tree. Berries dark purple.

crassifolia.

2. C. foliis ovatis acuminatis inæquaiiter serratis basi inæ。 qualiter cordatis subcoriaceis utrinque scabris, pedunculis subbifloris.-Willd. sp. pl. 4. p. 995.

C. cordifolia. Duham. 2.t.9.

In woods and near rivers: Virginia, Kentucky, and Tennassee. $\zeta$. May. $v . v$. Known by the name of Haglerry or Hoop-ash.

pumila. 
libus utrinque glabriusculis : junioribus tantum pu. bescentibus, pedunculis subtrifloris, tructu solitario.

On the banks of rivers: Maryland and virginia. $h$. May. $v . v$. A sinall stragging bush; berries ovate, black.

\section{TRIG YNIA.}

260. VIbURnUm. Gen. pl. 503.

i. V. glabrum; ramis patentissimis, foliis subrotundis cre- prunifolium. nato.se:ratis, petiolis læribus, cymis sessilibus, fructibus rotundatis.-IVilld sp. pl. 1.p. $18 \pm 7$.

Icon. Pluk. alm. t. 46.f.2. Duhain. 2. t.38.

Common in hedges and fields: New England to Carolina. $h$. May, June. $v . v$. Eerries dark blue; flowers, as all the following species, white.

2. V.glabrum; foliis ovatis subacutis subserratis, petiolis levibus, fructibus ovato-obiongis cymis subpedunculatis.-I.am. encycl. 8. p. 653.

On the banks of rivers: Pensylvania, New Jersey, \&c. h. May, June. v. v. Resembles the former, but is not so straggling in its growth; berries black.

3. V. glabrum; foliis lato-ovatis acuminatis uncinato-serratis, petiolis marginatis undulutis, cymis sessilibus.lVilld. sp.pl. 1. p. 1491.

Frequent among hedges and on borders of woods: New England to Carolina. $\zeta$. July. $v, v$. Is more inclined to grow to a tree tibu any of the rest; berries black.

4. V. glaberrimum; foliis ovalibus margine revoluto subintegerrimis, petiolis lævibus, cymis ebracteatis pedunculatis.-IVill.l. sp. pl. 1. p. 1487.

Icon. Mill.ic. 274.

In swamps, particularly on sandy soil : Canada to Georgia. h. May, June. v. v. Berries black; in the Southern States it becomes an evergreen; the young branches are ferruginous and sometimes the leaves on their under suriace.

5. V. glabrun ; foliis obovatis crenato-dentatis seu integerrimis obtusis, umbellis sessilibus, fructibus ovato-subrotundis.-Lam. encycl. 8. p. 658. IValt. fl.car. 116.

obov'atum.

pyrifolium.

Lentago.

nudum. 
V. cassinoides. Mich. fl. amer. 1. p. 179.

punicifolium. $\beta . V$. foliis obovatis integris seu apice laxe crenatis obtusis. Hort. par. 115.

In shady woods : Carolina and Georgia. $\eta_{2}$. May, June. v. s.

cassinoides. $6 . \mathrm{V}$. glabrum; foliis ovato-lanceolat's utrinque acutis cre natis margine subrevolutis, petiolis carinatis eglandulatis.-Willd. sp. pl. 1. p. 1491 .

In swamps: New York to Carelina. $\zeta$. June, July. $v, v$. Berries blueish-black.

lavigalum. 7.V. foliis lanceolatis lævibus remote-serratis basi integerrinis, ramulis ancipitibus.-Willd. sp. $p l .1$. p. 1492.

Icon. Mill. ic. t. S3.f. 1.

Near the sea-coast: Virginia and Caroliza. $\eta_{2}$.June, July. v. v. Berries black.

nitidum. $\quad$ 8. V. glabcrimum; foliis lineari-lanceolatis supra nitidis obsolete serratis integrisve; ramis tetragonis.-Willd. sp.pl. 1. p. 1492.

In sandy barren woods : Carolina and Georgia. $\eta_{2} v v \cdot v$. s. $f$. A low shrub with small leaves.

dentatum. $9 . \mathrm{V}$. glabriusculum; foliis suborbiculatis ovatisque acutis dentato-serratis plicato-sulcatis utrinque glibris, cymis pedunculatis, fructibus subglobosis.-lWilld. $s p . p l .1$. p. 1488.

Icon. Jacq. hort. t. 36.

In mountain woods; frequent: New York to Carolina. h. June, July. v. v. Berries dark blue; known by the name of Arrow-wood.

pulescens. 10. V. pubescens; foliis ovalibus acuminatis dentato-serratis plicato-sulcatis subtus villoso-tomentosis, cymis pedunculatis, fructibus oblongis.

V. dentatum pubescens. Ait. kew. 1. p. 168.

V. dentatum tomentosum. Mich. fl. anter. 1.p. 179 .

In the lower parts of Virginia and Carolina. $\zeta$. June. $v . v$. The whole of the shrub smaller than the preceding one.

lantanoides. 11. V. petiolis nervisque pulverulento-tomentosis, foliis amplis suborbiculato-cordatis abrupte acuminatis inæqualiter serratis, serraturis muticis, cymis arcte sessilibus, fructibus ovatis.-Mich. fl. amer. 1. p. 179.

V. Lantana grandifoliun. Ait. kew. 1.p. 168.

In shady woods on high mountains : Canada to Virginia; principally in the forests called Beech-u'oods. $\eta$. 
June, July. $v, v$. Berries red, but when ripe black; known by the name of Holble-lush.

12. V. ramulis petiolisque pilosis eglandulosis, foliis subcordato-ovatis trilobisve acuminat is argute-serratis subtus pubescentibus, cymis longe-pedunculatis.-Willd. $s p$. pl. 1. p. 1489.

Icon. Vent. hort. cels. t. 72.

In rocky mountainous situations : New England to Carolina. h. May, June. $v . v$. Berries black.

13. V. foliis suborbiculato-cordatis plicato-sulcatis dentatis molle. subtus pubescentibus, petiolis subglandulosis, cymis radiatis, fructibus oblongo-ovatis. Mich. fl. amer. 1. p. 1 so.

V. alnifolium. Marsh. arl. 162.

In hedges: Kentucky near Danville. Michaux. Tennassee and Upper Carolina. $\downarrow$. June, July. v. s. Berries red; resembles the following species.

14. V. foliis trilobatis postice acutis 3-nervibus: lobis divaricatis promisse acuminatis rariter dentatis, petiolis

Oxycoccos. glandulosis, cymis radiatis.

V. Opulus americanum. fit. kew. 1.p. 168.

V. Opulus Pimina. Mich. fl. amer. 1.p. 1 so.

V. trilobum. Marsh arl. 162.

In swamps and shady woods: Canada; on the mountains of New York and New Jersey. $\eta$. July. $v . v$. Berries red, of an agreeable acid; resembling that of Cranberries, Vaccinium macrocarpon, for which they are a very good substitute.

15. V. foliis trilobatis, postice obtusiusculis 3-nervibus : lobis brevissimis denticulato-serratis, serraturis acuminatis, petiolis glandulosis, cymis radiatis.

V. Opulus edule. Mich. fl. amer. 1. p. 180.

On the banks of rivers: Canada to New York. $\zeta$. July. $v . v$. A smaller and more upright shrub than the preceding species; berries the same colour and size, but, when completely ripe, more agreeable to eat.

\section{SAMBUCUS. Gen. pl. 505.}

1. S. ramulis petiolisque glaberrimis, foliolis sub-4-jugis oblongo-ovalibus nitidis glabris acuminatis: nervo canadensis. medio subpubescente, basi interdum appendiculatis, cymis laxis 5-fidis. - Willd. sp.pl. 1. p. 1494.

Icon. Schmidt arb. 142. 
In swamps and near hedges: Canada to Carolina. $h$. June, July. v. v. Berries ciarti parple or black.

watescens. 2. S. cortice rerrucoso, foliolis 2-jugis ovali-lanccolatis subtus pubescentibus, cymis confertis racemusis. - Mich. fl. amer. 1. p. 1 si.

On the highest momtains from Canala in Carolina. 々. July. v. v. Berries red; resembles $S$, racemosa very much.

\section{RHUS. Gen. pl.502.}

typhinum.

1. R. subarborescers; ramis petiolisque villosissimis, foliis pinnatis multijugis, foliclis lariceolato-oblongis argute serratis subtus subtomentosis.-Willd. sp. pl. 1. p. 1478 .

Icon. Duham. 2.t. 47.

In rocky dry situations: Canada to Virginia. h. July, Aug. v.v. The purple velvety berries appear in large close clusters.

šlalrum.

2. R. undique glabrum; foliis pimatis multijugis, foliolis lanceolato-oblongis serratis subtus albicantibus, fructibus holosericeis.-Willd. sp.pl. 1. p. 1478 .

coccineum. $\beta$. R. elegans. Ait. kew. 1. p. 162. Catesb. car, appen.t. 4. Icon. Dill. ellh. t. 213.f. 314 . Catesl.car.3.t. 4.

Common in old fields and along fences : New England to Carolina. h. July, Ang. v. v. Berries red; flowers grecnish-red; in var. $\beta$. scarlet.

viridifiorum.

3. R. glabriusculum; foliis pinnatis multijugis, foliolis lanceolato-oblongis serratis subtus subtomentosis, racemis erectis herbaceis.-Lam. encycl. 7. p. 504.

R. canadense. Mill. dict. no. 5 .

On the edges of woods, in dry sunny situations: Pensylvania and Virginia. $h$. July, Aug. v. v. Flowers yellowish-green; probably not much more than a variety of the furegoing species.

pumilum.

4. R. lumile; ramis petiolisque pubescentibus, foliis pinnatis multijugis, foliolis ovalibus vix acuminatis aut nuticis inciso-dentatis sublus tomentosis, fructibus holcsericeis. Nïh.fl. amer.1.p. 182.

In Upper Carolina. h. July. v. s. in Herb. Lyon.; $v$. $v$. in Hortis. Not above a foot high : it is the most poisonous of the genus, according to information from Mr. J. Lyon, who, by collecting the seed of this species, got poisoned all over lis body, and was lamed for a considerable time. 
5. R. arborescens, glaberrimum ; foliis pinnatis multijugis, foliolis ovalibus abrupte acuminatis integris, panicula Vernix. laxa, floribus dioicis, fructibus glabris. -Willd. sp. pl. 1. p. 1479 .

Icon. Dill. elth. t. 203. f. 377. Pluk. alm. t. 145. f. 1. In low copses: Canada to Carolina. $i$. July. v. $v$. Berries white.

ต. R. ramis punctatis, foliis pinnatis multijugis $(5-6)$, foliolis ovali-lanczolutis integerrimis supra lucidis, pa. nicula foliosa, racenis sessilibu;, fluribus dioicis.Willd. sp. pl. 1. p. 14 SO.

Icon. Hort. schoenbr. 3.1. Plak. alm.t.56.f. 1.

In dry fields and woods, particularly sandy soil: New Jersey to Carolina. h. July. v. v. Berries red. The leaves of this species are used as tobacco by the Indians of the Miss uri and Mississippi.

$7, R$. radicans; foliis ternatis, foliolis ventricoso-ovalibus integris aut sinuate-crenatis, racemis rameis et axillaribis sessilibus dioicis.-Willd. sp. pl. 1. p. 1481. Mich. fl. amer. 1. p. 183.

๙. R. radicante-scandens; foliolis amplis integris seu rariter

Copallinum, dentatis. Mich.l.c.

Toxicodendron.

vulgare.

R. radicans. Wilid.sp. pl. 1. p. 1481.

$\beta . R$. erectum, humile ; fuliolis varie sinuato-lobatis, sub quercifolium. floratione tomentosis. Mich.l. . .

$\gamma$. R. foliulis oblongo-ovalibus longe acuminatis subrhom- microcarpon. boideis, fructu multo minore. Mich. $l$. $c$.

Common in all woo's, fields, and along fences: Canada to Georsia. 々. inue, July. v. v. Berries white; known by the name Poison-nak or Poison-vine. There is no doubt but $R$. radicans and Toxicodendron are only local varieties.

8. R. fruticulosum, amentaceum, nudiflorum; foliis terna- aromaticun. tis, foliolis rhombeo-ovalibus dentatis subtus pubescentibus, floribus dioicis-Willd.sp.pl.1.p. 1482.

R. canadense. Marsh. arb. 129.

Icon. Turpin in annal. du mus. hist. nat. 5. p. 445. t. 30. In rocky situations, about springs: Pensylvania, Carolina, and Kentucky. $\quad$. Miy, June. $v . v$. Fiowers yellow, in catkins, which give it quite a different appearance from the habitus of the genus. Myrica trifoliata Hort, is the saine with $R$. suavenlens Ait and is nothing more than the male plant of this species. Berries brown. 


\section{STAPHYLEA. Gen. pl. 507.}

trifolia.

cistoides.

argentea.

linearis.

elliptica.

dentata. ratis, pedunculis axillaribus folio brevioribus.-Willd. sp.pl.1. p. 1505.

Icon. Plum. ic. t. 150.f. 1. Sloan.jam. 1. t. 127.f.7. In dry sandy woods, near the town of Savannah, Georgia. Enslen. $\odot$. July. v. s. in Herb. Enslen. Flowers yellow, resembling those of Cistus carolinianus.

265. CROTONOPSIS. Mich. fl. amer. 2. p. 185.

1. C. caule erecto dichotome ramosissima, foliis supra stellato-pilosis, subtus argenteo-lepidotis.

a. C. foliis lineari-lanceolatis. Willd.sp. pl.4. p.3so. Mich. fl.amer. 2. p. 186.

ß. C. foliis ellipticis utrinque obtusis. Willd. l.c.

In sandy soil near the sea-coast, Illinois country and on the Missouri. $\odot$. July. v. $v$. Flowers very minute.

\section{KOCHIA. Roth in Schrad.journ. 1800. p.307.}

1. K. foliis ianceolatis sinuato-dentatis, caule erecto ramosissimo.-Willd. hort. lerol. 1. t. 28.

Salsola radiata. Desf. in onnal. mus, nat.p. 28, t. 34.

Salsola platyphylla. Mich.fl. amer. 1.p. 174.

On the banks of the Mississippi, in the Jllinois country. $\odot$. June. $v . v$. This plant has the aspect of a Chenopodium in every part.

\section{AMARANTHUS. Gen. pl.1431.}

albus.

1. A. glomerulis axillaribus triandris, foliis obovatis retusis, caule tetragono simplici. Willd. sp. pl. 4. p. 382.

Icon. Willd. amaranth. t. 1.f.2.

A common weed in the gardens. ๑. May-Sept. $v . v$. 
2. 1. glomerulis axillaribus triandris, floribus trifidis, foliis obovatis emarginatis, caule teretiusculo ramoso. Willd. gracizans. sp. pl. 4. p.382.

Icon. Willd. anaranth. . 4.f.7.

In cultivated grounds: Virginia. $\odot$. Aug. v. v.

3. A. glomerulis trianciris subspicatis rotundatis, foliis elliplividus. ticis retusis, caule erecto. IVill!. amaranth. p. 20. t. $1 . f .1$.

In similar situations: Virginia. $\odot$. June-Aug. $v . v$.

4. A. glomerulis triandris subspicatis, floribus triphyllis, foliis ovatis retusis, caule diffiso. Willd. $s p . p l .4$. p. 387 .

Frequently a very troublesome weed in gardens. $\odot$. June-Sept. $v \cdot v$.

5. A. glomerulis axillaribus geminis triandris, floribus mas.culis triphyllis, folits ellipricis emarginatis margine undulatis. Willd. amarantí. 1S. $t$. S. f. 16.

Frequently found on road sices and among rubbish. $\odot$. July, Aug. $v . v$.

6. A. racemis pentandris decompnsitis congestis erectis, foliis ovato-lanceolatis. Wiild. amaranth. p. 26. t.9. f. 17 .

Common in cultivated grounds: New York to Carolina. $\odot$. June-Sept. $v . v$.

7. A. racemis pentandris supradecompositis, ramis patenti- paniculatus. bus pubescentibus, foliis ovato-lanceolatis. IVilld. amaranth.32.t.2.f. 2.

Among rubbish and in cullivated grounds: Pensylvania to Virginia. $\odot$. Aug. v. $v$.

B. A. racemis pentandris supradecompositis erectis, ramis patentibus glabris, foliis oblongis acutis. Willd. amaranth. 31.t. $2 . f .3$.

In cultivated fields: Virginia and Carolina. $\odot$. July. r'. $v$.

9. A. racemis pentandris supradecompositis confertis erectis, ramis pubescentibus, foliis ovatis undulatis. Willd. amaranth. 33. $t .11 . f .21$.

In cultivated grounds and on road sides : Pensylvania to Virginia. $\odot$. June-Aug. v. $v$.

10. A. racemis pentandris compositis confertis erectis, foliis hypochondrioblongo lanceolatis mucronatis. IVilld. amaranth. so.

Common in felds of Virginia. ๑. July, A ug. v. $v$.

sanguineus. Leaves red. 
spinosus.

cannabina.

ruscocarpa.

11. A. racemis pentandris terminalibus compositis, axillis spinosis. Willd. amaranth. 38. t. 4.f. 8.

On road sides and among rubbish; frequent. $\odot$. June -Sept. $v . v$.

269. ACNIDA. Gen. pl. 1521. Mich.fl. amer. 2.p. 233.

1. A. foliis lanceolatis, capsulis læviusculis acutangulis. Willd. sp. pl. 4. p.767.

On the banks of rivers and in marshes near the sea-coast : New England to Carolina. ๑. July, Aug. v. v.

2. A. foliis ovali-lanceolatis, capsulis obtusangulis rugosis. Willd. sp. pl.4.p.767.

Icon. Mich. fl. amer. 2. t. 50.

In close swamps, on the banks of rivers among bushes : Virginia. $\odot$. July, Aug. v. s. in Herl. Lyon. Very tall and robust.

\section{IV. $T E T R A G Y N I A$.}

269. PARNASSIA. Gen. pl.523.

palustris. 1. P. foliis radicalibus cordatis, nectariis multisetis, $-W i l l d$. sp.pl. 1.p. 1516.

Icon. Fl.dan. 584. Engl. bot. 82.

In bog meadows : Pensylvania and Virginia. 4. July, Aug. $v, v$. Flowers white, with netted veins of green or pale purple.

caroliniana. 2. P. foliis radicalibus suborbiculatis, nectariis trisetis. Mich. fl. amer. 1.p. 184.

Icon. Bot. mag. 1459 .

In swamps and mosses: New York to Virginia. 4. July, Aug. $v . v$. Flower the same as No. 1.

asarifolia.

3. P. foliis radicalibus reniformibus, petalis unguiculatis, nectariis trifidis. Vent malmais. 39. t. 39.

On high mountains in Virginia and Carolina. 4. July, Aug. $v . v$. Larger in leaves and flowers than the preceding species. 


\section{PENTAGYNIA.}

\section{2\%o. ARALIA. Gen.pl. 525.}

1. A. subacaulis, unifoliata ; folio triternato vel triquinato:

nudicaulis. foliolis oblongo-ovaiibus, scapo nudo folio breviore, umbellulis paucis.-Willd. sp. pl. 1. p. $15^{n 21}$.

Icon. Pluk. alm. t. 238. f. 5.

In shady rocky woods: Canada to Carolina. 4. May, June. v. v. Commonly called Sarsaparilla, and as such used in the shops.

2. A. divaricato-ramosa; petiolis 3-partitis, partitionibus 3-5-foliolatis, foliolis plerisque cordatis, ramulis a:illaribus foliosis, umbellulis pluribus subpaniculatis superne aphyllis. - Willd. sp. pl. 1. p. 1521 .

Icon. Cold. canad. t. 75. Moris, hist. 1. s. 1. t.2.f.9.

In rocky and shady situations: Canada to Virginia. $\psi$. June-Sept. $v . v$. Known by the name of Spikenard, and highly esteemed as a medicine.

3. A. humilis, suffruticosa ; caulibus petiolisque setis hispidis, foliis duplicato-pinnatis, foliolis ovatis incisoserratis inermibus glabris, umbellulis longissime pedunculatis.-Mich.fl. amer. 1.p. 185.

Icon. Bot. mag. 1055. Vent. hort. cels. 41.

In stony woods : Canada, New England, \&c. On high mountains: Pensylvania, Virginia. 々. June, July. v. v. Called Wild Elder.

4. A. caule arborescente foliisque spinosis, foliis duplicatopinnatis, foliolis leviter serratis, panicula ramosissima, umbellis numerosis.-Willd. $s p . p l .1 . p .1520$.

$\beta$. A. caule spinoso glauco, foliis inermibus.

Icon. Schmidt arb. 102 \& 103. Comm. hort. 1. t. 47.

In fertile low woods of Lower Virginia and Carolina, likewise in the Illinois country. h. Aug. Sept. v.v. Known by the name of Angelica-tree. The berries used in an infusion of wine or spirits are a remarkabie medicine for relieving rheumatic pains. The var. $\beta$. was found near Charlestown, South Carolina; I have not seen its flowers.

\section{ZANTHOXYLUM. Gen.pl. 1512.}

1. Z. aculeatum; foliis pinnatis, foliolis ovali-lanceolatis subintegerrimis sessilibus basi æqualibus, petiolo com-

racemosa.

hispila.

stinosa.

inermis.

ror. 1 .

fraxineum. 
nuni inermi, umbellis axillaribus.-Willd. $s p . p l .4$. p. 754 .

Z. Clava Herculis $\beta$. Linn. sp. pl. 1455.

Z. ramiflorum. Mich.fl. amer. 2. p. 235.

Icon. Duham. arb. 1.t. 97.

In shady woods, near rivers : Canada to Virginia and Kentucky. $\eta$. April, May. $v, v$. A tincture of the bark and capsules is recommended in rheumatism and tooth-ach, from which its name Tooth-ach-tree.

tricarpon. 2. Z. aculeatum ; foliis pinnatis, foliolis petiolatis oblongoovalibus acuminatis serrulatis basi obliquis, petiolo commnni aculeato, capsulis ternis sessilibus.-Mich. fl. amer. 2 p. 235.

In woods of Carolina and Florida. Michaux. $\uparrow$. July. $v$. $v$. in Hortis.

\section{LINUM. Gen. pl. 528.}

usitatissi- 1. I. foliolis calycinis ovatis acutis trinervibus, petalis cremum. natis, foliis lanceolatis alternis, caule subsolitario.IVilld.sp.pl. 1. p. 1533.

Icon1. Engl. bot. 1357.

Common flax is frequently found in old fields, apparently indigenous. $\odot$. June, July. v. v. Flowers blue.

Lewisii. 2. L. foliolis calycinis ovatis acuminatis, petalis cuneatis apice rotundatis, foliis sparsis lanceolato-linearibus mucronatis, caulibus alt is numerosis.

In the valleys of the Rocky-mountains and on the banks of the Missouri. M. Lewis. 4. July. v.v. Flowers large, blue; a very good perennial, and it probably might become an useful plant if cultivated.

virginicun. 3. L. foliolis calycynis acutis panicula terminali, floribus remote alternis, foliis lineari-lanceolatis sparsis : radicalibus ovatis.-Willd. sp. pl. 1. p. 1538.

On dry sunny hills and fields : New York to Virginia. $\odot$. July, Ang. v. $v$. Flowers small, yellow.

rigidum.

4. L. foliolis calycinis ovatis acuminatis trinervibus ciliatis, petalis oblongis angustissimis, foliis rigide-erectis linearibus brevibus.

On the Missouri. Nuttall. v. s. Flowers sulphuryellow.

273. DROSERA. Gen. pl. 531.

rotundifolia. 1. D. scapis radicatis simplicibus, foliis suborbiculatis basi attenuatis, petiolis elongatis pilosis.-Willd.sp.pl.1. p. 1543. Mich. A.amer. 1.p.1s6. 
Icon. Fl. dan. 1028.

In swamps filled with sphagnum, as all the following species, generally on sandy or gravelly ground. 4 . July, Aug. $v . v$. Flowers white; a very delicate and curious plant, as are all the rest of this genus.

2. D. scapis radicatis simplicibus, foliis spathulato-obovatis, petiolis elongatis nudis.-Willd. sp. pl. 1. p. 1544 . Mich.fl. amer. 1. p. 186.

Icon. Engl. bot. 868. Moris. hist. 1. s. 15. t. 4.f.2.

In similar situations: Canada to Carolina. 24. July. v. v.

3. D. pusilla ; scapis radicatis simplicibus, foliis brevibus cuneatis vix petiolatis, petalis ovalibus.

In sandy swamps of Georgia. Enslen. ๑. June. v.s. in Herb, Enslen. The smaliest of all the species known; flowers rose-coloured.

4. D. scapis radicatis subramosis, foliis filiformibus longissimis.

In the pine-barrens of New Jersey near Tuckerton. 4. June. $v . v$. Flowers large, purple.

Radix: Hybernaculum squamosum, extus ferrugineolanuginosum. Folia primordialia glabra, dilatatosubulata; secundaria radicalia spiraliter erumpentia, angustissime linearia subtus glabra, supra pilis rubris viscidis tecta, 9-12 pollices longa. Si:api erecti, pedales et ultra, teretes, glabri, interdum vivipari, bulbiferi. Racemus spicatus, unilateralis, recurvatus, simplex seu ramosus. Flores pedicellati, erecti, magni, purpurei. Styli sex, interdum novern.

This elegant species 1 discovered about 1805, in the place above mentioned : this extensive swamp, interspersed with barren sand hills, might be called a natural botanic garden, uniting a number of southern plants with those of the nor(h, as mentioned in the preface.

\section{SIBBALDIA. Gen. pl. 536.}

1. S. erecta, foliis linearibus multifidis. Willd. sp.pl. 1. p. 1567.

Icon. Amm. ruth. $t .15$.

On the banks of the Missouri. Nuttall. 4. July. v. s. in Herb. Nuttall. Flowers small, flesh-coloured.

2. S. procumbens, foliis tridentatis. Willd. sp. pl. 1. procumbens. p. 1567.

Icou, Fl. dan. 32. Pluk, alm. t.212.f.3.

On the Missouri. Nuttall. On high mountains of $\mathrm{Ca}-$ nada and Vermont. 4. April. v,s, Flowers yellow.

filiformis.

erecta.

brevifolia.

longifolia. 


\section{STATICE. Gen.pl.527.}

Armeria. 1. S. scapo simplici capitato, foliis linearibus planis obtusis. Willd.sp.pl. 1. p. 1522.

Icon. Engl. bot. 226.

Thrift. Sea Gilliflower.

On rocks near the sea-shore: Pensylvania to Virginia. July, Aug. v.v. Flowers rose-coloured.

saroliniana.

2. S. scapo tereti, panicula divaricato-ramosissima, calycibus acutis, foliis lanceolato-oblongis obtusiusculis glabris margine planis. - Walt. fl. car. 118.

In salt-marshes along the sea-coast: New Jersey to Carolina. 24. Aug. Sept. v. v. Flowers blue; resembles $S t$. gmelini in some respects.

\section{POLYGYNIA.}

\section{ZANTHORHIZA. Gen. pl. 1581.}

๓พyolia.

1. Zanthorhiza. Willd.sp.pl. 1. p. 1568.

Zanthorhiza simplicissima. Marsh. arb. 168.

Icon. L'Herit. stirp. 1. t. 38.

On shady banks of rivers: Virginia to Georgia. $\zeta$. May. v. v. A small shrub with compound leaves, and small dark-purple flowers in panicles.

277. SCHISANDRA. Mich. fl. amer. 2. p. 218.

coccinea.

1. S. glabra, foliis lanceolato-ovalibus utrinque acutis rariter subdentatis. Mich. fl.amer. 2. p. 219.

Icon. Mich. l.c.t.47. Bot.mag. 1413.

In shady woods of Carolina and Georgia. 々. June. ข. ข. A handsome climbing plant; flowers scarlet. 


\section{HEXANDRIA.}

\section{MONOGYNIA. \\ * Flores calyculati.}

278. BURMANNIA. Cal. inferus, 1-phyllus, prismaticus, coloratus. Pet. 3. Caps. 3-locularis. Sem. minuta.

279. TILLANDSIA. Cal. inferus, 3.fidus, persistens. Cor. 3-fida, tubulosa. Caps. 1-3-locularis. Sem. comosa.

280. TRADESCANTIA. Cal. inferus, 3-phyllus. Pet. 3. Filam. villis articulatis. Caps. 3-locularis.

281. DIPHYLLEJA. Cal. inferus, 3-phyllus, deciduus. Pet. 6. calyce opposita. Anth. membrana a basi ad apicem solubili dehiscentes. Bac. 1-locularis. Sem. 2-3. subrotunda.

282. CAUlOPHYLlUM. Cal. inferus, 6-phyllus. Pet. 6. calyce opposita. Anth. loculis margine dehiscentes. Drupa i-sperma.

283. BERBERIS. Cal. inferus, 6-phyllus, extus 3-bracteatus. Pet.6. ad ungues glandulis 2. Styl. 0. Stigm. umbilicatum. Bac. 1-locularis, 2-4-sperma. 284. PRINOS. Cal. inferus, 6 -fidus. Cor. 1-petala, rotata, 3-7-fida. Bac. 6-sperma. Dioicus.

285. GLEDITSCHIA. ఫ.Cal. 4 fidus. Pet. 4. Legu. men. 3. Cal. 3-phyllus. Pet. 3. \&. Cal. 5phyllus. Pet.5. Legumen. Polygama.

* Flores spathacei.

286. PANCRATIUM. Cor. supera, infundibuliformis: tubo longo. Nectar. campanulatum, 12-fidum. Stam. nectario imposita.

257. AMARYLLIS. Cor. supera, campanulata. Stam. inæqualia. Pist. declinatum. 
288. ALliUM. Cor. infera, 6-partita, patens. Spatha multiflora. Uinlella congesta. Capsula.

289. BRODIÆA. Cor. infera, campanulata, 6-partita. Filam fauci inserta. Germ. pedicellatum. Caps.3. locularis : loculis polyspermis.

250. PONTEDERIA. Cor. infera, 6 -fida, bilabiata. Stam. 3. summo, 3. medio tubo corollæ inserta, Caps. 3locularis.

291. HYPOXIS. Cor. supera, 6-partita, persistens. Spatha 2-valvis. Caps. elongata. Sem. subrotunda, nuda.

\section{*** Flores nudi.}

292. CONOSTYLIS. Cor. semi-supera, 6-fida, persistens, lanata pilis ramulosis. Anth. erectæ. Stylus conicus, tripartibilis. Stigm. simplex. Caps. apice dehis. cens, 3-locularis, polysperma.

293. ALETriS. Cor, semi-supera, tubulosa, 6-fida, rugosa, persistens. Stam. summo tubo inserta. Stylus triqueter, tripartibilis. Caps. apice dehiscens, 3.10cularis, polysperma.

294. AGAVE. Cor. supera, 6-fida : limbo erecto. Filam. corolla longiora, erecta.

295. PHALANGiUM. Cor. infera, 6-partita. Stam. filamentis filiformibus, nudis. Sem. angulata.

296. NARTHECIUM. Cor. infera, 6-petala, patens. Filam. filiformia, hirsuta. Caps. prismatica, 3-locularis, polysperma. Sem. utrinque arillo subulato instructa.

297. ORNITHOGALUM. Cor. infera, 6-partita. Filam. 3. alterna basi dilatata. Caps. subrotunda, 3-locularis. Sem. subrotunda, nuda.

298. YUCCA. Cor infera, campanulata, laciniis non nectariferis. Filam. clavata. Styl. 0. Caps. oblonga, obtuse 3-gona. Stm. plana.

299. LILIUM. Cor. infera, 6-petala, campanulata : linea longitudinali nectarifera. Stam. stylo breviora. Sligm. indivisum. Caps. 3-gona. Sem. plana.

300. FRITILlaARIA. Cor. infera, 6 -petala, campanulata, laciniis rectis supra ungues cavitate nectarifera. Stam. longitudine corollæ. Sem. plana.

301. ERITHRONIUM. Cior. infera, 6-petala, campanulata, laciniis a medio reflexis, 3 . interioribus basi intus 2. callosis. Caps. subglobosa. Sem. oblonga.

302. UVULARIA. Cor. infera, 6-petala, campanulata, laciniis rectis, unguibus fovea nectarifera excavatis. 
Filam. brevissima. Stigm. reflexa. Caps. trigona, 3-valvis : valvis medin septiferis. Sem. plura, subglobosa, ad hilum arillata.

303. STREPTOPUS. Cor. infera, 6-petala, subcampanulata. Stigm, brevisima. Bacca subglobosa, lævigata, carthacea, 3-locularis. Sem. pauca, hilo nudo.

304. CONVALLARIA. Cor. infera, 6-fida, campanulata. Stam. corolla breviora, ad basin inserta. Bacca globosa, 3-locularis: loculis 1-2-spermis. Scapus racemosus.

305. SMIJIACINA. Cor. infera, 6-partita, patens. Filam. divergentia, Jaciniarum basi infixa. Bacca globosa, 3-locularis. Flores terminales paniculati s. subumbellati.

306. POLYGONATUM. Cor infera, 6-fida, cylindrica. Filam. tubo superne inserta. Bacca globosa, 3-locularis: loculis 2-spermis. Flores axiliares.

307. ASPARAGUS, Cor infera, 6-partita, erecta : petalis 3. interioribus apice reflexis. Bacca 3-locularis, polysperma. Folia fasciculata.

***** Flores incompleti.

308. ORONTIUM. Spadix cylindricus, flosculis tectus. Spatha 0. Cal. 6.partitus. Stigm. 2-fidum. Folliculus 1 -spermus.

309. ACORUS. Spadix cylindricus, flosculis tectus. Cal. 6-partitus. Stigm. punctum prominens. Caps. 3locularis, 3-sperma.

310. JUNCUS. Cal. inferus, 6-partitus, æqualis. Stigm. 3-lobum. Caps. 1-locularis, polssperma.

311. PEPLIS. Cal. inferus, 12-fidus, Caps. 2-locularis, polysperma.

\section{DIGYNIA.}

312. NECTRIS. Cal. 6-partitus': laciniis 3. interioribus petaloideis minoribus obtusis. Utriculi bini 1-2spermi. Sem. globosa.

\section{TRIGYNIA.}

313. SABAL. Spathe partiales. Filam. libera, basi incrassata. Bacca l-sperma. Sem. osseum.

314. CHAMEROPS. Spatha compressa. Spadix ramo- 
sus. Cal.3-partitus. Pet.3. Filam. submonadelpha. Drupa 3, monospermæ. Polygama.

315. NOLINEA. Cor. 6-partita, patens: lacmiis subæqualibus. Styl. brevissimus. Stigm. recurva. Caps. 3-gona, membranacea, 3-locularis, dissepimentis bipartilibus debiscens. Sem. solitaria, hinc convexoincurva.

316. CALOCHORTUS. Cor. 6-partita, patens : laciniis 3. interioribus majoribus supra lanatis, basi macula glabra subrotunda notatis. Filam. brevissima, basi petalorum inserta. Anlh. erectæ, sagittatæ. Stigm. reflexa. Caps. 3-locularis.

31\%. MELANTHIUM. Cor. 6-partita, patens: laciniis æqualibus unguiculatis: unguiculis staminiferis, laciniis basi biglandulosis. Caps. subovata, apice subtrifida, 3-locularis. Sem. plura, alato-membranacea. Polygamum.

318. ZIGADENUS. Cor. 6-partita, patens : laciniis subæqualibus, supra basin angustatan biglandulosis. Stam. ad contactum ovarii inserta. Slyli 3. contigui. Caps. membranacea, 3-locularis. Sem. plurima, aptera.

319. VERATRUM. Cor. 6-partita, patens : laciniis sessilibus, eglandulosis. Stam. receptaculo inserta. Caps. 3. polyspermæ. Polygamum.

320. HELONIAS. Cor. 6-partita, patens : Jaciniis sessilibus eglandulosis. Caps. 3-locularis, 3-cornis seu 3cocca. Sem. pauca (1-2).

321. MEDEOLA. Cor. 6-partita, revoluta. Bacca 3. sperma.

322. TRILLIUM. Cor. 6-petala, patens : laciniis 3. exterioribus angustioribus calycinis. Bacca 3-locularis.

323. TOFIELDIA. Cor. 6 petala, æqualis, calyculo minimo 3-partito cincta. Caps. 3. polyspermæ, basi junctæ.

324. TRIGLOCHIN. Cal. 6-phyllus : laciniis 3. interioribus petaloideis. Cor. 0. Styl.0. Caps. basi dehiscens.

325. SCHEUCHZERIA. Cal.6-partitus. Cor. O. Styl.o. Stigm. lateralia. Caps. 3. inflatæ, distinctæ, 1spermæ.

326. RUMEX. Cal. 3-phyllus. Pet. 3. conniventia. Sem. 1. triquetrum. 
32\%. SMILAX. Cal. 6-phyllus. Cor. 0. Bacca 3-locularis. Sem. 2. Dioica.

328. DIOSCOREA. Cal. 6-partitus. Cor. o. Caps. 3 . locularis, compressa. Sem. 2, membranacea.

\section{TETRAGYNIA.}

329. SAURURUS. Cal. amentum squamis 1-floris. Cor.o. Bacce 4. monospermæ.

\section{POLYGYNIA.}

330. WENDLANDIA. Cal. 6-phyllus. Cor. 6-petala, succulenta. Styl. reclinati, Caps. 6. uniloculares, monospermæ.

331. Alisma. Cal. 3-phyllus, Pet. 3. Caps. plures, monospermæ.

\section{I. $M O N O G Y N I A$.}

\section{BURMANNIA. Gen. pl. 542 .}

1. B. flore gemino; alis semicuneatis apice truncatis.Willd. $s p$. pl 2. p. 16.

In swamps of Virginia. 24. Sept, v. s. in Herb. Gronov. Flower pale purple. This delicate little plant I never was lucky enough to find myself.

\section{TILLANDSIA. Gen. pl.541.}

1. T. cæspitosa, pruinosa ; foliis subulatis recurvatis, scapo setaceo foliis longiore summitate subbifloro.-Willd. recurvata. sp.pl. 2.p. 14.

Icon. Sloan. hist. 1. t. 121.f. 1.

Parasitic, on old trees: Florida and Georgia. 24. June. $v . v$. Flowers purple.

2. T. filiformis, intorta, pruinosa ; floribus solitariis sessilibus.-Willd. sp.pl.2.p. 15.

liflora. Icon. Sloan.jam. 1.t. 122. f. 2 छ' 3. Pet. gaz. t. 62. f. 12. 
Parasitic, on old trees, in shady woods: Virginia to Florida. 4 . July. $v$. $v$. Flowers yellowish-green. This singular plant, known by the name of Long-moss, does not extend further north than the neighbourhood of the Dismal Swamp in Virginia. The fibres of it, when divested of the outside coating, make excellent mattresses, and are a very good substitute for horse-hair for that purpose.

\section{TRADESCANTIA. Gen. pl. 543.}

virginica.

1. $T$. erecta ; foliis lanceolatis elongatis glabris, floribus sessilibus umbellato-congestis pubescentibus.-Willd. sp.pl. 2. p. 16.

Icon. Bot. mag. 105. Moris. hist. 3. s. 5. t. 2.f. 4 .

In shady woods: Pensylvania to Carolina. 4. May, June. $v . v$. Flowers blue or purple.

rosea.

2. T. erecta; foliis lineari-gramineis prælongis, pedunculis elongatis umbellatis paucifloris, calycibus glabris.Mich. fl. amer. 1. p. 193.

Icon. Vent. hort. cels. $t .24$.

In wet sandy fields: Carolina and Georgia. 24. June, $\mathrm{July.} v . v$. Flowers rose-coloured, small, but very handsome.

281. DIPHYLLEJA. Mich. $f$. amer. 1, p. 203.

cymosa.

1. D. glaberrima ; foliis subpalmatis angulato-lobatis serratis : lobis acuminatis, cyma multiflora. Mich. l. c.

Jcon. Mich. l. c.t. 19 छ 20.

Near rivulets on the high mountains of Virginia and Carolina. 4. May, June. v. v. Flowers white; berries dark blue: the whole of the plant has the appearance of Podophyllum peltatum.

282. CAULOPHYLLUM. Mich. fl. amer. 1. p. 204.

thalictroides. 1. C. glaberrimum; foliis supradecompositis, foliolis ovalibus, inferioribus petiolatis lobatisque, extremo trilobato.-Mich. l.c.t. 21 .

Leontice thalictroides. Willd. sp.pl. 2. p. 149.

In shady woods, on the side of fertile hills: New England to Virginia. 4. May, June. v. v. Flowers yellowish-green; berries large, blueislı-black; called by the Indians Co-hosh, and esteemed as a medicinal plant among them. 



283. BERBERIS. Gen. pl. 595.

1. B. erecta ; ramis confertim punctatis, aculeis triplicibus, canadensis, foliis simplicibus obovatis remote serratis, racemis brevibus subcorymbosis, drupis vix carnosis.

B. vulgaris var. Willd. sp. pl.2. p. 227. Mich. $f$. amer. 1. p. 2 ()5.

On fertile hills, among rocks, \&c. Canada to Virginia. h. April, May. v. v. Flowers yelow, in pendulous racemes; berries red, of an agreeable acid.

2. B. sarmentosa, inermis; foliis pinnatis: foliolis sub-3- Aquifolium. jugis oblongis repando-dentatis venosis, petalis bidentatis.

B. pinnata. Herl. Banks.

On the great rapids of Columbia River, among rocks, in rich vegetable soil. M. Lewis. h. April, May. $v$ s. in Fierb. Lewis. Flowers yellow, in large clusters ; berries dark purple, eatable ; called by Lewis's company Mountain-holly.

Caulis fruticosus, laxe ramosus: ramis sarmentosis, procumbentibus. Fulia sempervirentia alterna, petiolata, impari-pinnata. Foliola 3-juga, opposita, sessilia, inspari-petiolata, oblongo-ovata, basi oblique truncata, margine cartilaginea repando-dentata, coriacea, utrinque glabra, lævigata, nitida: dentibus aculeatis. Petioli teretes, glabri. Racemi congesti, bracteati, e gemna precedentis anni. Flores aurei. Bractea caducæ, solitariæ, subcordatæ, acuminatæ, membranaceæ. Caly $x$ triplex, deciduus, patens : exterior minimus, 3-phyllus: foliolis ovatis, acutis ; medius triplo longior: foliolis suborbiculatis, membranaceis, nervosis; interior longior : foliolis ovalibus, membranaceis, nervosis. Petala 6 . suberecta, oblonga, apice inciso-bidentata, vix longitudine calycis. Filamenta 6. corollæ breviora, crassa, medio bidentata : dentibus oppositis. Anlhere bilobæ, crassæ. Germen superum, ovatum. Stigma sessile, 3-lobum. Bacca 3-locularis, 3-sperma, abortione interdum monosperma.

3. B. sarmentosa, inermis ; foliis pinnatis : foliolıs 6 -jugis ovato-oblongis repando-serratis, sub-5-nervibus, petalis integris.

In the same situations, v. s. in Herb. Leuis.

The specific difference excluded, the description of the preceding species is applicable in every other respect, and together with another in the collection of $A . B$.

nervosa,

nervosa. 
Lambert, Esq., collected in Napaul by Mr. Buchanon, forms a new division of the genu; with pinnated leaves; which probably may become a new genus, whenever the fruit is perfectly known, as the statement I have given of it was taken from a single and imperfect berry.

\section{PRINOS. Gen. pl. 594 .}

verticillatus. 1, P. foliis deciduis ovalibus serratis acuninatis subtus pubescentibus, fasciculis florum masc. exillaribus umbelluliformibus; femineis aggregatis utrinque 6-partitis.-Willd. sp.pl. 2. p. 225.

P. Gronovii. Mich. fl. amer. 2. p. 236.

P. padifolius. IVilld. enum. 394.

Icon. Duham. arb. 1. t. 23.

In wet woods, on the banks of ditches; common: $\mathrm{Ca}$ nada to Virginia. h. June, July. v. v. Flowers small, white ; berries red or crimson.

amligius.

2. P. foliis deciduis ovalibus utrinque acuminat is mucronatoserrulatis subtus pubescentibus, floribus 4-5-fidis, masculis ad imos ramulos congestis, fuemineis solitariis.-Mich fl. amer. 2. p. 236.

Cassine caroliniana. Wult. fl. car. 242.

In sandy wet woods and on the borders of swamps: New Jersey to Carolina. $々$. July, Aug. v. $v$. Flowers white; berries red, larger than No. 1.

levigalus. $\quad 3 . \mathrm{P}$. foliis deciduis lanceolatis adpresso-serratis acuminatis utrinque glabris supra nitidis, subtus ad nervos vix pubescentibus, floribus fœmineis axillaribus solitariis subsessilibus : masculis sparsis: omnibus 6-fidis.

On the Allegany-mountains: New York to Virginia. দ. July. v. v. Berries large, dark-red.

lanceolalus. 4. P. foliis deciduis lanceolatis tenuissime et remote serrulatis utrinque acutis utrinque glabris, floribus femineis sparsis subgeminis pedunculatis 6 -fidis, masculis aggregatis 3 -andris.

In the lower counties of Caroina and Georgia. $\xi_{c}$. June. v.s. Berries snall, scarlet.

slaler.

5. P. foliis sempervirentibus cuneato-lanceolatis coriaceis glabris nitidis superne pariter subdentatis, pedicellis axillaribus subsolitariis plerumque 3 -horis.-Willd. $s p . p l .2$ p. 226 .

In sandy shady woods: Canada to Florida. $々$. July, 
Aug. $v . v$. A low and handsome shrub; berries black; called in Jersey Ink-berries.

6. P. foliis sempervirentibus cuneato-lanceolatis coriaccis glabris nitidis integerrimis, corymbis axillaribus brevissimis sessilibus nultifloris, floribus 6-fidis.

$\alpha$.P. foliis obovato-lanceolatis acuminatis.

$\beta$.P. foliis lanceolatis acutis.

In sandy woods, near the banks of rivers: Georgia. Enslen. 1. June, July. v. s. A handsome tall shrub, of the appearance of Ilex Dahoon.

Prinos lucidus Ait. is Ilex canadensis Mich. according to specimens in the Herbarium of A. B. Lambert, Esq.

\section{GLEDITSCHIA. Gen. pl. 1526.}

1. G. spinis robustis cruciatim ramosis, foliolis linearioblongis, leguminibus tongissimis compressis.-Willd. sp. pl. 4. p. 1097 .

G. Meliloba. Walt. Al. car, 25!

Icon. Duham. art. 1.t.195. Nich. art. t....

$\beta$. G. ramis subinermibus.

Near the sea-coast: Virginia and Carolina. h. July. inermis. $v$. $v$. A large tree; the pods contain a swcet pulp; known by the name Honey-locust.

2. G. spinis crassis brevibus subternatis, foliolis oblongis lrachycarpes, obtusis, leguminibus oblongis brevibus.

G. triacanthos $\beta$. bracliycarpos. Wich A. amer. 2. p. 257.

In the Allegany mountains : on the Indian river, Virginia. $h$. July. v. v. This species is certainly distinct from No. 1, baving short curved spines, sonetimes solitary, sometimes by threes, on the old branches.

3. G. ramis subspinosis, fuliolis ovato-oblongis acutis, monosperme. leguminibus ovalibus mucronatis submonospermis.Willd. sp.pl. 4.p. 1097.

G. carolinensis. Lam. encycl. 2. p. 461.

G. aquatica. Marsh. arl. 95 .

Icon. Mich. arb....

In the woods and on river banks : Carolina to Florida, and Illinois. 々. July. v. v. Swamp Locust-tree.

\section{PANCRATIUM. Gen. pl. 551.}

1. P. spatha subbiflora, foliis lanceolatis, nectariis dentibus sex staminiferis, intermediis simplicibus, Willd. sto. pl. 2. p. 42.

mexicanuti. 
Icon. Dill. elth.t. 222. f. 289.

Un the sea-coast of Carolina and Georgia. 24. July, Aug. $v . v$. Flowers white, as are all the following.

rolatum.

2. P. spatha multiflora, foliis lineari-lanceolatis, nectariis hypocrateriformibus, inferne tubulosis, dentibus sex staminiferis, intermediis inciso-dentatis, staminibus nectario duplo longioribus. - Ker in bot. mag. 827.

On the sea-coast: Virginia to Florida. 4. July, Aug. v. $v$.

maritimum.

3. P. spatha multifora, foliis lineari-lanceolatis, nectariis dentibus duociecim, non staminiferis. Willd. sp.pl.2. p. 42.

P. carolinianum. Linn. sp. pl.418.

P. verecundum. Ait. kew. 1. p. 412.

Icon. Catesl. car.2. app.5. t. 5. Salisl. in linn. trans. 2. t. 9 .

On the coast of Carolina and Georgia. 24. July, Aug. $v . v$.

\section{AMARYLIJS. Gen.pl. 554.}

Alamasco. 1. . spatha bifida acuta, flore pedicellato, corolla campanulata subæquali erecta, basi brevi tubulosa, staminibus declinatis æqualibus. Willd. sp. pl.2. p. 51 .

Icon. Bot. mag. 239. L'Herit. sert. angl. 10. Catesb. car. app.t. 12.

In shady woods and sıamps: Virginia and Carolina. 4. June, July. v. $v$. Flowers rose-coloured.

\section{ALLIUM. Gen. pl.557.}

vineale.

1. A. caule teretifolio bulbifero, staminibus tricuspidatis. Willd. sp. pl. 2. p. 73.

Icon. Lob. ic. 156.

In old fields; common. 4 . June, July. $v . v$.

fragrans. 2. A. scapo nudo subtereti, foliis linearibus planis acutis subcarinatis, corollis turbinato-campanulatis, laciniis obovatis, staminibus linearibus acuminatis tubo adnatis.-Vent. malmais. 26. Redouté lil. 2. t. 68.

A. inodorum. Bol. mag. 1129.

A. mutabile. Mich. fl. amer. 1. p. 105 ?

On the mountains of Virginia and Carolina. 24. June. $v, v$. Flowers white, with red veins.

siriatum.

3. A. scapo nudo subtriquetro, foliis linearibus convolutoconcavis obtusiusculis dorso striatis, corollis patentibus, 
lacinis oblongo-lanceolatis, staminibus alternis subulatis, alternis compressis.-Bot. mag. 1524. Jacq. ic. 2. t.366. Willd.sp.pl.2.p. 77.

A. ornithogaloides. Walt. fl. car. 121.

Ornithogalum bivalve. $S p$. pl. ed. 1. p.306.

In Virginia and Carolina. 24. June, July. v. s. in Herb. Walt. Flowers large, white, with a red carina.

4. A. scapo nudo ancipiti, foliis linearibus canaliculatis subtus subangulatis, umbella fastigiata. IVilld. sp. pl. 2. p. 76 .

Icon. Gmel. sib 1. t. 14.f.2. Jacq. austr. 5. t. 425.

On the banks of the Missouri. M. Lewis and Nuttall. 4. July. v. s. in Herb. Lewis. Flowers white.

5. A. scapo nudo tereti foliis breviore, foliis lanceolatis nervosis, umbella pauciflora.

In shady woods, on the high mountains of Pensylvania. 4. May, June. v. $v$.

Mountain Leeks.

6. A. scapo nudo tereti, foliis linearibus, capitulo bulbifero. Willd. sp. pl. 2. p. 78 .

In fields and woods : Canada to Carolina. 4. June. $v . v$.

7. A. scapo nudo semitereti, foliis lanceolato-oblongis planis glabris, umbella globosa, seminibus solitariis. IVilld. sp. pl. 2. p. 81 .

In shady woods : Pensylvania to Virginia. 24. July. $v$. $v$.

289. BRODIÆA. Smith in linn. trans. 10. p. 2.

1. B. umbella multiflora, floribus pedicellatis, staminibus alternis margine membranaceis.-Smith l.c.

Hookera coronaria. Salisb. par. lond. t. 93.

On the plains of the Columbia and Missouri rivers. M. Lewis. 24. April, May. v. v. This elegant bulbous plant, which M. Lewis, Esq. used to call Missouri Hyacinth, is certainly hexandrous; Dr. Smith having been misled, by dried specimens, to consider it to be only triandrous.

290. PONTEDERIA. Gen.pl. 545.

1. P. foliis oblongo-cordatis obtusis, spica confertim-multiflora, corollæ laciniis oblongis.-Willd. sp. pl. 2. grandiflora. triflorum. canadense. tricoscon. angulosum.

canadense. p. 23 .

cordata. 
Icon. Pluk. mant. t. 349.f. ult. Bot. mag. 1156.

On the edges of rivers in the lower countries, from Canada to Florida. 4. July. v. v. Flowers blue.

angustifolia. 2. P. foliis elongato-triangularibus sensim acutis basi truncato-subcordatis, corollæ laciniis lineari-lanceolatis.

In high mountain-lakes: New York to Carolina. $\boldsymbol{U}$. July. $v . v$. Flowers blue, smaller than the first species.

291. HYPOXIS. Gen. $p l .565$.

erecta.

1. H. pilosa; scapo 2-3-floro foliis lineari-lanceolatis breviore, corollæ laciniis lanceolato-oblongis.-Willd. sp. pl.2. p. 106.

Icon. Pluk. alm. t.315.f. 12 . Bot. mag. 710.

In pastures and or grassy hills : Canada to Virginia. 4. June, July. $v . v$. Flowers yellow : the root is reckoned one of the antidoies against the bite of the rattle-snake.

graminea.

2. H. pilosa ; scapo 4-floro foliis longissimis gramineis breviore, corollæ laciniis lineari-lanceolatis.

H. caroliniensis, Mïch. fl. amer. 1. p. 118.

In dry sandy fields and woods : New Jersey to Carolina. 4. June, July. $v \cdot v$. Leaves very narrow, and double the length of the scape.

juncea.

3. H. pilosa ; scapo unifloro, foliis filiformibus canaliculatis. - Smith spicil. $t$. 16.

On pine-barrens of South Carolina. 24. May-July. v. $v$. H. sessilis Willd. sp.pl.2. p.110. figured by Dillenius $t$. 220 . is only an accidental variety of $H$. erecta, as I frequently have found this species at an early part of the season to flower very near to the ground.

292. CONOSTYLIS. Brown $f$. nov. holland. 1. p. 300.

americana.

1. C. corollis intus lanatis, scapis corymboso-paniculatis, foliis gramineo-ensiformibus glaucis, filamentis æqualibus.

Argolasia aurea. Pursh catal.

In boggy soil, on the pine-barrens of New Jersey and Carclina. 24. July. v. v. Flowers golden-yellow.

Radix fibrosa, repens. Folia radicalia, scapo breviora, irideo-equitantia, angusto-ensiformia, acuta, glabra, lævigata, glaucescentia. Scapus erectus, teres, lanato-tomentosus, folio uno alterove brevi instructus. 


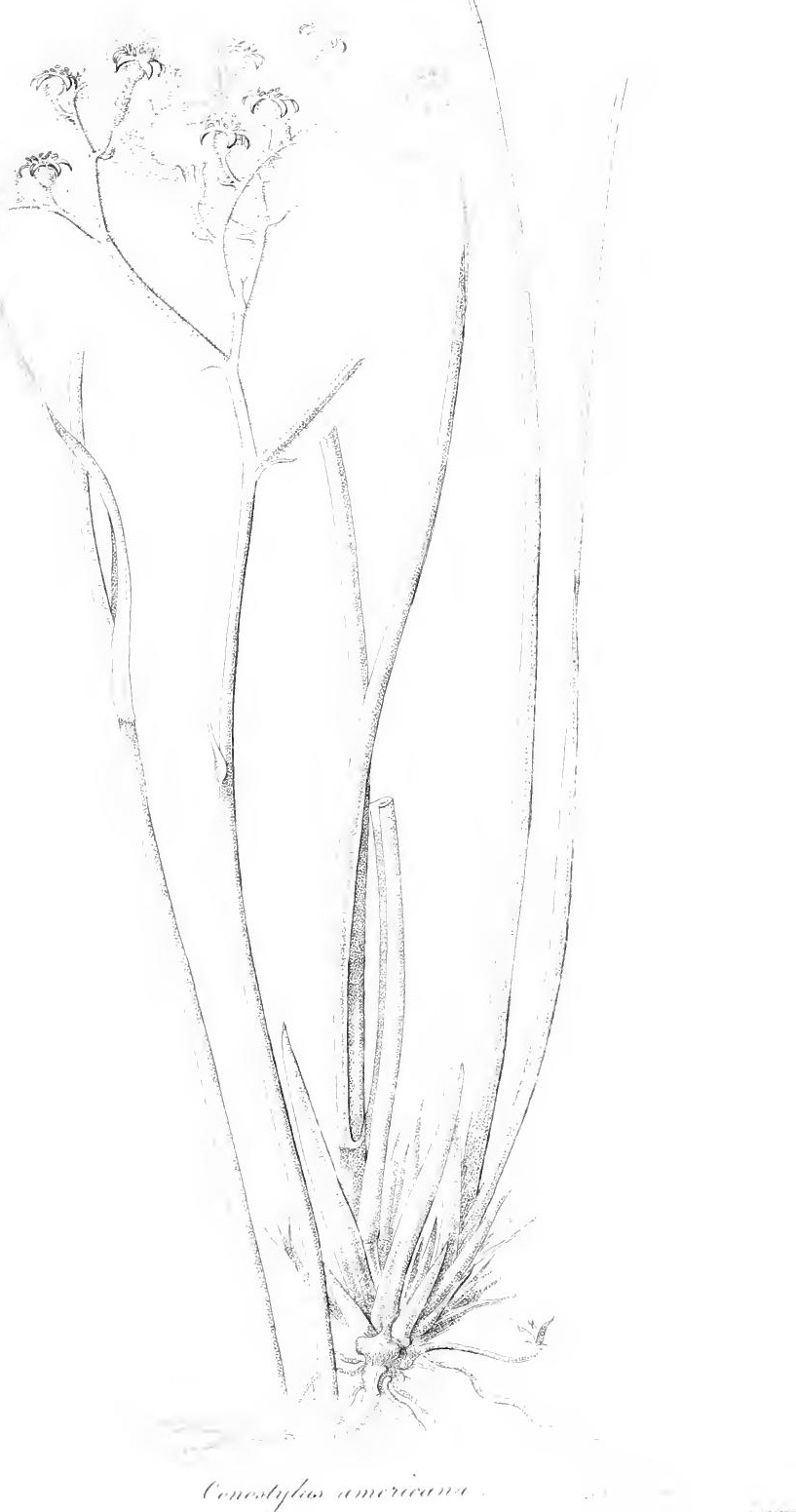



Corymbus dense multiflorus, lanato-tomentosus. Flores extus albo-lanati, intus flavi. Pediccili longitudine florum. Corolla 6-fida: laciniis oblongis acutis, 3. interioribus vix angustioribus, superne glabris fuscoJuteis, inferne densissime lanatis: pilis plumosis aureis. Filamenta 6. fliformia, glabra, corollæ vix breviora. Anthere ovati, erectx, aurantiacx. Germen superum, subrotundum, glabrum. Siylus subulitus, 3-partibilis, longitudine filanentorum. Stigma sinplex.

This singular and beautiful perennial I discoverad about the year $\mathbf{3} 805$, and considered it as a species of Argolasia of Jussien or Lanaria of Aiton, until I had the opportunity of seeing Mr. Irown's Prodromus, in which the genus Conostylis is the nearest of any genus I know, though it even differs from that genus materially by the germ being almost entirely superior, and not half inferior.

293. ALETRIS. Gen. $p l .579$. Micil. fl, amer. 1.p.189.

1. A. floribus pedicellatis oblongo-tubulosis, corollis fructiferis læriusculis farinosis, foliis lato-lanceolatis mualba. cronatis.- Nich. fl. amer. 2. p. 189.

A. farinosa. Willd.sp. pl.2.p. 183 .

Icon. I:luk. amalth. t. 437.f.2. Bot. mag. 1418.

In dry gravelly woods, on the side of hills: New England to Carolina. 24. June, July. v. v. Flowers white, in a long spike; known by the name of Stargrass or Colic-root; the last name, from its being considered an excellent remedy in that disease.

2. A. Aoribus subsessilibus breviter tubulatis subcampanulatis, corollis fructiferis rugosis scaberrimis, foliis lanceolato-ensiformibus acutis.-Mich. l. amer. 1. p. 190.

Wurmbea bullata. IViild. hort. berol. t. 8.

In sandy fields and woods : New Jersey to South Carolina. 24. July, Aug. v. v. Flowers covered with a mealy substance, as in the first species, but the divisions are tipped with golden-yellow; the leaves are narrower and longer. There is not any doubt of this plant properly belonging to Hexandria Trigynia; but the styles are glcied together during flowering, and only divide on the ripening of the fruit. 


\section{AGAVE. Gen. pl. 552.}

virginica. 1. A. acaulis, herbacea; foliis cartilagineo-serratis, scapo simplicissimo. Willd. sp. pl. 2. p. 193.

Icon. Jacq. ic. rar. 2.t.378. Bot. mag. 1157.

On the rocky and fertile banks of rivers: Virginia to Carolina. 24. July. v. v. Flowers greenish-yellow, very fragrant.

\section{PHALANGIUM. Tournef. Juss. gen. pl. 59 .}

croceum. 1.P bulbosum; scapo foliis gramineis multo brevioribus, spica pyramidali, bracteis convoluto-amplexantibus obtusis, seminibus subglobosis lævigatis. -Mich. $f$. amer. 1. p. 196 .

In low grounds of Georgia. Nichaux. 4. +. Flowers saffron-coloured; seeds biack.

Quamash.

2. P. bulbosum ; scapo foliis linearibus carinatis longiore, spica racemosa, bracteis linearibus, petalis 5 . adscendentibus : infimo deflexo, stigmate obtuso.

On the upper part of the Missouri, near the Rockymountains. M. Leuis. 24. June. v. s. in Herb. Lewis. Flowers large, pale blue.

Bullus tunicatus, subrotundus. Scapus simplex, nudus, erectus, teres, glaber, pedalis et ultra. Folia radicalia, pauca, longe linearia, subtus carinata, glabra, semiunciam lata. Flores spicato-racemosi, bracteati. Bractece marceseentes, solitariæ, lineares, membranacex. Pedunculi solitarii, uniflori, teretes, bracteis breviores. Corolla marcescens, infera, hexapetalopartita. Petala subrequalia, lineari-lanceolata : quinque adscendentia : sextum deflexum. Filamenta subulata, æqualia, petalis breviora, ad basin petalorum inserta. Germen trigonum. Stylus longitudine corollæ, stbclavatus. Stigna obtusum. Capsula subrotundo-triquetra, 3-locularis : loculis polyspernis. Semina oblonga, nigra.

It deviates from the character of Phalnngium in some respects, particularly in its ascending petals, but not sufficiently to give materials to frame a new genus.

This plant is known among the natives by the name Quamash, and the bulbs are carefully collected by them and baked between hot stones, when they assume the appearance of baked pears, and are of an 
agreeable sweet taste. They form a great part of their winter stores. Though an agreeable food to Gover nor Lewis's party, they uccasioned bowel complaints if eaten in any quantity.

296. NARTHECIUM. Smithfl. brit. 1. p.36s. Ker in lot. mag. 1505.

1. N. racemo interdum interrupte spricato laxo, bractea una americanum. caulina pediccllum amplexante, altera inferne pedicellari paleaceo-setacea, lana filamentorum brevissima. Ker l. c.

In boggy fields and wonds, on the pine-barrens of New Jersey. 4. June, July. $v . v$. Flowers yellow. It approaches very near to $N$. Ossifragum, and is only different in the situation of its bracteas, which nice distinction was very ingeniously observed by Mr. Ker. For a considerable time I considered this plant to be N. glutinosum of Michaux; but the close investigation of Mr. Ker on this subject has convinced me of haring been in an error. Vid. Bot. mag. 1505.

\section{ORNITHOGALUM. Gen. pl. 566.}

1. O. corymbo paucifloro, peduncelis bracteis longioribus, filamentis subulatis. IV illd.sp.pl.2. p.116.

lcon. Jacq. austr. 4. t. 343.

In grass-plots and near gardens; probably not indigenous. 4. Mily. v. v. Flowers white.

\section{IUCCA. Gen. pl. 580.}

1. Y. acaulis; foliis lato-lanceolatis integerrimis margine filarientosis, stigmatibus recurvato-patentibus.Willd. sp. pl. 2. p. 184.

Icon. Trew ehret.t. 37.

On the shores of Virginia and Carolina, and in the western parts thereof. 24. July, Aug. v. v. Flowers white, very showy; and the plant is from four to five feet high.

2. Y. acaulis; foliis longo-linearibus rigidis margine raro filamentosis, capsulis magnis obovato-cylindraceis.

On the banks of the Missuliri. 4. July, Aug. v.s. in Herl. Nuttall. From two to three feet high; leaves very narrow: capsules large.

filamentosa.

angustifolia. 
securvifolic.

3. $Y$. caulescens : foliis lineari-lancedatis tiridibus recurvo-defle $x$ is margine raro filant osis, petalis interioribus latioribus,--nalisb. in jarced lond. 31.

On the sandy shores of Gurgia. Loconte. $\eta$. Iuly,

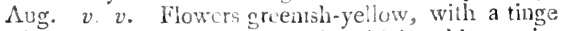
of vurple; stem about three feet high: this species lias been confunded with the following.

sloriosa.

4. Y. caulescens, ramosa; foliis lato-lanceolatis picatis integerrimis, petalis lanceolatis.-IVilll. sp. pl. 2. D. 183.

Icon. Rot. rep. 4\%3. Lot. mag. 1260.

On the seashore of Carolina. $\eta$. July, Aug. $v, v$. Flowers white; plant about ten feet high.

aloifolic.

5. Y. caulecens, ramosa; foliis lineari-lanceolatis callosocrenulatis strictis..-. Willd. sp. pl. 2. p. 184.

Icon. Dill. elth. 323 . f. 416. Comm. preel.t. 14.

On the cuast of Carolina and Florida. $々$. Aug. v.v. Flowers white.

\section{LILIUM. Gen. pl. 558 .}

Catesbrei.

1. L. foliis sparsis lineari-lanceolatis, caule unifloro, corolla erecta, petalis longe unguiculatis nargine undulatis apice retlexis. Willd. sp. pl.2. p. 80. Wall. fl. car. 259.

L. spectabiie. Salisb. icon. rar. 5. t. 5.

L. carolinianum. Lame. encycl.3. p. 554.

Jcon. Catest. car. 2. t. 58. Dot. mag. 259.

In low sandy meadows: Virginia to Carolina. 2 . June-Aug. $v, v$. Flower very handsome, scarlet, spotted with yellow and brown; stem about a foot high.

pudicum. 2. L. ? foliis sparsis lineari-lanceolatis, caule uniforo, corolla campanulata cernua, petalis erectis sessilibus spathulato-obovatis obtusis intus planis.

On the head-waters of the Missouri. M. Lewis. 4. May. v. s. in Fierb. Lewis. Flower pale yellow; stem about ten inches high.

This doubtful species is at first sight more related to Fritillaria; but the style, which is the length of the petals, with an obtuse stigma, associates it more closely to Lilium. The fruit 1 am unacquainted with; the root is a flat biscuit-shaped bulb. 

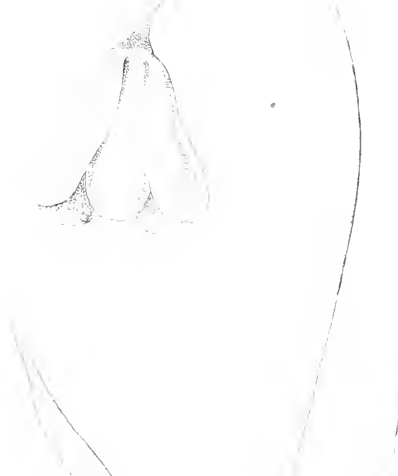

3. L. foliis sparsis lineari-lanceolatis : supremis 4.5. verticillatis ficremque subæquantibus, caule subunifuro subalato-pentagono, dunculo janato, coroila erecta turbinato-putterie extus floccoso-lanata, laciuits in timis ovali-lanceolatis. Yer in bot. mag. 372.

Icon. Catesli. car, 3, t. 8.

On the nountains of Pensylvanis and Virginia. 4 . July, Auz. v. v. Fower scriet, yellow at the base wih dirk spots. hesemb.es L. bulbijerum very nuch.

4. L. follis sparsis linear'bus brevibus: supremis rerticiliatis pedunculis brevioribus, floribus $3-5$. timbellatis erectis, petalis recurvo-prentibus subxqualibns ovatooblongis sthnnguicn?atis.

L. concolor. Parael. lond. 47?

On the banks of the Misiouri. Mr. Lewis and Nottull. 21. Iuly. v. s. Iy all appearance the plant foud by the above gentlemen, among the Mandan nation on the Missonit, appears to be the same with the one figured in the Paradisus Londinensis; the fowers are of an uniform deep scarlet colour, and are bighly or. namental.

5. L. foliis verticillatis lanceolato-linearibus, cal!e subbiforo, corolla crecta camparulata yatente, petalis lanceolatis ungaiculatis.- - Villd.sj. pl. 2.p. 90.

Icon. Mill. ic. . 105. $f$. 1. Bot. mag. 519 .

In woods and meadows : Canada to Virginia. 24. July, Aug. v. $\%$ Floweis large, scarlet, yellow near the bottom, with dark red spots; most generally it is found with only one flower, but sometimes even with three or more.

6. L. foliis remote verticillatis lanceolatis trinerviis, subtus ad nervos subhirsutis, pedunculis terminaiibus elongatis plerumque ternis, corollis cernuis turbinato-campanulatis recurvo-patentibus, laciniis lanceolatis.Willd. sp. pl. 2. p. 89 .

Icon. Catest. car. 3.t. 11 .

a. Bot. mag. 800 .

B. Bot. meg. 858 .

On mountain meadows : Canada to Virginia. 24. July, Aug. v. $\boldsymbol{y}$.

7. L. foliis plerumque verticillatis cuneato-lanceolatis seu obovalibus enervibus glaberrimis, ramis floriferis crassis

umiellatum.

pensylvani-

cam.

(a) philadelphicum.

canadense.

flavam. coccineum.

caralinia num. 
ternato-terminalibus, floribus reflexis, corollis revolutis.-Nich. fl. amer. 1. p. 197.

L. Martagon. Walt. fl. car. 123.

Icon. Calcsb. car. 2, t. 56.

In fertile meadow grounds : Lower Virginia and Carolina. 24. June, July. v.v. Resembles L. Martogon very much ; flowers larger and maculated.

superbum.

8. L. foliis lineari-lanceolat is trinervibus giabris, inferioribus verticllatis intermediis duplo Jongioribus superioribus sparsis, foribus racemoso-pyramidatis reflexis, corollis revolutis. - Villd. sp. pl.2. p. 88 .

Icon. Trew ehret. 2. t.11. Bot. mag 936.

In low copses and swamps, on blue clay soil : Canada to Virginia. 24. July, Aug. v. v. The most stately plant of this family in North America; the number aud elegance of its Howers are astonishing. I have, in farourable situation, seen stems of abont seven feet high, with from thirty to fifty flowers, disposed in a graceful manner in form of a chandelier.

300. Fritillaria. Gen. pl. 559.

lanceolata. 1. F. caule folioso 1-2-floro, foliis lineari-lanceolatis obtusiusculis: inferioribus verticillatis, petalis lanceolatis.

Lilium camschatcense. Willd. sp.pl.2.p. 89.

On the head-waters of the Missouri and Columbia. MT. Lewis. 24. July. v. s. Flowers dark purple with brown spots.

In the tenth rolume of the Linnean Transactions, A. B. Lambert, Esc. in his account of the Pallasian Herbarium, has given an excellent figure of this plant, and suspect. it very justly to be a Fritillaria : wben I examised he Lewisian Herbarium I had no idea of finding it under Lilium, and made a drawing and description under the above name, for the Travels of Lewis and Clark.

\section{ERYTHRONIUM. Gen. pl. 562 .}

lanceolatum. 1. E. petalis la!ceolatis basi dilatatis obtusiusculis, germine subgioboso, foliis lanceolatis.

E. Dens canis. Mrrib. fl. amer.1.p. 198.

In woods, near the roots of old trees, and on the banks of rivulets : Canada to Virginia, and on the Missouri. 
4. May. v. v. Flowers yellow : there is a variety with brown spots at the bottom of the flower.

2. E. petalis laeceolatis subunguiculatis acutis, germine oblongo, foliis lineari-lanceolatis.

On the Kooskoosky. M. Lewis. 4. May, June. v. s. Flowers double the size of the preceding, and of a pale yellow colour.

302. UVUlaria. Gen.pl.560. Mich. l. amer. 1.p. 198.

1. U. foliis perfoliatis ellipticis obtusis, corolla campanulata intus scabrata, antheris cuspidatis.-Willd. sp. pl. 2. p. 0.1. Smith exot. bot. 1. 95 .

U. perfoliata minor. Mich. fl.amer. 1.p. 199.

Icon. Smith l.c. t. 49 .

In shady woods, among rocks, in rich vegetable mould: Canada to Carolina. 24. May, June. v. v. Flowers pale jellow.

2. U. foliis perfoliatis elliptico-oblongis obtusis basi undulatis, corolla basi attenuata intus scabrata, antheris cuspidatis. Smith exot. lot. 1. p.97.t.50.

Anonymos pudica. Walt. fl. car. 123.

Icon. Bot. mag. 955. Smith l. c.

In shady woods, in sandy soil: New Jersey to Lower Carolina. 4. May, fune. v. v. Flowers larger than No. 1, of a deeper yellow.

3. U. foliis perfoliatis oblongis acutis, petalis intus lævibus, antheris obtusiusculis, nectaris subrotundis. Smith exot. l.ot. 1.p.99.t. 51 .

U. pertoliata major. Mich. fl. amer. 1.p. 199.

U. lanceolata. IVilld. sp.pl.2.p. 94 .

Icon. Corn. canad. t.39. Smith l. c.

On shady hills, in fertile soil, and among rocks : Canada to Carolina. 4 . June. v. v. Flowers larger than the other species, of a beautiful yellow. The $U$. lanceolata of the Hortus Kewensis is the same with Dr. Smith's $U$. grandifolia, according to specimens in the Herbarium of A. B. Lambert, Esq.

4. U. caule glabro, foliis sessilibus lanceolato-ovalibus subtus glaucescentibus, corollæ laciniis planis intus læsessilifolia. vibus, capsula stipitata.-Willd. sp. pl. 2. $p .95$.

Icon. Smith erot. lot. 1.p.101.t.52. Bot.mag. 1402. In shady woods: Canada to Carolina. 4. May, June. v.v. Flowers pale yellow.

perfoliala.

flave.

grandiflora. grandi;
ruml. srandithra. 
puberuli.

distortus.

roseus.

lanuginosus.

majalis.

umbellata.
5. U. caule puberu'o, foliis subamplexiculitus ovalibus basi rotundatis utrinque concoloribus, corollæe laciniis acutis intus levibus, capsela sessiii.-Micin.fl. cumer. 1. p. 1 (j9).

On the nomutains of Carolina. Micluaux. 4 + +. Resembles the foregoing species; flowers larger.

303. STREPTOPUS. Mich.fl. amer. 1.p. 260.

1. S. gliber; filiis amplexicaulibus, pedicellis solitariis unedio distorto-geniculatis. Mich.fl. amer, 1. p. 200. Uvularia amplexitolia. IVilld. sp.pl.2. p. 93.

Icon. Pl. rar, hung. t. 167.

In shady wools: Canada to Peusylvania on high mountains. 24. May, June, v.v. Flowers greenish-ycllew, the size of Convallaria majalis.

2. S. glaber lucidus; foliis anplexicaulibus serrulato-ciliolatis, antheris brevibus bicurnibus. Mich. Jl. amer. 1. p. 201.

Icon. Mich. l. c. t. 18.

Un the ligh mountains of Carolina, Pensylvania, and in Canada. 24. May-July. v. v. Hlowers rose-coloured.

3. S. subcandicanti-lanuginosus; foliis sessilibus basi subcordatis acumiratis, pedicellis in brevissimo stipite geminatis. Nich.fl. aner. 1.p. 201.

On the high mountains: Pensylvania to Carolina. 44. June. $v . v$. Flowers large, ycllowish-green; berries red.

304. CONVAlLARIA. Gen. pl.575. Desfont. in annal. mus. hist. nat.9.p. 46.

1. C. scapo nudo lavi, fuliis ovatis. Willd. sp. pl. 2. p. 160.

Icon. Fl. dan. 854 .

On the highest mountains of Virginia and Carolina. 4. May. v.v. Flowers white, fragrant.

305. SMILACINA. Desfont. in annal. mus, hist. nat. 9. p. 51 .

1. S. foliis radicalibus oblongo-ovalibus margine et carina ciliatis, scapo pubescente, umbella terminali, pedicellis bracteatis.-Desfont. l. c. 53 . 
Convallaria umbellata. Nich.fl. amer. 1. p. 202.

S. borealis. Ker in tot. mag.

Icon. Desfont. l. c. t. 8. Bot. mag. 1155.

On the Allegany monntains: Pensylvania to Carolina; rare. 24. May, June. v. v. lilowers white, tragrant.

2. S. subcaulescens ; foliis eliptico-obovatis margine ciliatis, scapo pubescente, unbelia corymbora incerdum prolifera, pedicellis nudis nutantibus.--Bot. mag. 1403.

Dracæna boreaiis. IV illd. sp.pl.2.p. 158.

Icon. Ait. kew. 1. t. 5 Bol. mas. 1403. Bot. repos. $20 \%$. On ti:e Aibuny mountains, in bogs, and in Canada and New England. 24. Jure, 'n'y. $v \cdot v$. Flowers large, greenish-yellow : fruit beautiful amethystine blue.

3. S. caule bifolio, foliis cordato-oblongis subsessilibus

canadensis. utrinque glaberrinus, racemo simplici terminali, flo. ribus retrandis.

Convallor ia bitolia. Mich. fl. amer. 1.p. 201.

Majan'hemum canadense. Destont.l. c. p. 54.

ק.S. foliis owatis basi vix cordatis.

$\gamma$.S. caule trifoliato, fuliis litu-cordatis.

lorealis.

Icon. Pluk, alm. t. $434 . f .4$.

In silady woods, round the roots of old trees and in the bogs on high mountains. 24. May. v.v. Flowers small, white.

4. S. caule alterne trifoliato pubescente, foliis oblongolanceolatis, racemo terminali laxo.-Desfont.l.c. p. 52 .

trifolia.

Convallaria trifolia. Wilid. sp.pl. 2, p. 103.

Icon. Gmel. A. silir. 1. t. 6 .

On the highest Allegany mountains, in deep sphagnous places : Pensylvania, New York, and in Canada. 4. June, July. $v . v$. Flowers small, white.

5. S. caule alterne folioso, foliis amplexicaulibus lanceolatis ovalis. trifolia. seu ovali-lanceolatis, racemo simplici terminali.Desfont. l. c. p. 52 .

Convallaria stellata. IVilld. sp. pl. 2. p. 163.

Icon. Corn. canal. t. 33. Moris. hist. 3. s. 15. t. 4. f. 7. Bot. mag. $1 \mathrm{C} 43$.

In Canada, and along the tract of mountains on siver banks as far south as Virginia. 24. May, June. v. v. About a foot high; flowers in a close spike, white.

6. S. caule alterne folioso arcuato, foliis sessilibus ovatis ciliata. ciliatis, panicula terminali conferta.-Desfont. $l$. c. p. 53.

Icon. Desfont. l. c. t.9. 
In Virginia and Canada. Desfontaines. $4 .+$. Flowers very small, white.

racemosa. 7. S. caule alterne folioso, foliis sessilibus oblongo-ovalibus acuminatis nervosis pubescentibus, floribus terminali bus racemoso-paniculatis.-Desfont. l. c. p.51.

Icon. Corn. canad. t.37. Pluk. alm. t.311.f. 2. Bot. mag. 890 .

In mountain woods : Canada to Carolina ; common. 4. June, July. $v, v$. Flowers small, yellowish.

306. POLYGONATUM. Desfont. in mus. hist, nat. g. p. 48.

angustifoliun.

canalicula. tum.

pulescens.

hirlum.

muliflorum.
1. P. caule tereti, foliis alternis sessilibus elliptico-lanceolaris sensim acutis subtrinervibus glabris, pedunculis axillaribus elongatis subbifloris.

Convallaria bifiora. Walt. $f$. car. 122 .

In ricky situations : Pensylvania to Virginia. 2. May, June. $v, v$. Fiowers yellowish-white, with green tips, as most of this genus.

2. P. caule canoliculato, foliis alternis amplexicaulibus oblongis margine pubescentibus, pedunculis axillaribus bifloris.

Convallaria canaliculata. Willd. hort. berol. 45 .

In shady woods: Pensylvania to Virginia. 4. June. v. $v$.

3. P. caule teretiusculo sulco exarato, foliis alternis amplexicaulibus ovatis subtus pubescentibus, pedunculis axillaribus subbifloris.

Convallaria pubescens. Willd. hort. lerol. 45. cum icone. On rocks, near water: New England to Carolina. 4. May, June. v. $v$.

4. P. caule angulato hispido, foliis alternis subamplexicaulibus ovatis obtuse acuminatis, pedunculis axillaribus trifloris.

Convallaria hirta Lam. encycl.4. p. 369 .

In North America. Bosc. 24. +.

5. P. caule tereti, foliis alternis amplexicaulibus oblongoovalibus, pedunculis axillaribus multifloris.-Desfont. l. c. p. 50 .

Convallaria multiflora. Willd, sp. pl, 2. p. 162.

Icon. Fl. dan. 152. Allot 77. Engl. Lol. 279.

In dry hilly woods : Canada to Carolina. $\psi$. June, July. ?. $v$. 
6. P. caule angulato, foliis sessilibus ovatis acuminatis, pedunculis uni-aut multiforis. Desfont.l.c. p. 50.

Convailaria latifolia. Willd. sp.pl. 2.p. 162.

Icon. Jacq. uustr. 3. t. 232.

On the sandy and gravelly banks of rivers, in shady wet. situations: Pensylvania and Virginia. 24. June, July. $v . v$. The tallest of all the species, sometimes four feet high.

\section{ASPARAGUS. Gen.pl.573.}

1. A. caule he:baceo inermi suberecto tereti, follis setaceis mollibus, stipulis subsolitariis. Smith fl.lrit.1.p.30y.

Will. sp. fl. 2.p. 1.0.

Icon. Fl dan. S03. Engt tot. 339.

Common $A$;. puragus is trejuently fond in an apparentiy wild staie, but has been introluced from Europe.

\section{Gronthum. Gen.pl.587.}

1. O. foliis lanceolato-ovatis, scupo cylindrico spicato.Willd. sp. pl. 2. p. 199.

Icon. Amien. acall. 3.t. 1.f. 3.

In rivulets and low stagnant waters: Canada to Florida. 4. April, May. v. $v$. Yellow flowers in a close cylindric spike, of a most singular smell. I observed a variety with almost linear leaves, in the Salt marshes near New York.

\section{ACORUS. Gen. pl. 556.}

1. A. scapo mucrone longissimo foliaceo. IVilld.sp.pl. 2. p. 199.

Icon. Allot 77. Engl. bot. 356.

In overflowed places and old ditches; frequent : Canada to Carolina. Has the appearance of a flag, and called Sweet-flag, from the aromatic smell and taste of its roots.

310. JUNCUS. Gen. pl. 590.

* Culmis nudis.

1. J. culmo nudo tereti, panicula terminali, involucro diphyllo spinoso, capsulis subrotundis mucronatis, Smith fl. brit. 1. p. 374. Willd. sp. pl. 2. p. 204.

J. maritimus. Lam. encycl. 3. p. 253. latifolium.

officinalis.

aquaticum.

Calamus.

acutus. 
Icon. Engl. lot. 1614 .

On the san:ly sea-cuast: New Jerser, \&c. 2! July. v.v.

conglomeratus.

efillsus.

filiformis.

bicornis.

selaceiss.

medosus.
2. J. culmo nudo stricto, panicula laterali conglobata, capsulis retusis, floribus triandris. Smith fl. brit. 1. p.376. Willd.sp.pl. 2. p. 205.

Icon. Hust. gram. 3. t. S2. Leers, f. hert. t. 13.f. I. In wet pastures, frequent. $\quad$. June, July. $v . v$.

3. J. culmo nudo stricto, panicula laterali efrusa supradecomposita, capsulis obtusis. Snith fi. brit. 1. p. 376 . IV'illd. s. p. pl. 2.p. 205.

Icon. Host. gram. 3. t. 83.

Frequent in low grounds, on road sides, \&c. 2. June, July. $v . v$.

4. J. culmo nudo filiformi nutante, panicula laterali bracteata subsimplici, capsulis subrotundis. Smith fl. brit.1. p.377. Willd. sṕp.pl.2. p.207.

Icon. Host. gram. 3. t. 8-1. Pluk. phyt. t. 40. f. 3.

In boggy mountain meadow3; frequent. 24. July, Aug. v. $v$.

5. J. culmo erecto nudn, follis subsetaceis canaliculato-planis, involucro setaceo diphyllo erecto paniculam superante, floribus distinctis, calyce lineari-lanceolato acuíssimo. - Mich.A. amer. 1. p. 191.

J. tenuis. Rostk.junc. 21, i. 1.f.3. MIoris. hist.3.s.8. t. 9.f. 1.5.

In s.mdy wet fields, near ponds : Carolina and Georgia. 4. Juiy. $v \cdot v$.

6. J. culno nuto filiformi nutante, umbella laterali composita patucifiora, pedunculis multifloris, calyce subulato. Rustk.junc. 13.t. 1.f. 2.

In luw grounds : Canada to Virginia. 4. July. v.v.

marginatus. 7. J. foliis planis glabris, corymbo terminali simplici prolifero, capitulis sub-10-floris, calyce capsulam obtusam æquante. Rostk. junc. 30. t.2.f.3.

On dry sinady hills: Pensylvania. 24. June. v.v.

s. J. foliis nodoso-articulatis teretibus, corymbo simplici, capitulis globosis, capsulis acuminatis calyce longioribus. Rosik. junc.t.2.f.2.

J. scirpoides. Lam. encycl. 3. p. 267.

Icon. Pluk. alm. t. $417 \cdot f .3$.

In inundated fields and ditches: Canada to Virginia. 4. July, Aug. v. $v$. 
** Culnis foliosis.

9. J. culmo erecto oligophyllo, foliis noloso-articulatis, polycephalus, capitulis globosis multifcris sabpariculatis, calyciuus linearibus trianáris.-NItch. R. cinct. 1. p. 192. Icon. Pluk alni. i. 92.f. . .

๘.J. najor, totis crassioribus compressis.

F.J. folits subfiliformibus.

In inundated phaces : I"ensylvania to Carolina. 24. June, July. $v v$.

10. J. culmo erecto, follis nocioso-ariculatis teretious, panicula supradecomposita, foliolis calycinis aristatis interioribus longioribus. Willd. sp.pl.2.p.211.

J. acutiflozus. Hofin. germ. 125.

Icon. Host. gram, 3. t. 86.

In inuadated woods and on river sides: Pensylvania to Virginia, 2f. July. v. v.

11. J. culmo decuribente, foliis setaceis, floribus glome- verticillatis. ratis verticillaris glomerulis foliosis. Willd. $s p \cdot p l .2$. t. 212.

J. uliginosus. Rt!h $f$ germ. 1.p. 155 .

J. fuitans. Lain encyel. 3. p. 26.

Icon. Fl. dan. 817 . Host. gram.3.t.83.

In rivulets and ponds: Canada, New York, \&c. $\%$. July, Ang. v. v.

12. J. culmo folioso erecto, foliis subnodoso-articulatis, panicula terminali composita, glomerulis subtriftoris pe. dunculatis sessilibusque, calycibus gracilibus acuminatis 3 andris. Mich. $f$. amer. 1. p. 192.

In stagnant waters and on river banks: Pensylvania to Carolina, 24. July, Aug. v. v. Resembles J. articulalus very much.

13. J. radice bulbosa, culmo foiloso erecto compresso, foliis angustis subcanaliculatis, panicula composita, giomerulis 3-foris, calycibus 3 -andris bracteisque aristatis. -Mich. fl. amer. 1.p. 192.

In low grounds of Georgia and Carolina. 24. July. v.s. Resembles the following species.

14. J. culmo subcompresso indiviso, foliis linearibus canaliculatis, corymbo terminali, calycibus obtusis capsula subrotunda obtusa brevioribus. IVilld. sp. pl. 2. p. 213.

J. compressus. Jacq. vind. 235.

Icon. Host. gram. 3. t. 89. Fl. dan. 431.

acuminaus.

crassifolius. tenuifolius.

sylvaticus. carminatuo.

aristablus.

bullosug. 
On dry barren soil, on road sides; frequent. \%. June, July. v. $v$.

ieruis.

15. J. culmo folioso simplici teretitisculo, foliis canaliculatis, corymbo terminali dichotomo bracteis breviore, capsula oblonga obtusa calyce beviore. Fostk. junc. 24 . t. 1.f. 3. Willd. sp.pl. 2.p. 214?

In Georgia and Carolina. $4 .+$

Eufonius.

16. J. culmo folioso dichotomo, foliis angulatis subsetaceis, fioribus oblongis solitariis sessilibus.-WVilld. sp. pl. 2 . p. 214.

Icon. Fl. aan. 1098. Host. gram. 3. t. go. Engl. lot. 802.

In overflowed fields, common. July, Aug. v. $v$.

campestris. 17. J. foliis planis pilosis, spicis pedunculatis ovatis subcernuis, internedia sessili, calycinis foliolis mucronatis capsula obtusa longioribus. Willd. sp.pl.2.p.221.

Icon. Engl. lot. 672.

On dry simny hills : Pensylvania to Carolina. 4. April, May. v. $v$.

melanocar- 18. J. culmo folioso, foliis sublanceolatis glabris, panicula pus. capillari Jaxa, floribus peclicellatis. - Mich. fl. amer. 1. p. 190.

Luzula melanocarpa. Desvoux in journal de lotanique 1. p. 142.t.5.f.2.

In the western part of Canada. Michaux. +. Seeds black.

repens. 19. J. culmis repentibus foliosis, foliis planis angustis, capi tulis pancis sessilibus pedunculatisque pauciftoris, calycibus subulatis 3-andris.-Mich. fl. amer.2. p.191.

Cephaloxis flabellata. Desvoux in journal de botanique 1. p. 324.t.11.f. 2 .

On sandy bills in Carolina and Georgia. 4. June. v.s.

\section{PEPLIS. Gen. $p l .605$.}

americana. 1. P. floribus axillaribus solitariis, foliis crassis spathulatoobovatis, floribus apetalis.

Inundated during its flowering time, in slow-flowing places of rivers, in Pensylvania; the flowers so diminutive that to examine them it requires a strong microscope. 


\section{1. $D I G Y^{r} N I A$.}

312. NECTRIS. Gen.pl. 610.

1. N. foliis demersis oppositis capillaceo-multifidis : emersis peltata. alternis orbiculatis pellatis integerrimis.

N. aquatica. IV illd. sp. pl.2. p. 248.

Cabomba acuatica, Aull. gui. 1.p. 321. $\iota .124$.

In the streams of Carolina and Georgia. 4. July, Aug. v. s.

2. N. foliis omnibus alternis demersis ternatis; emersis quipinnata. nato-pinnatis.

Floerkea proserpinacoides. Mullb. mss.

In ditches and slow-flowing rivers: Pensylvania and Virginia. 4. Aug. v.v. Flowers greenish-yellow in both species, on long axillary solitary petioles. The character of the last species deviates a little from Aublet's; but as I never had an opportunity of seeing his plant in a living state, I consider the difference so trifling that they will be better to remain united.

\section{TRIG YNIA.}

313. SABAL. Adanson. Pers. syn. 1.p.39g.

1. Sabal. Pers. l. c.

Adansoni,

Raphis acaulis. IVilld.sp.pl. 4.p. 1093.

Chamærops acaulis. Mich. fl. amer. 1. p. 207.

Corypha minor. Jacq. vind. 3. $t .8$.

Corypha pumila. Walt. $f$. car. 119 .

Icon. Bot.mag. 1434. Guersent. obs. in bullet. de la soc. philomat. no. 87 .

Along the sea-coast of Carolina and Georgia. $h$. Aug. $v . v$. A species of palm of but little beauty or use.

\section{CHAM EROPS, Gen. pl. $168 s$.}

1. C. candice repente, stipitibus aculeato-serrulatis, fronserrulata. dibus palmatis.-Willd. sp. pl. 4. p.1155. Mich. $f$. amer. 1.p. 206.

On the coast of Georgia and Florida. $\eta_{2}: v, v . s . f$. 
Hyslris. 2. C. caudice repente, stipitibus aculeis longissimis intermixtis, frondibus palmatis.

Near the town of Savannah, Georgia. $\quad$. $v . v$ s. $f$. This singular palm grows in company with others, and distinguisties itself by its long aculei resembling porcupine quills, and often growing to the length of more than fifteen inches.

Palmetlo. 3. C. caudice arboreo, stipitibus inermibus, spathis duplicatis, frondibus palmatis. Willd.sp. pl. 4.p. 1155.

Corypha Palmetto. Wait. fl. car. 119.

On the sea-coast of Carolina and Florida. $h . v$. v.s.fl. $A$ fine and useful plant; the wood used for forming almost everlasting piles for building wharfs, and the leaves can be manufactured into light and very durable hats.

315. NOLINA. Micir. fl. amer. 1. p. 207.

Ecorgiana.

1. N. foliis angustissimis longis aride-gramineis, scapo laxoramoso foliis subulatis sparsim vestito, floribus racemosis, pedicellis aggregatis.-Mich. A. amer. 1. p. 208. Phalangium virgatum. Lam. encycl. 5. p. 2.16.

In barren sandy woods: Georgia. Michaux and Fraser. 4. July. v. s. in Herb. Enslen. Root a tunicated bulb; stem two feet and more high; flowers white and small.

316. CALOCHOR'NUS. Pursi in linn. trans. v. 11. p....

elgans. 1. C. scapo subtrifloro folio unico breviore, petalis interioribus lanatis.

On the head-waters of the Kooskoosky. M. Leuis. 44. May. v. s. in Herl. Leuis. Flowers very elegant, white; the three inside petals are covered with a long down, and have a purple smooth spot on their base. The roots are eaten by the natives.

Bulbus solidus, subglobosus. Folium unicum, radicale, longe-gramineun, glabriusculuin, plicato-nervosum, scapo longiore. Scapus simplex, teres, glaber, bi-aut triforus. Bractece tot quod pedicelli, lineari-lanceolatæ. Pedicelli filiformes, bracteis vix longiores. Flores nutantes, magnitudine Hypoxidis erecti.

317. MELANTHIUM. Gen.pl.6I8.

virginicum. 1. M. elatum; panicula pyramidata, petalis ovalibus subhastatis planis bimaculatis, floribus plerumque hers 
maphroditis.-Willd. sp. pl. 2. p. 206 . Lam. encycl. 4.p. 2.5.

Helonias virginica. Bot. mag. 985.

In low grounds, anong luxuriant herbage : New York to Carolina. 2 . June, July. v. v. Flowers greenish-white at first, and turn to a dark brown after fowering for some time.

2. M. panicula inferne mascula, superne feminea racemomonoicum. sa, petalis oblongis planis brevi-unguiculatis bimaculatis, stylis germine duplo brevioribus.-Wult. $f$. car. 125.

M. pulygamum. Lam encycl. 4. p. 25.

On the mountains of Virginia and Carolina. 24. July. $v . v$. Flowers smaller, and not so apt to change colour.

3. I panicula superne racemosa feminea, petalis subrohylridum. tundis unguiculatis plicato-undulatis vix maculatis, extus hirsutis. - Walt. fl. car. 125.

M. latifolinm. Lam. encycl. 4. p. 25.

M. racemosum. Mich. fl. amer. 1. p. 251.

On the side of hilis, in moist fertile soil: Virginia and Carolina. 24. Iune, July. v. v. Flowers small, pale white, and do not change.

318. ZIGADENUS. Mich.fl. amer. 1.p. 213.

1. Z. scapo folioso, bracteis ovatis acuminatis, petalis acu- glaberimus. minatis.

Icor. Mich fl. amer. 1. p. 214. t. 22.

In low meadows : Virginia and Lower Carclina. 4. June, July. $v . v$, Flowers white, the size of Veratrum allium; leaves long, recurved and channelled.

2. Z. scapo subnudo, bracteis linearibus, petalis acutis.

On the waters of Cokahlaishkit river, near the Rockymountains. M. Lewis. 4. Ju'y. v. s. in Herb. Lewis. Flowers white.

Folia radicalia, erecta, longissime-linearia, glabra, lineato-nervosa, plana, scapo breviora. Scapus teres, simplex, unc alterove folio brevi instructus, subbipedalis. Racemus multitiorus, interdum basi ramosus. Bractece lineares, nervosæ, membranaceæ, longitudine pedicellorum. Flores albidi, magnitudine Melanthi virginici. Petalu ovata, acuta, subunguiculata, basi glandulis 2. cinnabarinis notsta. Filamenta corolla breviora. Stigmata2, reflexa. 
viride.

parviflorum.

latifolia.

erythrosper. ma.

angustifolia.

\section{VERATRUM. Gen. pl. 1564.}

1. V. racemis paniculatis, bracteis ramorum oblongo-lanceolatis, partialibus pedunculo subpubescente longioribus, foliis lato-ovatis plicatis. - Willd. sp.pl.4.p.896. V. album. Mich. fl. amer. 2 p. 249.

In swamps and on mountain bogs : Canada to Carolina. 24. July. $v . v$. A stately plant, from three to six feet high; flowers greenish-yellow.

2. V. racemis paniculatis, ramis filiformibus, floribus pedicellatis stellatis, petalis ovali-lanceolatis utrinque acutis ungue staminiferis, foliis ovalibus lanceolatisve planis glabris.-Mich. fl. amer. 2. p. 250.

Melanthium bracteolare. Lam. encycl. 4. p. 25.

On high mountains of Carolina. 24. July. v. $v$. et v. s. in Herb. Lyon. Flowers snall, green.

angustifulium. 3. V. altum, dioicum; panicula simplici, peta'is linearibus, foliis longissimis linearibus carinatis.

On high mountains of Virginia and Carolina. 4 . June. $v, v$. Flowers greenish-yellow.

320. HELONIAS. Gen. pl.622. MIich.flamer. 1. p. 211.

1. H. scapo subaphyllo, spica ovata conferta, bracteis lineari-lanceolatis, foliis lanceolatis mucronatis nervosis. - Mich. fl. amer. 1. p. 212.

H. bullata. Wilid. sp. pl.2. p.273.

Icon Bot. mag. 747. Bot. rep.352. Pluk. alm.t. 17.4.f.5.

In shady swainps on sandy soil : New Jersey to Virginia. 4. May. v. v. Flowers purple; anthers blue.

2. H. scapo folioso, raceno oblongo, bracteis brevibus oblongis, folits glatris lanceolato-linearibus, seminibus ovatis legumine carnoso rubentibus.-Mich. flamer. 1 . p. 212.

H. lata. Bot. mag. 803.

Melanthium lætum. Willd. sp. pl. 2. p. 267.

Melanthium phalangioides. Lam. encycl. 4. p. 28.

Melanthium Muscrtoxicum. Walt.fl.car. 125.

Anthericum subtrigynum. Jacq. ic. rar. 2. t. 419.

In shady moist situations on river batiks, and on high mountains: Pensylvania to Carolina. 4 . June, July. $v$ v. Rect a kirid of bulb; flowers first white, then changing to green; anthers white : seeds covered with a red substance.

3. H. scapo inferne folioso, raceno oblongo laxo, bracteis brevitus, folitis longissinis airustissimisque, capsulis 



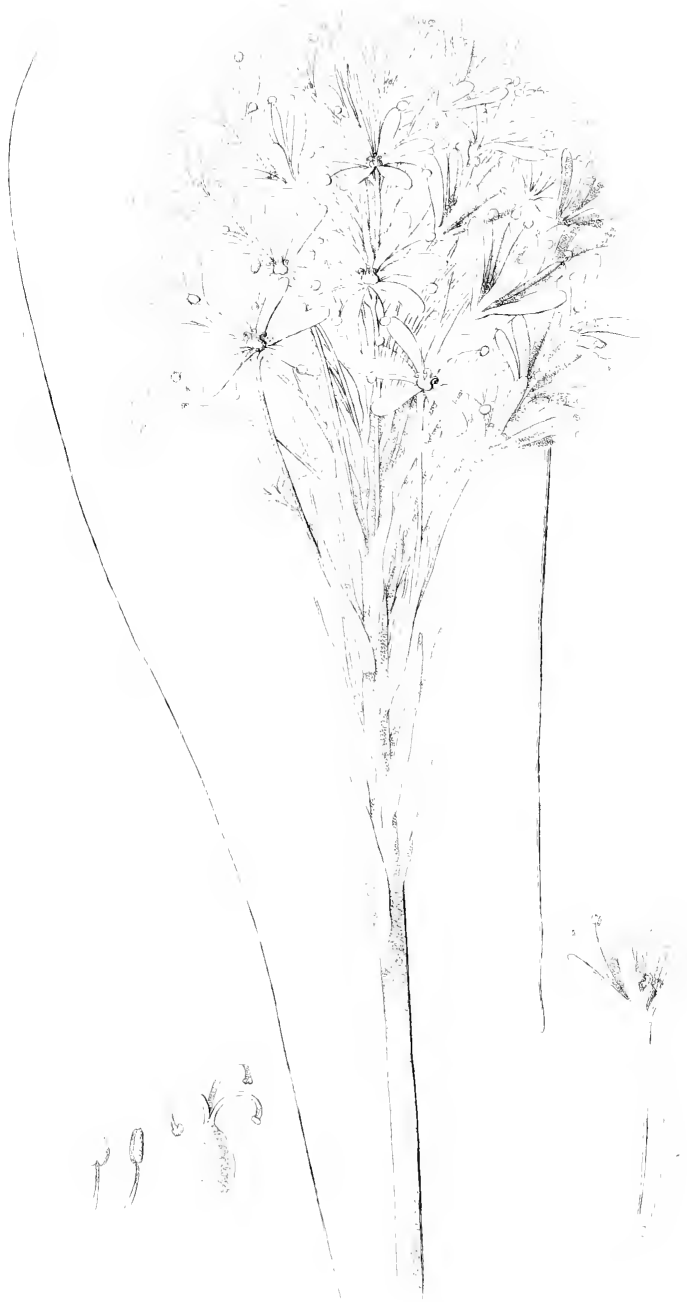

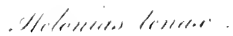


oblongis, seminibus angusto-linearibus.-Mich. fl. amer. 1. p. 212.

In shady wet woods of Carolina and Georgia. 24. July. $v$.s.

4. H. scapo folioso, racemo oblongo conferto, bracteis seta-asphodeloides, ceis, filamentis basi latioribus corollam æọuantibus, foliis subulato-setaceis.-Willd. sp. pl. 2. p. 275 .

Icon. Bot. mag.748. Pluk. mant. t. 342.f.3.

On the sandy plains of New Jersey and Carolina. 4. May, June. v. v. Flowers white, small ; ront a kind of bulb: the leaves form large tuits resembling those of some Carices.

5. H. scapo folioso, racemo specioso laxo, bracteis memtenar, branaceis, petalis eliipticis, filamentis filiformibus corollam superantibus, foliis subulato-setaceis longissimis.

On high lands near the Rocky-mountains. MT. Lewis. 4. June. v. s. Flowers white; anthers yellow. It approaches near to the foregoing species, but its flowers are three times larger, and probably an cssential distinction may lie in the seed-vessel, which I have not seen. This plant is very useful to the atives: out of its very tenacious leaves they weave thier watertight baskets, which they use for couking their victuals in.

6. H. scapo folioso, racemo spicato nutante, pedicellis dioica. brevissimis subebracteatis, filamentis corolla longioribus, petalis linearibus, folits oblongo-lanceolatis.

H. lutea. Bot. mag. 1062.

H. punila. Jacq. ic. rar. 2. t. 453.

Veratrum luteum. Willd. sp. pl. 4. p. s97.

Melanthium dioicum. Walt, fl. car. 126.

Melanthium densum. Lam. encysi. 4. p. 26.

In dry shady and hilly situations: Pensylvania to Georgia. 4. July. $v, v$. Root bulbous, known by the name of Star-wort, and considered a remedy in colic. Flower white, male and female on different plants, which is a sing ${ }^{-1}$ rity in this family of plants.

Jacquin's $H$. pumula is without doubt an unexpanded spike of a male of this species : the appearance of a germen inferum is occasioned by the male flower being divested of its petals; and no female fiuctification appearing, the smail pedicel was considered to be the rudiments of a germen. 
ciulia.

rirginica.

sessile.

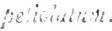

2. T. fore sessili erecto, petalis lincari-lanceolatis erectis calyce paulo longioribus, foliis longissime petiolatis ovali-lancerdatis acatis.

Cn the waters of the Knoskoosky. MI. Lewis. 4. Junc. v.s. This singular species, whose flowers resemb? those of the first species, has leaves very much like Planlago major.

fictum.

3. T. pedunculo erectiusculo, petalis ovali-lanceolatis acutis recurvatis calyce angusto subduplo longioribus, foliis ovalis atcuminatis basi rotundatis abrupte petio. latis.

T. erythrocarpum. Wirk. A. amer. 1. p. 216.

T. undulatum. Willd. horl. ler. 1. p. 55.

in sphagnous bogs, on the high mountains of Pensylva- 
nia, Carolina, and Canada. భ. May, June. v. v. Flowers white, with purple vins at the botion; berry scarlet.

4. $T$. pedunculo erecto, petalis oblongis acutis patentibus calyce lneari pauln longioribus, folis oratis sensim acutis arcte sessilitus.

On the rapids of Columbia river. IT. Lewis. $4 . \Delta$ pril. $v$.s. Fowers pale purple.

5. T. pedunculo erectn, petalis calyce vix longioribus, folits ovali-oblongis obtusis sessilibus.-Aich. fl. amer. 1.p. 215

In the pine-woods of Lower Carolina. Michanx. 2 . May. v.s. Flowers deep tlenb-colour.

6. T. pednonculo recurvato, petalis lancenlatis acumintis planis rertex is longitudine et latindine calycis, folis dilatato-rhomboideis abrupte acuminatis brevissime petiolatis. - Willd. sp. pl.2. p. 2-1.

Icon. But. mas. 9j4. Smitit sicil. +t.

In shady rocky situations: Pensylvania to Carolina ; particulariy on the bunks of Schuylkill near Philadelphia. 2). May. v. v. Petals white; berie, purple. This may be called the largest of the genus, as I have ofien seen it near two feet high, whl, kaves mensuring nine inches in diamctar. Caterby's fatre of this species is, according to Dr. Smith's obertation, so erroneously reprexenied that it would only create confusion to guote it here.

7. T. pelunculo inciinato, flore nutante, petalis ovatis acuminatis planis patentibus calyce vix longioribus multo latioribus, foliis lato-rinmboideis acuninat is sessilibus-Mrilid. sp. Hl.2 $p$ 271.

a.T. flore majore, peralis atropurpureis.

T. rhomboideum $x$. Mi:h. Al a:ner. 1. p. 215 .

T. fuetidum. Perral. leild. 35.

Icon. Bot may. 450 .

ค.T. Ho e ninore, petalis albis, germine rubro.

oratum.

punilum.

crnumin.

erectum.

atropurpun reuni.

album,

T. erectum B. Fit. mlig. 1027 .

On the mountains, in bogsy soil: Pensylvania to $\mathrm{Ca}-$ rolina. 24. May. v.v. Flowers either dark purpie or white, changing to red with a red germ; berries alumest black.

8. T. pedunculo erecto, petalis obovatis obtusiusculis planis patentibus calyce vix Io:grioribus et latioribus, föiis

olovatum. urato-rhombeis acuminatis arcte sessilibus. 
T. camtschaticum. Pallas in herb. Lambert.

In Canada near Montreal. 24. v. s. Flowers dark rose-colonred, probably white when first opening. The specimens in the herbarium of A. B. Lambert, Esq. agree in evcry respect with those from Canada.

pendulum. 9. T. pedunculo inclinato, flore pendulo, petalis ovatis brevi-acuminatis planis patentibus calycemovatum acuninatum subxquantibus, follis subrotundo-rhomboideis acuminatis subsessilibus. - Willd. hort. berol. $1 . t 35$.

On the mountains of Pensylvania. 2 . April, May. $v \cdot v$. Petals of a dirty white, with netted veins.

grandiflorum. 10. T. pedunculo inclinato, flore subcersuo petalis spathulato-lanceolatis basi erectis, limbo patentibus calyce multo majoribus, foliis late rhombeo-ovatis.-Parad. lond.t. 1. Bot. mag. 835.

T. thomboideum $\gamma$. grandiforum. Mich. fl. amer. 1. p. 216.

On the mountains and rocky banks of rivers: Virginia and Carolina. 24. May. v. v. Flowers large, white; berries dark purple. The roots of the whole genus are considered as possessing strong medicinal powers.

3ะ3. TOFIELDIA. Huds. $f$. angl. 157.

Narthecium. Jıss. Mich. Al. amer. 1.p. 209.

pusilla.

1. T. tota glabra, foliis brevissimis, scapo filiformi, spica pauciflora conginbata, calyculo rachi adnato, capsula globosa.--Mich.fl. amer. 1. p. 209.

In bogs on the mountains, near lakes, and particularly Lake Mistassius. - 4. June, July. v. v. Flowers greenish-white.

pubescens. 2. T. scapo, rachi pedicellisque pubescenti-asperis, spica oblonga interrupta, capsula subglobosa vix calycem superaste.-Mich.fl. amer. 1. p. 209.

Melanthium racemosum. Walt. fl. car. 126.

Anthericum calyculatum. Gronou. nec Linn.

In swamps and sphaguous woods : Virginia and Carolina. 4. July, v.v. Flowers white; anthers yellow.

glutinosa. 3. T. scapo pedicellicque glutinoso-scabro, spica fasciculis paucis alternantibus, capsula ovoidea calyce duplo longiore. - Mich fl. amer. 1. p. 210.

From Quebec to Lake Mistassins. Michaux. 24. +. It has the appearance of Anthericum Ossifragum, according to Michaux's observation; and as I have never 
seen any other plant approaching to it than Narthecium americanum, p. 227, I was induced to take them as synonymous; but after investigation,-vid. Bot. mag. 1505, - a specimen in the Banksian Herbarium seeins to apply better to Michraux's plant, if his short definition of the species is sufticient to decide on the subject.

\section{TRIGLOCHIN. Gen. pl. 616.}

1. T. foribus 6 -andris, capsulis brevibus ovatis sulcatis 6 locularibus.-Willd. $s p$ pl. 2. p. 205.

Icon. Fl. dan. 306. Engl. lot. 255.

On the inundated sea-coast of Canada and New England. 4. July. $v \cdot v$. A plant of a rush-like appearance; flowers very small.

2. T. foribus 3-andris, capsulis linearibus basi attenuatis lævibus 3-locularibus.-Willd. sp. pl.2. p. 264.

Icon. Fl dan 4yo. Engl. lot. 366.

In marshes round the Salt-lake of Onondago, New York. 24. July. v. v.

3. T. Aoribus 3-andris 3-fidis breviter pedicellatis, capsulis trigono-subrotundis, folits subsetaceis scapum spicamve subrequantibus. Mich. Al. amer. 1. p. 208.

In overtiswed marshes, near Chariestown, Carolina. Michaux. 4. +.

\section{SCHEUCHZERIA. Gen. pl. 615.}

1. Scheuchzeria. Willd. sp. pl. 2. p. 263.

Jcon. Fl. dan. 76 .

In swamps and on the borders of lakes, New York near Aloany. 4. June. v. v. Howers greenish-yellow.

326. RUMEX. Gen.pl. 613.

1. R. hermaphroditus; valsulis irtegerrimis oblongis, unica præcipue granifera, foliis cordato-lanceolatis. Willd.sp.pl. 2. p. 250.

Icon. Engl. lot, 1533.

In shady woods and moist meadows: Pensylvania to Virginia. 4. Junt, July. $v, v$. Leaves wich red veins; flowers, as in all the rest, very inconspicuous.

2. R. hermaphroditus; valvulis ovatis integris, omnibus graniferis, foliis lanceolatis undulatis acutis.-Willd. sp.

triandrum.

maritimum. palustre. criandrum.

palustris. pl. 2. p. 251 .

sanguineus.

crispus. 
Icon. Curt. lond.2.t. 20.

In dry fields and pastures, common. 24. July. v. $v$.

verticillatus. 3. R. hermaphroditus; valvulis integerrimis, omnibus graniferis, spicis aplyyllis, fuliis lanceolatis, vaginis cylindricis,-WTilld. sp. pl 2.p.,250.

In rivulcts and shady woods: Canada to Virginia. 4. July. $v . v$.

britanicus. 4. R. hermaphroditus; valvulis integerrimis, omnibus graniferis, paniculæ spicis aphyllis, vagin cobsolete laceris, folitin lato-lanceolatis planis lavibus-Willd. sp. pl. 2. p. 250.

Near risulets: Virginia and Carolina. 24. June, July. v. $v$.

persicarivides. 5. R. hermaphroditus; valvulis dentatis, omnibus graniferis, fuliis lanceolatis undatis integris.-Willd. $s p$. pl. 2. p. 252.

In shady wet woods, on the banks of ditches: Virginia and Carolind. ๑. July. r.v.

crispatulus. 6. R. hermaphoditus; valvulis obtuse cordatis utrinque cristatis tridentatis, uma muda, binis inæqualiter graniferis, spicis aphyllis, foliis inferioribus ovalibus, superioribus lanceolatis, omnibus undulatis.-Mich. $f$. amer. 1.p. 217 .

In Kentuchy. Michaux. +. Afinis $R$. persicarioideo.

oltusifolius. 7. R. bermaphroditus: valvulis dentatis, unica pracipue granifera, foliis radicalibus cordatis obtusis, caule scabriustulo.- Willd. sp.pl.2.p. 254.

Icon. Lingl. bot. 1699 .

In old pasiures and gartens, as a common weed; probably intrudiced. 24. June, Jaly. v. v. Common Dock.

aquaticus. 8. R. leemaphroditus; valuulis ovatis integris obonlete graniferis, follis cordato-lanceulatis acutis.-IVilld. sp. pl. 2. p. 255.

Icon. Engl. lot. $210 \%$.

In small pronds and ditches: Pensylvania to Virginia; rare. 2 . July, Aug. v. v.

digynus. 9. R. hermaphroditus, digynus; valvulis ovatis integris gran destitutis, folis'tadicahibus reniformibus longius petiolatis.--Wilid. sp. pl.2. p. 258.

Icon. Fl dan. 14. Plak. alm. l. 252 f. 2.

In Labrador. Colmaster. 24. June, July. v. s, in Herb. Dickson. 
10. R. dioica; foliis lanceolato-hastatis, valvulis grano desti- Acetosella. tut:s.-Will.l. sp. pl. 2. p. 260.

Icon. Engl. lot. 1574.

Common in all dry fields and gravelly hills. 4 . June -Aug. $v . v$.

\section{SMILAX. Gen.pl. 1525.}

* Caule fruticoso; ramis angulatis.

1. S. subinermis; foliis lanceolatis acuminatis basi auricuhastata. lato hastatis margine ciliato-acule:tis $3-5$-nervibus, baccis globosis.-IVilld.sp.pl. 4. p. 7\$2.

S. Bona n x. Mich. fl. amer. 2. p. 237. Wult. fl. car. 245.

S. aspera $\delta . ~ L a m . ~ e n c y c l .6, p .465$. icon. Pluk, alm. t. I l1. f. 3.

f. S. foliis longis angestis lanceolatis. Walt. fl. car. 245.

On the sea-cuast of Carolina and Florida. $\eta$. June, $\mathrm{July}, v \cdot v$.

2. S. inermis; foliis cordato-ovatis acutis ciliato-aculeatis 7-nervibus. Willd. sp.pl. 4.p. 701.

S. variegata. Walt. Al car. 244.

Icon. Pluḱ alm. t. 111.f. 1 .

In woods of Carolina and Georgia.

3. S. aculeata ; caule tetragono superne inerni, foliis iner- quadrangulamibus ovatis subcordatis acutis 5-1ervibus.-IVilld.sp. ris. pl. 4. p. 775 .

In diry woods, on the edges of ponds: Pensylvaniato

Carolina. $\quad h$. June, July. $v, v$. Berries black.

4. S. aculeata; foliis cordato-ovatis lævibus 3-nervibus, baccis acuminatis.

S. China? Italt.fl. car. 245 .

In the lower sandy countries of Virginia and Carolina, on river sides. 々. July. $v \cdot v$. Berries red.

5. S. aculeaia; foliis inermibus ovato-lanceolatis cuspidatis Sarsaparilla. sub-5-nervibus subtus glaucescentibus, pedunculo communi petiolo lengiure.- $I V i l l d . s p . p l .4 . p .776$.

S. glauca. Mich.flomir. 2.p.237. Walt.fl. car. 245 .

In hedges and swampi, common. 々. June, July. $v \cdot v$.

o. S. subinermis; foliis inermibus ovatis acutis cuspidatis

Walleri.

lanceolata.

Bona nox. 3-nervibus concoloribus, pedunculo communi petiolo breviore.

Near Savannah in Georgia. Enslen. h. July. v.s. Leaves very shining on both sides; berries black.

ovata. 
alla.

lanceolata.

pulera.

Psendo-China.

rotundifolia.

caduca.

laurijolia. 13. S. aculeata; ramis inermibus, foliis coriaceis ellipticis

7. S. subinermis; caule obsolete angulato, foliis elongato. lanceolatis curiaceis glabris integerrimis 3 -nervibus, unibellis paucifloris brevissime pedunculatis.

In sandy grounds, on the edge of rivulets: Carolina.

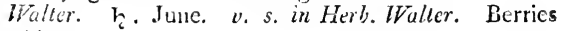
white.

** Caule fruticoso; ramis teretilus.

S. S. inermis; foliis inermibus lanceolatis, umbellis multifioris longe pedunculatis.-Willd. sp. pl. 4, p. 783 . Icon. Calest. car. 2. 1. S4.

Near the sea-const of Virginia and Carolina. $\zeta_{2}$. May, June. $v . v$. Berries red.

9. S. jnermis ; foliis oblongis acutis codatis sub-5-nervibus subtus molliter pubescentibus, umbellis breviter pediunculatis, pedicellis brevissimis, baccis oblongis acutis.-IVilld. sp. pl.4. p. ;85. Nich. fl. amer. 2. p. 238.

S. pumila. Wall. R. car. 244

In shady woods : Carolina and Georgia. 々. May. v. s. in Herl. Lyon. According to Walter, the berries are white.

Cliz- 10. S. inermis; foliis inermibus, caulinis cordatis, rameis ovato-oblongis 5-nervibus, pedunculis longissimis.Willd. sp.pl. 4. p. 785.

Icon. Sloan jam. 1. t. 143. f. 1.

In sandy fields and dry woods: New Jersey to Carolina. $\eta$. May, June. v.v. The roots very large, and are searched after by hogs.

11. S. sparse aculeata; foliis subrotundo-ovatis acuminatis levissime cordatis 5-nervibus, baccis sphæricis.Willd.sp. pl. 4.p. 779.

Common in hedge-rows: Canada to Carolina. $\zeta$. June. $v . v$.

12. S. aculeata; foliis ovatis mucronatis 5-nervibus, pelunculo communi vix petiolo longiore.-Willd. sp. pl. 4. p. 7 so.

In dry tields: Canada to Virginia. $々$. June. $v \cdot v$. vel elliptico-lanceolatis oblusis recurvato-acutis 3 -nervibus, umbellis brevisime pedunculatis._Willd. $s p$. pl. 4.p. 779 .

Icon. Catesb. car. 1. t. 15.

In sandy boĝ̣y woods: New Jersey to Georgia, h. 
July, Aug. v. v. A very handsome vine, with very thick smooth leaves.

14. S. aculeata; foliis ovato-panduræformibus acuminatis 3-nervibus, pedunculo communi petiolo duplo longiore.

In sandy woods: New Jersey to Carolina. $\zeta$. July. v.v. Leaves smooth and shining on both sides.

\section{*** Caule herlaceo.}

15. S. caule tereti scandente, foliis longe petiolatis triangulato-cordatis rotundato-obtusis, nervis glabris.-Willd. tamnoides. sp.pl. 4.p. 780 .

Icon. Catesb. car. 1, t. 52.

In sandy wet woods and bogs: Virginia and Carolina. 4. July. v. v.

16. S, caule angulato erecto simplici, foliis longe petiolatis ovalibus 7 -nervibus, umbellis longissime pedunculatis, pedinculo compresso, baccis depresso-globosis. Willd. sp.pl. 4. p. 782.

Icon. Pluk. alm. t. 225, f. 4 .

In dry fields, on the edges of woods : New York to Carolina. 4. June, July. $v, v$.

17. S. caule tereti scandente, foliis subrotundo-ovatis corda- peduncularis. tis acuminatis 9 -nervibus, umbellis longissime pedunculatis.-Willd. sp.pl.4. p. 786.

In old fields on the edges of woods : Canada to Pensyl. vania. 4. May-July. v. v.

\section{DIOSCOREA. Gen. pl. 1530.}

1. D. foliis verticillatis quaternis alternisve cordatis acuminatis utrinque glabris 9-nervibus, nervis lateralibus bitidis. - Walt. fl. car. 246.

In hedges and old fields: Virginia and Carolina. $\psi$. July. $v \cdot v$.

2. D. foliis alternis oppositis verticillatisque cordatis acuminatis subtus pubescentibus 9 -nervibus, nervis lateralibus simplicibus.-Willd. sp.pl.4. p. 796.

D. quinata. Walt. fl. car. 246.

D. paniculata. Mich. fl. amer. 2. p. 239.

Icon. Jacq. ic. t.626. Pluk. alm. t. 375.f.5.

In woods and hedges common: Canada to Carolina. 2. May, June. $v . v$.

quaternata.

villosa.

herlacea. 


\section{TETRAGY $\operatorname{T} I A$.}

329. SAURURUS. Gen.pl. 632.

cernuus. $\quad$ 1. S. caule folioso polystachyo, foliis sagittato-cordatis.Willd. sp.pl. 2. p. 202 .

Anonymos aquatica. Walt. $f$. car. 127.

Mattuschkea aquatica. Gmel. syst. nat. 589.

Icon. Pluk. alm. t. 117.f. 3 \& 4.

In swamps and shady wet woods, frequent: Canada to Carolina. 4. Aug. Sept. v. v.

\section{POLYGYNIA.}

330. WENDLANDIA. Willd. sp.pl.2.p. $2 \pi 5$.

populifolia. 1. Wendlandia. Willd. $l$. c.

Andropbylax scandens. IV endl. ols. 38.

Menispermum carolinianum. IValt. fl. car. 24S, Mich. fl. amer. 2. p. 242.

Cissampelos smilacina. Willd. sp. pl. 4.p. 863.

Icon. IVendl. hort.t. 16. Jacq. ic. rar.3.t.629. Catesl. car. 1. $t .51$.

In hediges and wonds: Carolina to Florida. h. Iune, July. $v . v$. Flowers very small, greenish-white; berries red. I venture to take Cisiampelos smilacina as a sjnonym, although Jacquin's figure deviates in character very much from the present grenus; but as I have had the opportunity of seeing the Menisformum of the above anthors fiequently in fower, I am convineed that ail the above synonyma are correct : the number of stanina being variabie, brings the genus so near to Menispermim, that I should not have taken it from it, if it were not on the authority of villdenow.

\section{ALISMIA. Gen.pl.625.}

trivialis. 1. A. foliis oralibus cordatis obtusissimis 9-nervibus, umbellis composite verticillato-paniculatis, fructibus ob1use-trigonis. 
A. Plantago. Mich. fl. amer. 1. p. 218.

In ditches and ponds, common : Canada to Florida. $\psi$. July. $v . v$.

2. A. foliis ovalibus subcordatis abrupte acuminatis 5-nervi- parviflora. bus unbellis composite verticillato-paniculatis, pedicellis filiformibus.

In salt-marshes, on the coast of New Jersey and Penoylvania. 24. July, ug. v. v. Leaves and flowers small. Foth species approach near to A. Plantagn, but are sufficiently distinct to admit them to be called species.

3. A. pusilla; foliis lineari-subulatis, umbellis subsimplici- sululala. bus.-Willt. sp. pl. 2. p. 279 .

In overflowed places : New York to Florida, scarce; plentifully on the shores of the Delaware near Philadelphia, to the edge of low water mark. $\odot$. Aug. $v . v$. A small plant, with flowers in proportion large.

4. A. foliis ovatis obtusis, pedunculis solitariis. Willd. sp. pl. 2. p. 278 .

In stagnant waters, on the banks of the St. Laurence. 24. July, v.s.

natans. 


\section{HEP'TANDRIA。}

\section{MONOGYNIA.}

332. TRIENTALIS. Cal. 7-phyllus, Cor. 7-partita, plana. Bac. 1-locularis sicca.

333. AESCULUS. Cal. 5-dentatus. Cor. 5-petala, inæqualis, calyci inserta. Caps, 3-locularis.

\section{MONOGYNIA.}

332. TRIENTALIS. Gen. $p l .626$.

americana. 1. T. foliis angusto-lanceolatis acuminatis obliquis.

T. europæa. Mich. fl. amer. 1. p. 220.

In cedar swamps and other sphagnous places on high mountains: Canada to Virginia. 4. July, Aug. $v . v$. Flowers white. This delicate little plant differs considerably from the European sort, although $\mathrm{Mi}$ chaux considers it to be the same.

\section{ESCULUS. Gen.pl. 623.}

Paria. 1. $\Lambda$. foliis quinatis glabris inæqualiter serratis, racemo laxo, fasciculis subtrifloris, corollis 4-petalis, petalo. rum conniventivm unguibus longitudine calycis, staminibus 7 . corolla brevioribus, fructibus inermibus. Willd. sp.pl.2.p. ¿80.

Icon. Schmidt arb. sy. Trew ehret. t. 15. Mich. arb....

In fertile valleys, on the mountains of Virginia and $\mathrm{Ca}$ rolina. $\zeta_{c}$. May, June. $v$. $v$. Floner scarlet; generally only a shrub or small tree. 
2. A. foliis quinatis utrinque acuminatis subtus tomentosis inæqualiter serrulatis, racemo thyrsoideo, fasciculis multifloris, corollis t-petalis, petalorum conniventium unguibus longitudine calycis, staminibus 7. corolla brevioribus, fructibus inermibus.

In Georgia, principally lie western territory. Lyo' . দ. May. $v . v$. Not above four feet high; flowers yellow, white, and purple variegated.

3. A. foliis quinatis subtus ad costam pube-centibus aqualiter serrulatis, racemo thyrsoideo, fisciculis multiforis, corollis 4-petalis, petalorum conniventiun unguibus calyce longioribus, staminibus corolla brevioribus, fructibus inermibus.-Willd. sp. pl. 2. p. 25 j.

1. lutea. Mich. fl. amer. 1. p. 219 .

Icon. Schmidt art. 40, Act. soc, nat, berol. 8, $t .6$. Mich. arb....

In the mountains of Virginia and Carolina, and woods of Kentucky. $h$. May, June. v. v. Grows to a large tree; flowers yellow.

4. A. foliis quinatis glaberrimis, corollis 4-petalis patulis, unguibus longitudine calycis, staminibus corolla longioribus, fructibus spinosis. Will. enum. pl.405.

In the western counties of Pensylvania and Virginia. $\hbar_{6}$. June. $v . v$.

5. $\Lambda$. foliis quinatis, corollis 4-petalis patulis, unguibus calyce brevioribus, staminibus corolla duplo longioribus, fructibus spinosis. Willd. enum. 106.

In the forests of Kentucky. $h$. June. $v$. s. A tall tree.

6. A. foliis quinatis subtus subtomentosis serrulatis, racemo longissimo laxo, fasciculis subtrifluris, curollis 4-petalis patulis, staminibus longissine exertis.-Mich. $f$. discolor.

fava.

glalra.

pallida. anicr. 1.p. 220.

A. parviflora. Walt., R. car. 128.

On the banks of rivers: Georgia, principally near St. Augustin. $\quad 2$. May, June. v. v. A small shrub; flowers white, very ornamental. The whole of this genus is known in their native countries by the name of Buck's-cye-tree.

macrostachya. 


\section{O C T A N D R IA.}

\section{MONOGYNIA.}

* Germen inferum.

334. rHEXiA. Cal. 4-fidus. Cer. 4-petala, calyci inserta. Anth. declinatæ. Caps. +locularis, intra ventrem calycis.

335. F.PILUBIUM. Cal. 4-fidus, tubulosus. Cor. 4-petala. Caps oblong:3, 4-locularis. Sem. papposa.

335. GAURA. Cal. 4-fidus, tubulosus. Cor. 4-petala, adscendeus. Nix 1-sperma. 4-angula.

537. ClarkIA. Cial 4-fidus, tubulosus. Cor. 4-petala: petala cruciatim 3-loba. Filum. 4. castrata. Caps. 4 hocularis.

33s. CENOTHERA. Cal. 4-fidus, tubulosus. Cor. 4peiala : peialis integris. Filam. omnia fertilia. Anth. lineares. Caps. 4. locularis.

339. OXYCOCCUS. Cal. 4-fidus. Cor. 4-partita: laciniis sriblinearibus, revolutis. Filam. conniventia. Anth. tubulosæ, bipartitæ. Bacca pulysperma.

\section{* Germen superum.}

340. MENZIESIA. Cal. 1-phyllus. Cor. 1-petala, ovata. Fil. receptaculo inserta. Caps. 4-locularis, dissepimenta e marginibus infexis valuularum. Sem. nu. merosa, oblonga.

3.1. DIOSFYROS. Cal. 4-fidus. Cor. urcenlata, 4-fida. Styl. 4-fidus. Bacca 8-sperma. Polygama.

342. ACer. Cal. 5-fidus. Pet. 5. Sumarce 2. basi unitre, 1-spermis, alatæ. Polygamum.

343. DIRCA. Cal. O. Cor. tubulosa, limbo obsoleto. Stam. tribo longiore. Bacia 1-sperma.

a.4. JEREE incurvo-patentia. Cafs, obovat?, stabstipitata, 1-10. 
cularis, infra apicem dehiscens. Sem. plura, oblonga, ad basin arillata.

345. PISTIA. Cal. spatha tubuloso-cucullata, lingulata. Cor. o. Filam. laterale. Anther. 3-8. Caps. 1locularis, polysperma.

\section{DIGYNIA.}

346. ChrysopteniUM. Cal. 4-fidus, coloratus. Cor. 0 , Caps. birostris, 1-locularis, polysperma.

\section{TRIGYNIA.}

347. POlygonum. Cal. o. Cor. 5.partita, calycina. Sem. 1. angulatum, tectum.

348. BRUNNICHIA. Cal. angulatus, 5-fidus, demum coriaceus. Cor. 0. Caps. 1-sperma, inclusa calyce valde aucto, pedicello ensiformi-dilatato suffulto.

349. CARdiospermum. Cal, 4-phyllus. Pet. 4. Nectar. 4-phyllum, inæquale. Caps. 3. connatæ, inflatæ.

350. SAPINDUS. Cal. 4-phyllus. Pet. 4. Caps, carnosæ, connatæ, ventricosæ.

\section{TETRAGYNIA.}

351. MYRIOPHYLlum. Cal. 4-fidus. Pet. 4. caduca. Stam. 4.6.8. Styl. 0. Sem. 4. corticata.

\section{MONOGYNIA.}

334. RHEXIA. Gen. pl. 636.

1. R. caule rufescenti hirsutissimo, foliis hirsutis subpetiolatis, ovali-lanceolatis, lanceolatis linearibusve, calyce longo tubuloso glabriusculo.- Wich. $f$. amer. 1 . p. 221. Willd. sp.pl. 2. p. 301.

Icon. Pluk. mant. t. 428. $f$. 1. Lam. illustr. 283. f. 1. ๙. R. foliis angusto-lanceolatis vel oblongis, floribus saturate purpureis, Mich.l.c.

mariana, 
rubella.

exalbida.

cilissa.

virginica.

7-nervia.

glalella.

Alifanus. $\quad$ G. R. foliis subovatis. Walt. fl. car. 130.

In sandy moist woods: Carolina and Georgia. 4 . July. v. s. in Herb. Enslen. Flowers the largest of the North American sorts, deep purple.

stricta.

5. R. caule stricte-erecto alato-tetragono glabro ad genicula brevi-barbato, foliis sessilibus erectis angusto-lanceolatis attenuato-acuminatis trinervibus utrinque glabris, corymbo dichotomo, calycibus glabriusculis.

In the bogs of Lower Carolina and Georgia. 24. June, July. v. s. in Herb. Enslen. Flowers very handsome, purple.

lutea. $\quad$ 6. R. caulequadrangulo hirsuto, foliis rariter longiusculeque hirsutis, inferioribus cuneato-oblongis obtusis, superioribus lanceolatis, antheris breviusculis. Mich. $f l$. amer. 1. p. 222. Walt.fl. car. 130. 

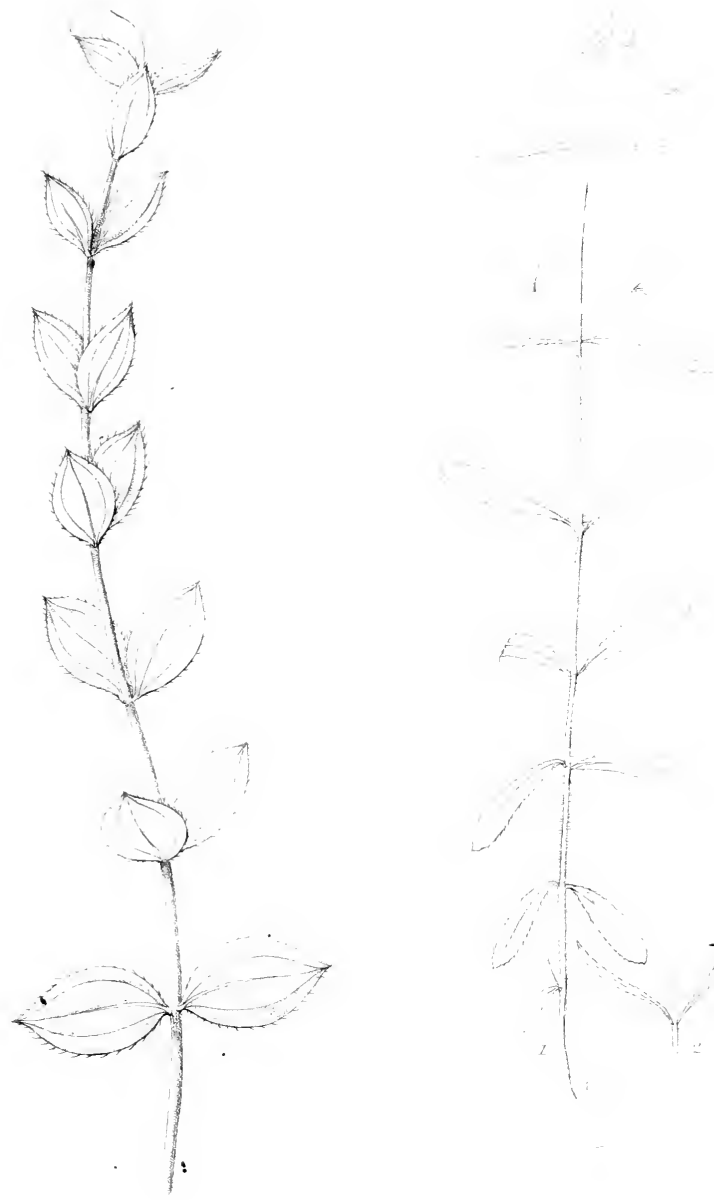

Silinevie cillesese.

-hlenes lelen. 

In pine-woods of Georgia and Florida. $\odot$. June, July. v. s. in Herl. Leconte. Flowers small, yellow.

7 . R. caule cylindrico subpubescente, foliis alternis linearibus oblongis obtusis sessilibus utrinque pubescentibus, floribus subsolitariis.-Lam. encycl. 6. p. 2.

In Carolina. Bosc. + . Flowers yellow.

\section{EPJLOBIUM. Gen. pl. 639.}

1. E. folitis sparsis lineari-lanceolatis venosis glabris, floribus inæqualibus, staminibus declinatis.-Willd. sp. pl. 2.

angustifoli. p. 313.

Icon. Fl. aian. 289. Curt.fl. lond. 2. t. 24.

In wet springy ground in the mountains of New Hamp. shire, New York, and Pensylvania, also in Canada. 4. July. v. v. Flowers beautiful purple, sometimes white; the plant often above five feet high.

2. E. foliis alternis lanceolato-ovatis subintegerrinis pubescentibus aveniis, floribus inæqualibus. $W^{\prime}$ illd.sp. pl. 2.

linearifolia. p. 314 .

Jcon. Fl. dan. 565 .

3. E. foliis angusto-lanceolatis integerrimis, caule pumilo. tetrapetalum. Pallas in Herb. Lamlert.

In Labrador. $\beta$. on the north-west coast. 24. July. $v$. s. in Herb. Lamlert. Flowers purple, large.

3. E. caule tetragono glabriusculo, foliis oppositis, supremis alternis lanceolatis acuminatis serrulatis, pedunculis axillaribus alternis elongatis. calycis laciniis angustis longitudine petalorum, stylo exerto, stigmate crasso 4. lobo.

On the north-west coast. Palias. 4. v. s. in Herb. Lamlert. Flowers yellow, the size of E. angustifolium.

4. F. caule lineis prominulis subquadrangulatis, foliis op- telragonum. positis, supremis aiternis lanceolatis serrulatis. - Willd. sp. pl. 2. p. 317 .

Icon. Fl.dan. 1029.

In low grounds : Canada to Carolina. 24. July. v, v. Flowers small, pale red.

5. E. caule tereti pubeccente superne virgatim ramoso, foliis caulinis oppositis, rameis alternis, linearibus integerrimis, floribus paucis terminalibus longissime pedinculatis.

luteum. 


\section{E. oliganthum. Mich.fl. amer. 1. p. 223 ?}

In Canada and on the high mountains of New York and Pensylvania. 4. July. v. v. Flowers very small, pale red or white.

coloratum. 6. E. caule tereti pubescente, foliis lanceolatis serrulatis petiolatis oppositis, superioribus alternis glabris rubrovenosis. Willd. enum. 411.

In Pensylvania. Muhlenlerg. 4. July. v. $v$.

palustre. 7. E. caule tereti, foliis sessilibus lanceolatis subdenticulatis, stigmate indiviso.-Willd. sp.pl.2.p.317.

lcon. Engl. lot. 346.

In low grounds: Pensylvania to Virginia. 4 . July. v. v.

alpinum.

8. E. caule simplici subtereti 1-2-floro, foliis oppositis ellipticis integerrimis, floribus sessilibus.-Willd. $s p$. pl. 2. p. 318 .

Icon. Fl. dan. 322.

In Labrador. Colmaster. 4. May, June, v. s. in Herb. Dickson. The smallest species, not above two inches high; flowers pale purple.

\section{GAURA. Gen. pl. 638.}

biennis. 1.G. foliis lanceolatis dentatis, spica conferta, fructibus subrotundo-4-gonis pubescentibus. - Willd. sp. pl. 2. p. 311 .

Icon. Bot. mag. 389. Pluk. amalth. t. 428.f. 2 .

On the edges of woods in fertile stony soil: Pensylvania to Carolina. $\delta$. July, Aug. $v . v$. Flowers rosecoloured, large.

angustifolia. 2. G. foliis crebris linearibus repando-undulatis, spicx fructibus dissitis oblongo-4-gonis utrinque acutis subcandicantibus. Mich.fl. amer. 2. p. 226.

In dry old fields and woods : Virginia to Carolina. $\delta$. July. $v . v$. Flowers scarcely half the size of the foregoing, pale red.

337. CLARCKIA. Pursh in linn. soc. trans. v. 11.

pulchella.

1. Clarckia. Pursh l. c.

On the Kooskoosky and Clarck's rivers. M. Lewis. $\delta$. June. $v$. $s$. Flowers beautiful rose-coloured or purple.

Caulis erectus, teres, superne subramosus, pedalis et ultra. Folia alterna, linearia, integerrima, glabra. 


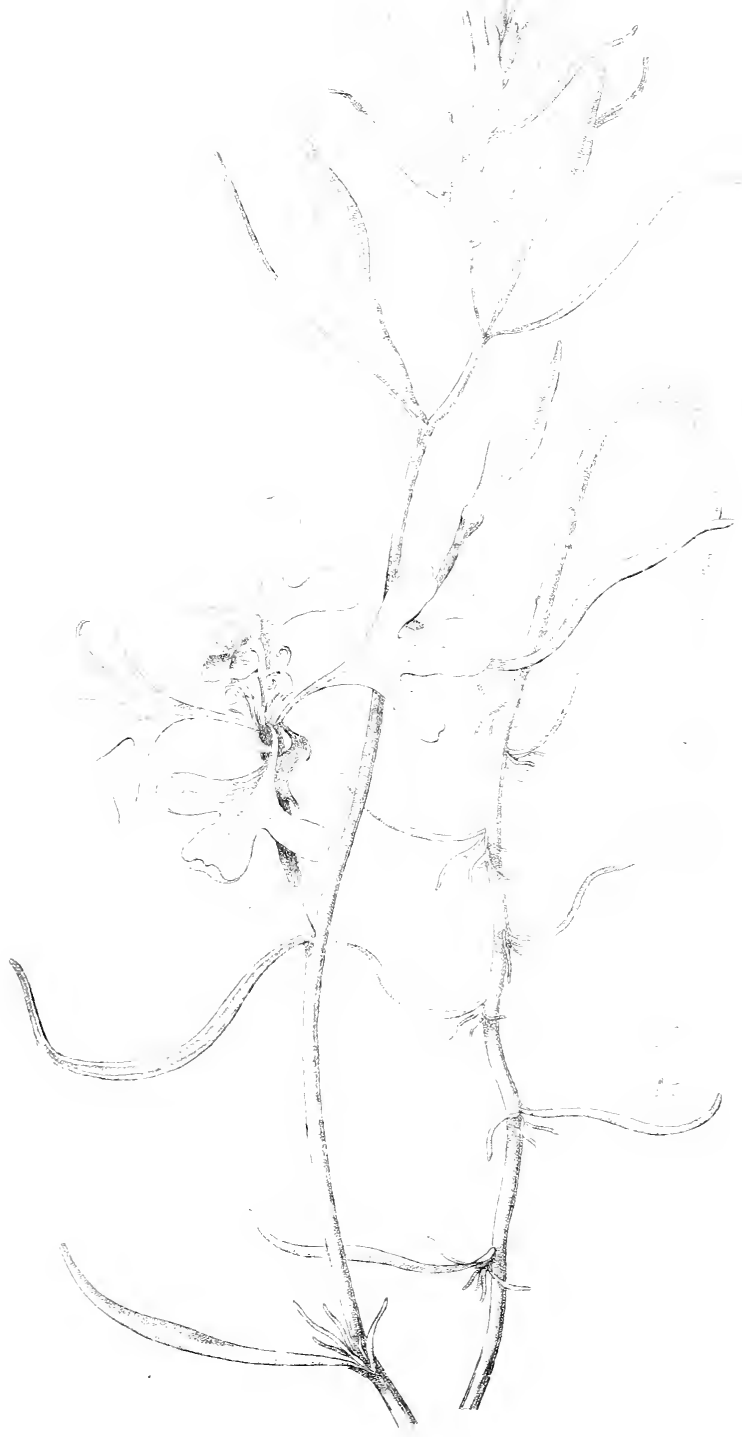

Courtice fuetothelle. 

Flores ex axillis superioribus, solitarii, subsessiles, magni, amœne purpurei. Caly $x$ œnotheræ. Petala unguiculata, 3-partita, laciniis lateralibus divaricatis. Stamina 4: antheris linearibus, involutis: altera 4. duplo breviora: antheris castratis, subrotundis. Stylus longitudine fere petalorum. Stigma pallide luteum, 4-partitum : laciniis subrotundis.

\section{OENOTHERA. Gen.pl. 637.}

1. O. caule villoso scabro, foliis orato-lanceolatis planis dentatis, floribus terminalibus subspicatis sessilibus, staminibus corolla brevioribus.-Willd. sp. pl. 2 . p. 306.

Icon. Fl. dan. 446 . Alp. exot. t.324.

Common in old fields : New England to Carolina. of. June, I'uly. $v \cdot \boldsymbol{v}$.

I have frequently observed a singularity in this plant, and it might be interesting to make further inquiry into its cause; it is, that in a dark night, when no objects can be distinguished at an inconsiderable distance, this plant when in full flower can be seen at a great distance, having a bright white appearance, which probably may arise from some phosphoric properties of the flowers.

2. O. caule purpurascente muricato, foliis lanceolatis planis, staminibus longitudine corollæ. Willd. sp. pl. 2. p. 807 .

Icon. Nurray com. gæett. 7. $t$. 1.

In old fields and along fences: Pensylvania to Carolina. $\delta$. July, Aug. v. v. Flowers smaller than the first species.

3. O. caule lævi subvilloso, foliis ovato-lanceolatis planis, staminibus corolla longioribus. Willd. sp. pl. 2. p. 306 .

Icon. Mill. ic. 189. f. 1. Meerb. ic. 34.

In fields and woods: Canada to Virginia; rare. $\delta$. July. $v . v$.

4. O. caule glabriusculo ramoso, foliis ovato-lanceolatis grandiflora. glabris, staminibus declinatis. Willd. sp. pl. 2. p. 306. farviflora.

biennis.

muricata. In woods and fields of Carolina. Bartram. $\delta^{2}$. July. $v . v$. Flowers larger than any other of the North American species, and of an agreeable scent.

5. O. caule diffuso molliter pubescente, foliis ovali-oblon- 
gis dentato-sinuatis, floribus axillaribus villosis, capsulis prismaticis.-Willd. sp. pl. 2. p. 309 .

Icon. Murruy com. gett. 5. t. 9. Pluk. alm.t.203.f. 3 In dry ficlds of Virginia and Carolina. $\odot$. June, Jaly $v, v$.

minima.

glauca.

fruticosa.

6. O. caule simplici unifloro, foliis pusillis lanceolatis integerrimis pilosis, flore sessili hirsuto, germine prismatico.

In barren pine-woods of Georgia. Enslen. ๑. June. v.s. Not above an inch high; flower smallest of all the genus.

7. O. glaberrima; foliis lato-ovalibus repando-subdentatis levigatis glaucis, capsula ovato-tetragona pedicellata. - Mich. fl. aner. 2. p. 224.

On the banks of the Mississippi, in Illinois, and on the Peaks of Otter, Virginia. 24. July. v. v. A handsome species with considerable large flowers.

8. O. glabriuscula ; foliis lanceolatis subdentatis acutis, capsulis pedicellatis oblongo-clavatis angulatis. Willd. sp. pl. 2. p. 310 .

Icon, Bot. mag. 332. Meerb.ic. 33.

In shady woods, on the edges of rivulets and springs : Pensylvania to Carolina, 4. July. v. v. Commonly: called Sun-drops.

pumila. 9. O. glabra; caulibus adscendentibus, foliis lanceolatis integerrimis obtusis, capsulis subsessilibus elliptico-obovatis angulatis.-Will. . p. pl. 2. p. 310.

Icon. Bot. mag. 355. Mill. 'ict. t. 188.

In dry fields of Virginia and Carolina. 24. July. v.v .

hybrida.

10. O. catle erecto villosn, foliis utrinque pubescentibus lanccolat is remote subdentatis undulatis, capsulis subspicatis breviter stipitatis ovato-tetragonis. Mich. $\mu$. amer. 1. p. 22.5.

O. mollissima. Wall. fl. car. 129.

Onagra floribus speciosis lnteis \&c. Gron. fl.virg. 59.

In sandy fields of Virginia and Carolina. 4. Jume, July. $v . v$.

linearis. 11. O. tota pubescens, gracilis; foliis linearibus integris, capsulis longiuscule stipitatis subrotundo-tetragonis villosis. Mich. fl. amer. 2. p. 225.

angustifolia. brevifolia. a. Pluk. mant. t. 426. f. 6 .

ß. Onagra 491 . Gron. Jl. virg. 59. In dry barren fields; Virginia and Carolina. 4. July. 
$v$ v. Flowers large, in proportion to the very low plant.

12. O. caule debili pubescente, foliis lanceolatis obtusiusculis planis integris, calycis tubo laciniis duplo breviore, capsula clavata acutangula sessili.-Mich. $f$. amer. 1. p. 225.

O. biennis. Walt. fl. car. 129 ?

In barren lands of Canada and on the mountains of Pensylvania and Carolina. 4. July, Aug. v.v. Flowers small, golden-yellow.

13. O. subpubescens; caule pum:lo subsimplici, foliis lanceolato-oblongis obtusiusculis integris, floribus ad summitatem axillaribus, capsulis sessilibus clavato-turbinat1s subæqualiter 8-gonis.-Mich. fl. amer. 1.p. 225.

On r cks near Lake Mistassins. Michaux. On high mountairs of Pensylvania and Virginia. 4. July, Aug. $v . v$. Plant upright, flowers small.

14. O. scapis radicalibus unifloris, foliis oblongo-lanceolatis repando-denticulatis decurrentibus, petalis obcordatis, staminibus corolla brevioribus.

On the falls of the Missouri. M. Lewis. 21. July. $v$. s. Flowers large, purple, with dark veins : resernbles $O$. acaulis $\mathrm{C}_{\text {avanill. }}$

All the species, excepting the last one, have yellow flowers.

\section{OXYCOCCUS. Pers. syn. 1. p. 419.}

1. O. repens; foliis ovalibus integerrimis margine revolutis subacutis glabris subtus albicantibus, pedicellis elonvulgaris. gatis, corollæ laciniis ovalibus.

O. palustris. Pers. syn. 1.p. 419.

Vaccinium Oxycoccus $\alpha$. ovalifolius. Mich. $f$. amer. 1. p. 228.

Vaccinium Oxycoccus. Willd.sp.pl. 2. p. 354.

Icon. Fl. dan. 80. Lam. illustr. t. 286.f. 3.

In bogs and mosses on the mountains, frequent : Canada to Pensylvania. $\quad$. May-July. $v, v$. A small evergreen creeping plant; flowers red; berries light purple, smaller than the following species.

scapigera.

chrysautha.

pusilía.

. repens; caulibus adscendentibus, foliis oblongis in- macrocarpus. tegerrimis planiusculis obtusis glabris subtus albicantibus, pedicellis elongatis, corollæ laciniis lanceolatis.Pers. syn. 1. p.419. 
Vaccinium macrocarpon. Willd.sp.pl. 2. p.355.

Vaccinium Oxycoccus $\beta$. oblongifolius. Mich. fl. amer. i p. 228.

Icon. Wangh. amer. t. 30.f.67. Pluk. alm. t. 326.f.6. In bogs, principally on sandy soil and high mountairis, frequent: Canada to Virginia. $\zeta$. May-July. v.v. Berries larger, bright red, known by the name of Crunberries, as a very agreeable tart, and collected in great abundance for that purpose.

erectus.

3. O. erectus; foliis ovalibus acuminatis serrulatis ciliatisque, pedicellis axillaribus, corolla longa demum revoluta.

Vaccinium erythrocarpum. Mich. fl. amer. 1, p. 227.

On high mountains of Virginia and Carolina. $\zeta$. June. $v$ v. Berries scarlet and quite transparent, of an exquisite taste.

340. MENZIESIA. Smith ic. inedit. 56.

ferruginea. 1. M. foliis obovato-lanceolatis subtus extra nervos glabris, calycibus sub-4-fidis, floribus urceolatis octandris.Willd. $s p . p l .2 . p .355$.

M. urceolaris. Parad. lond. 44.

Icon. Smith ic. inedit. 1. t. 56 .

On the Columbia river. M. Leuis. $h$. June. $v$. s. in Herb. Lambert. A considerable tall shrub; flowers of a ferruginous colour, as in the following species. Previous to my seeing Mr. Salisbury's account and the specimens in the herbarium of A. B. Lambert, Esq. I considered this and the following species to be the same, though I had seen specimens of the present one in the collection of M. Lewis, Esq.

globularis. 2. M. foliis lanceolatis subtus glaucis extra nervos pubescentibus, calycibus 4 -fidis, floribus globosis octandris. - Salisb. in parad. lond. 44.

M. Smithii. Mich. fl. amer. 1.p. 235.

Azalea pilosa. Lam. illustr. 1. p. ....

Icon. Parad. lond. 44.

On high mountains of Virginia and Carolina; plentifully on the Cacapon mountains near Winchester, Virginia. $h$. May, June. v.v. Not above four feet high. Flowers yellowish-brown.

empetriformis.
3. M. foliis linearibus serrulatis subtus concavis, pedunculis terminalibus aggregatis, floribus campanulatis decan- 
dris, calycibus obtusis. Smith in linn. trans. 10. p. 380 .

On the north-west coast. Menzies. On the Rockymountains and near the mouth of Columbia river. M. Lewis. $\quad$. July. $v, s$. Flowers pale red.

4. M. foliis sparsis confertis linearibus obtusis cartilagineo. denticulatis, pedunculis terminalibus aggregatis unifloris, floribus campanulatis 10-andris, calycibus acutissimis.-Swartz in linn. trans. 10. p. 377.t.30. J. 1. Andromeda taxifolia. Pall. fl. ross. t. 72. f.2.

Erica cærulea. Willd. sp. pl.2.p. 393.

Phyllodoce taxifolia. Parad. lond. 36.

On the White Hills of New Hampshire. Prof. Peck. On the north-west coast and Labrador. H:rb. Banks. 々. July. v.s. Flowers red.

\section{DIOSPYROS. Gen. pl. 1598.}

1. D. foliis ovatu-oblongis acuminatis glabris reticulato-venosis, petiolis pubescentibus, genmis glabris.-Willd. sp. pl. 4. p 1107.

Icon. Mill. ic. 126. Calest, car. 2. t. 76. Mich arb. 12. In woods and old fields: New York to Louisiana. $h$. May. v. $v$. A middle-sized tree; flowers pa'e yellow; fruic known by the name of Persimon, the size of a conimon plum, golden-yellow, of an agreeable taste, when perfectly ripe, but extremely astringent before that time. In the Northern States the truits are not eatable till the frost has mellowed them.

2. D. foliis oblongis acutis subtus pubescentibus, petiolis longis, fructibus oligospermis.

In the lower counties of Virginia, Carolina and Georgia. r. April. $v \cdot v$. Though Michaux in his Arbres forestiers considers this only as a variety, I am inclined to take it as a distinct species; not only sbape and pubescence of the leaf, but difference in the structure of the fruit and seeds, indicate it sufficiently.

\section{ACER, Gen.pl. 1590.}

1. A. foliis palmato subquinquelobis basi cordatis inæqualiter inciso-dentatis subtus glaucis, incisuris acutis, umvirginiana. corulka. 
Icon. Mich.arl.14. Schrmidt arl.1. t.6. Catesl. car.1. t. 62 .

In low woods: Canada to Florida. $h$. April, May. $v . v$. A middle sized rree : flowers and seeds red; commonly known under the name of Red-maple or Su'amp-matle.

dusycarpum. 2. A. foliis palmato-5-lobis basi truncatis inæqualiter inciso-dentatis subtus glabris glancisque, sinubus obtusis, floribus conglomeratis, pedicellis brevissimis, germinibus tomentosis.-Willd.sp. pl.4. p. 985.

A. eriocarpum. Mich.fl. amer.2. p. 253.

A. tomentosum. Hort. paris.

Icon. Mirh. arb. 13. Schmidt arb. 1. t.7.

On the banks of rivers : New England to Georgia. $h$. April, May. v. v. A large tree; flowers and seed greenisb yeliow; known by the name of White- or Soft-maple.

barbatum. 3. $\Lambda$. foliis ovato-cordatis breviter trilobis inæqualiter serratis subtus ad nervos pubescentibus glancisque, pedunculis pilosis masculis ramosis, fenineis simplicibus, calycibus intus barbatis, capsulæ alis erectis.-Mich. fl. amer. 2. p. 252.

A. carolinianum. IValt. fl. car. 251.

In deep pine and cedar swamps: New Jersey to Carolina. h. April, May. v.v. A small tree; flowers pale-green; leaves small.

saccharinum. 4. A. foliis palmato-5-lobis basi subcordatis acuminatis sinuato-dentatis subtus g'aucis, pedunculis corymbosis nutantibus.-Willd. sp pl. 4. p. 985.

Icon. Mich. arb. 15. Schmidt arl. 1. t.8.

In low rich valleys : Canada to Pensylvania. h. April, May. $v . v$. A large timber tree; flowers yellow. The sugar prepared from the sap of this tree is one of the gieatest conveniences for the inhabitants of the western countiles, is equal to any other sugar, and procured with little trouble.

nigrum.

5. A. foliis palmato-5-lobis sinu clauso cordatis, lobis divaricatis sinuato-subdentatis subtus pubescentibus, floribus corymbosis, capsulis turgide subglobosis.-Mich. arb. p. 238.

Icon. Mich. arb. 16.

On mountaiu lands : New York to Carolina. $h$. April, May. $v, v$. This large tree produces sugar similat 
to the foregoing species, and occupies the same situations where the other is not found; called Black. maple.

6. A. foliis digitato-5-lobis, sinubus rotundatis, lobis subtrilobatis repando-dentatis subtus pubescentibus, racemis erectis, filamentis 9. hirsutis, germinibus hirsutissimis.

On the great rapids of the Columbia river. MI. Leuis. $r_{c}$. April. v.s. A very tall tree; leaves larger than any other known species; flowers greenish-yellow, in long compound racemes.

Arlor grandis. Ramuli juniores purpurascentes, glabri. Folia magna longe petiolata, juniora pubescentia. Bractece gemmarum longissimæ, lineares, apice incisæ, sericeo-villosæ. Racemi terminales, erecti, elongati. Pedicelli inferne aggregati, superne soli. tarii, glabri. Calyx 9-fidus : laciniis obovatis, interioribus vix latioribus. Filamenta 9. subulata, supra medium barbata, calyce vix longiora. Germen hirsutissimum. Stylus glaber. Flores mas.uli decandri : filamentis calyce duplo longioribus.

7. A. foliis orbiculatis basi subcordatis 7 -lobis inæqualiter acute-dentatis utrinque glabris, nervis venisque ad axillas pilosis.

On the great rapids of Columbia river. $M$. Lewis. $h$. v.s.s.f. This beautiful species has leaves of the size of A.rubrum.

8. A. foliis inferne rotundatis, superne acuminato-tricuspi datis argute-serratis glabris, racemis simplicibus pendulis..-Mich.fl. amer. 2. $p 252$.

A. pensylvanicum, Willd.sp.pl.4 p. 989 .

A. canadense. Marsh arb.....

lcon. Mich. ari.17. Schmidt arb. 10. Wangh. amer. t. $12 f .28$.

In mountaiı woods: Canada to Virginía. দ. May. $v . v$. A small tree with an elegant striped bark; known by the name of Striped-maple or Moose wood.

9. A. foliis subquinquelobis acutis dentatis subtus pubescentibus, racemis compositis erectis.-Willd. sp. pl. 4 .

circinatum.
cind

macrophyl-

lume. p. 988 .

A. pencylvanicum. Wangh.amer. 82. t. 12.f. 30.

A. parviflorum. Ehrh. leitr. 4. p. 25.

A spicatum. Lam. encycl. 2. p. 377.

Icon. Schmidt arb. 11. Du Roi harlk. 1.t.2.

strialume.

montanum. 
In Canada and on the Allegany mountains; frequent. h. April, May. v. v. Flowers very small, greenishyellow.

Negundo. 10. A. foliis pinnatis ternatisve inæqualiter serratis, floribus dioicis. Willd. sp. pl. 4. p. 992 .

Icon. Mich arb. 18. Schmidt arb.12. Wangh. amer. t. 12.f. 29.

On the banks of rivers: Pensylvania to Carolina. $h$. May, June. v. v. A large tree, commonly called Bux Elder or Ash-leaved Maple.

343. DIRCA. Gen. pl.665.

palustris. 1. Dirca. Willd.sp.pl.2.p.424.

Icon. Duham. arb. 1. t.212. Amon. acad. 3. t. 1.f.7. In shady and boggv woods: New York to Carolina. h. March, April. v. v. A low shrub; flowers yellow; known by the name of Leather-wood, on account of the extraordinary toughness of its branches.

344. JEFFERSONIA. Barton in act. philad. Mich. $\boldsymbol{A}$. amer. 1.p. 236.

diphylla. J.Jeffersonia. Bart.l.c.

J. Bartonis. Mich. fl. amer. 1. p. 237.

Podophyllum diphyllum. Willd. sp.pl. 2. p.1141.

On the side of hills, in rich soil, particularly limestone :

Virginia and Tennassee; plentifully about Harper's

Ferry and the Sweet-springs, Virginia. 4. April, May. v. $\%$. Flowers white, resembling those of Sanguinaria; the capsule is covered with a lid, which opens with elasticity and scatters the ripe seeds.

345. PISTIA. Gen.pl.1112.

spathulate.

1. $P$ foliis in petiolum abrupte angustatis superne dilatatis rotundato-obtusis. Mich.fl. amer. 2. p. 162.

In Carolina. Michaux. +. Flowers white, axillary. 


\section{II. $D I G Y N I A$.}

346. CHRYSOSPLENIUM. Gen. pl. 763.

1. C. foliis oppositis subrotundis basi in petiolum attenuatis levissime crenatis.-Willd. sp. pl. 2. p. 638.

oppositifoli. Icon. Fl. dan. 365 . Engl. lot. 490.

On rocks in rivulets and springs, near cascades; in shady situations: Canada to Carolina. 2 . May. v. . Flowers brownish-yellow. Probably a distinct species, if compared in the living plants.

\section{I. TRIGYNIA.}

\section{POLYGONUM. Gen. pl. 677.}

* Floribus axillarilus.

1. P. floribus 8 -andris $\mathbf{3 - g y n i s , ~ o c h r e i s ~ o b t u s i s ~ l a c e r i s ~ m e m - ~}$ branaceis, foliis lineari-lanceolatis acutis margine revolutis carnosis, caule suffruticoso.-Willd. sp. pl. 2. p. 449.

Icon. Cam. epit. 691 .

B. P. maritimum floribus carneis speciosis. Clayt. n. 497 .

On the sandy beach: Pensylvania and Virginia. $\eta$. 4 .

marinum Aug. $v . v$. A small prostrate evergreen plant, with white or rose-coloured flowers.

2. P. floribus 8-andris 3-gynis, foliis lanceolatis margine scabris, ochreis nervis remotis, caule procumbente herbaceo. Willd.sp.pl. 2. p. 449.

Icon. Engl. lot. 1252. Mart. Rl. rust. t. 91.

๙. P. foliis pusillis lanceolato-oblongis. Mich. $f$. amer. 1. angustifulip. 237.

B. P. foliis lato-ovalibus obtusis quasi buxifolium. Mich. latifolium. l. $c$.

On pastures and road sides, in gardens, \&c. common. $\odot$. April-Oct. v. v. Flowers sessile, white, very small.

3. P. floribus 3-andris 3-gynis, foliis lanceolatis, ochreis abbreviatis margine laceris, ramis interrupte inultiflo-

ramosissi mum. 
ris, caulibus stricte-ramosissimis striatis.-Mich. $f$. amer. 1. p. 237.

P. erectum. Willd. sp. pl. 2. p. 450?

In cultivated grounds: Pensylvania and Kentucky. $\odot$. June-Aug. $v . v$. Flowers on short pedicels, green ish-white.

senue.

4. P. pumilum; fuliis longe-linearibus strictis acuminatis, ochreis tubulosis apice villosis, caule gracili erecto ramoso acutangulo, floribus alternis subsolitariis.Mich. Al. amer. 1. p. 238.

P. barbatum. Wall. fl. car. 131?

In sandy fields and pine-woods: Canada, New Jersey, and Carolina? ๑. July, Aug. v. v. Not above six inches high, very slender; flowers smail, white.

\section{** Spica gracili.}

Hydropiperoides.

mite.

hirsutum.

virginianum.
5. P. floribus 8 andris semi-3-gynis, foliis lanceolatis glabris, ochreis laxis glabris apice ciliatis maculatis, spicis filiformibus debilibus subcernuis, bracteis remotiuscule alternis.-Mich. fl. amer. 1. p. 238. sul. P. Hydropiperide.

In inundated and exsiccated places; common : Canada to Carolina. $\odot$. Aug. Sept. v. v. Flowers white; taste and appearance of $P$. Hydropiper, but different in the flowers.

6. P. floribus 8 -andris seni-3-gynis, foliis anguste larceolatis subhirsutis, ochreis hirsutis pronisse ciliatis, spi. cis linearibus, bracteis ciliatis subimbricatis.-Pers. syn. 1. p. $4 \cdot 16$.

P. lyydropiperoides. Mich. fl. amer. 1.p. 239.

In inundated places, along ditches and ponds: Pensylvania to Carolina. $\odot$. June-Sept. v. v. Fiowers pale purple; leaves not acrid.

7. P. floribus 8-andris seni-3-gynis approximatis, follis sessilibus lanceolatis, pedunculo elongato distachyo, spicis linearibus, caule adscendente hirsuto.- Walt. $f$. car. 132. Mich.fl. amer. 1.p. 239.

In low wet places and in ditches: Lower Carolina and Virginia. $\odot$. July-Sept. v. $v$.

8. P. Aloribus 5-andris 2-gynis inæqualibus, foliis lato-ovalibus, spicis longissime virgatis, floribus remotis.Willd. sp. pl. 2. p. 442.

In shady woods : Canada to Florida. 4. June, July. v. $v$. 
** Spica confertiflora.

9. P. caule simplici monostachyo, foliis ellipticis planis pe- listortoides. tiolatis, bracteis unifloris 2-3-valvis.

In low grounds on the banks of the Missouri, called Quamash-flats. M. Leuis. 4. June. v. s. Flowers white tinged with red.

Caulis teres, glaber. Folia elliptico-oblonga, in petio. lun decurrentia, integerrima, plana, utrinque glabra, subtus glauca, superiora !inearia, sessilia. Spira ob. longa. Bractece membranaceæ, unifloræ, 2-3-valves; vaivula exterior subrotunda, acuminata, carinata. Calyr subinfundibulifornis: laciuiis oblongis acutis. Filumenta 7-8. corolla longiora. Styli 3.

10. P. caule simplici monostachyo, foliiz lanceolato-linearibus glabris margine revolutis, spica lineari, bracteis viviparum. ovatis acuminatis.

In Carada. 24. June, July. v. s. in Herb. Lamlert. This almost stemles; variety I have seen in dried specimens coming from Lower Canada. The specimen in the coliection of A. B. Lambert, Esq. came from Labrador.

11. P. floribus 5-anciris semi-2-gynis, spica crlindracea, ochreis trutcatio glabris, foliis ovatis. Wrilld. enum. 429.

P. amphibium. Mich. fl. amer. 1. p. 240.

a. P. foliis ovato-ellipticis obtusis.

3. P. follis ovato-oblongis acuminatis. P. Bistorta. Walt. fl car. 131?

$\alpha$. In lakes and ponds: Canada to Pensylvania. $\beta$. In overflowed places on the Ohio and Nississippi. 4 . July, Aug. v. v. Flowers dark red.

12. P. Aloribus 8-andris semdigynis, spicis oblongis, pedunculis hispidis, follis lanceolatis, octreis glabris nudisque, caule tumide.geniculato. - Willd. sp. pl. 2. p. 448.

On the edge of ponds and ditches, in overfowed grounds; common: New York to Carolina, and principally in the western counties. $\odot$. June-Aug. v. v. Flowers large, rose-colotired.

13. P. floribus 6-andris semi-2-gyris, spicis ovato-oblongis Persicaria. erectis, pedunculis lavibus, foliis lanceolatis, ochreis glabriusculis apice ciliatis. - Willd. $s_{p}^{p}$ pl 2. p. $4.4 \hat{b}$.

Icon. Fl.dan.702. Engli. lot. 750 .

pensylvani. cum.

quaticum. terrestre. 
In overflowed and wet places; common. $\odot$. July, Aug. $v . v$. Flowers rose-coloured; leaves generally marked with a black spot in shape of a half moon; known by the name of Ladies-thumb.

orientale. 14. P. floribus 7-andris 2-gynis, foliis ovatis, caule erecto, ochreis hirtis hypocrateriformibus. Willd. sp. pl. 2. p. 448.

Icon. Bot. mag. 213. Mill. ic. 201.

Near gardens and in old fields : Virginia. ๑. July, Aug. v. $v$. Sometimes six feet high; flowers large, crimson.

\section{**** Florilus paniculatis.}

articulatum. 15. P. floribus 8 -andris 3 gynis, spicis paniculatis filiformibus, floribus solitariis pedunculatis, bracteis imbricatis truncatis, foliis linearibus, ochreis vaginalibus truncatis, caule herbaceo.-Willd. sp. pl. 2 p. 450.

In sandy barren fields: Canada to New Jersey. $\odot$. July, Aug. $v . v$. A handsome, delicate plant, about a foot high; flowers rose-coloured, mixed with white.

polygamum. 16. P. floribus 8-andris 3-gynis, spicis paniculatis, floribus solitariis, calycis laciniis obovatis, foliis spathulatis, ochreis integris latere altero lanceolatis, caule fruticoso. Vent. hort. cels. 65.

Polygonella parvifolia. Mich. fl. amer. 2. p. 241.

In the barrens of Carolina. $\zeta$. July. +. Flowers white. I strongly suspect this to be only a variety of $P$. articulatum, as the description and figure of Ventenat strongly indicate; but the northeru plant is certainly only an annual.

***** Floribus subracemosis; foliis lasi incisis vel cordatis.

sagittatum. 17. P. floribus 8 -andris semi-3-gynis capitatis, foliis sagittatis, caule retrorsum aculeato.-Willd.sp. pl. 2. p. 453. Icon. Gmel.sil.3.t. 13.f.2. Hort. cliff. t. 12. Pluk. mant.t. 398.f. 5 .

In low wet meadows and ditches, in open situations: New York to Florida. $\odot$. June-Aug. v. v. Flowers white.

arifolium. 18. P. floribus 6-andris semi-2-gynis distinctis, spicis patucifloris, foliis hastatis, caule retrorsum aculeato.IVilld.sp. pl.2. p. 453.

Icon. Pluk. amalth t. $398, f .3$. 
In low shady places, principally on the mountaina : New York to Carolina. $\odot$. July, Aug. $v . v$. Flowers white, tinged with red.

19. P. floribus 8-andris 3-gynis, racemis paniculatis, foliis cordato-sagittatis, caule erectiusculo inermi, seminum angulis æqualibus.-Willd. sp. pl. 2. p.455.

Icon. Engl. lot. 1044.

Common Buck-wheat, thongh not originally indigenous, is frequently found in old fields and woods, as it were in a wild state.

20. P. floribus 8-andris semi-3-gynis, foliis oblongis bastatocordatis, caule volubili angulato asperiusculo, laciniis calycinis obtuse carinatis. - Willd. sp. pl. 2. p. 455.

Icon. Fl. dan. 744 .

In cultivated grounds, along hedges : Pensylvania to $\mathrm{Ca}$ rolina. $\odot$. July, Aug. v. v.

21. P. floribus 8-andris semi-3-gynis, foliis cordatis, stipulis cilinode. subacutis basi extrorsum serie ciliorum circumdatis, caule anguloso prostrato aut scandente asperiusculo, laciniis calycis obtuse carinatis.-Mich. fl. amer. 1. p. 241.

In hedges and fields : Canada to New York. ๑. July. $v, v$.

22. P. floribus S-andris 3-gynis, foliis lato-cordatis, stipulis truncatis nudis, caule volubili glabro, calycibus fruc. tiferis tripteris.-Willd.sp. pl. 2. p. 456.

Icon. Pluk. alm. t. 177.f. 7. Sloan hist. 1.t. go.f. 1. In shady woods: New York to Kentucky. 24. July, Aug. $v$. $v$. Stems generally red, climbing to a consideralle height.

\section{BRUNNICHIA. Gart. Gen. pl.7it.}

1. Brunnichia. Willd.sp.pl.2.p.731.

Rajania ovata. Walt. fl. cur. $2+7$.

Icon. Gart. carp. 1. t. 45.f. 2.

In wet shady places, climbing among bushes : islands of Georgia ; in Tennassee, \&c. 4. June, July. v. v. A smooth vine; leaves cordate, acuminate; flowers in one-sided racemes.

scandens.

Figotyrum.

Convolvulus.

Con 
Icon. Bot. mag. 1049 .

On the banks of the Mississippi, near Kaskaskias. $\odot$. July. v. v. A small climbing plant; flowers small, herbaceous.

350. SAPINDUS. Gen. $p l .681$.

Saponaria. 1. S. foliis glabris abrupte pinnatis, foliolis ovali-lanceolatis, rachi alata, fructibus sphæricis.-Willd. sp. pl. 2. p. 468.

Icon. Comm hort. t. 04 .

On the sea-coast of Georgia and Carolina : probably introduced. $\zeta . \quad v, v . s . f l$. A small tree.

\section{TETRAGYNIA.}

351. MYRIOPHYLLUM. Gen. pl. 1440.

sijicatum.

1. M. foliis omnibus pinnatis capillaceis, spica nuda interrupta, Horibus masculis polyandris.-IVilld. sp. pl. 4. p. 400 .

Icon. Fl. dan.681. Engl. bot. 83.

In slow-flowing waters and ponds: Canada to New Jersey. 4. July, Aug. v, v. $\Lambda$ sub-aquatic small plant.

verticillatum.

2. M. foliis pinnatis capillaceis, superioribus pectinato. pinnatifidis, floribus omnibus axillaribus verticillatis, inferioribus fenineis, superioribus masculis aut hermaphroditis 8-andris.-Willd.sp. pl.4. p. 407.

Icon. Fl. dan. 1046. Engl. lot. 218.

In stagnant waters and ditches: Canada to Pensylvania. 2!. July, Aug. $v . v$.

scabratum. 3. M. foliis pinnatifidis, floribus omnibus verticillatis axillaribus, superioribus masculis 4 -andris, inferioribus femineis, fructu 8-angulato.-Mich.fl. amer. 2. p. 190.

Potamogeton pinnatum. IValt. $f$. car. 90.

In stagnant waters of Carolina and Georgia. 24. July. $v$. s.

heterophyl- 4. M. foliis inferioribus capillaceo-pinnatis, superioribus lum. floratibus ovalibus argute serratis, floribus masculis 6-andris. Hich. $f$ l aner.2.p. 191.

Potamogeton verticillatum. Iralt. fl. car. 90 .

In the waters of Carolina and Georgia. 4. July. v. s. in Herb. Walt. 


\section{ENNEANDRIA.}

\section{MONOGYNIA.}

352. LAURUS. Cal. 4-6-partitus. Nectar. glandulis 3 . bisetis, germen cingentibus. Filam. interiora quorum 3. alterna sterilia glandulifera. Drupa 1-sperma. Polygama.

353. ERIOGONUM. Cal. subcampanulatus, 6-fidus. Cor. o. Sem. 1. triquetrum, calyce tectum. Involucrum campanulatum.

\section{TRIGYNIA.}

354. PLEEA. Cor. 6-partita, patens. Caps. subrotundotrigona, 3-locularis. Sem. numerosa, oblonga, margini valvularum adnata. Spica spathis 1-floris.

\section{I. $M O N O G Y N I A$.}

352. LAURUS. Gen. pl. 6 ss.

1. L. foliis perennantibus ovato-lanceolatis ramulisque glabris nitidis, racemis corymboso-paniculatis terminalibus, calycis patuli laciniis oblongis obtusis subæqualibus deciduis, baccis ovatis.-Mich. fl. amer. 1. p. 244.

Laurus baccis atro-purpureis, pedunculis rubris insidentibus. Clayt. $n .485$.

Icon. Catesb. car. 2. t. 28.

On the sea-coast of Georgia and Florida. $h$. May. v. v. s.fl. Flowers white; berries black, on thick red peduncles.

Cateslyana. 
carolinensis. 2. L. foliis perennantibus ovali-lanceolatis opacis subtus glaucis, pedunculis simplicibus, fasciculo subcapitato paucifloro terminatis, calycis laciniis exterioribus duplo brevioribus, baccis globosis.-Mich. fl. amer.1. p. 245.

L. Borbonia. Hortul.

L. foliis acuminatis, flore albicante, baccis cæruleis, pediculis rubris insidentibus. Clayt. ult.

glabra.

Icon. Catesb. car.1.t.63. Mich. arl.....

pubescens.

obtusa.

a. L. foliis subtus glabris.

f. L. foliis subtus pubescentibus.

$\gamma$. L. foliis obovatis obtusis.

In deep cedar and cypress swamps: Virginia to Louisiana. $\eta_{2}$. May. v. $v$. A small tree; flowers greenish-yellow; berries dark-blue, on red peduncles; known by the name of Red Bay: the wood is very valuable.

Benzoin. 3. L. ramis virgatis sub floratione aphyllis, foliis deciduis cune to-obovalibus subtus albicantibus subpubescentibus, floribus glomerato-umbellatis, gemmis pedicellisque glabris. - Willd. sp.pl. 2. p. 485 .

L. Pseudo-Benzoin. Niich. fl. amer. 1. p. 243.

Icon. Comm. hort. 1. t. 97 .

In low grounds and on the banks of rivulets : Canada to Florida. $\quad$. March, April. v. v. A large shrub; flowers yellowish-green; berries scarlet; known by the name of Strice-u'ood.

Disspyrus. 4. L. humilis, virgata, nudiflora; foliis deciduis oblongoovalibus subtus venosis subtomentosis, fioribus glomerato-umbellatis, gemmis pedicellisque villosis.-Mich. fl. amer. 1. p. 243.

L. melissæfolia. IValt. $f$. car. 134.

Icon. Bot. mag. 1470.

In low grounds and near rivers: Virginia and Carolina. $\zeta$. April. $v . v$. A low shrub, resembling the pre. ceding very much ; Alowers greenish-yellow; berries small, scarlet or purple.

geniculata. 5. L. ramis divaricatis flexuosis, foliis deciduis ovalibus obtusiusculis glabris, basi subtus barbatis, sub floratione nullis, umbellulis terminalibus pancifloris, antheris 4-locularibus.-Mich. fl. amer. 1. p. 244. Walt. $f$. car. 133.

L. æstivalis. Willd. sp. pl. 2. p. 484.

L. foliis lanceolatis enervibus annuis. Gronov. virg. 159. 
Icon. Bot. mag. 1471.

In low grounds, near rivers and on islands: Carolina. h. April. v. v.; v. s. in Herl. Gronov. Flowers yellow; berries globous, scarlet.

6. L. foliis integris lobatisque. Willd. sp. pl. 2.p. 455. Icon. Trew ehret. t. 69 \& 70. Catesb. car. 1. t. 55. Mich. arl.t.....

In woods and along the banks of large rivers, frequent in old fields : Canada to Florida. $々$. March, April. $v$. $v$. Flowers yellow; berries blue. This valuable tree, in respect to its medicinal properties, grows to a large size in the southern regions, where I have seen trees two feet in diameter; but from Virginia northwards it decreases in size, until it becomes a mere straggling shrub.

\section{ERIOGONUM. MTich.flamer. 1.p. 246.}

1. E. caule erecto dichotomo, florum fasciculis axillatibus solitariis sessilibus, calycis laciniis subrotundis obtusis tomentosis, foliis ad genicula caulis sessilibus ternis quaternisve cuneato-obovalibus supra glabris.-Mich. fl. amer. 1. p. 246.

Icon. Mich. l.c. l.24.

In pine-barrens of Carolina and Georgia. 24. July. v. v. The whole of this plant, excepting the upper side of the leaves, is covered with a close tomentum or woolly coat ; flowers from twelve to fifteen collected in a cup or involucrum, white.

2. E. caule simplici nudo, florum fasciculis terminalibus umbellatis pedunculatis, umbella involucrata, calycis laciniis oblongis acutis sericeo-lanatis, foliis radicalibus petiolatis lanceolato-oblongis supra villosis.

On the prairies of the Missouri. Nuttall. 24. July. $v$. s. in Herl. Nuttall. The whole of this plant, as well as the foregoing, is tomentose, but of a more loose texture, approaching to villous ; the calyx is covered with long white silky down; flowers bright yellow. In the same country a third species has been discovered, of which I have not materials enough to give a description.

tomentositm.

sericeum.

Sassafras. 


\section{TRIYG YNIA.}

354. PLEEA. Mich. fl. amer. 1. p. 247.

tenuifolia. 1. P. glaberrima; foliis angustissime ensiformibus sensim p. 248.

Icon. l. c.t. 25.

In open wet woods of Lower Carolina. Michaux. 4. $v$. s. Flowers of a yellowish-brown, the size of Ornithogalum umlellatum. 


\section{D ECA N D R IA.}

\section{MONOGYNIA.}

* Monopetala.

355. ARBUTUS. Cal. 5-partitus. Cor. ovata : basi ore pellucida. Bacca supera, 5-locularis.

356. GAULTHERIA. Cal. 5-fidus, basi bibracteatus. Cor. ovata. Caps. 5-locularis, vestita calyce baccato.

357. VACCINIUM. Cal. 4-5-fidus. Cor. urceolata aut campanulata, 4-5-fida : laciniis reflexis. Filam. germini inserta. Bacca infera, 4-5-locularis, polysperma.

358. ANDROMEDA. Cal. 5-partitus. Cor. ovata: ore 5-fido, reflexo. Caps. supera, 5-locularis, valuulis dissepimento contrariis.

359. KALMIA. Cal.5-partitus. Cor.hypocrateriformis : limbo subtus 5-corni, in quorum foveis antheræ incumbunt. Caps. 5-locularis.

360. EPIGÆA. Cal. 5-partitus, extus tribracteatus. Cor. hypocrateriformis. Caps, 5-locularis. Recept. 5. partita.

361. RHODODENDRON. Cal.5-partitus. Cor. subinfundibuliformis, inæqualis. Stam. declinata. Caps. 5-locularis.

362. RHODURA. Cal.5-dentatus. Cor.3-petala. Stam. declinata. Caps. 5-locularis.

** Polypetalce; Regulares.

363. PYROLA. Cal. 5-partitus. Pet. 5. Stylus staminibus longior. Cats. 5-locularis, angulis dehiscens.

364. CHIMAPHILA. Cal. 5-partitus. Pet. 5. Stigma sessile crassum, orbiculatum, germine immerso. 
Antherce rostratæ, foramine subbivalvi dehiscentes. Caps. 5-locularis, angulis debiscens.

365. LEDUM. Cal. minimus, 5-dentatus. Cor. plana, 5-partita. Caps. 5-locularis, basi dehiscens.

366. AMMYRSINE. Cal. profunde 5-partitus. Pet.5. Stamina exerta. Caps. 5-locularis, apice dehiscens. 367. Cletthra. Cal. 5-partitus, persistens. Pet. 5. Slyl. apice 3-fidus, persistens. Caps. 3-locularis, 3-valvis.

36s. MYlOCARIUM. Cal.5 5entatus. Pet.5. Stigm. capitatum, trigonum, sessile. Caps. 3-4-alata, 3locularis.

369. MONOTROPA. Cal. o. Pet. 10. horum 5. exteriora basi txcavata, mellifera. Caps. 5-valvis, polysperma.

370. DION Ris. Cal. 5-phyllus. Pet.5. Stigm. fimbriatrm. Caps.1-locularis, gibba, polysperma.

71. JUSSI EAA. Cal. 4-5-partitus, superus. Pet. 4-5. Cops.4-5-locularis, oblonga, angulis debiscens, calyce coronata. Stm numerosa, minuta.

372. GYMNOCladDUS. Cal. tubulosus, 5-fidus. Pet.5. xqualia, tubo inserta. Stam. non exerta. Legumen 1. Joculare, intus pulposum. Flores racemosi. Dioicus.

373. ACACia. Cal.tubulosus, 5-dentatus. Pet.5. Stam. 5-10. exerta. Legumen 1-loculare, 2-valve. Po. lygama.

374. SCHRANKIA. Cal. tubu?osus, 5-dentatus. Pet. 5. Stam. 8-10, exerta. Siliqua 4-valvis. Polygama.

\section{*****is Polypetalce; Irregulares.}

375. CASSIA. Cal. 5-phyllus. Pet. 5. subæqualia. Anth. supremæ 3. steriles, infimæ 3 . rostratæ, in filamentis longioribus incurvis. Legumen membranaceum, 2-valve.

376. PODALYRIA. Cal. subbilabiatus, 5-fidus. Cor. papilionacea, alæ vexilli longitudine. Legumen læve, ventricosum, polyspermum.

377. CERCIS. Cal.5-dentatus, inferne gibbus. Cor. papilionacea : vexillo sub alis brevi. Legumen. Folia simplicia.

378. VIRGILIA. Cal.5-dentatus, inferne gibbus. Cor. papilionacea : alæ vexillo breviores. Legumen com* pressum, polyspermum. Folia pinnata. 


\section{DIGYNIA.}

379. HYDRANGEA. Cal. superus, 5-dentatus, Pet. 5. Caps. 2-locularis, 2-rostris, foramine inter cornua dehiscens.

3so. SAXIFrAGA. Cal.5-partitus. Pet. 5. Caps. 2 rostris, 1-locularis, polysperma.

381. TIARELla. Cal.5-partitus. Pet. 5. integra, calyci inserta. Caps. 1-locularis, 2-valvis : valvula altera majore

3S2. MITELLA. Cal.5-fidus. pet.5. pinnatifida, calyci inserta. Caps. 1-locularis, 2-valvis: valvulis æqualibus.

3s3. SAPONARIA. Cal. tubulosus, nudus. Pet. 5. mguiculata. Caps. oblonga, 1-locularis.

3s4. DIANTHUS. Cal. cylindricus, longus, coriacens, basi squamis 4-s. Pet. 5. unguiculata. Caps. c5lindrica, 1-locularis, apicc debiscens.

385. SCLERANTHUS. Cal. 1-phyllus, cui Stamina inserta. Cor. o. Sem. 1-2. calyce inclusa.

\section{TRIGYNIA.}

386. CUCubalus. Cal. inflatus. Fet.5. unguiculata, absque corona ad faucem. Caps. 3-locularis.

387. SILENE. Cal. cylindricus. Pet. 5. unguiculata, coronata ad faucem. Caps, 3-locularis.

388. STF.llaria. Cal. 5-phyllus, patens. Pet. 5. bipartita. Caps. ovata, 1-locularis, polysperma, apice 6-dentata.

3s9. ARENARIA. Cal. 5-phyllus, patens. Pet.5. in. tegra. Caps. 1-locularis, polysperma.

\section{TETRAGYNIA.}

3g0. Micropetalum. Cal. 5-phyllus, patens. Pet.5. minuta, integra ant nulla. Stigm.4, sessilia. Caps. ovata, calyce longior, 4-valvis.

\section{PENTAGYNIA.}

391. SPERGULA. Cal. 5-phyllus. Pet. 5. integra. Caps. ovata, 1-locularis, 5-valvis.

392. CERASTIUM. Cal. 5-phyllus. Pet. 5. bifida aut 
emarginata. Caps. 1-locularis, apice dentatim de. biscens.

393. AGROSTenma. Cal. 1-phyllus, coriaceus. Pet.5. unguiculata: limbo obtuso, indiviso. Caps. 1-locularis.

394. OXAl.Ts. Cal.5-phyllus. Pet. 5. unguibus connexa. Stamina inæqualia, 5. breviora, exteriora basi connata. Cafs, angulis elastice dehiscens, 5-gona. Sem. subarillata.

395. PENTHORUM. Cal.5-fidus. Pet. 0. aut 5. Caps. 5. cuspiciata, 5-locularis.

396. SEDUM. Cal. 5-fidus. Pet.5. Squame nectariferæ 5 , ad basin germinis. Caps. 5.

\section{DECAGYNIA.}

397. PHYTOLACCA. Cal. o. Pet.5. calycina. Bacca supera, 10-locularis, 10-sperma.

\section{MONOGYNIA.}

355. ARBUTUS. Gen.pl. 750.

laurifolia. 1. A. arborea; foliis oblongis utrinque acuminatis acnte serratis glabris, racemis axillaribus secundis sessilibus solitariis. Willd.sp.pl.2.p.617.

In North America. Linn. suppl. 238. h. +. What part of North America this tree comes from, I am unacquainted with; probably from the west coast, and very likely may be found on the Columbia, as well as the foregoing species.

Nothing can be found in the Linnæan Herbarium respecting the plant. J. E. Smith.

Menziesii. 2. A. arborescens; foliis lato-ovalibus integerrimis glabris, petiolis longis, racemis axillaribus et terminalibus paniculatis densifloris.

On the north-west coast of America. A. Menzies. 5 . $v$. s. in Herb. Banks.

iomentosa. 3. A. frutescens; ramis hispidis, foliis ovalibus acutis basi subcordatis subtus albido-tomentosis, petiolis brevibus, pedunculis axillaribus longitudine foliorum subcapitato-racemifluris, fiombus campanulato-urceolatis biacteatis. 



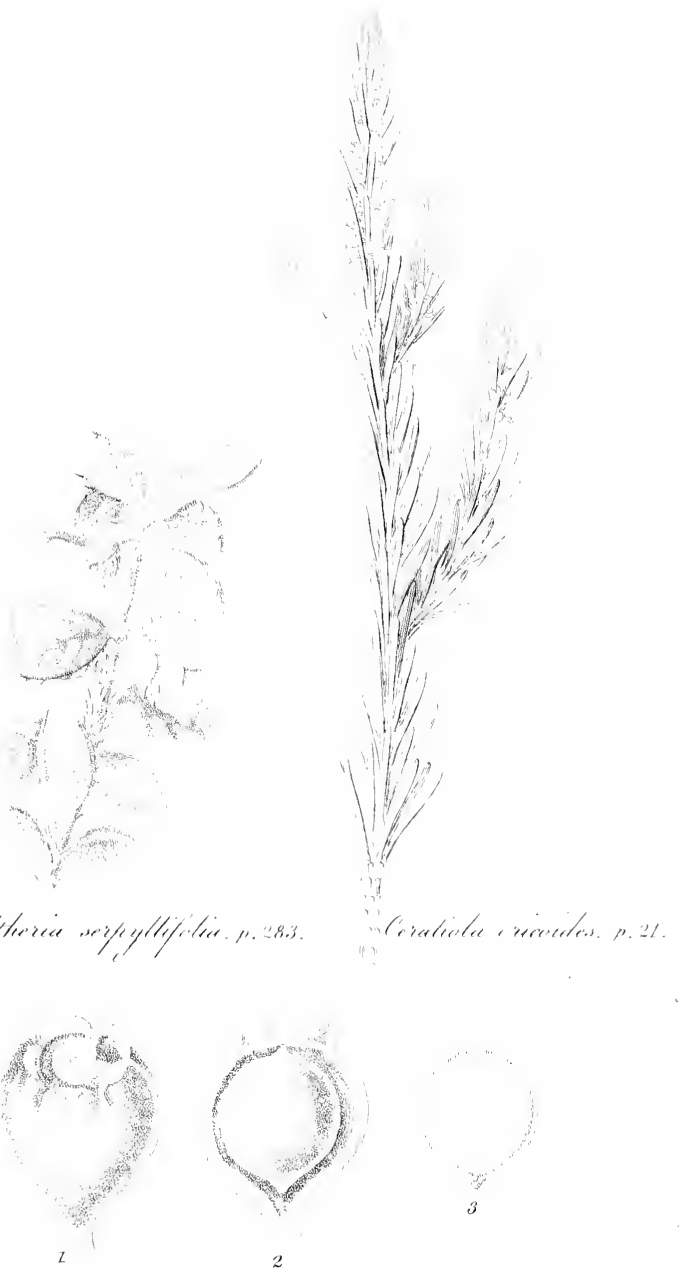

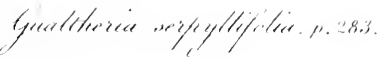



On the north-west coast of America. A. Menzies. $\eta$. $v$. s. in Herl. Banks.

4. $\Lambda$. caulibus procumbentibus, foliis obovatis acutis rngoaljina. sis serratis, racemis terminalibus.-Willd. sp. pl. 2 . p. 618 .

Icon. Fl. dan. 73. Engl. bot. 2030.

In Canada. $々$. May, June. v. v. Flowers white; berries black.

5. A. caulibus procumbentibus, foliis cuneato-obovalibus

Uva ursi. integerrimis margine convexis coriaceis, floribus fasciculatis, baccis 5-spermis.-Willd.sp.pl. 2. p. 618.

Icon. Schmidt arl.t. 138. Fl. dan.t.33. Engl. lot.714. In the pine-barrens of New Jersey, and in mountainous and rocky situations of Canada and New England. h. June. $v . v$. Hlowers pale red; berries scarlet. On the plains of the Mississippi the Indians smoke the leaves under the name of Sacacommis, and consider them of great medicinal virtue.

356. GAULTHERIA. Gen. pl. 749.

1. G. caule procumbente, ramis erectis, inferne nudis su- procumbens. perne confertim foliosis, foliis obovatis basi acutis tenuissime ciliato-dentatis, floribus paucis terminalibus nutantibus.-Willd. sp. pl. 2. p. 616 .

Icon. Bot. rep. 116. Duham. arb. 1.t. 113.

In dry woods, on mountains, and in sandy plains: Canada to Virginia. $々$. May. v. v. A little shrubby plant, resembling seedling plants of Kalmia latifolia; flowers white; berries red, eatable, and known by the name of Partridge-lerries. The leaves, if properly cured, make a most excellent tea, for which reason it is likewise known by the name of Mountain-tea.

2. G. caule repente hispido, foliis subrotundo-ovalibus acu- Serpyllifoliu. tis, floritrus solitariis axillaribus subsessilibus octandris, corollis brevi-campanulatis.

Vaccinium hispidulum. Willd. sp. pl. 2. p.355.

Arbutus filiformis. Lam. encycl. 1. p. 228.

Icon. Mich.fl. amer. 1. t. 23.

In sphagnous swamps, particularly where cedars and other evergreens abound: Canada to Pensylvania. $h$. April, May. v. v. A small creeping plant; berries white, very sweet, and agreeable to eat.

3. G. erecla fruticosa; foliis ovatis subcordatis serrulatis,

Shalion. 
racemis secundis bracteatis, pedicellis medio bibracteolatis.

On the falls of Columbia and near the Western Ocean. M. Lewis. On the North-west coast. A. Menzies. h. May, June. v. s. in Herb. Leuis. nec non Banks.

Frutex sempervirens. Rami teretes, verrucosi, glabri : juniores ferrugineo-pubescertes. Folia altema, brevissime petiolata, ovata vel lato-ovalia, interdum basi subcordata, abrupte acuminata, serrulata, coriacea, utrinque glabra, subtus nervis venisque reticulatis prominentibus. Racemi in apice ranulorum axillareset terminales, simplices, ferrugineo-pubescentes. Flores secundi, bracteati, albi, rore rubro pubescentes. Pedicelli solitarii, medio bibracteolati. Bracte爪 lanceolatæ. Corolla urceolata, limbo subclauso, 5-dentata. Bacca subglobosa, acuta, carnosa, purpurea, extus hirsuta, intus semi-5-valvis : loculis polyspermis. Semina ovato-subtriquetra.

This clegant evergreen shrub is in high esteem among the natives, on account of its berries, which they call Shallon, and which name I have adopted here. Mr. A. Menzies, wbo was the first discoverer of this shrub, observes one peculiarity, which is its growing under the shade of close pine forests, where scarcely any other plant thrives: this makes it so much more desirable for our plantations, as a highly ornamental shrub, since but few will bear such a situation. I was first inclined to take this species to belong to Arbutus, having only seen imperfect specimens; but through the liberal communication of Mr. A. Menzies, I have been enabled to class it more properly with this genus, though it deviates from both in some respects.

357. VACCINIUM. Gen. pl.65s.

+ Foliis deciduis.

* Corollis campanulatis.

stamineum, 1. V. foliis ovalibus acutis integerrimis subtus glaucis, pedicellis solitariis axillaribus filiformibus, corollis pattalo-campanulatis, laciniis oblongis acutis, antheris exertis, dorso aristatis, baccis pyriformibus.-Willd. $s p$. pl. 2. p. 349 .

Icon. Pluk. alm.t.339.f.3. lona.

In dry woods; common: New England to Florida. h. May, June. v. $v$. About two feet high; flowers white: berries green, or white when per- 
fectly ripe. In the mountains they are known by the name of Deer-lerries.

2. V. foliis ovalibus seu obovatis acutis integerrimis subtus album. glaucis, nervis venisque pubescentibus, pedicellis solitariis axillaribus filiformibus, corollis patulo-campanulatis, lacinis ovatis subacuminatis, antheris exertis dorso aristatis, baccis subglibosis. - Willd. sp. pl.2.p. 350 ?

Icon. Bot. rep. 263. V. stamineum.

In dry sandy woods: New Jersey to Carolina. April, May. $v . v$. Flowers white, larger than No. i; berries white or greenish-white. I am not certain whether this is the $V$, album of Linnæus or not. As I never could find any certainty about the authentic species, I venture to adopt this species for it. In the Banksian Herbarium it is under the name of $V$. elevatum.

3. V. foliis petiolatis obovalibus utrinque acutis mucronatis glanduloso-serrulati-, supra nitidis, reticulato-venosis, subtus subpubescentibus, racemis bracteatis nutantibus, pedicellis axillaribus solitariis filiformibus, corollis cylindrico-campanulatis; laciniis acutis, antheris inchinsis dorso aristatis. - Mich. fl. amer. 1. p. 230.

V. diffusum. Ait. kew. 2. p.11. Herb. Eanks.

In dry woods, on the rocky banks of rivers : North Carolina to Florida. $h$. May, June. $v . v$. A large shrub, sometimes twenty feet high, very elegant : flowers white, tinged with red; berries globular, black, almost dry.

4. V. ramulis, foliis racemisque hispidiusculis atomis resinosis irroratis, foliis obovato-oblongis basi acutis mucronatis integerrimis concoloribus, racemis bracteatis, pedicellis brevibus axillaribus subsolitariis medio bibracteatis, corollis campanulatis, laciniis rotundatis, antheris inclusis. Bot. mag. 1106. Bot. ref. 112.

V. hirtellum. Ait. kew. ed. 2. v. 2. p.357. Herl. Banks.

V. frondosum. Mich. Al. amer. 1.p. 230.

In dry sandy woods, particularly pine-forests : New Jersey to Florida. 2 . June, July. v. v. A low shrub; flowers large, white; berries black, globular.

5. V. foliis obovato-oblongis obtusiusculis muticis integerrimis glabris subtus glaucis copiose atomis resinosis irroratis, racemis laxis bracteatis, pedicellis longis fili-

arloreum.

dumosum.

frondosum. 
formibus bracteolatis, bracteis linearibus, corollis ovato-campanulatis, laciniis acutis, antheris inclusis.Willd. sp. pl. 2. p. 352.

V. glaucum. Mich. fl. amer. 1. p. 231.

Icon. Bot. rep. 140.

lanceolatum. $\quad \beta$.V. foliis lanceolatis utrinque acutis.

V. venustum, Ait. kew. 2. p. 11. Herb. Banks.

In open woods, sandy soil : New Jersey to Carolina. $々$. May, June. v. v.; v. s. in Herl. Banks. About three feet high ; flowers small, almost globular, white; berries large, blue, olobular, eatable; called by the country people Blue-tungles.

pallidum. $\quad 6 . \mathrm{V}$. foliis ovatis acutis serrulatis glabris, racemis bracteatis, corolllis cylindraceo-campanulatis. Ait. kew. 2.p. 10.

In North America. Aiton. h. May, June. t. A doubtful species. I have not been able to ascertain it, even after a strict examination of the Banksian Herbarium.

* Corollis urceolatis; Antheris inclusis.

\|f Floribus racemosis seu fasciculatis.

resinosun. $\quad 7 . \mathrm{V}$. foliis tenuibus petiolat is oblongo-ovalibus plerumque ubtusis muticis integerrimis subtus atomis resinosis irroratis, racemis lateralibus secundis, pedicellis brevibus subbracteolatis, corollis ovato-conicis 5-gonis.Willd. sp. pl. 2. p. 352.

Andromeda baccata. Wangh. amer. 2. t.30.f. 69 .

viridescens. $\alpha$.V. corollis Juteo-viridescentibus.

rubescens. $\quad \beta . V$. corollis rnbescentibus. Bot. mag. 1288.

lutescens. $\quad \gamma$.V. foliis lanceolatis, corollis rubro-lutescentibus.

V. parviflorum. Bot. rep. 125.

In woods and mountains; frequent : Canada to Carolina. h. May, June. v.v. From two to four feet high; berries black, eatable.

corymlosum. 8. V. ramis floriferis subaphyllis, foliis oblongo-ovalibus utrinque acutis mucronatis subintegerrimis, junioribus utrinque pubescentibus subtus subtomentosis, adultis supra glabris, subtus nervis venisque pubescentibus, racemis brevibus sessilibus squamoso-bracteatis, corollis cylindraceo-ovatis, calycibus erectis, stylo subexerto.-Willd. sp.pl. 2. p.351.

V. disomorphum. Mich. fl. amer. 1.p. 231.

V. album. Lam. encysl. 1. p. 73 .

In swamps and wet woods : Canada to Virginia. $h$. June. v. v.; v. s. in Herl. Banks. A shrub, rising 
sometimes to the height of seven or eight feet ; flowers white, sometimes tinged with red; berries black, insipid.

9. V. ramis floriferis aphyllis, foliis oblongis utrinque acutis integerrimis glabris nervis subtus subpulescentibus, racemis confertis bracteatis, corolliscylindraceis, laciniis acuris, calycibus reflexis, stylo incluso.-Willd. $s p$. pl.2. p.353. Ait. kew. 2. p. 12.

V. disomorphum var. Mich. fl. amer. 1. p. 231.

Icon. Bot. rep. 138.

In low grounds and swamps: New Jersey to Virginia. h. Mlay, June. $v . v . ; v$ s. in Herb. Banks. A tall slirub with red twigs: flowers large, white with a red tinge; berries black, insipid. This species has a number of varieties in size, shape, and colour.

10. V. ramis floriferis elongatis subaphyllis, foliis lanceolatooblongis utrinque acutis serrulatis glabris, racemis sessilibus corymbosis bracteatis, corollis cylindraceis, fauce coarctato, laciniis brevissimis, calycibus reflexis, stylo incluso.-Willd. sp. pl. 2. p.353. Ait. kew. 2. p. 12.

Icon. Bot. rep. 181.

In swamps of Virginia and Carolina. $h$. May, June. $v$. $v$. A middle-sized shrub; flowers tinged with crimson, very handsome.

11. V. foliis oblongis acutis serulatis glabris, racemis aggregatis terminalibus corymbosis bracteatis, pedicellis longis nutantibus, corollis cylindraceis, laciniis erectis brevibus, calycibus acutis erectis, stylo subexerto.Willd. sp.pl. 2. p.351. Ait. kew. 2.p. 11.

V. formosum. Bot. rep. 97 .

6. V. foliis angusto-lanceolatis utrinque acuminatis.

In swamps of Lower Carolina and Georgia. 々. May, June. v. v.; v. s. in Herb. Banks. An elegant small shrub; flowers red and white striped; calyx brown.

12. V. foliis sessilibus cuneato-lanceolatis subserrulatis venosis pubescentibus, fasciculis sessilibus, pedicellis brevissimis, calycibus acuminatis, corollis ovatis fauce valde coarctatis, stylo exerto.-Mich. fl. amer. 1. p. 232 .

In shady woods and swamps: Virginia and Carolina. $々$. May, June. v.v. Flowers snall, yellowish.white; berries small, globular, black. amœnum.

virgatum.

fuscatum.

angustifoli-

uns.

galezans. 
ligustrinum. 13. V. ramis angulatis, foliis subsessilibus erectis lanceolatis mucronatis serrulatis venosis pubescentibus, fasciculis gemmaceis sessilibus, pedicellis vix ullis, corollis oblongiuscule-ovatis.-Willd. sp. pl. 2.p.352. Mich. fl. amer. 1. p. 233.

In dry woods: Pensylvania to Virginia; common on the mountains. $\vdash_{2}$. May, June. v. v. An upright straight shrub; flowers purplish-red, berries black. This species varies extremely in the shape and size of the leaves.

tenellum. 14. V. ramis angulatis viridibus, foliis sessilibus ovato-lanceolatis mucronatis serrulatis utrinque lucidis, fasciculis confertifloris subterminalibus sessilibu, corollis ovatis.-Willd.sp.pl. 2. p.353. Ait. kew.2.p. 12.

V. pensylvanicum. Lum. encycl. 1. p. 72. Mich. fl. amer. 1. p. 232.

On dry hills, in gravelly soil : New England to Virginia. h. May. v. v.; v. s. in Herb. Banks. A low, very branching shrub; flowers pale red; caly $x$ green; berries large, blueish-black, extremely sweet and agreeable to eat. The mountains of Pensyivania produce an immense variety of this species, in size, and shape of the fruit, leaves and flowers.

\section{|| || Floribus solitariis.}

uliginosum. 15. V foliis parvis obovatis obtusis integerrimis supra glabris subtus venosis pubescentibus glaucisque. floribus subsolitariis, corollis brevi-urceclatis.-Willd. sp. pl. 2. p. 350. Mich. fl. amer. 1. p. 235.

Icon. Fl. dan. 231. Engl. bot. 581 .

In bogs of the more northern regions of America. $h$. April, May. v. s. From one to two feet high; flowers rose-coloured; stamens from eight to ten; berries blueish-black, eatable.

myrtilloides. 16. V. foliis angusto-lanceolatis membranaceis integerrimis subtus juxta nervos et margine pubescentibus, floribus sparsis subsolitariis brevissime-pedicellatis.-Mich. $f l$. amer. 1. p. 234.

V. angustifolium. Willd. sp.pl.2.p.351. Ait.kew. 2. p. 11.

In Canada about Hudson's Bay and Labrador. $々$. April, May. v. s. in Herl. Banks. Berries large, blueishblack, known by the name of Bluets. 
17. V. pusillum, cespitosum, glaberrimum; foliis cuneatoobovalibus rotundato-obtusis conspicue serratis membranaceis, floribus rameis solitariis subsessilibus, corolla breviter pedicellata. Mich. fl. amer. 1. p. 234.

In the more northern regions, particularly about Hud. sori's Bay. Michaux. h. A little shrub not above three inches high; berries black. Among the specimens of $\mathrm{A}$. Menzies from the north-west coast in the Banksian Herbarium is one very like the present species, but apparently evergreen.

\section{++ Foliis sempervirentibus. \\ * Corollis crampanulatis.}

18. V. humile; caulibus repentibus, ramulis erectis, foliis ubovatis emarginatis revolutis subjerrulatis supra lucidis, subtus punctatis, racemis terminalibus nutantibus, corollis cylindrico-campanulatis._Willd. sp. pl. 2 p. 354. Mich.fl. amer. 1. p. 229.

- Icon. Fl. dan.40. Engl. bot. 593.

On rocks near the sea-coast : Canada to New England. h. May, June. v.v. A low shrub; flowers pale red, generally 4-cleft with four stamina; berries red, acid. The American plant is more robust than the European, and the leaves are considerably larger.

19. V. repens, glaberrimum; foliis petiolatis ovalibus lucidis revolutis rariter denticulatis, fasciculis axillaribus subsessilibus paucifloris, corollis subgloboso-campanulatis brevissime 5 -denticulatis, antheris dorso muticis. Mich. fl. umer. 1. p. 229.

In Carolina. Michuux. h. +. Berries small, black.

20. V. diffusum; ramis adscendentibus laxis, follis oblongolanceslatis utrinque acutis serratis rigidis glabris, racemis terminalibus corymbosis bracteatis paucifloris, floribus nutantibus, calycibus adpressis, corollis patulo-campanulatis profunde acuteque 5-dentatis:Bot. rep. 105.

In Carolina. Fraser. 々. May, June. v. v. Flowers pink red, very ornamental.

\section{* Corollis urceolatis.}

21. V. erectum, ramosissimum; ramis distichis, foliis nitinitidum, dis obovato-ellipticis utrinque acutis glabris serratis, racemis terminalibus corymbosis bracteatis nutantibus, corollis cylindraceis, - Bot, rep. 480.

vor. 1 . 
In Carolina. h. May, June. $v . v$. Flowers pink-red. This species approaches near to No. 20, but differs in the shape of the corolla materially ; it is also near to the following, but sufficiently difietent.

myrsinitis. 22. V. erectum, ramosissimum, microphyllum; foliis sessilibus ovalibus mucronatis subserrulatis supra lævigatis lucidis subtus subhirsutis scabro-punctatis, fasciculis gemmaceis terminalibus lateralibusque, corollis oblongo-ovatis. --Mich. fl. amer, 1. p. 233.

lanceolatum. $\beta$. V. foliis lanceolatis utrinque acutis.

obtusums. $\quad \gamma$. V. foliis subrotundo-obovatis.

In dry sandy woods: Carolina and Florida. $\zeta$. May, June. $\quad v \cdot v . \quad \Lambda$ beautiful little shrub; calyx scarlet; corolla purple.

luxifolium. 23. V. pumilum; foliis obovatis crenato-dentatis glabris; fasciculis congestis subsessilibus axillaribus et terminalibus, corollis brevi-ovatis, filamentis glandulosis, stigmate capitato.-Bot. rep. 4. Bot. mag. 928.

V. brachycerum. Mich. Al. amer. 1.p. 234.

In dry woods, on limestone rocks : western parts of Virginia, near Winchester and the Sweet-springs. $h$. June. $v \cdot v$. A handsome little shrub; flowers white, delicately tinged with red.

ovatum. 24. V. foliis petiolatis ovatis acutis revolutis serratis glabris coriaceis, racemis axillaribus et terminalibus bracteatis brevibus, corollis cylindraceis, calycibus acutis.

. On the Columbia river. M. Lewis. On the north-west coast. Menzies. দ. May. v. s. in Herb. Banks.

altusum. 25. V. repens; foliis parvis ovalibus utrinque rotundatoobtusis nucronatis integerrimis glabris coriaceis, pedunculis axillaribus solitariis unifloris.

On the north-west coast. Mensies. h. v. s.s.fl. in Herl. Banks.

\section{ANDROMEDA. Gen. pl. 747 .}

* Ioliis perennartilus.

tetragona. 1. A. foliis imbricatis carinatis margine nudis, pedunculis axillaribus solıtariis filiformibus unifloris, corollis nutantibus canpanulatis.-IVilld. sp.pl. 2. p. 607. Icon. Pall. fl. rass. 2. t. 73. f. 4 . Fl. lapp. t. 1. f. 4. In Cinada ; Labrador. Colmasler. On the north-west coast. Nelson. দ. May, June. v. s. Flowers winite. 
2. A. foliis imbricatis subulatis glabris, ledunculis solitariis terminalibus unifloris, corollis nutantibus globosohypnoides. canmanulatis. - Wildd. sp.pl 2. p. 6r:8.

Icon. Fl. dan. 10. Pall. fl. ross. '2 t. 73. f. 2.

On the north-west coast. Nel.on. $\eta$. May. $v$ s. in Herb. Banks. A small creeping shrub, resembling a moss; Howers white, tinged with red.

3. A. foliis lineari-lancenlatis convevis revolutis subtus alpolifolia. bicanti-glaucis supra glauco-canescentibus, floribus aggregatis terninalibus. corollis subglobosis, antheris versus apicem aristatis.-Willd. sp. pl. 2. p 610. Mich. fl. amer. 2 . p 254.

a. A. foliis lanceolato-linearibus, laciniis calycinis oblongis rubris. Ait. kew, 2. p. 68 .

Iccn. Pall fl. ross. 2. $p$ 53. $t$. 70. f. B.

6.A. foliis oblongis, corollis ovatis incarnatis, lacinits calycinis patentibus ovatis albis interdum apice rubicundis. Ait. kew. 2. $p 68$.

In bugs of Canada and Labrador, and on the borders of mountain-lakes, in sphagnous grounds: New York and Pensylvania. $\eta$. June. v. $v$. A sma! shrub, about one foot high; flowers white, tinged with red. $I$ strongly suspect the variety $\alpha$. to be a distinct species, which might be called $A$. rosmarinifolia.

4. A. foliis lanceolato-oblongis obtusiusculis obsolete serrulatis subrevolutis squamoso-punctatis subtus ferrugineis, racemis terminalibus foliosis secundis, pedicellis brevibus solitariis axillaribus, calycibus acutis basi bibracteatis, bracteis lato-ovatis acummatis, corollis oblong()-cylindraceis. Willd.sp.pl.2.p.014.

Icon. Pall. fl. ross 2. p. 53. t. 7i.f. J.

In bogs and swamps; frequent, particularly on the mountains: Canada to Virginia. 々. April, May. $v$. $v$. Flowers white.

3. A. foliis lineari-lanceolatis acutis margine subundulatorevolutis squanoso-punctatis subtus subferrugineis, racemis terminalibur foliosis secundis, pedicellis brevibus solitaris axillaribus, calycibus acuninatis basi bibracteatis, bracteis minutis acutis, corollis oblongoovalibus.

A. calyculata $\gamma$. angustifolia. Ait. kew. 2. $p 70$.

In open swamp: : Carolina and Georgis. ?. April, May. v $v$.; v. s. in Herb. Lnmlert. This species approaches nearly to the preceding, but is sufficiently distinct to admit it to be more than a variety. 
ferruginea. 6. A. fruticosa ; ramis subflexuosis, foliis coriaceis distantibus longe petiolatis obovatis plerumque obtusis inte. gerrimis planis margine revolutis subtus squamosofarirosis reticulato-venosis, pedicellis aggregatis axillaribus simplicibus unifloris paucis furfuraceo-ferrugineis, corollis subglobosis, antheris muticis.

A. ferruginea. Walt. fl. car. 138.

A. ferruginea $\beta$. fruticosa. Mich. fl. amer. 1. p. 252. Icon. lent. malm. 80.

In the pine-woods of Georgia and Florida. $\zeta$. June. v. ข. A shrub from three to five feet high. Flowers smail, white inside and ferruginous outside.

rigida.

7. A. arborescens; ramis strictis, foliis coriaceis rigidis confertis brevi-petiolatis cuneato-lanceolatis acutis integerrimis convexis margine revolutis subtus squamosotonentosis subaveniis, pedicellis aggregatis axillaribus simplicibus unifloris numerosis furfuraceo-ferrugineis, corollis subglobosis, antheris muticis.

A. ferruginea. Willd. sp. pl. 2. p.609. Ait. kew. 2. p. 67 .

A. ferruginea $\alpha$. arborescens. Mich. fl. amer, 1. p. 252.

In barren sandy woods : Carolina to Florida. $h_{2}$. April. $v . v$. A shrub almost twenty feet high, or sometimes forming a small tree: though nearly allied to the former species, their habits, and particularly their flowering time, differ so materially, that I have al ways considered them to be distinct species.

nitida.

8. A. glaberrima; ramis subtriquetris, foliis coriaceis ovalibus acuminatis integerrimis lavigatis, costa marginem deflexum percurrente, fasciculis axillaribus, corollis cylindraceis, laciniis calycis elongatis linearibus coloratis, antheris basi bicorniculatis.-Mich. fl. amer. 1. p. 252.

A. coriacea, Willd. sp.pl. 2. p.613. Ait. kew. 2. p. 70.

A. lucida. Lam. encycl. 1. p. 157.

A. marginata. Duhum arb.....

A. mariana. Jacq. ic. 3, t. 465.

Icon. Bot. mag. 1095.

In the sandy forests of Carolina and Florida. $\zeta$. June, July. v. v. A handsome small shrub; flowers pale red; the calyx long, of a dark-red colour; leaves marked with very fine punctures.

axiliaris. 9. A. foliis oblongo-ovalibus basi acutis brevi-acuminatis cartilagineo-serratis lucidis glabris coriaceis, racemis 
spicatis axillaribus sessilibus squamoso-bracteatis undique confertifloris, eorollis cylindraceo-ovatis, antheris muticis.-Willd.sp.pl.2.p.613. Ait. kew. 2. p. 69 .

ß. A. foliis lineari-lanceolatis longissimis.

On the mountains of Virginia to Georgia. 5. May, June. $v \cdot v$. Flowers in short spikes, white; capsules depressed, globular.

10. A. foliis petiolatis ovato-oblongis basi rotundatis superne sensim angustatis acuminat:s subserrulatis, serraturis adpresso-spinulosis glabris coriaceis, racemis subspicatis axillaribus sessilibus squamoso-bracteat is secundis laxiusculis, corollis brevibus cylindraceo-ovatis, antheris muticis.

A. Catesbæi. Walt. fl. car. 137. Willd. sp. pl. 2. p. 613.

In Lower Carolina. h. May, June. v. v. Resembles the foregoing one in several respects. The figure of Catesl. car. 2. t. 43, is so very slightly dene, that there can be no reference made to it, and probably belongs to $A$. racemosa.

11. A. glaberrima; foliis ovato-lanceolatis superne sensin angustatis acuminatis integerrimis seu inæqualiterserratis glabris nitidis reticulato-venosis coriaceis, racemis axillaribus brevissimis corymbosis mudiusculis, floribus pedicellatis nutantibus, corollis cylindraceoovatis, antheris muticis postice gibbis.-Willit. sp. pl. 2. p.613. Ait.kew. 2. p. 70.

A. lucida. Jacq. ic. 1. 1.79.

A. populifolia. Lam. encycl.1.p. 159.

A. reticulata. W'alt. fl. cur. $13 \%$.

A. formosissima. Eurtr, catal.....

A. laurina. Nich. fl, amer. 1.p. 253.

Icon. Smith exot. bot. 89. lona. Jacq. ic. 79. mala.

In sandy swamps of Georgia and Florida. ケ. July. $v$ v. Flowers white, in great abundance; which gives this shrub a fine appearance. The stem is hollow in. side, and is used by the natives for making their pipe. stens of it, from which the name Pipe-stem wood.

12. A. glaberrima; folits oblongo-ovatis acutis tenuissime serrulatis adpresso-ciliatis glabris coriaceis, racemis secundis axillaribus et terminalibus congesto-paniculatis, pedicellis bibracteatis.

In the mountains of Georgia. Lyon. h. May, June. longifulia.

spinulosa.

acuminata.

floribundn 
v. $v$.; v. s. in Herb. Lyon. Flowers clear white, in great abundance.

\section{** Foliis deriduis.}

mariana.

13. A. foliis ovalibus utrinque subacutis integerrimis glabris subcoriaceis subtus pallidi ribus, ranus floriferis subaphyllis, pedunculis fascicularis, corol!in ovato cylindraceis, calycibus folinsis, antheris muticis, capsula convidea - Wild sp pl 2. p. 6. g. excl. syn. Jacyluini.

angustifolia. $\beta$. A. toliis angusio-lanceolar is.

Icon. Pluk mant. t. $44 \mathrm{~s}$.

In wood, and dry swamps, particularly in sandy soil : New England to Florida. $r$. May.- Ang $v, v$. A low shmb; flowers large, white, soneines tinged with red. This plant has a number of very striking varieties.

speciosa.

14. A. folits ovalibus obusis mucronatis crenatis serratisve reticulato venus, ramıs thrifer's denudatis ag regatoracemifloris corolit: cammanulatis, antheris apice geminatim 4 -aristaris - Mich fl. amer. 1, p. 256 .

nitida.

$\alpha . A$ foltis oblonge covatis seratis utrinque virtdibus.

A. cassinefiria $V i n t$ malm. 79 .

pulverulonia. $\beta$. A. foil roturiato-ovatis remote crenatis ramisque albo pulierulenti.

A. pulverulenta. Burtr. it. 476 . Bot. mag. 667.

A. cassinæfolia B. Vent hort cels 60

A. rvata. Sularder mss. in mus Banks.

In swamp, of North Carolina. $\mathrm{F}_{2}$. June. $v, v$. A very ornamental hitle hrub; flowers large, white. I certain'y u ust coincide with Michanx's idea of A. pulverulenta being only a variety, as I very frequetitly have seen intermediate varieties, and even had the trace of both on one plant.

racemosa. 15. A. foiiis ovali-lanceolatis acutis serrulatis membranaceis glabris, spicıs terninalibus secundis eiongatis simplicibus ranosisve, bracteis linearibus acutis, corollis cylindraceis, calycibus acutis basi bibracteatis, antheris apice geminatim quadriaristatis.-Willd. sp. pl. 2. p. 612 .

A. paniculata. Walt. fl. car. 138.

A. racemis simplicibus, foliis lanceolatis alternis, \&c. Gronov. virg 67.

In bogs and swamps; frequent: Canada to Florida. $h$. June, July. v. v. A middle-sized shrub, which may 
be reckoned one of the finest in North America, not only for the graceful appearance of its flowers, but the fine odour they have.

16. A. ramis teretibus, foliis oblongis acuminatis mucronato-serratis glabris, paniculis terminalibus polystachiis, corollis ovoideo-cylindraceis pubescentibus, antheris linearibus muticis. - IVilld. sp. pl. 2. p. 612.

Icon. Bot. mag. 905. Cutest. car. 1. t.71. Mich. arb.....

In the valleys of the Allegany-mountains: Pensylvania to Florida. $h$. June, July. v. $v$. A beautiful tree, from forty to sixty feet bigh. Flowers white. The leaves are of a very pleasant acid taste, from which it has been called Sorrel-tree. They are frequently made use of by hunters in ihose mountains to alleviate thirst.

17. A. pubescens; foliis obovato-lanceolatis acutis subintepaniculata. gerrimis, ramis floriferis terminalibus panioulatis nudiusculis, glomerulis pedunculatis, corollis subglobosis pubescentibus, antheris obtusis muticis. - W Villd. $s p$. pl. 2. p. 612 .

A. globulifera. Hortul.

A. racemosa. Lam. encycl. 1. p. 158.

Common in all swamps and woods : Canada to Carolina. $h$. June, July. v. $v$. Flowers small, white. There are a number of varieties of this shrub, in size, pubescence, shape of leaves, sic.

18. A. hispido-pubescens; foliis obovato-lanceolatis seu obfrondosa. longis acutis serrulatis, ramis floriferis toliosis, glomerulis axillaribus pancifloris subsessilibus, corollis globosis hispidis, antheris aristatis.

A. racemosa. Walt. fl. carr. 138.

A. paniculata foliositiora. Mich. fl. amer. 1. p. 225.

In the lower counties of Virginia and Carolina. $h$. May-July. v. v. Nearly allied to the former; but sufficiently distinct to form a species.

\section{KALMIA. Gen. $p l .743$.}

1. K. ramis, foliis calycibusque hirsutissimis, foliis oppohirsuta. sitis alernisque subsessilibus ellipticis, pedunculis axillaribus solitariis unifloris foliis longioribus. - Hilld. sp. pl. 2. p. 601. Wult. fl. car. 138. Mich. fl. amer. 1. p. 257. 
K. ciliata. Bartr. it. 18.

Icon. Bot.mag. 138.

In barren pine-woods: South Carolina and Georgia. $h$. June - Aug. v. v. A beautiful little shrub, but difficult to cultivate; leaves small, like thyme; flowers large, red.

slauca.

2. K. ramulis ancipitibus, foliis oppositis subsessilibus oblongis lævibus subtus glaucis margine revolutis, corymbis terminalibus bracteatis, pedunculis calycibusque glaberrimis.--Ait. kew. ed. 2. v. 3. p. 47. Willd.sp. pl. 2. p. 601 .

K. polifolia. Wangh. act. soc. berol. 8. p. 129.t.5.

Icon. Bot. mag. 177. Ait. keu'. 2. t. S. Lam. illustr. 363.

rosmarinifo-

lia.

$\beta$. K. foliis linearibus magis revolutis subtus viriditus.

In bogs of Canada and on the borders of mountain-lakes of New York and Pensylvania. h. April, May. v. $v$. An upright, small shrub; flowers pale red, very handsome $\mathrm{Tl}$ ie variety $\beta$. I discovered in a bog near Albany, New York, and am inclined to think it a distinct species.

cuneala.

3. $\mathbb{K}$. foliis sparsis sessilibus cuneato-oblongis subtus pubescentibus apice ininutim aristatis, corymbis lateralibus paucifloris. Mich.fl. amer. 1. p. 257.

On the mountains of Carolina. Michaux. $r_{2}+$ Flowers white, with red at the bottom. Resembles the following one in some respects, but is distinct; the leaves are like those of Axalea, Mich.

angustifolia. 4. K. foliis ternis petiolatis oblongis obtusis subtus subferrugineis, corymbis lateralibus, bracteis linearibus, pedunculis calycibusque glanduloso-pubescentibus.Ait. kew. ed. 2.v.3. p. 47. Willd. sp. pl.2. p.601.

Icon. Bot. mag. 331. Catesb. car.3.t. 17.f. 1. Trew ehret. t. $38 \mathrm{f} .2$.

orata.

$\beta$. K. foliis latioribus subovatis, caule altiore.

In bogs and swamps, and sometimes in dry mountain lands : Canada to Carolina. $\beta$. New Jersey mountains. $h$. May-July. v. $v$. A shrub from one to two feet high; flowers dark red; known by the name of Sheep Laurel, being considered very poisonous when fed upon by sheep.

latifolia. $\quad$ 5. K. foliis longe petiolatis sparsis ternisque ovalibus utrinque lævigatis et subconcoloribus, corymbis terminalibus viscido-pubescentibus.-Willd. sp. pl.2. p. 600. 
Icon. Bot. nagy. 175. Wangh.amer. t. 24.f.50. Catesb. car. 2.t. 98 .

On the sides of stony hills : Canada to Carolina. $h$. June, July. $v \cdot v$. A shrub from three to eight feet high, very elegant when in flower; called Laurel or in the mountains Callico-bush. The whole of this genus are evergreen.

360. EPIGÆA. Gen. pl. 748.

1. E. ramis petiolis nervoque hirsutissimis, foliis cordatoovatis integerrimis, corollis cylindricis.-Willd. $s p$. pl. 2. p. 615 .

Icon. Bot. rep. 102. Lam. illustr. t.367.f. 1. Pluk. alm. t. $107 . f .1$.

On shady rocks and in stony woods : Canada to Carolina. $h$. May-July. $\quad$. $v$. A snall trailing and creeping plant; flowers white, tiliged with red, very fragrant.

\section{RHODODENDRON. Gen.pl. 746.}

1. R. arborescens ; foliis oblongis acutis subtus discoloribus, umbellis terminalibus, calycis laciniis ovalibus obtusis, corollis campanulatis. - Willd. sp. pl. 2. p. 606.

a. R. foliis elliptico-oblongis convexis basi obtusiusculis subtus albicantibus vel ferrugineis, corollæ laciniis subrotundis, stylo staminibus vix longiore, floribus albido-roseis.

R. maximum Schmidt arl.t.121. Bot.mag.951. bona. Lam. illustr. $36+$.

ß. R. foliis cuneats-lanceolatis planis basi sensim acutis subtus pallidioribus, corollæ laciniis rotundato-oblongis, stylo staminibus vix longiore, fioribus minoribus albidis.

$\gamma$.R. altissimum; foliis majoribus oblongo-ellipticis planiusculis basi obtusiusculis utrinque viridibus, corollæ laciniis oblongis obtusis, stylo staminibus paulo longiore, floribus purpurascentibus.

$\alpha$. In the mountains, near rivulets and lakes : Canada to Carolina. $\beta$. In shady cedar-swamps of New Jersey and Delaware. $\gamma$. On the highest mountains of Virginia and Carolina, near lakes. $\zeta_{2}$. $\alpha$. June, July. $\beta$. July, Aug. $\gamma$. May, June. v. $v$. This elegant shrub, with its varieties, grows from four to twenty fuet high ; flowers large and in great abundance. The

maximum.

roseum.

album.

purpureum. 
varietg $\gamma$. approaches near to $R$. fonticum, but is different in its filiaccous calyx and otherwise; it occupies the borders of lakes on high mountains, and grows to an inmense size; its stem is ofien found eighteen inches and more in diameter, and its foliage triple the size of any other species : it might be cousidered as a distinct species. The only plant of this sort 1 have seen in England is in the garden of James Vere, E๙q̣. at kensingron Core. The leaves of var. $\beta$. are so distinct from var, $\alpha$, that it also has claims to be a species.

punctatum.

2. R. foliis ovali-lanceolatis utrinque acutis glabris subtus ferrugine is resinoso-punctatis, umbellis terminalibus, pedicellis brevibus, dentibus calycis brevissimis, corollis infundibuliformibus, laciniis ovatis subundulatis, capsulis elougatis.-Willd. sp. pl. 2. p. 607.

R. minus. Mich. f. amer. 1. p. 258.

Icon. Lot. rep. 30 . Tent. hort cels 15.

On the mountains of Carolina, perticularly on the head. water of the Savannah river. $h$. Julv, Aug. $v v v$. An elegant shrub, not near the size of No. 1 ; flowers pink-red and smaller.

calauliense. 3. R. fol is brevi-ovalibus utrinque rotundato-obtusis glabris subtus discoloribus, umbellis terminalibus, laciniis calycis elongato-oblongis, corollis campanulatis.-Mich. fl. amer. 2. p. 258 .

On the high monntains of Virginia and Carolina, particularly on the head-waters of the Catawta river. b. May, June. v. v. s. fl. The flowers are said to be scarlet.

\section{RHODORA. Gen. pl. 745.}

canadensis, 1. R'odora. Willd. sp. pl.2.p. 603.

Icon. Bot. mag. 474. Lam. illustr. 364. L'Herit. stirp. 1. t. 68.

In bogs of Canada, and on the high mountains of New York and Pensylvania. Ђ. April, May, v. $v, \mathrm{~A}$ shrub about two feet high, of the appearance of $A \approx a$. lea. Leaves elliptic, entire, of a glaucous hue, and pubescent underneath. Flowers in terminal umbels, pale purple. 
363. PYROLA. Gen. $p l .572$.

1. P. foliis rotundatis sive subrotundo-obovalibus obsolete rotundifolia. serrulatis, spica floribus undique versis, pistillo declinato.-. Willd. sp. pl. 2 p. 621.

Icon. Fl. dan. 110. Engl lot. 213. Lam. illustr. t.367. f. 1 .

In dry stony or sandy wonds : Canada to Carolina. $\mathcal{4}$. June, July. $v v$ Flowers white; the stigma is rotate, with five tubercles.

2. P. foliis reniformibus, scapo squamis nonnullis convolutis vaginantibus remote vestito, spica fioribus undi. que rersis, pistillo declinato. Mich fl. amer. 1. p. $: 51$.

In Canada. Michaux. On the mountains of Pensylvania, in beech-woods. P. 24. July. v. $v$. Flowers yellowish-green.

3. P. foliis aubrotundo-ovalibus serrulatis, scapo subnudo, asarifolia. spica floribus undique versis, pistillo recto.-Willd. sp.pl. 2.p.621.

Icon. Fl. dan. 55 . Engl. lot. 158.

In Canada and Labrador; rare in the western parts of New York. 4. July. v. v. Flowers smaller than the foregoing species, white, with a tinge of red; stigma peltated.

4. P. foliis rotundato-ovatis acutis serratis, spicæ floribus secunda. secundis, pistillo recto. - IV illıl sp. pl.2. p.621.

Jcon. Fl. dan. 402. Engl. lot. 517.

In sandy barren woods: Canada to New Jersey. $\mathcal{4}$. July. $v . v$. Flowers greenish-white; stigma peltate, gihbous.

5. P. foliis suberbiculatis serratis, scapo unifloro, stylo recto.

uniflora. Willd. sp. pl. 2. p. 62'2

Icon. Fl, dan.t. 8. Engl. lot. 146.

In shady woods and sphagnous swamps : Canada to New York. 4 . .July. v. v. This pretty little plant has large white and fragrant flowers; the stigma is fiveradiated. All theie species are evergreen, and known by the name of Winter-green. 


\section{CHIMAPHILA.}

naculata. 1. C. foliis lanceolatis basi rotundatis remote serratis fascia longitudinali discolore notatis, scapo 2-3-floro, filamentis lanuginosis.

Pyrola maculata. Willd. sp. pl. 2. p. 622.

Icon. Bot. mag. 897. Pluk. mant. t.349.f. 4.

In shady gravelly or sandy woods : Canada to Carolina. 4. July. v. v. Flowers white; leaves handsomely variegated. This plant is in high esteem for its medicinal qualities among the natives, they call it Sip-siseu'a. I have myself been witness of a successful cure made by a decoction of this plant, in a very severe case of hysterics. It is a plant eminently deserving the attention of physicians.

eorymlosa.

2. C. foliis cuneato-lanceolatis basi acutis serratis concoloribus, scapo corymbifero, filamentis glabris.

P. umbellata. Willd. sp. pl. 2. p. 622 .

Icon. Bot. mag. 778. Lam. iliustr. t. 357. f. 2.

In dry wonds, frequent: Canada to Virginia. 4. July. $v . v$. Flowers greenish-white, tinged with red; anthers purple. Both species are handsome evergreens, and known by the name of Winter-green. I have ventured to form a new genus of these two species of Pyrola, so very distinct in habit as well as character. The name I have given is taken from the common nameWinter-green: ¿elus hyems, and piros amicus.

\section{LEDUM. Gen. pl. 744.}

palustre. 1. L. foliis linearibus margine revolutis subtus ferrugineotomentosis, staminibus denis corolla longioribus. Lam. encycl.3. p.459. Willd.sp.pl.2. p.602.

Icon. Fl. dan. 1031. Duham. arb. 1.t.67. Schmilt arl. 163.

decumbens. $\quad \beta$. L. spithamæum decumbens. Ait. kew. ed. 2. v.3. p. 48.

In swamps of Canada and round mountain-lakes of New York. $\beta$. Near Hudson's Bay. 々. A pril, May. v. v. Flowers white.

latifolium. 2. L. foliis lineari-oblongis margine replicatis subtus ferrugineo-tomentosis, staminibus subquinis corollam $x$ quantibus. Lam. encycl. 3. p. 459. Willd. sp. pl. 2. p. 602 .

L. grœnlandicum. Retz. ols. 4.p. 26. 
1. palustre. Mich. Al. amer. 1. p. 259.

Icon. Schmidt arl. 164. Jacq. ic. 3. t. 464. Lam. ilinstr.t. 363.f. 3 .

In sphagnous swamps of Canada. $\zeta$. April, May. $v \cdot v$. $A$ larger and broader leaved plant than the foregoing one; commonly called Labrador Tea.

\section{AMMYRSINE.}

1. A. foliis pusillis convexis ovalibus glabris lucidis, corymbis terminalibus congestis.

Ledum buxifolium. Willd. sp. pl. 2. p.602. Ait. kew. 2. p. 65 .

Ledum thymifolium. Lam. encycl. 3. p. 459.

Icon. Bergius act. petrop. 1777. p. 1.t. 3. f. 2. Lam. illustr. t. 363. f. 2.

In pine-barrens of New Jersey and on the mountains of Carolina. 々. May, June. $v, v$. This elegant little shrub grows to the height of about six inches, and sometimes a foot ; the delicacy of its leaves and abundance of its white flowers are highly ornamental. I propose it as a distinct genus, being on one side related to Ledum, on the other approaching very near to Azalea procumbens, vid. p. 154. The name has been derived from aupsos sabulum, and $\mu$ voriv, myrtus pumilus; being known by the name of Sandinyrtle among the inhabitants of New Jersey.

\section{5\%. CLETHRA. Gen.pl.751.}

1. C. foliis cuneato-obovatis acutis superne grosse-serratis utrinque glabris concoloribus, racemis spicatis sinuplicibus bracteatis cano-tomentosis. - Willd. s.p. pl. 2. p. 619 .

C. alnifolia denudata. Ait. kew. 2. p. 73 .

Icon. Schmidt arb. 47. Lam. illustr. 36g. Mill. ic. 28. Catesb. car. 1.t. 66.

In swamps, frequent: New England to Virginia. $\eta$. July-sept. $v . v$. A shrub from three to four feet high; flowers white, as likewise all the following species are.

2. C. foliis cuneato-obovatis acutis superne tenue-serratis subtus albo-tomentosis, racemis spicatis simplicibus

tomentosa. bracteatis villoso-tomentosis. - Lam. encycl.2. p. 46.

C. aluifolia pubescens, Hit. kew. 2. p., 3 . 
In swamps of Virginia and Carolina. $h$. July, Aug. $v . v$. Though gererally considered a variety of No. 1, $\mathbf{i}$ take it to be a genuine species, as $I$ have seen seedling plants of both species keeping constantly their distinction.

scalra.

3. C. foliis lato-cuneato-obovatis acutis utrinque scabris grosse-serratis; serraturis uncinatis, racemis spicatis subpaniculatis bracteatis tenue-tomentosis. - Pers. syn. 1.p. 483 ?

In the western parts of Georgia. Lyon. $\zeta$. July. v. s. in Herl. Lyon.

paniculata. 4. C. foliis anguste cuneato-lanceolatis acutis acuminatoserratis utringue glabris, panicula terminali elongata racemiflora albo-tomentosa._Willd. sp.pl. 2. p.620. Ait. kew. 2. p. 73.

In Carolina. Bartram. $々$. July, Aug. v. s. in Herb. Banks.

acuminata. 5. C. foliis ovalibus acuminatis basi obtusiusculis serratis utrinque glabris subtus subglaucis, racemis spicatis subsolitariis bracteatis albo-tomentosis.-Mich. $f$. amer. 1. p. 260.

C. montana. Bartr. catal.

On the high mountains of Carolina. $\zeta$. July, Aug. $v . v$. Grows to the size of a tree; leaves large; flowers resembling those of No.1.

\section{MYLOCARIUM. Willd. enum.}

ligustrinum.

1. Mylocarium. IVilld. l.c.

Cliftonia. Herl. Banks.

On the dry borders of swamps: Georgia. h. May, June. v. v. An elegant evergreen shrub, growing to the height of eight or twelve feet; flowers white, sweet-scented, in terminal spikes; seeds resembling buck-wheat, from which it has been called Buck-wheat Tree.

Fruter sempervirens, 8-pedalis et ultra. Caulis ramosissimus, cortice cinereo. Rami sparsi, glabri, fusci. Folia sparsa in sumnitate ramulortm conferta, patentia, subsessilia, cuneato-lanceolata, acutiuscula, integerrima, utrinque glabra, lærigata, plana, coriacea, subtus glauca. Racemi terminales, solitarii, simplices seu interdum basi ramosi, erecti, bracteati. Bractece solitariæ, oblongæ, acutæ, membranaceæ, deciduæ, 


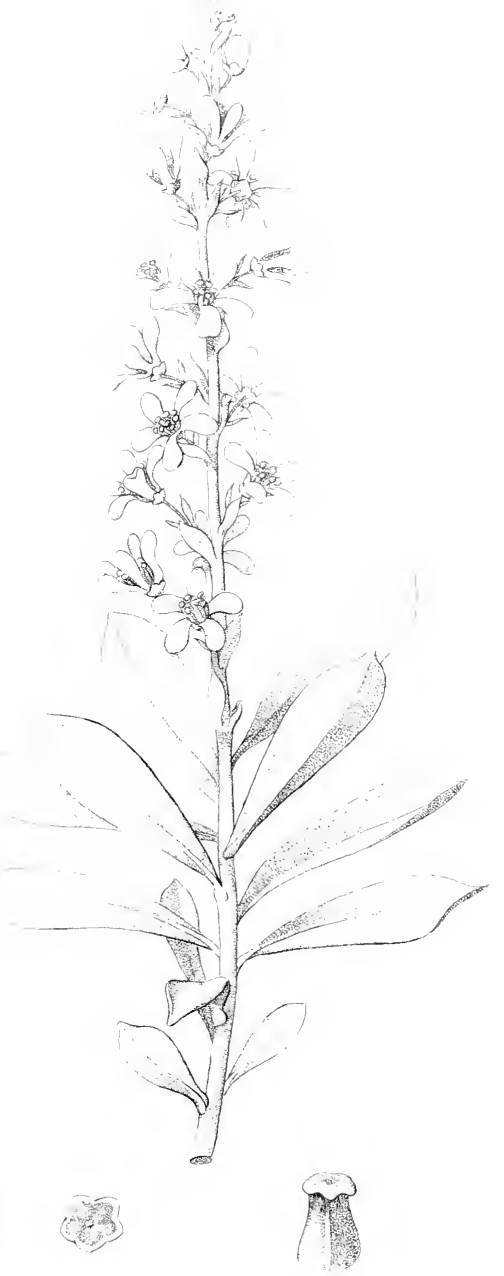

- Hytracuirem leigestrunem. 

pedicello trevines, albidæ, apice ferruminex. Pidicelli filiformes, rubelli, medio bibracteolati. Bracleole subulatx. Flores abi, sumeolentes, Calyx minimus, viriclis, albo-marginatus: lacinis subrotudis. Petala oblongo-obovata, obtusa, subunguiculata: nnguibus ercetis : lominæ crncaræ, patentes. Filanenta receptaculo inserta, 5. alierna longiora, curcila i ix breviora, inferne dilatata, crassa, superne subulat?. Anthere stbrotude, flaræ. Germen prismatico-34-goitan, viride. Stigma sessile, crasstim. Cupsula magnitudine et figua Polygini Figopyri, 3-4-ala:a, 4-locularis. Semina solitaria.

\section{MONOTROPA. Gin. $l$ l. 737.}

1. M. scapo spicifforo, squamis foribusque extus glabris ; floribus lateralibus octandris. - Willd. sp. pl. 2. p. 573 .

Icon. Fl. dan. 232. Engl. lot.69. Moris. hist.3. s. 12. t. 16.f. 20. Pluk alm. t. 20;.f. 5 .

Parasitic, on the roots of beech and other trees, in shady moist piaces: Canada to Pensylvania. 24. June, July. $v$. $v$. The whole plant is of a brownish-yellow appearance; it is smaller than the European species.

2. M. scapo spicifioro, bracteis floribusque undique lanuginosis.-Mich. fl. amer. 2. p. 266.

In similar places: Pensylvania to Carolina. 4. July. $v$ v. Of a light tan-colour.

3. M. scapo breviore crasso unifloro, squanis approximatis, flore cernuo decandro.- Wrilld. sp. pl. 2. p.573. excl. syn. Moris.

Icon. tluk. alm. t. 209. f. 2. Catesb car. 1. t.36. bona. In similar situations: New York to Carolina. 4. May, June. v.v. In general it appears in large clusters growing together; the whole plant is white.

4. M. scapo elongato rectissimo unifloro, squamis distanti- morisoniana. bus, flore erecto decandro.-Mich. fl. amer. 1. p. 266. Icon. Moris. hist. 3. s. 12.t. 16. f. 5. lona.

In shady woods : Virginia and Carolina. 24. June. v. v. The flower is lirger than No. 3, frequently with twelve stamina.

lanuginosa. uniflora, 
370. DIONÆA. Gen. pl. 729 .

muscipula. 1. Dionæa. Willd.sp.pl. 2. p.574.

Icon. Bot. mag. 785. Vent. malm. 29.

In bogs of North Carolina, near Wilmington. 24. July, Aug. $v . v$. This singular and interesting plant, known by the name of Venus's Fly-trap, is fully described by the authors above quoted.

\section{JUSSIEUA. Gen.pl. 741 .}

grandiflora. 1. J. erecta; foliis integerrimis, inferioribus spathulatis. superioribus lanceolatis, floribus decandris, pedunculis calycibusque villosis.-Mich. fl. amer. 1. p. 267.

Icon. Alotot. insect. 1. t. ....

In swamps and ponds of Carolina and Georgia, near Savannah. 4. July. v.s. Roots creeping; flowers large, yellow.

erecta.

2. J. erecta, glabra; foliis lanceolatis, floribus octandris sessilibus.-Willd. sp. pl. 2.p. 578 .

Icon. Sloan. jam. 1. t. 11.f. 1 .

In swamps of Virginia and Carolina, about the Dismalswamp. $\psi$. Aug. $v . v$. Flowers yellow, sinaller than the foregoing one.

sulacaulis. 3. J. repens, glabra ; foliis lineari-lanceolatis repando-dentatis, floribus solitariis octandris pedunculatis, filamentis alternis brevissimis, petalis obovatis.

On the banks of the Missouri. M. Lewis. 4. June. v.s. Flowers small, jellow.

\section{GYMNOCLADUS. Gen. $p l .1537$.}

canadensis.

1. G. foliis bipinnatis, foliolis ovalibus acuminatis pubescentibus.-Willd. sp. pl. 4.p.816.

Guilandina dioica. Sp.pl. 546 .

Icon. Mich. Al. amer. 1. p. 51. Mich. arb. 23. Lam. illustr. \$23. Duham.arl. 1.t. 103.

In the forests of Canada, western parts of New York, Tennassee, Ohio, and Kentucky. 々. May, June. v. $v$. A large tree, known by the name of Kentucky Coffee Tree, and among the Canadians Chicot. Flowers white. Seed-pods large, dark brown. 
373. ACACIA. Willd.sp.pl.4.p.1049.

1. A. inermis ; foliis bipinnatis, partialibus 8 -jugis, proprịis multijugis, glandula inter par infimum partialium, spicis globosis solitariis pedunculatis axillaribus, leguminibus lanceolatis rectis. Willd. sp. pl. 4. p. 1071. Mimosa illinoensis. Mich fl. amer. 2. p. 254.

In extensive natural meadows of Illinois and Kentucky. 4. June, July. $v . v$. Flowers white, with only five stamina.

2. A. inermis; foliis bipinnatis, partialibus 12-jugis, propriis multijugis, glandula inter omnia paria partialium, spicis globosis pedunculatis solitariis axillaribus, leguminibus falcatis. Willd. sp.pl.4. p. 1071 .

Mimosa glandulosa. Mich.fl. amer. 2. p. 254.

Icon. Vent. choix 27.

On the banks of the rivers Tennassee and Mississippi. 4. July. v.v. Flowers white, pentandrous.

\section{SCHRANKIA. Willd.sp.pl. 4.p. 1041.}

1. S. aculeata ; foliis bipinnatis, partialibus 6 -jugis, propriis multijugis, leguminibus acuminaris, caule pentagono. Willd. sp. pl. 4.p. 1043.

Mimosa horridula. Mich. f. amer.2. p. 254.

Mimosa Intsia. Walt.fl.car. 252.

In old fields and meadows: Virginia to Florida, 4. June, July. v. v. Flowers in globular spikes, red. It is known by the name of Sensitive Briar.

\section{CASSIA. Gen. pl. 700 .}

1. C. glabra ; foliis 3-jugis obovatis subretusis, exterioribus uncinata.

glandulosa.

lrachylola. glandulosa. majoribus, glandula subulata inter inferiora, pedunculis paucifloris axillaribus, leguminibus subtetragonis rectis.-IVilld. sp.pl.2.p. 515.

Icon. Dill. elth. t. 63.f. 73. Mill. dict. t. 82.

In sandy fields of Georgia, near Savannah. $\odot$. July. $v . v$. The flowers of all the species mentioned here are yellow.

2. C. glabra; foliis sub-5-jugis ovato-lanceolatis margine occidentalis. scabris, exterioribus majoribus, glandula basilari, pedunculis multifloris axillaribus et subpaniculato-termi-

Tora.

VOL. I. 
nalibus, leguminibus linearibus falcatis. Willd.sp.pl. $\mathbf{x}$. p. 518.

Icon. Comm. hort. 1. t. 26. Sloan. jam. 2. t.175.f.3 छ' 4.

In old fields : Virginia to Carolina. 4. দ. JuneAug. $v . v$.

ligustrina. 3. C. tenuissime pubescens ; foliis 7-jugis lanceolatis, extimis minoribus, glandula basilari, pedunculis terminalibus subpaniculatis, leguminibus oblongis subfalcatis - Willd. sp. pl. 2. p. 523.

Icon. Dill. elth. t. 259.f. 338 Mart. cent. 21.

In cultivated grounds: Virginia to Geprgia. 々. 4. July, Aug. v. $v$.

linearis.

4. C. glabra ; foliis 6 -jugis ovali-lanceolatis angustatis acutissimis, glandula bailari, pedunculis subbiftoris axillaribus et terminalibus, legumine lineari. Mich. $f$. amer. 1. p. 261.

In Carolina. Michaux. 24. May, June. +.

marilandica. 5. C. glabriuscula; foliis 8-jugis lanceolato-oblongis mucronatis subæqualibus, glandula petiolari obovata, racemis axillaribus et paniculato-terminalibus, leguminibus linearibus arcuatis glabris.-Willd. sp. pl. 2. p. 524 .

Icon. Dill. elth. t. 260. f. 339. Mart. cent. 23.

In low graveliy soil, on the banks of rivers: New York to Carolina. 2. June-Aug. v. $v$.

Chumacris- 6. C. glabriuscula ; foliis multijugis linearibus, glandula ta. petiolari subpedicellata, floribus subgeminis, pedicellis longis, petalis duobus maculatis, leguminibus pubescentibus.-Willd. sp. pl. 2. p. 528.

Icon. Bot. mag. 107. Comm. hort. 1. t. 37.

In cultivated grounds of Virginia and Carolina. $\odot$. July, Aug. $v . v$. The flowers large and handsome, with two purple spo:s at the bottom. There is a variety, the stem of which is covered with long brown hair.

fasciculata. 7. C. glabriuscula; foliis ad summum 9-jugis, glandula petiolari sessili submedia, fasciculis multifloris lateralibus, petalis staminibusque concoloribus, leguminibus glabris arcuatim adscendentibus.-Mich. $f$. amer. 1. p. 262.

In dry fields : New York to Carolina. ๑. June-Aug. $v . v$. The flowers are smaller than the foregoing species. 
8. C. patula, pubescens; foliis multijugis linearibus, glannictitans. dula petiolari pedicellata, pedunculis brevibus supra axillaribus 2-3-floris, florious pentandris.-Wilid. sp. pl. 2 p. 529.

Icon. Pluk. alm.t. $314, f .5$.

In sandy fields : New England to Carolina. $\odot$. JuneAug. $v . v$. The leaves are in a slight degree sensitive.

9. C. foliis multijugis eglandulosis, canle procumbente. procumbers. I illd sp.pl. 2. p. 530 .

In dry fields of Virginia. $\odot .+$. Flowers small.

\section{PODALYRIA. Lam. illustr.t.327.}

1. P. glaberrima ; foliis simplicibus perfoliatis suborbiculatis integerrimis, floribus axillaribus solitariis unifloris, leguminibus subglobosis.-Mich. fl. amer. 1.p. 263.

Crotalaria perfoliata. Sp. pl. 1003.

Sophora perfoliata. Walt. fl. car. 135.

Ratinia perfoliata. Willd. sp.pl. 3.p. 949 .

Icon. Dill. elth. t. 102.f. 122.

In dry barren fields: Carolina and Georgia. 24. July. $v$. v. Flowers small, yellow.

2. P. caule foliis calycibusque pubescentibus, foliis ternatis sessilibus, foliolis lanceolatis obtusis, stipulis setaceis minutis, floribus axillaribus solitariis pedicellatis.Mich. fl. amer. 1. p. 263.

Sophora lanceolata. Walt. fl. car. 135.

In Carolina and Georgia. Michaux. 4. +. Flowers yellow.

3. P. caule foliis subtus et margine calycibusque pubescentibus, foliis ternatis subsessilibus, foliolis ovali-oblongis obtusis, stipulis linearibus, racemo terminali subspicato, calycibus subsemi-4-fidis.-Mich. $f$ l. amer. 1. p. 264.

Sophora villosa. Walt. fl. car. 134.

In low sandy grounds : Virginia and North Carolina. 4. June, July. v. v. Flowers yellow; resembles a lupine very much.

4. P. glabra; foliis ternatis brevissime petiolatis, foliolis oblongo-cuneatis obtusis, stipulis lanceolatis acutis petiolo duplo longioribus, racemis spicatis elongatis, leguminibus acuminatis.-Mich fl. amer. 1. p. 264.

P. australis. Willd. sp. pl. 2.p. 503 .

$$
\mathrm{x} 2
$$

perfoliata.

uniflora.

villosa.

corulea. 
Sophora australıs. Syst.veg. 325.

1con. Bot. mag.509. Vent. hort. cels 46. Trew pl. rar. t. 14.

On the banks of rivers : Virginia and Carolina, particularly in the western districts. 2. June, July. v. v. Flowers blue.

alla.

5. P. ramis divaricatis flexuosis glabris, foliis ternatis petiolatis, foliolis oblongis obtusis glabriuculis, stipulis subulatis petiolo brevioribus, racemo spicato elongato, leguminibus obovatis.-Willd. sp.pl.2. p. 503.

Sophora alba. Syst.veg. 325.

Crotalaria alba. Sp. pl.2. p. 1006.

Icon. Bot. mag. 1177. Mart. cent. 44.

In the western parts of Virginia and Carolina, on river banks. 4. June, July. v. $v$. Flowers white.

mollis.

6. P. caule foliis calycibusque minutim pubescentibus, foliis ternatis, foliolis subrhomboideo-lanceolatis, stipulis foliace is lanceolatis, racemo spicato terminali, calycis dentibus acutis.-Mich. fl.amer. 1.p. 264.

In the county of Mecklenburg in Upper Carolina. Michaux. $4 .+$.

linctoria. $\quad$ 7. P. glaberrima, ramosissima, microphylla ; foliis ternatis subsessilibus, foliolis cuneato-obovatis rotundato-obtusis, stipulis obsoletis oblongis acutis petiolo multoties brevioribus, racemis spicatis terminalibus, leguminibus ovatis longe-stipitatis.-IVill. sp. pl. 2. p. 503.

Sophora tinctoria. Sip.pl. 534.

Icon. Bot. mag. 1099. Lam. illustr. t.327.f. 1.

In woods, on dry hilis : Canada to Carolina. 24. July, Ang. v. v. Flowers yellow; called Wild Indigo.

\section{CERCIS. Gen. pl. 696.}

canadersis. 1. C. foliis subrotundo-cordatis acuminatis, ad axillas nervorum villosis, stipulis minutis, leguninibus brevi-sti. pitatis.-Willd.sp. pl.2. p. 508 .

Icon. Schmidt arb. 21. Mill. ic. 2.

pubescens. $\quad \beta$.C. foliis subrotundis acutis subtus pubescentibus.

On the banks of rivers: Canada to Virginia. $\beta$. In Georgia. $々$. May. $v \cdot v$. A handsome tree, generally called Judas-trce. Flowers crimson. 
378. VIRGILIA. Lam. illustr. $\iota .326$.

1. V. foliis pinnatis, foliolis alternis ovatis brevi-acuminatis lutea. glabris, racemis elongatis pendulis, leguminibus petiolatis planis. - Mich. arl. $t$. ....

On the mountains between Georgia and Tennassee. $r_{2}$. June. v. v. s. fl.; v.s. c. fl. et fr. in Herb. Lyon. A handsome tree, resembling Cytisus Laburnum very much. Its bark gives a beautiful yellow dye.

\section{II. $D I G Y N I A$.}

379. HYDRANGEA. Gen. pl. 760 .

1. $\mathrm{H}$. foliis oblongo-ovatis basi obtusis acuminatis dentatis subtus glabris, cymis nudis.

H. arborcscens. Willd. sp. pl. 2. p. 633.

Icon. Bot. mag. 437. Lam. illustr. t. 370. f. 1. Mill. ic. 251.

On the banks of rivulets, in shady situations: Pensylvania to Virginia. $々$. July, Aug. v. v. A shrub about five feet high ; flowers white.

2. H. foliis lato-ovatis basi subcordatis acuminatis grosse dentatis subtus glabris, cymis subradiatis.

H. vulgaris. Mich. $f$ l. amer. 1. p. 268.

On the mountains of Carolina. $々$. June, July. $v . v$. This, though nearly allied to the preceding, is a very distinct species, and easily known from that by its more robust appearance and larger leaves.

3. H. foliis ovatis acuminatis dentatis subtus niveo-tomentosis : serraturis mucronatis, cymis radiatis.-Mich. fl. amer. 1.p. 263.

H. radiata. IVal't, fl. car. 251.

Icon. Lam. illustr. t. 307.f. 2.

On the head-waters of the Savannah river; in Tennassee, \&c. $h$. July, Aug. $v . v$. A very ornamental shrub.

$4 \mathrm{H}$. foliis oblongis sinuato-lobatis dentatis subtus tomentosis, cymis radiatis thyrsuideo-paniculatis.-Willd. sp. pl. 2. p. 634 .

H. radiata. Smilh ic. pict. 12.

cordata.

nivea. 
Icon. Bartr. it. ell. germ. $t .7$.

On banks of rivers: Georgia and Florida. h. July, Aug. $v . v$. A handsome shrub; flowers in large clusters, white, changing to red.

\section{3so. SAXIFRAG.A. Gen.pl. 764.}

* Foliis indivisis radicalibus; caule sulnudo.

Livoon.

1. S. foliis radicalibus aggregatis spathulatis acutiusculis glabris cartilagineo-dentatis, caule simplici folioso piloso, calycibus glabris.-Willd. sp. pl. 2. p.639.

Icon. Jacq. austr. 5. t. 438. Fl. lap. t. 2.f. 2.

In Labrador and probably in Canada. Colmaster. 4. June, July. v. s. in Herl. Dickson. Not above three inches high.

stellaris.

2. S. foliis cuneatis serratis margine pilosis, caule nudo simplici, petalis acutis, capsula supera.-Willd. $s p$. pl. 2. p. 644 .

Icon. Encl. lot.167. Fl dan. 23. Jacq. coll. 1. t.13.

In Labrador and Canada. Colmaster. 24. June, July. v. s. in Herl. Dickson. Flowers white.

serpyllifolia. 3.S. microphylla, erecta; follis ovalitus glabris, caule uniforo oligophyllo, petalis obovatis.

On the north-west coast. Nelson. 4. v, s. in Herb. Banks. Flowers large.

androsacea. 4. S. pubescens; foliis spathulato-linearibus petiolatis, caule fulioso 1-2-toro.

S. androsacea. Jacq. austr. 389 ?

On the north-west coast. Nelson. 24. v.s. in Herb. Banks. Flowers white, small.

lronchialis. 5. S, stojonifera; foliis imbricatis subulatis planis mucronatis spinoso-ciliatis, caule subnudo paniculato.IVilld. sp. pl. 2. p.644.

On the north-west coast. Nelson. 24. v. s. in Herl. Banks.

nivalis.

6. S. folijs subrotundo-cuneatis antice crenatis in petiolum decurrentibus, caule nudo simplici, foribus congestia racemosis.- IVilld. sp. pl. 2. p.645.

Icon. Fl. lapp. i. 2.f. 5. Fl. dan.t. 12.

In Labrador and Canada. 24. May, June. v. s. in Herb. Dickson. Not above two inches high; flowers white.

virginiensis. 7. S. tota minutim pubescens; foliis ovalibus obtusis crenatis in petiolum decurrentibus, caule subaphyllo pa. 
niculato, ramulis dichotomis, floribus subsessilibus.Mich. fl. amer. 1. p. 269.

S. pilosa. Fierb. Banks.

Icon. Pluk. alm.t. 222,f. 5 .

On rocks and dry hills: New England to Virginia, and on the Carolina mountains. 4. May, June. v. v. Variable in size; flowers white.

s. S. foliis reniformibus dentatis utrinque pilosis aveniis,

Geum. caule nudo panicu'ato. - IVilld. sp. pl. 2. p. 648 .

Icon. Lapeyr. t. 14. Magn. hort. 8s. Moris, hist. 3. p. $12 . t .9 . f .12$.

On the north-west coast. Nelson. 4. v. s. in Herb. Banks. Flowers small.

9. S. hirsutissima ; foliis elongato-spathulatis acute dentatis, leucanthemicaulibus divaricato-dichotomis, paniculis capillaribus folia. laxis, calyce reflexo, petalis inæqualibus. Mich. $f$. amer. 1. p. 268.

On high mountains of Carolina. Michaux. On the Peaks of Otter, Virginia. P. 24. June. v.v. About eight inches high; flowers white, elegantly red and yellow punctated. This and the $S$. sarmentosa ought to form a separate genus.

10. S. pubescens; foliis oblongo-lanceolatis utrinque acutis ob-pensylvanica. solete denticulatis, caule nudo, panicula oblonga, ramis summitate fasciculifloris.-Willd. sp. pl. 2. p. 6.10 .

Icon. Dill. elth. t. 253. $f$ 3.8.

In wet meadows: New York to Virginia. 2\%. June. $v$. $v$. Above a foot high; flowers small, yellowishgreen.

11. S. glabrituscula ; foliis oblongo-lanceolatis acutis erosocrosa. dentatis, caule nudo, panicula oblonga, ramis divaricato-ramosissimis laxifloris, pedicellis tiliformibus.

In stony rivulets on the high mountains of Virginia and Carolina. 24. June, July. v. $v$. Resembles the foregoing one in some respects very much.

\section{* Foliis indivisis; caule folioso.}

12. S. caspitosa; foliis caulinis oppositis imbricatis ovatis oppositifolia. obtusis, summis ciliatis, floribus terminalibus solitariis sessilibus.-Willd. sp. pl. 2. p. 648.

Icon. Engl. bot. 9. Fl.dan.34. F' lapp. t. 2.f.1.

In Newfoundland and Labrador. 4. May. v. v.; v.s. in Herl. Banks. Flowers purple, large. 
aizoides.

13. S. decumbens, cæspitosa; foliis caulinis linearibus alternis dentato-ciliatis, panicula pauciflora, petalis longitudine calycis.-Willd. sp. pl. 2. p. 650 .

Icon. Engl. lot.39. Fl. dan. 72.

In Newfoundland and Labrador. 4. v. s. in Herl. Banks. Flowers yellow.

setigera. 14. S. pubescens; foliis radicalibus aggregatis spathulatis acutis spinoso-ciliatis, caule folioso subbifloro, calycibus hispidis, flagellis setaceis longissimis in axillis foliorum.

On the nortb-west coast. Nelson. 2l. v. s. in Herb. Banks. Flowers small, white. A very singular species.

*** Foliis lobatis.

rivularis.

15. S. erecta; foliis palmatis petiolatis : summo spathulato, caule paucifloro, radice fibrosa, germine semi-infero. Smith fl. brit 2. p. 454 .

Icon. Fl. dan. 118. Fl. lasp. 2.f.7.

In Labrador. Chaterux. 4 . June. v. s. in Herb. Banks. Flowers white, small.

silirica.

16. S. adscendens; foliis reniformibus palmatis pilosis, petiolis hirsutis, caulinis sessilibus, pedunculis longissimis filiformibus bifidis nudis.-Willd. sp. pl. 2. p. 653 .

Labrador and Newfoundland. 2. v. s. in Herb. Banks. Flowers white, large.

pectinala. $\quad 1 \%$. S. cæspitosa, multicaulis ; foliis 3-lobatis, laciniis 3-fidis linearibus acutis glabris, nervo medio exarato, caule folioso racemifloro.

On the noith-west coast. Menzies. 4. v. s. in Herb. Banks. Pesembles S. petrcea; but the leaves are narrow, and the divisions divaricated.

cespitosa. 18. S. foliis radicalibus aggregatis carnosis linearibus obtusis integris trifidisve subtus nervosis, caule erecto nudiusculo paucifloro, petalis calyce duplo longioribus.IVilld. sp.pl. 2. p. 450 .

Icon. Waldst. h:ng. 88. Engl. lot. 794.

grcenlandica. $\beta . S$. foliis caulinis palmato-multifidis, laciniis acutis.IVilld. $l$. $c$.

Icon. Dill elth. $353 \cdot f .3 \&$ ?.

On the north-west coast. 4 . June. $v$, s, in Herb. Banks. Hlowers pale yellow.

tricuspidata. 19. S. foliis radicalibus aggreg.tis cuneifurmibus ciliatis 
acute tridentatis, caule adscendente racemoso, petalis lanceolatis calyce triplo longioribus. IVilld. sp. pl. 2. p. 657 .

Icon. Fl. àan. 976 .

On Hudson's Bay. 2. June. v. s. in Herb. Banks. Flowers large, white, handsomely punctated.

\section{TIARELLA. Gen. $p l .765$.}

1. T. foliis cordatis acute-lobatis dentatis, dentibus mucronatis, scapo racemoso.-Willd. sp. pl.2. p. 659.

Icon. Herm. parad. 129. Lam. illustr. 373.

In shady woods of Canada, and on the high mountains of New York and Pensylvania. 4. April, May. v.v. Flowers white.

2. T. foliis ovatis cordatis acntis brevi-lobatis dentatis, caulinis alternis distantibus, racemo filiformi subspicato, calycibus tubulosis.

On the north-west coast. Menzies. 24. v. s. in Herl. Banks. More than a foot high, with five or six alternate leaves on the stem.

3. T. foliis ternatis, foliolis subrhomboideis serratis pilosis, racemis terminalibus, corymbulis florum alternis, calycibus campanulatis.-Willd. sp. pl. 2. p. 659 .

On the north-west coast. Menzies. 4. v. s. in Herl. Banks.

4. T. foliis biternatis, foliolis ovato-cordatis obliquis incisolobatis dentatis, caule folioso, panicula terminali divaricato-spiciflora. Vent. malm. 54.

On the mountains of South Carolina. 24. May. v. v. This plant resembles Spircea Aruncus in habit ; How. ers yellowish-white. The specimens I had an opportunity to examine were destitute of petals, though they are so distinctly described by Ventenat. It is however probable that some individuals may be petaliferous, while others are apetalous.

\section{Mitella. Gen. pl. 766 .}

1. M. foliis sublobato-acutangulis dentatis, caule erecto superne opposite diphyllo.-Willd. sp. pl. 2. p. 659.

Icon. Rob. ic. 80. Schkuhr handl. 1. t. 120. L.am.il. lustr. t. 373. $f .1$.

In shady places, among rocks, near springs. 4. May.

Menziesii.

trifoliata.

liternata.

cordifolia. 
$v$. $v$. Flowers white, which is the colour of all the following species.

cordifolic. 2. M. foliis orbiculato-reniformibus subduplicato-crenatis lucidis, scapo setaceo aphyllo. Mich. $f$. aner. 1. p. $270 . \quad$ Lam. encycl.4. p. $1 \mathrm{~S} 5$.

Icon. Lum. illustr. t. $373 . f .3$.

In Canada. Michaux. On high mountains of New York and Pensylvania. 24. May, June. v. v.

reniformis. 3. M. foliis reniformibus repandis ciliatis, scapo nudo.Lam. encycl 4,p. 185.

M. nuda. Willd.sp.pl.2.p. 660.

Jcon. Lam. illustr. t.373.f.2. Gmel. sib. 4. t.68.f.2. On the mountaius of New Hampshire and Vermont, and probably in Canada. 24. Jane. v. v.

prostrata. 4. M. radice repente, caulibus prostratis, foliis alternis rotundato-cordatis subacutis obtuse sublobatis. Mich. $l$. ancr. 1.p. 270.

In the most southern parts of Canada. Michaux. On the mountains of Virginia, near the Sweet-springs. 4. Nay, June. v. v.

grandifora. 5. M. hirsutissima; foliis rotundato-cordatis obtuse-lobatis - dentatis, scapo folio uno alterove instructo, floribus pedicellatis, calycibus campanulatis.

On the north-west coast. Menzies, 24. v. s, in Herb. Banks. The flowers are more than four times the size of the other species.

\section{SAPONARIA. Gen. pl. 769.}

officinalis. 1. S. calycibus cylindricis, foliis ovato-lanceolatis. Willd. sp.pl. 2.p.667.

Icon. Fl. dun. 543. Engl. lot. 1060.

Among rubbish, near buildings and cultivated grounds; somelimes in gravel-pits and on dry hills; probably introduced from Europe. 24. July, Aug. v. v. Flowers white, frequently semi-double.

\section{DIANTHUS. Gen. pl. 770.}

Armeria. 1. D. foribus aggregatis fasciculatis, squanis calycinis lanceolatis villosis tubum æquantibus. Willd. sp. $p l .2$. p. 673 .

Icun. Fl. dan. 230. Engl. bot. 317. 
In sandy fields and pine-woods: New Jersey, near Cooper's Ferry. $\odot$. July. $v$. v. Flowers small, rose-coloured.

2. D. floribus aggregatis, pedunculis longis, squamis tubo carolinianus. dimidio minoribus. Walt. fl. car. 140.

In Carolina. Walter. + .

\section{SCLERANTHUS. Gen. $p l .767$.}

1. S. calycibus fructus patulis acutis, caulibus patentibus. annuนs. Sinith fl. brit. 2. p. 458 . Willd. sp. pl. 2. p. 660. Icon. Fl. dan. 504. Engl. bot.351.

In dry sandy fields, on the shores of the Delaware, New Jersey opposite Philadelphia. ๑. June, July. v. v.

\section{III. $T R I G Y N I A$.}

\section{3s6. CUCUBALUS. Gen. pl. 771 .}

1. C. glaber, ghucus, decumbens; foliis oblongo-ovalibus Behen. acutis enerviis, calycibus in 1 ato-membranaceis venosis. Mich.fl. amer. 1.p. 271. Willd sp.pl.2.p.684. Silene intata. Smith fl. lrit. 467.

Icon. Fl. dan.914. Engl. bot. 164.

In cultivated grounds, near Quebec, Canada. Michaux. 4. July. v. v. Flowers white.

2. C. pubescens, erectus; foliis quaterno-verticillatis ovalilanceolatis longissime acuminatis,-IVillx. sp. $p l .2$. p. 686.

Icon. Bot. mag. 1107.

In hilly and shady woods: New England to Virginia. 4. July, Aug. v. v. Flowers white; the petals are without a corona.

\section{SILENE. Gen. pl. 772.}

1. S. hirsuta; foliis cuneato-oblongis, summis linearibus, petalis sulrotundis integerrimis, calycibus tructiferis erectis subspicatim alternis.-Willd. sp. pl.2. p. 691.

Icon. Rob.ic. 1s3. Engl. bot. 86 .

On the sa-coast of Carolina; near Charlestown. $\odot$. June, July. v.v. Flowers small, crimson.

quinquevulnera. 
pensylvanica. 2. S. viscido-pubescens; foliis cuneatis, caulinis lanceolatis, cauliculis in summitate pancifloris, petalis obtusissimis leviter emarginatis subcrenatis. Mich. fl. amer. 1. p. 272 .

S. virginica. Willd. sp. pl. 2. p.702.

S. caroliniana. Walt. fl. car. 142.

In dry sandy wonds, and on rocks: New York to Virginia. 24. May, June. v.v. Flowers purple, very handsome.

virginica.

3. S. decumbens, tota viscoso-pubescens; foliis oblongis margine asperiusculis, panicula dichotoma, petalis bifidis, genitalibus exertis. Mirh. fl. amer. 1, p. 272.

S. Catesbæi. Walt. fl. car. 141. Willd. sp. pi. 2. p. 706.

Icon. Catesb.car. 2. t. 4. Pluk. alm. t. 203.f. 1.

In the western parts of Virginia and Carolina, and in the Illinois country. $\psi$. June, July. v.v. A beau. tiful species; flowers dark crimson.

ovata.

4. S. foliis ovato-lanceolatis acuminatis glabriusculis, racemo terminali composito, calycibus ovatis, genitalibus exertis, caule simplici.

Cucubalus polypetalus. Walt. fl. car. 141 ?

In the western part of Georgia and Carolina. 4 . Iuly. $v$. s. in Herb. Banks. Flowers white or pale red.

antirnina. 5. S. foliis lanceolatis subciliatis, pedunculis trifidis, petalis emarginatis, caljcibus ovatis. Willd. sp.pl.2.p. 702. Icon. Will. elth. t. 313 f. 403.

In old fields and on the banks of rivers: Pensylvania to Carolina. $\odot$. June, July. $v . v$. Flowers small, white or greenish.

nocturna. 6. S. floribus spicatis alternis sessilibus secundis, petalis bifidis. Willd. sp. pl.2. p. 692.

Icon. Dill. elth.t.310. f. 400.

On the banks of the Potowmac, near Harper's Ferry, Virginia. $\odot . \delta$. June. v. v. Flowers white.

acaulis.

7. S. acuulis depressa; foliis linearibus carnatis, peduncu. lis terminalibus solitariis erectis unifioris, petalis emarginalis.- Willd. sp. pl. 2. p. 709 .

Icon. Fl. dan. t. 21. Dill. elth. t. 167.f. 206.

In Labrador. 24. June, July. v. s. in Herb. Lamlerl. Flowers rose"coloured. 
388. STFLllaria. Gen. pl. 773.

1. S. pubescens; foliis sessilibus ovatis ciliatis, pedicellis erectis, petalis calyce longioribus.-Mich.fl.amer. 1. pulera. p. 273.

In shady woods, on rich soil : Perssylvania to Carolina. 4. May. v. $v$. Flowers large, white, which is the colour of the whole genus.

2. S. foliis ovatis glabris, canlibus procumbentibus linea laterali pilosa alterna. Smith fl. Urit.2. p. 473 .

Alsine media. Sp. pl.389.

Icon. Engl. bot. 573. Fl. dan. 438 ङ 525.

In cultivated grounds : common. $\odot$. April-Sept. $v . v$. A common weed, known by the name of Chickweed. The number of stamina is variable, three, five, or ten.

3. S. cæspitosa ; foliis subulatis congestis, ramis bipartitis, petalis emarginatis, calycibus striatis.-IVilld. $s p . p l .2$.

liflora. p. 715.

Icon. Fl. dan. 12. Swartz. nov. act. holm. 1788. t. 1. $f .1$.

In Labrador and Canada. 24. May, June. $v$ s. in Herb. Dickson. This is rather an Arenaria than a Stel. laria.

389. ARENARIA. Gen.pl. 774.

* Foliis oblongis.

1. A. caule dichotomo, foliis ovatis acutis carnosis, calyci- peploides. bus acuminatis. - Willd. $s p$ pl. 2 p. 7 i 6.

Icon. Gmel. sib. 4. t.64. Loes. pruss t. 2.

In Labrador. 24. June, July. v. s. in Herl. Banks.

2. A. caule filiformi simplici, foliis ovatis obtusis subtriplinervibus, pedunculis lateralibus solitariis elongatis bifidis, pedicello altero medio bibracteato, corollis calyce longioribus. - Willd. sp. pl. 2. p. 718.

About Hudson's Bay. In the state of New York. Dr. Murtin. 24. July. v. s. in Herb. Banks.

3. A. canle dichoiomo diffuso, folits ovatis acutis subciliatis, serpyllifolia. calyci'us acutis suburinus, petalis calyce brevioribus. - Wi.ld sp pl. 2.p 720 .

Iron. $F i$ ling

In $r$ " "timls and on road-sides: New York to i: Aug. v. $v$. 
dunculis alternis axillaribus solitariis elongatis, calycíbus acutis, petalis longitudine calycis.

On the sea-shore of Labrador. ○. v. s. in Herb. Banks. **: Foliis subulato-linearibus.

macrocarpa. 5. A. caspitosa; foliis congestis subulato-linearibus planis margine ciliatis, pedunculis terminalibus unifloris foliosis, calycis foliolis linearibus, petalis ovatis calyce duplo Jongieribue, capsulis clongato-oblongis calyce triplo longioribus.

On the north-west coast of America. Nt $l$ son. 24.v.s. in Herb. Banks. This approaches near to A. grandiflore, but differs in the long capsule and the linear leaves of the calyx materially.

patula. $\quad$ G. $\Lambda$. pubescens; caulibus filiformibus naniculatis multifloris, foliis setaceo-subulatis patentibus, petalis sub. enarginatis calyce acutissino et striato paulo longioribus.- Mich. fl. aner. 1.p. 273.

On rocka, near Fnoxville, Kentucky. Hichaux. $\boldsymbol{\psi}$. +. Resembles A.tenuifulia.

squarrosa. 7. 1. crespitosa; folits imis squarroso-imbricatis canaliculatis glabris, cauliculis simplicissimis o'igoplyllis, floribus terminalibus paucis erectis, petalis calyce subrothindo multo majoribus. Mich. fl. amer. 1, p. 273 .

A. imbricata. Herl. Banks.

A. caroliniana. Wult. H. car. 141 .

In sondy pine-barrens: New Jersey and Carolina. $\boldsymbol{4}$. July, Aug. $v . v$. Resembles A. saxatilis.

stricta.

S. A. ghabra, crecta, muiticaulis ; foliis subulato-inearibus erectis, panicnia rariflora, petalis calyce ovali-lanceolato conspicue stiato multo longioribus. Mich. $f$. amer. 1.p. 274 .

On rocks of Canada, New England, and on the high mountains of Carolina. 24. ivay, June. v.v.; v.s. in Herb. Lyon. specimen carolinianum. Resembles A. striata, but is a larger and nore upright plant.

glalra.

9. $\Lambda$. glaberrima, erectiuscula, fliformi-multicaulis ; foliis subulato-linearibus planis patulis, pedicellis unifloris elongatis divaricatis, calycis foliolis ovalibus obtusiusculis levibus petalis brevioribus. Mich. fl. amer. 1. p. $27 \%$.

Stellaria uniffora. Walt. fl. car. 141.

On rocks in North Carolina. Michaux. 4. +.

juniperina. 10. A. subpubescens, erecta, multicaulis, foliis subulatis 
subtriquetris pungentibus, panicula terminali dichotome-multiflora, calycis foliolis ovato-lanceolatis strutis mucronatis petalis vix duplo brevioribus. - Willd. sp. pl. 2. p. 725 .

Icon. Smith ic. ined. 1. t. 35.

In Labrador and Newfoundland. 2\%. v. s. in Herb. Banks.

11. A. pubescens, cæspitoso-multicaulis; folits setaceis, canliculis 1-3-floris erectis, calycis foliolis linearibus sub. hirsutis petalis duplo brevioribus.-Willa. $s p . p l .2$. p. 726 .

Icon. Jacq. austr. 3. t. $2 \% 2$.

On the north-west coast of America. Menzics. 4 . v. s. in Herl. Banks.

laricifolia.

12. A. glabriuscula, cáspitosa ; cauliculis stricto-erectis, foliis subulatis pungentibus striatis, floribus densefasciculatis, calycibus subulatis striatis, petalis brevissimis._Willd. sp.pl. 2. p.727.

Icon. Jact. atstr. 2. t. 182.

In Canada. $\odot$. v. s. in Herl. Lambert. specimen Hort. Kew.

13. A. glabra, humifusa; foliis linearibus carnosis internocanadensis. diis multo longioribus, stipulis membranaceo-connatis vaginantibus, staminibus quinque, capsulis globosis. -Pers. syn. 1. p. 504.

A. rubra 6. Mich. Al amer, 1, p. 2,4.

A. marina. Smilh fl.brit.2. p. 480 ?

On the sea-coast, in salt-marshes: Canada to Carolina. $\odot$. June, July. v. v. Flowers pale-red.

fasciculata.

\section{TETRAGYNIA.}

3̧o. MiCROPETALUM. Pers.syn. 1.p. 509.

Spergulastrum. Mich. fl. amer. 1.p. 275.

1. M. dense pubescens; foliis lanceolatis in petiolum an- lanuginosum. gustatis, peciunculis subsolitariis elongatis demum reflexis, floribus apetalis.-Pers.l.c. Mich. l.c.

In the mountains of Virginia and Carolina. 24. June, July. $v . v$. 
lanceolatum. 2. M. glabrum; foliis lanceolatis utring̨ue angustatis, flom ribus paniculatis, petalis ovatis brevissimis.-Pers.l.c. Mich.l. c.

On moist rocks: Canada to Pensyluania, 24. July. v. v.

gramineum. 3. M. glaberrimum ; foliis linearibus erecis, panicula terminali laxa, pedicellis filiformibus, petalis laaceolatis longitudine calycis-Pers.l.c. Mich.l.c.

Near springs and sharly rocks: New York to Virginia. 4. June, July. v. v.

A. fasciculata probably belongs to this genus.

\section{PENTAGINIA.}

391. SPERGULA, Gen. pl. 798.

arvensis. 1. S. foliis filiformibus verticillatis, panicula dichotoma, pedunculis tructiferis reflexis, seminbus reniformibus. Willd. sp. pl. 2. p. 818 .

Icon. Fl. dan. 1033. Engl. lot. 1535.

In sandy fields: Pensylvania, New Jersey, \&c. $\odot$. June, July. $v, v$.

saginoides.

2. S. folis oppositis subulatis nudis, pedunculis solitariis longissinis glabris. Smithfl. brit. 2. p.504.

Icon. Engl. lot.'2105.

In sundy fieids: Carolina. $\odot$. June, July. v. s. in Herl. Enslen.

\section{CERASTIUM. Gen. $p l .797$.}

vulgatum. 1. C. hirsutam, viscidum, cæspitosum ; foliis ovatis, petalis oblongis cal ce subæqualibus, floribus pedunculo longioribus. Snith fl. lrii. 2. p. 496. Willd, sp. 11.2.p. 511 .

Icon. Engl. vot.789. Vaill. par. t.30.f. 3.

In dry tields and among rocks; freqnent: New England to Fensylvania. $\odot$. April-June. $v . v$. The flowers of the whole genus are white.

viscosum. 2. C. hirsutum, viscosum, diffusum ; foliis lanceolato-oblongis obtusiusculis, petalis obovatis calyce vix longioribns, floribus pedunculo brevioribus.-IVilld.sp. pl.2. p. $\$ 12$. 
Icon. Engl. bot. 790. Vaill. par. t. 30.f. 1.

In pastures and on old walls : Canada to Carolina. 4. May-Sept. $v . v$.

3. C. hirsutum, viscidum; foliis ovato-oblongis acutis, petalis calyce brevioribus emarginatis, pedunculis calyce longioribus, floribus pentandris.-Willd. sp. pl. 2. p. 812 .

Icon. Engl. bot. 1630. Vaill. par. t.30.f. 2.

On dry, barren, and sunny hills; frequent: Pensylvania and Virginia. $\odot$. May, June. v. v.

4. C. pubescens, cæspitosum; foliis lineari-lanceolatis obtusis basi ciliatis internodiis brevioribus, petalis obcordatis calyce duplo longioribus, calycis foliolis obtusis. - Willd. sp. pl. 2. p.813.

Icon. Fl. dan. 626. Engl. bot. 93. Vaill. par. t. 30.f.4. On dry hills and rocks; frequent: Pensylvania, \&c. 4 . May-Aug. v. v. Flowers large.

5. C. tenuissime pubescens, cæspitosum; foliis angustolinearibus internodiis longioribus, petalis obovatis enuarginatis calyce acuto subtriplo longioribus.

On the banks of Schuylkill and Delaware, Pensylvania. 4. May, June. $v . v$. Resernbles the foregoing one very much.

6. C. hirsutum; foliis linearibus internodiis longioribus di-

elongatum. varicatis, pedunculis terminalibus elongatis bis 3-chotomis, bracteis oppositis ovatis, petalis emarginatis calyce acuto duplo longioribus, capsulis subglobosis.

On the plains of Columbia river. $N T$. Lewis. 4 . April. $v$. s. in Herb. Leuis.

\section{AGROSTEMMA. Gen.pl. 795.}

1. A. hirsuta; calyce corollam superante, petalis integris nudis. Willd. sp.pl.2. p. 805 .

Icon. Fl. dan. 576 . Engl. bot. 741 .

Common Cockle is frequently found among the grain, but is not indigenous in America. $\odot$. June, July. $v . v$.

\section{LYCHNIS. Gen. pl. 796.}

1. L. glabra; floribus densis umbellato-capitatis, petalis bifidis, floribus tetragynis.-Willd.sp.pl. 2. p. 809.

semidecan. drum.

arvense.

tenuifolium.

Githago,

Icon. Fl. dan. 65. Hall. helv. 1. t.7. VOL, I. 
In Lahrador and Hudson's Bay. 4. v. s. in Herl. Dicksnn. nec non Banks. About a span high; flowers red, with membranaceous bracteas.

\section{OXALIS, Gen. pl. 794. Wood-Sorrel.}

Acelosella. 1. O. acaulis ; scapo uniflorn follis longiore, foliis ternatis dilatato-obcordatis, lobis rotu datis, stylis longitudine stamimu interiorum, radice dentata.-Willd. $s p$. pl. 2 p. 7 so.

Icon Fl. dan 950. Engl. 10t. 762.

In shady woods: Canada Mhthoux. On the high monintains of Pensylvania and New lork round the roots of old trees. P. 2u. Nay, v,v. Flowers large, white, with red veins and yellow at the buttom: the petals are cuneate, emarginate, and narrower than the European species.

violacea. 2. O. acaulis; scapo umbellifero, pedicellis subpubecentibus, floribus nutantibus, foliis ternatis iboordatis giabris, caly cis laciniis apice callosis, stylis stamin!ıbus exterioribus brevioribus, $-W$ illd. sp. pl. 2. p. 780 .

Icon. Jacq. oxal. t. 80. f. 2 . Jicq. hurt. 2. t. 180. Pluk. alm.t. $102 f 4$.

In shady woods, on the side of hills, in fertile soil: New England to Carolina. 24. April, May. $v v$. Flowers pink-coloured.

Lijoni.

3. O. tota sericec-pilosa; canle ramoso decumbente, pedunculis biforis petiolis longioribus, fol is lernatis bilobo-obcordatis, laciniis rotundatis divaricatis, petalis cuncatis, siliquis tomentosis calyce lanceolato duplo longioribus.

On Cumberland Island, Georgia. Lyon. 24. June. v. s. in Herl. Lyon. Flowers yellow.

corniculata. 4. O. tota pubescens; caule ramoso diffuso seu procumbente, pedunculis umbellatis petiolis brevioribus, $\mathrm{f}$ liis ternatis obcordatis, petalis obcuneatis aptce erosis, stylis longitudine staminum interiorum.-Willd. $s p$. pl. 2. p. 800 .

Icon. Jacq. oxal. t. 5. Salisb. in act. soc. linn. lond. 2. t. 23. f. 5. O. pusilla.

In cultivated grounds : Canada to Carolina. ๑. 24. May -Oct. v. $v$. Flowers yellow; the American plant has larger flowers than the European; in every other respect they are very much alike. 
5. O. tota hirsuta; caule erecto ramoso, pedunculis um. belliferis petiolis brevioribus, foliis ternatis obcordatis, petalis obovatis, stylis longitudine staminum interiorum.--Willd. sp. pl. 2. p. 800 .

O. ambigua. Salisb. in act. soc. linn. lond. 2. t. 23.f. 4.

O. corniculata. Fl, dan. $t .873$.

Icon. Jacq. oxal. t. 4. Dill. elth. t. $221, f .4$.

In cultivated grounds: Pensylvania to Virginia. 4 . June, Jaly. v. v. Flowers yellow.

6. O. hirsuta; caule folioso erecto hirto, pedunculis umbelliferis foliis longioribus, foliis ternatis obcordatis, corollis emarginatis. IV illd. sp.pl. 2. p. 799.

Icon. Dill. elth. $t .221$.

In Carolina. Dillenius. $\odot .+$. Flowers yellow, larger than the preceding one, with which it generally is confounded.

\section{PENTHORUM. Gen. pl. 790.}

1. P. caule ramoso, angulato; foliis lanceolatis subsessilibus sedoides. inæqualiter dense-serratis, spicis terminalibus paniculatis alternis cymosisque, seminibus scrobiformibus.IVilld. sp.pl.2.p.770.

Icon. Act. ups. $1744 . t .2$.

In ditches and small ponds: New England to Carolina. 4. June, July. $v . v$. Flowers white or pale yellow. In the Herbarium of A. B. Lambert, Esq. is a second species, brought by Sir George Staunton from China, which I distinguish by the following characters: Penthorum chinense, caule simplici tereti, foliis elongato-lineari-lanceolatis subpetiolatis inæqualiter serratis, spicis cymosis terminalibus, seminibus ovatis corneis.

\section{SEDUM. Gen. pl. 789 .}

1. S. erectum, glabrum, 1-2-unciale; foliis alternis teretiusculis oblongis, floribus ad summitatem paucioribus alternis subpedicellatis. Mich. fl. amer. 1.p. 276 .

In North Carolina, on flat rocks. Michaux. On the east banks of the Shanadoah River, Virginia. $P$. 4. June, July. v. $v$. Flowers white, with eight stamina.

2. S. glabrum; caulibus assurgentibus, foliis sparsis planiuscule linearibus obtusis, cyma polystachya, floribus sessilibus octaturis.-Mich. fl. anier. 1. p. 277.

pusillum.

pulchellum. 
On rocks near Knoxville. Michaux. 4. July. + Flowers purple. Resembles S. reflexum.

steropetalum. 3. S. glabrum; caulibus assurgentibus, foliis sparsis congestis adnato-sessilibus compresso-subulatis acutis, cyma terminali trichotoma dichotoma, spicis recurvatis, floribus sessilibus 10-andris, petalis linearibus calyce multo longioribus.

On rocks on the banks of Clarck's river and Kooskoosky. 4. June, July. v. s. in Herb. Lewis. Flowers golden yellow; has some affinity with $S$. reflexum.

ternatum.

4. S. pumilum, repens; foliis planis rotundato-spathulatis ternis, cyma subtristachya, floribus sessilibus 8-andris, centro 10-andro.-Mich.fl. amer. 1. p. 277.

S. saxatilis floribus albis \&c. Clayt. virg. 891.

S. americanum. Herb. Banks.

On rocks in the western parts of Pensylvania, Virginia, and Carolina. 24. May, June. v. v. An elegant little species; flowers white.

telephioides.

5. S. foliis planis ovalibus utrinque subacutis dentatis, corymbo nultiplici fasciculato. Mich. fl. amer. 1.p.277.

On rocks on high mountains: Virginia and Carolina. 4. June, July. $v, v$. Flowers pale purple.

\section{VI. $D E C A G Y N I A$.}

398. PHYTOLACCA. Gen. pl. 800.

decandra. 1. P. foliis ovatis utrinque acutis, floribus decandris decagynis.-Willd.sp.pl. 1. p. 822.

Icon. Dill. elth.t. 339. f. 399. Pluk. alm. t. 225.f.3.

In open woods and old fields : New England to Carolina. 24. June, July. $v . v$. Flowers white, on red peduncles; berries black, and give an elegant purple colour to any liquor. The young sprouts in spring give a fine vegetable for the table, resembling asparagus. The plant is known by the name of Poke-u'eed. 


\section{ICOSANDRIA.}

\section{MONOGYNIA.}

399. CACTUS. Cal. superus, monophyllus, imbricatus. Cor. multiplex. Stigm. multifidum. Bacca l-lo. cularis, polysperma.

400. BARTONIA. Cal. superus, 5-fidus. Cor. polypetala. Caps. cylindrica, 1-locularis, apice operculatim 3-5-valvis. Recept. 3-5. parietalia, duplici serie seminifera.

401. DECUMiaria, Cal. superus, 8-12-fidus. Pet. 8 -12. Caps. 7-10-locularis, polysperma.

402. PHILADELPHUS. Cal. superus, turbinatus, 4-5fidus. Pet. 4-5. Styl. 4-fidus. Caps, 4-5-locularis, polysperma.

403. CHKYSOBALANUS. Cal. inferus, campanulatus, 5-fidus. Pet. 5. Stylus lateralis. Drupee nux ovata, 5-falcata, 5-valvis, 1-sperma.

404. PRUNUS. Cal. inferus, campanulatus, 5-filus, deciduus. Pet.5. Stylus terminalis. Drupe nux suturis prominulis.

405. TIGAREA. Cal, inferus, campanulatus, 5-partitus. Pet. 5. Caps. folliculiformis, sutura laterali dehis. cens. Sem. unicum.

406. LYTHRUM. Cal. inferus, tubulosus, 12-dentatus, basi æquali. Pet.6.æqualia. Caps. 2-locularis, polysperma.

407. CUPHEA. Cal. inferus, tubulosus, 6-12-dentatus, basi hinc gibbus. Pet. 6. inæqualia. Caps. 1-locularis, hinc cum calyce longitudinaliter dehiscens.

\section{DI-PENTAGYNIA.}

408. FOTHERGILLA. Cal. inferus, truncatus, obsolete - crenatus. Cor. 0. Germen bifidum. Styli 2. Caps. 2-locularis. Sem. solitaria, ossea. 
409. AGRIMONIA. Cal. inferus, 5-dentatus, aitero obvallatus. Pet. 5. Styli 2. Sem. 2. in fundo calycis.

410. CRAT ÆGUS. Cal. superus, 5-fidus. Pet. 5. Styli 1-5. Bacca seu Pomum 2-5-spermum. Sem. ossea.

411. PYRUS. Cal. superus, 5-fidus. Pet. 5. Styli 5. Pomum 5-loculare, polyspermum. Sem. cartilaginea.

412. SORBUS. Cal. superus, 5-fidus. Pet. 5. Styli 3. Bacca 3 -sperma. Sem. cartilaginea.

413. SPIR EA. Cal. inferus, 5-fidus. Pet. 5. Styli 5. Caps. polyspermæ.

\section{POLYGYNIA.}

414. ROSA. Cal. urceolatus, collo coarctatus, 5-fidus. Pet. 5. Sem. plurima, hispida, calycis interioris lateri affixa.

415. RUBUS. Cal. patens, 5-fidus. Pet. 5. Bacca composita, acinis monospermis.

416. Dalibarda. Cal. patens, 5-fidus. Pet. 5. Pistilla 5-8. Styli longi, fliformes, decidui. Sem. exsucca.

41\%. DRYAS. Cal. patens, 8-fidus. Pet. 8. Sem. plurima: arista lanata.

418. GEUM. Cil. 10.fidus. Pet. 5. Sem. aristata : arista plerumque geniculata.

419. POTENTILla. Cal. 10-fidus, Pet.5. Sem.sub. rotunda, receptaculo parum exsucco affixa.

420. COMARUM. Cal. 10-fidus. Pet.5. calyce minora. Recept seminum ovatum, spongiosum, persistens.

421. FRAGARIA. Cal. 10-fidus. Pet. 5. Recept. seminum ovatum, baccatum, deciduum.

422. CALYCA.NTHUS. Cal. 1-phyllus, urceolatus, squarrosus, foliolis coloratis. Cor. calycina. Styli plurimi. Sigm. glandulosa. Sem. plurima, caudata, intra calycem succulentum. 


\section{I. $M O N O G Y N I A$.}

399. CACTUS. Gen.pl. 838.

1. C. articulato-prolifer; articulis compressis ovatis, spinis

Opuntia. setaceis... Willd. sp pl. 2. p. 943 .

Icon Kiorr thes. 1. t. F. $a$.

In line-barrens and sandy fields: New Jersey to Carolin. h. June, July. v. v. Flower large, yelow; berries red, eatable, know'n by the name of Prickly Perrs.

There are two or three more species growing on the Missouri ; but having had no opporiuntty to see them myself, I only mention it here, to draw the attention of the butanists in those regions towards them.

400. BARTONIA. Sims in lot.mag. 1487.

1. B. germine folioso, seminibus nudis.

ornata.

B. decaperala Sims l. $c$.

On chaiky soil and arid volcanic grounds, on the borders of the Nisinuri. M. Leuis. ठ大. July, Aug. v. s. in Herb. Lewis.

Ruäix bieunis, fibrosa. Caul's ramosus, teres. Rami patentes, scabri. Folia atterna, semi-amplexicaulia, obionga, basi dilatata, superne sensim a'gustiora, inciso dentata seu subpinnatifida, utrinque icabra, glancescentia. Flores magni, alti, ex axillss superioribus, solitarii, pedunculari Pedunculi foliosi, folio breviores. Caly $x$ superus campanulatus, 5-partitus; laciniis ovatis, longissime acuminatis, pesals paulo brevioribus. Petala 0. alba, lanceolato-oblonga, acrita, unguiculata. Stamina numerosa, filitormı, pe:alis breviora. Antherce luteæ, oblongæ, biloculares. Germen inferum, oolungum, foliis pinnatifidis calyce brevioribus ornatum. Styius staminibus longior, tiliformis. Stigma simplex. Capsula cylindrica, calyce coronata, apice operculatin 5 -valvis. Semina oblonga, plana.

This bedutiful plant, whose large white flowers open during the night and spread a most agreeable odour, was discovered in the gear $180 \%$, on the white bluft3 near the Maha village, by the late M. Lewis, Esquire. In 1807 I made a drawing and description of it, for 
the publication of that gentleman's Tour acruss the Continent of America to the Pacific Ocean. In 1812, Mr. Nuttall, on his return from a journey in those parts, brought seeds and specimens of this and another species to London; and having by those means the living plants, I agreed with Mr. Nuttall to dedicate it to the memory of Dr. B. S. Barton, of Philadelphia, our mutual friend; under which name it was published in the Botanica! Magazine. Since that publication, Mr. Nuttall, whose name has occurred in several pages of this work, with all the credit due to his valuable discoveries, has found himself rather offended at not having given him all the exclusive credit of discovery, which with justice and propriety to the memory of M. Lewis, Esq. I never could do.

nuda.

2. B. germine nudo, seminibus alatis. Sims l.c.

On the banks of the Missoui i. Nutlall. $\delta$. July, Aug. $v . v$. This species has smaller flowers, and the leaves are not so glaucous as the foregoing : in every other respect the above description is applicable to the present one, with little deviation. The number of petals is variable, from ten to fifteen.

\section{DECUMARIA. Gen. $p l .815$.}

barbara. 1. D. foliis ovato-oblongis utrinque acutis obsolete serratis. Willd. enum. p. 516 . Willd. sp. pl.2.p.850.

In South Carolina. h. July, Aug. v. v. Stem climbing; flowers in corymbous panicles, white, very sweet-scented.

sarmentosa. 2. D. foliis ovatis acutis basi rot undatis, apice serratis. Willd. enum. 516. Willd. sp.pl. 2.p.850.

Forsythia scandens. Walt. fl. car.....

Icon. Bosc. in act. hist. nat. paris. 1. $t .13$.

In deep cedar-swamps of Virginia and Carolina ; particularly plentiful in the Dismal-swamp, near Norfolk. $r_{c}$. July, Aug. $v . v$. This climbing shrub resembles the first species, but grows taller, and is in every other respect larger in all its parts. It ascends, in company of Zizyphus volubilis, the tallest cypress trees in those swamps. 
402. PHILADELPHUS. Gen. $p l .840$.

1. P. foliis ovatis acuminatis integerrimis, calycis laciniis inodorus. acutis, stylo staminibus longiore indiviso, stignatibus quatuor oblongis.-Willd.sp. pl. 2. p. 948 .

Icon. Catesb. car. 2. t. 84. Bot. mag. 1478.

On the banks of rivers in South Carolina. $々$. Tune, July. $v . v$. An elegant shrub : flowers large, white.

2. P. foliis ovatis acutis subintegerrimis, margine ciliatis, calycis laciniis acutis, stylo longitudine staminum 3 fido, stigmatibus tribus.

On the waters of Clarck's river. $々$. July. v. s. in Herl. Lewis. The flowers are smaller than the preceding species.

3. P. foliis ovatis acuminatis denticulatis, axillis venarum grandiforus. subtus fasciculato-pilosis, calycis laciniis acuminatis, stylo staminibus longiore indiviso, stigmatibus quatuor linearibus.-Willd. enum. 511.

P. inodorus. Hortul.

On river banks in South Carolina and Georgia. $h$. June, July. $v . v$. This is generally found in most gardens, under the name of P. inodorus, which is by far a more scarce plant.

\section{CHRYSOBALANUS. Gen. pl. 850.}

1. C. foliis subcuneatim oblongis vel etiam oblanceolatis ollongifolius. subtus lanuginoso-incanis, petalis subrotundo-ob-ovalibus, staminibus glabris, fructibus oblongo-ovatis. Aich. fl. amer. 1. p. 253.

Icon. Bartr. iter, $t$. ....

In the barren sands of Georgia and Florida. h. May, June. $v$. s. in Herb. Lyon. Flowers white, very small, in large panicles; they are generally dioicous : the fruit is the size of a common plum. This shrub runs with its branches under ground, without making any fibres, for a considerable distance; and its side branches appear from one to two feet above ground, as a separate small shrub, by which more properly it might be considered as a tree under ground.

\section{PRUNUS. Gen.pl. 849 .}

1. P. floribus racemosis, racemis erectis elongatis, foliis devirginiana. ciduis ovali-oblongis acuminatis inæqualiter duplicato- 
dentatis utrinque glabris, petiolis subquadriglandulosis. -Willd.sp. pl. 2.p. 985 .

P. rubra. Ait. kew 2.p. 162.

Icon. Willd. arb. $t .5 f$. Mich. arb. t. ....

In woods, frequent : Canada to Florida. 々. April, May. $v v$. A handsome tree: flowers white, as all the following are ; berries red. The wood is very useful and handsome, and is manutactured in to elegant furniture.

serotina.

2. P. flotibus racemosis, racemis laxis, foliis deciduis simpliciter serratis, serraturis infinis subglandu osis, costa media basin verutus barbata.-Willd. sp. pl. 2. p. c86.

P. virginiana. Mill. dict. n. 3. Du $R$ i harbk. 2.p. 191. Icon. Willd arb. t. 5. f. 2. Wangh. amer t. 14. $f 33$. In monntain woods: Pensylvania to Carolina. $h$. May, June. $v \cdot v$. Resembles the first species very much.

canadensis. 3. P. floribus racemosis, foliis deciduis eglandulosis latolanceolatis rugosis argute serratis utrinque subpubescelltibus, in petiolum attenuatis.-Willd. sp. pl. 2.p. 986. Icon. Pluk. alm. t. 358.f. 4 .

In North America. Sp. pl. . $^{+}+$. I strongly suspect this to be nothing more dian P. hiemalis, No.9.

caroliniana. 4. P. floribus racemosis, foliis sempervirentibus oblongolanceoiatis m:ucronatis serratis eglandu.osis lævigatis.Willd. $s p$ pl. 2 p. 9 s.

In South Carolina and Georgia. $々$. May. v. v. $\mathbf{A}$ handsome evergreen shrub, resembling $P$. lusitanica.

semperflorens. 5. P. floribus racemosis, racemis foliosis pendulis, caly cibus serratis, foliis ovatis serratis glabris basi glandulosis. Willı. sp pl. 2. p. 992.

P. serntina. Roth catalect. 1. p. 58.

In the western parts of Virginia. $\eta$. May. v. $v . \mathrm{A}$ small shrub.

yorealis. $\quad 6 . \mathrm{P}$. floribus corymbosis, pedicellis elongatis, foliis ovaliob'ongis acuminatis eroso-denticulatis membranaceis glabris, fructu subovato.-Mich. fl. amer. 1.p. 286.

Icom Mirh. arb.t....

In Canada and on the high mountains of New England and Pensylvania. 々. May, June. v. v. A very handsome small tree; the wood exquisitely hard and fine grained; the cherries hang in clusters, are small, red, and argreeable to the taste, but or casion an astringency in the mouth, from which they are.called Choke-cherries. 
7. P. umbellis subsessilibus aggregatis multiforis tandem pensylvanica. paniculæformibus, foliis oblongo-lanceolatis serratis glabris basi biglandulosis, ranulis punctatis.-IVilid. sp. pl. 2. p. 993.

P. lanceolata. Willd arl.t. 3.f. 3.

In woods and near plantations: New England to Virginia. $\quad h$. April, May. $v . v$. This resembles $P$. Cerasus very much: the cheiries are small, and itgreeable to eat.

3. P. umbellis sessilibus solitariis pauciforis, foliis deciduis ovatis acuminatis inæqualiter argute serratis utrinque glabris, petiolis biglandulosis.-Willd. sp. pl. 2. p. 993.

Icon Bot. mag. 1117 .

In Canada and on the Allegany mountains. 々. May, June. $v . v$.

nigra.

9. P. umbellis sessilibus aggregatis paucifloris, calycis laciniis lanceo'atis, stipulis setaceo-compositis, foliis oblongo-ovalibus obovalibnste abrupte promisseque acuminatis, tructu suborato.-Mich.,fl. amer. 1. p. 284.

In Canada and on the western mountains of Virginia and Carolina. 々. May. $v, v$. The fruit small, biack, extremcly astringent, but eatable in winter; called Black Choke-cherry.

10. P. umbellis sessilibus aggregatis pauciforis, foliis ovatoellipticis acuti; utrinque glabris argute serratis basi biglandulosis. - Willd. $s p$ pl. 2. p. 993 .

In the western parts of Pensylvania and Virginia. $h$. May. $v . v$. A slirub about four or five feet high; the fruit very indifferent, black, the size of a large pea.

11. P. umbellis sessilibus aggregatis paucifloris, pedunculis calycibusque pubescentibus, foliis brevi-ovalibus serrulatis basi plerumque biglandulosis, drupa sphærica, nuce subrotundo-ovoidea.

P. sphærocarpa. Mich.fl. amer. 1. p. 284.

On the sea-coast of New Engiand. Michaux. In the western parts of Pensylvania on the borders of lakes. P. $h$. May. v. $v$. A small shrub; flowers smaller than any other American species; fruit brownish-purple, very astringent.

12. P. umbellis sessilibus aggregatis paucifloris, calycibus hiemalis.

pygmasa.

pubescens. acutis, ramis virgatis teretibus, foliis angusto-lanceo- 
latis superne serratis subtus pallidis.-Willd. sp. pl. 2. p. 990.

Icon. Mill. ic. t. 89.f. 2.

In low grounds and swamps: Pensylvania and Virginia. $h$. May. v. v. A small sbrub of the appearance of Amygdalus nana; fruit red, very acid.

depressa. 13. P. umbellis sessilibus aggregatis paucifloris, calycibus obtusis, ramis angulatis depresso-prostratis, foliis cuneato-lancenlatis rariter serratis glabris subtus glancis, fructu ovato.

P. pumila. Mich. fl. amer. 1.p. 286.

On the sandy shores of rivers and lakes: Canada to Virginia. h. May. v. v. This low shrub, which spreads its branches very much, and does not rise above one foot from the ground, is known by the name of Sand-cherries. The fruit is black, small, and agreeably tasted.

Chicasa. 14. P. gemmis aggregatis bifloris, pedicellis brevissimis, calycihus glabris, laciniis obtusis, foliis oblongo-ovalibus acutus seu acuminatis serrulatis, fructu subglobuso, ramis spinescentibus glaberrimis.-Mich. fl. amer. 1. p. 284.

P. insititia. Walt. R. car. 146.

In Virginia and Carolina. h. A pril, May. v. v. Known by the name of Chicasaw Plum. The fruit is yellow and agreeably tasted. It is mentioned in Michaux's Flora, that it was introduced by the Indians; which probably may be the case, as it generally only occurs where ancient camps of Indians have been.

naritima. 15. P. pedunculis subsolitariis, foliis ovato-oblongis acuminatis duplicato-serratis. Willd. enum. 519.

P. acuminata, fruticosa ; ramulis glabris, foliis oblongoovalibus longiuscule acuteque acuminatis, calyce glabro, drupa longiuscule pedunculata ovata acuminata. Mich. fl. amer. 1. p. 284 ?

On the sea-coast: New Jersey to Carolina. 万. May. $v . v$. Fruit the size of a pigeon's egg, very good to eat, dark purple.

Susquehan. 16. P. pedunculis solitariis, foliis obovato-oblongis subtus ra. glaucis serratis basi integerrimis. Willá. enum. 519. On the banks of the Susquehammah, Pensylvania, $h$. May. +. It appears to me that this species approaches very near to No. 13. 



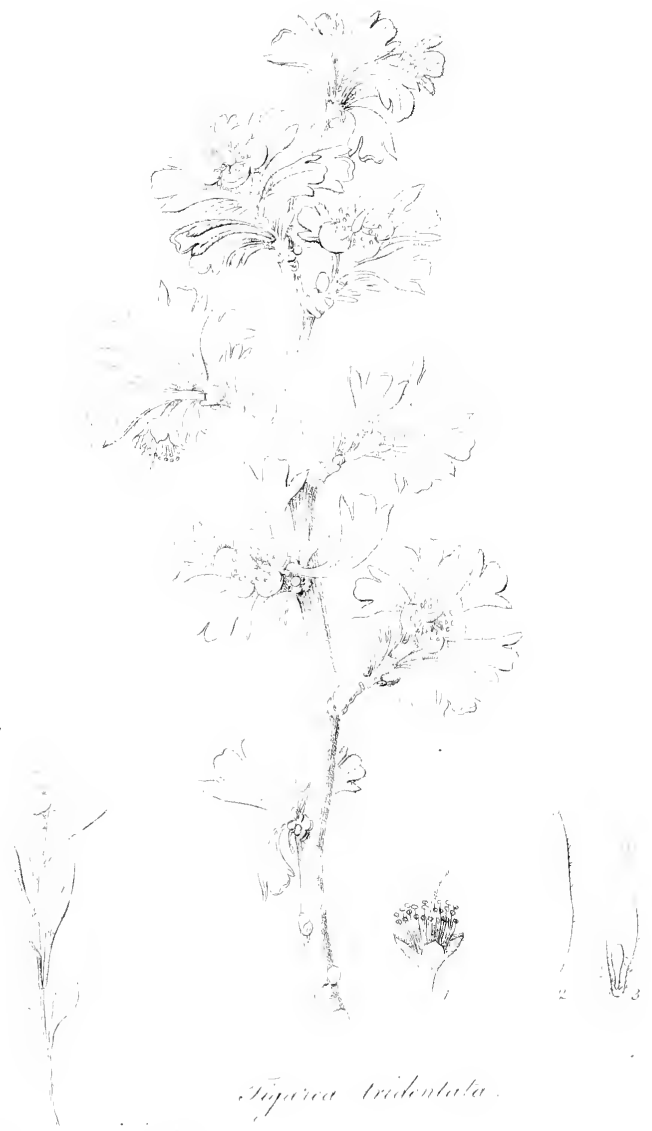

lemellient mintill 
17. P. pedunculis solitariis, foliis ellipticis glabris, fructibus pendulis, ramis subinernibus. Willd. sp.pl. 2. p.997.

cerasifera.

Near habitations, frequent. $々$. April, May. $v . v$. This is the common Myralolan Cherry, and had its origin from America, according to authors.

18. P. pedunculis solitariis, foliis elliptico-lanceolatis subtus pubescentibus, fructibus rectis, ramis spinosis. Willd. sp. pl. 2. p. 997 .

The common Black Thorn, or Sloe, is frequently found in hedge-rows, particularly in Pensylvania, but has been introduced from Europe.

40. TIGAREA. Aubl. guj. 2.p.917. Pursh in linn. trans. v. 11 .

1. . toliis in apice ramulorum confertis, obcuneatis, 3 -dentatis, supra villosis subtus cano-tomentosis, floribus terminalibus solitariis brevissime pedunculatis.

In the prairies of the Rocky-mountains and on the Columbia river. $\hbar_{2}$. July. v. s. in Herl. Lewis. Flowers yellow.

Frutex ramosissimus. Cortex cinerea. $R$ mmuli brevissimi, gibbosi, apice fasciculatim foliosi. Gemmce: squamis subrotundis, glabris, fuscis. Folia cuneiformia, quasi in petiolum angustata, apice 3-dentata sen 3-ficla, laciniis lateralibus acutis, intermedia subemarginata, margine revoluta, supra strigoso-villosa, subtus cano-tomentosa, subtriplinervia, seniuncialia. Pedunculi brevissimi, terminales, solitarii, uniflort. Flores lutei, magnitudine Cratcogi oxyacanthi. Calyx extus hirsutissimus, Jaciniis acutis. Petala obovata, subunguiculata, calyce paulo longiora. Filamenta circiter 20. longitudine petalorum. Antherce oblongæ, biloculares. Germen oblongum, hirsutum, longitudine staminum. Stylus brevis, obliquus. Stigma simplex. Capsula immatura calyce persistente cincti.

This singular shrub approaches the nearest to Tigarea of Aublet : the seeming difference in character may only be owing to the imperfect state of the specimens Aublet's description seems to be made of. It certainly deserves to be separated from Tetracera, though generally united with that genus. 
406. LYTHRUM. Gen. pl. 825.

Suliraria. 1. L. pubescens ; foliis oppositis ternatisque sessilibus lan$\beta$. pubescens. ceolatis basi cordatis, floribus terminalibus verticillatospicatis 12-andris, capsulis oblongis.-Willd. sp. pl. 2. p. 865.

Icon. Fl. dan. 6r1. Engl. loot. 1061.

In wet meadows : Canada and New England. 24. July, A ug. $v v$. About two feet high; flowers very showy, purple.

verticillatum. 2. L. pubescens ; foliis oppositis lanceolatis petiolatis, floribus axillaribus corymbosis subverticillatim aggregatis decandris, fructibus globosis.-Willd.sp.pl.2.p. 966.

Decodon aquaticum. Gmel. syst. 677.

Anonymos aquatica. Walt. fl. car. 137.

In swamps: Canada to Florida; not common.. July, Aug. v. $v$. A showy perennial, from two o four feet high ; the stems are declinate, and strike $\mathrm{ft}$ quently roots on their summits; flowers large, $f_{i}$ purple.

virgatum. 3. L. foliis oppositis lanceolatis glabris, caule paniculatc floribus axillaribus ternis pedicellatis 12-andris.Willd. sp pl. 2. p. 865.

L. virgatum. Walt. $f$. car. 120.

In low sandy meadows and swamps. Bosc. 24. Juy Aug. v. s. in Herb. Enslen. Flowers pale purple Walter in his Flora Caroliniensis has it as an bexan. drous plant ; which probably may be the case.

alatum.

4. L. glaberrimum; foliis oppositis ovato-oblongis acutis basi subcordatis arcte sessilibus, ramis virgatis 4-gonoalatis, floribus axillaribus solitariis sessilibus hexandris.

In Lower Georgia. Enslen. 2u. June, July. v. s. in Herb. Enslen. From three to four feet high; flowers small, purple.

lineare. 5. L. glabrum, virgato-paniculatum; foliis suboppositis linearibus, floribus axillaribus solitariis 6 -andris.Willd. sp.pl. 2. p. 868 .

Near the sea-coast of Virginia and Carolina. 24. July, Aug. v. v. Three or tour feet high ; Howers small, white. 
407. CUPHEA. Jacq. hort. 2. p. 83.

1. C. viscosa ; foliis oppositis petiolatis ovato-oblongis, finviscosissina. rił.us 12 -andris lateralibus solitariis brevissime pedunculatis. Willd sp.pl.2. p. 870.

Balsamona Pinto. Vundell. fasc. $t .3$.

Lythrum Cuphea. Li»n. suppl. 249.

Lythrum petiolatum $I V i l l d . s p . p l .2 . p .867$.

Icon. Jucq hort 2. t. 177.

In the mountains of Virginia and Kentncky. $\odot$. June, July. v. v.; v. s. in Herb. Gronov. Flowers, large, purple.

\section{DI-PENTAGYNIA.}

408. FOTHERGILLA. Gen. $p l .922$.

1. Fothergilla. Willd. sp. pl. 2. p. 1224.

F. Gardeni Wich fl, amer. 1. p....

a. F. fo!iis cuneato-oboratis superne crenato-dentatis.

Icon. Bot. mag. 1341. Lam. illustr. 450.

$\beta$. F. folis ovatu-oblongis basi subcordatis stiperne crenatodentatis.

Icon. Bot.mag. 1342.

$\gamma$. F. foliis ovatis acutis subintegerrimis.

F. Gardeni. Jacq. ic.rar. 1. t. 100.

In shady woods, on the side of hilis : Virginia to Carolina $r$. March, April. $v$. $v$. Flowers in close spikes or catkins, white. The different varieties here mentioned are rather to be considered as distinct species.

409. AGRIMONIA. Gen. pl. 830.

1. A. hirsuta ; foliis interrupte-pinnatis, impari petiolato, foliolis obovatis inciso-argute-dentatis glabriusculis, Eupatoria. spicis virgatis, floribus subsessilibus, petalis calyce duplo longioribus, fructibus obconicis divaricato-hispidis basi sublævibus.-IVilld sp. pl.2.p.375.

Icon. Fl. dan. 580. Curt. lond.32.

Near the edge of woods on smuny hills : Pensylvania to Carolina. 4. June, July. v. v. Flowers yellow.

alnifolia.

obtusa. major.

acuta. 
parviflora. 2. A. hirsuta ; foliis interrupte pinnatis, impari sessili, fo. liolis plurimis lineari-lanceolatis inciso-serratis, spicis virgatis, floribus brevissime pedicellatis, petalis calyce sesquilongioribus, fructibus subrotundis divaricatohispidis.-Willd. sp. pl.2.p. 876 .

In woods, on the side of hills : Pensylvania to Virginia. 4. June, July. $v . v$. Flowers small, yellow.

suaveolens. 3. A. hirsutissima; foliis interrupte-pinnatis, impari sessili, foliolis plurimis lanceolatis argute serratis subtus hirsutis, spicis virgatis viscosis, floribus brevi-petiolatis, petalis calyce duplo longioribus, fructibus obconicis divaricato-hispidis.

On high mountain-meadows : Virginia and Carolina. $\psi$. July, Aug. $v . v$. Grows to the height of five feet; is covered with very long brownish hairs : the flower spikes are likewise very closely covered with viscous hairs, and have a very agreeable balsamic scent : the flowers are small and pale yellow.

striata.

4. A. spicis virgatis, fructibus reflexis turbinatis sulcatostriatis apice tantum et quasi coronatim hispidis. Mich. fl. amer. 1.p. 287.

In Canada. Michaux. 24. +. Flowers white.

410. CRAT EGUS. Gen. pl. 854.

apiifolia. 1. C. spinosa; fuliis deltoideis inciso-lobatis, lobis acutis inciso-dentatis, corymbi pedicellis subsimplicibus, calycis tubo oblongo, laciniis subserratis. - Mich. fl. umer. 1.p. 287.

C. Oxyacantha. Walt. fl. car. 147.

In low woods and on the banks of rivers: Virginia and Carolina ; plentifully on the banks of Roanoke-river, Southampton. h. May, June. v. v. This shrub, with its elegant foliage and scarlet berries, would be one of the finest ornaments to be introduced into the gardens, particularly for the purpose of making hedges; which object has been so much neglected in North America.

spathulata.

2. C. ramulis spinescentibus fasciculatim foliosis, foliis parvis longissime deorsum angustatis subspatbulatis trifidis, corymbis paucifloris, pedicellis brevibus, calycibus tomentosis.-Mich. fl. amer. 1. p. 288.

In dry woods, near rivers: Virginia and Carolina. $\zeta$. May, June. $v . v$. The thorns are very large and crooked; leaves small. 
3. C. spinosa ; foliis cordato-ovatis inciso-angulatis glabris coccinea. acute-serratis, petiolis calycibusque pubescentibus glandulosis, petalis orbiculatis, floribus 5-gynis.Willd. sp.pl.2. p. 1000.

Mespilus æestivalis. Walt. fl. car. 143.

Icon. Pluk. alm. t. 46. $f .4$.

In woods and hedges : Canada to Carolina. $\zeta$. April, May. v. v. Berries red, large, and agreeable to eat.

4. C. spinosa; foliis cordato-ovatis basi truncatis incisoangulatis glabris, petiolis calycibusque eglandulosis, floribus pentagynis. Walt. $f$. car. 147 .

C. corallina. H. $P$.

C. cordata. Willd. sp. pl. 2. p. 1000.

Mespilus acerifolia. Lami. encycl. 4. p. 442.

Mespilus Phœenopyrum. Linn. suppl.254.

Mespilus cordata. Mill. ic.t. 179 .

In hedge rows and on the banks of rivers: Canada to Virginia. $\hbar$. May, June. v. v. Berries small, scarlet.

5. C. spinosa inermisve; foliis ovato-ellipticis inciso-serratis subplicatis subhirtis, calycibus villosiusculis, foliolis lineari-lar.ceolatis serratis, floribus trigynis. Willd. $s p$. pl. 2. p. 1001.

C. leucophleos. Moench. weissenst.p. 31. t.2.

C. tomentosa. Du Roi harlk. 1.p. 183.

C. edulis. Loddiges catal.

Mespilus calpodendron. Ehrh. beitr. 2. p. 67.

Mespilus latifolia. Lam. encycl. 4. p. 444.

In rocky and gravelly woods, and on banks of rivers : Pensylvania to Carolina. h. June. v.s.

6. C. spinosa; foliis ellipticis inæqualiter serratis glabris, pyrifolia.

populifolia. petiolis calycibusque glandulosis, laciniis calycis obtusis, baccis globosis 5-spermis.-Willd.sp.pl.2.p. 1002.

C. prunifolia. Lam. encycl.4. p. 443.

In copses and dry swamps: Canada to Carolina. $\zeta$. April, May. v.v. Fruit red, small.

7. C. spinosa; foliis obovato-cuneiformibus angulatis gla- glandulosa. bris nitidis, petiolis stipulis calycibusque glandulosis, baccis ovalibus 5-spermis. Willd. sp. pl. 2. p. 1002.

C. sanguinea. Pall. fl. ross. 1. p. 25. t. $\mathrm{J1}$.

Mespilus rotundifolia. Ehrh. beilr. 3. p. 20.

In Canada and on the Allegany mountains. $\zeta$. April, May. $v, v$. Berries middle-sized, scarlet. M. Lewis, Esq. collected it on the Rocky-mountains, 
flava.

8. C. spinosa ; foliis obovato-cuneiformibus sublobatis crenato-serratis, petiolis brevibus, stipulis cordatis caly- cibusque glandulosis, floribus subsolitariis, baccis turbinatis tetraspermis. -Willd. sp.pl.2. p. $\mathrm{J} 002$.

C. viridis. Walt. fl. car. 147.

C. glandulosa. Mich. fl. amer. 1. p. 288.

C. Michauxii. Pers. syn. 2. p. 38.

Mespilus flexispina. Moench. weissenst. p.62.t.4.

Mespilus caroliniana. Lam. encycl. 4. p. 442.

In sandy, shady places: Virginia to Carolina. $\zeta$. May. $v$. v. Eerries large, yellow, eatable; flowers large.

parvifolia. 9. C. spinosa; foliis cuneiformi-ovatis incisis serratis sub. tomentosis, foliolis calycinis lanceolatis incisis longitudine fructus, floribus solitariis 5-gynis, fructibus subturbinatis punctato-verrucosis.-Willd. $s p . p l .2$. p. 1002.

C. tomentosa. Sp. pl. 682.

C. uniflora. Du Roi harlk. 1.p. 184.

Mespilus Xanthocarpos. Linn. suppl.254.

Mespilus laciniata. Wult. fl. car. 147.

In sandy, shady woods: New Jersey to Carolina. $\zeta$. May, June. $v . v$. A low shrub; leaves small; fruit large, greenish-yellow.

punctata. 10. C. spinosa inermisve; foliis obovato-cuneiformibus subplicatis glabris incisis serratis in petiolum decurrentibus, calycibus villosis, laciniis subulatis integerrimis, baccis subglobosis umbilico depresso.-Willd. sp.pl.2. p. 1004.

C. Crus galli. Du Roi harbk. 1. p. 195.

Mespilus cuneifolia. Ehrh. leitr. 3.p. 21.

Mespilus cornifolia. Lam. encycl. 4. p. 444.

Icon. Jacq. hort. 1. t. 28.

rubra. $\quad \alpha$. C. fructibus rubris. Ait. kew. ed.2.t.3.p. 202.

aurea. $\quad \beta$. C. fructibus flavis. Ait. l.c.

In the woods and swamps of Virginia and Carolina. $\zeta$. May, June. $v . v$. Is inclined to grow to a handsome tree; berries yellow, with dark spots.

Crus galli. 11. C. spinosa; foliis obovato-cuneiformibus subsessilibus nitidis coriaceis, corymbis compositis, foliolis calycinis lanceolatis subserratis, floribus digynis. Willd. sp. pl. 2.p. 1004.

C. hyenalis. Walt. fl. car. 147.

C. Jucida. Wangh. amer. p.53. t. 17.f. 42.

Mespilus lucida. Ehrh. beitr. 4. p. 17. 
Icon. Trew ic. rar. 2. t. 17.

a. C. foliis obovato-cuneiformibus. Ait. kew. ed, 2. t.3. splendens. p. 202.

ß. C. foliis oblongo-lanceolatis subcuneiformibus. Ait.l.c. pyracanthifo-

$\gamma$. C. foliis lanceolatis. Ait. l. c. salicifolia.

In woods and hedges, on the banks of rivers, common: Canada to Carolina. h. April, May. v. v. Berries small, scarlet.

411. PYRUS. Gen. pl. 858.

1. P. inermis; foliis obovato-oblongis acutis crenato-dentaarlutijolia. tis subtus tomentosis, rachi supra glandulosa, floribus corymbosis, calycibus tomentosis.-Willd. sp. pl. 2. p. 1012.

Cratægus pyrifolia. Lam, encycl. 1. p. 83.

Mespilus arbutifolia. Sp. $p l .685$.

Mespilus arbutifolia erythrocarpa. Mich. fl. amer. 1. p. 291.

Mespilus pumila. Schmidt arb. 88 .

Icon. Mill.ic. 109.

In low copses and swamps; common : Canada to Carolina. h. May, June. v. v. A low shrub; berries red: leaves more or less tomentose.

2. P. inermis; foliis obovato-oblongis acuminatis serratis melanocarpa, subıus glabris, rachi supra glandulosa, floribus corymbosis, calycibus glabris. Willd. enum. 525 .

Cratægus arbutifolia. Lam. encycl. 1.p.83.

Mespilus arbutifolia. Schmidt arl.86.

Mespilus arbutifolia melanocarpa. Mich. $f$. amer. 1. p. 292.

In bogs of Canada and on the high mountains of Pensylvania, Virginia, and Carolina. 5. May, June. v.v. Berries large, black, and resembling in taste those of Vaccinium pensylvanicum.

3. P. inermis; foliis oblongo-ellipticis cuspidatis adultis Botryapium. glabris, floribus racemosis, petalis linearibus lanceo. latis, germinibus pubescentibus, calycinis segmentis glabris. Willd. sp. pl.2.p. 1013.

Cratægus racemosa. Lam. encycl. 1. p. 84.

Mespilus canadensis. Sp. pl. ös5.

Mespilus canadensis $\beta$. cordata. Mich. fl. amer. 1 , p. 291.

Icon. Schmidt arb. 84. 
In woods and hedges; frequent: Canada to Carolina. $h$. April, May. v. $v$. A small tree; leaves covered with a white tomentum, when young; berries black, very agreeably tasting.

ovalis.

4. P. inermis; foliis subrotundo-ellipticis acutis glabris, floribus racemosis, petalis obovats, germinibus calycinisque segmentis pubescentibus. Willd. sp. pl. 2. p. 1014.

Cratægus spicata. Lam. encycl. 1.p. 84.

Mespilus Amelanchier. Walt. fl. car. 184.

Mespilus canadensis $\alpha$. obovalis. Mich. fl. amer. 1. p. 291.

In swamps : New Jersey to Carolina. $h$. April, May. $v . v$. A small shrub; berries black and eatable.

sanguinea. 5. P. inermis; foliis ovalibus utrinque obtusis mucronatis tenuissime serratis basi subcordatis, racemis paucifloris, calycibus glabris, petalis linearibus obtusis.

Mespilus canadensis $\gamma$. rotundifolia. Mich. $f$ l. amer. 1. p. 291.

In Canada, and on the banks of the Columbia. h. April, May. v.v. A small tree with blood-red branches; berries red, eatable.

Malus. 6. P. umbellis sessilibus, foliis ovato-oblongis acuminatis serratis glabriusculis, unguibus calyce brevioribus, stylis glabris. Willd.sp.pl.2.p. 1017.

The Common Apple-tree frequently occurs in woods apparently wild, but has been seminated by birds.

coronaria. $\quad$ 7. P. foliis latomovalibus basi rotundatis subangulatis serra. tis lævibus, pedunculis corymbosis.-Willd. sp. pl. 2. p. 1018.

In woods and near plantations: Pensylvania to Carolina. h. May. v.v. The Sweet-scented Crab-tree, the fruit of which is well known as a most excellent preserve for the table, is a very fine ornamental tree, not only for the beauty but particularly for the fine violetscent of its flowers.

angustifolia. 8. P. foliis lanceolato-oblongis basi acutis leviter crenatodentatis nitidis, pedunculis corymbosis. - Willd. $s p$. pl. 2. p. 1020.

P. coronaria. Wangh. amer. t.21.f. 47.

In low woods of Carolina. $\zeta$. May. v. v. Resembles the foregoing species; the fruit very small. 


\section{SORBUS. Gen. pl. 855.}

1. S. foliis pinnatis, foliolis acutis subæqualiter serratis petioloque communi glaberrimis. Willd. enum. 520 .

S. Aucuparia B. Mich. fl. amer. 1. p. 290.

In Canada and on some of the northern mountains, $\eta$. May, June. $v \cdot v$. Berries purple, not scarlet as in the European species.

2. S. foliis pinnatis, foliolis acuminatis inæqualiter incisoserratis pitioloque communi glabris, serraturis setaceomucronatis.

S. Auc uparia $\alpha$. Mich. fl. amer. 1. p. 200.

On the peaks of bigh mountains: New Jersey to Carolina. h. June. v.v. A large shrub; the young branches covered with a shining, dark brown gloss; berries small, scarlet. This species is very distinct from the Canadian Sorbus.

\section{SPIRÆA. Gen. pl. 862 .}

\section{* Fruticose.}

1. S. foliis lanceolatis argute-serratis glabris, racemo terminali composito paniculato, floribus 5-gynis.-Willd. sp. pl. 2. p. 1055.

๙. S. foliis lanceolatis, racemis paniculatis divaricatis, petalis albis cortice ramorum rubris, Ait. kew. 2. p. 198.

S. alba. Ehrh. beilr. 7. p. 137.

Icon. Mill. ic. $t .257$. $f .2$.

B.S. foliis ovato-oblongis, racemis paniculatis, petalis albis. cortice ramorum rufescente. Ait.l. c.

In swamps and on the edge of ditches and slow-flowing rivers : Canada to Carolina; particularly on the mountains. $h$. June-Aug. v. $v$. This shrub is very variable in size, shape, and colour.

2. S. foliis lanceclatis inæqualiter-serratis subtus tomentosis, racemo terminali composito confertifloro, floribus 5gynis - Willd. sp. pl. 2. p. 1056.

Icon. Schmidt arb. 57. Pluk. alm.t.321,f.5.

In Canada and on the Allegany mountains: New York to Carolina. $h$. July-Sept. $v . v$. A small shrub; flowers red.

3. S. foliis obovatis integerrimis seu apice dentatis glabris, hypericifolia. umbellis sessilibus.-Willd. sp. pl. 2. p. 1057 .

Icon. Schmidt arb.56 \& 57. 
In dry swamps of Canada and New York. 々. May. $v v v$. Flowers white, small, and in g? eat abundance.

chamcedrifo- 4. S. foliis obovatis apice inciso-dentatis glabris, corymbis lia.

media. pedunculatis.-Willd. sp.pl. 2. p. 1058. Icon. Schmidt arl. 53.

ß.S. foliis utrinque subvillosis paucidentatis. Schmidt art 54.

In Canada and on the north-west coast. $h$. May, June. $v$. $v$.

letulifolia. 5. S. foliis lato-ovatis inciso-serratis glabris, corymbis terminalibus compositis fastigiatis foliosis.-Pall. $f l$. ross. 1. p 33.t. 16.

In the mountains of Virginia. h. May-July. v. $n$. Not above a foot high: flowers tunged with red. This species is very distinct from $S$. ulmifolia Willd. $s p$. pl. 2. p. 1058, to which it has been reterred as a synonym.

of ulifolia. 6. S. foliis ovatis lobatis duplicalo-dentatis crenatisve glabris, corymbis terminalibus confertifluris, toribus 3 . gynis, capsulis intlatis.-Willd. sp. pl. 2. p. $105 y$.

Icon. Schmiut arb.32. Rol. ic. 134. Comm. hort.1. t. 87 .

On the banks of rivers, particularly in the mountains: Canada to Carolina. $h$. June, July. $v, v$. Flowers white; generally known by the name of Nine-burk.

copitata. 7. S. foliis oratis sublobatis duplicato-dentatis subtus reticulatis tomentosis, corymbis terminalibus congestis subcapitatis longissime pedunculatis, calycibus tomentosis.

On the north-west coast. MTenzies. h. June. $v \cdot s$. in H.rl. Banks. An imperfect specinen of this species I observed in the Lew isian Herbarium, gathered on the Columbia.

discolor. 8. S. foliis oratis lobatis dentatis subplicatis subtus niveotomentosis, paniculis terminalibus pedunculatıs ramosissimis.

On the banks of the Kooskoosky. 上. June, July. v. s. in Herb. Lewis. A shrub abcut five feet bigh.

sorbifolia. 9. S. foliis pinnatis, foliolis nuiformibns serratis, floribus paniculatis. Willd.sp.pl.2.p. 1060.

Icon. Schmidt arl. 58. Pall. fl ross. 1. t.24.

On the norh-west coast, and probably in Canada. $h_{c}$. July, Aug. v. v. A handsome small shrub; flowers white. 
10. S. foliis 2-3-pinnatis, spicis paniculatis, floribus 3-gynis dioicis.-IVilld. sp. pl. 2. p. 1060.

Icon. Pall. fl. ross. 1. $t$. 26.

$\beta$. S. foliis lucidis, panicula oblonga, spicis gracilibus hermaphroditis.

In the mountains: Pensylvania to Georgia. 24. June, July. $v . v$. Flowers white; a very elegant plant.

11. S. foliis pinnatis glabris, impari majore 7 -lobo, lateraliAruncus. bus 3 -lobis, corymbis proliferis. IVilld. sp. pl. 2. p. 1062.

S. palmata. Linn. suppl. 262.

Icon. Jacq. hort. 1. t. 88.

In fertile wet meadows : Virginia and Carolina. 4 . Julv, Aug. v. $v$. A beautiful perennial; flowers red, in large clusters.

12. S. foliis ternatis lanceolatis serratis subæqualibus, stipulis linearibus interris, floribus terminalibus laxe panicu. latis 5-gynis, calyce tubuloso campanulato.- $\mathrm{W}$ illd. sp.pl. 2. p. 1063.

Gillenia trifoliata. Monch. meth. suppl.p. 286.

Icon. Mill. ic. 256. Bot. mag. 489.

In shady woods and on bogs : Canada to Florida ; principally in the mountainous parts thereof. 4 . June, July. v. v. A very fine perennial; Howers large, white. It may, with the following species, with all propriety form a distinct genus.

13. S. foliis ternatis lanceolatis inciso-serratis subæqualibus, stipulis foliaceis ovatis inciso-dentatis, floribus terminalibus laxe paniculatis 5-gynis, calyce campanulato.

trifoliata.

americana.

lolata.

-Will. enum. p.....

ß. S. foliis ternatis, foliolis pinnatifidis inciso-dentatis.

stipulacea.

In shady woods: Kentucky and lennassee. 4. June, July. $v . v$. Flowers resembling the former species. The variety $\beta$. appears very different; but, as I have not seen it in flower, I did not renture to inake it a distinct species. 


\section{POLYGYNIA.}

414. hOSA. Gen. pl. 863.

landa. 1. R. germinibus globosis glabris, caulibus adultis pedunculisque lavibus inermibus, foliolis ( 7 ) oblongis subæqualiter serratis glabris, petiolis glabris subaculeatis. -Willd.sp. pl.2.p. 1065.

Icon. Andreu's's roses. Miss Lawr. roses 27.

In Canada, near Hudson's Bay, and on the river St. Laurence. $h$. May-Aug. $v . v$. The younger branches are covered with straight red spines; the older ones unarıned and shining red.

parviflora.

2. R. germinibus depresso-globosis pedunculisque hispidis, petiolis pubescentibus subaculeatis, caule glabro, aculeis stipularibus rectis, foliolis elliptico-lanceolatis simpliciter serratis glabris, floribus subgeminatis.-Willd. sp. pl. 2. p. 1068.

R. carolina. Du Roi harlk. 2. p. 335. Mich.fl. amer.1. p. 295 .

R. pensylvanica. Wrangh. amer. p. 113.

R. bumilis. Marsh arb. 285.

In woods on the side of hills : New York to Carolina. $h$. June, July. v. $v$. About two feat high. There are a number of varieties of this species.

nitida.

3. R. germinibus globosis, calycibus pedunculis ramisque hispidis, petiolis pilosiusculis inermibus, foliolis (7) oblongo-lanceolatis utrinque nitidis glaberrimis.Willd enum. 544.

In Pensylvania and Virginia, . June-Aug. v. v. Petals red, obcordate.

lucida.

4. R. germinibus depresso-globosis pedunculisque subhispidis, petiolis glabris subaculeatis, caule glabro, aculeis stipularibus rectis, foliolis ovato-lanceolatis obtusiusculis grosse serratis glabris nitidis, floribus subgeminis, calycinis foliolis integris.-Willd. sp.pl.2.p.1068.

R. carolina. Walt. fl. car. 149.

Icon. Dill. elth. t. 245.f. 316.

On the borders of swamps: New York to Carolina. h. July, Aug. v. v. From four to six feet high.

gemella.

5. R. germinibus depresso-globosis pedunculisque glabris, floribus subgeminatis, foliis oblongis acutis opacis, pe- 
tiolis venisque subtus pubescentibus, aculeis uncinatis infra axillaribus caulinis geminatis.-Willd. enum. 544.

On dry sunny hills: New England to Carolina. $\zeta$. July, Aug. $v v$. A low shrub; flower red, large.

6. R. gerninibus subglobosis glabriusculis, pedunculis hispidis, petiolis subaculeatis, caule glabro, aculeis sparLyonii. sis rectis, foliolis $(3-5)$ ovato-oblongis acutis serratis, supra glabriusculis, subtus tomentosis, superioribus simplicibus, floribus subternatis, stipulis linedribus, calycis laciniis tomentosis linearibus vix laciniatis.

In Tennassee. Lyon. h. July. v. s. in Herl. Lyon. Flowers pale red; leaves small, with coloured veins.

$\boldsymbol{7}$. R. germinibus globosis, petiolis nervisque aculeatis, ramis glabris, aculeis geninis sparsisque, foliolis $(3-5)$ acuminatis glabris, calycinis foliolis subpennatim setigeris.-Mich. fl. amer. 1. p. 295.

In swamps of Virginia and Lower Carolina. $h$. June, July. $v . v . c . f r$. From five to eight feet high.

B. R. germinibus globosis pedunculisque subhispidis, petiolis pilosis subaculeatis, caule glabro, aculeis stipularibus subuncinatis, foliolis $(5-7)$ oblongo-lanceolatis acutis argute serratis subtus glaucis, floribus corymbosis.-Willd. sp. pl. 2. p. 1009.

R. corymbosa. Ehrh. veitr. 4. p. 21.

R. virginiana. Du Roi harbk. 2.p. 353.

R. pensylvanica. Mich fl. amer. 1.p. 296.

Icon. Andrew's roses. Miss Lawr. roses 3. 24.36.54. 66. 68.

In swamps and on the banks of ponds: New England to Virginia. $\eta$. June, July. v. v. From five to six feet high. There are a great number of varieties of this species.

9. R. germinibus globosis pedunculisque hispidulis, calycibus inexpansis muticis, foliis ternatis subtus pubescentibus, petiolis glandulosis aculeatisque, caule glabro, aculeis stipularibus sparsisque subaduncis, floribus corymbosis. Ait. kew. ed. 2.t. 3. p. 260.

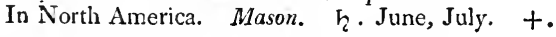

10. R. germinibus ovatis promisse hispidissimis, calycis laciniis integris, aculeis geminatis recurvis, petiolis subaculeatis, foliolis (3-5) lanceolato-ovalibus subener-

carolina.

rulifolia.

lavigata. 
vibus lærigatis, stipulis angustis subulato-mucronatis. - Nich. Al. amer. 1. p. 295.

In shady woods of Georgia. $h \cdot v \cdot v . s . f l$. An evergreen; climbing to a great height.

suaveolens. 11. P. germinibus ovatis, pedunculis petiolisque glanduloso. hispidis, petiolis subaculeatis, caule glabro, aculeis sparsis rectis tenuibus, foliclis $(5-7)$ ovatis serratis subtus vix glanduloso-pilosis, ramulis unifloris, calycis laciniis inite gris.

R. Eglanteria americana. Andreu's's roses, cum icone.

gendulina. 12. R. inermis; germinibus oblongis, pedunculis petiolisque hispidis, canle ramisque glabris, fructibus pendulis. Wilid. sp. pl. 2. p. 1076 .

Icon. Miss. Law r. ros. 9. Dill. elth. t. $245 \cdot f .317$.

In North America. h. May, June. v. v. in Hortis. Known by the name of Rose uithout Thorns. I never have seen this plant in its indigenous state.

\section{RUBUS. Gen.pl. 864. * Fruticosi.}

1deus. $\quad$. R. foliis quinato-pinnatis ternatisque rhombeo-ovatis acuminatis subtus tomentosis, petiolis canaliculatis, caule aculeato-hispido, Horibus subpaniculatis.-Willd. s.p. pl. 2. p. 1081 .

Iccn. Fl. dan. 7 s 8 .

In hedge-rows: Conada to Pensylvania. $々$. May, June. v. $v$. The Wild Rasplerry has a number of varieties.

iillosus.

2. R. pubescens, hispidus aculeatusque; foliis $3-5$-digitatis, foliolis ovato-oblongis acuminatis serratis utrinque pubescentibus, caulibus petiolisque aculeatis, calyce brevi acuminato, racemo laxo, pedicellis solitariis.-Willd. sp.pl. $2 . p .1085$.

In old fieids and commons; frequent: New England to Carolina. $h$. June, July. v. v. Known by the name of Black-berries.

strigosus.

3. R. inermis, rigide hispidissimus; foliolis 3. ant pinnatoquinatis ovalibus basi obtusis acuminatis subtus lineatis et candido-tomentosis, calycibus acuminatis, fioribus in apice ramulorum axillaribus solitariis, pełunculis caly cibusque hispidis.-Mich. fl. amer. 1. p. 297.

R. pensylvanicum. Lam. encycl. 6. p. 246.

On the mountains : Canada to Virginia. ?. June, July. $v$. $v$. An upright shrub; berries very agreeable to eat. 
4. R. glabriuscula ; foliis digitatis denis quinis ternatisque, folinlis !anceolatis utrinque nudis argute serratis, ciule inemi, bracteis lanceulatis. - Willd. sp. pl. 2. p. 1085.

In $r$ cks barren woods: Canada and New England. $\zeta$. June, July. v. $v$. Stem and old branches purple.

5. R. ramis petiolis pedunculisque tomentosis sparsim recursitu-acu!eatis, foliis $3-5$-digitatis, foliolis cuneatooinovatis superne inæqualiter dentatis plicatis margine integerr mo revolutis subtus tomentosis, racemis terminalıbus paniculatis, pediceliis divaricatis nudiusculis.

R. parvifolins. Walt, Al. cur. 149 .

In sandy fields and woods : New Jersey and Carolina. $h$. June, July. v. $v$. A straggling briar of a gray a-pect; the berries hard and dry.

6. R. ramis petiolisque glaucis et aculeatis, foliis ternis ovalibus acuminatis sublobatim duplicato-serratis subius cano-tomentosis, petiolis teretibus, acule is recurvatis, racemis terminalibus.-Willd.sp.pl. 2. p. 1082.

Icon. Dill. elth t. 217.f. 319 .

In rocky and mom:tainous situations: Canada to Carolina. h. Mry, June. $v . v$. The stem is smooth, and covered with a blueish dew. Berries black or red; known in the gardens by the name of Virginian Rastiterry.

7.R. sarmentoso-procumbens; caulibus petiolis pedunctilisque setis rigids hispidissimis, follis ternatis incisoserratis nudis, intermedio pedicellato.-IVilld. sp. $p l .2 p 1083$.

In Canala. Kulm. $h .+$. Resembles some of the following species, particularly No.9.

8. R. sarmentoso-procumbens; petiolis pedunculisque recurvato aculeato-hispids, stupulin ubulatis, follis ternatis quinatisve oblongo-ovalibus acntis inæqualiter serratis subpubescentibus, pedicellis solitariis elongatis, petalis obovatis calyce triplo longioribus. - Mich. $f l$. aner. 1. p. 296.

In old fields, common : New England to Carolina. $h$. May, June. $v . v$. Flowers large; berries black, large, and very agreeably tasting; known by the name of Dewlerries.

9. R. sarmentoso-procumbens; caule tereti petiolisque recurvato-aculeatis, foliis ternatis glabris inæqualiter

canadensis.

cuncifolius.

occidentalis.

hispidus.

trivialis.

fligellaris. 
serratis, intermedio ovato basi cuneato, lateralibus rhombeis.-Willd. entum. 549 .

R. truvialis. Att.kew.et. 2. t. 3. p. 269.

In fields and sandy woods: Virginia and Carolina. $\eta_{\text {. }}$ June, July. $v . v$. The leaves are smaller, smooth, and equal on the base; petals more orbicular than No. 8.

inermis. $\quad$ 10. R. caule petiolis pedunculisque inermibus, foliis ternatis ovatis acutis inæqualiter serratis subtus tomentosis, lateralibus subincisis, stipulis setaceo-subulatis.Willd. enum. 548.

R. hispidus, Walt. fl. car. 149 ?

In Pensylvania. $h$. + .

spectabilis. 11 . R. inermis glabra; foliis ternatis ovatis acutis duplicatoinæqualiter serratis subtus pubescentibus, pedunculis terminalibus unifloris solitariis, petalis ovatis.

On the banks of the Columbia. M. Lewis. On the north-west coast. Menzies. h. April, May. $v$. s. in Herl. Leuis. nec non Banks. The figure was taken from a specimen in the collcction of A. B. Lambert, Esq.

Frutex elegans, 4-5-pedalis. Rami geniculati, subflexuosi, teretes, læuigati. Gemmce alternæ, ferrugineæ, squamæe obtusæ. Folia e gemmis subfasciculata, ternata. Foliola ovato-oblonga, acuta, inciso-duplicatoserrata, supra glabra, subtus pubescentia, lateralia basi obliqua, intermedio petiolato. Petioli pubescentes, aculeo parvo recurvato uno alterove instructi. Stipula lineares. Pedunculi terminales uriflori solitarii. Flores maguiludine $R$. odorati, profunde et amone purpurascentes. Calyx laciniis oblongis, brevi-acuminatis, pubesceutibus. I'etala ovata, calyce plusquam duplo Jongiora.

odoratus. 12. R. incrmis, erectus, viscido-hispidus; foliis simplicibus acute $3-5$-lobat is, corymbis terminalibus divaricatis, calycibus appendiculatis, petalis suborbiculatis.-Willd. sp. pl. 2. p. 108.5 .

Icon. Bot. mag. 323. Nill. ic. 223. Corn. canad. t. 159. In the woods of Canada and on the Allegany mountains: New York to Carolina. h. June, July. v. v. A fine ornatmental shrub ; flowers rose-coloured or crimson; berries yellow, of a very fine flavour and large size, but scarcely ever produced in the gardens. 


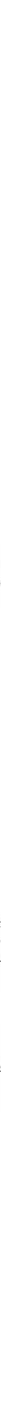





\section{** Subherbacei.}

13. R. herbaceus, pubescens; Alagellis reptantibus, foliis tersaxatilis, natis rhombeis acutis inciso-dentatis nudis, impari pe- $\beta$.canadensis. tiolato, floribus subternis, pedicellis elongatis.-Mich. fl. amer. 1. p. 298.

In Canada, and on the mountains of New York to Virginia. 4. June, July. v. v. Berries small, black.

14. R. fruticescens, pilis rigidis hispidus; foliis ternatis rotundato-obovalibus serratis nudis, stipulis setaceis, racemis floriferis subcorymbosis paucifloris, bracteis ovatis, pedicellis elongatis.-Mich. fl. amer. 1. p. 298. In swamps, among sphagnum, on the mountains : New York to Carolina. 24. May-July. v. v. Berries with only a few large grains black and sweet.

15. R. herbaceus, pusillus; caule inermi subunifloro, foliis ternatis glabris obtuse serratis, petalis subrotundis emarginatis.-Willd. sp. pl. 2. p. 1088.

Icon. Engl. bot. 1585. Bot. mag. 132.

In Labrador and near Hudson's Bay. 24. May, June. v. s. in Herl. Lambert. ; v. v. in Hortis. Flowers of a beautiful rose colour ; berries amber, very delicious.

16. R. herbaceus, pusillus; caule inermi uniforo, foliis ternatis glabris argute serratis, petalis oblongis integris, stylis approximatis. Smith exot. bot. 2. p.53.t. $\subseteq 0$.

R. acaulis. Mich. fl. amer. 1. p. 298.

In bogs of Canada, and on the north-west coast. $\psi$. Jane, July. v. s. in Herb. Dickson. Resembles the foregoing one very much.

17. R. herbaceus, pusillus, repens; foliis pedato-quinatis incisis, pedunculis filiformibus medio bracteatis, ca. lycibus glabriusculis reflexis. Smith ic. inea. f.3.p.63. t. 63 .

On the north-west coast. Menzies. 4 . v. s. in Herl. Banks. Petals white? This species may probably belong to the genus Daliliarda.

18. R. herbacens, pusillus; caule inermi unifloro erecto, foliis simplicibus cordatis trilotis rugoso-venosis, petalis lanceolatis.-Willd.sp.pl.2.p. 1089. Smith ic. ined.f. 3. t. 64 .

On the north-west coast. Menzies. $4 . \quad v$. s. in Herl. Banks. Flowers purple.

arcticus.

pistillatus.

pelatus.

stellatus.

19. R. herbaceus, pusillus; caule inermi unifloro erecto, Chamamo- 
foliis simplicibus subreniformibus rotundato-lobatis, petalis oblongis.-Willd. sp. pl. 2. p 1090.

Icon. Engl. bot.716. Fl. dan. 1. Linn. fl. lapp.t.5. $f .1$.

In sphagnous bogs of Canada, and on high mountains of New England. 4. May, June. v. v. Flowers white; berries yellow or amber-coloured.

\section{DALIBARDA. Mich. $f$. amer. 1. p. 299.}

repens.

1. D. villosa ; stolonibus reptantibus, foliis simplicibus cordatis crenatis, pedunculis unifloris. Lam. encycl. 6. p. 250.

D. violacoides. Mich. fl. amer. 1. p. 299.

Rubus Dalibarda. Willd. sp. pl. 2. p. 1090.

Icon. Mich.l.c.t.27. Smithic.ined.t.20. Lam.illustr. $t .441 . f .3$.

In shady woods and bogs of Canada, and on the high mountains of New England and Pensylvania. 24. May, June. v. $v$. Flowers white.

frogaroides.

2. D. foliis ternatis, foliolis cuneatis serrato-incisis ciliatis, pedunculis multifloris, calycis tubo obconico.-Mich. fl. amer. 1. p. 300.t. 28.

Dryas trifoliata. Pallas in Herl. Lambert.

In shady beech-woods of Canada, and on the Allegany mountains. 24. May, June. v. v. Flowers yellow.

417. DRYAS. Gen.pl. 868.

octopetala. 1. D. foliis orato-oblongis grosse-dentatis rugosis subtus niveo-tomentosis, pedunculis unifloris.-IVilld. $s p$. pl. 2, p. 1118.

Icon. Engl. lot. 451 . Fl. dan.31.

On high mountains in the north-west parts of Canad? 4. July, Aug. v. s. Flowers large, white.

tenella.

2. D. microphylla; foliis ovatis acutis basi cordatis integ, rimis planis subtus niveo-tomentosis, pedunculis ur. floris.

Icon. Egede, descrip. of Greenland, p. 42. t. B.f. 3. On the white hills of New Hanıshire. Prof. Peck. 4. July. v.s. in Herb. Bunks. Flowers not half the size of the former. 


\section{GEUMT. Gen. pl. $80 \%$.}

1. G. hirsutum; foliis omnibus interupte pinnatis, impari stricturn. ampliore, foliolis ovatis dentatis, stipulis incisis, calycis laciniis 5. alternis linearibus brevibus, floribus erectis, petalis suborbiculatis calyce longioribus, aristis nudis uncinatis.-Willd. sp.pl. 2. p. 1113.

G. canaderise. Murr. in comment. grett. 5. p.33.f.4. B.

G. aleppicum. Jacq. ic. rar. 1.t. 93 .

In wet meadows and bogs : Canada and New York. 4. May, \{nne. v. v. Flowers large, yellow.

2. G. hirsutissimum; foliis omnibus pinnatis, follolis sub-agrimonoider. æqualibus inæqualiter inciso-dentatis, stipulis oratis subintegris, floribus erectis, calycis laciniis subæq̨ualibus, petalis ovalıbus longitudine calycis.

G. laciniatum. Murr. in comm. geets. 5. p. 36.t.2 ?

On the rocky banks of the Susquehamna, Pensylvania, and on the upper parts of the Missouri. 2l. June, July. $v . v$. Flowers white.

3. G. pubescens; foliis radicalibus pinnatis, cantinis ternaallun. tis, summis simplicibus trifidis, stipulis inferioribus incisis, floribus erectis, petalis longitudine calycis, aristis uncinatis nudis apice pilosis.-Willd. enum. 550 .

G. canadense. Jacq. hort. 2. p. 82, t. 175 .

G. carolinianum. Walt. fl.car. 150?

On the banks of rivers : Pensylvania to Carolina. 24. June, July. $v . v$. Flowers white.

4. G. pubescens; foliis radicalibus caulinisque infimis ter-virginianus. natis, superioribus lanceolatis, stipulis ovatis subintegris, floribus erectis, petalis calyce brevioribns, aristis uncinatis nudis apice pilosis tortuosis. - Willd. $s p$. pl. 2. p. 1113 .

Icon. Murr. in comm. gett. 5. p. 32.

In shady woods, common: Canada to Carolina. 24. July, Aug. v. v. Flowers white, very small.

5. G. subpaniculatim multiflorum; foliis caulinis subsessi- geniculatus: libus tripartitis, stipulis integris, petalis cuneato-obcordatis, aristis prorsus pubescentibus medio geniculatis.-Mich.fl. amer. 1. p. 300.

In Canada. Michaux. $24 .+$.

6. G. pubescens ; caule simplici, foliis radicalibus interrupterivole. pinnatis, caulinis trifidis, floribus nutantibus, petalis longitudine calycis, aristis phumosis superne nudius- 
culis minutissime uncinatis.-Willd.sp.pl. 2. p. 1115. Mich. Al. amer. 1. p. 301.

Icon. Fl. dan. 722. Engl. bot. 106.

In wet boggy meadows : Canada and on the New York and Pensylvania mountains. 24. June, July. v. v. Flowers yellowish purple. The flowers are smaller, the petals more rounded on the top, and the leaves with deeper incisions, than the European plant : compared in a living state, they may be found different species.

ciliatum. 7. G. pubescens ; caule simplici, foliis glabriusculis margine ciliatis, inferioribus pinnatis, caulinis pinnatifidis, superioribus palmatis : laciniis linearibus incisis, floribus corymbosis.

On the banks of the Kooskoosky. 4 . June. v.s. in Herb. Lewis. An elegant species; flowers resembling those of No. 6.

radiatum. 8. G. hirsutissimum; caule simplici, foliis radicalibus pi: natis, impari amplissimo reniformi radianti-nervose dentato, caulinis amplexicaulibus inciso-laceris, pedunculis axillaribus solitariis, aristis glabris apice simplicibus.-Mich. $f$. amer. 1. p. 300.

G. camtschaticum. Pallas in Herb. Lambert.

On high mountains of Carolina. Michaux. On the north-west coast. Menzies. Likewise a handsome plant; flowers yellow.

Peckii. 9. G. glabriusculum; caule unifloro, foliis radicalibus reniformibus circinatis basi subtruncatis inciso-dentatis, petiolis longissimis interdum appendiculatis, petalis longitudine calycis.

On the white hills of New Hampshire. Prof. $F$ : 4. July. v. s. in Herb. Banks.

anemonoides. 10. G. glabrum; caule unifloro, foliis pinnatis, foliolis $\mathrm{C}_{\mathrm{L}}$ neiformibus apice dentatis, aristis rectis villosis. IVilld. sp.pl. 2. p. 1117.

Dryas anemonoides. Pall. itin. 3. app. n. 92. nota 2. t. Ee.f. 4.

Dryas pentapetala. Sp.pl. 717 .

Caryophyllata Kamtschatica. Lam. encycl. 1. p. 395.

Icon. Egede, descrip. of Greenland, p. 42. t. 2.

On the north-west coast and the Kuril Islands. Merk. 4. July. v. s, in Herb. Lambert. specimen Pallasia. nuาn. 


\section{POTENTILLA. Gen.pl.866.}

* Foliis ternatis.

1.P. assurgen ${ }^{\mu}$ glabriuscula; stipulis subulatis, foliis tertridentata natis oblongo-cuneiformibus apice tridentatis adpressopilosiusculis, corymbo laxo paucifloro, petalis oblongoobovatis calyce longioribus, -Willd. sp.pl. 2. p. 1110.

Icon. Ait. kew. 2. t.9. Engl. bot. ....

On rocks in Canada and on the highest peaks of the Allegany mountains, particularly at Grandfather-mountains, Carolina. 4. June, July. v. s. in Herl. Dickson.; v. v. in Hortis. Flowers white. According to Willdenow, and the figure of $P$. retusa in the Flora Danica, which is quoted as a synonym, the flowers are yellow; but this figure, if correct, presents most certainly a different plant, as the petals are round, and only the length of the calyx.

2. P. assurgens, hirsuta; stipulis ovatis integerrimis, foliis ternatis, foliolis sessilibus approximatis ambitu incisodentatis utrinque hirsutis, pedicellis paucis terminalibus elongatis unifloris, petalis cuneato-oblongis emarginatis calyce duplo longioribus.

In Labrador. Colmaster. 4. v. s. in Herb. Dickson. A small species; flowers large in proportion.

3. P. assurgens, lanato-tomentosa ; stipulis ovatis integerrimis, foliis ternatis, foliolis sessilibus approximatis ambitu inciso-dentatis supra hirsutis subtus niveo-tomentosis, pedunculis paucis terminalibus unifloris, petalis

. ${ }_{23} 9$ lato-obcordatis calyce vix longioribus.-Willd. sp.pl.2. p. 1109.

Icon. Gmel. sil. 3. t. 36.f. 1. Gunn. norv. t. 3.f 1.

In Labrador. Colmaster. 4. June, July. v. s. in Herl. Dickson. Flowers yellow.

4. P. assurgens, sericeo-villosissima ; stipulis latis membranaceis integerrimis, foliis ternatis, foliolis sessilibus approximatis ambitu inciso-dentatis, supra villis nitidis adpresso-villosis, subtus cano-tomentosis, pedunculis brevibus aggregatis, petalis obcordatis calyce longioribus.

P. villosa. Pallas in Herl. Lambert.

On the north-west coast. $\psi$. v. s. in Herl. Lambert. This species approaches in general character very near to the foregoing one, but in habit they differ striking. ly ; the last is a more robust plant, covered with shin- 
ing silky hairs, and the flowers are more than 'double the size of the former, which is a small plant covered with a white woolly tomentum. It approaches also to P. subacaulis Willd. sp.pl.2.p.1111. according to description, but Gmelin's figure is extremely different from it.

hirsuta. 5. P. erecta, simplex, hirsutissima; stipulis lanceolatis integris, foliis ternatis obovalibus laciniato-incisis, panicula pauciflora, pedicellis brevibus, petalis calyce minoribus.-Mich. fl. umer. 1.p. 303.

In Canada and the western parts of New York. 4. July, Aug. $v . v$. Flowers white, small.

worwegica. 6. P. erecta, ramosa, pubescens; stipulis ovalibus dentatis, foliis ternatis rhombeo-lanceolatis inciso-dentatis, ramis dichotomis, pedicellis brevibus axillaribus solitariis, petalis calyce brevioribus.-Willd. sp. pl. 2 . p. 1109.

Icon. Fl. dan. 171.

In fields of Canada and New York. $\odot$. June, July. $v . v$. Flowers pale yellow.

\section{** Foliis digitatis.}

pumila:

7.P. erecta, subacaulis, pubescens; foliis quinatis cuneiformibus apice dilatatis incisis subtus lanuginosis, pedunculis petiolo brevioribus simplicibus unifloris, petalis rotundatis calyce vix longioribus.-Lam. encycl. 5. p. 594.

In dry fields and pastures: Canada to Virginia. 4 . May-July. $v . v$. It has a strong resemblance to P. verna; flowers pale yellow.

canadensis. 8. P. procumbens, subramosa, candicanti-sericea; stipulis ovatis incisis, foliis quinatis cuneato-obovalibus incisodentatis, caule adscendente hirsuto, pedunculis solitariis elongatis, calycis laciniis lineari-lanceolatis, petalis orbiculatis subintegris longitudine calycis.-Willd. sp. pl. 2. p. 1106.

In fields and pastures, common: Canada to Carolina. 4. May-Aug. v. $v$. Has the appearance of a strawberry plant ; flowers bright yellow.

simplex. 9. P. erecta, simplex, hirsuta; stipnlis incisis, foliis quinatis oblongo-ovalibus grosse-serratis superioribus sessilibus, pedunculis axillaribus solitariis elongatis unifloris, calycis laciniis lineari-lanceolatis, petalis rotundato-obcordatis calyce longioribus.-Mich. $f$. amer. 1. p. 303. 
P. sarmentosa. Willd. enum. 554 .

P. caroliniana. Lam. encycl. 5. p. 595.

In fields, meadows, and dry woods : Canada to Carolina. 4. May-Aug. v. v. Flowers yellow.

10. P. decumbens, filiformis, hirsuta ; stipulis lineari-oblonopace gis integris, foliis radicalibus septenatis quinatisque lineari-cuneiformibus dentatis, pedunculis axillaribus solitariis unifloris, petalis retusis calycis longitudine.Willd.sp. pl.2.p. 1103.

Icon. Jacq. ic. rar. 91.

In Labrador. 24. June, July. o. s. in Herb. Banks. Flowers yellow, small.

11. P. erecta, ramosa, glabriuscula ; foliis quinatis, foliolis pinnatifidis, laciniis integris acutis, floribus terminalibus subcorymbosis.

Near Hudson's Bay. 4. v. s. in Herb. Banks.

12. P. erecta, ramosa, niveo-tomentosa ; stipulis ovatis acutis, foliis quinatis cuneatis inciso-dentatis subtus tomentosis, floribus terminalibus corymbosis, petalis retusis vix calyce longioribus.-Willd. sp.pl. 2. p.1101. Icon. Fl. dan. 865. Engl. bot. 89 .

In Canada, and on rocks in New Hampshire and Vermont. 24. June, July. $v$. $v$. Flower's small, yellow.

\section{*** Foliis pinnatis.}

13. P. erecta, ramosissima, hirsuta ; stipulis ovatis integris, fruticosa. fuliis quinato-pinnatis, foliolis lineari-oblongis planis, petiolis longis, ramulis 1-2-floris, calycis laciniis 5 . alternis linearibus, cæeteris lato-ovatis acutis, petalis obovatis calyce longioribus.-Willd. sp. pl. 2.p. 1094 . Icon. Engl. lot. 88. Amm. ruth.t. 17.

On the banks of rivers in Canada, and on the waters of the Rocky-mountains. Lewis. June-Aug. v. $v$. in Hortis; v. s. in Herb. Lewis. Flowers large, yellow. This shrub is from three to five feet high.

14. P. erecta, ramosissima, hirsutissina ; stipulis ovatis intedissecta.

argentea. gris, foliis quinato-pinnatis, foliolis lineari-oblongis margine revolutis, petiolis brevibus, corymbis terminalibus dichotomis dense-multifloris, calycis laciniis subæqualibus, petalis subrotundis longitudine calycis.

P. fruticosa alpestris. Pallas in Herb. Lambert.

Icon. Amm. ruth. t. 18. $f .1$. 
In bog meadows and on the borders of lakes : Canada and on the mountains of New York and New Jersey. $\eta$. July, Aug. v. $v$. This is a low-growing shrub, not above eighteen inches high. Though it appears to be no more than a variety of the preceding, the difference of habit is so great, that I was persuaded to propose it as a distinct species : both cultivated near one another, will decide whether it shall be adopted as such or not.

Anserine. 15. P. repens; foliis interrupte-pinnatis numerosis incisoserratis sericeis subtus niveo-tomentosis, pedunculis solitariis unifloris. - Willd. sp. pl. 2. p. 1095.

Icon. Engl. bot. 861.

On the banks of rivers and lakes: Pensylvania, New York, and Canada. 24. May-Sept. v. v. Flowers yellow, large. Specimens from Labrador in the Herbarium of A. B. Lambert, Esq. seem to differ in the form of its petals from the European plant; they are obovate, and longer than the calyx.

pensylvanica. 10. P. erecta, mollissime subcandicanti-villosa; foliis pinnatis, foliolis oblongis obtusis subsemi-pinnatifidis tomentosis, panicula stricta multiflora, calycis tomentosi laciniis semiovalibus. Mich. Al, amer. 1 p. 304. Willd. sp.pl. 2.p. 1099 .

Icon. Jacq. hort. $t .189$.

rigosa. $\quad$ B.P. cano-pubescens; foliis pectinato-dentatis margine revolutis, floribus corymbosis.

P. strigosa. Pallas in Herl. Lambert.

Icon. Gmel. sil. 3. t.34. f. 1.

In Canada and New England. $\beta$. on the Missouri. 24. June, July. v. $v$. B. v. s. in Herb. Leuis. Flowers yellow. The variety $\beta$. appears to be a distinct species.

supina. 17. P. procumbens, dichotoma; foliis pinnatis, foliolis ob. longis profunde dentatis, pedunculis lateralibus solitariis unifioris patulis. - Willd. sp. pl.2. p. 1099.

Icon Gmel. it. 1.t.27.f. 2. Pluk.alm.t. 100.f.7.

In overlowed places, on the banks of rivers: Caneda to Pensylvania, principally in the westcrn parts thereof. $\odot$. June-Aug. v.v. Flowers small, yellow.

420. COMARUM. Gen.pl.869.

palustre. 1. Comarum. Willd. sp.pl.2.p.1119. Icon. Fl. dan, 636. Engl. bot. 172. 
In swamps : Canada and on the banks of rivers and lakes in the western parts of New York and Pensylvania. 4. June, July. $v . v$. Flowers dark purple.

\section{FRAGARIA, Gen.pl. 865.}

1. F. calyce fructus reflexo, pubescentia petiolorum patentissima, pedunculorum adpressa. Willd. sp. pl. 2. p. 1090.

Icon. Engl. lot. 1524.

In Canada and New England. 4. April, May. v. v. The common Strawberry is frequently found wild.

2. F. calyce fructus patente, pubescentia petiolorum erecta, pedunculorum adpressa, foliis supra glabriusculis. Willd. sp. pl.2.p. 1091 .

F. glabra. Duham. arb. 1.t. 5 .

In woods and fields, frequent : Canada to Carolina. $\psi$. April, May. $v . v$.

3. F. major; foliolis amplo-ovalibus, lateralibus manifeste petiolatis, pedicellis longis recurvo-pendulis, receptaculis seminum globosis favoso-scrobiculatis villosis. Mich. fl. amer. 1. p. 299.

In shady wet woods: Canada and on the Allegany mountains. 24. April, May. v. v.

\section{CALYCANTHUS. Gen. pl. 870.}

1. C. laciniis calycis lanceolatis, foliis lato-ovalibus acutis subtus tomentosis, ramis patentibus.-Willd. sp.pl. 2 . p.1119. Willd. enum. 559 .

C. sterilis. Wall. fl. cur. 151 .

Icon. Bot. mag. 503.

On the banks of shady rivulets: Carolina. $\zeta$. MayJuly. $v . v$. The fragrant flowers are, as all the following, dark purple. This so much esteemed shrub is generally known by the name of Carolina Allspice or Sweet-scented Shrul.

2. C. laciniis calycis lanceolatis, foliis ovato-lanceolatis acuminatis subtus glaucis pubescentibus, ramis patentibus.

virginiana.

canadensis.

floricius. - Willd. enum. 559 .

C. fertilis. Walt. fl. car. 151.

Icon. Bot. rep. 539. Schmidt arl. 129.

In the mountains of Carolina. 5 . May-Aug, $v, v$,

glaucus. 
The scent of this species is not quite so agreeable as the foregoing one, and more faint.

lavigatus. 3. C. laciniis calycis lanceolatis, foliis oblongis vel ovalibus sensim acuminatis subrugosis utrinque glabris viridibus, ramis stricte erectis.-Willd. enum. 559 .

C. ferax. Mich. fl. amer. 1. p. 305.

On the mountains of Pensylvania, Virginia, and Carolina. h. May--July. $v . v$.

END OF THE FIRST TOLUME. 
Flora America Septentrionalis; oR, A

S Y STEMATIC ARRANGEMEN' AND

D E S C R I P T I O N

OF

\section{Ebe AJauts}

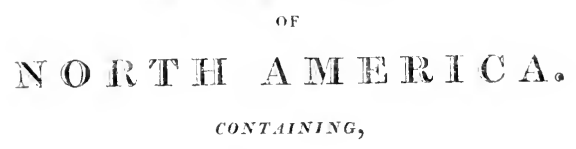

BESIDES WHAT HAYE BEEN DESCRIBED BY PRECEDING AUTHORS,

HANY NEH AND RARE SPECIES,

COLLLCTED DURING TWELVE YEARS'TRAVELS AND RESIDENCE IN THAT COUNTRY.

\section{BY FREDERICK PURSH.}

I N T W O VOL U M E S. U"ITI TUENTY-FOUR ENGRAVIVGS.

VOL. II.

SECONDEDITION

\section{Lonoon:}

PRINTED FOR JAMES BLACK AND SON; TAVISTOCK-STREET, COVENT.GARDEN. 



\section{POLYANDRIA.}

\section{MONOGYNIA.}

423. Bejaria. Cal.7-fidus. Pet.7. Siam.14. Caps. 7-locularis, polysperma.

424. TILIA. Cal.5-partitus, deciduus. Pet. 5. Stigma sub-5-lobum. Caps. immatura 5-locularis, 5-valvis, 5-sperma: matura submonosperma, basi dehiscens. 425. HELIANTHEMUM. Cal. Jaciniis 5. sæpius inæqualibus: 2. extimis minoribus. Pet. 5. Caps.1. locularis, 3-valvis; valvis medio septiferis.

426. HUDSONIA. Cal. 3-partitus, tubulosus. $\boldsymbol{p}_{\text {et. }} 5$. Stam. 10-15. Caps. 1-locularis, 3-valvis, 3-sperma. 427. TAlinum. Cal.5-phyllus. Pet. 5. Caps, 1-locularis, 3-valvis, polysperma.

428. PORTUlaCCA. Cal. 2 -fidus. Pet.5. Caps.1-10cularis, circumscissa.

429. Chelidonium. Cal. 2-phyllus, deciduus. Pet.4. Caps. 1-locularis, linearis. Sem. plurima, cristata.

430. GLAUCiUM. Cal. 2-phyllus, deciduus. Pet. 4. Siliqua 2-locularis, linearis. Sem. plurima, punctata.

431. PAPAVER. Cal. 2phyllus, deciduus. Pet.4. Caps. 1-locularis, sub stigmate persistente poris dehiscens.

432. SANGUinakia. Cal. 2-phyllus. Pet. 8. Caps. ovata, 1-locularis.

433. ARGEMO $\backslash$ E. Cal. 3-phyllus, deciduus. Pet. 6. Caps. semivalvis.

434. PODOPHYLlUM. Cal. 3-phyllus. Pet.9. Bacca 1-locularis, coronata stigmate.

435. ACTÆA. Cal. 4.phyllus, deciduus. Pet. 4. Bacca 1-locularis. Sem. semiorbiculata.

436. SARRACENIA. Cal. duplex, 3-phyllus et 5-phyllus. Pet. 5. Caps. 5-locularis. Stulus stigmate clypeatus.

vor, II. 
437. LEWISIA. Cal. 7-9-phyllus, scariosus. Pet. 1418. Stylus 3-fidus. Caps.3-locuiaris, polysperma. Senina nitida.

438. NYMPHAiA. Cal. 4-5-phyllus. Pet. plurima, germini sub staminibus inserta. Stigma radiatum, sessile, medio nectariferum. Bacca multi'ocularis, polysperma.

439. NUPHAR. Cal. 5-6-phyllus, Pet. plurima, receptaculo cam staninibus inserta, dorno nectarifera. Stigma radiato-sulcatum, sessile. Bacca multilicularis, polysperma.

440. CERATOPHYLIUM. Cal. multipartitus: femineus 6-phyllus, inzbricatus. Cor. O. Anth. tricuspldatæ. Nux 1-sperma. Monoicum.

\section{DI-PENTAGYNIA.}

441. Calligonum. Cal. 5-partitus. Cor.o. Slylit. Nux 1-locularis, 4-alata. Dioicum.

412. DAIISCA. Cal. 5-phyllus: femineus 2-dentatus. Cor. 0. Anth.sessiles, oblongæ, 15. Styli 3. Caps. 3-angularis, 3-cornis, 1-locularis. Dioica.

13. MENISPERMUM. Cial. o. Pet. 4. exteriora; 8 . interiora. Stam. 6.8. 12. 16. Pist. 2-3. Bacce 1-2, monospermæ. Dioicum.

444. DeLPhINIUM. Cal. o. Pet. 5. Nectar. 2-fidum, postice cornutum. Caps. 1-3. seu 5.

4.15. ACONITUM. Cal o. Pet. 5. supremo fornicato. Nectar. 2. pedunculata, recurva. Caps. 3. seu 5.

440. AQUilegila. Cal. O. Pet. 5. Nectar. corniculata, inter petala. Caps. 5. distinctæ.

447. Cimicifuga. Cal. 4-5-phyllus, Pet. 4-8. car. tilaginea. Cajs. 1-5. seu plures, oblongæ, sutura laterali debiscentes, polyspermæ.

448. ASCYRUM. Cal. 4-phyllus : 2. interioribus majoribus. Pet. 4. Filam. in 4. phalanges digesta. Caps. oblonga, 1-locularis, 2 -valvis, calyce inclusa.

449. HYPEKICUM. Cal. 5-partitus, laciniis subæqualibus. Pet. 5. Filam. vix basi connata. Caps. subrolunda : Joculis numero stylorum : $1-2-3-5$.

450. ELODEA. Cal. 5-partitus, æequalis, Pet.5. unguibus nectariferis. Filam. 10-15. in 3. phalanges connata. Glandule inter phalanges. Styli 3 . di. vergentes. Cups.3-locularis. 


\section{POLYGYNLA.}

\section{* Flores vagi.}

451. Illiciun. Cal.6-phyllus. Pet. 27. Caps. plures, in orbem digestæ, 2-valves, 1 spermæ.

452. Niagolia. Cal. 3-phyllus. Pet. 6-9. Caps. 2-valves, 1-sperma, in strobilum inbricatæ. Sem. pendula.

453. LIRIODENDRON. Cal. 3-phyllus. Pet. 6. Samarce imbricatæ in strobilum. Caps. 1-2-spermæx, non dehiscentes.

454. PORCELIA. Cal. 3-phyllus. Pet. 6. interiora ma. jora. Stigmata sessilia, obtusa. Bacce plures aut abortione subsolitariæ, ovoideo-subreniformes, polyspermæ. Sem. sutura interna adnexa, arillata.

455. ATRAGENE. Cal.o. Cor.4-6-petala. Neciaria 4. spathulata, petalis alternantia. Filam. exteriora dilutata subantherifera. Sem, aristata, aristis pilosis.

456. Clematis. Cal. o. Pet. 4-G. Sem. caudata, cauda plumosa.

457. ANEMIONE. Cal. o. Pet. 6-9. Sem. ecaudata.

458. THALICTRUM. Cal. o. Pet. 4-5. Stam. longissima. Sem. ecaudata, striata, teretia.

459. HYDRASTIS. Cal.o. Pet. 3. Bacca composita, acinis monospermis.

460. BRASENIA. Cal. o. Pet. 6. persistentia: 3. interiora longiora. Caps. 6-10. oblongæ, dispermæ.

461. CaLTHA. Cal. 0. Pt. 5. decidua. Caps. plurimæ, polyspermæ.

462. COPTÍs. Cal. o. Pet.5-6. caduca. Nectar. 5-6. cucullata. Caps. 5-8. stipitatæ, stellatæ, rostratæ, polyspermæ.

463. TROLliUs. Cal. o. Pet.5-8. decidua. Nectar. 5-8. linearia. Caps. plurimæ, sessiles, polysperinæ.

464. HePATICA. Cal. 3-phylits. Pet. 6-9. Sem. nuda.

465. RANUNCULUS. Cal. 5-phyllus. $P_{t} t$. 5. intra ungues poro mellifero. Sem. nuda.

166. SAgitTaria. Cal. 3-phyllus. Pet.3. Caps,aggregatæ, 1-spermæ. Polygama.

407. CYAMUS. Cal.4-5-phyllus. Pet. plurima. Fructus turbinatus, in disco truncato foveis plurinis excavatus 1-spermis. Nuces ovatæ, stylo persistente coronatæ. 
** Flores spathacei. Spadix simplex.

468. POTHOS. Spatha cucullata. Spadix floribus tectus. Cal. 0. Pet. 4. Bacce 2-spermæ.

469. CALLA. Spatha planiuscula. Spadix floribus tectus. Cal. et Cor. o. Baccae polyspermæ.

470. ARUM. Spatha cucullata. Spadix supra nudus, inferne femineus, medio stamineus. Cal. et Cor. o. Bacce utplurimum 1-spermæ.

\section{I. $M O N O G Y N I A$.}

423. BEJARIA. Gen. pl.811. Vent. hort. cels p. 51.

racemosa. 1. B. foliis ovato-lanceolatis glabris, floribus racemoso-paniculatis terminalibus.-V'ent. l.c.

Befaria paniculata. Mich. fl. amer. 1. p. 280.

Icon. Nich.l.c. t. 26 . Vent.l.c. t.51.

a. B. foliis utrinque acutis, caule hispido.

$\beta$. B. foliis obovatis obtusiusculis, canle glabro.

In sandy woods, on the banks of swamps and ponds :

Georgia and Florida: particularly plentiful on the Island of St. Mary's. h. June. v. v. A beautiful shrub, from three to four feet high ; flowers white, tinged with red, of an agreeable scent.

\section{TIL.IA. Gen. pl. 894.}

glabra.

1. T. foliis suborbiculato-cordatis abrupte acuminatis argute serratis subcoriaceis glabris, petalis apice truncatis crenatis, stylo pctalis subæquali, nuce ovata subcostata.Vent. in mem. de l'instit. sc. phys. 4. p. 9. t. 2.

T. americana. Willd. sp. pl. 2. p. 1162 .

T. caroliniana. Wangh. amer. 56.

T. canadensis. Mich. fl. amer. 1. p. 306.

Icon. Vent.l.c.t.2. Mich. art. t.....

In the woods of Canada and the northern United States, and on the mountains, as far south as Carolina. h. May, Jure. $v . v$. This tree is known by the name of Lime-or Line-tree; Basswood; Spoonwood; and is both useful and ornamental. 
polyandria MONOGYNia. Tilia.

2. T. foliis cordatis sensim acuminatis rariter dentatis membranaceis glabris. paniculis laxifloris, petalis emarginatis, stylo petalis longiore, nuce globosa.-Mich. $f$. amer. 1. p. 300 .

Icon. Mich. arb. $t$. ....

Near the sea-coast: Maryland to Georgia. h. May, June. $v, v, s$, $f$. A very distinct species, though generally confounded with the foregoing one.

3. T. foliis basi truncatis obliquis acuminatis denticulatoserratis subtus pubescentibus, paniculis confertifloris, petalis emarginatis, stylo petalis subæquali, nuce globosa lævi. - l'ent. in mem. de l'instit. sc. phys. 4. p. 10. t. 3. Willd. sp pl.2. p. 1162 .

T. caroliniana Mill. dict, no. 4 .

T. americana. Wult. $f l$ car. 153, Wangh.amer. 55.

ค. T. foliis laxe serratis tenuissimis subpapyraceis. Vent. l. c. p. 11.

In close copses and on the banks of rivers: Virginia to Georgia. h. May-July. v. v. The variety $\beta$. can scarcely be considered a distinct species, unless the flowers and fruit should prove it so, both of which I liave not seen.

4. T. foliis ovatis basi oblique aut æqualiter truncatis cor-heterophylla. datisciue argute serratis subtus niveo-tomentosis, nuce globosa subcostata. Vent.l. c. p. 16.t.5.

On the banks of the Ohio and Mississippi. $\zeta$. June. $v$.s. A very handsome and desirable ornamental tree.

\section{HELIANTHEMUM. Juss, gen. pl. 326.}

\section{Cisti spec. Gen.pl. 913.}

1. H. exstipulatum, erectum ; foliis allernis erectis linearilanceolatis planis subtus tomentosis, racemis terminaJibus paucifloris, calycis laciniis lato-ovatis acuminatis, capsulis calyce brevioribus. - Willd. sp.pl.2. p. 1199. sul Cisto.

In dry fields and pine woods : Canada to Carolina. 4. June. $v . v$. Flowers, as in all the following species, yellow.

2. H. exstipulatum, erectum, pulverulento-tomentosum; ramuliflorum. foliis alternis oblongis acnt is margine revolutis subtus tomentosis, racemis brevissimis, summitate subtrifloris, calycis laciniis orbiculatis pulverulentis, capsulis globosis longitudine calycis.-Mich. fl. amer. 1. p. $30 \%$. 
Menandra ramis alternis. Clayt. fl. virg. 20.

In sandy fields : New Jersey to Carolina. 24. July. $v . v$. Flowers small.

rorymbosum. 3. H. exstipulatum, erectum, ramosum, minutim pubescens; foliis alternis lanceolatis subtus cano-tomentosis, corymbis fastigiatis confertim multifloris, calycis laciniis ovatis acutis, capsulis ealyce vix longioribus.Mich fl. amer. 1.p. 307.

In dry barren sand-fields, particularly along the seacoast: New Jersey to Georgia. 4. June-Aug. $v . v$. Flowers very small, sometimes without petals; from which circumstance this and the foregoing species have been mistaken for Lcchea major.

rosmarinifolikm.

ckirolinianum.
4. H. exstiptlatum, stricte-erectum, simplex, canescens; foliis linearibus margine revolutis subtus cano-tomentosis, raccnulis axillaribus interrupte confertifloris, calycis laciniis ovatis acutis, petalis calyce triplo longioribus.

In pine-barrens: Georgia. Enslen. 24. July. v. s. in Herl. Enslen. Flowers bright yellow.

5. H. exstipuhatum, hirsutum, erectum; foliis alternis oblongonovalibus subdenticulatis, imis obovalibus utrinque hirsutis, pechneulis terminalibus paucis ealycibusque villosissimis, calyeis laciniis oblongis acutis petalis brevioribus. - Nicli. fl. amer. 1. p. 307 .

Cistus carolinianus. Walt. fl. car. 152.

Icon. Vent. cels 54.

In pine-barrens of Carolina and Georgia. 2\%. JuneAug. $v, v$. Flowers and leaves larger than in any other species.

426. HUDSONIA. Gen. pl. 822. Willd. hort. berol.15.

en tille. 1. Hudsonia. Willd.sp.thl.2. p. 858.

Icon. Willd. hort. lerol. 15. Berg. act. holm.1778. t.2. In pine-barrens of New Jcrscy and Virginia. h. May, June. $v, v$. Fiowers yellow. This delicate little shrab, not above six inches ligh, covers large tracts of sandy pine-woods in a similar manner as common heath. 
427. TAlinUM. Jilss. gen. pl. $3+46$.

1. T. foliis cylindricis carnosic, corymbis terminalibus pe- teretifolium. dunculatis.

On sunny rocks: Delaware and Virginia. 4. July. $v . v$. Flowers purple.

428. PORTULACCA. Gen. pl. 824.

1. P. foliis cuneiformibus, floribus sessilibus. Willd. $s p$. oleracia. pl. 2. p. $\$ 59$.

Icon. Schkulir handl. 130.

Purslane is a common weed in garders.

429. CHELIDONIUM. Gen.pl.880.

1. C. foliis alternis pinnatis lobatis, umbellis axillaribus pedunculatis.-Willd. sp. pl. 2. p. 1141 .

Icon. Fl. dan. 542. Engl. but. 1581.

Near old building, and among rocks: New England and Pensylvania; probably intruduced. 4. May, June. $v \cdot v$. The yellow fluid winich it afrords by breaking the stems, is considered an infaliible renedy in curing warts and corns.

2. C. caulibus in sumnitate geminatim diphyllis, foliis sessilibus lobato-pinnatifidis, pedunculo solitario unifloro, capsula oblongo-ovata.-NTich. fl. amer. 1. p. 309.

In shady woods, near rivulets: Kentucky and Temnassee. Michaux. 4. May. v.s. Resembles Sanguinaria very much, and seems to be the comnecting ink to both genera.

430. GLAUCIUM. Juss. gen. pl. 261.

1. G. caule glabro, foliis caulinis amplexicaulibus repandis, pedunculis unitloris, siliqua tuberculato-scabriuscula. lutersin. Smith̆ fl. brit. 2. p. 563.

Chelidonium Glancium. Willd. sp. pl.2. p. 1142.

Icon. Fl. dan. 585. Engl. lot. 8.

On the sea-coast of Virginia and Carolina. ๑. June, July. $v . v$. Flowers large, yellow.

diphyllum. majus.

\section{PAPAVER. Gen. pl. 881 .}

1. P. capsulis hispidis, scapo unifloro nudo hispido, foliis subpinuatis, foliolis lancerlatis; inferioribus subincisis. nudicaule. -Willd. sp. pl.2. p. 1145. 
Icon. Fl. dan. 41. Dill. elth. t. 224. f. 291.

In Labrador. Colmaster. o. v. s. in Herl. Dickson. Flowers yellow.

\section{SANGUINARIA. Gen.pl.878.}

canadensis.

stenopetala.

mexicana.

peltatum.

americana.

alba.
1. S. folio subreniformi sinuato-lobato, scapo unifloro.IVilld. sp. pl. 2. p. 1140. Icon. Bot. mag. 162. Dill. elth. t. 252.

ß.S. petalis linearibus.

In dry woods, generally in fertile soil: Canada to Florida. 4. March, April. v.v. Flowers white; the number of petals is variable; and with little care and attention a fine double variety might be produced. It is known by the name of Blood-wort.

\section{ARGEMONE. Gen. pl. 882.}

1. A. capsulis 5-valvibus, foliis pinnatifidis incisis spinosis, Horibus axillaribus.-Willd. sp. pl.2. p.114s.

Icon. Bot.mag. 243.

On banks of rivers : Carolina to Florida. $\odot$. July, Aug. $v . v$. Flowers yeliow, large. In Georgia is a variety with white flowers, which has a beautiful appearance.

\section{PODOPHYLLUM, Gen. pl. 879 .}

1. P. caule unifolio uniforo, follio pcltato palmato: lobis cuneatis inci,is.--lVilld. sp.pl.2. p. 1141.

Icon. Trew ehret. l. 29 Catesb car. 1. $t 24$.

In shady wouds, in large patches, generally on moist ground: New Englind to Carolina. 4. March, April v. $v$. Flower white; the fruit is the size of a common plum, green, eatable, and known by the name of Mry-apple: the root is sometinues used as Ipecacuanha.

\subsection{ACTFEA. Gen. pl. 877.}

1. A. foliis decompositis : foliolis oblongis sensim acutis inciso-serratis, racemo ovato, petalis staminibus brevioribus.

A. spicala. Mich. $f$. amer. 1.p. 308.

A. rubra. Willd, enum. 560 .

a. A. baccis niveis.

Icon. Corn, canad. t. 77. Moris, hist. 2. s. 1. t. 2.f. 7 . 
$\beta$. A. baccis rubris.

In shady rocky woods, in rich vegetable mould: Canada to Virginia; principally on the mountains. 4 . April, May. ข. v. Flowers white; berries white or red; known by the name of Red and White Cohosh, and considered by the natives as a valuable medicine. $A$. spicata differs uot only in its foliage, but the petals are the length of the stamina.

\section{SARRACENIA. Gen. pl. 885 .}

1. S. foliis brevibus, tubo ventricoso-gibbo, fauce coarctato, ala ventrali arcuatim elatiore, appendice erecta subreniformi-cordata mutica sessili. Mich. fl. amer. 1. p. 310. Willd. sp. pl. 2. p. 1150.

Icon. Bot. mag. 849. Mill. ic. 241. Catesb. car. 2. t. 70. Pluk. amalih. t. 376.f. 6.

Iir cedar swamps and sphagnous marshes: Canada to Carolina. 2 . June, July. v. v. Flowers purple, large. This singular and handsome plant is, $w$ th all the following, a very desirable object in the collection of the admirers of nature; they bear cultivation, in pots filled half way with sphagnum, extremely well.

2. S. follis elongatis, tubo superne dorso maculato, in appendicem fornicatim incurvatam brevem desinente, ala ventrali lineari-lanceolata. Niich. fl. amer. 1. p. 310 .

S. minor. Walt. Al. car. 153.

S. adunca. Snith exot. brt. 1.t. 53 .

In open swamps, on sandy soil : North Carolina to Flo. rida. 24. June, July. v. $v$. Flowers yellow. The transparent spots on the back of the leaf distinguish this species very easily from the following, with which it has often been confounded.

$3 . \mathrm{S}$. foliis strictis longissime infundibuliformibus, fauce

fla'u, patula, ala ventrali subnulla, appendice erecta basi coarctata ima parte lateribus retroflexis, mucrone su. bulato. Mich. fl. amer. 1.p. 310. Willd. sp. pl. 2. p. 1150.

Icon. Bot. mag. 780. Bot. rep. 381. Catesb. car. 2. t.69. Pluk. amalth.t. 376.f. 5 .

In open swamps : Virginia to Florida. 24. June, July. v. v. Flowers yellow. This is the tallest growing sort; the leaves are often two feet long.

purpurea.

variolaris. 
psitlacina.

rediviva.

ndorata.
4. S. foliis brevibus superne coloratis venoso-reticulatis, ala ventrali sursum subcuneatim latescente, tubo sensim in appendicem recurvatam rotundatim fornicatam mu. cronatam desinente. Mich.fl. amer. 1.p. 311.

S. rubra. Walt. fl. car. 152.

Icon. Pluk. amalth. t. 152, f. 3 ?

In swamps of Georgia and Florida. 24. June, July. $v . v$. Flowers on very long peduncles, purple; leaves small, very bandsomely marked with purple veins.

\section{LEWISIA. Pursh in linn. lrans. v. 11.}

1. Lewisia. $l$. $c$.

On the banks of Clarck's river. 24. July. v. s. in Herb. Lewis. Petals white; calyx elegantly red-veined, of a consistency like paper.

Radix fusiformis, ramosa, sanguinea. Folia radicalia linearia, subcarnosa, obtusinscula. Scapus uniflorus? an biflorus. Pedicellus basi geniculatus. Calyx coloratus, scariosus, $7-9$-phyllus, patens : foliolis ovatis, acutis, concavis, nervoso-venosis, interioribus angustioribus. Petala 14-1s. alba, lanceolata, patentia, calyce vix duplo longiora. Filamenta $14-18$. receptaculo petalis opposite inserta, filiformia, calyce breviora Antherce oblongæ, erectæ. Germen superum, ovatum, glabrum. Stylus filiformis, staminibus paulo longior, superne trifidus. Stigmata 3. bifida. Capsula oblonga, 3-locularis : loculis bispermis. Semina lenticularia, nitida, nigra.

This elegant plant would be a very desirable addition to the ornamental perennials, since, if once introduced, it would be easily kept and propagated, as the following circumstance will clearly prove. The specimen with roots taken out of the Herbarium of M. Lewis, Esq. was planted by Mr. M'Mahon of Philadelphia, and vegetated for more than one year : but some accident happening to it, 1 had not the pleasure of seeing it in Hower.

438. NYMPHÆA. Gen. pl. 886.

Castalia. Salisb. in annals of lot. 2. p. 71 .

1. N. foliis orbiculato cordatis integerrimis subemarginatis, lobis divaricatis, acumine obtuso, petalis calyce 4- 
4-phyllo æqualibus, stigmate radiis 16-20. erectis.Willd. sp.pl. 2. p. 1153 .

N. alba. Mich. fl. amer. 1. p. 311. Walt.fl. car. 155.

Castalia pudica. Salist. l. c. p. 72 .

Icon. Bot. mag. 819. Bot. rep. 297.

6.N. foliis cordatis integerimis obtusis, lobis divaricatis acutis, petiolis pedunculis foliisque subtus purpureis, calycibus petalisque extus roseis.

Icon. Willd. hort. lerol. 39 ?

In ponds and slow-flowing waters: Canada to Carolina. 4. July. $z \cdot v$. Flowers white, fragrant. The variety $\beta$. is probably a distinct species, which only further observation can decide. It resembles $N$. pygmea.

439. NUPHAR. Smith prodr. fl. grae. 1. p.36!.

Nymphæa. Gen.pl.8s6. Salisl. in annals of bot. 2.

$$
\text { p. } 71 \text {. }
$$

1. N. foliis cordatis integerrimis, lobis approximatis, calyce 5-phyllo, stigmate repando 14-20-radiato profunde unbilicato.--Ait. keu'. ed. $2 . v .3$ p. 295.

Nyniphra lutea. Willd. sp.pl.2. p. 1151.

Nymphæa umbilicalis. Salisb. l.c.

Icon. Engl. I:ot. 159.

In lakes on the Allegany mountains. 2\%. June, July. ข. v. Flowers yellow, as are all the following species.

2. N. foliis erectis cordatis integerrimis, lobis divaricatis, calyce 6 -phyllo, stigmate leviter umbilicato 13-radiato, pericarpio sulcato.-Ait. kew. ed.2. v'.3.p. 205.

Nymphæa advena. Willd.sp.pl. 2.p. 1152.

Nymphæa arifolia. Salist. l.c.

Icon. Bot. mag. 684. Willd. hort. berol.38.

In all ponds and ditches, even in salt water: Canada to Carolina. 24. July, Aug. v. v. Resembles the foregoing species, but is distinguished at first sight by its upright leaves.

3. N. foliis cordatis, lobis subapproximatis, calyce 5-phyllo, stigmate inciso 8-12-radiato. Ait.kew.ed.2. v. 2. p. 295.

Nymphæa lutea B. Kalmiana. Mich. $f$. amer. 1.p. 311.

Nymphæa lutea. Walt. fl. car. 154.

Icon. Bot. mag. 12.13.

In ponds : Canada to Carolina; rare. 4 . July, Ang. $r v$. Flowers very small in comparison with others. 
strgittofolia. 4. N. foliis elongatis sagittato-cordatis obtusis, calyce $\sigma$ phyllo, petalis nullis, antheris subsessilibus.-Salisb. l. $c$.

Nymphæa sagittifolia. Wait. fl.car. 155.

Nivmphra longifolia Mich. fl. amer. 1.p. 312.

In slow-flowing waters: Carolina and Georgia. 4 . July, Aug. v. s. Flowers small.

440. CERATOPHyllum. Gen. pl. 493. Willd. act. ac. berol. 1798. p. 84.

dincrsum. 1. C. foliis verticillatis octonis dichotomo-bigeminis dorso dentatis spinulosis, floribus axillaribus solitariis sessilibus, fructibus 3-spinosis.-Willd.sp. pl.4.p. 405.

Icon. Engl. lot. 947 .

In ditches and stagnant waters, floating: New York to Virginia. 24. July, Aug. v. $v$. Flowers exceeding snall.

\section{DI-PENTAGYNIA.}

\section{CALLigONUM. Gen.pl. 834 .}

canescens. 3. C. dioicum, pulverulento-tomentosum; foliis lanceolatis, floribus axillaribus glomeratis in apice ramulorum subspicatis, fructibus alatis, alis venosis cristato-dentatis.

In the plains of the Missouri, near the Big-bend. $h$. July, Ang. v. s. in Herb. Lewis. Flowers exceeding small. Groats delight to feed upon this shrub.

\section{DATISCA. Gen. pl. 1543.}

hirla. 1. D. caule hirsuto, foliis pinnatis, foliolis basi confuentibus. - Willd. sp. pl. 4. p. 823.

In Pensylvania. Kalm. 4 . +. Flowers yellow, small, in terminal paricles. I never had an opportunity of sceirg this plant myself.

443. MENISPERMUM. Gen. pl. 1544.

can ulense. 1. Mi. foliis peltatis cordatis subrotundo-angulatis, racemis compositis.-IVilld. sp. pl. 4. p.824. 
B. M. foliis lobatis.

M. virginicum. Willd. sp.pl.4.p. \$24. excl. syn. Dill. lobatum. elth.

On the banks of rivers and sides of fertile hills, climbing among other shrubs. h. July. v. v. Flowers greenish yellow; berries black, resembling grapes. M. folio hederaceo, Dill. elth. t. 178.f.219. belongs to $M$. carolinianum or Wendlandia.

2. M. foliis cordatis palmato-lobatis longissime pedicellatis, racemis simplicibus, floribus hexapetalis dodecandris.

In Kentucky and Tennassee. 4. June, July. v. v. s. fl.; v. s. in Herb. Lyon. Berries large, black, oneseeded. Stem climbing to the height of twenty feet; leaves large.

\section{DeLPHINIUM. Gen. pl.g24.}

1. D. pumilum; caule simplici, foliis palmato-multifidis, laciniis sublanceolatis obtusiusculis, fasciculo paucifloro, cornu recto corolla breviore, capsulis 3 . conspressis arcuatis subreflexo-patulis.-Mich. $f$. amer. 1. p. 314.

On the side of shady and fertile hills, on the banks of rivers: Virginia to Carolina; particularly plentiful about Harper's Ferry on the Potowmac, Virginia. 4. April, May. $v . v$. Not above eight inches ligh; flowers beautiful blue.

2. D. caule stricto simplici, foliis lineari-multipartitis, spica floribus breviter pedicellatis, cornu sursum arcuato, petalis villosissimis, capsulis ternis. Mich. fl. amer. 1 . p. 314 .

D. carolinianum. Walt. fl. car. 155.

On the borders of wouds, in sandy soil: Carolina and Georgia. On the banks of the Missouri and Missis. sippi. 4. May, June. v. s. Flowers beautiful skyblue, large. W. Bartram mentions this very handsome species in his Travels.

3. D. caule glabro subramoso, foliis tripartito-palmatis, laciniis lanceolatis subtrifidis, spicis strictis, cornu recto longitudine corollæ, capsulis ternis.-Willd. $s p . p l .2$. p. 1230 .

D. tridactylum. Mich. fl. amer. 1. p.314.

D. urceolatum. Jacq. collect. 1.p. 153.

Icon. Mill. ic, t. 250.f. 2. Jacq. ic, rar. 1. t. 101.

ararewan,

\section{tricorne.}

azaresats

exoltatum. 
In rocky shady places, in the moutains of Virginia and Carolina. 24. July. $v, v$. From two to four feet high.

Consolida.

4. D. pubescens; caule erecto ramoso, foliis lineari-multipartitis, cornu adscendente corollam subæquante, nectario monophyllo, capsula solitaria.-Willd. sp. pl. 2. p. 1226.

Icon. Fl. dan. 683 .

In fields and woods: Pensylvania and Virginia. $\odot$. June, July. $v . v$. Common Lark-spur, probably in= troduced with the seeds of grain from Europe.

\section{ACONITUM. Gen. pl. 925.}

uncinalum.

1. A. floribus subpentagynis, foliis $3-5$-lobis inciso-dentatis, corollarum galea longius extensa-Willd. $s p$. pl. 2. p. 1233.

In swamps and on the side of rivulets, on the high mountains of Virginia and Carolina. 24. June, July. $v v$. Fluwers large, of a fine blue and singular structure. On the foot of the Peaks of Otter and about the Sweet-springs another species occurs, with smaller flowers, and a climbing stem which sometimes attains the height of nine feet; but unfortunately I lave no materials at present to give a correct description thereof.

\section{AQUILEGIA. Gen. pl. 934.}

canadensis. 1. A. cornibus rectis, staminibus exertis.-Willl.sp. pl.2. p. 1247 .

Icon. Lot. mag. 246. Rob.ic. 296.

In the crevices of rocks: Canada to Carolina. 24. April, May. $v . v$. Flowers scarlet, mixed with yellow.

\section{CLMiCIFUGA. Gen. pl. 993.}

Serpentaria. 1. C. foliis decompositis, fuliolis ovato-oblongis incisis dentatis : dentibus nucronatis divaricatis, racenis virgatim paniculatis elongatis, floribus submonogynis, capsulis ovatis.

Actæa racemosa. Willd. sp. pl. 2.p.1139.

Actæa monogyna. Walt. fl. car. 151.

Icon. Dill. elth. t. 67.f.78. Schkuhr handb. 139. Pluk. amalth. $t .383, f .3$. 
In shady, stony woods: Canada to Florida. 4 July, Aug. $\quad v, v$. A tall sately plant; spikes long, white; generally known under the name of Black Snake-root.

2. C. foliis decompositis, foliolis ovatis incısis dentatis, dentibus acutis, racemis paniculatis nutantibus, $₫$ ribus foetida. 5 -gy'nis, capsulis ovatis uncinatis.-Wilid. sp. pl. 2. p. 1244.

Actæa Cinicifuga. Sp. pl. 722.

Icon. Lam. illustr. 457. Amon. acad. 7. t. 6.f.2.

On the north-west coast. 24. July, Aug. v. v.

3. C. foliis decomposito-biternatis, foliolis cordatis lobatis cordifolia. serrato-dentatis, racemis virgatim-paniculatis elongatis, tloribus $2-5$-gynis, germınibus glabris.

C. americana. Mich. fl. amer. 1.p. 316.

In shady woods, on high mountains of Carolina. $\mathcal{L}$. July. $v . v . ; v . s$. in Herb. Lambert. Resembles the foregoing very much in general habit.

4. C. foliis simplicibus palmatis, floribus dichotome-paniculatis subcorymbosis polygynis, capsulis brevissimis subgloboso-capitatis - Mich. fl. amer. J. p. 316.

Actæa racemosa. Herb. Walt.

In the beds of mountain rivulets in Virginia and Carolina. 2. July, Aug. $v \cdot v$. A very tall and handsome plaut ; the leaves very large, and the flowers in great abundance.

\section{S. ASCYRUM. Gen. pl. 1225.}

1. A. pusillum, simplex; foliis ovalibus obtusis, pedicellis longis reflexis, floribus i-2-gyuis.-Mich. fl. amer. 2. p. 77 .

A. nummularifolium. Herb. Banks. mss.

In pine-barrens of Georgia. 4. June-Aug. v. s. Not above three inches high; flowers small, yellow, as are all the fullowing species.

2. A. multicaule, diffusum; foliis sublanceolato-oblongis obtusis, corymbo terminali, floribus subsessilibus 2gynis, caule subtereti.--IVilld. sp. pl. 3. p. 1472.

A. multicaule. Mich. fl. amer. 2. p. 77 .

In sandy fields and woods : New Jersey to Carolina. h July. $v . v$. Not above a foot high; flowers pale yellow; petals narrow.

3. A. erectum, ramosum; ramis ancipitibus, foliis oblon- hypericoides. 
gis basi biglandulosis, floribus terminalibus solitariis breviter pedicellatis 3-gynis.-Willd.sp. pl.3. p. 1473.

A. stans. Mich. Al.amer. 2. p. 77 .

In low overflowed open places, generally in sandy soil : New Jersey to Carulina. $h$. July, Aug. $v, v$. Flowers larger than the former species : it is from one to two feet high.

amplexicaule. 4. A. erectum; caule superne dichotome-paniculato, ramis ancipitibus, foliis ovato-oblongis amplexicaulibus, foliolis calycinis exterioribus cordatis, floribus 3-4gynis.-Mich. Al. amer. 2. p. 77 .

A. stans. Wiild. sp. pl. 3. p, 1475.

Hypericum tetrapetalum. Lam. encycl. 4 p. 153.

In low grounds and woods: Virginia to Florida. $\eta$. July, Aug. $v . v$. The flowers and leaves larger than any other sort.

449. HYPERICUM. Gen.pl. 1224.

* Penlagyna.

Kalmianum. 1. H. fruticosum, ramosissimum; ramulis 4-gonis, foliis lineari-lanceolatis, corymbis terminalibus $3-7$-floris, laciniis calycis lanceolatis obtusiusculis, capsulis longitudine calycis.-Willd. sp. pl.3.p. 1438.

H. Bartramianum. Mill. dict. $n$. 10.

In Pensylvania and Virginia. $h$ June, July. vs s. in Hert. Lambert. v. v. in Hortis. From three to five feet high: the flowers of the whole genus are yellow.

pyramidatum.

ascyroides.
2. H. herbacenm, erectum; caule subteragono ramoso, foliis sessilibus oblongis acutis glabris, floribus terminalıbus, stylis stammibus brevioribus, calycinis foliolis ovatis acutis.- IVilld sp. pl.3. p. 1444.

H. amplexicaule. Lam encycl. 4. p. 147.

Ionn. Ient, min/m, 118.

In Canada? 4. July, Aug. v. v. in Hortis. Flowers the size of $/ 1$. Ascyrum.

3. H. be bareum, glabrum; caule simplici 4-gono, foliis sessilibus oblongin acutis glabris, fioribus terminalibus, st lis longitudine staninum calycinis fuliolis ovatolanceolatis_-:Villd sp. pl. 3. p 1443.

H. maciocarpun. Mich fl umer. 2. p. 82.

In Canada ant the u entern parts of New York and Pensylvan a. 24. July, Aug. v. v. Flowers the largest of all the species here enumcrated. 


\section{* Trigynce. Fruticose.}

4. H. ramis ancipitibus, foliis ovali-oblongis obtusis mucronatis basi angustatis, floribus terminalibus subsolitariis, calycinis foliolis oblongis acutis staminibusque petalis æquantibus, stylis coadunatis longitudine staninum. Mich.fl. amer. 2. p. 81.

H. elatum. itt. kew. 3. p. 104 ?

In shady rocky places in Kentucky and Tennassee. $h$. July, Aug. v. $v$. Resembles $H$. Aicyrum very much; the leaves of the calyx are broad, and sometimes longer than the petals.

5. H. ramis ancipitibus, foliis ellipticis margine crispatorevolutis supra opacis subtus glaucis, floribus terninalibus subsolitariis sessilibus, calycinis foliolis oratis acuminatis, petalis deflexis staminibus longioribus, stylis coadunatis longitudine staminum.

In South Carolina and Georgia. Lyon. h. July, Aug. $v$. $v$. This elegant species grows to the height of about two feet or more. Every branchlet has fron: one to three large flowers, of a bright golden yellow; the petals turn downwards, and leave the large crown of stamina in an upright situation, which, with the beautiful red ovate germen in the centre, gives the flower a particularly pleasing appearance.

6. H. ramis ancipitibus, foliis lanceolato-linearibus obtusiusculis, corymbis axillaribus et terminalibus paucifloris, floribus primordialibus sessilibus staminibus stylisque longitudine petalorum, calycinis foliolis lanceo. latis.-Willd. sp.pl. 3. p. 1453.

H. Kalmianum. Du Roi harbk. 1. p. 310.

In Virginia. Gronov. 々. June-Aug. v. v. in Hortis. The most common and most hardy species in the gardens. I rather suspect its native country to be $\mathrm{Ca}$ nada, as most of the shrubby kinds coming from the southern parts are extremel; tender.

7. H. ramis alatu.4-gonis, foliis oblongo-lanceolatis obtusiusculis sessilibus, panicula pedunculata dichotoma nudiuscula, florıbus solitariis subsessilibus, calycınis laciniis lanceolatis petalis duplo brevioribus, stylis coadunatis staminibus longioribus. - Mick. fl. amer. 2. p. 78 .

H. lævigatum. Ait. kew. 3. p. 106 ?

H. ligustrinum. Herl. Banks, Mss.

VOL, II. frondosum.

amonum.

prolificum.

nudiflorum. 
In Carolina. Michaux. h. July, Aug. v. v. Flowers small. Willdenow in the Species Plantarum considers this to be an herbaceous plant, whereas it certainly is a shrub.

glaucum.

3. H. ramis teretibus, foliis oblongis cordatis amplexicaulibus obtusinsculis lævigatis glauris coriaceis, panicula divaricato-dichotoma foliosa, calycinis foliolis ovatis acutis petalis longioribus, staminibus petalis subæquantibus, stylis coadunatis.-Mich. fl. amer. 2. p. 78.

H. myrtifolium. Lam. encycl. 4. p. 180.

In Florida. Michaux. b. July, Aug. v. v. Flowers large.

densifor:m. 9. H. ramosissimum; ramulis subteretibus, foliis linearilanceolatis obtusitusculis basi attenuatis, paniculis terminalibus conposite-dichotomis subfoliosis densifloris, fistibus solitariis pedicellatis, calycinis laciniis brevissimis uvatis deciduis, staminibus stylisque coadunatis petalis brevioribus.

7.1. rosmarinifolium. Lam. encycl. 4. p. 159?

On the dry ridyts and savannals of the Virginia mountains. $h$. June, July. v.v. A bout two feet high; fowers middle-sized, in rery abundant and close panicles.

galioides. 10. H. ramulis tetragonis, foliis linearibus sessilibus margine revolutis, axillis fasciculato-foliolosis, paniculis terminalibus divaricato-dichotomis, petalis staminibus $\mathfrak{x}$ quantibus calyce lineari vix longioribus, stylis coadunatis subexertis.-Lain encycl 4. p. 161.

In sardy' moist places, near rivulets : New Jersey to Carolina. $h$. July-sept. v. v. About two feet high; flowers the size of No.9.

aspalathoides. 11. H. ramis subteretibus dichotomis, foliis fasciculatis linearibus acutis striatis, floribus solitariis axillaribus subsessilibus, staminibus petalis brevioribus, stylis coadunatis.--Willd. sp. pl. 3. p. 1451.

H. fasciculatum. Lam. encycl. 4. p. 160.

In Carolina. Fraser. 々.+. Flowers of middle size.

fascicuialum. 12. H. ramulis teretibus, foliis quasi verticillatim-fasciculatis lineari-lanceolatis acutis basi attenuatis petiolatis margine revolutis, pedunculis in apice ramorum axillaribus trifloris, flore medio sessili, calycibus foliiformibus, stylis coadunatis._Willd.sp. pl.3. p. 1452. excl. syn. Michaux. 
H. axillare. Lam. encycl. 4. p. 161.

H. Coris. Walt. $f$. car. 190.

In pine woods of Georgia and Florida. $\hbar_{c}$. July. v.v. Flowers the size of $H$. perforatum.

13. H. ramulis angulosis, foliis confertis quasi verticillatim tenuifolium. fasciculatis filiformi-linearibus convexis obtusis sessilibus, pedunculis in apice ramulorum axillaribus $1-3-$ floris, calycibus foliitormibus, stylis coadunatis.

H. fasciculatum. Mich. fl. amer. 1. p. so.

In Georgia. Enslen. v. s. in Herb. Enslen. Resem. bles the foregoing species in many respects.

\section{*** Trigyna. Herlacea.}

14. H. erectum, ramosum; caule ancipiti, foliis oblongis obtusis pellucido-punctatis, panicula terminali brachiato-foliosa, petalis calyce acuto lanceolato duplo longioribus.-Willd. sp. pl. 3. p. 1460.

H. virginicum. Walt. $f$. car. 189 .

Icon. Fl. dan. 1043. Engl. lot. 295.

In old fields, meadows, and on dry hills; common. 4 . June-Aug. v. v. Common St. John's IFort has probably been introduced from Europe, but become one of the most pernicious weeds, and is considered very injurious to horses; for, when they feed upon it, blindness and other diseases are said to be the consequence.

15. H. erectum, glabrum, nigro-punctatum; caule tereti perforatum. ramoso, foliis amplexicaulibus oblongo-ovalibus ob. tusis, corynubis terminalibus brachiatis densiftoris, calycinis laciniis lanceolatis acutis.-Willd. sp. pl. 3 . p. 1457 .

H. maculatum. Walt. fl. car. 189.

H. punctatum. Lam. encycl. 4. p. 164.

In shady woods : New England to Carolina; particularly in the range of the mountains. 4. June-Aug. $v . v$. Flowers pale yellow, smaller than the foregoing one.

16. H. erectum, ramosissimum, glabrum; caule subtetragono, foliis ovato-oblongis subcordatis oblusis nervosis sessilibus, paniculis terminalibus dichotomo-corymbosis, petalis calyce lanceolato brevioribus.-Willd. sp. pl. 3. p. 1456.

H. quinquenervium. Walt. fl. car. 190.

H. mutilum. Willd. sp. pl. 3. p. 1471 .

In overflowed places: Canada to Carolina. 4. JuneSept. $v$. $v$. Flowers small; size very variable. 
triplinere. $17 . \mathrm{H}$. erectum, subramosum; caule subancipiti, foliis li. nearibus patentissimis triplinerviis, floribus racemosopaniculatis, corolla inæquali, calycibus acutis petalisque serrato-glandulosis.-Vent. hort. cels $5 \mathrm{~s}$.

On the banks of the Ohio. Michaux. 24. July, Ang. + . Flowers the size of $H$. perforatum, pale yellow.

dolabrifurme. 18. H. erectum, ramosum; caule ancipiti, foliis linearilanceolatis patentibus obtusis, corymbo terminali dichotomo, calycibus inæqualibus lanceolatis, petalis dolibriformibus.-V'ent. hort. cels 45.

On dry hills of Kentucliy. Michaux. 24. June, July. + Flowers golden yellow.

angulosum. 19. H. erectum ; caule tetragono, foliis oblongis acutis arcte sessilibus, panicula terminali dichotoma, ramis divaricatis distanter alternifloris, calycibus subcampanulatis, laciniis !anceo'atis acutis inferne carinatis longitudine fere corollæ, petalis dente unico laterali. $-W$ Willd. sp. H. 3. p. 1454? Mich.fl. amer. 2. p. 78.

H. denticulatum. Wull. fl. car. 190.

In bogs and cedar-swamps: New Jersey and Carolina. 4. June, July. v. v. About a foot high; flowers of a besutiful copper colour, of considerable size.

pilarencarpum.

ranaderse.

Sirotizu.
20. H. erectum, glaberrimum; foliis oblongis, panicula nuda dichotoma, dichotomis omnibus unifloris, stylis coadunatis, capsula globosa.-Mich. $f$. amer. 2. p. 78. In Kentucky. Michaux. 24. + .

21. H. erectum, pusillum, parviforum; caule tetragono superne dichotono, foliis sessilibus linearibus basi attenuatis, panicule ramis primariis oppositis, secundariis dichotomis, capsulis longis convideis coloratis.Wilid.sp.pl.3.p. 1455.

In low gravelly soil; Canada to Carolina. $\odot$. June-Aug. v. v. Flowers very small; capsules red.

22. H. pusillum, erectum, setaceo-ramosissimum; quasi aphyllum; folis numatis appressis, floribus in ramulis solitarie alternis 5--10-andris, capsulis oblongis 1-10cularibus.-Aich. fl. amer. 2.p. 79 .

H. nndicaule. Wall. fl. car. 190.

Sarothra gentianoides. IVilld. sp.pl. 1.p. 1515.

Icois. I'luk, mant. t. $342 . f .2$.

In dry sumy situations: New Engiand to Carolina. $\odot$. June-Aug. $v \cdot v$. A singular little species; flowers very small; the number of stanina is very variable, according to soil and situation. 
23. H. erectum, simplicissimum, lanulosum ; caule tereti, simplex. folis oblongis adpressis, floribus paucis terminalibus. - Mich. fl. amer. 2. p. 80.

H. pilosum. Wait. fl. car ? 90 .

$\mathrm{H}$. ferrugineum. Iterb. Binks, mss.

Ascyrum villosum. Willd. s/. pl.3.p. 1474.

Icon. Pluk. alm.t. 2+5. f. 6 .

In Lower Carolina and Georgia. ๑. July, Aug. v. s.

24 . H. procumbens, glaberrimum; ramis ancipitibus sum- procumbens. mitate paucifloris, foliis linearibus enerviis patulis, calycinis foliolis cbiongo-lanceolatis acutis, staminilus corolla brevioribus, stylis coadunatis.-Mich. fl. amer. 2. p. 81. Willd.sp. pl.3. p. 1450?

On dry sunny hills of Kentncky. Michaux. t. The calyx is as large as the corolla.

\section{ELODEA. Adanson.}

\section{Hyperici $s p$. Linn.}

1. E. foliis sessilibus amplexicaulibus corlato-oblongis ob- campanulata. tusissimis, fasciculis pedunculatis pauciloris axillaribus et terminalibus, corollis subcampanulatis, staninibus 9-12. levissime basi coalitis.

Hypericum virginicum. Willd.sp.pl.3. p. 1455.

Hypericum campanulatum. Walt. fl. car. 191 .

Icon. Bot. rep. 552.

. E. foliis cordato-ovatis emarginatis, pedunculis axillari- emarginata. bus elnngatis.

Hypericum emarginatum. Lam. encycl. 4. p. 15.4.

In bogs and wet meadows: Canada to Carolina. $2 \%$. July-Scpt. v. v. B. v. s. in Herl. Lamlert. Flowers yellowish-red, very handsome.

2. E. foliis sessilibus, corollis tubulosis, staminibus plusquam ad medium commatis.

Hypericnm tubulosum. Wait. fl. car. 191.

In Carolina. Walter. + . I observed in the vicinity of the Dismal-swamp in North Carolina, a species belonging to this genus, of which thave no specimen in my Herbarium, and which probably may he the species alluded to by Waitcr. The leaves are elliptic and actite; the flowers nearly sessile in the axts of the leaves, solitary or by two or three; the petals are long and acute, pale red ; capsules long, prismatic.

3. E. foliis petiolatis oblongo-ovalıbus rotundato-obtusis, tululosa. 
floribus oppositis axillaribus subsessilibus subternis, staminibus ad medium usque connatis, capsulis oblongis.

Hypericum petiolatnm. Walt. fl. car. 191.

Hypericum axillare. Mich. fl. amer. 2. p. s1.

On banks of lakes and rotten wood: Virginia and Carolina. 4. July, Aug. v. $v$.

\section{POLYGYNIA.}

451. ILLICIUM. Gen.pl.940.

foridanum. 1. I. foliis acuminatis, petalis numerosis oblongis linearibusque.-Willd. sp. pl.2. p. 1254.

Icon. Bot. mag. 439 .

On the banks of the Mississippi, in West Florida. $\zeta$. Mav, June. v. v. Flowers dark purple, large ; leaves of a very aromatic anise-scent, when bruised.

parvifforum. 2. I. foliis obtusis, petalis sex calyceque rotundatis concavis. - Mich Al. amer. 1. p. 326.

I. anisatum. Burtr. trav. 24.

Icon. lent. hort. cels 22.

In East Florida, on the banks of the river St. John. Michaux. h. May, June. v, v. in Hortis. Flowers small, yellow.

\section{MAGNOLIA. Gen.pl. 942.}

grandifiora. 1. M. foliis perennantibus ovalibus crassis coriaceis, petalis dilatato-obovatis abrupte in unguem angustatis.Willd. sp.pl.2.p. 1255.

elliptica.

a. M. foliis oblongo-ellipticis subtus ferrugineis, floribus subcontractis. Ait. kew. 2. p. 251.

Icon. Bot. rep. 518 . Trew ehret. 33.

obovata. $\quad \beta$.M. foliis obovato-oblongis, floribus expansis. Ait.l.c.

lanceolata. $\quad \gamma \mathrm{M}$. foliis oblongo-lanceolatis apice flexis concoloribus, floribus subcontractis. Ait. l.c.

Icon. Mill. ic. 172. Catesl, car. 61. Mich. arb.t. 1.

In the forests of South Carolina and Georgia, reaching west to the Mississippi. h. May-Aug. v. v. This stately tree, with its elegant foliage and large white flowers, is the prince of the forests of North America. The varieties here mentioned might easily be considered as good species, if there were not so many intermediate ones, which connect them too closely to- 
gether. In Carolina it is known by the nane of $B$ ig Laurel.

2. M. foliis ovalibus subtus glaucis, petalis obovatis basi attenuatis.-IVilld. sp. pl. 2. p. 1256.

๙. M. foliis deciduis ovali-oblongis obtusiusculis.- Ait. glauca. kew. 2. p. 251.

Icon. Dill. elth. t. 168. f. 205. Catesb. car. 1. t. 39. Trew ehret. 9. Mich. arl.t.2.

. M. foliis perennantibus ellipticis utrinque acutis.-Ait. I. c.

In swamps covered with wood: New Jersey to Carolina. ß. Georgia and Florida. h. May-luly. v. v. A small tree; flowers white, very fragrant. The variety $\beta$. is a taller tree the branches more upright, and the leaves narrow and long; it might with propriety be considered a distinct species. This species is known by the names of Su'amp Sassafras, Su'eet Bay, Swamp Laurel, and Beuter-u'oud.

3. M. ramis medullosis fragilibus, foliis amplisissimis ob- macrophylla. longe subcuneato-obovalibus basi sinuata subauriculatis subtus glaucis, petalis 6 . ovatis obtusis.-Mich. $f$. amer. 1.p. 327 .

Icon. Nich arb. $t .7$.

In the deep forests of Tennassee. $\eta$. May-July. v. v. s. $f$. This stately small tree, with its extremely large leaves and white flowers, tinged at the bottom with red, which are larger than $M$. grandiflora, is one of the most ornanental trees America pruduces.

4. M. foliis amplis oblonge subcuneato-obovalibus acutis, junioribus holosericeis, petalis 9. ellipticis acutis, exterioribus reflexis.-Willd. sp.pl.2. p. 1258.

M. umbrella. Lam. encycl.3.p. 044.

Icon. Catesl. car. 2. t.80. Mich. arl.t. 5.

In the mountains of Virginia and Carolina. $\zeta$. June, July. $v . v$. Leaves large; flowers white, the size of $M$. grandiflora, and very fragrant. It is generally known by the name of Umbrella-tree; in the mountains they call it Elk-wood.

5. M. foliis ovalibus acuminatis subtus pubescentibus, petalis obovatis obtusiusculis.-IVilld. sp. pl.2. p.1257.

Jcon. Catesb. car. 3. t. 15. Mirh. arb.t 3.

In high mountain-valleys, in fertile soil: Pensylvania to Carolina. $h$. June, July. v. v. Flowers a dim yellow mixed with a faint blue, not much larger than those

tripetala.

acuminata. 
of $M$. glaucr. It is generally known by the name of Cucumber-tree, and its fruits are used as a wholesome bitter among the inhabitants.

cordata.

6. M. foliis cordatis subtus subtomentosis, petalis lanceolato-oblongis acutis.-Mich. $f$. amer. 1. p. 328.

Icon. Mich arb. $t .4$.

On dry ridges of mountains in Ufper Carolina and Georgia. $h$. v. v. s. $t h$ Flowers yellow.

auriculala. 7. M. foliis amplis obovato-lanceolatis acuris subtus glaucis basi cordatis auriculatis, Jobis approxinatis, petalis ovais acutis sub-unguiculatis.-Willd. sp. pl. 2. p. 1258 .

M. auricularis. Parad. Iona'. 43.

M. Fraseri. Walt. fl. car. 159.

İcon. Bot. mag. 1206. Bot.rep.573. Mich. arb.t.6. In the Allegany mountains, from the head-ivaters of the Susquehanna to Carolina. h. April, May. v. v. A beautiful tree; flowers yellowish white, large. The bark of this and some of the foregoing species is esteemed a valuable medicine, partic ularly in intermitting fevers; from which circumstance it is known in some places by the nanse of Iniian Physic.

Pyramidata.

8. M. foliis rlomboideo-oboralibus abrupte acutis concoloribus basi subcordatis auriculatis, lobis divaricatis, petalis lanceolatis sensim acutis.-Bartr. trav. p.....

M. auriculata. . ich. $f$. amer. 1.p 328.

In the w estern parts of Carolina and Georgia. $\hbar$. April, May $v . v$. This species has generally been confounded with the foregoing one, from which it not only differs in the distinctions g.ven above, but in general habit : the tree is of a more upright pyramidal growth, and the leaves not one fourth the size of M. auriculata.

\section{LIRIODENDRON. Gen. pl. 941 .}

tulipifera. 1. L. foliis abscisso-truncatis 1-lobatis, calyce triphyllo.Willd. sp. pl. 2. p. 1254.

acutiloba. $\quad \alpha$. L. lobis acutis acuminatisque. Mich. Al. amer. 1. p.326. 1con. Bot. mag. 275. Schmidt arb.45. Catesb. car. 1. t. 48. Miich arl. $t$.....

obtusiloba. $\quad \beta$. I, lobis roturidato obtusissimis. Mich. l. $c$

In tertile ground: Canada to Florida. B. in Pensylvania. $\eta$ : June, July. $v \cdot v$. A highly ornamental and use- 
ful timber tree; flowers yellow and red, mixed with green. Generally known by the name of Tulip-tree, or IVlite and Yellow Poplar.

\section{PORCELIA. Prodr. $f$. peruv. p. 84.}

Orchidocarpum. Mich.fl amer. 1.p.329.

1.P. foliis glabriusculis oblonge cuneato-obovatis, petalis trilota. exterioribus orbiculatis, fructibus magnis carnosis.Pers. syn. 2. p. 05 .

Anona triloba. Willd. sp. pl. 2. p. 1267.

Orchidocarpum arietinum. Mich. fl. amor. 1.p 329.

Icon. Catesb. car. 2. t. 83. Trew chret. 5. Duham. arl. 1. t. 19 .

On the overflowed banks of rivers: Pensylvania to Flo. rida. $h$. March, April. v. $v . \Lambda$ small tree; flow. ers dark brown; fruits large, eatable.

2. P. foliis cuneato-obovatis basi acutis ramulisque rufopubescentibus, petalis omnibus ovalibus, fructibus ovatis subcarnosis.-Pers. syn. 2. p. 05 .

Orchidocarpum parviflorum. Mirh. fl. amer, 1. p. 329.

In shady wonds, near rivers and lakes : V'irginia to Georgia. $々$. April, May. $v$. $v$. A low sbrub, sometimes not above two feet high, when in full fruit; flowers small, dark purple.

3. P. foliis elongato-lanceolatis cuneatisve lævigatis, petalis exterioribus majoribus obovato-oblongis, interioribus longioribus.-- Pers. syn. 2. p. 95.

Orchidocarpun pygmaum. Mich. fl. amer. 1. p. 330.

Anona pygmæa. Willd. sp. pl. 2. p. 1263.

Icon. Bartr. trav, $t .1$.

In sandy fields : Georgia and Florida. $h$. v. v. Flowers the size of Anona squamosa; the whole shrub not above a foot high. 4. P. foliis cuneato-obovalibus basi obtusis ramulisque rufo- grandifiora. pubescentibus, petalis exteroribus majoribus obovatis, interioribus oblongis.-Pers. syn. 2. p. 95 .

Orchidocarpum grandiflorum. Mich. fl. amer. 1. p. 330. Anona obovata. Willd. sp. pl. 2. p. 1269.

Icon. Bartr. trav. $t$. 2 .

In sandy woods, in shady places: Georgia and Florida. h. May. v. s. A small shrub: flowers very large in proportion, white.

pygmax.

parviflora.

.


455. ATRAGENE. Gen. pl. 949. Sims in bot. mag. 887.

mericana. 1. A. foliis quaternis ternatis, foliolis cordatis subintegerrimis, nectariis acutis. Simes l. c. cum icone.

In shady places, on the side of rivulets, climbing and creeping among loose rocks : New York and Pensylvania, near the foot of the Blue-mountains. $\zeta$. May, June. $v . v$. Flowers large, purple.

\section{CLEMATIS. Gen. $p / .960$.}

virginica.

1. C. scandens; foliis ternatis, foliolis ovatis subcordatis inciso-dentatis lobatisque, corymbis dichotomis paucifloris, petalis staminibus longioribus, floribus dioicis. -Willd.sp. pl. 2.p. 1290.

In hedge-rows and among small shrubberies on the side of woods : Canada to Florida. $\eta$. June-Aug. v. $v$. Flowers sma!l, white, and fragrant.

cordata.

2. C. scandens ; foliis pinnatis bijugis, foliolis cordatis lobatis acuminatis inciso-dentatis, dentibus mucronatis, racemis compositis elongatis multifloris, staminibus petalis subrquantibus, fioribus dioicis.

On high mountains: Virginia. $\zeta_{2}$. July. v. v. Flowers resembling the former species. In general appearance it approaches near to $C$. Vitalba.

holosericea. 3. C. scandens, tota holosericeo-pubescens; fuliis ternatis oblongo-lanceolatis integris utrinque pubescentibus, corymbis trichotomis pauciforis, petalis linearibus staminibus longioribus, floribus dioicis.

In Carolina. h. v. s. in Herl. Walter. The flowers small, white; tails of the seeds very long, feathered.

Wulteri. 4. C. scandens; foliis pinnatis cirrhosis trijugis, foliolis divaricatis petiolatis lineari-lanceolatis acutis integerrimis subtus glaucis, floribus solitariis, petalis ellipticis staminibus duplo longioribus.

In Carolina. $々$. v. s. in Herb. Walter. Flowers white.

crispa.

5. C. scandens ; foliis pinnatis ternatisque, foliolis divaricatis ovato-lanceolatis acutis trilobisve integerrimis, floribus solitariis, corollis'campanulatis acuminatis revolutis margine undulatis: aristis seminum subulatis nu. dis.-Willd.sp. pl. 2. p. 1289.

Jcon. Dill. elth. t. 73.f. 84.

In hedges and among bushes on the side of rivers: Vir- 
ginia and Carolina. 々. July, Aug. v. v. Flowers large, purple.

6. C. scandens ; foliis pinnatis, foliclis ovatis utrinque acutis glabris simplicibus pedicellatis, pedunculis terminalibus solitariis, corollis cernuis cylindricis, petalis subcoriace is undulatis conniventibus, aristis seninum plumosis.-Sims in lot. mag. 1160.

C. Viorna. Bot. rep. 71.

In Virginia and Carolina. $h$. June-Aug. $v . v$. Flowers large, of a fine pale purplish blue.

7. C. scandens; foliis pinnatis 4-jugis, foliolis ovatis utrinque obtusis omnibus integris petiolatisque membranaceis utrinque reticulato-venosis, floribus solitariis, petalis subcoriaceis, aristis seminum plumosis.-Walt. $f$. car. 156. Mich.fl. amer. 1. p. 318.

C. rosea. Allot insect. $t$. ....

In Georgia and Carolina. h. June, July. v. s. in Herb. Walter. Flowers resembling the following species, pale purplish-red.

8. C. scandens ; foliis divaricato-compositis decompositis. cylindrica.

reticulata. que, foliolis ovali.-lanceolatis utrinque acutis trifidisque integerrimis, foribus solitariis campanulatis, petalis crassis acuminatis.-Willd. sp. pl.2. p. 1288.

Icon. Bot. rep.71. Dill. ellh.t.118.f.144.

In hedges and copses : Virginia and Carolina. $\zeta$. June -Aug. $v . v$. Flowers dark blue, large.

9. C. erecta, simplex ; foliis hirsutissimis bipinnatifidis in- hirsutissima. cisis, laciniis linearibus acutis, caulinis compositemultifidis, pedunculo terminali solitario, flore erecto campanulato, petalis 4 . erectis ovatis obtusiusculis apice reflexis.

On the plains of Columbia river. 24. May. v. s. in Herb. Lewis. The whole plant is covered with a close coat of long hairs like Anemone Pulsatilla, which it very much resembles in several respects. I consider all the division of Anemones with caudated seeds to belong to this genus, or at least to one separate from Anemone.

10. C. erecta, simplex, pubescens; foliis simplicibus ovalibus integerrimis, junioribus calycibusque extus incano-sericeis, pedunculo terminali solitario, flore cernuo.-Mich. fl. amer. 1. p. 319.

C. ochroleuca. Willd. sp. pl. 2. p. 1294.

Icon. Bot. mag. 1175. 
On the banks of rivers: Pensylvania and Virginia; rare. 4. May-uly. v. v. About a foot high; flowers inside yellow.

457. ANEMONE. Gen. pl. 948 .

nemorosa. 1. A. caule unifloro, foliis caulinis ternis ternatis, foliolis cuneatis inciso-lobatis dentatis acitis, corollis 5-6petalis, seninibus ovatis stylo brevi uncinatis.-IVilld. sp. pl. 2. p. 1281.

Icon. Fl. dan. 549. Engl. bot. 355.

yuinquefolia. F. A. foliis lateralibus profunde bipartitis. Willd.sp.pl. 2. p. 1281.

Jcon. Pluk. alm.t. 106.f. 3 .

In shady woods, round the roots of trees: Canada to Carolina. 24. March, April. $v v$. Flowers white, with a tinge of red on the under side; sometimes nearly double. Var. $\beta$. can never be considered as a species, as there are intermediate varieties between it and the original species.

lancifulia. 2. A. caule unifloro, foliis caulinis ternis ternatis, foliolis lanceolatis crenato-dentatis, corollis 5-petalis, seminilus ovatis stylo brevi uncinatis.

A. trifolia. Willı. sp.pl.2.p. 1281 ?

On high mountains, in boggy soil : Pensylvania and Virginia. 24. May-July. $v, v$. Resembles the foregoing species; fiowers larger, and clear white.

cuneifolia. 3. A. caule unifloro involucrato, foliis ternatis, foliolis ses. silibus cuneatis apice trurcato-crenatis, involucro 3 phyllo, corollis 5-petalis, seminibus capitato-globosis lanatis acuminatis.-Juss. in annal. du mus. 3. p. 248. t. $21 . f .1$.

A. parviflora. Mich. fl. amer. 1. p.319.

A. tenella. Herb. Banks.

On the banks of rivulets, near Hudson's Bay and Labrador. 24. March-May. v. s. in Herl. Dickson. Flowers white, the size of No. 1.

teneila.

4. A. caule unifloro involucrato, foliis subbiternatis, foliolis 3-fidis seu 3-dentatis acutis involucro 3-partito, laciniis incisis, petalis 12-15-linearijus, seminibus lanatis mucronatis, radice tuberosa.

A. caroliniana. Itralt. $f$. car. 157.

On the banks of the Missouri. M. Lewis. In Carolina. Walter. 24. May. v. s. in Herl. Lewis Flowers 
purple, small; the whole plant very slender and de. licate; roots tuberous.

5. A. caule unifloro nudo, foliis palmatis longius petiolatis, Walteri. corolla 5-petala, radice tuberosa.

Thalictrum carolinianum. Walt. fl. car. 157.

In Carolina. Walter. $21 .+$. I was not able to find any information respecting this plant in the Walterian Herbarium, but consider it to belong rather to this genus than to Thalictrum.

6. A. floribus umbellatis involucratis, foliis radicalibus bi- thalictroides. ternatis, foliolis subcordatis 3-dentatis, involucro 6 phyllo, foliolis petiolatis confornibus, umbelia pauciflora, seminibus nudis striatis, radice tuberosa.Willd. sp.pl.2. p. 1284.

Thalictrum anemonoides. Mich.fl.amer. 1. p. 322.

Icon. Bot.mag. 866. Annales du mus. 3. t. 21.f. 2. a. EF b. Pluk. alm. t. 106.f.4. Willd. hort. berol.44.

$\beta$. A. involucro unifloro. Gronov. virg.

uniflora,

In woods, frequent: Canada to Carolina. 4 . March -May. v. v. Flowers white. A beautiful double variety is cultivated in the gardens, which in delicacy of figure and colour exceeds any other species of this elegant genus.

7. A. floribus umbellatis involucratis, foliis radicalibus mul- narcissiflora. tifido-palmatis incisis, laciniis linearibus, involucris sessilibus incisis, umbella panciflora, pedicellis involucro longioribus.-Willd. sp. pl. 2. p. 1283.

In Canada and on the north-west coast. 4 . April, May. v. s. Flowers white.

8. A. caule dichotomo, foliis radicalibus palmatis, caulinis pensy:vanica. sessilibus amplexicaulibus 3-fidis: infinis ternatis: lobis acute lanceolatis inciso-serratis, pedunculis solitariis unifloris, seminibus capitulo globoso nudis subulato-rostellatis.-IVilld. sp.pl. 2. p. 1280.

A. aconitifolia. Mich. fl. amer. 1.p.320.

In meadows and on the borders of woods : Canada to Pensylvania. 4 . June, July. v. v. Flowers large, white; anthers yellow.

9. A. caule dichotomo, foliis caulinis omnibus oppositis amplexicaulibus trifidis, lobis cuneato-lanceolatís superne inciso-serratis, pedunculis solitariis unifloris, seminibus capitulo globoso nudis recurvato-mucronatis. Willd. sp.pl.2.p. 1280.

A. irregularis. Lam. encycl. 1.p. 167.

dichotoma. 
Icon. Linn. fil. dec. 2. t. 15.

In wet woods and natural meadows: Canada and the western parts of New York. 4. May, June. v. $v$. Flowers white, with a tinge of red on the under side, smaller than the foregoing species.

virginians. 10. A. caule dichotomo, foliis ternis ternatis, superioribus oppositis, foliolis inciso-lobatis serratisque acutis, pedunculis solitariis unifloris elongatis, seminibus capitulo oblongo lanatis mucronatis.-Willd. $s p$. pl. 2. p. 1279 .

Icon. Herm. parad. $t$. 18.

In woods, on the side of dry sandy hills : Canada to $\mathrm{Ca}$ rolina. 4. May, June. v. v. Flowers small, green. ish-yellow.

\section{THALICTRUM. Gen.pl. 951.}

Cornuli 1. T. foliis supradecompositis, foliolis ovatis trifidis, pani = culis terminalibus. - Willd. sp. pl. 2.p. 1296.

Icon. Corn. canad. 186.

On the banks of rivers and in wet meadows : Canada to New Fingland. 4 . June, July. v. v. From two to three feet high; flowers small and greenish-yellow.

dioicum. 2. T. lævigatum; foliis supradeconpositis, foliolis subrotundis cordatis obtuse-lobatis subtus glaucis lævibus, paniculis axillaribus filiformibus folio brevioribus, flo. ribus parvis in umbellis paucifloris.-Willd. sp. pl. 2. p. 1296.

T. lavigatum. Mich.fl. amer. 1.p. 322.

In shady woods and on the banks of rivers: Canada to Virginia. 24. May-July. v. v. Not above a foot high ; flowers white.

" 3. Tosum. caule striato, foliis supradecompositis, foliolis ovatis lanceolatisque rugosis venosis obtuse-lobatis, paniculis amplis terminalibus.-Willd. sp. pl. 2. p. 1298.

On the banks of rivers and in swamps: Pensjlvania to Carolina. 24. June-Aug. v. v. Very tall, some. times above five feet high; flowers white.

oulescens. 4. T. tenui tomento pubescens; foliis supradecompositis, foliolis ovatis subcordatis cuneatisque apice 3-lobis, supra subrugosis, subtus subtomentosis, paniculis terminalibus, pedicellis subumbellatis divaricatis, floribus poligamis.

T. polygamum. Muhlb. mss. 
On the banks of ditches and rivulets: Pensylvania and Virginia. 24. June-Aug. $v, v$. A tall species; flowers white.

5. T. caule foliis duplo altiore, foliis compositis, foliolis furpurascens. subrotundis 3-fidis incisis, paniculis nudiusculis, floribus cernuis, staminibus coloratis.-Willd. sp. pl. 2. p. 1299.

On dry sunny hills: Pensylvania and Virginia. 4. May, June. v. $v$. A small plant; stem and filaments purpie.

j. T. foliis simplicibus 5-lobis serratis, floribus corymbosis. - Willd. enum. 585.

In Carolina. Willdenow. 24. +. Flowers resembling those of T. speciosum.

\section{HYDRASTIS. Gen. pl.958.}

1. H. caule superne opposite diphyllo, folis petiolatis basi canadensis. emarginatis palmatis serratis incisis, pedunculo termi. nali solitario unifioro.-Willt. sp. pl. 2. p. 1340.

Icon. Mill. ic. t. 285.

In shady woods, on fertile soil and among rocks : Canada to Carolina, principally in the Allegany mountains. 4. April, May. $v, v$. Flowers pale rose-coloured; berry red. The roots are yellow, and afford a fine dy'e.

460. BRASENIA. Gen. pl. 938.

Hy'dropeltis. Mich.fl. amer. 1. p. 323.

ฉ. B. foliis centro peltatis ovalibus integerrinis, pedunculis solitariis unifloris.

Hydropeltis purpurea. Mich.,fl. amer. 1. p. 324. t. 29.

Icon. Bot. mag. 1147. Pluk. alm.t. 349.f.3.

In lakes and slow-flowing waters: New Jersey to Carolina. 24. June-Aug. $v . v$. Floating on the water; the whole plant has a purple colour; the flowers dark purple, the size of Caltha; the petioles and under surface of the leaves are covered with a transpurent gelatirious substance.

\section{CALTHA. Gen. pl. 957.}

1. C. caule erecto unifloro unifolio, foliis radicalibus cor- ficarioides. dato.ovatis obtusissimis paucidentatis multinervious, petalis ellipticis.

ranunculinum.

canadensis.

peliata. 
Ranunculus Ficaria. Walt. $f$. car. 159.

In shady cedar-swamps of New Jersey and Carolina. 4. June, July. $v v$. Flowers deep yellow, the size of Ranunculis' Ficaria.

integerrima. 2. C. caule erecto corymbose, foliis integerrinis sinu clauso orbiculato-cordatis, floralibus sessilibus reniformibus basi obsolete crenatis, petalis obovalıbus.

In wet meadows and small rivulets: New England to Virginia. 2f. May-July. v. v. Flowers yellow, smaller than the following species.

pailuslris.

3. C. caule erecto corymboso, foliis cordato-reniformibus : lobis patulis, circumeirca acute-crenatis, floralibus subsessilibus, petalis ovatis.-Willd. sp. pl. 2. p. 1338.

Icon Fl. dan.668. Engl. bot. 506 .

In low bosgy meadows: Canada to Pensylvania. 4. April-June. $v . v$. Flowers golden yellow, lirge.

flabellifolia. 4. C. caule procumbente, foliis dilatato-reniformibus: lobis patentissimis, circumcirca argnte acuteque dentatis, pedunculis axillaribus so'itariis unifloris, petalis obovatis, capsulis rostro adunco.

In a large sand-spring on Pukono-mountain, Pensylvania. 24. July, Aug. $v$. $v$. Flowers yellow, the size of Ranunculus arvensis. This plant has some atfirity with C. natans Willd. sp.pl.2.p. 1330. of which I have seen perfect specimens in the Herbarium of $\mathrm{A}$. B. Lambert, Esq., collected by Pallas in the most eastern parts of Sibcria, under the name of $C$. pusilla, which I distinguish by the following diagnosis: Caltha natans, caule procumbente natante, foliis cordato-re. nitormibus: lobis subapproximatis, postice obsolete crenatis, antice dentatis, petalis ovalibus, capsulis rostro recto. The flowers of that species are white, with a tinge of red, of the same size as the present species.

462. COPTIS. Sulist. in linn.trans. 8. p. 305.

trifolia.

1. C. foliis ternatis, foliolis rotundato-obovalibus acuminato-crenatis, scapo unifloro.-Salisb.l. c.

Helleboru; trifulius. Willd. sp.pl 2. p. 1338.

Icon. Fl.dan 566.

In cedar-swal th and mountain bogs : Canada to Virginia. 24. Mity-July. v. v. A delicate small plant; flowers whice. 
4
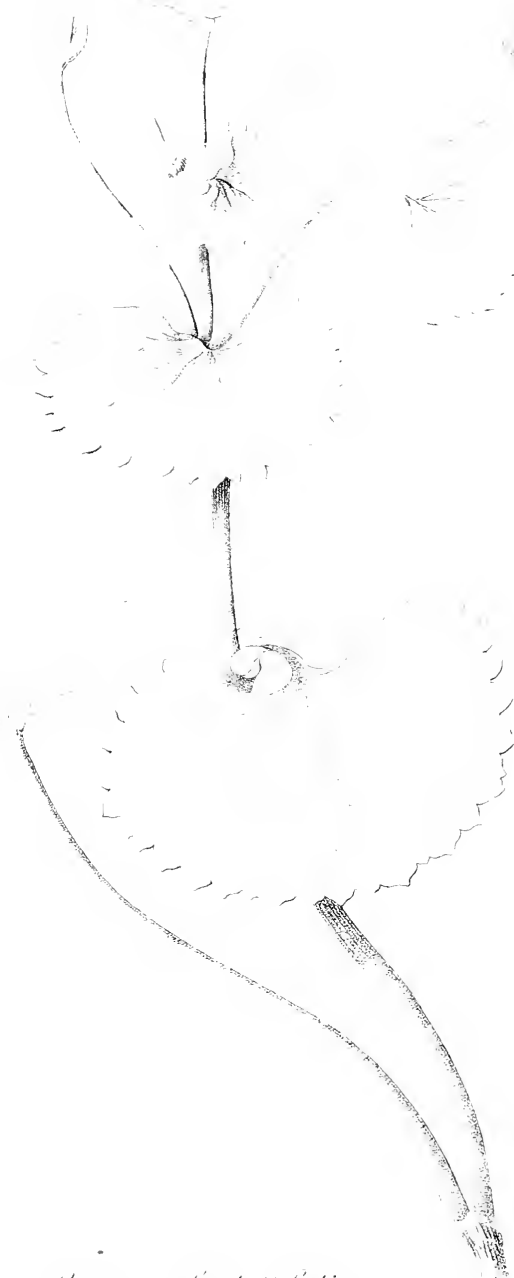

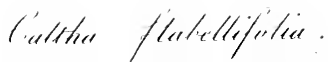



2. C. foliis biternatis, foliolis subpinnatifidis, scapo biforo. asplenifolia. -Salisb. l. c. p. 306.

On the north-west coast. Menzies. 4. v. s. in Herl. Banks. Flowers larger than the foregoing one.

\section{TROLLIUS. Gen. pl. 954.}

1. T. petalis 5 . obtusis patulis, nectatiis staminibus breviolaxus. ribus. Salisl. in linn. trans. 8. p. 303.

T. americanus. Donn catal.

T. pentapetalus. Herl. Banks.

In shady wet places, on the mountaius of New York and Pensylvania. 4. May-July. v. v. Flowers yellow, the size of Ranunculus acris.

\section{HEPATICA. Willd. enum.....}

1. H. foliis trilobis integerrimis, scapis unifloris.-Willd. enum.

Anemone Hepatica. IVilld.sp. pl. 2. p. 1273.

Icon. Bot.meg. 10. Fl. dan. 610.

a. FI. lobis rotundatis obtusis.

$\beta$. H. lobis ovalibus acutis.

In woods, on the side of fertile and rocky bills : Canada to Carolina. 4. March-May. v. v. Flowers blue or purple; generally smaller than in the European plant.

\section{RANUNCULUS. Gen. pl. 953.}

* Foliis simplicilus, integris.

1. R. glaber, caule declinato, foliis angusto-lanceolatis acutis integerrimis denticulatisque, inferioribus petiolatis, pedunculis terminalibus axillaribus unifloris, calycibus subreflexis.-Willd.sp. pl. 2. p. 1307.

Icon. Fl. dan. 575 . Engl. lot. 387 .

In inundated places and small rivulets: Pensylvania and Virginia, 4. July-Sept. v.v. Flowers deep yellow, small.

2. R. adpresso-pilosus; foliis lanceolatis subdenticulatis acuminatis subsess:libus, caule erecto multifloro.IVilld. sp. pl. 2. p. 1308.

Icon. Engl. lot. 100 . Fl. dan. 755.

On the banks of rivers, among scirpus and other river Vol. II. plants: Pensylvania and Virginia. 24. July, Aug.

trilola.

obtusa. acuta.

Flammula.

Lingwa. 
v. $v$. Resembles ihe preceding one, but is upright, the flowers larger and in greater abundance.

pusillus.

3. R. glaber; foliis petiolatis, inferioribus ovatis dentatis, superiorinus lneari-lanceolatis apice dentatis, suprenis linearibus bracteiformibus, pedunculis alternis solitariis unifloris.

R. flammula. Wall. fi. car. 159. Nich. fi. aner. 1. - p. 32$\}$.

4. June-Aug. v. s. in Herb. Enslen. A small spe. cies, with exceeding small flowers, petals pale yellow.

fliformis. 4. R. glaber, pusillus; canlibus filiformibus repentibus geniculatis, geniculis uniforis, $f$ liis lineari-subulatis obtowis.--Mich. $f$ amer. 1. p. 320.

In inundated places, on the river St. aurence, Hudson's Bay, and I abrador. 24. June, July. v. s. in Herl. Einks. Resembles $R$. reptans very much.

Cymbalan ia. 5. R. glaber, minimus, filiformis, repens, ad genicula radicans; foliis curdato-renitormibus obıuse 5 -dentatis, pedunculis radicalibus solitaris plerumque bifloris, petalis linearibus, fructibus oblongis.

In saline marshes near the salt-works of Onondago, New York. 4. June, July. v. v. Flowers the size of the foregoing one, pale yellow, sometimes white. This little plant has some recemblance to $R$. salsuginosus of Pallas, whose specimens I had an opportunity of seeing in the collection of A. B. Lambert, Esq. and which may be distinguished by the following diagnosis: R. glaber, filifurmis, repens, ad genicula radicans; foliis or at s rariter corlatis apice 3 -dentatis, pedunculis radicalibus solitariis plerumque unifloris, petalis obovatis, fructibus subglobosis. The flowers are more than ten times larger than in R. Cymbalaria.

** Foliis dissectis et divisis.

abortivus. 6. R. glaber; caulibus striatis inferne nudis, foliis radicalibus cordato-reniformibus obtuse-crenat is, caulinis petiolati, ternatis angulatis, superioribus sessilibus, ramulis subtrifloris. - Willd. sp. pl. 2. p 1314.

In wet places on the side of ponds and ditches: New York to Carolina. 24. July, Aug. v. v. Flowers small, yellow.

nitidus. 7. R. glaberrimus; caulibus fistulosis, foliis radicalibus ro. tundato-subreniformibus obtuse-crenatis, caulinis ses- 
silibus digitatis, foliolis incisis, laciniis obtusis, seminibus subglobosis glaberrimis,-Walt. fl. car. 159. Lam. encycl. 0.p. 126.

In inusudated grounds: New York to Carolina. 4. July, Aug. $v \cdot v$. Flowers small; petals white. This and the foregoing one are nearly related to each other, and probably inly varieties of the same species, though distinguished by Walter and Lamarck.

8. R. glaber ; foliis inferioribus palmatis, superioribus sessihbus digitatis, fructibus oblongis.-Willd. sp.pl. 2. p. 1315.

Icon. Fl. dan. 571. Engl. bot.6s1.

In ponds and ditches : Canada to Virginia. 24. JuneAng. v. v. Flowers yellow, small.

9. R. pubescens; foliis radicalibus reniformibus tripartitis inciso-crenatis, caulinis sessilibus digitatis linearibus, caule multifloro, calyce colorato patente.-Willd. sp. pl. 2. p. 1314 .

Icon. Fl. dan. 665. Engl. bot. 624.

In old meadows and woods: Pensylvania. 24. May, June. v. $v$. Flowers yellow, middle-sized.

10. R. pusillus, glaber; foliis radicalibus subcordato-reniformibus inciso-centatis, caulinis sessilibus digitatis, laciniis linearibus integerrimis, caule paucifloro, petalis oblongis calyce subæquantibus.

In Labrador. Colmaster. 4. May, June. v. s. in Herb. Dickson. Flowers small, yellow; it approaches very near to R. nivalis.

11. R. pilosus, erectus, ramosus; foliis ternatis trifidis incisis subtus pilosis, pedunculis teretibus, calycibus reflexis, peralis calyce subrquantibus.-Willd. sp. $p l .2$. p. 1323.

R. canadensis. Jacq. ic, rar. 1. t. 105.

In low meadows : Canada to Pensylvania; rare. $\mathcal{\psi}$ July, Aug. v. $v$. Flowers the size of $R$ acris.

12. R. hirsutissimus ; foliis compositis : ternatis trifidis incisis dentatisque, cauie erecto multifloro, pedunculis sulcatis, calycibus retruflexis, radice bulbosa.-Willd. $s p$. pl. 2. p. 1324.

Icon. Fl. dan.5.51. Engl. bot.515.

In meadows and grass pluts, common. 2. May-Aug. $v . v$.

13. R, hirsutus; foliis ternatis inciso-lobatis, caule erecto

scelerains.

auricoms:

pygmaks.

pensylianz. cus.

bulbosus. D 2

Philonotis. 
multifloro, peduncnlis sulcatis, ealycibus retroflexis acuminatis, seminibus tuberculatis, radice fibrosa.Willd sp.pl. 2. p. 1324.

R. hirsutus. Curt. lond. 2. t. 40. Engl. lot. 1504.

In old meadows and low wet fields: New England to Pensylvania. 4. June-Oct. v. v. fiesembles the foregoing one.

repens. 14. R. hirsutus; foliis compositis: ternatis trifidis incisis, sarmentis repentitus, peduncuiis sulcatis, calycibus patulis. Willd. sp. pl. 2. p. 1325.

Icon. Fl. dan. 795. Engl. bot. 510.

In shady wet woods, particularly in the momintains: Pensylvania to Virginia. 4. July, Aug. v. v. Flowers deep yellow.

acris. 15. R. adpresso-pilosus; foliis tripartito-multifidis, summis linearibns, pedunculis teretibus, calycibus patulis.Willt. sp. pl. 2. p. 1326.

Icon. Engl lot.65\%.

In wet meadows, in the western parts of New York and Canada. 24. May-Aug. v.v.

lanuginoszs. 16. R. hirsutus; foliis trifidis lobatis dentatis holosericeis, pedunculis elongatis teretibus, calycibus patulis.Willd. sp.pl.2.p. 1327 .

Icon. Fl. din. 397 .

In old fields and meadows: Pensylvania to Carolina. 4. June-Oct. $v . v$.

tomentosus. 17. R. villosissimus, bumilis ; caule repente 1-2-floro, foliis tomentosis tribobatis, calycibus hispidis subreflexis.Lam. encycl.6. p. 127.

In Carolina. Bosc. 4. +. Flowers yellowish-white.

marylandicus. 1S. R. pubescens; caule simplici subnudo, foliis radicalibus ternatis, fol!olis trilobatis, Jobis acutis incisis, caly cibus reflexis. Lam.encycl. 6. p. 126 .

In shady woods: Pensylvania to Virginia. 2. MayJuly. $v \cdot v$. Flowers pale yellow.

recurvatus. 19. R. pubescens; foliis trilobis, lobis basi cuneiformibus, apice incivis acutis, caule nultifloro, corolla calycibusque recurvis, petalis linearibus.-Lam. encycl. 6 . p. 125.

In shady woods: New York to Carolina. 4. JuneAug. v. $v$. Flowers small; petals almost white.

septentriona- 20. R. glabriusculus; foliis membranaceis glabris ternatis, lis. feliolis subtrilobatis incisis acutis, caule petiolisque 
basi hirsutis, pedunculis subbiforis, calycibus reflexis. Lam, encycl. 6. p. 125.

In North Anerica. Lamurck. $4 .+$. Flowers pale yellow.

21. R. hirsutissimus, erectus ; foliis ternatis, foliolis acute lobatis, caulibus infia primun periunculum nudis pauhispidus. cithoris, calyce appresso. Mich. fl. amer. 1.p.321.

In wet fieids and on the banks of ditches: Virginia and Carolina. 4. June-Aug. v. v. Flowers small, pale yellow.

22. R. foliis suomersis capillaceis, emersis peltatis. Willd. aquatilis. sp.pl. 2. p. 1332 .

R. heterophyllus. Roth fl. germ. 1.p. 240.

Icon. Engl. bot. 101. Fl. dan. 3700 .

In ponds and slow-flowing rivulets: Canada to New York. 4. June, July. v. v. Flowers white.

23. R. foliis omuibus dichotomo-capillaceis, caule natante. fluviatilis. Willd. sp. pl.2.p. 1333.

Icon. Fl. dan. 370 .

In tranquil rivers: Pensylvania to Carolina. 24. June -Aug. v. v. Flowers white.

*** Seminilus aculeatis.

24. R. glabellus, diffusus; foliis simplicibus subrotundis trilobatis, calycibus longitudine corollarum.-Will. $s p$. pl. 2. p. 1329 .

Icon. Lam. illustr.t. 498. f 2. Alp. exot. 262.

In old fields: Virginia and Carolina. $\odot$. June, July. $v, v$. Hlowers yellow.

25. R. glabelius, simplex; foliis simplicibus subrotundis triechinalus. lobatis, petalis calyce duplo longioribus.-Vent. hort. cels 73 .

Near Charlestown, South Carolina, Bosc. +. Flowers yellow, more than twice the size of the preceding one.

\section{SAGitTARIA. Gen. pl. 1441.}

1. S. foliis lanceolatis acutis sagittatis, lobis lanceolatis acutis rectis, scapo simplici, floribus monoicis, bracteis muricatus. calycibusque lanceolatis acutis.-IVilld. sp. pl. 4 . p. 408.

Icon Fl. dan. 172 .

In small ponds and ditches: Pensylvania to Carolinas.

sagittifolia, $\beta$. minor. 
4. July, Aug. $v . v$. J eares not above two inches long; flowers, as in all the following species, white.

latifolia.

2. S. foliis ovatis acutiusculis sagittatis, lobis ovatis tenuissime acuminatis rectis, scapo simplici, floribus monoicis, bracteis subrotundis obtusis.-Willd. sp. pl. 4. p. 409 .

major.

S. sagittifolia. Mich. fl. umer. 2.p. 189.

$\beta$.S. foliis amplis abrupte acutis, scapo subramoso, floribus dioicis.

In ponds and ditches: Canada to Caro'ina. 2\%. JuneAug. $v . v$. Leaves large and broad.

oltusa. 3. S. foliis dilatato-ovatis rotundato-obtusis mucronatis sagittatis, lobis approximatis oblorigis oblique-acuminatis rectis, scapo simplici floribus dioicis, bracteis ovatis acutis.-Willd. sp.pl. 4. p. 409.

In ditclies and shallow ponds: Pensylvania to Virginia. 4. June-Sept. $v$. $v$. Leaves the size of Calla palustris.

hastata. 4. S. foliis oblongo-lanceolatis sensim-acutis sagittatis, lobis patentibus lancenlatis longissime acuninatis, scapo simplici, floribus dioicis, bracteis calycibusque subrotundis obtusis.

In old ditches: Pensylvania. 24. July, Aug. v. $v$. Leaves the size of $S$. sagittifolia; the lobes very spreading.

gracilis.

5. S. foliis linearibus obtusiusculis 3-nervibus sagittatis, lobis patentibus linearibus elongatis sensim tenuissime acuminatis, scapo simplici paucifloro, floribus dioicis, bracteis brevibus suborbiculatis.

In bogs and ditches: Pensylvania to Virginia, particularly on the mountains. 4 . July, Aug. $v . v$. Leaves very slender, about three inches long, measured from the beginning of the petiole.

heterophylla. 6.S. foliis simplicibus linearibus lanceolatisque utrinque acutis, seu ellipticis acutis basi obtusis sagittatis, lobis divaricatis linearibus, scapo simplici paucifloro, floribus monoicis, fermineis subsessilibus, bracteis latoovat is acuminatis.

In small ponds and ditches: Pensylvania and New Jersey. 4 . June-Aug. $v$. $v$. Leaves about two inches and a half long: this species is easily distinguished by the female flowers being almost sessile. 
7. S. foliis lato-lanceolatis interne angustatis, scapo subra. moso, seminibus phan's fairatis rontratis.

S. lancifolia. Wiich $f$ l. amer. 2 p. 189.

In ponds: Carolina. 24. July Aug v. s, in Herb. Lyon.

8. S. foliis angusto-lanceolatis inferne carinatis rigidis utrinque acutissimis, scapo ramoso, fioribus monoic is.

In still and deep waters of Oswegn river near the great falls, New Youk. 4 July, Aug $v v$. i his sle. cies grows in a deplh of nose than seven feet water; the petioles are strong and stiff; the flowers very numerous.

9. S. foliis lineari-lanceolatis acutis inferne angustatis, scapo simplici multiflorn, thoribus dioicis, uracieis calycibusque rotunda:is uhtusis.

In small ponds: New Jersey. 4 . July, Aug $v . v$. Leaves about six inches long and hait an inco wide; flowers fr: $m$ twelve to eighteen in a scape.

10. S. foliis linearibus longissinnis 3 nervibus, scapo sim. plici panciftoro, floribus monoicis, bractels ubungis obtusis.

S. graninea : foliis lanceolato-linearibus, capitulis pistillorum pusillis Mich $f$ lamer \&. p. 1go?

In Carolina. Lyon. Canada. Michaux. 4. July, Aug. v. s. in Herl. I yon.

11. S. foliis subulat s basi vaginantibus dorso convexis, ucapo simplici paucifloro, fluribus monoicis, bracters cilata. tis acumillatis.

In small iivulets and ditches, near Philadelphia. 7 . July, Aug. v. $v$. A small species; leaves sometines with a cilated point, represen ing a leaf.

12. S. foliis natantibus elliptico-lanceolatis obtusi 3 -nervitus basi attenuatis, intiuis sulicordatis, scapo simpuci paucifloro, pedunculis inferioribus elongatıs.-Mich. fl. amer. 2. $p 1$ igo.

In rivulets of Lower Carolina. 4. July, Ang. v. s. in Herb. Lyon. Flowers small; leaves about an inch and a half le.ng.

aculifolia.

natars.

falcata.

rigida.

simplex.

g.uminea.

armigolia.

natans. 
467. CYAMUS. Salisb. in annals of bot. 2. p. 75.

Nelumbium. Willd. sp.pl.2.p......

favicomus. 1. C. foliis peltatis orbiculatis integerrinis, corolla polypetala, antheris superne linearibus. - Salist. l. $c$.

Nelumbium luteum. Willd. sp. pl. 2. p. 1259.

Nymphæa Nelumbo $\beta$. Sp. $p l .730$.

Icon. Bartr. ic. ined. in mus. Banks.

In ponds and lakes of Carolina and Virginia; also near Philadelphia, in ditches and ponds of Brobston's meadow's. 24. July. v. v. Flowers large, yellow, resembling a double tulip. The seeds are very agreeable to eut, and eagerly sought for by children and Indians. By the latter it is supposed they were introduced to those ponds near Philadelphia, as there is no other instance known to have been found so far north. Walter mentions his Neluml:o to have white flowers; this variety I have never seen.

pentapetalus. 2. C. foliis peltatis orbiculatis integerrimis, calyce pentaphyllo, corolla pentapetala.

Nelumbium pentapetalum. Willd.sp. pl. 2. p. 1259.

Nymphæa pentapetala. Walt.fl.car. 155.

In North and South Carolina. 4. July. v. s. Flowers large, white. A specimen seen in the collection of a gentleman in Carolina ascertains the existence of this furmerly doubtful plant; but unfortunately I took no notes at that time, being in expectation of seeing the living plant.

reniformis. 3. C. foliis reniformibus, corolla polypetala.

Nelumbium reniforme. IVilld. sp.pl.2.p. 1260.

Nymphæa reniformis. Walt. $f$ car. 155.

In Carolina. Walter. 4 . +. This is a doubtful species, and probably a plant belonging to a different genus.

\section{POTHOS. Gen.pl. 210.}

fatida.

1. P. acaulis; foliis ovatis cordatis, spadice subgloboso.Mich. fl. amer. 2. p. 186.

Dracontium foetidun. Willd.sp. pl.2. p. 288.

Icon. Bot. mag. 836. Catesl. car. 2. t.71.

In low grounds, on the side of shady rivulets and springs : Canada to Virginia. 24. Feb.-April. v.v. Leaves large; flowers several, almost sessile on the ground, 
of a singular shape, spotted yellow and brown; the whole plant very toetid, fron which it has the name of Skunk.weed or Shunk-cnlbage. It has four distincr, truncated, fleshy petals, and four stamina to each germ.

469. CALLA. Gen. pl. $13 s 8$.

1. C. foliis subrotundo-cordatis acutis, spatha ovata cuspi- palustris. data.-. Willd. sp. pll. 2. p. 290.

Icon. Fl. dan. 422 .

In splagnous swamps, on the mountaius and near rivulets: Canada to Pensylvania. 4. July, Aug. v. v. llowers white.

\section{ARUM. Gen. pl. 1387.}

1. A. acaule; foliis hastato-cordatis acutis, lobis obtusis, spatha elongata incurva, spadice superne longius masculifloro.-Willd. sp. pl. 4. p. 484.

Calla virginica. Mich. fl. amer. 2. p. 187.

In overflowed places on the banks of rivers, among Scirpi and Iunci. 24. June, July. v. v. Spatha long, iuvolute, green.

2. A. acaule; fuliis subhastato-sagittatis, lobis oblongis, sagittifolium. spatha cucullata superne ovali, spadice longo a medio ad apicen masculifloro.

Calla sagittifolia. Miich. fl. amer. 2.p. 187 .

Caladium sagitifolium. Willd. sp. pl.4. p.45g?

On the bauks of rivers and old swamps: Pensylvania to Carolina. 2?. July, Aug. v. v.

3. A. acaule ; foliis ternatis, foliolis ovatis acuminatis, spadice cylindrico spatha sessili ovata acuminata horizontaliter pateuti altiore.-IVilld. sp. pl.4. p. 481.

Icon. Pluk. alm. t. 148.f.6. lona.

In swamps of Virginia and Maryland. 24. May, June. $v . v$. Spatha dark brown, of a disagreeable smell.

4. A. subcaulescens ; foliis ternatis, foliolis ovatis acuminatis, spadice clavato spatha ovata acuminata plana pedunculata dimidio breviore, floribus monoicis.-IVilld. sp. pl.4. p. 480 .

a. A. spatha virescente.

Icon. Pluk. amalth. t. 376. f. 3.

atroruliens.

triphyllum.

$\beta$. A. spatha atropurpurea.

Icon. Pluk. alm. t.77.f. 5.

In shady wet woods: Canada to Carolina. 4. June,

virens.

at ropurpu-

reuns. 
July. v. v. Flowers handsomely green and yellow, or green and purple striped. Roots known as a medicine among the natives, particularly in colics: they are generally called Indian Turnips.

Dracontium. 5. A. acaule; foliis pedatis, foliolis lancenlato-oblongis integerrimis, spadice subulato spatha oblonga convolut longiore-Willd. sp. pl. 4. p. 478.

Icon. Pluk. alm. t. 27 J.f. 2.

In shady woods: Virginia to Florida. 24. June, July, v. $v$. 


\section{DIDYNAMIA.}

\section{GYMNOSPERMIA.}

* Calyces subquinquefidi.

471. AJUGA. Cor. labium superius minimum bidentatum. Stamina labio superiore longiora.

472. TEUCRIUM. Cor labium superius nullum, sed fissura ejus loco in qua Stamina jacent.

473. MENTHA. Cor. subæqualis, 4-fida: lacinia latiore emarginata. Stam. erecta, distantia.

474. ISANTHUS. Cal. campanulatus. Cor. 5-partita: tubo recto, angusto: laciniis ovatis æqualibus. Stam. subrqualia. Stigm. linesria, recurva.

475. CUNILA. Cal. cyliudricus, 5-dentatus, fauce villosus. Cor. ringens: labio superiore erecto, plano, emarginato. Stam. 2. sterilia.

476. HYSSOPUS. Cor. labium inferius tripartitum, lacinula intermedia crenata. Stam. recta, distantia.

477. NEPETA. C'al, aridus, striatus. Cor. tubo longiusculo: labio inferioris lacinula intermedia crerida; faux margine refiexo. Stam, approximata.

478. LAMIUM. Cor. labium superius integrum, fornicatum : labium inferius bilobum : faux utrinque margine dentata.

479. GALEOPSIS Cor. labium superius subcrenatum, fornicatum : labium interius supra 2-dentatum.

480. ST $\Lambda$ CHYS. Cor. labium superius fornicatum: labium inferius lateralibus reflexum: lacinia intermedia majore emarginata. Stam. deflorata versus la. tera reflexa.

481. LEONURUS. Cal. 5-gonus, 5-dentatus. Cor. labium superius villosum, planum, integrum : inferius triparitum, lacinia media indivisa.

182. GLECHOMA. Cat. 5-fidus. Antherarum singulum par in formam crucis connivens. 
453. Marrubium. Cal. hypocrateriformis, rigidus, 10-striatus. Cor. labium superius bifidum, lineare, rectum.

454. HYPTIS. Cal. 5.dentatus, crescens. Cor. ringens: labium superius tifidum, inferius tripartitum, lacinia media sacculiformi. Stam. tubi ventri inserta, declinata.

485. PYCNANTHEMUM. Involucrum multibracteatum, capitulis subjectum. Cal. tubulatus, striatus. Cor. labium superius subintegrum, inferius trifidum. Stam. suba qualia.

$$
\text { * Calyces lilabiati. }
$$

456. CLINOPODIUM. Involucrum multisetum, verticillo subjectum. Cor. labium superius planum, obcordatum; rectum.

487. ORIGANUM. Strolitus tetragonus, spicatus, calyces colligens. Cor. labium superius erectum, planum: inferius tripartitum: lacinits æqualibus.

488. DRACOCEPHALUM. Cor. faux inflata, labium superius concavum.

489. PRUNELLA. Cor. labium superius dilatatum. Filam. bifurca : altero apice antherifera. Sligm. bifidum.

490. SCUTELLARIA. Cal. ore integro, post florescentiam clanso, operculato. Cor. tubus elongatus.

491. THYMUS. Cal. campanulatus, faux villis clausa. Cor. labium superius planum, emarginatum.

492. CALAMINTHA. Cal. defloratus villis clausus. Cor. fauce inflata, labio superiore emarginato, inferiore tripartito : lacinia intermedia integra, subemarginata aut crenulata.

493. HEDEOMA. Cal. basi gibbus. Cor ringens. Stam. 2. sterilia.

494. TRICHOSTEMA. Cor. labium superius falcatum. Stam. longissima.

\section{ANGIOSPERMIA.}

* Calyces quinquefidi.

495. LINN FA. Cal. superus, duplex : fructus 2-phyllus; floris 5-partitus. Cor. campanulata. Baccu sicca, 3-locularis.

496. PHRYMA. Cal. cylindricus, supra longior, trifidus, infra bidentatus. Cor labium superius emarginatum, inferius majus. Sem. unicum. 
497. VERBENA. Cal. 5 fiulus. Cor. infundibuliformis, tubo incurvo, limbo inæquali, 5-fiło. Sem. 2-4.

498. ZAPANIA. Flor. capitati. Cal. 5-dentatus, Cur. 5-fida. Stam. 4. fertilia. Stigm. peltato-capitatum, obliquun. Fructus tectus utricuiaris, evanescens, nectens semina 2 .

499. CAPRARlA. Cal. 5-partitus. Cor. campanu'ata, 5-fida, acuta. Caps. 2-valvis, 2-locularis, polysperma.

500. HERPESTIS. Cal. inæqualis, basi 2-bracteatus. Cor. tubulosa, subbilabiata. Stam. inclusa. Cups. 2-valvis, 2-locularis, dissepimento valvis parallelo.

501. LINDERNIA. Cal. 5-partitus, æqualis. Cor. ringens, labio superiore brevissimo, inferiore 3-fido, basi bicarinata. Anther per paria cohærentes. Stigm. bilamellatum. Caps. 2-locularis, 2-valvis, dissepi. mento valvis parallelo.

502. SCROPHULARIA. Cul. 5-fidus. Cor. subylobosa, resupinata. Caps. 2-locularis.

503. BIGNON1A. Cal.5-fidus, cyathiformis. Cor. fauce campanulata, 5-fida, subtus ventricosa. Sili;ua 2locularis. Sen. membranaceo-alata.

504. RUELLiA. Cal. 5-partitus. Cor. subcampanulata, limbo 5-fido. Stum. conjugata Caps. uirinque attenuata, dentibus elastice dehiscens. Sem. panca.

505. BUCHNERA. Cal. 5-dentatus. Cor. limbus 5-fidus, æqualis : lobis cordatis. Caps. 2-locularis.

506. AN ITRRHINUM. Cal. 5-phyllus. Cor. calcarata, ringens: rictu clauso palato prominente. Caps. 2 locularis, 2-valvis.

507. GERARDIA. Cal.5-fidus. Cor, 2-labiata : labio inferiore 3-partito: lobis emarginatis : medio bipartito. Crip:. 2 -locularis, dehiscens.

508. PEDICULARIS. Cal. 5-fidus. Cor ringens, Caps. 2-locularis, mucronata, obliqua. Sem. tunicati.

509. MIMUi.US. Cial. prismaticus, 5-dentatus. Cor. ringens : labio superiore lateribus replicato. Stigm. crassum. Caps. 2-locularis, polysperma.

510. CHELUNE. Cal. 5-partitus, 3-bracteatus. Cor. ringens, ventricosa. Filam. quintum sterile, cxteris brevius. Caps. 2-locularis, 2-valvis. Sem. pluriuna, margine mẹmbranaciea.

511. PENTSTEMON. Cal. 5-phyllus. Cor. 2-labiata, ventricosa. Filam. quintiun sterile, cæeteris longius, superne barbatum. Caps. compressa, 2-locularis, 2-valvis. Sem. numerosa, subglobosa. 
512. MARTYNiA, Cal. 5-fidus. Cor, ringens. Caps. lignosa, corticata, rostro hamato, 4-locularis, 2valvis.

$$
\text { * Caiyces quadrifidi. }
$$

513. SCHWALBEA. Cal ventricoso-tubulosus, 4-fidus : lacinia superiore minima. Infina maxima, emargi. nata. Cor. ringens. Caps. 2-locularss, 2-valvis : dissepimento duplicato. Sem. paleacea.

514. RHINANTHUS. Cal. sentricosit, 4-fidus. Cor. ringens: labio supenore compresso. Caps. 2-locularis, compressa, obtusa.

515. BARTSIA. Lal. 2-lubus, emarginatus, coloratus. Cor. minus ipso calyce: labio superiore lungiore. Caps. 2-locular!s. Stm. angulata.

516. EIJPHRASIA. Cal. cylindricus, 4-fidus. Cor. bilabiata: labium superuus 2 -fictum, inferius 3-lobum: laciniis bifidis. Anth. interiores lobis spinosis.

517. MELAMPYRUM. Cal. 4-fidus. Cor. labiun superius compressum, margine replicato. Caps. 2-iocularis, obliqua, hinc dehiscens. Sem. 2. gitba.

*** Calyces lifidi.

518. OBOLARIA. Cor. campanulata, 4-fida. Stam. ex divisuris corollæ. Caps. 1-locularis, 2-valvis, polysperma.

519. OROBANCHE. Cor. ringens. Caps. 1-locularis, 2-valvis, polysperma. Glandula sub basi germinis.

\section{I. $G Y M N O S P E R M I A$.}

471. AJUGA. Gen.pl. 959 .

Chamapithys.
1. A. foliis trifidis, floribus axillaribus solitariis folio brevioribus, caule diffuso. Willd. sp. pl.3. p.10.

Teucrium Chamæpithys. Sp. $p l .787$.

Icon. Fl. dan. 733. Rivin.t. 24.

In sandy fields of Virginia. Gronov. $\odot$. June, July. v. s. in Herl. Gronov. Flowers pale yellow. 


\section{TEUCRIUM. Gen.pl.g60.}

1. T. cano-hirsutissinum ; foliis ovato-lanceolatis serratis. omnibus petiolatis, caule erecto, spicis verticillatis confertis, bracteis calyce duplo longioribus.- IVillal. sp. pl. 3.p. 22.

In low grounds, on the borders of ponds and lakes: $\mathrm{Ca}$ nada to New York. 4. July, Aug. v. v. Flowers purple.

2. T. pubeicens; foliis ovato-oblongis serratis, superioribus subsessilibus, caule erecto, spicis verticillatis contiel. tis, bracteis longitudine calycis.-Willd. sp. $p$. 3. p 22.

Icon. Schkuhr handb. 160.

In low grounds and bogs: New York to Carolina. if June-Aug. v. v. Resembles the foregoing specie: very much.

\section{MENTHA. Gen. $p l .96 \%$.}

1. M. floribus verticillatis, foliis lanceolatis serratis petiola. tis pilosis, stamınibus corollam requantibus. Willd. sp.pl. 3. p. 82 .

In Canada. Kalm. 4 . + .

2. $\mathbf{M}$ assurgens, pubescens ; foliis petiolatis ovali-lanceolatis utrinque acntissimis, foribus verticillatis, staminibus exertis.-Mich. fl. amer. 2. p. 2.

On the banks of rivers and near springs: Canada to Per. sylvania 4 . July, Aug. $v . v$. Flowers pale purple.

3. M. erecta, glabriuscula ; foliis lanceolato-oyatis subsesconwöensis. silibus, spica gracıli, verticillis minimis interrupta. stamiuibus non exertis-Mich. $f$. amer, 2. p. 2.

M. viridis. Walt. fl. car. 161 .

In wet places, near springs : Pensylvanid to Georgia. 4 . June-Aug. $v$. v. Flowers white.

474. ISANTHUS. Mich. $f$. amer. 2. p. 3.

1. I. viscido-pubescens; foliis ovali-lanceolatis utrinque acutis 3-nervibus, pedunculis 1-2-floris. Mich. $f$. amer. 2. $p 4$.

Icon. Mich. $f l$ amer 2. $t$. 30.

On dry hills, in lime-stone soil : Virginia and Kentucky.

๑. July, Aug. v. $v$. Flowers pale blue.

virginicsm.

lorealis.

tenuis.

ccerulese.

canadense 


\section{CUNILA. Gen. pl. 46.}

mariana.

1. C. foliis ovatis serratis sessilibus, corymbis terminalibus dichotonis.-Willd sp.pl. 1. p. 122.

Icon. Pluk. mant.t. 344.f. 1.

On dry shady hills: New York to Carolina. $\psi$. June, July. v. v. Flowers red. The whole herb has an aromatic scent, and is used as tea in severe colds and other complaints, under the name of Dittany.

\section{HYSSOPUS. Gen. pl. 963.}

uepetoides.

1. H. epicis verticillatis cylindricis, stylis corolla brevioribus, foliis subcordatis ovatis acuminatis acute dentatis.Willd. sp.pl.3.p. 48.

Icon. Jacq. hort. 1.t.69. Pluk. alm. t. 150. f.3.

In fertile shady woods, along hedges: Pensylvania to Virginia. 2u. July, Aug. v. v. From three to five feet ligh ; flowers in long close spikes, yellowish.

scrophularifolius.

2. H. spicis verticillatis cylindricis, stylis corolla longioribus, foliis cordatis ovatis acuminatis obtuse dentatis.Willd. sp. pl. 3.p. 48.

Agastache. Gronov. $f$. virg. 88.

Icon. Herm. parad. $t .106$.

In wet copses and on the banks of rivers: Pensylvania to Virginia; rare. 4 . July, Lug. v. v. Seldom above two feet high; Howers purple.

477. NEPETA. Gen.pl. 964.

Cataria. 1. N. foribus spicatis, verticillis subpedicellatis, foliis petiolatis cordatis dentato-serratis. Willd. sp. pl. 3. p. 49 .

Icon. Fl. dan. 580. Schkuhr handl. 157.

On road sides and in cultivated grounds : frequent. $\psi$. July, Aug. v. v. Flowers white. Common Cot. nep, so well known as a domestic medicine, has probably been introduced from Europe.

478. LAMIUM. Gen.pl. 971.

amplexicaule. 1. L. foliis floralibus sessilibus amplexicaulibus ottusis. Willd. sp. pl. 3. p. 90 .

Pollichia amplexicaulis. Roth germ. 1. p. 254.

Icon. Fl. dar. 752. Schkuhr handb. 159. 
In cultivated grounds, common; probably introduced. $\odot$. May-Aug. v. $v$. Flowers purple.

2. L. caule hispido, foliis longe petiolatis lato-cordatis pubescentibus, axillis unifloris.-Mich. $f$. amer. 2. p. 4 .

In shady woods of Tennassee. Michaux. +. Flowers large, white.

\section{GALEOPSIS. Gen.pl. 972.}

1. G. internodiis caulinis superne incrassatis, verticillis summis subcontiguis, calycibus pungentibus, corollis calyce parum longioribus, caule hirto. Willd. sp.pl. 3 . p. 92 .

Icon. Engl.bot. 207.

On road sides, in the western parts of Pensylvania. $\odot$. July, Aug. $v . v$. Flowers white, with purple spots.

\section{STACHYS. Gen.pl. 974 .}

1. S. glabriuscula, gracilis, erecta ; foliis sessilibus linearilanceolatis rariter subdentatis, verticillis subquadrifloris.-Mich. Al. aner. 2. p. 4.

S. palustris, Walt. fl. cur, 162.

In Carolina. Michaux. +.

2. S. caulibus erectis, retrorsum hispidissimis, foliis subpetiolatis lanceolatis acute serratis glaberrimis, verticillis subsexfloris, calycibus divaricato-spinescentibus.Mich.fl. amer. 2. p. 5.

S. tenuifolia. Willd.sp.pl.3.p. 100.

S. arvensis. Walt. fl. car. 162.

In low fields and on the banks of rivers: New York to Virginia. 4. June-Aug. v. v. Resembles S. pa. lustris; flowers purple.

3. S. caule foliisque hispido-pilosis; foliis petiolatis ovatooblongis obtuse-serratis, verticillis subsexfloris, calycibus glabriusculis.

Galeopsis floris galea rubente, \&c. Gron. $f$. virg. n. 271. In old fields and low pastures : Virginia to Carolina. 4. July. $v . v$. Flowers purple. Gronovius's synonym has been placed under $S$. annua, from which it is widely different, as his specimen in the Banksian Museum sufficiently demonstrates.

4. S. erecta, pubescens ; foliis cordato-ovatis dentatis, suhyssopifolia.

hispidulum.

Tetrahit.

aspera.

hispida! pra glabris subtus albicantibus tomentosis, verticillis subsexfloris.

VOL. II. 
On the banks of the Missouri. $\odot$. July. v. s. Flowers blue. The whole of this plant has a scent extremeiy like that of fennel.

\section{LEONURUS. Gen. pl. 977.}

Cardiaca.

1. L. foliis cuneiformi-ovatis trilobis dentatis, corollis calyce pungente majoribus, lacinia media labii inferioris acuta. Willd.sp.pl. 3.p. 114.

Icon. Fl. dan.727. Engl. bot. 286.

In old fields and hedges: Pensylvania to Virginia ; probably introduced from Europe. 4. July, Aug. v. $v$. Flowers white, mixed with red.

\section{GLECHOMA. Gen. pl. 970.}

hederacea. 1. G. foliis reniformibus crenatis. Willd. sp.pl. 3.p.85. Icon. Fl. dan. 789. Curt lond. 2. t. 44.

In orchards and on grassy hills: Pensylvania to Virginia. 4. May, June. v. v. Flowers handsome, blue.

\section{MARRUBIUM. Gen. pl. 976 .}

sulgare.

1. M. foliis subrotundo-ovatis dentatis rugoso-venosis, calycibus dentibus setaceis uncinatis. Willd. sp. pl. 3. p. 111 .

Icon. Fl. dan. 1036. Engl. bot. 410.

On road sides; frequent. $\psi$. July, Aug, v. v. Flow. ers small, white.

\section{HYPTIS. Gen. pl. 969 .}

capitata. 1. H. capitulis oppositis, pedunculo internodiis longitudine, bracteis lanceolatis calyce frugifero brevioribus, foliis oblongis utrinque attenuatis inæqualiter serratis.Willi. sp. pl.3.p. 84. Poiteau in annal. du mus. 7 . p. 464.

Clinopodium capitatum. Swartz. prodr. 88.

Icon. Jacq. ic. rar. t. 114. Annal. du mus. 7. t. 27.f. 1.

In Lower Carolina. Michaux. 4. July, Aug. v, $v$. Flowers white.

radiata. 2. If. capitulis oppositis, pedunculo internodiis longitudine, bracteis lanceolatis calyce frugifero longioribus, foliis oblongis serratis.-Willd.sp.pl. 3.p.84. Poiteau in annal, du mus. T. p. 466. 


\section{Didynamia gymospermia. Hyptis.}

Clinopodium rugosum. Sp. pl. 822 .

Icon. Dill, elth. t. 75.f. 86. Annal, du mus. 7. t. 2\%.

f. 2

In Lower Carolina. 4 . + .

485. PYCNANTHEMUM. Mich.fl. amer. $2 . p .7$.

Brachystemum. Mich.fl. amer. 2. p. 5.

* Siaminilus exertis.

1. P. foliis oblongo-ovatis acutis subserratis cano-tomentosis, capitulis compositis, lateralibus pedunculatis, bracteis setaceis. - Mich. fl. amer. 2. p. 7 .

Clinopudium incanum. Willd. sp. pl. 3. p. 132.

Icon. Dill. elth. t. 74.f. 85. Pluk. mant.t. 344.f.7.

In low fields and copses : New York to Carolina. 4. July-Oct. v. $v$. About three feet high; flowers white, tinged with red.

2. P. foliis lanceolato-ovatis subserratis brevissime petiolatis subcandicantibus, capitulis sessilibus, bracteis aristatis. - Mich. fl. amer. 2. p. 8.

Nepeta virunica. Willd.sp.pl. 3.p. 56.

Icon. Wich. fl. amer. 2. t.33. Pluk. alm. t. 85.f. 2.

In dry woods, in lime-stone soil: Maryland to Carolina. 4. July, Ang. v. v. Flowers white, very small.

3. P. foliis ovali-lancenlatis serratis subsessilibus, capitulo sessili, calycibus approximatis erectis breviter dentatis. Mirh. fl. amer. 2 . p. 3.

On high mountains of Carolina. Michaux. $\psi$. Stem and leaves tinged with purple.

4. P. hirsutum ; foliis abrupie petiolatis subcordato-ovali- Monardella; bus serratis, bracteis magnis coloratis, bracteolis ciliatis, calycibus summitate barbatis.-Mich. $f$. amer. 2 , p. 8 .

Origanum incanum. Walt. fl. car. 165.

Icon. Mich. fl. amer. 2, t. 34.

On the mountains of $\mathrm{Virginia}$ and Carolina. 4 . June -Aug. v. v. Flowers small, pale red.

3. P. caule stricto ramosissimo asperiusculo, foliis linearibus

montanum.

aristatum.

incanum. 3-nervibus integerrimis, capitulis terminalibus fasciculato-corymbosis.

Brachystemum virginicum. Mich. fl. amer. 2. p. 6.

Brachystemum linitoliun. Willd. enum. 623.

Thymus virginicus. Willd. sp. pl. 3. p, 145. 
Satureja virginiana. Sp. pl. 2.p. 793.

Origanum flexuosum. Walt. fl. car. 165.

Icon. Herm. parad. t. 218. Pluk. alm. t. 54.f. 2.

In dry swamps and mountain meadows: New England to Carolina. 4 . July, Aug. v. v. Flowers very small, entirely white. This and the following species approach so near to the genus Westringia, that they almost ought to be added to that genus.

\section{* Staminibus inclusis.}

lanceolatum. 6. P. caule stricto ramosissimo asperiusculo, foliis lineariJanceolatis venosis integcrrimis, capitulis terminalibus fasciculato-corymbosis.

Brachystemum lanceolatum. Willd. enum. 623.

In dry swamps and on the banks of rivers: Pensylvania to Virginia. 4. July, Aug. v.v. Resembles the foregoing species very much; flowers white; the lower lip of the corolla has purple dots.

viuticum.

7: P. foliis ovato-lanceolatis subdentatis glabriusculis, capitulis terminalibus, bracteis lanceolatis acutiusculis.Pers. syn. 2. p. 128.

Brachystemum muticum. Mich. fl. amer. 2. p. 6.

Icon. Mich. fl. amer. 2. t. 32.

In Upper Carolina. Michaux. $4 .+$.

verticillatum. 8. P. foliis ovato-lanceolatis integerrimis, verticillis sessilibus compactis, bracteis acuminatis.-Pers. syn. 2 . p. 128.

Brachystemum verticillatum. Mich. $f$ l. amer. 2. p. 6.

Origanum clinopodioides. Walt. fl. car. 165.

Icon. Mich. fl. amer. 2. t.31.

In the mountains: Pensylvania to Carolina. \%. July, Aug. v. $v$.

\section{ClINOPODIUM. Gen. pl. 980 .}

vulgare. 1. C. capitulis verticillatis, bracteis setaceis hispidis, foliis superne pilosis remote dentatis, caule subsimplici. Willd. sp.pl.3. p. 131.

Icon. Fl. dan. 930. Engl. bot. 1401.

In dry stony fields and woods : Canada to Virginia. 4. July, Aug. Flowers pale purple or rose-coloured. 


\section{ORIGANUM. Gen. pl. 981.}

1. O. spicis subrotundis paniculatis conglomeratis, bracteis vulgare. calyce longioribus ovatis. IVilid.sp. pl.3.p. 135.

Icon. Fl. dan. 638.

In dry stony fields and woods: Pensrlvania to Virginia. 4. July, Aug. v. v. Flowers pale red.

\section{9's. DRACOCEPHALUM. Gen. pl. 984.}

1. D. spicis brevibus tetragonis, bracteis ovatis acutis, caly- variegatum. cis dentibus inæqualibus, foliis arcte sessilibus ovalioblongis superne denticulatis. Vent. hort. cels $\mathbf{t . 4 4}$. cum icone.

Prasium incarnatum. Wult.fl. car. 165.

In Lower Carolina. 4. Aug. Sept. v. v. Flower's blueish-red, with white stripes, very ornamental.

2. D. spicis elongatis confertitloris, bracteis subulatis, ca- virginianum. lycis dentibus brevibus subæqualibus, foliis linearilanceolatis serratis.-Willd.sp. pl.3. p. 149.

Icon. Bot. mag. 467. Rob.ic. 207.

In mountain meadows: Virginia and Carolina. 4. July--Sept. $v$. $v$. Flowers reddish-purple. There is a taller variety with dark purple flowers.

3. D. spicis elongatis remotifloris, bracteis subulatis, ca- denticulatum. lycis dentibus subæqualibus, foliis obovato-lanceolatis superne denticulatis.--Willd. sp.pl. 3. p. 150.

Prasiun purpureum. Walt. fl. car. 166.

Icon. Bot, mag. 214.

In the nountains of Virginia and Carolina, 24. JulySept. $v . v$. Resembles the former very much; it is always smaller in size, and weakly in stem.

489. PRUNella. Gen. pl. 990.

1. P. foliis petiolatis oblongo-ovatis basi dentatis, calycis vulgario. labiis inæqualibus, superiore truncato aristato, caule adscendente.-Willd. sp. pl.3.p. 176.

Icon. Fl.dan. 910 . Engl. bot.961.

In fields and meadows: New England to Carolina. 24. July, Aug. v. $v$. Flowers violet purple.

2. P. foliis petiolatis ovato-lanceolatis basi dentatis, calycis pensyluanice. labiis æqualibus, superiore truncato triaristato, caule adscendente. Willd. hort. berol.p.9. t. 9 . 
P. laciniata. Wult. fl. car. 163 .

P. sylvestris autumnalis, \&ic. Gron. fl. virg. 91.

In woods and meadows: Pensylvania to Carolina. $\delta$. July, Aug. $v . v$. Perembles the foregoing species; the spikes are longer, and the flowers pale blue.

490. SCUTEllaria. Gen. pl. 989 .

lateriftora. 1. S. ramosissima, glabriuscula; foliis longissime petiolatis ovatis dentatis, caulinis subcordatis, racemis lateralibus toliosis. - Willd. sp. pl. 3. p. 172 .

On the side of ditches and ponds : Canada to Carolina. 4. July-Sept. v. v. Flowers blue, small.

nervosa. 2. S. simpliciuscula, glabra; foliis sessilibus ovatis dentatis nervosis, racemo terminali laxo folioso.

On the banks of rivulets: Virginia. 24. July, Ang. $v$. v. Flowers, as the most of this genus, blue, larger than the foregoing species.

galericulala. 3. S. simplicituscula, glabra; foliis subsessitibus ovato-Janceolatis basi subcordatis crenatis, Horibus axillaribus solitariis.-Willd. sp. pl. 3. p. 173.

Icon. Fl. dan. 637. Engl lot. 523.

In Canada and in the salt-marshes of Cnondago, New York. 4. July, Aug, v.v. Flowers large, pale blue.

angustifolia. 4. S. simplex, tenuissime pubescens; foliis linearibus, floribus axillaribus oppositis, genitalibus subesertis.

On the river Kooskoosky. M. Lewis. 24. June. v. s. in Herb. Lewis.

parvula.

5. S. simplex, pusilla, dense pubesceus; foliis sessilibus ovatis intege rrimis, omnibus conformibus, floribus axillaribus solitariis.-Mich. fl. amer. 2. p. 11.

In Canada and the Illinois country. Michaux. On banks of rivers in Virginia. $P h$. $\delta$. June, July. $v . v$. Not above two inches high ; flowers small, pale blue.

caroliniana. 6. S. ramosa, glaberrima; foliis petiolatis lineari-lanceolatis acutis integerrimis, racemis laxis foliosis, calycibus obtusis.-Lam.encycl. 7. p. 700 .

Icon. Lam. illustr. t. 515. $f 3$.

In Carolina. Fraser. $44 .+$

întegrifolia. 7.S. simpliciuscula, dense pubescers; foliis subsessilibus oblongis linearibusve obtusis integerrinis basi attenuais, racemis laxiusculis foliosis.p. 173. 
Icon. Pluk. alm. 441,f. 6.

3. S. foliis omnibus linearibus, $-W i l l d . s p$. pl. 3. p.174. hyssopifolia,

On dry hills, in rich soil : New York to Carolina. 4. July-Sept. $v \cdot v$. Flowers large, handsome blue. This species is very variable, in size and figure of leaves, simple and branched stems, \&c.

8. S. ramosa, elata, pubescens ; foliis ovatis acuminatis serserrute. ratis breviter petiolatis, racemis terminalibus laxiusculis plerumque paniculatis, bracteis lanceolatis brevibus. Bot. rep. 494.

S. integrifolia. Auctorum.

In fields and meadows : Virginia and Carolina. 4 . July -Sept. $v . v$. The tallest species; flowers large and handsome.

9. S. simpliciuscula, pubescens; foliis remotis rhomboideoovatis obtusis rotundato-crenatis basi attenuatis, petiolis brevibus, racemis terminalibus laxis plerumque ramosis, bracteis lanceolatis integris.-Mich. $f$. amer. 2. p. 11.

S. ovalifolia. Pers. syn. 2. p. 136 ?

S. caroliniana. Walt. fl. car. 163.

Icon. Pluk. alm. t. 313.f. 4.

In shady woods: Virginia and Carolina. 24. July, Aug $v . v$. Resembles the foregoing one; it is a smaller plant, with only a few leaves.

\section{THYMUS. Gen. pl. 982.}

1. T. floribus capitatis, caulibus repentibus, foliis planis obtusis basi ciliatis. Willd.sp.pl.3.p. 138.

Icon. Enyl. bot.1514. Schkuhr handl. 144.

Common Thyme occurs frequently in an apparently wild state, particularly on the commons near Philadelphia. 4. দ. July, Aug. v. v. Flowers purple.

\section{CALAMINTHA. Tourn. inst. 193.}

1. C. pubescens, ramosissima ; foliis ovatis obtusis subserSerpyilum. ratis, verticillis pedunculatis dichotomo-corymbosis folio longioribus, villis calycinis prominentibus.

Melissa Nepeta. Willd. sp. pl. 3. p. 147. Thymus Nepeta. Smith fl. brit. 2. p. 642. Icon. Engl. bot, 1414. Curt. lond, 6. t, 40. 
In lime-stone soil, on dry barren hills : Virginia. $\mathbb{Z}$ June, July. Flowers white, tiuged with red.

grandiflora.

2. C. erecto-cespitosa; foliis rhomboideo-ovalibus superne obsolete dentatis glabriusculis, verticillis subpedunculatis subdecemfloris folio brevioribus, villis calycinis inclusis.

Thymus grandiflorus. Bot. mag. 997.

Thymus carolinianus. Mich. fl. amer. 2. p. 9 .

Thymbra caroliniana. Walt. fl. car. $\mathrm{j} 62$.

On the banks of the river Savannah, in Georgia and Carolina. $4 . h$. July, Aug. v. v. Flowers large, pale purple.

\section{HEDEOMA. Pers. syn. 2.p. 131.}

glabra.

1. H. erecta, glabra ; foliis inferioribus oblongis, superioribus lanceolatis remote serratis, pedunculis terminalibus ternis.-Pers. syn. 2. p. 131 .

Cunila glabella. Mich. fl. amer. 1. p. 13.

On rocks on the river Tennassee, near Nashville. 4. + .

pulegioides.

2. H. pubescens; foliis oblongis serratis, pedunculis axillaribus verticillatis, calycis labio inferiore biseto, setis ciliatis.-Pers. syn. 2. p. 131.

Cunila pulegioides. Willd. sp. pl.1.p. 122.

In fields and on dry hills : Canada to Carolina. $\odot$. June, July. $v . v$. A small plant; flowers small, pale blue.

hispida.

3. H. ramosa, undique hispido-pilosa ; foliis linearibus nervosis margine revoluto integerrimis, verticillis subquadrifloris, calycibus hispidissimis laciniis subulatis.

On the banks of the Missouri. $\odot$. June, July. $v . s$. Not above two inches high; flowers very small.

\section{TRICHOSTEMA. Gen. $p l .988$.}

dichotoma. 1.T. foliis rhomboideo-lanceolatis, ramulis floriferis bifurcatis, staminibus longissimis.-Willd. $s p . p l .3$. p. 170.

linearis.

B.T. foliis linearibus. Walt. fl. car. 164.

In fields and on sunny hills: Pensylvania to Carolina. $\odot$. June-Aug. $v . v$. Flowers large, fine blue; the whole plant has an agreeable resinous scent. 
2. T. foliis ovato-lanceolatis, ramulis floriferis oppositis paniculatis, staminbus brevibus inclusis, - Willd. $s p$. lrachiata. pl. 3. p. 170 .

Icon. Dill. elth. t. 285. f. 369.

In Virginia, Dillen. $\odot$. v. s. in Herl. Banks. Flowers blue.

\section{II. $A N G I O S P E R M I A$.}

495. LINNÆA. Gen. pl. 1037.

1. L. caule prostrato, ramulis floriferis erectis biforis, foliis subrotundis antice crenatis.-Willd.sp. pl. 3. p. 340.

borealis. Icon. Fl.dan. 3. Engl. bot. 433. Fl.lapp.t. 12.f. 4. In old thr-woods of Canada and New England, and on the mountains of New York and Pensylvania. Plentifully in the woods near Wiscasset, Province of Main, and near the White Lake, on the mountains of New Jersey. 4. $\zeta$. May, June. v. v. Flowers white, tinged with red. This interesting and handsome little plant will for ever be the admiration of the botanist, should it even be only for the sake of its name.

496. PHRYMA. Gen.pl.994.

1. P. foliis ovatis grosse serratis petiolatis, spicis terminali- Leptostachia. bus gracilibus, floribus oppositis.-Willd. sp. pl. 3. p. 179 .

Icon. Pluk. amalth. t. 380.f. 5. Lam. illustr. t. 516. In shady, rocky woods: Canada to Carolina. 24. June -Aug. v.v. Flowers small, white with purple.Walter in his Flora Caroliniana has another species which he calls P. caroliniensis, foliis sessilibus obovatooblongis serratis scabris, spica terminali. Of this plant I was not able to find any information in his Ferbarium, and strongly suspect he means Salvia urtisifolia by it.

497. VERBENA. Gen. pl. 43.

* Foliis laciniatis.

1. V. assurgens; spicis solitariis pedunculatis imbricatis, corollarum laciniis emarginatis, foliis ovalibus incisoAubletia. serratis petiolatis.-Willd.sp.pl. 1.p. 119. 
V. longiflora. Lam. illustr. 1. p. 57.

Buchnera canadensis. Linn. mant. 88.

Glandularia caroliniensis. Gmel. syst. nat. 2. p. 920.

Anonymos caroliniensis. Walt. fl. car. 164.

Icon. Jacq. hort. 2. t. 176. Rozier journ. d'hist. nat. 1. t. 2.

In Carolina and Georgia. $\delta$. June, July. v.v. Flowers large, of a beautiful purple.

bracteosa. 2. V. pumila, decumbens, hirsutissima; foliis laciniatis, spica floribus subimbricata, bracteis linearibus longissimis et undique patentibus squarrosa. Mich. fl. amer. 2. p. 13.

Zapania bracteosa. Lam. encycl. 8. p. 8.13.

In Illinois and Kentucky. 4. July. v. s. in Herb. Lyon. Flowers light purple.

spuria.

3 . V. caule decumbente ramosissimo divaricato, foliis multifido-laciniatis, spicis filiformibus, bracteis calyces superantibus. -Willd.sp.pl. 1. p. 119.

On slate-hills and lime-stone rocks : Illinois, Virginia and Kentucky. $\delta$. July, Aug. $v . v$. Flowers very small, blue.

hastata. 4. V. erecta, elatior; foliis lanceolatis acuminatis incisoserratis nonnullis inciso-hastatis, spicis linearibus paniculatis subimbricatis.-Willd.sp. pl.1.p. 118.

Icon. Herm. parad. 242.

pinnatifida. $\quad \beta . V$. foliis inciso-pinnatifidis grosse serratis. Lain.illustr. 1. p. 57 .

On road sides, in wet soil, and on the banks of rivers : Canada to Carolina. 24. July, Aug. v. v. From two to tire fect high ; flowers purple, sometimes white.

\section{** Foliis integris.}

paniculata. 5. V. erecta, scabriuscula ; foliis lanceolatis grosse serratis inclivisis, spicis filiformibus imbricatis corymboso-paniculatis.-Lam. encycl. 8. p. 548.

On the natural meadows of the high mountains of Virginia and Carolina. 4. July, Aug. v. v. From four to six feet high ; flowers very numerous, purple.

urticifolia. 6. V. erecta, subpubescens; foliis ovatis acutis serratis petiolatis, spicis filiformibus distinctifloris axillaribus terminalibusque.-Willd.sp. pl. 1.p. 119.

Jcon. Riv. monop. 57. Rob. ic. 26.

On road sides and cultivated grounds: New England to 
Carolina. 24. June-Sept. v. v. Flowers very snall, white.

7. V. erecta, ramosissima; foliis ovato-Janceolatis serratis difiusa. subpubescentibus, spicis longissimis laxis paniculatis valde diffusis.-Lam. encycl. 8. p. 550 .

In North America. Lamarck. 24. $h$. t. Flowers very small, somewhat purple. This species has a very near resemblance $t$, the foregoing.

8. V. humilis, erecta; foliis lineari-Janceolatis basi attenuatis rariter serratis lineato-venosis, spicis filiformibus solitariis terminalibus axillaribusve. - Willd. enum. 633.

V. angustifolia. Mich. fl. amer. 2.p. 14.

In dry soil, on road sides, particularly in lime-stone soil : Pensylvania to Tennassee. 4 . June-Aug. v. v. Not above a foot high; Howers fine blue.

9. V. erecta, scabra ; foliis oblongo-obovalibus obtusis incaroliniana. æqualiter serratis basi attenuatis subsessilibus, spicis longissimis filiformibus distinctifloris. - Willd. sp.pl. 1. p. 119.

Icon. Dill. elth. t. 301.f. 388.

In dry sandy fields : Carolina to Georgia. 4. June, July. v. s. Flowers pale red.

10. V. hirsuta, albicans; caulibus rigide erectis, foliis sessistricla. libus obovalibus serratis subtonentoso-hirsutissimis, spicis strictis imbricatis subfasciculatis.-Willd. enum. 633. Vent, hort. ce's p. 53. cum icone.

V. rigens. Mich. fl. amer. $2 . p .14$.

In Carolina and the Illinois country. 4 . Juiy, Ang. v. s. in Herb. Lambert.

\section{ZAPANIA. Lam. illustr. 1.p.58.}

1. Z. foliis cvato-cuneiformibus superne serratis, spicis capitato-conicis solitariis elongato pedunculatis, caule nodifiora. herbaceo repente.-Lam. illustr. 1. p. 59 .

Verbena nodifiora. Willd. sp. pl. 1. p. 117 .

Lippia nodiflora. Mich. $f l$. amer. 2. p. 15.

Blairia noditlora. Gert. de fruct. et sem. 1. p. 266. t. 56 .

Icon. Lam. illustr. 1. t. 17.f. 3. Rob. ic. 30.

On the coast of Virginia and Carolina, and on the banks of the Ohio. $\psi$. July, Aug. v. v. Flowers white, small.

2. Z. foliis lineari-lanceolatis argute serratis, spicis capitato.

lanceolata. 
conicis solitariis elongato-pedunculatis, caule herbace repente. - Pirs. syn. 2. p. 140.

Lippia lanceolata. Mich. fl. amer. 2. p. 15.

In Carolina and Georgia, on the banks of rivers. 4. July, Aug. v. v. Flowers white.

\section{CAPRAR!A. Gen.pl. 1030.}

multifida. 1. C. erecta, viscido-pubescens; foliis superioribus terno. verticillatis multifidis, pedicellis solitariis. - Mich. $f$. amer. 2. p. 22, t. 36 .

Cn the banks of rivers, in the western parts of the settlements, particularly on the Missouri and Mississippi. $\odot$. July, Aug. v. s. Flowers small, greenishwhite.

500. HERPESTIS. Gert. carp. 3.p. 1S7.t. 214.

Monniera. Mich. Al. amer. 2. p. 22.

roluntifolia. 1. H. minutim pubescens; foliis subovali-orbiculatis multinervibus, pedunculis passim oppositis folia subrquantibus.

Momiera rotundifolia. Mich. $f$ l. amer. 2. p. 22 .

On overflowed banks of rivers, in the lllinois and other western parts. 4 . July, Aug. v. s. Flowers pale blue, small.

amplexicai-

2. H. caulibus lanatis, foliis breviter cordato-ovalibus amlis. plexicaulibus integris obtusis, pedunculis folio brerivribus.

Monniera amplexicanlis. Mich. $f$. ame', 2. D. 22.

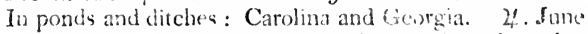
- Ang. $v$. v. Fiswers blue, larger han the other species.

cuneifalia. 3. H. glaberrima; foliis cuneato-obovalibus superne obsolete subcrenatis, pedunculis folia subæquantibus.

Monniera cuneifolia. Mich. Jl. aner. 2. 1,. 22.

On the overflowed banks of rivers, near the sea-shore: Pensylvania to Carolina. 24. Aug. v. v. Leaves thick; flowers very small, pale blue.

micrantha. 4. H. glabra, succulenta ; foliis arcte sessilibus ovalibus obtusis integerrimis striato-nervosis, pedunculis folio brevioribus, calyce 5-phyllo, stylo bifido.

Gratiola repens. iVilld.sp.pl. 1.p. 103 ?

Icon. Swarlz. ic, $t, 33$. 
On the banks of rivers, to the edge of low water mark : Pensylvania to Virginia. ๑. July, Aug. v. v. Flowers very small, white. It approaches ncar to Lindernia.

\section{LINDERNIA. Gen.pl.1031.}

¿. L. glaberrima; foliis oblongo-ovatis obsolete dentatis sessilibus, pedunculis axillaribus unifioris, corollis calyce duplo longioribus, capsulis calyce brevioribus.Willd. sp. pl. 3.p.325?

Gratiola inæequalis. Walt. fl.car. 61.

Gratiola anagalloidea. Mich. fl. amer. 1. p. 6.

Gratiola floribus pedunculatis, foliis ovatis crenatis. Gron. fl. virg. 3.

-. L. foli.s repando dentatis, pedunculis brevibus.

On the banks of ponds and rivers, in gravelly soil: New York to Virginia. ๑. July, Aug. v.v. Flowers bive. The European plant, figured by Schkuhr and $\mathrm{K}$ rocker, seems to be a very different species from the presut one, as the corolla is shorter than the calyx.

\section{SCROPHULARIA. Gen.pl. 1014.}

1. S. fulis cordatis serratis acutis basi rotundatis, petiolis marylanaiza. inferne cilinis, paniculæ fasciculis laxe paucifloris,Willd. sp.pl.3. . . 269.

S. nodosa B. americana. Mich. fl. amer. 2. f 21.

In low grounds: Pensylvania to Caro'in. It. JuneAug. $v, v$. Flowers greenish-bruwn. The plant often more than four feet high.

2. S. foliis lanceolatis inæequaliter serratis acuminatis basi pysidaria. major. acutis, petiolis nudis, panicula fasciculis corymbosis.

In wet meadows and woods: Pensylvania. 24. Aug. Sept. v. $v$. Flowers greenish-yellow.

\section{BIGNONIA. Gen.pl. 1018。}

1. B. foliis conjugatis cirrbosis, inferioribus ternatis, foliolis ovato-cordatis acuminatis, racemis axillaribus, caule muricato. Wille, sp.pl. 3. p. 296.

Icon. Plum. ic. t. 53.

In shady woods: Carolina to Florida. $\zeta$. June, July. $v$ v. Flowers yellowish-scarlet.

2. B. foliis conjugatis cirrhosis, foliolis oblongis basi sublanceolata. cordatis, imis simplicibus.-Willd. sp. pl. 3. p. 297. 
Icon. Bot. mag. 864. Jacq. hort. schoenlr. 363.

In shady woods, on the banks of rivers and lakes : Virginia to Florida. $\eta$. July, Aug. v. v. Flowers scarlet.

radicans.

flammea.

coccinea.

strepens.

ollongifolia.

hylrida.

ciliosa.
3. B. foliis pinnatis, foliolis ovatis dentatis acuminatis, corymbo terminali, tubo corolla calyce triplo longiore, caule radicante.-Willd. spp. pl. 3. p. 301 .

Tecoma radicans. Juss.

a. B floribus luteo-coccineis.

Icon. Schmidt arl. t. 42.

B. B. floribus coccineis.

Icon. Schmidt arb. t. 43 E 44. Bot. mag. 485. Catest car 1. t. 65.

On the banks of rivers: Pensylvania to Florida. $\zeta$. July, Aug. $v \cdot v$. This highly ornamental creeper ascends the tallest trees and highest rocks, and with its large scarlet flowers produces one of the most. pleasing effects in ornamental gardening.

504. RUEllia. Gen. pl. 1050.

1. R. erecta, hirsuta ; foliis petiolatis lanceolato-ovatis integerrimis, pedunculis $1-3$-floris, calycis laciniis lanceolatis hispidis tubo corollæ duplo brevioribus.Willd. sp. pl.3. p. 363.

İcon. Schkuhr handl. 177. Dill. elth. t. 249.f. 321.

On dry hills, in shady woods: Virginia to Carolina. 4. June, July. $v . v$. Flowers large, pale blue, as are all the following.

2. R. assurgens, dense pubescens; foliis subsessilibus obovato-oblongis, floribus solitariis, bracteis longitudine calycis, calycis laciniis filiformibus longitudine tubi corollæ.-Mich. Al. amer. 2. p. 23.

R. biflora. Willd. sp. pl. 3. p.368?

In sandy pine-woods : Georgia. 24. June, July. v.s. Flowers yellowish-blue.

3. R. erecta, ramosissima, pilis albidis hirsuta ; foliis sub. sessilibus oblongis utrinque subacutis dense hirsutis, bracteis calyce brevioribus, calycis laciniis linearibus tubo corollæ vix brevioribus.

In sandy fields near Savannah, Georgia. 24. July. v.s. in Herb. Enslen.

4. R. erecta, ramosa; foliis subsessilibus ovato-oblongis wargine nervis venisque pilis albis longe ciliatis, brac- 
teis lanceolatis brevibus, calycis laciniis subulatis tubo corollæ quadruplo brevioribus.

Near Savannah, Georgia. 4. July. v. s. in Herb. Enslen.

3. R. glabriuscula, diffusa, radicans ; foliis in petiolum lonhumistrata. giuscule angustatis ovalibus obtusis, floribus subsessilibus, capsulis linearibus. Mich. fl. amer. 2. p. 23.

In Georgia and Florida. Michaux. +.

\section{BUCHNERA. Gen. $p l .1035$.}

1. B. caule simplici, foliis lanceolatis subdentatis asperis americana. trinervibus, spicis remotilloris.-Willd. sp. pl. 3 . p. 334 .

On dry sandy hills: Pensylvania to Carolina; rare. $\mathcal{\psi}$. July. v. v. Flowers deep blue.

\section{ANTIRRHINUM. Gen. pl. 1007.}

1. A. procumbens, pilosum; foliis alternis hastatis integerrimis, pedunculis solitariis longissimis.-Willd. $s p$.

Elatine pl. 3.p. 234.

Icon. Fl. dan. 426. Engl. bot. 692 .

In sandy fields: Pensylvania to Virginia. ๑. July, Aug. $v . v$. Flowers yellow mixed with purple.

2 A. erectum, glabrum; foliis sparsis lanceolato-linearibus confertis, spicis terminalibus densifloris, calycibus glabris calcare brevioribus. - Willd. sp. pl. 3 . p. 253 .

Icon. Fl. dan. 982. Engl. lot. 658.

In fields and dry hills, near bouses; frequent. 4 . June -Aug. v. $v$. Elowers large, yellow. This finelooking plant is one of the worst and most troublesome weeds in several parts of Pensylvania and Virginia.

3. A. assurgens, glabrum, simplicissimum; foliis sparsis canadense. erectis angusto-linearibus obtusis remotis, floribus $\mathrm{ra-}$ cemosis, stolonibus procumbentibus.-Willd. sp. pl. 3 . p. 255 .

Icon. Vent. hort. cels 40.

In low grounds: Canada to Carolina. ๑. June-Aus. $v$. $v$. Flowers small, purple.

A. A. pusillum, simplex, glabrum; foliis oppositis linearibus tencllum. acutis, floribus axillaribus brevi-pedunculatis, calycibus campanulatis. 
On the banks of the Missouri. M. Lewis. $\odot$. July v. v.; v. s. in Herb. Lewis. Flowers bright blue, large in proportion to the size of the plant.

Crontium. 5. A. erectum, ramosum, pubescens; foliis alternis lan. ceolatis, floribus subspicatis, calycibus digitatis corolla longioribus, corollis ecaudatis._Lilld. sp. pl. 3 . p. 258.

Icon. Curt. fl. lond. 4. t. 45. Piv. t. 82.

In fields: Virginia; rare. $\odot$. July, Aug. v. $v$. Flowers pale purple.

507. GERARDIA. Gen. pl. 1004.

* Flores purpurei.

purpurea. 1. G. caule opposite ramosissimo, foliis linearibus, floribus axillaribus oppositis sủbsessilibus.-Willd. sp. pl. 3 . p. 221.

Icon. Pluk, mant. t.388.f. 1.

crassifolia. $\quad$ B. G. foliis carnosis brevioribus.

In fields and woods: New England to Carolina. $\beta$. In salt-marshes, near New York, \&c. $\delta$. July, Aug. $v . v$.

tenuifolia.

2. G. paniculato-ramosa; foliis linearibus, pedunculis axillaribus oppositis flore longioribus. - Willd. sp. pl. 3 . p. 222.

G. erecta. Walt. fl. car. 170. Mich. fl. amer. 2. p. 20.

Icon. Pluk alm. t. 12.f. 4 .

In fields and woods: Pensylvania to Carolina. $ð$. July, Aug. $v . v$.

setacea.

3. G. caule ramosissimo, foliis setaceis, ramulis axillaribus folio longioribus plerumque unifloris.-Walt. fl. car. 170.

In sandy fields: Pensylvania to Virginia. $\odot$. Aug. v. $v$. Resembles the foregoing one; but the flowers are not axillary but terminal, very seldom two on a branch.

auriculata. 4. G. subsimplex, tcta aspera; foliis ovato-linceolatis basi 2-auriculatis integerrimis, floribus axillaribus oppositis foliisque arcte sessilibus.-Mich. $f l$. amer. 2. p. 20.

In dry stony fields : Virginia and Illinois. ๑. July, Aug. $v . v$. Not above eight inches high, without branches.

cuneifoli.:.

5. G. paniculato-ramosa ; ranis erectis, fuliis cuneatolanceolatis inæqualiter serratis superioribus alternis, 



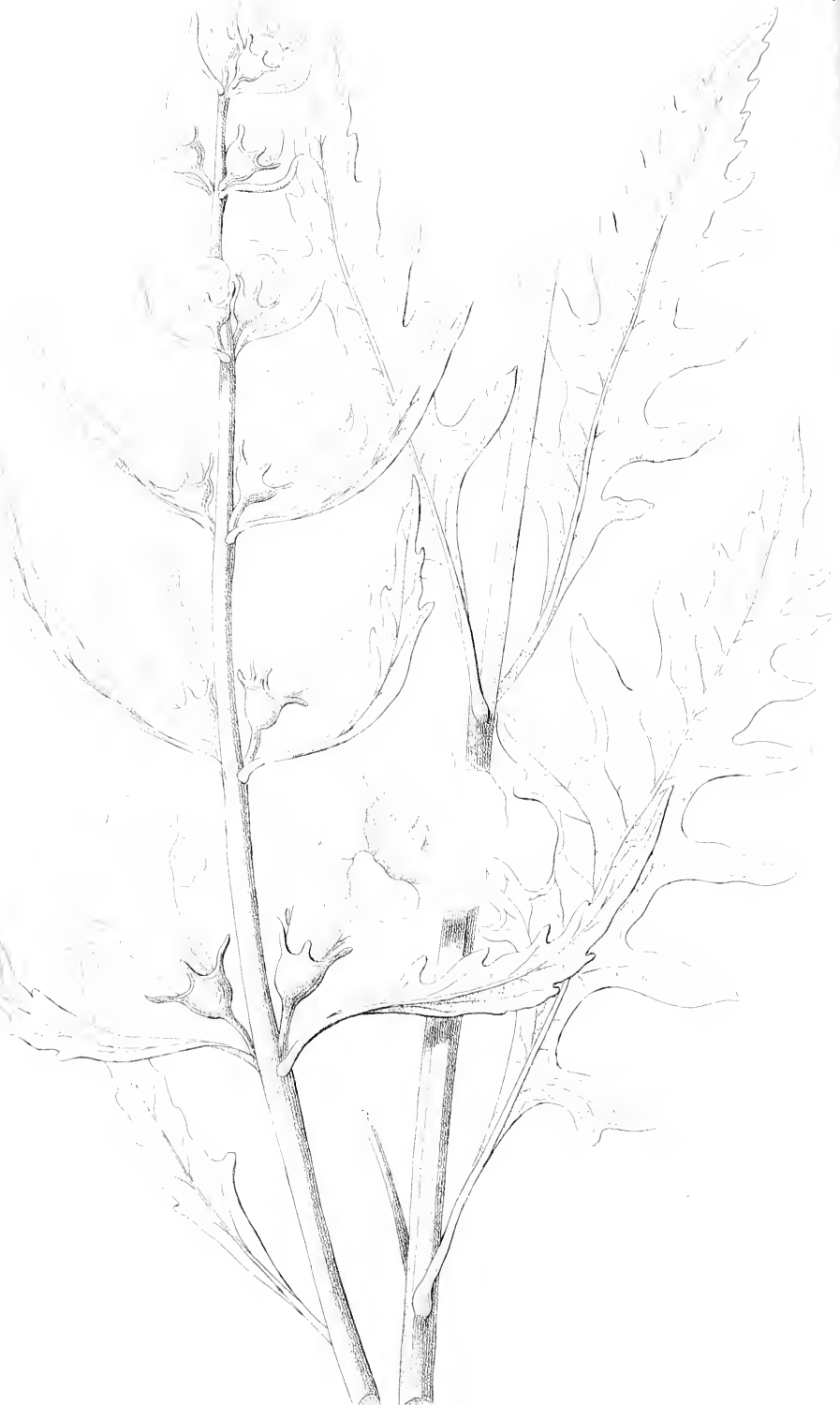



Tir6. 78.7 .423$.

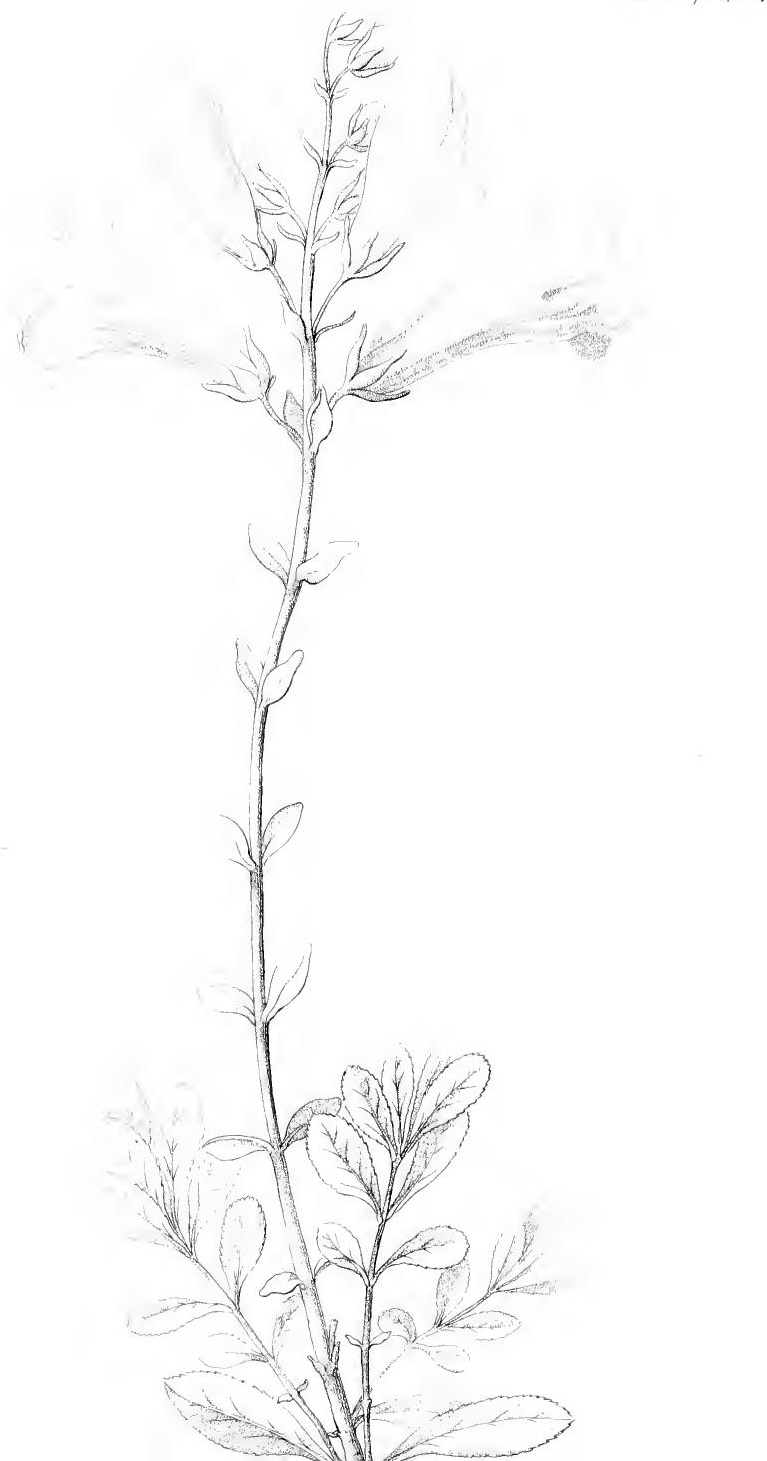


redunculis axillaribus folio longioribus, calycibus 5partltis.

In Georgia. Bartram. v. s. in Herl. Banks.

6. G. ramosissima ; foliis lanceolatis serratis basi attenuatis subpetiolatis, racemis terminalibus, floribus oppositis bracteatis.

In great abundance in the pine-forests of the Rockymountains. A1. Leuis. h. June. v. s. in Herb. Lewis.

Frute: elegans $3-4$-pedalis ramosissimus. Rami teretes, dense foliosi, tenuissine pubescentes. Folia semuncialia, opposita, lanceolata, acuta, interdum obtusa cum mucrone, superne acute serrata, inferne quasi in petiolum attenuata, integerrima, utrinque glabra. $R a$ cemi terminales, simplices, erecti, bracteati. Flores oppositi, pedicellati, magnitudine et colore Digitalis purpurei. Bractece oppositæ, sessiles, oblongæ, acutæ, integerrimæ, pedicellis vix breviores. Calyx profunce 5-partitus, basi unibracteolatus : laciniis lanceolatis, acutis. Bracteola lineares, calyce breviores. Corolla: Tulus calyce quadruplo longior, superne ventricosus. Limlius patens, subxqualis, 5-fidus : $L a$ ciniis rotundatis. Filamenta tubo duplo breviora, imo corolla inserta. Anthera oblongæ, hirsutissimæ. Stylus longitudine tubi. Capsula......

$$
\text { * Flores flavi. }
$$

7. G. pubescens; caulibus subsimplicibus, foliis subsessilibus lanceolatis integerrinis vel dentatis, inferioribus subpinnatifido-incisis, floribus axillaribus oppositis subsessilibus.-Willd. sp.pl. 3.p. 223.

Icon. Pluk. mant. t. 389. $f .3$.

In dry shady and rocky woods : New England to Florida. 24. July-Sept. $v, v$. Flowers large, and, as all the following, yellow. It is seldom more than two feet high.

8. G. glabra ; caule paniculato, foliis petiolatis pinnatifidis : laciniis lanceolatis acutis integris vel postice incisodentatis, summis lanceolatis integris, floribus axillaribus oppositis pedicellatis.

Rhinanthus virginicus. Willd. sp.pl. 3.p. 191.

Icon. Pluk. alm. t.389.f: 1.

On the banks of rivers, in rich shady places: Pensylvania to Carolina. 4. July, Aug. v. v. From three to five feet high. This fine species has been generally

fruticosa.

flava.

quercifolia: 
confounded with the foregoing one, but differs widely from it. The stem is smooth, purple, with a blue dew over it, and very much branched. The flowers are nearly the size, shape, and colour of the precerling spccies. The original specimen of Gronovius of Rhinanthus virginicus, in the Banksian Museum, is evidently our present plant.

Pcdicularia. 9. G. pubescens, brachiatim-paniculata; foliis oblongis duplicato-inciso-serratis pimnatifidisque, floribus axillaribus oppositis pedicellatis, calycis laciniis foliaceis inciso-dentatis.-Willd. sp.pl.3.p. 223.

Icon. Lain. illustr. t. 529.f.2.

In dry shady woods: New York to Carolina. o. June -Aug. $v . v$. A very handsome species, of which there are several very striking varieties.

cassioides. 10. G. virgatim-paniculata; foliis setaceo-pinnatifidis : laciniis linearibus.

G. Afzelia. Mich. Al.amer.2.p. 20.

Afzelia cassioides. Gmel. syst. nat. 927 .

Anouymos cassioides. Walt. fi. car. 171.

In dry sandy woods of Carolina and Georgia. ๑. July, Aug. v.s. Flowers small, yellow.

508. PEDICULARIS. Gen.pl. 1003.

euphrasioides. 1. P. caule ramoso pubescente, foliis pinnatifidis dentatis, calycibus tubulosis bipartitis truncatis, corollæ galea bidentata. Willd.sp. pl. 3.p. 204.

Icon. Houttuyn. linn. syst.8. t.57.

In Labrador. Colmaster. 24. v. s. in Herl. Dickson. Flowers yellow; from six to eight inches high.

fallicia.

2. P. caule ramoso elato giabro, foliis suboppositis lanceolatis crenatis dentatis, spica aphylla glabra, corollæ galea obtusa, calyce bifido rotundato.-Herb. Banḱs.

P. virginica. Lam. encyci.5. p. 126.

In swamps, on lime-stone soil: Virginia. Lamarck. In a swamp near King's-bridge, New York. Ph. 24. July, Aug. v. v.; v. s. in Herb. Banks. Flowers yellow; grows upwards of three feet high. I considered this species to be the Rhinanthus virginicus, which Linnaeus had adopted from Gronovius's Flora Virginica; but on examining the Gronovian Herba. rium in the Banksian Museum, I found his Rhinanthus to be the Gerardia quercifolia.

lanceolata. 3. P. caule simplici, foliis lanceolatis inciso-dentatis, spica 
aphylla, calycibus glabris, capsulis brevibus. Mich. fl. amer. 2. p. 18.

In the Illinois country. Michaux. 4.

4. P. canle simplici, foliis lanceolatis pinnatifidis dentatis, spica foliosa alterniflora hirsuta, capsulis in mucronem gladiatum exertum protractis.-Wich. fl. amer. 3 . p. 18.

In rich soil, in grassy moist places: Pensylvania to Virginia. 24. May, June. v. v. Flowers yellow, tinged with purple; sometimes a foot high.

5. P. caule simplici, foliis pinnatifidis inciso-dentatis, capitulo basi folioso hirsuto, corollis galea setaceo-bidentata, calycibus deorsum truncatis.-Willd. sp. pl. 3. p. 211.

In woods and meadows: Canada to Carolina. 2\%. May -July. v. v. About a span high; flowers yellowishwhite, with a tinge of purple.

6. P. caule simplici glabro, foiiis lanceolatis dentatis crenatis, calycibus bifilis truncatis, corollæ galea acuta. IVilld.sp.pl. 3. p. 206.

Icon. Gmel. fl. sib. 3, t. 44.

In Canada. 4. July. v.s. About a foot high; flowers deep purple.

7. P. caule simplici, foliis profunde pinnatifidis, pinnis lanceolatis pinnatifidis dentatis, spica compacta foliosa, calycibus glabris quinquedentatis, corollæ galea obtusissima. Willd.sp.pl.3.p. 210.

Icon. Jacq. fl. austr. 258.

On the north-west coast. A. Menzies; and probably throughout Canada. 24. July. v. s. in Herl. Bunks. Flowers purple.

8. P. canle simplici, foliis profunde pinnatifidis, pinnis lineari-lanceolatis crenatis, spica laxa subfoliosa, calycibus glabris 5 -dentatis, corollæ galea obtusa truncata. Villd.sp. pl. 3. p. 210.

In low plains, on the waters of Clarck's river. MT. Lewis. 4. July. v. s. in Herl. Leuis. Near two feet high; flowers purple.

9. P. caule simplici, foliis pinnatifidis, pinnis serratis, cacanadensis. gladiuta.

resupinata.

recutila. elata.

lapponica. lycibus bifidis oblongis, corollæ galea uncinata truncata. Willd. sp.pl. 3.p. 207.

Icon. Fl. dan. 2. Fl. lapp. t. 4.f. 1.

In Labrador. Colmaster. 4 . July. v. s. in Herl. Dickson. Flowers yellow. 
grønlandica. 10. P. caule simplici, foliis profunde pinnatifidis, pinnis lanceolatis acuminatis serratis, calycibus glabris 5-dentatis, corollis clausis, galea uncinato-subulata. Willd. sp. pl. 3.p. 212.

Icon. Fl. dan. 1166. Retz. obs, 4. t.1.

In low plains of the Columbia. M. Lewis. 24. July. $v$. s. in Herú. Lewis, nec non Lamlert. Flowers purple.

verticillata. 11. P. caule simplici, foliis caulinis profunde pinnatifidis quaternis, pimnis linearibus acute dentatis, spica capitata involucrata, calycibus villosis 5 -fidis, corollæ galea obtusissima.

P. verticillata $\beta$. Willd. sp. pl. 3.p. 214.

P. lanata. Pallas in Flerb. Lambert.

On the north-west coast. Nelson. 4 . v. s. in Herl. Banks. nec non Lambert. Not above two inches high ; flowers purple.

flammea. 12. P. caule simplici, foliis pinnatis, pinnis imbricatis ovatis obtusis duplicato-dentatis, calycibus 5 -dentatis, corollæ galea obtusa. W'illd. sp.pl.3. p. 215.

Icon. Fl.dan. 30. Fl. lapp. t. 4.f.2. Hall. fl. helv. t. 8.f. 3 .

In Labrador. Colnaster. 24. v. s. in Herb. Dickson. Not above three inches high ; flowers yellow, with a scarlet helmet.

\section{0g. MIMULUS. Gen.pl. 1049.}

ringens.

1. M. erectus, glaber; foliis sessilibus lanceolatis acuminatis serratis, pedunculis axillaribus oppositis flore longioribus, dentibuscaly cis oblongis acuminatis.-Willd. sp. pl. 3. p. 360 .

Icon. Bot. mag. 283. Pluk. amalth. t. 393.f.3.

In low grounds, on clay soil: Pensylvania to Carolina. 4. July, Aug. v. v. Flowers pale blue, large.

alalus. 2. M. erectus, glaber; foliis petiolatis ovatis acuminatis serratis, pedunculis axillaribus oppositis flore brevioribus, dentibus calycis rotundatis mucronatis, caule tetragono alato.-Willd. sp.pl. 3. p. 361 .

In ditches and on the borders of ponds: Pensylvania to Carolina. 24. July, Aug. v. $v$. Flowers the size and colour of the foregoing.

luteus. 3. M. erectus, glaber, stoloniferus ; foliis subrotundo-ovatis nervosis dentatis, inferioribus obtusis petiolatis, superioribus acutis arcte sessilibus, racemo terminali, 



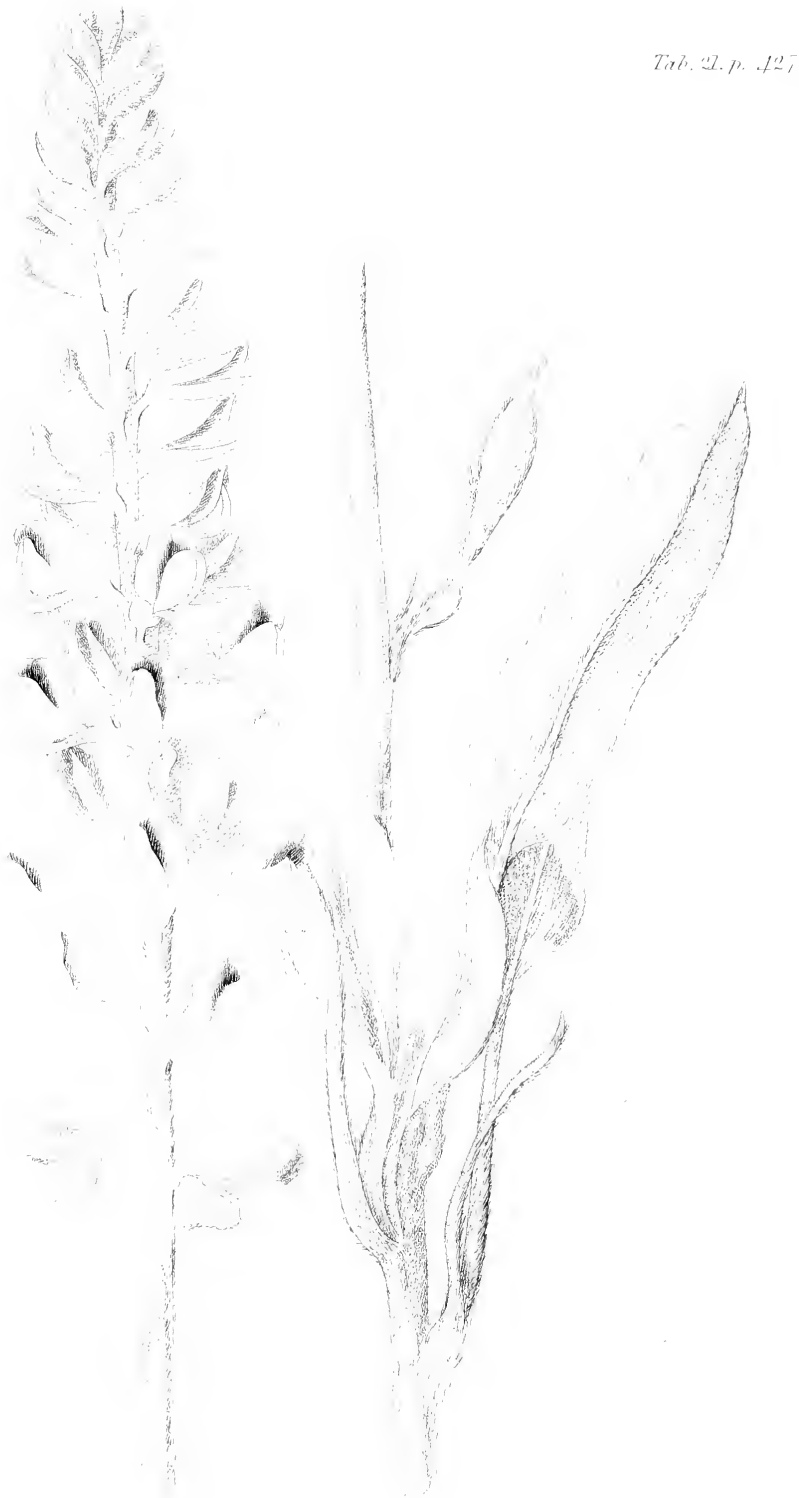



Tath.20.p :2?\%

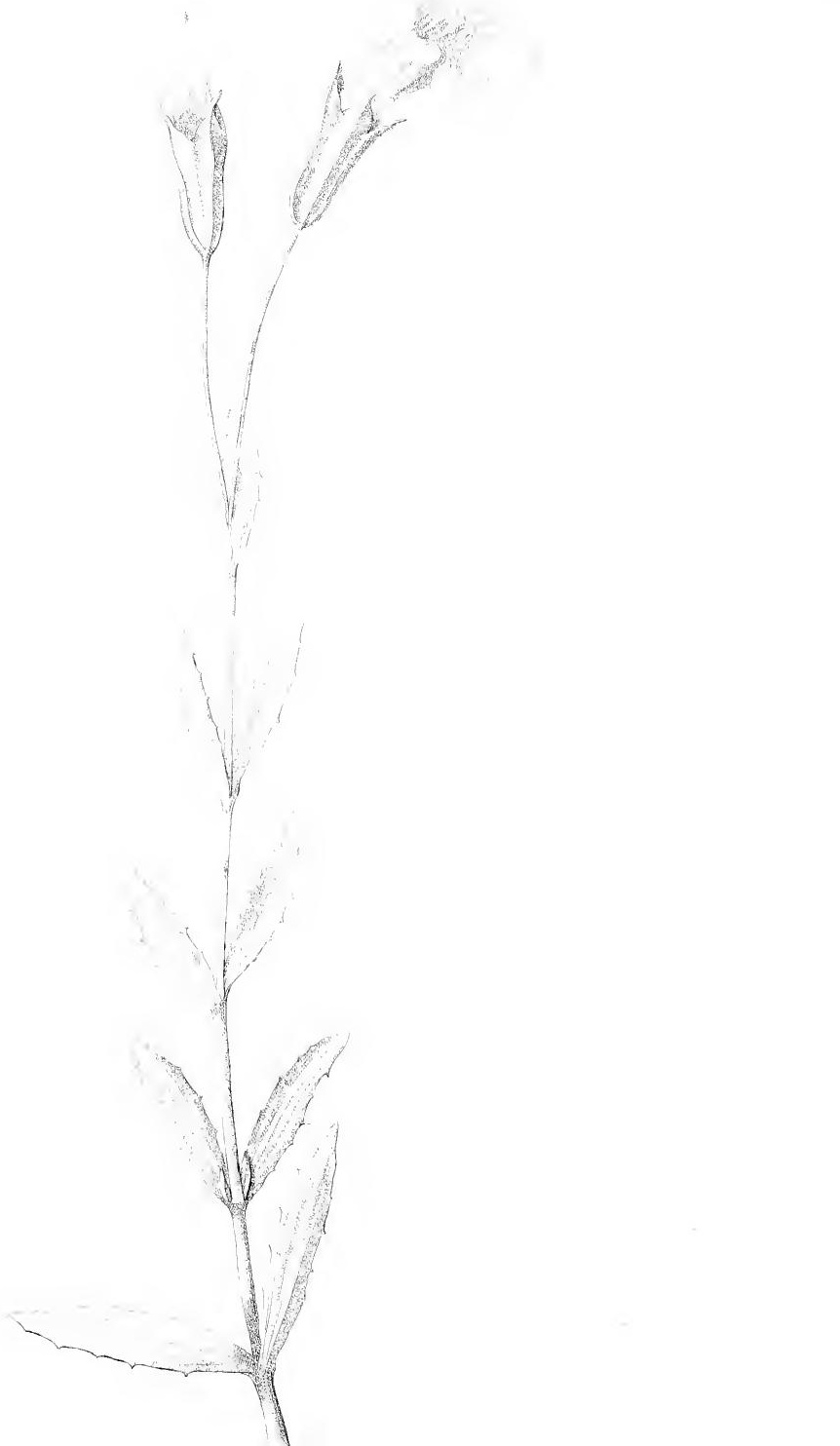


peclunculis axillaribus oppositis e!nngais, calyce inæquali, rentibus acutinsculis.-Willd sp. pl.3. p.361. Ic n. Fe'ill. peruv. 2. $t .34$.

On the banks of Clarck's river. N. Lewis On the notth west coast. Pallas. 24. July, Aug. v.s. in Herb. Lewis. nec non Lambert. Flow ers golden-yel. low. It has lately beeu introduced into the garlens, and will be a fine addition to our hardy peremual plints.

4. M. erectus, pusillus, pubescens; folii-sessilibus oblongolanceolati, acutis nerwis nucronato-denticulatis. foribus pancis ter minalibus long is sime f edunculatis, dentibus calycis acuminatis.

On the head springs of the Missouri, at the foot of Portage hill. 17. Lert is. 4 Ang $r . s$ in Herl. Lewis. Not above eight inches high; fowers two or three, larger than any other known sperien, ot a beautiful pale purple.

\section{CHELONE. Gen.pl. 1005.}

1. C. foliis oppositis lanceolato-ob!ongis acuminatis serratis, spicis termmalibus densitoris.-IVild. sp. pl. 3. $p 225$.

a. C. foliis subsessilibus, foribus albis.

$\beta$. C. foliis brevi-petiolatis, floribus purpureis.

C. obliqua. Wille sp pl. 3 p. 225

C purpurea. Nitl. dict n. 2

Icon Sihkulir handb. 172. Nill. is. 93. P/uk mant. ¿. $348 . f .3$

On the banks of rivers, ponds, and swamps: New England to Canolina $B$ In rivules on the high monntains of Virginal and Caro ina. 4. Jui:, Ano. " ". Flowers large, in clire spikes, in var. a. whi e; pu ple in var. 3 . I have not heen able to fint nubcen distinctions between $C$. y'urra and $\ldots$ obluqua, so as to consider them distinct specres.

\section{PENTSIEMON. Gen. pl. 1758.}

1. P. caule glabro, follis levigatis ovatn-oble is basi amplexicaulibus tenuissime dentralatis. anerioribus integerrimis, floribus paniculatis, filamento s!erili su. perne barbalo. Willd sp. $p l 3$ p 228.

Chelone Penntemon J. F. Miller. ic 4.

Icon. Lam. illustr.528. Arduin. spec. t. 5. Moris, hist. 2. s. 5. t. 8.f. 6 . 
In stony low grounds: Pensylvania to Carolina. 4. July-Sept. v.v. From one to two feet high; flowers yale purple.

fulcscens. 2. P. caule pubescente, foliis serrulat is lancenlato-oblongis sessilibus, floribus paniculatis, filamento sterili ab apice infra medietatem barbato.-Willd. sp.pl. 3. p. 227.

Chelone Pentstemon. Mant. 415.

latifolia. a.P. foliis levigatis serratis latioribus.

Icon. Moris. hist. 3. s. 11.t. 21.f. 2.

angustifolia. $\quad \beta$. P. foliis pubescentibus obscure denticulatis angustis.

P. hirsuta. Willd. sp. pl.3. p. 227.

Chelone hirsuta. Mill. dict. n. 3.

Icon. Moris. hist.3. s. 11.t.21.f. 3.

On the side of hills and in dry meadows: New York to Virginia. 24. July-Sept. v, v. About a foot high; flowers pale purple, longer than the foregoirg species.

frulescens.

3. P. caule fruticoso, ramis angniatis superne pubescentibus, foliis lanceolatis obsolete denticulatis sessilibus glabriusculis, racemis terminalibus subcorymbosis, filamento sterili longitudinaliter barbato._Lamlert in linn.trans. 10. D. 259.

Icon. Linn. trans. 10, t. 6.

On the north-west coast. M. Lewis. Unalaslika. Pallas. h. v. s. in Herl. Lamlert. nec non Lewis. A small shrub, about a foot or more high; flowers purple.

\section{MaRTYNin. Gen. pl. 1010.}

probosciciea. 1. M. caule ramoso, foliis alternis cordatis integerrimis villosis.-Willd.sp. pl. s. p. 264.

M. alternifolia. Lam. encycl.2.p. 112.

M. anıua. Sp.pl. 862.

Icon. Bot. mag. 1056. Mill. ir. 286.

On the banks of the Mississippi. ๑. July. v. v. Flowers large, white, speckled with purple and yellow. The singular shape of its fruit, connected with the beanty of its flowers, makes this annual a desirable plant in all collections.

\section{SCHWALBEA. Gen. $l .1001$.}

americana. 1. S. simplex, pubescens; foliis lanceolatis, racemo terminali, florıbus alternis. - Willd. sp. pl. 3. p. 201.

Icon. Lam. illustr. 520. P'uk. mant. t. 3+8. f. 2. In pine-barrens: New Jersey to Carolina. 4. $\delta$. June, July. v. v. Flowers yellowish-brown. 


\section{RHINANTHUS. Gen.pl.997.}

1. R. corollarum labio superiore emarginato bidentato, lacinia media labii inferioris brevissima. Willd. sp.pl.3. p. 1 s8.

Icon. Schkuhr handl. 169. Fl.dan.951. Engl. lot.657. In fields and meadows: Lower Canada. $\odot$. June, July. $v . v$. Flowers yellow. R. virginicus. Vid. Gerardia \& Pedicularis pallida.

\section{BARTSIA. Gen. pl. 996.}

1. B. foliis alternis linearibus indivisis, superioribus lanceolatis, floralibus subovalibus summitate subdentatis,omnibus 3-nervibus, dentibus calycis acutis.-Willd. $s p$. pl.3.p.186. Mich. fl. amer. 2. p. 17.

Icon. Gmel. fl. sil. 3. t. 42 .

In Canada and Labrador. On the White-liills of New Hampshire. Prof. Peck. 4. July. v. s. in Herb. Lambert. Flowers pale yellow; the floral leaves purple.

2. B. foliis alternis prælongo-linearibus, floralibus ovatis longissime acuminatis 3-nervibus, omnibus indivisis, floribus bracteis brevioribus, dentibus calycis acutis.

On the north-west coast: Unalashka. 2. v. s. in Herb. Lamlert.

3. B. hirsutissima; foliis alternis linearibus inciso-pinnatifidis : laciniis filiformibus, bracteis membranaceis oblongis obtusis basi utrinque hastato-unidentatis floribus longioribus, calycibus brevibus pilosis, dentibus subulatis.

On the banks of Clarck's river. M. Lewis. 4. July. v. s. in Herl. Lewis. About a foot high; flowers deep yellow; floral leaves tinged with purple.

4. B. foliis alternis linearibus inciso-pinnatifidis, laciniis linearibus, bracteis dilatatis plerumque trifidis floribus longioribus, dentibus calycis rotundato-obtusis.Willd. sp.pl. 3.p. 185.

Icon. Pluk. alm.t. 102.f.5. Moris. hist. 3. s. 11.t.13. $f .28$.

$\alpha$. B. bracteis coccineis.

B.B. bracteis lutescentibus. Rarior.

In wet meadows : Canada to Florida. $\delta$. 24. June, July. $v . v$. Flowers yellow, involved in scarlet floral leaves, which give this plant a very elegant appearance.

acuminaia.

tenuifolia.

coccinea.

coccinea. pallens. 
alpina.

Gymnandra.

6. B. folits suboppositis ovatis crenatis, binis radicalibus petiolatis, spica oblonga, verticillis bracteatis coarctatis. -Willd. sp. pl.3.p. 186.

Gymnandra torealis. Pall.itin.3.t. A.f. 1 .

Lagotis glauca. Gart. act. petrop. 14. t. 18.

On the mouth of the river Columbia. MI. Lewis. In Unalashka. Herb. Pallas. 4. v. s. in Herb. Lewis. nec non Lambert. About a span high; flowers pale blue. This singular plant grows on the most unfertıle rocks, exposed to the most rigorous cold winds, in places where vegetation seems entirely to cease.

\section{EUPHRASIA. Gen.pl.g93.}

officinalis.

latifolia.

lineare.

1. E. foliis ovatis obtuse-dentatis, laciniis labii corollæ inferioris emarginatis. Willd.sp.pl.3.p. 193.

Icon. Fl. dan. 1037. Engl. lot. 1416. Salbl. hort. 3 . t. 9 .

In Canada. Michaux. $\odot$. July-Sept. v.s. Flowers white, with purple veins.

2. E. foliis ovatis dentato-palmatis, floribus spicatis, corollis tubulosis, laciniis labii inferioris obtusis. Willd. sp. pl. 3. p. 192.

Icon. Salb. hort. 3.t. 7. Moris. hist.3. s. 11. t. 24. f. 8. In Labrador. Colmaster. $\odot$. July. v. s. in Herb. Dickson. Flowers smaller, pale purple.

\section{MELAMPYRUM. Gen.pl.999.}

M. gracile; foliis inferioribus linearibus integris, floralibus lanceolatis postice dentatis, floribus axillaribus distinctis. - Lam. encycl. 4. p. 23.

M. americanum. Mich. fl. amer. 2.p. 16.

In shady woods, particularly on the mountains : Canada to Carolina. ๑. July, Aug. v. v. Flowers yellow. 


\section{OBOLARIA. Gen.pl. 1044.}

1. O. caule simplici, foliis oblongis truncatis carnosis subtus purpureis, floribus axillaribus solitaris sessilibus.Willd. sp.pl. 3. p. $3+6$.

Icon. Pluk alm. t. 209. f. 6. Moris. hist.3. s. 12. t.16. f. 23 .

In shady rocky places: Pensylvania to Virginia; rare. Not above thre-inches high; flowers pale red, in a spike, supported by purple bracteas.

\section{OROBANCHE. Gon. pl. 1045.}

1. O. caule ramoso, floribus alternis distan+ibus, corollis deciduis 4 dentatis. - Willd. sp pl. $3 . p .351$.

Icon. Moris. hist.3. s. 12 t. $16 \mathrm{f}$. 9 .

Parasitic on the roots of beech-trees : Canata to Georgia. 4. July-Sept. $v . v$. Flowers small, purple. This plant is known by the name of Cancer-root, beingr tbought to be a never-failing remedy in cancerous ulcers.

2. O. caule simplicissimo squamis ovali-lanceolatis imbrica-

americana. tis obtecto, spica terminali glabra, coinlis recurvatis, staminibus exertis,-IVilld. sp pi. 3. \%. 351.

Parasitic on the ronts of trees: Pensyly to Carclina. 4. July. v. v. About a span high, of a brownishyellow culour.

3. O. scapis nudis unifloris, calyce ebracteato, corolla recurvata.-Willd.sp. pl. 3. p. 352.

Icon. Pluk. mant. t. 348 . f. 3 .

Parasitic on the roots of different plonts and shrubs: $\mathrm{Ca}$ nada to Virginia. 4. June, Juiy. v. v. Not above two or three inches high, of a $\tan$ colour; flowers pale purple.

virginiana.

virginica.

americana.

uniforc. 


\section{TETRADYNAMIA.}

\section{SILICULOSA.}

* Silicula integra.

520. DRABA. Silicula integra, ovali-oblonga, valvis planiusculis dissepimento parallelis.

521. MYAGRUM. Silicula suberosa, evalvis, loculis fertilibus atque spuriis, sibi mutuo superimpositis. Stylus persistens.

522. CAKILE. Silicula lanceolata, subtetragona, medio utringue dente instructa, biarticulata, ad articulos secedens : articulis monospermis, evalvibus.

*** Silicula apice emarginata.

523. ALYSSUM. Filamenta quædam introrsum denticulo notgata. Silicula en arginata, pilerumque pilosa.

524. CORONOPUS. Silicula reniformis, compressa, corrugata, loculis evalvibus nonospermis

525. LEPIDIUM. Silicula emarginata, cordata, polysperma : valvulis carinatis dissepimento contrariis.

526. THLASPI. Silicula emarginata, obcordata, polysperma : valvulis navicularibus, marginato-carinatis.

\section{SILIQUOSA.}

* Calyx clausus, foliolis longitudinaliter conniventilus.

527. ERYSIMUM. Siliqua columnaris, tetraëdra.

528. CHEIRANTHUS. Silicula compressa. Stigma bilobum. Germen utrinque denticulo glandulato.

529. HESPFRIS. Petala oblique flexa. Siliqua stricta. Stigma basi bifurca apice connivente. Glandula intra stamina breviora.

530. ARABIS. Siliquce compressæ. Glandula nectari- 
feræ 4. singula intra calycis foliola, squamæ instar reflexæ.

531. TURRITIS. Siliqua longissima, angulata, striata. Cal. connivens, erectus. Petala erecta.

532. BRASSICA. Cal. erectus, connivens. Dissepimentum prominens. Sem. globosa. Glandula inter stamina breviora et calycem. Siliqua teres, rostrata.

533. DENTARIA. Siliqua elastice dissiliens, valvulis re. volutis. Dissepimentum subfungosum. Stigma emarginatum. Cal. connivens.

** Calyx hians, foliolis superne distantibus.

534. CARDAMINE. Siliqua elastice dissiliens, valvulis revolutis. Sligma integrum.

535. SISYMBRIUM. Siliqua rostro brevi tereti dehiscens, valvulis rectiusculis. Corolla patens.

536. CLEOME. Glandula nectariferæ 3. ad singulum sinum calycis singulæ, excepto intimo. Petala omnia adscendentia. Germen stipitatum. Siliqua 1-locularis, 2-valvis.

\section{SILICULOSA.}

520. DRABA. Gen.pl. 10;6.

1. D. scapn nudo, foliis oblongis acutis subscrratis hirtis, verna, petalis bifidis, stigmate sessili.-Willd. $s p . p l .3$. p. 426.

Icon. Fl. dan. 983. Engl. lot. 586 .

In cultivated grounds and old fields: Canada to Virginia. $\odot$. March-May. v. $v$. All the species of this genus are small plants with white flowers.

2. D. scapo nudo, foliis ovalibus acutis hirsutissimis, siliculis longo-linearibus glabris approximatis.-Niich. $f l$. amer. 2.p. 2 S.

D. caroliniana. Walt. fl. car. 174.

In sandy fields: Virginia and Carolina, and on the banks of the Missouri. $\odot$. April-June. v. v.

3. D. scapo subunifolio adscendente, foliis lanceolatis intehispidula. gerrimis subtomentosis : pilis stellatis, petalis retusis. -Willd.st.pl. 3.p. 427 .

nivalis. 
Icon. Fl. dan. 142. Liljeblad nov. act. ups. 6. t. 2. f. 2. In Labrador. Colmaster. $\odot$. May fv. s. in Hert. Dickson.

slatella.

incana.

aralisans.

argentcum.

mariima.

1. C. foliis pinnatis, pinnis linearibus subdentatis. sp.pl. 3.p.416.

Bunias Cakile. Sp. pl. 936.

Icon. Engl. lot. 231.

On the sea-coast: Canada to Virginia. ๑. July, Aug. $v$. $v$. Flowers purple.

\section{ALYSSUM. Gen. pl. 1081.}

luperioreun. 1. A. canibus herbaceis, foliis incanis dentatis, staminibus 4. bifurcatis. Willd. sp.pl.3.p. 463. Icon. Krasthen. act. petr. 1747, t. 15. $f .1$. On the norih-west coast. $\frac{1}{\circ}$. 


\section{CORONOPUS. Gart. sem.t. 142.}

1. C. siliculis integris cristato-muricatis, stylo porrecto, coRuellii. rymbis paucitoris. Smith fl. brit. 2. p.600.

Cochlearia Coronopus. Willd. sp. pl. 3. p. 450.

Jcon. Fl. dan. 202. Engl. bot. 166 io.

Cn road-sides: Virginia and Carolina. $\odot$. June-Aug. $v$. $v$. Flowers very small, white.

2. C. siliculis emarginatis didymis reticulato-rugosis, stylo obsoleto, corymbis multifloris. Smith, fl. lrit.2. p.6g1.

dìlyma.

Cocblearia humifusa. Mich. fl. amer. 2 p. 27.

I.epidium didymum. Willd. sp. pl.3.p. 439 .

Lepidium anglicum. Huds. angl. 250.

Biscutella apetala. Walí.fl. car. 174 .

In cultivated grounds of Virginia and Carolina. $\odot$. June -Aug. v. $v$. Smaller than the foregoing epecies; both have pinnated leaves.

\section{LEPIDIUM. Gen. $p l .10 \% 7$.}

1. L. foliis radicalibus pinnatifidis, caulinis lineari-lanceolatis subinciso-serratis, floribus 4 -petalis diandris, siliculis virginicum. lentiformibus.-IVilld.sp.pl.3. p.440.

Icon. Sloan. jam. 1. t. 123. f. 3. Moris. hist. 2. s. 3. t. $21 . f .2$.

In dry fields and orchards: New York to Carolina. $\delta$. June-Aug. v. $v$. About a foot high; flowers not conspicuous.

\section{THLASPI. Gen. pl. 1078.}

1. T. siliculis orbiculatis compressis levibus, foliis oblongis

arvense. dentatis glabris.-Willd. $s p . p l .3 . p .4+2$.

Icon. Fl. dar. 793. Engl. lot. 1659 .

In stony fields: New York and Pensylvania; rare. $\odot$. June, July. $v . v$.

2. T. hirsutum, siliculis deltoideo-obcordatis, foliis radica- Bursa pastolibus pinnatifidis. - Willd. sp. pl. 3. p. 447.

Icon. Engl. lot. 1485. Schkuhr handl. 180. ris.

A common weed, every where to be found in cultivated grounds. $\odot$. April-Sept. v. $v$. 


\section{II. $S I L I Q U O S A$. \\ 527. ERYSIMUM. Gen. pl. 1090.}

officinale. 1. E. siliquis spicæ adpressis, foliis uncinatis. Willd. sp. pl. 3. p. 509 .

Icon. Fl. dan. 560. Schkuhr handb. 183.

On road sides, frequent : Canada to Carolina. $\odot$.June, July. v. v. Flowers small, yellow.

cheiranthoides.

2. E. siliquis erectis, pedicellis fructiferis patentibus, foliis lanceolatis subintegerrimis. - Willd. sp. pl.3. p. 511. Icon. Fl. dan. 731 E 923. Engl. bot. 942. Jacq. Al. austr. 23.

In old fields and on road sides: Virginia; rare. $\odot$. June, July. $v . v$. Flowers yellow.

lanceolatum. 3. E. foliis lanceolatis inferioribus dentatis, unguibus calyce longioribus, laminis orbiculato-obovatis, stigmate sessili. Ait. kew. ed.2.t. 4. p. 116.

Cheirantbus erysinoides. Willd.sp.pl. 3.p. 514.

Icon. Jacq. Al. austr. 74 .

On the banks of the Missouri. $\delta$. June. $v . s$.

\section{CheIRANTHUS, Gen. pl. 1091.}

Pallasii. 1. C. caule simplici tereti glabriusculo, foliis glabris lanceolato-linearibus attenuatis repando-dentatis.

On the north-west coast. Pallas. Jo. July. v. s. in Herl. Lamlert. Hlowers dark red, the size of C. Cheiri.

\section{HESPERIS. Gen. pl. 1093.}

pinnatifida.

1. H. foliis argute serratis: superioribus lanceolatis, inferioribus inferne pinnatifidis, siliquis brevi-pedunculatis breviusculis. MTich. fl. amer. 2.p.31.

In shady wocds: Kentucky and Tennassee. $\delta$. June. $v . v$.

\section{ARABIS. Gen.pl. 1049.}

alpina.

1. A. foliis oblongo-lanceolatis amplexicaulibus acute dentatis. Willd. sp.pl.3.p. 534 .

Icon. Bot.mag. 226. Fl. dan. 62.

I1 Labrador. Colnaster. 24. May, June. v. s. in Herb. Dickson. Flowers, as all the following, white. 
2. A. foliis radicalibus oblongis petiolatis, caulinis lanceothaliana. latis sessilibus, caule erecto basi hirto, petalis calyce duplo longioribus. IVilld. sp. pl.3.p. 535.

Icon. Schkuhr handl. 185. Curt. fl. lond. 2. t. 49.

In dry sandy fields and on old walls: New Eiglind to Virginia. ๑. April-July. $v . v$.

3. A. foliis subrotundis integerrimis hirsutis, surculis reptantibus. Willd. sp.pl.3. p. 536.

Icon. Pluk. alm.t.51.f.5.

In sandy fields : Pensylvania to Virginia. 24. June, July. $v . v$.

4. A. foliis glabris, radicalibus lyratis, caulinis linearibus. Willd.sp. pl. 3.p. 538.

In fields and on dry hills: Canada to Pensylvania. $\bigcirc$. March-May. v. $v$.

5. A. foliis dentatis obtusis hispidis, radicalibus sublyratis, caulibus hispidis, petalis erectis.-Wiill. sp. $p l$. 3. p. 539 .

A. lispida. Ait. kew. 2.p. 400.

Icon. Engl. bot. 614.

In Labrador. Colmaster. 24. May. v. s. in Herb. Dickson.

6. A. foliis lanceolatis utrinque angustatis remote denfatis hastato-sessilibus, siliquis pendulis ancipitibus falcatis.-Mich. Jl. amer. 2. p. 31.

A. canadensis. Wilid. sp. pl.3.p.540.

Turritis foliis lanceolatis dentatis, radicalibus maximis, siliquis compressis falcatis. Gron. fl. virg. 1.p.77.

İcon. Pluk. alm. t. $86 \mathrm{f}$. 8 .

In rocky shady situations: Canada to Virginia. 24 . May, June. v. v. ; v. s. in Herb. Gronov. From two to five feet high.

7. A. foliis glabris rhomboideis repando-obsolete-dentatis, infimis longe petiolatis, radice tuberosa.-Pers. syn. 2.

reptans.

lurata.

stricta. p. 204

A. bulbosa. Muhlb. in list.

A. amara. Herb. Banks.

A. foliis ovatis denticulatis glabris. Gronov virg. 99 .

On the borders of rivulets and springs. 24. MarchMay. $v . v$. This is one of the early spring flowers; the taste resembling spring cresses. It would be desirable to have it introduced into the gardens for that purpose, as it will grow in any soil. 


\section{TURRITIS. Gen.pl.jogj.}

lavigala. 1. Г. foliis glabris, radicalibus obovatis serratis, caulinis lancenlato-linearibus integerrimis amplexicaulibus. Willd. sp.pl.3.p. 543.

On rocks: Pensylvania to Virginia; rare. $\delta$. May, June. $v \cdot v$. Very smooth and glaucous, about a foot high.

orcuia.

2. T. pubescens; folis radicalibus petiolatis ovatis dentatis obtusis, caulinis amplexicaul:bus ublongis serratis acutis.

On rocks: Pensylvania to Virginia. $\delta$. May, June. Resembles T. hirsula.

\section{BRASSICA. Gen. pl. 1096.}

Napus.

Rapa.

1. B. radice caulescente fusiformi, foliis lævibus, superioribus curdato-lanceolatis amplexicaulibus, inferioribus lyratis dentatis. IVilld. sp.pl. 3.p. 547 .

Icon. Engl. lol. 2140.

Rape frequently is found wild, but is of European origin. ठ. May, June. v. $v$.

2. B. radice caulescente orbiculari depressa carnosa, foliis radicalibus ly ratis scabris, caulinis integerrimis lævibus. IVilld. sp. pl. 3. p. 5-s.

Icon. Enst. lint. 2176.

Turnips ille likewise apparently indigenons.

\section{DENTARIA. Gen.pl. 10s7.}

luciniuta, I. D. foliis ternis ternatis, foliolis tripartitis lineari-oblongis incisis dentatis, radicis tuberibus moniliformibus.Willd. sp. pl.3. p. 479 .

D. concatenata. Mich. fl. amer. 2. p. 30.

In shady mountainous situations: New England to $\mathrm{Ca}$ rolini. 4. May, June. v. v. Flowers large, pale purple.

diphylla.

2. D. caulibus approximate diphyllis, foliolis ternis ovatooblongis inequaliter inciso-dentatis, radice dertata.Mich.fl. amer. 2.p. 20.

Icon. Bot. mag. 1465.

In shady beech-woods, on high mountains: Pensylvania to Carolina. 24. May, June. v. v. Flowers pale red, with at tinge of yellow. The roots of this plant 
are of a pungent mustarl-like taste, and are used by the natives instead of mustard; in the mountains it is generally known by the name of Pepper-root. The figure in the lotanical Magazne is taken from an in. dividual plant, in which the radical tear is bitobaced, which is not always the case.

3. D. caule distanter diphyllo, foliis sessitibus ternaits, fotenella liolis lineari-ellipticis integris, petalis cunentis.

On the banks of the Colunbia. 24. April. $v$, s. in H.rb. Lewis. Very slender; leares small; fluwers purple.

\section{CARDAMINE. Gen.pl. 1098.}

1. C. foliis simplicibus suborbicnlatis integriusculis, cauli- rotundifolia. bus simpliciusculis dejiliter procumbantibus. Mich. $f$. amer. $2 . p .30$.

On rocks, in the rivulets of the ligh mountains of Virginia and Carolina. 2. May, Jume. $v v$. The flowers of all the following species are white and small.

2. C. caule nudo, foliis radicalibus lanceolatis inciso-dentatis glabris. siliquis turgidis subarticulatis.

On the north-west coast. Nelson. 2\%. v. s. in Herb. Banks. A doubtful species.

3. C. parvula ; caulibus decumbentibus, foliis radicalibus spathulatis pubescentibus, caulinis lineari.cuneatis integris dentatisque, siliquis divaricato-Jaxis.-Mich. $f$. amer. 2. p. 29.

On high mountains of Carolina. Michanx. + .

4. C. pusilla, acaulis; foliis obtuse lyrato-pinnatifidis, pedunculis radicalibus unitoris. Wich. fl. amer. 2. p. 29.

ariculata.

On rocks near Knoxville, Kentucky. Michaux. +.

5. C. pusilla, erecta, ramosa; foliis omnibus sublyratopinnatifidis, siliquis brevibus linearibus acuminatis teretibus, brevissime pedicellatis. Hich. fl. anier. 2. p. 29.

In overflowed places: New England to New Jersey. 4. June, July. v. v.

6. C. glabra, erecta; foliis pinnatis, foliolis lanceolatis subauriculatis, siliquis longis stricte erectis.- $W$ illd. sp. pl. 3. p. 488.

Icon. Pluk. alm. t. $101 . f .4$. Petiv. gaz. t. 105.f. 18. In low meadows: Canlata to Carolins. 24 . May, June. v. $v$. 
pensylvanica. 7. C. glabra, ramosa; foliis pinnatis, foliolis subrotundooblongis obtusis angulato-dentatis, siliquis angustis erectis.-Willd. $s p . p l .3$. . .486.

In low meadows : New York to Pensylvania. 24.June. v. $v$.

pratensis. 8. C. glabra, erecta, simplex ; foliis pinnatis, foliolis radicalibus subrotundis dentatis, caulinis lanceolatis subintegris, racemis subcorymbosis.-Willd. sp. $p l .3$. p. 487 .

Icon. Fl. dan. 1039. Engl. lot. 776.

In meadows: Hudson's Bay. 4. May. v. s. in Herl. Banks. Flowers large, reddish purple.

multifida. 9. C. pubescens, ramosa; foliis interrupte pinnatis, pinnis bipinnatitidis, laciniis rotundatis incisis, siliquis brevibus.-Herb. Banks.

In Flurida. Bartram. 24. v. s. in Herb. Eanks.

\section{SISYMBRIUM. Gen. pl. 1059.}

Nasturtium. 1. S. siliquis declinatis brevibus, foliis pinnatis, foliolis subrotundis repando-pauci-dentatis. - Willd. sp. pl. 3. p. 489 .

Icon. Fl. dan. 690. Schkuhr handl. 187.

In rivulets and springs : New England to Virginia. 4 . June, July. $v . v$. IVater-Cress is found in most countries; I observed it in abundance in the rivulets on the high mountains of the island of Dominica.

palustre.

2. S. siliquis declinatis oblongo-ovatis, foliis pinnatifidis serratis, petalis calyce brevioribus. Willd.sp.pl. 3. p. 490 .

S. terrestre. Sinith fl. brit. 2 p. po1.

Icon. Fl. clan. 409. Schkuhr handl. 187.

In inundated and low gromuds: Canada to Carolina. $\odot$. July, Aug. $v . v$. Flowers yellow.

amphilium. 3. S. siliquis declinatis oblongo-ovatis, foliis oblongo-lanceolatis pinnatifidisve serratis, petalis calyce longioribus. Willd. sp.pl. 3.p. 491 .

Icon Fl.dan. 984.

In ponds and ditches: Pensylvania to Virginia. 24. June, Aug. $v . v$. Flowers yellow.

Sophia. 4. S. foliis pinnato-deconıpositis subpilosis, petalis calyce minoribus. Willd. sp. pl. 3. p. 500.

Icon. Fl. dan. 528. Engl. bot. 963.

On road sides: Virginia; rare. ๑. July, Aug. v. v. Flowers very small, pale yellow. 
536. CLEOME. Gen. pl. 1099.

1. C. floribus gynandris, foliis quinatis, caule inermi. pentaphylla. Willd. sp. pl. 3. p. 564 .

Icon. Jacq. hort. vind. 24. Rheed. mal.9. t. 24.

In cultivated grounds: Pensylvania and Virginia; rare. $\odot$. July. $v, v$. Flowers pale red, of a singular structure.

2. C. glabra; floribus hexandris, foliis ternatis, foliolis serrulata. lanceolatis tenuissime serrulatis, racemo elongato, bracteis linearibus.

On the banks of the Missouri. ๑. Aug. v. s. in Herl. Lewis. Flowers pale purple or white.

3. C. glabrum; floribus dodecandris, foliis ternatis ellipticis, dodecandra. floriuus axillaribus solitariis.-Willd. sp. pl. 3. p. 566 . Icon Sloan. hist, 1. t. 124.f. 1.

On the banks of the Mississippi. $\odot$. July. v. v. Flowers purple. 


\section{MONADELPHIA.}

\section{TRIANDRIA.}

537. PHYLLANTHUS. Cal. 6-partitus, campanulatus, Cor. o. Styli 3. bifidi. Caps. 3-locularis. Sem. solitaria. Monoicus.

538. MELOTHRiA. Cal.5-dentatus. Cor. campanulata. Stigm. 3. Bacca 3-locularis, polysperna.

539. MOMORDICA. Cal. 5-fidus. Cor. 5-partita. Styl. 3-fidus. Pefo sicca elastice dissiliens. Sem. compressa. Mionoica.

540. SICYOS. Cal. 5-dentatus. Cor. 5-partita. Styl. 3-fidus. Pepo monosperma. Monoica.

\section{PENTANDRIA.}

541. PASSIFlORA. Cal. 5-partitus. Pet. 5. calyci inserta. Neitar. corona filamentosa. Styli 3. Pepo pedicellata.

542. IRESINE. Cal. 2-phyllus. Pet.5. Nectar.5-6-7. Stigm. 2. sessilia. Caps. seminibus tomentosis. Dioica.

543. ILLECERRUM. Cal.5-phyllus, cartilagineus. Cor.o. Squamula 5. basi in tubum connatæ. Stigma 2-fi. dum. Caps. 1 -sperma, calyce tecta.

544. GALAX. Cal. 5-partitus. Pet. 5. imo staminum affixa. Urceolus 10-fidus, laciniis 5. alternis brevioribus, antheriferis. Stigm. 3-lobum. Caps. 3-locularis, 3-valvis, polysperma.

545. LOBELIA. Cal.5-fidus. Cor. r-petala, irregularis, sæpius fissa. Caps. infera, 2-3-iocularis. 


\section{DECANDRIA.}

546. GERANIUM. Cal.5-phyllus. Pet. 5. Stam. 10. Stigm. 5. Arilli 5. monospermi, aristati.

\section{POLYANDRIA.}

547. HALESIA. Cal. 4-dentatus, superus, Cor. 4-fida. Stam. 8-12. Nux 4-angularis, 2-sperma.

548. STYRAX. Cal. subinteger, inferus. Cor. infundibuliformis, 5-7-partita. Stam. 8-16. Drufa 12-sperma, coriacea.

549. HOPEA. Cal. 5-fidus, superus. Cor. 5-petala. Stam. multa, connata in 5. corpora. Styl. 1. Drupa nuce 3-loculari.

550. GORDONIA. Cal. 5-phyllus. Pet. 5. basi connata. Slyl. 5-gonus, stigmate 5-fido. Caps. 5-locularis. Recept. centrale, columnare. Sem. bina, ala foliacea. 551. STEWARTIA. Cal. 5-partitus. Pet. 5. Styl. 5. connati s. liberi. Stigm. capitatum, sub-5-lobum. Caps. 5-locularis, 5-valvis, valvulis medio septiferis, loculis 1-2-spermis. Sem. 1-2. ossea.

552. SIDA. Cal. simplex, angulatus, Styl. multipartitus. Caps, plures, 1-spermæ.

553. CRISTARIA. Cal. simplex, 5-fidus. Pet.5. unguiculata. Styli plures. Fructus orbiculato-depressus, pellicula tectus, dehiscens in Arillos bialatos.

554. MALVA. Cal. duplex : exterior 3-phyllus. Pet. 5. Caps. plurimæ, evalves, 1 -spermæ.

555. MALOPE. Cal. duplex : exterior 3-phyllus. Caps. absque ordine glomeratæ, monospernæ.

556. HIBISCUS. Cal. duplex : exterior polyphyllus. Pet.5. Caps. 5-locularis, polysperma.

I. TRIANDRIA.

537. PHYLLANTHUS, Gen. pl. 1412.

1. P. foliis obovatis obtusiusculis, floribus geminis axillaribus pedicellatis, caule erecto ramoso tereti. Willd. sp. olovalus. pl. 4.p. 574 . 
P. carolinensis. Walt. fl, car. 228. Mich. fl, amer. 2. p. 209 .

In gravelly soil, on the banks of rivers: Pensylvania to Georgia. $\odot$. June, July. $v . v$. About a span or more high; the branches grow regularly in two rows.

538. MELOTHRIA. Gen. $p l .68$.

pendula.

1. M. foliis subreniformibus lobato-angulosis : lobo impari cæteris æquali, bacca cylindraceo-ovata. $M i h . f l$. amer. 2.p.217. Willd. sp.pl.1.p.189.

Icon. Pluk. olm.t. 85. $f 5$.

In sandy, wet places, pa:ticularly on the islands of large rivers: Virginia to Georgia. $\odot$. June. 1.v. Flowers small, yeilow. Fruit the size of a pea, black.

\section{MOMORDICA. Gen. pl. 1477.}

echinata. 1. M. pomis tetraspermis subrotundis setoso-echinatis, foliis coldatis 5-lobo-angulatis acuminatis integerrimis glabris. Willd. sp. pl. 4. p. 605 .

Sicyos lobata. Mich. fl. amer. 2. p. $21 \%$.

In the western parts of the United States: On the banks of the Ohin and Mississippi. $\odot$. July. v. v. Fruit the size of a gooseberry.

\section{SICYOS. Gen. pl. 1481.}

angulata. 1. S. foliis angulo obtuso cordatis 5-angularibus denticulatis scabris, fructibus capitatis, hispidis.-Willd. sp.pl. 4 . p. $6 \leq 5$.

Icon. Dill. elth.t 51.f.59. Herm. parad.t. 133.

On the banks of rivers: Canada to Carolina. $\odot$. June, July. $v . v$.

\section{1. $P E N T A N D R I A$.}

541. PASSIELORA. Gen. pl.50g.

lutea.

1. P. foliis cordatis trilobis obtusis glabris, petiolis eglandulosis, pedunculis axillaribus geminis, petalis calyce duplo angustioribus. Willd. sp.pl.3.p.615.

Icon. Cavan. diss. 10. t. 267. Jacy. ic. 3. t. 607 . 
On the banks of rivers, in shady rocky situations : Virginia to Florida. 4. June-Aug. v. $v$. Flowers small, greenish-yellow.

2. P. foliis peltatis profunde trilobis glabris, lobis linearilanceolatis divaricatis, petiolis biglandulosis, pedtunculis solitariis axillaribus, floribus apetalis. Willd. sp. pl.3.p.617.

Icon. Cavan. diss. 10. t. 274. Pluk. alm. t. 210 f. 4.

In Virginia and Georgia. $々$. v. s. Flowers of a middle size.

3. P. foliis trilobis serratis, lobis oblongis aculis, petiolis biglandulosis, involucro triphyllo, foliolis lanceolatis glanduloso-dentatis, filis corunæ corolla longioribus. Will.t. sp.pl.3.p.621.

Icon. Cavan. diss. 10. 293. Hern. mex. t. 8ss. Rol. ic. 193.

On the banks of rivers of Virginia and Carolina. 4 . June-Aug. v. v. Flowers beautiful, blue and variegated.

\section{IRESINE. Gen. pl. 1519 .}

1. I. foliis punctato-scabris, inferioribus lato-ovalibus, siscelusioides. perioribus ovato-lancenlatis, pinicula ramosa conferta, caule sulcato.-Willd.sp. pl. 4. p.765.

In overflowed grounds, on the banks of rivers: Virginia to Florida. $\odot$. July, Aug. v. v. Flowers exceeding small.

\section{ILLECEBRUM. Gen. pl. 407.}

1. I. caulibus repentibus hirsutis, foliis lato-lanceolatis pe- polygonoides. tiolatis, capitulis oroiculatis uudis sessilibus.-Willd. sp.pl. 1. p. 1208.

Gomphrena polygonoides. Sp.pl. 225.

I. Achyrantha. Walt. $f l$. car. 103.

Icon. Sloan. hist. 1. t. 86.f. 2.

On the sea-coast: Virginia to Carolina; plentifully about Charlestown, South Carolina. 4. JuneAug. $v . v$. A low creeping plant, with small flowers, in spiny clusters.

2. I. caulibus repentibus glabris, foliis lato-lanceolatis petiolatis, capitulis orbiculatis pubescentibus. Willd.sp. pl. 1.p. 1203.

Achyranthes ficoidea. Pers. syn. 1. p. 259.

incarnata.

pellata.

incarnata.

.


Icon. Jacq. amer. t. 60. f. 4 .

On the sea-coast: Carolina to Florida. 24. July, Aug. $v . v$. Resembles the former one.

e'ermicula-

tum.

dichotomum.

4. I. caulibus suffruticosis diffusis, foliis linearibus planis acutis margine scabris, cyma dichotoma. -Willd. sp. pl. 1. p. 1196.

In Virginia. $h$. + . I never saw this plant either live ing or in a dried state.

544. GALAX. Gen. pl. 382.

Erythrorhiza. Aich. fl. amer. 2. p.34.

solundifolia. 1. G. glaberrima; foliis orbiculato-reniformibus dentatis, spica longissima.

Galax aphylla. Willd. sp. pl. 1.p. 1146.

Blandfordia cordata. Bot. rep. 343.

Solanandra cordifolia. Vent. malm. 69 .

Erythrorhiza rotundifolia. Mich. Al. amer. 2. p. 36.

Icon. Mich. Al. amer. 2. t.36. Vent. l. c. Bot. rep.343.

On the side of shady hills, near rivulets, in the high mountains of Virginia and Carolina. 2. May, June. $v \cdot v$. Flowers white, in long and close spikes. In the Virginia mountains this plint is known by the name of Carpenter's-leaf, being used in healing all kinds of wounds and cuts.

\section{LOBELLA. Gen. pl. 1363.}

Dortmanna. 1. L. foliis radicalibus linearibus recurvis fistulosis bilocularibus integerrimis, scapo simplici subnudo racemoso, floribus remotis pendulis._-Willd. sp.pl. 1. p. 938 .

Icon. Fl. dan. 39. Engl. bot. 140.

On Hudson's Bay. Michaux. 24. July, Aug. थ. s. Flowers light blue.

Kalmii. 2. L. tenuis, erecta, simpliciuscula; foliis radicalibus spa. thulatis, caulinis linearibus tenuissine denticulatis, floribus racemosis alternis remotis pedicellatis. - Willd. sp.pl. 1.p.g39. 
In low sandy fields and meadows : Canada to Caroliua. d. $\odot$. July, Aug. v. v. Flowers small, blue.

3. L. erecta, simplex, subpubescens; foliis oblongis obtusiusculis, radicalibus integerrimis, canlinis superne denticulatis, racemo virgato, bracteis subulatis.Mich. fl. amer. 2. p. 153.

Rapuntium foliis villosis mollibus, \&c. Gron. virg. 135.

L. spicata. Lam. encycl.3. p.587.

L. goodenioides. Willd. hort. berol.30. cum icone.

In shady woods and on grassy hills : New York to Carolina. 4. July-Sept. v. v. About eighteen inches high; flowers pale blue, small.

4. L. erecta, glaberrima; foliis lato-lanceolatis serratis, spica multiflora secunda, calycis lacisiis integerrimis, corollæ laciniis inferioribus ovalibus acutis.-Mich. $f l$. amer. 2. p. 153.

On the mountains of Virginia and Carolina. 24. July, Aug. v. v. Flowers of a beautiful sky-blue. From two to three feet high.

5. L. erecta, subramosa, subpubescens, lucida; foliis lanceolatis glanduloso-serrulatis subcarnosis, floribus ra. cemosis brevi-pedunculatis, calycis laciniis revolutis dentatis.-Walt. Al. car. 218.

L. crassiuscula. Wich. fl. amcr. 2. p. 152.

In pine-swamps: Virginia to Florida. 24. July, Aug. $v$. $v$. From eight inches to a foot high; flowers dark blue.

6. L. erecta, simplicissima, pubescens: foliis oblongo-ovalibus repando-serrulatis, floribus spicatis alternis sub. sessilibus, germinibus hispilis, calycibus ciliatis. Mich. fl. ainer. 2. p. 152.

In the range of mountains, from Virginia to Carolina. 4. July, Ang. $v . v$. From one to two feet high; flowers middle size, sky blue.

7. L. erecta, simplex, hirtella ; foliis ovato-lanceolatis subserratıs, racemo folioso, calycibus hirsutis, sinubus reflexis.-Willd. sp. pl. 1.p. 945 .

Icon. Rol.ic. 136. Jacq. ic. 3.t.597.

In low grounds, on the banks of rivers and near springs : New York to Carolina. 4. July, Aug. v. v. Flowers large, blue. This piant is possessed of great medicinal virtues; on account of which it was introduced into Elurope nearly two humcied years ago.

Claytoniana.

amoena.

glandulosa.

puleru?a.

Siphilitica. 
cardinulis.

8. I. erecta, simplex, pubescens; foliis ovato-lanceolatis acuminatis eroso-denticulatis, racemo subsecundo nultifloro, genitalibus corolla longioribus.-Willd. st. pl. 1. p. g44.

Icon. Lot. mag. 320. Rol. ic. 137. Knorr delic. 2. t. L. 2 .

In swamps and meadows near springs : Canada to Carolina. 24. uly-Sept. v. v. This beautiful plant, with its bright scarlet flowers, rises to the height of from two to fular feet. I have seen a white variety of it.

fulgens.

9. L. erecta, simplex, subpubesrens; foliis elongato-lanceolatis attenuatis subintegerrimis, racemo multifloro, genitalibus longitudine corollæ.-Donn. cutal.

Icon. Bot. rep. 659 .

On the Mississippi. 24. June, July. v. v. in Hortis. This species exceeds in splendour of colour and in size the preceding one.

inflata. 10. L. erecta, ramosa, hirsutissima; foliis ovatis serratis, racemis foliosis, capsulis inflatis.-Willd. sp. pl. 1. p. 946 .

In field; and woods, common: Canada to Carolina. $\odot$. jure-Aug. v. v. Flowers blue, small.

Cliffortiana. 11. L. glabra, superne ramosa; foliis petiolatis ovatis crenato-dentatis, infimis suborbiculatis, racemis laxis, pedunculis elongatis. - W Villd. sp. pl. 1.p. 946.

Icon. Plum. ic. 235. 1.2.

In cld fields: Virginia. $\odot$. June, July. v. v. Flowers very small, purple.

\section{II. $D E C A N D R I A$.}

\section{GERANIUM. Gen.pl. 1118.}

maculatum. 1. G. erectum, retrorsum pubescens; caule dichotomo, folis oppositis 3-5-paititis incisis, sumnis sessilibus, pedunculis elongatis bifloris, petalis obovatis. - IVilld. sp. pl. 3. t. 705 .

Icon. Cavan. diss. 4.t.86.f.2. Dill. ellh.t. 132.f.15g. In shady woods and meadows: Canada to Carolina. 24. May-July. $v$. $v$. Flowers purple, large. This 
species is known in some parts of the mountains by the name of Alum-root, on account of the astritgent taste of its ronts, which are very successfully cimployed in curing the flux amng children, which is a disease very prevalent in those countries.

2. G. diffusum, pubescens; foliis oppositis 5-lobis, lobis carolinianum. trifido-incisis, pednnculis bitloris subfasciculatis, petalis emarginatis longitudine calycis aristati, arillis villosis.-Willd. sp. pl. 3. p. 711.

G. lanuginosum. Jacq. hort. schæent. 2. t. 140.

Icon. Caran. diss. 4. t. 84.f. 1. Ó t. 124. f. 2 . Dill. elth. t. 135.f. 162.

In fields: Virginia to Georgia. of. June, July. v.v. Flowers small, white, with red veins.

3. G. diffusum, pubescens; foliis oppositis 5 -partitis, lobis dissectum. 3-fidis incisis linearibus, pedunculis biflcris elongatis, petalis emarginatis longitudine calycis aristati, arillis pilosis, pilis glandulosis.-Willd. sp. pl. 3. p. 712.

Icon. Cavan. diss. 4. t. 78. f. 2.

In fields: New York. $\odot$. June, July. v. v. Flowers rose-coloured, larger than the foreguing one.

4. G. diffusum, hirsutum ; foliis oppositis teruatis quina- robertianım. tisque trifido-pinnatifidis, pedunculis bifloris, petalis integris calyce aristato duplo longioribus, arillis reticulatis. - Willd. sp. pl.3.p. 714.

Icon. Fl.dan. 69t. Cavan. diss. 4. t. S6. f. 1.

In shady moist places, on rocks : New York to Virziginia; rare. J. June-Aug. v. v. Flower, pale red. It is singular, that the American plant has not that heavy scent the European is so well known by, though its other characters agree exactly.

\section{POLYANDRIA.}

\section{HALESIA. Gen.pl.s14.}

1. H. foliis ovatis acuminatis argute serratis, floribus dodecandris, fructu subæqualiter rhomboideo-tetraptero.IVilld. sp. pl. 2.p. 849 .

Icon. Bot. mag. 910. Cavan. diss. 6. t. 186. Catest. car. 1. t. 64 . 
In shady woods, on the banks of rivers: Carolina. $\zeta$. April, May. $v . v$. A handsome small tree; flowers white, resembling those of Snow-drops, from which it has been called Snow-drop Tree or Silver-lell Tree.

diptera.

parvifura.

2. H. foliis oblongo-ovatis obtuse-acuminatis membranaceis, Horibus octandris, fructu subelliptico, alis alternis majoribus._Willd. sp. pl. 2. p. 849 .

Icon. Cavan diss. 6. t. 187.

In shady forests of Georgia. $h$. April, Mav. v. v. s. fl.; v. s. in Herb. Lyon. Flowers larger than the preceding species.

3. H. fructu inaqualiter subtetraptero clavato floribusque parvulis.-Mich. Al. aner. 2. p. 40.

In Florida near Matanza. Michaux. n. +.

\section{STYRAX. Gen. pl. 753 .}

srandifolium.

pulverulentum.

slatrum.
1. S. foliis lato-obovatis acuminatis subtus tomentosis, racemis multifloris elongatis, pedunculis inferioribus axillaribus solitariis unifloris.-Willd. sp.pl.2. p.622. S. officinale. Walt. fl. car. 140.

S. grandiflorum. Mich. $f$ l. amer. 2. p. 41.

In woods, on the banks of rivers : Virginia to Georgia. h. June-Aug. $v \cdot v$. A fine ornamental shrub, as the two following likewise are; flowers white.

2. S. foliis subsessilibus ovalibus s. obovatis obtusis subtus pulverulento-tomentosis, floribus axillaribus et subterno-terminalibus brevissime pedicellatis. $-M i c h . f$. amer. 2.p. 41.

S. lævigatum. Bot. mag. 921.

In woods of Virginia and Carolina. $\zeta$. June-Aug. v. $v$. Resembles the foregoing one. The figure referred to represents the present species, S. lovigatum or the following species bas to my knowledge not yet been introduced into Europe.

3 . S. foliis ovali-lanceolatis utrinque acutis glabris, pedunculis axillaribus unifloris solitariis binisve. - Cavan. diss. 6. t. 188. f. 1.

S. lævigatum. Willd. sp. pl. 2.p. 624.

S. americanum. Lam. encycl. 1.p. 82.

S. læve. Walt. fl. car. 140.

In the swamps of Virginia and Carolina. hุ. July, Aug. $v . v$. Not above three or four feet high; the number of stamina is from six to ten. 
549. HOPEA. Gen.pl. 1222.

1. H. foliis oblongo-lanceolatis glaucis, floribus axillaribus tirctoria. aggregatis brevissime pedicellatis.-Linn, mant. 105. Symplocos tinctoria. Willd. s;. pl.3. p. $1+30$. Icon. Mich. arb. t.... Catesl. car. 1. p. 54 .

In low woods of Virginia and Carolina. $\zeta$. April, May. $v . v$. A small tree or shrub, variable in size, of which there is a variety with leaves pubescent underneath; flowers yellow, small, very sireet scented. The leaves dye a very fine yellow, and have a sweet taste; from which circumstance it is known by the inlabitants under the name of Sweet-leaf:

\section{GORDONIA. Gen. pl. 1144.}

1. G. foliis lanceolato-oblongis glaberrimis nitidis coriaceis, floribus longe pedunculatis, capsulis conoideis acuminatis.-Willd.sp. pl.3. p. 840 .

Hypericum Lasianthus. Sp. pl. 1101.

Icon. Bot. mag. 568. Mich. arl.t.... Cavan. diss. 6. t. 161. Catesl. car. 1.t.44. Pluk amalin. t. 352. f. 3 .

In cedar-swamps, near the sea-coast: Virginia to Florida. h. Aug-Sept. $v, v$. A beautiful small erergreen tree; flowers white, the size of a rose.

2. G. foliis cbovato-lanceclatis subtus pubescentibus submembranaceis, fioribus subsessilibus, capsulis sphæricis.-Willd. sp.pl. 3.p. 841 .

G. Franklinia. Willd. sp. pl. 3. p. 841 .

Franklinia Alatamaha. Marsh. arb. $4 \mathrm{~s}$.

Lacathea florida. Parad. Lond. 56. cum icone.

Icon. Cavan. diss, t. 102. Mich. arl.t....

On the banks of the Alatamaha, near Fort Barrington, Georgia. h. Aug. Sept. v. v. This elegant tree, whose large white flowers with yellow anthers hide a most agreeable appearance, though a native of a very southern latitude, is able to stand a considerable northern climate.

\section{STUARTIA. Gen. pl. 1142 E 1143.}

1. S. foliis ovatis acutis, floribus axillaribus subbinis, calycibus ovatis obtusis, petalis integris, stylis coalitis.

Lasionthus.

pulesiens.

S. Malachodendron. Willd. sp.pl. 3. p. 840. 
Stewartia virginica. Cavan. diss. 5. t. 159.f. 2 .

Stewartia marilandica. Rot. rep. 397 .

Icon. L'Herit. sirp. 1. t. 73. Catest. car. 3. t. 13. Duhum. a) b. 2. t.78.

In swamps in the lower counties of Virginia and Carolina. $r_{c}$. July-Sept. $v . v$. From five to seven feet high, very ornamental ; Howers large, white. There are a number of varieties, with more or less serrated leaves, more or less pubescent, \&c.

pentagyna.

2. S. foliis ovatis acuminatis, floribus axillaribus solitariis, calycibus lanceolatis calyculatis, petalis undulato-incisis, stylis distinctis.-Willd. sp. pl.3. p. 840.

Malachodendron ovatum. Cavan. diss. 5. t. 158.f. 2.

Icon. Exot. bot. 101. L'Herit. stirp. 1. t.74. J. Miller. ic. 3.

In the mountains of Carolina and Georgia. $\eta_{2}$. Aug. $v . v$. This beautiful shrub, whose large flowers are of a cream colour, deserves a place in the collection of every admirer of ornamental shrubs. It has generally been considered as $a^{*}$ distinct genus; but I follow Dr. Smith's observations in Exotic Bo,any, considering it always unnecessary to split a small genus on slight differences, though the same differences might be sufficient reasons for establishing a distinction where the genus is numerous.

\section{SIDA. Gen. pl.1129.}

spinosa. $\quad$ 1. S. caule patulo, axillis subspinosis, foliis longe petiolatis ovato-lanceolatis obsolete cordatis dentatis, pedunculis solitariis axillaribus, stipulis setaceis pedunculo longioribus, capsulis birostratis:-Willd. sp.pl. 3. p. 736 . Icon. Cavan. diss. 1.t.1.f.9. Pluk. alm.t. 9.f.6. Among rubbish and on road-sides: Pensylvania to Carolina. ๑. July, Aug. v. v. Flowers yellow, small.

hispida.

2. S. hispido-pilosa; foliis lanceolatis serratis, pedunculis solitariis axillaribus longitudine petiolorum, calyce exteriore filiformi.

In sandy plains of Georgia. Lyon. 4. v. s. in Herl. Lyon. Flowers yellow.

rhombifolia. 3. S. foliis oblongo-lanceolatis dentatis basi cuneiformibus integerrimis, pedunculis petiolis multo longioribus, capsulis bicornibus. Willd. sp.pl. 3. p. 740 .

Icon. Cavan. diss. 1.t. 3.f. 12. Dill. elth. $t .172 . f .212$. 
In cultivated grounds and among rubbish : Virginia to Florida. $\odot . দ$. June-Aug. $v . v$. Flowers yel. low, small.

4. S. foliis oblongo-cordatis acuminatis crenatis summis sessilibus, pedunculis solitariis petiolo longioribus fructicrispa. feris deflexis, capsulis inflatis muticis undulato-crispis. Willd. sp.pl. 3.p. $7+7$.

Icon. (avan. diss. 1. t. . . f. 1. Dill. eith.t. 5.f. 5.

On the sea-coast of Carolina. $\odot$. Juiy-Sept. v. v. Flowers white, small.

5. S. foliis subrotundo-cordatis acuminatis dentatis tomentosis, pedunculis solitariis petiolo brevioribus, capsulis biaristatis truncatis. Willd. sp. pl.3.p. 750.

Icon. Schkuhr handl. 190.

In cultivated grounds: Pensylvania to Carolina. ๑. July, Aug. v.v. A tall plant; flowes dark yellow.

6. S. foliis cordatis 5-lobis glabris, lobis oblongis acuminaNapea. tis dentatis, pedunculis multifloris, capsulis muticis acuminatis. Willd.sp.pl.3.p. 766 .

Napæa lævis. Syst.veg. 750.

Napæa hermaphrodita. Sp. pl. 965 .

Icon. Cavan. diss. 5. t. 132. f. 1. Herm. lugdl.t. 23.

In shady rocky places: Pensylvania to Virginia; rare. 4. July-Sept. v. v. From two to four feet bigh; flowers white.

7. S. foliis 7 -lobo-palmatis scabris, lobis lanceolatis incisoAbutilon. dentatis, floribus dioicis corymbosis bracteatis. IVilld.

divica. sp. pl. 3. p. 7000.

Napæa scabra. Syst. veg. 750.

Napæa dioica. Sp. pl. 905.

Icon. Cavan. diss. 5. t.132.f. 2. Elsret.pict. 7 \& 8.

In stony ground, in the upper parts of Virginia. 4. July, Aug. v. v. Flowers white.

8. S. foliis inferioribus triangulo-cordatis incisis, superiorialcaoides. bus palmato-multifidis, corymbo terminali, calycibus hispidis. Mich.fl. amer. 2. p. 44.

In stony fields of Kentucky, Temnassee, \&c. 4. July, Aug. v.s. Resembles in habit Malva Alcea.

553. CRISTARIA. Cavan.ic.5.p. io.

1. C. undique cano-tomentosa et pilis stellatis obsita ; foliis $3-5$-fidis, laciniis incisis acutis, racemis terminalibus, coccinea. caule diffuso. 
Malva coccinea, Fraser, catal.

On the dry prairies and extensive plains of the Missouri. 4. Aug. Sept. v. v.; v.s. in Herb. Lewis. Flowers scarlet.

Caulis tere;, subpedalis, ramosus, ramis diffusis, tomentosis, pilis stellatis distinctis obsitis, uti tota planta. Folia alterna, petiolata, palmato-3-5-partita : laciniis subpinnatifido-incisis, lobis simbugque acutis. Petioli teretes, longitudine folii. Slipulce lineares, erectæ, marcescentes. Flores terminales, racemosi, coccinei, diametro pollicari. Caly $x 5$-fidus, lacinis lar:ceolatis acutis. Petala 5. oblique cuneato-obcordata, subunguiculata, ad ungues fasciculato-villosa, calyce duplo longiora. Filamenta monadelpha, numerosa, in columnam brevem connata, superne libera, patentia. Slyli circirer 10. Fruclus orbiculatus.

The singularly stellated fasciculi of hair, placed on the close tomentum, and its bright scarlet flowers, make this plant particularly interesting.

\section{MALVA. Gen.pl. 1134.}

alutiloides. 1. M. foliis 5 -angulari-lobatis tomentosis, pedunculis sub4-floris bifidis axillaribus, capsulis polyspermis. IVilld. sp.pl. 3.p. 780 .

Icon. Jacq. hort. schonlr. 3. t. 293. Cavan. diss. 2. t. 16. f. 2 .

On the sea.coast of Carolina. 24. June-Aug. v. $v$. Flowers large, purple.

carcliniana. 2. M. foliis 5-Jobis palmatisve inciso-dentatis, pedunculis petiolo longioribus, petalis integris, fructu villoso, caule prostrato. Willd.sp. pl.3. p. 784 .

Icon. Cavan. diss. 2. t. 15. f. 1. Dill. elth. t. 4.f. 4. Schkuhr handl. 192.

In fields: Virginia and Carolina. ๑. July-Sept. $v . v$. Flowers dark red.

rotundifolia. 3. M. caule prostrato, foliis cordato-orbiculatis obsolete 5lobis, pedunculis fructiferis declinatis. Willd.sp.pl.3. p. 786 .

Icon. Fl. dan. 721. Cavan. äss. 2. t.26.f.3. Schkuhr handb. 1.

In cultivated grounds: Pensylvania to Virginia. 24. June -Sept. v. v. Flowers white, small. 
555. MALOPE. Gen. pl. 1136.

1. M. foliis oblongis obtusis integris crenatis supra glabris, pedunculis solitariis axillaribus. Willd. sp. pl. 3 . p. 799.

Icon. Cavan. diss. 2. t.27. f. 1. Salb. hort. 1. t. 50. Rol. ic. 189.

In Carolina. IValter. $\odot .+$. Though I doubt of this plant having been found in America, yet it is worth drawing the attention of the botanist to find out what Walter means by it.

\section{HIBISCUS. Gen. pl. 1139.}

1. H. foliis ovatis acuminatis serratis subtrilobis sub-5-nerMoscheutos vibus subtus incano-tomentosis, pedunculis floriferis, calycibus tomentosis, capsulis glabris. - Willd. sp. pl. 3.p. 806.

H. palustris. Walt. $f$. car. 176 .

Icon. Caran. diss. 3. t.65. f. 1. Bot. mag. 852. sub $H$. palustri.

In swamps and salt-marshes: New York to Carolina; plentifully in the marshes round the Salt-lake, Onondago, New York. 4. Aug.-Oct. v. v. Flowers large, white, with a purple bottom, or sometimes pale purple.

2. H. foliis lato-ovatis obtuse-serratis subtrilobis 3 -nervibus subtus tomentosis, pedunculis axillaribus petiolo longioribus.-Willd. sp. pl.3. p. sos.

Icon. Cavan. diss. 3. t. 65. f. 2.

In swamps and marshes: Canada to Virginia. 24. Aug. -Oct. $v . v$. Flowers large, purple. This plant has been generally confounded with the former, but is very distinct.

3. H. foliis amplis coriaceis triangulato-cordatis trilobis grandiflorus. utrinque eximie tomentosis subtus incanis, capsulis tomentoso-hirsutissimis subtruncatis.-Mich. $f$. amer. 2. p. 46 .

In salt-marshes of Georgia and Florida, and on the banks of the Rississippi. 4. Ang.-Oct. v. v. Flowers very large, Alesh-coloured, with a red bottom; the fructifications yellow.

4. H. foliis ovatis acuminatis obtuse serratis utrinque incapalustris.

malacoides . 
Icon. Wendl. hort. herrenh. 4. t.24. Bartr. ic. ined. in Mus. Banks.

In Carolina. 24. Sept. +. Flowers very large, sulphur-coloured.

esculentus.

5. H. foliis cordatis 5-lobis obtusiusculis dentatis, petiolis flore longioribus, calycibus exterioribus subdecaphyllis deciduis, interioribus longitudinaliter rumpentibus. Willd. sp.pl. 3.p. 827 .

Icon. C'avan. diss. 3, t. 61.f 2. Comm. hort. 1.t. 19.

In cultivated grounds: Virginia and Carolina. $\odot$.June -Sept. $v . v$. Flowers yellow. It is generally cultivated by the name of Olra for the sake of its unripe capsules, which give a fine dish for the table.

virginicus.

6. H. undique tomentosus, asper ; foliis acuminatis inæqualiter dentatis, inferioribus cordatis indivisis, superioribus cordatis oblongis trilobis, pedunculis axillaribus et racemoso-terminalibus, floribus cernuis, pistillis nutantibus. Willd. sp.pl. 3.p. 831 .

H. clypeatis. Walt. $f$. car. 177.

Icon. Jacq. ic. rar. t. 142. Pluk. phyt. t. 6. f.4.

In salt-marshes, on the sea-coast: New Jersey to Carolina. 2 . Aug. Sept. $v$. $v$. Flowers small, rosecoloured.

mililatis. $\quad$ \%. H. glaberrimus; foliis 3-lobo-hastatis acuminatis serratis, corolla tubulato-campanulata, capsulis ovatis acuminatis glabris, seminibus holosericeis.-Willd. sp. pl. 3 . p. 608 .

H. lævis. Scop. del. insul. 3.t. 17.

H. virginicus. Walt. $h$. car. 177.

H. hastatus. Mich. fl. amer. 2. p. 45.

H. riparius. Pers. syn. 2. p. 254 .

Icon. Sint. del. insub.3.t. 17. Cavan, diss.6.t. 198. f. 2 .

On the banks of rivers in Louisiana and the western parts of Pensylvania and Carolina. 24. Aug. Sept. v. v. Flowers purpie, large.

speciosus. $\quad 8 . \mathrm{H}$. glaberrimum; foliis palmato-5-partitis, laciniis lanceolatis acuminatis apice remote serratis, calycibus exterioribus decaphyllis, corolla patula, capsula glabra 5-gono-ovata.-IVilld. sp.pl.3.p. 822.

H. coccineus. Walt. . . car. 177 .

Icon. Bot. mag. 360. Wendl. hort. herrenh. t. 11.

On the banks of rivers of South Carolina and Florida. 4. Aug. Sept. v. v. A most elegant peren- 
nial. When in high perfection, the stem will rise to more than eight feet, and the deep scarlet flowers grow to a larger size than any other Hibiscus I know.

9. H. caule petiolisque inermibus, foliis palmato-digitatis 7 -partitis, laciniis linearibus, pedunculis hispidis, calyce Manihot. exteriore 1-phyllo, interiore hinc lacero, capsula hirsutissima pyramidata.-Willd. sp. pl.3. p. 825.

Icon. Cavan. diss. 3. t.63.f. 2. Dill. elth. t.156.f. 189 . On the banks of the Mississippi. 24. July-Sept. v. $v$. Flowers sulphur-yellow, with a purple bottom, very large when in rich soil.

10. H. caule scabro, foliis asperis basi truncatis circumscriptione subrotundis, superioribus palmatis, lobis superne dilatatis crenatis, floribus subsessilibus, calycibus hispidissimis exteriore furcellato. Mich. Jl. amer. 2.p. 45 .

H. aculeatus. Walt. $f$. car. 177 .

Near the sea-coast, in marshes: Carolina to Florida. 4. July-Sept. v. v. Flowers very handsome and large, bright yellow with a dark purple bottom. 


\section{D I A D ELPH I A.}

\section{PENTANDRIA.}

557. Petalostemum. Pet. 4. staminibus interjecta : utraque in tubum fissum connata. Vexillum nullum, ejis loco quintum petalum. Legum. calyce tectum, 1.spermum.

\section{HEXANDRIA.}

558. CORYDALIS. Cal. diphyllus. Cor. ringens. Filam. 2. membranacea, singula Antheris 3. Caps. siliquosa, polysperma.

559. FUMARIA. Cal. diphyllus. Cor. irregularis, basi calcarata. Filam. 2. singula Antheris 3. Caps. 1locularis, eralvis, 1-sperma.

\section{OCTANDRIA.}

560. POLYGALA. Cal. 5. phyllus : foliolis duobus alæformibus, coloratis. Caps. obcordata, 2-locularis, 2-vaivis.

\section{DECANDRIA.}

* Slamina omnia connexa.

561. Amorpha. Cal. campanulatus, 5-fidus. Cor. vexillum ovatum, concarum. Ala Carinaque nullæ. Legum. 2-spermum, falcatun.

562. ERYTHRINA. Cal. 2-lobatus. Cor, vexillum longissimum, lanceolatum. Legumen torulosum.

563. LUPINUS. Cal. 2-labiatus. Anth. 5. oblongæ, 5. subrotundæ. Legum, coriaceum.

564. CROTALARIA. Cor. vexillum cordatum, magnum, carina acuminata. Filam. connata cum fissura dorsali. Legum. pedicellatum, turgidum. 
* Stigma pulescens. (Nec priorum notæ.)

565. PHASEOLUS, Carina cum Staminilus Styloque spiraliter torta.

566. DOLICHOS. Veruilli basis callis 2. parallelis oblongis, alas subtus comprimentibus.

567. PISUM. Cal. laciniæ foliaceæ æquales. Fexillum plicas 2. protrudens. Slylus compressus, carinatus, supra villosus. Legum. ad suturas nudum.

568. LATHYRUS. Cal. laciniæ superiores 2. breviores. Stylus planus, supra villosus, superne latior.

56y. VICI $\Lambda$. Cal. superne emarginatus, 2-dentatus, inferne dentibus 3 . rectis longis. Vexillum emargina. tum. Stigma latere inferiore transverse barbatum.

** Legumen subliloculare. (Nec priorum.)

570. ASTRAGALUS. Carina obtusa. Legum. biloculare aut subbiloculare, sutura inferiore introflexa.

571. OXYTROPIS. Carina in mucronem superne desinens. Legum. biloculare aut subbiloculare, sutura superiore introflexa.

572. APIOS. Cal. campanulatus, bilabiatus. Carina vexillum reflectens. Appendix : tubulus ex centro disci, denticulatus, vaginans basin stipitis germini. Legumen coriaceum, biloculare, dissepimentc seminibus interceptum.

**** Legumina sulmonosperma. (Nec priorum.)

573. DALEA. Cal. glandulosus, subsemi-5-fidus. Alce et Carina columnæ staminum adnatæ. Vexill. breve. Stam. omnia connata. Legum. 1-spermum, calyce brevius.

574. PsORALEA. Cal. longitudine leguminis. Stam. diadelpha. Legum. 1-spermum, subrostratum, evalve.

575. MELILOTUS. Cal. tubulosus, 5-dentatus. Carina simplex, alis et vexill ' brevior. Legum. calyce longius, rugosun. Flores racemosi.

576. TRIFOLIUM. Legum. calyce tectum, evalve, 24-spermun. Flores subcapitati.

577. LUPINASTER. Cal. campanulatus, 5-dentatus, dentibus setaceis, uno sub carina. Stigma uncinatum. Legum. enode, teres, polyspermum.

578. STYLOSANTHES. Cal. tubulusus, longissimus, coroilifer. Germen sub corolla. Lomentum 1-2-articulatum, hamatum. 
579. GLYCyrRhiZA. Cal. 2-labiatus, basi gibbus. Cor. vexillum alas et carinam includens. Legum. ovatum, compressum, hispidum, 2-4-spermum.

580. LESPEDEZA. Cal. 5-partitus, laciniis subæqualibus. Cor. carina transverse obtusa. Legum. lenticulare, inerme, 1 -spermum.

********i Legumen in articulos secedens. (Nec priorum.)

581. HEDYSARUM. Cal. 5-fidus. Cor. carina transverse obtusa. Lomentum pluri-articulatum : articulis 1-spermis, compressis, utplurimum hispidis.

582. ZORNIA. Cal. campanulatus, 2-labiatus. Vexillum cordatum, revolutum. Anlherce alternæ oblongæ, alternæ globosæ. Lomenlum articulatum, hispidum.

583. ÆSCHYNOMENE. Cal. bilabiatus. Lomentum compressum. sutura altera recta, altera lobata, articulis truncatis, 1-spermis.

584. SESBANIA. Cal. dentibus subæqualibus. Legum. elongatum, subcylindricum, 2-valve.

******* Legumen uniloculare polyspermum. (Nec priorum.)

585. GLYCINE. Cal. bilabiatus: dente labii inferioris longiore. Cor. carina apice vexillum reflectens. Stylus incurvus. Legum. oblongum, compressum.

586. GALACTIA. Cal.4-dentatus, 2-bracteatus. Petala omnia oblonga, vexillo latiore incumbente. Stigm. obtusum. Legum. teres. Sem. subrotunda.

587. CLITORIA. Cal. tubuloso-campanulatus. Cor. resupinata : vexillo maximo, patente, alas obunbrante. Legum. lineare, longissimum, acuminatum.

588. ROBINIA. Cal. 4-fidus, lacinia superiore bipartita. Vexillum reflexo-patens, subrotundum. Legum. gibbum, elongatum.

539. INDIGOFERA. Cal. patens. Cor. carina utrinque calcari subulato patulo. Legum. lineare, parvulum, teres, subquadrangulare.

590. TEPHROSIA. Cal. dentibus subulatis, subæqualibus. Stam. monadelpha. Legum. compressum, subcoriaceum.

591. LOTUS Cal. tubulosus. Ala sursum longitudinaliter conniventes. Filam. cuneiformia. Legum. cylindricum, strictum.

592. MEDICAGO. Carina corollæ a vexillo deflectens. Legum. compressum, cochleatum. 


\section{PENTANDRIA.}

557. PETALOSTEMUM. Mich. f.amer. 2, p. 48.

Dilea. Juss. gen. pl. 392.

1. P. spica cylindrica pedunculata, bracteis fore longior:bus, calycibus glabris, foliis trijugis lanceolatis.- Hich. $j t$. amer. 2. p. 49.

Dalea candida. Willd. sp.pl.3.p. 1337.

Icon. Nich. l. c. t.37.f. 1.

In Tennassee, Illinuis, and on the banks of the Missouri, 4. July, Aug. v. s, in Herb. Lewis. ac. Flowers white.

2. P. spica cyllndrica pedunculata, bracteis subulatis longicarneum. tudine calycis, bracteolis setaceis peristentibus, c.lycibus glabris, fuliolis lanceolatis.-Mich. Jl. amer. 2. p. 49 .

In pine-barrens of Georgia and Florida. 24. July, Aug. v. s. in Hert. Enslen. \&ac.

3. P. spica cylindrica pedunculata, bracteis calycenı subæquantibus, bracteolis spathulatis deciduis, calycibus sericeis, foliis bijugis linearibus.-Mich. fl. amer. 2. p. 50 .

Dalea violacea. Willd.sp.pl.3.p. 1337.

Icon. Mich. l. c. t. 37.f. 2.

In Tennassee, Illinois, and on the banks of the Missouri. 4. July-Sept. v. v. A beautiful platst; the close spikes are of a delicate rose-purple.

4. P. spicis cylindricis pedunculatis terminalibus, bracteis calyce brevioribus, calycibus villosis, fuliis sub-10jugis ellipticis retusis mucronatis.

Dalea alopecuroides, Willid.sp.pl.3.p. 1336.

In Georgia and Florida. 24. July, Aug. v. s, in Herb. Enslen. Flowers pale blue.

5. P. capitulis squamoso-involucratis, pedunculis paniculato- corymlosum. corymbosis, calycibus plumosis, foliolis linearibus muticis.-Mich. Al. amer. 3. p. 50.

Dalea Kubnistera. Willd. sp.pl.3. p. 1337.

Kuhnistera carolinensis. Lam. encycl. 3. p. 371.

Kuhniæ affinis pinnata. Walt.,f. car. 103.

In pine-barrens of Carolina and Georgia. 24. June-

candidum,

violaceum.

alopecuroideum. 
Aug. $v . v$. Flowers white. This singular plant appears, at first sight, to belong to the class Syngenesia, and certainly is the connecting link between that class and the present.

\section{II. $H E X A N D R I A$.}

558. CORYDALIS. Vent. choix de pl. 19 .

Fumaria. Gen.pl. 1154.

* Corollis licalcaratis. Perizomanthi.

Cucullaria. 1. C. scapo nudo, racemo simplici secundo, nectariis divaricatis longitudine corollæ, stylo incluso, radice bulbosa. -Pers.syn. 2. p. 269.

Fumaria Cucullaria. Willd.sp. pl. 3. p. 857.

Icon. Bot.mag. 1127 . Rol. ic. 222. Pluk. alm. t.90. f. 3 .

On the side of shady hills, in rich vegetable mould, among rocks: Canada to Virginia. 2. May. v. v. Flowers white, with a yellow moutb. This singularly constructed flower is known among the inhabitants by the name of Breeches-Aow'er or Yellow-lreeches; and as I consider that all those species with two spurs or nectaries might form, with propriety, a good genus, $I$ have given it the name of Perizomanthus.

formosa.

2. C. scapo nudo, racemo subcomposito nutante multifloro, nectariis brevissimis incurvis, stylo porrecto, laciniis foliorum oblongis inciso-pinnatifidis, radice tuberosa.

Icon. Bot. rep. 393 . Bot. mag. 1335. sub Fumaria.

In Canada, and on the highest peaks of the Virginia and Carolina mountains, in the cliffs of shady rocks. 24 . May-July. $v . v$. Flowers a lively bright red. This elegant perennial deserves a place in every collection. The Canada plant is somewhat different ita aspect from the Virginian, but not sufficiently distinct to make it a species.

tenuifolia. 3. C. scapo nudo, racemo simplici nutante paucifloro, nectariis brevissimis incurvis, stylo longe exerto, foliis te. nuissime laciniatis, radice tuberosa.

On the north-west coast. 4 . June. v. s. in Herl. 
Lambert. specimen Pallasianum. Flowers of nearly the same shape and colour as the foregoing species.

4. C. caule scandente, foliis cirrhosis, racemis axillaribus corymbosis cernuis, coroilis monopetalis basi bigibbis. -Pers. syn. 2. p. 269.

Fumaria fungosa. Willd. sp pl.3.p. 857 .

Fumaria recta. Mich. fl. amer. 2. p. 51.

In moist and shady places, in the beech-woods of Cana$\mathrm{da}$ and Pensylvania. $\delta$. June-Sept. v. v. A delicate twining plant; flowcrs pale red and in great abundance.

\section{* Corollis unicaliaratis.}

5. C. caule ramoso erecto, foliis glaucis, caulinis biternatis, racenis subcorymbosis, bracteis minutis, siliquis li. nearibus pedunculo triplo longioribas.-Psrs. syn. 2. p. 269.

Fumaria sempervirens. Willd. sp. pl. 3.p. s63.

Icon. Bot. mag. 179. Corn. conad. 57.

In the cliffis of rocks, in Canada, and on the Allegany mountains. $\odot . \delta^{\pi}$. June-Aug. v. $v$. Flowers very handsomely variegated wilh yellow, red, and green.

6. C. cande ramoso diffuso, foliis bipinnatis, fuliolis partitis lineari-lanceolatis utrinque acutis, racemis secundis, bracteis lato-lanceolatis subdenticulatıs, siliquis teretibus turgidis pedunculo duplo longioribus.-Wilid. enum. 740 .

On shady rocks: Pensylvania to Virginia. $\odot$. MayJuly. v. v. Flowers bright yellow; the leaves and the size of the flowers resemble those of the preced. ing species.

\section{FUMARIA. Gen.pl. 1154.}

1. F. caule ramoso diffuso, foliis supradecompositis, foliolis officinalis. cuneiformi-lanceolatis incisis. - Wrilid. sp. pl. 3 . p. 867.

Icon. Fl. dan. 940. Engl. bot. 589 .

In cultivated grounds: Pensylvania to Virginia; rare. $\odot$. May-Aug. v. v. Flowers small, red, mixed with green. 


\section{III. $O C T A N D R I A$.}

\section{POLYGALA. Gen.pl. 1154.}

* Cristatce. Floribus appendice penicilliformi.

incarnata. 1. P. caule simpliciusculo erecto, foliis sparsis subulatis, spicis ovali-oblongis, corollis tubo gracili elongato.Willd. sp.pl. 3. p. 871 .

In low sandy fields and on the edge of rivulets : Jersey to Carolina. $\odot$. June, July. v. v. A delicate little plant; flowers of a bright thesh-colour.

rubella.

2. P. pubescens; caule simplici erecto, foliis angusto-lanceolatis acutis, racemo terminali, bracteis subulatis solitariis caducis, alis calycinis nervoso-venosis truncato-rotundatis corolla longioribus.

P. rubella. Willd.sp.pl.3.p. 875?

In woods and on dry shady hills : Pensylvania to Georgia. 24. June, July. $v$. v. Flowers pale red. This species approaches ncar to P.vulgaris. Whether Willdenow's plant is the same or not, I am not able to determine; but I strongly suspect he had but an imperfect specimen, in which the very minute bracteæ had disappeared. If his specimen has come from Dr. Muhlenberg, it certainly is the same plant.

paucifolia.

3. P. pumila, grandiflora; caulibus simplicissimis erectis inferne nudis, foliis ovatis acutis glabris, floribus terminalibus subternis.-Willd. sp. pl. 3. p. 880 .

In sphagnous swamps and bogs: Pensylvania to Virginia; principally on the mountains. 24. May-Aug. $v . v$. Not above three or four inches high; flowers the largest of those mentioned here, about the size of $P$. myrtifolia, of a fine pale red colour.

\section{** Imberbes.}

uniflora. 4. P. pumila; caulibus simplicissimis erectis inferne nudiusculis, foliis paucis lato-ovatis in petiolum angustatis, floribus solitariis sparsis pedicellatis nutantibus. - Mich. fl. amer. 2.p. 53 .

On the banks of lake Ontario. Michaux. 4. +.

Senega. 5. P. caulibus erectis simplicissimis foliosis, foliis alternis lanceolatis, spica terminali filiformi, floribus alternis. Willd. sp. pl.3.p.894. 
Icon. Bot. mag. 1051. Milll. dict. 3. t.5. Amcen. acad. 2. t. 2 .

a.P. foliis lanceolatis, vel ovalibus, spica confertiuscula, floribus albidis subsessilibus.- Mich. fl. amer. 2. p. 53 .

ß.P. glabella vel pubescens; foliis lineari-lanceclatis, spica laxiuscula alterniflora, floribus roseis.-Mich. $f l$. amer. 2. p. 53 .

On the side of hills and in dry woods : $\alpha$. Canada and throughout the Allegany mountains. $\beta$. in Carolina and Georgia. 4 . Jume--Aug. $v, v$. This is the famous Seneca Snake-root, formerly so celebrated for the bite of rattle-snakes; but other more efficacions remedies have supplanted it. Vid. Prenanthes and Liatris.

6. P. caule simplici vel ramoso; foliis radicalibus infimisque albida. rosea. spathulatis, cæeteris lanceolatis, spica cylindraceo capitata confertifora pedunculatid. - Willd. sp. pl. 3. p. 894 .

Icon. Pluk. amalth.t. 43s.f. 6 .

๙. P. caule subvirgatim elatiore.

$\beta$. P. subacatulis, foliis omnibus spathulatis, capitulo majore.

In wet woods and bogs : New Jersey to Florida. $\beta$. in low meadows of Carolina. $\odot$. ठै. July, Aug. v. v. A fine species; flowers of a yolden yellow; the var. $\beta$. does not grow above three or four inches high.

7. P. caule erecto simplicissimo, foliis lineari-lanceolatis obtusiusculis, capitulo terminali globoso-capitato.Willd. sp.pl. 3. p. 895 .

In dry woods : Pensylvania to Carolina. ๑. July, Aug. $v . v$. Flowers greenish-white, with some red. In general babit it resembles $\boldsymbol{P}$. incarnata.

8. P. caule setaceo subaphyllo simplici, summitate subramoso, foliis parvis setaceis sparsis, floribus minutis dense spicatis.-Mich. fl. amer. 2. p. 52.

In Carolina and Georgia. ๑. July, Aug. v. s. in Herb. Lyon.

9. P. caule erecto summitate corymboso-ramoso, foliis alternis linearibus, spicis capitatis, pedunculis squarrosis.-Willd. sp. pl. 3. p. 896.

Icon. Pluk. mant. t. $438 . f .5$.

In woods on the side of hills : New England to Carolina. ๑. July, Aug. v. v. Flowers rose-coloured.

10. P. caule a basi ramoso, foliis alternis ellipticis obtusis basi

viridescens.

lutea.

elatior. nana.

setacea.

sanguinea. attenuatis, spicis terminalibus oblongis, floribus alter-

polygama. 
nis pedunculatis, spicis inferioribus depressis apetalis. - IValt. fl. car. 179 .

In the pine-barrens of Carolina. ๑. July, Aug. v. s. Calyx greenish-white, with pale yellow petals.

vericillata. 11. P. caule erecto ramoso, foliis verticillatis linearibus, spicis setaceis pedunculatis, floribus distincte alternis approximatis. - Willd. sp.pl. 3. p. 897 .

Icon. Pluk, mant. $t$. 435. $f .4$.

On the sides of dry hills and in pine-woods : New York to Carulina. $\odot$. June-Aug. v. v. Flowers very small, whice, or sometimes pale red.

cruciata. $\quad 12$. P. caule erecto ramoso alato-anguloso, foliis quaternis lineari-lanceolatis, capitulis spicatis sessilibus.-Willd. sp. pl. 3. p. s97.

In wet places, on the edge of bogs and rivulets; Canada to Carolina. $\odot$. July-Sept. v. v. Flowers red nuixed with green.

\section{IV. $D E C A N D R I A$.}

\section{AMORPHA. Gen.pl. 1170.}

fruticosu. $\quad$ 1. A. glabra, subarborescens; foliis petiolatis, spicis aggregatis elongatis, calycibus nudiusculis pedicellatis, dentibus 4. obtusis, unico acuminato, leguminibus oligospermis.-Willd.sp.pl. 3.p. 970 .

Icon. Schmidt arl. 30. Schkuhr handl. 197. Hort. cliff. t. 19. Mill. ic. 27. Duham. arb. t. 46.

vulgaris. emarginata. angustifolia.

$\alpha$. A. foliis mucronatis, calycibus glabris.

$\beta$. A. toliis emarginatis, calycibus canis.

$\gamma$. A. foliis lineari-ellipticis basi subacutis.

On the banks of rivers: Carolina and Florida. $\hbar$. June, July. v. v. Var. y.v. s. in Herl. Lewis. A shrub from nine to twelve feet high. Flowers of a very fine blue, in close and long spikes. It is generally known by the name of $W$ ild Indigo. The leaves, as in all the following species, are beset with glands, which are transparent.

microphylla. 2. A. glabriuscula, pumila; foliis brevissime petiolatis utrinque obtnsis, spicis solitariis abbreviatis, calycibus nudiusculis pedicellatis, dentibus omnibus acuminatis, leguminibus monospermis. 
A. nana. Fraser. calal. 1813.

Un the banks of the Missouri. $\eta$. July, Aug. v.s. in Herb. Lewis. From one to two feet high; flowers purple and fragrant. A very elegant little shrub.

3. A. humilis, frutescens; foliis brevissime petiolatis sine mucrone utrinque obtusis glabriusculis, spicis paniculatis elongatis pubescentibus, calycibus subessilibu;, dentibus omnibus acuminatis, - Hilll. sp. pl. 3. p. 970 .

A. herbacea. Walt. fi. car. 179 .

A. pumila. Mich. $f$. amer. 2 . p. 64 .

In sandy dry fields: Carolina and Georgia. 12. June, July. v. v. From two to three feet high; flowers a fine blue, smaller than No. 1 .

4. A. undique cano-tomentosa, humilis ; foliolis approximatis subsessilibus ovato-ellipticis acutis mucronatis, spicis paniculatis cano-tomentosis, calycibus sessilibus, dentibus omnibus acuminatis.

On the banks of the Missouri and Mississippi. 々. July, Ang. v. $v$. Resembles the foregoing one rery much; flowers of a more beautiful blue.

\section{ERYTHRINA. Gen. pl. 1163.}

1. E. pumila; foliis ternatis rhombeis glabris, spicis long!ssimis, caule herbaceo inermi.-Willd. sp. $p l .3$. p. 912 .

Icon. Bol.mag. 877. Treav. ehret. t. 58. Calest. car. 49. Dill. elth. l. go.f. 106.

In sandy woods and fielis: Carolina and Florida. 21. Iune, July. $v . v . \Lambda$ beautiful perennial; flowers scarlet.

\section{LUPINUS. Gen.pl.1176.}

1. L. perennis, repens; caule foliisque glabriusculis, foliis perennis. digitatis: foliolis $(8-9)$ lanceolatis obtusiuscnlis, calycibus alternis inappendiculatis: labio superiore emarginato; inferiore integro.-Willd. sp.pl. 3.p. 1022.

Icon. Bot. mag. 202 . Mill. dict. t. 170. $f .1$.

On dry hills, in gravelly soil: Canada to Florida. 24 . May-July. v. v. Flowers blue, purple, and some. times white.

2. L. perennis; caule foliisque hirsutis, foliis digitatis: nootkatensis.

foliolis $(7-8)$ lanceolatis cbtusis, calycibus verticillatis

pulescens.

canescens.

herlacea.

perennis. 
inappendiculatis: labio superiore emarginato, inferiore integro.-Donn. catal. hort. cantal.

Icon. Bot. mag. 1311 .

On the north-west coast. Menzies. 24. June, July. $v$. s. in Herb. Lambert. This stately perennial approaches near to the foregoing one in its general character, but the flowers are larger and beautifully variegated. In the Herbarium of A. B. Lambert, Esq. is a specimen from Professor Rudolph, of St. Petersburg, collected in Unalashka, under the name of $L$. regius, decidedly the same with the present species, the name of which sufficiently shows the grandeur of this plant in its rative state.

sericeus. $3 . \mathrm{L}$. perennis; caule foliisque sericeo-tomentosis, foliis digitatis : foliolis (7-8) lanceolat is acutis utrinque sericeis, calycibus subverticillatis inappendiculatis: labio superiore inciso; inferiore integro.

On the banks of the Kooskoosky. MI. Lewis. 24. July. $v$. s. in Herl. Lewis. Flowers pale purple, or rosecoloured.

argenteus. 4. L. perennis ; foliis digitatis : foliolis (5-7) lineari-lanceolatis acutis supra glabris subtus argenteo-sericeis, calycibus alternis inappendiculatis: labio superiore obtuso ; inferiore integro.

On the banks of the Kooskonskv. M. Lewis. 4 . June, July. v. s. in Herb. Lambert. Flowers small, cream-coloured.

pusillus. 5. L. biennis, pusillus, undique pilis longis albidis hirsutissimus; foliis digitatis : foliolis (7) lineari-ellipticis supra glabris, calycibus alternis inappendiculatis: labio superiore bipartito; inferiore integro, leguminibus subdispermis.

On the banks of the Missouri. $\delta$. June. v. s. in Herl. Lewis. Flowers small, a fine blue mixed with some red.

villosus. 6. L. perennis, villosissimus; foliis simplicibus oblongis, spicis elongatis, calycibus alternis inappendiculatis: labio superiore bifido; inferiore integro elongato.Mich. fl. amer. 2. p. 56.

L. pilosus. Walt. fl. car. 180 .

In dry sandy fields: Carolina and Florida. 24. JuneAng. $v . v$. A beautiful perennial, but very shy of cultivation; flowers very variable in colour: white, rose red, and purple. 
564. CROTALARIA. Gen.pl. 1172.

1. C. hirsuta, erecta, ramosa ; foliis simplicibus oblongolanceolatis, stipulis lanceolatis acuminatis decurrentibus, racemis oppositifoliis subtrifloris, corollis calyce minoribus.- $l W$ illd. sp. pl. 3.p. 972 .

C. sagittalis $\beta$. oblonga. Mich. fl. amer. 2. p. 55 .

In pine-barrens: Virginia to Georgia. $\odot$. July. v. v. Flowers, as all the following, yellow.

2. C. hirsuta, erecta, ramosa ; foliis simplicibus lineari-lanceolatis, stipulis superioribus decurrentibus brevissime bidentatis, racemis oppositifoliis, corollis calyce minoribus.-Willd. sp. pl.3. p. 973 .

C. sagittalis $\alpha$. linearis. Mich. fl. amer. 2.p. 55 .

In sandy fields : New York to Carolina. $\odot$.June, July. $v, v$.

3. C. hirsuta, diffusa, ramosa ; foliis simplicibus petiolatis subrotundo-ovalibus, stipulis summis vix decurrentibus brevissimis, racemis oppositifoliis elongatis, corollis calycem æquantibus.

C. sagittalis $\gamma$. ovalis. Mich. fl. amer. 2. p. 55 .

Anonymos rotundifolia. Walt. fl. car. 181 .

In pine-barrens of Carolina and Georgia. ๑. June, July. v. s. in Herb. Enslen.

4. C. glabra, erecta, simplex; foliis lanceolato-oblongis, stipulis lanceolatis acuminatis decurrentibus, racemis oppositifoliis subtrifloris.

C. sagittalis glabra, longioribus foliis, americana. Pluk. alm.122.t. $277 \cdot f .2$.

In pine-woods of Virginia and Carolina. $\odot$. July. v. $v$.

\section{PHASEOLUS. Gen. pl. 1180.}

1. P. volubilis, totus pubescens; foliolis lato-ovatis impari perennis. subcordato, racemis geminatis folio longioribus, pedunculis geminatis, bracteis obsoletis, leguminibus pendulis.-Willd. sp. pl.3. p. 1031. Walt. fl. car. 182.

P. paniculata. Mich. fl. amer. 2. p. 60.

Dolichos polystachyos. Willd. sp.pl .3. p. 1049 .

On the side of fertile hills, near the banks of rivers, among rocks : Pensylvania to Carolina. 2 .July, Aug. v. v.; v. s. in Herb. Gronov. Flowers purple, in great abundance, which gives this plant a very ornamental appearance.

parviflora.

ovalis.

lavigata.

sagiltalis. 
vexillatus.

2. P. volubilis, pubescens; pedunculis petiolo crassioribus capitatis, alis subfalcatis difformibus, leguminibus linearibus strictis. Willd.sp.pl.3.p. 1032.

Icon. Jacq. hort. t. 102. Dill. elth. t. 234. f. 302.

On the sea-coast of Carolina and Georgia. $\odot$. July, Aug. $v . v$. Flowers large, purple.

helvolus.

3. P. volubilis, perennis, hirtellus ; foliolis oblongo-ovalibus subdeltoideis obtusiusculis, capitulis longe pedunculatis, vexillis brevibus, alis expansis maximis, leguminibus tereti-linearibus.-Willd.sp. pl.3. p. 1032.

Glycine umbellata. Willd.sp. pl. 3. p. 105 s.

Icon. Dill. elth. t. 233.f.300.

In chry gravelly soil, in old fields and pastures: New York to Carolina. v. v. Flowers of a rose-colour, carina purple.

trilolus.

4. P. volubilis, pubescens; foliolis inferioribus rhomboideoovalibus, superioribus trilobatis, capitulis longe pedunculatis, leguminibus linearibus. Mich. fl. amer. 2 . p. 60 .

P. vexillatus. Walt. Al car. 182.

Glycine angulosa. Wilid. sp. pl. 3.p. 1056.

On banks of rivers in gravelly soil : Pensylvania to $\mathrm{C} a$ rolina. $\odot$. June, July. v. $v$. Flowers resembling the foregoing species.

560. DOLICHOS. Gen. pl. 1181.

luteolus. 1.D.volubilis, pubescens; foliclis ovatis acuminatis, pedunculis folio longioribus, spicis brevibus subcapitatis, vexillo lato reflexo, alis rhomboideis.-Willd. $s p$. pl.3.p. 1038.

Icon. Jacq. hori. t. oo.

In rice fields of Georgia. Ensien. $\odot$. June, July. v. $v$. Flowers bright yellow.

\section{PISUM. Gen. pl. 1184.}

naritimum. 1. P. petiolis supra planitisculis, caule angulato, stipulis sagittatis, pedunculis multifloris. Willd. $s p . p l .3$. p. 1071 .

Icon. Fl. dan.338. Engl. lot. 1046.

In rocky and sandy situations, near the sea-coast: $\mathrm{Ca}$. nada to New York. 2. July, Aug, v. v. Flowers large, handsome, purple and blue. 


\section{LATHYRUS. Gen. pl. 1186.}

1. L. caule alato, stipulis semisagittatis lanceolatis, foliolis sex lineari-lanceolatis acutis, pedunculis sub-3-floris. Will.l. sp. pl. 3.p. 1000 .

Icon. Fl. dan. 399. Engl. lot. 169 .

In low grounds of Canada. Michnux. 4. July, Ang. $v$. $s$. Flowers pale purple, of midd'e size.

2. L. caule nudo tetragono, stipulis semisagittatis lanceolatis acuminatis, foliolis quatuor oblongo-lanceolatis acutis mucronatis renoso-reticulatis, pedunculis folio longioribus sub-3-floris.-Willd. sp. pl. 3. p. 1091.

In salt-marshes : Pensylvania and New York; particuJarly plenty about Lake Onondago. 4 . July, Aus. $v . v$. Resembles the foregoing species; flowers smaller, purple and rose-coloured.

3. L. caule nudo tetragono, stipulis semisagittat is ovatis acuminatis, foliolis numerosis subalternis ovatis obtusis mucronatis venosis, pedunculis folio brevioribus 5 10-floris.-Willd. sp. pl. 3. p. 1092.

In low meadows: Pensylvania. 24. July, Aug. v.s. Flowers purple.

4. L. caule tetragono, stipulis semisagittatis linearibus, foliis 5-jugis : foliolis oblongo-ellipticis mucronatis, pedunculis 3-4-floris.

On the banks of the Missouri. 24. v. s. Flowers purple, large; pods large.

\section{VICIA. Gen.pl. 1187.}

1. V. pedunculis solitariis unifloris capillaribus, stipulis semisagittatis integerrimis, foliolis subsenis lineari-lanceolatis obtusiusculis, leguminibus parvis oblongis glabris.-Willd. sp. pl.3. p. 1106.

In low grassy grounds: Pensylvania to Virginia. $\odot$. July, Ang. $v$. $v$. Flowers exceeding small, white, with a tinge of red.

2. V. floribus binis subsessilibus, stipulis dentatis macula notatis, foliolis oblengo-ovatis retusis mucronatis, leguminibus erectis subtereti-linearibus glabris. - $\mathrm{W}$ illd. sp.pl.3.p.1104? Walt.fl.car. 183.

In Lower Carolina. $\odot$. July, Aug. v. s. Flowers purplish-blue.

3. V. pedunculis submultifloris folio brevioribus, stipulis vol. II. palustris

myrtifolius.

venosus,

decaphyllus.

pusilla.

sativa.

americana. 
semisagittatis dentatis, foliolis 8-12. elliptico-lana ceolatis obtusis glabris.-Willd.sp. pl. 3. p. 1096.

In Pensylvania. Muhlenlerg. 4 . + . Flowers the size of $V$. sylvatica, to which it bears a great resemblance.

Cracca.

4. V. spicis multiforis retrorsum imbricatis folio longioribus, stipulis semisagittatis lineari-subulatis integerri. mis, foliolis numerosis lanceolato-oblongis pubescentibus.-Willd.sp. pl. 3. p. 1098.

Icon. Fl. dan. 8i)4. Mart. fl. rust. 117.

In woods and meadows: Canada to Virginia. 24. July, Aug. $v . v$. Flowers pale blue.

caroliniana. 5. V. pedunculis multifloris, floribus distantibus, stipulis ovato-lanceolatis integerrimis, foliolis $8-10$. elliptico. lanceolatis glabriusculis, caule glabro. - Willd. sp. pl.3. p. 1094. Walt. fl. car. 182.

V. parviflora. Mich.fl. amer. 2. p. 69 .

In the mountains from Pensylvania to Carolina. $2 \ell$. July, Aug. $v . v$. Resembles the foregoing species; but the flowers are white, with a vexillum black on the tip, and a great deal smaller.

\section{AStragalUS. Gen. pl. 1208.}

carolinianus. 1. A. caulescens, erectus; foliolis (41) oblongis subtus pubescentibus, spicis pedunculatis, bracteis lanceolatis pedunculi longitudine, leguminibus ovatis tumidis rostratis. Willd.sp.pl.3.p. 1273.

Icon. Dill. elth. $i .39 . f .45$.

In the mountains of Virginia and Carolina. 24. June, July, $v, v$. Flowers pale yellow.

canadensis. 2. A. caulescens, diffusus; foliolis (21) utrinque glabris, leguminibus subcylindricis mucronatis. $-W$ illd. $s p$. pl.3.p. 1274 .

Icon. Dodart. mem. t. 65. Rol.ic. 314.

In the mountains: Canada to Carolina. 2. July, Aug. v.v. Flowers yellow.

glaver.

3. A. caulescens, glaber; foliolis lanceolato-oblongis subeiliatis, spicis longe pedunculatis, floribus laxiusculis, leguminibus distantibus incurvis teretibus glabris.Mich.fl. amer. 3. p. 66.

In the sands of Georgia. Michaux. 4. +. Flowers white.

alpinus. 4. A. caulescens, procumbens ; floribus pendulis racemosis, 
diadelphia decandria. Astragalus.

leguminibus utrinque acutis pilosis. Willd. sp.pl. 3. p. 1297.

Icon. Fl. dan. 51. Pall. astrag. t. 32.

In Labrador. Colmaster. 24. July, Alig. v. s. in Herb.

Dickson. Flowers pale purple.

5. A. caulescens, procumbens ; foliolis ovatis pubescentibus,

securdus. spicis pedunculatis, leguminibus secundis rectis atrinque acuminatis pendulis.-Mich. fl. amer. 2. p. $6 \%$.

In the north of Canada. Michaux. Labrador. Colmaster. 4 . July, Aug. v. s. Flowers dark purple.

6. A. caulescens, glaber; foliolis linearibus alternis, spicis pedunculatis folio longioribus, bracteis minutis, leguminibus subteretibus rostratis.

On the banks of the Missouri. M. Leuris. \#. Aug. $v$. s, in Herb. Lewis. Flowers smali, yellowish-white.

7. A. subacaulis, pilosissimus; foliolis ovalibus supra glabris, pedunculis folia subæquantibus, spicis paucitioris, leguminibus incano-villosissimis assurgentibus oblongis.-Mich. fl. amer. 2. p. 67 .

In sandy pine-woods of Georgia. 4. July, Aug. v. s. in Herl. Enslen.

\section{OXYTROPIS. Decand. astrag. $p 24$.}

1. O. acaulis ; foliolis obovato-lanceolatis sericeo-argenteis, scapis folia æequantibus, floribus capitatis, bracteis lanceolatis longitudine calycis sericei.-Pers. syn. 2 . p. 331 .

Astragalus argentatus. Willd. sp.pl. 3.p. 1310.

Icon. Pall. astrag. $t .43$.

On the banks of Clarck's river. M. Lewis. 4 . July. $v$. s. in Herb. Leu'is.

argentato.

\section{APIOS.}

Glycine. Gen. pl. 1182.

1. A. volubilis, glabra; radice tuberosa, foliis impari-pintulerosa natis : foliolis $5-7$. ovato-lanceolatis superne angustatis, spicis confertis folio brevioribus.

Glycine Apios. Willd. sp.pl. 3. p. 1067.

Icon. Bot. mag. 1198. Schkuhr handb.198. Rob. ic. 317.

In hedges and on mountain meadows: Pensvlvania to Carolina. 4. July. v. v. Flowers dark brown, sweet-scented; roots eatable, growing sometimes to an enormously large size. 
frutescens.

2. A. volubilis ; foliis impari-pinnatis novenis ovatis pubescentibus, racenis terminalibus bracteatis, leguminibus coriaceis.

Glycinc fitescens. Willd.sp. pl.3.p. 1067.

Anonymos frutescens. Walt. fl. car. 186.

In swamps of Virginia, Carolina, and Illinois. 々. June, July. v. v. Flowers purplish-blue, It is a fine ornamental plant.

573. DALEA. Hort. cliff. p. 363. Mich. fl. amer. 3.

$$
\text { p. } 50 \text {. }
$$

Cliffortiana. 1. D. spicis oblongis confertis pedunculatis terminalibus sericeis, bracteis calycis longitudine, foliis subsexjugis lineari-cuneatis retusis apice subdentatis.-Willd. $s p$. pl.3.p. 1336.

Psoralea Dalea. Sp. pl. 1076.

Icon. Hort. cliffort. $t .22$.

In Georgia and Florida. $\odot . v . v$. in Hortis. Flowers blue.

alopecuroides. 2.D. spicis cylindricis pedunculatis terminalibus sericeis confertis, bracteis calyce brevioribus, foliis 10-12jugis ellipticis retusis mucronatis. Wiild. sp. pl. 3 . p. 1336.

D. linnæi. Mich. fl. amer. 2. p. 57.t.38.

On the banks of the Mississippi. ๑. July, Aug. v. v. Flowers pale blue.

pedunculata. 3. D. glabriuscula; spicis oblongis axillaribus subconfertis brevibus, pedunculis folio triplo longioribus, bracteis minutis longitudine pedicellorum, dentibus calycis subulatis, foliis subsexjugis linearibus acutis mucronatis.

On the banks of the Mississippi. Enslen. ๑. July, Aug. v. s. in Herl. Enslen. Flowers rose-coloured.

parviflora.
4. D. cano-pubescens; spicis filiformibus elongatis laxifloris axillaribus, pedunculis folio duplo longioribus, bracteis minutis, calycis tomentosi dentibus acutis brevibus, foliis sub-5-jugis linearibus obtusis.

On the banks of the Missouri. $\odot$. July, Aug. v. s. Flowers small, white. 



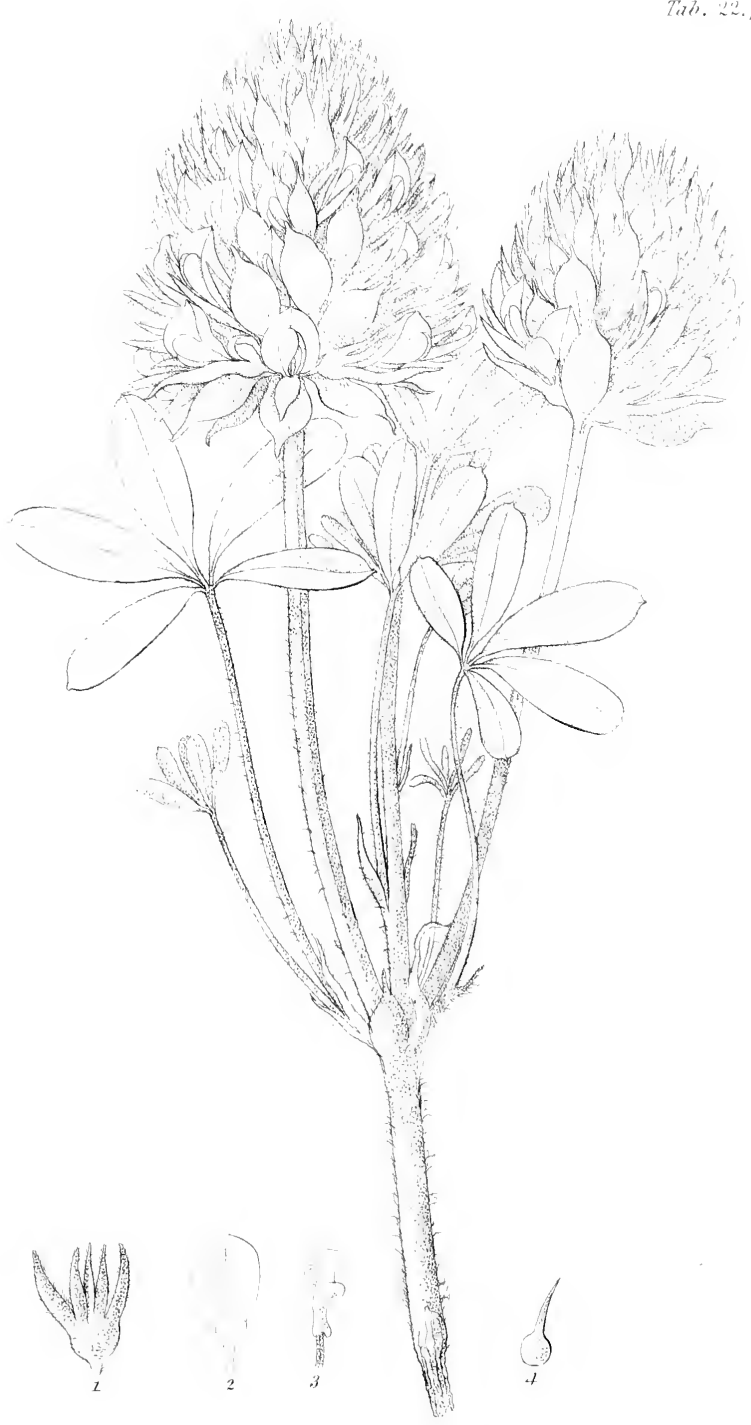

Sherater siscetente. 
574. PSORALEA. Gen. pl. 1210.

1. P. tota canescens; foliis breviter petiolatis trifoliatis, spicis laxifloris, floribus pedicellatis, calycibus villosissimis. Mich. fl. amer. 2. p. 57.

In barren sandy fields of Carolina and Georgia. July. $v$. s. Resembles in appearance Cytisus Cajan.

2. P. parce pubescens; foliis ternatis: foliolis lanceolatis, spicis oblongis, bracteis lato-cordatis longissime acuminatis, leguminibus rotundatis nervoso-rugosissimis. - Mich.fl amer. 2. p. 58.

Melilotus flore violaceo, odore remisso. Clayt. n. 103. Trifolium psoraloides. Walt. fl. car. 184.

In pine-barrens : Carolina to Florida. 24. June-Aug. v. s. in Herl. Leconte. Flowers blue.

3. P. pubescens, ramosissima; foliis ternatis: foliolis ellipticis utrinque rugoso-punctatis, pedunculis axillaribus folio longioribus sub-3-floris.

On the banks of the Missouri. M. Lewis. 24. Sept. $v$. s. in Herb. Lewis. Flowers very small, pale blue.

4. P. pubescens; foliis ternatis : foliolis elongato-lanceolatis, petiolis crassis, spicis axillaribus folio vix longioribus densifloris, floribus pedicellatis, bracteis pedicello vix longioribus, dentibus calycis coloratis.

On the banks of the Missouri. 4. July, Aug. v. s. Flowers bright blue, small.

5. P. undique argenteo-tomentosa; foliis ternatis: foliolis lanceolato-oblongis, spicis terminalibus interruptis, bracteis ovatis acuminatis, floribus suboppositis sessilibus.

On the banks of the Missouri. 24. v. s. Flowers purple: the silvery tomentum gives this plant a particularly handsome appearance.

6. P. undique villosa; foliis digitato-quinatis: foliolis lanceolatis inzequalibus planis integerrimis, spicis axillaribus densiforis, laciniis calycis lanceolatis corolla paulo brevioribus, leguminibus ensiformi-rostratis, radice fusiformi.

On the banks of the Missouri. M. Lewis. 4. June, July, v. s. in Herb. Lewis. Flowers pale blue.

'Tota planta pilis longis albidis tecta. Radix fusiformis, crassa, exsiccatione farinosa. Caulis erectus, subramosus, teres, sulcatus, pedalis et ultra. Folia alterna,

melilotoides.

tenuiflora.

lanceolata.

argophylla.

esculenta. 
petiolata, digitato-quinata. Foliola subpetiolata, lanceo. lata, utrinque acuta, integerrima, plana, supra glabra, punctis vix conspicuis confertissime adspersa, subtus pilosa, uncialia. Petioli conmunes teretes, folio longiores. Stipula persistentes, ad basin petiolorum oppositæ, oblongo-lanceolatæ, acutæ. Spice axillares, pedunculatæ, densifloræ, bracteatæ, foliis longiores. Bractece lato-ovatæ, acuminatæ, calyce breviores. Flores sessiles, cærulei, magnitudine et figura Vicia sativa. Caly $x$ hirsutissimus, 5 -fidus s. profunde 5 dentatus : dentibus lineari-lanceolatis: 2. lateralibus subfalcatis : inferus latior. Corolla: Vexillum obovatum, inferne utrinque glandula instructum, calyce paulo longiore. Ala semi-ovatæ, vexillo breviores. Carina oblonga. Legumen calyce tectum, monospermum, hirsutum, rostro ensiformi, glabro, calyce longiore instructum. Semen reniforme, nigrum.

It approaches very near to $P$. pentaphylla $W$ illd. $s p$. pl. 3. p. 1352. which is fully described and figured by B. Jussieu in stct.par. 1744.p.351.t. 17. But not only the botanical difference, but the medical use made of the Mexican plant, proves their distinctness. The present plant produces the famous Bread-root of the American Western Indians, on which they partly subsist in winter. They collect them in large quantities, and if for present use, they roast them in the ashes, when they give a food similar to yams : if intended for winter use, they are carefully dried, and preserved in a dry place in their huts. When wanted for use, they are mashed between two stones, mixed with some water, and baked in cakes over the coals. It is a wholcsome and nourishing food, and, according to Mr. Lewis's observation, agreeable to most constitutions; which, he observed, was not the case with the rest of the roots collected by those Indians for food. This root has been frequently found by travellers in the canoes of the Indians, but the plant which produces it has not been known until lately.

Lupinellus. 7. P. foliis quino-digitatis: foliolis angustissime linearibus, spica pauciflora, leguminibus ovoideis, uncinato-mucronatis, rervoso-rugosis.-Mich. fl. amer. 2. p. 58.

In barren fields of Carolina. 4 . v. s. in Herb. Lyon. Flowers very small. The leaves of the whole genus ate covered with resinous dots. 
575. MELILOTUS. Tournef. inst.p. 407.t. 229.

1. M. caule erecto, foliolis obovatis serratis, spicis axillariofficinalis. bus paniculatis, leguminibus dispermis rugosis acutis. Trifolium officinale, Willd. sp. pl. 3. p. 1355.

Icon. Fl. dan. 934. Mart. ft. rust. t. 72.

On the gravelly shores of rivers: Pensylvania to Virginia. $\delta$. ๑. June, July. v. v. Flowers white.

\section{TRIFOLIUM. Gen. pl. 1211.}

1. T. prucumbens, pubescens; foliolis obovatis, stipulis oblique cordatis, capitulis multifloris, floribus pedicellatis demum omnibus reflexis, leguminibus sub-3spermis.-Willd.sp.pl.3.p.1357.

On dry hills and among rocks: Pensylvania, Kentucky, and the Carolina mountains. 4. June, July. v. $v$. Flowers of a fine purplish-red.

2.T. repens; foliolis ovato-oblongis emarginatis serrulareflexum. tis, capitulis umbellaribus, calycinis dentibus subæqualibus, leguminibus tetraspermis. -Willd. sp. pl.3. p. 1359.

lcon. Fl. dan. 990. Mart. fl. rust. 34.

ln fields, pastures, and cleared lands on the mountains. 4. May-Sept. v. v. This species, generally known by the name of $W$ hite Clover, makes its appearance wherever lands are cleared of timber, in the most remote parts of the country; I have seen it springing forward on new plantations, from sixty to one hundred miles distant from any place where it naturally was found. A number of plants of this description have struck my attention, among which are Verbascum Thapsus and Senecio hieracifolius in particular, whose dissemination is really problematical.

3. T. erectum, pusillum; foliolis rotundato-obcordatis gla- carolinianum. bris margine ciliatis crenulatis, stipulis bifidis, capitulis umbellaribus pedunculatis reflexis paucifloris, corollis vix exertis, leguminibus subtrispermis. - Mich. fl. umer. 2. p. 5 s.

T. arvense. Walt. $f$. car. 183.

T. comosum. Willd. sp. pl. 3.p. 1360 ?

In sandy fields, near Charlestown, South Carolina. 4. June-Aug. v. s. Flowers small, white. In Lam. encycl. 8. p. 2. it has bcen suggested, that T. como- 
sum of Linnæus and the present plant are the same, and I believe with very good reasou, as l suppose the little difference between then may have been occasioned by culture.

microcephalum.

pratense.

pensylvanicum.

arvense.

agrarium.
4. T. adscendens, pubescens ; foliolis obovatis emarginatis denticulatis, stipulis ovatis acum:natis, capitulis pusillis pedunculatis paucifloris, floribus sessilibus, invoJucris ovatis aristatis, calycibus aristatis longitudine corollæ.

On the banks of Clarck's river. M. Lewis. 24. July. $v$. s. in Herb. Lewis. Flowers exceeding small, pale purple.

5. T. adscendens, glabriusculum; foliolis ovalibus subintegerrimis, stipulis aristatis, spicis densis ovatis, calycis dente infimo tubo corollæ monopetalæ inæqualis breviore. -Willd. sp. pl. 3. p. 1366.

Icon. Fl. dan. 989. Mart.fl. rust. 3.

In fields and woods, frequent. 4. May-Sept. v. v. Common Red Clover is apparently in a native state, but very probably has been introduced.

6. T. adicendens ; caule ramosissimo flexuoso, foliolis ovato-ellipticis obtusis integrerimis, stipulis aristatis, spicis ovato-cylindıaceis solitariis densis, calycis dente infimo corollæ monope'alæ breviore.-Willd. enum. p. 793 .

In woods and fields : Pensylvania to Virginia. 24. June -Sept. v. v. Resembles T. medium very much ; flowers a fine red. It is known by the naine of Buffalo Clover.

7. T. erectum, ramosissimum, villosum; foliolis linearilanceolatis apice serrulatis, stipulis connatis apice subulatis, spicis villosissimis subcylindraceis, dentibus calycinis setaceis corolla longioribus.-Willd. sp. pl.3. p. 1373 .

Icon. Fl. dan.724. Curt. fl. lond. 50.

In dry and sandy fields : Canada to Virginia. ๑. July, Aug. $v . v$. Flowers small, white; the wings have a red spot.

8. T. erectum, subpubescens; foliolis lanceolato-cuneatis obtusis: intermedio sessili, stipulis lanceolatis acutis, spicis ovalibus imbricatis, vexillis deflexis persistentibus, calycinis dentibus subulatis glabris inæquali. bus - Willd. sp. pl. 3. p. 1382.

T. aureum. Pollich. fl. palat. n. 708. 


T. strepens. Crantz. fl. austr. 411.n.S.

Jcon. Fl. dan. 558.

In meadows: Pensylvania to Virginia. $\odot$. June-Aug. $v \cdot v$. Flowers small, yellow.

9. T. procumbens; caule piloso; foliolis obovatis subemarginatis glabris, stipulis brevibus lanceslatis acutis, spicis ovalibus imbricatis, vexillis deflexis persistentibus sulcatis.-Willd.sp.pl.3.p.13s3.

Icon. Fl. dan. 796.

On dry gravelly soil : Pensylvania to Virginia. ๑. June -Aug. v. v. Flowers yellow, resembling those of the foregoing species.

577. LUPINASTER. Mœench. meth. suppl.p. 50.

Pentaphyllon. Pers. syn. 2. p.352.

1. L. foliolis novenis oblanceolatis, petiolis longissimis, sti- macrocephapulis cuneatis inciso-3-dentatis, calycinis dentibus fili- lus. formibus plumosis.

At the head-waters of the Missouri. M. Lexis. 4. April, May. v. s. in Herb. Lewis. Flowers yellowishwhite, with a pale purple carina, very handsome and showy: the flower-heads sometines grow to an extremely large size.

Caules plures, simplices, angulosi, pilosi. Folia petiolata, suprema opposita, novena. Foliola inæqualia, cuneatolanceolata, inæqualiter mucronato-denticulata, supra glabra, subtus pilosa, lineato-venosa, uncialia. Petioli inferiores longi, subteretes. Siipula inferiores petiolo adnatæ, superiores liberæ, cuneato-oblongæ, apice inciso-3-dentatæ, margine serrulatæ, consistentia et pubescentia foliorum. Capitulum speciosum, dimidiatum. Flores lutescentes, carina purpurascente. $\mathrm{Cal}$. campanulatus, subæqualiter 5-deutatus, villosissinus : dentibus subulatis piloso-plumosis corollam subxquantibus. Corolla: Vexillum magnum, oblongo-lan. ceolatum, acutum, cæteras partes fructificationis in. volvens. Ala carina adnatæ, lineares. Carina uncinata, integra, vexillo vix breviore. Filamenta 10. diadelpha : 1 . liberum, reliqua superne libera, inferne monadelpha, carina adnata. Germen oblongum, glabrum. Stylus filiformis. Stigma simples, hirsutum. Legumen 3-4-spermum, inflatum, calyce longius. 


\section{STYLOSANTHES. Gen. $p l .1203$.}

hispida.

erectu.

procumbens.

1. S. caule uno latere pubescente, foliolis lanceolatis glabris, bracteis lanceolatis ciliatis, capitulis 2-3-floris-Mich. fl. amer. 2. p. 75 .

Trifolium biflorum. Sp. pl.10ss. Arachis aprica. Walt. fl. car. $1 \mathrm{S2}$.

a. S. caule simplici erecto superne breviter ramoso.

Icon. Su'artz. act. holm. 1789.t. 11.f. 2.

$\beta$. S. caule procumbente a basi ramoso.

In dry gravelly fields and woods; Pensylvania to Carolina. 4. July, Aug. v. v. Flowers yellow, small.

\section{GLYCYRRHIZA. Gen. pl. 1197.}

lepidota.

1. G. foliolis oblongis acutis sericeo-villosis, leguminibus ra. cemosis oblongis hispidis.-Fraser, catal.

On the banks of the Missouri. 4. July, Ang. v.s. v.v. s. $\boldsymbol{l}$.

580. LESPEDEZA. Mich. fl. amer. 2. p. 70.

sessiliflora. 1. L. erecta; foliolis oblongis, fasciculis florum sessilibus numerosis, lomentis calyce minuto subnudatis acutis. Mich. fl. amer. 2. p. 70.

Hedysarum junceum. Walt. fl. car. 184.

Hedysarum sessiliflorum. Lam. encycl. 6. p. 414.

Hedysarum reticulatum. Willd. sp. pl. 3. p. 1194 .

Medicago virginica. Syst.veg. 3. p.573.

In old fields and on the borders of woods: New York to Carolina. 4. July, Aug. v. v. Flowers purple.

capitata.

2. L. erecta, simplex ; foliis subsessilibus : foliolis ellipticis, spicis capitatis brevi-pedunculatis axillaribus et conglobato-terminalibus, calycibus villosis longitudine corollæ lomentis calyce multo minoribus. Mich. $\mathrm{fl}$. amer. 3. p. 71 .

Hedysarum conglomeratum. Lam. encycl. 6. p. 416.

angustifolia, $\quad \beta$. L. foliolis linearibus, pedunculis longioribus.

Trifolium erectum haud ramosum, foliis longis, \&c. Clayt. n. 934.

In sandy soil, in old fields and borders of woods: New York to Carolina. 24. June, July. v.v. From one to three feet high ; flowers pale purple.

polystachya. 3. L. erecta, ramosa, villosissima ; foliis subsessilibus : foliolis rotundato.ovalibus, spicis axillaribus longe-pe- 
dunculatis, corollis calyce subæqualibus, lomento calycem subrquante.-Mich.fl. amer. 3. p. 71 . Hedy'sarum hirtum. Willd. sp.pl.3. p. 1193. Icon. Mich. fl. amer. 2. t. 40.

In copses and old fields : Pensylvania to Carolina. 24. June-Aug. v. v. From two to three feet high; flowers small, white, with a red spot on the vexillum.

4. L. diffusa, ramosissima; foliis longe-petiolatis: folicits ellipticis obtusis subtus adpresso-pilosis, racemis brevibus umbellatis, floribus geminatis, lomentis rhombeis reticulatis glabris.

Hedysarum violaceum. Willd. sp. pl.3.p. 1195.

On gravelly dry soil: Virginia to Carolina. 24. July. v. v. Flowers small, purple or violet.

5. L. diffusa, ramosa; foliolis oblongis obtusis subtus adpresso-pilosis, racemis petiolo longioribus, floribus geminis, lomentis ovatis reticulatis glabris.

Hedysarum divergens. Willd. sp. pl. 3. p. 1196.

In North America. Muhlenlerg. 4 . +. Approaches very near to the foregoing species, and is probably only a variety.

6. L. procumbens, gracilis, pubescens; foliolis ovalibus, pedunculis longissimis, setaceis spicifloris, leguminibus calyce minuto nudatis.-Mich. fl. amer. 3.p.70.

Hedysarum Lespedeza. Lam. encycl. 6. p. 415.

In sandy and gravelly so:1: New York to Carolina. 2 . June, July. $v . v$. Flowers violet-purple, with yellow spots.

7. L. prostrata; foliis petiolatis: foliolis ellipticis obtusis subtus pilis raris adpressis tecta, racemis axillaribus foprostratu lio longioribus, lomentis ovatis pubescentibus.

Hedysarmin prostratum. Willd. sp. pl.3.p. 1200.

In Pensylvania. Muhlenberg. 24. +. Resembles Hedysarum repens greatly.

\section{HEDYSARUM. Gen.pl. 1204.}

1. H. erectum, glabriusculum; foliis ternatis oblongo-lanprocumlens. divergens.

violacea. divergens. ceolatis, stipulis filiformibus, floribus racemosis, articulis lomenti obtuse triangulis hispidis.-Willd. $s p$. pl.3. p. 1157 .

Icon. Moris. hist. 2. s. 2. t. 11.f. 9 .

In sandy barren fields and woods: Canada to Carolina. 4. July, Aug. v. v. Flowers middle-sized, of a handsome purplish-red. 
canescens.

marylandicum.

obtusum.

viridiflorum.

glaliellum.

bracteosum.

ciliare.
2. H. erectum, pilosum : caule angulato-ciliato hispido, foliis ternatis subrotundis subtus adpresso-pilosis, stio pulis ovatis acuminatis, racemis paniculatis, bracteis cordatis, lomenti articulis triangularibus hispidis.Willd. sp. pl. 3. p. 1188 .

In dry barren woods : Virginia and Carolina. 4 . June -Aug. v. v. Flowers middle-sized, pale purple.

3. H. erectum, ramosum, pilosum; foliis ternatis oblongis subtus viliosis, stipulis subulatis, racemis paniculatis, lomentis triarticulatis, articulis rhombeis reticulatis $\mathrm{pi}$ losiusculis.-Willd. sp. pl. 3.p. 1189.

Icon. Dill. elth. $t, \mathbf{i} 74 . f .171$.

In dry swamps and woods: New York to Carolina. 4. June-Aug. v. $v$. Flowers large, a fine purple, with a green spot at the bottom of the vexillum, which mark occurs in most species.

4. H. erectum, pubescens ; foliis ternatis ovatis obtusis basi subcordatis, stipulis lanceolato-subularis, panicula terminali, articulis lomenti semiorbiculatis reticulatis hispidis.-Willıl. sp. pl. 3. p. 1190.

In dry swamps, old fields and woods: Pensylvania to Virginia. 4. July, Aug. v. v. Flowers violet.

5. H. erectum, ramosum, pubescens ; foliis ternatis ovatooblongis subtus scabris, stipulis lanceolato-cuspidatis, racemis paniculatis bracteatis, lomentis asperis, articulis ovalibus.-Willd. sp. pl. 3. p. 1192.

lcon. P/uk. alm. t. 308.f.5.

In woods and old fields: New Jersey to Carolina. $\boldsymbol{\psi}$. July-Sept. $v$. $v$. About three feet ligh; flowers reddish-purple, which turns green after flowering.

6. H. erectum, glabrum; foliis ternatis ovatis obtusis sub. tus subglaucis, stipulis parvis subulatis, panicula terminaii, lomenti articulis triangulo-rhomboideis. Mich. fl. amer.3. p. 73 .

In fields and woods: Virginia and Carolina. 4. July, Aug. v. v. Hlowers purple, small.

7. H. erectum, glabrum; foliis ternatis oblongo-ovalibus acuminatis, stipulis subulatis, racemo terminali sparsifloro, bracteis ovatis acuminatis striatis glabris, lomenti articulis subovalibus.-Mich. fl. amer. 2. p. 73 .

In the western parts of Pensy!vania and Virginia. 4 . July-Sept. v. v. Flowers large, purplish-red.

8. H. erectum, glabriusculum; foiiis ternatis ovatis subtus 
pubescentibus margine ciliatis, stipulis filiformibus, panicula terminali, lonenti articulis (2-3) semiorbiculatis hispidis._-Willd. sp.pl.3.p.1196.

In North America. Muhlenterg. 4. +. Flowers small, violet.

9. H. erectum, glabrum; foliis ternatis oblongo-lanceolatis pariculalum. vel ellipticis glabris, stipulis subulatis panicula terminali, lomenti articulis (4) rhombeis pubescentibus.Willd.sp.pl.3.p. 1196.

Icon. Pluk, mant. t. 432 . f. 6.

In dry woods and fields: New York to Carolina. 4. June-Aug. $v . v$. Flowers purple.

10. H. stricte-erectum, glabrum, simplex; foliis petiolatis ternatis lineari-ellipticis glabris reticulato-venosis subtus glaucis, stipulis subulatis, panicula terminali pedunculata pauciflora.

In pine-woods of New Jersey. 24. July, Aug. v. $v$. Flowers small, pale purple; seeds not known.

11. H. erectun, glabrum; foliis ternatis petiolatis ovatooblongis longe-acuminatis glabris margine scabris, stipulis ovato-lanceolatis, panicula terminali, articulis lomenti triangularibus reticulatis glabris margine pubescentibus.—Willd. sp. pl.3. p. 1198.

In shady woods : Pensylvania and Virginia. 24. July, Aug. v.v. Flowers violet.

12. $\mathrm{H}$. erectum, simplex, pubescens, summitate frondosum; foliis ternatis ovatis longe acuminatis utrinque rariter alpresso-pilosis longissime petiolatis : impari rotundato-subrhomboideo, panicula terminali longissime pedunculata.-Mich. fl. amer. 2. p. 72.

In shady woods : New England to Carolina. 24. July, Aug. v.v. Not above a foot high ; flowers purple. It approaches near the foregoing species, and is the connecting link between that and the following.

13. H. erectum, simplex, glabriusculum ; foliis ternatis lato.

nudiflorum. ovalibus acuminatis, scapo paniculato glabro radicali caule foliifero altiore, lomenti articulis subrotundo-triangularibus glabriusculis.-Willd. sp.pl. 3.p. 1198.

In woods and old fields : New England to Carolina. 4. June-Sept. $v . v$. About a foot high; flowers purple.

14. H. erectum, simplex ; foliis longe petiolatis ternatis subrotundo-ovatis acuminatis, panicula scapiformi e caulis

strictum.

cuspidatum.

acuminatum.

glutinosum. 
basi, pedunculis piloso-viscosis, lomenti articulis oblongo-triangularibus glabriusculis.-Willd. $s p . p l .3$. p. 1198.

In dry shady places, in the western parts of Pensylvania and Virginia. 24. July, Aug. v. v. Flowers purple.

lineatum. 15. H. caule repente viridi lineato, foliis subsessilibus ternatis suborbiculatis, racemis elongatis laxe parvifloris, Jomenti articulis lenticularibus.-Mich. fl. amer. 2. p. 72 .

In Carolina. Michaux. 4. +.

rotundifoli- $16 . \mathrm{H}$. prostratum, hirsutum; foliis ternatis orbiculatis un. utrinque pilosis, stipulis rotundato-cordatis reflexis, racemis axillaribus et paniculato-terminalibus paucifloris, bracteis cordatis, lomenti articulis subrhomboideis reticulatis scabris.-Mich. fl.amer. 2. p. 72 .

In rocky, dry situations: Pensylvania to Carolina. 4. July, Aug. $v, v$. A handsome species: flowers purple.

alpinum. $\quad 17 . \mathrm{H}$. erectum ; foliis pinnatis : foliolis ovali-oblongis pi$\beta$. americanum. losis, stipulis subvaginantibus, leguminibus patulis glabris ex utraque sutura articulatis : articulis brevi-ovalibus. Mich. fl. amer. 2. p. 74 .

In the north of Canada, and near the cataracts of the Ailegany mountains. Michaux. $4 .+$. Flowers purple.

582. ZORNIA. Mich.fl.amer. 2.p. 76. Gmel. syst. veg. 1096.

letraphylla. 1. Z. foliis digitato-quadrifoliatis: foliolis lanceolatis glabris, spicis axillaribus pedunculatis, floribus alternis bibracteatis, bracteis suborbicuiatis.-Mich.fl. amer.2. p. 76 .

Z. bracteata. Gnel.

Hedysarum tetraphyllum. Lam. encycl.6. p. 405.

Anonymos bracteata. Walt. fl. car. 181.

Icon. Mich. $f$. amer. 2. $t$. 41.

In sandy fields of Lower Carolina. 2. July, Aug. v.s. in Herl. Enslen. About a foot high, very branching; Howers yellow. 


\section{ESCHYNOMENE. Gen. pl. 1202.}

ג. A. caule prostrato gracili viscido-pubescente, foliolis $7-9$. obovalibus, pedunculis subbifioris, lomento pubescente profunda incisura articulata.-Mich. $f l$. $a$ mer. 3. p. 74 .

On the overflowed sands of Florida, and Cumberland island, Georgia. Michaux. $\odot$. +.

2. A. caule erecto petiolisque tuberculato-hispido, foliis multijugis : foliolis linearibus obtusis, stipulis membranaceis semisagittatis, racemis simplicibus paucifloris, lomentis hispidis.-Willd. sp. pl.3. p. 1163.

Hedysarum virginicum. Willd. sp. pl. 3,p. 1212.

On the banks and islands of the principal rivers, as far as the tide flows: Pensylvania to Carolina. $\odot$. July, Aug. v. v.; v. s. in Herb. Gronov. Flowers yellow, finely veined with red.

5S4. SESBANIA. Poiret in lam. encycl.7. p. 126.

1. S. glabra; foliis sub-20-jugis: foliolis oblongis obtusis glabris margine ciliatis, racemis pedunculacis pauciforis folio brevioribus, tomentis lato-lanceolatis compressis longe stipitatis subdispermis.

S. platycarpa. Pers. syn. 2.p. 316 .

Robinia vesicaria. Jacq ic. rar. 1.t. 48.

Pliaca floridana. Pers. syn. 2. $p$ 331.

Eschynomene platycarpa. Ilich. $f$. amer. 2. p.75.

In overflowed places : Carolina and Florida. $\odot$. v.s. Flowers yellow.

\section{GLYCINE. Gen. pl. 1182.}

1. G. caule volubili, foliis ternatis ovatis acutis glabris, racemis filiformibus sub-3-fioris, floribus apetais, leguminibus oblongis dispermis.-Willd. sp.pl.3. p. 105.5.

G. monoica. Schkuhr bot. annal. 12. p. 20.t. 2 .

In low grounds, among bushes: Virginia and Carolina. $\odot$. July, Aug. v. v. It might with propriety form a separate genus, if the following species did not show the strong claim it has to be still considered a Glycine.

2. G. caule gracili retrorsum piloso, foliis ternatis ovatis monoica, glabris membranaceis, racemis caulinis pendulis laxis corollatis plerumque sterilibus, bracteis suborbiculatis

sarmentosa.

disperma.

viscidula.

hispida. disperma. 
concavis, pedunculis radicalibus floribus apetalis fructiferis.-Will. sp.pl. 3. p. 1055.

G. bracteata. Sp. pl. p. $: 34$.

On the banks of rivujets in stony and shady places: New York to Carolina. O. July-Scpt, v. v. The flowers on the stem resemble those of Vicia Cracca, they are pale blue, and seldom produce ripe fruit ; the long radical tendrils have exceeding small fowers which produce a pod, generally with only one seed, which drops into the ground before maturity.

comosa.

3. G. caule volubili, foliis ternatis ovato-lanceolatis acutis hirsutis, racemis lateralibus pendulis confertifloris. floribus on nibus fructiferis.-Willd. sp. pl. 3. p. 1058.

In hedyes near rivers and ditches: New York to Virginia. 4. July-Sept. v. v. Flowers blue, of the size and shape of the preceding species, to which it has a strong resemblance, but differs in being a perennial and robust plant, besides the other characters given.

tomentosa. 4. G. caule volubili anguloso, foliis ternatis ovato-oblongis acutis pubescentibus, subtus rugoso-venosis tomentosis, racemis axillaribus petiolo brevioribus, leguminibus oblongis dispermis.-Willd.sp. pl.3.p.1061.

Icon. Dill. clih.t. $26, f .29$.

erecta. $\quad \beta$. G. tomentosior; caule erecto, folits oblongo-ovalibus.

Trifolium erectum. Walt. $f$. car.....

In sandy ground, among hedges: $\beta$. on road sides and old fields: Virginia to Georgia. 4 . June-Aug. v.v. Flowers yellow.

reniformis. 5. G. erecta, humilis, pubescens; foliis on nibus simplicibus reniformi-rotundatis rugosis reticulatis, junioribus tomentosis, racemis subsessilibus paucifloris, legumibus compresso-ovatis dispermis.

G tomentosa $\gamma$. monophylla. Mich. $f$ amer. 2. p. 63.

Trifolium simplicifolium. Walt. fl. car. 184.

In barren pine-woods : Carolina and Georgia. 2. July, Aurg. v.s. Hlowers yellow.

586. GALACTIA. Brown. Mich.fl.amer. 2.p. 61.

mollis.

1. G. volubilis, molliter pubcscens, subcanescens; foliis ternatis ovato-oblongis obtusis glabriusculis subtus glaucis, racenis axillaribus simplicibes elongatis paucifloris, leguminibus villosis.-Mich. fl. amer. 2. p.61. 
Hedysarum volubile. IVilld.sp. pl. 3. p.1204.

In pine-barrens: New Jersey to Carolina. 24. July, Aug. $v . v$. Flowers purple, with yellow and white, the size of Hedysarum paniculatum.

2. G. prostrata, subvolubilis, glabriuscula ; foliis ternatis elliptico-oblongis obtusis utrinque emarginatis utrinque glabris, racemis axillaribus simplicibus abbreviatis paucithoris, calycibus glabris, leguminibus villosis.- Mich. fl. amer. 2.p. 62.

Dolichos regularis. Willd.sp. pl. s.p. 1049.

Ervum volubile. Walt. fl. car. 187.

In pine-woods and sandy fields: New Jersey to Carolina. 4. June-Sept. $v . v$. The roots are fusiform, and extend to a great depth: the flowers, though not large, are extremely pretty, purple, red and white mixed.

557. CLITORIA, Gen. pl. 1183.

1. C. foliis ternatis ovatis calyce bracteis longiore 5-partito: virginiand, laciniis subulatis incurvis divergentibus, leguminibus subensitormibus. - Willd. sp.pl.3.p. 1069.

Icon. Dill. elth.t.76.f. 87 .

In hedges: Virginia and Carolina. 24. July, Aug. v. v. Flowers large, beautiful blue, very handsome and ornamental.

2. C. foliis ternatis, calyce bracteis lineari-lanceolatis multoties majore, oblongo-tubuloso 5 -fido, legumine $\mathrm{fa}$ ciebus convexis toruluso, seminibus glutinosis. Mich. fl. amer. 2.p.62. Willd.sp.pl.3.p. 1070.

In liedges on the banks of rivulets: Virginia and Carolina. 24. Juiy-Sept. v. $v$. Flowers smaller and of a paler blue than the preceding.

\section{8s. ROBINIA. Gen. pl. 1195.}

1. R. foliis impari-pinnatis, stipulis spinescentibus, racemis Pseudacacia, pendulis, calycis dentibus inuticis, leguminibus lævibus.-IVilld.sp. pl. 3. p. 1131 .

Icon. Schmidt arb.32. Duham. arb. ed. nov. 16. Wangh. arb.t.7.f. 19. Pluk. alm.t. 4 .

On dry fertile ridges on the mountains, from Canada to Carolina. $h$. May, June. $v . v$. Flowers white, sweet-scented. This highly ornamental tree is at the same time a most useful one: its wood is almost in. 
corruptible, and particularly calculated for posts of gates and fences. It is universally known by the name of False Acacia, in America Locust-tree.

viscosa.

2. R. folis impari-pinnatis, racemis axillaribus erectis conferifforis, calycibus acuminatis, ramis petiolis pedunculis leguminibusque glanduloso-viscosis. -Willd. $s p$. pl.3. p. 1131 .

R. glutinusa. Bot. mag. 560 .

Icon. l'ent. desc. pl. nov. t. 4. Duham. art. ed. nov. 17. On the banks of rivers in Sonth Carolina, particularly on the Savannah. $\eta$. June, July. $v . v$. Flowers pale red, with white. This tree is highiy ornamental; but its creeping roots are a great nuisance in small plantations.

hispida.

3. R. foliis impari-pinnatis: foliolis rotundato-ovalibus mucronatis, racemis axillaribus suberectis, calycibus acuminatis, caule subinermi, ramis pedunculis calycibus leguminibusque hispidis.-Willd. sp.pl. 3. p. 1132.

R. montana. Bartr. catal.

R. rosea. Duham. arl. ed. nov. 18.

Icon. Bot. mag. 311 . Schmidt arl.31. Catesb. cur.3. t. 20. Mill. ic. 244.

rosea. $\quad$ B. R. foliolis plerumque alternis, ramulis glabriusculis. On the high mountains of Virginia and Carolina. $\zeta$. May-Sept. $v \cdot v$. Flowers large, a benutiful rosecolour, inodorous. This elegant little shrub is one of the highest ornaments of our gardens and plantations. The var. $\beta$. is less hispid, and grows to a considerable large upright shrub, whereas the original hispida is a low straggling plant.

\section{INDIGOFERA. Gen. pl. 1205.}

caroliniana. I. I. herbacea, erecta ; foliis pinnatis : foliolis obovalibus, spicis folio longioribus pedunculatis, floribus distantibus, leguminibus pendulis subdispermis reticulatovenosis.-W'alt. $f$ l. car. 187. Mich. fl. amer. 2. p. 68 .

In sandy fields: Carolina to Florida. 2f. v. s. Flowers blue. 
590. TEPHROSIA. Pers.syn. 2. p. 329.

1. T. erecta, candicanti-rillosa; foliolis $(17-21)$ ovall- virginiana. oblongis acuminatis, racemo terminali brevi subsessili, leguminibus retrofalcatis villosis, calycibus lanatis.Pers. syn. 2. p. 329.

Galega virginiana. Pluk. alm. t. 23.f. 2.

In sandy and dry woods: Canalla to Florida. 24. June, July. v. $v$. About a font high ; fowers very handsome, rose-coloured and yellowish white.

2. T. prostrata, pubescens; foliis pinnatis quinis subsessili- chrysophylia. bus : foliolis cuneato-obovatis obtusissinis supra glabris, subtus sericeis, pedunculis oppositifoliis elonga. tis sub-3-floris, leguminibus rectiusculis.

Galega villosa. Mich. fl. amer. 2. p. 67?

In Georgia. Enslen. 4. July, Aug. v. s. in Herb. Enslen. Flowers purple. The singular circumstance of the nearly sessile leaves, gives it the appearance of a trifoliate plant, the lower pair representing stipulæ. Though Michaux's description answers very well in any other respect, I was led to doubt by his not mentioning the number of leaves, which is one of the most striking characters.

3. T. gracilis, hunifusa, pubescens ; foliolis $(13-15)$ oblongo-ellipticis truncato-obtusis mucronatis, peduncuhispidula. lis oppositifoliis elongatis 3-5-floris, leguminibus oblongis falcatis hispidis.

Galega hispidula. Mich. $f$. amer. 2. p. 6s.

Galega spicata. W'alt. fl. car. 188.

In pine-woods and on slate-hills: Virginia to Georgia. 4. July-Sept. v.v. Flowers pale red.

\section{LOTUS. Gen.pl. 1212.}

1. L. foliis ternatis subsessilibus oblongis acutis sericeo-vilsericeus. losis, pedunculis axillaribus unifloris folio longioribus, flore unibracteato, calycinis laciniis linearibus, legumine glabro longissimo.

On the banks of the Missouri. ๑. v. s. Flowers yellow. 


\section{MEDICAGO. Gen. pl. 1214.}

lupulina.

1. M. spicis ovalibus, leguminibus reniformibus monospermis stipulis integerrimis, foliolis obovatis, caulibus procumbentibus.-lVilld. sp. pl. 3. p. 1406.

Icon. Schkuhr hand'b. t. 212.

In gravelly soil, on road sides: Canada to Carolina.

June-Sept. $v . v$. Flowers small, yellow.

intertexin. 2. M. pedunculis subbifloris, leguminibus cochleatis ovalibus, aculeis pubescentibus setaceis distichis adpressis, stipulis ciliato-dentatis, foliolis obovatis dentatis.IVilld. sp.pl. 3. p. 1411.

M. polymorpha intertexta. Sp. $p l .1098$.

Icon. Si hkuhr handl. 212. $b$.

In sandy fields: Carolina. July, Aug. v.v. Flowers yellow.

Note.-In addition to the observations under $P_{\text {soralea }}$ esculenta, p. 475 . it may be interesting to state, that A. B. Lambert, Esq. raised in the summer of 1812 a number of plants, the seeds of which were taken out of a specimen collected in the year 1805 by M. Lewis, Esq. Also, that this highly interesting plant is now growing at Messrs. Frasers, Sloane Square. 


\section{SYNGENESIA.}

\section{I. $\mathbb{E} Q U A L I S$. \\ * Ligulate.}

593. CICHORIUM. Recept. subpaleacenm. Pappus polyphyllus, paleaceus. Cal. calyculatus.

594. APARgia. Recept. nudum. Pappus plumosus, sessilis. Cal. imbricatns.

595. SCORZONERA. Recept. nudum. Pappus plumosus, substipitatus. Cal. imbricatus, squamis margine scariosis.

596. LEONTODON. Recept. nudum. Pappus plumosus, stipitatus. Cal. imbricatus, squamis laxiusculis.

597. CHONDRILLA. Recept. nudum. Pappus pilosus, stipitatus. Cal, calyculatus. Flosculi multiplici serie. Sem. rugosa.

598. PRENANTHES. Recept. nudum. Pappus simplex, subsessilis. Cal. calyculatus. Flosculi simplici serie.

599. LACTUCA. Recept. nudum. Pappus simplex, stipitatus. Cal. imbricatus, cylindricus, margine membranaceo. Sem. lævia.

600. SONCHUS. Recept. nudum. Pappns pilosus, ses. silis. Cal. imbricatus, ventricosus.

601. HIERACIUM. Recept. nudiusculum. Pappus simplex, sessilis. Cal. imbricatus, ovatus.

602. KRIGIA. Recept. nudum. Pappus membranaceus, 5-phyllus, setis 5. iterstinctis. Cal. polyphyilus, simplex.

603. HYOSERIS. Recept. nudum. Pappus duplex : exterior capillaceus; interior paleaceo-aristatns. Cal. calyculatus.

604. TROXIMON. Recept. nudum, puncticulatum. Pappus pilosus, sessilis. Cal. oblongus, conicus, simplex, aut squamis inæqualibus imbricatus. 
** Flosculos $a$.

605. STOKESIA. Recept. nudum. Pappus 4-setosus. Ca?. foliaceus, subimbricatus. Cor. radiata : corollulis radii infundibuliformibus, irregularibus.

606. ARCTIUM. Recept. paleaceum. Pappus setosopaleaceus. Cal. globosus: squamis apice bamis inflexis.

607. C: ICUS, Recept. villosum. Pappus plumosus. Cal. imbricatus, ventricosus.

60s. CARDUUS. Recept villosum. Pappus capillaris. Cal. imbricates, ventricosus.

609. LIATRIS. Recept. nudum. Pappus plumosus, coloratus. Cal. oblongus, imbricatus.

6io. VERNONIA. Recept. nudum. Pappus duplex : exterior paleaceus, brevis; interior capillaris. $\mathrm{Cal}$. ovatus, imbricatus.

611. KUHNIA. Recept. nudum. Pappus plumosus. Cal. imbricatus, cylindraceus.

612. EUPATORIUM. Recept. nudum. Pappus pilosus. Cul. imbricatus, cylindricus. Stylus semibifidus, longus.

613. MiKANIA. Recept. nudum. Pappus pi'osus s. plumosus. Cal. 4-6-phyllus, 4-6-florus. Stylus semibifirlus, longus.

614. CHRY :OCOM 1. Recept. nudum. Pappus pilosus. Cal. imbricatus. Stylus vix flosculis longior.

615. CACALIA. Recept. nudum. Pappus pilosus. Cal. cylindricus, basi calyculatus.

616. SPARGANOPHORUS. Recept. nudum. Sem. coronatum cupula subcartilaginea, integerrima, nitida. Cal. subglobusus, imbricatus: squamis apice recurvatis.

617. HYMENOPAPPUS. Reccpt. nudum. Pappus polypliyllus, paleaceus. Cal. polyphyllus, patens.

618. MELANANTHERA. Recept. paleaceum : paleis flosculos inferne amplexantibus. Pappus aristis inæqualibus, 4-5-inermibus. Cal. imbricatus: squamis ovatis, appressis, subæqualibus.

619. MARSHALLIA. Rerept. paleaceum. Puppus paleis 5. membranaceis, acuminatis. Cal. imbricatus : squa. mis sublanceolatis incumbentibus.

620. SANTOLINA. Recept. paleaceum. Pappus nullus. Cal. imbricatus, hemisphæricus : squamis carinatis apice scariosis. 


\section{SUPERFLUA.}

* Discoidei.

621. ARTEMISIA. Recept. subnudum. Pappus nulhs. Cor. radii nullæ. Cal. imbricatus : squamis rotundatis, conniventibus.

622. TANACETUM. Recept. nudum. Pappus submarginatus. Cor. radii obsoletæ, 3-fidæ. Cal. imbricatus, hemisphæricus: squamis acuminatis.

623. BACCHARIS. Recept. nudum. Pappus pilosus. Floscul. feminei bernaphroditis immixti. Cal. imbricatus, cylindricus : squamis ovatis subcoriaceis.

624. CONYZA. Recept. nudum. Pappus simplex, capillaris. Cor. radii 3-fidæe. Cal. imbricatus : squamis linearibus aut ovatis.

625. GNAPHALIUM. Recept. nudum. Pappus plumosus. Cal. imbricatus: squamis narginailibus rotundatis, scariosis, coloratis.

\section{** Radiali.}

626. BELLIS. Recept. nudum. Pappus nullus. Cal. hemisphæricus : squamis æqualibus. Sem. obovata.

627. CHRYSANTHEMUM. Recept. nudum. Pappus nullus. Cal. hemisphæricus, imbricatus; squamis intimis scariosis.

628. PYRETHRUM. Recept. nudum. Prppus marginatus. Cal. squamis acutiusculis margine scariosis.

629. ARNICA. Recept. nudum. Pappus simplex, pilosus. Cal. hemisphæricus; foliolis subæqualibus disco longioribus. Cor, radii (luteæ) sæpius filamentis 5. absque antheris.

630. CINERARIA. Recept. nudum. Pappus simplex. Cal. simplex, polyphyllus, æqualis.

631. SENECIO. Recept. nudum. Pappus simplex. Cal. cylindricus, calyculatus : squamis apice sphacelatis.

632. TUSSILAGO. Recept. nudum. Pappus simplex. Cor. femineæ ligulatæ s. edentulæ. Cal. simplex : squamæ æquales, discum æquantes, submembranaceæ.

633. INULA. Recept. nudum. Pappus simplex. Cal. imbricatus. Cor, radii numerosæ (luteæ).

634. ERIGERON. Recept. nudum. Pappus pilosus, Cor. radii capillares (coloratæ). 
635. SOI.IDAGO. Recept. nudum, punctis exaratum. Pappus simplex. Cor. radii circiter 5. (flavæ). Cal. squamæe in bricatæ, clausæ.

636. ASTER. Receft. nucium, scrobiculatum. Pappus pilosus. Cor. radii plures, sæpin!s 10. (ant pauciores, colorati). i.al. imbricati squamæ inferiores patulæ.

637. DONIA. Rectpt. nutum, favosum. Pappus 3-4aristatus, deciduus. Cor. radii plures ( $30-35$ fiavi). Cal. hemispharicus, imbricatus : squamis interioribus cartilagineis, coloratis.

638. BOEBERA Recept. nudum. Pappus pilosus. Cal. duplex : exterior polyphyllus, interiur octophyllus.

639. ACIINELLA. Recept nudum. Pappas poiyplyyllus $(4-6)$, paleaceo-aristatus. Cal. polyphyllus, $x$ qualis.

640. HeLenIUM. Recept.nudum : radii palenceum. Pappus 5-aristatus. Cor. radiis 3-fidis. Cal. simplex, multipartitus.

641. BOLTONIA. Recept. favosum. Pappus dentatoaristatus : aristis duabus oppositis interdum elongatis. Cor. radii plurimæ. Cal. imbricatus.

642. SIEGE BECKIA. Recept. paleaceum. Pappus nullus. Rudius dimidiatus. Cal. exterior 5-phyllus, proprius patens. Sem. sub-4-gona.

643. PHATHUSA. Recept. paleaceum. Pappus nullus. Flosculi radii 1-3. Cal. inbricatus. Sem. hispida.

644. ECLIPTA. Recept. paleacenm. Pappus uullus. Cor. disci 4-fidæ. Sem. subcompresso-marginata, obsolete 2-3-centata.

645. ANTHEMIS. Recept paleaceum: paleis planis, apice acuminatis, rigidis. Pappus nullus s. margo membranaceus. Flores radii plures quam 5 . Cal. hemispharicus, subæqualis.

646. ACHILLEA. Recept. paleaceum. Pappus nullus. Flosc. radii circiter 5., dilatati. Cal. ovatus, imbricatus. (Flores corymbosi.)

647. TETRAGONOTHECA. Recept. paleaceum. Pup. pus nulius. Cal. monophyllus, 4-gonus, 4-partitus;, latissimus.

648. HE! IOPSIs. Rerept. paleaceum, conicum. Pappus nullus. (or. radii lineares, magne. Cal. imbricatrs: squanis ovatis, lineatis. Sem. 4-gona.

649. BUPHTHALMUM. Recept. paleaceum. Pappus nargo obsoletus s. 4-dentatus. Cal. foliaceus, Sem. la. tera, presertion radii, marginata. 
650. AMelluS. Recept. paleaceum. Pappus pilosus. Cor. radii indivisæe $\quad$ al. imbricatus.

651. VERBESINA. Recept paleaceun. Pappus aristatus. Flose. rali circier 5. Cal. duplici ordine.

652. ZINNIA. R cept. palesceum. Pappus aristis 2. erectis. Railu: $:$-Porus, persistens. Cal. imbricatus, ovato-cylindricus.

\section{FRUSTRANEA.}

653. BIDENS. Recept paleaceum: paleis extimis quasi ca'ycem communem constituentibus. Papbus aristis 2. s. 4. retrorsum. Flores flosculosi aut etian radiati : radiis neutris aut imperfecte masculis. $\mathrm{Cal}$. subæaualis, calyculatus.

654. COREOPSIS. Receft. et Cal. comm. Bidentis. Fiores rucliati : radiis neutris, prolixis (iuteis). Sem. compressa aut emarginda, aut bidentata, ant etiam bisetosa: setis inermibus nec retrorsun aculeatis.

655. HElit NTHUS. Recept. paleaceum, pianum. Pappus ciiphyilus, caducus. C'al. inbricatus, subsquarrosus, foliticeus

656. GALARDiA Recept paleaceum, hemisphæricum. Papisus paleaceus, polyphyllus. Cor radii 3 -partitæ. Cal. pol! phyllus, planus.

657. RUDBECKiA. Recept. paleaceum, conicum. Pappus margine 4-dentato. Cal. duplici ordine squamarum.

658. CENTAUREA. Recept. setosum. Pappus pilosus. Cur. radii infundibulitormes, irregulares. Cal. varius.

\section{NECESSARIA.}

659. CHAPTALIA. Recept. nudum. Pappus capillaris. Flosculi radii in duplici serie difformes, feminei. Flosculi disc i masculi bilabiati.

660. SILPHIUM. Recept. paleacenm. Pappus marginatob.cornis. Cal. squarrosus, foliaceus, Sem. compressa, obcordata, maryinata.

661 POLYMNIA. Recept. paleaceum. Paptus nullus. Cal. dupiex : exterior 4-5 phyllus; interior 10-phy]lus, foliolis concavis.

662. CHRYSOGONUM. Recept. paleaceum. Pappus 1- 
phyllus, 3-dentatus. Cal. 5-phyllus. Sem. calyculo 4-phyllo involuta.

663. BALTIMORA. Recept. paleaceum. Pappus nullus. Flosc. radii 5. Cal. cylindricus, polyphyllus. Sem. 3-quetra.

664. PARTHENIUM. Recept. paleaceum, planum. Pappus nullus. Cal. 5-phyllus. Sem. obovata.

665. IVA. Recept. pilosum. Pappus nullus. Cor. radii 5. Antherce approximatæ, non coalitæ. Styli 2. longi. Cor. radii 5. femineis minimis. Cal.3-phyllus.

606. AMBrosiA. Monoica. Masc. Recept. nudum. Anthere approximatæ, non coalitæ. Cal. 1-phyllus, hemisphæricus, multiflorus. Fem. Cal. 1-phyllus, subinteger aut 5-dentatus, 1-florus. Cor. nulla. Styli 2. Nux e calyce indurato, 1-sperma.

667. XANTHIUM. Monoicum. Masc. Recept. paleaceum. Anthere approximatæ, non coalitæ. Cal. polyphyllus, imbricatus, hemisphæricus, nultiflorus. Fem. Cal. involucrum 2-phyllum, 2-florun. Cor. 0. Stigm. 2. Drupa sicca, nuricata, 2-fida. Nucleus 2-locularis.

\section{SEGREGATÁ.}

668. ELEPHANTEPUS. Recept. nudum. Pappus setacens. Calyculus 4 -florus. Corollulce ligulatæ, bermaphroditæ.

\section{I. $A Q U A L I S$.}

\section{CICHORIUM. Gen. pl. 1251.}

Intyius. 1. C. floribus axillaribus geminis subsessilibus, foliis runcinatis. Willd. sp. pl. 3.p. 1624.

Icon. Fl. dan. 907. Engl. bot.539.

In fields and on road sides: Pensylvania, near Philadelphia. Most certainly introduced from Europe. 4. July, Aug. $v \cdot v$. Flowers beautiful blue. 
504. APARGIA. Gen.pl. 1232.

1. A. scapis ramosis declinatis squamosis, foliis lanceolatis autumnalis. runcinato-pinnatifidis glabriusculis. Willd. sp. $\mu l .3$. p. 1550.

Leontodon autumnale Sp.pl. 1123.

Hedypnois autumnalıs. S.mith fl. lrit. 2. p.826.

Icon. Fl. dan.501. Engl. bot. 830.

In pastures and on road sides : New England. 24. Aug. Sept. $v . v$. Flowers golden-yellow, outside red. It is probably an introduced plant.

\section{SCORZONERA. Gen. pl. 1230.}

1. S. caule erecto 3 -floro, pedunculis elongatis, foliis lanpinnatifida. ceolatis acurissinis acute-pinnatifidis interdum rariter dentatis. Wich. fl. umer. 2. p.89.

Leontodon carolinianum. Walt. fl. car. 102. In waste places: Carolina. Michaux. t.

\section{LEONTODON. Gen. pl. 123\%.}

3. L. calyce exteriore reflexo, scapo unifloro, foliis runciTaraxacum. natis glabris, laciniis lanceolatis dentatis. IVilld. sp. pl.3. \$. 15+4.

Icon. Fl. dan. 574. Engl. lot. 510.

Common in fields and grass piots; probably introduced. 4. April-July. v. v. Flowers yellow; it is generally known by the name of Dandelion. There is another speces, found in shady wet wools, which I consider indigenous, but I have no materials in hand to give its description.

\section{CHONDRILLA. Gen. pl. 1235.}

1. C. glaberrimum, multicaule; folis lineari-lanceolatis inlavigata. tegerrimis, pedunculis 2-3. longissimis subaphyllis unifloris.

In Lower V'irginia. $\precsim$. Aug. Sept. v. v. Flowers bright yellow; pappns turns a pale red; the peduncles are from six to ten inches long, with a few linear, small leaves. 


\section{5.)8. PRENANTHES. Gen. $p l .12 j 0$.}

juncer.

aitissina.

irdata.

virgata.

$\therefore$ mpiex.
1. P. caule virgatim-ramosissimo sulcato glabro, foliis caizlinis remotis subulatis brevissimis, ramulis unifloris, calycibus 5-fidis 5-floris: foliolis nargme membranaceis.

On the banks of the Missouri. 2f. v. s. Flowers purple; it ha ; a striking resemblance to Chondrilla juncea; but the leaves are shorter, and the pappus entirely sessile; the radical leaves I have not seen.

2. P. caule ramoso, foliis trilobis petiolatis angulatis denticulatis margine scabris, racemis axillaribus, floribus nutantibus, calycibus sub.5-floris.-Willd. sp. pl. 3. p. 1537.

Icon. Pluk. alm.t.317.f. 2.

In shady woods: Canada to Virginia. 24. July-Sept. $v v v$. Flowers yellow. Generally a very tall robust plant.

3. P. canle superne paniculato, foliis petiolatis cordatis dentatis ciliatis, foralibus sessilibus oblongis integerrimis, panicula laxa raceniflora, floribus mutantibus, calycibus 6-fidis 6-floris.-W Willd. hort. lerol. 25.

In shady woods, about rocks; New York to Virginia. 4. Aug.-Oct. $v, v$. llowers pale yellow. It is an intermediate species between the preceding and P.alla.

4. P. glabra; canle simplicissimo, foliis omnibus lyratosinuatis, racemulis subsecundis, floribus pendulis, calycibus glabris 8-fidis 10-floris.-Mich. fl. amer. 2. p. 83.

P. autumnalis. Walt. fl. car. 193.

In sandy fields, near ditches: New Jersey to Carolina. 21. Aug. Sept. v. v. From three to six feet; flowers palc purple. This plant has a very fine effect in large piantations. Michaux quotes Gronovius; but his $P$. autumatis belongs to $P$. ruticunda.

5. P. caule simplicissimo, foliis superioribus lineari-lanceolatis integerrimis, radicalibus lanceolatis sinuatis, racemo terminali simplicissimo, foribus nutautibus, calycibus sub-S-Aoris.

P. virgata. W ilid. sp. p/.3. p. 1533.

In Carolina. Enslen. 24. Iuly, Aug. v. s. in Herl. Enslen. About two fcet bigh; flowers purple. 



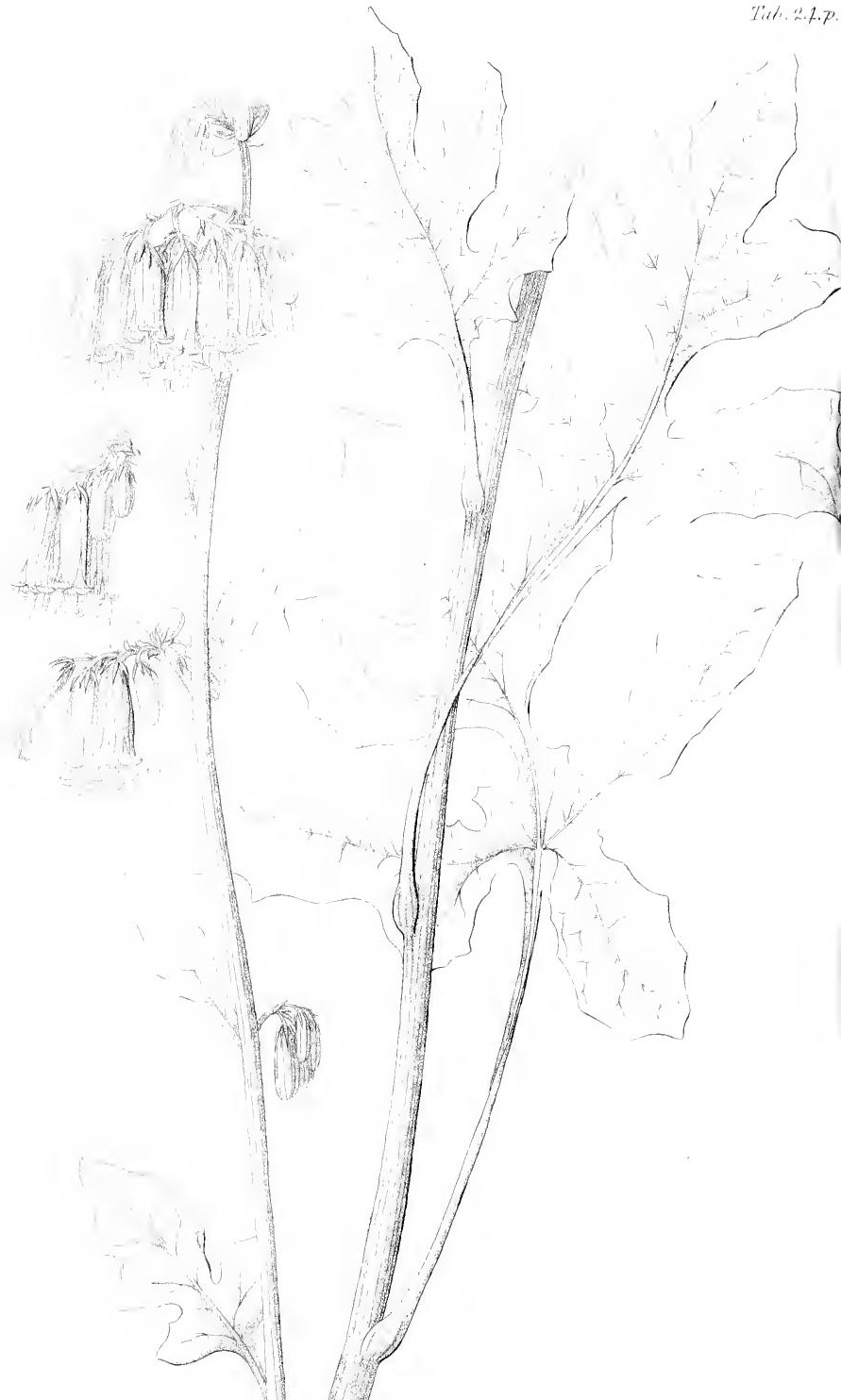


0. P. foliis lato-lanceolatis in petiolum attenuatis inæqualiter crepidina. angulato-dentatis, panicula fasciculis terminalibus paucifloris nutantibus, calycibus lirsutis $10-12$-fidis sub-20-floris.-Mich. Al. amer. 2. p. S4.

In Illinois and on the high mountains of Carolina. NFichaux. 4. +.

7 P. foliis radicalibus angulato- hastatis dentatis sublobatis; alla. caulinis subrotundo-ovatis dentatis petiolatis, summis lanceolatis, panicula laxa, fasciculis terminalibus nutantibus, calycibus 8-fidis 9-10-foris.-Wille. $s \%$. pl. 3.p. 1536.

P. suavis. Parad. lond. 85.

Icon. Bot. mag. 1079.

In shady woods : New England to Carolina. 24. Ang. Sept. $v . v$. About two feet high; calyces purple, flowers white.

8. P. foliis ciliatis, radicalibus hastato-angulatis subintegerrimis, inferioribus obovatis basi attenuatis subangulatis, summis lanceolatis integerrimis, racemo simplici, thoribus nutantibus. - Willd. sp. pl. 3. p. 1537.

P. alba f. Sp. pl. 1122.

P. autumnalis. Gron. fl.virg. 1.p. 89.

In shady woods: Pensylvania to Carolina. 4. Aug.Oct. $v . v$. Resembles the preceding; not above eighteen inches high.

9. P. foliis dentatis asperis, radicalibus palmato-sinuatis,

Serpentarin. caulinis longe petiolatis sinuato-pinnatifidis subtrilobis: lacinia intermedia 3-partita, summis lanceolatis, racemis terminalibus subpaniculatis brevibus nutantibus, calycibus S-fidis 12-floris.

On the mountains of Virginia and Carolina. 2\%. Aug. -Oct. v. v. About two feet high; flowers pale purple. This plant is known by the inhabitants under the name of Lion's-foot, and is in high esteem as is specific in curing the bite of the rattlesnake. During my travels through the mountains of Virginia. I had an opportunity of being a witness of the efficacy of this remedy. A man living in Cove-mountains, near the Sweet-springs, was bit in the foot by a Mocassin snake, a species considered the most dangerous. An inflammation and swelling of his whole leg took place immediately ; but by taking the milky juice of this plant boiled in milk, inwardly, and applying to the wound the steeped leaves, which were very frequently changed, be was cured in a few days. As this plant deserves

rubicunda. 
the attention of the physician, I have given a figure of it, it being frequently confounded with another species of this genus, which probably may not have quite so strong an effect, as the inbabitant; are very careful to have the true Lion's-fvot, in case of accidents happening, and usually call the other species of Prenanthes False Lion's-foot. Gronovius, in his Flora, pag. 113, mentions Dr. Witt's Snake-root under P. auiumnalis or Willdenow's rubicunda, as a remedy for the bite of the rattlesnake; which shows that he had information of the use made of this plant, though he did not know the genuine species. In the Canksian Herbarium is a specimen of $P$. rubicunda, with the following note in the hand-writing of Clayton: "This is the rattlesnake-root that Dr. Witt supposes to be the best cure for the bite of the snake, a very odd plant, hardly two leaves alike upon a plant, as to strape or the indentings of the leaves."

racemosa. 10. $\mathrm{P}$. caule simplici, foliis omnibus indivisis lævibus, radicalibus ovali-lanceolatis, caulinis semiamplexicaulibus, racemo oblungo hirsutissimn, fasciculis cernuis, calycibus 3-9-partitis 9-12-floris. Mich. fl. amer. 2. p. 84 .

In the northern parts of Canada. Michaux. + .

illinoensis. 11. P. caule simplici, foliisque asperrinis, foliis omnibus indivisis ovali-lanceolatiss, raceno longo, fasciculis sub. sessilibus erectis hirsutis. Pers. syn. 2.p. 366.

P. aspera. Nich.fl. amer. 2. p. 83 .

In natural meadows in the Illinois country. Michaux. + .

\section{LACTUCA. Gen. pl.1234.}

elongata. 1. L. foliis subtus lxvibus, inferioribus runcinatis integerrimis amplexicaulibus, infimis dentatis, summis lanceolatis, floribus corymboso-paniculatis. Willd. enum. 817. Willd. sp. pl.3.p. 1525.

L. longifolia. MIich. Al. amer. 2. p.s5 ?

In woods, on road sides, in fertile soil : Canada to $\mathrm{Ca}$. rolina. $\succsim$. Aug. Sept. v. v. From three to six feet high. Elowers snall, pale yellow.

graminifolia. 2. L. caule erecto simplici, foliis inernibus plerisque indivisis basi simplici longissime linearibus, panicula aphylla laxa, ramis rarifioris, floribus omnibus pedun. culatis. Mich.fl. amer. 2.p. 85.

In Lower Carolina. Michaux. +. 


\section{SONCHUS. Gen.pl.1233.}

1. S. pedunculis calycibasque hispidis subumbellatis, foliis arvensis. runcinatis denticulatis basi cordatis, radice repente. Snith fl. brit. 2. p. 81,. IVilld. sp.pl.3.p. 1512. Icon. Engl. lot. 674. Curi. ft. lond.53. Among rubbish and in cultivated grounus: Pensylvania. 4. Aug. Sept. v. v. Flowers large, deep yellow.

2. S. pedunculis subtomentosis umbellatis, calycibus glabris, oleraceus. foliis oblongo-lenceolatis amplexicaulibus denticulatis subsinuatis. IVilid. sp.pl. 3.p. 1514.

Icon. Fl. dan. 682. Curt.fl. lond. 58.

A common weed in most gardens and fields. $\odot$. July

-Sept. v.v. Flowers yellow.

3. S. pedunculis hirsutis nudis, floribus paniculatis, foliis macrophyllus. lyratis basi cordatis subtus hirtis. Willd. sp. pl. 3 . p. 1519 .

S. canadensis. Frolich. in usteri annal. 1.p. 29.

Chondrilla sylvestris alta. Gronov. virg. 115.

In shady low grounds, near springs : Pensylvania to $\mathrm{Ca}$ rolina. 24. Aug. Sept. v. v. From four to seven feet high; flowers blue, the size of Cichorium Intylus; root tuberous.

4. S. pedunculis hirsutis nudis, floribus racemosis bracteatis, alpinus. foliis runcinatis basi sagittatis glabris subtus glaucis. Willd.sp.pl.3.p. 1519 .

S. montanus. Lam. encycl. 3. p. 401.

S. cæruleus. Smith fl. brit. 2. p. 815.

S. canadensis. Sp. pl. 1115 .

Hieracium cæruleum. Scop. fl. carn. n. 976 .

Icon. Fl. dan. 182.

In Canada. 4 . Aug. Sept. v.s. Flowers blue, and sometimes white.

5. S. pedunculis squamosis, floribus racemosis, foliis run- leucophous. cinatis acuminatis, caule paniculato-virgato. Willd. sp.pl. 3. p. 1520 .

S. spicatus. Lam. encycl.3.p. 401.

On the borders of woods, on road sides: New England tc Virginia. of. July-Sept. v. v. Flowers small, white, tinged with blue.

6. S. pedunculis subsquamosis, floribus paniculatis, foliis ly- floridanus. rato-runcinatis denticulatis petiolatis. - IVilld. sp. pl.3. p. 1520. 
On road sides, in shady woods: Virginia and Carolina. o. July-Sept. v. v. Flowers very small, blue. This plant has been used for curing the bite of the rattlesnake, in the same manner as Prenanthes Serpentaria, and is known by the name of Gall of the Earih.

acuminatus. 7. S. pedunculis subsquamosis, floribus paniculatis, foliis radicalibus subruncinatis, caulinis ovatis açuminatis petiolatis medio denticulatis. - Willd. sp. pl. 3. p. 1521 .

Lactuca villosa. Jacq. hort. schœenb. 3. t. 367 ?

In low shady places: Pensylvania to Virginia. 8 . Aug. Sept. $v . v$. Flowers small, blue.

pallidus. 8. S. racemo composito terminali, foliiis lanceolato-ensiformibus amplexicaulibus dentatis. Willd.sp. pl. 3. p. 1521 .

Lactuca canadensis. Sp. pl. 1119 .

Icon. Rol. ic. 148 E' 151.

On road sides and in woods: Canada to New England 4. July-Sept. v.v. Flowers small, yellow.

pulchellus. 9. S. pedunculis squamosis, floribus corymboso-racemosis, foliis caulinis cordato-amplexicaulibus ovato-oblongis acutis integerrimis glabris.

On the banks of the Missouri. 24. Sept. v. s. Flowers large, beautiful blue.

\section{HIERACIUM. Gen.pl. 1238.}

fiusillum. 1. H. pusillum, villosissimum; caule simplici erecto unifloro remote subbifoliato, foliis lanceolatis attenuatis acutis integerrimis, caulinis linearibus, calyce villosissimo..- Il illd. sp. pl. 3. 1561 .

In Labrador. Colmaster. 4 . July. v. s. in Herl. Dictson. A yer: small plant; flowers, as in ail the following species, ye low, the size of a common daisy. It strongly resembies $H$. alpinum, and is probably only a diminutive variety thereof.

venosum. 2. H. scapo nudo cor: nibcso-paniculato glabro, pedicellis fihformiitus, feiis otovato-ianceolatis supra rariter piJosis, subius nudis mangine riliatis glanduloso denticulatis, venis coloratis, calycibus glabris.-Willd. $s p$. pl. 3. p. $15 \% \mathrm{C}$.

In shady ferrile woods: Canada to Carolina. 24. June -Aug. v. v. Flowers middle size, of a beautiful 
yellow; the light green leaves are clegantly marked with blood-red veins. It is known by the rame of Poor Robin's Plantain, and thought to pos:ess considerable medicinal powers.

3. H. scapo folinso corymbo:o-paniculato, calycibus pedunculisque ryandulos(s-pilosis, foliis obovatis oblasin integerrimic, supra rariter strigoso-villosis, nervo medio subtus villısissimo - - Willd. sp. pl. 3. p. 1570 .

a. H. caule subrnifoliato, panicula subfastigiata. Mich. $f$. amer. 2. p. 87.

B. H. caule parce folioso, panicula oblonga. Mici. l. c.

H. marianum. IV illd sp. pl 3.p. 15\%'2.

Icon. Pluk. mant. t. 320 f: '2.

In woods and on dry hills: Canada to Carolina. 24. July, Aug. $v v$. Elowers small.

4. H. pilosum ; caule erecto simplici folioso, corymbo patl-

Gronovii. ciforo, roliis oblongo-lanceolatis attenuatis inferne pancelentatis, radicalibus petiolatis.-IVilld. sp. pl. 3 . p. 1577?

Icon. Jucy. austr.t. 119.

In Labrafor. Col naster. 24. July-Sept. v. s. in $H_{c l} l$. Dickson. Flowers middle size.

5. H. glabriuscultum ; caule erecto fnlingo paniculato inferne paniculatum. albo-lanato, perlicellis capillaribus, folits lanceolatis nudis dentatis membranaceis. - Willd. sp. pl. 3. p. 1572 .

In sbady wonds: Canada to Carolina; mincipally on the numantains. 2\%. July-ept. $v, v$. Flowers very small.

6. H. eanle erecto molifioro glabro, foliis subsessilibus lanKalmii。 ceolatis acuminaits s."orim argute deutatis, pedunculis in apice caulis an rais subuniturito tomentusis.Willd. spi pl. 3. p. :5er.

In Pensylvania. Kutm. +. Flowers smail, upright, leaves snall. It is siagular, that in n ' part of North America could I fint a plant anseveriig to this doscription given by Limatus.

7. H. caule erecto simplici villoso, foilis sessilibus lanceolatis acutis glabris subtus pilosis margine cilvaicatovirgatum, argute-dentatis versus apicem integer! imis: denibus divaricatis, panicula sulbory mbosa, calyciuits pedunculisque tonsentosis. - - L $r$ intert. he:b $\mathrm{m}$.

H. canadense. Mich. fl. amer. 2. p. 86?

In the western part of New York and Canada. 4. 
July-Sept. v. v.; v. s. in Herb. Lamlert. Flowers middle size.

fasciculutun. 3. H. glabriusculum ; caule erecto folioso simplici glabro; foliis sessilibus oblongis acutis argute-dentatis: dentibus elongatis, ramis paniculæ divaricatis brevibus, pedicellis subfasciculatis pubescentibus.

In Canada. Masson. 24. v. s. in Herl. Lambert. A tall robust plant; flowers middle size.

scallum. 9. I. hirsutissimum; canle erecto folioso hispido punctis fuscis scaberrimo, foliis oblongo-ovatis integris utrinque hirsutis, paniculia simpliciuscula multiflora calycibusque glanduloso-hispidis, pedicellis brevibus divaricatis.-Mich. $f$. amer. $2 . p$. 86.

In woods, in shady, rocky situations: Pensylvania. 24. Aug. Sept. v, $v$. From three to five feet high; flowers small.

maerophyl- 10. H. altissimum ; caule erccto folioso hispido sulcato, folum. liis cordato-semiamplexicaulibus ovato-oblongis remote grosse-dentatis nudiusculis, nervis venisque subtus pubescentibus, panicula divaricato-corymbosa, pedunculis elongatis nudis calycibusque glabris.

In Canada. 24. v. s. in Herb. Lamlert. A very robust plant; leaves the largest of the genus; flowers large.

602. KRIGIA. Gen. pl. 1244.

virginica.

1. K. pusilla ; foliis lyratis glaucis glabriusculis margine ciliatis, scapo 1 -floro foliis duplo altiore, calyce sub-8. phyllo.-Willd. sp. pl. 3. p. 1618.

Hyoseris virginica. Sp. pl. 1138.

Icon. Lam. journ. hist. nat. 1. t. 12.

In pastures, grassy hills, fields, and road sides : Canada to Florida. $\odot$. May-July. v. v. Flowers deep yellow, small.

\section{HYOSERIS. Gen.pl. 1242.}

nontana.

1. H. glaberrima, procumbens ; foliis lanceolatis integerrimis, seapo 1-floro. - Mich. fl. amer. 2. p. 87.

In the mountains of Carolina. Michaux. +.

angustifolia. 2. H. foliis lineari-lanceolatis sensim acutissimis glabellis, dentibus rarioribus exertis, scapo 1-floro. Mich, $f$. amer. 3. p. 87.

Hyoseris major. Walt. fl. car. 194. 
SYNGENESIA RQUALIS. Hyoseris.

In fields and pastures. Virginia and Carolina. $\odot \cdot \hat{\delta}$. July, Aug. v. v. Flowers large, bright yellow.

3. H. foliis lyratis basi acutis superne dilatatis apice trunca- caroliniana. tis hirsutis, scapis 1-floris. - Iralt. fl. car. 19t.

In Carolina. Walter. + .

604. TROXIMON. Gart. carp. 2. p. 3Go. Pers. syn. 2.

$$
\text { p. } 360 \text {. }
$$

1. T. scapo uniforo, calycinis follolis imbricat is cuspidatis,

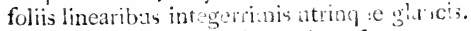

On the banks of the Hissouri. on. v. s.; v. v. in Hortis. Flowers bright yellow.

2. T. glabrum, glaucum ; caule erecto 2-3-filo subnudo, foliis glabris, radicalibu; sublyratis, caulisis amplexicaulibus lanceoluns integren rimis glabris.-Pers. syn. 2. p. 260 .

Hyoseris amplexicaulis. Mirh. $f$ amer 2.p. 87 .

Hyoseris prenanthoides. IVlld sp.pl. 3. p. 1615.

Hyoseris billora. Walt. fl. car. 194 .

Tragopogon virginicum. Sp.pl. p. 1111.

In meadows and moist shady woods: Pensylvania to $\mathrm{Ca}$ rolina. 4 . July, Aug. v. v. About a foot high; flowers handsonie, yellow.

605. STOKESIA. L'Herit, sert. angl. 27.

1. S. foliis lanceolatis, caule folioso, pedunculis axillaribus glaucum。

virginicuns. 1-Horis.-Willd. sp. pl. 3.p. 1703.

Carthanus lævis. Fill. kw p. 57. t.5.

Icon. L'Herit. I. c. t. 38 .

In South Carolina. 4. v. s. in Herl. Banks. Flowers large, purple, very handsome.

\section{ARCTIUM. Gen.pl.1253.}

1. A. foliis caulinis cordatis petiolatis denticulatis. foribus paniculatis globosis, calycibus lævibus. - Willd. sp. pl. 3. p. 1631 .

Icon. Fl. dan. 642, Engl. bot. 1229.

On road sides, among rubbish, and in cultivated grounds; frequent. $\delta$. July, Aug. $v$. $v$. Flowers purple. Common Burdock. Has probably been introduced.

cyanea. 


\section{CNICUS. Gen.pl. 1255.}

lanceolatus. 1. C. foliis decurrentibus hispidis pinnatifidis, laciniis bilobis divaricatis spinosis, calycibus ovat is arachnoideo-pubescentibus, squamis lanceolatis spinosis patentibus. Willd. sp pl.3.p. 1666.

Carduus lanceolatus. $S p, p l .1149$.

On road sides; common every where. $\sigma^{\star}$. JuneSept. $v . v$. Flowers large, purple.

altissimus.

2. C. foliis sessilibus oblongo-lanceolatis scabris subtus tomentosis dentatis ciliatis, radicalibus pinnatifidis, calycibus bracteatis ovatis, squamis ovato-lanceolatis spinosis adpressis. Willd. sp.pl.3.p.1671.

Carduus altissimus. Sp. pl. 1154.

Carduus virginianus. Walt. l. car. 195.

Cirsium repandum. Mich. fl. amer. 2. p. 89 .

Cirsium altissimum. Gron. fl. virg. 117.

In old fields: Virginia and Carolina. 4. July-Sept. v. $v$. Flowers large, purple.

areensi: $\quad 3$. C. foliis sessilibus pinnatifidis glabriusculis ciliatis spinosis, caule paniculato, calycibus ovatis mucronatis, squanis lato-lanceolatis adpressis margine lanatis.

Carduus arvensis. Smith fl. brit. 2. p. 850.

Serratula arvensis, IVilld. sp. pl.3.p. 1646.

Icon. Fl. dan. 644. Engl. lot.975. Mart. fl. rust. 132. In fields and on road sides : Canada and New England. 4. July-Sept. $v . v$. Flowers small, purple. It is one of the most troublesome weeds, and when once introduced on a plantation it is almost impossible to get rid of it.

muticus.

4. C. foliis omnibus pinnatifidis subtus lanuginosis: laciniis spinulosis sublanceolatis acutis, ramis in summitate pluribus rudiusculis unifloris, calyce globoso, squamis muticis.

Cirsium muticum. Mich. Jl. amer. 2. p. 89.

Carduus carolinianus. Walt. $f$. car. 195.

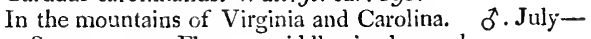
Sept. $v . v$. Flowers middle-sized, purple.

virginianus. 5. C. simpliciusculus; foliis sessilibus lanceolatis subtus cano-tomentosis remote dentatis, dentibus spinosis, floribus solitariis, calyce globoso, squamis mucronatis.

Carduus virginianus. Willd. sp. pl.3.p. 1659.

Cirsium virginianum. Mich.fl. amer. 2. p. 90 .

Icon. Jacq. obs. lot. 4. t.99. 
In the mountains of Virginia and Carolina. 4. JulySept. $v v$. Flowers purple.

6. C. elatius; foliis sestilibus pinnatifidis acute incisis spi-

horridulus. nosissimis, involucro terminali unifloro polyphyllo: foliolis geminatim spinosissimis, calycibus inermibus.

Serratula discolor. Lum. encycl. 6. p. 565.

Cirsium horriduinm. Mich. A. amer. 2. p. go.

Carduus spinosissinus. WValt. fu. car. $19^{4}$.

On the banks of rivers and borders of woods: Pensylvania to Carulind. 24. Jnly-Sept. v. v. Very tall; flower's large, pale yeliow.

\section{0s. CARDUUS. Gen. pl, 1254.}

1. C. inermis; foliis decurrentibus lanceolatis pinnatifido. pectinatis, pedunculis terminalibus ioncissimis unifloris subaphyllis, floribus defloratis cernuis calycinis squamis linearibus patulis.-Willd. sp. pl. 3. p. 1655. In Pensylvania. $\delta .+$. Flowers purple, the size of Arctium Lappa. It probably is a species of Cnicus.

\section{LIATRIS. Gen. pl. 1263. \\ * Spicata seu racemosa; bulbosa.}

1. L. caule simplici, elato; foliis linearibus glabris basi ciliatis nervosis et punctatis, spica longissina, floribus sessilibus, squanis calycinis lineari-oblongis obtusis appressis.-Mich. fl. amer. 2. p.91.

L. spicata. Willd. sp. pl. 3. p. 1636.

Anonymos graminifolius. Walt. fl. car. 197.

Serratula spicata. Sp. pl. 1147.

Icon. Bot. rep. 401. Pluk. alm. t.424.f.6.

In natural meadows: Pensylvania to Carolina. 4. Aug. -Oct. $v$. $v$. From three to six feet high ; flowers, as all the following species, purple, in very long and close spikes.

2. L. caule simplici hirsuto, foliis strictis angusto-linearibus pubescentibus, spica longa, floribus confertim sessilibus, calycibus appressis superne squarrosis.-Mich. $f$.

macrosta. chya.

pycnostachya. amer. 2.p. 91 .

Anonymos pilosa. Walt. fl. car. 197.

Icon. Dill. elth.t. 72.f. 83.

In mountain meadows : Virginia, Illinois, and Carolina. 4. Aug.-Oct. v. v. From two to four feet high; flowers smaller than No. 1. 
graminifolia. 3. L. caule simplici glabro, foliis linearibus longissimis glabris nervosis margine scabriusculis costa media interne stibpilosis, floribus spicatis remutiusculis subsessilibus, calycinis squarnis oblongis obrusis mucronatis ciliatis appressis, interioribus coloratis,-Willd. sp. pl. 3. p. 16.36 . exilus, :yn. Willeri.

Scrmatula compta. Herl: Brintis. mss.

In South Carolina and Genria. Bartram. 24. Aug.Oct. v. v. About two or three feet high; flowers the size of $\mathrm{No.2}$; haves very long and narrow.

hetcrophylla. 4. L. caule simplici glabro, twiis lanceolatis glabris lævibus : superioribus lin ari-lanceolatis muloties minoribus, calycibus spicatis brevissime pedunculatis subsquarrosis: squami lancenlatis acutis nud!s. - Willd. enum. 503.

I, varia $H$ r\% Bailks. mss.

In South Carulima and Georgia. Froser. Bartram. 4 . Atg._(Bct, v. s. in Hert. Bunks. nec non Lamlert. Howers the rize of the precedng.

asfera. 5. L. canle subramono scabro-pubescente, foliis linearilanceolatis asperrimis, calycibus brevibus spicatis distincte alternis solitariis sessilibus: squanis rotundatoobtusis conniventibus.--Mich. Al. amer. 2. p. 92 .

Anonymos ramosus. Walt. fl. car. 198.

In South Carolina and llinois. Wiatter. Michanx. 4. Aug. - Oct. v.s. Flowers Jarger than any of the foregoing species.

cylindracea. 6. L. gracilis, tota hiranta ; folis gramineis, spica rariflora, calycubus subsessitibue cylindraceis panciforis, squamis apice rotundatis abrupie mecronatis. Mich. fl. amer. 2. p. 93 .

In woods and meadow's of South Carolina and Illinois. 4. Aug. Sept. v. s. in Hol. Fraser.

pilosa.

7. L. caule simplici pubesconte, foliis linearibus pilosis ciliatis, calycibus racemosis luxiusculis : squamis linearioblongis obtusiusculis, pedicelits bracteolatis.-Willd. sp.pl.3. p. 1636.

Anonymos ciliatus. Walt. fl. car. 107.

In pine-barrens and sandy ficids: New Jersey to Carolins. 2. Sept.-Nov. v.v. A low species; flowers the size of No.2.

gracilis. 8. L. caule simplici glabro, foliis linearibus nudis, calycibus raccmosis subglobosis : squamis oblongis obtusiusculis appressis, pedicellis elongatis patentibus squamoso. bracteolatis. 
In Georgia. Barlram. Ang.-Oct. v. s. in Horl. Banks. Flowers smaller than any preceding species.

9. L. caule simplici villoso, foliis linearibus subfalcatis scaelegans. bro-punctatis, spica sulfoliosa, pedicellis brevibus, calycinis squamis intimis ligulatis coloratis. - IVilld. sp.pl. 3.p. 1635.

Serratula speciosa. Ait. keu. 3. p. 138.

Stæhelina elegans. Itúlt. fl. car. 202.

Eupatorium speciosun. Vent. hort. cels. 79 .

In sandy fields : Carolina to Florida. 24. Sept.--Nov. $v . v$. A beantiful perennial; flowers in long close spikes, purplish-red.

10. L. caule simplici pubescente, folis lævibus: inferioribus petiolatis lato-lanceolatis, superioribus lanceolato-linearibus, calycibus racemosis solitariis alternis subglo. bosis: squamis ovatis acutiusculis erectis, margine ciJiatis.-Mich. Al. amer. 2. p. 92 .

On high mountains of Virginia and Carolina. 2. Aug. -Oct. $v . v$. Flowers large and hands me.

11. L. caule simplici subpubescente, foliis lanceolatis utrinque attenuatis glabris margine scabris, calycibus racemosis alternis distantibus inferne squarrosis; squamis spathulatis margine membranaceo coloratis, - IFilld. sp.pl. 3.p. 1635.

L. squarrulosa. Mich. fl. amer. 2.p. 92.

Serratula scariosa. $S p . p l .1117$.

Icon. Pluk alm. t. $177 \cdot f .4$.

In mountain meadows: Virginia to Carolina. 24. Aug. -Oct. v. $v$. Flowers the size of No. 10.

12. L. caule simplici pubescente, foliis longissinue linearibus nervosis margine scabriusculis, racemis paucifloris foliosis, calycinis squamis superne foliaceis lanceolatis rigidis patentibus.-Willd. sp. pl.3.p.1634.

Serratula squarrosa. Hort. cliff. 392.

Pteronia caroliniana. Walt. fl. car. 202.

Icon. Dill. elth. t. 71.f.82.

In sandy woods and fields: Virginia, Kentucky, and Carolina. 21 . Sept. Oct. v. v. Flowers large, very handsome. This and the preceding are known among the inhabitants of those countries by the name of Rattle. snake's Master. In case of being bit by this horrible animal, they bruise the kulbs of this plant and apply it to the wound, while, at the same time, they make

spharoidea.

scariosa. 
a decoction of it in milk, which is taken inwardly, in the sane manner as I have mentioned under Prenanthes serpentaria.

\section{* Paniculaire seu corymbosa ; non bulbosa.}

pauciflora. 13. L. caule simplici glabro; fllis linearibus, panicula virgata toilosa, ranis brevibus paucilloris, calycibus subsessilibus secundis $3-5$-floris: squanis erectis lanceolatis acutio glabris.

In Georgia. Bartram. 4. v. s. in Herb. Banks, Flowers small, the size of No. 4 .

paniculata. 14. L. caule simplici panicula calycibusque piloso-viscosis, folii, inferioribus lanceolatis attenuatıs nervosis głabris: canlinis minoribus sessilibus, panicula coarctata fasciculati, calycibus sub-5-floris: squamis lanceolatis acutiusculis.-IVilld. sp. pl.3.p. 1637.

Anonymos paniculatus. Walt. fl. car. 198.

In pine-barrens: Virginia to Florida. 4. Aug.--Oct. $v$ s. in Herb. Enslen. Flowers the smallest of all the species here enunerated.

odoratissima. 15. L. glaberrima; caule simplici; foliis radicalibus oblongis, caulinis amplexicaulibus, panicula corymbosa laxodivaricata, calycibus sub-8-floris : squamis lanceolatis obtusiusculis.-Wilid.sp.pl. 3. p. 1637 .

Anonymos odoratissimus. W' 'alt. $f$ l. car. 198.

Icon. Bot. rep. 633.

In open swamps: Carolina to Florida. 4 . Sept. Oct. $v . v$. Howers a little larger than the preceding. It is generally called Carolina Vunilla-plant. The leaves, when dry, give a very agreeable scent, resembiing somewhat that of Vauilla, which they maintain for years if kept dry and inclosed.

tomentosa. 16. L. caule simplicissimo foliisque cuncato-lanceolatis hirsutis, corymbo paucifloro depresso divaricato, ramis 1-2-foris, calycibus tomentosis: squamis ovatis acutis.-Mich. fl. amer. 2. p. 93 .

In open swamps : Virginia and North Carolina. 4. Aug.-Oct. $v$. v. About eighteen inches high; flowers the size of No. 1.

bellidifolia. 17. L. pumila, glabella ; foliis cuneato-oblanceolatis, corymbo inæquali, floribus omuibus longiuscule pedicellatis, calycinis squamis oblongo-obovalibus obtusis. Mich, fl. amer. 2, ${ }^{\prime}, 9^{3}$. 
Anonymos uniforus. Wult.fl. car $! 95$.

In dry gravelly fields of North Carolina. Michaux. 4. + .

\section{VERNONIA. Gen.pl. 1262.}

1. V. caule simplici nudiusculo, foliis serrais: radicalibus oblongo-ovatis, caulinis lanceolatis, corymbo paniculato.- Mirh fl aner. 2. $p$.4.

Chrysocoma aciulis. Walt. fl. car. 196.

$\alpha$. V. utrog te Roüe, ednecuiato.

$\beta$. V alter the subse-sili.

In Souih Carilina if. v. s. in Herb. Walter. Flowers, as all the to!lo: ing, purple.

2. V. caule simplici, fuliis crcbris longe angustegne linearibus subintegris, corymba subumbellato, calycinis squamis rigide mucronatis. Wich. fl. amer. 2. p.94.

Chrysoconia angustifulia. Wilt.fl. car 100

In barren s.ndy woods: Virgina to Go orgia. 4. Aux. Sept. $v$ s. in tert. Erisien. Flowers the size and figure of $V$.prcealta.

3. V. foliis longo-Jinearibus rariter serratis, floribus corymbovis erecto approximatis, calycions ovnicieis levibus, squamis muticis. Ali h. fl. umer. 2 p. 85.

In natual mendows : Illinois Michaux. Virginia. the 4 Ang.-Cht. v. $v$. Flowers small.

4. V. caule altissimn :mouluso dense pubescente, follis crebris lanceolatis ariue serritis subt:1s puie,centibus, corymbo fastig dito, calycinis squamis ovatis acutis muticis -- Willd sp.pl. 3. p. 1033.

Serratula præalta. Sp. $p l .: 140$.

Chry socoma tomentosa. Wait. fl. car. 196.

Icon. Dill. eith t. 264. f: 343. Mill. ic. 234. Pluk. alm. $t .250 . f .6$.

On road sides and borders of woods : New Englard to Carolina. 24. Aug.-Oet. v. v. A tall roughlooking plant.

5. V. altissima ; foliis crebris lanceolatis serrulatis scabris, noveboracer. corymbo fastigiato, calycinis squamis apice filifurmi- sis. bus.- Willd. sp.pl. 3 p. 1632.

Serratula noveboracensis. Hort. cliff. 3,2.

Chrysocoma gigantea. Walt. fl. crir. 196.

Icon. Dill. elth. $t$. 263. $f$ : 342 . Pluk, alm.t. 109. $f .3$.

On road sides and old pastures : Canada to Carolina. 4. Aug.-Oct. v. v. About five teet high.

fasciculata.

oligophylla.

verna.

autununalis.

angustifolia.

\section{practia.}




\section{KUHNIA. Gen. $p l \cdot 12 \% 2$. \\ Critonia. Gart. carp. 2. p. 411. \\ Dalea. Brown.jam. 314.}

eupatorioides. 1. K. glabra; folits petiolatis lato-lanceolatis serratis, $c 0-$ rymbo terminali paucifloro coarctato.- W I ilid. sp. $p l$. 3. $1.17 \% 2$.

Eupatorium alternifolium. Ard.spec. 2. p 40.t. 20. Icon. Limn. fil. dec. t. 11 . Pluk alm.t.87.f. 2.

In shady wools, about rocks: Pensylvania to Virginia. 24. Aug. Sept. $v \cdot v$. Flowers white; resembles an Eupatorium exceedingly.

Critonia. 2. K. pubescens; foliis angusto-lancedatis inferne subdentat is petiolat is stibtus punctatis: superioribus linearibus integerrimis sessilibus, panicula terminali divaricata.IV illd. sp. H.3. p. 1773.

Critonia liubnia, Mich. fl. amer. 2. p. 101.

Icun. Geert. carp. 2.t.17-1.f: 7 .

On high mountains of Pensylvania and Virginis. $\mathcal{\psi}$. Aug. Seyt. $v \cdot v$. Fluwcrs pale yellow.

\section{EUPATORIUM. Gen.pl.1272. \\ * Calycilus 3-5-floris.}

foriculue um.

coronopifulium.

hyssopifuli. um.
1. E. caule paniculato, foliis glabris inferioribus pinnatis, superioribus fasciculatis, omnibus filiformibus.IV illil.sp.pl.3.p. 1750 .

E. fouiculoides. Walt. $l$ l. car. 199.

Chrysocoma capillacea. Mich. fi. aner. 2. p. $10 \mathrm{~J}$.

In fields and on road sides, near the sea-const : Virginia to Florida. 24. Aug.-Oct. $v . v$. From two to five feet high, resembling an Artenisia very much; flowcrs in great abundance, small, pale yellow.

2. I. caule paniculato, foliis infimis pinnatifidis, reliquis indivisis fasciculatis linearibus integerrimis. If illd. $s p$. pl. 3. p. $1 \% 50$.

E. compositifolium. Walt. $f$. car. 199.

Chrysocoma coronopifolia. Mich.fl. amer. 2. p. 102.

In dry woods, on road sides: Carolina. 24. Aug. Sept. $v$. $v$. Elowers white, double the size of the preceding.

3. E. folitis oppositis subverticillatis linearibus integerrimis pubescentibus trinervibus punctatis, radicalibus sub. dentatis. Willd.sp.pl.3.p.1749. 
Icon. Dill. eth t. 115. f. 140. Pluk alm. t. 88.f. 2.

In dry pure-bariens and sandy fielis : New Jersey to Calina. 24. Aug - ct. v. v. About a foot bigin; leaves mall : flovers white, as ail the following are, unless a different colour is mentioned.

4. E. foliis lineari lanceolatis denticulatis nbsolete 3-nervi-linearifolium. bus pubescen ibus, inf roribus opoutis verialilatis, superioribus ateruis. IFilld sp. pl.3. p. 1750. Walt. fl. cor. 100

Ir. low sanily fieids: New Jersey to Carn!ina. 24. Aug. - Nov. v. $v$. The caly $\mathrm{x}$ is corered with resinous dots.

5. E. foliis sesilibus amplex caulibus distinctis ovato-lan-sessilifolium. ceolatis basi rolumatis ser:atis glaberrimis, caule glabriusculo. Wh/ld.p.p. 3. p 1751.

About rocks, particniariy lime-sone, and throughout the Allegany moantains. $u$. Ang. Sept. $v$. $v$. About two feet ligh; rery sm whih.

6. E. follis sessilinus amplericulubus distinctis lanceolatis basi truncitis serratis gliuriuculis, caule pubescente. It illd. sp. pl. 3. p. $175 \mathrm{l}$.

In shady wo kis, about rucks: Pensylvania to Virginia. $2 !$. July-Oct. $v \cdot v$. Resembles the preceding species

7. E. foliis subsescilibus oblon?o-lanceolatis scabriusculis

album. serratis, calycinis squanis intrioribus elongatis lanceolatis scariosis coloratis. Willd. sp. pl. 3. t. 1752.

In woods and swamps: Yensylvamia and Vir_inia. 4. Aug.-Oct. v. v. Abotit eigliteen inch $=s$ high.

8. E. foliis sessilibus distinctis oblungu-lanceolatis scabris lanceolatum. basi profunde serratis, calucinis squanis concoloribus. - Willl. sp. pl. 3. p. : $7,2.2$.

In low copses and diry suamps: Pensylvania to Virginia. 24. Aug.-Nov. v. v. Resembles the preceding species.

9. E. foliis scssilibus distinctis ovatis scabris, superioribus teucrifolium. basi grosse serra::s, summis integerrimis. IVilld. sp. pl. 3.p. 1753.

E. pilosum. il alt. $f$. crr. 109 .

E. verbenæfolimm. is ich. $\ddot{f}$. amer. 2. p. 98.

lcon. Willd hort. eerol 32

In swamps and low woods: New England to Carolina. 4. Aug.-Nov. v. $v$. About two feet high. 
cuncifoinum. 10. E. folis petiolatis obovato-lanceolatis apice subserratis triplinervibus titringue pubescentibus. IVilld. sp. pl. 3. p. 1753 .

E. Marrubium. Italt. fl.car. 190.

In low sandy felds: Virginia and Carolina. 24. Aug.Oct. $v . v$. Not above a foot ligh.

melissoides. 11. E. foliis peticlatis ovatis obtusinsculis obtuse serratis venosis glabriusculis. Willd. sp. tl.3.p. 1754 .

In Pensyivania. 24. Aug.-Oct. +. Resembles No. 9 ; but the leavcs are smaller, petiolated, and smooth.

rotundifoli. 12. E. folis sessilibus distinctis subiotundo-cordatis obtuse um. serratis venosis, calycinis squamis acuminatis.-Willd. sp.pl. 3.p. $175-1$.

Tcon. Plik, alm. t. 85.f. 4 .

In swamps and shady woods: Canada to Carolina. 4 . Aug.-Nov. $v . v$. About a foot or eighteen inches ligi.

pulescens. 13. E. foliis sessilibus distinctis ovatis scabris venosis, inferioribus duplicato-serratis, superioribus stibserratis, caule paniculato pubescente, ramis fastigiatis. Willd. $s p$. pl.3. p. 1755 .

E. glandulosum. Mich. l. aner. 2. p. 99 ?

In dry sandy woods: New Jersey to Carolina. 4. Aug. - Oct. v. v. Not above two feet high.

ceanothifoli. 14. E. foliis petiolatis ovatis acuminatis dentatis triplinerviunเ. bus glabris. Willd.sp.pl.3.p. 1755 .

In shady words, about rocks: New York to Virginia. 2. Aug.-Nov. v. v. Resembles Ceunothus americanus in its foliage exceedingly.

altissimum. 15. E. foliis subsessilibus lanccolatis 3-nervibus utrinque attenuatis pubescentibus, inferioribus medio serratis. Willd. sp. pl.3.p. 1754 .

Icon. Jac\%. hort. vind. 164.

In low sandy woods: Pensylvania and Virginia, and on the banks of the Mississippi and Missouri. 24. Aug. -Oct. v. $v$. From three to seven feet high.

amcenum. 16. E. foliis brevi-petiolatis oppositis ternatisque lanceolatooblongis utrinque acutis serratis glabriusculis subrugosis subtus reticulato-venosis, panicula corymboso-fasciculata confertifora, calycinis squamis oblongis acuiusculis coloratis.

On the New Jersey mountains. 24. Sept. Oct. ". 2 
About two feet high; stem solid, smooth, purple; peduncles tomentose; flowers small, but very closely collected in a corymbose panicle, of a beautiful pale purple inclining tu flesh colour.

i7. E. foliis petiolatis ternis quaternisve ovatis utringue attenuatis serratis scabriusculis. Willd. sp. pl. 3. p. 1750.

In swamps and on the tanks of rivers: Now York to Virginia. 23. Aug.-Oct. v. v. A tail plant with. out branches.

38. E. glabellum; foliis quaternis ovali-lanceolatis utringue acuminatis sabfalcatis rariter serratis. squamis calycinis extinis brevibus ovalibus, - Mich. fl. aner. 2. p. 99 .

On the banks of the Ohio and Scioto rivers. Michaux. 4. +. A tail plant, resembling E. allum.

$$
\text { * Calycilus ples quam 5-foris. }
$$

19. E. fohis petiolatis quaternis quinisve ovato-lanceolatis serratis rugoso-renosis scabrinsculis, caule fistuloso. livilld. sp.pl. 3.p. 1759 .

Icon. Rol.it.217. Corn. canad. t.72. Mioris, hist. 3. s. ..t. 13.f.4. Dot.mem.t.217.

In swamps, wet woods, and on the hanks of rivulets: Canada to Tirginia. 2k. Aug.-Oct. v.v. Very tall ; flowers purple.

20. E. foliis petiolatis quatemis quinisve ovato-lanceolatis inxqualiter sertatis subtus pubescentibus, caule solicio sulcato. Willd. sp.pl.3. p. 1760.

Icon. Hern. parad. t. 158. Moris hist. 3. s. 7. t. 18. f. 3 .

In swamps and near ponds and rivulets: Canala to Can rolina. 24. Aug.-Oct. v. $v$. Stem marked with purple lines, not so tall as the preceding species; flowers purple.

21. E. foliis petiolatis quatemis quinisve ovatis acuminatis serratis utrinque scabris, eaule solido tereti. Ifilld.

purpureum.

falcritum.

trifoliatumi. Julcritine

macrilatum. cnum. 853 .

F. maculatuin. Hortul.

In the Blue-mountains: New Jersey and Pensylvania. 4. Aug.-Oct. v. v. Not so tall as the preceding; flowers purple, very ornamental.

22. E. foliis petiolatis ternis quaternisve ovato-lanceolatis, verticilatum. basi cuneatis inæqualiter serratis glabriusculis, caule solido lrvi. Willd. sp.pl. 3, p, 1760 . 
On the banks of rivers and in swamps ; frequent : New York to Carolina, $v \cdot v$. From four to six feet high; flowers purple. It differs from No. 18 in its stem, broader and smoother leaves, and white calyces; from No. 19 in its stem and smooth leares.

perfoliatum. 23. E. foliis connato pe foliatis oblongis sursum angustatis serrotis rugosis subtus tomentusis, caule villoso.Willd sp.pl.3.p. 1761 .

E. comatum. Mich, fl. amer. 2. p. 99 .

Icon. Pluk alm t.87.f.6.

In low meadow's and about springs: Canada to Florida. 24. Aug.--Oct v. v. From two to three feet high; fowers white. The whole plant is exceedingly bitter, and has been used for ages past $b$ the natives and inlabitants in internitting fevers. It is generally known by the name of Tharwigh unt or Bome-set. I have stated a case of its efficacy in those dineases in a letter to William Royston, Esq who inserted it in the Nedical and Physical Journal. In which istated the benefits derived from this plant, by myself and others Uuring my stay in the neightourhood of lake Ontario, when both the infuenza and lake fever (similar to the yellow fever) were raging among the inhabitants. It is generally used as a decoction, or, which I consider the more effectual way, as an infusion in gin or rum.

colestinum. 24. E. foliis petiolatis cordato-oratis obtusinsculis triplinervibus obtuse scrratis, thoribus corymbosis. Willd. sp. pl. 3. p. 1764 .

Icon. Dill. clth t. 1] 4. f. 159 .

In mountain-woods of Virginia to Carolina. 24. Aug. --Oct. $v . v$. Flowers large, beautiful blue.

aromaticum. 25. E. foliis petiolatis ovatis acutis trinervibus obtuse-serratis glabris, caule superme paniculato, floribus corymbosis, calycibus simplicibus. Willd. sp. pl.3. p. 1765.

Icon. Pluk alm. t. $88 f$. 3 .

In woods and on the banks of rivers: Pensylvania to Florida. 4 Aug.--Oct. v. v. Flowers large, clear white, sweet-scented.

ageratoides. 26. E. foliis petiolatis ovatis acuminatis trinervibus inæqualiter grosse serratis glabris, corymbo multtfloro divaricato, calycilus subsimplicibus. Willd sp. pl.3. p. 1765.

E. urticætolinm. Mich. fl. amer. 2. p. 100.

Ageratum altissimum. Sp.pl.ed. 2. p. 1176 .

Icon. Moris, nist. 3. s. 7. t. 18. f. 11. 
The most common species in the Allegany mountains, and near the sea-coast from Canadi to Pensylvania. 24. Aug.-Oct. v.v. About two feet high; Howers white.

27. E. foliis longe-petinlatis subdeltoideo-lanceolatis rariter serratis, calycinis squanis tomentosis obtusis, calule pulverulento.--Mich. fl. amer. 2. p. 100.

On the sea-coast of Carolina, anong Scirpus, \& $c$. Mechaux. 24. Sept.-Nov. +t. Fluwers white.

613. MIKANIA. Willd.sp.pl.3.p. 1\%+2.

1. M. caule scandente glabro, foliis cordatis repando-dentatis acuminatis lobis divaricatis inæqualibus, floribus

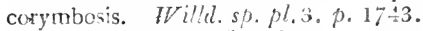

Eupatorium scanciens. Sp. pl. $11 \% 1$.

Icon. Jacq. ic. var. 1. t. 169 . Plik. alm. t. 163.f. 3.

On the banks of rivers and ditches : Canada to Carolina. 2l. July--Sept. v. v. A twining plant; flowers very numerous, white with a tinge of blue. There is another species, found in Carolina, with flesh-coloured fragrant tlowers, but 1 lave no materials at hand to give its description.

\section{CHRYSOCOMA. Gen.pl. 1019.}

1. C. foliis radicalibus spathalato-lancecolatis, caulinis linearibus rariter sparsis, caule subnudo, corymbo composito fastigiato, calycibus oblongis $3-4$-floris. Mich. fl. amer. 2. p. 101.

In low grounds, in the forests of North and South $\mathrm{Ca}$ rolina. 24. Aug.-Oct. v. v. A plant of singular appearance, the stem almost leafless; the large flat corymbus consists of small flowers, entirely yellow; even the caly $\mathrm{x}$ is deephy coloured.

2. C. glabra; foliis linearibus 3-nervibus punctato-scabris, floribus corymbosis congestis, calycibus laxis 5-floris glabris.-Lam. encycl. 2. p. 192.

C. biflora. Sp.pl.1178. secundurn specimen Pallasianum in Herbario Lambertiano asservatum.

On high cliffs on the banks of the Missouri. MI. Lewis. 4. Oct. v. s. in Herb. Lewis. From one to two feet high; flowers large, yellow.

3. C. calycibus pedunculis foliisque sublanato-pubescenti- serotinkw.

scandens,

nudala.

dracunculoides.

nauseosa. 
bus ; foliis angustissime linearibus, corymbo laxiuscu. lo, calycibus laxis 5 -floris: squamis interioribus divaricatis glabris -Pallas. mss. in Her b. Lamlert.

On the banks of the Missouri. M. Lewis. 4. Oct, v. s. in Herb. Lewis. Flowers yellow, somewhat smaller than the preceding.

\section{CACALIA. Gen. pl. 1275.}

suaveolens.

1. C. caule herbacen, foliis petiolatis hastato-sagittatis serratis glabris concoloribus, foribus corymbosis erectis, calycibus mulifforis. - Willd. sp.pl.3.p. 17.34.

On the banks of rivers: Pensylvania to Carolina. 4. Ang.--Oct. $v v$. From three to four feet ligh; flowers white; anthers yellow.

atriplicifolia. 2. C. caule herbaceo, foliis petiolatis glabris subtus glaucis, radicalibus cordatis dentatis, caulinis rhombeis utrinque subbidentatis, floribus corymbosis erectis, calycibus 5 - floris. - Willd. sp.p.l.3.p. 1734.

Icon Pluk. aln.t.101.f. 1. Moris. hisi.3.s.7.t. 15. f. 7 .

In low and overfowed places, near rivers: Canada to Carolinat. 24. Aug.-.. Oct. v. v. Flowers white, considerably smaller than the preceding.

reniformis. 3. C. caule herbaceo, foliis petiolatis glabris subtus ad venas pilosis, radicalibus amplis cordatis reniformibus repando-dentatis, caulinis oblongis denta!is basi cuneatis integerrimis, corymbis fastigiatis, calycibus multifloris. Willd. sp pl.3.p. 1735 .

On the banks of rivers: Pensylvania to Virginia. 4. Aug. - Oct. v. $v$. From five to ten fect high; flow. ers white.

\section{SPARGANOPHORUS. Gart. carp. 2. p. 395.}

verticillatus.

1. S. foliis setaceo-linearbus verticiliatis, caule subunifloro, pappo campanulato 5-dentato.--Mich. fl. amer. 2. p. 05 .

Ethulia uniflora. Walt. fl. car. 195. Willd. sp pl. 3. p 1742.

Icon. Wich.fl. amer. 2 t. 42.

In overfl wels s:amps and rivulets: New Jersey, Carolina, and Plorida. 24. Aug -.olot. v. v. Floating in the water; flowers purple, the size of a large daisy. 
617. HYMENOPAPPUS. L'Terit. monog. irich. $f$. amer. 2. p. 103.

Rothia. Lam. illuslr. t. 667.

1. H. candicanti-lanuginos'ss; follis profunde pinnatifidis, scaliosaus, laciniis lineari-obiongis subdestatis, floribus corymboso-paniculatis. - Mich. fl. omer. 2. p. 104.

Rothia caroliniensis. Journ. de hist. nat. no. 1. cum icone. In Carolina. $\odot .+$ Flowers white, the size of Liatris scariosa.

61s. MELANANTEERA. Mich.fl. amer. 2. p. 106.

1. M. foliis triplinerviis ovatis acuminatis scabris inæqualiter dentatis, inferioribus subcordatis, superioribus hastato-trilobis, pedunculis terminalibus corymhosis, paleis receptaculi lanceolatis acuminatis.-Mich. fl. $a$ mer. 2. p. 107.

Bidens nivea. Willd. sp.pl. 3.p. 1721 .

Athanasia hastata. Walt. $f$. car. 201.

a. M. foliis profunde trilobatis.

Icon. Dill. elth. t. $47 . f .55$.

B. M. foliis leviter lobatis panduræformibus,

Icon. Dill. clih. t. $46, f .54$.

On the banks of rivers: Carolina to Florida. 4. Aug.

-Oct. v.v. Flowers large, white.

hastala,

\section{MARSHALLIA. Gen. $p l . .$. .}

Trattenickia. Pers. syn.2.p. 403.

Persoonia. Mich.fl.amer. 2. p. 104.

1. M. caule simplici inferne folioso superne nudato, foliis lanceolata. longo-lanceolatis, calycinis foliolis obtusis, paleis spathulatis.

Persoonia lanceulata. Mich.fl.amer. 2. p. 105.

Athanasia oborata. Wult. fl. car. 201.

In the Carolina mountains. 24. v. s. in Herb. Walter. Flowers resembling a Scabious, pale purple, and like all the following very ornamental.

2. M. caule simplici, foliis lanceolato-ovalibus acuminatis latifolia. trinervibus, infimis vaginantibus, calycinis foliolis acutis, paleis angusto-linearibus.

Persoonia latifolia. Mich. fl. amer. 2. p. 105. t. 43. voL. II. 
Athanasia trinervia. Walt. fl, car. 201.

In the Carolina mountains. 2\%. v. s. in Herb. Walter.

crgustifolia. 3. M. caule ramoso, foliis infimis angusto-lanceolatis, rameis angustissime linearibus, calycinis foliolis rigidis superne angustatis acutissimis, paleis setaceis.

Persoonia angustifolia. Mich. fl amer. 2.p. 106.

Athanasia graminirilia. Walt. fl. car 200.

In Tennassee. Michaux. In swamps, near Wilmingron, Nortb Carolina. Ph. 24. June, July. v. $v$. The handsoniest species of this genus.

\section{0, SANTOLINA. Gen.pl. 1278.}

sisuveolens. 1. S. glabra ; caule corymboso-ramoso, foliis subbipinnatifidis, laciniis acutis linearibus, pedunculis terminalibus unifloris.

On the banks of the Kooskoosky. M. Lewis. $\odot$. June-Aug. v. v.; v. s. in Herb. Lewis. A small plant of an agrecable sweet scent ; flowers yellow.

Planta glabra. Caulis erectus, ramosus : rami corymbosi uniflori. Folia sessilia tenuissime pinnatifida, laciniis inciso-2-3-fidis, omnibus acutis angusto-linearibus. Pedunculi terminales, solitarii, uniflori. Calyx hemisphæricus, subimbricato-polyphyllus: foliolis ovalibus, obtusis, glabris, viridibus, margine albido-membranaceis, laceris. Cor. discuidea. Discus globosus, luteus. Corollulce germine oblique insertæ, tubulosæ, 4-fidæ? laciniis erectis. Genitalia inclusa. Receptaculum conicum, paleaceum. Paleis sparsis, oblongis, obtusis. Pappus nullus. Semina oblique obovata.

\section{II. $S U P E R E U A$.}

\section{ARTEMISIA. Gen.pl. 1281.}

* Foliis simplicilus.

integrifulia. I. A. cano-tomentosa; caule erecto virgato; foliis linearilanceolatis acuminatis subtus tomentosis subdentatis, floribus ovatis subsessilibus erectis tomentosis. -Willd. sp.pl.3.p. 1846 . 
Icon. Gmel.fl. sil. 2. t.48. f. 1 E 2.

On the cliffs and dry savannahs of the Missouri. $M$. lewis. 4. Oct. v. s. in Herl. Lewis. About three feet high.

2. A. glabra; foliis lineari-lanceolatis utrinque attenuatis, Dracunculus. floribus subrotundis pedunculatis erectis.-Willd. $s p$. pl.3.p. 1848 .

Icon. Gmel. fl. sil. 2. t. 59 \& 60.f. 1.

On the Missouri. MI. Lewis. 4. Aug.-Oct. v. s. in Herl. Leu'is.

3. A. canescens; foliis longe lineari-lanceolatis acutis uervosis utrinque canis : infer:oribus cuneiformibus acute3-lobis, floribus ovalibus glomeratis sessilibus axillaribus.

On the Missouri. M. Lewis. 4. Sept.-Nov. v. s. in Herl. Lewis.

4. A. canescens: foliis inferioribus cuneiformibus obtusis trilobis, superioribus linearibus obtusis, floribus globosis pedunchlatis cernuis. Willd. sp.pl. 3. p. $18+8$.

Icon. Gmel.fl.sil.2.t.61.f. 1 E 2. Pluk. amalth. t. 353.f. 5 .

On the north-west coast. 2 . Sept. Oct. v. s. in Herl. Lambert. Flowers large.

* Foliis compositis; caule paniculato.

5. A. foliis caulinis pinnatis linearibus glabris, ramis indivisis, spicis secundis reflexis, floribus subsessilibus 5floris. Willd. sp.pl. 3 p. 1826.

Icon. Gmel.fl. siv.2.t.51. Lob. ic. 756.

On the plains of the Missouri. M. Lewis. 4. Sept. Oct. v. s. in Herl. Lew is.

chinensig.

cana.

chinensis.

6. A. foliis caulinis setaceis pinnatis glabris. radicalibus pinSantonica, natis, laciniis $3 \cdot$ fitis in canis, caule procumbente ramoso virgato, floribus ovatis pedunculatis. Willd.sp. pl. 3. p. 1827 .

Icon. Engl. lot. 338.

On the piains of the Missouri. M. Lewis. 4. Sept.Nov. v. s. in Herl. Lewis.

7. A. foliis incanis pinuatis, pinnis tripartitis linearibus acutis, floralibus pinn 3 -partitisve, caule adscenfrigida. dente, floribus globosis nuiantibus. Willd. sp. pl. 3 . p. 1838.

campestris. 
On the plains of the Missouri. M. Lewis. 4. Occ. Nov, v. s. in Herl Lewis.

liennis. $\quad$ 8. A. foliis glabris, radicalibus tripartito-pinnatis, caulinis inferioribus pinnatitidis, st.periorious indivisis linearibus cauls siricto, Aoribus subrotundis subsessilibus erectis. WVilid.sp.pl.3.p. 1842.

A. hispanica. Jacq. ir. rar. 1.t.172.

On the banks of the Iissouri. $\delta^{t}$. v. s. in Herb. Lamlert.

vulgaris.

9. A. foliis subtus tomentosis, caulinis pinnatifidis, laciniis lanceolitis subcientatis acutis, floralibus indivisis linearibus lanceolatis, floribus subsessilibus oblongis erectis, calycibus tomentosis. Wild. sp. pl. 3. p. 1845

Icon. Engl. bot. 978 .

On the banks of rivers: Canada to New England. $\boldsymbol{\psi}$. Sept.-Nov. $v \cdot v$.

canadensis. 10. A. subdecumbens, parce pubescens; foliis planis linearipinnatifidis, ramulis spicifloris, floribus subbemisphæricis, calycibus scariosis. Mich. fl. anter. 2. p. 129 .

In the noveable sands about Hudson's Bay. Michaux. + Receptacle smooth.

raudata. 11. A. erecta, glabra; foliis subsetaceo-pinnatifidis, laciniis convexis, ramulis confertis, racemis terminalibus lon. gissimis strictis, floribus pedicellatis globoso-ovatis.Mich. Al. amer. 2. p. 129.

On the gravelly banks of the Missouri. Michaux. + +

**** Foliis compositis; caule simplicissimo.

spithamaa. 12. A. pumila, sericeo-pubescens; foliis inferioribus linearibus superne pinnatifidis, laciniis paucis linearibus acutis, floralibus simplicibus, foribus racemosis brevipedunculatis hemisphæricis, calycibus scariosis.

In Labrador. Colmaster. 4 . Sept. Oct. v. s. in Herl. Dickson. Flower large, in proportion to the size of the plant; receptacle naked.

622. TANACETUM. Gen.pl. 1280.

vulgare. $\quad$. T. foliis bipinnatis incisis serratis. Willd. sp. pl. 3. p. 1814.

Icon. Oed. dan. 871 . 
In cultivated grougis and on road sides : New England tc Ponsjuxila. 24. July-Sept. v. v. Common Ta 1 is is probably introuced from Europe.

\section{2?. P.ACCHAY'A. Gen.pl.1285.}

1. R. giverrind, faniculato-ranosis ina; foliis angustolinesuihus "egerimi, panicula composita multiflora, calycibus paivulis sub-20-Horis.-Mich. flamer. 2. p. 125.

On the sea-const: Carolina to Florida; on the banks of the Missis api. M. Lawis. h. July-Sept. $v, v$.; $v$.s. in Ite b. Lewis. Hlowers white, as all the following ale.

2. B. foliis levibus cuneato-obovalibus superne dentatis, glomerulifloglomerulis form axi'laribus sessilibus remotis, squamis calycinis superue rais.-Wich. fl. amer: 2. p. 125 .

In woods, on the coast of Virgisia and Carolina. $h$. Aug.-Oct. v. v. Resembles the follow'ng.

3. B. foliis obo atis superne inciso-dentatis, panicula composita foliosa, fasciculis pedunculatis.-Willd.sp. pl.3. p. 1915.

Icon. Schmidt arb. 82. Herm. parad. 225. Pluk. alm. t. $27 . f .2$.

On the sea-coast: Maryland to Fiorida. $h$. Sept.Nov. $v . v$. The whole shrub is covered with a white powder.

\section{CONYZA. Gen. pl. 1286.}

1. C. herbacea, pubescens; foliis sessilibus !ato-lanceolatis marylandica. acutis serratis : serraturis apice cartilagineis, corymbis terminalibus fastigiatio coarctatis subaphyllis, calycinis squamis subulato-mucronatis floscul's brevioribus.Mich. A. amer. 2. p. 126. exclus. syn. Walteri.

Erigeron camphoratum. Willd.sp. pl. 2.p. 1960.

Icon. Dill. elth. $t .88 . f .104$.

In overflowed places, near rivers and ponds : New York to Carolina. $\odot$. Ang.-Oct. v. v. About a root high; flowers reddisli-purple; the whole plant emits a strong scent of camplior, only inore disagreeable.

2. C. herbacea, subpubescens; foliis petiolatis ovato-lanceo- camphorata. latis acutissimis subrepando-denticulatis: centiculis 
glandulosis, corymbis terminalibus et axillaribus folio brevioribus, calycinis squamis acutis flosculos subæquantibus.

Baccharis fotida. Willd.sp.pl.3.p. 1918. Walt.fl. car. 202.

Icon. Dill, elth. t. 89. f. 105.

On the banks of rivers and in large swamps : Sorth $\mathrm{Ca}$ rolina and Georgia. 4. Aug. Sept. v. v. Flowers purple, smaller than the preceding; stem about three feet high.

bifrons. 3. C. herbacea, subglutinosa; foliis amplexicaulibus spathulato-oblongis acutis serratis, paniculæ corymbulis capitato-glomeratis.-Willd. sp. pl. 3. p. 1920.

C. anplexicaulis. Mich. fl. amer. 2.p. 126.

C. uliginosa. Pers. syn. 2. p. 427.

Baccharis viscosa. IValt fi. cur. 202.

Icon. Pluk. alm.t. 87.f.4.

In low and overflowed fields: Carolina. 24. July, Aug. $v$. s. in Herl. Gronov. Flowers pale yellow.

pycnostachya. 4. C. caule alato, foliis lanceolatis subtus tomentosis subintegerrimis, spica cylindrica densiflora.-Mich. $f$. amer. 2. p. 126.

C. spicata. Cav. ic. 1.p. 8.t. 12 ?

Gnaphalium undulatum. Walt. $\{$. car. 203.

In dry fields and barren woods: Carolina to Florida. 4. July-Sept. $v, v$. A singular-looking species, nearly allied to $C$. virgata.

\section{GNAFHALIUM. Gen. $p l .1282$.}

marcaritaceum.

polycephalum.
1. G. herbaceum; foliis lineari-lancenlatis sensim angustatis asutis, caule superne ramoso, corymbo fastigiato, floribus pedicellatis.-IVilld. sp. pl. 3. p. 1881.

Icon. Engl. bot. 2018.

In Carada and on the mountains of New York and New Jersey. 24. Aug.-Oct. v. v. About eighteen inches high; flowers lurge, white, with a yellow disk, very handsome.

2. G. herbaceum, erectum ; foliis lineari-lanceolatis acutis, supra glabris, subtus pubescentibus, caule paniculato tomentoso, corymbis terminalibus coarctatis.-Mich. A.amer. 2. p. 12\%. 
G. obtusifolium. Willd. sp. pl. 3. p. 1890 . excl. syn. Dilienii.

In old fields and woods : New England to Carolina. (.) July-Sept, $v . v$. About a foot high, spreading: flowers yellowish-white, not shining.

3. G. herbaceum; foliis lineari-spathulatis subtus tomenpurpurean. tosis, caule erecto simplicissimo, floribus sessilibus glomeratis terminalibus et axillaribus. - Willd. sp. pl.3. p. 1884 .

Icon. Dill. elth. $t .109 . f .132$.

In sandy barren soil: New York to Carolina. 24. July -Oct. $v . v$. Not above a span high; flowers small, calyces purple.

4. G. sarmentis procumbentibus, caule simplicissimo, folits radicalibus ovatis nervosis mucronatis, corymbo coarctato, floribus dioicis, squamis calycinis interioribus elongatis acutiusculis coloratis.-Willd. sp. pl. 3. p. 1882 .

Icon. Pluk. alm. t. 348.f.9.

In woods and on sunny hills : Canada to Carolina, and in the Allegany mountains, 24. May-July. v. v. Not above six inches high; leaves large, resembling plaintain leaves; flowers white.

5. G. caule non sarmentoso simplicissimo, foliis radicalibus lanceolatis, floribus terminalibus aggregatis sessilibus, calycinis squamis interioribus elongatis acutis membranaceis. Willd.sp.pl.3.p. 1883.

Icon. Fl. dan. 332.

In Labrador. Colmaster. 24. v. s. in Herb. Dickson Not above four inches high ; resembling $G$. dioicum.

6. G. caule herbaceo simplicissimo erecto, foliis angustosylvaticum. lanceolatis utrinque attenuatis et lanatis, floribus terminalibus axillaribusque sessilibus spicatis. Willd. sp. ol. 3.p. 1884 .

Icon. Fl. dan. 254 .

In stony woods: New York and Canada. 24. July, Aug. $v$. v. About a foot or less high; calyces shining, strawcoloured with brown.

7. G. caule herbaceo erecto ramoso, foliis obovato-spathu- americanum. lat is subtus pubescentibus, foribus axillaribus et terminalibus glomeratis spicatis. Willd. sp. pl. 3. p. 1887 .

prentagine $u \mathrm{~m}$.

alpinum. 
G. spathulatum. Lam encycl. 2. p 728 .

In dry, sunny, and rocky situations: Pensylvania to Virginia. $\odot$. July - . ept. $v . v$. About a span high; flowers small, pale straw-coloured.

zhiginosum. 8. G. caule ber aceo ramoso diffuso lanato. foliis linearilanceolat is utrinque angustatis tomentosis, floribus terminalibus congentis. Willd. sp. pl. 3. p. 1591 .

Icon. Fl. dan. 859 .

In exsiccated pools: Canada to Virginia. $\odot$. Aug. Sept. v. v. About a span high; Howers smal!, ca. lyces brown.

germanicum. 9. G. herbaceum, caule erecto dichotomo, foliis linearilanceolatis acut is tomentosis, floribus globoso-capitatis alaribus terminalibn-que. Willil. sp.pl.3.p. 1894.

Filago germanica. Sp.pl. 1311.

Icon. Fl. dan. got. Engl. lot. 0.16.

In dry fields and pastures: Pensylvania to Virginia. $\odot$. July, Aug. v. v. About a span high : calyces strawcoloured.

\section{BELLIS. Gen.pl. 1300.}

integrifolia. 1. B. caulescens, divaricato-ramosa ; foliis integerrimis, inferioribus obovatis, supremis lanceolatis, calycinis foliolis acutissimis pilo acuminatis.-Mich. fl. amer. 2. क. 131 .

On banks of rivers and on shady hills in Temnassee. Michaux. + .

\section{CHRYSANTHEMUM. Gen. pl. 1307.}

Lucanthe- 1. C. foliis amplesicaulibus lanceolatis serratis, basi inciscimum. dentatis, caule erecto ramoso. Willd. sp. pl. 3. p. 2142 ,

Icon. Fl. dan. 994. Engl. lot. Go1.

In meadows and ficlds: common every where, and probably introluced from Europe. 24 . June, July. v. $v$. A very troublesome weed; flowers large, white, resembling a daisy.

arclieum. 2. C. foliis radicalibus tripartitis inciso-dentatis, caulinis cuneiformibus 3-partitis obtusis. Willt. sp. pl. 3. p. 2146.

Icon. Gmel. fl. sib. 2. ‘. Si. 
SyNGeNFia SUPERfuA. Chrysanthemum.

On the north-west coast. 4. $v$. s. in Herl. Lamlert. Abont a fon: high; flowers purplish-white, the size of the preceding species.

628. PYRETHRUM. Smithfl. brit. 2. p. g00.

2. P. foliis lanceolatis, inferioribus apice serratis, superioribu, integerrimis, ramis corymbosis. Willd.sp. $p l .3$. p. $2: 51$.

Chrysanthemam serotinum. Sp. pl. $125 \mathrm{I}$.

Icun. Pluk alm. t.:7, f. 2. Moris. hist. 3. s. 6. t. 9 . $f .11$.

In North America. 2. Oct. Nov. v. s. in Herb. Lamlert. Flowers white, smaller than Chrysanthemum Leucanthemum.

- 629. ARNiCA. Gen.pl.12g6.

1. A. foliis remote dentatis subtus lanato-hirsutis, radicalibu: petwlatis oblongis basi angustatis, caulinis alternis oblongr lanceolatis, caule unithoro.-Willd. sp. pl. 3 . p. 2108.

Icon. Jai\%. fl. austr. 1. t. 92. Allion. fl.ped.t. 17. f. 1 \& 2.

In I abrador. Colmaster. 24. July, Aur. v. s. in Herb. Dickson. Not above a span bigh; flowers large, yellow.

2. A. glabra; folits integerrimis utrinque glabris acutis tri- plantuginea. nervibus, radicalibus spathulato-lanceolatis basi in petiolun angustatis, caulinis opposicis lanceolatis sessilibus, canie unifloro.

In Labrador. Coimaster. 24. July, Aug, v. s. in Herl. Dickson. About a span ling ; thower the size of the preceding, yellow, the rays broad and 3 -dentated.

3. A. pubescens; foliis radicalibus lanceolatis obtusiusculis basi attenuatis petithatis trinervibus, caulinis oppositis remotis linearibus, culule mifforo.

On the banks of the Missouri. 24. v.s. About a foot or more high, very slender; leaves on the ste!n generally two pairs; Howers somewhat smaller than the preceding, of a very deep and beautiful yellow.

4. A. hirsuta; foliis radicalibus cecussatim oppositis oblongo-ovatis subdentatis, caule subaphyllo summitate in pedunculos 1-floros diviso.

Doronicum.

fulgens.

Clayıoni. 
Doronicum nudicaule. Mich. $f$ l. amer. 2. p. 121.

Doronicum acaule. Walt. fl. car. 205.

Doronicum foliis Plantaginis, \&ic. Clayt. fl. virg. no. 37 .

In shady woods: Virginia to Florida. 4. July, Aug. $v$. s. in Herb. Gronov. nec non IValter. About two feet high ; flowers large, of a fine yellow.

maritima. 5. A. foliis lanceolatis, inferioribus serratis, caule folioso multifloro. Willd.sp. pl. 3. p. 2110.

On the north-west coast. 4. v. s. in Herl. Banks. Flowers large, very haudsome.

\section{Cineraria. Gen.pl.1294.}

integrifolia. $\beta$. minor.

1. C. Ianato-tomentosa; caule simplici, foliis inferioribus, spathulatis subdentatis, superioribus aigusto-lanceolatis integerrimis erectis, floribus subumbellatis.-IVilld. sp. pl. 3. p. 2082.

Senecio tomentosus. Mich. fl. amer. 2. p. 110.

On the banks of the Missouri. M. Lewis. In Carolina near Flat-rock. Michaux. 24. Aug. Sept. v. s. in Herb. Lewis. About a foot ligh ; flowers the size of Senecio Jacolian, yellow; the rays very short.

heterophylla. 2. C. lanato-tomentosa; foliis radicalibus longe petiolatis spathulato-obovatis, ovatis acutiusculis pinnatifidisque, caulinis 2-3-linearibus pinnatificlis, fioribus corymbosis.

On dry sumny rocks, in the Blue-mountains: Pensylva. nia. 24. May, June. v. v. About a span high; flowers deep yellow, the size of the prececting.

canadensis. 3. C. villosa ; foliis pinnatifidis subvillosis, laciniis sinuatis, floribus paniculatis. - W Villd. sp. pl. 3. p. 2085.

In Canada. Kalm. 4. +. Resembles C. maritima, but is not tomentose.

631. SENECIO. Gen. pl. 1290.

* Floribus flosculosis : radiis nullis.

vulgaris. 1. S. foliis amplexicaulibus pimatifidis dentatis, floribus corymboso-coarctatis. - IVilld.sp.pl. 3.p. 1979 .

Icon. Fl. dan. 513 . Engl. lot. $7+7$.

In cultivated grounds as a weed; about Pbiladelphia and some other places in Peusylvania; introduced from Europe. $\odot$. April-Oct. v. v. Flowers, as all the following, yellow. 
2. S. caule virgato-paniculato, foliis amplexicaulibus ob- hieracifolizs. longis acutis inæqualiter acuteque profunde dentatis, calycibus lævibus.-Willd.sp. pl.3. p. 1974.

Icon. Pluk. phyt. t. 112.f. 1. mala.

On road sides and in newly cleared grounds : Canada to Carolina. $\odot$. July, Aug. v. v. From two to five feet high. This is one of the plants which spring up in the most remote western countries, when the land is cleared of timber, particularly when the brushwood is burnt on the ground; from which circumstance it is generally known by the name of Fire-weed. I have frequently found it covering a square piece of cleared land, when there was not a single plant to be found in any other place for a considerable distance round it.

3. S. glaber; foliis radicalibus spathulatis serratis in petiolun attenuatis, caulinis pinnatifidis dentatis remotissimis, pedunculis elongatis umbellato-corymbosis.

On rocks, near the banks of rivers : about Easton, Pensylvania. 24. July, Aug. v. v. Resembling No. 8, but is destitute of a ray.

4. S. glaber; foliis radicalibus longe petiolatis ovato-subrotundis subcordatis dentatis, caulinis 2 . remotis pillnatifidis dentatis, pedunculis brevibus stebternis umbellatis.

S. tussilaginoides. Walt. fl. car. 208 ?

In Labrador. Colmaster. In Carolina. Walter. 4 . v. s. in Herl. Dickson. Not above a span high.

$$
\text { * Floribus radintis. }
$$

5. S. caule simplicissimo rigide erecto subnudo, foliis omnibus lanccolatis, radicalibus subintegris inciso-dentatisque, coryınbo paucitloro, calycibus glabellis, radiis parvulis.-Nich. fl. comer. 2. p. 120.

Abont lakes: Canada. Michaux. +. A small plant; flowers the size of $S$. Jacolica.

6. S. foliis radicalibus longissine petiolatis orbiculatis subgracilis. cordatis crenatis, caulinis paucis remotissimis linearioblongis basi dilatatis inciso-dentatis, pedunculis brevissimis hirsutis subumbellatis, caly'cibus glabellis, radiis paucis brevissimis.

S. strictus. Herl. Banks. mss.

On the rocky banks of rivers; Pensylvania. 24. May -Aug. v. v.; v. s. in Herl. Banks. About a foot 
high, rery slender; flowers the smallest of all the species here entmerated.

olovatus. T.S. fulin radicalibus obovatis crenato-serratis petiolatis, caulinis pimatifidis dentatis, floribus subumbellatis longe pedunculatis, caule glabriusculo. - Willd. sp. pl. З. p. 19.9.

S. obtusatus. He, B. Ranks. mss.

On the sicle of hills and rocks, near rivers : New York to Virginia. 24. June, July. v. v.; v. s. in Herb. banks. Flowers nearly the size of $S$. Jacobaa.

Balsamilce. 8. S. foliis radicalibus oblongis serratis petiolatis, caulinis inferioribus lyrato-pimatifidis serratis, stinmis pinnatifidis dentatis, floritus subumbellatis, caule pedunculiscue basi villoso.--iVilld. sp. pl.3. p. 1998.

S. lysatus. Mich. fe, umer. 2, p. J20.

S. glabellius. Lam. encycl. 7. p. 102.

In rocky fertile soii : Pensylvania to Virginia. 4. June, Ju!y. v. v. Flowers the size of the preceding.

aureus. 9. S. follis radicalibus ovatis cordatis serratis petiolat is, caulinis pinmatifidis dentatis, laciuia terminali lancelata, pedunculis stibumbellatis incrissatis. - Villd. sp. pl.3. p 1995.

In shady woods, about rocks: Conada to Virginia. 4 . June, July. $v . v$. Flowers the same size as the preceding,

Cymbalaria. 10. S. foliis radicalibus petiolatis subrotundis basi tiuncatis dentatis, petiolis appendiculatis sublyratis, caulinis seswilibus linearibus inciso-dentatis, "caule subuniAloro.

On the north-west coast. D. Nelson. v, s. in Herb. bianks.

cancdensis. 11. S. foliis bipinnatis linearibus glabris, summis pinnatis, corgmbis compositis fastigiatis.-Willd. sp. pl. 3. p. 1 gge.

In Canada. $K \mathrm{c} / \mathrm{m} .+$.

ciliatus. 12. S. canle pileso, foliis lanceolato-linearibus ciliatis.-Walt. fi. car. 208.

In Carolina. Walter. +. From six to eight feet high ; rays of lie fower white. 


\section{TUSSILAGO. Gen. pl.1289.}

3. T. thyrso fastigiato, floribus radiatis, foliis subrotundocordatis inæequaliter dentatis subtus tomentosis. IV illd. sp.pl.3.p. 1968.

Icon. Fl dan.61. Gmel.flesib. 2. t. 70.

In Canada, and on the hibest peaks of the Vermont and New Hampshire mountains. 24. May. v, $v$. Flowers of the ray white, disk pale purple.

2. T. thyrso ovato fastigiato, floribus radiatis, foliis radicalibus oblongis acutis sagittatis integerrimis, lobis obtusis. Herl. Banks. mss.

On Hudson's Bay. Hutchinson. 4. v. s. in Hert. Banks.

3. T. thyrso fastigiato, floribus obsolete radiatis, foliis sub. rotundo-cordatis semi-septemirbis inciso-dentatis subtus tomentosis. Willd. sp. pl.3. p. 1972 .

Icon fit. keu'. 3, t. 11 .

In Labrador. Colmaster. 4. April, May. v. s, in Herl. Dickson.

\section{INULA. Gen. pl. 1295.}

1. I. foliis amplexicaulibus ovatis rugosis subtus tomentosis, Helenium. calycum squamis ovatis. Willd. sp.pl.3.p. 2089.

Icon. Fl. dan. 728. Engl. lot. 1540.

In low meadows and on road sides: New England to Pensylvania; criginally brought from Europe. 24. July, Aug. $v \cdot v$. A tall rough-looking plant; flowers large, and, as all the rest, yellow.

2. I. villosa ; foliis sessilibus oblongo-lanceolatis basi attenuatis obtusis glanduloso-denticulatis, inferioribus petiolatis ser ratis, pedunculis axillaribus corymbosis glanduloso-pilosis.-IVilld. sp. pl. 3. p. 2099. excl. syn. Plukenetii.

I. glandulosa. Lam. encycl. 3. p. 259.

Icon. Nill. dict. ic. t. 57 .

In dry sandy wonds and fields: New Jersey to Carolina. 24. Aug.-Oct. v. v. A foot or more high; flowers the size of $I$. Britannica.

3. I. hispido-pilosa, scaberrima; foliis arcte sessilibus obpalmata.

sagitiala.

frigida. segillate.

mariane. longis acutis superne sucdentaits utrinque scabris, pe. dunculis axillaribus corymbosis hispidis.

I. subaxillaris. Lam. encycl. 3. p. 250. 
Icon. Pluk. mant.340. $f$. 1. no. 5.

In the pine-barrens of South Carolina. 21 . Aug. Sepi. v. s. in. Herl. Enslen. About two feet high; flowers smaller than the preceditig.

falcala.

4. I. lanato-villosa; foliis sessilibus linearibus acutissimis subfalcato patentibus nervosis utrinque pilosis, pedunculis paucis ax.llaribus corymbasis calycibusque villosis.

Aster gracilentus. Herb. Banks. mss.

In sandy pine-woods: New Jersey. 4 . Sept. Oct. $v . v$. Not abore a span high; flowers the size and shape of Nu.2.

gossypina.

5. I. lanuginoso-candicans; foliis sessilibus oblongo-spathuJatis obtusis integerrimis, corymbo subfastigiato.Mich.fl. amer. 2. p. 122.

Inula lanata. Herb. Banks. miss.

On the sea-coast of Carolina and Florida. 24. Aug.Oct. v. s. About a foot high; flowers the size of No. 3.

graminifolia, 6. I. argenteo-sericea; caule simplicissimo, foliis longissime lanceolato-linearibus integerrimis erectis nervosis, corymbo composito laxo, calycibus turbinatis, squamis acutissimis carina serrato-glandulosis.-Mich. $f$. umer. 2. p. 122.

In sandy dry waods : Pensylvania to Florida. 24. Aug. -Oct. v. v. About a foot high ; flowers small.

argentea.

7.I. sericea; foliis lanceolatis trinerviis ercctis Alexuosis, corymbo subcomposito stricto, squamis calycinis planis pubescentibus.-Pers, syn. 2. p. 452.

In Pensylvania. Persoon, $2 \% \cdot+$. Flower a great deal larger than the preceding species, with which it has a great affinity.

\section{3.. ERIGERON. Gen. pl. 1287.}

alpinum.

1. E. villosun ; caule plerumque unifloro, calycibus villosis, ratio patente, foliis lanceolatis nbtusiusculis.Willd. sp.pl. 3. p. 1959. Smithgl. brit.2.p. 877. Icon. Engl.bot. 464. Fl. dan. 292.

In Labrador. Colmaster. 24. June, July. v. s. in Herl. Jickson. The Labrador specimen is not above two inches high ; flower large, rays purple.

bellidifolium. 2. E. hirsutum, incanum; foliis radicalibus obovatis sub. serratis, caulinis paucis distantibus lanceolatis integer- 
rimis, caule sub-3-floro, radiis elongatis.-Willd. sp. pl. 3. p. 1958.

E. serpentaria. Hcrl. Banks. mss.

E. pulchellam. Mich. fl. aner. 2. p. 224.

F. caule simplicissimo, \&c. Gron. jl. virg. 122.

In shady woods, principally throughout the mountains : Canada to Carolina. 2\%. June-Aug. v. v. A foot or eightcen inches high; Howers large, rays blueishwhite; sometimes it produces only one flower, and sometimes more than three. It is known by the name of Poor Rotin's Plantain.

3. E. glabrum; foliis radicalibus orali-lanceolatis acutis nudicaule. subdentatis, caule simplicissimo subaphyllo elongato, corymbis terminalibus paucifloris, radiis longitudine calycis.-Mich. fl. amer. 2. p. 224.

Aster vernus. IVilld. sp. pl. 3. p. 2029. secundum specimen Clayton.

In low grounds of Carolina and Georgia. 4. JuneAug. v. v.; v. s. in Hert. Gronov. A foot high; flowers small, rays blucish-white.

4. E, tenue pubescens; foliis larceolatis acutis, inferioribus quercifolium, sublyratis grosse dentatis supremis integerrimis, caule subsimplici summitate 3 -floro, radiis calyce hemisphærico duplo longioribus.-Lam. encycl. 8. p. 491.

Icon. Lam. illustr. t.681.f. 4 .

In Carolina and Florida. 24. July, Aug. v. s. in Herl. Enslen. Not above a span high; flowers pale blue or white.

5. E. pubescens ; foliis cuneato-oblongis rariter inciso-dentatis, caulinis semiamplexicaulibus, canle debili simplici superne corymboso, pedunculis elongatis unifloris, radiis capillaceis calyce lemisphærico duplo longioribus.-Wilid. sp. pl.3.p.1957. Mich. fl. amer. 2. p. 223.

In fields and dry woods: Canada to Carolina. 24. Aug. Sept. $v . v$. A delicate and handsome plant, from one to two feet high; flowers the size of a common daisy, rays of a beautiful blueish-purple.

6. E. pubescens ; foliis oblongis dentatis amplexicaulibus, superioribus integerrimis, pedunculis corymbosis incrassatis, inferioribus elongaris, calycinis squamis carina pilosis, radiis calyce duplo longioribus.-Willd. sp.pl.3. p. 1958.

In pastures and on fertile hills, near tite banks of rivers:

philadelphicuin.

purpureum. 
Canada to Virginia. 4. July, Aug. v. v. A foot or eighteen inches high; flowers large, purple, and very ornamental.

strigosum.

nervosum.

7. E. strigoso-pilosum ; foliis lanceolatis utrinque attenuatis medio grosse pancidentatis seu integerrimis, floribus corymboso-paniculatis - Willd. sp.pl.3.p. 1956. In fields and dry pastures; common : Canada to Virginia. $\delta^{\lambda}$. July, Ang. $v v$. A very troublesome weed; flowers white, rcsembling the common daisy.

nervosum

8. E. albido-pubescens; foliis lineari-lanceolatis integerrimis sericeis nervosis, floribus paniculatis.-Willd. $s p$. pl.3. p. 1953.

In wld fields and woods; common: Canada to Virginia. 4. July-Sept. v.v. Likewise a troublesome weed; flow rs resembling the preceding.

heterophyl- 9. E. foliis radicalibus subro*undo-ovatis profunde dentatis lum. petiolatis, caulinis lanceolatis acutis medio serratis, cory mbo terminali. Willd. sp. pl. 3.p. 1956.

Aster annuus. Willd. sp. pl. 3. p. $204 \mathrm{I}$.

Icon. Fl. dan. $4 \mathrm{~S} 6$.

In old waste fields and on road sides; common. $\delta$. June-Aug. v. v. Flowers white.

canadense. 10. E. caule hispido paniculatim ramosissimo, foliis lanceolato-Jinearibus ciliatis, calycibus cylindricis, radiis multiplici serie confertis brevissimis.-Willd. sp. pl. 3. p. 1954.

In dry fields and on road sides; common: Canada to Florida. ๑. July-Sept. v. v. A common weed; flowers small.

divaricatum. 11. E. divaricato-ramosissimum, subfastigiato-paniculatum; foliis subulatis, floribus brevissine radiatis, corollulis disci 4-fidis. - Mich. $f l$ amer. 2. p. 123.

In fields and meadow's of Kentucky, and on the banks of the Missouri and Mississippi. $\odot$. July-Sept. v. s. Resembles the precening.

longifolium. 12. E. glaberrimums: caule virgatim-paniculato, ramis strictis, tolii- longissime-]ir.earibus stricti-, caly cibus ovatis, racliis vix ralvce longioribus.-- Lam. encycl. 8. p. tro.

In Carolina. $4 \mathrm{July}$-Sept. v. s. About two feet high ; rays yellow.

hyssopifo- 13. E. caule rami steritibus paniculato: pancis in pedunlium. culos nudus protractis, foliis linearibus glabris ciliatis, 
radiis calyce cylindraceo multo longioribus. - Mich. $f$. amer. 2. p. 123.

E. carolinianum. WVilld.sp. pl. 3.p. 1953.

Icon. Dill. elth.t. 30ô. $f$. 394 .

In low grounds: Canada to Carolina; rare. 4 . July -Sept. v. s. Resembles the preceding; rays yellow.

14. E. pilosum, subacaule; foliis radicalibus longe petiolatis triplicato-3-partitis, lacinis linearibus divaricatis, caucompositum. linis linearibus plerumque indivisis, caule superne nudo unitloro.

On the banks of the Kooskoosky. M. Lewis. 24. July, Aug. v.s.; v. v. cultum. Not above a span high; flowers resembling a daisy exceedingly; they change during their flowering, from white to a lively pale red.

\section{SOLIDAGO. Gen. pl. 1292.}

* Racemis secundis; foliis triplinervibus.

2. S. caule villoso, foliis lanceolatis serratis triplinervibus scabris, racemis paniculatis secundis recurvis, ligulis abbreviatis. Willd. sp.pl. 3. p. 2055.

Icon. Pluk. alm. t. $263 . f .1$.

In hedges, old fields, and along fences: Canada to Pensyliana. 24. July-Sept. v. v.; v. s. in Herl. Banks et Lambert. From eighteen inches to tive feet high; the flowers of all the following species are, like the present, yellow and small.

2. S. caule villoso erecto, foliis lanceolatis serratis triplinervibus scabris subtus villosis, racemis spiciformibus erectis, innuptis nutantibus, ligulis abbreviatis. Willd. sp. pl. 3. p. 2055.

In swamps, hedges, and about fences : Canada to Vir ginia. 24. July-Sept. v. v.; v. s. in Herb. Banks. From four to seven feet high.

3. S. caule erecto tereti lævi, foliis lineari-lanceolatis serratis glabris margine asperis triplinervibus, racemis pzniculatis secundis, pedunculis pubescentibus. - Willd. sp.pl. 3.p. 2056.

In woods and hedges: New England to Pensylvania. 24. Sept. Oct. v. v.; v. s. in Herb. Banks.

4. S. caule erecto glabro, foliis lanceolatis serratis margine scabris obsulete triplinervibus, racemis paniculatis se.

canadensis.

procera

serotina. VDL. 11 . 
cundis, pedunculis hirtis, ligulis abbreviatis. Will. sp. pl. 3. p. 2056.

In open low places, on the side of fertile hills : New England to Virginia. 24. Aug.-Oct. v. v.; v. s. in Herl. Banks. From four to seven feet high.

ciliaris.

5. S. caule erecto glabro, foliis lanceolatis subtriplinervibus glabris margine scabris subserratis, racemis paniculatis secundis, pedunculis glabris, bracteis ciliatis, ligulis abbreviatis. IVilld. sp. pl.3. p. 2056.

In Pensylvania. Mullenlerg. 4. +.

reflexa. $\quad 6$. S. caule erecto villoso, foliis lanceolatis subserratis triplinervibus scabris reflexis, ramis panicuiatis subsecundis reflexis. Willd. sp.pl. 3.p. 2056.

In pine-woods and old felds: New Jersey to Carolina. 24. Aug. Sept. v. v.; v. s. in Herb. Banks.

laterifiora. 7 . S. caule erecto pilosiusculo, foliis lanceolatis subtriplinervibus glabris margine scabris, inferioribus subserratis, racenis paniculatis subrecurvis secundis. Willd. sp.pl.3.p. 2057 .

In old fields and dry woods: Canada to Carolina. 4. Aug.-Oct. v. v.; v. s. in Herb. Banks. Not more than half the size of No. $i$; flowers larger than any of the preceding.

\section{* Racemis secundis ; foliis venosis.}

aspera.

8. S. caule erecto tereti piloso, foliis ovatis subellipticis sciberrimis rugosis seratis enervibus, racemis paniculatis secundis. IVilld.sp.pl.3.p. 2057.

Icon. Dill. elth. $t$.305.f. 392 .

In barren dry fields and woods : New York to Carolina. 4. Sept.-Nov. v. v. v. s. in Herb. Bunks.

altissima. 9. S. caule erecto hirto, foliis lanceolatis inferioribus profunde serratis scaberrimis rugosis, paniculis secundis. IVilld. sp.pl. 3.p. 2057.

Icon. Murt. cent.' 4 .

vulgaris.

a. S. caule 5-pedali piloso, serraturis profundis inæqualibus, racemis divaricatis. Ait. kew. 3.p. 212.

recurvata. $\quad \beta$.S. caule 3-pedali villoso, serraturis profundis subæqualibus. Ait.l. $c$.

virginiana. $\quad \gamma$.S. caule 5.pedali villosissimo, serraturis magnis, racemis vix divergentibus. Ait.l. c. Mill. dict.

In hedges and fields; common. 4. Aug.-Oct. v. v.; $v$. s. in Herl. Banks. et Lamliert. It is a very variable species, and scarcely two individuals look alike. 
10. S. caule erecto hirto, foliis lanceolatis scaberrimis rugosis inferioribus adpresso-serratis, racemis paniculatis serugosa. cundis patentissimis. Willd. sp.pl.3.p.2058. Mill. dict.

S. altissima \&. Ait. kew.3. p. 213.

Icon. Dill, etth. t. $308 . f$. $3 y 6$.

In dry barren soil: Canada to Virginia. 24. Aug.Oct. v. v.; v. s. in Herb. Banks. et Lamlert.

13. S. caule erecto villoso, foliis lanceolatis molliuscu'is serratis enervibus, racemis paniculatis secundis. Herl. Banks. mss.

S. altissima B. Ait. kew. 3. p. 213.

S. pilosa. Mill. dict.

In fields and woods; frequent. 24. Alig.-Oc.. v. v.; v. s. in Herl. Banks. et Lambert. From eighteen inches to three feet high.

12. S. caule erecto hirto sulcato, foliis oblongis utrinque attenuatis acuminatis, supra glabris, subtus rugosis scabris, medio adpresso-serratis, racemis secundis.-Willd. sp. pl.3. p. 2059.

In old fields and about fences: Pensylvania to Virginia. 2. Aug.-Oct. v. v.; v. s. in Herb. Lamlert.

13. S. caule erecto tereti hirto, foliis oblongis acutis subamplexicauli-sessilibus glabris margine scabris rariter obsolete dentatis, panicula nuda secunda pyramidata, ramis reflexis, pedunculis glabris.

In pine-barrens of Georgia. Enslen. 2\%. Aug. Sent. v. s. in Herb. Enslen. About two feet high; the leaves decrease toward the beginning of the panicle, which consists of lively yellow and very small flowers.

14. S. caule erecto tomentoso, foliis caulinis lanceolatis hispidis integerrimis, radicalibus subcuneiformibus serratis, racemis paniculatis secundis. Willd. $s p . p l$. 3. p. 2059.

In sandy and barren fields; common: Canada to Carolina. 2. Aug.-Ost. v. v.; v. s. in Herb. Bunks. The whole plant has a gray aspect, and is about a foot, or sometimes two, high.

15. S. caule erecto glabro, foliis ellipticis serratis glabris, rascatira.

villosa.

Tyramidata. dicalibus oblongo-spathulatis, racemis paniculatis sepalula. cundis patentibus, pedunculis pubescent:bus. Willa. sp.pl. 3. p. 2059.

In shady woods, in fertile soil : New York to Virginia, 4. Sept. Oct. v. v. Two feet hight. 
ulnifolia.

16. S. caule erecto glabro striato, foliis ellipticis profunde serratis acuminatis subtus villosis, radicalibus obovatis, racemis paniculatis secundis, pedunculis villosis, ligulis abbreviatis.-Willd. sp. pl. 3. p. 2060.

In swamps and shady woods: New York to Virginia. 4. Aug.-Oct. v. v.

argula.

17. S. caule erecto glabro, foliis glabris argute inæqualiter serratis, caulinis ellipticis, radicalibus ovato-oblongis, racemis paniculatis secundis, ligulis elongatis. Willd. sp. pl. 3. p. 2060.

In woods and meadows: Canada to Virginia. 24. Sept. -Nov. v. v.; v. s. in Herl. Banks.

juncea. 18. S. caule erecto glabro, foliis lanceolatis glabris margine scabris, inferioribus serratis, racemis paniculatis secundis. Willd. sp.pl.3.p. 2060.

In sandy fields and wods : New Jersey to Carolina. 4. Aug.--Oct. v. v.; v. s. in Herb. Banks.

elliptica. 19. S. caule erecto glabro, foliis ellipticis lævibus serratis, racemis paniculatis secundis, ligulis mediocribus. Willd. sp. pl.3. p. 2060.

S. latissimifolia. Mill. dict.

In shady woods, among rocks: New York to Virginia. 24. Aug.-Oct. v. v.; v. s. in Herb. Banks.

asperata. 20. S. caule paniculato-corymboso, racemis suberectis, floribus adscendentibus, foliis lanceolatis serratis scabris. Herl. Banks. mss.

In Canada. 24. v. s. in Herb. Banks.

recurvata. 21. S. caule erecto pubescente, foliis lanceolatis serratis margine scabris, racemis elongatis secundis recurvatis paniculatis. Willd. enum. 889 .

In shady woods: Pensylvania and Virginia. 24. Sept. -Nov. v. $v$.

sempervirens. 22. S. caule erecto glabro, foliis lineari-lanceolatis subcarnosis lævibus integerrimis margine scabris, racemis paniculatis secundis, pedunculis pilosis. Willd. sp.pl.3. p. 2060.

Icon. Pluk. alm. t.235.f. 5. Moris. hist. 3. s. 7. t. 23. f. 15.

In swamps and on the banks of rivers: Canada to Pensylvania. 4. Sept.-Nov. v. v.; v. s. in Herb. Banks. et Lambert.

virgata. 23. S. caule glabro simplicissimo, foliis subcuneato-lanceolatis obtusis integerrimis glaberrimis appressis, supe- 
rioribus sensim minoribus, ramis paniculæ elongatis apice racemithoris, pedunculis glabris secundis.-Mich. fl. amer. 2. p. 117 .

In shady wet woods of Lower Carolina and Georgia. 4. Aug.-Oct. v. $v$. About two foot high; extremely smo th and slender.

24. S. caule erecto pubescente, foliis lineari-lanceolatis integerrimis glabris margine scabris, racemis paniculatis odora. secundis. Willd. sp.pl.3. p.2061.

Icon Pluk. alm. 116 f. 6 .

In dry sunny situations, on fertile woodlands: Canada to Carolina; principally throughout the Allegany monntains. 24. Ang. Oct.-v. v.; v. s. in Herb. Banks. This is most generally and principally known among the inliabitants by the name of Golden-rod, and used as a wholesome tea. The flower, gathered when fully expanded, and carefully dried, give a most agreeable substitute for tea, which for some time has been an article of exportation to China, where it fetches a high price.

25. S. caule erecto tereti aspero, foliis arcte sessilibus reflexis lineari-lanceolatis mucronatis subtus subcarinatis margine asperis, panicula racemis recurvatis.-Mich. fl. amer. 2.p. 117 .

In open swamps of Virginia and Carolina. 24. Aug. Sept. $v \cdot v$.

$$
\text { *** Racemis erectis. }
$$

26. S. glabra, suffruticosa ; foliis lanceolatis obtusis enervibus, pauciflosculopanicula composita multiflora, fasciculis erectis, caly- $s a$. cibus angusto-oblongis 5 -floris, radio unico.-Mich. $f$. amer. 2.p. 116.

In the sand-barrens of Virginia and Carolina. 4. Aug. -Oct. $v . v$.

27. S. caule foliisque ellipticis pilosis, inferioribus serratis, ramis foliolosis, racemis erectis, foliolis calycinis obtusis. Villd.sp.pl.3. p. 2001.

Icon. Pluk. alm. t. 114.f. 3.

In woods and on dry hills : Canada to Carolina. 4 . Aug.-Oct. v.v.; v.s. in Herb. Banks. It is easily distinguished from the rest, by the short and close racenes and white rays.

28. S. caule erecto villoso, foliis ellipticis scabriusculis petiolatis, racemis erectis, ligulis elongatis. Willd. sp.

retrorsa. pl.3.p. 206\%. 
In dry sandy soil: New Jersey to Carolina. 4. Sept. - Nov. v. v.; v. s. in Herl. Banks.

stricta.

29. S, caule erecto glabro, foliis caulinis lanceolatis integerrimis glabris margine scabris, radicalibus serratis, racemis paniculatis erectis, pedunculis glabris. Willl. sp.pl 3́.p. 20 '万2.

In sandy woods: New Jersey to Carolina. 24. Aug. -Nov. ". v.; v. s. in Herb. Banks. et Lamítr. About two feet high, very smooth.

lanceolata. 30. S. caule hirto angulato ramosisimo, foliis lanceclato. linearibus integerimi, erectiusculis $3-5$-nervibus scabriuculis: nerris subrus pilosis, axillis nudis, corymbis terminalibus fastigiatis, ramulis capitatis, ligulis altitudine cisci.-n Willd. sp. pl. 3.p. 2062.

Chrysocoma graminifolia. Sp. pl. 1178.

In fields and meadows, on the side of wonds and rivers: Canada to Pensylvania. 24. Sept. - Nov. v. v.; $x . s$. in Herl. Bamis. et Lambert. From four to five feet high; fowers small.

tenaifolia. 31. S. caule scabro angulato corymboso-ramoso, foliis angustissime-linearibus patulis obsolete 3 -nervibus scabris, axillis foliosis, corymbis terminalibus fastigiatis, ramulis capitatis, ligulis disco vix altioribus.

S. lanceolata 3 . minor. Mich. fl. amer. 2 p. 116.

In pine-barrens: New Jersey to Carolina. 24. Sept. Oct. $v . v$. Not above a foot high; leaves very small and narrow.

Sarolhrc. 32. S. caule angulato scabro inferne nudo, superne corym. boso, ranis summitate paucifloris, folis linearibus stricte-appressis obsolete 3-nervibus utrinque scabris, axillis nudis, ligulis disco duplo longioribus.

On the plains of the Missouri. M. Lewis. 24. Sept. $v$. $s$ in Herl. Lewis. About a span high; resembling Hypericum Sarothra in general habit very much. This and the two preceding bave a great affinity to one another; but I consider them good and permanent species, as there are no intermediate varieties, which night lead to the suspicion that all belong to one genuine species.

casia.

33. S. caule lævi erecto, foliis lanceolatis glabris, racemis erectis, ligulis mediocribus. Willd. sp. pl. 3. p. 2062.

Icon. Dill. elth. t. 307.f.395. 
In woods and low fields: New England to Carolina. 4. Aug.-Oct. $v, v$.

34. S. caule glabro paniculato, foliis lanceolatis serratis glabris margine scabris, ramis apice racemosis, ligulis elongatis.-I'ilid. enum. 891.

In sandy fields and woods: New York to Virginia. 4. Sept. Oct. $v . v$.

35. S. caule erecto hispido scabro, follis lanceclatis scabris integerrimis, radicalibus serratis, racemis erectis, ligulis mediocribus. Willd. sp p,l.3.p. 2033.

In grassy fields and woods: New Jersey to Virginia. 4. Oct. Nov. $v \cdot v$. Resembles No. 33.

36. S. caule paniculato hirto, foliis lanceolatis utrinque scabris, caulinis serratis, rameis integerrimis, racenis erectis, ligulis elongatis. Willd. enum. 891 .

In North America. Wilidenow. 4. + .

37. S. caule ramoso pubescente, foliis lanceolatis utrinque scabris attenuatis 3-nervibus integerrimis, racemis erectis, ligulis elongatis. Willd. enum. 891.

livida.

hispida.

Jirta.

In sandy barren woods: New Jersey to Carolina. 4. Aug.-Oct. $\quad v \cdot v$.

33. S. caule erecto lavi, folitis lanceolatis carnosis integerrimis undique læribus, racemis paniculatis erectis, pedunculis squamosis villos!s, ligulis elongatis. Willd.sp. pl.3. p. 2063.

In salt-marshes: Canada to Virginia. 24. Sept.-Nov. v. v.; v. s. in Fierl. Banks. A tall robust species, resembling the following one very much, and probably nothing more than a variety.

39. S. caule obliquo glabro, foliis lanccolatis subcarnosis integerrimis undique lævibus, racemis paniculatis erectis, pedunculis squamosis glabris, ligulis elongatis. Willd. sp. pl.3. p. 2063.

Icon. Dodart. act. 4. t. 219 .

On the banks of rivers and ditches, near salt-water. 4 . July-Sept. $v . v . ; v$. s. in Horb. Banks, et Lamlert. Tall ; flowers large.

40. S. caule erecto subpubescente, foliis lineari-lanceolatis membranaceis basi attenuatis glabris margine scabris, infimis subserratis, racemis erectis, ligulis elongatis. Willd.sp. pl.3.p. 2064.

S. integerrima. Mill. dict.

On the banks of rivers and ditches : Canada to Virginia.

lithospermifolia.

lovigata.

mexicans.

viminea. 
2. Aug.-Oct. v. v. ; v. s. in Herl. Banks. et Lantbert. Resembles the preceding, but the leaves are membranaceous, \& c c.

erecia. 41. S. caule subvilloso, foliis lanceolatis venosis glabris integerrimis subpetiolatis. Herb. Banks. mss.

In North America. 24. v. s. in Herl. Banks.

nacrophylla. 42. S. foliis inferioribus ovatis acuminatis attenuatis inæqualiter argute serratis glabris, cululinis lanceolatis uırinque attenuatis subsessilibus serratis, racemis axillarious pedunculatis foliosis, longitudine foliorum, calycibus oblongis turgidis multifloris, ligulis subelongatis.Herb. Eanks. mss.

In Canada. 4. v. s. in Herl. Banks. About three feet high; it is intermediate between this genus and Asier.

glomerala. 43. S. caule humili simplicissimo, foliis glabris oblongo-lanceolatis serratis, racemo simplici e glomerulis axillaribus: superioribus capitato-congestis, calycibus turgidis multifloris.-Mich. fl.amer. 2. p. 117.

In the mountains of Carolina. Michaux. $4 .+$.

flexicaulis. 44. S. caule flexuoso glabro angulato, foliis ovatis acuminatis serratis glabris, racemis erectis axillaribus, ligulis mediocribus.-Willd. sp. pl. 3. p. 2064.

Icon. Pluk. alm. t. 235. f. 3. Rob. ic. 22.

latifolia. $\quad$ G.S. Pluk. alm. t. 235.f. 4 .

In woods and fields; common: Canada to Carolina. 2 . Ang. ... Oct. v. v.; v. s. in Herl. Banks. This is the most common species.

axillaris. 45. S. caule glabro tereti stricto, foliis lanceolatis serratis glabris, racemi; axillaribus subglobosis erectis, ligulis elo: gatis. Herl, Eanks. mss.

In shady woods: Canada to Virginia. 24. Aug.-Oct. v. v.; v. s. in Hirb. Banks.

Virgaurea. 46. S. caule erecto tereti superne ramoso et pubescente, foliis caulinis lances:latis utrinque attenuatıs serratis, inferioribus ellipticis pilosiusculis, racemis erectis, ligulis elongatis. Willd sp pl. 3. p. 2065.

Jcon. Engl. bot. 301.

In abrador. Colmaster. 4. Aug,-Oct. v. s. in Herb. Dickson.

multiradiata. 47. S. caule villosiusculo. foliis sessilibus kanceoiatis glabris ciliatis, inferioribus apice serratis, racemo terminali 
erecto, ligulis elongatis numerosis. WVilld. sp. pl. 3. p. 2000 .

In Labrador and Hudson's Bay. 24. Aug.--Oct. v. s. in Herl. Dickson. et Banks.

48. S. canle simplici erecto glabro, foliis lanceolatis serratis humilis. glabris basi attenuatis elongatis, racemo erecto. Herl. Banks. mss.

In North America. 2. v. s. in Herb. Banks.

49. S. caule piloso tereti, foliis lanceolatis subtus pilosiusculis, racemis erectis, ligulis elongatis. Herl. Banks. mss.

In North America. 4. v. s. in Herl. Banks.

50. S. caule foliisque ovato-oblongis pilosis scabris, caulinis integerrimis, infimis serratis, ramis floriferis paniculatis, racemis compactis, ligulis elongatis. $\quad \mathrm{Villd} . s p$. pl.3. p 2067.

Icon. Herm. paraa. 243.

In the tract of mountains : New Jersey to Carolina. 4. Aug.-Oct. v. v.; v. s. in Herl. Banks. et Lambert. Flowers large; leaves very rough.

51. S. foliis radicalibus ovato-oblongis petiolatis, caule nu- noveloracendiusculo ramoso fastigiato. Willd. sp. pl. 3. p. 2067.

elata. rigida.

In sandy fields and woods. 4 . Sept. Oct. $v$. $v$. Leaves rough; flowers large.

\section{ASTER. Gen. pl. 1291.}

\section{* Foliis integerrimis.}

3. A, foliis lineari-lanceolatis 3-nervibus punctatis acutis hyssopifolius. margine scabris, ramulis corymboso-fastigiatis coarctatis, radio sub-5-floro, calycibus imbricatis disco duplo brevioribus. Willd. sp.pl. 3. p. 2022.

In sandy fields and woods : New Jersey to Carolina. 4. Aug.-Cct. v. v.; v. s. in Herb. Banks. et Lambert. From a foot to two high; flowers in a close and flattened corymb; ray white, with a tinge of purple; disk yellow.

2. A. foliis lineari-lanceolatis obsolete trinervibus integerrimis obtusis margine scabris, ramis corymboso-fastigiatis, floribus sessilibus aggregatis, radio 5-floro, caJycibus disco brevioribus imbricatis, squamis oblongis obtusis adpressis apice subreflexis.-lVilld. sp.pl. 3. p. 2024.

Conyza linifolia. Sp.pl. 1205. 
Icon. Pluk. alm. t. 79.f. 2.

In dry swamps and on the borders of woods: Pensylvania to Carolina. 2f. Aug.--Oct. v. v.; v. s. in Herl. Banks. et Lambert. About two feet high; the scales of the calyx white, with green tips; rays long, white.

tordifolius. 3. A. foilis cuneato-obovatis acutis enervibus utrinque scabris tortuoso-patulis, cory mbo composito subfastigiato, calycibus cylindricis imbricatis basi bibracteatis, squamis oblongis acutiusculis adpressis, radio 5-10ro.Mich. fl. amer. 2.p. 109 .

Conyza bifoliata. IValt. fl. car. 204.

In Lower Carolina and Georgia. 24. Aug.-Oct. v. s. in Herl. Enslen. About a foot high; flowers the size of the preceding, rays white.

lcdifolius.

4. A. foliis lineari-lanceolatis basi attenuatis enervibus scabriusculis margine revolutis, ramis corymbosis, ramulis filiformibus uniforis nudiusculis, calycibus laxis imbricatis disco duplo brevioribus, foliolis acutissimis, radio sub-20-Horo.

A. nemoralis. Ait. kew. 3.p. 198.

uniflorus. $\quad \beta$.A. caule simplicissimo unifloro.

A. unillurus. Mich. fl. amer. 2. p. 110 ?

In spliagnous bogs and about mountain-lakes: Canada to New Jersey. 2. Sept. Oct. v. v.; v. s. in Herl. Banks. et Lamlert. About a foot high ; flowers midcle-sized; disk yellowish white; ray's lilac or reddishpurpie, twice the length of the disk. Sometimes the leaves have a small indenture on each side.

rigidus.

5. A. foliis linearibus mucronatis subcarinatis rigidis margine scabro-ciliatis, caulinis refexis, rameis patentibus subulatis, caule erecto superne subramoso, ramulis 1 -floris 'corymbosis, calycibus imbricatis disco duplo brevioribus, squamis carinatis obtusiusculis, radiis sub-10-foris reflexis. - Willd. sp.pl.3. p. 2032. Mich. fl. amer. 2. p. 118.

A. nemoralis. Willd. sp. pl. 3. p. 2021. excl. syn. Aiton. A. linariifolius. Herb. Banks. et Lambert.

Icon. Pluk. alm. t. 14. f. 7 .

In sandy fields and pine-barrens: New Jersey to Carolina. 4. Aug.-Oct. v. v.; v. s. in Herb. Banks. et Lambert. About a foot or less high ; flowers nearly the size of the preceding, rays a beautiful pale violetblue, disk yellow. 
6. A. foliis crebris linearibus mucronatis enervibus impunc. linariifolius. tatis carinat is scabris rigidis, rameis recurvatis, caule subdecumbente, ramis fantigiatis 1 -tioris, calycibus imbricatis longitudine disci.-Wilıl. sp. pl.3. p. 20.4. Mich. fl. amer. 2. p. 110.

A. squarrosus. Herl. Bants. mss.

In dry, sandy and gravelly field, and among rocks: Pensvlvania to Carolina. 2 2 . Ang--Nov. v. v. $;$. s. in Herb. Bank. Resembles the preceling, but is more branching and of lower growth; the stems are rongh, and grierally of a purple colour ; leares more crowded, smaller, and nore retlex; finwers of the same colour, but smaller, and not raised on almost nalied peduncles.

7. A. foliis angusto-linearibus enervibus impunctatis glabris graminifoliks, erectis, ramulis termmalibus nudiusculis $i$-floris, calycibus Jaxis discum subrquantibus,- Herl. Banks. mss.

At Hudson's Pay. 24. Augr. Sept. v. s. in Herb. Banks, Fowers pale-purple; not above six inches high.

8. A. foliis linearibus enervibus punctatis scabris reflexo-patentibus, ramis corymbos -fastigiatis toliosis, calycilinifolius. bus imbricatis bresibus, radiis disco subæequalibus.IV illd. sp.pl 3. p. 2024

In dry shady woods anci exsiccated swamps: Pensylvania to Virginia. 2 . Sept.-Nov. $v$. $\imath$. About eighteen inches or two feet high ; flowers the size of a large daisy; rays whire or faintly purple.

9. A. foliis lineari-lanceolatis albo-villosis, caule ramoso villoso, ramis recurvato-paiulis, ramulis subsecundis uniforis, calycibus wblongis laxis imbricatrs, squamis lanceolatis nucronatis - Willd sp.pl.3.p.20:5.

A. vill sus. Mich. fl. amer. 2. p. 113.

In natural meadows of the lllinois country. 4. Aug. -Oct. + .

10. A. glaberrimus, parviflorus; canle pariculato, ramis multifloris, foliis lineari-subulatis, calycibus cyliniraceis, ligulis radii minutis. Mich. $f$ lamer. $2 . p .111$. In salt-marsies: Pensylvania to Carolina. 4. Aug.Nov. + .

11. $\Lambda$. foliis lineari-lanceolatis utrinque attenuatis acuminatis, caule pubescente paniculato erecto, ramis pauciforis, calycibus imbricatis, squamis linearibus acutis adpres. sis. Willd. sp.pl.3.p. 2025.

pilosus.

sululatus.

foliolosus. 
Icon. Dill. elth.t. $35 . f .39$ ?

In dry barren fields and on road sides: Canada to Caro= lina. 4. Aug. -Oct. v. v. ; v. s. in Herl. Lamleri. Flowers small, white; scarcely a distinct species from the following. There is no specimen of it in the Lanksian Herbarium.

tenuifolius. 12. A. foliis lineari-lanceolatis utrinque attenuatis margine hispidis, caule glabro ramoso erecto, ramulis unifloris, calycibus imbricatis, squamis oblongis acutis laxis. IVilld. sp.pl. 3. p. 2020.

Icon. Pluk. alm. 78. f. 5.

On road sides and barren fields. Aug.-Nov. v. v.; $v$. s. in Herl. Banks, et Lamlert. Flowers the same as the preceding, which I consider only a variety of the present species.

dumosus. 13. A. foliis linearibus glabris, ramulorum brevissimis, ramis paniculatis, calycibus cylindraceis arcte imbricatis. Willd.sp.pl.3.p. 2026.

violaceus. a. A. radio pallide violaceo, caule pubescente. Att. kew.3. p. 202.

albus. $\quad$ B.A. radio albo, caule glabro. Ait. l. c.

Icon. Herm. parad. 95. Pluk. alm. t. 78. f. 6.

In dry barren fields and sand-barrens: New England to Carolina. 24. Aug.-Nov. v. v.; v. s. in Herb. Banks, et Lambert. Flowers small, rays white, disk yellow.

ericoides. 14. A. foliis linearibus glaberrimis, ramulorum subulatis approximatis, caulinis elongatis, calycibus subsquarrosis, foliolis acutis, caule glabro. Willd. sp. pl. 3. p. 2027.

In barren grounds and on road sides; common: Canada to Carolina. 4. Aug.-Nov. v. v.; v. s. in Herl. Banks, et Lambert. Flowers the size and colour of the preceding.

multiflorus. 15. A. foliis linearibus glabriusculis, caule ramosissimo diffuso pubescente, ramulis secundis, caly cibus imbricatis, squarnis oblongis squarrosis acutis. Willd. $s p$. pl. 3. p. 2027.

Icon. Diil. elth. t. 36. f. 40.

In cry fields, and on road sides: Canada to Carolina. 4. Aug.-Nov. v. v.; v. s. in Herl. Banks. et Lambert. Probably only a variety of the preceding.

chans, 16. A. fnliis ciliatis, caulinis lineari-lanceolatis nervosis, rameis brevissimis lanceslatis 3 -nervibus, caule ramoso 
pubescente, ramis paniculatis, calycibus imbricatis, squamis spathulatis squarrosis. Willd. sp. pl. 3. p. 2027.

In North America. Ifuhlenlerg. $4 .+$. Resembles the precedirg one.

17. A. cano-pubescens, foliis linearibus, panicula corymbosa ramosissima foliosa, calycibus imbricatis acutissimis disco longioribus.

On the banks of the Missouri. 4. Aug.-Nov. v. s. Flowers the size of a daisy, rays pale purple.

18. A. foliis remotis linearibus amplexicaulibus erectis glaberrimis margine scabris, pedunculis fere nudis, calycibus squarrosis basi foliis 2 . suffultis. - Willd. $s p$. pl.3. p. 2033.

In marshes and swamps of Lower Carolina. 24. Aug. -Nov. v.s. in Herb. Banks. et Lambert. Flowers large, rays blue, disk yellow.

19. A. glaberrimus; foliis subulato-linearibus subcarnosis subreflexis, caule tenui ramosissimo, ramis ramulisque patulis setaceis 1 -floris, squamis pedunculorum divaricatis subulatis, calycibus imbricatis, squamis adpressis acutis.-Nich. fl. amer. 2. p.112.

In salt-marshes: New York to Carolina. 24. Sept.Nov. v. $v$. Resembles the preceding one; flowers smaller; rays pale purple or white, disk brownishyellow.

20. A. humilis; radice repente, caulibus debilibus simplicibus, foliis longe lancenlatis glabriusculis, radicalibus sparhulatis, corymbo terminali incompte rarifloro, caJycis squamis lineari-oblongis obtusiusculis. Mich. $f$. amer. 2.p. 113.

In woods of North Carolina, in the county of Burke. Michaux. +.

21. A. foliis creberrimis linearibus obtusis reflexis margine bispidis, caule ramoso diffuso glabro, ramulis unifloris, calycibus imbricatis, squanis lineari-spathulatis obtusis.-Willd. sp. pl. 3. p. 2028. Mich. fl. amer. 2. p. 112.

In dry barren soil in Lower Carolina. 24. Aug.-Nor. $v$. s. Resembles the following species; flowers bright blue.

22. A. foliis creberrimis ovatis acuminatis reflexis margine hispidis, caule ramoso hirto, ramulis unithoris, caly-

canescens.

paludosus.

sparsiflorus.

surculosus.

coridifolius.

squarrosus. 
cibus imbricatis, squamis lineari-cuneatis acutis scitarrosis. Willd. sp.pl.3. p. 2028. Walt. fl.car. 209. In pine-barrens of Lower Carolina. 2!. Aug.-Nor. v. v.; v. s. in Herb. Lamlert. Has a striking resemblance to $A$. reflexus from the Cape of Good Hope, and is a very ornamental plant ; flowers blue and large.

concolor.

23. A. foliis oblongo-lanceolatis utrinque cano-pubescentibus, caule simplicissimo erecto pubescente, racemo termicali, calycibus imbricatis, squamis Janceolatis sericeis adpressis. Willd.sp.pl.3.p. 2029.

In sandy pine and oak woods near the sea-coast: New rersey to Florida. 2. Aug.-Nov. v. v.; v. s. in Herl. Banks. et Lambert. About a foot high ; flowers, both ray and disk, of an agreeable reddish-purple. 'I his is one of the handsomest of the American Asters, and highly deserves to be introduced as an ornamental plant.

"ericens. 24. A. foliis ollongo-ianceolatis sessilibus sericeo-tomentosis, caule gracili decumbente laxe ramoso, ramis ramulisve subunifioris, calycibus foliaceis subsquarrosis. - Willd.sp.pl.3.p. 2016.

$\Lambda$. argenteus. Mich. fl. amer. 2. p. 111.

Jcon. I'ent. hort. cels.t.33.

On the banks of rivers, among rocks, in the Illinois country, and on the Mississippi and Missouri. 4. Sept. ()et. v. s. in Herb. Lambert. A beautiful species; leaves resemble those of Protea argentea; flowers jarge, rays a fine purple, disk pale-jellow.

raticklatus.

25. A. undique cano-tomentosus; foliis lanceolato-oblongis utrinque acutis sessilibus margine revolutis, subtus reticulato-venosis triplinervibus, caule superne ramoso, ramis apice corymboso-racemifloris, pedunculis subaphyllis, calycibus imbricatis laxiusculis, squamis acutissimis.

In dry swamps of Carolina and Georgia. 24. Aug.Oct. $v . v$. About three feet high ; flowers middlesized, rays and florets white.

eornifolius. 26. A. Slaber; foliis oblongo-ovatis acuminatis brevi-petiolatis margine scabris, caule glabro, panicula pauciflora, ramis bifloris, calycibus subimbricatis.-Willd. sj. pl. 3.p. 2039.

In Pensylvania. Muhlenlerg. $4 .+5$.

humilis. $27 . \Lambda$. foliis subriomboideis ovali-lanceolatis utrinque acu- 
minatis subpetiolatis glabris margine hispidis, corymbo divergenti-dichotomo nudiusculo paucifloro, calycibus laxis imbricatis, radiis 8 -floris.-Willd. $s p . p l .3$. p. 2038.

A. infirmus. Mich. fl. amer. 2. p. 109.

A. divaricatus. IVilld. sp. pl. 3. p. 20-1. secundum speo cimen Gronov, et Banks.

Icon. IVilld. hort. lerol.67. Pluk. alm. t. 79.f.1.

In shady and rocky places: Canada to Carolim. 24. Aug.-Oct. v. v.; v. s. in Herb. Batís. ¿ Gronov. Not above a foot high; flowers clear white, and large in proportion to the plant.

28. A. foliis lanceolatis basi attenuatis acuminatis margine amygdulinus. scabris, caule simplici apice corymboso-fastigiato, calycibus laxis imbricatis, squanis lanceolatis obtusis.Lan. cncyci. 1. 2. 30.5.

A. unbellatus. Ait. kew.3.p. 100 .

On the banks of rivers and in swamps: Canada to $\mathrm{Ca}$ rolina. 24. Sept-Nov. v. v. ; v. s. in Herb. Banks. et Lamkert. Rays large, white.

29. A. folis lineari-lancenlatis subintegerrimis glabris, catle glabro apice paniculato, calycibus laxis imbricatis, squamis acutis apice patulis.-Willd. sp. pl. 3. p. 2030.

A. præaltus. Lam. encycl. suppl. 1. p. 493.

Icon. Pel. ic. 307 .

in low grounds, on the side of ditches: New Ynrk to Virginia. 24. Aug.-Oct. v. v.; v. s. in Herl. Bunks. et Lamlert. From four to six feet high; flowers middle-sized, reddish-biue.

30. A. foliis lanceolatis subamplexicaulibus apice attenuatis margine scabris, caule a basi ramoso erecto hispido, ramulis pilosis, calycinis squamis laxis linearibus acutis æqualibus. - Willd. sp. pl. 3.p. 2030.

In dry swamps and copses: New York and Pensy'vania. 24. July-Sept. v. v.; v. s. in Herb. Banks. et Lamlert. Not above two feet high; flowers resembling the preceding, rays blue.

31. A. foliis lineari-lanceolatis pilosis amplexicaulibus basi nove andira auriculatis, caule simpliciusculo piloso stricto, floribus subsessilibus terminalibus confertis, calycinis squamis laxis coloratis lanceolatis disco longioribus. - Willd. s'p. pl.3. p. 2032.

Icon. Herm. parad. 98 . 
On the banks of rivers and borders of meadows: $\mathrm{Ca}$ nada to Virginia. 4. Sept.-Nov. v. v.;v. s, in Herl. Banks. et Lamlert. A highly ornamental species; in rich moist soil it will grow to the height of ten feet: flowers large, rays blue or purple, and almost every shade between red and blue.

cyaneus. 32. A. foliis lineari-lanceolatis amplexicanlibus lævigatis, caule virgato-paniculato glaberrimo, ramis racemifloris, calycinis squamis laxis lanceolatis discum æquantibus, interioribus apice coloratis.-Hofjim. phytogr. 1. p. 7 1.t. B. f. 1 .

A. rubricaulis. Lam. encycl. 1.p. 305.

A. spurius. Willd. sp. pl 3.p. 2032.

A. Novæ angliæ. $\beta$. Ait. kew. 3. p. 201.

In old meadows and dry swamps : New England to Carolina. 24. Sept.-Nov. v.v.; v. s. in Herb Lam。 lert. From three to four feet high; flowers large, in great abundance, of various tints of blue and purple; the handsomest of the genus.

carolinianus. 33. A. foliis oblongis utrinque attenuatis sessilibus, caule subscandente ramosissino, ramulis pubescentibus summitate paucifloris, calycinis squamis lanceolatis squarrosis.-Willd.sp.pl. 3.p.2017. Walt fl. car. 208.

In shady moist hedges and swamps : Carolina and Georgia. 4. $h$. Aug. Sept. v. v. From six to fifteen feet high; flowers large; rays purple or flesh-colonred, disk yellowish-purple.

grandiflorus. 34. A. foliis linearibus rigidis acutiusculis subamplexicaulibus, rameis reflexis, margine ciliato-hispidis, caule ramoso hirto, ramis unifloris, calycinis squamis squarrosis lineari-lanceolatis. Willd. sp. pl. 3. p. 2033.

Icon. Mill. ic. 282. Dill. elth t. 36.f. 41. Mart. cent. 19. Hoffm. phyt. 1.p.65.t. A. f. 1.

In dry sandy woods: Virginia to Carolina. 24. Sept. -Nov. v. v.; v. s. in Herl. Banks. About two feet high ; leaves small; flowers large, rays purple and blue, disk yellow.

phlogifolius. 35. A. foliis lanceolatis cordatis amplexicaulibus subtus pubescentibus, margine scabris, caule simplicissimo pubescente, panicula terminali laxa rarifora, calycinis squamis laxis imbricatis lanceolatis. - W Willd. sp. pl. 3. p. 2034.

A. amplexicaulis. Mich. $f$. amer. 2. p. 114.

In shady moist places: New Jersey to Virginia. $\psi$. 
Aug.-Nov. $v . v$. From eighteen inches to a foot high ; flowers middle-sized, ray's violet.

36. A. foliis oblongo-lanceolatis ciliatis cordatis amplexicaulibus utrinque scabris pilo;is, canle ramuso hirto, ramis patentibus elongatis pauciatoris microphyllis, calyrinis squanis imbricatis lanceolatis patulis. - Willd. sp.pl. 3. p. 2034.

A. dirersifolius. Mich, fl, amer. 2. p. 113?

In hedges, old drving uin swamps, and sometimes among rocks: New Engiand to Carolina. 4. Sept.-Nov. v. v.; r. s. in Herb Bunks. et Lamlert. From a foot to two high; flowers middle-sized, rays purple or blue, disk yeilow.

* Foliis cordatis ovatisque, scrratis.

37. A. foliis oblongis cordatis amplexicaulibus integerrimis pilosis subundulatis, inferioribus ovatis cordatis subserratis petiolatis, petiolis alatis, caule paniculato hispido, ramulis secundıs foliosis unifloris. Willd. sp. pl. 3. p. 2035.

Icon. Holfm phyt. 1.t. C. f. 1. Herm. parad. 96 .

In dry woods and old fields: New England to Carolina. 4. Sept-Nov. v. v.; v. s. in Herh. Banks, et Lamlert. Flowers smaller than the preceling; rays pale violet.

38. A. foliis oblongo-lanceolatis acuminatis sessilibus medio serratis, radicalibus oblongis cordato-sagittatis serratis petiolatis, caule ramoso giabro, squamis calycinis laxis imbricatis lanceolatis. - Willd. sp. pl. 3. p. 2035.

In North America. IVedemeyer. $24 .+$. Flowers blue, the size of the following species.

39. A. foliis ovato-lanceolatis subserratis petiolatis glabris, radicalibus ovato-cordatis serratis scabris petiolatis, petiolis nudis, caule amosissimo glabro, ramulis pilosis, calycibus laxis subimbricatis. Willd. sp.pl.3. p. 2035.

Icon. Corn. canad. 65. Moris. hist. 3. s. 7. t. 22.f. 34 . In meadow's, hedges, and on the borders of woods : Canada to Virginia. 24. Ang.-Nov. v. v.; v. s. in Herb. Banks. et Lamlert. From two to four feet high ; flowers rather small, but in great abundance, changing from white to blue in the ray, and from yellow to purple or brown in the disk, which gives the whole plant a beautiful variegated appearance. 
cordifolius. 40. A. foliis cordatis subtus pilosis argute serratis petiolatis, petiolis alatis, caule paniculato glabriusculo, panicula divaricata, calycibus laxis subimbricatis. - Willd. sp. pl.3.p. 2036.

In shady woods, throughout the mountains : Canada to Florida. 4. Sept.-Nov. v. v.; v. s. in Herl. Banks. Flowers small, white, or pale purple.

corymlosus. 41. A, foliis ovatis argute serratis acuminatis glabriusculis, inferioribus cordatis petiolatis, petiolis nudis, caule glabro superne corynboso-fastigiato, ramis pilosis, calycibus oblong is imbricatis, squamis obtusis arcte adpressis.-Willd. sp. pl.3.p. 2036.

In shady woods : Canada to Florida. 24. Aug.-Nov. $v . v . ; v . s$. in Herl. Banks. et Lamlert. A foot or two high ; flowers white, larger than the preceding.

macrophyllus. 42. A. foliis ovatis petiolatis serratis scabris, summis ovatocordatis sessilibus, inferioribus cordatis petiolatis, petiolis submarginatis, caule ramoso diffuso, calycibus cylindricis arcte imbricatis, squamis oblongis acutis. -Willd. sp.pl.3. p. 2037.

In shady woods about rocks; Canada to Virginia. 4. Sept.-Nov. v. v. ; v. s. in Herl. Banks. et Lamlert. A foot or two high; flowers above the middle size, rays white, and sometimes blue.

heterophyllus. 43. A. foliis glabris, caulinis ovatis subcordatis acuminatis profunde serratis apice integerrimis, ramorum ovatooblongis subserratis, ramulorum lanceolatis minutis. sime reflexo-patentibus, caule paniculato glabro, caly • cibus arcte inbricatis. Willd. enum. 882.

In North America. Willdenow. 4. +.

*** Foliis lanceolatis ovatisque, inferioribus serratis.

amplexicau - 44. A. foliis ovato-oblongis acutis amplexicaulibus cordatis lis. serratis glabris, caule paniculato glabro, ramulis 1-2floris, calycinis squamis lanceolatis arcte imbricatis.Willd. sp.pl. 3. p. 2046.

A. pensylvanicus. Lam. encycl. suppl. 1. p. 498.

On the borders of roods, in sandy soil : New Jersey to Virginia. 2. Sept.-Nov. $v . v$. Flowers middlesized, blue.

prenanthoi- 45. A. foliis amplexicaulibus spathulato-lanceolatis acuminades. natis medio serratis basi cordatis, ramulis pilosis, calycinis squamis lanceolatis squarrosis.-Willd. sp. pl. 3 . p. 2046. 
In Pensylvania. Muhlenlerg. $4 .+$. Flowers blue.

16. A. foliis amplexicaulibus lanceolatis, inferioribus subserratis glabris, ramulorum linearibus squarrosis, calycibus squarrosis disco brevioribus, squamis lineari-cuneatis.- I'illd. erum 884.

In Not th America. Iyilldenow. 24. +. Rays violet; disk yellowish-brown.

47. A. foliis subamplexicaulibus lato-lanceolatis suberratis lævibus, caule ramosissimo glabro, ramulis nultitlo. ris, calycinis squamis lanceolatis laxis discum subæquantitus. - Willd. sp. pl.3.p. 2046.

In swamps and wet woods: Pensyluania to Virginia. 4. Sept.-Nov. v.v.; v. s. in Herl. Lamlert. Flowers large, pale rose- or flesh-cololoured, with a tinge of purple.

49. A. foliis subamplexicaulibus lato-lanceolatis subserratis glabris, radicalibus medio serratis, caule ram sinsino glabro, calycinis squamis lancedatis laxis disco brevioribus. Willd. st. pl. 3. p. $20+5$.

In old tields and on the borders of wools: New Jersey to Carolina. 24. Aug.--Uct v. v.; v.s in Herl. Lamlert. A beautitul species; flowers hrge and in great abundance, disk yellow, ray, white, changing to a deep violet; so that at the same time there are flowers of different colours on the same plant; which bas a very pleasing effect.

49. A. foliis subamplexicaulibus, superioribus lanceolatis acuminatis integerrimis, inferioribus lanceolatis basi angustatis serratis, ramulis virgatis, calycibus disco brevioribus laxis, caule glabro. Willd. sp. pl. 3. p. 2045.

Icon. Pluk. alm.t. 326.f. 1. Ferm. lugdl. 67.

In old fields and woods: Yensylvania to Virgioia. 4. Aug.-Oct. v.v.; v. s. in Herl. Lamlert. Flowers middle-sized; rays deep purple, disk yellow, changing tos purple.

50. A. foliis subamplexicaulibus remotis oblongis integerriadulterinus.

lavigatus.

versicolor.

mutalilis. mis lucidis, radicalibus șbserratis, ramis simplicibus unifloris, calycibus imbricatis, foliolis subcuneiformibus acutis apice incrassatis, caule glabro angulato.Willd. sp. pl. 3. p. 20-i4.

In woods and on the sides of ponds and ditches: New York to Virginia. 4. Sept.-Nov. v. v. Rays blueish-purple. 
concinnus. 51. A. foliis lanceolatis subamplexicaulibus inferioribus sub. serratis glabris, caule simplici apice paniculato, calycibus arcte inbricatis. Willd. enum. 884.

In fields and woods: New York and Peusylvania. $\mathcal{4}$. Sept.-Nov. v. v.; v. s. in Herl. Lamlert. Leaves resembling those of Phlox maculata; rays blueishpurple.

puniceus. 52. A. foliis amplexicaulibus lanceolatis serraris scabriusculis, ramis paniculatis, caly cibus laxis discum superantibus, foliolis lineari-lanceolatis subæqualibus, caule hispido. Willd. sp.pl.3. p. 2040.

Icon. Herm. lughl. 651 .

purpureus. a. A.septenıpedalıs, caulibus saturate purpureis. Ait.kew. 3 . p. 203.

A. amonus. Lam. encycl. 1. p. 306.

rufescens. F. A. octopedalis, caulibus e viridi-rufescentibus. Ait. l.c.

A. hispidas. l.am encycl 1. p.307.

On the banks of rivers and ditches, particularly near salt-water: Canada to Carolina, and in the range of mountains, about lakes. 4. Sept-Nov. v. $v$; $r$. s. in Hurb. Banks, et Lambert. From three to ten feet high; Howers large, purple or blue.

foribundus. 53. A. foliis subamplexicaulibus lanceolatis, inferioribus serratis, caule glabro, ramis corymbosis, ramulis nultiforis pilosis, calycinis squamis laxis lanceolatis imbricatis. Willd.sp.pl.3. p. 2048.

In North Amerca. Willdenow. 24. +. Resembles the following species.

novi lelgii. 54. A. foliis subamplexicaulibus lancenlatis glabris margine scabris, inferioribus subserratis, ramis subdivisis, calycibus lave-imbricatis, foliolis lineari-lanceolatis, caule tereti glabro. Willd. sp. pl. 3. p. 2048.

Icon. Herm. lugdl: 69 .

In hedges and old fields: New England to Virginia. $\mathcal{\Psi}$. Aug.-Oct. v. v.; v. s. in Herb. Lamlert. Flowers midile-sized, pale purple.

bellidiflorus. 55. A. foliis amplexicaulibus angusto-lanceolatis supra scabris, inferioribus subserratis, canle ramosissimo, calycis squamis lanceo'atis patentibus. IVilld. enum. 856 .

In North America. IVilldenow. $4 .+$. Ray pale red, disk yellow, changing to brown.

spectalilis. 56. A. foliis lancenlatis scabriusculis subamplexicaulibus, inferioribus medio serratis, ramis corymbosis, foliolis 
calycinis laxis foliaceis subcuneiformibus acutiusculis squarrosis. Willd sp.pl.3. p. 2049.

In low meadows, on the sides of woods: Pensylvania to Virginia. 2f. Aug.-Nov. v. v.; v. s. in Herl. Lamlert. About two feet high; flowers large, blue.

57. A. foliis oblongo-lanceolatis acuminatis sessilibus glabris serotinus。 margine scabris, inferi ribus serratis, ramis corymbosis clabris, ranulis unitloris, calycinis squamis lanceolatis acuminatis patentibus.-IVilld. sp. pl. 3. p. $20+9$.

In low grounds and on the banks of ditches: New York to Virginia. 24. Sept-Nov. v. v.; v. s. in Herl. Lamlert. About three feet high; flowers large, blue.

58. A. foliis sessilibus serratis glabris spathulato-lanceolatis basi attenuatis et margine utroque latere defiexis, ramis divaricatis, calycibus laxis, foliolis lanceo!atolinearibus subæqualibus glabris.-Willd. $s p$. pl. 3 . p. 2049.

In low overflowed grounds: New York to Virginia; rare. 24 . Oct. Nov, v.v. Flowers below the mic!dle size; rays pale blue.

59. A. foliis subamplexicaulibus oblongo-lanceolatis acuminatis serratis glabris, caule pyramidato-ramoso, ratmis axillaribus racemitloris folio vix longioribus, pedunculis tomentosis nudis, calycibus laxis subæqualibus disco brevioribus.-Herl. Banks. mss.

In Canada. 4. Oct. Nov. v. s. in Herb. Banks. Flowers above the middle size; rays pale purple.

6o. A. foliis lato-lanceolatis inferne atteutatis integris superne inzequaliter serratis longissime acuminatis, caule simplici flexuoso anguloso, panicula corymbosa divaricato-dichotoma, calycinis foliolis laxis linearibus disco brevioribus.-Mich. $f$. aner. 2. p. 109.

a. A. caule altiore, panicula multiflora foliosa.

A. latifolius. Herl. Banks. et Lamlert.

$\beta$. A. caule pumilo, corymbo paucithoro nudo vix foliis altiore.

In Canada and on the Allegany mountains, in rocky shady situations. $\beta$. On the highest mountains of Virginia and Carolina. 4. Aug.-Oct. v. v. About a foot or more high ; flowers middle-sized; rays white.

61. A foliis oblongis 3 -nervibus basi angustatis acutis, superioribus sessilibus subintegerrimis, inferioribus iotiolatis serratis, caule simplici apice corymboso, calyci-

tardiflorus,

llandus,

acuminatus.

elatior. pumilus,

conyzoides. 
bus cylindricis squarrosis, radiis 5 . brevissimis.Willd. sp.pl.3.p. 2043.

A. marylandicus. Mich. fl. amer, 2.p. 108.

Conyza asteroides. Sp. pl. 1206.

In fields and woods: Pensylvania to Carolina. 4. Aug. -Oct. $v . v$. About a foot high; flowers small; rays only five, white.

peregrimus. 62. A. foliis sessilibus remotis oblongo-lanceolatis sensim acutis glabris, caule erecto subsimplici glabro superne hirto summitate 1-3-floro, calycinis squamis lanceolato-linearibus villosis acutissimis laxis longitudine disci, radiis numerosis.-Herb. Banks. mss.

On the north-west coast: Unalashka. D. Nelson. 24. $v$ s. in Herb. Banks. Flowers large, violet.

Radula. 63. A. foliis lanceolatis serratis acuminatis rugosis scaberrimis, caule erecto angulato simplici, corynibo terminali, caJycibus imbricatis, foliolis lanceolatis obtusiusculis subsquarrosis.-Willd. sp. pl.3. p. 204t.

In Nova Scotia and on the high mountains of New York and Pensyliania. 24. Sept-Nov. v. v.; v. s. in Herb. Banks. et Lamlert. Flowers middle size; rays short, white.

strictus. 64. A. foliis sessilibus angusto-lanceolatis serratis scabris, caule superne uno aut paucitloro, calycinis squamis imbricatis adpressis oblongis acutis discum subæquantibus.-Herb. Banks. mss.

A. biflorus. Mich. Al amer. 2. p. 114?

In Labrador, at Hudson's Bay, and on high mountains in Pensylvania. 24. Sept. Uct. v.v.; v. s. in Herl. Banks. From four incbes to a span high; flowers midule-sized; rays pale violet, disk brownish-yellow.

Traciescanti. 65. A. foilis lanceolatis serratis sessilibus glabris, ramis virgatis, calycibus imbricatis, caule tereti glabro. Willd. sp. pl.3.p. 2047.

A. vimineus. Lam. encycl. 1. p. 306.

In hedges and diy swanps; frequent: Canada to Virginia. 24. Aug.--Oct. v. v.; v. s. in Herb. Lambert. Three or four feet high; flowers very small; rays white, and sometimes pale purple.

recurvatus. 66. A. foliis sessiiibus angnsto-lanceolatis basi attenuatis, inferioribus medio serratis, caule ramoso glabro recurvato, calycinis squamis laxis imbricatis lineari-lanceolatis subrequalibus.-Willd. sp. pl. 3, p. 20-17.

A. salicifulius. Lann. encycl. 1.p. 305. 
In fields and on road sides: New England to Pensylvania. 4. Sept.-Nov. $v$. $v$. Resembles the preceding ; flowers pale blue.

67. A. foliis lineari-lanceolatis acuminatis margine scabris, infimis subserratis, caule paniculato, ramulis unifloris, calycibus laxe imbricatis, foliolis lanceolatis. IVilld. enum. 886.

In North America. Willdenow. 4. Sept.-Nov. v. «. in Herl. Lamlert. Flowers of middle size; ray's pale lilac, disk yellow, changing to red.

6s. A. foliis lineari-lanceolatis acuminatis margine scabris, infimis subserratis, caulinis subreflexis, rameis patentissimis, caule laxo apice paniculato, calycibus imbricatis, foliolis lanceolatis acutis apice reflexis. Willd. enum. 886.

In low sandy fields: New Jersey to Virginia. 24. Sept. -Nov. v. $v$. Rays white ; disk yellow.

69. $\Lambda$. foliis lanceolatis acuminatis margine scabris, caulinis apice serratis, rameis integerrimis, caule glaberrimo apice paniculato, calycibus laxe imbricatis, foliolis lineari-subulatis. Willd. enum. 887.

In North America. Willdenow. 4. +. Rays white, disk yellow.

70. A. foliis linearibus integerrimis, radicalibus nblongis subserratis, caule ramosissimo pubescente, calycibus laxe imbricatis. Willd. enum. 888.

In North America. Willdenow. 4. +. Rays white, disk yellow, changing to red or brown.

71. A. foliis lanceolato-linearibus sessilibus glabris, infimis subserratis, ramulorum lanceolatis, caule paniculato glabro, ramis virgatis, calycibus imbricatis. Willd. sp. pl. 3. p. 2050.

In swamps and ditches: Pensylvania to Virginia. $\mathcal{\psi}$. Aug.-Oct. $v . v$. From four to sin feet high; flowers flesh-coloured.

72. $\Lambda$. foliis lineari-lanceolatis sessilibus integerrimis glabric, infimis lanceolatis subserratis, caule ramoso diffuso glabriusculo, calycibus imbricatis, foliolis lanceolatis subpatulis.-Willd. sp. pl. 3. p. 2050.

In North America. Willdenow. 4. Aug.-Nov. +. Resembles the preceding; flowers smaller, rays white, changing to a pale violet.

73. $\Lambda$. foliis linearibus acuminatis integerrimis, inferioribus

eminens.

laxus.

simplex.

polyphyllus.

juncens.

lanceolatus.

dracunculoides. 
lineari-lanceolatis subserratis, ramis corymbosis, calycibus in mbricatis, caule glabriusculo. Willd. sp. $p l .3$. p. 2050.

A. artemisiflorus. Lam. encycl. suppl. 1. p. 500 .

In Jow grounds and on sides of ditches: New Jersey to Carolina. 24. Sept-Nov. v. v.; v. s. in Herb. Lamlert. About four feet or less bigh ; flowers about half the size of No. $; 1$, rays white.

fragilis.

74. A. foliis linearibus acuminatis integerrimis, radicalibus oblongis serratis, ramis corymboso-paniculatis, calycibus imbricatis squamis adpressis, caule glabriusculo. Willd. sp pl. 3. p. 2051.

In North America. Nuhlenberg. 4 . v. s. in Herb. Lambert. About two feet bigh; flowers white, smaller than the preceding. This and the three preceding species are very nearly allied to one another, so much so that it is difficult to find sufficient cararacters to distinguish them, though their general appearance and the size of the flowers separate them at first sight.

miser. 75. A. foliis sessilibus lanceolatis serratis glabris, calycibus imbricatis, foliolis acutis, disco radii æquali, caule villosiusculo. Willd.sp.pl.3.p 2051 .

In old barren fields: Canada and New England. $\mathcal{\psi}$ Aug.-Oct. v. v.; v. s. in Herl. Lamlert.

divergens. 76. A. foliis elliptico-lanceolatis serratis glabris, caulinis lineari-lanceolatis elongatis, ramis patentibus, calycibus imbricatis, caule pubescente. Willd. sp. pl. 3 . p. 2052.

In old fields and barren woods : New York to Carolina. 4. Sept.-Nov. v. v.; v. s. in Herb. Lambert. From three to five feet high; flowers small; rays white, disk reddish-brown.

diffusus. 77. A. foliis elliptico-lanceolatis serratis glabris proportionatis, ramis patentibus, calycibus imbricatis, caule pubescente. Willd. sp. pl.3.p. 2052.

In fields and hedges; frequent : Canada to Carolina. 4. Sept.-Nov. v. v.; v. s. in Herb. Lambert. Flowers white, small.

pendulus. 78. A. foliis elliptico-lanceolatis serratis glabris, ramulorum remotiusculis, ramis divaricatissimis pendulis, caule pubescente. IVilld.sp.pl.3.p. 2052.

In old fields; common. 4 . Oct. Nov. $v . v . ; v$. in Herl. Lambert. Resembles the preceding; but the 
stem forms a loose panicle with pendulous branches;

the disk turns brown.

\section{DONIA. Ait. kew.ed. 2. t. 4. p. 82.}

1. D. herbacea; foliis oblongis amplexicaulibus scratis, calycinis squam:s apice tiliformibus revoluto-squarrosis.

In open prairies, on the banks of the Missouri. MI. Leu'is. 4. Aug. Sept. v. s. in Herl. Lewis.; v. v. cult. Flowers yellow, resembling those of Inula. The whole plant is viscous, and has a strong resiniferous or balsamic scent.

Caulis erectus, teres, albidus, corymboso-ramosus. Pami alterni, angulati, api e uni- aut triflori. Folia alterna, basi diatata, amplexicaulia, oblonga, acuta aut obtusa, serraa, glabra, utrinque squamulis punctiformibus resimfer is obsita. Flores 1-3. in summitate ramulorum, curymbosi, flavi, ante explicationem copiose resiniferi. Calyx hemisphæricus, arcte imbricatus: Squamis apice filiformibus, revolutis et quasi caput Wedusæ referentibus. Flosculi radii linearilanceolatæ, acutæ. Semina oblongo-obovata. Pappus : aristis $2-4$. deciduis. Receptaculum planum, nudum, farulosum.

It approaches near to Aster glutinosus Cav. ic. 2. p.53. t. 163. which is the Donia glutinosa Ait.kew. ed. 2. t. 4. p. 82. which I distinguish by the following diagnosis : Donic glutinos ؛ : frutescens; folis oblongoobcuneatis sessilıbus serratis, calycinis squamis linedribus erectis.

\section{BCEBERA. Willd. sp.pl.3.p 2125.}

1. B. caule paniculato, foli:s oppositis subbipinnatis glabris acutis.-IVilld. sp. pl. 3. p. 2125.

Tagetes papposa. Mich. fl. amer. 2.p. 132.

Tagetes pumila. Hort. pisan.

Dyssodia glandulosa. Cav. demonstr. loot. p. 202.

On the overflowed banks of the Missouri and Missis. sippi. $\odot$. Aug. Sept. v.s. Flowers small, goldenyellow.

spuarrosa.

chrysanthemoidey. 


\section{ACTINELla. Pers. syn. 2. p. 469 .}

Actinea. Juss. in annal. mus. 2. p. 425.

lanata. $\quad$ 1. A. undique lanato-tomentosa; foliis linearibus superne pinnatifidis, pedunculis elongatis unitloris, radiis bidentatis, seminibus glabris 5 -gonis.

On the high lands of the Kooskoosky. M. Lewis. 4 . June, July. v. s. in Herb. Leuis. Flowers orangeyellow. It resembles in habit Jussieu's Actinea, in Annal. du mus. 2. t. 61.f. 2.

Planta omnibus partibus tomento albo lanato tecta. Cau . lis ramosus, teres. Rami alterni, superne subdivisi. Ramuli uniflori. Folia caulina alterna, linearia, superne dilatato-pinnatifida, dentata; ramea linearia, integra. Pedunculi terminales, elongati, superne incrassati. Flores aurantiaci, magnitudine Tagetidis erectce. Calyx oblongus, simplex, polyphyllus: foliola 12-14. lineari-lanceolata, acuta. Corollulce radii 12-14. oblongæ, bidentatæ, nervosæ: disci tubulosæ, concolores. Pappus: paleis 4-6. scariosis, albidis, acutis, interdum laceris. Semina prismaticooblonga, 5-gona.

\section{HELENIUM. Gen. pl. 1299.}

antumnale. 1. H. foliis lanceolatis serratis subdecurrentibus, caule superne corymbeso, corollulis disci 5 -fidis : radii planis reflexis.-Willd. st. pl. 3. p. 2120.

putescens. Icon. Pluk. amalth. t. 372. f. 4. Corn. canad. 63. 3. H. foliis pubescentibus. Willd. sp. pl.3. p. 2121.

On the banks of rivers, ponds, and ditches : Canada to Carolina. 24. Oct. Nov. v. v. About two feet high; flowers bright yellow.

canalicula-

tum.

quadridentatum.
2. H. folis lanceolatis serratis subdecurrentibus, caulibus simplicibus, corollulis disci 5 -fidis : radii canaliculatis. Lamarck in journ. hist. nat. 213. t.35.

3. H. foliis lato-decurrentibus, inferioribus subpinnatifidis, superioribus lanceolatis integeırimis glabris, corollulis disci 4-dentatis._- Willd.sp. pl. 3. p. 2121.

Rudbeckia alata. Jacq. ic. rar.t. 593.

Icon. Labillard. in act. soc. inist. nut. par. 1. t. 4. On the banks of the Mississippi. 4. July, Aug. v. $v$. Frons three to four feet high; flowers smaller than the preceding 
641. BOLTONIA. Gen.pl. 1309.

1. B. foliis integerrimis, foribus longe pedunculatis, seminibus ovalibus glabris subinuticis.-IVilld. sp. pl. 3 . p. 2162.

Matricaria asteroides. Linn. mant. 116.

Chrysanthemum carolinianum. Walt. $f$. car. 204.

Icon. L'Herit. sert. angl.t. 25. ined.

On the banks of ponds and swamps : Carolina and IIIinois. 24. Aug.-Oct. v. s. Rays flesh-coloured; disk ycllow.

2. B. foliis inferioribus serratis, floribus breviter peidunculatis, seminibus obcordatis conspicue alatis pubescentibus, aristis pappi duabus ipsorum longitudine.IVilld. sp.pl.3.p. 2163.

Icon. I'Herit. sert. angl. t. 26. ined.

On the banks of rivers and ponds. Pensylvania to Virginia. 2f. July, Aug. v. $v$. Resembles the preceding very much.

\section{SIEGESBECKIA. Gen. pl. 1320.}

1. S. foliis sessilibus ovatis dentatis, floribus disci tridentatis triandris. Willd. sp.pl.3.p. 2220.

Icon. L'Herit. stirp. $t .19$.

On the north-west coast. $M T$. Lewis. $\odot$. July, Aug. v. s. in Herl. Lewis. Flowers yellow.

\section{PHethuSA. Gen. pl. 1319.}

1. P. foliis oppositis ovatis acuminatis serratis triplinervibus, americana. corymbo terminali brachiato.-Willd. sp. pl. 3. p. 2221.

Icon. Pluk. mant. t. 342.

In North America. 24. +. I strongly suspect this to be the same with Verbesina Siegesbeckia, althongh Mi. chaux declares it to be different.

\section{ECLIPTA. Gen. pl. 1316.}

7. E. erecta, dicholoma, strigosa ; foliis lanceolatis basi aterectrt. tenuatis rariter serratis, pedunculis geminis elongatis, calycinis foliolis ovatis acuminatis.-Willd. $s p . p l .3$. p. 2217.

Verbesina alba. Sp.pl.12ð2. 
Cotula alba. Syst. nat. 2. p. 564.

Icon. Dill. elth. t. 113. f. 137. Pluk. alm. t. 109. f. 1 。 Moris. hist. 3. s. 6. t. 13.f. 16.

In dry gravelly soil : Virginia to Florida. $\odot$. June, July. $\boldsymbol{v} \cdot \boldsymbol{v}$. Flowers small, white.

procumlens. 2. E. procumbente-assurgens; foliis longo-lanceolatis inferne angustatis rariter subserratis, pedunculis longiusculis, calycinis foliolis acute-lanceolatis, flosculis 4 fidis.-Mir h. $A$ amer. 2.p. 129.

In Lower Carolina. $\odot$. July, Aug. v. s. Flowers small, white.

brachypoda. 3. E. divaricato-prostrata ; foliis lancenlatis subserratis, pedunculis solitariis gemini-que brevibus, calycinis foliolis ovali-lanceolatis, flosculis 5-fidis.-Mich. $f$. amer. 2. p. 130.

Amellus carolinianus. Walt. fl. car. 213.

In low sandy fields : Carolina. $\odot$. July, Aug. v. v.

\section{ANTHEMIS. Gen. pl. 1312.}

arvensis. 1. A. receptaculis conicis, paleis lanceolatis, seminibus coronato-marginatis, foliis bipinnatis laciniis lanceolatolinearibus. Will.t. sp. pl. 3.p. 2180.

Icon. Engl. lot. 602 .

In waste grounds and on road sides: Pensylvania to Virginia. $\delta . \odot$. Aug. Sept. v.v. Rays white, disk yellow.

repens.

2. A. caule repente, folis ovali-lanceolatis subintegris, pedunculis terminaiibus unifloris longissimis, calycibus subæqualibus 10-12. phyllis.-Walt. fl. car. 211.

Spilanthus repens. Mich.fl. amer. 2. p. 131

On overflowed banks of rivers: South Carolina. $\odot$. July-Sept. v.v. Flowers yellow.

\section{ACHILlEA. Gen. $p l .1313$.}

Ptarmica. 1. A. foliis linearibus acuminatis æqualiter argute serratis glabris. Willd. sp.pl.3. p. 2191.

Icon. Fl. dan. 643. Engl. lot. 757.

In open dry swamps : Canada and New York. 24. Aug. Sept. v. v. Flowers white.

asplenifolia. 2. A. foliis radicalibus bipinnatifidis, caulinis incisis, laciniis ovatis serrato-mucronatis obtusis.-Vent. hort. cels 95 . 
In North America. Bosc. 4 . +. Flowers rose-coloured.

3. A. foliis bipinnatifidis pilnsis laciniis linearibus dentatis mucronatis, cauibus sulcatis. Smilh fl. lrit. 2. p. 908 . Willd. sp. pl. 3. p. 2208.

Icon. Fl. dan.737. Engl. lot. 758.

In fields and on road sides; common. 24. June-Aug. $v$. $v$. Probiably introduced from Europe. Flowers white or rose coloureit.

4. A. foliis bipinnatifidis villosis, pinnis confertissimis, latomentosa. ciniis lineari-lancenlatis integerrimis; corymbo composito. Willd.sp.pl 3. p. 2209.

Icon. Bot. mag. 4g8. Gmel. it. 1. t. 25.f. 2.

On the banks of the Kooskoosky. MI. Lewis. 4. June. v. s. in Herb Leuis. Flowers yellow.

\section{TETRAGONOTHECA. L'Heril. stirp.p. 177.}

1.T. hirsutissima; foliis oppositis amplexicaulibus spathu- helianthoides. lato-ovatis, sumnis o:atis acuminatis dentatis triplinervibus.-Willd.s;.pl.3.p. 2116.

Polymuia letragonotheca. Syst. veg. 658.

Icon. Dill. elth. $t .283 . f$. 365.

In fertile soil, on the borders of woods and along hedges: Virginia to Florida. 4. July-Sept. v. v. From four to six feet high; howers large, yellow.

64s. HELIOPSI's. Pers. syn. 2.p. 473.

1. H. foliis oppositis ovatis serratis triplinervibus. Pers. lavis. syn. 2. p. 473.

Buphthal num helianthoides. IVilld. sp. pl. 3.p. 2236.

Helianthus lævis. Sp. pl..1278.

Rudbeckia oppositifolia. Sp. pl. 1280.

Silphium solidaginoides. Sp. pl. 1302.

On the banks of rivers, and in rocky shady places : Pensylvania to Carolina. 24. Aug.-Oct. v. v. A tall plant, resembling a species of Helianthus.

\section{BUPHTHALMUM. Gen. pl. 1231.}

1. B. foliis oppositis cuneato-lanceolatis carnosis incanis, petiolis bidentatis, caule fruticoso.-IVilld. sp. pl. 3 .

frutescens. p. 2229.

Icon. Dill. elth. t. 28. f. 4. Pluk alm. t. 115. f. 4. Catesb.fl. car.1. t. 93 . 
On the sea-coast: Virginia to Florida. $\zeta$. Aug. Sept. $v . v$. A shrub about fire feet high.

angustifolium.

sagitiatum.

villosus.

spinulosus.

virginica.
2. B. foliis alternis linearibus superne latioribus integerri. mis glabris, calycinis foliolis acute-lanceolatis.-Herb. Banks. mss.

In Georgia and Florida. Bartram. 4. v. s. in Herb. Banks.

3. B. tomentosum; foliis radicalibus longissime petiolatis oblonyis sagittatis integerrimis subtrinervibus, caulinis oblungis in petiolum attencatis, caule subtrifloro, ca. lycinis foliolis exterioribus disco longioribus.

On dry barren hills, in the Rocky-mountains. M. Leuis. 4. June, Jaly. v. s. in lierb. Lewis. Flowers large, yellow. The natives eat the young stems as they spring up, raw.

\section{AMELLUS. Gen. pl. 1315.}

1. A. villosissimus; foliis sessiilbus oblongis acuminatis integerrimis, floribus axillaribus brevi-petiolatis, radiis integris, paleis setaceis.

On the Missouri. 4. v. s. Rays yellow.

2. A. canescens; foliis bipinnatifidis inciso-dentatis, laciniis linearibus rigido-mucronatis, floribus lateralibus et terninalibus congestis, radiis bidentatis, paleis setaceis.

In open prairies on the Missouri. M. Lewis. 4. Aug. Sept. v. s. in Herl. Lewis. Rays yellow.

Tota planta rigida, scabra, cano-viridescens. Caulis ramosissimus. Rami angulosi. Ramuli laterales breves, uniflori. Folia alterna, bipinnatifida, rigida, laciniis linearibus, spinula terminatis, inferioribus inciso-dentatis. Flores laterales solitarii et terminales congesti, subcorymbosi, lutei. Calyx imbricatus : squamis exterioribus brevioribus, acutis, hirsutis ; interioribus linearibus, scariosis. Corollula radii lineari-lanceolatæ, bidentatæ. Receptaculum: Paleis brevibus, subulatis.

Both species are an intermediate link between Aster and Inula. They approach the nearest to Amellus; but the receptacle is not, properly speaking, paleaceous, but only setaceous.

651. VERBESINA. Gen.pl. 1317.

1. V. caule angusto alato, foliis alternis lato. lanceolatis subserratis, corymbo composito, calycibus oblongis pubescentibus.-IVilld.sp. pl.3.p. 2222 . 
In shady woods on the mountaius: Pensyluaria to $\mathrm{Ca}$ rolina. 4. July-Sept. v. v. Rays from three to four, white.

2. V. caule alato, foliis oppositis ovato-lanceolatis utrinque acuminatis acute serratis, panicula brachiata, ramulis

Siegesleckia. summitate fasciculifloris.-Willd. $s p$. pl. 3. p.2224.

Siegesbeckia occidentalis. St. pl. 1269.

In shady woods: Virginia to Carolina. 24. July-Sept. $v . v$. Rays from one to three, yellow. It has a strong resemblance to Phathusa.

3. V. caule alato, foliis alternis lanceolatis serratis, panicula corymbosa laxa foliosa, calycibus laxis patulis, disco subsloboso.-Mich. fl amer. 2. p. 134.

Coreopsis alternifolia. Willd.sp. pl.3. p. $225 \%$.

a. V. radiata aut Mosculosa luteiflora. Mich. l.c.

Icon. Jacq. hort. vind. t. 110. Pluk. alm. t. 159. f.3.

$\beta$. V. semper floiculosa albiliora. Mich. ..c.

Athanasia paniculata. Wilt. fl. car. 201.

In the mountains of Virginia and Carolina. $\beta$. On the Carolina coast. 24. July-Sept. v. v. From three to seven feet high; flowers yellow. The white variety I bave only seen in the Walterian Herbarium, and I strongly suspect it to be a very distinct species.

4. V. caule alato, foliis alternis lato-lanceolatis acutis levi-helianthoides. ter dentatis subtus albido-villosis, supra aspero-pubescentibus, pedunculis unifloris aggregatis.-Mich. $f l$. amer. 2. p. 135.

In the western parts of the Allegany mountains: Tennassee and Illinois. 24. Aug. Sept. v. s. Flowers like Helianthus.

\section{ZINNIA. Gen. pl. 1304.}

1. Z. floribus pedunculatis, foliis oppositis ovato-lanceolatis multiflora. subpetiolatis. Willd.sp.pl.3.p. 2139 .

Icon. Linn. dec. t. 12. Jacq. ous. 2. t. 40. Bot. mag. 149.

Or, the banks of the Mississippi. ๑. July, Aug. v. $v$. Rays yellow, orange, and sometimes brick-red. 


\section{FRUSTRANEA.}

\section{PIDENS. Gen.pl. 1267.}

cerrua.

minina.

Coreopsis.

chrysanthe. moides.

frondiosa.

connala.

pilora.

1. B. fforibus subradiatis cernuis, calyce exteriore flore lon?giore, foliis lanceolatis subconnatis dentatis. IVilld. sp. pl. 3. p. 1716.

Icon. Fl. dan. 841. Curtisfl. lond. 3. t. 55. Pet. hort. lrit. t. 20 f. 6.

ß.B. foliis lanceolatis sessilibus, floribus seminibusque erectis. S/s. pl. 1165.

Icon Fl. dun.312. Ijill. in Raiis syn.t.7.f. 2.

$\gamma$. B. foliis lanceolatis serrat is oppositis amplexicaulibus. $S p$. pl. 1281 .

Icon. Burrel. ic. t. 1209. Less. fl. pruss.t. 11.

About ponds, ditches and springs: Canada to Pensylvania. $\odot$. Aug. Sept. The flowers of this and all the following species are yellow, and the nost of them are either without or with rays.

2. B. floribus radiatis cernuis, radio calyci subæquali triplo longiore, foliis oblongis utrinque attenuatis dentatis basi comnatis. Willd. sp. pl. 3. p. 1717. Mich. $f$. amer. 2. p. 136 .

Coreopsis flummula. Herl. Banks. mss.

Coreopsis perfoliata. Halt. fl. car. 215.

In overflowed places and about ponds : New England to Carolina. $\odot$. Aug.-Uct. $v$. $v$. Flowers large, bright yellow. The awns of the sceds are by two, three, or four ; not always by two, as Michaux asserts.

3. B. foribus di-coideis, calyce exteriore fore sexduplo Jongiore, foliolis basi ciliati, foliis inferioribus pinnatis, superioribus ternatis lanceolatis serratis. Willd. sp. pl. 3 p. 1718.

Icon, Moris hist. 3. s. 6.t. 5.f. 21.

In shady fertile woods and fields: Pensylvania to Carolina. $\odot$. July-Uct. $v . v$.

4. B. foribus discoideis, calyce exteriore ficre triplo longiore, foliis caulinis ternatis, foliolis lateralifus connatis, floralibus oblongo-lanceolatis. Willd. sp. pl.3. p. : $: 18$.

In fields and woods; frequent: Canada to Carolina. $\odot$. July-Oct. $v . v$.

5. B. floribus discoideis, calyce exteriore longitudine interioris, foliis inferioribus pinnatis, superioribus ter- 
natis, foliolis oblongis, terminali lanceolato reliquis duplo longiore. Willd. sp. pl. 3. p. 1720.

Icon. Dill. elth. t. 43.f. 51 .

In old fields and cultivated grounds: Pensylvania to $\mathrm{Ca}-$ rolina. ๑. July_-Oct. v. $v$. A common weed.

6. B. florihus subradiatis, calyce exteriore longitudine interioris, folits bipimnatis, foliolis lanceolatis pinnatifidis. Willd.sp.pl.3.p. 1721.

Icon. Herm. parad. t. 123. Moris. hist. 3. s. 6. ¿.7. f. 23.

A common weed in all old fields. $\odot$. July-Oct. v. v.

65\%. COREGPSis. Gen. pl. 1325.

* Foliis opponsitis, indivisis.

1. C. foliis sessilibus lanceoldto-linearibus integerrimis ciliatis, pedunculss elongatis nudis, seminibus orbiculatis scabris alatis apice bidentatis emarginatis. - Willd. sp. pl.3.p. 2256.

Icon. Dill. eith. t. 48.f.56. Mart. cent. 26.

ß. C. caule foliisque canescenti-villosis. Mich.fl. amer. 2.

lipinnato. p. 137.

C. crassifolia. Willd. sp. pl. 3.p. 2256.

In mountainous situations: Virginia and Carolina. 24 . Aug.-Oct. v. v. Flowers deep yellow; rays broad with four or five teeth.

2. C. glabra ; foliis petiolatis lanceolato-ovatis sensim acuminatis argute serratis, pedunculis axillaribus terminalibusque dichotnme-corymbosis.

In Carolina. P. Miller. 24. v. s. in Herb. Banks. Flowers middle size. This and all the rest are of a bright yellow colour.

3. C. foliis ovatis acuminatis serratis petiolat is triplinervibus decurrentibus.

In Virginia. Bartran. o. v. s. in Herl. Banks.

4. C. foliis ovatis acuminatis crenato-dentatis, dentibus mu-

lanceolata. villosa。 cronatis, petiolis brevibus, radiis integris, seminibus cuneato-oblongis apteris apice nudis.-Willd.sp. pl.3. p. 2257. Mich.fl. amer. 2. p. 137.

On the high mountains of Virginia and Carolina. 4. July-Sept. $v, v$. A tall growing species; flowers rather small. 


\section{** Foliis opposilis, divisis.}

aristata.

5. C. pubescens; foliis quinato-pinnatis serratis, radiis integris lato-ovalibus, seminibus cuneato-obovatis biaristatis, aristis divaricatis.-Willd. $s p . p l .3 . p .2253$.

C. aristosa. Mich. fl. amer. 2. p. 140.

In South Carolina and Illinois. 4. Aug. Sept. v. s. Flowers large; rays very broad.

trichosperma. 6. C. glabella, dichotoma; foliis subquinato-pinnatis lanceolatis serratis, calycis exterioris foliolis (S) spathu. Jatis ciliato-serratis, radis integris, seminibus cuneatis sub-4-dentatis.-Willd. sp. pl. 2. p. 2252. Mich. $f$. amer. 2. p. 139 .

In cedar-swamps: New Jersey and Carolina. $\delta$. Aug. -Oct. $v, v$. Flowers small; resembles $C$. coronata.

auriculata. 7. C. pubescens; foliis subsessilibus ovali-lanceolatis integerrimis, inferioribus ternatis, calyce exteriore profunde partito, radiis 4-dentatis, seminibus subrotundoohovatis apice emarginato-bidentatis.-Willd. sp. pl. 3 . p. 2256 .

lcon. Pluk, alm, t. \$3.f.5. Eீ t.242,f. 4.

On the high mountains of Virginia and Carolina. 24. Aug.-Oct. v. $v$.

tripteris. $\quad$ 8. C. glabra; foliis petiolatis lanceolatis integerrimis, radicalibus pinnatis, caulinis ternatis, radiis integris, seminibus obovatis apice nudis.-Willd. sp. pl. 3. p. 2253.

Icon. Moris, hist 3. s. 6.t.3.f. 44 .

On high mountains : Virginia to Carolina. 4 . Aug.Oct. $v . v$.

senifolia. 9. C. subpubescens; foliis sessilibus integerrimis ternatis, radiis integris, seminibus cuneato-oblongis.-Willd. sp.pl. 3.p. 2254.

C. major. Walt. $f l$ car. 214.

C. stellata. Herb. Banks, mss.

On dry stony hills, in the mountains of Virginia and Carolina. 24. Aug.-Oct. v. v.

area. 10. C. foliis serratis, radicalibus 3-partitis, caulinis trifidis integrisve lanceolato-linearibus. Willd. sp. $p l .3$. p. 2253 .

In North America. 4 . +

trifida. 11. C. glabra; foliis trifidis subulatis fasciculatis, pedunculis terminalibus unifloris, radiis 3 -fidis, caule subflexuoso.-Lam. encycl. suppl. 2. p. 353. 
Icon. Lam. illustr. t. 704.f. 2.

In Nortia America. Lamarck. 4 . +. Resenbies C. verticillata.

12. C. foliis verticillatis ternis quinisve pinuatis, pinnis linearibus tripartitis indivisisque, disco concolore. Willd. tenuifolia. sp.pl. 3.p. 2252.

C. verticillata. Lam. encycl. 2. p. 103.

Icon. Pluk. mant. t. $344 . f .4$.

On high dry mountain lands: Virginia and Carolina. 4. Aug.-Oct. v. v.

13. C. foliis verticillatis ternis quinisve pinnatis, pinnis lineverticillata. aribus tripartitis indivisisque, disco discolore. Willd. sp.pl.3.p. 2151.

C. delphinifolia. Lam. encycl. 2.p. 108.

Icon. Bot. magr 156. Ehret pict.t. 9. f. 1 .

On high mountanns: Virginia and Carolina. 4. Aug. -Uct. v. $v$.

14. C. glabra; foliis petiolatis, inferioribus bipinnatifidis, mitis. superioribus lineari-3-partitis, calycibus simpliciusculis, senuinibus nudis.-Wilid.sp. pl.3.p. 2253.

In low grounds of Carolina. Michanx. On the Missouri. M. Lewis. б. July, Aug. v. v.

\section{*** Foliis alternis.}

15. C. foliis ovato-lanceolatis acntis denticulatis subhirtis, acuta floribus corymboso-paniculatis.

In Georgia. Bartram. o. v. s. in Herb. Banks.

16. C. caule glabro superne nudiusculo dichotrmo, foliis plerumque alternis indivisis integerrimis in petiolum angustatis, seminibus obovatis bisetosis scabris, ala marginali fimbriato-lacera.-Mich. fi. amer. 2. p. 137.

C. gladiata. Wult. fl. car. 215 .

In shady sphaynous swamps of New Jersey and Carolina. $\odot$. July-Oct. $v, v$.

17. C. foliis ellipticis acuminatis serratis petiolatis venosis decurrentibus, inferioribus verticillatis, superioribus alternis. Willd. sp.pl. 3. p. 2258.

In North America. Aiton. $4 .+$

18. C. foliis lineari-lanceolatis integerrimis lævibus, radiis oblongis trifidis, lacinia media majore.-Willd. $s p$. pl. 3. p. 2257.

In Carolina and Florida. Luartram. 24, v. s. in Herb. Banks. 
aspera.

19. C. foliis lanceolato-linearibus asperis, superioribus alier nis, inferioribus oppositis, caule unifloro.

In Maryland. v. s, in Herl. Banks.

\section{HELIANTHUS. Gen. pl. 1322.}

* Folitis oppositis.

atrorulens. 1. H. tofus hispidus; caule superne nudiusculo laxe pariculato, folis spathulatis ovatis crenatis triplinervibus scabris, squamis calycinis ovato-lanceolatis longitudine disci atropurpureo.- $I$ Villd. sp.pl. 3. p. 2245.

Icon. Dill. elth. t. 91.f. 110. Murt. cent. t. 20.

In gravelly and slate soil, in the western parts: Pensylvania to Carolina. $4 . \delta$. Aug. Sept. v. $v$. Rays yellow ; disk dark purple.

pubescens. 2. H. cano-pubescens; caule villoso, foliis sessilibus cotdato-ovatis amplexicaulibus triplinervibus adpressosubserratis, calycinis squamis lanceolatis villosis.Willd. sp. pl. 3. p. $22+4$.

H. mollis. Lam. encycl.3. p. 81 .

H. canescens. Nich fl amer. 2. p. 140.

In wet meadows of Kentucky and Tennassee. $\delta$. Aug. -Oct. v.s. Both ray and disk are yellow, which is the case with all the following species.

ainnricatus. 3. H. caule glabro ramosissimo, foliis suboppositis sessilibus lanceolato-ovatis trinervibus, panicula trichotoma gracili parvifora.-Willd. sp. pl 3. p. 2244.

Jcon. Moris hist.3. s.6. t.7.f 66. mala.

On the borders of woods and in hedges : Canada to Pensylvania. 24. Aug.-Nov, v. v. About five or six feet high; flowers smaller than any other species here enumerated.

frondosus. 4. H. caule inferne glabro, foliis ovatis argute serratis, pedunculis scabris, calycibus sçuarrosis undulatis fiondosis ciliatis, radiis 8-foris.-Willd.sp.pl.3.p.2241.

In Canada. $24 .+$. About four feet high; resembles $H$. decapetalus and multiflorus in several respects, but is distinct.

trachelifolius. 5. H. foliis ovato-lanceolatis acuminatis serratis triplinervibus utrinque scaberrimis, calycinis squamis linearilanceolatis ciliatis, exterioribus longioribus. Willd. sp. pl. 3. p. 224 I.

H. Gigas. Mich. $A$. amer. 2. p. 141. 
In woods and dry swamps: Canada to Carolina. 4. Aug.--Oct. v.v. Resembles H. decapetulus. About three feet higi'.

o. H. glaberrimus; caule paniculato, ramis summitate pauciflori, foliis subsestilibus longinsime-lanceolatis triplinerribus integerrimis, inferioribus serratis, calycinis squamis ovatis acutis, exterioribus linearibus diva icatis.

In the western parts of Georgia. Lyon. 2l. Aug.Oct. $v . v$. From four to seven feet high; stem dark purple and very smooth; flowers midale size.

\section{* Foliis superiorilus alternis.}

7. H. foliis alternis lanreolatis serratis scabris obsolete triplinervibus utrinque attenuatis subsessilibus basi ciliatis, calycinis sq:anis lanceolatis ciliatis. Willd. $s p$. pl.3.p. 23.42 .

In dry swamps and on mountain meadows: Canada to Carolina. 4. Ang-Oct. v. v. A ta!l, roughlooking plant; horses are fond of its young shoots. Stems rough and green.

8. H. foliis alternis ovato-lanceolatis serratis scabris triplinervibus, apice attenuatis petiolatis, petiolis ciliatis, calycinis squamis lanceolatis ciliatis. IVilld. sp. pl.3. p. 2243 .

Icon. Jacq. hort. wind. $t$ 160.

In copses and mountain meadows: Pensylvania to Carolina. 4. July-Sept. $v . v$. Resembles the preceding; stems smooth and purple; the chaff of the receptacle is green in this species, but black in the preceding.

9. H. foliis ovatis acuminatis serratis triplinervibus subtus scabris, calycinis squamis lineari-lanceolatis basi ciliatis. Willd. sp.pl.3. p. 2242.

Icon. Bocr. sic. $i .27 \cdot f .4$.

In Canada and New England. 2f. Aug.-Oct. v. v.

10. H. caule debili prostrato, foliis lanceolatis acuminatis scalris serratis triplinervibus, superioribus in tegerrimis, calycinis squamis lanceo' tis ciliatis.-Willd. sp. pl.3. p. 2242.

In North America. Willdenow. 24. + .

11. H. foliis ovatis acuminatis remote serratis triplinervibus longifolius.

giguntelus,

altissimus.

strumosus. scabris, calycinis squamis lanceolatis subæqualibus 
subciliatis, radiis denis duodenisve.-Willd. sp. pl. 3. p. 2241 .

Icon. Rob. if. 235.

In dry sony soil, in woods, and on road sides: Canada to Virginia. 24. Aug-Oct. v,v. About three or fur fee high. $\mathbf{R}$ rembles the following.

multiflorus. 12. H. foliis triplinervibus scabris, inferioribus cordatis, superioribus ovatis, radio multiforo, calycinis squamis lanceolatis. iVill. sp. pl.3.p. 2239.

Icon. Hot. mag. 227. Hluk. phytogr.t. 159.f.2.

In diy mountain woods: Pensyivania to Carolina. 4. July-Sept. v. $v$.

mollis.

13. H. foliis ovatis acuminatis triplinervibus adpresso-serrat is supra scabris, subtus cano-pubescentibus mollissinis, calycinis squanis lancenlat is adpressis. IVilld, enum. 920. Willd. sp.pl. 3. p. 2240.

H. tomentosus. Mich., /l. umer. 2. p. 1.11.

In exsiccated swamps: Peusylvania and Virginia. 4. July-Oct. $v \cdot v$. Leaves very rough on the upper surface, and soft undertieath.

macrophyllus. 14. H. foliis ovatis acuminatis tripl nervibus serratis supra scabris, subtus cano-pubescentibus, calycinis squan is linearibus squarrosis. $\mathrm{W}$ illd, horl. lerol. 50 . cum icone.

In Pensylvania and Virginia, on the borders of woods. 4. Aig.-Oct. $v . v$.

angustifolius. 15. H, caulibus gracilibus subunifloris, foliis linearibus margine revolutis asperis.-Willd. sp. $p l .3 . p .2244$.

Rudberkia angustifolia. Willd. sp.pl.3.p. 2250.

Icon. Mill. ic. $t .224 . f .2$.

In cedar-swanps: New Jersey to Florida. 4 . Sept.Nov. $v, v$. Rays deep yellow, disk brown.

\section{GALARDIA. Gen. pl. 1323.}

bicolor.

1. G. caule ramoso, foliis amplexicaulibus lanceolatis inciso-dentatis ohtusis, paleis pappi integerrimis aristatis. -Willd. sp pl. 3. p. 2245 .

G. lanceolata. Wich. fl. amer. 2. p. 142.

Gaillarda pulchella. Fougeroux ast. par. 1785.

Colonnea pulcherima. Buchoz. ic. $t .126$.

Virgilia helioides. L'Herit. monog. Smith.cxot. bot, p. 71.1 .37 . 
Leysera caroliniana. Wult. $f l$. car. 211 . secundum Herb. Icon. Lam. illustr. t. 708

In d:y sandy soil: Cambina to Florida. O. July, Aug. $v$. $v$. About two teet high ; flowers large and very showy; rays orange with red towards the base, disk dark purple with orange.

2. G. caule simplicissimo uniftoro, foliis radicalibus oboratis, caulinis linearibus, paleis pappi laceris. Willd. sp. pl. 3. p. 2240 .

In open swam?s of Carolina and Florida. Michaux. $+$

3. G. hirsutissima, scabra ; caule ramoso, foliis linearilanceolatis sessilibus, paleis pappi $(5-7)$ ovato-lanceolatis longissime aristatis.

On dry hill on the Rocky-mountains. M. Lazeis. $\delta$. $v$ s. in Herb. Leu'is. Flowers orange-coloured.

Planta hirsutissima. Caulis erectus, teres, ramosus. Rami uniftori. Folia caulina alterna, longe-lincarilanceolata, sessilia, scabra, hirsutissima. Cialyx subimbricatus, polyphyllus : foliolis lineari-oblongis, acutissimis, disco duplo longioribus, margine coloratis. Corollula: Radii circiter 12. obcuneatæ, 3-tidæ: laciniis oblongis, subæqualibus, obtusiusculis, Disci tubulosæ, 5-fidæ: laciniis extus purpurascentibus hirsutissimis. Receptaculum in ambitu subpaleaceun, centro setosum. Pappus: paleis 5-7. scariosis, ovatis, longissime-setaceo-aristatis.

\section{RUDBECKìA. Gen. pl. 1324.}

1. R. aspera; foliis inferioribus lato-ovatis basi attenuatis remote dentatis, canlinis lanceolato-ovatis utrinque purpurea. acuminatis subintegerrimis, radiis longissimis depenJentibus bifidis.- IVilld. sp. pl.3. p 2249 .

Icon. Bot. magr. 2. Catesb. car. 2. t. 59. Pluk. alm. t. $21 . f .1$.

In the mountains: Virginia to Florida. 24. Aug.Oct. $v . v$. A lighly ornamental perennial; flowers large, rays purple, disk brown.

2. R. glabra; foliis oblongo-lanceolatis cordatis amplexi- amplexifolia: caulibus, inferioribus serratis, disco cylindraceo-conico.-Willd. sp. pl. 3. p. 2249.

R. amplexicaulis. Vahl in act. soc. nat. scrut. haf. 2. p. $29 . t .4$. 
R. perfoliata. Cav. ic. 3. p. 27. t. 252.

Icon. Jueq. ic. rar. 3. t. 592 .

In Lower Louisiana, on the banks of the Mississippi. ○. July, Ang. v. $v$, Flower, deep yellow.

lavigata. 3. R. undique gl berrima; canle levigato paniculato, ramis corymbesis, pedunculis elongatis unifloris, foliis ovato-lanceolatis utrinque achininatis triplinervibus integerrimis aur dence uno aiterove instructis lævigatis, calycinis foliolis lanceolatis Jongitucine radii.

In Georgia. Lyon. 4. v. s. in Herl. Lamlert. Rays pale yellow, stiort.

discolor.

4. R. ramis corynbosis uniforis, pedunculis nudis elongatis, foliis lanceolatis strigeso-pilosis subintegerrimis, calycinis foliolis ovatis actits, petalis lanceolatis integerrimis discoloribus longituline calycis.

In Filorida. Bartram. 24. ". s. in Herb. Banks. Flowers suali, rays yellow, and decp orange or purple underneath.

spathulata. 4. R. gracilis, pubescens ; caulibus nnifloria, foliis obovatospathulatis integerrinus, calyce patulo imbricato, radits tridentatis.-Willd. sp. pl. 3. p. 2249 .

R. gracilis. Herb. Zanks. mss.

In the mountains of Carolina. Michanx. In Florida. Bartram. o . July, Aug. v. s. in Herl. Banks.

aristata. 5. R. caule hispido, ramis elongatis corymbosis unifloris, $f_{0}$ lis lanceolato-oblongis serratis hispidis, disco subhenispherico, paleis papji subulatis aristatis. - Herb. Banks. mss.

In South Carolina. v. s. in Herb. Banks. Flowers small, deep ycllow.

fulgida. 6. R. caule hispido, ramis virgatim elongatis unifloris, fo. liis oblongo-lanceolatis denticulatis hispidis basi angust atis subrordatis, calyce foliaceo radium subæugante, disco ternisphrerico, palcis lanceolatis.-Willd.sp. $p l$. 3. 1. 2248 .

In mountain meadows and woods: Pensylvania to Carolina. 24. July--Oct. v. v. Rays dark orange-co. loured, disk deep purple.

hirta. 7. R. hirsutissima; caulibus virgatis subramosis unifloris, pedunculo nudo, foliis ovato-spathulatis triplinerribus serratis hirtis, calyce foliaceo radium subrequante, disco conico, paleis lanceulatis._- W'illd. sp. pl. 3. p. $22-18$.

Icon. Dill. elth. t. 218.f.285. Pluk, alm, t.242.f. 2. 
In the mountains: Virginia to Forida. $\delta$. JulySept. $v . v$. Resenbles the preceding; rays yellow, disk dark brow'ı.

8. R. caule inf rne hispido, superne glabro nudiusculo, peRadula . dunculis longissimis unifioris, foliis ovatis attenuatis tuberculatio hicpidis, calycibus imbricatis, squamis ovatis acuminatir ciliatis.

In Georgia. Bartram. o . v. s. in Herl. Banks.

9. R. hispido-pitosa; caule paniculato, ramis divaricatis mult floris folio-is, follis lanceolatis utringre acuminatis serrats, inferi rib's tribobis, calycinis foliolis linearibus dellexis longitudine radii.-Willd. sp. pl. 3. p. 2247.

Icon. Plak. olm. 22.f. 2.

In the Virginia and Carolina mountains. 2! . $\delta$. Ang. Sept. $v . v$. Abont four or five fect high; flowers small, pale yellow.

10. R. brevi pubescentia subtomentosa; caule ramoso, ra. subtomentosa nnis er ctis multifloris, foliis oblongo-lanceolatis acutis subserratis, inferioribus trilobis, calycinis foliolis incumbentibus radio brevioribus.

R. triloba B. ATih. Al.amer. 2. p. 144.

In mountain meddow: Virginia and Illnois. 4. Aug. Sept. $v . v$. Not near so high as the preceding, from which it is very distinct, thougin Michaux considers it only a varieny.

11. R. canle stricto simplici summitate pauciforo, pedunculis elungatis, foliis pinratibutis incisis, liciniis linearibus, calyce simplici 5-pínllo, radiis 5-8., disco cylindraceo elonirat.).

R. colnmuifera. Fraser catal. 1813.

On the Missouri. vs. $s$. The singular appearance of the receptacle of this plant distinguisises it from all the other known species.

12. R. foliis inferioribus pinnatis, pinnis 3-lobis, summis oratis, pappo crenato, caule glabro. Sinrad. new. journ. 2. p. 31. Willd. enum. 92!.

Icon. Moris. hist. 3. s. 6. t. 6 f. 53. Corn canad.t. 179. On the edges of swamps and ditches: Canada to Virginia. 4. Aug.-Uct. v. v. From five to ten teet high.

13. $R$. foliis inferioribus pinnatis, pinnis pinuatifidis, superioribus simplicibus pinnatis, sumnis $\dddot{3}$-fidis, pappo

columnaris.

laciniata.

digitata, 
crenato, caule lavi. Schrad. new. journ. 2. p. 61. Willd. enum. 921 .

Icon. Moris. hist. 3. s. 6. t. 6.f. 54.

In the mountains of Virginia and Carolina. 24. Aug.Oct. $v . v$. Resembles the preceding.

pinnata. 14. R. folis omnibus pinnatis, pins una alterave inferiorun bipartita, reliquis indivisis, pappo integerrino, caule sulcato hispido. Schrad. new. journ. 2. p. 61. irilld. enum. 021. Mich.fl. amer.2.p. 144.

R. digitata. Willd. sp pl. 3.p.2247. excl. syn. Morison. et siilon.

R. odorata. Hortul.

Icon. Snilh exot. lot. 38. T'ent.jard cels 71.

In the westein parts of Carolina and Georgia. 4. July -Oct. v. $v$. Flowers very showy, of an anise scent; rays long, bright yellow, hanging downwards ; disk ovate, purple.

658. CENTAUREA. Gen. pl. 1331.

Cyanus. $\quad$ 1. C. squamis calycinis serratis, foliis linearibus integerrimis, inferioribus dentatis. Smith fl. brit. 2. p. 911. Willd. sp pl.3. p. 2291.

Icon. Engl. lot. 277. Fl. dan. 993.

In rye and wheat fields; rare. Brought from Europe with the grain. $\odot$. July, Aug. v. v. Flowers blue.

solstitialis.

2. C. calycibus palmato-spinosis solitariis, spinis rectis, foliis canescentibus lineari-lanceolatis decurrentibus integerrimis, radicalibus lyratis. Willd. sp. pl. 3. p. 2300 .

Icon. Engl. lot. 243.

In sandy fields and woods: New Jersey: introduced from Europe. $\odot$. July, Aug. v. v. Flowers yel$10 w$. 


\section{IV. $N E C E S S A R I A$.}

659. CHAPTALIA. Vent. hort. cels 61.

1. C. foliis ovato-oblongis integerrimis subtus argenteo tomentosis, scapo nudo unifloro, flore nutante.-Vent. l. c. cum icone.

Tussilago integrifolia. Mich. Al amer. 2. p. 121. Perdicium semitlosculare. IValt. fl. car. 204.

In sand fiettr and woorls, in moist soil: Carolina to Florida. 24. May, June. v. v. Elowers white, with a tinge of pale purple.

660. SILPHIUMI. Gen. pl. 1334.

1. S. caule superne hispido, foliis radicalibus caulinisque pinnatifidis, laciniis dentato-sinuatis, calycinis foliolis

laciniatum. subcord.tis acuminatis.-W alle. sp. pl. 3. p. 2330.

Icon. Linn. fil. fasc. 1. t. 3.

On the banks of rivers in the western territories, parti. cularly on the Mississippi. 4. Aug._Oct. v. $v$. From eight to twelve feet high ; flowers large, and, as all the rest of the genus, yelluw.

2. S. caule lævi, foliis caulinis siuuato-pinnatifidis, radica- composilum. libu; teratis sia 11 o- inultitidis, foribus parvis paniculatis._Willd. sp. pl. 3. p. 2331.

S. laciniatuns. Wult. fl. car. 217 .

S. sinuatum. Helb. Banks. mss.

In gravelly woods, near the sea-coast: Virginia and $\mathrm{Ca}$ rolina. 4. Aug.--Oct. v. $v$. Not above two feet high ; flowers sinall.

3. S. caule lævi, foliis radicalibus amplis cordatis, caulinis terelinthinaalternis ovatis serratis scabris.-Willd. sp. pl. 3 . ceum. p. '2331.

Icon. Jacq. hort. 1. t. 43.

In the western mountains and Louisiana. 24. Aug.Oct. $\quad v . v$. About five feet high; radical leaves very large.

4. S. caule tetragono lævi, foliis oppositis connatis ovatis perfoliatum. serratis._Willd. sp. pl. 3. p. $233 \mathrm{t}$.

B.S. squamis calycinis quatuor exterioribus calyce interiore conjunctum. longiore. Willd enum. 933.

In the Allegany mountains : Pensylvania to Carolina. 
24. July-Oct. v. '. A tall robust plant. Var. B. though considered by Wilderiow as a disinet species, appears to be firle dectet'in a variety.

connalum.

Asleriscus.

mamilum.

inlegrifolium.

8. S. canle tetragono aspero, foliis oppositis sessilibus oblongis integerrimis scabris, floribus paucis breviter pedunculatis--Willel. sp. pl. 3. p. 2333.

On the most western of the Allegany mountains and Illinois. 24. Aug.-Oct. v. 2. About four feet high.

lavigatum. g. S. caule simplici tetragono sulcato glabro, foliis opposicis sessilibus ovatis acuminatis tenuissime serratis basi subcordatis utriuque glabris, calyciuis squamis ovatis ciliatis.

In Georgia. Enslen: 24.v. s. in Merl. Enslen. About two feet high; flowers in a close corymb.

trifoliatum. 10. S. caule sexangulo bevi, foliis terno-verticillatis ovatolancenlatis inæqualiter dentato-serratis scabris, superioribus sessilibus, panicula trichotona.-Willd. sp. pl.3. p. 2333.

S. ternifolium. Mich. $l$ amer. 2. p. 146.

Icon. Moris. hist. 3. s. 6. t. 3.f. 08.

Un the high mountains of Virginia and Caroina. 4. Sept. Oct. $v, v$. About six feet high.

ternatum. 11. S. caule tereti lævi, foliis terno-verticillatis petiolatis lanceoldtis subdenticulatis scabriusculis basi ciliatis, su. pei ioribus sparsis sessilibus, panicula dichotoma, calycibus ciliatis. - Willd. sp.pl. 3. p. 2333. 
In North America. Relz. 2\%. v. s. in Herl. Lambert.

12. S. canle tereti lævi, foliis subquaterno verticillatis lanceolatis scabris subintegerrimis subsessilibus basi ciliatis, superioribus sparsis, panicula dichotona.--Will W. so. pl. 3. p. 233\%.

In Carolina and Georgia. Lyon. 24. Aus. Sept. v.v. Resembles the preceding; but its purple smooth stem distinguishes it at first sight.

33. S. canle petioliqque tomentosis, ramis uniforis, foliis tomentosum. airemis cordatis ovetis serratis petiolatis villosis, seminibus nuticis.-Het. Banks. mss.

In Georgia. Bartram. 2\%. v. s. in Herly. Ban?s.

i4. S. folits alternis petiolatis cordatis sinutis, squanis caly-

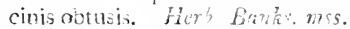

In Carolina. 24, u. s. in Herb. Bunks.

15. S. foliis alternis ovatoncelatis coriatis serratis obtusi- reticulatum. usculis villosinculis. Forl. Earks. mss.

In Florica. 2t. v. s. in Herl. Banks.

\section{POLIMTNA. Gen.ple 1305.}

1. P. viscido-villon; co iis denticalatis acummatis, inforioribus pinatifidis, snerioribus trilobis integrisue-Willd. sp.pl. 3. p. 2235 .

Icon. Amon. acred. 3. $t .1 . f .5$.

In shady mountains: Canata to Virginia. 24. Jnne, Julv. v. u. Two or three feet high; flowers yelicw; the whole plant has a strong balsmic scent.

2. P. foliis nppositis tritobis actitis in petinlum checurrentibus, lobis angeloso-sinu.tis, rallis elongatis.--Milid. sp. pl.3. p. 233.5 .

P. maculata. Cav. ic. 3. 1.227 .

Icon. Pluk alm. $t .83$. f.3. Mcris, hist.3. s. 6.t.7. f.55. Treu pict. suppl. 112.

In the monis dins of Virginia and Carolina. 4. July-. Sept. v. $v$. From four to eight feet high.

662. CHAY-OGONUM. Gen.pl. 1337.

1. C. pumilum, lanato-villosum; foliis in petiolum argus. virginianum. tatis ovalibus dentatis. - W Villat. sp. pl. 3. p. $\measuredangle 337$.

Icon. Pluk.alm. $t$. 83.f. 4. Eं t. 212.f. 3.

On dry hills: Virginia and Carolina. 2!. May, June. v. v. Not above a span hight ; flowers yeilow.

canadensis.

Uieúain:

atropurpureum.

elatum. 


\section{BALTIMORA. Gen.pl. 1333.}

recta.

1. B. scabra; caule dichotomo, foliis oppositis ovatis acuminatis serratis petiolatis.-Willd. sp. pl. 3. p. 2329.

Icon. Pluk, mant. t. 342, $f 3$.

In Maryland near Laltimore Sp. $t$ l. $\odot$. July. v. $v$. cult. Flowers small, yellow. I have never seen this plant in any part of the United States, and suppose it to be only an iuhabitant of Vera Cruz.

\section{PARTHENIUM. Gen.pl. 1428.}

integrifolium. 1. P. foliis oblongis inxequaliter dentatis asperis, superioribus anplexicaulibus.-Willd. sp.pl. 3. p. 2385.

Icon. IF illt. hort. lerol. t. 4. Dill. elth. $t .225 . f .292$. Pluk. alm. t. 53.f.5. E t. 219.f. 1. Lam. illustr. t. 766 .

In dry places on the mountains of Virginia and Carolina. 4. Sept. Oct. v. v. About a foot bigh; flowers white.

\section{IVA. Gen. pl. 1429.}

ciliata. 1. I. caule herbaceo, foliis lanceolato-ovat is subserratis, spica confertiuscula, bracteis lanceolatis acuminatis petiolisque longe ciliatis. - IVilld. sp.pl. 3.p. 2386.

In natural meadow's : Kentucky and Illinois. $\odot$.July, Aug. v. s. About two feet high.

imbricala. 2. I. fruticosa, glabra; foliis lineari-lanceolatis cuneatis integerrrimis glabris, calycibus imbricatis.-Willd. $s p$. pl. 3. p. 2387. Walt.fl. car. 232.

I. integrifolia. Herb. Banks. mss.

On the sea.coast of Carolina and Georgia. 々. v. s. in Herv. Walter.

frutescens. 3. I. fruticosa; foliis lanceolatis punctato-scabris profunde serratis, glomerulis florum depresso-globosis. - Willd. sp.pl. 3.p. 2387.

Icon. Lam. encycl. 766. Pluk. alm. t. 27.f. 1.

On the sea-coast : New England to Florida. ط. Aug. Sept. v. v. A shrub about four fcet high.

666. AMBROSIA. Gen. pl. 1427.

integrifolia. 1, A. foliis ovatis sessilibus acuminatis serratis utrinque his. pidis basi ciliatis, racemis terminalibus plerumque tcrnis.-Willd. sp. pl. 4. p. 3,5. 
On the banks of ponds and ditches: Pensylvania and Virgiria. ๑. July-Sept. $v . v$. The flowers of this genus are very inconspicuous.

2. A. hircutiscina ; foliis arcte sessilibus simplicibus oblongis supra basin litescentem utrinque unidentatis, frucin tetragono infra apicem quadrispinoso. Mich. $f l$. amer. 2. p. 182.

In the western parts of the Allegany mountains $\odot$. July-Sept. $v \cdot v$.

3. A. hirsuta, aspera ; foliis 3-lobis serratis, lobis ovali-lan-

lidentata. ceoiatis acuminatis, fructu infra apicem 6 -spinoso.Willd. sp.pl.4. p. 375.

Icon. Moris. hist. 3. s. 6. t. 1.f. 4.

On the banks of rivers and ditches: Pensylvania to Carolina. $\odot$. Aug. Sept. $v . v$. From five to eight feet high.

4. A. foliis bipinnatifidis glabriusculis, petiolis longe cilia tis, racemis terminalibus paniculatis, caule virgato. Willd.sp. pl. 4. p. 376.

In old fields: Canada to Carolina. ๑. June-Aug. v.v.

5. A. foliis bipinnatifidis subtus canescentibus summis pin-artemisifolia. natifidis, racemis terris terminalibus, ramis fastigiatis. Willd. sp. pl. 4. p. 370 .

In fields and waste grounds: Pensylvania to Carolina. ○. Aug. Sept. $v . v$.

6. A. foliis glabris bipinnatifidis summis pinnatifidis, racemis terminaibus solitariis, ramis fastigiatis. Willd. $s p$. paniculata. pl. 4.p. 376 .

Icon. Pluk. alm.t. 10.f.5.

In old fields and on road sides: Canada to Florida. $\odot$. July - Sept. v. v.

7. A. foliis caulinis pinnatifidis subdentatis petiolatis, rameis heteropkylla. summis lanceolatis sessilibus, petiolis longe ciliatis, racemis terminalibus solitariis, catle paniculato. II illd.sp.pl.4.p.379.

On the banks of rivers and ditches: near Philadelphia. ๑. July-Sept. $\quad$. $v$.

\section{XANTHIUM. Gen. pl. 1426.}

1. X. caule inerni ramoso, foliis cordatis lobatis serratis Strkmarium. scabris basi trinervibus, fructibus ellipticis pubescentibus setis rigidis uncinatis, - Willn. st.pl.pl. 4. p. 373. 
Icon. Fl. dan. 9 ro $^{\circ}$.

On road sides, among rubbish and cultivated grounds: New England to Pensylvania. $\odot$. Aug. Sept. $v . v$. The fruit resembles the common Burdock.

\section{SEGREGATA.}

\section{ELEPHANTOPUS, Gen. $p l .1347$.}

carolinianus. 1. E. foliis radicalibus caulinisque oblongis basi angustatis utrinque pilosis, caule simplici erecto piloso.-Willd. sp.pl. 3.p. 2390.

E. scaber. Mich. fl amer. 2. p. 148.

Icon. Dill. elth. t. 106. f. 126. Sloan. hist. 1. t. 156. $f 1$.

In shady woods: Virginia to Florida. 24. Aug.-Oct. v. v. Flowers red.

tomentosus.

2. E. foliis radicalibus caulinisque ovatis basi attenuatis utrinque tomentosis, caule simplici tomentoso.-Willd. sp. pl.3.p. 23 g.

On dry sunny hills : Lower Virginia and Carolina. 4. Aug.-Oct. v. v. Flowers deep red. 


\section{GYNANDRIA.}

\section{MONANDRIA.}

* Calyculata; filamentum basi styli insertum.

66g. THALIA. Cal.minimus, triphyllus. Cor.5-petala: duo interiora minora. Anthera simplex, ovata, fila. mento proprio depresso innixa. Stylus simplex, ab anthera deflexus. Sligma perforatum ringens. Bacca 1 -sperma.

670. CANNA. Cal. 3-phyllus. Cor. 6-partita, erecta. Nectar. bipartitum revolutum. Styl. lanceolatus, corollæe adnatus. Caps. muricata, 3-locularis, polysperma.

** Ecalyculatce; filamentum nullum; anthera apice styli inserta, biloba.

671. ORCHIS. Cor. ringens : petalo superiore fornicato. Lalellum dilatatum, basi subtus calcaratum aut saccatum. Anthera terminalis, adnata.

672. NEOTTIA. Cor. ringens: petalis lateralibus exterioribus antice circa basin labelli ventricosum connexis. Anthera stylo parallela, postice inserta.

673. ARETHUSA. Cor. subringens: petalis subconniventibus. Labellum ecalcaratum. Anthera opercularis, persistens. Pollen pulvereo-granulatum.

674. EPIPACTIS. Cor. erecto-patens. Labellum ecalcaratum, planum, pendulum, apice bifidum. Anthera opercularis, persistens.

675. MALAXIS. Cor. patens, resupinata. Labellum concavo-patulum, adscendens. Anthera opercularis.

676. CYMBIDIUM. Cor. erecta vel patens. Labellum basi concavum, ecalcaratum, lamina patula. Anthera opereularis, decidua. Pollen globosum.

VOL. II. 
677. CALYPSO. Cor. 6-petala: 5. sursum expansa. Labellum sacciforme, dorso basis 2-calcaratum. Stylus late alatus. Stigma operculo 2-lobo absconditum. Pollen lamellis 4. solidis.

\section{DIANDRIA.}

678. CYPRIPEDIUM. Co*. 4-petala, patens. Labellum ventricoso-inflatum, obliquum. Stylus superne lobo petaloideo appendiculatus.

\section{HEXANDRIA.}

679. ARISTOLOCHIA. Cor. 1-petala, tubuloso-ligulata, basi ventricosa. Styl. o. Caps. infera, 6-locularis.

\section{DODECANDRIA.}

6so. ASARUM. Cor. tubuloso-campanulata, 3-4-fida. Anthere mediis filamentis adnatæ. Caps. infera, coronata, 6-locularis.

\section{MONANDRIA.}

669. THALIA. Gen. pl. 10.

deallata. 1. T. panicula albido-pulverulenta, spathis bifloris, foliis ovatis apice revolutis.- Roscoe in linn. trans. 8. p.340. Icon. In a single plate of J. Fraser.

In impenetrable swamps of South Carolina. 2. Aug. Sept. v. v. s.fl.; v. s. c. fl. in Herb. Lambert. A tall and handsome plant; flowers small, purple. J. Millington, Fsq. of South Carolina, is, to my knowledge, the first discoverer of this elegant plant. It was introduced into the English gardens by the Messrs. Frasers. 
670. CANNA. Gen. pl. 1.

3. C. foliis petiolatis lanceolatis costatis, corollæ limbo in- angustifolia. teriore trifido : laciniis strictis emarginatis. - IVilld. $s p$. pl. 1.p. 3 ?

C. glauca. Walt. fl. car. 59 .

In deep and almost impregnable swamps of Georgia. Enslen. 4. July, Aug. v. s. in Herb. Enslen. Flowers scarlet. It approaches near to $C$. indica, and probably may be a new species, if not the true $C$. angustifolia.

2. C. foliis sessilibus lanceolatis glaucis, corollæ limbo in. teriore trifido: laciniis flaccidis.-Roscoe in linn.

flaccida. trans. 8. p. 339 .

C. glauca $\beta$. flaccida. Willd. sp.pl. 1.p. 4.

C. angustifolia. Walt fl. car. 59 .

Icon. Salisb. stirp. rar. 3. t. 2. Thomps. lot. t. 1. Re. douté liliac. 107.

In swamps of South Carolina. 4. Aug. Sept. v. v. Flowers iarge, yellow.

671. ORCHIS. Suartz act. holm. 1800, p. 205.

* Radicilus testiculatis.

1. O. labello oblongo-lanceolato pinnatim ciliato petalis du. plo longiore, cornu germine longiore. Willd. sp. pl. 4 . p. 8.

Icon. Bot. rep. 42.

In old meadows and exsiccated swamps : Canada to Carolina. 4. June, July. v. v. Flowers a bright golden-yellow, very handsome.

2. O. labello lanceolato ciliato longitudine petali supremi, llephariglotcornu germine longiore. Willd.sp.pl.4.p. 9 .

ciliaris.

Orchis testiculata floribus niveis, \&c. Clayt. no. 560.

In low swampy bottons : New Jersey to Carnlina. 4. June, July. $v \cdot v$. Flowers clear white; resembles the preceding very much.

3. O. labello 3-partito, laciniis capillaceo-multifidis, petalis obtusis, cornu filiformi-clavato adscendente germinis psycodes. longitudine. Willd.sp.pl.4.p.39.

In old fields, on the side of swamps : Canada to Virginia. 4. June-Aug. v. s. Flowers yellow.

4. O. labello oblongo pinnatim-ciliato, petalis rotundatis, binis lateralibus dentatis, cornu germine breviore.

cristata. Willd. sp.pl.4.p.9. Mich. fl. amer, 2. p. 156. 
In exsiccated swanps and mountain meadows : Pensylvania to Carolina. 24. June, July. $v v$. In colour and shape resembling No 1; but the flowers are smaller and closer, in a short spike.

lacera. 5. O. labello 3-partito, laciniis subdigitato-filiformibus, cornu germen subæquante, floritus alternis.-Mich. fl. amer. 2. p. 156.

O. radice palnata, foliis lilii, Rc. Clayt. n. 644 .

In low meadows: Pensylvania to Virginia 4 . July. $v$. $v$. Flowers greenish-white. Roots not known.

clavellata. 6. O. labello ovato integerrimo petalis conniventibus, cornu clavato longitudine germinis, caule unifoliato. Willd. sp.pl. 4.p. 10. Mich. Al. amer. 2. p. 155.

In Carolina. Michaux. 24. +. A loose spike, with few flowers; bractes very short.

quinqueseta. 7. O. labello 5-partito: laciniis setaceis, cornu germine dtaplo longiore.--Mich. fl. amer. 2. p. 155.

In sandy low fields, on the side of swamps : Virginia and Carolina. 24. June, Julv. v. v. A loose spike, with alternate and distant flowers; bractes acuminate; leaves ovate, acute.

discolor.

S. O. labello petalis lonoriore tripartito: laciniis lateralibus brevibus acutis, inteı media producta spathulata, cornu filiformi germine subduplo-longiore, folio unico radicali ovato-cordato.

Orchis foribus sparsis, nectario pedunculum superante, \&c. Gron.virg. 137.

In pine-barrens: New Jersey to South Carolina. 4. July. $v . v$.

Bullis testiculatis, ovatis, acutis. Folium unicum, ovatum, petiolatum, plicato-nervosurn, glabrum, subtus purpurascens. Petiolus margine plicato-undu. latus. Scapus pedalis, nudus, vagina una alterave instructus, teres, glaber. Flores laxe spicati, brevissime pedicellati, nutantes, tristi- seu exviridi-purpurascentes. Petala oblonga, acutiuscula, flexuosa. Lavellum petalis longius, margine subundatum. Cornu adscendens, filiforme, flexuosum, purpureum.

\section{* Radicibus palmatis.}

flav'a.

9. O. labello trifido integerrimo: lacinia media majore, cornu filiformi longitudine germinis, spica elongata congesta, bracteis flore longioribus.-Willd. sp. pl. 4 . p. 33 . 
In Virginia. 4. July. v. s. in Herb. Gronov. Flowers yellow.

10. O. labello lineari apice tridentato, petalis conniventibus, c.rnu obtuis scrotiformi, bracteis flore sesquilongioribus. Willd.sp.pl. 4 p. 33.

Satırium viriı!e. $S p p l .1357$.

Icon. Ft dan. 77. Hall helv. t. 26.

In dry grassv places, on the high mountains of Virginia and Carolina. 24. June, July. v. v. Not above three inche, high; flower small, greenish-white.

11. O. laivelo 'anceolato apice tridentato, petalis obtusis, curnu filiformi apice clavato-adscendente germine longrore Willd.sp.pl.4.p.41.

On the high mommtains of Pensylvania and Virginia. 4. June, Jily. $v \cdot v$. Spike consisting of but a few small white flowers.

12. O. labello lineari apice emarginato obsolete 3-dentato, petalis subconmentibus, lateralibus ovatis latioribus, cornu obtuso scrotiforme, bracteis flore duplo longio. ribus patentibus. Willd.sp.pl. 4.p.34.

Icon Parad.lond. 110.

O. follis duobus inferioribus ovatis, superioribus, \&c. Gron. virg. 136.

In low shady places: Pensylvania to Virginia. 4. July, Aug. v. v. About a span high; flowers green.

13. O. labello oblongo lanceolato indiviso, petalis erectis, coruu obtnso scrotiform!, germinibus pedicellatis, scapo nudo. Willd. sp. pl. 4 p. 34 .

Serapias foliis ovatis radicalıbus, scapo nudo multilloro. Gron. virg. 137.

In low shady places: New England to Virginia : rare. 4. July, Aug. v. v. The bractes are very short.

\section{*** Radicilus fasciculıtis.}

14. O. labello ovato bas: dentato, petaiis patentibus, cornu subulato germinis longitudine. Willd. sp. pl. 4. p.35. Icon. Gnel. fl. sib. 1. p. 20 t. 4.f. 2.

On grassy hills: Pensylvania. 4 . July. v. v. Flowers in long spikes, dark or brownish yellow; bractes very long, acuitinate, and longer than the flowers.

15. O. labello obovato indiviso crenato retuso, petalis rectis, jateralibus longioribus, cornu clarato germine breviore, bracteis flore longioribus, caule aphyllo. Willd. sp. pl. 4. p. 36 .

fuscescens.

spectabilis. 
O. humilis. Mich. fl.amer. 2. p. 155.

In shady, rock situations: New York to Carolina; particularly on the mountains. 24. May, June. v. v. About a span high; flowers large, purple and white, very handsome.

orbiculata. 16. O. labello lineari integerrimo obtusiuscuio, petalis 3. sum perioribus conniventibus, 2. lateralibus patentibus basi obliquis, cornu germine longiore, scapo basi diphyllo, foliis planis orbiculatis.

In shady beech-wonds: on the mountains of Pensylvania and Virginia. 4. July, Aug. v. v. Resembles O. bifolia. Two leaves of a fleshy texture are spread flat on the ground, between which rises the stalk about a foot or eighteen inches high, which bears a loose spike of greenish-white flowers. It is known in the mountains by the name of Heal-all.

dilatata. 17. O. labello lineari integerrimo obtusiusculo, basi subrotundato-dilarato, cornu longitudine labelli : germine breviore, bracteis longitudine florum, caule folioso.

O. acuta. Herl. Banks. mss.

In Labrador. Colmaster. 4. v. s. in Herl. Dickson.

virescens. 18. O. labello lanceolato crenato, petalis conniventibus, cornu obturo scrotiformi, bracteis flore longioribus. Willd. sp. pl. 4. p. 37.

In buggy meadows: Pensylvania. 24. July. v. s. From a foot to eighteen inches high; flowers green.

hyperborea. 19. O. labello lanceolato magnitudine petalorum patentium, cornu stoulato germine breviore, spica ovata, bracteis longitudine florum.-Willd. sp. pl. 4. p. 37.

Ico!s. Retz obs, bot. 4 t. 3.

In Hudsor;'s Bay, near Albany. Hutchinson. 24. June, July. v. s. in Herl. Banks. Flowers greenish-yellow.

obtusata. 20. O. labello lineari integerrimo cornu longiore, cornu longitudne germinis, folio unico radicali subcuneiformiobiuso-Herl. Banks. mss.

On Hud:son's Bay, near Fort Albany. Hutchinson. 4. $v$. s. in Herl. Banks. A small species, with a few flowers only.

rotundifolia. 21. O. labello 3 -fido; intermedio bifido, cornu germine breviore, foliis ovali-subrotundis.-Herb. Banks, mss. On Hudson's Bay. 24. v. s. in Herb. Banks.

fimbriata. 22. O. labello tripartito, laciniis cuneiformibus ciliato-fimbriatis, petalis Jateralibus ovatis dentatis, cornu fili- 
formi clavato germine longiore. Willd. sp. pl.4. p. 39 .

In low meadows and on high mountain bogs : Canada to Pensylvania. 24. July. $v, v$. From a foot to two high; flowers purple, very handsome.

23. O. labellotripartito, laciniis cuneiformibus inciso-dentatis, intermedia emarginata, petalis lateralibus obtusis sub. dentatis, cornu subulato adscendente germinis longitudine. Willd. sp. pl.4. p. 40.

In low meadows: New York to Virginia. 4. July. $v . v$. Resembles the preceding; flowers smaller and paler in colour. In the mountain meadows it grows, like the following, to a very great height, sometimes exceeding three and four feet.

24. O. labello tripartito, laciniis cuneiformibus dentatis, intermedio bilobo, cornu filiformi apice clavato adscendente germine longiore. Wilid.sp.pl.4. p. 40.

In mountain meadows: Pensylvania to Virginia. 4. July, Aug. $\quad v . v$. Resembles the preceding; flowers dark purple.

672. NEOTTIA. Swartz. act. holm. 1800.p. 224.

1. $\mathrm{N}$. foliis radicalibus linearibus, scapo vaginato, floribus spiraliter-secundis, labio trifido; medio majori crenulato.-Willd. sp. pl. 4. p. 74 .

Satyrium spirale. Suartz. prodr. 118.

Ophrys æstivalis. Mich. fl. amer. 2. p. 157.

Limodorun præcox. Walt. $f$. car. 221.

In low spongy meadows: Pensylvania to Carolina. 4. June, July. $v . v$. From ten inches to a foot high; flowers white. This and the following species are known by the name of Ladies Traces.

2. N. foliis lanceolatis trinervibus, caule vaginato, spica cernua. oblonga densiflora, floribus recurvato-cernuis, labello oblongo integerrimo acuto.-Willd. sp. pl. 4. p. 75.

Ophrys cernua. Sp. pl. 1340.

Limodorum autumnale. Walt. fl.car. 221.

In grassy and springy places : Canada to Carolina. $\psi$. July, Aug. v. v. Resembles the preceding, but the spikes are closer and the flowers double the size.

3. N. foliis radicalibus ovatis petiolatis reticulatis, scapo vaginato Horibusque pubescentibus, floribus secundis, labello petalisque lanceolatis. Willa. sp. pl. 4.p. 76 .

tortilis.

fissa.

incisa. Satyrium repens. Sp. pl. 1339. 
Icon. Jacq. austr. 369. Hall. helv. t. 22. Com. horto t. 35 .

In rocky, shady pine-woods, on the high mountairs of Virginia. 4. July. v. $v$. Not above three inches high ; stem creeping; leaves delicately veined; flowers white.

pubescens. $\quad 4$. N. foliis radicalibus ovatis petiolatis reticulatis, scapo vaginato floribusque pubescentibus, labello ovato acuminato, petalis ovatis. Willd.sp.pl.4.p.76.

Satyrium repens. Mich. fl. amer. 2. p. 137.

In shady and rocky situations : Canada to Florida. 4. July. v. ". Resembles the preceding; is more robust, and the leaves more distinctly and handsomely variegated with white veins. This plant has lately made a great noise among the country people, as infallibly curing the bite of a mad dog.

673. ARETHUSA. Swartx. act. holm.1800. p. 230.

bulbosa. 1. A. aphylla ; radice globosa, scapo vaginato unifloro, calyce laciniis superioribus incurvatis, labello subcrenulato.-IVilld. sp. pl. 4. p. 80.

Icon. Lam. illustr. t.729. f. 1. Pluk. mant. t. 348.f. 7. In sphagnous swamps: Canada to Carolina. 24. June. v. v. Flowers large, purple, sweet-scented.

ophioglossoides.

2. A. radice fibrosa, scapo dissite bifoliato $1-2$-floro, foliis ovali-lanceolatis, labello fimbriato.-Willd. sp. pl. 4. p. so.

Icon. Lam. illustr. t. 729.f. 2.

In bogs and sphagnous swamps: Canada to Carolina. 4. June, July. $v . v$. Flowers nearly the size of the preceding, purple, sometimes white.

divaricata. 3. A. radice subpalmata, scapo remote bifoliato unifloro, folii; oblongis obtusiusculis, petalis exterioribus adscencientibus longo-linearibus, labello eroso-subcrenulato. -iv illd sp.pl. 4. p. 81 .

Icon. Lam. illustr. t. 729. f. 3. Catesb. car. 1. t. 58. In swamps near the sea-coast : Virginia to Florida. 4. July. v. v. Flowers larger than any of the preceding, purple.

pendula.

4. A. radice tuberosa, caule folioso summitate subtrifloro, foliis ovatis alternis, floribus longo-pedunculatis alternis, labello integro.-Willd. sp. pl. 4. p. 82.

A. trianthophoros. Swartz. act. holm. 1800. p. 230. 
A. parviflora. Mich. fl. amer. 2.p. 160.

Icon. Pluk. mant. t. 3ts.f.6.

In shady woods, round the roots of beech-trees: New York to Kentucky. 24. July. v. v. Not above three or four inches high; flowers pale purple, small.

5. A. foliis quinis oblongo-lanceolatis verticillatis, caule unifloro, petalis tribus exterioribus longissimis linearibus, interioribus lanceolatis, labello trilobo, lacinia media undulata. Willd.sp.pl.4. p. 81 .

Icon. Pluk mant. t. 34S.f. 1. lona.

In shady woods, near the banks of rivulets : Pensylvania to V'irginia. 4. July. v, v. A very scarce and handsome species; flowers, the size and shape of $A$. divaricata, of a dull purple mixed with yellow. It has sometimes two or three fiowers.

6. A. foliis verticillatis oblongis acuminatis, caule uniforo, flore subsessili, petalis tribus exterioribus linearibus, interiorihus brevioribus oblongis obtusis, labello petalis consimile.

In shady woods on the Blue-mountains. Vunvleck. 24 . July. v. s. in Herb. Vanvleck. Resembles the pre. ceding in general habit.

674. EPIPACTIS. Su'artz. act. holm. 1800.p. 231.

1. E. foliis radicalibus ovatis acutis, scapo aphyllo pubescente laxifloro, floribus pedicellatis, labello bilobo vix petalis conniventibus longiore, capsulis clavatis, radice palmato.

Opbrys pubera. Mich. fl. amer. 2. p. 158.

Arethusa racemosa. IVult. fl. car. 222.

Serapias foliis ovatis radicalibus, scapo nudo multifloro. Gron.fl. virg. 137.

In pine-barrens of Carolina and Georgia. 24. June. $v$. s. in Herb. Gronov. et Walter. Flowers small, greenish-white.

2. E. caule bifolio, foliis oppositis cordato-subrotundis acu tis, spica parviflora, labello oblongo apice dilatato obtuse bilobo, germine subgloboso, radice fibrosa.-Willd. sp. pl. 4. p. 88.

Ophrys cordata. Mich.fl. amer. 2.p. 158.

In shady cedar-swamps and sphagnous woods : Canada to New Jersey; rare. $\chi$. May. v. $v$. A very small plant; flowers dark-brown, mixed with green.

pulescens.

convallarioi. des.

medeoloides.

verticillata. medcoloides. 
675. MALAXIS. Swartz. act. holm. 1800. p. 233.

ophioglossoides.

liliifolia.

pulchellum.

verecundum.
1. M. folio solitario ovato amplexicauli, scapo pentagono, labello apice bifido. Willd. sp. pl. 4. p. go.

M. unifolia. Mich. fl. amer. 2. p. 157.

In shady woods: Pensylvania to Florida. 2. May, June, $v . v$.

2. M. foliis binis ovato-lanceolatis, scapo triquetro, petalis interioribus filiformibus reflexis discoloribus, Jabello concavo obovato apice acuto.-Willd. sp. pl. 4. p. 92.

Ophrys trifolia. Walt. fl. car. 221.

Ophrys scapo nudo, foliis radicalibus, \&c. Gron. virg. p. 138.

Epidendrum caule erecto sirmplicissimo nudo, racemo simplici erecto. Gron. virg. p. 140.

Icon. Bot. rep. 65.

In shady wet woods, round the roots of trees: Canada to Virginia. 4. June, July, $v . v$. The three outside petals are sharp-pointed, white; the two inside ones thread-shaped, yellowish, and reflex; the lower lip broad-oborate with an abrupt point of a pale olive colour.

676. CYMBIDIUM. Swartz. nov. act. ups. 6. p. 70.

1. C. foliis radicalibus en iformibus nervosis, scapo paucifloro, labello erecto basi attenuato, lamina expansa, disco concaro barbato.-Willd. sp. pl.4.p. 105.

Limodorum tuberosum. Syst. veg.680. Mich.fl.a. mer. 2. p. 159.

Limodorum pulchellum. Salisb. prodr. 8.

Ophrys barbata. Walt. fl. car. 221.

Icon. Bot. mag. 110.

In sphagnous swamps: Canada to Florida. 2. July. v. v. Flowers purple, very handsome.

2. C. foliis radicalibus lato-lanceolatis plicato-nervosis, scapo multifloro, petalis interioribus conniventibus, labello ventricoso, lamina emarginata crispa sulcata. Willd. sp. pl. 4.p. 105.

Limodorum verecundum. Salisb. prodr. 9 .

Limodorum tuberosum. Jacq. collect. 4. p. 108.

Limodorum altum. Jacq. ic.rar. 3. t.602.

Limodornm trifidum. Wich. fl. amer. 2. p. 159.

Icon. Mart. cent.t. 50. Mill. ic. 145. 
In Carolina and Florida. 24. July, Aug. v. v. Resembles the preceding, but is larger.

3. C. foliis radicalibus geminis ovatis multinervibus, scapo simplici vaginato erecto, petalis erectis, tribus exterioribus lanceolatis, interioribus oblongis, labello obo. vato margine undulato-crenato.-Willd. sp. $p l .4$. p. 107.

Arethusa spicata. Walt. fl. cur. 222.

On the side of fertile hilis, under the shade of trees: Pensylvania to Cirolina. 4. May. v.v. Flowers greenish-ptrple. It is known among the inhabitants by the name of Adam and Eve. 'The roots bruised, with a small addition of water, give a strong cement, which when applied to broken china and glass is exceedingly durable.

4. C. scapo vaginato aphyllo, floribus pedicellatis, petalis lanceolatis æqualibus, labello ovato obtuso. "l'illd. sp. pl. 4. p. 110.

Ophry's corallorhiza. Mich. fl. amer. 2.p. 158.

Icon. Pluk. $a / m . t .211 . f .1$ \& 2.

In shady woods, about the roots of trees: Canada to Virginia. Flowers small, dark purple mixed with yellow.

677. CALYPSO. Salist. in parad. lond.t.89.

1. C. folio radicali unico subrotundo-ovato nervoso, scapo unifloro vaginato. - Salisb. l. c.

Limodorum boreale. Willd sp pl. 123.

Cypripedium bulbosum. Sp. pl. 13+7.

Cymbidium boreale. Surartz. nov. act. ups. 6.p.76.

Icon. Parad. lond. 89. Sinith spicil. t. 11. Gmel.ft. sil. 1. t. 2.f. 5 .

In Nova Scotia. Menzies. On the Columbia river. M. Lewis. 4. May, June. v. s. in Herb. Lewis. Flower large, purplish rose-coloured; the lower lip resembling Cypripidium.

borealis.

Odontorhizon. 


\section{II. $D I A N D P I A$.}

678. CYPRIPEDIUM. Su'artz, act. holm. 1800, p. 250.

candidum. 1.C. canle folioso, foliis onlongo-lanceolatis, jobo styli lanceolato obtusinsculo, labelo petalis lanceolatis brevinre compresso. - Willd. sp $p l .4$. p. 142.

In Pensylvana. Muhlenlerg. $4 .+$ Pesembles C. Calceolus; but the flowers are white, and not half the size: the form of the leaves and lobe of the style distinguish it sufficiently.

parvifurum. 2. C. caule folioso, lollo styli triangulari acuto, petalis exteroribus ovato-oblongis acuminatis, interioribus linearibus contortis, labelio petalis breviore compresso. Willd. sp. pl. 4. p. 143.

C. Caiceolus. Mir h. Al amer. 2. p. 161.

Icon. Salist. in tinu. trans. 1. p. 77. t. 2.f. 2. Pluk. mant.t 418. f. 2.

In sharly fertile woods: New Jersey to Carolina. $\mathcal{\psi}$. May, June. $v v$. Petals greenish-brown; lower lip yellow, with brown spots.

pubesiens. 3. C. caule folioso, lobo styli triangulari-oblongo obtuso, petalis exterioribus ovato-oblongis acuminatis, interioribus longissimis linearibus contortis, labello petalis breviore conipresso. Willd sp. pl.4.p.143.

C. flavescens. Redout. pl. liliac.

C. Calceolus. B. Sp. pl. 1346.

Icon. Willd. hort. berol. 1. $t$ 13. Moris, hist. 3. s. 12. t. $11 f .15$.

C. Calceolus Walt. fl. car. 222.

On sunny fertile hills, among small trees and bushes, generally in rocky situations: Pensylvania to Carolina. 4. May. v. v. Petals greenish-yellow with red spots; lower lip yellow. It approaches near to the preceding. Sometimes it is found with two or three flowers.

spectalile.

4. C. caule folioso, lobo styli elliptico-cordato obtuso, petalis exterioribus lato-ovalibus obtusis, labello petalis longiort antice fisso.- $I$ Villd. sp. pl. 4. p. 143.

C. album Ait. ken. 3.p. 303.

C. canaden.e. Mich. Al. ainer. 2. p. 161.

C. reginæ. Walt. fl. car. 222. 
C. Calceolus $\gamma$. Sp. pl. 1346.

Icon. Bot. mag. 216 . Plık. mant.t.418. f. 3. Moris. hist 3.s.12.t.11.f. 17 .

In low meadows and bogs, particularly in the mountainous tract; : Carada to Carolina. 4. May, $\mathrm{J} u n: v, v$. From eighteen inches to three feet high. The plant in its foliage resembles Helletorus viridis; the flowers are generally by $(w o$, sometimes three, very large, the lower lip white with red veins, and crimson spots inside.

5. C. canle folioso, lobo styli orbiculato obtusiusculo, petalis 5. duobus inferioribus Jineari-lanceolatis deflexis, lateralibus linearibus horizontalibus, supremo ovatooblongo acuto, labello longitndine petalorum antice obverse-conico saccato.-Att. kew. ed.2. tom.5. p.....

In shady sphagnous woods, about Montreal, Canada. $M^{6}$ Kenzie. 4. May. v. v. Flower small, petals greenish-brown; lower lip white, with crimson veins; of a very singular structure, resembling at a front view a sheep s head, the two lateral petals forming the horns. 'I he stem is pubescent, not a span high; leaves smooth, in general alternately by four. It distinguishes itself very strongly from all the rest by having five petals, and by the singular structure of its lower lip.

6. C. scapo aphyllo unifloro, foliis radicalibus geminis oblongis obtusis, lobo styli subrotundo-rhombeo acuminato detlexo, labello petalis lanceolatis longiore antice fisso. Willd. sp. pl. 4.p. 144.

C. acaule. Ait. kew. 3.p. 161.

Icon. Bot. mag. 192. Salist. in linn. trans. 1.t.3.f. 4. Catesl. car. app.t.3. Pluk. mant.t. +13.f.1.

In shady rocky situations and on dry mountain bogs : Canada to Carolina. 4. May, June. v. v. Not much above a span high; tlower purple, large. [ have observed a white variety on the Broad mountains, Pensylvania. The whole of this geus is known among the inhabitants by the name of Mocassim Flower, or sometimes Ladies Slippers.

Arietinum.

humile. 


\section{III. $H E X A N D R I A$.}

\section{ARISTOLOCHIA. Gen. pl. 1383.}

Sipho.

1. A. foliis cordatis acutis, caule volubili, pedunculis unifloris bractea ovata instructis, corollis adscendentibus, limbo trifido æquali. Willd. sp. pl.4.p. 155.

A. macrophylla. Lam. encycl. 1. p. 252.

Icon. Bot. mag. 534. L'Herit. stirp. t. 7.

On the mountains: Pensylvania to Carolina. $\zeta$. June. $v$. $v$. A very high running vine; leaves large, and well calculated to form shady bowers ; flowers very singular in structure, yellowish-brown; the leaves are more or less pubescent.

Serpentaria. 2. A. foliis cordatis oblongis acuminatis, caule flexuoso adscendente, pedunculis radicalibus, corollæ labio lanceolato. Willd.sp. pl. 4.p. 159.

In shady woods, on fertile soil : New England to $\mathrm{Ca}$ rolina; principally throughout the mountains. 4 . May, June. $v$. $v$. This is the famous Virginia Snake-root, so very highly and, 1 thiuk, deservedly esteemed by the Indians and white inhabitants of America. I have seen a very narrow and long-leaved variety of it, which, if there were any difference in the flowers, might claim to be a distinct species.

\section{IV. $D O D E C A N D R I A$.}

680. ASARUM. Gen. pl. 801.

canadense. 1. A. foliis lato-reniformibus geninatis, calyce lanato profunde tripartito, laciniis sublanceolatis reflexis.Mich.fl. amer. 1. p. 279. Willd. sp.pl. 2. p. 838.

A. carolinianum. Wilt. fl. car. 143.

A. latifolium. Salisb prodr. 344.

Icon. Moris. hist. 3. s. 13.t.7.f.4. Corn. canad.t. 25. In shady rocky situations : Canada to Carolina. $\mathcal{\psi}$. April. v. v. The root is highly aromatic, and known by the inhabitants under the name of $W$ ild Ginger. It is said to be made use of by the Indian fenzales to prevent impregnation. 
GYMANDRIA DODRCANDRIA. Asarum.

2. A. foliis solitariis rotundato-cordatis glabris coriaceis, virginicum. flore subsessili, calyce extus glabro breviter campanulato.--Mich. fl. amer. 1. p. 279. Willd. sp.pl. 2. 1). 838 .

In shady rocky woods: Virginia and Carolina. 4 . May. v. $v$. Leaves white speckled, very smooth.

3. A. foliis subhastato-cordatis coriaceis, calyce tubuloso infra limbum brevissimo trifidum coarctato. Mich. $f l$.

arifolium. amer. 1. p. 279 .

A. virginicum. Walt. fl.car. 143.

In shady woods of Lower Carolina. 4. May. v. $v$. Leaves spechled. 


\section{DICLINIA.}

\section{SEGREGATZE.}

* Uniloculares.

681. VAlisneria. Dioica. Masc. Spatha 2-partita. Spcriix conicus tectus flosculis. Cal. 3-partitus. St,m. 2. Fem. Spatha tubulosa, 2-fida, 1-flora. Cal. superus, longissinus, limbo 6. partito, laciniis alternis linearibus. Stigmata 3. semibifida. Caps. cyindrica, 1-locularis, polysperma.

682. NAJ.1S. Roprica. Masc. Cal, cylindricus, 2-fidus. Stanien 1. filamento lougo, anthera 4 -valvi : valvis paicutibus. Fem.Cal.0. Styl. 1. Stigm.2. Nux 4-sperma.

633. Drolis. Mjonoica. Masc. Cal.4-phyllus. Stam. 4. Fem. Cal. 1-phyllus, hicornis Stylus 2-partitus. Sem. 1. villosum, calyce bicorni tectum.

* Tricoccee ; Capsula 3-locularis, 3-sperma. Stamina monadelpha. Monoica.

684. RICINUS. Masc. Cal. 5-partitus. Stam. numerosa. Fem Cal. 3-partitus, Styli3. bifidi. Caps echinata.

685. JATROPHA. Masc. Cor. 1-petala, infundibuliformis. Stam. 10. alterna breviora. Fem. Cor. 5-petala, patens. Styli 3. biridi.

686. CRO ON. Masc. inl cylindricus, 5-dentatus. Cor. 5-petala, aut o. Stam. 10-15. Fem. Cal. polyphyltus. Cor. o. Styli 3. bifidi.

687. ACA,Y PHA. Cal.3-4 partitus, 1-bracteatus. Masc. Bractea squamiformis. Stam. $8 \cdots 16$ Fem. Brac. tea nagna cordata involucrifornis. Styli 3. bifidi.

688. TRAGIA. Masc. Cal. 3-partitus. Stam.3. subsessilia. Fem. Cal. 5-partitus. Stylus 3-fidus. 
ö9. EUPHORBIA. Involucrum commune calyciforme, limbo extrorsum appendicibus petaloideis, plerumque 5.; introrsum lacinulis totidem alternis et denticulatis. Masc. tot quot lacinulæ. C'al. polyphyllus : foliolis pinnatim laciniatis. Stam. 4-5. aut plura. Flos fem. centralis, nudus, solitarius, stipitatus. Styli 3. bifidi.

69o. STILLINGIA. Involucrum coriaceum, urceolatum, in masculis multiforum, 1 -florum in fenineis. C'al. tubulosus, infundibuliformis, limbo ciliato. Masc. Stam. 2. exerta, basi coalita. Fem. Stylus filiformis. Stigm. 3.

\section{AMENTACEE.}

* Flores dioici.

691. SALIX. Amenta cylinóracea, imbricata: squamis 1floris. Cal. o. Masc. Glandula baseos nectarifera. Stam. 1-6. interdum monadelpha. Fem. Styl. bifidus. Caps. 1-locularis, 2-valvis, polysperma. Sem. papposa.

692. POPULUS. Amenta cylindracea, laxe imbricata: squanis margine haceris, 1-floris. Cal. urceolatus, integer. Masc. Stam. S. exerta. Fen. Stigma 4fidum. Caps. 2-locularis, 2-valvis, polysperma. Sem. papposa.

693. MYRICA. Amenta ovata, inbricata: squamis lunatis, trifloris. Cal. o. Masc. Squama 4-andra, rarius 6-andra. Fem. Styli 2. Drupa I-sperma.

\section{*** Flores monvici.}

694. BETULA. Amenta imbricata: squamis peltatis, 3floris, 3-fidis. Masc. Cal. 4-partitus. Siam. 1012. Fem. Squama 2-flora. Cal. o. Stigm. 2. Sem. 1. utrinque membrana alatun.

695. ALNUS. Amentum receptaculis cuneiformibus truncatis 3-floris compositum. Masc. Cal. 4-partitus. Stam. 4. Fem. squama biflora. Cal. o. Stigm.2. Sem. 1. compressum, ovatum, apterum.

606. CARPINUS. Amenta laxe imbricata: squamis 1floris. Cal. o. Masc. Squnma ovata, ciliata. Stam. 6-10. Antherce apice villosæ. Fem. Squama lanceolata, ciliata, biflora. Germen apice denticula. 1um. Stigm. 2. Nux ovata, sulcata.

VOL. II. 
697. OSTRYA. Amenta imbricata. Masc. Cal. squams. Fil. ramosa. Fem. Amentum nudum. Caps. inflatæ, imbricatæ, basi monospermæ.

698. FAGUS. Masc. Amentum subrotundum. Cal. 5fidus, campanulatus. Stam. 8-12. Fem. Cal. 4dentatus, setosus. Germ. 2. Nuces 2. calyce echinato, coriaceo, 4-fido inclusæ.

699. CASTANEA. Masc. Amentum nudum, lineare. Cal. sub-6.phyllus. Stam.5-20. Fem. Cal. 5-6-phyllus, muricatus. Germ. 3. Stigm. penicilliformia. Nuces 3. calyce echinato inclusæ.

700. QUERCUS. Masc. Amentum nudum, lineare. Cal. sub-5-fidus. Stam. 4-10. Fem. Cal. plerumque 6-dentatus, scaber. Styli 2-5. Nux coriacea, calyce persistente basi cincta.

701. CORYLUS. Masc. Amentum imbricatum : squamis 3-fidis uniforis. Cal. o. Stam. 8. Fem. Cal. bipartitus, lacerus. Styli 2. Nux ovata, calyce persistente cincta.

702. LIQUIDAMBAR. Masc. Amentum conicum, involucro 4-phyllo cinctum. Filam. numerosa. Fem. Amentum globosum, involucro 4-phyllo cinctum. Cal. urceolatus, biflorus. Styli 2. Caps. 2. basi cinctæ, 2-valves, polyspermæ.

703. COMPTONIA. Masc. Amentum cylindricum, laxe inbricatum; squamis 1-floris. Cal. 2-phyllus. Fi. lam 3 bifurcata. Fem. Amentum ovatum. Cal.6. phyllus. Styli 2. Nux ovata, 1-locularis.

704. PLATANUS. Amentum globosum. Masc. Cor. vix manifesta. Antherce filamentum circumnatæ. Fem. Cor. polypetala. Styli stigmate recurvo. Sem. subrotunda, stylo mucronata, basi papposa.

705. JUGLANS. Masc. Amentum imbricatum. Cal.6partitus. Filam.4-18. Fem. Cal. 4-fidus, superus. Cor. 4-partita. Styli 2. Drupa coriacea, nuce sulcata.

706. MORUS. Amentum subglobosum. Masc. Cal. 4partitus. Filam.4. Fem. Cal. 4-phyllus. Siyli 2. Cal. baccatus. Sem. 1. 


\section{CONIFERE.}

* Flores monoici.

707. PINUS. Masc. Amentum imbricatum. Cal. 4-phyl. lus. Stam. plurima. Anth. nudæ. Fem. Cal. strobili s. coni : squama biflora. Pistill. 1. Nux ala membranacea excepta.

708. CU: RESSUS Masc. Amentum ovatum, imbricatum: squamis (20) oppositis, apice peltatis, basi 4-andris. Anth. sessiles. Fem. Conus subrotundus : squamis $(8-10)$ oppositis, peltatis. Germina sub singulis plurima minima serie simplici. Styl. o. Stigm. cylindricum, fistulosum. Nux angulosa 1sperma.

709. THUYA. Masc. Amentum ovatum : squamis 6 . trino ordine oppositis, apice obtusis, basi 4-andris; Anth. substipitatæ. Fem. Conus subovatus : squamis oblongis apice incrassatis, longitudinaliter conniventibus. Germina 2. Styl. brevissimus. Stigm. concavum. Caps. 1-spermæ, margine alato.

** Flores dioici.

710. JUNIPERUS. Amenta ovata: squamis stipitatopeltatis. Masc. Squamce ternatim verticillatæ, stipite 2-3-4-antheritero. Fem. Squame pauciores, cruciatim oppositæ. Germ. 1. Styl. o. Stigm. tubulosum. Fructus bacciformis, carnosus. Nux 1locularis.

711. TAXUS. Gemma polyphylla, opposite-imbricata. Cal. 0. Masc. Antherce peltatæ, 8-fidæ. Fem. Germ. 1. Styl. 0. Stigm. 1. Receptaculum cupulæforme, nuce ovata, nuda.

712. ZAMIA. Amentum strobiliforme. Masc. Squama obovata. Cal. 0. Antherce plures, globosæ, rima dehiscentes, in squama sessiles. Fem. Squamie peltatæ. Germ. 2. Styl. 0. Bacce 2. 7-spermæ. 


\section{SEGREGATAE.}

681. VALLISNERIA. Gen. pl. 1491.

americana. 1. V. folis linearibus, pedunculis masculis femineisque rectis. Willd.sp.pl.4. p. 651. Mich. fl. amer. 2. p. 220

At the bottom of muddy and slow-flowing rivers: Mississippi and St. John's, Florida. Michaux. In Os. wego river, New York; Delaware, Pensylvania, and James's and Greenbriar rivers, Virginia. Ph. 2\%. 0 ? Aug. Oct. v. v. This most interesting and singular plant I obscrved in the Delaware, near Philadelphiil, in 1800 ; which discorery 1 communicated, accompanied with a drawing and desciption, to Dr. B. S. Barton, of Ptriladelphia. The cenomy of its feccundation is highly iateresting to the young student of the serual system. Michanx and IVhlide. now consider it as specifically distinct from $V$. spiralis; but I have always comidered it only a local va. riety, as the peduncles of the female flowers are in deep water really spiral.

682. NAJAS. Willd act. acal. lerol. 1798, p. 85.

canadensis. 1. N. pusilla, filiformis, lævis; foliis angustissime linearibus. Mich. fl, amer. 2. p. 220 .

In lakes: Canada, on Lake St. John's. Michaux. +.

\section{6s3. DIOTIS. Gen. pl. 1423.}

lanala.

1. D. omnibus partibus cano-tomentosa; caule flexuoso, glomerulis spicarum confertinsimis.

On the banks of the Missouri, in open prairies. $M$. Leuvis. h. Aug. Sept. v. s. in Herb. Lewis. Resembles Diotis ceratoides, but is distinct at first sight by its long woolly tomentum.

6s4. RICINUS. Gen. pl. 1464.

communis.

1. R. foliis peltatis palmatis, lobis lanceolnt is serratis, canle herbaceo pruinoso, stim matibus tribus apice bifidis,

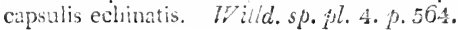

Icon. Blackw. t. 148. 
In cultivated grounds, frequent in old plantations in Virginia and Carolina. ๑. Aug. Sept. v. $v$. Introduced by the Negroes. Known by the name of Castor-oil Bean.

\section{JATROPHA. Gen.pl. 1463.}

1. J. herbacea, stimulis putulis horridissima; foliis subpalmato-lobatis, lobis obtusiusculis subsinuato-incisis, cymis brevi-pednnculatis. Mich. fl. amer. 2.p. 216.

J. urens. Whalt. Al. car. 239.

Icon. Pluk alm. t. 220 f. 3. Marcg. lrass. 79. f. 2.

In fields and plantations: Virginia to Florida. 24. July, Aug. $v . v$. Flowers white; roots tuberous and eatable, the same as J Marihot, which is so generally cultivated in the West indies under the name of Cassada. The present piant is a very injurinus weed in some parts of Carolina, as it mins the Negroes' feet when they tread upon it ; from which it is known by the name of Tiead-sofily.

\section{CROTON. Gen.pl. 1462.}

1. C. foliis ellipticis integerrimis obtusiusculis incanis subtus tomentosis petiolatis, spicis terminalibus paucifloris. Willd sp. pl. 4. p. 532. Walt. fl. car. 239.

C. disjunctiflorum. Mich, fl. amer. 2. p. 214.

$\beta$. C. spicis dichotonaibus, flore fenineo unico pedicellato. monanthogyMich.fl. amer. 2.p. 215.

On the sea-coast of Carolina; $\beta$. in Tennassee, near Nashilie. $r .24$. June, July. v.s. The fiowers of this genus are small and inconspicuous. The branches somerimes live over winter, but it cinnot be considered a real shrub. Most of the species here mentioued are covered with stellated hairs.

2. C. suffuticosum, stellato-tomentosum; foliis oblongis integerrinis subtus tomentosis petolatis, pedunculis uuun.

stimulosa,

maritimum. terninalibus subbifloris.-Willd. sp.pl.4. p. 535.

C. punctatum. Jalq. ic. rar. 3.t. 621 .

In sterie woous of Georgia and Florida. h. 21. July, Aug. v.s.

3. C. hispidissimum; foliis oblongis serratis subtus hirtis glandulosum. basi subintegerrimis biglandulosis, caule trichotomo, spicis alaribus, capsulis glomeratim sessilibus.-Willd. sp pl. 4. p. 540 .

C. scordioides, Lam, encycl.2.p.214. 
Icon. Jacq. ic. rar. 1. t. 194.

On the sea-coast of Carolina and Florida. $\odot$. July, Aug. v. $v$.

capitatum.

4. C. tomentoso-lanatum; foliis oblongo-ovalibus obtusis basi rotundatis integris, utrinque tonientosis, flo:ibus femineis ad basin spicillæ marium capitatim congestis. -Mich. Al. amer. 2.p. 214.

In the Illinois country. Michaux. $\odot .+$. Resembles $C$. argenteum.

\section{ACALYPHA. Gen.pl.1461.}

virginica.

1. A. floribus femincis ad basin spicæ masculæ, involucris ovatis acuminatis dentatis, foliis breviter petiolatis oblongo-lanceolatis remote obtuse-serratis. - Willd. $s p$. pl. 4. p. 521 .

Icon. Pluk.phyt. t. 99.f. 4 .

In fields, cultivated grounds, and on road sides: Canada to Virginia. ๑. June-Aug. v. $v$.

caroliniana. 2. A. floribus femineis ad basin spicæ masculæ, involucris cordatis dentatis, foliis longe petiolatis subrhombeoovatis serratis basi integerrimis.-Willd. sp. pl. 4. p. 521. Walt. Al. car. 238.

In cultivated grounds : Virginia to Florida. $\odot$. July, Aug. v. $v$.

688. TRAGIA. Gen. pl. 1410.

urens.

subovalis.

lanceolata.

1. T. erecta; foliis lanceolatis sessilibus obtusis apice sub. dentatis, cauleque ramoso pubescentibus. Willd. sp. pl. 4. p. 325.

a. T. foliis cblongo-ovalibus nonnullis subcuneatis. Mich. $f$ amer. 2.p. 175.

Icon. Pluk. alm. t.:07.f. 5.

ß. T. foliis lanceolatis subdentatis integrisque. Mich. l.c.

T. innocua. Walt. fl.car. 229 .

linearis.

. T. foliis linearibus tere omnibus integris. Mich. l. $c$.

In waste places, on road sides and cultivated grounds : Virginia to Carolina. ๑. June-Aug. v. $v$.

urticifolia. 2. T. erecta caule hirsutissimo, foliis cordatis ovatis serratis.-IVilld. sp. pl. 4. p. 324.

T. mercurialis. Walt. fl. car. 229 .

In fields: Virginia to Georgia. $\odot$. July. v. s. in Herl. Lyon. 
3. T. scandens, hispida; foliis profunde cordatis ovatis acute macrocarpa. dentatis.-Willd. sp. pl. 4. p. 323.

In Kentucky. Michaux. $\odot$. July. v. s. in Herl. Lyon.

689. EUPHORBIA. Gen. pl. $\$ 23$.

\section{* Floribus fasciculato-terminalibus.}

1. E. fruticescens ; foliis petiolatis ovatis subdentatis pandu- cyathophora. riformibus, summis involucellisque coloratis, floribus subumbellatis.-Willd. sp. pl. 2. p. 891 .

E. heterophylla. Jacq. collect. 1. p. 157.

Icon. Jacq. ic. rar. 3. t. 480. Murr. comm. gæt.7. p.s1.t. 1 .

On the banks of the Mississippi, and in Georgia and Florida. $々$. $\odot$. June, July. v. v. About three feet high; upper leaves and involucres painted deep red.

2. E. pumila, hirsuta; foliis oppositis ovalibus dentatis, flores ad summitates congestis. Mich. $f$. amer. 2. p. 211 .

In shady rocky situations: Pensylvania to Tennassee. $\odot$. July, Aug. v.v. The upper leaves spotted.

3. E. pusilla, erecta, ramosa, pubescens ; foliis sparsis line- graminifolia. aribus integerrimis, supremis basi discoloribus. - Mich. fl. amer. 2. p. 210.

On the sea-coast of Georgia and Florida. Michaux. +. Resembles $E$. hyssopifolia.

** Dichotoma. (Umbella bifida aut nulla.)

4. E. glabra, ramosissima, patulo-erecta; ramis divarica- hypericifolia. tis, foliis oppositis serratis ovali-oblongis subfalcatis corymbis terminalibus.-Willd.sp. pl. 2. p. 895 .

Icon. Comm. pral.60.t. 10. Rol. ic. 11. Sloan. hist. jam.1.t.126.

On the banks of rivers and in cultivated sandy grounds : Canada to Florida. $\odot$. June-Sept. $v$. $v$.

5. E. erecto-patula ; foliis oppositis serratis oblongis pilosis, maculata. floribus axillaribus solitariis, appendicibus calycinis coloratis.-IVilld. sp. pl. 2 p. 896.

Jcon. Jacq. hort. vind.t. 186 . Pluk. alm. t. 65.f.8.

In cultivated grounds: Pensylvania to Carolina. $\odot$. July-Sept. v. $v$. Leaves marked with a brown spot. The involucrum of the florets white. 
thymifolia. 6. E. lumifusa, gracilis, pubescens; foliis oppositis ovalio oblongis obtusis superne subserratis, capitulis axillaribus glomeratis subsessilibus.-Willd. sp.pl.2. p. 898.

Icon. Pluk. alm. t. 113.f.2. Burm. zeyl.t. 105.f. 3. On the banks of the Ohio and Mississippi. $\odot$. JuneAug. $v . v$.

polygonifolia. 7. E. glaberrima, diffusa; foliis oppositis integerrimis lineari-lanceolatis obtusis, floribus solitariis axillaribus.Willd. $s p \cdot p l .2 . p .900$.

Icon. Jacy. collect. suppl. t. 13.f. 3.

In cultivated grounds: Canada to Virginia. 24. JuneSept. $v . v$.

Ipecacuanho. 8. E. procumbens, pumila, glabra; foliis oppositis obovalibus seu lanceolatis, pedunculis axillaribus unifloris elongatis.-IVilld. sp.pl. pl. 2. p. 900 .

Icon. Bot. mag. 1494.

In pine-barrens: New Jersey to Carolina. 24. June, July. $v . v$. This humble species has perhaps the deepest root of any perennial I know; I frequently have dug to the depth of more than six feet, and was by appearance as far off from its end as ever.

portulaccoi- 9. E. erecta ; foliis integerrimis ovalibus retusis, peduncudes. lis axillaribus unifloris folia æquantibus. - Willd. $s p$. pl. 2. p. 901 .

In sandy soil, and cultivated grounds: Pensylvania. 24. June-Aug. $v, v$.

tulentissima. 10. E. erecta; caule calycibusque pubescentibus, foliis oppositis sessilibus subcordato-ovalibus obtusis, pedunculis solitariis capillaribus unifloris, appendicibus calycinis coloratis petaloideis. Mich. f. amer. 2. p. 212.

In Carolina. Michaux. $2 \% .+$

\section{** Umbellala; involucrala.}

Peplus. 11. E. umbella 3-fida: dichotoma, involucellis ovatis, foliis integerrimis obovatis petiolatis. Willd. sp. pl. 2. p. 903 .

Icon. Engl. lot. 959.

In cultivated grounds: Pensylvania and Virginia. $\odot$. July, Aug. $v . v$.

obtusata. 12. E. umbellata 3-fida: bis dichotoma, involucellis ovatis obtusiusculis subcordatis, foliis alternis sessilibus spathulatis involucellisque serrulatis glabris, capsulis muricatis. 
In cultivated grounds: Virginia, near Staunton. 4. July, Ang. v. v. Resenibles E. spathulata.

13. E. caulibus gracile-dcbilibus, simpliciter 3 -fidis, foliis morcurialina. oppositis ternisve subseriilibus ovalibus integris, pedunculis terminalibus suitariis unforis.-Mich. $f$. amer. 2. p. 212.

In shady rocky situations: Pensylrania and Kentuchy. 24. July, Aug. v. 2 . Resembles in aspect Mitercuialis annila.

i4. F. umbella 3-fita: bis cicirstoma, involucro foliiforme, involucellis oblongis cordans margine membranaceis coloratis, foliis lanceolato-oblongis subcordato-am. plexicaulibus acutis glauccscentibus glabris, appendicibus calycinis petaloiceis subrutundis, capsuilis pilosis.

On the Yellow-stone river. M. Lewis. ๑. July. i.s. in Herb. Lewis. A very handsome species; the white margin of the mvolucre and white petal-like appendices have a fine contrast with the elegant soft green leaves.

15. E. umbella 4-fida: dichotoma, foliis oppositis lanceolatis integerrimis. Willd.sp.pl.2.p. 000 .

Icon. Blackw. t. 123.

Not native, but frequentl; found near gardens and in cultivated ground d. July, Ang. v. v. It is generally known in Anerica by the name of Moleplant, it being supp sed that no moles disturb the ground where this plant grow:s.

16. F. umbella 5 -ficla : 3-fida: dichotoma; involncellis foliisque oblongis obiusis, appendicibus calycinis potaloideis obovitis.-Willd. sp. pl. 2. p. 916.

Icon. Pluk mant. t. 446. f. 3.

In ciry felds: Canada to Carolina. 24. July, Aug. v. $v$. It is very variable in its foliage: sometimes the leares are quite linear.

17. E. umbella 5-fida: trifida: bifida, involucris ovatis, marginale.

Lathyris.

crorulliata. petalis integris, follis lanceolatis subpilosis apice serrulatis. Willd. sp. pl. 2. p. 917 .

Icon. Gmel. sil. 2. t.93.

In shady wet woods, in the mountains of Maryland and Virginia. 24. June, July. v. v. From two to four feet high. 


\section{6go. STILliNGIA. Gen. pl.1470.}

sylvatica. 1. S. herbacea; foliis sessilibus oblongis obtusis basi atte. nuatis serrulatis, flosculis masculis squamam floralem vix superantihus.-Willd.sp. pl. 4. p. 588.

In pine-barrens: Virginia to Florida. 24. May, June. $v$. $v$. Flowers yellow, in a spike, resembling a catkin.

ligustrina. 2. S. fruticosa; foliis petiolatis ovali-lanceolatis utrinque attenuatis integerrimis, flosculis masculis brevissime podiceilatis.-Willd. sp. pl. 4. p. 588.

In shady woods : Carolina and Georgia. 々 . June, July. v. $v$.

selifera. 3. S. arborea ; foliis petiolatis rhombeis acuminatis integerrimis, infra basin glandula petiolari, floribus masculis pedicellatis. - IVilld. sp. pl. 4.p. 588.

Croton sebiferum. Sp. pl. 1425.

Icon. Pet.gaz. t. 54.f.3. Pluk. amalth. t. 390.f. 2.

On the sea-coast of South Carolina; originally a native

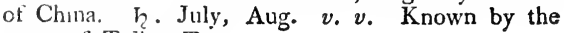
name of Tallow Tree.

\section{II. $A M E N T A C E A$.}

\section{SALIX. Gen.pl. 1493.}

* Foliis integerrimis aut obsolete serratis; vernatio revoluta.

viminalis. 1.S. foliis lanceolato-linearibus longissimis acuminatis integerrimis subundulatis subtus sericeo-argenteis, versus marginem sparse.glandulosis, stipulis exiguis, amentis præcocibus, squamis subrotundis pilosissimis, germinibus sessilibus ovatis, stylo filiformi, stigmatibus acutis indivisis.-Willd.sp.pl. 4.p. 706.

Icon. Hoffm. salic. 1.t.2.f. 1 छ' 2.t.5.f.2. t. 21,f.e. f.g.

On the banks of rivers and about plantations; introduced from Europe. $々$. April, May. v. v. Filaments yellow, anthers orange.

candida.

2. S. foliis lineari-lanceolatis longissimis apice obsolete denticulatis supra pubescentibus subtus niveo-tomentosis margine revolutis, stipulis lanceolatis petiolum subæ- 
quantibus, amentis præcocibus cylindraceis, squamis obovato-lanceolatis longissime villosis. - Willd. $s p$. pl. 4. p. 708 .

In dry shady woods: New York to Pensyivania. $h$. April, May. v. $v$. The native place of this willow is not mentioned by IVilldenow; but a plant in the collection of G. Anderson, Esq. which was found among a promiscuous collection of willows made by me on the Catskill mountains, New York, decides the question. To this gentlemain's actite observations l am indebted for the present division of Salices "vernatio revoluta," as likewise for the greater part of the present arrangement of American willows.

3. S. foliis lanceolatis acutiusculis subintegerrimis pubescenti-canis, subtus rugoso-venosis, margine revolutis, stipulis deciduis lanceolatis, amentis præcocibus diandris, squamis oblong is margine villosis, germinibus ovato-lanceolatis sericeo-villosis longe pedicellatis, stylo brevi, stigmatibus bifidis.-IVilld. sp. pl. 4. p.692,

S. tristis. Muhll. in annals of lot. 2. p. 08. t. 5.f.9.

S. alpina. IValt. fl. car. $2+3$.

S. Hava. Schoepf. mal. med. amer.

In shady dry woods : New York to Virginia. $々$. April. $v . v$. From three to five feet high; branches greenishyellow, with black dots; the anthers are purple, changing to yellow when burst; scales white with a red tip, which gives the catkins a very pleasing appearance. In this and the following species I have not been able to ascertain whether the vernatio is revolute; but their natural affinity to the preceding ones strongly indicates that they are so.

4. S. foliis lineari-lanceolatis utrinque acutis integerrimis margire revolutis supra glabriusculis subtus rugosovenosis tomentosis, stipulis nullis, amentis precocibus oblongis. -Willd.sp. pl.4. p. 693.

In dry sandy woods: New Jersey to Carolina. $h$. March, April. v. v.; v. s. in Herb. Banks. Approaches near to the preceding.

5. S. foliis obovato-lanceolatis acutis integerrimis margine glandulosis glabris subtus glaucis, junioribus sericeis, stipulis nullis, amentis præcocibus recurvatis, squamis apice nigris, pilis longitudine germinis, germinibus ovatis brevi-pedicellatis sericeis, stýlo brevissinı, stigmatibus bifidis.
Muhlentergiana.

tristis.

recurvata. 
In shady woods, in the mountains of New Jersey and Pensylvania. h. April. $v$. $v$. A low shrub; branches brown, smooth; buds yellow.

** Foliis integerrimis aut olsolete serratis ; vernatio equitans.

+ Caule repente, depresso aut diffuso.

repiens. $\quad 6 . \mathrm{S}$. repens; foliis elliptico-lanceolatis integerrimis acutis glabris subtus subsericeis, stipulis nullis, amentis præcocibus ovatis diandris, squamis obovatis obtusis pilosis apice fuscis, germinibus ovato-oblongis pedicellatis pubescentibus, stylo brevissimo, stignatibus bilobis, capsulis glabris.-Willd. sp. pl. 4. p. 693.

S. depressa. Họfin. salic. 1. t. 15 E 16.

S. polymorpha. Ehrh. frut. 49 .

In Nova Scotia and Newfoundland. h. May. v. s. in Herl. Banks. A very small creeping species.

reticulata. $\quad$ 7. S. repens; foliis elliptico-orbiculatis obtusis integerrimis glabris reticulato-venosis subtus glaucis, stipulis nullis, amentis serotinis pedunculatis diandris, squamis obovatis obtusis pubescentibus, germinibus ovatis sessilibus villosis, stigmatibus subsessilibus bipartitis.-Willd. sp.pl. 4. p. 685 .

Icon. Fl dan. 212. Hofm. salic. t. 15.16.17. Fl. lapp.t. 8.f. L. छ t. 7.f. 1 छ 2.

In Labrador, Newfoundland, and on the north-west coast. h. June. v. s. in Herb. Banks. A very low creeping species; leaves very bandsomely marked with coloured reins.

vestita.

8. S. repens; foliis suborbiculatis integerrimis supra glabris reticulato-venosis subtus villis sericeis longissimis adpressis tectis, stipulis nullis, amentis serotinis peduncnlatis linearibus sericeis, germinibus ovatis sessilibus villosis, stylo profunde bipartito, stigmatibus bifidis.

In Labrador. $々$. June. $v$. s. in Herl. Lamlert. et Banks. A very elegant species, resembling the preceding.

Uva ursi. 9. S. depressa ; foliis spathulato-obovatis obtusis integerrimis, inferne margine sparse glandulosis, glabris, supra nitidis, stipulis nullis, amentis serotinis laxis, squamis oblongis ciliatis, germinibus ovatis pedicellatis glabris, stylo bipartito, stigmatibus bilobis.

In Labrador. h. April, May. v. v. in Hort. Anderson. 
For this beantiful little species I am indebted to $\mathbf{G}$. $\Lambda$ nderson, Esq.; it has all the appearance of Arlutus Ura ursi in habit, as well as in the form of its leaves.

10. S. depressa ; foliis ovalibus subacutis basi cordatis integerrimis reticulato-venosis supra glabris, stubtus pallidis nervo margineque pilosis, stipulis semicordatis.

In Labrador. $h$. v. v. s. $\Omega$. in Hort. Anderson. In general habit it resembles $S$. myrsinites.

11. S. diffusa ; folitis obovatis obtusis integerrimis supra glabris, subtus sericeo-villosis, stipulis uullis, amentis subcoætaneis sessilibus oblong is 2 -andris, squamis obovatis apice nigris pilosis.

In Labrador. . Colmaster. North-west coast. Nelson. h. May. v. s. in Herb. Dickson. et Bunks. This species is allied to S. Arenaria Linn. and is more inclined to be upright than the preceding.

i2. S. erectincula, divaricata; ramulis lævigatis, foliis oblongo-lanceolais utrinque acutis medio semulatis glaberrimis patentibus planis discoloribun, stipulis nullis.

In Labrador. $\zeta_{s} . v$ v. s. $f$. in Hont. Anderson. This singular specie's distinguis' es iteelf at first sight by its remarkable plain and patent leaves; it is inclined to rise from the ground on a single low stem, and approaches to the following division.

\section{it Coule erecto.}

13. S. ramulis levigatis, foliis obovato-lanceolatis acutis intepedicellaris. gerrimis utrinque glabris concoloribus, stipuiis nuilis, amentis coxtaneis pedunculatis glaberrimis, squamis oblongis pedicello duplo brevioribus vix pilo-is, germinibus ovato-oblongis longisime pedicellatis glabris, stigmatibus sessilibus bifidis.

S. pensylvanica. Hortul.

On the Catskill mountains, New York. h. April. v.v. This elegant and singular species flowered in the garden of $G$. Anderson, Esq., from a plant brought by me from America. He ha, one ihrough another channel, which appears to be the male to this species.

14. S. foliis suboppesitis obovato-lanceolatis acutis glabris Lamlertiana. apice subserratis discoloribus, stipulis nuili, amentis precocibus, squamis orb:culatis nigris, fiamento unico, anthera geminata, geminibus sessilibus ovato-ellipticis sericeis, stvlo brevissimo, stigmatibus ovatis emarginatis.-Willd. sp.pl.4. p.673. 
Icon. Engl. bot. 1359.

On the banks of rivers and in willow grounds; intro. duced from Europe. h. March, April. v. v. It is cultivated on account of its exceeding tough branches for the use of making baskets.

rosmarinifo- 15 . S. foliis strictis lineari-lanceolatis utrinque acutis integerlia. rimis margine subglandulosis supra deciduo-pubescentibus, subtus sericeis, stipulis exiguis lanceolatis erectis, amentis præcocibus ovatis recurvatis, squamis oblongis obtusis ciliatis, gerninibus pedicellatis lanceolatis villosis, stigmatibus subsessilibus bifidis.Will. sp. pl.4. p. 679 .

Icon, Engl. lot. 1365.

In wet meadows and mountain swamps: Pensylvania to Carolina. $h$. March, April. $v . v$. Not above three feet high. This species, though mentioned as a British plant in the Flora Britannica, is decidedly of American origin; as both sexes have been introduced from that country by G. Anderson, Esq. It has a great resemblance in general character to $S$. recurvata, but the vernatio equitans removes them far from one another.

fuscata. 16. S. foliis obovato-lanceolatis acutis glabris subserratis subtus glaucis, junioribus pubescentibus, stipulis exiguis, amentis præcocibus nutantibus, squamis obtusis intus vix pilosis, germinibus brevi-pedicellatis ovatis sericeis, stigmatibus sessilibus bilobis.

In low overflowed grounds, on the banks of rivers: New York to Pensylvania. $々$. March, April. v. $v$. Branches of the preceding year covered with a dark brown or black tomentum.

\section{*** Foliis remote obtuseque serratis.}

conifera. 17. S. foliis oblongo-lanceolatis remote serratis acutis supra glabris subtus pianis tomentosis, annotinis glabris, stipulis lunatis subdentatis, amentis præcocibus diandris, squamis lanceolatis obtusis villosis, gerninibus pedicellatis lanceolatis sericeis, stylo bifido, stigmatibus bilobis.-Willd. sp. pl. 4. p. 705.

S. longirostris. Mich. fl. amer, 2.p. 226.

Icon. Wangh. amer. t.31.f. 72.

In shady woods on gravelly dry soil : New York to Carolina. $h$. April. $v . v$. The cone-like excrescence at the end of the branches, occasioned by an insect, is not unfrequently found on other species belonging 
to the present division, but particularly on $S$. prinoides.

18. S. foliis oblongo-lanceolatis acutis basi biglandulosis obtuse serratis glabris subtus glancis, stipulis ovatis acutis glanduloso-serratis, amentis coætaneis villosis basi foliosis, squamis lanceolatis obtusis villosis atris, ger. minibus longe pedicellatis lanceolatis glabris, stylo bifido, stignatibus bifidis.-Willd. sp. pl. 4. p. 666.

Icon. Muhll. in annals of bot. 2. t. 5.t. 2.

In wet meadow's and woods: New England to Virginia. $h$. April. $v . v$. Branches green; younger ones purple, smooth.

19. S. foliis ovali-oblongis acutis remote undulato-serratis glabris subtus glaucis, stipulis semicordatis inciso-dentatis, amentis præcocibus villosis, germinibus pedicellatis ovatis acuminatis sericeis, stylo longo, stigmatibus bifidis.

On the banks of rivers: Pensylvania to Virginia. $h$. March, April. v. v. Midule-sized; resembles $S$. discolor.

20. S. foliis oblongis obtusiusculis glabris remote-serratis apice integerrimis subtus glaucis, stipulis deciduis lanceolatis serratis, amentis subcoætaneis diandris oblongis tomentosis, squamis oblongis acutis atris pilosis, germinibus subsessilibus lanceolatis tomentosis, stylo mediocri, stigmatibus bipartitis.-Willd. sp. pl. 4 . p. 665.

Icon. Muhll. in annals of bot. 2.t.5.f. 1 .

In low grounds and on the banks of rivers; common: New England to Carolina. $\eta$. April. v. v. Branches dark brown; filaments white; anthers red, yellow when burst. This is the most common in use for basket-making.

21. S. foliis lanceolatis acutis longissimis basi sensim attenuatis serrulatis glaberrimis subconcoloribus, stipulis semicordatis, amentis præcocibus erectis glabriusculis, germinibus pedicellatis ovatis glabris, stylo bifido, stigmatibus 2-lobis.

In shady woods on the banks of rivers : New York and Pensylvania. $h$. March, April. v. v. Leaves very long; resembles $S$. prinoides.

22. S. foliis linearibus utrinque acuminatis elongatis remotissime denticulatis glabris concoloribus, stipulis exi-

longifolia.

prinoides.

discolor.

angustata. guis lanceolatis denticulatis, amentis serotinis pedun-

myricoiles. prinoiles.

discolor. angustata. 
culatis tomentosis diandris, squamis planis retusis, filanentis basi barbatis squama duplo longioribus.-Willd. sp. pl.4. p.670.

Icon. Muhll. in annals of lot. 2. t. 5.f. 6.

On the banks of the Susquehannah. Muhlenberg. $h$. July. + . Not above two feet high; branches brown; brauchlets white.

\section{**** Foliis dense acnteque serratis.}

\section{+ Triandre. (Filamentis 3-6.)}

lalylonica. 23. S. ramis pendulis, foliis lanceolatis acuminatis serratis glabris discoloribus, stipulis exiguis subrotundis, amentis coætaneis, germinibus sessilibus ovatis glabris. Willd. sp. pl. $4 . p .671$.

On road sides and abunt plantations; introduced from Europe. b. Mily, v. v. The Wroping Willow is now almost naturalized, being every where planted for ornament.

Iloustoniana. 24. S. foliis lineuri-lanceolatis acutis tenuissine serratis utrin.que glabris nitilis concoloribus, stipulis nullis, amentis contaneis cylindricis villosis, squanis oratis acutis, filanent is $3-5$. usque 1 medium barbatis.

S. tristis. Hortul.

In Virginia and Carolina. . v. v. s. $l$. ; v. s. c.fl. in Herl. Fanks. specinen Houstonianum. This species, so fiequently found in the gartens under the name of $S$. tristis, is very far from being in any way related to it. The specimen in the Banksian Herbarium was collected $\mathrm{by}$ Houston, and, as it is said, in Vera Cruz. But I an confident it is a more northern plant, as I frequently have seen it in Virginia. The branches are extremely brittle at their basc.

faliaia. 25. S. foliis longissimis lineari-lanceolatis superne sensim attenuatis subfalcatis basi acutis approximato-serratis utrinque glabris, junionbus sericeis, stipulis lunatis dentatis deflexis.

On the barks of rivers: Pensylvania to Virginia. $h \cdot 1$ $v$. v. s. fl. A very smooth species; branches very slender and brown.

nigra. 26. S. foliis lanceolutis utrinque acutis serrulatis concoloribus glabris petiolis et nervo medio supra tomentosis, stipulis exiguis dentatis, amentis coætaneis erectis cylindricis villosis, squamis chlongis villosissimis, flamentis 3-6. basi babats, ceminibus pedicellatis ovatis gla- 
bris, stylo brevissimo; stigmatibus bifidis.-Willd. $s p$. pl. 4. p. 657. Marsh. arb. $2 y 3$.

S. caroliniana. Mich. fl. amer. 2. p. 226.

S. pentandra. Walt. fl. car. 243.

S. vulgaris. Clayt. fl. virg.

Icon. Mich. arb. 3.t.... Muhlb. in annals of lot. 2. t.5.f. 5 .

On the banks of rivers : Pensylvania and Virginia. $h$. May. $v . v$. A tree about twenty feet high; branches smooth, very brittle at the base.

27. S. foliis ovato-oblongis cuspidato-acuminatis basi rotundatis serratis glandulosis utrinque glabris nitidis, stipulis oblongis glanduloso-serratıs, anentis coætaneis sub3-andris, squamis lanceolatis obtusis basi pilosis apice serratis glabris, germinibus lanceolato-subulatis glabris, stylo bificio, stigmatibus obtusis. - Willd. $s p$. pl. 4. p. 667.

Icon. Muhlb, in annals of bot. 2. t. 5.f. 7. Mich. arl.3. t. ....

In low grounds, about springs : New York to Virginia. h. May. v. v. A very smooth and handsome species; branches yellowish brown; sometimes it grows to the size of a tree, but more generally it is only a shrub. It approaches to $S$. amygdalina of Europe.

28. S. foliis oblongo-lanceolatis acuminatis basi subcordatis rigidis glabris argute serratis, serratura infima elongata, petiolis villosis, stipulis amplis cordatis obtusis glanduloso-serratis, amentis coætaneis sub-3-andris, squamis lanceolatis atris lanatis, germinibus longe pedicellatis lanceolatis glabris, stylo brevissimo, stigmatibus biparitis. - Willd. sp.pl. 4. p.667.

S. cordata. Mich. fl. amer. 2. p. 225.

S. cordifolia. Fierb. Banks. mss.

Icon. Muhlb. in annals of bot. 2.t. 5.f. 4.

In swamps and hedges : New England to Virginia. $\zeta$. April, May. v.v. Branches green, red towards the end, younger ones pubescent. It is very tough, and much in use by the basket-makers.

29. S. foliis oblongo-lanceolatis acuminatis basi cordatis argute serratis glabris subtus pallidioribus, stipulis amplis ovato-subrotundis cartilagineo-serratis, amentis coætaneis sub-3-andris, squamis lanceolatis lanatis atris, germinibus pedicellatis lanceolatis glabris, stylo vol. $n$. 
brevissimo, stigmatibus bifidis.-Willd. sp. pl. 4. p. 666.

Icon. Muhll. in annals of bot. 2. t. 5. f. 8.

In low and swampy grounds, on the banks of rivers: New York to Virginia. n. April, May. v. v. A very elegant species, about six or eight feet high.

\section{t+ Diandra.}

grisea. $30 . \mathrm{S}$. foliis lanceolatis acuminatis serrulatis supra glabris nervo medio tomentosis subtus sericeis nudisve, stipulis linearibus deflexis deciduis, amentis præcocibus, squamis oblongis pilosis apice atris, germinibus oblongis pedicellatis sericeis, stigmatibus sessilibus obtusis.Willd. sp. pl.4. p. 699 .

S. sericea. Muhll. in annals of bot. 2. t. 5.f. 8. Marsh. arb.

In low overflowed grounds: Pensylvania to Virginia. h. April. v. v. About eight feet high ; branches greenish-purple, very brittle at the base.

petiolaris. $\quad 31 . \mathrm{S}$. foliis lanceolatis undique serratis glabris subtus glaucis sericeis basi plerımque inæqualibus, stipulis lunatis dentatis exiguis, amentis præcocibus laxis, squamis obovatis obtusis nigris pilosis, germinibus longe pedicellatis ovatis sericeis, stigmatibus sessilibus bilobis.Willd. sp.pl. 4. p. 605.

S. pensylvanica. Horlul.

Icon. Engl. lot. $11+7$.

In swamps and on the banks of rivers; common. $\eta$. April. v. v.; v. s. in Herl. Lamlert. et Anderson. Branches slender, smooth, dark brown. It has been by mistake adopted as a native of Great Britain.

alla.

32. S. foliis lanceolatis acuminatis serratis utrinque sericeis, serraturis infimis glandulosis, stipulis obsoletis, amentis coætaneis elongatis, squamis elliptico-lanceolatis concoloribus pubescentibus, germinibus subsessilibus ovato-oblongis denique glabratis, stylo brevi, stigma. tibus bipartitis crassis.-Willd. sp. pl 4. p. 710.

Icon. Hoffin. salic. 1.t. 7. छ॰ 8. Eซ t. 24.f. 3.

On road sides and river banks; introduced from Europe. h. April, May. v. v. A tall tree.

vitellina. 33. S. foliis lanceolatis acuminatis crebro-serratis supra glabris subtus discoloribus subsericeis, stipulis nullis, amentis subcoætaneis cylindricis, sq̨uamis ovato-lan- 
ceolatis concoloribus extus pubescentibus, germinibus sessilibus ovato-lanceolatis glabris, stigmatibus subsessilibus bilobis.-Willd. sp. pl. 4.p. 668.

Icon. Hoffm. salic. 1. t. 11. छ 12. छ t. 24, f. 1. Engl. bot. 1050.

On road sides and about plantations; common. Introduced from Europe. $\eta$. May. v. $v$. A midulesized tree.

34. S. foliis lanceolatis acuminatis concoloribus glabris glanduloso-serratis, amentis coætaneis, nectario gemino majusculo: lobis lanceolatis difformibus apice dentatis glabris, flosculis terminalibus 3 -andris.

In low grounds: New York and New Jersey. I . April. $v . v$. Resembles in leaves and habit the preceding, and in fructification the following.

35. S. foliis lanceolatis acuminatis undique serratis glaberrimis concoloribus, petiolis dentato-glandulosis, stipulis rotundatis, amentis subcoætaneis, squamis obovatis villosis, nectario masculorum gemino, germinibus subsessilibus lanceolatis glabris, stigmatibus sessilibus bipartitis.-Hoffm. salic. 2. t.31. Engl. lot. 1937.

On road sides and about plantations. Introduced from

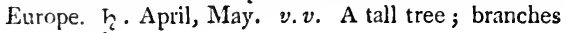
very brittle.

36. S. foliis elliptico-ovatis undique serrulatis utrinque glabris nitidis concoloribus, stipulis lanceolatis serratis, ramulis hirtis, amentis subpræcocibus erectis cylindricis, squamis lanceolato-oblongis longe villosis, germinibus ovato-lanceolatis sessilibus sericeis, stigmatibus subsessilibus bifidis.-Willd. sp. pl.4. p.678.

Icon. Fl. lapp.t. 8. f. f. t. 7.f.6. Fl. dan. 1054. Hoffm. salic. $t .18$.

In Labrador. $\zeta$. May. v. v. in Hort. Anderson.; v. s. in Herl. Lambert. A small straggling bush, not above a foot high ; branches purplish-yellow.

37. S. foliis orbiculatis subretusis serratis utrinque glabris niherbacea. tidis, stipulis nullis, amentis serotinis paucifloris, squamis obovatis obtusis villosis, germinibus oblongoovatis subsessilibus glabris, stigmatibus brevissimis subsessilibus.-Willd. $s p$. pl. 4. p. $6 \mathrm{~s} 2$.

Icon. Fl. dan. 117. Hoffm. salic. 1. t. 20. Fl. lapp. t. 8. f. h.t.7.f. 3. छ 4.

On the north-west coast. D. Nelson. 々. June, July.

amligua,

decipiens,

myrsinites, 
v. s. in Herl. Banks. The smallest of all the knowr species; the stems not above an inch bigh.

\section{POPUlUS. Gen. pl. 1531.}

Lalsamifera. 1. P. foliis ovatis acuminatis adpresso-serratis subtus albidis reticulato-venosis, gemmis resinosis. Willd. sp. pl. 4. p. 805.

Icon. Mich. arl. 3.p. 306. t. 13.f. 1. Duham. arb.ed. nov. 2. t. 50. Pall. fl. ross. 1. t.41. Wangh̆. amer. t. 28.f.59. Trew ehret. t. 46. bona.

In Canada, particularly plenty about Hudson's Bay. $h$. March. v. v. From seventy to eighty feet high; the young buds are covered with a very odoriferous balsam, from which it is called Ealsam Poplar; the natives call it Tacamahac.

candicans. 2. P. foliis cordatis ovatis acuminatis obtuse inæqualiter serratis subtus albidis subtriplinervibus reticulato-venosis, petiolis hirsutis, gemmis resinosis, ramis teretibus. Willı. sp. pl.4. p. 806 .

P. latifolia. Mroench. method.p. 338.

P. canadensis. Monch, weissenst. 81.

Icon. Catesb. car. 1. $t .34$.

In New England. $h_{2}$. March. $v . v$. From forty to fifty feet high; the buds are strongly covered with a balsamic fluid.

trepida.

3. P. foliis suborbiculatis abrupte acuminatis dentatis basi supra biglandulosis glabris, junioribus sericeis.-Willd. sp.pl. 4. p. 803.

P. tremuloides. Mich. $f$. amer. 2. p. 243.

Icon. Mich. arl.3.p. 285. t. 8.f. 1. Duham. arb. ed. nov. 2.t. 53.

In extensive swamps: Canada to Pensylvania. $h$. April. v. v. From twenty to thirty feet high. Generally known by the name of American Aspen Tree.

monilifera.

4. P. foliis subcordato-deltoidibus glabris basi glandulosis, serraturis cartilagineis hamatis pilosiusculis, nervis patulis, petiolis superne compressis, ramis adultis teretibus.-Willd. sp. pl.4. p. 805.

P. glandulosa. Miench. method. p. 339.

P. caroliniensis. Moench. weissenst. 81.

Icon. Mich. arl. p. 295. t. 10.f.2.

In North America. $h$. April. v. v. in Hortis. From sixty to seventy feet high. Michaux says that it has 
not been observed in any part of North America growing wild.

5. $\mathrm{P}$. foliis rhomboideis promisse acuminatis circumcirca

betulifolia. dentatis glabris, ramulis junioribus pilosis.

P. hudsonica. Mich. arb. 3. p. 293.t. 10.f. 1 .

P. nigra. Mich. fl. amer. 2. p. 244.

On the Hudson- or North-river, and about Lake Ontario. $h$. March. $v, v$. From thirty to forty feet high; petioles and young branches yellow.

6. P. foliis subrotundo-ovatis acutis inæqualiter sinuato- grandidentagrandi-clentatis glabris, junioribus villosis, petiolis su- $t a$. perne compressis.-Mich. fl. amer. 2. p. 243.

In Canada. $h$. April. v. v. From forty to fifty feet bigh.

7. P. foliis subrotundo-ovatis deltoideis acuminatis subcordatis inæqualiter serratis glabris basi glandulosis, petiolavigata'. lis compressis, ramis junioribus angulatis.-Willd. $s p$. pl. 4. p. 803.

P. canadensis. Mich. arb. 3. p. 29s. t. 11.

In high rocky situations: Canada to Virginia, and about the Western lakes. $h$. March. v.v. From seventy to eighty feet bigh. In Vi:ginia it is called Cotton Tree.

8. P. foliis ovato-deltoideis acuminatis obtuse uncinatodentatis glabris, junioribus amplissimis cordatis, ramis angulata. alato-angulosis.-Willd. sp.pl. 4.p. 805.

P. heterophylla. Du Roi harlk. 2. p. 150.

P. basamifera. Mill. dict. $n .5$.

Icon. Mich. arb. 3. p. 302. t. 12.

In morasses, on the banks of rivers : Virginia to Florida, and on the Mississippi. h. April. v. v. About eighty feet high; leaves very large; branches brittle. It is known by the name of Mississippi Cotton Tree.

9. P. foliis subrotundo-ovatis sinu parvo cordatis subauricu- heterophylla. latis obtusis uncinato-dentatis, junioribus tomentosis. Willd. sp.pl. 4.p. 806.

Icon. Mich, arb.3. p. 290. $t$ 9. Duham. arl. ed. nov. 2. t. 51 .

In swamps : New York to Carolina, and on the western rivers. h. May. v. v. About seventy or eighty feet high.' The leaves are on their base, properly speaking, more auriculated than cordated. 


\section{MYRICA. Gen. pl. 1510.}

Gale.

cerifera.

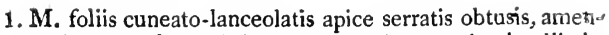
tis masculis imbricatis, squamis acuminatis cidiatis, fructibus squamoso-capitatis.-Willd. sp.pl.4. p.745. Icon. Fl. dan. 327 .

In boggy grounds in Canada, and about lakes on high mountains; plentifully on the Broad mountains, Pensylvania. $\eta$. May. v. v. A low shrub, like all the following, of an agreeable sweet scent.

2. M. foliis cuneato-lanceolatis apice rariter serratis acutis, amentis masculis laxis, squamis acutis, fructibus glo. bosis minoribus.-Willd. sp. pl. 4. p. 745 .

Icon. Catesb. car. 1.t.69. Pluk. alm. t. 48.f. 9 .

pumila.

ß. M. foliis lineari-lanceolatis, Mich. fl. amer. 2. p. 228.

In shady dry woods: Virginia to Carolina. $\beta$. In Carolina and Florida. h. May, June. v. v. A shrub sometimes more than twelve feet high. The berries of this and the following species produce a white vegetable wax, which the inhabitants manufacture into candles equal to those made of bees-wax.

saroliniensis. 3. M. foliis cuneato-oblongis grosse dentatis, anjentis masculis laxis, squamis acutis, baccis globosis majoribus. - Willd.sp.pl. 4.p. 746.

M. cerifera $\beta$. Mich. fl. amer. 2. p. 223.

Icon. Catesl. car. 1. p. 13.

In wet places about rivers and swamps: New England to Florida. $h$. May. v. $v$. Not above three or four feet high.

pensylvanica. 4. M. foliis oblongis utrinque acutiusculis integerrimis aut apice rariter subserratis margine revolutis, amentis masculis laxis, squamis acutis, baccis globosis majusculis.-Lam. encycl. 2. p. 592 .

Icon. Duham. arb. ed. nov. 2. t. 55.

In shady rocky situations: New Jersey and Pensylvania. h. May. v. v. Not above three feet high. It generally is confounded with the preceding, but is a very distinct species.

694. BETULA. Gen. pl. 1419.

populifolia. 1. B. foliis deltoidibus longe acuminatis inæqualiter serratis glaberrimis, strobilorum squamis lobis lateralibus subro. tundis, petiolis glabris. Willd.sp.pl.4. p. 463 . 
B. acuminata. Ehrh. beitr. 6. p. 98.

B. lenta. Du Rni harbk. 1. p. 92. Wangh. amer. p. 45. t. $29 . f .38$.

Icon. Mich. arb. 2. p. 139. t. 2. Willd. arb.t.2.f.5.

In barren rocky woodi and old fields: Canada to Pensylvania. h. June, July. v. v. From thirty to forty teet higis. It is hnown by the name of White Birch or Old Field Birch.

2. B. foliis oratis acutis serratis, petiolis pubescentibus pe-

excelsa. duncuir brevioribus, strobilorum squamis lobis lateralibus rotundatis. Willd. sp. pl.4.p. 463.

B. lutea. Mich. arb. 2.p 152 .

Icon. Mich. l.c. t. 5. Willd. arb. t. 2. f. 2.

In low grounds : province of Maine, Hudson's river. $h$. May, June. $v, v$ From seventy to eighty feet high; generaily called Yellow Birch.

3. B. foliis rhombeo-ovatis duplicato-serratis acutis subtus pubescentibus, basi integris, amentis femineis ovatis, squamis villosis, laciniis linearibus æqualibus. - Willd. sp.pl. 4.p. 464 .

B. lanulosa. Mich. fl. amer. 2. p. 181.

B. rubra. Mich. arl. 2. p. 142.

Icon. Mich. l.c.t. 3. Willd. arb. t. 2.f. 6.

On the banks of rivers: New Jersey to Carolina. $h$. May. $v . v$. About seventy feet high when full grown; the wood very fine. It is generally called Red Birch.

4. B foliis ovatis acuminatis dup'icato-serratis, venis subtus hirsutis, petiolo glabro, amentis femineis pedunculatis nutantibus, squamis lobis lateralibus brevibus suborbiculatis.-Willd.sp.pl. 4. p. 464.

B. papyrifera. Mich. fl. amer. 2.p. 180.

Icon. Mich. arb. 2. p. 133. t. 1. Willd. arb. t. 2.f.1.

In the forests of Canada to a great northern latitude, and as far south as the Hudson's river. h. May, June. $v . v$. A large tree, highly useful to the natives for constructing their large portable canoes, from which circumstance it is known by the name of Canoe Birch.

5. B. foliis cordato-ovatis argute serratis acuminatis, nervis papyracea. nigra. subtus petiolisque pilosis, strobilorum squamis glabris, lobis obtusis æqualibus elevato-venosis.-Willd. sp. pl.4. 464 .

B. carpinifolia. Ehrh, beitr. 6. p. 99 . 


\section{B. nigra. Du Roi harlk. 1. p. 93. Wangh. amer. t. 15.} f. 34 .

Icon. Mich. arb. 2. p. 145. t. 4.

In Canada and throughout the Allegany mountains, to their termination in Georgia. h. May, June. v. v. This elegant and large tree is the most interesting of this genus, on account of the excelience of its wood. It is known by the name of Mountain Mahogany, Black Birch, Cherry Birch, and Su'eet Birch. This last appellation it has from the sweet scent the branchlets give when bruised.

pumila.

6. B. ramis pubescentibus impunctatis, foliis orbiculatoobovatis petiolatis subtus dense pubescentibus, amentis femineis cylindricis.-Willd. sp.pl.4.p. 467 .

B. nana. Kalmitin. 2. p. 263.

Icon. Jaeq. hort. vind. $t$. 122. Du Roi harlk.1.t.3. Wangh. amer. $t .29 \cdot f .61$.

In bogs of Canada, and on high mountains of New York and Pensylvania. h. May, June. v. v. A low shrub, not above two or three feet high.

glandulosa. 7. B. ramis glanduloso-punctatis glabris, foliis obovatis serratis basi integerrimis glabris subsessilibus, amentis femineis oblongis, squamis semitrifidis, seninibus orbiculatis angusto-marginatis.-Willd. sp. pl. 4. p. 466 .

In Canada, about Hudson's liay, and on the oorders of lakes on the high mountains of New Jersey and Pen. sylvania. $h$. May. $v . v$. A handsome little shrub, not above two feet high.

nana.

8. B. humillima, glaberrima; foliis orbiculatis crenatis subtus reticulato-venosis, amenti squamis profunde 3-partitis, laciniis obl.ngis, seminibus orbiculatis subapteris.-Willd. sp. pl. 4. p. 465.

Icon. Amon. acad. 1.t. 1. Fl. dan. 91. Pall.fl. ross. 1. t. 40. Amman. act. 9.t. 14.

In splagnous swainps about Hudson's Bay and other parts of Canada. $\vdash$. April, May. v. s. in Herb. Lamlert.

6g5. ALNUS. Willd.sp.pl.4.p.331.

Betula. Gen.pl. 1419.

glutinosa. 1. A. foliis subroturdo-cuneatis obtusis subretusis glutinosis, axillis venarum subtus villosis. Willd. sp. pl. 4. p. 334 . 
Betula Alnus. Sp. pl. 1394.

Icon. Engl. bot. 1508. Los. pruss.t. 1.

On the banks of rivers, in the interior of Canada, and on the north-west coast. $h$. April. $v \cdot v$. A large tree, known every where under the name of Alder.

2. A. foliis oblongis acutis basi rotundatis duplicato-serratis, petiolis venisque subtus pilosis, axillis venarum nudis, stipulis ovato-oblongis.

A. undulata. Willd. sp.pl.4. p.336.

Betula Alnus crispa. Mich. fl. amer. 2. p. 181.

Betula crispa. Ait. kew. 3. p. 339.

In Canada and on high mountains, in sphagnous swamps, of Pensylvania. $h$. April. $v \cdot v$. A shrub not above three or four feet high.

3. A. foliis obovatis acuminatis venis et axillis venarum subtus pilosis, stipu is ellipticis obtusis. Willd. sp. pl. 4. p. 336.

Betula serrulata. Ait. kew 3.p. 333.

Betula rugosa. Ehrh. bettr. 3. p. 21.

Icon. Altot. insect. 2.t.92 Wangh amer.

In swamps and on river sides. comnon every where. h. March. v. $v$. A shrub trom six to ten feet high, growing in close thickets.

696. CARPINUS. Gen.pl. 1449.

1. C. foliis oblongo-ovatis acuminatis inæqualiter serratis, strobilorum squamis tripartitis, lacinia intermedia obliqua ovato-lanceolata uno latere dentata.-W Wlld. $s p$. pl.4. p. +68 .

C. virginiana. Mich arb. 3. t. 8.

In shady woods and hedges: Canada to Florida. $\zeta$. May. $v . v$. This specrs of Hornleam resembles the European very much, and it's wood is of the same qualities: it rives to about fitieen feet high.

\section{OSTRYA. Nich. gen. 223.}

1. O. foliis ovato-oblongis basi subcordatis acuminatis inæqualiter serratis. strobilis oblongo-ovatis erectis, gemivirginica. nis acutis.--IVilld. sp. pl. 4. p. 469

Carpinus virginiana. Ait. kew. 3. p. 363.

Icon. Albot. insect. 2. p. 151.t. 75. Pluk. alm. t. 156. f. 1 .

In shady woods : New England to Caroina. 々. May.

americana. 
$v . v$. A small tree, of exceeding hard and heavy wood, from which it is generally known under the name of Iron-wood; in some parts they call it Leverwood. I observed a variety in Pensylvania, of which the younger branches were covered with glandulous hairs. It is rather singular to observe that the plate in Mich. arb. 3.t.7. intended for the present plant, represents Ostrya vulgaris with hanging cones, which is never the case in the American species.

\section{FAGUS. Gen. $p l .1448$.}

sylvatica.

ferruginea.

1. F. foliis ovatis acuminatis leviter dentatis margine ciliatis basi acutis, nucibus ovato-triquetris obtusis cum mucrone.-Willd. sp. pl. 4. p. 459. Mich. arb. 2. p. 170 .

Icon. Mich. l. c. t. 8.

In extensive forests : New Hampshire to Georgia. $\zeta$. May. $v . v$. This species of beech forms those extensive and beantiful woods generally known by the name of Beech-woods, and always gives the indication of a fertile soil. It is distinguished by the name of White Beech from the following.

2. F. foliis ovato-oblongis acuminatis subtus pubescentibus grosse dentatis basi obtusis subcordato-inæqualibus, nucibus acute ovato-triquetris acutissimis. - Willd. $s p$. pl. 4.p. 460 .

Icon. Mich. arb. 2. p. 174.t.9. Abbot, insect. 2. t. 75. In rich level lands, at the foot of mountains : Canada to New England. 々. May, June. $v . v$. It is distinguished by the inhabitants by the name of Red Beech, the wood being of a darker colour than the preceding. Both species are highly useful timber trees.

\section{CASTANEA. Tournef. inst. t.352.}

vesca : americana.

1. C. foliis lanceolatis acuminatis mucronato-serratis utrinque glabris. -Willd. sp. pl.4. p. 460.

Fagus Castanea. Hort. cliff. 447.

Icon. Mich. arl. 2. p. 156.t. 6 .

In the mountainous parts: New England to Carolina. h. May, June. v. v. The American Chesnut differs so little from the European, that no specific distinction can be drawn. 'It is one of the largest and 
most useful trees of the forests, the wood being extremely durable, and in high esteem for posts and rails to construct fences. The nuts are very delicious.

2. C. foliis oblongis acutis nucronato-serratis subtus albotomentosis - Willd. sp.pl. 4.p. 461 .

Fagus pumila. Sp. pl. 1418 .

Icon. Mich. arb.2. p. 166. t.7. Wangh. amer.t. 19. f. 44. Allot. insect. t. 57. Catesb. car. 1. t. 9. Pluk. alm, t. 156.f. 2 .

In dry barren and sandy fields and woods: New Jersey to Georgia. b. May, June. v. v. This small tree, or rather shrub, grows to the height of thirty feet and upwards in the southern regions, but to the north it seldom exceeds seven or eight feet. The fruit is very sweet and agreeable to eat, and is generally known by the nane of Chinquapin.

\section{QUERCUS. Gen. pl. 1446.}

* Fructificatio biennis; fructibus subsessilibus; foliis setaceo. mucronatis. (in specie 1. muticis.)

\section{+ Foliis integerrimis.}

1. Q. foliis deciduis lineari-lanceolatis utrimpue attenuatis integerrimis glabris mucronatis, cupula scutelląta, glande subrotunda.-Willd.sp. pl.4.p. 423.

Q. Phellos sylvatica. Mich. querc. $n .7$.

Icon. Mich.l. c. t. 12. Mich. arb.2. 1. 12. Catesl. car. 1. t. 16. Ablot. insect.2.t.91. Wangh. amer. t. 5.f.11. Pluk. amalth.t. $441 . f .7$.

B. Q. foliis brevioribus. Catesb. car. 1. t. 22. Wangh. amer. t. 5.f. 12.

In low swampy forests, near the sea-coast: New Jersey to Florida. $々$. May. v. v. The Willow Oak grows to the height of about fifty or sixty feet. The young leaves are dentated. The variety $\beta$. is of low straggling growth.

2. Q. foliis perennantibus coriaceis lanceolatis integerrimis glabris basi attenuatis, apice acutis inucronatis, cupula scutellata, glande subroturda.-Willd. sp. pl. 4. p 424.

Q. Phellos maritima. Mich. querc. t. 13.f. 1.

On the sea-coast of Virginia and Carolina. $\eta$. May, June. $v . v$. A low shrubby species, from three to eight feet high. 
sericea.

myrtifolia.

virens.

cinerca.
3. Q. foliis deciduis lanceolato-oblongis integerrimis subundatis basi at ienuatis obtusis, apice dilatatis acutis subtus sericeis, cupula scutellata, giande subglobosa.-Willd. sp. pl. 4. p. 424.

Q. Phellos pumila. Mich. querc.t. 13.f. 1. E 2.

Q. I'hellos sericea. Ait. kew. 3. p. 35.1. Abbot. insect. 2. t. 51 .

Q. punila. Mich. arb. 2. p.84.t.15. Walt. $A$ car. 234.

Near the sea-cnast: Carolina to Florida. h. May. v.v. The Running Oak is perhaps the smallest of all the species, scarcely ever exceeding two feet in height.

4. Q. foliis peremantibus coriaceis oblongis integerrimis glabris utrinque acutis supra nitidis margine revolntis. - Willd. sp. pl. 4.p. 424.

In Carolina. Willdenow. $\vdash .+$. Leaves resemble those of Myrtus communis with large leaves; the fruit is not known.

5. Q. foliis perennantibus coriaceis oblongo-ellipticis integerrimis margine revolutis basi obtusis apice acutis muticis subtus stellatim pubescentibus, fructibus pedunculatis, cupula turbinala, squamis abbreviatis, glande oblonga - Willd. sp.pl.4. p. 425.

Q. Phellos B. $S p$. pl. $1+12$.

Q. sempervirens Walt fl. car. 234.

Icon. Mikh.querc. t. 10. E11. Mich.arb.t.11. Catesb. car. 1.t. 16 .

Near the sea-coast: Virginia to Floricla and Mississippi. h. May. v. v. The Live Oak grows to the height of forty or fifty feet, spreading its branches, when in open places, extremely wide: it yields the finest and nost durable ship-timber of any species known; for which reason it is considered one of the most valua. ble trees in America.

6. Q. foliis perennantibus coriaceis lanceolato-oblongis integerrimis margine revolutis basi attennatis apice obfusiusculis mucronatis subtus stellatim tomentosis, fruc.. tibus sessilibus, cupnla scutellata, glande subglubosa. -Willd. $s p$ pl. 4. p. 425.

Q. Phellos B. Ait. kew. 3. p. 354 .

Q. humilis. Walt. fl. car. 234.

Icon. Mích. querc. u. 8. t. 14. Mich. arb. 2. p. so. t. 14.

In dry barren soil and pine-forests : Virginia to Georgia. $\eta$. May, June. v. v. The Upland Willow Oak is 
vary variable in size, sometimes not above four feet, at others nearly twenty feet high. The younger Michaux considers Q. nana of Willdenow to be only a variety of the present species; which I very much doubt.

7. Q. foliis deciduis oblongis utrinģue acutis mucronatis integerrimis nitidis subtus pubescentibus, cupula scutellata: squanis lato-ovatis, glande subglobosa.Willd. sp. pl. 4. p. 428.

Icon. Mich. querc. n. 9.t. 15. E' 16. Mich. arl.2. p. $78 . t .13$.

On the banks of rivers, within the Allegany mountains, and in the western countries thereof. $\zeta$. May, June. $v$. v. The Shingle Oak rises to abont forty or fifty feet. The younger Michaux considers the wood of this - species of little value.

8. $\boldsymbol{Q}$. foliis deciduis obovato-lanceolatis acutis basi attenuatis integerrimis utrinque glabris, cupula scutellata: squamis lanceolatis, glande subovata.-Willd. $s p$. pl. 4.p. 427 .

Icon. Nich. querc. n. 10.t. 17.

E. Q. foliis apice obtusis. Mich. querc. t. 18.

In South Carolina and Georgia. b. May. v. v. The

imlricaria. Laurel Oula, or as it is sometimes called SwamplWillow $\mathrm{Oak}$, is about fifty or sixty feet high: its wood, according to the elder Michanx, is very valuable, and almost preferable to that of $Q$. virens. For what reason the yuunger Michaux does not mention this species, I cannot teil, unless he considers it only a variety of the preceding; which nost ccrtainly is not the case.

什 Fulizs dentatis aut lreviter lobatis.

9. $Q$. foliis subrotundo-ovatis subcordatis utrinque glabris remote spinoso-dentatis, cupula hemisphærica : squalaurifolia. obtusa. mis laxis, glande ovata acuta.-Willd. sp. $p l .4$. p. 431 .

Icon. Pluk. phytogr. $t, 196 . f .3$ ?

On the north-west coast, about Nootka Sound. Nee. h. + .

10. Q. foliis longe petiolatis ovato-lanceolatis oblongisve in- heterophylla. tegris vel inæqualiter grandidentatis, cupula hemisphærica, glande subglobosa.-- Mich arl. 2. p.87.

Icon. Mich. l. c. t. 16.

On the banks of the Delaware, Pensylvania. $\eta$. May. v. $v$. Of this singular species there is but one indivi. 
dual known, which grows on the plantation of the Messrs. Bartrams near Philadelphia. It probably is oniy a bybrid plant on that account, and cannot with propriety he considered a genuine species : but the younger Michaux having given a good figure of it, I insert it here on that account only.

aquatica. 11. Q. foliis ohovato-cuneiformibus glabris integerrimis apice obsolete trilobis, lobo intermedio majore, cupula hemisplærica, glande subglobosa.-Willd. sp. pl. 4. p. 441 .

Q. nigra. Sp. pl. 1413.

Q. uliginosa. Wangh. amer.t.6.f. 18.

Icon. Mich. quers. n. 11.t.19.t. 20. f.1.3.4.5. E t. 21 . Nich. arb. 2.p.89.t. 17 .

In swamps: $M$ aryland to Florida. $\zeta$. May, $v . v$. The Water $O a k$ is about forty feet high when full grown ; its wood is but little valued. Its leaves vary, according to soil and age, ad infinitum. There is scarcely one tree found having leaves like the other, and the same tree is almost as variable in its different branches.

hemisphari- 12. Q. foliis perennantibus oblongo-lanceolatis indivisis trica. lobis sinuatisque, lobis mucronatis, utrinque glabris. Willd.sp.pl.4. p. 443. Burtr. itin. 320.

Icon. Mich. querc. t. 20. $f .2$.

In Georgia and Florida. h. May. y. v. s. This is probably nothing more than a young, plant of $Q$. aquatica, which is so very apt to vary in its foliage.

nana.

13. $Q$. foliis cuneiformibus glabris apice trilobis basi subsinuatis, lobis divaricatis mucronatis intermedio majore, axillis venarum subtus pubescentibus, cupula scutellata, glande ovato-subglobosa.-Willd. sp. pl. 4. p. 443 .

Q. aquatica elongata. Ait.kew. 3.p.357.

Icon. Ablot. insect. 2. t. 59.

In pine-barrens of South Carolina. $々$. May. v. v. $s$. fr. A low-growing species, always keeping distinct from Q. aquatica.

triloba. 14. Q. foliis oblongis cuneiformibus basi acutis, apice subtrilobis, lobis æqualibus mucronatis, intermedio longiore, subtus tomentosis, cupula scutellata, glande depresso-glohosa.-Willd. sp.pl.4.p. 443.

Q. cuneata. Wangh. amer.p. 78. t. 5.f. 14.

Icon. Mich.querc. n. 14. t.26. Allot. insect. 1. t. 50? In pine-barrens, near the sea.coast : New Jersey to Geor- 
gia. h. May. v. v. The Downy Black Oak is from twenty to forty feet high, according to Michaux, of very rapid growth, and extremely well calculated for inclosing of lands.

15. Q. foliis coriaceis cuneiformibus basi subcordatis, apice dilatatis retuso-subtrilobis, junioribus mucronatis, supra glabris, subtus rubiginoso-pulverulentis, cuno? turbinata: squamis obtusis scariosis, glande bres ovata.-Willd. sp. pl. 4. p. 442.

Q. nigra $\beta$. Sp. pl.1413.

Q. ferruginea. Wich. arb.2. p. 92 .

Icon. Mich. querc. n. 12. t. 22. 23. Mich. arb.t. 18. Catesb. car. 1. t. 19. Wangh. amer. t. 5.f. 13. Allbot. insect. $t .58$.

In barren sandy or gravelly woorls : New Jersey to Flo. rida. $h$. May. v. v. The Barren Oak or Black

Jack of the Virginians is of low growth, especially in the more northern states: it bears very abundantly and furnishes a fine mast for hogs : the wood is small, but excellent for fuel.

16. Q. foliis obovato-oblongis levissime sinuatis subtus pubescentibus, lobis oblongis obtusis obsolete denticulatis setaceo-mucronatis, cupula scutellata, glande depresso-globosa.-Willd. sp. pl. 4.p. 444.

Q. tinctoria angulosa. Nich. querc, n. 13. t. 24 .

Q. discolor. Willd. nov. act. soc. nat. sc, ut. berol.3. p. 399 .

Q. velutina. Lam. encycl. 1. p. 173

In all large woods, particularly in the mountainous parts : New England to Georgia. $h$. May. v. v. The Black Oak, or Quercitron, is one of the largest trees of the American forest, and highly valuable on account of its tirrber as well as its bark, which is so very superior in tanning to any other species of oak.

17. Q. foliis oblongis pinnatifido-sinuatis subtus pubescentibus, lobis oblongis dentatis setaceo-mucronatis, cu. pula turbinata, glande ovata.-Willd. sp. pl. 4. p. 444.

Q. tinctoria sinuosa. Mich. querc. n. 13. t. 25.

Icon. Abbot. insect. 2. p. 111 . ङ 56. Pluk. alm. t. 54. f. 5 .

In large forests: Pensylvania to Carolina. $h$. May. $v: v$. Resembles the preceding, and likewise $Q$. coc. cinea. The young expanding leaves are covered with 
a white down on both sides, which is not the case with either $Q$. rubra or $Q$. coccinea. Whether the figure of Q. tinctoria Mich. arl.2. t.22. belongs to this or the preceding species, I have not been able to decide.

t† Foliis profunde sinuatis lobatisque.

coccinea. 18. $\mathbf{Q}$. foliis longe petiolatis oblongis profunde sinuatis glabris, lobis divaricatis dentatis acutis setaceo-mucronatis, cupula turbinata insigniter squamosa, glande breviovata.-Willd.sp. pl. 4.p. 446.

Jcon. Mich. querc. n. 18. t.31.32. Mich. arb.2.p. 116. t.23. Wangh. amer. t. 4.f.9.

In fertile woods: New England to Georgia. $\zeta$. May. $v . v$. The Scarlet Oak is a very large tree, and changes its leaves in autumn to a bright red, which give the woods a very picturesque appearance.

amligua. 19. Q. foliis sinuatis glabris basi acutis, sinubus subacutis, cupula subscutellata, glande turgide ovata.-Mich. a) l. 2. p. 120.

Icon. Mich.l. c.t.24.

On Hudson's Bay and in Nova Scotia. Michanx. $h$. May. + . This is an intermediate species, between the preceding and following one, and probably only a hybrid plant. Michaux calls it Gray Oak.

rulra.

20. Q. foliis longe petiolatis oblongis glabris obtuse sinuatis, lobis acutiusculis dentatis setaceo-mucronatis, cupula scutellata sublævi, glande subovata turgida.-Willd. sp.pl. 4. p. 445.

Icon. Mich. querc. n. 20, t.35. 36. Mich. arl.2. p. 126. t. 26. Wangh. amer.t.3.f.7. Pluk.alm. t.54.f.4. Du Rni harlk. 2. t. 5. f.2.

In fertile forests: Canada to Pensylvania, and in the Allegany mountains. $\eta$. May. $v . v$. This large and fine timber tree is exclusively known by the name of Red Oak, which name is likewise applied to $Q$. tinctoria, coccinea, falcata, palustris, phellos, amligua, and aquatica, in several parts of America.

Cateslai. 21. Q. foliis brevissime petiolatis basi cuneatis oblongis profunde sinuatis glabris, lobis tribus quinisve divaricatis dentatis acntis setaceo-mucronatis, cupula turbinata ampla : squamis obtusis marginalibus introflexis, glande subglobosa.-Willd.sp. pl. $4 . p .446$.

Icon. Mich. querc.n.17.t.29.30. Mich.arl.2, p.101. t. 20. Catesb. car, 1.t.23. 
In pine-barrens: Carolina and Georgia. দ. May. v.v. The Barren Strut Ouk is of hrubby growth, not above fifteen feet high, and occurs in the most sterile soil of those countres in great abundance.

22. Q. foliis longe petiolatis basi obtusis subtus tomentosis trilobis sinnative, lobis subfalcatis setaceo-mucronatis, terminali eloncat, cupula crateriformi, giande globosa.-Mich. fl. imer. 2. p. 199.

Q. elongata. Will.l. sp.pl. 4.p. 444 .

Icon. Mich. querc. n. 16. t. 28. Mich. arl. 2. p. 104. t. 21 .

In sandy soil, near the sea-coast : New Jersey to Georgia. h. May. $v . v$. A very large tree, commonly called Spanisli Oak. In the southern states it is known by the name of Red Oak.

23. $Q$. foliis longe petiolatis oblongis profunde sinuatis glabris, axillis venarum subtus villosis, lobis divaricatis dentatis acutis setaceo-murronatis, cupula scutellata lævi, glande subglobosa.-Willd.sp. pl.4. p. 4.46.

Icon. Mich. quere. n. 19. t.33.34. Mich. arl. 2. p. 123. t.25. Du Roi harlk. 2. t. 5.f.4. Wangh. amer. t.5. f. 10.

In low swampy woods: New England to Pensylvania, and in Ill!nois. h. May. v. v. The Swamp Spanish Oak or Pin Oak is a large tree; leaves rather small and handsomely divided; the acorns small, and generally in great abundance.

24. Q. foliis longe petiolatis obovato-cuneiformibus tri-quinquelobisve margine integerrimis subtus cinereo-tomentosis, Jobis setaceo mucronatis, cupula subturbinata, glande subglobosa.-Mich. l. amer. 2.p. 199.

Q. ilicifolia. Willd.sp. pl. 4. p. 447. Wangh. amer. 79. t. $6 . f .17$.

Icon. Mich. querc. n. 15. t. 27. Mich. arl.2.p. 96. t. 19. Albot. insect. 2. t.79?

In dry barren fields and on the mountains: New Jersey to Virginia. $\eta$. May. $v$. $v$. This shrub, about four or six feet high, covers large tracts of ground wherever it occurs, called Oak-barrens : it is known by the name of Bear Oak, Black Scrul Oak, and Dwarf Red Oak.

palustris,

Bunisteri.

falcala.

palustris, 


\section{** Fiuctificatio annua; fructilus pedınculatis; foliis muticis.}

oltusiloba.

\section{+ Foliis lol atis.}

25. Q. follis oblongis sinuatis basi cuneatis stibtus pubescentibus, lobis obtusis superioribus uilatatis bilobis, cupula hemispharica, glande ovali.-Mich. fl. amer. 2. p. 194.

Q. stellata. Willd. sp pl.4.p.452. Wangh. amer. 78. t. 6.f. 15.

Icon. Mich.querc. n. 1.t. 1. Mich. art, 2. t. 4.

In most forests: Canada to Florida. h. May. v. $v$. The Upland While Oak or Iion Oak is a spreading tree about fifty or sixty feet high; its timber is of great value in ship-building.

macrocarpa. 26. $Q$. foliis subtus tomentosis profunce lyratim sinuatolobatis, lobis obtusis repandis, superioribus dilatatis, cupula craterata; squamis superioribus setosis, glande turgide ovata.--lVilld. sp. pl. 4. p. 4:3.

Jcon. Nich. querc. n. 2. t. 2. छ' 3. Mich.arl.2.t.3.

Within the mountains, on dry slate or lime-stone hills: Kentucky, Tennassee, Illinois, Mississippi, and Missouri. $\hbar_{\imath}$. May. v. $v$. A large tree, called Overcup White Oak by the inhabitants; the fruit is the largest of the American species; the wood very excellent.

alive formis. $27 . \mathrm{Q}$. foliis oblongis glabris subtus glaucis profunde inæqualiter simuto-pinuatifidis, fructu elliptico-ovato, cupula profunde craterata superne crinita, glande elliptico. ovali.-Mich. art. 2. p. 32.

Icon. Mich. arb. 2. t. 2 .

On the banks of Hudson's river and the western parts of New York. Michaux In Pensylvania and Virginia, on iron-ore hills. Ph. $h$. Mav. $v . v$. The Mossy-cup Oak is a large tree; the foliage handsome, and somewhat resembling the preceding species.

lyrata. 28. Q. foliis brevissime petiolatis glabris ly rato-sinuatis sum. mitate dilatatis, lobis oblongis acutis superioribus angulato-truncatis, cupula depresso-globosa tubercuJoso-muricata glande globosa subtecta.-Willd. sp. pll. 4. p. 453. Walt. fl.car. 235.

Icon. Mich. querc. n. 3. t. 4. Mich. arb. 2. p. 42.t.5. In swamps : Carolina to Florida, and on the Mississippi. h. May. v.s. This oak is from eight to fifteen feet 
high, and known under the names Over-cup Oak, Su'ump-post Oak, and Water White Oak. The truit is almost entirely covered with the cupula or calyx.

29. $\mathbf{Q}$. foliis oblong is pinnatifido-sinuatis subtus pubescentibus, lobis lineari-lanceolatis obtusis intererimis basi alla. attenuatis, fiuctibus pedunculatis, cupula subcraterata tuberculosa, basi plána, glande ovata.-IVilld. $s p$. pl. 4. p. 449 .

Icon. Mich querc. n. 4.t. 5. Mich. arb. 2. p. 13.t. 1. Du Roi hurbk. 2. t. 5.f.5. Wangh. amer. t. 3.f. 6 . Catest. car. 1. ᄂ.21.f. 2.

ß. Q. toliis levissime lobatis utrinque viridibus. Mich. l. $c$. t. 5.f. 2.

In tertile forests: New England to Carolina. $\beta$. Pensylvania and Carolina. $\eta$. May. v. $v$. The th hite Ouk is one of the most abundant and useful of this genus in America; it grows in the middle states to an immense size.

\section{十卜 Foliis integris, dentatis.}

30. Q. foliis longe petiolatis obovatis acutis subtus pubcecen-

Prinus. tibus grosse dentatis, dentibus subæṛualibus dilatatis apice callosis, cupula craterata basi attenuata, glande ovata.W - vlld. sp.pl.4. p. 439 .

Q. Prinus palustris. Mich. fl. amer. 2. p. 195.

Icon. Mich. querc. n. 5. t. G. Mich. arb. 2. t.7. Du Roi harlk. 2. t. 6. f. 3. Wangh. amer. t. 4. f. 8. Catesb. car. 1.t. 18. Pluk. alm. t. 5. f. 3.

In low shady woods and on the banks of rivers: Pensyl. vania to Florida. h. May. v. v. This large and useful tree is known by the name of Chesnut IVhite Oak, Swamp Chesnut Oak, and, to the south, White Oak. The fruit is large, and of a sweet taste.

31. Q. foliis brevi-petiolatis oblongo-obovatis subtus albo. tomentosis grosse dentatis basi integerrimis, dentibus inæqualibus dilatatis acutiusculis apice callosis, fructibus geminis longe pedunculatis, pedunculo in setam terminante, cupula hemisphærica, glande oblongo. ovata.-Willd. sp. pl. 4. p. 440.

Q. Prinus tomentosa. Mich. querc. n. 5.t. $9 . f .2$.

Q. Prinus discolor. Mich. arb. 2. p. 46.t.6.

In low wet woods: Pensylvania to Carolina. $々$. May. v. v. The Swamp White Oak grows to a very large tree; the acorn, as of most of the chesnut oaks, is șweet. 
montona. 32. Q. foliis modice petiolatis lato-obovaris cblongis subtus albo-tomentosis supra nitidis grosee dentatis basi obtusis inequalibus, deutibus subrequalibus obtusissimis brevibus, fructibus geminis breri-pedunculatis, cupula henisphærica, squamis tuberculatis rugosis, glande ovata.-Willd sp.pl.4.p 44!).

Q. Prinus monticola. Mich. Al. amer. 2. p. 196.

Icon. Mich. quere. n. 5, t.7. Mach. arb. 2. t. s. Altot. insect. 2. t. 82.

In rocky situations on the mountains: New Fngland to Carolina. h. May. $v . v$. The Rock Chesnut Oak rises to about sixty feet; its timber is in high value, and its bark tans extremely well.

Caslanea. 33. Q foliis longe petiolatis oblongo lanceolatis basi obtusis acuminatis subtus tomentosis grosse dentatis, dentibus subrequalibus dilatatis acutis apice callosis, cupula hemispliærica, glatsde ovato-subglobosa.-Wilid. $s p$. pl. 4.p. 441.

Q. Prinus acuminata, Mich. fl. amer. 2. p. 196.

Icon. Mich. querc. n. 5. t. 8. Mich. arl. 2. p.61.t.9. In the Allegany mountains and on the banks of the Delaware. $h$. May. v. $v$. The Yellow $O$ ak is a beautiful and large tree; the acorns are eatable.

Chinquafin. 34. Q. foliis brevi-petiolatis obovatis basi acutis grosse dentatis subtus glaucis, dentibus subæqualibus dilatatis apice callosis, cupula hemisphærica, glande ovata.

Q. Prinus Chinquapin. Mich. arl. 2. p.65.

Q. prinoides. Willd. sp. pl.4. p. 440.

Icon. Mich. querc. n. 5. t. 9.f. 1. Mich. aru. 2. t, 10. lona.

On dry mountain lands: Pensylvania to Carolina. $\zeta$. May. v. v. The Chinquapin or Durarf Chesnut Oak is a low-growing shrub, not exceeding three or four feet in height; it is highly ornameutal when in full bloom.

\section{CORYLUS. Gen.pl. 1450.}

americana. 1. C. foliis subrotundis cordatis acuminatis, calycibus fructus subrotundo-campanulatis nuce subglobosa majoribus, limbo dilatato dentato-serrato.-Willd. sp. pl. 4. p. 471 .

Icon. Wangh. amer, t. 29.f. 63.

In low shady woods : Canada to Florida. $h$. Marcb, April. v.v. The Hazel Nut or Wild Fillert is a shrub from four to eight feet high; the nuts very fine. 
2. C. foliis oblongo-ovatis acuminatis, stipulis lineari-lanrostrala. ceolatis, calycibus fructu, campanulato tubulosis nuce majoribus biputitis, laciniis inciso-dentatis. Willd. sp. $p l .+p .471$.

Icon. illd arl. t. 1.f. 2.

In the mountains: Canada to Carolina. $々$. April. v. $v$. This species is not above four or tive feet high.

\section{LIQUIDAMBAR. Gen.pl. 1452.}

1. I. foliis palnat:s, lobis acuminatis, serratis, sinubus bascos venarum vilusis. - W'illd.sp. pl. t. p. 475.

Icon. Nich arl 3. p. 194. t. 4.

In lor woods, on fertile soil : New England to Florida, and in all the western countries. h. May. $v . v$. The Surect.gum Tree is sometimes found of an immense cize, purticularly in the southern states; its wood is of an exquinite bard rexture and fine grain, and furmiture made of it has a very handsome appearance.

\section{COMPTONIA. Gen. pl. 1764.}

1. C. foliis longo-linearibus alternatim crenato-pinnatifidis. -Willd.sp. pl. 4 p. 320.

Liquidambar peregrinum. Syst. reg. $\$ 60$.

Liquidambar asplenifo'ium. Sp. pl. $1+18$.

Icon. Pluk. alm. t. 100. f. 6 .

In sandy, stony, or shaty won's: New England to Virginia. h. March, April. v. $v$. The Sicect-fern Bush rises to about three or four feet high; the whole of the plant when rubbed has a strong resinous scent.

\section{PLATANUS. Gen. pl. 1451.}

1. P. foliis quinquang!naribus obsoiete lobatis dentatis, ramulis albentibus. - Willd. sp. pl. 4. p. 47.4.

Icon. Catesl. car. 1. t.56. Duham arb. t.35. Mirh. arb.3. t. 3.

On the banks of rivers : Canada to Florida, and in Louisiana. h. May. $v . v$. 'This tree is known by the name of Button-wood, WVater Beech, Sycamore and Plane Tree; in Canada Colton Tree. It is perhaps the largest tree in North America : on the fertile banks of the Ohio and the Mississippi there are trees measuring from ten to sixteen feet in diameter.

occidentali.

asplenifolia. slyracifua.

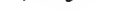


705. JUGLANS. Gen. $p l .1446$.

* Amentis masculis simplicilus, polyandris: Walnuts.

xigra.

1. J. foliolis numerosis ovato-lanceolatis serratis subcordatis superne angustatis, subtus petiolisque subpubescentikus, fructibus globosis scabro punctatis, nuce corrugata.-Willd. sp.pl. 4. p. 456.

Icon. Mich. arb. 1. p. 157.t. 1. Jacq. ic. rar. 1.t. 191. IV angh. amer.t. 8 f 20 . Catest. car. 1. t.67.

In fertile woods: New England to Florida. $h$. A pril, May. $v . v$. The Bluck Walnut is, like all the following, a tree of large size, and its nuts are eaten by men and several species of animals. The wood is put to various mechanical and ceconomical uses; for which information I reter to the different authors on forest trees, but particularly to the works of the younger Michaux.

cinerea. 2. J. foliolis numerosis lanceolatis serratis basi rotundatia subtus pubescenti-mollibus, petiolis villosis, fructibus oblongo-ovatis apice mammosis viscidis longe pedunculatis, nuce oblonga acuminata insigniter insculpto-scabrosa.-Willd. sip. pl. 4 . p. 456.

J. cathartica. Mich. arl. 1, p. 165.

J. oblonga. Mill. dict. n. 3. Retz. ols, 1.p. 10.

Icon. Mich art. 1. t. 2. Jucq. ic, rar. 1. t. 192. Wangh. amer. t. 9. f. 21.

Near the sea-coast: Canada to Virginia, and on the Allegany mountains, $\eta$. April, May. $v$. $v$. It is known uuder the name of Butter Nut, Oil Nut, and White Walnut. The younger Michaux has altered the adopted name, and substituted one indicating the medicinal use made of it, which certainly would be a very good name if the old one had not been so long established.

* Amentis masculis compositis, tetrandris. Hickory.

olivaformis. 3. J. foliolis numerosis $(13-15)$ lanceolatis subfalcatis serratis, impari petiolato, fructibus oblongis tetragonis, nuce olivæformi lævi.-Willd. sp. pl. 4. p. 457.

J. angustifolia. Ait kew.3.p. $36 \mathrm{I}$.

J. Pecan. Muhll. in nov. act. soc. nat. scrut. berol. 3. p. 392.

Icon. Mich arb. 1.t.3.

On the banks of the Olio, Mississippi, and other rivere 
in Upper Lovisiana. h. April, May. v. $v$. It is generally known under libe nase of fecan or llinoris Nut; the thut is small, with a very thin shell, and a delicions kernel.

4. J. folinlis ubnovenis nbovato lanceolatis acuminatis sersulcala. ratis ubtus pubescontibus, impari subsessili basi attenuato, frucibus subritundis 4 -carinatis, nuce subglobosa levitr compressa lavi longe mucronata.-Willd. sp. p:. 4. $p$ 4;

J. murrouata. Mich., fl. amer, 2. p. 192.

J. laciniona, Wich arl. 1.p. 199.

Icon Mich art. 1.t.8.

In ferile ralleys of the Allegany mountains. 5. April, Mar. v. v. It is called Thick Shell-lark Hickory, Siring fitd or Glocester Nut. The nuts are large and fine lated; the bark is torn lengthways in long lrose fiagments, as in the following species.

5, I. folic lis subaeptenis longe petiol tis oblongo-lanceolatis acuninatis argute serratis, subtus villosis, impari sessili, amentis filiformibus glabris, fructibus depressoglobo-is, wuce compressa obligua.-Aich. fl. amer. 2. $p$ lys. Sp.pl. $1+15$.

J. compressa. Willd. sp.pl. 4. p. 458. Muhlb. in nov. a.t. soc. nat. scrut. lerol. 3. p. 390.

J. squamosa. Mich. arb. 1. p. 190.

Icon. Mich. arb. 1. $t$ 7. Pluk. alm. t. 309.f. 2. Gert. carp 2. t. sy. sul J. compressa. Catesb. car. 1.t.38.

In shady fertile forests: New England to Carolina, and throughout the Allegany mountains. $h_{\text {. A }}$ April, May. v. v. This usetul tree is known by the name ot Shell-lark Hickory. Shug-bark and Scaly-burk Hickory, on account of its balk, which is lorn in loose fragments like the preceding: its nuts are white, with a thin shell and very swew and large kernel.

ต. J. foliolis stibuovenis oblongo-lanceolatis acuminatis leriter serratis subur pubescentibus scabris, impari subpetiolato, amentis tiliformibus longissimis tomentosis, fructibus subglobosis lavibus, pericarpio crassissimo, nuce subsexangulata putamine crassa durissima.Mich. $f$ amer. 2. p. Jy'.

J. alba. Willd. sp. pl. t. p. 457 .

Icon. Nich. arl. 1.p. 186. t. 6 .

In fertile forests : New England to Virginia, and on the Allegany mountains. $\zeta$. April, May. v. v. This 
is known under the name of Mocker Nut, Whiteheurt Hickory or Common Hickory. The wood is excellent for mechanical purposes, and particularly esteemed as fire-wood; but the nuts are very hard, with but little kernel in tliem.

amara.

7. J. foliolis subnovenis orato-oblongis acuminatis argute serratis utrinque glabris, impari breviter petiolato, fructibus subglobosis, superne suturis prominulis, nuce lævi subglobosa nucronata, putamine fragli. - Mich. arb. 1. p. 177 .

In dry fertile woods: New England to Maryland, and on the mountains. h. May. v. v. This is known by the name of Bit!er Nut, White or Suump Hicko$r y$. The nuts are small, the kermel bitter.

porcina.

8. J. foliolis subseptenis lanceolatis acuminatis serratis utrinque glabris, impari subsessili, fructibus pyriformibus vel globosis, nuce lavi durissima-Mich. arb. 1. p. 206 .

obcordata. $\quad$ a. J. fructu globoso, nuce obcordata-Mich. arb. 1.p. 206. t $9 . f .3$. שै 4 .

J. obcordata. Willd. sp.pl. 4.p. 4.58.

ficiformis. $\quad$ B. J. fructu turbinato, nuce oblonga.-Mich. arl. 1. p. 209. t. $9 . f .1$. ซ 2 .

J. glabra. Willd. sp. pl. 4.p. 458.

In dry fertile forests: New England to Virginia. $\zeta$. May. $v . v$. It is known by the name of Pig or Hog Nut, also Broom Hickory. The natives and inhabitants make brooms of it by slitting the very tough wood into narrow slips, which finally form a very good and durable broom. The nuts are very small and extremely hard.

aqualica. $9 . \mathrm{J}$. foliolis subundenis angusto-lanceolatis acuminatis subserratis sessilibus, impari breviter pedicellato, fructibus pedunculatis ovatis suturis 4 . prominulis, nuce subdepressa rubiginosa tenera.-Mich. arb. 1. p. 182.

Icon. Mich. arb. 1. $\ell .5$.

In swamps and rice-fields : South Carolina and Georgia. 々. M:ay. v. s. Michaux calls it Water Bitter-nut Hickory. The fruit is extremely bitter.

myristicafor - 10. J. foliolis quinis ovato-lanceolatis acuminatis serratis gla. mis. bris, impari subsessili, fructibus ovalibus rugoso-scabris, nuce ovali brevi-acuminata sulcato. lineata duris. sima.-Mich. arb.1.p. 211.

Icon. Mich. arb. 1.t. 10. 
DiCLINIA AMENTACE.E. Juglans.

In South Carolina. Michaux. $h$. + . The Nutmeg Hi kory is but little known; the nuts are very hard, and brown with white lines.

\section{MORUS. Gen.pl. 1424.}

1. M. foliis cordatis ovatis acuminatis trilobisve, æqualiter rulra. serratis scabris, subtus pubescentibus, amentis fernineis cylindricis._Filld. sp. pl. 4.p 360 .

Icon. Jich art. 3. p. 232. t. 10 . Wangh. amer. $t, 15$. f. 35. Pluk, alm, t. $246 . f .4$.

In fertile vallevsthrotghout the middle States. h. June. $v . v$. The Reel Mullerry is a very handsome tree, and the wood useful and sery durable.

\section{CONIFERR.}

707. P1NUS. Gen. pl. 1451.

* Foliis solitariis, lasi distinctis. Abies.

1. P. foliis solitariis planis emarginatis integrisve subtus glaucis suopectinatis supra suberectis recurvato-patent:bus, coni; cylindraceis erectis, bracteolis abbreviatis oboratis longe mucronatis subsemulatis. - Willd. sp. p.. 4.p. 504.

Abies balsamifera. Nich. fl. amer. 2. p. 207.

Icon. Lamlert nonogr. p. 48, t. 31 . Mich.ari. 3. t. it. In Canala, Nora Scotia, New England, and on the Allegany mountains, in high and cold situations. $h$. Niay. $v \cdot v$. This elegant tree is known by the nane of Balsam of Gilead Fir, Fir Balsam, and American Silver Fir. It grows to the height of about forty or fifty feet.

2. P. foliis solitariis planis brevioribus emarginatis subtus glancis subrecundis supra crebris erectis, conis ovatooblongis erectis, bracteolis elongatis reflexis oblongocuneatis emarginatis brevi-mucronatis inciso-denticulatis.

On high motntains of Carolina. Fraser. On the Broadmountains, Pensylvania. Ph. $h$. Mav. v. v.; v. s. in Herb. Lamlert. This species, known among the inhabitants by the name of Doulle-lalsam Fir, re-

Balsamea.

Fraseri. 
senbles the prececling in several respecta, but difters at first sight in being a snaller tree, the leaves shorter and more erect, and the cones not one fourth the size. Messrs. Frasers incroduced this rree into England a fow ycars aso.

taxifolia.

3. P. foliis solitaris planis subdisticlis, conis oblongis, antheris didrmis - Lamlert. monogr. p. 51.t. 33.

On the binks of the Columbia. M. Lewis. On the north-west coast. Menaies. h. v. s. in Herb. leu'is. This elcgant and tall tree has some resemblance to the following one, bit the leaves are more than wice the length. I liave among my specimens two varieties, or probably distinct species, which for want of tructification I camnot lecide: one has acute leaves, green on both sides; the other emarginate leaves, glaucous underiseath.

anadensis.

4. P. foliis solitariis planis denticulatis subuintichis, strobilis ovatis terminalibus vix folio longioribus. Lamtert. monngr. P. 50, t.32.

P. americana. Du Roi harlik. 2. p. 107.

Icon. Lamierl.l. c. Mich. arv́. 1. p. 137.t. 13. Wangh. amer t. 15. f. 30 .

In the most northern regions of Camada and on the highest monntains, as far souh as Carolina. $h_{2}$. May. $v$. $v$. The Hemlock Siruce is a very elegant tree, and grows in some situations to an enomous size; its bark is a fine substitute for oak-bark in tanning.

nigra.

5. P. foliis solitariis tetragonis undique sparsis erectis strictis strobilis oratis, squanis ellipticis margine undulatis apice croso-denticulatis.-Lamlert. monogr. p. 11 . t. 27.

P. mariana. Du Roi harlk. 2. p. 16\%.

P. denticulata. Wheh. fl. wmer. 2. p. 206.

Icon. Lambert. l. c. Mich. arb. 1.t.11. Mill. ic. 1. $t$. 1 .

From the more northern parts of Canada to Carolina, throughout the tracts of high mountains. 々. May. v. v. The Black Spruce or Double Spruce is, berides its great mechanical use, the tree of which that wholesome beverage calld Spruce Beer is made.

*ulra.

6. P. foliis solitariis subulatis, strobilis oblongis obtusis, squamis rotundatis subbilobis margine integris. Lamlert. monogr. p. 43. t. 28.

Abies pectinata, Lamarck. encycl. 6. t.523. 
Icon. Lamlert.l.c.

In Nova Scotia and about Hudson's Bay. W. May. v. s. This species of Siruce Fir is nearly relited to the preceding. It is, as yet, a very scarce tree in the gardens.

7. P. foliis solitariis tetragonis incurvis, strobilis subcylinalla. dricis laxis, squamis obovatis integermis. Lamlerl. monogr. p. 39. t. 26 .

P. laxa. En'h. leitr 3. p. 24.

P. canadensis. Du Risi harlk. 2. t. 12.t.

Icon. Lamlert. l. c. Míh arl. 1. t. 12. Wangh. aner. 5.t. 1.f. 2.

In similar situations with $P$. nigra. $\zeta_{\text {c }}$. May. $v v$. The While Spruce is of lower growth than the Black Soruce, iis word not so good as that, and its branches unfit for insking spruce beer.

* Foliis plurilus, lasi vaginalis. Pinus.

8. P. foliis brevibus geminis, strobilis recurvis oblongo-conicis longitudine foliorum, aculeis squamarum subulatis rectis.-Lamtert. nonugr. p. 18. t. 13.

P. virginiana. Du Roi harlk. 2. p. 35.

Icon. Lamlert. I. c. Mich. arl. 1. t. 4.

In dry barren soil : New Jersey to Carolina. 5 . Mav. $v v$. The Jersey Pine, Pitch or Sorul Pine, is of middie size, straggling growth, and fill of resin. Its branches are tougher than any other pine I know, and might be uned for several useful purposes if its wood was not so apt to an eaily decay. A. B. Lambert, Esq. in his magnificent Nionograph on this interesting and useful genus, made similar observations, which the younger Michaux in his Ailres forestiers, p. 60. has taken up as a point of criticism. On this subject Mr. Lanibert favoured me with his observations respecting this and some other remarks made by Mr. Michaux, $u$ bich I think proper here to insert; it is in the following words: "The criticisms made by Mr. Michuux on my "Description of the genus Pinus" are so inaccurate, that I did not think them worth my notice befure, nor should I now, were it not to jrevent Mr. Pursh from being misled by them, though I believe he is already well aware of their fallacy: I shall therefore beg of hin to insert a few observations in the different subjects to which they respectively beiong, if they neet with his approbation and con- 
currence. Whether Mr. Michaux has been successful in changing the specific wames of the pines, I shall leave to future botanis!s to decide: but 1 must correct him in respect to the strecific name he has adied to my own, which certainly does not belong to it." The voswration which Mr. Lambert malies in this place is, " Michaux's ouservations relative to the bianches of $P$. inops beiug not fit for hoops appear to be mere matler of opinion, as well as mine, without experience."

resinosa.

9. P. foliis elongatis geminatis, vaginis elongatis, strobilis ovalo-conicis basi rotundatis subsolitariis folio dimidio brevionas, squarnis medio dilatatis mernibus.-Lamtert. manngr. p. $20 . t .14$.

P. nubra. Mich. arl. p. 45.t.1.

In Canala and the westem parts of New York. $\eta \cdot v \cdot v$. This tree, called by Aiton Pitch Pine, is generally known in its mative country by the name of Norway Pine; sometimes, particularly among the Candian French, Red Pine. It grows in close forests, is very tall, and its hark is remarkably smooth and red; the timber is very heavy, for which reason it is rejected for masts, though its size and shape are apparently very recommendable for that purpose. Mr. Lambert in his note, quoted above, observes, "In confirmation of what I have said relative to the tiniber of $P$. resinosa, Mr. Michanx mentions the exportation of it being much diminished, as it has been found to contain too much sap; but he still thinks, from some planks he has seen, it is without foundation."

Banksiana. 10. P. foliis brevibus geminatis rigidis divaricatis obliquis, strobilis recurvis turtis, squanis inernibus. - Lamtent. monogr.p.7.t.3.

P. rupestris. Mich arl. 1. p. 49.t.2.

I. hudsonia. Lam. ancycl.5. p.339.

P. sylvestris $\delta$. divaricata. Ait. kew. 3. p. 366.

In cold barren an i rocky situations: Nova Scotia, Hudson's Bay, parts of Canada and Province of Maine. h. April, May. v. '. The Scrub Pine, or, as Michaux calls it, the Gray Pine, is a small straggling tree, which in some instances, when growing anong the barren rocks, does not rise above five or eight feet high, though it will grow to a considerable size when, by accident or culture, it is brought on good soil. Mir. Lambert observes in his note, "that the trees of this 
species now in England exude a great quantity of resin from their branches."

11. P. foliis elongatis binis ternatisque tenuibus canaliculatis, strobilis ovato-conicis subsolitariis, squamarum aculeis ncurvis.-Lambert. nonogr. p. 22. t. 15.

P. mitis. Nich.art. 1. p. 52. 63 .

In most pine-forests: New England to Gcorgia. $\zeta$. May. v. v. The Yellue Pine is the most in nee for building of houses as well as shipping. Mir. Lamberts note on this species says, "The height and size of $P$. varialilis I have taken trom Wangenheim, who saw it growing in America, and see no reason for doubting his authority."

12. P. foliis ternis, vaginis abbreviatis, anentis masculis erecto-incumbentibus, strobilis ovatis sparsis vel asgregatis, squamarum spinis reflexis. - Lambert. monogr. p. 25.t. 18. 19.

Icon. Lamlert.l. c. Mich. arb. 1. p. 89. t. 8.

On the plains: New England to Virginia. h. Mav. $v, v$. The common Blatk or Pitch Pine growis in fisvourable sitnations to a very large tree; it is found promiscuonsly in diy sol and very wet low ground. Mr. Lambert says that his observations on this species were taken from IVangenheim.

13. P. foliis elongatis ternis, amentis masculis erecto-incumbentibus, strolitis ovatis, squamarum aculeis rectis tenuissimis.-Nich. fl. amer. 2. p. 205.

P. Tæda alopecuroides. Ait. kow. 3. t. 363.

Icon. Mich. arb. 1. p.86.t.7. Lambert. monogr. t.19. f. 5 .

On the edges of ponds and swamps: New Jersey to Carolina. $r$. May. v. v. This and the preceding species ripen their seeds only after the second year. I strongly suspect them to be only varieties; and if it had not been introduced as a species by a very good figure of Michaux's, I should have only given it as such.

14. P. foliis geminis brevibus acutis, strobilis ovato-conicis, aculeis squamarum elongatis subulatis incurvis, inferior bus reflexis.-Lamlert. monogr. $p .91$.

Icon. Lambert. monogr. t. 16.f. c. Mich. arï.1.p.61. t. 5.

On high mountains: on the Grandfatter and Table

varialilis.

rigsila.

serotina.

prongeriso 
mountains, Carolina. $\eta$. v. s. in Herl. Lambert. The cones are large and arned with strong spines. The cone figured $t$. 16. $f$. c. in Lambert. monogr. is genuine, but the branch belongs to a separate species.

Tada.

15. P. foliis elongatis ternis, vaginis elongatis, strobilis oblongo-conicis deflexis folio brevioribus, spinis inflexis. -Lnmlert. monogr. p. 23. t. 16. 17.

Icon. Lambert. l. c. Mich arb. 1. p.07.t.9.

ln barren and sandy sitnations: Virginia to Florida. h. April, May. $v . v$. The Lollolly or Old:field Pine is found in large tracts in the southern states: all the woods seem to be seeded with it; for when any picce of cleared land is neglected for any space of time it will be covered with those pines. It is difficult and in some cases almost impracticable to recover those lands run over with young pines, as the ground appears to have lost all fertile properties for ary other vegetable than those trees. 'The account Mr. Michaux gives of this tree is very correct and instructive; as also is the plate of Mr. Lambert; but unfortunately the lat. ter, considering $P$. teda Wangh. amer. 41. a genuine synonym, although it evidently belongs to $P$. rigida or serotina, has inadvertently been led into some errors in his description.

palustris. 16. P. foliis ternis longissimis, stipulis pinnatifidis ramentaceis persistentibus, strobilis subcylindraceis muricatis. - I.cimbert. monogr. p. 27.f. 20.

P. australis. Mich. arb. 1. p.64.t.6.

Icon. Lambert. et Mich. l. c. Ablot. insect. 1. t. 42.

In the forests, near the sea-coast: North Carolina to Florida. h. May. v. $v$. The Long-leaved, Yellow, Pitch, or Broom Pine is a beautiful as well as very useful tree. Mr. Lambert's remarks respecting the quality of the wood he has taken from Wangenheim, whom he considers sufficient authority; but on the observations of Michaux respecting the male flowers, he mentions in his uote, "I can only suppose Mr. Michaux has never seen my plate with the nale flowers, or he never would have made such an obser. vation about them."

Strobus. $\quad$ 17. P. foliis quinis gracilibus, vaginis brevissinis, strobilis pendulis cylindraceis folio longioribus, squamis laxis. -Willd. sp.pl.4. p.501. Lamlert. monogr.p.31. t. 22 . 
Icon. Lamlert. l. c. Mich. arl. 1. p. 103. t. 10. Wingh. amer. 1.t.1.f. 1 .

In fertile soil, on the side of hills: Canada to Virginia. h. May. $v . v$. The White or Weymouth Pine is the largest and most useful of all the species above mentioued; in the State of Vermont they grow to an enormous size; it is the best timber in America for masts.

**** Foliis fasciculatis. Larix.

18. P. foliis fasciculatis deciduis, strobilis oblongis, squamapendula. rum marginibus inflexis, bracteolis panduræformibus acumine attenuato. Lamlert. monogr. p. 55. t. 36. Ait. kew. 3. p. ง69.

In low cedar swamps: Canada to New Jersey. $h$. A pril, May. v. v. The Black Larch, Tumarack, or Hack-matac of the Americans, is a beautitul tree, resembling the European Larch in appearance, as well as in the excellent qualitics of its wood and bark.

19. P. foliis facciculatis deciduis, strobilis stibrotundis paucifluris, squamis reflexis, bracteolis ellipticis obtuse acrminatis. l.amlert. monogr. p. 56. t. 37 .

P. pendula. Willd art: 215.

P. laricina. Du Roi harlk. 2. p. 83.

Larix americana. Mich. fl. amer. 2. p. 203.

Icon. Lamlert. l. c. Mich. arb. 3. t. 4. Wangh amer. t. 1 ij. f. 37 .

About Hudren's Bay and on high mountains of New York and Pensylvania. $h$. May. $v, v$. The Red Larch resembles the preceding, and both have been considered as one species by Michaux; but they are specifically and constantiy different ; I never saw them both growing in the same place, or even near one another. Mr. Lambert likewise observes that they have always kept distinct, when raised from seed.

\section{CUPRESSUS. Gen. pl.1458.}

1. C. foliis distichis planis deciduis, foribus masculis aptyylo-paniculatis, strobilis subglobusis.-Willd.sp. pl. 4. viztichas p. 512.

Icon. Mich. arl. 3. p. 4. t. 1. Catesb. car. 1. t. 11. Comm. hort. 1.t.59. Pluk. alm.t. 85.f.8.

In extensive swamps and on the banks of large rivers from Indian-river Delaware to Florida, and on the Mis- 
sissippi. h. May. v. v. The Bald or Decidunus $C y$. press is one of the largest trees of the New Continent. The extensive use made of its wond, and other particulars respecting this interesting toe, are fully elucidated in the exceilent work of the younger Michaux, who paid particular attention to the use and properties of the different American forest trees.

thyoides.

2. C. ramulis compressis, foliis quadrifariam imbricatis ovatis basi tuberculatis, strobilis globulosis.-IVilld. sp. pl. 4.p. 512 .

Icon. Mich. arb. 3. p. 20. t. 2. Wangh. amer. t.2.f. 4 . Pluk. mant.t. 345.f: 1 .

In deep swamps: New England to Carolina. h. April, May. v. v. The White Cedar, so well treated upon by Michaux, is the principal tree, composing what is called Cedar-swamps, throughout the niddle and southern States.

\section{THUYA. Gen. pl. 1457 .}

occidentalis.

1. T. ramulis ancipitibus, foliis quadrifariam imbricatis ovato-rhombeis adpressis nudis tuberculatis, strobilis obovatis, squanis interioribus truncatis, infra apicem gibbosis. IVilld. sp. pl.4. p. 508.

Icon. Mich. arl. 3. p. 29.t 3. Wangh. amer. t.2.f.3. From Canada to the nountains of Virginia and Carolina. h. Nay. $v . v$. The American Arivor Vita is rather scarce in the southern States, and only found on the steep banks of mountain torrents. The branches are extremely tough.

\section{JUNIPERUS. Gen. pl. 1552.}

communis.

erecta. depressa.
1. J. foliis ternis patentibus mucronatis bacca longioribus. IVilld. sp. pl. 4. p. 853 .

a. J. ramis erectis.

ß.J. ramis depressis.

$\alpha$. About rocks, near the falls of rivers, in Canada and the western part of New York. $\beta$. in New York, and particularly in the province of Maine, in rocky or gravelly situations. $h$. May. $v, v$. The Ciommon Juniper may probably have been originally brought fron Europe ; but the variety $\beta$., or probably a distinct species, seems to be really an original native; it does not grow above a foot or two high, and one single 
root will cover sometimes a space of from fifteen to twenty feet in diameter.

2. J. foliis ternis basi adnatis, junioribus imbricatis, senioribus patulis. Willd. sp. pl.4.p. 863 .

Icon. Mich. arl.3. p. 42. t. 5. Wangh.amer. t.2.f. 51 . In dry and rocky woods and fields: Province of Maine to Georgia. h. May. v. v. The Red Cedar, so useful and durable a wood, for whose history I refer to Michaux's work so often quoted, is as yet in great abundance in most parts of that country ; but its extermination is going on so rapidly, that future inhabitants will be very much at a loss, and will feel the want of it when it is too late.

3. J. foliis oppositis obtusis medio glandulosis, quadrifarian imbricatis, tenellis acutis oppositis, caule fruticoso.

B. Willd.sp.pl. 4.p. 852 .

In the clefts of rocks: Canada. Michaux. $\beta$. Within the Rocky-mountains. M. Lewis. h. v. s. in Herl. Lewis. Not above six inches high.

4. J. foliis oppositis obtusiusculis, medio glandulosis, quadrifariam imbricatis, tenellis acutis ternis patulis, caule arboreo. Willd. sp. pl. 4. p. 852.

J. Sabina varietas. Pall. ross. 2. p. 15.

On the banks of the waters of the Rocky-mountains. M. Lewis. h. May, v. s. in Herb. Lewis. A lofty elegant tree. Specimens of Pallas in the Herbarium of A. B. Lambert, Esq. seem to be the same with those collected by Mr. Lewis.

5. J. foliis omnibus quadrifariam imbricatis, junioribus ovatis, senioribus acutis. Willd. sp.pl.4.p. 851 .

Icon. Pluk. alm. t. 197.f. 4 .

On the coast of Florida. Michaux. 々. v. v. in Hortis.

\section{TAXUS. Gen. pl. 1553.}

1. T. foliis linearibus distichis margine revolutis, receptaculis masculis globosis. Willd.sp. pl. 4. p. 856 .

T. baccata minor. Mich. $f$. amer. 2. p. 245.

In shady, rocky places: Canada. Michaux. On the banks of the Antietum, Maryland. Ph. March, April. $v . v$. The plants I observed on the Antietum cover a great part of the rocky banks of that river. Under the shade of other trees it does not rise above two or three feet.

vol. II.

canaderisis.

virginiana.

Salina.

procumbens.

exielsa.

Garladensis. 


\section{ZAMIA. Gen.pl. 1700.}

integrifolia. 1. Z. frondibus pinnatis, foliolis lanceolatis rotundato-obtusis basi attenuatis latere extericre ad apicem serrulatis, stipite glabro subtetragono. Willd. sp. pl.4. p.847.

Z. pumila. Sp. pl. 1659. excl. synon.

Icon. Jacq. ic. 3.t. 635.

In East Florida. $\quad$. + +. This species of palm is only found in Florida, as I have made all inquiries to find it in Georgia, but without success. 


\section{CRYPTOGAMIA,}

\section{GONOPTERIDES.}

713. EQUISETUM. Recept. peltata, pentagona, spicata. Indusium corniculatum. Stam. 4. Styl. 0. Sern.1.

\section{STACHYOPTERIDES.}

714. LYCOPODIUM. Capsula reniformes, 1-loculares, 2-valves, polyspermæ. Sem. minutissima, pulveriformia.

715. BERNHARDIA. Capsula 3-coccæ, 3-loculares: loculis superne dehiscentibus, semibivalvibus.

716. OPHIOGLOSSUM. Capsula nudæ, uniloculares, in spicam articulatam disticham connatæ, 2-valves, transverse dehiscentes.

717. BOTRYCHIUM. Capsulce sutgirhosæ, rachi adunatæ in racemum compositum d to itæ, 1 -loculares: valvulis binis postice connexis tıansverse dehiscen. tibus.

\section{SCHISMATOPTERIDES.}

718. HYDROGLOSSUM. Spica unilaterales. Capsulae biseriales, latere interiore a basi ad verticem dehiscentes. Indusium squamiforme quamlibet capsulam obtegens.

719. SCHIZÆA. Spica unilaterales, flabellatæ, aggre。 gatæ. Capsula vertice radiatim striatæ, subturbinatæ, poro oblongo latere hiantes. Indusium continuum e margine inflexo spicæ formatum.

720. OSMUNDA. Capsula subglobosæ, pedicellat $x_{\text {, }}$ striatæ, semibivalves, paniculatæ. Lndusium nullum. 


\section{FILICES.}

721. ACROSTICHUM. Capsule sparsæ, discum totum inferiorem frondis vel ejus partem occupantes. Indusium nullum.

72. POLYPODIUM. Sori subrotundi, sparsi. Indusia nulla.

723. IVOODSIA. Sori subrotundi, sparsi. Indusium calyciforme, apertum, margine crinitum, includens Ciapsulas pedicellatas.

724. ASPIDIUM. Sori subrotundi, sparsi. Indusium umbilicatun vel uno latere dehiscens.

725. ONOCLEA. Capsula partem frondis inferiorem dense tegentes. Indusia squamiformia, in formam baccæ connata non dehiscentia.

726. STRUTHIOPTERIS. Capsula partem frondis inferiorem dense tegentes. Indusia squamiformia, marginalia, interius dehiscentia.

727. ASPLENIUM. Sori lineares, transversales, sparsi. Irdusia e venis lateralibus orta, costam versus dehiscentia.

728. SCOLOPENDRIUM. Sori lineares, transversales, sparsi. Indusium duplex, ad utrumque latus sori situm.

729. PTERIS. Sori continui, lineares, marginales. Indusium e margine frondis, inflexum, interius dehiscens.

730. VITTARLA. Sori lineares, longitudinales, continui vel in margine vel in disco frondis. Indusium duplex, ad utrumque latus suri.

731. BLECINUM. Sori lineares, longitudinales, continui, ad utrumque latus costæ frondis. Indusium superficiarium, interius dehiscens.

732. WOODWARDIA. Sori oblongi, distincti, recti, ad utrumque latus costæ frondis. Indusia superficiaria, fornicata. interius dehiscentia.

733. ADIANTUM. Sori oblongi vel subrotundi, Indusiis membranaceis, e margine ortis, interius debiscentibus inserti.

734. CHEILANTHES. Sori punctiformes, discreti, marginales, tecti Indusio squamiformi marginali interius debiscente.

735. DICKSONIA. Sori punctiformes, marginales, subrotundi, distincti. Indusium duplex, alternum superficiarium, exterius dehiscens, alterum marginale interius dehiscens. 
736. HYMENOPHYLLUM. Sorus marginalis, receptaculo cylindraceo insertus. Indusium bivalve, sorum includens.

\section{HYDROPTERIDES.}

737. ISOETES. Capsula membranacea, non dehiscens, frondis basi immersa, 1-locularis. Semina angulata, receptaculis pluribas filiformibus inserta.

738. SALVINIA. Indusia imbricata, connata, capsulam unilocularem mentientia. Semina receptaculo centrali inserta.

739. AZOLLA. Capsula unilocularis, radicalis, globosa, polysperma.

\section{GONOPTERIDES.}

\section{EQUISETUM. Gen.pl.1614.}

1. E. caulibus sterilibus simpliciter ramosis, ramis scabrinsculis tetragonis, fructificationibus simplicibus, vaginis arverise. cylindraceis inciso-dentatis, dentibus acutis. Willd. enum. 1065. Willd.sp.pl.5.p.1.

Icon. Schkulir filic. t. 167.

In low and sandy fields : Pensylvania and Virginia. 4. April, May. $v . v$.

2. E. caulibus sterilibus fructificantibusque duplicato-ramosis, ramis scabriusculis deflexis tetragonis, ramulis subtriquetris, Willd. enum. 1065 . Willd. sp.pl. 5. p. 3.

Icon. Schkulir filic. t. $166 . \quad F l$. dan. 1182.

In low shady woods: New York to Virginia. 4. April -June. $v . v$.

3. E. caulibus subramosis, ramis subquaternis tetragonis glabris, spica cylindracea terminali.-Willd. sp. pl. 5 . p. 4.

In swamps : New York to Virginia. 24. May. v. v. Resembles E. limosum.

4. E. caulibus simpliciter ramosis glabris sulcatis, ramis sylvaticum. uliginosum. pentagonis apice spiciferis. Willd. enum. 1000. palustre. IVilld. sp. pl.5. p. 5 . 
Icon. Schkuhr filic. t. 168, 169. Fl.dan. 1183.

On the banks of rivers and in deep swamps: Virginia. 4. May, June. v. $v$.

scirpoides.

5. E. caulibus simplicibus adscendentibus glabris filiformibus apice spiciferis, vaginis 3 -dentatis sphacelatis, dentibus aristatis apice caducis. Willd. sp.pl.5.p.7. Mich. Al. amer. 2. p. 281.

E. reptans. Swartz. in litt.

In shady woods, round the mossy feet of trees : Canada and on the Green mountains, Vermont. 2. July, v. v. A small species.

hycmale. 6. E. caulibus simplicibus erectis scaberrimis apice spiciferis, vaginis discoloribus basi apiceque sphacelatis, dentibus aristatis omnino caducis. Willd. sp. pl. 5. p. 8.

Icon. Schkuhr filic. t. 172 .

On the banks of rivers and in swamps: Canada to Vir. ginia. 4. July, Aug. v. $v$.

\section{I. STACHYOPTERIDES.}

\section{LYCOPODIUM. Gen.pl. 1615.}

\section{* Spicis pedunculatis.}

carolinianum. 1. L. caule repente, foliis subdistichis patulis lanceolatis su. perficialibus adpressis, pedunculo erecto solitario elongato monostachyo, bracteis sublanceolatis. $-W$ illd. $s p$. pl. 5. p. 14.

Icon. Dill. musc. t. 62. f. 5 .

In low neadows and woods: Pensylvania to Carolina. 4. July. v. v.

claraium. 2. L. caule repente, ramis adscendentibus, foliis sparsis enervibus incurvato-setigeris, spicis geminatis cylindricis pedunculatis, squamis ovatis acuminatis eroso-dentieulatis. Willd. sp.pl.5.p.16.

Icon. Sclikuhr filic. t. 162. Fl, dan. 126 . Dill. musc, t. 58. f. 1. Pluk. alm. t. 47.f. 8.

In dry pine woods : Canada to Pensylvania. 24. July. $v . v$. It sometimes bas only one spike.

complanatum. 3, L. caule erecto, ramis alternis dichotomis, foliis bifariis connatis apice patentibus, superficialibus solitariis adpressis, pedunculis quadrifidis tetrastachyis, spicis tea retibus cylindricis. $W$ illd. sp.pl. 5. p.19. 
Icon. Fl. dan. 78. Dill. musc.t. 59.f. 3.

In shady woods, on rocky soil: Canada to Virginia. 4. July, $v . v$.

4. L. caulibus erectis, ramis alternis dichotomis subcompressis, foliis lanceolatis aculis quadrifariis adpressis, pedunculis solia riis elongatis tristachyis, spicis teretibus, squamis subrotundis acuminatis.

On high mountains in Virginia, near the Sweet-springs. 4. July. $v . v$. This species is intermediate between the preceding and following one.

5. L. caule erecto, ramis alternis dichotomis, foliis lanceolatis acutis quadrifariis adpressis convexis, pedunculis solitariis monostachyis, spicis teretibus, squamis subcordatis acuminatis.-Willd. sp.pl.5. p. 20.

L. alpinum. Mich. fl. amer. 2. p. 282.

Icon. Dill. musc. t. 58. f. 2 ?

In Canada. Michaux. 24. July. +.

* Spicis sessilibus; foliis caulem circumolsidentilus.

6. L. caule erecto, ramis alternis confertis dichotomis pa-dendroideum. tentibus, foliis sparsis sexfariis lineari-lanceolatis patulis, spicis solitariis terminalibus sessilibus. Willd. $s p$. pl.5.p. 21.

L. obscurtim. Sp.pl. 1566.

Icon. Schkuhr filic. t. 164. Dill. musc. t. 64, f. 12.

In dry shady woods: Canada to Carolina. 24. July. $v . v$. This and some other species are known by the name of Ground Pine, and made use of for ornamenting rooms and chimney-pieces, it forming, when properly tied up, beautiful festoons.

7. L. caule repente, ramis adscendentibus basi bis bipartitis, ramulis simplicibus, foliis quinquefariis linearilanceolatis mucronatis apice serrulatis patentibus, ad incrementa annua contractis, spicis solitariis sessilibus terminalibus. Willd. sp. pl. 5. p. 23.

Icon. Schluhr filic. 162. Fl. dan. 127. Dill. musc. t. 63. f. 9 .

In shady woods: Canada to Pensylvania. 24. July. v.v.

8. L. caule subramoso repente, ramis simplicibus solitariis

sabinafolium. erectis apice monostachy is, foliis linearibus sparsis acu. tis integerrimis supra curvis, spica sessili foliosa. IVilld. sp. pl. 5. p. 2.5.

icon. Schkuhr filic. 160. Fl. dan, 336. Dill. musc. t. $61 . f .7$.

annotinum.

inundatum. 
In cedar swamps and overflowed woods: Canada to New York. 24. July. $v, v$.

alopecuroides. 9. L. caule repente subramoso, ramis subsimplicibus elongatis adscendentibus apice monostachyis, foliis linearisubulatis basi ciliato-dentatis patulis, spica sessili foliosa. Willd. sp. pl. 5. p. 26.

Icon. Schkuhr filic, t. 160. Dill. musc. t. 62. f.6.

In sphagnous swamps: New York to Carolina. 2. July. $v . v$. It is known by the name of Walking Fern.

selaginoides. 10. L. caule repente, ramis adscendentibus simplicibus, foliis sparsis lanceolatis patulis ciliato-deniticulatis, spicis terminalibus solitariis foliosis sessilibus. IVilld. sp. pl. 5. p. 28.

Icon. Schkuhr filic, t. 165. Fl. dan. 70. Dill. musc. t. 68.f. 1 .

In mossy woods: Canada and New Hampshire. $\mathcal{\psi}$. July. $v . v$. The American plant is smaller than the European.

rupestre. 11. L. caule repente ramoso, ramis subdivisis adscendentibus, foliis sparsis imbricatis lineari-lanceolatis ciliatis apice piliferis, spicis solitariis sessilibus terminalibus. IVilld. sp. pl. 5. p. 30.

Icon. Schkuhr filic, t. 165 . Dill. musc. t. 63. f. 11.

On rocks: Canada to Virginia, and on the Carolina mountains. $\psi$. July. v. v. A snall species.

*****is Spicis sessilibus; foliis distichis.

albidulum. 12. L. foliis bifariis ovatis acutis denticulatis, superficialibus alternis distichis adpressis, spicis terminalibus elongatis sessilibus tetragonis. Willd.sp.pl.5.p. 37 .

In moist shady places: Pensylvania. 4 . Aug. $v . v$. A very small, moss-like species, very múch resembling the following.

apodum。

13. L. foliis bifariis subrotundo-ovatis acutis planis denticulatis cum superficialibus acuminatis alternantibus, caule ramoso basi radicante, spicis terminalibus sessi. libus subsolitariis. Willd. sp.pl. 5. p. 38.

Icon. Dill. musc. t. 64.f. 3.

In shady woors: Pensylvania to Florida. 24. July. $v, v$.

**** Capsulis axillaribus.

lucidulum. 14. L. foliis octofariis lineari-lanceolatis denticulatis acutis patenti-reflexis, caule adscendente bifido. Willd. sp. pl. 5. p.51. 
L. reflexum. Schkuhr flic. $t .159$.

Icon. Dill. musc. t. 56.f.2.

In low sphagnous grounds and on the banks of shady rivulets : Canada to Carolina. 4 . July. v. v. Resembles L. Selago; it frequently bears bulbs instead of capsules.

715. BERNHARDIA. Willd. act. acad. erford. 1802. p. 11.

1. B. caule nudo dichotomo ramisque triquetris.-Willd. sp.pl. 3. p. 56 .

Hoffmannia aphylla. Wild. in Roem. et Usteri bot. mag. 6. p. 17.

Psilotum triquetrum. Swartz. synop. filic. 187.

Psilotum floridanum. Mich. fl.amer. 2. p. 281.

Lycopodium nudum. Sp. pl. 1564.

Icon. Schkuhr filic. t. 165. b. Dill. musc.t. 64.f. 4.

On the cliffs of rocks, near the sea-coast, in Florida. 24. June. $v, s$.

\section{OPHIOGLOSSUM. Gen. pl. 1621.}

1. O. spica caulina, fronde ovata obtusa, arcte reticulata. vulgatim. Willd. sp. pl. 5. p. 58.

Icon. Schkuhr filic. t. 153. Fl. dan. 147.

In low grassy open places, in woods and on the sides of hills : New York to Pensylvania. 4. May. v. v.

2. O. spica caulina, fronde subcordato-ovata obtusa, radice bulbosa. Willd. sp. pl. 5. p. 60 .

O. crotalophoroides. Walt. fl. car. 256.

In low sandy grounds: New Jersey to Carolina. 24. May. $v . v$.

\section{BOTRYCHIUM. Swartz. synop. filic. 8.}

1. B. scapo nudo, frondibus glabris radicalibus tripartitobipinnatis, foliolis lunatis crenatis, spicis pinnatis.Willd.sp.pl. 5. p. 63.

B. lunarioides. Swartz. synop. flic. 172.

Botrypus lunarioides. Mich. fl. amer. 2.p. 274.

Osmunda biternata. Lam.encycl. 4. p. 608.

Icon. Schkuhr. filic. t. 157.

In pastures and open woods: New York to Carolina. 4. June. $v . v$.

2. B. scapo inferne unifrondoso, fronde subbiternata, foliolis oblongo-lanceolatis serrulatis basi dilatatis inæqualiter obliquum. cordatis, spicis bipinnatis,-Willd. sp. pl. 5. p. 63 . 
In open woods: Pensylvania and Virginia. 24. June, July. $v . v$. Resembles the preceding very much, and is probably only a variety.

dïssectum. 3. D. scapo inferne unifrondoso, fronde tripartito-bipinnatifida, laciniis linearibus bipartitis apice bidentatis. IVilld. st.pl.5.p. 64.

Icon. Schkuhr filic.t. 158. Plilk. amalih.t. 42\% f. 5 .

In pastures and open dry woods: New York to Florida. 4. June. $v, v$.

virginicum. 4. B. hirsutum; scapo medio frondoso, fronde subterna tripartito-bipinnatifida, foliolis inciso-pinnatifidis, laciniis obtusis subtridentatis, spicis bipinnatis divaricatis. - IVilld. sp.pl. 5. p. 64 .

Botrypus virginicus. Mich. fl. amer. 2. p. 274 .

Osmunda virginica. Sp. pl. 15\%.9.

Osmunda nultifida. Gmel. nov. com. petrop. 12.t.11. f. 1 .

Icon. Schkulir filic. $t .156$.

In shady woods, on rich vegetable soil : Canada to $\mathrm{Ca}$ rolina. 4 . June, July. $v \cdot v$. This is the largest of the species bere described; it is known by the name of Rattle Snake Fern, probably from the circumstance of growing near the places where those venomous animals generally are found.

gracile.

5. B. glabrum ; scapo medio frondoso, fronde tripartitobipinnatifida, laciniis inciso-subpinnatifidis acutis subdentatis, spicis graeilibus pinnatis erectis.

In shady fertile woods: Virginia. 24. June. $v, v$. This species approaches near to the preceding in its first appearance, but is by far a smaller and more slender plant, besides the other distinctions.

\section{SCH IS MATOPTERIDES.}

719. HYDROGLOSSUM. Willd. sp. pl.5.p. ז.

Ophioglossum. Linn.

falmatum. 1. H. caule fexuoso-scandente, frondibus conjugatis cordatis quinęuelobo-palmatis, lobis lanceolatis integerrimis obtusis obsolete sinuatis, spicillis terminalibus composite paniculatis oblongo-linearibus. - Wilid. $s$, . t?. 5. p. 84. 
Lygodium palmatum. Suartz. synop. filic. 154.

Cteisium paniculatum. Mich. fl. amer. 2. p. 275.

Icon. Schkuhr filic. 140. Willd. act. acad. erford. 1802. t. $1 . f .2$.

In low copses, climbing among small shrubs. 24. July. $v$. $v$. This is the most beautiful and singular of all the North American ferns, and is a highly ormamental plant when cultivated in pots.

719. SCHIZÆA. Smith act. taur. 5. p.419.

1. S. fronde simplicissima lineari-compressa, spicis conglo. pusilla. meratis intlexis secundis.

In barren sandy but moist grounds: New Jersey, Burlington comnty, near a place called Quaker Bridge. 2 . Aug. Sept. $v . v$. This singular little fern is very scarce, and so small that it generally escapes the notice of the botannst, tultess accident points it out.

\section{OSMUND.1. Gen. pl. 1622.}

1. O. frondibus sterilibus pinnatis, pinnis pinnatifidis, la- cinnamomea. ciniis ovato-oblongis obtusis integerrimis, stipite lanato, fructificantibus bipinnatis lanuginosis. - Willd. sp. pl. 5.p. 08.

Icon. Sch kuhr filic, t. 146. Moris. hist. 3. s. 14. t. 4. f. 3 .

In low open woods and exsiccated swamps: New England to Floricla. 4. June-Aug. v. v. This is a fern of the size and habit of Polypedium Filix mas; the fertile stems are covered with a cinuamon-coloured down.

2. O. frondibus pinnatis ferrugineo-tomentosis, pinnis pinnatifidis apice coarctato-fructificantibus. - Willd. sp. pl. 5. p. 96 .

In Virginia. Clayton. 24. April. + . This is probably only a variety of the preceding. I have no specimen in my herbarium; but recollect very well that the fructiferous stems of that species very frcquently grow out into leaves, which may have given rise to the formation of the present species.

3. O. frondibus pinnatis glabris, pinnis oppositis pinnatifdis, laciniis oblongis acutiusculis integerrimis, pinnis aliquot intermediis fructificantibus.-Wrilld. $s p . p l .5$. p. 96 .

Claytoniana.

interrupta. 
O. basilaris. Sprengel. aul.3.p. 160.

Icon. Schkuhr filic. t. 144.

In low and swampy grounds: Canada to Virginia, and in the western territories. 24. June, July. v. v. This singular fern is about two feet kigh.

spectalilis. 4. O. frondibus bipinnatis, pinnulis oblongis obtusiusculis argute serrulatis basi truncatis inæqualibus, omnibus alternis, panicula bipinnata fructificante in apice frondis.-IVilld. sp. pl. 5. p. 98.

O. regalis $\beta$. Sp. pl. 1521. Mich. fl. amer. 2. p. 273.

Icon. Pluk. alm. t. 184.f. 4 .

In mountain swamps: Canada to Carolina. 4 . July. $v . v$. A very elegant species.

\section{FILICES.}

\section{ACROSTICHUM. Gen. pl.1625.}

aureum.

1. A. frondibus pinnatis, pinnis alternis oblongo-lanceolatis integerrimis, basi cuneatis æqualibus, omnibus acuminatis, superioribus fructificantibus. Willd. $s p$. pl.5. p. 116.

Icon. Schkuhr filic. t. 1. Petiv. fil. t. 8. f. 5. Plum. amer. t. 7. Pluk. alm. t. 288.f. 2.

In deep swamps near the sea-coast: Florida. 24. July. $v . v$. This is the largest of the North American ferns, the leaves being sometimes above five feet long.

722. POLYPODIUM. Swartz. synop. filic.3.

vulgare. 1. P. frondibus profunde pinnatifidis, laciniis lineari-lanceolatis obtusis crenulatis approximatis, superioribus sensim minoribus, soris solitariis, caudice paleaceo. lVilld. sp. pl.5. p. 172.

Icon. Schkuhr filic. t. 11. Plum. fil. t. A.f. 2.

On rocks and old rotten trees : Canada to Carolina. 24 . July. $v, v$.

virginianum. 2. P. frondibus profunde pinnatifidis, laciniis lanceolatis obtusis integerrimis approximatis, superioribus sensim minoribus, soris solitariis, caudice nudo. Willd. $s p$. pl. 5. p. 174.

Icon. Petiv. flic. t.7. f. 9. Plum. amer, t. 36. filis. t. 77 . 
On the trunks of trees: Virginia? 4 . July. + . Willdenow doubts whether this is really a native of Virginia, and I believe with much propriety, as I likewise never have seen any other species than $P$. vulgare under the name of $P$. virginicum.

3. P. frondibus profunde pinnatifidis, laciniis alternis lineaincanum. ribus integerrimis obtusis, superioribus sensim nuinoribus, subtus stipiteque squamulosis, apice fructiferis, soris solitariis. Willd. sp.pl.5.p. 174 .

P. ceteraccinum. Mich. fl. amer. 2.p. 271 .

Acrostichum polypodioides. $S p . p l .1525$.

Icon. Schkuhr filic. $t$. 11.6 .

On rocks and trunks of old trees: Virginia to Florida, Kentucky and Tennassee; on the rocks of the Natural bridge, Virginia, and on the stems of trees in the Dismal-swamp. Ph. July. v. $v$.

4. P. frondibus bipinnatifidis glabriusculis, pinnis duabus hexagcnopteinfimis deflexis, laciniis lanceolatis obtusis ciliatis, pinnarum inferiorum inciso-crenatis superiorum integerrimis, infimis adnato-decurrentibus, soris minutis solitariis. Willd. sp.pl. 5.p. 200.

Icon. Pluk. alm. t. 294. f: 2. bona. Schkuhr filic. t. $20 . l$.

In shady moist woods on fertile soil: New York to $\mathrm{Ca}-$ rolina. 4 . July. $v . v$. The whole leaf forms a triangle in its circumference; the stem is smooth.

J. P. frondibus bipinratifidis ciliatis, pimnis oppositis conconnectile. tiguis adnatis, pinnulis subellipticis, stipite paleaceo, suris minutis. Willd. sp.pl. 5. p. 200.

In shady woods: Canada to New York. 24. July. v. v. Resembles the preceding.

6. P. frondibus ternatis bipinnatis rectis rigidulis, laciniis obtusiusculis subintegerrimis, soris marginalibus conrum. flucntibus. Willd. sp.pl.5.p.210.

P. Dryopteris. Boiton filic. 53.t. 1.

Nephrodium Dryopteris. Mich.fl. amer. 2. p. 270.

In sluady beech-woods: Canida to Petrsylvania. 4. July. $v . v$. This is a very rare fern in Pensylvania. I only found it on the western mountains in deep shady beech forests.

calcareum. 


\section{WOODSIA. Brown in linn. trans. 11. p.173.}

hyperborea. 1. W. frondibus pinnatis, pinnis tripartitis vel pinnatifido. incisis cuneiformibus obtusis dentatis subtus hirtis, soris solitariis demum confluentibus.-Brown $l$. c. cum icone.

Polypodium hyperboreum. Willd. sp. pl.5. p. 197.

Polypodium arvonicum. Smith fl. brit. 3. p. 1115.

Acrostichum ilvense. Huds. angl. 451.

Acrostichum alpinum. Bolton filic. 76. t. 42.

Acrostichum byperboreum. Liljellad act. holm. 1793. p. $201 . t$ s.

Icon. Schkuhr filic. t. 17. b. Pluk. phytogr. t. 89. f.5. Moris. hist. 3. s. 14. t. 3. f. 23.

In the clefts of rocks : Canada and on the high mountains of Pensylvania and Virginia. 4. July. v. v. $\Lambda$ small fern growing in large tufts, and covered with long brown chaffy hair.

iltensis.

2. W. frondibus bipinnatifidis, laciniis oblongis obtusis in. ferioribus repandis, superioribus integerrimis subtu\& hirtis, soris submarginalibus demum confluentibus, stipite superne villoso.-Brown $l$. $c$.

Polypodium ilvense. Willd. sp. pl.5.p. 198.

Polystichum Marantæ. Roth fl. germ. 3. p. 92.

Acrostichum ilvense. $S p$. pl. 1528.

Icon. Schkuhr filic. t. 19. Fl. dan.391.

On rocks: Canada to Virginia. 24. July. v. v. Resembles the preceding very much; but the leaves are smaller divided and covered with fine woolly hair, not chaffy as in the other.

\section{ASPIDIUM. Swartz. synop. filic. 3.}

Neplirodium. Mich.fl. amer. 2. p. 266.

* Frondibus ternatis.

cicutarium. 1. A. frondibus ternatis, foliolis pinnatifidis, laciniis acuminatis sinuato-pinnatifidis integerrimis, lateralium infima et exteriore lacinia elongata, soris serialibus. Willd. sp.pl.5. p. 215.

Folypodium cicutarium. Sp.pl. 1549 .

Polypodium appendiculatum. Swar $t$. $f$. ind. occid. 3. p. 1677.

Icon. Pluk. alm. t. 289.f. 4. छ t. 296.f. 2.

On rocks in the mountains of Virgiaia. $4 .+$ 
** Frondilus pinnatis.

2. A. frondibus pinnatis, pinnis lanceolatis falcatis acutis acrostichoides. ciliato-serratis, basi superio:e mucronato-auriculatis, inferiore cuneatis, superioribus fructificantibus minoribus, stipite rachique paleaceis, soris solitariis demun confluentibus. Willd. sp.pt.5.p.225.

A. auriculatum. Schkuhr fitic, 31,t.30. excl. synon.

Nephrodium acrostichoides. Mich fl. amer. 2. p. 267.

On rocks, in shady low places : New England to Carolina. 24. June-Aug. v. $v$. Resembles $N$. auriculatum.

*** Frondilus sulbipinnatis; inclusiis dimidiatis reniformilus.

3. A. frordibus pinnatis, pinnis lineari-lanceolatis pinnatifidis, laciniis oblongis obtusiusculis subintegerrimis ciliatis, soris marginalibus, stipite lævi.-Willd. sp. pl. 5. p.'24s.

A. thelypterioides. Swartz. synop. filic. 57.

Nephrodium thelypterioides. Mich. fl. amer. 2. p. 267.

Polypodium noveboracense. Sp. pl. 1552.

Icon. Schkuhr filic. t. 46 .

On river sides and the banks of ditches and ponds: $\mathrm{Ca}$ nada to Carolina. 2. July. v. v.

4. A. frondibus pinnatis, pinnis lineari-lanceolatis pinnatifidis glabris, lacinis ovatis acutis integerrimis, soris unarginalibus contiguis demum confluentibus. Willd. sp.pl. 5.p. 249.

Polypodium Thelypteris. Mant. 505 .

Polystichum Thelypteris. Roth fl. germ. 3. p. 77.

Acrostichum Thelypteris. Sp. pl. 1528.

Icon. Schkuhr filic. t. 52. Fl. dan. 760. Engl. bot. 1018.

In low grassy fields and swamps : Canada to Virginia. 4. July. v. v. It is very seldom found with fructi. fications; the leaves are smaller than in the preceding.

5. A. frondibus lanceolato-ovatis glabris pinnatis, pinnis subcordato-oblongis pinnatifidis, laciniis oblongis obtusis dentato-serratis, stipite paleaceo.-Willd. $s p$. pl. 5. p. 252.

Polypodium cristatum. Sp.pl. 1551.

Icon. Schkuhr filic. t.3\%. Afzel. act. holm. 1787. 6. 9.

novebaracense.

Thelypteris.

criskatum. 
Cailipteris. F.A. majusculum ; pinnis alternis, laciniis oblongis inæ. qualiter adpresso-serratis, fronde apice fructificante.

Polypodium Callipteris. Ehrh. leitr. 3. p. 77.

Polystichum cristatum. Roth germ. 3.p. 84.

lancastriense. $\gamma \cdot$ A. pinnis suboppositis, laciniis triangulari-ovatis acute serratis, stipite nudo.-Willd. sp. pl. 5. p. 261. Schkuhr filic, $t .41$.

In moist rocky situations: New York to Virginia. 4. $\mathrm{Jnly}, v, v$. Of middle size.

\section{***** Frondilus lipinnatis triplicato-pinnatisve; indusiis dimidiatis reniformibus.}

oltusum. T. A. frondibus bipinnatis, pinnulis oblongis obtusis superioribus coadunatis dentato-crenatis, rachi superne pubescente. Willd. sp. pl. 5. p. 254.

Polypodium obtusum. Swartz. synop. filic. 39. Schkuhr filic. 18.

Icon. Schkuhr filic. t. 21. ซ 43. $b$.

In clefts of rocks : Pensylvania and Virginia. 4. July. i. $v$. A small species, not above four or five inches high.

ackleatum. 7. A. frondibus bipinnatis, pinnulis ovatis subfalcatis acutis mucronato-serratis, basi superiore truncatis, inferiore abbreviato-cuneatis, superioribus fructificantibus, stipite rachique paleaceis. Willd.sp.pl.5.p.258.

Polypodium aculeatum. $S p . p l .1552$.

Polystichum aculeatum. Roth fl. germ. 3. p. 79.

Icon. Scinkuhr filic. t.39. \& 40. Bolt. filic. t. 56. Pluk. alin.t. 1s0.f. 1 .

In shady rocky places, on the Green mountains, Vermont. 4. Aug. v. v. The size of No. 5, of a shining and strong texture.

marginale. 8. A. frondibus bipinnatis, pinnulis oblongis obtusis decur. rentibus crenatis, crenis baseos profundioribus, soris marginalibus, stipite paleaceo. Willd. sp. pl. 5. p. 259 .

Polypodium marginale. $S p$. pl. 1522.

Nephrodium marginale. Mich. fl. amer. 2. p. 267.

Icon. Schkuhr filic, t. 45, b.

In rocky shady places: Canada to Carolina. 24. July. $v, v$ Resembles the following.

Filix mas. 9. A. frondibus bipinnatis, pinnulis oblongis obtusis serratis, serraturis muticis, soris costre mediæ approximatis, stipite rachique paleaceis. Willd. st). $p l .5$. p. 259. 
Polypodium Filix mas. Sp. pl. 1551.

Polystichum Filix mas. Roth. $f$. germ. 3. p. 82.

Icon. Schkuhr filic. t. 44. Bolt. filic. t. 24. Moris. hist. 3.

s. $14 . t .3 . f .6$.

ß. A. pinnulis eroso-serratis remotioribus.-Sclkulır filic. t. 45.

ercsum.

In shady pine forests: New Jersey to Virginia. $\beta$. in Carolina. 24. July. $v . v$. From two to three feet high; the leatlets ara move obtuse, and more frequently doubly serrated, than in the European plant.

10. A. frondibus bipinnatis, pinnulis linearibus pinnatifido- intermedium. incisis, laciniis apice submucronato-serratis, stipite paleaceo. Willd. sp. pl. 5. p. 262.

In Pensylvania. Muhlenterg. 24. + . Resembles the following in several respects very much.

11. A. frondibus bipinnatis, pinnulis oblongis decurrentibus confluentibus inciso-dentatis, laciniis mucronato-serratis, stipite paleaceo, indusiis glandulosis. Willd. $s p$. pl. 5. p. 262.

Polypodium spinulosum. Retz. prodr. $f l$. scand. n. 1295.

Polypodium cristatum. Hofm. $l$. germ. 2. p. s.

Polistichum spinosum. Roth. fl. germ. 3. p.91.

Icon. Schkuhr filic. t. 4S. Fl. dan. 707. Fr. Mill. icon.t. 2.f. 2.

In shady woods, in fertile soil : Pensylvania to Virginia. 4. July. v. $v$. A large species.

12. A. frondibus bipinnatis, pinnulis oblongis distinctis pinnatifido-incisis, laciniis mucronato serratis, stipite paleaceo, indusiis lævibus. IVilld. sp. pl. 5. p. 263.

Polypodium dilatatum. Hoffm. $\mathrm{fl}$. germ. 2 p. 7.

Polypodium aristatum. Villars $f$. delph. 3.p. 8-14.

Polypodium cristatum. Huds. angl. 457.

Polystichum multiflorum. Roth. fl. germ. 3.p. 87.

Nephrodium cristatum. Mich. fl. amer. 2. p. 269.

Icon. Schkuhr filic. t. 47. Bolt. filic. t. 23. Fr, Mill. ic. t. 2.f.t. Pluk.alm.t.1si.f.2.

In shady rocky woods: Pensylvania and Virginia. 24. July. $v . v$. Resembles $A$. Filix femina; it is larger, broader, and more compound in its leaves.

***** Frondilus lipinnatis triplicato-pinnatisve; indusiis lateralilus.

13. $\Lambda$ frondibus bipinnatis oblongo-lanceolatis, pinnulis oppositis oblongis obtusis serratis, inferioribus pinnatifi-

spinulosum.

dilatatum.

VOL. II. 
dis, rachi bulbifera, soris subrotundis. Willd. sp. pl. 5 . p. 275 .

Polypodium bulbiferum. St. pl. 1553.

Nephrodium bulbiferum. Mich. fl. amer. 2. p. 268.

Icon. Schkultr filic. t.57. Curn canad. 5. Moris. hist.3. s. 14. t. 3. f. 10.

In shady woods, about rocks : Canada to Pensylvania. 4. July. $v . v$. The leaf is narrow, and produces generally some small bulbs on its midrib.

sspicnioides. 14. A. frondibus bipinnatis, pinnulis lineari-lanceolatis inciso-serratıs, serraturis bi-s. tridentatis terminalibus acutioribus, soris oblongis lunatis. Willt. sp. pl. 5. t. 276 .

Nephrodium asplenioides. Mich. $f$ amer. 2. p. 268.

l'olypodium pensylvanicum. Muhlb. in litt.

Asplenium Athyrium. Sprengel, anleit. 3. p. 113.

Icon. Schkuhr filic. $t$. 75 .

In shady woods, on the banks of rivulets and ditches : New England to Carolina. 24. July. v. v. A tall species, very much resembling the following in many respects.

Filix femina. 15. A frondibus bipinnatis, pinnulis oblongo-lanceolatis inciso-serratis, serraturis bi- s. tridentatis acutiusculis, soris oblongis rectis. $\quad W$ illd.sp.pl.5.p. 270 .

A alpestre. Schkuhr filic p. 58.

Polypodium Filix femina. Sp. pl. 1551.

Polypodium molle. Schrob. spiril 7o.

Polypodium dentatum, incisum et trifidum. Hoffm. $l$. germ $2 p \tau$.

Aiburium molle, trifidum, ovatum et Filix femina. Rith. fl. germ. 3. p. $61-65$.

Icon. Srhkuhr filic. t. 58.59. ซ 60. Pluk. phytogr. t. 180.f.4. Moris. kist. 3. s.14.t.3.f. 8.

In low shady grounds: Canada to Virginia. 4. July. $v . v$.

angustum. 16. A. frondibus bipinnatis, pinnulis lanceolat is inciso-serratis, serraturis subbidentatis, in fima superiore elongata, soris oblongis sublunatis. Willd. sp. pl. 5 p. 277.

Nephrodium Filix femina. Mich. $f$. amer 2. p. 208.

In shady low wonds: Canada to Pensylvania. 4 . July. $v$. $v$. Resembles the preceding.

frunctilolum. 17. A. frondibus bipinnatis, pinnulis decurrentibus ovatooblongis pimnatitidis, laciniis subquadridentatis, soro 
solitarin instructis, rachibus pubescentibus, stipite gla. bro. IVilld. sp. pl. 5. p. 279 .

Nephrodium punctilobulum. Mich. $f$. amer. 2. p. 268.

In shady woods, on the banks of small rivulets : Canada to Virginia. 4. July, v,v. From two to three feet high.

13. A. frondibus bipinnatis, pinnulis decurrentibus ovatooblongis pinnatifidis, laciniis dentatis, soris sparsis. Willd. st.pl. 5.p. 279.

In Pensylvania. Muhlenberg. $\psi$. + . Not much above a span high; fructification small.

19. A. frondibus bipinnatis, pinnulis ovatis decurrentibus dentatis, soris solitariis juxta dentes pinnularum. IFilld.

tenuse. sp.pl. 5. p. 279 .

Nephrodium tenue. Mich. fl. amer. 2. p. 269.

In clefts of rocks : Canada to Virginia. 4 . July. $v, v$. A small species; fructifications large.

20. A. frondibus bipinnatis, pinnulis subtus paleaceo-setosis oblongis obtusis crenatis coadunatis, soris demum confluentibus. Willd. sp.pl.5.p. 282.

Nephrodium rufidulum. Nich. $f$. amer. 2. p. 269.

On rocks: Canada to Pensylvania. 4. July. $v$. 2 . A small species, growing in large tufts; it resembles Woodsia hyperborea very mucl.

725. ONOCLEA. Willd. in mag. ges.naturf. fr. $x$. lerl. $1809 . p .160$.

1. O. frondibus sterilibus pinnatis, pinnis lanceolatis acutis sensibilis. inciso-dentatis, superioribus coadunatis, fructificantibus bipinnatis, pinnulis recurvato-globosis glabris, rachi glabra.-W illd. sp. pl. 5. p. 287 .

Icon. Schkuhr filic. t. 102. Pluk. mant. t. 404.f. 2. Breyn. cent. t. $56 . f$. B.

In low pastures and open woods: New Iork to Florida. 4. July. $v . v$. About a foot high; leaves pale green.

2. O. frondibus sterilibus pinnatis, pinnis oppositis pinnati- oltusilolats. fidis, lobis rotundatis : ipferioribus sensim minoribus, superioribus coadunatis, fructificantibus bipinnatis, pionulis incisis recurvato-globosis villosis, rachi squanosa.-Schkuhr filic. p. y5. t 103.

In low grounds: Pensylvania. 4 . July. v. v. Not so large as the preceding. 
726. STRUTHIOPTERIS. Willd. in mag. ges, nat. fr. $x$. lerl. $1809 \cdot$. p. 160.

pensylvanica. 1. S. frondibus sterilibus bipinnatifidis, laciniis integerrimis obtusis, infima elongata acuta. Willd. sp. pl.5. p. 259 .

Onoclea nodulosa. Schkukr filic. p. 96. t. 104.

In Pensylvania. Muhlenberg. 24. +. Resembles S. germanica.

\section{ASPLENIUM, Swartz. synop. filic.p.4.}

rhivophyllum. 1. A. frondibus lancenlatis stipitatis subcrenatis, basi auriculato-cordatis, apice longissimo lineari-filiforme radicante. IVilld. sp.pl. 5. p. 305.

Ic n. Pluk. alm. t. 105.f.3. Petiv. gasoph. t. 105.f.7. Moris. hist. 3. s. 14. t. $5 . f .14$.

On wet shady rocks: Canada to Carolina. 24. July. v. v. This fern is highly ornamental to rock-works, and very singular in its striking root at the elongated points of the leaves.

angustifolium.

eleneum.

welanocaulon.
2. A. frondibus pimatis, pinnis alternis, superioribus subo:positis, lineari-lanceolatis subrepandis, basi superiore truacatis, inferiore leviter rotundatis. Willd. sp.pl.5. p. 313 .

A. pycnocarpon. Sprengel. anleit.3.p. 112.

Icon. Schhuhr filic. 1. 67 . E 69. Moris. hist. 3. s. 1.4. t. 2. f. 25.

In shady wools, on the banks of rivers: western parts of New York and Pensylvania. 4. July. $\cdots v$. A very elegant fern about a foot high.

3. A. frondibus pinnatis, pinnis sessilibus lanceolatis serrulatis basi cordatis, sursum auriculatis. Willd. sp.pl. 5 . p.329.

A. polypodioides. Swartz. synop. filic. 79. E 272 .

A. trichommoides, Mich. fl. amer. 2.p. 265.

Acrostichnm platyneuron. Sp. pl.1527. excl. synon.

Icon. Schkuhr, filic. t. 73. Plith. alm. t. 287. f. 2. et t. 89. f 8. Moris. hist. 3. s. 14.t. 2.f. 12 .

In clefts of rocks: New England to Carolina. 24.July. $v . v$. A smail species.

4. A. frondibus pinnatis, pinnis subrotundis obtusis crenatis basi cuneatis, stipite discolore. Willd. enum. 1072 . Willd.sp.pl. 5. p. 332. 
A. trichomanes. Mich. fl. amer. 2.p. 264.

On rocks: Canada to Carolina. 24. July. v. v. Very small : stem polished, black.

5. A. frondibus pinnatis, pinnis sessilibus lanceolatis acnminatis profunde pinnatifidis, laciniis oblongis obtusis obtuse-serratis, soris paralielis denum confluentibus. -IVilld. sp. pl. 5. p. 336.

A. acrosticboides. Swartz. synop. filic. S2. Eా $2 ; 5$. Icon. Schkuhr filic. t. 70. $b$.

In shady woods on the sides of rivulets : Pensylvania to Carolina. 24. July. v. v. Resembles Astidium Thelypteris very much; it is from eighteen inches to two feet high.

6. A. frondibus basi bipinnatis, apice simpliciter pinnatis, pinuulis rhombeo-oblongis obtusis, apice obtuse denti. culatis. Willd. sp.pl. 5. p.341.

Icon. Scinkuler filic. t. so. $i$. Fl. dan. 190.

In clefts of rocks: New York to Carolina. 24. July. $v . v$. The American plant is very small, scarcely ever exceeding an inch or two in height.

7. A. frondibus glabris bipinnatis, pinnulis lanceolatis pinnatifidis, laciniis tri-vel bidentatis.-IVilld. sp. pl. 5 . p. 342 .

A. Adiantum nigrum. Nich.fl. amer.2. p. 265.

In clefts of rocks, on the mountains of Virginia and $\mathrm{Ca}$ rolina. 4. July. $v$. $v$. A much smaller plant than A. nigrum, to which it has some resemblance.

72S. SCOLOPENDRIUM. Sinith act.taur. 5.p. 410.

$$
\text { t. } 9 . f .2 \text {. }
$$

1. S. frondibus lato-lanceolatis basi cordatis, stipite paleaceo. IVill. sp.pl.5.p. 348.

Asplenium Scolopendrium. Sp. pl. 1537.

Icon. Schluihr filic. t. 83. Pluk. phytogr. t.248.f.1.

In shady woods, among loose rocks in the western parts New York, near Onondago, on the plantations of J. Geddis, Esq. 24. July. v. $v$. This species I have seen in no other place but that here mentioned, neither have I had any information of its having been found in any other part of North America.

Ruta mura. ria.

montanum.

thelypierioides.

Montanum.

\section{officinarum.}




\section{PTERIS. Gen.pl. 1626.}

pedata.

1. P. frondibus profundissime quinquelobo-palmatis, lobis pinnatifidis, laciniis lineari-lanceolatis acutis, infima lobi intermedii utrinque pinnatifida, lobo intermedio basi longissime cuneato, sinubus acutis.-Willd. sp. pl. 5. p. $35 \mathrm{~S}$

Icon. Schkuhr filic. t. 100. Plum. amer t. 34. fil.t. 152. Petiv. filic. t. 8.f.12. Pluk. alm. t.2ø6.f.5.

On rocks: Virginia. 4. July, v.s. About six inches high.

atropurpurea. 2. P. frondihus pinnatis, pinnis inferioribus ternatis pinnati ve lancerratis obtusis, basi obtuse truncatis subcordative. Willd.sp.pl. 5.p. 375.

venosa. $\quad \alpha$. P. pinnulis sutrus venosis, stipite angulato.

Icon. Sihkuhr fiic. t. 101. Pluk. mant. t.349.f. 1.

punctata. $\quad \beta$.P. pinnulis subius punctatis, stipite terete.

P. spiculata. Schhuhr filic. $t$. 100.

In cleft of rocks : Pensylvania to Carolina. 24. July. $v . v$. About a span high; grayish-green with dark purple stems.

gracilis.

3. P. frondibus pinnatis, pinnis lanceolatis obtusis alternis sessilibus, inferioribus pinnatifidis, fertilibus integerrimis, sterilibus crenatis rotundato-obtusis. Willd. $s p$. pl. 5. p. 376 .

On rocks in Canada. Michaux. 4. July. v. s. Not above four inches high; stems yellowish-green, smooth and shining.

caudata.

4. P. fronde pinnato-tripartita, ramis sterilibus bipinnatis, pinnulis linearibus elongatis obtusis integerrimis, inferioribus bipinnatifidis, fructificantibus pinnatis, pinnis remotiusculis inferioribus basi pinnatifido-dentatis.-Willd. sp. pl. 5. p.401.

Icon. Jacq. ic. rar. 3. t. 645. Plum. amer. t. 22. filic. t. 29 .

In shady stony woods, on the side of rivulets: Pensylvania to Carolina. 4. Aug. v. v.

aquilina.

5. P. fronde pinnato-tripartita, ramis sterilibus bipinnatis, pinnis lineari-lanceolatis obtusis pinnatifido-dentatis, fructificantibus pinnatis, pinnulis pinnatifidis, laciusiis acutiusculis, omnibus ciliatis.-Willd. sp. pl. 5. p. 402.

Icon. Schkuhr filic. t. 95. 96. b. Plum. filic. $\iota$. A. f. 1 . In dry barren woods: Canada to Florida. 4. Aug. 
$v, v$. It deviates in some respects from the European p'ant, but is not sufficiently distinct to form a separate species, as it is well known how much the European species itself assumes different appearances in different soils.

730. VITTARIA. Smith act. taur. 5. p.4i3.t. 9.f.5.

1. V. frondibus linea ihus longissimis pendulis, soris solilineabs. tariis intra marginalibus. Willd.sp.pl. 5. p.404.

V. angustifions. Mich. Al. amer. 2. p. 201.

I teris lineata. $S p . p l .1530$.

Icon. Schkuhr filic. t. 101. b. Plum. amer. t. 41. filic. t. 143. Petiv. filic. t. 14.f. 3.

On the banks of the rivulet Aisa-hatcha, Florida. Michaux. $4 .+$. The leaves resemble those of a commor grass.

\section{BLECHNUM. Gen. pl. 1627.}

1. B. frondibus sterilibus pinnatifidis, laciniis lanceolatis boreals obtusiusculis parallelis, fructiferis pinnatis, pinnis linearibus acuminatis. IVilld. sp.pl. 5. p. 408.

B. Spicant. Roth.fl. germ. 3. p. 44.

Onoclea Spicant. Holfm.fl. germ. 2. p.11.

Osmunda Spicant. Sp. pl. 1522.

Icon. Schkuhr,filic. t. 110. Fl.dan.99. Bolt. filic. 1.6. Moris. hist. 3. s. 14.t. 2.f. 23.

On the north-wet coast. M. Lewis. 4. Aug. v.s. in Herb. Lewis.

2. B. frondibus pinnatis, pinnis lanceolatis utrinque attenuatis basi decurrentibus argute serratis. Willd. sp. pl.5. $p 411$.

On the banks of the rivulet Aisa-hatcha, Florida. Michaux. 2f. +.

732. WOODWARDIA. Smith act. taur. 5. p.411.

$$
\text { t. } 9 . f .5 \text {. }
$$

1. W. frondibus sterilibus pinnatifidis, laciniis lanceolatis repandis tenuissime serrulatis, fructiferis pinnatis, pinnis linearibus integerrimis acutis. Willd. sp. pl. 5. p. 416.

W. angustifolia. Smith act. taur. 5. p. 411.

W. foridana.. Schkuhr filic. p. 103. t. 111.

Onoclea nodulosa. Mich. fl. amer. 2. p. 272. Swartz. synop. filic. $11 \mathrm{l}$. 
Acrostichum areolatum. Sp. pl. 1526.

Osmunda caroliniara. Walt. fl. car. 257.

Icon. Schkuhr l.c. Pluk. phytogr. t.399.f. 1. Moris. hist.3. s. 14.t. 2.f. 24.

In cedar and cypress-swamps: New Jersey to Florida. 4. Aug. v. v. About a foot high.

virginica.

2. W. frondibus glaberrimis pinnatis, pinnis sessilibus lanceolatis pinnatifidis, laciuiis oblongis obtusis crenulatis, fructiferis elongati, stipite glabro tereti--Willd. sp. pl. 5. p. 418.

W. Banisteriana. Mich. fl. amer. 2. p. 263.

Blechnum virginicum. Nhant.307.

Blechnum carolinianum. IVult. fl. car. 257.

Icon. Pluk. alm. t. 179.f. 2.

In swamps and shady woods: Virginia and Carolina. 4. July. $v \cdot v$. Above a foot high.

thelypterioides.

3. WV. frondibus pinnatis, piunis sessilibus basi villosis lineari-lanceolatis pinnatifidis, laciniis sterilium oblongis obtusiusculis, fertilium abbreviato-triangularibus acutis, ommibus integerrimis, stipite pubescente angulato.

In sandy swamps: South Carolina, near Charlestown. 4. July. $v \cdot v$. Resembles the preceding, but is not half the size.

\section{ヶ33. ADJANTUM. Gen.pl. 1633.}

pedatum.

1. A. fronde pedata, ramis pinnatis, pinnis dimidiatis oblongis lunatis margine superiore incisis, laciniis sterilibus dentatis, fertilibus integerrimis, soris linearibus, stipite glabro. IV illd sp. pl. 5. p. 438.

Icon. Schkuhr filic. t. 115. Pluk. alm, t. 124. f. 2. Corn. canad. . 6.

In shady woods: Canada to Virginia. 4. July. v. v. A very elegant fern.

\section{CHEILANTHES. Swartz. synop. filic. p. 5.}

vestita.

1. C. frondiluns bipinnatis utring e hirtis, pinnulis pinnatifidis, Jaciniis oblongis cobtusis integerrimis, stipite rachibusqu hirtis. Willd sp.pl. 5.p.458.

Adiantum vestitum. Sprengel anleit.3. p. 122. Aspidium lanosum. Swarls. synoif filic. p. 58. Nep rodium lanosun. Mich.fl. amer.2. p. 270. Icon. Schkuhr filic, $t .124$. 
On rocks : Pensylvania to Virginia and on the Missouri. 4. July. $v \cdot v$. A handsome very small fern, covered with long brownish hair.

2. C. frondibus triplicato-pinnatis, pinnulis ovalibus distincdeallata. tis apice crenatis aut emargiuatis subtus dealbatis.

On rocks, on the banks of the Missouri. 2!. July. v.s. A very delicate small ferm, very much resembling C. tenuifolia.

\section{DICK SONIA. L'Herit. sert. angl. 30.}

1. D. frondibus bipinnatis, pinnulis oblongo-lanceolatis pin- pilosiuscula natifidis, laciniis margine superiore inciso-dentatis, rachibus pilosiusculis. Willd. sp. pl. 5. p.434.

D. pubescens. Schkuhr filic. 1. 125.t.131.

Polypodium pilosiusculum. Muhll. in litt.

In shady woods, among recks : Pensylvania and Virginia. 4. v. v. A foot or more high, resembling Aspidium dilatatuni.

736. HYMENOPHYLLUM. Smith act. taur. 5. p. 418.

1. H. frondibus pinnatis, pinnis infinis majoribus, supeciliatum. rioribus sensim minoribus pinnatifidis, laciniis linearibus obtusis bifidis ciliatis, venis hirtis, rachi stipiteque alatis ciliatis. Willd. sp. pl. 5. p. 519.

Trichomanes ciliatum. Swartz prodr. 136.

In shady forests, on the trunks of old trees : Pensylva. nia and Virginia. 4. v. v.

\section{HYDROPTERIDES.}

737. ISOETES. Gen. pl. 1620.

1. I. frondibus subulatis semiteretibus. Willd. $s p . p l$. 5. lacustris. p. 534.

Icon. Schkuhr filic. t. 173. Fl. dan. 191. Dill. musc. t. $80 . f .1$.

On rocks, on the botton of rivers: New York, in the Oswego river, near the Falls. 4 . v. v. This singular plant, resembling a zoophyte, is about two inches high. 


\section{SALVINIA. Gen. pl. 1617.}

ratens.

1. S. foliis ellipticis obtusis supra fasciculato-setosis, petiolis pilosis, fructibus subsessilibus aggregatis. IVilld.sp. pl. 5. p. 536.

Marsilea natans. $S p . p l .1562$.

Icon. Schkuhr filic, t. 173. Lam. illust. 863.

Floating, like Lemna, on the surface of stagnant waters : in several of the small lakes in the western parts of New York and Canada. $\odot . v . v$.

739. AZOLLA. Lam. encycl. 1. p.340.

caroliniana. 1. A. foliis imbricatis ovato-oblongis obtusis patentibus subtus rubris.-Willd. sp.pl.5. p.541.

Floating on the waters of Lake Ontario. ๑. v, $v$. Resembles a floating moss or Jungermannia. 


\section{TABLE}

OF

\section{ANOMALOLS FLOWERS.}

\section{MONANDRIA. MONOGYNIA.}

Kyllingia. 47. Cyperus. 50. Scirpus. 54. Thalia. 584. Canna. 585. ORCHIDEA omnes 585-594.

MONANDRIA. DIGYNIA.

Agrostis. 64. Saccharnm. 73. Uniola. 84. A!chemilla. 112.

\section{DIANDRIA. MONOGYNIA.}

Salicornia. 2. Boerhavia. 31. Kyllingia. 46. Anychia. 176. Lepidium. 435. Cypripedium. 594. Vallisneria. 602. Salix. 608.

\section{DIANDRIA. DIGYNIA.}

Podostemum. 3. Muhlenbergia. 61. Anthoxanthum. 65. Holcus 78. Festuca. 83. Salix. 608.

\section{TRIANDRIA. MONOGYNIA.}

Galium. 102. Anychia. 176. Prinos. 220. Brodiæa. 223. Juncus. 237. Melothria. 444. Sicyos. 444. Momordica. 444.

\section{TRIANDRIA. DIGYNIA.}

Salix. 608. Comptonia. 635.

\section{'TR!ANDRIA. TRIGYNIA.}

Amaranthus, 206. Triglochin. 247. Phyllanthus. 443. Polygonum. 209. Tragia. 604. Juniperus. 646. 


\section{TETRANDRIA. MONOGYNIA.}

Gratiola. 12. Elytraria. 13. Monarda. 16. Collinsonia. 20. Anychia, 176. Prinos. 220. Smilacina. 233. Clarckia. 260. Pothos. 308. Class. XIII. DIDYNAMIIA. 401 -431. Diotis. 602. Alnus. 622.

\section{TETRANDRIA. DIGYNIA.}

Gentiana. 185. Myrica. 620. Juglans. 636. Morus.639 Cupressus. 645. Thuya. 646.

\section{TETRANDRIA. TETRAGYNIA.}

Proserpinaca. 92. Myriophyllunı. 274.

\section{PENTANDRIA. MONOGYNIA.}

Catalpa. 10. Cornus. 107. Echites. 178. Gonolobium. 178. Apocynum. 179. Asclepias. 180. Ceropegia. 184. Amsonia. 184. Gelseminum. 184. Gentiana. 185. Prinos. 220. Polygonum. 269. Cassia. 307. Passiflora. 444. Illecebrum. 445. Galax. 446. Lobelia. 446. Petalostemum. 461. Class. XVII. SYNGENESIA. $491-582$.

\section{PENTANDRIA. DIGYNIA.}

Polygonum. 270. Seleranthus. 315. Iresine. 445. Salix. 605. Quercus. 625.

\section{PENTANDRIA. TRIGYNIA.}

Polyggonum. 270. Arenaria. 319. Hypezicum. 37s. Pas. siftora. 444 .

\section{PENTANDRIA. PENTAGYNIA.}

Spergula. 320. Cerastium. 320.

\section{HEXANDRIA. MONOGYNIA.}

Commelina. 31. Trientalis. 252. Laurus. 274. Lythrum. 334. Class. XIV. TETRADYNAMIA. 432-441, Corydalis. 462 . Fumaria. 463 . Aristolochia. 596.

$$
\text { HEXANDRIA. DIGYNJA. }
$$

Folygonum. 271.

HEXANDRIA. TRIGYNIA.

Lechea. 90. 
TABLE OF ANOMALOUS TLOWERS.

HEXANDRIA. TETRAGYNIA. Myriophyllum. 274.

HEPTANDRIA. MONOGYNIA. Sabbatia. 137 .

HEPTANDRIA. TRIGYNIA.

Polygonum. 271.

HEPTANDRIA. TETRAGYNIA. Saururus. 252.

OCTANDRIA. MONOGYNIA.

Esculus. 253. Gaultheria. 252. Vaccinium. 284. Mo. notropa. 303. Halesia. 449. Polygala. 464. Populus. 618 .

OCTANDRIA. DIGYNIA.

Polygonum. 271. Corylus 634.

OCTANDRIA. TETRAGYNIA.

Myriophyllum. 274.

OCTANDRIA. PENTAGYNIA.

Sedum. 323.

ENNEANDRIA. MONOGYNIA. Acer. 267 .

ENNEANDRIA. TRIGYNIA.

Lechea. 90. Elodea. 379.

DECANDRIA. MONOGYNIA.

Sabbatia. 137. Azalea. 151. Asclepias. 150. Menziesia. 264. Jeffersonia. 208. I ythrum. 334. Portulacca. 365. Galax. 446. Geranium 448. Halesia. 449. Styrax. 450. Class. XVI. DIADELPHIA. 460-490. Betula. 620. Carpinus. 623. Ostrya. 623.

\section{DECANDRIA. DIGYNIA.}

Chrysosplenium. 269. Fagus. 624. Quercus, 625.

\section{DECANDRIA. TRIGYNIA.}

Jatropha. 603. Croton. 603. Acalypha. 604. Castanea. 624. 
DECANDRIA. PENTAGYNIA.

Drosera. 210. Portulacca. 365. Geranium. 448.

DODECANDRIA. MONOGYNIA.

Sabbatia. 137. Decumaria. 328. Lythrum. 334. $\mathrm{Cu}-$ phea. 335. Rejaria. 362. Hudsonia. 364. Talinum. 365. Portulacca. 365. Cleome. 441. Halesia. 449. Styrax. 450. Asarum. 596. Betula. 620.

DODECANDRIA. DIGYNIA.

Agrimonia. 335. Callignnum. 370. Fagus. 624.

DODECANDRIA. TRIGYNIA.

Datisca. 370. Menispermum. 371. Elodea. 379. Croton. 603. Acalypha. 604. Euphorbia. 605.

POLYANDRIA. MONOGYNIA.

Jeffersonia. 268. Class. XV. MONADELPHIA.. Polyandria. 449. -456. Asarum. 596. Taxus 647.

POLYANDRIA. DIGYNIA.

Fothergilla. 335.

POLYANDRIA. TRIGYNIA.

Ricinus 602. Juglans. 636. Zamia. 648.

POLYANDRIA. TETRAGYNIA.

Myriophyllum. 274.

POLYANDRIA. POLYGYNIA.

Zostera. 2.

DIDYNAMIA. GYMNOSPERMIA.

Lycopus. 16. Monarda. 16. Salvia. 19. Collinsonia. 20.

DIDYNAMIA. ANGIOSPERMIA.

Catalpa. 10. Gratiola. 12. Elytraria. 13.

MONADELPHIA. TRIANDRIA.

Sisyrinchium. 31. Pistia. 268.

MONADELPHIA. PENTANDRIA.

Anagallis. 135. Lysimachia. 135. Linum. 210. Petalo. stemum. 461. 
MONADELPHIA. OCTANDRIA.

Cardiospermum. 273. Polygala. 464.

MONADELPHIA. DECANDRIA.

Acacia. 305. Schrankia. 305. Oxalis. 322. Class. XVI.

DIADELPHIA. Decandria. 466-490.

MONADELPHIA. POLYANDRIA.

Pinus. 639.

DIADELPHIA. DECANDRIA.

Podalyria. 30\%. Cercis. 308. Virgilia. 309.

POLYADELPHIA. POLYANDRIA.

Ascyrum. 373. Hypericum. 374. Elodea. 379. Hopea. 451 .

SYNGENESIA. MONOGAMIA.

Solanum. 156. Impatiens. 171. Viola. 171. Melothria.

444. Momordica. 444. Sicyos. 444. Lobelia. 446.

GYNANDRIA. PENTANDRIA.

Passiflora. 444 .

GINANDRIA. HEXANDRIA.

Cleonie. 4.41 .

GYNANDRIA. POLYANDRIA.

Zostera. 2. Pothos. 398. Cilla. 399. Arum. 399.

MONOECIA. MONANDRIA.

Zostera. 2. Caulinia. 2. Salicornia. 2. Hippuris 3. Callitriche. 3. Zannichellia. 4. Chara. 4. Calla. 399. Arum. 309. Liquidambar. 635. Platanus. 635.

MONOECIA. DIANDRIA.

Podostemum. 3. Frasinus. 8. Lernna. 22.

MIONOECIA. TRIANDRIA.

Sparganium. 33. Typha. 34. Carex. 34. Scleria. 45. Zea. 46. Milium. 63. Andropogon. 74. Holcus. 7s. Surghum. 78. Chloris. 87. Rotiboellia. 88. Tripsacum. 8s. Eriocaulon. 91. Empetrum. 93. Amarmthus. 206. Phyllanthus. 443. Melothria. 444. Momordica 444. Si. cyos. 44. Tragia. 604. Comptonia. 635. 
MONOECIA. TETRANDRIA.

Serpicula. 33. Boehmeria, 112. Untica. 112. Parietaria. 114. Planera. 115. Pachysandra. 117. Myriophyllum. 271. Alnus. 622. Morus, 639.

\section{MONOECIA. PENTANDRIA.}

Nyssa. 177. Panax. 191. Atriplex. 199. Celtis. 200. Rhus. 204. Crotonopsis. 206. Amaranthus. 206. Zantorrhiza. 212. Schisandra. 212. Iva. 580. Ambrosia. 580. Xanthium. 581. Fagus. 624. Quercus. 625.

\section{MONOECIA. HEXANDRIA.}

Zizania. 60. Eriocaulon. 91. Planera. 115. Celtis. 200. Melanthium. 240. Veratrum. 242. Myriophyllum. 274. Betula. 620. Quercus. 625.

\section{MONOECIA. OCTANDRIA.}

Acer, 265.

\section{MONOECIA. POLYANDRIA.}

Sparganium. 33. Acer. 267. Myriophyllum. 274. Laurus. 275. Acacia. 305. Schrankia. 305. Chrysobalanus. 329. Ceratophyllum. 370. Sagittaria. 395. Pothos. 398. Calla. 399. Arum. 399. 1etula. 620 Carpinus. 623. Ostrya. 623. Fagus. 624. Castanea. 624. Quercus. 625. Corylus. 634. Juglans. 636. Liquidambar. 635. Platanus. 635.

\section{MONOECIA- MONADELPHIA.}

Podostenum. 3. Phyllanthus. 443. Melothria. 444. Momordica. 444. Sicyos. 444. Ricinus. 602. Jatropha. 603. Croton. 603. Acalypha. 604. Euphorbia. 605. Stillingia. 605. Platanus. 635. Pinus. 639. Cupressus. 645. I huya. 646.

\section{MONOECIA. SYNGENESIA.}

Schisandra. 212. Melothria. 444. Momordica. 444. Sicyos. 444.

\section{DIOECIA. MONANDRIA.}

Najas. 602. Salix. 608. 


\section{DIOECIA. DIANDRIA.}

Olea. 7. Fraxinus. 8. Ceratiola. 21. Borya. 22. Vallisneria. 602. Salix. 605.

\section{DIOECIA. TRIANDRIA.}

Carex. 34. Empetrum. 93. Zanthoxylum. 209. Prinos. 220. Salix. 608.

DIOECIA. TETRANDRIA.

Urtica. 112. Viscum. 114. Elæagnus. 114. Hippophïe. 115. Ilex. 117. Prinos. 220. Myrica. 620.

\section{DIOECIA. PENTANDRIA.}

Caprifolium. 161. Vitis. 169. Nyssa. 177. Hamiltonia 178. Zizyphus. 188. Panax. 191. Atriplex. 199. Cannabis. 199. Humulus. 199. Celtis. 200. Rhus. 204. Acnida. 208. Zanthoxylum. 209. Prinos. 220. Iresine. 445. Salix. 608 .

\section{DIOECIA. HEXANDRIA.}

Prinos. 220. Gleditschia. 221. Chamærops. 239. Rumex. 249. Smilax. 249. Dioscorea, 251. Laurus. 275.

DIOECIA. OCTANDRIA.

Diosyrus. 265. Acer. 26s. Polygonum. 272. Populus. 618.

DIOECIA. DECANDRIA.

Gymnocladus. 304 .

DIOECIA. DODECANDRIA. Calligonum. 370. Datisca. 370. Menispermum. 370.

DIOECIA. ICOSANDRIA.

Spiræa. 343. Rubus. 346.

DIOECIA. POLYYNDRIA.

Menispermum. 370. Clematis. 384. Thalictrum. 388. Sagittaria. 395. Arum. 399. Populus. 618. Zamia.648.

\section{DIOECIA. MONADELPHIA.}

Iresine. 445. Sida. 453. Juniperus. 646. Taxus. 646. 


\section{POLYGAMIA. MONOECIA.}

Fraxinus. 8. Andropogon. 74. Atheropogon. 75. Holcus. 78. Sorghum. 78. Chloris. 87. Parietaria. 114. Planera. 115. Ilex. 117. Atriplex. 199. Celtis. 200. Rhus. 204. Zanthorhiza. 212. Melanthium. 240. Ve- ratrum. 242. Asculus. 254. Acer. 265. Acacia. 305. Schrankia. 305.

\section{POLYGAMIA. DICECIA.}

Fraxinus. 8. Empetrum. 93. Nyssa. 177. Hamiltonia. 178. Panax. 191. Gleditschia.221. Chamærops. 239. Diospyros. 265. 


\title{
LATIN AND ENGLISH
}

\author{
I N D E X.
}

\begin{tabular}{|c|c|c|}
\hline A cer. & Maple-tree. & 265 \\
\hline Waccharinnm. & Sugar-tree. & 266 \\
\hline _ striatum. & $\begin{array}{l}\text { Fowering Ash. Box Elder. } \\
\text { Moose-wood. }\end{array}$ & 267 \\
\hline Achillea. & Milfoil. & 562 \\
\hline $\begin{array}{l}\text { Millefolium. } \\
\text { Ptarmica. }\end{array}$ & Yarrow. & 563 \\
\hline cnida. & Sneeze-wort. & 562 \\
\hline $\begin{array}{l}\text { Acnida. } \\
\text { Aconitum. }\end{array}$ & River.hemp. & 208 \\
\hline $\begin{array}{l}\text { Aconitum. } \\
\text { Acorus. }\end{array}$ & $\begin{array}{l}\text { Wolfs-brane. Monk's-hood. } \\
\text { Suceet-flag. }\end{array}$ & 372 \\
\hline Acrostichum. & Full-fern. & 658 \\
\hline Actæa. & $\begin{array}{l}\text { Herb Christopher. Banelerry. } \\
\text { Red and White Cohosh. }\end{array}$ & 366 \\
\hline Adiantum. & Maiden-hair. & 733 \\
\hline Esculus. & $\begin{array}{l}\text { Horse Chesnut. Buck's-eye } \\
\text { Tree. }\end{array}$ & 254 \\
\hline Agave. & Sweet Virginian Aloe. & 226 \\
\hline Agrimonia. & Agrimony. & 335 \\
\hline Agrostemma. & Corn Cockle. & 321 \\
\hline Agrostis. & Bent-grass. & 63 \\
\hline Aira. & Hair-grass. & 76 \\
\hline Ajuga. & Bugle. Ground Pine. & 404 \\
\hline Alchemilla. & Ladies' Mantle. & 112 \\
\hline - Aphanes. & Parsley-piert. & 112 \\
\hline Aletris. & Star-wort. Devil's-lit. & 225 \\
\hline Alisma. & Water Planiain. & 352 \\
\hline Allium. & Garlic. & 222 \\
\hline Alnus. & Alder. & 622 \\
\hline Alopecurus. & $\begin{array}{c}\text { Fox-tail grass. } \\
\times 2\end{array}$ & b5 \\
\hline
\end{tabular}


Alyssum.

Amaranthus.

Mad-wort.

Amaranth.

Blitum.

Blite.

hypochondriacus. Prince's Feather.

Amaryllis. Atamasco Lily.

207

Ambrosia.

Hog- or Iron-u'eed.

222

Ammi.

Ammyrsine.

Amorpha.

Anagallis.

Andromeda.

Bishop's-weed.

580

Sand-myrtle.

Bastard Indigo.

192

301

466

Pimpernel.

135

Bastard Huckle-lerry.

290

Sorrel-tree.

295

Wild Rosemary.

Man's Beard.

291

Andropogon.

Anemone. Wind-flower.

74

Anemone.

Anthemis.

Chamomile.

May-weed.

Anthoxanthus.

Antirrhinum.

Spring-or Sweet-grass.

562

562

Snap-dragon.

Fluellin.

Toad-flax.

Calf's Snout.

421

Apocynum.

Aquilegia.

Arabis.

Columbine. Honey-suckle.

422

Aralia nudicaulis.

Wall-cress.

Sarsaparilla.

Poison Elder.

Angelica-tree.

179

- hispida.

Spikenard.

372

436

209

209

209

Strawlerry-tree.

209

Arbutus.

Uva ursi.

Arctium.

Arenaria.

Aristolochia.

Bear-berry. Saca-commis.

282

283

Eurdock. Clot-bur.

505

Sand-wort.

Birth-wort.

Virginia Snake-root.

Artemisia.

Wormwood.

Tarragon.

Mug-wort.

Arum.

Wake-Rolin.

Green Dragon.

Arundo.

Reed-grass.

Sea-mat-grass.

Asarum.

Asarabacca.

Wild Ginger. Colt's Foot. $\quad 596$

Asclepias.

canadense.

Swallow-wort. 
LATIN AND ENGLISH INDEX.

Asclepias tuberosa.

Ascyrum Crux.

Aspidium.

Asplenium.

Ipecacuanha. Butterfly-

flower.

183

St. Andrew's Cross. $\quad 373$

Shield Fern.

660

Spleen-wort. . 666

Wall-Rue. $\quad 667$

Star-wort. $\quad 532$

Aster.

Astragalus.

Atriplex.

Milk Vetch.

472

Orache.

199

Ont-grass. Oats.

Upright or American Honeysuckle.

Azalea.

Baccharis.

Batschia.

Bejaria.

Bellis.

Berberis.

Betula.

- lenta.

Bidens.

Bignonia.

Blechnum.

Blitum.

Botrychium.

Brassica.

Briza.

Bromus.

Buphthalmum.

Cactus.

Cakile.

Callitriche.

Caltha.

Calycanthus.

Campanula.

Canna.

Cannabis.

Caprifolium.

Cardamine.

Cardiospermum.

Carduus.

Carex.

Carpinus.

Groundsel-tree.

Puccoon. Indian Paint. 132

Catch-fly-lush. $\quad 362$

Daisy.

526

Berlerry. Pipperidge. 219

Birch-tree.

620

Mountain-Mahogany. 621

Bur-marygold.

Trumpet-flower.

Ril Fern.

Strawlerry-blite.

Rattle Snake Fern。 $\quad 655$

Cablage.

Quaking-grass.

Brome.grass.

Ox-eye.

\section{6}

419

669

4

438

82

8.5

563

Prickly-pear. Indian Fig. 327 Sea-rocket. $\quad 434$

Water Star-wort. 3

Marsh-marygold. $\quad 389$

Carolina Allspice. Su'eetscented shrub. . $\quad 357$

Bell-flower. $\quad 159$

Indian Reed or Shot. $\quad 585$

Hemp. $\quad 399$

Honey-suckle. Woolline. 160

Ladies' Smock. $\quad 439$

Heart-seed. 273

Thistle. $\quad 507$

Sedge. $\quad 34$

Hornleant-tree. $\quad 623$ 
Cassia nictitans.

Castanea.

Catalpa. pumila.

Caulsphyllum.

Ceanuthus.

Celastrus.

Celtis.

Cenchrus.

Centalurea.

Cyanus.

m.n- solstitialis.

Centunculus.

Cephalanthus.

Cerastium.

Ceratophyllum.

Cercis.

Chara

Chærophyllum.

Chamærops.

Cheiranthus.

Chelidonium.

Chenopodium.

__ viride.

\section{Anthelminticum}

Chinaphila.

Chiococca.

Chionanthus.

Chloris.

Chondrilla.

Chrysanthemum.

Chresocoma.

Chrysosplenium.

Cichorium.

Cicuta.

Cimicifuga.

Circæa.

Serpentaria.

Cissus.

hederacea.
Sensitive Pea.

Chesnut-tree.

Chinquapin.

Catalpa-tree.

Blue Cohosh.

Red-rcot. New Jersey

Ten.

624

625

10

218

167

Staff:tree.

Neltle-tree. Hag-lerry. Hoop-ash.

167

Bur-grass.

200

60

Centaury.

Blue-boitle.

St. Barnaly's Thistle.

Chatf-weed.

Bulton-wood.

Nou-e-ear Chick-weed.

576

576

576

(:7

$11+$

220

Horn-u'orl.

Judas-iree.

Feather.beds.

370

308

4

cou parsley. Wild Cher. vil

Palmelto-lree. Callagetree.

Slock. Wall-flou'er.

Celandine.

Goose-foot.

Lainl's-quarter.

195

239

436

305

107

195

198

Winter-green. Sipsisewa. 300

Snow-litry.

Fringe-trce. Snow flock-tree.

Snow-flou'er.

Wire-grass. Couch-grass.

Gtım. Sucrory.

Ox eye Daisy.

407

526

Goidilucks.

Golden Saxifrage.

269

Succory.

IÉater Cowbane.

496

195

Bug-wort.

372

Black Snake-root.

372

Enchanters' Nishtshade.

21

Pepper-vine.

170

Virginia Creeper. 
Clematis.

Clinopodium.

Cnicus.

Collinsonia.

Comarum.

Comptonia.

Conium.

Convallaria.

Convolrulus.

Conyza.

Coreopsis.

Corispermum.

Cornus.

Coronopus.

Corydalis.

Corylus.

Cratægus.

Crotalaria.

Cucubalus.

Cunila.

Cupressus.

Cuscuta.

Cynoglossum.

Cyperus.

Cypripedinn.

Dactylis.

Datura.

Daucus.

Delphinium.

Dentaria.

- diphylla.

Dianthus.

Dionæa.

Dioscorea.

Diospyros
Virgin's Bower. Traveller'sjoy.

Wild Basil.

Thistle.

Horse-weed.

fiarsh Cinquefoil.

Sweet Fern-bush.

$H$ mlock.

Lily of the Valley. Sneexewort.

Bind-weed.

Flea-bane.

Tick-seed Sunflower.

Tick-seed.

Dogrwood.

Red Osier.

Suine's-Cress.

Fumitory.

Breeches-fiower.

Hazel-nut. Fillert.

Cuckold's Nut.

384

410

506

20

356

635

195

232

143

523

567

4

107

109

435

462

462

634

635

336

$46 y$

315

406

645

646

116

133

50

Nut-grass.

Ludies' Slipper. Mocassinflower.

594

Cock's-foot-grass. Orchardgrass.

84

Thorn-apple. Stramonium. 141

Carrot.

Lark-spur.

Tuoth-wort.

Pepper-root. Indian Mus. tard.

391

371

438

438

Pink.

Venus's Fly-lrop.

Yam.

314

304

251

Dase-plum. Porsimon. 
Dipsacus.

Dirca.

Dodecatheon.

Draba.

Dracocephalum.

Drosera.

Echium.

Elæagnus.

Elephantopus.

Elymus.

Empetrum.

Epigæa.

Epilobium.

Equisetum.

Erigeron.

bellidifolium.

Eriocaulon.

Eriophorum.

Eryngium.

Erysimum.

cheiranthoides.

Erythrina.

Erythronium.

Eupatorium.

Euphrasia.

Evonymus.

americanus.
Teasel. Fullers-thistle.

Leather-wood.

Americun Cowslip. Mitreflower.

Whitlow-grass.

Dragon's-head.

Sun-dew.

Viper's Bugloss.

Missouri Silver-tree.

Elephant's-foot.

Lyme.grass. Wild Rye.

Crake- or Crow-berry.

Ground lvy.

Willow-herb.

Horse-tail. Shave-grass.

Rug-weed.

Poor Rolin's Plantain. Rattlesnake Plantain.

Pipe-wort.

Cotton-grass.

Eryngo.

Hedge Mustard.

IVorm-seed.

Coral-plant.

Dog's-tooth Violet.

Hemp Agrimony.

130

114

582

s9

93

297

259

651

532

532

9 l

57

189

436

436

467

230

512

Thorough-wort. Bone-set. 516

Eye-bright.

Spindle-tree.

Burning-lush.

430

168

168

Beech-tree.

Fescue-grass.

Strawlerry.

Ash tree.

Fumitory.

Carpenter's-leaf. Heal-all.

Dead-nettle.

Ladies' Bel-straw. Cleavers. Goose-grass.

Mountain-tea. Partridgeberry.
624

83

357

8

463

446

407

102

283 
Gelseminum.

Gentiana.

Geranium.
Carolina Jasmine.

184

Gentivn.

Crane's lill

185

$4+8$

448

449

3.51

176

408

221

4 s

521

451

12

12

Golden-pert.

Kentucky Coffee-tree. Chicot. 301
Halesia.

Hamamelis. Hamiltonia.

Hedeoma.

Helianthemum.

Helianthus.

Heliotropium.

Helonias dioica.

Hepatica.

Heracleum.

Hesperis.

Hibiscus esculentus.

Hieracium.

Hippophaë.

Hippuris.

Holcus tragrans.

Hopea.

Hordeum.

Hottonia.

Hudsonia.

Humulus.

Hydrastis.

Hydrocotyle.

Hydrophyllum.

Hyoscyamus.

Hyoseris.
Snow-drop-tree, Silver-belltree.

Witch-hazel.

Oil-nut.

Pennyroyal.

Rock-rose.

Sun-flower.

Turnsol.

Star-wort. Colic-wort.

Liver-wort.

Cow Parsnep.

Rocket.

Okra or Okro.

Itau'k-ueed.

Sea Buckthorn.

Mare's-tail.

Serieca-grass.

Sivect-leaf.

449

116

178

414

363

570

130

243

391

192

436

456

502

115

3

;8

451

Barley.

Wrater violet.

Water-iolet. Feather-foil. 138

Yellow American Heath. 30.

Hop.

199

Yellow-root. Turmeric. $\quad 389$

Penny-wort. $\quad 190$

Water-leaf. 134

Henbane. 141

Swine's Succory. $\quad 504$ 
Hypericum.

St. John's-wort.

densiflorum. American Yellow-heath.

Jatropha.

Wild Cassava. Tread-

Ilex.

$$
\text { soflly. }
$$

Holly. Dahoon.

vomitoria.

South-sea Tea.

Illecebrum.

Knot grass.

Aniseed-tree.

Illicium.

Balsam. Touch-me-not.

Impatiens.

Indigofera.

Indigo-plant.

Elecampane.

Inula Helenium.

Cypress-rine.

Flag. Flower de-luce.

lilalnut. Hickory.

Juglans.

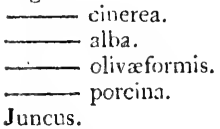

Butter-nut. Oil-nut.

Shell-or Shag-bark.

636

Pecan-nut.

637

Hog-or Pig-nut.

636

Rush.

638

Juniper.

235

Juniperus.

Red Cedar.

646

Bastard Jesuit's-lark.

Iva.

American Laurel.

580

Kalmia.

Sheep Laurel.

295

angustifolia.

Calico-flower.

Lactuca.

Lettuce.

500

Lamium.

Archangel.

406

Henlit.

Laurel. Su'eet-lay.

Laurus.

amplexicaule.

Spice-wood. Benjamin-

406

2,75

Benzoin. tree.

caroliniensis.

Red-lay.

276

Sassafras.

Sassafias-tree.

Ledum latifolium.

Lalrador Tea.

277

300

Duck's-meat.

Dandelion.

Pepper.wort.

Button Snake-root.

Rattle-snake's-master.

Privel. Prim. 
Lilium.

Lily.

228

229

210

Linum.

American Martagon.

Flax.

635

Liquidambar.

Swet-gum.

Tulip-lree. American Poplar.

382

Gromuell.

131

Cordinal's.flower.

448

Eye-lright.

448

American Mercury. $\quad 4.17$

Bird's foot Trejoil

450

Lupine.

Box-thorn.

Clul-moss.

467

97

6.52

Ground Pine. $\quad 053$ dendroideun. Ground Pine.

654

Wild-Bugloss. 132

iitater Hirehound. 16

Loose-sti ifé.

135

Magnolia acuminata. Cucumber-tree.

381

Indian Physic.

382

Su'amp Sassafras. Sweet Bay. Swamp Laurel. Beaverwood.

Big Laurel. $\quad 380$

grandiflora.

Big Laurel.

380

$\begin{array}{ll}\text { Umitrella-tree. Elk-wood. } & 351 \\ \text { Mallow. } & 454\end{array}$

Horehound.

408

Cuckold's Horns. $\quad 428$

Medick. Nonsuch. $\quad 490$

Indian Cucumber. $\quad 244$

Cow-wheat. 430

Melic-grass. 77

Melilot.

Moon-seed.

Sarsaparilla.

477

370

370

Mint.

405

Mentha.

Buck-lean. Marsh Tre.

foil.

139

Cunes. $\quad 59$

Miegia.

Milium.

Millet-grass.

Monkey-flower.

62

Mimulus.

Mitchella.

Eye-bright. 
Momordica.

Monarda.

Kalmiana.

Monotropa.

Morus.

Myosotis.

Myrica.

Gale.

Myriophyllum.

Neottia.

Nepeta.

Nicotiana.

Nuphar.

Nymphæa. $\}$

Nyssa.

candicans. villosa.

Oeranthe.

Oenothera.

Olea.

Onoclea.

Ophioglossum.

Origanum.

Ornus.

Orobanche.

Oryzopsis.

Osmunda.

Ostrya.

Oxalis.

Oxycoccus.

Panax.

Panicum.

Papaver.

Parietaria.

Parnassia.
Balsam apple.

Mountain-mint.

Oswego Tea.

Gravel-u'ort.

Yellow Bird's-nest.

303

Mulberry.

639

Scorpion-grass.

J33

Candlelerry Myrtle. Wax Myrtle.

Sweet-gale.

620

620

líater-milloil.

274

Ladies' Traces.

Cat-nep. Cat-mint.

Tobacco.

589

406

141

IVater Lily.

Tupelo-tree.

177

Ogochee Lime.

177

Sour Gum-tree.

177

Water drop-wort.

Tree Primrose.

194

261

Sun-drop.

262

Olive-tree. Devil's-wood.

Sensitive fern.

Adder's tongue.

Marjoram.

Flowering-Ash .

Broom-rape.

Cancer-root.

Mountain-rice.

Flowering-fern.

Virginian Hornleam. Ironwood. Lever-wood. $\quad 623$

Woodsorrel.

Cranelerry.

Ginseng.

Panic-grass.

Poppy.

Pellitory.

Grass of Parnassus.
322

263

191

66

365

114

665

655

411

8

431

431

60

657

208 
Passitiora.

Pastinaca.

Pedicularis.

Peplis.

Phalaris.

Phaseolus.

Phellandrium.

Philadelphis.

Phleum.

Passion flow'er.

Parsnep.

444

Louse-uort.

196

424

Water.Purslane. 238

Canary-grass. $\quad 65$

Kidney-liean. $\quad 469$

Water Hemlock. 195

Mock-Orange. $\quad 329$

Cat's tuil-grass. 65

Timothy-grass. $\quad 65$

Ground Cherries. $\quad 157$

Poke-root. $\quad 32 t$

Butter-uort. 14

Physalis.

Phytolacca.

Pinguicula.

Pinus.

Pisum.

Plantago.

lanceolata.

Platanus.

Pine. Fir-tree. Himlock.

Spruce. Larch-tree. 639

Pea. $\quad 470$

Plantain. 98

Ril-wort. $\quad 99$

Plane-tree. Sycamore.

Button-wood.

635

Meadow-grass. 78

Poa.

Podophyllum.

Polemonium.

Polygala.

Polygonatum.

Polygonum.

bistortoides.

Duck's-foot. May-apple.

366

Greek V'alerian. Jacol's Ladder.

Milk-u'ort.

Seneca Snake-root 464

Solomon's Seal. $\quad 234$

Persicaria. 269

Knot-grass. 269

Snake-weed. 271

Black Bind-ueed. $\quad 273$

Buck-uheat. 273

Water Pepper. 270

Poplar. 618

Tacamahac. 613

Asp or Aspen-trec. $\quad 618$

Pap:u'-tree. $\quad 383$

Purslune. $\quad 305$

lond-u'eed. $\quad 120$

Cinquefoil. $\quad 353$

IVild Tansey. $\quad 356$

Anserina. Wild Tansey. Scunk-cal.

Pothos foetid.

lage.

Mili-weed.

Prenanthes.

Lion's-foot. 
Prinos.

Prunella. glaber.

Prunts.

Pulmonaria.

Pycnanthemum.

Pyrola.

Pyrus. ambiguus.

Pteris.
IVinter-berry.

Black Alder.

Ink-berry.

Self-heal.

Plum-tree. Cherry-tree. Brake.

Lung-wort.

Horse- or Mountain-mint.

Winter-green.

Apple-tree.

May-bush.
220

220

220

411

329

668

130

409

299

339

339

625

Quercus.

Oak-tree.
Crow-foot.

Buck-thorn.

Yellow-rattle.

Ro:e Bay. Mountain

$$
\text { Laurel. }
$$

Sumach.

Rhus.

Poison Oak.

Currant-tree. Gooseberry.

Palma-Christi. Castor-oil. tree.

False Acacia Locust-tree. 457

Robinia.

Rosa. Rose-Hep-tree.

Hard grass.

Rottboellia.

Rubia.

Rubus.

Madder.

Bramlle. Rasplerry.

Dewlerry.

Cloud-berry.

Black-lerry.

Dock. Sorrel.

Tassel Pond-weed.

C'entaury.

Wild Sugar-cane.

Pearl-wort.

Arrow-head. Arrow-root.

Salt-or Glass-u'ort. Samphire.

Willow. Osier.

Salt-wort.

Sage.

391

166

429

297

204

205

163

602

487

344

88

102

346

347

349

346

247

121

137

73

119 395

Sagittaria.

Salicornia.

Salix.

Salsola.

Salvia. 
Sambucus.

Samolus.

Sanguinaria.

Sanguisorba.

Santolina.

Sapindus.

Saponaria.

Sarracenia.

Saururus.

Saxifraga.

Schonus,

Schrankia.

Scirpus.

Scleranthus.

Scolopendrium.

Scorzonera.

Scutellaria.

Secale.

Sedum.

Selinum.

Senecio.

Seseli.

Silene.

Sison.

Sisymbrium.

hieracifolius.

- amphibium. Sophia.

Sisyrinchium.

Sium.

Smiax.

Smyrnium.

Solanum.

- Dulcamara.

Solidago.

Sorbus.

Sorghum.

Sparganium.

Spergula.

Spermacoce.

Spigelia.
Elder.

203

Brook-weed. Water Pimpernel.

158

Blood-wort. Puccoon. 365

Creat Burnet. 110

Lavender Cotlon. $\quad 520$

Soap-lerry. 274

Socip-wort. $\quad 314$

Side-saddle flower. $\quad 367$

Lizard's-lail. $\quad 252$

Saxifrage. $\quad 310$

Sengreene. $\quad 310$

Bog Rush. $\quad 47$

Sensilive Briar. $\quad 305$

Club Rush. 5 .

Knawel. $\quad 315$

Hurt's-tongue. $\quad 667$

Viper's-grass. $\quad 497$

Scull-cap. $\quad 412$

P.ye. $\quad 90$

Slone crop. Orpine. $\quad 323$

Milk Parsley 192

Groundsel. Rag-wort. 528

Butter uetd. Fire-weed. $\quad 529$

Meadow Sarifrage. $\quad 107$

Calch-Aly. Wild Pink. 315

Hone wort. $\quad 194$

Water-cress. $\quad+40$

Water-radish. $\quad 4 \mathrm{HO}$

Flix-weed. $\quad 4: 0$

Blue-eyed Grass. 31

Water Parsnep. 194

Green Briar. Poison Briar. 249

Alexanders. $\quad 196$

Nightshade. $\quad 156$

Bittersu'eet. $\quad 156$

Golden-rod. $\quad 535$

Service-tree. N'ountainAsh. $\quad 3+1$

Indian Millet. Broom grass. 78

Bur-reed. 33

Spurrey. $\quad 320$

Button-ueed. 105

Worm grass. Indian Pinkroot. 
Spiræa.

Meadow'sweet.

Virginian Guelder-rose.

Indian Physic. Ipecacuanha. 343

Stachys. trifoliata. Hedge Nettle. 407

Staphylea.

Statice.

Stellaria.

- media.

Stillingia sebifera.

Stipa.

Swertia.

Symphoria.

Bladder-nut.

Thrift. Sea Lavender.

206

Stitch-wort.

Chick-weed.

Tallow-tree.

Feather-grass.

Marsh Feluort.

St. Peter's-wort.

212

317

317

608

72

100

162

Tanacetum.

Taxus.

Tephrosia.

Teucrium.

Thalictrum.

Thesium.

Thlaspi.

Thuya.

Thymus.

Tilia.

Tradescantia.

Trientalis.

Trifolium.

Triglochin.

Triosteum.

Triticum.

Trollius.

Turritis.

Tussilago.

Typha.

Ulmus.

Uniola.

Urtica.

Vaccinium.

_- frondosum.

frondosum. Vitis Idæa.

Tansey.

523

Yew-tree.

Goat's Rue.

647

Germander.

489

Meadow Rue.

Bastard Toad-flax.

405

388

Bastard cress. Penny-cress. Shepherd's-purse.

177

American Arbor-vila.

Thyme.

Lime tree. Linden-tree. Bass wood. White-wood. Spoon-wood.

435

616

413

Spider wort.

Winter green.

Trefoil. Clover.

Arrow grass.

Fever-urort. Gentian.

Wheat.

Globe-flower.

Tower-mustard.

Colts'-foot.

Cat's tail. Reed Mace.

Elm.

Sea-sile Oat.

Nettle.

Whortle-berry. Huckleberry.

362

218

254

477

247

162

90

391

438

531

3.4

199

82

112

Blue Tangles.

Deer-berry.

Bilberry. 
Valeriana.

Veratrum.

Verbascum.

Verbena.

Veronica.
Valerian.

Green Hellevore.

Mullein. High-taper.

Vervain. Iron-weed.

Stietiwell.

Paul'. Betony.

Brosk-lime.

Arrou'-wood.

Holile-lush. Wayfaring-

$$
\text { tree. }
$$

Cassiclerry-bush.

Cranelerry-lree. American

Guelder-rose.

Sheep-lerry.

Vetch.

Violet. Heart's-ease.

Misletoe.

Grape-vine.

Small Burdock.

Adam's Needle. Cablage-tree. 227

Horned Pond-weed.

Yellow-root.

Tooth-ach Tree.

Maize. Indion Corn.

Canada or Indian Rice.

Supple-Jack.

Grass-wrack.
23

242

142

415

10

11

11

202

202

203

203

202

471

171

114

169

$58 \mathrm{i}$

4

212

209

46

60

188

22 


\section{ENGLISH AND LATIN}

\section{N D E X.}

A cacia. FaiseAdam's Needle. Adder's Tongue. Agrimony.

-. Hemp-

Aider.

Alexanders.

Allspice. Carolina-

Aloe. Sweet Virginian-

Alum-root.

Angelica-tree.

Aniseed-tree.

Apple-tree.

Arbor-vitæ.

Archangel.

Arrow-grass. head. root. wood.

Asarabacca.

Ash. Flowering-

-. Mountain-

Ash-tree.

Asp. Aspen.

Avens.

Balm of Gilead. Balsam. Apple.
Rolinia.

Yucca.

Ophioglossum. Agrimonia.

Eupatorium. Alnus.

Prinos.

Smyrnium.

Calycanthus.

Agare.

Geranium maculatum.

Aralia spinosa.

Illicium.

Pyrus.

Thuya.

Lamium.

Triglochin.

\} Sagitlaria.

Viburnum dentatum. Asarum.

S Acer Negundo.

\{ Ornus.

Sorbus.

Fraxinus.

Populus trepida.

Geum.

Pinus Balsamea. 
ENGLISH AND LATIN INDEX.

\begin{tabular}{|c|c|c|}
\hline & & \\
\hline Baneberry. & Actera. & $366^{\circ}$ \\
\hline Barley. & Hordeum. & 89 \\
\hline Bass-wood. & Tilia. & 302 \\
\hline Bay-tree. & Lullrus. & 275 \\
\hline Bear bind. & Caing & 142 \\
\hline Eearberry. & Arlutu: Uva ursi. & 283 \\
\hline Beavu-wood. & Ma: nolia glanca. & $3 S 1$ \\
\hline Beech-tree. & 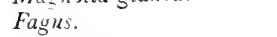 & 624 \\
\hline —. Water- & Platullus. & 634 \\
\hline Bell-flower. & Campanula. & 15 \\
\hline Benjamin-tree. & Laurus Benzoin. & 276 \\
\hline Bent-grass. & Agrostis. & 63 \\
\hline Berberry. & Berleris. & 219 \\
\hline Bilberry. & Vuccinium Vitis Idœa. & 289 \\
\hline Bind-weed. & Convolvulus. & 143 \\
\hline … Black- & Polygonum Convolvulus. & 273 \\
\hline Pirch-tree. & Belula. & 620 \\
\hline Bird's-nest. Yellow. & Monotropa. & 303 \\
\hline Birth-wort. & Aristolochia. & 596 \\
\hline Bishop's-weed. & Ammi. & 19 \\
\hline Bistort. & Polygonum Bistorta. & 36 \\
\hline Bitter-sweet. & Solanum Dulcamara. & 15 \\
\hline Blackberry. & Rubus villosus. & 34 \\
\hline Bladder-nut. & Staphylea. & 20 \\
\hline Blite. & Amaranthus Blitum. & 20 \\
\hline —. Strawberry & Blitum. & \\
\hline Blood-wort. & Sanguinaria. & 36 \\
\hline Bluebottle. & Centaurea Cyanus. & 57 \\
\hline Blue-eyed Grass. & Sisyrinchium. & \\
\hline Bluetangles. & laccinium frondosum. & 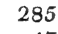 \\
\hline Bog-rush. & Schœnus & \\
\hline Boneset. & Eupatorium perfoliatunz. & 51 \\
\hline Box lider. & Acer Negundo. & 2 \\
\hline Box Thorn. & Lycium. & $g$ \\
\hline Brake. & Pteris. & \\
\hline Bramble. & Rulus. & 3 \\
\hline Breeches-flower. & Corydalis. & \\
\hline Briar. Green- & Smilax. & 2 \\
\hline _. Sensitive- & Schrankia. & 30 \\
\hline $\begin{array}{l}\text { Sweet- } \\
\text { uvild- }\end{array}$ & Rosa. & \\
\hline Brook-lime. & $\begin{array}{l}\text { Veronica Beccalunga. } \\
\text { Samolus. }\end{array}$ & \\
\hline Brome- & $\left\{\begin{array}{l}\text { Bromus. } \\
\text { Sorghum. }\end{array}\right.$ & \\
\hline
\end{tabular}


Broom-rape.

Buck-bean.

Buck's eye-tree.

- thorn.

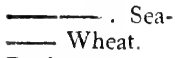

Bugle.

Buglose. Wild-

Bug-wort.

Bull-rush.

Burdock.

- Small-

Bur-grass.

- reed.

Cu net. Great-

Burning-bush.

Butterfly-flower.

Butter-but.

weed.

Button-weed.

wood.

Cabbage.

Calico-tree.

Calf's-snout.

Campion.

Canary-grass.

Cancer-root.

Candleberry Myrtle.

Cane.

Cardinal's-flower.

Carpenter's-leaf.

Carrot.

Cassava. Wild.

Cassioberry-bush.

Castor-oil tree.

Catalpa-tree.

Catclifly.

Catmint.

Cat's-tail.

Grass.

Cedar. Red-
Orobanche.

$43 i$

Menyanthes.

Asculus.

Rhanmus.

Hippophaë.

Polyyonum Fagopyrum.

sjuga.

Lycopsis.

Ci:vicifuga.

Scirpus lacustris.

Arctium.

Xanthum.

Cenchrus.

Sparganium.

Sanguisor la.

Evonymus americanus.

Asclepias tulerosa.

Juglans cinerea.

Senecio hieracifolius.

Pinguicula.

Spermacoce.

? Platanus.

\} Cephalanthus.

134

254

166

115

273

404

133

372

54

505

581

60

33

116

168

183

636

520

14

105

635

114

Brassica.

Chamcerops. Yucca.

Kalmia latifolia.

438

239

$296^{\circ}$

Antirrhinum Orontium.

422

315

65

Phalaris.

Orobanche virginica.

431

620

Myrica.

Miegia.

Lolelia Cardinalis.

59

448

446

191

603

201

602

10

315

362

406

34

65

645 
ENGIISH AND LATIN INDEX.

Cedar. White-

Celandine.

Centaury.

Chaff-weed.

Chamomile.

Cherr-tree.

Chervil.

Chesnut-tree.

Chickweed.

Chicot.

Chinquapin.

Cinquefoil.

- - Marsh-

Cleavers.

Clot-bur.

Clond-berry.

Clover.

Club-noss.

Clıb-rush.

Cockle. Corn-

Cock's-foot Grass.

Coffee-tree. Kentucky-

Cohosh. Blue-

- - Red and

Colt's-foot.

Columbine.

Coral-plant.

Cotton-grass.

tree.

Couch-grass.

Cowbane. Water-

Cowslip. American-

Crakeberry.

Craneberry.

-

Crane's-bill.

Creeper. Virginian-

Cress. Bastard.

- Swine-

-. Wall-

-. Water-

Crow-berry.
Cupressus thyoides.

Chelidonium.

$\{$ Centaurea.

$\{$ Sallatia.

Centunculus.

Anthemis.

Prunus.

Chcer phyllum.

Castanea.

Aiculus.

Stellaria media.

Gymnoclalus.

Castaneu punila.

putentilla.

Comarum.

Galium.

Arctium.

Rubus Chamemorus.

Trifolinm.

Lycopodium.

Scirpus.

Agrostemima.

Liut'ylis

Gymnocladus.

Carlliphyllum.

646

365

576

137

97

562

329

195

624

254

617

301

625

353

356

102

505

345

477

652

54

321

84

304

218

366

531

596

372

467

57

635

613

87

197

136

94

263

203

448

170

435

435

436

440

23 
\begin{tabular}{l} 
Crow-foot. \\
Cuclioidi'-nut. \\
Cucumber-tree. \\
Cudweed. \\
Currant-tree. \\
Cypress. \\
\hline
\end{tabular}

Dahoon.

Daisy.

- Ox-eye-

Dandetion.

Date-plum.

Deerberry.

Devil's-bit.

Dewbed.

Dewberry.

Dittany.

Dock.

Dodder.

Dog's-bane.

Dog's-foot Violet.

Dog wood.

Dragon's head.

Dicp-wort. Water-

Duck's-foot.

- mead.

Elder.

Elecampane.

Elephant's-foot.

Elk-wood.

Elm-tree.

-Witch-

Eringo.

Everlasting.

Eye-bright.

Featherfoil.

- - beds.

- grass.

Felwort. Marsh-

Fennel, Dog's-
Ranunculus.

Corylus rostrata.

Martynic.

Magno'ia acuminata.

Gnaphalium.

Rilies.

Cupressus.

Ipomoea Quamoclit.

$39 \mathrm{I}$

635

428

381

524

163

645

145

Jlex.

117

Bellis.

526

SChrysanthemum Leucanth. $\quad 526$

Buphthalmum. $\quad 563$

Leontodon. $\quad 497$

Diospyros. $\quad 265$

Vaccinium stamineum. 284

Aletris. $\quad 225$

Olea. $\quad 7$

Rulus trivialis. $\quad 347$

Cunila. $\quad 406$

Rumex. $\quad 247$

Cuscuta. $\quad 116$

Apocynum. $\quad 179$

Erythronium. $\quad 239$

Cornus. $\quad 107$

Dracocephalum. 411

Oenanthe. $\quad 194$

Podophyllum. $\quad 366$

Lemna. 22

Sambucus. $\quad 203$

Inula Helenium. 531

Elephantopus. $\quad 582$

Magnoliu tripetala. $\quad 381$

Ulmus. $\quad 199$

Planera. 115

Eryngium. $\quad 189$

Gnaphalium. $\quad 524$

Euphrasia. $\quad 430$

$\begin{cases}\text { Mitchella. } & 101\end{cases}$

Lolelia inflata. $\quad 448$

Hottonia. $\quad 138$

Chara. 4

Stipa. $\quad 72$

Swertia. 100

Eupatorium faniculaceum. $\quad 512$ 
ENGLISH AND LATIN INDEX.

Fescue-grass.

Fever-wort.

Filbert. Wild-

Fire-weed.

Fir-tree.

Flag.

- Sweet-

Flax,

Flea-bane.

Flix-weed.

Flower-de-luce.

Flowering-fern.

Fluellin.

Flux-weed.

Fly-catch-bush.

Fox-tail-grass.

Fringe-tree.

Full-fern.

Fumatory.

Fuller's Thistle.

Garlic. Wild-

Gentian.

Germander.

Ginger. Wild-

Ginseng.

Glass-wort.

Globe-flower.

Goat's Rue.

Golden-rod.

- - pert.

Goldilocks.

Gooseberry.

Goose-foot.

Grape-vine.

Grass of Parnassus.

Wrack.

Gravel-wolt.

Green Dragon.

Gromwel.

Ground Ivy.

Ground Pine.
Fe`tuca.

Triosteum.

83

Corylus.

Senecio hieracifolius.

Pinus.

Iris.

Acrirus.

Linum.

Cunyza.

Sisymlrium Sophia.

Iris.

Osmunla.

Antirrhinum Elatine.

Geraninm maculalum.

Bejaria.

Alotecurus.

Chionanthus.

Acrostichum.

Fumaria. Corydalis.

Dipsacus.

162

634

521

669

29

235

210

523

440

29

657

421

440

362

65

7
658

463

96

Allium.

S Gentiana.

$\{$ Triosteum.

Teucrium.

Asaruin.

Panax.

Salicornia.

Trollius.

Tethrosia.

Solidayo.

Giatiola aurea.

222

185

162

405

596

191

2

391

$4 \mathrm{sg}$

535

92

517

$\begin{array}{ll}\text { QRanunculus Auricomus. } & 391 \\ \text { Riles. } & 163\end{array}$

Chenopodium. $\quad 197$

Galium. $\quad 102$

Iritis. $\quad 169$

Parnassia. $\quad 208$

Zistera. 2

Monarda punctata. $\quad 18$

Arum Dracunculus. $\quad 400$

Iithospermum. 131

\{ Glichoma. 408

$\{$ Epigaa. 297

$\{$ Lycopodium dendroideum. 653

$\left\{\begin{array}{l}\text { Ajuga Chamcepithys. } \\ 404\end{array}\right.$ 
Ground Cherry.

Physalis.

Groundsel.

Serierio.

tree.

Baccharis.

Guelder-rose, Ameri- $\{$ Viburnum. can

Spircea opulifolia.

Gun-tree. Sour-

Nyssa villosa.

177 Sweet. Liquidamlar.

Hag-berry.

Celtis.

200

Hackmatack.

Pinlis pendula.

Hair-grass.

Aira.

639

Hard-grass.

Rotuloellia.

Hart's-tongue.

Scalopendrium.

Ihieracium.

88

Hawkweed.

Crategus.

Hawthorn.

Corytus.

Hazel-nut.

SGalax.

Heal-all.

Heart-seed.

Heart's-ease.

$\{V$ iola clandesina.

667

502

$376^{\circ}$

634

446

171

Cardiospermum.

273

I iola.

171

SHudsonia.

364

Heath. Yellow-

Heliot rope.

Hypericum densiflorum.

376

Heliotropium.

130

Hellebure. Green-

l'eralrum viride.

242

Heminck.

Conium.

195

Pinus canadensis.

Phellanirium.

639

19.5

Cannalis.

199

Apacynum.

179

Acnida.

208

Henbane.

Hyoscyamus.

141

Henbit.

Lamium amplexicaule.

406

Heptree.

Rosa.

G'um.

344

351

Acteca.

366

Geranium Rolerlianum.

449

Verlascum.

142

High-taper.

Juslans.

Viburnum lantanoides.

636

Hobble-bush.

Hog-nut.

Juglans porcina.

201

Ambrosia.

638

weed.

Ilex.

580

Holly.

Sison.

Hone-wort.

Honey-suckle.

$\{$ Caprifolium.

$\{$ Aquilegia.

117

194

160

372

Moop-Ash.

\section{Upright- Azalea.}

Celtis. 
ENGLISH AND LATIN INDEX.

Hop.

Humulus. $\quad 199$

Hornbeam.

Ostrya.

623

Manutiun. 405

Horehound.

Lycofizs.

16

Ciertinus.

623

Ceratophillum. $\quad 370$

Hor bean-tree.

Equisetum.

Collinumia.

651

Horse-rail.

Cynoglossum.

20

Hiorse-nect.

Vaccinium.

133

28.4

Huckleberry.

Andrometia.

200

Hysingus.

Gratiola.

406

Polemionium.

151

Jacob's Ladder.

S Ipomiea Julapa.

147

Jalap.

$\left\{\begin{array}{l}\text { Convolvu!us panduratus. } \\ \text { Gelsen }\end{array}\right.$

143

Gelseminum.

184

Jesult's Park-tree. Bastard- Ita.

580

Indian Corn

Zera.

46

244

Medeola.

Caitus.

Sorrinum.

327

73

SMasnolia muriculala. 352

i Spirce trijoliata. 341

$Z$ zania.

60

Cominu.

Indigofern.

Amorpha.

Irinos glaler.

SAsclepine lulerosa. $\quad 1>3$

Euphortia. 605

Ipecacuanha.

Sprerea trifoliata.

$3+1$

Snitrosia. 550

Iron-weed.

- wood.

Sterlena.

$4 ! 5$

Q.trua. $\quad 623$

Cerici.

308

$\{$ Juniperus. $\quad 646$

Juniper.

$\{$ Cnpressus.

645

Kidney Bean.

Phaserilus.

469

Scleramthus. $\quad 315$

Knawel.

Sillecelrum.

Knot-grass.

Ladies' Bedstraw.

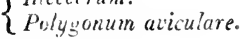

445

Gatium.

319

silliemilla.

102

112 


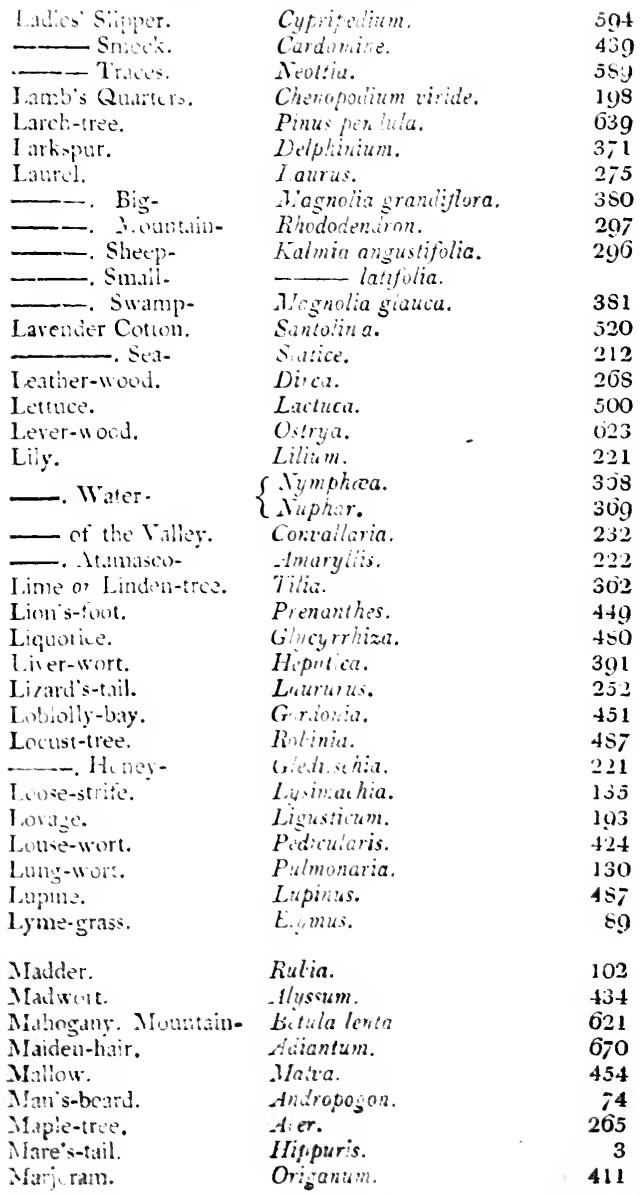


Martagon.

Mar!gold. Bur-

May-apple.

- burh. weed.

Meadox-grtass.

rlie.

Medick.

Melic-grass.

Melijot.

Mercurs. Anerican-

Milfuil.

- Hooded-

- Water-

Mik-weed.

- wert.

Molet-grass.

Mint.

- Horseor Moun tain.

Mitre-Aower.

Misle-tive.

Mocsin-fiower.

Mocher-nut.

Muck (range.

Monkinhod.

Moriker-fioner.

Monn-seed.

Mons-wood.

M u-e-ear Chickweed.

Mingunt.

Multersy.

Muliein.

Mustard. Hedge-

- - Inl in.

- Touer.

Myrue. Can'leberry-? Wal. Sund-

Neitle.

--. Dead.

Nettle-tree.
Lilium.

Bicters.

Coltha.

Fodothylinum.

Purus Eolryatium.

Anthemis.

Por.

Thalictum.

Sitirita.

Tertiago.

Minca.

Melilotus.

Lotelia nitiona.

Achillez.

Etricularia.

Nuriuthellam.

Prenanthes.

Polngala.

Miniam.

Mentha.

S Monarda.

$\{$ Pronarthemum.

Didicatheon.

tricum.

C.pripetium.

Jugrans.

Pilidtolins.

femilum.

Minalus.

lienstermin.

ficer strictun.

cerastion?.

Alemisio ingaris.

Mirus.

Fellascum.

Erysimum.

Dentaria.

Turritis.

229

$500^{\circ}$

$3=9$

$35 j$

330

562

72

35s

3 ss

400

is

47

417

502

15

274

403

464

02

405

16

409

130

114

504

630

329

372

426

3,0

267

3.0

322

039

142

$43 j$

4is

438

620

301

Aminzrsine.

112

Irtica.

407

407

200 
Nightshade.

Solanum.

- Enchanter's-

Circcea.

Nonsuch.

Médicago Lupulina.

Nut-grass.

Cyperus.

490

50

Oak.

Quercus.

Oat. Sea-side-

Uniola.

625

Oit-grass.

Avena.

Ogechee-line.

Nussa candicans.

Dil-nut.

Okro.

Ulive-tree.

Orache.

Orchard-grass.

Orpine.

Osier.

Himilionia.

$\{\mathrm{J}$ glans cincrea.

177

178

Hitiscus esculentus.

$630^{\circ}$

Olea.

Alrinier.

Dactylis.

Sedrim.

456

Salix.

Cornizs.

608

IOg

Palmetto-tree.

Palma Christi.

Panic-grass.

Pansy.

Papaw-tree.

Parsley. Cow -

Chamcerops.

Ricinus.

Panirum.

Viola tricolor.

Porcelia.

Clicerophyllum.

Selinum.

299

602

Alchemilla arvensis.

Paitinara.

60

171

383

195

192

112

196

Heracli um.

192

siium.

Gaulhoria.

194

Paltridge-berry.

Passion-tiower.

Paul's Betony.

Pea.

Pasiflora.

Veronica serpyllifolia.

283

4.4

Pi,um.

10

Sugina.

470

Pearl-wort.

Pear.

Pecan-nut.

Pellitory.

Penny-cress.

royal.

Pyrus.

119

Jikglans.

Parietaria.

339

636

Thlaspi-arvense.

114

Hedeuma.

435

Hyilrocotyle.

414

Lepidium.

190

Pepper-wort.

Dentaria.

435

- root.

- vine.

Cissus lipinnata.

438

Polygonum.

170

Persicaria.

Diospyros.

269

Persinon.

265 
FNGLISH AND LATIN INDIX,

Pig-nut.

Pimpernel.

\section{Pine-tree.}

Pink.

Pink-root.

\section{- Wild-}

Pipe-wort.

Piperidge-bush.

Plane-tree.

Plantain.

Juglums porcina.

638 Anagallis. $\quad 135$

158

639

314

139

31.5

91

210

Plat.nus. $\quad 035$

Plantago. $\quad 98$

Erigeron lellidifolium. $\quad 532$

Alisma. $\quad 352$

Prunus. $\quad 329$

Aralia hispida. 200

Rhus Toxicociendron. 20.5

Ithy telacica.

Potamogeton. $\quad 120$

Zannichellia. 4

Rupisa. $\quad 321$

jobulus. 018

Liriodendron. $\quad 382$

lofacir. $\quad 365$

Cictus. 327

Lisutrin. 7

Amaranthus. $\quad 207$

Ligustrum.

fSingulsorla. 116

SBuschia. $\$ 32$

iturtulaciot. 305

Peplis. 238

Priva. $\quad 82$

Phalangium. 226

Erigeron. $\quad 532$

Sinecio. $\quad 528$

Rulus. $\quad 346$

Crotalaria. 400

Liatıs squarrosa. $\quad 500$

Erigeron lelliaiifolium. 533

Polygala. 401

Sonchus floridanus. $\quad 501$

YPrenanihes. 498

Ceanothus. 167

Lewisia. 308 


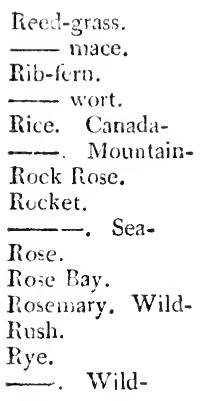

Saca-commis.

Sage.

St. Andrew's Cross.

St. I'arnaby's 'I'histle.

St. John's-wort.

St. Peter's-wort.

Salt-wort.

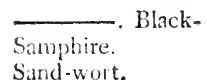

Sarsaparilla.

Sassafras-tree.

Savin.

Saxifrage.

\begin{tabular}{l}
\hline Golden- \\
\hline Scorpion-grass. \\
Scull-caip. \\
Scunk-weed. \\
\hline Sea-mat-grase. \\
Self-heal. \\
Sensitive-fern. \\
- pea. \\
Sedge.
\end{tabular}

Arundo.

Typha.

Blechunum.

Plantago lanceolata.

Zixanin.

Oryzopsis.

Helianthemum.

Hesperis.

Cakile.

Rosa.

Rhododentron.

Andromeda polifolin.

Juncus.

Secale.

Elymus.

Arbutus Utia ursi.

Saliza.

Aryrum.

Centrurea solstitialis.

Hypericum.

Symiphoria.

ISalicornia.

\{ Sulstila.

Glanx.

Salicornia.

Airenaria.

$\{$ Arufia mudicaulis.

Smilar.

Menispermum.

Laurus Sassafras.

Magnolia gliuca.

Juniperus Salina.

Saxifraga.

Chrysosplenium.

Seseli.

Myosotis.

Scutellaria.

\}Pothos.

Arundo arenaria.

Prunella.

Onoclea.

Cassia nicticans.

Schrankia.

$\{$ Carer.

$\left\{\begin{array}{l}\text { Schcenus } \\ \text { Sarer. }\end{array}\right.$
60

69

363

436

434

344

297

$29 \mathrm{t}$

235

90

89

283

19

373

576

374

162

2

197

176

2

317

209

249

370

277

381

646

310

269

197

133

412

398

87

411

665

305

365

34

47 
RNGLISH AND LATIN INDEX.

Seneca Grass.

Sengreen.

Service-tree.

Shave-grass.

Shell- or Shag-bark.

Sheep berry.

Shepherd's-purse.

Shield-fern.

Side-saddle-flower.

Silver-tree. bell tree.

Snake-root.

—. BlackButtonPlantainFern.

weed.

Snap-dragon.

Sneeze-wort.

Snow-berry.

Snow-drop-tree.

- flock-tree. flower.

Soap-berry.

-wort.

Solomon's Seal.

Sorrel.

- tree.

Spear-wort.

Speedwell.

Spice-wood.

Spider-wort.

Spikenard.

Spindle-tree.

Spleen-wort.

Spoon-wood.

Spring-grass.

Spruce-pine.

Spurrey.

Staff-tree.

Star-wort.
Holcus fragrans.

310

Sorlus. 341

\{ Pyrus. $\quad 339$

E'quisetum hyemale. $\quad 651$

Juglans alla. $\quad 637$

Vilurnum prunifolium. 201

Thluspi. 435

Aspirtinn. 660

Sarrccenia. $\quad 307$

Elacagnus. $\quad 114$

Halesia. $\quad 449$

Aristolochia. $\quad 506$

Cimicifinga Serpentaria. $\quad 372$

Liatris. $\quad 507$

Erigeron lelitidifolium. $\quad 532$

Boirychizm. 655

Prolyconum listortoides. $\quad 271$

Antirrhinum. 421

I Achillea Ptarmica. $\quad 562$

\{Convallaria. 232

Chiocorca. 160

Hulesia. $\quad 449$

\}Chionmathus. 7

Sapindus. 274

Satonaria. 314

Polysonatum. $\quad 234$

Rimex. $\quad 247$

Andiomeda arlorea. $\quad 295$

Rnnmulus Lingua. 3.11

leionica. 10

Laurus Benzoin. $\quad 275$

Tradescrimtia. 215

Araliz ruemosa. $\quad 209$

Evonymus. $\quad 169$

Asplinizm. $\quad 605$

Tisia. 302

Anthoxanthum. 65

Pinus. $\quad 039$

Spergula. $\quad 320$

Celastrus.

Aster. $\quad 5.13$

Aletris. 225

Melanthium dioicum.

Callitriche. 
Stitch-wort.
Stock.
Stone-crop.
Stramonium.
Strawberry.
Succory.

Sugar-cane. Wild-

Sugar-tree.

Sumach.

Sun-dew.

drop.

-flower.

Supple Jack.

Swallow-wort.

Sweet-bay.

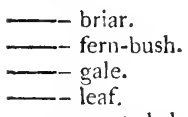

- scented shrub.

Sycamore.

Tacamahac.

Ta!low-tree.

Taniarack.

Tansey.

Therrald-

Tarragon.

Tea. Labrador-

-. Mountain-

-. New Jersey-

-. Oswego-

-. South Sea-

Teasel.

Thistle.

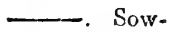

Thorn-apple.

Thorough-wort.

Thrift.

Thyme.

Tick-seed.
Stellaria.

Cheiranthus.

Sed'rm.

Datura.

Fragaria.

Blilum.

Arlutus.

Cichorinm Irtybus.

Chondrilla.

Saccharum.

Acer saccharinum.

Rhuns.

Droser.x.

Oenothera fruticosa.

Helianihus.

Coreopsis.

Zizuphus.

Asclepias.

SLaurus.

$\{$ Magnolia glauca.

Rosa.

Comptonia.

Myrica

Hopea.

Calycanthus.

Platanus.

Populus balsamifera.

Stillingia.

Pinus pendula.

Tanacetum.

Potentilía Anserina.

Artemisia Dracunculus.

Ledum latijolium.

Gaultheria.

Ceanothus.

Munarda.

llex vomitoria.

Dip:acus.

$\left\{\begin{array}{l}\text { Carduus. } \\ \text { Cnicus. }\end{array}\right.$

Sonchus.

Datura.

Eupatorium perfoliatum.

Statice.

Thymus.

Corispermum.
317

436

323

141

357

4

282

496

497

73

266

204

210

262

570

567

J 88

180

275

381

344

635

620

451

357

635

618

608

639

523

356

521

300

283

167

17

118

96

507

501

141

516

221

413

4 
ENGLISH AND LATIN INDEX.

Timothy-grass.

Toad-flax.

Tobacco.

Tooth-ach-tree.

Tcoth-wort.

Touch-me-not.

'Traveller's-joy.

Tread-sofily.

Tree Primrose.

'Iretoil.

- Bird's-foot-

-.. Marsh-

Trumpet-flower.

Tulip-tree.

Tupelo.

Turnerick.

Turnsole.

Umbrella-trce.

Valerian.

- Greek-

Venus's-Aly-trap.

Vervain.

Vetch.

_-. Milk-

Vine-grapc.

Violet.

. Water-

Viper's Bugloss.

- grass.

Virgin's-bower.

Wake-Robin.

Walking-fern.

Wall-flower.

- nut-tree. Rue.

Water-leaf.

- Radish.

Wax Myrtle.

Way-faring-tree.

Wheat.

White-wood.

vol. 11 .
Phleum pratense.

65

Antirrhinum Linaria. $\quad 421$

Thesium. $\quad \mathbf{i 7 7}$

Nicoizana. $\quad 1.14$

Zanthoxylum. $\quad 209$

Dentaria. 438

Imbations. $\quad 171$

Clematis. $\quad 334$

Jatrotila. 603

Oenothera. 261

Trifolium. 477

Lolus. $\quad 489$

Menyanthes trifolia. $\quad 139$

Bignonia. 419

Liriodendron. $\quad 352$

Nissa. 177

Hyilustis. $\quad 389$

Heliotropium. 130

Magnolia tripetala. 381

Valeriana. 26

Polemonium. $\quad 151$

Dioncea. $\quad 304$

Verlena. $\quad 415$

Vicia. $\quad 471$

Astragalus. $\quad 472$

Vilis. $\quad 169$

Viola. $\quad 171$

Hottonia. 138

Echium. $\quad 130$

Scorzonera. $\quad 497$

Clematis. 354

Arum. $\quad 399$

Lycopodium alopecuroideum. 654

Cheiranthus. $\quad 436$

Juglans. $\quad 636$

Asplenium Ruta. $\quad 666$

Hydrosillum. $\quad 134$

Sisymlrium amphilium. $\quad 440$

Myrica. $\quad 620$

Vilurnum lantanoides. $\quad 20 \mathrm{l}$

Triticum. 90

Melampyrum. $\quad 43$

Tilia.

362 
ENGLISH ANDLATIN INDEX.

Whitlow-grass.

Draba.

433

Whortle-berry.

Vaccinium.

284

Willow.

Salix

608

Epilubium.

Wind-flower.

Anemone.

Winter-berry.

Prinos.

220

green.

Pyrola. Chimaphila.

299

Wire-grass.

Chick weed-Trientalis.

254

Chloris

Hamamelis.

87

Witch Hazel.

Aconitum.

Wolf's-bane.

Wood-bine.

Caprifolium.

116

Oialis.

372

160

Spigelia.

322

Worm-grass.

Chenopodium Anthelminticum. 198 Erysimum cheiranthoideum.

436

Yam.

Dioscorea.

251

Yarrow

Achillea millefolium.

563

Yellow Rattle.

Rhinanthus.

429

Zantorrhiza.

212

Hydrastis.

389

Yew-tree.

Taxus. 


\section{N D EX}

\section{GENERUM ET SYNONYMORUM.}

\begin{tabular}{|c|c|c|c|c|c|}
\hline$A_{B I E S .}$ & & 639 & Aira. & & 85 \\
\hline Acacia. & i. 373$)$ & 305 & Ajuga. & ii. 471) & 404 \\
\hline Acalypha. & ii. 687$)$ & 604 & Alchemilla. & i. 139) & 112 \\
\hline Acer. & i. 342$)$ & 265 & Aletris. & i. 293) & 225 \\
\hline Achillea. & ii. $6+6$ ) & 502 & Alisma. & i. 331 ) & 252 \\
\hline Achyrunthes. & & 445 & Allionia. & i. 118) & 97 \\
\hline Acnida. & i. 268) & 208 & Allium. & i. 288) & 222 \\
\hline Aconitum. & ii. 445) & 372 & Aluus. & ii. 695 ) & 622 \\
\hline Acorus. & i. 309 ) & 235 & Alopecurus. & i. 77) & 65 \\
\hline Acrostichum. & ii. 721$)$ & 658 & Alsine. & & 317 \\
\hline Acrostichum. & $6.59,600$, & & Alyssum. & ii. 523 ) & 434 \\
\hline & 661,666, & 670 & Aniaranthus. & i. 267) & 206 \\
\hline Actæa. & ii. 435) & 366 & Amaryllis. & i. 287 ) & 222 \\
\hline Actaa. & 372, & 373 & Ambrosia. & ii. 666) & 580 \\
\hline Actinea. & & 560 & A mellus. & ii. 650 ) & 564 \\
\hline Actinella. & ii. 639) & 560 & Amellus. & & 562 \\
\hline Adelia. & & 22 & Ammannia. & i. 135) & 107 \\
\hline Adiantum. & ii. 733$)$ & 670 & Amıni. & i. 238) & 192 \\
\hline Agilops. & & 88 & Ammyrsine. & i. 366 ) & 301 \\
\hline Aeschynomene & e. ii. 583) & 485 & Amorpha. & ii. 561$)$ & 466 \\
\hline Aeschynomene. & & 485 & Ampelopsis. & & 170 \\
\hline Esculus. & i. 333) & 254 & Amsonia. & i. 225) & 184 \\
\hline Afzelia. & & 424 & Anagallis. & i. 166$)$ & 135 \\
\hline Agave. & i. 294) & 226 & Andromeda. & i. 358 ) & 290 \\
\hline Ageratum. & & 516 & Andromeda. & 264 , & 286 \\
\hline Agrimonia. & i. 409) 3 & 335 & Andropinylax. & & 252 \\
\hline Agrostemma. & i. 393$)$ & 321 & Andropogon. & i. 85$)$ & 74 \\
\hline Agrostis. & i. 73 ) & 63 & Andropogon. & & 73 \\
\hline Agrostis. & &, 87 & Androsace. & i. 170 ) & 137 \\
\hline Aira. & i. 89) & 76 & Anemone. & ii. 457) & 386 \\
\hline
\end{tabular}


Anemone. 391 Aspidium.

Angelica. i. 243) 193 isfitium. Anona. 353 A iplesium.

Anomymos Walteri. 10, $13,28,31,115,132$, Asplenium. Aster. 130, 185, 187, 231, $252,334,416,424$, $474,484,507,508$, 510,511

Aster.

Astragaluse. Astrogalus.

Athenasin.

ii. 724) 660 ii. 727$) 666$ 664,667 ii. 636) 543 $532,533,534$ ii. 570 ) 472 473 519,520

Anthemis. ii. 645) 562 Anthericum. 242,246

Anthoxanihus. i. 74) 6.5 Anthoxenthum. 73

Antirrhinum.

ii. 506) 421

Anychia.

i. 2,7$) 176$

Apargia.

Aphunes.

ii. 594$) 497$

A heropegon. i. 86) 75 Alhyrium.

Atragene. 664 Atriplex. Atropa.

Avena.

Aiena.

Azalea.

Apios.

Apium.

ii. 572$) 473$

Aporynum.

i. 223) 179

Aquilegia.

Arabis.

Arathis.

Aralia.

ii. 440$) 372$

ii. 530$) 436$ 480

Arbutus.

Arlutus.

Arctium.

Arenaria.

Arethusa.

Arethusa.

Argemone.

Asalta.

Azolia.

ii. 455) 384

i. 255) 199

158

i. 100$) 85$ 76

i. 190$) 151$

264

ii. 739$) 6 \% 2$

Baccharis.

ii. 623) 523

Baccharis. 524

Balsamona. 335

i. 270$) 209$

i. 355$) 28$ ?

Baltimora. 580

Bartonia.

Burtonia.

ii. 606$) 505$

Partsia.

i. $389 \quad 317$

ii. 6,3$) 500$

Batschia.

L'efaria. $59 !, 593$

Argolasia.

Aristida.

ii. 433$) 366$

Pejaria.

Bellis.

Berberis.

i. 82) 72

Aristulochia.

i. 679) 506

Arnica.

ii. 629) 527

Bernhardia.

Becula.

Belula.

ii. 621) 520

Artenisia.

Arum.

ii. 470$) 399$

Bidens.

Bidens.

Arundinaria.

Arundo.

Arundo.

Asarum.

Asclepias.

59

Bignonia.

i. 101) 80 59,65

Bignonia.

Biscutella.

i. 400$) 327$

100

ii. 515) 429

i. 160$) 132$ 362

ii. 423) 362

ii. 626) 526

i. 253) 219

ii. 715) 655

ii. 694) 620 623

ii. 653) 566 519

ii. 503 ) 419 10,185

435

ii. 680) 506 Blairia. 417

i. 224) 180

Blandfordia. 446

Ascyrum. Ascyrum.

ii. 448) 373 Blechnum.

ii. 731) 669 Asparagus. 379 Blechnum. Blitum.

i. 307$) 235$ 
Eocbera.

Boehmeria.

Boerhavia.

Boltonia.

Borya.

Botrychium.

Botrypus.

Brachystemum.

Brasenia.

Brassica.

Briza.

Brodiæa.

Bromus.

Brumnichia.

Buchnera.

Buchnera.

Bumelia.

Bunias.

Buphthalmum. ii. 649) 563

Buphthalmum.

Burmanuia.

Cabomla.

Cacalia.

Cactus.

Cakile.

Caladium.

Calamintha.

Calla.

Calla.

Callicarpa.

Calligonum.

Callitriche.

Calochortus.

Caltha.

Calycantbus.

Calydermos.

Calypso.

Calystegia.

Campanula.

Canna.

Cannabis.

Cantua.

Capraria.

Caprifolium. i. 278$) 217$

ii. 638) 559

i. 140) 112

i. 39) 31

ii. 64i) 5(61

i. $3(0) 22$

ii. 717$) 65.5$

655

409,410

ii. 460,389

ii. 532$) 438$

i. 94) 82

i. $2 \div 9) 223$

i. (8) 8.5

i. 343$) 273$

ii. 505) $4: 1$ 416

i. 191) 155 43.4 503

i. 78 ) 7

239

ii. 615) 518

i. 399$) 327$

ii. 522) 434 399

ii. 492$)+13$

ii. 409) 399 399

i. 120) 97

ii. 44 !) 370

i. 6) 3

i. 316$) 240$

ii. 461) 389

i. 422$) 357$ 158

ii. 677) 593

i. 183) 142

i. j97) 159

ii. 670) 585

i. 256) 199

i. 186) 147

ii. 499) 418

i. 199) 160
Cardamine. ii. 534) 439

Cardiospernum. i. 349) 2,3

Carduus. ii. 608) 507

('arduus. $\quad 506$

Carex. i. 47) 34

Curer. $\quad 45$

Carpinus. ii. 696) 623

Carpinus. 623

Carthamus. $\quad 505$

Cassia. i. 375) 305

Crisine. $\quad 118$

Castalia. $\quad 368$

Castanea. ii. 699) 624

Catalpa. i. 16) 10

Caulinis. i. 2) 2

Caulophyllum. i. 282) 218

Ceanothus. i. 206) 167

Celastrus. i. 207) 167

Celtis. i. 259) 200

Cenchrus. i. 66) 60

Centaurea. ii. 65s) 576

Centaurella. i. 124) 99

Centunculus. i. 121) 97

Cephalanthus. i. 144) 114

Ctphalotis. 238

Cerastium. i. 392) 320

Ceratiola. i. 29) 21

Ceratophyllum. ii. 440) 370

Cercis. i. 377$) 308$

Ceropegia. i. 224 b.) 184

Chærophyllum. i. 2+9) 195

Chamærops. i. 314) 239

Chamcerops. 239

Chaptalia. ii. 659) 577

Chara. i. 10) 4

Cheilanthes. ii. 734) 670

Cheiranthus. ii. 528) 436

Cheiranthus. $\quad 436$

Chelidonium. ii. 429) 365

Chelidonium. $\quad 365$

Chelone. ii. 510) 427

Chelone. $\quad 427,428$

Chenopodium. i. 254) 197

Chimaphila. i. 364) 300

Chiococca. i. 198) 160 
Chionanthus. i. 13) 7 Chironia. $\quad 137$

Chlora.

Chloris. 137

Chondrilla.

Chrysanthemum.

$$
\text { ii. 627) } 526
$$

Chrysanthemum. 527,561

Chrysobalanus. i. 403) 329

Chrysocoma. ii. 614) 517

Chrysocoma. 511, 512, 540

Chrysogonum. ii. 662) 579

Chrysosplenium. i. 346) 269

Cichorium. ii. 593) 496

Cicuta.

Cicuta.

i. 247) 195

Cimicifuga.

Cineraria.

Cinna.

Circæa.

Cirsium.

Cissampelos.

Cissus.

Cistus.

Clarckia.

Claytonia.

Clematis.

Cleome.

Clethra.

Cliftonia.

Clinopodium. ii. 4S6) 410

Clinopodinm.

Clitoria.

Cnicus.

Cochlearia.

Collinsonia.

Colonea.

Comarum.

Commelina.

Commelina.

Comptonia.

Conium.

Conostylis.

Convallaria. 408, 409

ii. 587) 487

ii. 607$) 506$

i. 27) 20

ii. 447) 372

ii. 630) 528

i. 28$), 75$

506

252

i. 210) 170 363

i. 337) 260

i. 215) 175

ii. 456) 384

ii. 536) 441

i. 367$) 301$ 302

Convallaria. 572

i. 420$) 356$

i. 40) 31

32

ii. 703) 635

i. 248) 195

i. 292) 224

i. 304) 232

$233,234,235$
Convolvulus. i. 154) 143

Convolvulus. 142, 145, 146

Conyza. ii, 624) 523

Conyza. 543, 544, 556

Coptis. ii. 462) 390

Coreopsis. ii. 654) 567

Coreopsis. $\quad 565,566$

Corispermum. i. 8) 4

Cornucopice.

Cornus.

i. 137) 107

Coronopus. ii. 524) 435

Corydalis. ii. 558) 462

Corylus. ii. 701) 634

Corypha. 239, 240

Cotula. $\quad 562$

Cratægus. i. 410) 336

Cratagus. $\quad 339,340$

Cristaria. ii. 553) 453

Critonia. $\quad 512$

Crotalaria. ii. 564) 469

Crotalaria. $\quad 307,308$

Croton. ii. 686) 603

Croton. 608

Crotonopsis. i. 265) 206

Cteisium. 657

Cucubalus. i. 386) 315

Cucubalus. $\quad 316$

Cunila. ii. 475) 406

Cunila. 414

Cuphea. i. 407) 335

Cupressus. ii. 708) 645

Cuscuta. i. 149) 116

Cyamus. $\quad$ ii. 467) 398

Cymbidium. ii. 676) 592

Cymlidium. $\quad 593$

Cynanchum. $\quad 179$

Cynoctonum. $\quad 139$

Cynodon. i. 80) 70

Cynoglossum. i. 163) 133

(ynosurus.

Cyperus.

87

Cyperus. $\quad 53$

Cypripedinm. ii. 678) 594

Cypripedium. $\quad 593$

Cyrilla.

i. 211$) 170$ 
INDEX GENERUM ET SYNONYMORUM.

\begin{tabular}{|c|c|c|c|c|c|}
\hline Dactylis. & i. 97) & 84 & Dulichium. & i. 57) & 53 \\
\hline $\begin{array}{l}\text { Dactylis. } \\
\text { Dalea. }\end{array}$ & & $\begin{array}{r}59 \\
474\end{array}$ & Dyssodia & & 559 \\
\hline $\begin{array}{l}\text { Dalea. } \\
\text { Dalea. }\end{array}$ & ii. 573$)$ & $\begin{array}{l}474 \\
512\end{array}$ & Echites. & i. 221) & 178 \\
\hline $\begin{array}{l}\text { Dalea. } \\
\text { Dalibarda. }\end{array}$ & $\begin{array}{r}461, \\
\text { i. } 416)\end{array}$ & 350 & Echium. & i. 156$)$ & 130 \\
\hline Datisca. & ii. 442 ) & 370 & Eclipta. & ii. 644) & 561 \\
\hline Datura. & i. 179) & 141 & Elæagrus. & i. 145) & 114 \\
\hline Daucus. & i. 237 ) & 191 & Elephantopus. & ii. 66s) & 582 \\
\hline Daucus. & & 194 & Eleusine. & i. 102) & 87 \\
\hline Decodon. & & 334 & Ellisia. & i. 178$)$ & 141 \\
\hline Decumaria. & i. 401) & 328 & Elodea. & ii. 450 ) & 379 \\
\hline Delphinium. & ii. 444) & 371 & Elontea. & & 33 \\
\hline Demidofia. & & 187 & Elymus. & i. 106) & 89 \\
\hline Dentaria. & ii 533) & 438 & Elytraria. & i. 20) & 13 \\
\hline Dianthera. & & 13 & Empetrum. & i. 1160 & 93 \\
\hline Dianihus. & i. 384) & 314 & Epigæa. & i. 300$)$ & 297 \\
\hline Diapensia. & i. 187) & 147 & Epirobium. & i. 335) & 259 \\
\hline Dichondra. & i. 229 ) & 187 & Epipactis. & ii. $67+4$ & 591 \\
\hline Dichromena. & i. 52) & 47 & Equisetum. & i⿱亠. 713$)$ & 651 \\
\hline Dicksonia. & ii. 735$)$ & 671 & Erianthus. & & 3,74 \\
\hline Diervilla. & i. 202) & 162 & Erica. & & 204 \\
\hline Digitaria. & i. 79) & 69 & Erigeron. & ii. 634) & 532 \\
\hline Digitaria. & & 70 & Es & & 523 \\
\hline Dilatris. & i. 37) & so & Erioc & i. 113) & 91 \\
\hline Dilepyrum. & & 61 & Eri gonum. & i. 353$)$ & 277 \\
\hline Diodia. & i. 133) & 105 & Eriophorum. & i. 60) & 57 \\
\hline Dionæa. & i. 370 ) & 304 & Eriophorum. & & 57 \\
\hline Dioscorea. & i. 328 ) & 251 & Ervum. & & 487 \\
\hline Diospyros. & i. 341 ) & 205 & Eryngium. & i. 233) & 189 \\
\hline Diotis. & ii. 683) & 602 & Erysimum. & ii. 5271 & 436 \\
\hline Diphylleja. & i. 281 ) & 215 & Er! & ii. 562 ) & 467 \\
\hline Dipsacus. & i. 117$)$ & 96 & Erihronium. & i. 301 ) & 230 \\
\hline Dirca. & i. 343 ) & 268 & Erythrorhiza. & & 446 \\
\hline Dodecatheon. & i. 168 ) & 130 & Ethulin. & & 518 \\
\hline Dolichos. & ii. 566) & 470 & Eupatorium. & ii. 612 ) & 512 \\
\hline Dolichos. & 469, & 487 & Eupatorium. & 512 &, 517 \\
\hline Donia. & ii. 637) & 559 & Euphorbia. & ii. 689 ) & 605 \\
\hline Doronicum. & & 528 & Euptırasia. & ii. 516$)$ & 430 \\
\hline Draba. & ii. 520) & 433 & Evolvulus. & i. 230 ) & 187 \\
\hline Dracana. & & 233 & Evonymus. & i. 208) & 168 \\
\hline Dracocephalum & 8) & 411 & Exacum. & i. 125) & 100 \\
\hline Dracontium. & & 398 & & & \\
\hline Drosera. & i. 273 ) & 210 & Fagus. & ii. 698) & 624 \\
\hline Dryas. & i. 417 ) & 350 & Fagu & & 624 \\
\hline Dryas. & 350 , & 352 & Fedia. & i, 33) & 28 \\
\hline
\end{tabular}


INDIX GENERUM ET SYNONYMORUM.

\begin{tabular}{|c|c|c|c|c|c|}
\hline Ferula. & i. 240$)$ & 102 & Gonclobium. & i. 222) & 178 \\
\hline Festuca. & i. goj) & 83 & Genointus. & & 178 \\
\hline Fulago. & & $520^{\circ}$ & Goudsaia. & ii. 550) & 45 \\
\hline Finuoristylis. & i. 55) & $4 y$ & Graticla. & i. 19) & 1 \\
\hline Floerkea. & & $2: 39$ & & 418 & 419 \\
\hline Forsythia. & & 328 & Guilandina. & & 30 \\
\hline Fothergilla. & i. 40S) & 335 & Gymnundra. & & 430 \\
\hline Fray & i. 421$)$ & 357 & cladus. & i. 372$)$ & 304 \\
\hline Franklinia. & & 451 & & & \\
\hline Fra & i. $12 \%)$ & 101 & Halesia & ii. 547 ) & 44 \\
\hline ius. & i. 15) & 8 & melis. & i. 148) & 11 \\
\hline aria. & i. 300$)$ & 230 & Hamiltonia. & i. 220 ) & $17 \mathrm{~S}$ \\
\hline Fui & i. 02) & 58 & Hed. & ii. 493 ) & 41 \\
\hline Fui & & 58 & Helyotis. & 102 , & 10 \\
\hline Fun & ii. 559$)$ & 463 & Hedypnois. & & 497 \\
\hline Fur & 462, & 463 & ysarum. & ii. 581) & 48 \\
\hline & & & Hed & 480 & \\
\hline ia. & ii. 586$)$ & 456 & & 484,485 , & , 4S7 \\
\hline dia. & ii. 6500 ) & 572 & $\mathrm{H}$ & ii. 640$)$ & 560 \\
\hline irda. & & 572 & enut & n. ii. 425$)$ & 36 \\
\hline $\mathrm{x}$. & ii. 541) & 446 & inthus. & ii. 655) & 570 \\
\hline$a$. & & 489 & thus. & & .503 \\
\hline psis. & ii. 479) & 407 & $\mathrm{He}$ & ii. 648) & 563 \\
\hline & i. 131$)$ & 102 & Heliotropiu & i. 157$)$ & 130 \\
\hline eria. & i. 350$)$ & 283 & Hellelorus. & & 390 \\
\hline $\mathrm{Ga}$ & i. 336) & 260 & Helonias. & i. 320 ) & 242 \\
\hline ninum. & i. 226$)$ & 184 & & & 241 \\
\hline $\mathrm{Ge}$ & i. 227) & 185 & ica. & ii. $46-1)$ & 391 \\
\hline $\mathrm{am}$. & ii. 546$)$ & 4.48 & cleun. & i. 241$)$ & 192 \\
\hline $\mathrm{Ge}$ & ii. 507$)$ & 422 & era. & & \\
\hline Geum & i. 415) & 351 & tis. & ii. 500) & 418 \\
\hline Gilia. & & 147 & & ii. 529) & 436 \\
\hline Gillenia. & & $: 243$ & thera. & . i. 42 ) & 32 \\
\hline Glandularia. & & $4 ! 6$ & era. & i. 231) & 187 \\
\hline am. & ii. 4.30$)$ & 365 & & ii. 556) & 455 \\
\hline & i. 216$)$ & 176 & um. & ii. 601) & .502 \\
\hline ma. & ii. 482 ) & 408 & ium. & & 501 \\
\hline hia. & i. 285 ) & 221 & llä̈. & i. 146$)$ & 115 \\
\hline fera. & & 10 & & & \\
\hline ine. & ii. 58.5$)$ & 485 & toffmannia. & & 655 \\
\hline$G l$ & 470,473, & 474 & Holcus. & i. 91) & 78 \\
\hline $\mathrm{Gi}$ & ii. 579$)$ & 480 & Holcus. & & 82 \\
\hline alium. & ii. 025$)$ & 524 & Holosteum. & i. 110) & 90 \\
\hline & & & & & 223 \\
\hline Gnn & 2 & & a. & ii. $5+9$ ) & 451 \\
\hline
\end{tabular}




\begin{tabular}{|c|c|c|c|c|c|}
\hline Hordeum. & i. 107) & 89 & Juglans. & ii. 70.5$)$ & 635 \\
\hline Hottonia. & i. 172 ) & 139 & Juncus. & i. 310$)$ & 235 \\
\hline Houstonia. & i. 134) & $100^{\circ}$ & Juniperus. & ii. 710$)$ & 6400 \\
\hline Hudsonia. & ii. 426$)$ & 304 & Jussiæa. & i. 371$)$ & 304 \\
\hline Humulus. & i. 257$)$ & $1 \iota 9$ & Justicia. & i. 21) & 13 \\
\hline Hydrangea. & i. 379$)$ & 309 & Justicia. & & 13 \\
\hline Hydrastis. & ii. 4.59$)$ & 389 & Iva. & ii. 665 ) & $5 \mathrm{SO}$ \\
\hline Hydrocotyle. & i. 234$)$ & 190 & Ixia. & i. 35$)$ & 29 \\
\hline glossum. & ii. $7(8)$ & 656 & & & \\
\hline Hydrolea. & i. 228$)$ & 187 & Kalmia. & i. 359$)$ & 295 \\
\hline Hydropeltis. & & 389 & Knoxia. & & 107 \\
\hline Hydrophyllum. & 1. i. 165) & 134 & Kochia. & i. 266) & $200^{\circ}$ \\
\hline Hyoscyamus. & i. 180) & 141 & Koeleria. & i. 99) & 85 \\
\hline $\mathrm{Hyo}$ & ii. 603 ) & 504 & Krigia. & ji. $6(2)$ & $50 t$ \\
\hline Hyoseris. & 504 & 505 & Kuhnia. & ii. 611) & 512 \\
\hline nopapplis & s. ii. 617 & 519 & Kuhnistera. & & 461 \\
\hline nophyllu & $\mathrm{m}$. & & Kyllingia. & i. 50$)$ & 46 \\
\hline & ii. 736) & 671 & Kyllingia. & & 8,59 \\
\hline Hypericum. & ii. 449$)$ & 374 & & & \\
\hline$H z$ & 374,379, & & Lacathea. & & 451 \\
\hline Hypoxis. & i. 201) & 231 & Lac & 9) & 500 \\
\hline Hyptis. & ii. 484$)$ & 408 & $\begin{array}{l}\text { Lactuch. } \\
\text { Lagotis. }\end{array}$ & & $\begin{array}{l}502 \\
430\end{array}$ \\
\hline Hyssopus. & ii. 476$)$ & $400^{\circ}$ & Lamium. & ii. 478 ) & $406^{\circ}$ \\
\hline & & & La & & 645 \\
\hline Jatr & ii. 685) & 603 & Lathyrus. & ii. 568) & 471 \\
\hline Jeffersonia. & i. 344) & 258 & Laurus. & i. 352) & 27.5 \\
\hline Ilex. & i. 152 ) & 117 & Lechea. & i. 112$)$ & yo \\
\hline llex. & & 221 & l.edum. & i. 305) & 300 \\
\hline Illecebrum. & ii. 543) & 445 & Ledum. & & 301 \\
\hline Illicium. & ii. 451) & 380 & Leersia. & i. 71$)$ & 02 \\
\hline tiens. & i. $2(3)$ & 171 & Lemna. & i. 31$)$ & 22 \\
\hline Indigofera. & ii. 589 ) & 488 & Leontice. & & 218 \\
\hline Inula. & ii. 633) & 531 & Leontodon. & ii. $59^{6}$ ) & 497 \\
\hline Ipomøea. & i. 185) & 145 & Leontodon. & & 407 \\
\hline Ipomœa. & & 147 & Leonurus. & ii. 481$)$ & 408 \\
\hline Ipomopsis. & & 147 & Lepidium. & ii. 525 ) & 43.5 \\
\hline Iresine. & ii. 542 ) & 445 & Lepidium. & & 435 \\
\hline Iris. & i. 36$)$ & 29 & Leptanthus. & & 32 \\
\hline Isanthus. & ii. 4,4$)$ & 405 & Lespedeza. & ii. 580 ) & 480 \\
\hline Ischaemum. & & 88 & Lewisia. & ii. 437$)$ & 368 \\
\hline Isnardia. & & 111 & Leysera. & & 573 \\
\hline Isoëtes. & ii. 737$)$ & 071 & Liatris. & ii. 609) & 507 \\
\hline Itea. & j. 212 ) & 171 & I.igusticum. & i. 242) & 193 \\
\hline ltea. & & 171 & Ligustrum. & i. 11) & 7 \\
\hline
\end{tabular}




\begin{tabular}{|c|c|c|c|c|}
\hline Lilium. & i. 209) & 228 & schkea. & \\
\hline Lilium. & & 230 & Mayaca. & \\
\hline imnetis. & i. 65) & 59 & Medeola. & \\
\hline imodorum. 5 & 589,592 , & 593 & Medicago. & 490 \\
\hline rnia. & ii. 501 ) & 419 & $M e$ & 480 \\
\hline & ii. 495) & 415 & yrum. ii. 517) & 430 \\
\hline 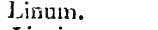 & i. 272$)$ & 210 & era. ii. 618) & 519 \\
\hline int & 417, & 418 & ium. i. 317) & 240 \\
\hline mbar. & ii. 702) & 635 & thicum. 242,243 , & 246 \\
\hline bar. & & 635 & i. 90$)$ & 75 \\
\hline & ii. 453 ) & 382 & ii. 575$)$ & 477 \\
\hline $\mathrm{m}$ & n. i. 1 & 131 & & 413 \\
\hline ith & & 132 & ii. 538 ) & 444 \\
\hline & ii. 545) & 446 & rmunı.ii. 443) & 370 \\
\hline & 160 , & 162 & um. & 252 \\
\hline & ii. 5 & 489 & ii. 473 ) & 405 \\
\hline & i. 138 ) & 110 & i. 173) & 139 \\
\hline & ii. 5 & 479 & & 139 \\
\hline & & 467 & i. 340$)$ & 264 \\
\hline & & 238 & 37,338 & \\
\hline & i. 394 ) & 321 & 339 & 340 \\
\hline & i. 119$)$ & 97 & n. i. 17) & 10 \\
\hline um. & ii. 714$)$ & 6.52 & 1. i. 390$)$ & 319 \\
\hline & & 655 & i. 64) & 59 \\
\hline & $162)$ & 132 & ii. 613 ) & 517 \\
\hline & i. 24) & 16 & i. 72$)$ & 62 \\
\hline & & 657 & $M i$ & 71 \\
\hline & i. 167$)$ & 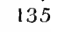 & & 305 \\
\hline & i. 406) & 334 & ii. 509) & 426 \\
\hline & & 335 & & 101 \\
\hline & & & & \\
\hline & i1. 2 & 38 & i. 114) & 92 \\
\hline$a j a$ & & 233 & ii. 539 ) & 444 \\
\hline al & & 452 & i. 25$)$ & 16 \\
\hline & ii. 675 ) & 592 & & 418 \\
\hline & ii. 555$)$ & $45 \overline{5}$ & i. 369 ) & 303 \\
\hline & ii. 55 & $45-1$ & ii. 706$)$ & 639 \\
\hline & & 454 & sergia. i 69 ) & 61 \\
\hline & i. 51) & 47 & ii. 521) & 434 \\
\hline & $63 \hat{\prime}$ & 58 & i. 368 & 302 \\
\hline & ii. 483 & 408 & i. 164 & 133 \\
\hline & ii. 699) & 519 & ii. 693 ) & 620 \\
\hline & & & & 274 \\
\hline : & ii. & 428 & & 196 \\
\hline
\end{tabular}


INDEX GENERUM ET SYNONYMORUM.

Najas.

Napaea.

Narthecium,

Narthecium.

Nectris.

Nelumbium.

Neottia.

Nepeta.

Nepeta.

Nephrodium. 659, 661, $663,664,665,670$

Nicandra.

Nicotiana.

Nolina.

Nuphar.

Ny'mphæa.

Nymphaa.

Nyssa.

i. 194$) 158$

i. 181) 141

i. 315$) 240$

ii. 439) 369

ii. 438) $36 \mathrm{~s}$

$369,370,398$

i. 219) 177

Obolaria.

Oeranthe.

Oenothera.

Oldenlandia.

Olea.

Onoclea.

Onoclea.

Onosmodium. i. 161) 132

Ophioglossum. ii. 716) 655

Ophiorrhiza. i. i76) 139

Ophrys. 589, 591, 592, 593

Orchidocarpum.

Orchis.

Origanum.

Origanum.

ii. 518) 431

i. 245$) 194$

i. 338$) 261$

i. 129) 102

i. 12) 7

ii. 725) 665 666,669

Ornithogalun. ii. 207) 227

Ornithogalum.

Ornus.

Orobanche. ii. 519) 431

Orontium. i. 309) 235

Oryzopsis.

Osmunda.

Osmunda.

Ostrya.

Oxalis.

Oxycoccus. ii. 671) 585

ii. 487) 411 409,410

ii. 297) 227

$\begin{array}{rrr} & 222 \\ \text { i. } & 14) & 8 \\ \text { ii. } & 519) & 431 \\ \text { i. } & 309) & 235 \\ \text { i. } & 67) & 60\end{array}$

ii. 720$) 657$

$655,659,670$

ii. 697) 623

i. $3 9 5 \longdiv { 3 2 2 }$

i. $3 3 9 \longdiv { 2 6 3 }$
Oxytropis. ii. 571) 473

Pachysandra. i. 151) 117

Panax. i. 235) $19 t$

Pancratium. i. 2\$6) 221

Panicum. i. 78) 66

Panicum. $\quad 69,70$

Papaver. ii. 431) 365

Parietaria. i. 142) 114

Parnassia. i. 269) 208

Parthenium. ii. 664) 580

Paspalum. i. 81) 70

Paspalum. $\quad 69,70$

Passiflora. $\quad$ ii. 541) 444

Pastinaca. i. 250) 196

Pedicularis. $\quad$ ii. 508) 424

Penthorum. i. 396) 323

Pentstemon. ii. 511) 427

Peplis. i. $3 1 1 \longdiv { 2 3 8 }$

Perdicium. $\quad 577$

Persoonia. 519,520

Petalostemum. ii. 557) 461

Phaca. 485

Phacelia. i. 17\%) 140

Phæthusa. ii. 643) 561

Phalangium. i. 295) 226

Phalangium. 240

Phalaris. i. 75) 65

Phaseolus. ii. 565) 469

Phellandrium. i. 246) 195

Philadelphus. i. 402) 329

Phlcum. i. 76) 65

Phlox. i. 188) 148

Phryma. ii. 496) 415

Phyllanthus. ii. 537) 443

Phyllodoce. 264

Physalis. i. 193) 157

Phytolacca. i. 398) 324

Pinguicula. i. 22) 14

Pinckneya. i. 196) 158

Pinus. ii. 707 639

Pistia. i. 345$) 268$

Pisum. ii. 567) 470

Planera. i. 147) 115

Plantago. i. 122) 98 
Platanus.

Jieea.

F'leuranthus.

Poa.

Pora.

Podalyria.

Podophyllum.

Podolinyllum.

Podostemum.

Poireíia.

Polemonium.

Polemonium.

i olycarpon.

Polygala.

Polygonatum.

Polygonella.

Polygonum.

Polymnia.

Polymnia.

Polypodium.

Polypodium.

Folypremum.

Polysichum.

Pontederia.

Ionte'eria.

Populus.

I'urcelia.

Portulacca.

Putamogeton.

Potamogeton.

Potentilla.

Pothos.

Prasium.

Prenauthes.

Primula.

Prinos.

Iroserpinaca.

Prunella.

Prunus.

Psilotum.

Psoralea.

Psoralea.

Ptelea.

Pteris.

$$
\begin{aligned}
& \text { ii. } 704) 635 \\
& \text { i. } 354) 278
\end{aligned}
$$

53

i. 93) 78 85

i. 376$) 30 \%$

ii. 43t) 360

263

i. 5) 3 106

i. 189) 151 140,147

i. 111$) \quad 00$

ii. $5 6 0 \longdiv { 4 0 4 }$

i. 306$) 234$ 272

i. 347$) 369$

ii. 60i) 579 563

ii. 722$) 658$

660,661 , c03, 604, 671

i. 1.3) 99 600, 061,600 i. 290$) 223$

38

ii 602) 613

ii. 451$) 385$

ii. 428) 365

i. 154) 120

274

i. 419) 3.53

ii. $4 0 8 \longdiv { 3 9 8 }$ 411

ii. 595$) 408$

i. $1 6 9 \longdiv { 1 3 7 }$

i. $2 8 4 \longdiv { 2 } 2 2 0$

i. 115 92

ii. 489) 411

i. 404) 329 655

ii. 574) 475 474

i. 136) 107

ii. 729) 668
Pteris.

669

Ptirmia. 509

Pulmonaria. i. 158) 130

Py cnanthemum.

ii. 485) 409

Pyret rum. ii. 62s) 527

Pyrola. i. 363) 209

Pijrola.

300

l'yrularia.

Pyrus.

178

Pyxidanthera.

i. 411) 339

Quercus.

Queria.

ii. 700$) 625$ 176

Refnia.

307

Riajania.

273

Ranunculus. ii. 465) 391

Ranunculus. $\quad 390$

Raphis.

Rhannus.

Rhamnus.

i. 205) 160

Rhexia. i. 334) 257

Rhinanthus. ii. 514) 429

Rhinanthus. 423

likododendron. i. 361) 207

Rhodora. i. 362$) 298$

khus. i. 202) 204

Rhvuchospora. i. 54) 48

Ribes.

Ricinus.

i. 204) 163

Robinia. ii. 588) 487

Rolinia. 485

Rosa.

i. 414) 344

Rothia. 519

Rottboellia. i. 104) 88

Rubia.

Rubus.

i. 130) 102

Rubus.

i. 415) 346

Rudbeckia. ii. 657) 573

Rudleckia. $\quad 500,503,572$

Ruellia.

ii. 504) 420

Rumex.

Ruppia.

i. 326) 247

i. 155) 121 
INDEX GINERUM ET SYNONYMOKUM.

Sabal.

Sabbatia.

Saccharum.

Sayina.

Sagina.

Sayittaria.

Salıcomia,

Salix.

Salsola.

Salsola.

Salvia.

Salvinia.

Sambucus,

Samolus.

Sanguinaria.

Sangusurba.

Samcula.

Santolina.

Sapindur.

Saponaria.

Sarracenia.

Sarnthra.

Satureja

Satyrium.

Saururus.

Saxitraga.

Scondix.

Scheuchzeria.

Schisandra.

Schizea.

Schornus.

Schoenis.

Schrankid.

Scirpus.

Scirpus. 47, 49, 51, 54.

57,50

Schwaluea. ii. $5 ! 3) 428$

Scleria.

i. 48) 45

Scleranthus. i. 385) 315

Scolopendrium. ii. 728) 607

Scorzmera.

ii. 595$) 497$

Scrophularia.

Scutellaria.

Secale. i. 313$) 239$ Sedum.

Selitum.

Senecio.

Sencio.

Serpiculia.

Serratula.

Sesbania.

Seseii.

Sibbaldia.

Sicyos.

Sicyos.

Sidi.

Sicroxylum.

siegesbeckia. ii. 642) 501

Sergesteckia.

silene.

Silene.

Sitphitum.

Silphium.

Sison.

Sison.

Sin mbrium.

Sisjrinchium.

Situm.

Snilacina.

Smiax.

Smyrninm.

Solinandia.

solanum.

Solidityo.

Sonclius.

Sophora.

sorbus.

Sorghum.

Sparganium.

33

Sparginophorus. ii. 616) 518

Spergula. i. 391) 320

spermacoce. i. 132) 105

Spergulastrum. $\quad 319$

Spigelia. i. 175) 139

Spitontlus. $\quad 5002$

spirza. i. 413$) 341$

St:lebys. $\quad$ i. 450$) 407$

Stcehelina. 
Staphylea.

Statice.

Stellaria.

Stellaria.

Stewartia.

Stillingia.

Stipa.

Stipulicida.

Stokesia.

Streptopus.

Struthiopteris.

Stuartia.

Stylosarithes.

Styrax.

Sueda.

Swertia.

Swertia.

Syena.

Symphoria.

Symplocos.

Syntherisma.

Tabernemontana.

Tagetes.

Talinum.

'Tanacetum.

Taxus.

Tecoma.

Tephrosia.

Tetragonotheca.

Teucriun.

Teucrium.

Thalia.

Thalictrum.

Thalictrum.

7 hapsia.

Thesium.

Thlaspi.

Thuya.

Thymlra.

Thymus.

Thymus.

Tiarella.

Tigarea.

Tilia. i. 263) 206

i. 275) 212

i. 388$) 317$

317

452

ii. 690) 608

i. 83$) 72$

90

ii. 605) 505

i. 303) 232

ii. 726) 665

ii. 551) 451

ii. 578$) 480$

ii. 548) 450 197

i. 126) 100 138

i. 41) 32

i. 201) 162 451

69,70

Triticum.

184 Trollius.

559 'Iroximum.

ii. 427) 365

ii. 622) 522

ii. 711) 647 420

ii. 590$) 489$

ii. 647$) 563$

ii. 472) 405

404

ii. 669) 584

ii. 458) 388

387

196

i. 218) 177

ii. 526) 435

ii. 709) 646 414

ii. 491) 413

$409,413,414$

i. 381$) 313$

i. 405) 333

ii. 424) 362

Tillandsia.

Tofieldia.

Tragia.

Trientalis.

Trifolium.

Trifolium.

Triglochin.

Trillium.

Triosteum.

Tripsacum.

Tripterella.

Trisetum.

Tuliflora.

Turritis.

Turnera.

Tussilago.

Tussilago.

Typha.

Ulmus.

Uniola.

Uniola.

Urtica.

Utricularia.

Uvularia.

Uvularia.

Vaccinium.

Vuccinium.

Vaginaria.

Valantia.

Valeriana.

Valeriana.
Trachynotia.

Tradescantia.

Tragopogon.

Trattinickia.

Trichodium.

Trichomanes.

Trichophorum.

Trichostema. ii. 494) 414 i. 279$) 217$

i. 323) 246

59

i. 280) 218

ii. 688) 604

505

i. 70$) 519$

i. 332) 254

ii. 576$) 477$

$475,480,486$

i. 324) 247

i. 322) 244

i. 203) 162

i. 105) 88

i. 34) 28

i. 87) 76

i. 109$) 90$

ii. 463) 391

ii. 604) 505

ii. 531$) 438$

i. 264) 206

ii. 632) 531 577

i. 46) 34

i. 258) 199

i. 95) 82

34

i. 141) 112

i. 23) 15

i. 302$) 231$

232

i. 357) 284

263, 283

i. 61) 58

102

i. 32) 28

28 
INDEX GENERUM ET SYNONYMORUM.

Vallisneria.

ii. 681) 602

Woodsia.

ii. 723$) 660$

Veratrum.

i. 319$) 242$

Woodwardia. ii. 732) 669

Veratrum. 243

Verbascum. Wurmlea.

Verbena.

Verbena.

i. 182) 142

ii. $4 9 7 \longdiv { 4 1 5 }$

Xanthium. ii. 667) 581 417 Xylosteum. i. 200) 101

Verbesina.

Verlesina.

ii. 651) 564 Xyris.

i. 44) 33

Vernonia.

Veronica. 561

ii. 610) 511

i. 18) 10

Viburnum.

i. 260) 201

Vicia.

ii. 569) 471

Villarsia.

i. 174) 139

Yucca.

i. 298) 227

Vincetoxycum

Viola.

179

Zamia.

Zannichellia.

ii. 712) 648

Zanthorrhiza. i. 276) 212

i. 9) 4

i. 214) 171

Zapania.

i. 378) 309 Zapania. 572 Zea.

i. 271) 209

Virgilia.

Virgilia.

Viscum.

Vitis.

Vitis.

Vittaria.

Vogelia.

Zigadenus.

i. $143 ; 114$

Zinnia.

i. 209) 169

170

Zizania.

ii. 730) 669 Zizyphus.

29 Zornia.

Zostera.

ii. 498) 417

i. 49) 410

i. 318$) 241$

ii. 652) 565

i. 68) 60

i. 232) 188

ii. 582) 484

Wendlandia.

i. 330$) 252$

i. 1) 2 



\section{SUPPLEMENTUM.}

Lycopus exaltatus.-I. foliis basi pinnatifido-serratis, laciniis integerrimis subserratisque, calycibus spinescentibus.IVilld. sp. pl. 1.p.121.

Icon. Fl. greec. t. 12.

In iow shady woods: Virginia to Carolina; rare. 4. July, Aug. v. v.; v. s. in Herl. Sherard. From three to six feet high. This species I omitted for want of a specimen in my Herbarium, though I found it myself in Virginia; but seeing a specimen of Catesby's in the Sherardian Herbarium, I was convinced of its being a real American species.

Monarda rugosa.-M. glabriuscula; capitulis mediocribus subsimplicibus, bracteis exterioribus ovatis undulatis pilosis, calycibus corollisque glabris, lacinia media labii inferioris bidentata, foliis ovatis subcordatis acutis rugosis, nervis subtus petiolisque pilosis, caule acutangulo glabriusculo.-Willd. sp. pl. 1.p. 125.

In Canada and on the mountains of Virginia. 4. July -Sept. v. v. in Hort. Lambert. About four feet high; flowers small, white.

Valeriana dioica.-V. glabra; foliis radicalibus subspathu. lato-ovatis integris longissime petiolatis, caulinis paucis pinnatifidis, laciniis lanceolat is integerrimis subdentatisque obtusiusculis.-Willd. sp. pl. 1. p. 176.

Icon. Fl. dan. 687 .

In swamps at Hudson's Bay. Tilden. 24. June, v.s. in Herb. Sherard. About a span high ; flowers fleshcoloured.

Fedia chenopodifolia.-F. dichotoma; foliis ovatis acutis in. ferne dentatis, cymis nudis divaricato-dichotomis, fila. mentis longis. 
Valeriana virginiana, pedis anserinæ folio. Pet. H. S. in Herl. Sherura'.

In Virginid. $\odot$. v. s. in Herb. Sherard. About a span high; flowers the size of $V$. officinalis.

p. 72. Aristida pallens.-A. culmo erecto simplici, foliis filiformibus, radicalibus culmo brevioribus, panicula pauciflora, pedicellis alternis brevibus bifloris, aristis elongatis. Cav. ic. 5. t. 468 f. 2.

In Upper Louisiana. Bradlury. 4. v. s. in Herb. Brad. bury. About a foot high; the awrs more than three inches high.

p. 73.

Stipa memlranacea.-S. foliis convoluto-filiformibus glabris, panicula laxa, pedicellis flexuosis, calycibus membranaceis 3-nervibus longe acuminatis, corollis calyce brevioribus sericeo-villosis, villis corollam superantibus, arista nuda recta calyce paulo long:ore.

On the banks of the Missouri. Bradbury. v. s. in Herb. Bradlury. About eighteen inches high; flowers oval, covered with long silky hair.

p. 85. Bromus altissimus.-B. panicula nutante, spiculis oblongís sub.6-floris, flosculis pubescentibus, valvula exteriore 3-nervata breviter aristata, foliis vaginisque glabris, culmo glabro altissimo.

On the banks of the Missouri. 24. July, Aug. v. v. in Hort. Lamberl. From five to eight feet high.

p. 88.

Cynosurus secundus.-C. glaber; foliis linearibus, spica elongata unilateralis, spiculis solitariis, defluratis reflexis, calycibus lineari-lanceolatis acutissimis.

In Upper Louisiana. Bradlury. v. s. in Herb. Bradbury. Resembles $C$, retroftexus very much.

p. 97. Allionia linearis.-A. caule erecto tereti, foliis linearibus subcarnosis, floribus racemosis, pedicellis aggregatis, staminibus longissime exertis.

Calymenia angustifolia. Fraser Catal. 1813.

In Upper Louisiana. Bradlury. v. s. in Herl. Bradlury.

Alitonin hirsuta.-A. caule erecto angulato, foliis lanceolatis nervosis utrinque hirsutis, calycibus hirsutissimis sub3 -floris.

In Upper Louisiana. Brad́lury. v. s. in Herb. Bradlury. 
Plantago elongala.-P. foliis linearibus integerrimis glabris, scapo spicis elongatis subimbricatis foliis longiuribus, bracteis ovatis acutis margine membranaceis.

In Upper Louisiana. Bradlury. v. s. in Herl. Brad. lury. Resembles $P$. panciflora.

Pulmonaria lanceolata - P. glabra, erecta ; foliis radicalibus longissime pedicellatis lanceolatis, caulinis linerioblongis, floribus subpaniculatis, calycibus abbreviatis.

In Upper Lonisiana. Brallury. 24. 2. so in Herb. Bradlury. Fowers small, resembling those of $P$. pani. culata.

Pulmonaria silirica.-P. calycibus abbreviatis, foliis radica. libus cordatis. Willl.sp.pl.1.p.770.

Anchusa. Gmel. sib. 4. p. 75. no. 15.t.39.

In Canada. Masson. 4. July. v. s. in Herl. Lamlert. Flowers purple, in terminal corymbs; it resembles $P$. virginica very much.

Cynoglossum glomeratum.-C. hispicum; foliis spathulatis obtusis, Horibus glomeratis.

p. 133,

C. glomeratum. Fraser, catal. 1813.

In Upper Louisiana. Bradlury. 4. v. s. in Herl. Bradlury.

Lysimachia lanceolata.-L. glaberrima ; foliis quaternis subpetiolatis lanceolatis promisse acuminatis, pedunculis quaternis nultifloris, floribus summis racemosis, corol. læ laciniis oratis acutis, caule erecto simplici.

L. caroliniana quadrifolia, foliis acutis. Herl. Sherard.

In Carolina Catesly. $\varkappa_{\text {. }} v$. s. in Herb. Sherard. Flowers the size of L. vulyaris.

Calystegia Cateskeiana.-C. volubilis, tomentosa ; foliis oblongis sagittatis acumininatis, pedunculis uniflor is folio brevioribus, bracteis ovalibus obtusis calyce longio. ribus.

In Carolina. Catesly. v. s. in Herl. Sherard. Flowers large, purple.

Calystegia paradoxa.-C. htimifusa, tomentosa; foliis oblongis corlato sagittatis acutis, peduncuiis uniforis elongatis folio longioribus, bracteis a flore remotis line. aribus, calycibus nudis glab:is acuminatis.

Convolvulus virginianus, læviter hirsutis et oblongis foliis, flore maximo albicante. Pluk. mant. 54. secundum Herl. Shererd. 
In Virginia or Carolina, v. s. in Herl. Sherard. Flowers large, white.

p. 143. Convolvulus Sherardi-C. humifusus, pubescens; foliis ellipticis utrinque retusis mucronatis, floribus solitariis subsessilibus.

C. forte monococco Banist. similis, sed vasculis sessilibus. Herb. Sherard.

In Carolina. Calesly. $\odot$. v. s. in Herb. Sherard. Resembles $C$. trichosanthes very much; I have only seen a specimen with fruit.

p. 147. Cantua parviflora.-C. pubescens, diffusa; foliis pinnatifidis, laciniis linearibus elongatis, pedunculis solitariis unifloris terminalibus et oppositifoliis, corollis calyce vix longioribus.

Ipomopsis inconspicua. Smith exot bot. 1. t. I4.

In North America. Hoy. $\odot$. June. v. v. in Hortis. Flowers small, pale blue. I insert this plant on the authority of Exotic Botany; but at the same time I doubt very nuch of its being a native of North Ameri$\mathrm{ca}$, and more strongly suspect it to come from Mexico.

p. 148. Phlox acuminata.-P. erecta, pubescens; caule angulato, foliis ovato-lanceolatis acuminatis inferne angustatis sub. petiolatis subtus pubescentibus, floralibus subcordatis, corymbis paniculatis, corollæ laciniis rotundatis, tubo pubescente, calycibus aristatis.

Phlox decussata. Lyon catal. 1812.

On the mountains of Georgia and South Carolina. Lyon. 4. Aug. Sept. 2. v, in Hort. Lambert. From four to five feet high ; flowers very handsomely variegated, with dark and light shades of purple.

p. 149. Phlox nitida. - P. erecta, glaberrina; caule tereti maculato lævigato, foliis ovato-oblongis subcarnosis supra nitidis atrovirentibus, subtus pallidis, corymbis fastigiatis, ramis inferi rribus elongatis nndiusculis, corollæ laciniis lato-obovatis subretusis, dentibus calycinis lanceolatis mucronatis.

P. suffruticosa, Hortul.

In South Carolina. Fraser. 24. Aug.-Oct. v.v. in Hortis. Near two feet high; flowers of a brilliant purple, which is deeper than in any other species. This species approaches near to $P$. Carolina ; but besides its other characters it distinguishes itself very easily by flowering later and longer than that species. 
Solanum helerandrum.-S. annuum ; caule foliisque aculeap. 156 . tis, foliis ovatis pinnatifidis utrinque birsutis, lacinits obtusiusculis, antheris declinatis distantibus, ima corniformi productiore, bacca calyce eclinato inclusa.

Icon. Tab. 7.

The present description has been taken from a living plant raised by $A$. B. Lambert. Esq fiom seeds received of Mr. Nuttall. The native specimen the former description was made from was very imperfect.

Physalis somnifera-P. perennis, tomentosa; foliis oratis integerrinis, fioribus confertis brevissime pedicellatis, corollis campanulatis. Willd. sp pl. 1.p. 1019.

Icon. Cav. ic. 2. t. 103.

In South Carolina. Catesby. 24. July. v. s. in Herb. Sherard. Flowers small, brownish-yellow.

Campanula nitida.-C. glaberrima; foliis radicalibus spathulato-oblongis coriace is cartilagineo-crenatis, caulinis lanceolato-oblongis subintegerrimis, floribus racemosis, corollis campanulato rotatis. - Wilid. sp. pl. 1. p. 899.

C. americana minor, flore cœruleo patulo. Rob ic.

In North America. 24. July. v. s. in Herb. Lamlert. nec non Sherard. About a span high; flowers middle size, fine blue. What part of America it is from is not known, but I suppose it to be Hudson's Bay. Misled by Michaux, this plant had been inserted as a synonym to C.acuminata, with which it has not the least connection.

Riles la iflorum.-R. inerme; foliis cordatis 5-lobis incisodent.stis glabris, petiolis gracilibus, racemis laxis erectis longitudine foliorum, bracteis subulatis, pedicellis elongatis, calycibus campanulato-tubulatis, baccis globosis hispidis.

Cn the north-west coast. Menzies. h. v. s. in Herl. Banks. The flowers appear to be yellow, about the size of $R$. floridum.

Ribes speciosum.-R. sub gemmis 3-plicato-aculeatum; foliis cuneato-subrotundis inc so-crenatis glabris nervosis sultus pallidioribus, petiolis brevibus, pedunculis sub-3-tloris foliis longioribus, pedicellis germinibuique glanduloso-pilosis, caly cibus tubulatis pedicellis !ongioribus, staninibus longissime exertis.

On the north-west coast. Menzies. h. v. s. in Herl. Banks. The younger branches are hispid; the flowers 
large, purple. The leaves are small, and have some resemblance to those of Thalictrum.

p. 165.

Ribes Nenziesii- R. sub gemmis 3-plicato-aculeatum; ramis hispldissimis, foliis basi truncatis sub-5-lobis incisodentatis, Jowis lateralıbus brerioribus, subtus tomentosis, pedunculis subbifloris foliis subæquantibus,',calycibus tubulosis: limbo patente, staminibus longitudine calycis, stylo exerto, baccis globosis aculeatis.

On the north. went coast, near Fort Trinidad. Menzies. h. v. s. in Herb. Bunks. The flowers of the size and colour of R. sanguineum.

p. 173. Viola asarifolia.-V. acaulis, pubescens; foliis dilatato-reniformibus acutis circumcirca crenato-dentatis basi flabellatim in petiolum attenuatis, pedunculis folis multo brevioribus.

Viola caroliniana maxima, foliis cucumerinis, floribus ad radicem pediculis brevibus natis. Herb. Sherard,

In low rich woods: Virginia to Carolina. Catesty. 4 . May. v. s. in Herl. Sherard. I have seen this species several times in Virginia, but generally with out flowers; which has been the reason that no specimen was in ny collection.

p.190. Indrocotyle ambigua.-H. folio radicali composito, caule subapbyllo 2-3-umbellifero, umbellulis sub-3-floris, petalis lanceolatis.

In Upper Louisiana. Bradbury. v. s, in Herb. Bradlury. A very snall plant; flowers in proportion large, white, with purple anthers; resembling $H$ composita.

p. 192. Selinum acaule.-S. glabrum, acaule; foliis bipinnatis, foliolis linearibus superioribus confluentibus, scapis radicalibus foliis brevioribus, umbellulis radii masculis.

In Upper Louisiana. Bradlury. 4. v. s. in Herb. Bradlury. Not above two or three inches high; the seeds resembling those of Pastinaca sativa.

p. 197. Seseli divaricatum.-S. caule ramosissimo divaricato, foliis bipinnatifidis, laciniis lanceolatis incisis, involucris nullis, involucellis linearibus.

In Upper Lovisiana. Bradbury. v. s. in Herb. Bradbury. Resembles $S$. tortuosum very much.

p. 223. Allium cernuum.-A. scapo nudo tetragono umbellifero, foliis linearibus planiusculis, umbella cernua, staminibus simplicibus, germine sex-dentato. Roth in. Annals of lot. 2. p. 27 . 
Icon. Cat. lot.fasc. 2. t. 2. Bot. mag. 1324.

On the mountains of Virginia and Carolina. 4. July, Aug. $v, v$. Flowers large, rose-coloured, sweetscented; the leaves have scarcely any scent.

Smilacina stellata, B. unitiora. - S. foliis subfalcato-lanceolatis glabriusculis, crule vinifuro.

Polygonatum monanthemuin, Hore parvo erecto. Sherard. II.rl.

In Hndson's Bay. Tilden. 4. v. s. in Herl. Sherard. As I have teen but one individual specimen, I consider it only as a variety, though it is probable it may be a distinct species.

Helonias graminea.-H. scapo folioso paniculato, racemis divaricasis, bracteolis ovatis pedicellis longioribus, petalis oblongis acumiuatis, staminibus corolla triplo brevioribus, folis linearibus canaliculatis subtus glaucis.Brst. mag. 1599 .

On the mountains of Georgia. Lyon. 4 . Aug. v.s. in Herl Lyon. This species has a strong affinity with Nulina Georgiana.

Rumex venosus, - R. valvulis maximis integerrimis reticulatovenosis, foliis lanceolatis integerrimis parallelo-venosis.

In Upper Louisiana. Bradlury. 4. v. s, in Herl. Bradlury. The seeds resemble those of $R$. vesicarius.

Smilax circidifolia.-S. aculeata ; foliis inermibus orbiculatop. $2-13$. cordatin acuminatis 5-nervibus utrinque glabris reticulato-venosis breviter petiolatis.

S. floridana ; vitictlis spinosis judaica arboris folio maximo corlato. Plak. amalth. 194.

In South Carolina. Catesby. h. v.s.s.fl. in H.rb. She. rard. Though the description was taken from a specimen without flowers, 1 ain convinced of its being a distinct species from any one described.

Gaura coccinea.-G. sericeo-pubescens; foliis lineari-lanceolatis subdenticulatis, spica conferta, petalis longitudine calycis, stigmate subintegro.

G. coccinea. Fraser. catal. 1813.

In Upper Louisiana Bradlury. v. s. in Herb. Bradlury. About a span high; flowers smaller than $G$. biennis, scarlet. In the Catalogue quoted this plant is marked as a perennial, but by the appearance of the specimen I should take it to be only annual.

Oenothera all;icaulis.-O. tenuissime pubescens ; caule nervisque foliorum albidis, foliis pinnatificlis, laciniis diva- 
ricatis, floribus subspicatis, germinibus sessilibus cylindraceis, staminibus corolla brevioribus, petalis obcordatis.

O albicaulis. Fraser. catal. 1813.

In $\mathrm{U}_{1}$ per Louisiana. Bradbury. o. v. s. in Herb. Bridlury. Not above four inches high ; flowers large, white. This species is intermediate between O.tetraptera and $O$ sinuata.

Oenothera Fraseri.--O glabriuscula ; caule inferne simplici, superne ramulo:o, foliis ovatis petiolatis glandulosodenticulatis, racemis foliosis, capsulis pedicellatis obovatis 4 .gonis.

In South Curolina. Fraser. 24. June, July. v. v. in Hortis. This species approaches so near to O. fruticosa that it is difficult to define the distinction, though their other habits are so very different. The present species flowers a short time, the stems decay, and form immediately a tuft of large radical leaves. O. fruticosa flowers till late in autumn, and never siows its radical leaves in that manner. The differentia specifica of $O$. fruticosa will be $O$. fruticosa, tenue pubescens ; caule a basi ramosa, divaricata, foliis sessilibus lanceolatis subdentatis acutis, capsulis pedicellatis oblongo-clavatis angulatis.

Oenothera macrocarpa.-O. glabriuscula; caule ramoso, foliis lanceolatis, petiolatis, distanter glanduloso-denticulatis margine nervisque sericeo-albidis, petalis cum acumine obcordatis, capsulis ellipticis 4 -alatis brevissime pedicellatis.

O. missourensis. Bot. mag. 1592.

On the banks of the Mississippi, near St. Louis. $\delta$. July-Oct. v. v. in Hort. Lambert. This species exceeds in size and beauty of its flowers any other one known; they are of a bright yellow, very large, and open about five o'clock in the evening. The calyx is covered with a very fine and white silky down, and is spotted with purple. The figure in the Botanical Magazine is apparently taken from a very weak and starved plant : the flowers of those in possession of A. B. Lambert, Esq., were nearly six inches in diameter, and the tube nearly seven inches long. There is an inequality on the edges of the petals, but by no means can it be called serrulate, which term has been introduced in the differentia specifica, and strongly but erroneously expressed in the figure. The specific name given there is inapplicable, as it never was found any where else, 
but near St. Louis, where Mr. Nuttall gathered the ripe fruits of it, specimens of which 1 have seen.

Oenothera cesfitos $a-O$. acaulis ; foliis lnnceolatis incisodentatis, capsulis oblongis sessilibus, calyci, tubo longissimo, petalis bilobis distantibus. Sims in But. mag. 1593.

O. scapigera. Fl. amer. sept. 1: p. 263.

On the banks of the Missouri. Lewis. 24. Tune. July. $v$. v. in Hort. Freser; $v$. s. specimen in perfertum in Herb. Lewis. This singular species resembles $O$. acaule of Cavanilles. The flower open in the evening, are white, changing to red, and of an agreeable scent. The errc neous discripticm giten in the place above quoted was ow ing to a very inperfect specimen in the Lewisian collection.

Eriogonum paucifonum.--E. canle simplici basi folioso, umbells paucituris, foribus subsessilibus, folitis linearilanceolutis utrinque cano-tomentosis.

In Upper Lovisiana. Bradlury. 4. v. s, in Herl. Bradlury. This is the smallest species, generally from two to three inches high; the flowers appear to be white.

Cactus viviparns - C. subrotundus multiplex, tuberculis cjlindracei, barbatis supra sulca exaratis proliferis.

C. viviparus. Iraser. catal. 1313 .

In Upier Louisiana. 1.. v., v. s. $A$. in Hort. Lamlert. Rescmbles C. mammiliuris; the tlowers are large and red; the fruit the size of a grape, green and eatable. In the same collection are also the two other species mentioned in Fraser's Catalogue; but only seeing the plants without towers, I could not define therr characters.

Cratcegus turlinata.-C. inermis, glabra; foliis cuneatoobovatis incisis selrats, corymbis paucifloris, pedicellis brevibus, fructibus turbinats.

In Carolina and Virginia. 5. June v. v.; v. s. in Herb. Shrard This species approaches near to $C$. spathulata, but its fi uit distinguishes it from ail the rest of the Anerican species.

Rosa lutescens.- R. germinibus globrsis pedunculisque glap. 336 bris, ramulis hispido-spinosis, foliolis $(7)$ glabris ovalibus acuminato-serratis, petiolis inermibus, Horibus so- 
litariis, laciniis calycis lauceolatis cuspidatis, petalis ovalıbus obtusissimis.

In Carolina. h. May, June, $v, v$, in Hurt. Lee. Flowers white, with a faint tint of yellow.

p. 352. Geum triflorum.-G. pilosum; caule simplici subtrifloro, foliis radicalibus interrupte pinnatis, foliolis cuneatis in ciso-dentatis, petalis oblungis longitucitue calycis, arıstis longisoimis villosis.

In Upper Lowisiana. Bradlury. 4. v. s. in Herl. Bradbury. The aristas of the seeds are resembling those of clematis.

p. 550. Potentilla arguta.-P. erecta, simplex, pubescens; foliis pinnatis, foliolis ovatis argute dentatis, exterioribus ma. joribus, stipulis rhomboideis incisis, floribus terminalibus conferto-corymbosis.

In Upper Louisiana. Bradlury. 4. v. s. in Fierb. Bradluiy. Flowers yellow: leaves large.

p. 344. Clematis Catesbyana.-C. scandens, pubescens; foliis biteruatis, foliolis subcordatis trilobis, paniculis divaricato-dichotomis, petalis staminibus longioribus, fluribus subdioicis.

In Soth Carolina. Catesly. h. v. s. in Herl. Sherard. Resembles $C$. viroinica. The filaments of the female flowers are membranaccous, linear, and without anthers.

1.385. Clematis ovata.-C. erecta, simplex; foliis oratis sensim acutis brevi-petiolatis glabris utrinque reticulato-reno. sis, inferioribus subcordatis pedunculo terminali sulitario uniforo, aristis plumosis longissimis.

In South Carolina. Catesly. 24. v. s. in Herb. Sherard. Resembles C. integrifolia. In the Sherardian Herbarium the figure of Pluk. mant. t.379. $f$ 4. is quoted; but I consider that figure to be an imperfect specimen of a Clematis with compound leaves.

p. 395.

Ranunculus multifidus.- $\mathrm{R}$. foliis tripartito-multifidis : laciniis incisis approximatis, caule natante, foliolis calycis subrotundis petalis paulo brevioribus.

In Upper Louisiana. Bradlury. 4. v. s. in Herb. Bradbury. Flowers yellow; resembles $R$. fluviatilis.

p. 424. SEYMERIA. Cal. campanulatus, 5-partitus : laciniis linearibus, equalibus. Cor. campanulata. Tubus calyce 
vix longior. Limlus 5-fidus: laciniis subærualibus, oblongis, patentibus. Filamenta 4. brevia, fauce inserta Anthere erectæ, oblongæ, nudæ, longitudine corcllæe. Sty/us declinatns, longitudine staminum. Stigma simplex. C'aps, subrotunda, 2-locularis, 2ralis, apice delsiscens.

Seymeria tenuifolia.-S. glabriuscula, virgatim paniculata; foliis setacen-pinnatitidis, laciniis divisis.

Gerardia Cassioides. Vol 2. p. 424.

In dry sandy woods of Caroliwa and Georgia. $\odot$. July, Ang. v. s. in Herl. Sherard. Flowers small, dark yellow.

Seymeria pectinata.-S. viscido-pubescens, brachiatim ramosisima; foliis pectinato-pinnatifidis, laciaiis indivisis linearibus acutis.

In South Carolina. Catesiy. $\odot$ July. v. s. in Herb. Sherard. Flowers the size and coiour of the preceding. While writiog the genus Grardia, I strongly suspected $G$. rassioides to be a distinct genus, which aiready had been considered so by Walter and Gmelin. Having no materials then at hand, I followed the authority of Miclsaux. But finding in the Sherardian Herbarium not only that species, but also a new nne dercribed here, I was convincel of its generic distinction, the character of whicis is well expressed us $W_{a}$ lt $f$ to car.171. I have names this cenus in memory of the late Hency Seyner, Esq. of fiantord, D rneisisire, a gentleman much celeorated for his extrnsive collections in natural history, and for whom Di: solander had so great a regard as to desicate the plant which afterwards was called Solandra granliffura to his memory, as 1 have seen it named Seymera in the flerbarium of A. B. Lambert, Esq., in Dr. Solander's own handwriting.

Chelone Lyoni - C. glabra, ramosa ; foliis petiolatis cordatop. 427. ovatis serratis, spicis terminalibus densifloris.

In Lpper Carolina and Georgia. Lyon. 24. JulySept. v. s. in Herb. Lamlert. This is a very fine and large species; flowers purple.

Pentstemon erianthera.-P. caule pumilo pubescente, foliis p. 428. oblongis acutis obsolete denticulatis subhirsutis, floribus racemosis, pediceliis plerumque sulitariis, filamente sterili exerto apice revoluto iongitudinaliter barbato, ca. lycis foliolis linearibus hirsutissimis. 
P. erianthera. Fraser. catal 1813 .

In Upper Lovisiana. Bradlury $4 . v$ s, in Herb. Bratlury. Not above a span high; flowers large in proportion, of a deep purple; the hars of the infertile anthera are long and golden yellow. It appioaches near to $P$ frutescens.

Pentstcmon angustifolia.-P. caule vix pubescente, foliis glabris longe linearibus integerrimis, floribus racenosu- paniculatis, filamento sterili reliquis breviore superue sub. hirsuto, calycis foliolis lanceolatis glabis.

P. angustifolium Fiaser. catal. 1813.

In Upper Lonisiana. Bradbury. 4. v. s. in Herb. Bradlury. Flowers resembling those of P. pulescens.

Pentstemon glabra.-P. canle foliisque glabris, foliis subamplexicanlibus ovato-oblongis integerrinis, floribus racemoso-paniculatis, filamento sterili nudo clavato apice retuso, calycis foliolis subrotundis acuminatis, laciniis corollæ subæqualibus rotundatis, antheris hirsutis.

In Upper Louisiana. Bradliury. 4. v. s. in Herl. Bradlury. A fine and large species; flowers dark purple.

Pentstemon Bradlurii.-P. glaberrina; foliis subamplexicaulibus ovato-oblongis integerrimis, superioribus subrotundis, floribus verticillatis, filamento sterili apice brevi barbato, calycis foliolis oblongis acutis.

P. grancititorun. Fraser. cotal. 1813.

This is the finest and largest of all the species; the flowers very large, and variable in their colour.

p. 431. Castilleja sessiliflora.-C. foliis apice palmato-incisis, floribus sessilibus.

In Upper Lonisiana. Bradbury. 24. v. s. in Herb. Bradbury.

Caulis ramosus, teres, dense pubescens. Folia alterna, sessilia, utrincue pubescentia, apice in lacinias $3-5$. divisa: laciniis linearibus, elongatis, acutis. Flores in apice ramorum axillares, solitarii, ses.iles, coccinei? Caly $x$ tubulosus, basi ventricosus, 4-fidus ? Corolla ringens. Lalium superius acutum ? inferius trifidum : Jaciniis linearibus, acutis, labio superiore vix brevioribus. Stamina fauci corollæ inserta, filiformia, longitudine labii superioris, glabra. Anthera lineares. Stigma exertum. 
This highly interesting plant has some distant afuinity with C. fissifolia. Smith ic. ined. t. 40.

Cleome pinnata.-C. subpubescens, hexandra; foliis pinnatis, foliolis lanceolatis inferne attenuatis rariter dentatis, superioribus confluentibus, floribus racemosis, pedicellis aggregatis,

In Upper Louisiana. Bradbury. v. s. in Herl. Bradlury. About two feet high; flowers of a bright yellow; the pods are on very long pedicels.

Polygala corymlosa.-P. caule inferne simplicissimo, summitate ramosa corymbose multifloro, foliis linearibus.Mich. fl.amer. 2 p. 54.

P. cymosa. Walt. fl. car. 179.

In swamps: Carclina to Florida. 24. July, Aug. v. s. Flowers yellow, when dried green.

Vicia stipulacca.-V racemis subquadriforis folio longioribus, stipulis foliformibus basi semisagittatis integris, foliolis 8--10. lineari-lanceolatis utringue acutis nervosis glabris.

In Upper Louisiana. Bradlury. 24. v. s. in Herl. Bradlury.

Caulis subtetragonus, striatus, simplex, vix pedalis. Foliola 8-10. opposita lineari-lanceolata acuta glabra utrinque elevato-nervosa. Stipula longitudine foliorum, basi semisagittatæ, auriculis acutis. Cirrhus obsoletus, setaceus. Pedunculi axillares folio duplo longiores. Racemi plerumque 4-Hlori. Flores magni, purpurei. Legumen glabrum.

Ervum multiflorum.-E. racemis pedunculatis multifloris folio longioribus, leguminibus lanceolatis giabris sub4-spermis, stipulis ovatis acuminatis, foliolis linearibus obtusis, cirrhis nullis, caule paniculato.

Astragalus tenellus. Vol. 2. p. 473 .

In Upper Louisiana. M. Lewis and Bradlury. 24. Aug. v. s. in Herl. Lewis. nec non Bradlury.

Caulis erectus, paniculato-ramosus, teres. Ramuli juniores sericei. Foliola plurima, alterna linearia, obtusa, glabriuscula. Cirrhi nulli. Stipulce ovatæ longe acuminatæ. Racemi axillares, elongati, pedunculati. Bracteæ minutæ, ovaræ, acuminatæ, vix longitudine pedicellorum. Pedicelli flore breviores. Flores parvi albidi, vexillo oblongo. Caly $x$ sericeus, corolla triplo brevior, dentibus subulatis. Stylus filiformis, glaber, 
inflexus. Stigma acutum, glabrum. Legumina pendula, oblongo-lanceolata, glabra, 3-4-sperma.

Of this plant $I$ had an imperfect specimen in the Lew. isian Herbarium, together with some pods of an Astragalus, which led me into the error of placing it under that genus; but having since seen fine specimens in the collection of Mr. Lradbury, I was enabled to correct this error.

Astragalus racemosus.-A. caulescens, erectus, subpubescens ; foliolis (21) lanceolatis superne sensim minoribus, stipulis ovatis acuminatis, spicis racemosis pedunculatis folio longioribus, densiforis, bracteis linearibus pedicellis brevioribns, calycibus glabriusculis, dentibus subulatis.

In Upper Louisiana. Bradlury. 4. v. s. in Herl. Bradbury. Hlower white. Resembles A. carolinianus.

Astragalus carnosus.-A. calescens, diffusus, albido-sericeus, foliolis ('21) ellipticis supra glabris, subt us sericeis, stipulis subulatis, spicis subsessilibus, leguminibus globosis inflatis carnosis.

In Upper Louisiana. Bradlury. v. s. in Herl. Bradlury. The fruit resembles that of $A$. psysodes. Flowers appear to have been white. This is probably the $A$. crassicarpus Fraser. calal. 1813.

4. 473. Astragalus triphyllus.-A. acaulis, argenteus, foliis ternatis, foliolis sessilibus Janceolatis, scapo nullo, leguninibus sessilibus oblongis.

In Upper Louisiana. Bradlury. 4. v. s. in Herl. Bradlury. A most singular species, the leaves of a shining silver colour; the flowers were too much decayed when I examined the specimens.

Oxytropis Lamlertii.-O. acaulis, sericeo-pilosa ; foliolis (19) lanceolato-ellipticis utrinque acntis, scapis folia æquantibus, spicis capitatis, bracteis linearibus longitudine caly cis.

On the Missouri. Bradlury. 24. Aug. Sept. v. v. in Hort. Lambert. Flowers a beautiful purple. It approaches near to $O$. argentata and setosa.

p.474. Dalea aurea-D. sericeo-villosa; spicis oblongis terminalitus solitariis, bracteis oblongis acuminatis calycis longitudine ciliatis, calycibus villosissimis, fuliis sub-3jugis oblongis obovatisque obtusis. 
D. aurea. Fraser. catal. 1813.

In Upper Louiniana. Bradliury. 2\%. v. s. in Hert. Bradlury. Elowers bright yellow, in oblong hairy spikes.

Dalea laxifora.-D. glabriuscula; caule superne ramosissimo, ramis laxis elongatis, spicis paniculatis elongatis, floribus remotiusculis, bracteis subrotundis mucronati, carinatis, fluribus enneandris, calycibus sericeo-villosis, foliis sub- 4 -jugis linearibus.

D. enueandra. Fiuser. catal. 1813.

In Upper Louisiana. Bralbury. 24. r. s. in Herl. Bradlury. This is the tallest of the gentis. The white flowers are in narrow spikes, and have remarkable silky calyces, which form a fine contrast with the rest of the plant, being entirely destitute of hair.

Psoralea elliptica.-P. subpubescens; foliis ternatis : foliolis ellipticis obtusis, pedunculis axillaribus folio longioribus, spicis conferto-pancifloris, dentibus calycis abbreviatis.

In Upper Louisiana. Brallury. 4. v. s. in Herl. Bradlury. Flowers small, white with a tinge of purple.

Psoralea longifolia.-P. undique sericeo-villosa; foliis ternatis: foliolis linearibus elongatis, spicis axillaribus pedunculatis laxifloris folio brevioribus, dentibus calycis bracteingue subulatis.

In Upper Louisiana. Bradlury. 2f. v. s. in Hert. Brudlury. Flowers midde-sized, apparently whiie. The leave's have none of those glandular dots so general in this genus.

Psoralea cuspidata.-P. villosa; foliis digitato-quinatis, foliolis obovatis mucronatis integerrimis, spicis axillaribus deusifloris, laciniis calycis bracteisque ovatis cuspidatis conspicue punctatis.

P. macrorhiza. Fraser, catal. 1813.

In Upper Louisiana. Bradlury. 24. v. s. in Herb. Bradlury. This species has some resemblance to $P$. esculenta.

Cytisus rhomlifolius.-C. pubescens; racemis terminalibus erectis, leguminibus falcatis subarticulatis, foliolis ob. longo-rhomboideis obtusis, stipulis rotundato-oratis obliquis. 
C. rhombifolius, Fraser, catal. 1813.

In Upper Louisiana. Bradlury. v. s. in Herb. Bradlury. The stipulæ are large and foliaceous; the specimen I have seen was in fruit, and Mr. Bradbury has seen only one plant in flower.

p. 505. Troximum glaucum.-T. scapo unifloro glabriusculo, foliis lineari-lanceolatis planis integerrimis utrinque glaucis, calycinis foliolis imbricatis acutis pubescentibus.-Vol. 2. p. 505.

Troximum cusfidatum.-T. scapo unifloro superne subtomentoso, foliis linearibus margine undato tomentosis, calycinis foliolis imbricatis cuspidatis glabris.

In Upper Louisiana. Bradlury. 2\%. v. s. in Herl. Bradlury. Flowers large, yellow. Resembles the preceding.

p. 519. Hymenopuppus scabiosaus.-H. candicanti-lanuginosus; foliis profunde pinnatifidis, laciniis lineari-oblongis subdentatis, fioribus simpliciter corymbosis, calyce sub-10phyllo flosculis majore, seminibus pubescentibus.Vol.2.p.519.

Hymenopappus tenuifolius.-H. candicanti--lanuginosus; caule corymboso-ramoso, foliis subbipinnatifidis, lacinis anguste linearibus integris, foribus composite corymbosis, pedicellis confertis, calyce sub-6-phyllo flosculis breviore, seninibus villosissinis.

In Upper Lousiana. Bradbury. ๙. v. s. in Herb. Bradbury. At first sight I considered this to be the same with the preceding species; but comparing the figure and description in the Journal d'Histoire Naturelle, vol. 1. p. 16. t. 1. with my specimen, I found then materially distinct. The flowers are white, and not half the size of the former.

p. 521. Artemiria dracunculoides.-A. glabra; ramis nutantibus, foliis longo-linearibus subfalcatis, radicalibus trifidis, racemis foliosis, pedicellis brevibus, foribus erectis, calycibus subghobosis paucifloris, foliolis scariosis.

A. nutans. Fiaser, calal. 1813 .

In Upper Louisiana. Bradlury. 24. v. s. in Herb. Bradbury. From three to four feet high; flowers very
small.

p. 532. Erigeron hirsutum.-E. undique hirsutissimum; caule sim- 
plici unifloro, foliis linearibus integerrimis cnervibue, calycibus hirsutis

E. uniflorum. Willd.sp. pl 3. p.1960?

In Upper Lonisiana. Bractury. 24. v. s. in Herb. Bridlury. Not above five inches high; flowers large, ray white and long.

Galardia acanlis.--G. pilosa; scapo unifloro, foliis linearispathalatis, paleis pappi $(5-7)$ ovatis brevi-aristatis.

In Ipper Louisiana. Bradlury. 24. vs s. in Herb. Braitury. Not sbove a span high ; flower small, simply yellow.

Iy a axillaris.--I. herbacea, subpilosa ; foliis plerumque opp. 580 . positis lineari-lanceolatis integerrimis, floribus axillaribus solitariis nutantibus, calycibus simpliciusculis, foliolis ovatis.

In Upper Louisiana. Bradlury. $\odot$. v. s. in Herl. Bradlury. About a span ligh ; flowers white.

Ambrosia hispida.-A. undique canescenti-hispida; foliis bipinnatifids, laciniis incisis, racemis terminalibus sub. paticulatis.

In South Carolina. Catesly. $\odot$. v. s. in Herb. Sherard. About a foot high; Howers larger than A. trifida.

Orchis herliola.-O. cornu filiformi germine breviore, labello oblongo obtuso basi utringue centato; palato unidentato, bracteis thore lon gionibus.

Habenaria herbiola. Brown in Ait. kew. ed. 2. vol. 5. p. Iy.3.

In North America. Fothergill. 4 . +. This species, unknown to me, appears to approach near to Orchis fuscescens.

Aristolochia tomentosa. - A. caule volubili frutescente, foliis petiolatis cordatis subtus tomentosis, pedunculis solitariis ebr icteatis, curollæe tubo retorto; limbo subæqualiter tritido: ore hinte. Sims in lot. mag. 1369.

On the mountains of South Carulina. Lyou. $\quad$. June. $v . v$. Resembies A. Siflo. Flowers yellow.

Alnus glanca-A. foliis oblongis acutis duplicato-serratis stobus glatcis, axillis venarum nudis, stipulis lanceolatis - hich. arb 3 p. 322. t. 4 .

In New ngidud and on the high mourtains of Pensylvania. r. Mnch, Aprii. v. v. This shrub, which is known by the name of Black Alder, has a strong tesemblance to $A$ incuna.

YOL, II. 


\section{ADDENDA ET CORRIGENii..}

VOL. 1. pag.

1 lin. 4 loco Monoicum lege Monoica. This error occurs in this and the next table of genera.

15 adde Monoicum.

22 adde Monoica.

23 adde Monoica.

37 Hippuris vulgaris. In the Sherardian Herba. rium are specimens collected at Hudson's Bay which I compared with the European Hippuris, and found them entirely distinct. I rather suspect this plant ought to be placed among the Filices.

55 adde Dioica.

712 adde Dioica.

13 adde Dioica.

15 adde Monoica.

7 ab infer. adde Mich. arb.3.p.50. t. 6 .

\& $\quad 17$ ab infer. lege Mich. arb.3.p. 122. t. 12.

11 ab infer. lege Mich. arb.3.p. 118.t.11.

3 et 5 ab infer. delendæ sunt.

95 delenda est.

6 lege Mich.arl.3.p. 106.t.8.

14 dele Nich. arb. ejus loco Catest. car. 1. t. 80.

19 dele Catesb. car. t.80. et lege Mich, arb. 3. p. 128. t. 13.

28 lege Mich. arb.3. p. 112, t. 9 .

3 ab infer. lege F. viridis. Mich. arb. 3. p. 115. t. 10.

105 adde Mich.arl.3.p. 217. t. 6.

16 Monarda Kalmiana, adde Icon. $t$. 1.

17 i3 post Flowers adde pale.

21 Ceratiola ericoides, adde Icon. $\iota .13$.

2425 Rynchospora lege Rhynchospora. 
pag. lis.

2030 dele genus ANTHIstiRiA.

Iris cuprea, adde I. fulva. Bot. mag. 1496.

Iris verna, conf. Bot. mng. 1393 olserv.

Iris prismatica, adde Bot. mag. 1504.

16 loco foliis lege foliisque.

18 loco $E$ lege $C$.

9 et 1.4 loco Dilepycum lege Dilepyrum.

Milium amphicarpon adde Icon. Tab. 2.

6 ab infer. loco $A$ lege $S$.

23 dele 2, ante biloculari.

7 al infer. loco involucro lege involucris.

8 ad marginem loco data lege cordata.

ultima, loco caule lege scapo.

Oldenlandia glomerata. Willdenow's and Lamarck's synonym seem to belong to a very ambiguous species of this genus, or, as I strongly suspect, to Ludurigia nitida, as I bave seen this plant in the Sherardian Herbarium under the name and synonyms of Oldenlandia uniflora.

Planera aquatica, adde P. ulmifolia. Mich, arl, 3. p. 283.

120 is loco Gonololus lege Gonololinm.

20 lnco Appendix lege Appendices.

inter 224 et 225 insere CEROPtGIA. Folliculi 2. erecti. Sem. plumosa. Cor. urceolatæ limbus connivens.

inter 244 et 245 insere SISON. Fructus ovatus, striatus. Intol. sub-4-phylla.

8 al infer. post palustris adde $\beta$. inflata.

Iponıœa Jalapa, adde Convolvulus Jalapa. Bot. mag. 1572 .

Pinkneya pubescens, adde Mich. art. 2. p. 276. $t$....

11 et 12 delendæ sunt.

Ribes resinosum, adde Icon. Bot. mag. $15 \mathrm{S3}$.

7 ab infer. adde Mich. fl. amer. 1. p. 109.

7 ab infer. loco lacustris lege lacustre.

1 loco subgeminis lege sub gemmis.

6 adule Bot. mag. 1479.

ultima, ante utrinque adde foliis.

Claytonia lanceolata, adde Icon. Tab.3.

Nyssa villosa, adde N. sylvatica. Mich. arb. 2. p. 260. t. 21 .

Nyssa biflora, adde Mich. arb. 2. p. 265. t. 22 . 
pag.

177

178

181

186

187

199

200

223

221

229

232

200

219

lin.

Nyssa candicans, adde Mich. arb. 2. p.2.57.t.20.

Nyssa tomentosa, adde Mich. arb.2.p.252.t. .

1 loco 1187 lege 1181.

1 adde Bot. mag. 1551 .

20 loco unifloribus lege unifloris.

ultima, adde Mich. arb. 3. p. 26g. t....

Ulmus fulva, adde U. rubra. Mich, arb. $\Xi$. p. $278 . t$....

Ulmus alata, adde Mich. arb. 3. p. 275. $t \ldots$.

Celtis occidentalis, adde Mich. arb. 3. p. 226. t. 8 .

Celtis crassifola, adde Mich arl. 3. p. 223. t.9.

17 loco ramosissima lcge ramosissimo.

Berberis aquifolium, adde Icon. Tab. 4 .

Berberis nervosa, adte Icon. Tab. 5.

221 Gleditschia triacanthos, adde Mich. arb. 3. $\%$ 164.t...

Gleditschia nonosperma, adde Mich̆. arb. 3. p. $169 . t$...

Allium angulosum, adde A. stellatum. Bot. mag. 1576 .

Conostylis americana, adde Icon. Tab. 6. Lophiola aurea. Bot. mag. 1596 . In this figure the flowers are more than twice the size of those in its native state.

Phalangium Quamash, adde Scilla esculenta. Bot. mag. 1574. I Iaving not seen the living plant when I made my description, I was misled by Mr. Lewis in describing one of the petals to be dependent and the rest ascendent, which is not the case.

Lilium pudicum, adde Icon. Tab.s.

Strepiopus roseus, adde Uvularia rosea. Bot. mag. 1489.

Streptopus lanuginosus, adele Uvularia lanuginosa. Bot. mag. 1490.

Chamzerops Palmetto, adde Mich. arl. 2. p. $186 . t \ldots$.

Nolina georgiana, adde Asphodelus minor albus ex Provincia mariana. Pluk. mant. 29. t.34z. f. 1. (pars paniculæ), secundum Herb. Sherard. Very fine specimens of this rare plant I found in the Sherardian Herbarium collected by $M$. Catesby on the Savamuah river. It resembles Helonias graminea, Bot. mag. 1599. 
log. lin.

exccedingly, and I should have taken it to be the same if the pediccls were not solitary, and, as Mr. Kerr observes, the germ polyspermous, which in Noline is only 3-spermous.

Veratrum viride, adde Helonias viridis. Bot. mag. 1006.

Yeratrum angustifolium.-Of this species I have seen a fine specimen in the Sherardian Herbarium, under the name Phalangium canadense majus ramosum, Iridis folio, by which it appeared to grow likewise in Canada. The panicle was monoic not dioic, as I observed it in Virginia, the sceds lanceolate, membranaceous.

$21214 a b$ infer. loco legumine lege tegumine.

24323 loco thier lege their.

Helonias tenax, adde Icon. Tab. 9 .

255

Asculus tlava, adde Mich. arb. 3.p. 238. t..

Asculus glabra, adde Mich. arl. 3. p. 242.

$4 \mathrm{ab}$ infer. adde nomen specificum, rosmarinifolium.

263 dele Oenothera scapigera. Ejus loco vid. Supplementum sub nomine Oenothera cæspitosa.

264

Menziesia globularis, adde $M$. ferruginea $\beta$. Bot. mag. 1571. Though Dr. Sims considers this species only as a variety, I still think the distinctions given by A. Salisbury, Esq. are sufficient to keep it as a species.

Diospyros virginiana, adde Mich. arb. 2. p. 195. t. 12.

Acer rubrum, aclde Mich. arb. 2. p. $210 . t .14$. Acer dasycarpum, adde Mich. ar b. 2. p. 205. t. 13.

Acer saccharinum, adde Mich. arb. 2, p. 218. t. 15.

Acer nigrum, adde Mfich. art. 2.p. 238. t. 16 . Acer striatum, adde Mich arb.2.p. 242.t. 17. Acer Negurdo, adde Mich. arl, 2. p. 247. t. 13. inter AGROSTEMMA et UXALIS, adde 39-1. LYCHNIS. Cal. 1-phyllus, oblongus, levis. Pet. 5. unguiculata, limbo subbifido. Catss. 1-5-locularis.

6 loco 394 lege 395.

20 loco 395 lege 396. 
pag. lin.

12 Jeco 395 lege 307.

15 loco 397 lege 398 .

283

Gaultheria serpyllifolia, adde Tat. 13.

254

Gaultheria Sha!lon, adde Tal. 12.

289

293

Vaccinium nitidum, adde Bot. mag. 1550.

Andromeda floribunda, adde Bot. mag. 1560. In the extensive collection of the Sherardian Herbarium I met with most of the species of Vaccinium and Andromeda described in the present work; but meeting with none that were new, convinced me of the idea that this extensive family is nearly fully described here.

Andromeda mariana, adde var. ovalis. Bot. $\operatorname{mag} .1579$.

Andromeda arborea, adde Mich. arb. 3. p. 222. t. 7 .

297 Kalnia latifolia, adde Mich. art.3.p. 147.t. 5. Rhododendron maximum, adile Mich. arb. 3. p. 144.t. 1.

Rhodudendron cataubiense. I have had an opportumly of seeing this species in flower at Messrs. Lee and Kinnedy's ; the plant was not above a fort high; the flowers rose-coloured, similar to those of R. maximum; but having scarceiy any maxks or spots on the upper part of the corolla.

Mrlocarium ligustrinum, adde Icon. Tab. I4. 'The original drawing of this plant was taken by me at Messrs. Bartrams' near Philadelphia. Monotropa morisoniana. I had the pleasure of secing, in the Oxford Herbarium, the origi. nat specimen from which the figure in Mo. risun's History has been taken, and which so eroneously has been quoted under Monotropa unizlora.

Gymnocladus canadensis, adde Mich. arb. 2 . p. $272 . t .23$.

Podalyria mollis, adde $v$. s. in Herb. Lamlert.

BARTONIA. Since writing the above article I had an opportunity of seeing both species there described in a living state; the first in the garden of $\Lambda$. B. Lambert, Esq. at Boyton, 
where it flowered in very high perfection and formed seeds; the other at Messrs. Frasers', Sloane Square. From the latter I have taken the following description.

Bartonia nuda.-Caulis ramosus, angulatus, glanduloso-pubescens. Folia oblonga, sessilia, basi attenuata, repando-dentata, utrinque scabra, viridia. Inflorescentia B. ornatee. Flores duplo minores, lutescentes, germine nudo, angusto. Petala 10. angusto-lanceolata. Filamenta exteriora longiora, plerum. que castrata et petaloidea.

1 al infer. adde Mespilus arborea. Mich. arb. 3. p. 68. t. 11.

340 Pyrus coronaria, adde Malus coronaria. Mish. arb. 3. p. 65. t. 10.

34-1 Rosa blanda. Differentia specifica lege R. germinibus globosis pedunculisque hispidis, ramis aculeato-hispidissimis, foliolis \&c.

Dalibarda fragaroides, adde Bot. mag. 156\%.

VCL. II.

Tilia glabra, adde $\mathrm{T}$. americana. Mich. arl.3. p.311.t. 1 .

363 Tilia pubescens, adde Mich. arb.3.p. 317.t.3. Tilia heterophylla, adde T. alba. Mich. ar $b .3$. p. 315.t.2.

Talinum teretifolium, adde Pluk, alm. t. 223. f. 2. secundum Herl. Sherard.

Caltha Habellifolia, adde Icon. Tal. 17 .

104 Cor. bilabiata, labio inferiore trifido, glandulis duabus inter lacinias. Caps. bilocularis.

Prunella pensylvanica, adde Icon. Mart. cent. $t .5$.

Gerardia fruticosa, adde Icon. Tab. 18.

Gerardia quercifolia, adde Icon. Tab. 19.

424 Gerardia cassioides dele. Ejus loco vide Supplementum sub nomine Seymeria.

427 Nimulus Lewisii, adde Icon. Tab. 20.

Pentstemon lævigata, adde Bot. mag. 1425.

Pentstemon pubescens, adde Bot. mag. 1424. 
pag. lin.

$441 \quad 13$ loso glabrum lege glabra.

Hopea tinctoria, adde Mich. art. 3. p. 61.t.9.

Gordnia Lasianthus, adde Wich. ar b. 3. p. 131. t. 1.

Gordonia pubescens, adde Mich. ark.3.p. 135. t. 2 .

inter 591 et 592, arde CYTISUS. Cal. bilabiatus : labio superiore bilientaro. Carina erecta. Legum. basi attenuatum, 1-loculare, compressum. Stam. monodelpha.

inter 587 et 588, adde ER IUM. Cal. 5-dentatus, dentibus subulatis. Stigma simplex, incurvum. Legum. compressum, oligospermum. Stum. diadelpla.

Polygala Seneca, adte var. $\%$. tenuifolia-foliis linearious, spicis confertifloris.

On the Missouri. Lew is and Bradlury. v. s.

Lupinus villosus, adde Icon. Tab. 21.

Vicia americana, adde $v$. s. in Herb. Bradiury. var. foliis linearibus.

Psoralea esculenta, adde Icon. Ta?, 22.

Lapinaster macrocephalus, adde Icon. Tab. 23.

G]ycyrihiza lepidota, loco sericeo-villosis lege itrinque lepidotis.

Robinia P'seudacacia, adcle Mich. arb. 3. p. 245. t. 1 .

Robinia viscosa, adde Mich. arb. 3.p. 252. t. 2. Prenanthes Serpentaria, arde Icon. Tab. $2 \dot{4}$. Liatris macrostaciya, adde Bot. mag. 1411. Senecio pauperculus, adde v. s. in Horb. Eradlury.

3 loco t. 4. !ege vol. 5.

Amellus villosus, ailde Sideranthus integrifolins. Fraser. catal. 1813. v. s. in Herb. Bradlury. Amellus spinulosus, adde sideranthus pinatifidus. Fraser. catal. 1813. v. s. in Herb. Bradiuy.

Galartua biculo:, adde G. bicolor; canle ramoso, foliis caulinis lanceolatis subdentatis, radicalibus dentato-pinmatifidis, paleis pappi integerrimis aristatis. Sims in jot mag. 1002.

Virgilia granditiora. Fraser. cotal 1813.

Ihis elegant plant, which has been proved to be a perennial, though it was always considered 
pag. lin.

an annual, is very variable in its size, colour, and number of florets in the ray. Native specimens collected by Mr. Bradbury are covered with rigid hairs, and have but one flowcr. Cultivated plants raised from seeds of the same spccies are nore smooth, branch more or less; the leaves are deeper divicied, and produce several flowers double the size.

Ruclbeckia colummaris, arde R. columnaris; folis pinnatifidis: foliolis lanceolatis, exterioribus ordinatim majoribus, receptaculo cylindraceo elongato. Sims in Bot. mag. 1601. This species is not abore a foot high, and appears to be annual.

Iva ciliata, adde Iva annua. Mich.fl. amer. 2. p. 184 .

5S5 Orcisis ciliaris, adde Habenaria ciliaris. Brown in Ait. kew. ed. 2. vol. 5. p. 194.

Orchis cristata, adde Habenaria cristata. Brown in Ait. kew. ed. 2. vol. 5. p. $19 \div$.

Orchis viridis, adde Fabenaria viridis. Brown in Ait. k+w. cd. 2. 2'ol. 5. p. 192.

Orchis bracteata, adde Habenaria bracieata. Brown in Ait. kew ed. 2, vol. 5. p. 102.

Orchis hyperborea, adde Habenaria hyperborea. Brown in Ait. kıw. el. 2, 2ol.5.p.193.

Orchis fimbriata, adde Habenaria fimbriata. Brou'n in Hit $k \leq u$ ed.2. vol. 5. p. 193.

Neottia cernua, adde Bot. mas. $156 \mathrm{~s}$.

Neottia repens. adde Goodyera repens. Brown in Ait. kell. ed. 2. vol. 5.p. 193.

$590 \quad$ Nentria pubescens, alile Gondyera pubescens. Broun in Ait. kiw. ed. 2. vol.5. p. 198.

Arethusa divaricata, adde Pogonia divaricata. Brown in Ait. kew. ed. 2. vol. 5. p. 203.

Cymbidium puichellum, adde Calopogon pulchellus. Lrou'n in Jit.kew. ed.2. vol. 5.p. 204. Cymbidium verecundum, adde Bletia verecunda. Broun in Ait. kew. ed. 2. vol. 5. p. 200. Bot. mag. 930 . 



\section{VALUABLE WORKS}

\section{IN

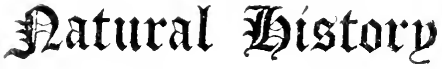

PUBLISHED BY

WHITE, COCHRANE, AND Co.g

HOPACE'S HEAD, FLEET STREET。

ORIENTAL MEMOIRS; sclected and abridged from a Series of Faniliar Lettors written duriug teventeen Years' Residence in India: including (Observations on Parts of Africa and South America; and a Narrative of Uccurrences in four India Voyages. By Javes Forbes, F.R.S. Ac. Elesantly printed by Bexslex; in 4 vols. royal 4 to. Price 161. 16s. in hoards. With a Portrait of the Author, and 93 Engravings from original Drawings, illustrative of the Natural History, Scenery, Antiquities, and Costume, and including Portraits of several distingruished Characters.

The Subjects of Nitural History have becu engraved and coloured by HoOker in a tyle of great accuracy and beauty; and the Landscapes and other suljects by C. Hziti, Ances, Sroner, Greig, \&c.

TIE NATURAL IISTORY AND ANTIQUITIES OF SELBORIE, in the County of Sonthampton. 'To which are added: The Nateralist's Callidar; Observations on Various Parts of Nate in: and Poins. By the late Rev. Gilbert Winte, formerly Fellow of Oricl Cullege, Oxtord. A new Edition, elewantly printed in post 4 to. by BexsLeY, with Additions, and 12 Engravings, several of which are new. Price $21.1 \%, 6 \mathrm{~d}$. in toards.

Fifty Copies are printed on royal quarto paper, (uith the copy of a curious old Painting, leantifilly colonted,) and done up in 2 vols. Price 5l. $5 \mathrm{~s}$. in loards. Of these very ficw now remain.

To those who are acquainted with this Work, any recemmendation of it is smperfluous : to those who are not, the testimonies borne to its merits, both as to matter and style, by some of the mont eminent Writers of the present day, by Dr. Whisakr, 1)r. Aikin, Mr. Engworth, \&c. may offer some inducement ti its perusal. Without exaggeration, it may he said to stand at the head of, aul to serve as a model for, all Works of a sunilar description. 


\section{Fulualle Works lateiy pultished ly}

At the same time is putlisied, hand-omely printed in \& rols. ovo. with Four Engraringa, price 10js in boards, a new Edition of

THE NATERAL HISTRY OFEELBORNE: To whicis are added,

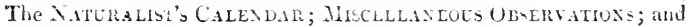
PuEMIs.

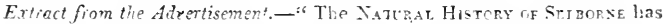
probably theen sup; osed by nany to be formed upon a more lyeal and confined plan than it realy is. In fact, the greater part of the Observations are applicable to all that purtion of the island in which the Anthor resdech, and were indeed mide in rarins places. Alm is the only matier abohitely leal, is the account if the Artiquilies of the Villnge of Seltorne; and this scemed to staurl so much apart, that, bonever well calculated to gratify the lovers of topograthical studies, it was thought that its entire omision would be moss to the Work. cousidered as a pubication in Natural Historr."-' The Editor flaters lumself shat, in its prent furm, it will prove an accepiable addition to the lisrary of the Naturolist, and will in particnlar be useful in inspiring young per re, and thosenho pas their time in retiremeit, with a taste for the very ileasing bracin of kawiedge on which it treats."

FATNA ORRADENsIS; ö, Tie Natural History of the Quadrupeds, Birds, Reptiles, and Fisies of Urhney and shetland. By the Hev. Grolige Lu, Minisier of Birsa and Horay. From a Manuscript in the possesion of Willian Elfurd LEACif, M.D. F.L.S. Sc. Elegantly printed in 1 vol. sm. fto. Price 1l. 1s. in boards.

NATTRAL HISTORY; Generol and Particular. By the Corxt DE BUFis. Illustrated with ahore sis Ifundred Copper-plates. The History of Han and Quadrupeds translated, with Notes and Observations, Wy Whar Sulleie, Memher of the Antiquarian and Royal Societies of Fdinbureti. A new Edition, carefilly corrected, and consideratbly collarged hy masy ad htional Articles, Xutcs, and Plates, and some Account it the Life of burfux, by Willax Wood, F.L.S. In 20 rols. Bro. Price 12l. in toarts.

AN TSAAY ON THE PHILOSOPIY, STUDY, AND USE OF NATLidL Histury. By Cimris Fothergilz. Beatifully printed in foolscap 8ro. Trice 8s. in Luards.

LACHESIS LAPPONICA: or, A Toxk IN LAPLAND. Now first puhtished from the origial Mamocript Journal of the celebrated LixN.tes. Py Jame Edwan Smin, M.I). F.R.S , Nc. President of the L muan Suciety. 1 andoncly printed in 2 vols. 8 ro. with above 60 bi wod Cut, from the extemp ancus snctche ot the illustrious Author. Prace 11. 13, in boards.

"Al. An sh the preceding notices and extracts can convey to our readers 3 rery inadeinate dea of the qmatity of m nute details which has been pressed into thi intresting diar, they way scrve to furnish exemplifications of its

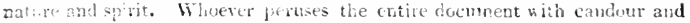

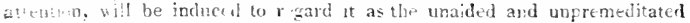

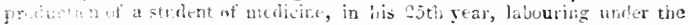
ealy Itratic of wan confult, and traving culd, tempist, and danger, ia 


\section{White, Cochrane, and Co. Flest Street.}

the eager prosention of natural ccicnce. In this Itinerary we perecive no traces of that vanity for which its Aubor was subsequently too much distingtuished."-Monthly Review, March $181 \%$.

"Be ore we close our report of this wery extraordinary prodnetion. we deem it only an act of justice to the learned and laborious bilitor, to nention,

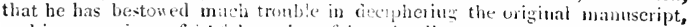
and in procuring a faithul verion of its miscellaneous contents. Even the fac-similes of the mugh drawing, though executed in a vety dilicrent style from the pretty plates of Mr. Ackermann's Rejositny, contribute, nevertheless, to the graphic and ghustly air of the whole perfurmatice." - Edenturgh Rerieu, Fol. 1812.

PETRALOGY: A Treatise on Rocks. By Jomn Pixkerton, Author of hodern Gemenphy, \&c. Handsomely printcd in a large vols. 8vo. with 25 Vignette atud other Lingravings. Price 21. 2s. in boards.

Extracts from the Intmduction.- "I would propose, in the present advanced state of science, that the mineral $k$ ing flom be diviterl into three provinces: 1. Perralogy, or the knonledge of rocks, or stones which oceur in large masses. 2. Lithology; the knomledge of gems and smail stimes. 3. Netalloggy; or the knowleclse of metals. Fach of the branches $i$ is eren at present so important, and ollers sucb numerous topics of disquisition and research, that in the course of no long period a Profess.r of cach will appear in Luiversities; and each might occury the sole pursuli of an Author who is zealous to make diseoreries, or to eompose complete and cla sical work." - " In the present Work it is io be hoped that the want of attention, care, or labour will not be accused. The Author has seculou-ly employed the intervals of ten years in this production, partienlarly three which he pased at Paris, where he had constant opportunities of seeing the most opulent cabinets, aud of conversing

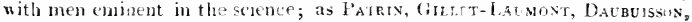
and others: not to meutinn intervews with IAiz and with Whrer, curing his short stay in that capital.- - He hopcs the Work may at lcast aspire to the humble praise of utility, the chite ain of his lahours."

MINERALOGICAI TRATELS THROLGII TIE HEBRDES, ORKNEY AND SHETLAND ISLANDS, AND HAINLAND OF SCOTLAND; with Dissertations upon Pe.T and KLLP. By ReBERT Jamesox, Regius Professol of Natural History, Liceper of the Museum, and Lecturer on Mincralogy in the University of Edinburgh, President of the Wermerian Suciety, Ec. Ec. In 2 vols. 4to. witi Maps and Plates. Price 11. 10s, in boards.

POMONA HEREFORDIENSIS: heing a descriptive Account of the old Cider and PERrY lRuTs of llerefordonte, which have always been estecmed the best of their. Kind; with such new Fruts as have been found to posscss superior Excellence. Accompaniced by 50 highly-finished coloured Engravines, by Wilian Huskith, from Drawings principally by Miss Mirnews. Published under the Patronate of the Asricultural Socicty of Herefordshe. The Descriptions by T. $A$. KNight, Esy. In 1 vol. royal 4 to. Price 41 10s, in buards.

POMONA LONDINFNSIS. Containim colocred Representarross of the BEST EtuITs cultivated in the Eritish Gardens: with De- 


\section{Ialualle Works lately pullished ly}

seriptions, in which the Antlor is assisted by the President and $\mathbb{I} \mathrm{cm}$ : bers of the Horticultural Socicty. By Willia Ifookzk, I.H.S. Dranghisman and Fngraver to the Socicty.

The First and Seconin Numbers, handsomely printed on extra su= per-royal 4to. with seven Plates in cach, Price 11. 1s. per Number, are now ready for delivery.

A fiv Copies are taken off on atlas 4to. and coloured in a superior manner. Price 1l. 15 s.

The probable extent of the Work wil! be abont Eighteen Numbers. A Number will be published every Four Montis.

POMONA BRITANNICA: or, A Collection of the most estecmed Fruts at prosent cultivated in this Country: together with the Blossoms and Jeares of snch as are neecssary to distingnish the various Sorts from each other. Selected from the Ruyal Gardens at Hampton Court, and the remainder from the most celetrated Gardens round London. Accurately drawn and coloured from Nature; with full Descriptions of their various Qualities, Scasons, \&c. By George BrooksHaw. In Atlas folio: the Letter-press printed by BENSLEY in the first style of elegance; with 90 Engravings, engraved and coloured in a novel and beautiful style. Price 45l. in hoards.

This Work was originally pullished in Thirty Numbers, at 1l. 10s. each. Sulto scribers who have not yet completed their Copies, may do it ly an early application to the Publishers.

iIORTUS CANTABRIGIENSIS: or, A Catalogue of Plants, IxDigexous and Exotic. By James Donn, Curator, Fellow of the Limman and IIorticultural Societies. The Seventh Edition, in small Sro. Price 10s. in boards.

MAWE'S GARDENER'S CALENDAR, AND GENERAL DIRECTORY. By Jom ABErcronbie. The Twentieth Edition, currected and greatly enlarged, in 1 thick vol. $12 m 0$. Price $7 \mathrm{~s} .6 \mathrm{~d}$. in boards.

AN ESSAY ON TIE PROBABILITY OF SENSATION IN VEGET A BLES. By J. P. Tupper, F L.S. Member of the Royal Cotlege of Surgeons. In 8vo. Price 6s. in boarits.

FLORA GRECA: sive Plantarum rariorum Ilistoria, quas in Prorinciis ant Insulis Graccia legit, investigavit, et depingi curavit, Jomaxnes Sintiorp, M.D. S.S. Reg. et Limn. Lond. Sucius, Bot. Professor Regrins in Academia Oxonicnsi. Ific illic etiam insertae sunt paucula species yuas Vir idem clarissimus, Graciam versus navigans, in Itinere, prescrtim apud Italiam et Siciliam, invenerit. Characteres omniun, Descriptiones et Symonyma elahoravit Jacobus EDvardus Surtm, M.D. \&c. Societatis Linneane Londinensis Prases.

Colume the First, containing Two Fascictir ; and the First Fascrcules of the Second Volume, are now published. This Work is bcautifully printed in folio, and each Fasciculus contains 50 Plates engraved and coloured in the most fiushed manner by SowEres, from drawings by FrrD. Bauer. Price Twelve Guineas each.

The whole Work will extenl to Ten Volumes, or Twenty Faseicnli. Fron the nature of the Work, and the grest expenses attending it, only Fifty r'upies are prepared for Sale. 


\section{White, Cochrane, and Co. Fleet Street.}

FLORE GRECE PRODROML'S : sive Plantarun omnium EnLmeratio, quas in Provinciis aut Insulis Grecia invenit Jonaxyes SibTHORP, M.D. \&c. Hic illic etiam inserte sunt pancule Species quas Vir idem clarissmus, Greciam vorsus navigans, in Itinere, presertin apud Italiam et Siciliam, incuerit. (haracteresomnium, l)escriptiones

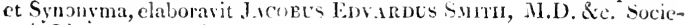
tatis Linneana Londinensin Prases.

Volcue the Finst, contaning Two Parts, and the First Part of the Second Volume, handsonely printed in royal $8 \mathrm{ro}$ are publisled, Price 10s. 6d. each Part in boards.

The Fourth Part (which is in progress) will complete the Wonk.

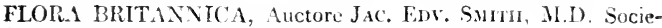
tatis Linncane Praside, Sc. Ac.

Volumes the First, Second, and Third, in sro. Price 1l. bis. 6d. in boalds,

The Fourth and Fifth Volumes are in preparation.

AN INTRODTCTION TO PHYSOIUCICAT, AND SYSTE-

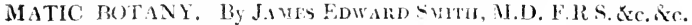
President of the Linnem Socicty. The Third Eoition; in 3ro. with Engrarings. Price 14s. in boatris.

\section{A feu: Copies with coloured Plates. Price 1l. 8 s. in loards.}

The Elinburgh Reviewers, at the conclusion of their review of "1)r. Smith's Intruduction to liotany," observe that "Botany is daily becoming a more fashimable female study; and this is an elementary book whieh may be put with contideme into the hands of womes, without any risk of wounding the most delicale mind. We are happy, for the sake of thuse fair stedente, to wherre, that Dr. Smith promine's a trantetion of his Flora Britannica; for this, "ie doubt not, will, when accomplished by lr. Smith himself, form the best popular llerbal ever jublistied. In thr: mean time he rery candirlly recommend: Dr. Withering's Arrangenent of British Plants: to which we wonld take the liberty to add Mr. Cialpine's Compendium of British Botany, (whicit is indeed nearjy a translation of Ir. Suith's Compendium Florce Britannica,) as a most useful aud commod.ous pocket companion in botanical excursions."

A SYSTEHATIC ARRANGEIENT OF BRITISH PLANTS: with an easy Introduction to the Study of Botany. Illistrated hy Copper-plates. By W. Witherisg, M.T. F.R.S. Kc. 'The Fifth Edition, currected and considerably enlarged, by William Witherixg, E=q. I11 4 vols. 8vo. Price 21. 3s. in boards.

A SINOPTICAL COMPEND OF BRITISH BOTANY; (from the Class Nonandria to Polygamia inclusive; arraned after the Linnean System; and contrining the essential Characters of the Genera, the specific Characters, English Names, Places of Growth, Suil, and Situation, Colour of the Flowers, Times of Flowcring, Duration, and References to Figures. By Jolis Galpixe, A.L.S. In toolscap 8vo. with a Frontispiece. Price 10s. $6 \mathrm{~d}$. in boards.

LETTERS ON THE ELFMENTS OF BOTANY. Addressed to a Lady, by the colehrated J. J. Rousseat. Translated intu English, 


\section{Works lately pullished by White and Co. Fleet Streot.}

with Notes, and Twenty-four additional Letters fully cxplaining the System of Linneus. By TuOmas Martyn, B.D. F.R. \& L.S.S. Regius Profesor of Botany in the University of Cambridge. The Scventh Edition, with Corrections and Inyprovements, in 8vo. Price 8s, in boards.

THIRTY-EIGHT PLATES, with Explanations, intended to illustrate Limmon's System of Vesctables, and particularly adapted to the Letrers on the Lliments of Botary. By the savir Author. In 8 ovo. Price 9s. in buards, or coloared, Price 13s. in boards.

TIIE LANGUACE (IF BOTANT; bcing A DICTIONARY of the Terms made use of in that Science, principally by Limmus; with fatmiliar Explanations, and as Attenpt to establish surificant Endish Terms. By the SAWE ACTHor. The Third Edition, corrected and enlarged, in Evo. Price is, in boards.

AN INTRODUCTION TO THE SCIENCE OF DOTANY, chicfl extrated from the Writus of Linmeus. Wy the hate J.mes Ines Nurseryman and llorit. Tho which are added several new Tables and Notes, and a life of the Anthor. Furth Edicion, currected and conlared by Jane LeE, bin and Stacenter to the Author. in 8ro. with a Portarit and Plates, f'rice 1 is. in hourds; or with the Plates colourcd, 2is, in bourds.

AN TNTRODTC'T ON TO TIE STIITY OF CRYPTOGAMOUS

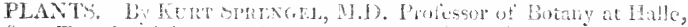

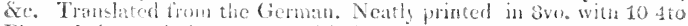
Plates, Price 9s. In buards; or wit! the Iläics coloured, 18s. in boards.

FERDINANDI BALER ILLUSTRATIONES FLOR/E NOVE

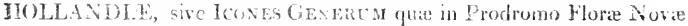
Hollandie et Insulit: Van B)icmen descripe-it RoBertes Brown.

Nos. I and II. handouncly printed in folio, with Five Plates in each, price is. per Number.

THEMPIRASTI ERTSI DE IISTORTA PLANTARUM Libr X. Griecè, cum Sylinbo Gencrum et specicrum, Glossario et Nutis. Curance J. STAChH UsF, Arm Soc. Linh. S.

I'ars I. continens Libus V. prisies. Handsomely printed in crown 8vo. with a Portait of the Author, Price 1's. in buards.

MR. PENNANTS BRITISH ZOOLOGY; a new Edition, in 4 vols. 8vo. with 298 Engravings, many w! which are new. Prace 6 l. in boards: or in royal 3 vo. 31 . 8s. in bontds.

In this Edition the Additions by the Editor constitute an increase of nearly a third to the preceding Ldition.

Printeu ly R. E A. 7 ayior, Shoc-Lane, London 




QK 110. New $1816 \mathrm{v}$ vork 1
Pursh, Frederick/Flora Americae Septentr

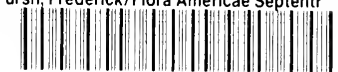

35185000877306 
